\title{
PRÁCTICAS PRODUCTIVAS Y TRADICIONES \\ TECNOLÓGICAS: LA MANUFACTURA CERÁMICA PREHISPÁNICA TARDÍA Y COLONIAL EN LA CUENCA SUR DE POZUELOS Y EL ÁREA DE SANTA CATALINA, PUNA DE JUJUY, ARGENTINA.
}

Arql. María Josefina Pérez Pieroni

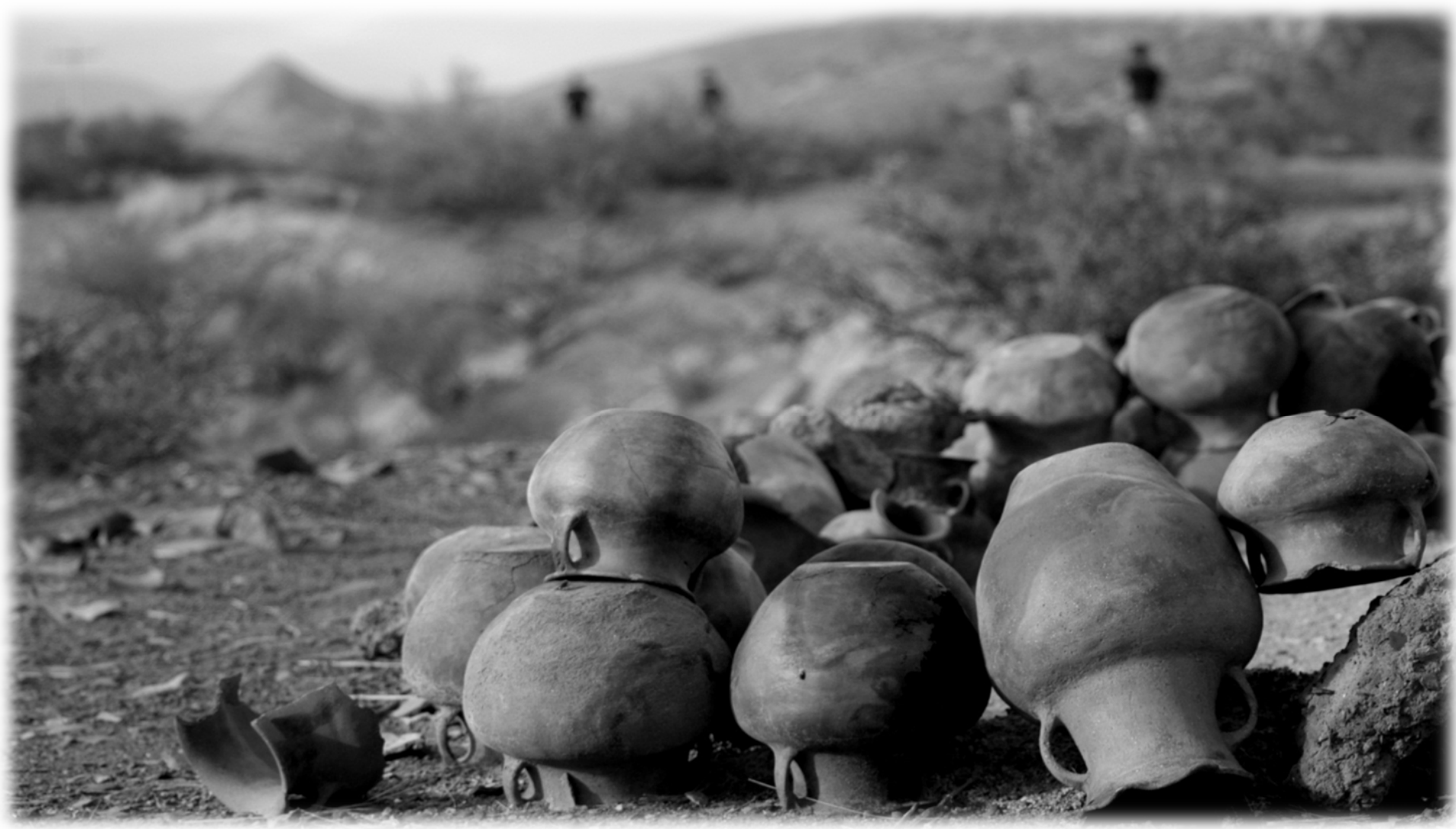

Trabajo de Tesis para optar por el título de Doctor en Ciencias Naturales.

Director: Dr. Carlos I. Angiorama

Co-Directora: Dra. Bárbara Balesta

Facultad de Ciencias Naturales y Museo

Universidad Nacional de La Plata

Año 2013 

Dedicada a Diego, mi amor A mis hermanas $Y$ a mis viejos 



\section{Agradecimientos}

Cinco años de trabajo en esta tesis han hecho que deba mi profundo agradecimiento a una gran cantidad de personas que de una manera u otra han colaborado en su producción.

A mi director, Carlos Angiorama, por su guía y sus consejos y por todos estos años de trabajo y de ayudar en mi formación. A mi co-directora, Bárbara Balesta, quien también me supo guiar y orientar, y por su ayuda y colaboración desinteresada en todos los trámites y gestiones en La Plata.

La carrera de doctorado fue realizada en el marco de dos becas de posgrado del CONICET. Las tareas desarrolladas en el campo y en el laboratorio que sirvieron de base a esta tesis fueron parte de los siguientes proyectos de investigación: PIP CONICET 2006 n 6243 "La Cuenca Sur de Pozuelos (Jujuy) en Tiempos Prehispánicos: Comunidades Locales e Interacción Regional"; PIP CONICET 2010 № 11220090100617. "Población y paisaje en la cuenca media del río Grande de San Juan (900-1550 d.C.)" y Proyecto PICT 2010-2557, financiado por FONCyT, "De pastores, agricultores y mineros. Cambios y persistencias en las poblaciones del sur de la cuenca de Pozuelos y la vertiente occidental de la Sierra de Carahuasi".

A los encargados de los depósitos de los museos y la gente que me ayudó a gestionar el ingreso a los mismos. En el Instituto Interdisciplinario Tilcara, a don Armando, encargado del depósito, que puso a disposición el material, su colaboración e interés en mi trabajo, y a Pablo Ochoa que me ayudo con el permiso y la estadía. En el Museo Quai Branly, a Paz Núñez Regueiro, quién fue indispensable en la gestión del permiso, y a Marie-Laurence Bouvet y el resto del personal del museo, que me recibieron y pusieron a mi disposición el material necesario y se esforzaron por ayudarme y comunicarse conmigo. A Ana Igareta, del depósito 25 del Museo de Ciencias Naturales de la UNLP.

A Constanza Taboada, también le debo mi agradecimiento, porque los años de trabajo en su proyecto, las charlas y las salidas al campo me han enriquecido enormemente. 
A la profe de cerámica de la Escuela de Artes de la UNT, Alicia Peralta, que a través de los dos cursos de cerámica que dictó y en los que participé durante mi carrera de grado, sumado a las charlas que compartimos, me transmitió mucho sobre la artesanía cerámica, su producción, los gestos asociados a ella y la percepción mediante la práctica de hacer.

A los docentes de los cursos de posgrado que he realizado en el transcurso de estos años, que han enriquecido considerablemente esta tesis con aportes bibliográficos y su lectura crítica de los trabajos finales, muchos de los cuales forman parte o contribuyeron a este manuscrito. A Nora Zagorodny y Martín Morosi, quienes me dictaron una pasantía de petrografía cerámica, y pusieron su tiempo y conocimientos a mi disposición. Asimismo, algunas determinaciones y fotografías se realizaron con el instrumental del Centro de Tecnología de Recursos Minerales y Cerámica (CETMIC, CIC - CONICET - UNLP). A Raquel Gil Montero por haberme comentado sobre la falta de registros sobre la producción cerámica puneña en las fuentes y haberme provisto los datos de los que disponía en su base de datos.

Al Instituto de Arqueología y Museo (IAM-ISES, CONICET-UNT) y a toda su gente. A las mis compañeras de la cátedra de Bioarqueología de la Facultad de Ciencias Naturales e IML, UNT, Norma Nasif y Gabriela Aguirre.

La foto empleada en la portada ha sido tomada por Gustavo Spadoni, a quién le debo un agradecimiento muy grande por permitirme usarla.

A los pobladores de las distintas comunidades de la puna con los que tuvimos ocasión de compartir muchos momentos, que siempre mostraron interés en los trabajos realizados y nos brindaron su apoyo, especialmente a la gente de Rinconada, Pan de Azúcar, Muniayoc y Santa Catalina. Particularmente, Lucía y Sergio Flores me han hecho valiosos comentarios sobre la cerámica actual local. También estoy profundamente en deuda con las alfareras y los alfareros de Casira que se tomaron su tiempo para responder mis preguntas, me mostraron sus herramientas y sus piezas, y me brindaron muestras de sus materias primas. Sus aportes fueron fundamentales.

A todos los que compartieron las tareas de campo durante estos años de participación en el proyecto, porque también, indirectamente, son parte de esta tesis. 
Mi familia siempre ha sido un pilar muy importante para mi desarrollo como profesional y persona, brindándome su contención y amor en todo momento. Con ellos mi deuda es muy grande, así que mi más profundo agradecimiento a July, Ri, Manu y Palo. Mi otra familia, la política, también me han brindado su afecto y su ayuda en estos últimos años, y les estoy muy agradecida.

Otro agradecimiento muy grande es para mis amigos. A Flor uno especial, por compartir tanto en estos años de doctorado: cursos y viajes, presentaciones, el espacio de todos los días, las charlas y las angustias, y por estar al pendiente de qué dato o qué trabajo podía serme útil, pero fundamentalmente por tu amistad. También a Lucre y Viqui por compartir tanto y ser amigas desde primer año de la carrera. A los chicos del grupo de "geólogos" y los no tan geólogos, especialmente a Kari, May, Gus, Flaco, Dani y Mochi. A todo el resto de los amigos de la facultad y de la vida, que aunque no los nombre individualmente saben quiénes son, y que a pesar de que los caminos converjan y diverjan, siempre están cuando se los necesita, para ellos también va mi agradecimiento porque han sido muy importantes en todo este proceso.

A mi amor, Diego, un agradecimiento fundamental, por amarme, aguantarme, compartir lo cotidiano conmigo en estos últimos años y por nuestros proyectos juntos, de los cuales nuestras profesiones son una pequeña parte. Te amo. 


\section{ÍNDICE}

Agradecimientos 1

Resumen 9

$\begin{array}{ll}\text { Abstract } & 13\end{array}$

$\begin{array}{ll}\text { 1. INTRODUCCIÓN } & 17\end{array}$

2. CONCEPTOS TEÓRICOS: Materiales cerámicos, tradiciones tecnológicas y prácticas productivas $\quad 21$

Tecnología, técnicas y elecciones tecnológicas 21

Tradiciones tecnológicas, habitus y cadenas operativas 23

La cadena operativa cerámica 28

3. LA ARQUEOLOGÍA DE LA PUNA DE JUJUY:

Secuencia, sitios y materiales 33

La arqueología de la puna de Jujuy: trabajos previos 33

La puna de Jujuy después de la conquista española 39

Los estudios cerámicos en la puna de Jujuy 41

Nuestros trabajos $\quad 47$

Discusión y perspectivas $\quad 50$

4. LA MUESTRA ESTUDIADA: Procedencia y características 53

Material fragmentario 53

Río Herrana

Pan de Azúcar 58

Chajarahuayco 25 61

Tabladitas 63

Santa Catalina $\quad 64$

Timón Cruz $\quad 65$

$\begin{array}{ll}\text { Colecciones en museos } & 67\end{array}$

Muestras de arena y materias primas actuales $\quad 70$

5. DE LAS CADENAS OPERATIVAS A LAS TRADICIONES

TECNOLÓGICAS: Metodología empleada 73 
Tradiciones tecnológicas y cadenas operativas en el

contexto de la producción cerámica de la puna de Jujuy

Caracterización de las materias primas y su posible origen y preparado

Análisis del modelado y las morfologías

Acabados de superficie y decoración

Secado, cocción, reparación y reutilización

La producción alfarera en los S XIX y XX en la puna de Jujuy y el sur del altiplano boliviano

6. LA OBTENCIÓN Y PREPARACIÓN DE LAS MATERIAS PRIMAS

La geología de la puna

Clasificación submacroscópica de pastas

Las piezas de colección y sus pastas 103

Caracterización petrográfica de las pastas $\quad 105$

Caracterización de muestras de arena 118

Observaciones en lupa binocular $\quad 118$

Observaciones en microscopio petrográfico 120

Síntesis y discusión del análisis de pastas 123

7. EL MODELADO Y LAS MORFOLOGÍAS

Las técnicas de modelado y sus atributos en el material

Fragmentario

Evidencias del modelado en las pastas cerámicas 138

Evidencias de modelado en piezas de colección 142

Las morfologías presentes en las colecciones $\quad 146$

Morfología de bordes, bases y asas $\quad 157$

Las morfologías en el material fragmentario $\quad 164$

Morfologías de bordes, bases y asas 173

$\begin{array}{ll}\text { Síntesis y conclusiones } & 179\end{array}$

8. LOS ACABADOS DE SUPERFICIE Y LA DECORACIÓN 185

Acabados de superficie en piezas de colección 185

Acabados de superficie en el material fragmentario 201

La decoración y las pastas $\quad 216$

Discusión y conclusiones $\quad 220$ 
9. SECADO Y COCCIÓN. REPARACIÓN Y RECICLADO 227

$\begin{array}{ll}\text { EI secado } & 227\end{array}$

La cocción de los recipientes cerámicos $\quad 230$

Observaciones sobre el material fragmentario 231

Observaciones sobre el material de colección 237

Evidencias de reparación y reciclado 240

Síntesis y discusión 245

10. LA PRODUCCIÓN ALFARERA EN LOS S XIX Y XX EN LA PUNA

DE JUJUY Y EL SUR DEL ALTIPLANO BOLIVIANO 249

Quiénes producen $\quad 250$

Obtención de materias primas $\quad 251$

Preparación de materias primas $\quad 252$

Modelado 253

Las morfologías elaboradas $\quad 255$

Acabados de superficie y decoración $\quad 257$

Secado 258

Cocción 258

Tratamientos poscocción $\quad 259$

Comercialización, intercambio y uso 260

Síntesis y discusión 263

11. DE LAS CADENAS OPERATIVAS A LAS TRADICIONES

TECNOLÓGICAS: Discusión de los resultados 271

Cadenas operativas en el material analizado 271

Variaciones contextuales 286

Variaciones cronológicas $\quad 290$

La tecnología cerámica de Pozuelos y de Santa Catalina

en un marco regional 296

Las tradiciones tecnológicas puneñas: conclusiones 301

12. CONCLUSIONES Y PERPSECTIVAS FUTURAS 303

Conclusiones sobre los objetivos y su cumplimiento 303

Conclusiones sobre la metodología de análisis 305

Aportes a las problemáticas y perspectivas futuras 307

$\begin{array}{ll}\text { BIBLIOGRAFÍA CITADA } & 311\end{array}$ 
ANEXO I: Descripción macroscópica del material fragmentario

ANEXO II: Descripción de materiales de colecciones de museo

ANEXO III: Descripción de fracturas frescas en lupa binocular

391

ANEXO IV: Descripción de cortes delgados en microscopio petrográfico

425 


\section{Resumen}

Con el objetivo de contribuir a la comprensión de la organización de la producción de la cerámica en las sociedades puneñas de la provincia de Jujuy, en este trabajo intentamos caracterizar las secuencias de procedimientos técnicos empleados en la elaboración de las piezas cerámicas en dos áreas de la puna jujeña, la cuenca sur de Pozuelos y el área de Santa Catalina, para el período prehispánico tardío y momentos coloniales. Asimismo, nos planteamos objetivos más particulares consistentes en reconocer las variaciones a nivel cronológico y espacial para el área, identificar posibles áreas de procedencia de las materias primas y comparar los materiales analizados con los de áreas vecinas.

Partimos de conceptualizar la manufactura cerámica dentro de lo que se ha denominado tradiciones tecnológicas, aquí entendidas como partes de habitus compartidos por grupos de artesanos, y compuestas por el "saber-cómo", o el conocimiento surgido de la práctica situada, y las cadenas operativas, con sus elecciones tecnológicas.

En base a esta conceptualización teórica, se planteó una metodología orientada por los pasos de la cadena operativa, de manera de reconocer las recurrencias en las prácticas de manufactura que permitan acercarnos a las tradiciones tecnológicas. La misma contempló diferentes tipos de materiales, incluyendo fragmentos cerámicos procedentes de excavación y recolección superficial, como también piezas completas depositadas en colecciones. Sobre los mismos se registraron tanto atributos macroscópicos, como submacroscópicos y microscópicos.

La obtención de materias primas es abordada mediante la clasificación de las pastas cerámicas con lupa binocular, su posterior caracterización petrográfica y comparación con la geología local, con muestras de arenas y materias primas obtenidas en el campo. Se clasificaron las pastas en nueve grupos, que presentan inclusiones con características ópticas comparables a las de las muestras obtenidas en el campo y a las descripciones presentes en la bibliografía geológica del área. Por lo que se plantea una posible manufactura local de los materiales analizados, aunque algunos grupos de pastas presentes en baja cantidad y de momentos poshispánicos pueden ser no locales. Asimismo, se detectan diferencias entre los grupos de pastas presentes en ambos sectores del área analizados. 
Posteriormente, se caracterizan las técnicas de modelado mediante la observación de marcas y huellas asociadas, que permiten identificar el modelado por superposición de rollos de arcilla como la técnica dominante tanto en momentos prehispánicos como coloniales, seguido por el modelado manual y en menor medida el uso del torno alfarero, en momentos posteriores al contacto hispano indígena. Mediante estas técnicas se manufacturaron diferentes morfologías, abiertas y cerradas, que son clasificadas tanto para el material fragmentario como para el de colección de acuerdo a la relación de alturas y diámetros en diferentes categorías. Se observan variaciones en las morfologías presentes en las dos zonas analizadas y entre los diferentes momentos cronológicos. Además se reconocen morfologías comparables a las descritas en la literatura tanto del área de estudio como de otras zonas y morfologías de momentos inkaicos. Asimismo se registran las formas de las distintas porciones morfológicas de las piezas (bordes, asas y bases) y sus variaciones.

A continuación, se describen y clasifican los acabados de superficie y la decoración presentes en los materiales analizados, observándose un predominio de recipientes con las superficies alisadas y registrándose diferencias en la presencia y frecuencia de acabados de superficie entre las dos zonas del área bajo estudio y entre los tipos de contextos representados por el material analizado, así como también entre los distintos momentos cronológicos presentes en la muestra.

Al relacionar los acabados de superficie con las morfologías, se definieron categorías morfo-estilísticas, que a su vez se asocian a determinados tipos de pastas y presentan una distribución diferenciada entre los sitios representados por el material bajo estudio. Por otro lado, las mismas se relacionan a los estilos cerámicos definidos en la literatura previa (Yavi y Casabindo), aunque se reconocen variaciones, especialmente con posterioridad al contacto hispano indígena, y la presencia de materiales de posible origen no local.

Posteriormente, mediante la observación del color y su distribución en fracturas frescas, se abordan las atmósferas de cocción para el material fragmentario, y en base al color de las superficies, las de las piezas de colección. Se observa un predominio muy amplio de atmósferas oxidantes, completas e incompletas, con variaciones entre ambas de acuerdo a los grupos de pastas identificados. Algunos recipientes abiertos presentan el exterior oxidado y el interior reducido y corresponden a lo que se conoce 
como "pucos interior negro pulido". También se observan algunos casos de atmósferas reductoras, pero muy escasas.

Seguidamente, se aborda la producción cerámica en los siglos XIX y XX, en base a la lectura de la literatura de viajeros, etnográfica y etnoarqueológica; a fin de aproximarnos a los procesos bajo estudio en la larga duración, y considerar el impacto de la economía de mercado en la producción cerámica tradicional puneña. Dada la falta de documentación colonial para esta manufactura, la revisión realizada nos permite observar algunos cambios y continuidades en las cadenas operativas con respecto a momentos prehispánicos.

Mediante estos procedimientos y sus resultados, planteamos como hipótesis que la producción cerámica puneña habría sido básicamente una producción doméstica, que habría involucrado a la unidad familiar en diferentes tareas, en un contexto productivo agropastoril. Dentro de esta producción, pudimos reconstruir en parte las cadenas operativas de las categorías morfo-estilísticas definidas y vincularlas a dos tradiciones tecnológicas prehispánicas tardías para la puna, una relacionada a lo que se ha denominado estilo Casabindo o Agua Caliente, con pastas con inclusiones de cuarzo, plagioclasas, biotita y pelitas en diferentes proporciones, en vasijas subglobulares con pintura tricolor y bicolor, pucos interior negro pulido, vasos chatos y recipientes abiertos y cerrados alisados o pulidos. La otra se relaciona al estilo Yavi, con pastas con inclusiones de litoclastos pelíticos predominantemente, con botellas, escudillas, vasijas y otros recipientes de forma indeterminada, con las superficies engobadas y pulidas y ocasionalmente con pintura negra desleída. Igualmente se observan algunos entrecruzamientos y variaciones entre estas tradiciones.

Posteriormente, en momentos de la conquista, se habrían introducido algunos elementos de origen no local, con diferentes pastas, secuencias de producción y superficies vitrificadas, aunque en cantidades muy bajas. Sin embargo, las tradiciones de manufactura puneñas, con su selección de materias primas y sus técnicas de modelado habrían llegado hasta momentos recientes, en el seno de las unidades familiares rurales, perdiendo algunos elementos, como la decoración o ciertas formas. 


\section{Abstract}

With the main objective of contributing to the comprehension of the organization of pottery production in the societies of the highlands of Jujuy province, this thesis intends to characterize the technical procedures employed in the manufacture of ceramic materials in two areas of the Jujuy's puna: the southern Pozuelos basin and the Santa Catalina area, for late prehispanic and colonial times. We also pose more particular aims, like recognizing chronological and spatial variations, identifying possible provenience areas for raw materials, and comparing the analyzed materials with those of neighboring areas.

We conceptualize pottery manufacture in terms of technological traditions, understood as part of habitus shared by groups of artisans, and constituted by the know-how, or the knowledge originated in a situated practice, and the chaînes opératoires, or manufacture sequences, with their technological choices.

The methodology was thus oriented by the steps of the chaîne opératoire, in order to recognize the recurrences in the manufacture practices, which allow approaching the technological traditions. Different types of materials were analyzed, including pottery fragments from excavation and superficial collections, as well as complete vessels deposited in museums. Macroscopic, sub macroscopic and microscopic attributes were registered over them.

The raw materials procurement is addressed through the classification of the ceramic pastes using binocular microscope, and through posterior petrographic characterization and comparison with the local geology and with sand and raw material samples gathered in the field. Nine pastes groups were recognized, which show non-plastic inclusions with optical properties similar to those of the sand samples and to the geological characterizations in the literature of the area. Therefore, a possible local (understood in terms of region) manufacture of the analyzed pottery is postulated, although some pastes groups present in low quantities and from post-Hispanic moments might not be local. There are also differences between de pastes groups identified in the two zones of the puna under study.

Subsequently, the modeling techniques are characterized through the marks and traces related to them, which allow identifying coiling as the main manufacture method 
for prehispanic and colonial times, followed by pinching and drawing techniques, and in less degree by the use of the throwing wheel, after the contact with the Europeans. Through these techniques, different morphologies were constructed, open and restricted, which are classified according to the relations between height and diameters for both the fragmented material as for the complete vessels. Variations between the morphologies present in the two areas under analysis and between the different chronological lapses are observed. Morphologies similar to those described in the literature for the study area and for neighboring ones are also recognized. The morphologies for the different portions of the vessels (border, base and handles), and the variations present are registered as well.

The surface finishes and decoration are described and classified next, observing a prevalence of those vessels with smoothed surfaces and registering differences in the presence and frequencies of surface finishes between the two analyzed areas and between the types of contexts present in the analyzed materials, and also between de different chronological moments represented by the sample.

Different morpho-stylistic categories were defined through the relation of surface finishes and morphologies, which are also associated to certain types of pastes, and exhibit a different distribution between the sites represented by the sample under study. They are also related to the ceramic styles defined in the previous literature (Yavi and Casabindo), although there are variations recognizable, especially after the Hispanicindigenous contact, as well as the presence of possible non local materials.

The atmospheres of the pottery firing are examined through the observation of color and its distribution in fresh fractures for the fragmented materials, and through the surface colors in the museum vessels. A high percentage of oxidizing atmospheres, complete or incomplete, is observed, with variations between both according to the groups of pastes identified. Some open vessels are oxidized in the outer surface and reduced in the inner, and belong to the category named pucos with black polished inner surface ("pucos interior negro pulido"). We also observed same cases of reduced firings, but their frequencies are very low.

Also, the pottery production of the $\mathrm{XIX}$ and $\mathrm{XX}$ centuries is analyzed through the travelers, anthropological and ethnological literature, with the aim of approaching the processes under study in the long duration, and considering the impact of the market economy in the traditional pottery production in the puna. Given the lack of references in 
the colonial documents for this manufacture, this approach allows us to observe some changes and continuities with the prehispanic chaînes opératoires.

Through these procedures and its results, we postulate the hypothesis that the pottery production in the puna would have been basically a domestic production, involving the family unit in different tasks, in an agro-pastoral productive context. Inside this production, we were able to reconstruct the manufacture sequences for the different morpho-stylistic categories defined, and relate them to two prehispanic technological traditions for the puna, one related to what has been defined as the Casabindo o Agua Caliente style, with pastes with quartz, plagioclase, biotitic and shale inclusions, in different proportions, in sub globular vessels with two and three color painting, pucos with their inner surface polished and reduced, and open and restricted vessels with their surfaces smoothed or polished. The other one is related to the Yavi style, with pastes with shale inclusions mainly, including shapes like bottles, bowls, vessels and other unidentifiable ones, with their surfaces with a polished slip, and occasionally, with painted motifs. We also observe some crossing over and variations between these traditions.

After the Hispanic conquest, some non-local elements were probably introduced, with different pastes, productions sequences and sometimes vitrified surfaces, although in very small quantities. Despite this, the puna's manufacture traditions, with their raw materials selection and their modeling techniques, would have persisted to recent times, within the family units, losing some elements, like decorations or certain shapes. 


\section{1.}

\section{INTRODUCCIÓN}

Los materiales cerámicos en la arqueología de la puna de Jujuy, al igual que para el resto del noroeste argentino, siempre han sido fundamentales para definir secuencias cronológicas y delimitar espacios socioculturales. En este sector del altiplano, donde se han definido diferentes estilos cerámicos, con valor cronológico (como en el resto de la arqueología del NOA) en base a características morfológicas y decorativas, y algunos atributos de las pastas, surge el interés de analizar si estos están asociados a otros atributos tecnológicos, resultado de las prácticas de grupos de artesanos con saberes y modalidades productivas propias o si las similitudes estilísticas encubren diferentes formas de hacer.

La presente tesis está enmarcada dentro del proyecto mayor dirigido por C. I. Angiorama y A. E. Nielsen, que desde el año 2005, viene desarrollando tareas de prospección y excavación arqueológicas en dos porciones de esta puna: la cuenca sur de la laguna de Pozuelos y el área del río San Juan Mayo. Las mismas estuvieron orientadas por los objetivos de, por un lado, identificar los diversos modos de uso del espacio durante época prehispánica y colonial y sus transformaciones a lo largo del tiempo, y, por otro, entender el rol desempeñado por las comunidades agropastoras del área en el tráfico interregional.

En este marco mayor, nuestro trabajo está orientado al análisis tecnológico de los materiales cerámicos, con el objetivo general de contribuir a la comprensión de la organización de la producción de la cerámica en las sociedades puneñas a través de la caracterización de las elecciones técnicas en las dos áreas abarcadas por los proyectos marco, para el período prehispánico tardío y momentos coloniales.

Dentro de ese objetivo general, la investigación estuvo guiada por los siguientes objetivos particulares:

- Caracterizar las secuencias de procedimientos técnicos empleados en la elaboración de las piezas cerámicas.

- Abordar los posibles usos de los productos cerámicos en relación a su morfología, las características tecnológicas y los contextos en que fueron recuperados. 
- Reconocer posibles variaciones a nivel cronológico y espacial para el área de estudio.

- Identificar las posibles áreas de procedencia de las materias primas empleadas en la manufactura, a nivel regional.

- Comparar los materiales analizados con conjuntos publicados para áreas vecinas, para poder detectar posibles casos de intercambio de bienes o información.

Estos objetivos se formularon a fin de aproximarnos a las diferentes modalidades productivas, conceptualizadas en términos de tradiciones tecnológicas, que están constituidas por distintas elecciones técnicas, y que son parte de habitus compartidos por los grupos de artesanos. Algunas de esas elecciones pueden mantenerse en el tiempo, mientras que otras son modificadas. Los objetivos planteados apuntan a reconocer estas variaciones de las tradiciones tecnológicas a través del tiempo, y relacionarlas a otros cambios producidos en el seno de las sociedades puneñas.

Asimismo, este trabajo se propone contribuir a profundizar los conocimientos de las sociedades que habitaron estas dos áreas de la puna, tanto en momentos prehispánicos como coloniales, y a entender su dinámica dentro de la propia puna y con áreas vecinas. Considerando que ambas zonas han sido poco investigadas hasta la fecha, nuestro trabajo contribuye al conocimiento general de la arqueología de las mismas.

Por otro lado, la mayoría de los estudios sobre materiales cerámicos en la puna jujeña, como así también en el resto del NOA, se han orientado a temas de identidad e interacción basados en análisis estilísticos, relacionando patrones decorativos y formales con grupos sociales o "culturas", y éstos a su vez con períodos cronológicos concretos, generando esquemas taxonómicos y cronológicos (Cremonte 2001; Balesta y Williams 2007). Nuestro trabajo pretende aportar a entender a los materiales cerámicos y su rol en las sociedades desde la secuencia de manufactura completa, no solo desde la perspectiva decorativa o estilística, y contribuir con nueva información a los problemas de identificación de los grupos sociales y su interacción.

Igualmente, el rango cronológico elegido pretende contribuir a la comprensión del impacto primero de la conquista Inka, y luego de la española en esta porción de la puna, especialmente en lo referente a los cambios que estas pudieron haber suscitado en la producción de manufacturas cerámicas y su circulación, o a la persistencia de patrones de producción de las mismas. 
Cabe destacar, como se mencionara posteriormente, que en el resto del Noroeste Argentino, los estudios de tecnología cerámica han cobrado gran relevancia. Sin embargo, en la Puna jujeña los materiales cerámicos no han sido analizados en sus aspectos tecnológicos (exceptuando García 1995, Cremonte 2007a y Solá 2007), aunque sí sus características estilísticas, como acabamos de notar.

En cuanto al desarrollo concreto de la tesis, en primer lugar (Capítulo 2), comenzamos esbozando los conceptos que orientaron nuestro trabajo, es decir, definiendo qué entendemos por tecnología y tradiciones tecnológicas, y como las conceptualizamos dentro de la teoría de la práctica, especialmente desde la noción de habitus. Asimismo, consideramos los aportes dentro de lo que se ha denominado cadenas operativas y su relevancia para los análisis cerámicos.

Posteriormente (Capítulo 3), recapitulamos los antecedentes del área de estudio, la secuencia cronológica construida para la misma, y la importancia de los materiales cerámicos dentro de las investigaciones previas, como así también las particularidades de los trabajos que venimos desarrollando en la puna de Jujuy en el marco de los proyectos mencionados anteriormente. A continuación (Capítulo 4), exponemos las características de la muestra analizada en esta tesis y sus contextos de procedencia.

Proseguimos describiendo la metodología empleada (Capítulo 5), que se orientó siguiendo los pasos de la cadena operativa de producción, en el análisis de material fragmentario y de colección, destacando su relevancia para los objetivos propuestos. Se describen las diferentes etapas del análisis, que consistió en observaciones macroscópicas, submacroscópicas y microscópicas.

Seguidamente se exponen los resultados de nuestras investigaciones, ordenados por los pasos de la cadena operativa de producción cerámica, que orientó nuestras observaciones en el laboratorio. En el Capítulo 6 se aborda la procedencia de las materias primas, al nivel que nos permiten las técnicas empleadas, describiendo la geología local y las características de las pastas mediante de lupa binocular y petrográficamente, lo que permite efectuar comparaciones y realizar una primera clasificación de las pastas cerámicas para las dos zonas de la puna.

Posteriormente (Capítulo 7), detallamos los atributos vinculados con el modelado, las morfologías resultantes del mismo, y las características morfológicas de las distintas porciones de las piezas, tanto para material fragmentario como para piezas de colección. A su vez, se describen y clasifican los acabados de superficie y decoraciones 
presentes en ambos tipos de materiales y se los compara con los aportes previos (Capítulo 8).

El Capítulo 9 aborda aquellos atributos vinculados al secado y la cocción, que son muy escasos, y se discuten las limitaciones del abordaje de estos pasos de la cadena operativa en los materiales cerámicos arqueológicos estudiados.

También incluimos un capítulo (Capítulo 10) que desarrolla una breve investigación sobre producción cerámica en los siglos XIX y XX, en base a la lectura de la literatura de viajeros, etnográfica y etnoarqueológica; a fin de abordar los procesos bajo estudio en la larga duración, y considerar el impacto de la economía de mercado en la producción cerámica tradicional puneña. Dada la falta de documentación colonial para esta manufactura, la revisión realizada nos permite observar algunos cambios y continuidades con respecto a momentos prehispánicos.

Finalmente, se integran y discuten los resultados en función de los objetivos propuestos y comparando con lo que se conoce para áreas vecinas, a fin de integrar nuestros aportes en un marco regional más amplio (Capítulo 11) y se concluye sobre las contribuciones y las perspectivas futuras del trabajo (Capítulo 12). 


\section{2.}

\section{CONCEPTOS TEÓRICOS:}

\section{Materiales cerámicos, tradiciones tecnológicas y prácticas productivas}

En este capítulo definiremos aquellos conceptos y categorías que se emplearon en el trabajo con los materiales cerámicos. En lugar de buscar estructurar un marco teórico, tratamos, más bien, de elaborar un conjunto flexible de herramientas conceptuales y teóricas, que fueron operativas e instrumentales durante el trabajo y para entender los objetos bajo estudio desde una perspectiva que tenga en cuenta a los grupos de personas y sus interacciones. Sin embargo, no deja de ser un conjunto que puede ser modificado, agrandado o reducido en función de la materialidad que se busca analizar con el mismo.

Como punto de partida, tomamos la teoría de la práctica, que a partir del concepto de habitus (sensu Bourdieu 1993), nos permite pensar a los artesanos y sus prácticas productivas, junto con los resultados materiales de las mismas.

\section{Tecnología, técnicas y elecciones tecnológicas:}

En primer lugar, dado que la producción cerámica es parte de la tecnología de una sociedad, vale abordar qué se entiende por tecnología y técnicas. Una de las conceptualizaciones que más se ha empleado en la arqueología de los últimos tiempos es la de Lemonnier (1992), quien conceptualiza a la tecnología como abarcando a todos los aspectos del proceso de la acción sobre la materia y la concibe como una producción sociocultural, sin distinguirla a priori de otras producciones socioculturales (Lemonnier 2004). Este autor conceptualiza como "acciones tecnológicas" a aquellas que involucran al menos "alguna intervención física que lleva a una transformación real de la materia, en términos de las leyes científicas actuales del mundo físico" (Lemonnier 1992: 3). 
Desde esta perspectiva, se considera a la tecnología como parte de la sociedad total, y que los procesos productivos y sus productos no solo involucran materialidad sino también aspectos simbólicos a través de los cuales se percibe y se responde al mundo (Lemonnier 1992; Dobres y Hoffman 1994). La tecnología abarca tanto a la interacción social, incluyendo la división del trabajo, los sistemas de creencias relacionados a ella, el conocimiento práctico de técnicas y del ambiente (Dobres y Hoffman 1994).

Dentro de las tecnologías, las técnicas involucran cinco componentes, interrelacionados entre sí (Lemonnier 1992):

1) la Materia sobre la que actúa la técnica, que incluye el propio cuerpo;

2) la Energía o fuerzas que mueven los objetos y transforman la materia;

3) los Objetos, artefactos, herramientas o medios de trabajo, es decir las "cosas" que se usan para actuar sobre la materia;

4) los Gestos, organizados en secuencias, que mueven los objetos involucrados en una acción tecnológica. Al estar organizados en secuencias, se analizan mediante el concepto de cadena operativa (García Roselló 2010); y

5) un Conocimiento específico, que puede o no ser expresado, que puede ser consciente o inconsciente, y que está formado por un "saber-cómo" o habilidades manuales. Ese conocimiento específico es el resultado final de las elecciones individuales y/o sociales que dan forma a la acción tecnológica, y Lemonnier (1992) denomina representaciones sociales a las posibilidades percibidas y las elecciones dentro de estas.

Dentro de la tecnología así entendida, las elecciones tecnológicas son muy importantes, dado que las sociedades aceptan o ignoran respuestas tecnológicas, de manera intencional o no, que pueden desarrollar ellos mismos o tomar de otros grupos sociales (Lemonnier 1992). En la mayoría de los casos, hay más de una tecnología o procedimiento técnico que satisface los requerimientos mínimos para cualquier tarea, y la elección de una de estas alternativas satisfactorias puede estar fuertemente influida por las creencias, la estructura social y las elecciones previas de la sociedad (Killick 2004: 571). Además, son estas elecciones técnicas, individuales y/o sociales, las que producen como resultado final el conocimiento tecnológico o "saber-como" (Lemonnier 
1992). Por todos estos motivos, el estudio de las elecciones tecnológicas sería sumamente importante para entender la tecnología de una sociedad.

Ingold (1990) también le da un papel importante a las habilidades o al "saber cómo" en su conceptualización de las técnicas, a las que concibe como habilidades que se adquieren en el "actuar en el mundo" como modo de conocerlo. De esta manera, el conocimiento tecnológico se obtiene y se aplica en contacto directo con los materiales, mediatizados o no por herramientas, y la habilidad constituye así un conocimiento y una forma de práctica. Asimismo, estos saberes o habilidades son conceptualizados como prácticos, subjetivos, dependientes del contexto, adquiridos a través de observación e imitación. Esto va muy en sintonía con el concepto de habitus de Bourdieu, que discutiremos en relación a la producción tecnológica más adelante y creemos que en cierto sentido se separa de la forma en que lo concibe Lemonnier (1992), que, a nuestro entender, le da un carácter más consciente o intencional.

\section{Tradiciones tecnológicas, habitus y cadenas operativas:}

Las tecnologías no son entes abstractos, sino que ponen en relación a personas y objetos. Dentro de la diversidad de las mismas, entendemos a la tecnología cerámica como aquella que relaciona a grupos de artesanos, saberes tradicionales, materias primas, combustión, productos terminados, usuarios, etc. Consideramos a los grupos de artesanos y artesanas como individuos que contribuyen a producir y reproducir las estructuras sociales (sensu Giddens 1995; Bourdieu 1993, 1997) a través de sus prácticas productivas y de su interacción con los objetos; como así también, en su interacción con otros artesanos y artesanas mediante relaciones sociales de aprendizaje, de imitación, etc.

La producción se da así dentro de lo que se ha denominado tradiciones tecnológicas, que entendemos como productos de habitus compartidos por grupos de artesanos. Los habitus dan origen a prácticas productivas, que pueden ser semejantes inintencionalmente y sin referencia consciente a una norma. Estas prácticas son originadas en condiciones de existencia y de aprendizaje relativamente homogéneas (Bourdieu 1993). El habitus, de acuerdo a como lo define Bourdieu (1993: 91), es un sistema de disposiciones estructuradas y estructurantes, duraderas y transferibles, constituido en la práctica y orientado para funciones prácticas. En el caso de los grupos sociales como los productores y productoras de cerámica, estos habitus serían 
compartidos y no individuales, se trataría de un sistema subjetivo de estructuras interiorizadas, de principios comunes de percepción, concepción y acción (Bourdieu 1993: 104). De esta manera, el habitus permite dar cuenta de la unidad de estilo en las prácticas y bienes de un grupo de personas (Bourdieu 1997).

Siguiendo a Ingold (2000), los artesanos no imponen "modelos mentales" sobre el material en la producción de artefactos, por lo que pensar en grupos de artesanos y artesanas que comparten habitus tecnológicos o modos de hacer tradicionales, no debe ser pensado como algo estático, o como la transferencia de un esquema ideal. Sino, más bien, los artefactos se producen en la práctica material a través de un compromiso activo y sensorial del practicante. Como el habitus es una lógica práctica, no es estático, sino que es recursivo, es decir que mientras pasa el tiempo, este tiene un rol importante en la acción social y es transformado por esa acción (Hodder y Hutson 2003).

Las tradiciones tecnológicas están conformadas por el conjunto de elecciones técnicas y los pasos de la producción (o "cadenas operativas" sensu Lemonnier 1986); y por el "saber cómo" que mencionamos en el apartado anterior (van der Leeuw 1993; cito en Pauketat 2001: 78; Lemonnier 1992) y que involucra habilidades manuales y procedimientos, como también un conjunto de representaciones culturales de la realidad (Lemonnier 1986, 1992) y que al ser práctico, subjetivo, dependiente del contexto, adquirido a través de observación e imitación, como destaca Ingold (1990) consideramos que es parte del habitus de los grupos de artesanos y artesanas. Este conocimiento práctico no es resultado de la trasmisión de información, sino de la práctica guiada y situada, repetida, y a veces sin palabras, de tareas que requieren determinadas posturas y gestos (Ingold 2008).

Sin embargo, que el habitus y el saber cómo estén guiados por el contexto social y el contexto de aprendizaje de la artesanía no quita que la creatividad del artesano no juegue un rol importante en la manufactura (Sanhueza 2000).

El proceso de aprendizaje de la artesanía, además de una trasmisión individual de conocimientos o del "saber cómo" de la artesana o artesano al aprendiz, se debe tener en cuenta que es un proceso a nivel social que abarca el conocimiento tecnológico que tiene el grupo. Por lo que "no se trasmite un conocimiento tecnológico individual sino el conocimiento tecnológico social" (Calvo Trias y García Roselló 2011: 3). Es este proceso de aprendizaje social y su transmisión de generación en generación que le da a la manufactura cerámica su carácter tradicional y su proyección temporal. De manera 
que no se la debe concebir como tradicional en términos de permanencia de rasgos en el tiempo, como comúnmente se entiende a la tradición en arqueología (Sanhueza 2000)

Asimismo, como sugieren Sillar y Tite (2000: 11), las tradiciones tecnológicas permanecen en el tiempo porque las elecciones tecnológicas están vinculadas a otras actividades, lo que hace que las tecnologías estén insertas en prácticas técnicas y sociales más amplias. Las diferentes tecnologías se relacionan entre sí en el seno de una sociedad y están insertas en ella, permitiendo que ciertas soluciones técnicas se basen en herramientas o prácticas de otra tecnología.

Desde la teoría de la práctica y de la estructuración, se puede considerar que las personas llevan adelante, encarnan o representan tradiciones en formas que continuamente alteran esas tradiciones (Pauketat 2001). Pauketat (2001) ve las prácticas como medio de la tradición y como medio de cambio social, lo que va en contra del supuesto común de que, por un lado, la tradición (y el ritual) es conservador mientras que, por el otro lado, los comportamientos políticos y las innovaciones tecnológicas son dinámicos. La alfarería es parte de un diálogo cotidiano en el que el poder y la tradición son negociados a través de la preparación, distribución y consumo de alimentos. Se negocian el género, la etnicidad, la cosmología y las alianzas políticas rutinariamente en los contextos de la producción, uso y descarte de alfarería (Pauketat 2001).

También se ha empleado el concepto de estilo tecnológico en vez de tradición tecnológica. El mismo sería la sumatoria de las opciones tecnológicas, arbitrarias, que son aprendidas y traspasadas de generación en generación, en su contexto (Stark 1999, Gosselain 1998; citos en Sanhueza 2004); por lo que es asimilable al concepto de tradición tecnológica entendida como habitus, que venimos discutiendo. No se lo concibe como algo "agregado al objeto, que señala la identidad social, sino que, por el contrario, es parte constitutiva del mismo, a partir de las opciones que se tomaron para su producción" (Sanhueza 2004). Sin embargo, dado que el término tradición refleja la transmisión entre generaciones de saberes sociales tecnológicos que mencionamos, preferimos hablar de tradiciones tecnológicas que de estilos.

Como se indicó anteriormente, el otro componente de las tradiciones tecnológicas es la cadena operativa. La misma (chaîne opératoire) es definida por Lemonnier (1986) como una serie de operaciones que lleva del material primario en estado natural a un 
estado fabricado. Corresponde a operaciones necesarias para la ejecución de un proceso técnico que no pueden ser alteradas, eliminadas o reemplazadas sin afectar el resultado del mismo (Rye 1981).

El estudio de las cadenas operativas a nivel arqueológico se realiza mediante el análisis de las evidencias materiales que las operaciones secuenciadas dejan en los objetos durante la fabricación y uso, y que se manifiestan en atributos observables o en cambios físico-químicos. Esta secuencia de acciones no surge de la nada, sino que es resultado del aprendizaje, de las elecciones técnicas y del contexto social mayor donde tienen lugar (García Roselló 2010: 115). Por lo que el estudio de estos atributos producto de las cadenas operativas en los materiales cerámicos nos va a acercar a los habitus o saberes de los grupos de artesanos.

Por otro lado, consideramos que los artefactos cerámicos no son simples objetos pasivos. Gell (1998) considera que la agencia no es sólo un atributo de las personas, y que otras entidades pueden exhibirla. Asocia el concepto de agencia con el de voluntad o intención, es decir que un agente "ocasiona" que los eventos ocurran. Sin embargo distingue entre agentes "primarios", es decir, seres intencionales que se distinguen de las "meras" cosas o artefactos; y agentes "secundarios", que son los objetos o artefactos a través de los cuales los agentes primarios distribuyen su agencia en el medio causal y, por lo tanto, hacen efectiva su agencia. Considera que la agencia tiene lugar en un medio que consiste (en buena medida) de artefactos y que, por lo tanto, los agentes "son", y no simplemente "usan", los artefactos que los conectan con los otros sociales (Gell 1998).

De esta manera, podemos considerar a los objetos como "agentes secundarios", a través de los cuales las personas ("agentes primarios") distribuyen su agencia y se conectan con los otros sociales (Gell 1998). Esta perspectiva es interesante, porque permite considerar a los objetos arqueológicos como "índices" de los grupos de artesanos que los producen y que comparten determinadas formas de hacer (Knappett 2002). Los productos del trabajo pueden ser tratados como indéxicos, ya que el productor puede verse en el producto porque lleva la estampa evidente de su trabajo. La actividad humana deja su marca en, y es entonces indexada por, todo lo que toca (Keane 2005: 187).

Knappett (2002) considera que, al momento de ser manufacturados, los artesanos y las artesanas imbuyen agencia a los artefactos, que se convierten en índices de su 
inversión productiva y de su sensibilidad cultural. Este aporte puede o no ser conspicuo en el artefacto cuando es consumido. Mientras el artefacto se mueve subsecuentemente a través de diferentes esferas de consumo, se forman nuevas conexiones (humanas y no humanas). En el marco de las tradiciones tecnológicas cerámicas, los artefactos serían índices de los grupos de artesanos y artesanas que los producen y que comparten determinadas formas de hacer, más que de personas específicas. Las pastas pueden ser índices del lugar de origen, mientras que las técnicas empleadas y la energía invertida también pueden estar indexadas en los propios objetos, y a través de ciertas técnicas, pueden ser índices de grupos de artesanos y artesanas concretos (Knappett 2005).

También para Gell (1998) los artefactos tienen la capacidad de ser índices de su "origen" en un acto de manufactura. El índice, como objeto manufacturado, está en la posición de paciente en una relación social con su creador. Sin embargo, el origen de los objetos de arte muchas veces puede ser olvidado o enmascarado, bloqueando la abducción que lleva de la existencia del índice material a la agencia del artista. Así el objeto puede ser índice de su "destinatario" o receptor previsto.

Por otro lado, la perspectiva de Gell (1992) destaca el "encantamiento" que produce la tecnología en la incertidumbre del artesano o artesana del resultado de los procesos técnicos. Esto no se opone a la noción de conocimiento y de la persecución de soluciones técnicas racionales a problemas técnicos, sino que es una parte inherente de ellos. Al considerar que la actitud mágica es un subproducto de la incertidumbre, Gell (1992:57) propone también que la actitud mágica es un subproducto de la búsqueda racional de objetivos técnicos usando medios técnicos.

Este punto resulta sumamente interesante al considerar los numerosos tabúes, ritos y restricciones documentados etnográfica y etnoarqueológicamente en la producción cerámica. Por ejemplo, Gosselain (1999) destaca que en diferentes comunidades de África subsahariana, infringir un tabú puede afectar las diferentes etapas del proceso de manufactura (por ejemplo, en el secado o la cocción, las vasijas pueden agrietarse o explotar si no se respetan los tabúes). Estos tabúes pueden entenderse desde el encantamiento de la tecnología, a partir de la incertidumbre que generan ciertos procesos técnicos, aunque se posean conocimientos de procedimientos tecnológicos muy elaborados (Gell 1992). Esta incertidumbre requeriría de otros conocimientos sobre procedimientos mágicos y rituales, que se incluyen en la secuencia productiva y son fundamentales para la obtención del resultado esperado. En este sentido, se relaciona 
con la perspectiva de Lemonnier (2004), y de Dobres y Hoffman (1994), mencionados anteriormente, que consideran que la tecnología abarca a las creencias relacionadas a ella.

Si bien este punto es difícil de demostrar arqueológicamente, consideramos que al ser parte de las cadenas de acciones que conforman las tradiciones tecnológicas, se debe tener presente la existencia de prácticas rituales, tabúes, etc., en la producción de cerámicas prehispánicas o coloniales, además de aquellas producciones documentadas etnográficamente, donde puede darse la referencia a este tipo de prácticas.

\section{La cadena operativa cerámica:}

Como el punto de partida para el análisis es la cadena operativa o la secuencia de acciones involucrada en la manufactura, se hace necesario entender estos procesos y que correlatos materiales tienen para el análisis arqueológico. Esto nos permitirá reconstruir las elecciones tecnológicas que son resultado de los habitus de los grupos de artesanos, y que son parte de las tradiciones tecnológicas cerámicas.

La secuencia de manufactura cerámica conlleva ciertas acciones que son necesarias y otras que no, que pueden o no ser parte de la cadena operativa (Rye 1981). Entre los pasos indispensables están la obtención de materias primas, la preparación de las mismas, el modelado de las piezas cerámicas, su secado y finalmente su cocción. Entre aquellos procedimientos que no son indispensables están los acabados de superficie, la decoración, la aplicación de asas, la aplicación de sustancias después de la cocción para "curar", etc. (Rye 1981). Aquí describiremos brevemente algunos de estos procesos, ya que los mismos son abordados en profundidad en muchas de las publicaciones citadas.

El primer paso es la obtención de las materias primas y su preparación, incluyendo la arcilla y frecuentemente algún material que es empleado como antiplástico. En muchos casos las arcillas pueden ser usadas en su estado natural, sin modificaciones. Sin embargo, la mayor parte de las veces, debe ser procesada para posibilitar su uso, mediante la limpieza de impurezas (por tamizado, suspensión, levigación, etc.), la incorporación de inclusiones no plásticas, agua, y finalmente su amasado (Shepard 1985, Rice 1987). Las inclusiones no plásticas pueden ser tanto 
agregadas intencionalmente como pueden estar incluidas naturalmente en la arcilla (Rice 1987).

Las características de estas materias primas y su posible procedencia pueden ser estudiadas mediante el análisis de la composición y abundancia relativa de las inclusiones minerales, ya que las arcillas son alteradas durante la cocción y no pueden ser identificadas mineralógicamente (Rye 1981, Cremonte 2001). También en ocasiones puede determinarse el agregado intencional o no de inclusiones (Rice 1987). Ya sean agregadas intencionalmente o que se haya seleccionado una arcilla con inclusiones naturales, la naturaleza y abundancia de las inclusiones pueden ser muy informativas respecto a las tradiciones tecnológicas de los ceramistas.

Para construir la pieza, hay numerosas técnicas de modelado manual, tales como el ahuecado y estiramiento del bollo original (pinching, drawing); la preparación y unión de placas (slab building); la superposición de rollos para formar las paredes (coiling); el uso de moldes, etc. (Rye 1981, Shepard 1985). Asimismo, hay una gran variación dentro de cada una de estas técnicas, como por ejemplo, distintos espesores de rollos, que son colocados en espiral o en anillos, en forma horizontal o en bisel sobre el rollo anterior, etc. (García Roselló 2010), lo que también son particularidades de las distintas tradiciones tecnológicas de cada grupo social. Después de la conquista española, también tenemos la incorporación del torno alfarero en el modelado. Frecuentemente se usa más de una técnica para levantar una pieza (Rye 1981). Muchas de estas técnicas dejan marcas y huellas características que pueden ser estudiadas en las piezas que permiten inferir los gestos de modelado (Rye 1981, Wynveldt 2008; García Roselló 2010). Sin embargo, los atributos resultantes de las primeras etapas de ejecución pueden ser obliterados por los pasos posteriores (Rye 1981).

Las técnicas de acabado de superficie en estado plástico sirven para eliminar irregularidades, remover material excedente y rellenar las depresiones, como también para adelgazar el espesor de las paredes (Rye 1981, Shepard 1985). Aquellas que alteran la forma de las vasijas incluyen el paleteado, el raspado, cortado, etc. Las que no involucran la aplicación de color y que pueden afectar la superficie completa de la vasija son el alisado, el pulido y el bruñido (Rye 1981, Sinopoli 1991). Estas técnicas pueden ocultar o enmascarar las de modelado descritas arriba (Orton et al. 1997), y también pueden dejar sus marcas y huellas características. 
Por otro lado, una serie de técnicas plásticas se emplean en la "decoración" de la alfarería, y que también pueden ser consideradas dentro del acabado de superficie de la vasija. Estas técnicas incluyen por ejemplo la incisión, el peinado, el perforado o excavado de la superficie, y la impresión de motivos sobre la misma. Otras técnicas plásticas que incluyen el agregado de material son la aplicación y el modelado (Cremonte 1988, Sinopoli 1991). Las técnicas con las que se agrega color a la vasija incluyen los baños o engobes, el esmaltado y la pintura (Shepard 1985, Sinopoli 1991).

Todas las técnicas de acabado de superficie y decoración pueden cubrir la superficie completa o parte de la misma, algunas son aplicadas antes de la cocción, en distintos momentos del proceso de secado (en estado cuero o con la pieza ya seca por ejemplo), y otras después de cocidas (Rye 1981, Rice 1987; García Roselló 2010).

El último paso en el proceso de manufactura cerámica es la cocción de las piezas ya modeladas y que previamente se han dejado secar bien. La aplicación de calor a las vasijas resulta en transformaciones químicas del cuerpo de arcilla, obteniendo un producto duro y durable que ha perdido su plasticidad original. La apariencia y estructura de una vasija al final de este proceso está determinado por tres factores principales: la máxima temperatura obtenida, la duración de la cocción y la atmósfera de cocción (Rye 1981, Rice 1987, Sinopoli 1991). La cocción puede abordarse en alguna medida a través de sus productos, tomando en cuenta el color y la presencia de núcleos en la pasta, que pueden dar alguna información sobre la atmósfera de cocción, su variabilidad y los ritmos de enfriamiento, pero no indican las temperaturas y pueden sufrir modificaciones posteriores a la cocción (Rye 1981, Sinopoli 1991, Orton et al. 1997).

Una vez que las vasijas se han enfriado y han sido removidas del lugar de cocción, las mismas pueden ser sujetas a tratamientos de superficie subsiguientes, que pueden incluir la aplicación del color, determinados tratamientos para el uso posterior, etc. (Sinopoli 1991).

Estos son los pasos más básicos que se pueden reconocer en la literatura citada, y a partir de los mismos estructuramos el análisis y la exposición de los resultados en los capítulos subsiguientes.

Un punto que merece ser destacado, es que se ha propuesto que hay aspectos del proceso de manufactura cerámica que son más susceptibles de ser modificados que 
otros. Los conocimientos vinculados con la extracción y preparación de materias primas y los gestos técnicos vinculados al modelado de las piezas cerámicas suelen permanecer más en el tiempo que aquellos como la forma y la decoración, para los que se ha planteado que es más sencillo introducir cambios, sin modificar los complejos conocimientos y habilidades técnicas que requiere la manufactura (Rye 1981; Gosselain 1992, 2000; Sanhueza 2000; Cremonte 2001, Calvo Trias y García Roselló 2011, entre otros). Por lo que los atributos vinculados al primer conjunto de aspectos suelen ser empleados con mayor frecuencia para delimitar las tradiciones tecnológicas.

Como destaca Gosselain (1992), las técnicas de modelado no están restringidas por factores externos, por lo que su elección sería cultural, además de que una misma morfología de piezas puede ser modelada mediante diferentes procedimientos (Gosselain 2000). Aunque, en sus trabajos etnográficos en África, este autor documenta que las técnicas de modelado no son conceptualizadas en términos de elecciones, sino que se conciben como la única alternativa posible dentro de la tradición tecnológica. Estás técnicas no son pensadas o decididas, sino que involucran esquemas psicomotores, adquiridos e internalizados durante el aprendizaje y la práctica (Gosselain 1992), como hemos descrito anteriormente.

Eso no quita que el estudio de las formas y la decoración no sean útiles, sino que responden a otras necesidades y estímulos sociales e ideológicos, además de que son más visibles y pueden ser más fácilmente copiados o modificados por influencia de terceros (Gosselain 2000; Sanhueza y Falabella 2009). Además, estás cualidades, que son muy visibles, son más susceptibles de estar vinculadas con valores estéticos, simbólicos o económicos (Gosselain 2000: 191). Por lo tanto, se debe tener en cuenta que todos estos aspectos presentan diferentes velocidades de cambio en el tiempo y son afectados por distintos factores, que incluyen interacciones con personas a diferentes niveles, por lo que proveen diferente información sobre las relaciones sociales del pasado (Gosselain 2000). 
3.

\section{LA ARQUEOLOGÍA DE LA PUNA DE JUJUY:}

Secuencia, sitios y materiales

En este capítulo sintetizamos los trabajos que se han llevado a cabo previamente en la puna de Jujuy, a fin de contextualizar nuestras tareas, destacando la información sobre momentos prehispánicos tardíos y coloniales. Asimismo, sintetizamos los principales aportes realizados con respecto a los materiales cerámicos del área y concluimos con un resumen de los trabajos y aportes efectuados en el marco de las investigaciones que se vienen llevando adelante desde nuestro equipo de trabajo.

\section{La arqueología de la puna de Jujuy: trabajos previos}

Si bien la puna Jujeña ha sido trabajada arqueológicamente desde fines del XIX, algunos aportes han sido aislados y esporádicos, mientras que otros tuvieron un carácter más sistemático, por lo que lo el conocimiento actual de la historia prehispánica local es parcializado. Sin embargo, sintetizaremos aquí las referencias más relevantes para nuestro trabajo, enfatizando en los aportes al período prehispánico tardío.

Las primeras visitas a la puna por expediciones científicas fueron las de Max Uhle, que envía materiales de Casabindo a Berlín, y la de Moreno, Holmberg y Gerling, que recogieron datos y objetos (Krapovickas 1968). Sin embargo, estas tareas no resultaron en publicaciones, aunque Ambrosetti (1902) y Lehmann-Nistche (1904) publican los objetos recuperados por Gerling y depositados en La Plata. En años posteriores, otras dos importantes expediciones extranjeras incluyeron la Puna, resultando en sendas publicaciones: la de Boman (1908) y von Rosen (1924; cito en Krapovickas 1968).

Particularmente, la visita de Boman a diferentes puntos del NOA, dentro de la expedición de Créqui-Montfort y Sénéchal de la Grange, tuvo como resultado la edición de dos tomos, uno de los cuales sintetiza la información por él reunida en la puna, describiendo gran cantidad de sitios y materiales arqueológicos, que interpreta como pertenecientes a los grupos indígenas conocidos por los españoles en el siglo XVI, y en base a las fuentes escritas y a las semejanzas que encontró entre los hallazgos de la 
puna y aquellos de Calama (norte de Chile) atribuye al pueblo de los Atacameños ${ }^{1}$ (Boman 1908). Uno de los sitios importantes trabajados por Boman (1908) y que se localiza en nuestra área de estudio, es el Pucará de Rinconada, donde además relevó las mesadas que lo rodean, describiendo su arte rupestre y excavando algunas tumbas en abrigos (Boman 1908).

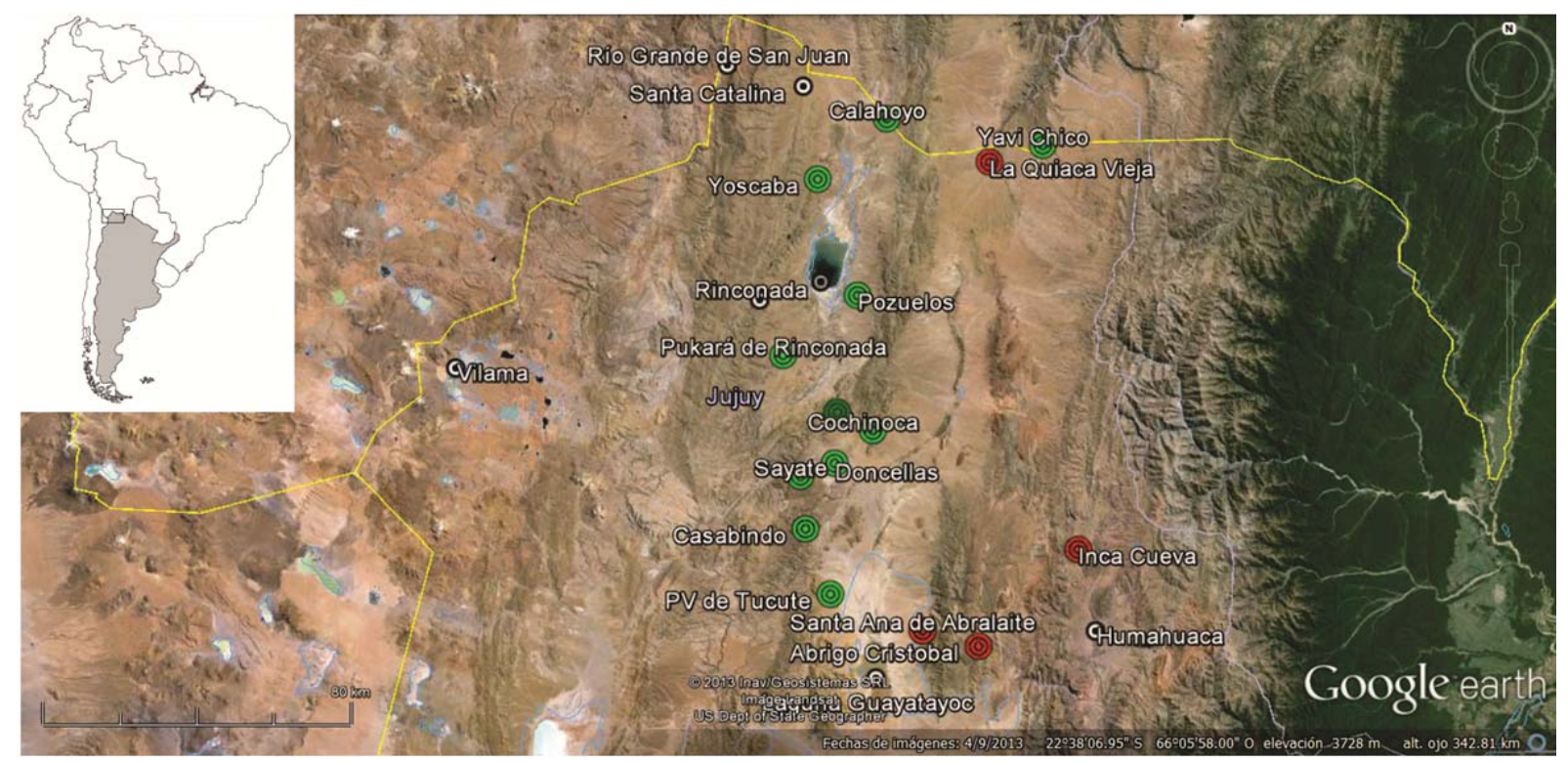

Figura 3.1 Mapa con los sitios mencionados en el texto. En rojo los sitios arqueológicos del período Temprano y Medio y en verde los del Tardío.

Buena parte de esta arqueología temprana se centraba en la excavación de contextos funerarios a fin de obtener materiales para las colecciones de museos. Por ejemplo, además de los trabajos citados previamente, entre 1919 y 1921, Weiser realizó excavaciones en tumbas localizadas en grutas en el área del río San Juan Mayo, financiados por Muñiz Barreto, siendo acompañado en su última visita por Debenedetti, quien describe los hallazgos efectuados (Debenedetti 1930). Asimismo, en Doncellas, en la cuenca de Miraflores-Guayatayoc, desde 1941 a 1944 Casanova realizó excavaciones en contextos funerarios, obteniendo una importante colección para el Museo Etnográfico de Buenos Aires, aunque los hallazgos fueron escasamente publicados (Casanova 1938, 1943, 1944).

\footnotetext{
${ }^{1}$ Hipótesis seguida por Lafón (1965), quien considera que en la puna de Jujuy, en tiempos prehispánicos, habitó una "Cultura Atacameña de tipo Doncellas", y criticada posteriormente por Vignati (1931) y Krapovickas (1978).
} 
Las investigaciones a partir de la década del '60, al igual que en el resto de la arqueología del NOA, intentaron caracterizar las ocupaciones prehispánicas y se preocuparon por la cronología, otorgándole a las tareas realizadas un carácter más sistemático. De esta manera, se incrementan las publicaciones sobre sitios ya trabajados por autores previos y sobre nuevos sitios y nuevas evidencias, especialmente para el período Tardío. Estos trabajos llevan a formular una secuencia cronológica local y un esquema espacial, con correlatos materiales para cada área y período.

Dentro de esta secuencia cronológica, el lapso comprendido por el período Temprano o Formativo es poco conocido, y se cuenta con escasas evidencias, que incluyen sitios como el Abrigo Cristóbal, en la vertiente occidental de la Sierra del Aguilar, donde se definió un tipo cerámico denominado Cristóbal Imbricado (Fernández 1988-89); Munitayoc, en la cuenca Miraflores-Guayatayoc (Fernández 1996); la Quiaca Vieja y Cerro Colorado 2, ambos sitios monticulares en el departamento de Yavi (Krapovickas 1987-88) e Inca Cueva, alero 1 y cueva 5 (García 1995).

El período Medio, como destaca Albeck (2001), no se distingue del Tardío en la puna, ya que no hay diferencias notables en los patrones de asentamiento ni en los objetos. Se destaca el hallazgo de dos vasos tipo "kero" de plata dorada, relacionados por Rolandi (1974) con Tiwanaku, en la zona de Doncellas, y una estructura escalonada con piedra canteada que según la autora también se vincularía con ese grupo altiplánico. Por otro lado, el sitio Santa Ana de Abralaite, un poblado prehispánico con estructuras agrícolas asociadas que se localiza en la ladera occidental de la sierra del Aguilar, habría sido ocupado durante este período de acuerdo a los tipos cerámicos hallados (Krapovickas et al. 1979).

Las evidencias documentadas para momentos tardíos son más abundantes e incluyen mayor cantidad de sitios, algunos de los cuales han sido trabajados con continuidad. A partir de la cerámica, como veremos más adelante, se han definido dos estilos, que se han vinculado con grupos sociales concretos o culturas, asociándoles otras evidencias materiales que los distinguen, como la arquitectura y el tipo de inhumaciones (Krapovickas 1965; 1973; Ottonello y Krapovickas 1973). El primero, Yavi (o Yavi Chico), ocupa el NO de la puna. Se le ha asignado una posición cronológica del período Medio y Tardío (900 - 1500 d. C.), perdurando hasta momentos del Inka, e hispano-indígena, basándose en las asociaciones cerámicas y en cuatro fechados radiocarbónicos (Krapovickas 1973; Krapovickas et al. 1989). 
Esta "cultura" ha sido nombrada y definida en base al sitio homónimo, localizado en el departamento La Quiaca. Se ha caracterizado básicamente por los atributos de su cerámica, como veremos más adelante, y secundariamente por los tipos de inhumaciones, que son variados, los asentamientos tanto en lugares defensivos (Cerro Colorado 1) como en conglomerados asociados a los cursos de agua y a los espacios productivos agrícolas (Yavi Chico), entre otros atributos (Krapovickas y Aleksandrowicz 1986-87).

En segundo lugar, la "Cultura" o "estilo Casabindo" (o Agua Caliente en Ottonello 1973) sería también tardía, perdurando en momentos inkaicos e hispano indígenas, y la localizan en el sur de la puna, con influencia en la cuenca de Pozuelos y del Río Grande de San Juan (Ottonello y Krapovickas 1973; Krapovickas 1983). Es definida basándose en el asentamiento de Agua Caliente de Rachaite (o Doncellas), un poblado conglomerado con estructuras de cultivo asociadas, menhires e inhumaciones en cuevas tapiadas y "casas tumbas", que ha sido estudiado por Alfaro (1983) y Ottonello (1973) principalmente. Este sitio cuenta con un fechado de $740 \pm 50$ AP (Alfaro 1983). Otros sitios incluidos en el área de dispersión de esta "cultura" o "estilo" son Sorcuyo y el Pucará de Rinconada (Ottonello 1973; Ottonello y Krapovickas 1973, Albeck y Ruiz 1997).

El área de Casabindo ha sido trabajada también por el equipo dirigido por Albeck (Albeck et al. 1995, 1999; Albeck y Dip 1996; Albeck y Ruiz 1997), reconociendo 20 sitios de vivienda con diferentes patrones de asentamiento. El patrón típico definido por Albeck (2001) para el período tardío de este sector de la puna corresponde a asentamientos semiconglomerados, sobre terrenos fácilmente accesibles y con viviendas de planta rectangular con muros de piedra. También es frecuente la presencia de áreas productivas agrícolas y pastoriles, en las inmediaciones de los poblados (Albeck y Ruiz 1997; Albeck 2001).

Pueblo Viejo de Tucute, o Sorcuyo, también se encuentra en esta área, sobre la quebrada de Tucute y se trata de un importante poblado con recintos de planta circular predominantemente, lo que lo distingue de los poblados "Casabindo", aunque sería contemporáneo a ellos (Albeck et al. 1999; Albeck 2001). A su vez, se distancia por los materiales arqueológicos hallados y su vinculación con el Pucará de Tucute. Estas evidencias conducen a las autoras plantear diferencias étnicas entre los pobladores de este sitio y los de otros sitios del área (Albeck et al. 1995, 1999; Albeck 2001). 
La cuenca sur de Pozuelos fue incluida dentro del área de "influencia Casabindo" como hemos mencionado, a pesar de que no se contaban con investigaciones sistemáticas hasta años recientes. Por su parte, la porción norte y central de la laguna fue asociada al área de influencia Yavi (Krapovickas 1984).

Dentro de la porción sur de la cuenca, que nos interesa particularmente por ser parte de nuestra área de estudio, el único sitio trabajado previamente es el ya mencionado Pucará de Rinconada, donde, después del trabajo citado de Boman (1908), se retomaron las investigaciones en la década del '70 por Alfaro y Suetta (Alfaro 1969; Alfaro y Suetta 1970; Suetta y Alfaro 1979), quienes relevaron estructuras, realizaron recolecciones superficiales y excavaciones; y posteriormente por Ruiz (1996), quien, de acuerdo a los materiales y las estructuras analizados, plantea una ocupación preinkaica y otra con presencia Inka. Una serie de fechados radiocarbónicos sobre éstos materiales abarcan desde 1080 d.C. a 1490 d.C. (Ruiz y Albeck 1997). También se ha señalado y publicado la presencia de arte rupestre en las mesadas cercanas a la del pukará (Alfaro 1978; Ruiz y Chorolque 2007), parte del cual es el previamente descrito por Boman (1908).

Otros investigadores realizaron tareas en otros sitios de la laguna de Pozuelos, como González (1963), que llevó a cabo sondeos en sus bordes orientales en 1960, en un sitio caracterizado por montículos. Allí obtuvo muestras para las dos primeras fechas radiocarbónicas de la puna: $820 \pm 150$ y $810 \pm 150$ AP. En la década de 1990, se retomaron las investigaciones de ese mismo sitio, denominado Pozuelos, excavando un montículo considerado basurero, en las proximidades de un sitio de vivienda permanente o semipermanente. En base a una serie de fechados radiocarbónicos se propone una serie de ocupaciones ininterrumpidas entre cal AD 1250-1392 y cal AD 1302-1455, con una intensificación de las mismas en el lapso AD 1435-1486 (Alonso y Fernández 1996).

Otros aportes dentro de esta área incluyen los de Mamaní (1998), quien realizó tareas de prospección en la porción occidental de la Cuenca, detectando sitios residenciales (algunos ya mencionados en la literatura previa), sitios temporales, sitios transitorios con arte rupestre o parapetos, diversos hallazgos aislados y quebradas con restos de estructuras agrícolas. De acuerdo a los materiales arqueológicos recolectados (cerámica), la mayoría de estos sitios corresponderían a momentos tardíos e Inka. 
Por otro lado, se ha planteado que la puna estuvo integrada a una amplia red de intercambio que, durante el Tardío, habría estado basada en el tráfico caravanero y que habría vinculado el área de Casabindo con grupos Yavi, y a éstos con grupos de la quebrada de Humahuaca, y posiblemente también con aquellos de la región de Atacama en Chile (Albeck y Ruiz 1997; Albeck 1994, 2001). Para Tarragó (1977) la movilidad y el intercambio entre zonas como San Pedro de Atacama, la quebrada de Humahuaca y la puna se estableció desde momentos tempranos y continuó durante las etapas posteriores. En otro trabajo (Tarragó 1984), la autora enfatiza la demanda de productos tropicales que tuvieron las sociedades puneñas y establece ejes de interacción, uno de los cuales (el más importante) vincula el Salar de Atacama, San Juan Mayo, Pozuelos, Yavi Chico, la quebrada de Humahuaca, serranías, bosques de Iruya y Santa Victoria. Las autoras citadas basan sus planteos en evidencias indirectas, tales como mates o calabazas, cascabeles de nueces, plumas de aves tropicales, maderas y distintos minerales.

Sin embargo, otros autores enfatizan las evidencias directas del intercambio, tales como las propias rutas, vestigios de campamentos de descanso de los llameros (estructuras, restos de fogones, desechos, etc.), ofrendas, entre otros (Nielsen 1997a). Restos de minerales y cuentas se hallaron en Mayu Puncu, al occidente de la Laguna de Pozuelos (Mamaní 1998), aparentemente vinculados al ceremonialismo caravanero. Zaburlín (1998; cito en Nielsen 1997a) ha registrado algunos casos de mineral de cobre y cuentas en abras o cumbres de la zona de Casabindo. Para la vecina zona de sud Lípez se publicaron evidencias de campamentos, especialmente para el período Tardío, incluyendo cerámica Yavi (Nielsen 1997a).

Las tareas realizadas también han detectado evidencias que corresponderían a momentos inkaicos. Raffino (1978) identifica los siguientes sitios con evidencias estatales en lo que él denomina Puna Norte: Rinconada, Casabindo, Cochinoca, Sayate, Rincón de las Salinas y El Moreno; asociados, según el autor, a obras viales Inka. Rincón de las Salinas y El Moreno son sitios Inka puros, mientras que los otros representan un asiento imperial sobre otro preexistente. En un trabajo posterior, el autor menciona los sitios de Toroara, $3 \mathrm{~km}$ al sur de La Quiaca; Queta Viejo, en el abra de Queta, dentro del sector oeste del bolsón de Cochinoca; el tambo de Pozuelos, en la vertiente oriental de la laguna; Salviayoc, sobre la ruta que conduce de Abra Pampa a Rinconada y Calahoyo, en el límite de Argentina con Bolivia. Todos presentan evidencias arquitectónicas inkas y cerámica cuzqueña e inka provincial (Raffino et al. 1986). 
Krapovickas (1984, 1987-88) asigna a este período el sitio de La Quiaca Vieja, por los materiales cerámicos recolectados en superficie. Las estructuras están muy destruidas por acción de la población actual y se supone la existencia de recintos rectangulares, que habrían pertenecido a un tambo. También menciona Cerro Colorado 1, poblado tardío que ocupa la cumbre del cerro homónimo, que presenta algunos materiales cerámicos incaicos, junto con alfarería Yavi, y un fechado de 1520 d.C. (Krapovickas 1987-88).

En la zona de Casabindo, Albeck et al. (2007) atribuyen a la presencia imperial sectores agrícolas con fuerte inversión en infraestructura productiva (canales, represas y andenería). También identifican la sección del camino imperial en el tramo CasabindoDoncellas y el pequeño tambo de Liristi asociado a un tramo colateral del camino.

El momento cronológico posterior a la conquista inka es aquel iniciado por la llegada de los españoles al área, que exponemos brevemente a continuación.

\section{La puna de Jujuy después de la conquista española:}

De acuerdo a las investigaciones arqueológicas citadas y las etnohistóricas, en momentos del contacto hispano indígena, la puna de Jujuy estaba habitada por los grupos Casabindo y Cochinoca en la sección central y septentrional de la cuenca Miraflores-Guayatayoc-Salinas Grandes, y los grupos Yavi-Chicha en el nordeste de la región, en la subcuenca de Yavi-La Quiaca (Krapovickas 1983). El territorio chicha también comprendía los grandes valles en el sur del actual territorio boliviano y Tarija (Albeck 2007). El primer grupo se asocia a las evidencias materiales atribuidas a la "cultura Casabindo", con su cerámica diagnóstica, mientras que el segundo, de igual manera, con aquellos materiales denominados como "cultura" o "estilo Yavi" (Krapovickas 1983). Por lo que cada uno de estos grupos étnicos de momentos del contacto tendría su correlato arqueológico prehispánico.

La cuenca de Pozuelos, como se mencionó anteriormente, fue ocupada en su porción norte y central por los chichas mientras en el sur hubo importantes instalaciones de los Casabindos y Cochinocas. En el noroeste del sector, el valle del río Grande de San Juan, se habrían instalado grupos de diversas parcialidades que convivirían, tal vez en colonias multiétnicas (Krapovickas 1983, Albeck y Ruiz 2003; Albeck 2007). Sin 
embargo, teniendo en cuenta el impacto primero de la conquista inkaica y posteriormente de la española, con los movimientos poblacionales que implicaron, no podemos tomar este cuadro territorial como fijo y estable desde tiempos prehispánicos (Ávila 2005).

Algunos grupos de la puna y la quebrada de Humahuaca fueron repartidos en encomienda muy tempranamente. Los Casabindo y Cochinoca fueron otorgados en 1540 a Martín Monje y Juan de Villanueva por Francisco Pizarro (Sica y Ulloa 2007). Sin embargo, estas encomiendas no se hacen efectivas hasta la década de 1590, ya fallecidos sus primeros dueños (Krapovickas 1978). Posteriormente, sobre la base de las mismas, se conformó lo que se conoció como Marquesado del Valle de Tojo, título que se concedió en 1708 a Juan José Campero de Herrera y sus herederos. Su centro administrativo se localizó en Yavi y tuvo una perduración, incluyendo la encomienda sobre la que se basaba, hasta comienzos del siglo XIX (Madrazo 1982).

Por otra parte, el análisis de las mercedes de tierra otorgadas y las posteriores compraventas muestra como las tierras fueron progresivamente concentrándose en manos de unos pocos propietarios, en desmedro de las poblaciones indígenas, que iban siendo reducidas (Albeck y Palomeque 2009).

Durante el período colonial, la economía regional se volcó fundamentalmente al pastoreo de camélidos, de ovejas, y en algunos lugares de vacas, así como a la minería a pequeña escala y la extracción de sal. La población indígena vivía dispersa en el ámbito rural, mientras que los pequeños poblados, cabeceras de los curatos, eran habitados por autoridades civiles y eclesiásticas y por comerciantes (Gil Montero 2002, 2004). Por otro lado, la puna se conformó como una zona de paso muy importante entre la Gobernación de Tucumán y las regiones mineras del norte, como Potosí, Porco, Lipez, entre otras. (Sica y Ulloa 2007). Hacia fines del siglo XVIII, más del $60 \%$ de la población de la actual provincia de Jujuy vivía en la Puna, que funcionó como área de captación de migrantes, atraídos por la exención de la mita y por las explotaciones mineras (Gil Montero 2002, 2008).

Estos procesos generaron cambios en las relaciones de mercado, mediante la relocalización forzada de indios, las haciendas, el establecimiento de redes comerciales para la Corona, las minas, mediante la introducción de la religión, etc. (Buechler 1983). El comercio y los mercados fomentados por el estado florecieron junto con el comercio y los mercados de subsistencia y de caravanas de llamas en los siglos XVI y XVII en todo 
el altiplano. Como ya mencionamos, esta era una zona de paso importante a los centros mineros, y buena parte del intercambio tenía lugar alrededor de las operaciones mineras de Potosí (Buechler 1983).

Los indígenas de la Puna se integraron tempranamente al comercio español, especialmente mediante el transporte o arriería y la tropería o conducción de ganado en pie, que cobraron gran importancia en vinculación al desarrollo de los mercados mineros. Esta integración se dio tanto como trabajadores como como propietarios de animales y se basó en buena medida en los conocimientos prehispánicos sobre cría de ganado y tráfico caravanero (Sica 2010).

En el siglo XIX, las guerras de independencia convirtieron a la región puneña de Jujuy en parte de la frontera internacional con Bolivia, separándola del resto de las "tierras altas", también con predominancia de población indígena, y de los mercados de abastecimiento e intercambio, dejando de ser la zona de paso importante hacia los centros mineros del norte. De esta manera, se genera un cambio radical en los siglos XIX y XX, que llevan a la situación actual de la puna, que es una región expulsora fundamentalmente de hombres, donde la población residente es menor al $6 \%$ del total provincial (Gil Montero 2002: 13).

\section{Los estudios cerámicos en la puna de Jujuy}

Para la cerámica de momentos prehispánicos tardíos, que es la de nuestro interés, tradicionalmente se han definido dos estilos, que han sido vinculados a grupos sociales diferenciados, como hemos mencionado anteriormente. El primero, Yavi (o Yavi Chico), que ocupa el NO de la puna, fue definido a partir de los hallazgos en el sitio Yavi Chico y materiales similares de áreas vecinas. Se consideran como formas muy características las vasijas con asas asimétricas y modelados antropomorfos o zoomorfos. La decoración generalmente es en negro y los motivos son geométricos (triángulos espiralados, formas "arriñonadas", etc.) y suelen aparecer sobre superficies engobadas. Otras formas comunes son los que denomina "baldes", escudillas y vasijas globulares de bases planas, con asas laterales verticales, labioadheridas, y los cántaros con pie cónico en la base (Krapovickas 1965, 1968, 1973, Krapovickas et al. 1989, Ottonello y Krapovickas 1973). Dentro de este estilo se han definido diferentes tipos, de acuerdo las características de las pastas y de la decoración (Krapovickas 1975; Krapovickas et al. 1989). 
Las pastas más conspicuas de esta cerámica (tipos Portillo ante liso; Portillo morado sobre ante, Portillo polícromo) son predominantemente compactas, de color ante, anaranjado o rojo claro, con inclusiones de gránulos blancos: lutitas areniscosas de la Formación Acoyte según Krapovickas (1975, 1978, Krapovickas et al. 1989) o pelitas alteradas a muscovita-sericita-cuarzo de la Formación Acoyte, en los análisis de Cremonte et al. (2007a). Sin embargo, la mayoría de las pastas de la cerámica Yavi son "toscas", de color castaño o rojizo, con o sin gránulos blancos (Krapovickas et al. 1989), a veces con clastos de cuarzo en la superficie interna (tipo Pozuelos con cuarzo, que también presenta improntas textiles) (Krapovickas y Aleksandrowicz 1986-87).
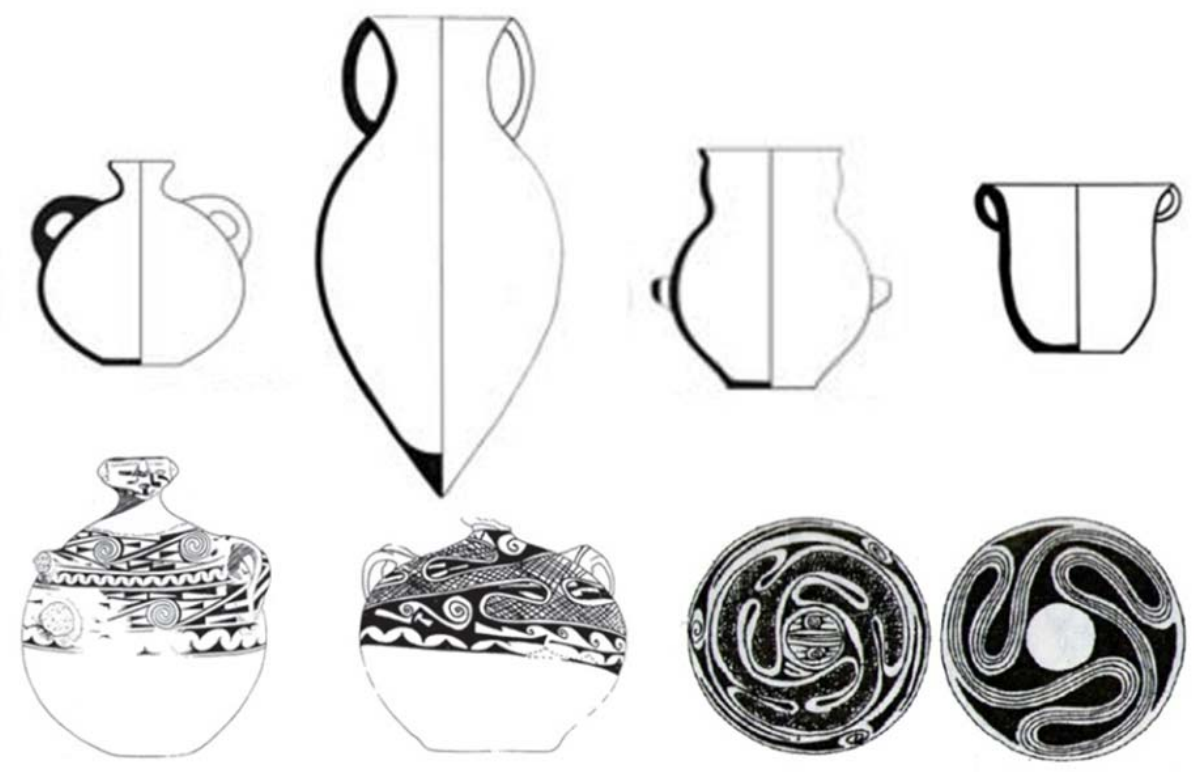

Figura 3.2 Algunos ejemplos de vasijas "estilo Yavi" (tomados de Ávila 2006).

Otros tipos presentan abundante mica (Yavi Chico negro con mica, Portillo negro con mica, Portillo con mica) (Krapovickas 1975). También se mencionan pastas muy semejantes a las del tipo Portillo ante liso, pero sin litoclastos blancos visibles o muy pequeños y dispersos (tipos Yavi Chico pasta ante, Yavi Chico polícromo) (Krapovickas y Aleksandrowicz 1986-87).

Ávila (2006) analizó las características morfológicas y estilísticas de las vasijas Yavi procedentes de colecciones, y en base a materiales hallados en sitios datados de la quebrada de Humahuaca, separa al estilo Yavi en dos momentos. El primero, 
"componente yavi temprano" (900-1250 d.C.) se caracteriza fundamentalmente por la alta proporción de piezas policromas y por el tamaño relativamente pequeño de las piezas. En el segundo momento, o "componente yavi tardío-inka" (1250-1530 d.C.), disminuyen las piezas con combinaciones cromáticas policromas, aumentan las configuraciones pictóricas, hay nuevas variedades morfológicas y aumenta el tamaño medio de las piezas (Ávila 2006: 94). También distingue variaciones en la morfología de las piezas Yavi y sus combinaciones cromáticas y configuraciones pictóricas entre las zonas de la quebrada de Humahuaca, puna oriental y puna occidental.

Los sitios con materiales Yavi identificados son numerosos y se distribuyen en la zona de Yavi-La Quiaca, en la cuenca de Pozuelos, en el valle del Río Grande de San Juan y en el sur de Bolivia (Krapovickas et al. 1989). También se han hallado materiales atribuidos a la "cultura" o "estilo" Yavi en contextos de la quebrada de Humahuaca y de la región atacameña chilena (Ávila 2006).

En el Río Grande de San Juan, de acuerdo a las descripciones de Lehmann-Nistche (1904), los materiales cerámicos consisten en escudillas o pucos y algunas piezas cerradas, con o sin pintura, oxidante, que puede presentar motivos en negro desleído sobre rojo, formando motivos de triángulos con espirales, reticulados, etc., todos comparables a los descritos para la cerámica estilo Yavi (Krapovickas 1975; Ávila 2006).

Por su parte, Krapovickas y Cigliano (1962-63) atribuyen los materiales cerámicos hallados en los sitios por ellos visitados en esa zona al Puna Complex de Bennett. Sin embargo, de acuerdo a las descripciones que aportan, la cerámica hallada es comparable a los tipos descritos para el estilo Yavi, con piezas cerradas de perfiles discontinuos, escudillas o pucos, motivos reticulados y "arriñonados", de triángulos y espirales, pintados en negro desleído sobre engobe rojo o ante. Asimismo, observan cerámica sin decorar, con engobe rojo, antiplástico blanco, pies cónicos, improntas textiles, etc., (Krapovickas y Cigliano 1962-63); todos también vinculables a la cerámica Yavi (Krapovickas 1975; Krapovickas y Aleksandrowicz 1986-87).

Para momentos inkaicos se ha destacado como esta cerámica Yavi incorpora elementos imperiales, aunque también se conservan los tipos definidos para momentos previos (Krapovickas 1983; Raffino 1986). Krapovickas (1983) destaca las similitudes del tipo Inca Paya o Casa Morada polícromo con el Yavi Chico polícromo, por lo que propone que este último tipo pudo dar origen al primero. El estilo Inka Paya, asociado a su vez al grupo etnográfico chicha, habría circulado ampliamente en este momento, 
llegando a sitios como Potrero Chaquiago e Ingenio del Arenal Médanos (Williams y Cremonte 1997), por ejemplo. A este estilo se le asocia también el Inca Pacajes en algunos sitios trabajados por Ottonello y Krapovickas (1973).

Raffino y colaboradores (1986) denominan a la alfarería Yavi como "Complejo Chicha", para el momento inkaico, y distinguen las variedades Chicha morado, Chicha naranja natural (comparable al Portillo ante liso definido por Krapovickas 1975), Chicha bicolor morado sobre naranja (semejante al Portillo morado sobre ante en Krapovickas 1975), Chicha bicolor negro sobre morado o naranja y Chicha rojizo. También mencionan un grupo denominado "Interior gris pulido" que incluye pucos hemisféricos, el grupo "Poma bicolor", que incluye pucos evertidos con superficie externa decorada en bandas negras ondulantes sobre fondo rojizo (Raffino et al. 1986).

Por su parte, la cerámica de la "cultura Casabindo" o "Agua Caliente" ha sido caracterizada por diferentes autores, incluyendo entre sus formas diagnósticas los "vasitos chatos", escudillas pequeñas de paredes rectas y altas, sin decoración; vasijas subglobulares, con cuellos cortos, subcilíndricos, que pueden estar decoradas en la mitad superior del cuerpo, delimitada por dos líneas horizontales, una a la altura de las asas y la otra en la unión del cuerpo con el cuello (Ottonello 1973; Albeck 2001). Dentro del campo se delimitaron triángulos con trazos negros, que pueden aparecer solos (Agua Caliente pintado en Ottonello 1973), o con círculos blancos dentro (tipo Queta Tricolor en Krapovickas 1984a, Peñas Coloradas en Ottonello 1973) o vírgulas también de color blanco (Krapovickas 1983). Los Pucos interior negro se hallan asociados a esta cerámica, presentan distintos tipos de pasta y se caracterizan por la cocción reductora en el interior de la pieza (Ottonello 1973).

Por su parte, Albeck (2001) denomina a éstos materiales "estilo Casabindo" y amplía la caracterización, incluyendo otra "pieza típica", una pequeña vasija con boca ancha y asas verticales, de superficies pulidas y decorada en negro sobre rojo. La decoración se da en dos campos limitados por las asas, con líneas reticuladas oblicuas.

Otros trabajos sobre materiales del estilo Casabindo buscan distinguir los modos de confección y las características de los puntos blancos de este estilo de aquellos ejecutados en tipos de la cerámica de la quebrada de Humahuaca (Zaburlín 2012). 

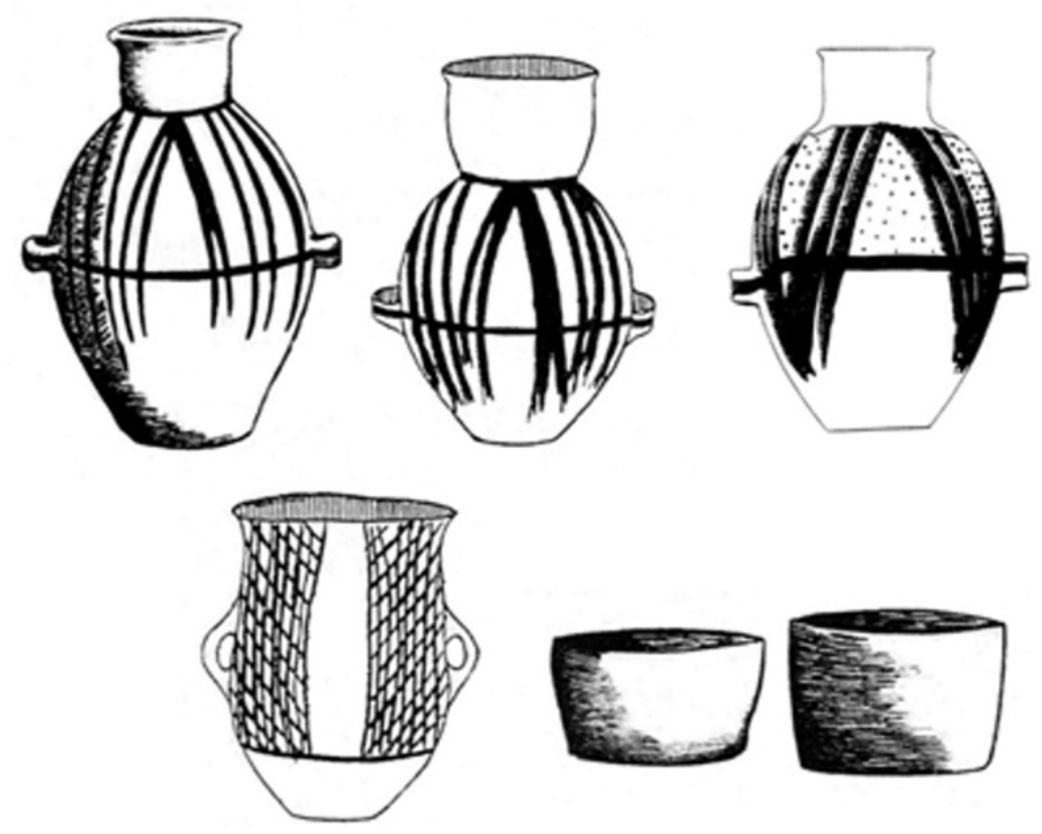

Figura 3.3 Algunos ejemplos de vasijas "estilo Casabindo" (tomadas de Krapovickas 1958-59, Albeck y Ruiz 1997).

Si bien se encuentra en el área de "influencia Casabindo", el sitio Pueblo Viejo de Tucute, además de diferenciarse de los otros en la arquitectura, como se mencionó anteriormente, su cerámica también se distingue de la del "estilo Casabindo". La de Tucute se caracteriza por la presencia de piezas alisadas sin decoración o con un baño rojizo muy liviano. Predominan las de contorno restringido de diverso tamaño (Albeck et al. 1995, Albeck y Ruiz 1997). En este sitio, en el recinto R-1, la autora plantea la fabricación de cerámica como una de las actividades allí desarrolladas, en base a la presencia de núcleos de arcilla rojiza y pulidores (Albeck 1995-96).

En relación a la producción cerámica para momentos coloniales, es poco lo que se conoce hasta la fecha. Para los Andes centro sur en general, se plantea que la invasión española provocó cambios rápidos e importantes en muchas manufacturas tradicionales, incluyendo la alfarería. Ello abarcó la tributación en vajilla y la elaboración de tejas y ladrillos, como de vasijas de morfologías españolas. Sin embargo, la alfarería doméstica continuó manufacturándose según su propias tradiciones (Varela Guarda 2002). También se plantea un cambio radical en la selección de fuentes de materias primas, probablemente vinculado al nuevo patrón de uso de la tierra (Ravines 1978; cito en Varela Guarda 2002: 226). En la cerámica arqueológica del sitio Turi Pukara (Provincia El Loa, Chile) se documenta un hecho probablemente vinculado, 
identificándose un estándar de pasta datado en momentos coloniales que difería de estándares más tempranos, a pesar de que las características morfológicas y tecnológicas eran semejantes a las prehispánicas (Varela Guarda 2002: 226).

Si bien los trabajos sobre tecnología cerámica son importantes en otras zonas del NOA, incluso en la vecina Quebrada de Humahuaca (Cremonte 1991, 2001; López 2007 ; entre otros), en la puna de Jujuy estos trabajos son muy escasos. Los primeros aportes se dan en los trabajos de Krapovickas. Para la cerámica Yavi realizó el primer análisis petrográfico, determinando la naturaleza de las inclusiones blancas (descrita arriba) y sugiriendo que las mismas estarían naturalmente presentes en la arcilla empleada en la manufactura. Además destaca la distribución irregular de estas inclusiones y su tamaño variable, y menciona que las observaciones efectuadas permitieron inferir el modelado por superposición de rollos (Krapovickas 1975: 295).

Para la cerámica formativa también se han hecho aportes, como los de Fernández (1988-89) que realiza descripciones petrográficas de la cerámica Cristóbal imbricado, del Abrigo Cristóbal, determinando la presencia de litoclastos graníticos, que analiza por fluorescencia de rayos $\mathrm{X}$ a fin de determinar la procedencia mediante la comparación de elementos traza.

Asimismo, García (1995) realiza análisis tecnológicos sobre materiales cerámicos tempranos, de los sitios de Inca Cueva, alero 1 y cueva 5. A fin de conocer su procedencia realiza estudios de difracción de rayos $X$, estimando que las piezas fueron manufacturadas con materias primas locales.

Solá (2007), por su parte, realiza descripciones petrográficas de materiales cerámicos tardíos y coloniales de Susques, al sur de nuestra área de interés, donde distingue dos zonas de producción diferenciadas por las recetas para elaborar el barro, en contextos de producción que caracteriza como domésticos.

Cremonte y colaboradores (2007a) han analizado pastas de fragmentos de estilo Yavi procedentes de sitios ubicados en la provincia de Jujuy, el norte de Chile y el sur de Bolivia, determinando petrográficamente la naturaleza de las inclusiones cerámicas. Como mencionamos arriba, han determinado que los litoclastos blancos que se observan en la cerámica de este tipo son pelitas alteradas a muscovita-sericita-cuarzo, que procederían de la Formación Acoite. Asimismo, profundizan la caracterización 
mineralógica mediante difracción de rayos $X$ y la química mediante microscopía electrónica.

\section{Nuestros trabajos:}

Desde 2005, la zona sur de la cuenca de Pozuelos está siendo investigada por el proyecto arqueológico dirigido por el Dr. C. I. Angiorama, cuyo objetivo ha sido el de conocer los diversos modos de ocupación y uso del espacio de los grupos sociales que los habitaron y sus cambios a lo largo del tiempo. Los trabajos que se han realizado hasta el momento estuvieron orientados a formular un marco cronológico para la etapa agropastoril en la zona, identificar tendencias en los modos de uso del espacio regional en cada momento y establecer relaciones entre las ocupaciones de esta zona y regiones vecinas. Los trabajos de campo consistieron en prospecciones extensivas e intensivas en toda el área, relevando y muestreando sitios y vestigios, como así también en excavaciones de algunas unidades arquitectónicas y sondeos en otras (Angiorama 2011).

Hasta el momento se han registrado unos trescientos sitios arqueológicos, que han sido asignados tentativamente a los diferentes períodos de la secuencia cronológica del noroeste argentino. Para momentos arcaicos y formativos las evidencias son escasas, e incluyen algunas concentraciones de artefactos líticos en superficie, sin arquitectura asociada, una pequeña cueva con arte rupestre y un alero (con un fechado de $10220 \pm$ 170 AP, Angiorama 2011). Por otro lado, un número de paneles de arte rupestre, un par de fragmentos cerámicos y algunas puntas de proyectil serían de cronología formativa (Angiorama et al. 2013) Sin embargo, estos son hallazgos aislados en una cantidad muy grande de sitios detectados mediante prospección y de fragmentos recolectados en las mismas (mayor a 3500). Cabe agregar que son más numerosos y dispersos en los

distintos sectores del paisaje, los sitios con arte rupestre y puntas asignables a momentos arcaicos que aquellos que podrían corresponder a momentos formativos (Angiorama et al. 2013).

Las evidencias materiales asignables al Tardío son mucho más numerosas, y se trata de concentraciones de artefactos en superficie, estructuras habitacionales, estructuras de cultivo, arte rupestre, entierros en oquedades, estructuras de almacenaje, sitios extractivos, canteras de diversos tipos de minerales, tramos de sendas formatizadas y sitios de ritualidad caravanera o "tapados". Las estructuras habitacionales presentan 
diferentes características arquitectónicas y de emplazamiento, siendo la mayoría circulares y cercanos a algún curso de agua. Pueden hallarse solas, asociadas a algunos otros recintos ( 3 a 6 ) y/o a estructuras de cultivo y corrales. Catorce de estos recintos fueron excavados y seis sondeados, además de otros sondeos en otros tipos de estructuras. De acuerdo a las 22 dataciones realizadas, la mayoría de estos contextos excavados correspondieron a este período (s. XIV y XV) (Angiorama 2011).

Estas evidencias indicarían que en este momento (Tardío e Inka) habitaron estos espacios poblaciones rurales dispersas en lugares propicios para el cultivo, en pequeños caseríos entre las estructuras agrícolas, en contraste con el conglomerado mucho más importante que constituyó el Pucará de Rinconada, mientras que otros sectores del área (lagunas y ciénegos de altura) habrían servido como espacios de tránsito, manifiesto en evidencias tales como tramos de sendas, arte rupestre y ofrendas (Angiorama 2011).

Otra parte de los sitios excavados mencionados corresponden a momentos coloniales, y consisten en tres estructuras de planta irregular, dos rectangulares, un basurero, una estructura de depósito y un refugio bajo un alero (Angiorama 2011). Estos se suman a otros contextos vinculados a actividades minero metalúrgicas, como sitios de extracción de oro, pequeños complejos con socavones, pozos, hornos de fundición y escorias (Angiorama y Becerra 2010); y materiales de superficie sin asociación. En general, las características arquitectónicas, de emplazamiento y los materiales asociados a estos contextos son muy similares a los datados en momentos prehispánicos tardíos, y solo los fechados radiocarbánicos y algunos tipos cerámicos, presentes en muy escasa cantidad, permiten identificarlos como coloniales, estando ausentes otros materiales de origen hispánico que se encuentran en otros sitios coloniales del NOA (loza, vidrio, metal, armas, cuentas, etc.) (Angiorama y Pérez Pieroni 2012). Sin embargo, el uso del espacio sufrió cambios considerables, pasando de un asentamiento orientado hacia las actividades agrícolas y pastoriles, a uno localizado en proximidades de las fuentes minerales (Angiorama 2011). 


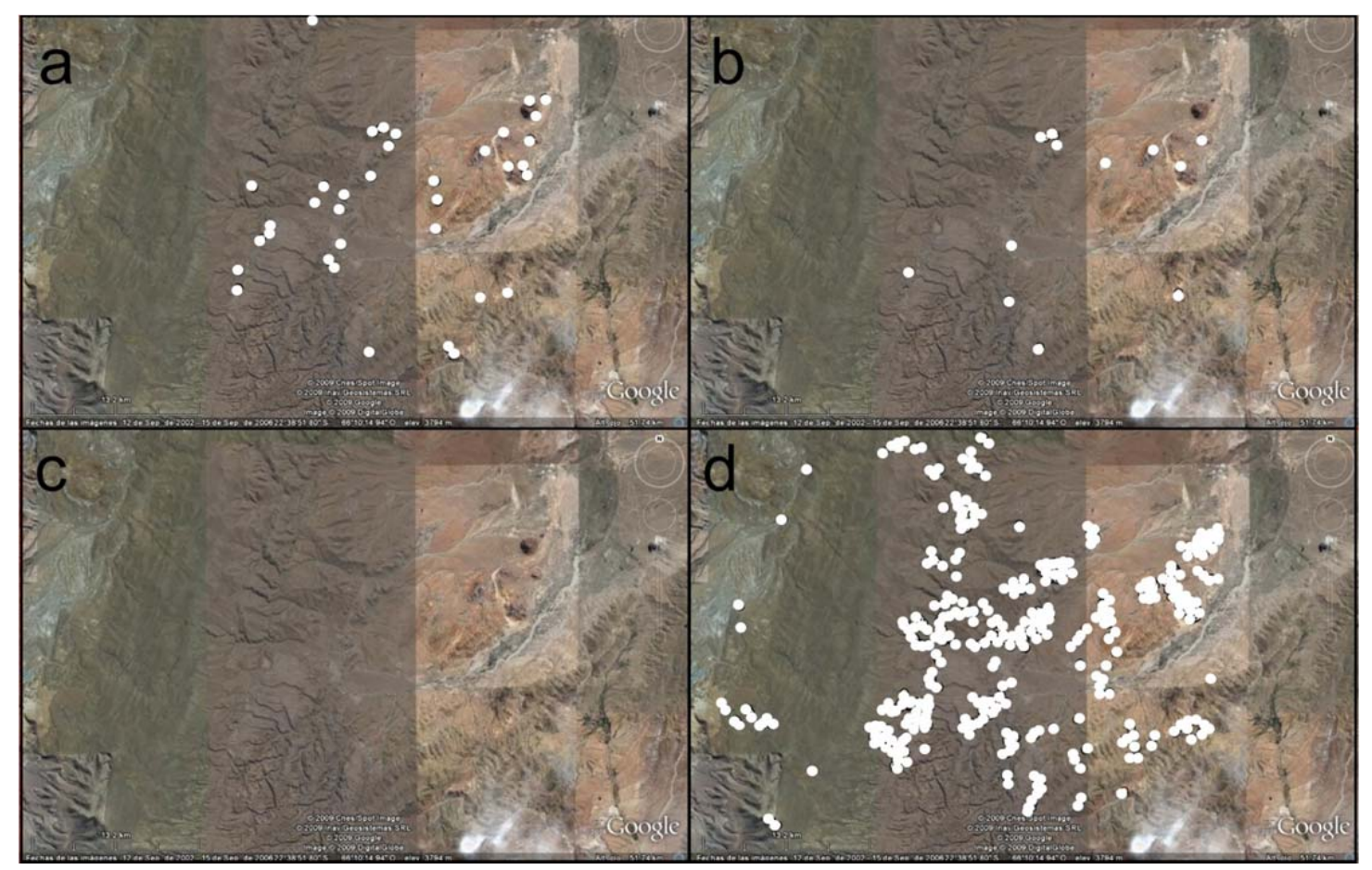

Figura 3.4 Sitios arqueológicos de la cuenca sur de Pozuelos (tomado de Angiorama et al. 2013). Referencias: a: arcaicos; b: formativos tempranos; c: del primer milenio de nuestra era; $d$ : posteriores al 1.200 d.C.

Por otro lado, en el área del Río Grande de San Juan, desde 2007 se viene llevando a cabo un proyecto financiado por la Agencia Nacional de Promoción Científica y Técnica, dirigido por el Dr. A. Nielsen. Las tareas llevadas a cabo han incluido la realización de prospecciones en distintos sectores, como el fondo de valle, las quebradas laterales y la puna del área de Santa Catalina, que han permitido localizar distintos sitios correspondientes mayormente a momentos prehispánicos tardíos y algunos coloniales (Nielsen et al. 2013).

Los sitios identificados para momentos prehispánicos tardíos corresponden a sitios habitacionales, con arquitectura en piedra y tierra, y de dimensiones muy diferentes, ubicados principalmente en el fondo de valle. También se localizaron estructuras agrícolas, en fondo de valle y quebradas laterales; cámaras en cuevas, aisladas o en grupos, que anteriormente se han denominado chullpas (Debenedetti 1930), estructuras aisladas y un sitio con arte rupestre (Nielsen et al. 2013). 
En base a estos trabajos y los fechados radiocarbónicos obtenidos se ha planteado que el Período de Desarrollos Regionales local tuvo un primer momento de poblaciones dispersas, seguido por una concentración de la población en conglomerados defensivos en los siglos XIII y XIV, de manera comparable al proceso registrado en otras áreas, como la quebrada de Humahuaca (Nielsen et al. 2013).

\section{Discusión y perspectivas:}

A partir de todos los antecedentes sintetizados hasta aquí, en relación al estudio de la cerámica arqueológica, podemos observar que en los trabajos citados los materiales cerámicos en general han sido empleados básicamente a fin de estudiar sus características morfo estilísticas, de manera de emplear la información en la generación de esquemas cronológicos y territoriales, definiendo culturas o estilos que se correlacionarían a grupos étnicos y áreas geográficas concretos. En el resto del Noroeste argentino, los estudios sobre tecnología cerámica han cobrado una gran relevancia en las últimas décadas (por ejemplo Baldini y Balbarrey 2004; Cremonte 1991, 1994, 2001; De La Fuente 2011; López 2007; Palamarczuk y Palamarczuk 2007; Puente 2012; Ratto et al. 2004, 2007; Solá 2007; Wynveldt 2008; Zagorodny 1995, 1996, entre otros), abordando distintas problemáticas, como por ejemplo la procedencia de bienes, la interacción regional e interregional, la caracterización de los modos de hacer y la identidad étnica (Balesta y Williams 2007).

Sin embargo, en la puna jujeña estos tipos de trabajos son muy escasos (correspondientes a aquellos que hemos citado en las secciones previas) y varios están centrados en momentos tempranos y tardíos, sin aportes para momentos posteriores al contacto hispano indígena. Ello hace relevante estudios de este tipo en el resto del área puneña, que permitan discutir no sólo la cronología y la circulación de bienes a través de atributos decorativos de los materiales; sino también las similitudes y diferencias entre las secuencias de producción cerámica, y la interacción entre grupos a través del intercambio de piezas, de personas o de conocimientos sobre producción, empleando otros atributos, como los que provee el análisis de la secuencia de manufactura y los de pasta.

Asimismo, del estado de cuestión que hemos esbozado, surge el interés de analizar si los estilos que se han definido para la puna, básicamente a partir de atributos morfológicos y decorativos, y en ocasiones de pastas, están asociados a otros atributos 
tecnológicos, resultado de las prácticas de grupos de artesanos con saberes y modalidades productivas propias o si las similitudes superficiales encubren diferentes formas de hacer. 
4.

\section{LA MUESTRA ESTUDIADA:}

Procedencia y características

El material analizado consistió tanto en fragmentos cerámicos procedentes de diferentes estructuras de la cuenca sur de la laguna de Pozuelos y del área de Santa Catalina, como de piezas completas depositadas en diferentes colecciones de museos a los que pudimos acceder. A continuación se describen brevemente los contextos y algunas características de los mismos.

\section{Material fragmentario:}

Los fragmentos cerámicos de la cuenca sur de la laguna de Pozuelos proceden de ocho estructuras excavadas por completo, fechadas tanto en momentos prehispánicos tardíos como coloniales, y de un sondeo en un basurero, con un fechado colonial. Se consideraron tanto los fragmentos procedentes de las excavaciones como los de las recolecciones superficiales en las inmediaciones de las estructuras. En la Figura 4.1 se puede observar la localización de los sitios mencionados en el texto.

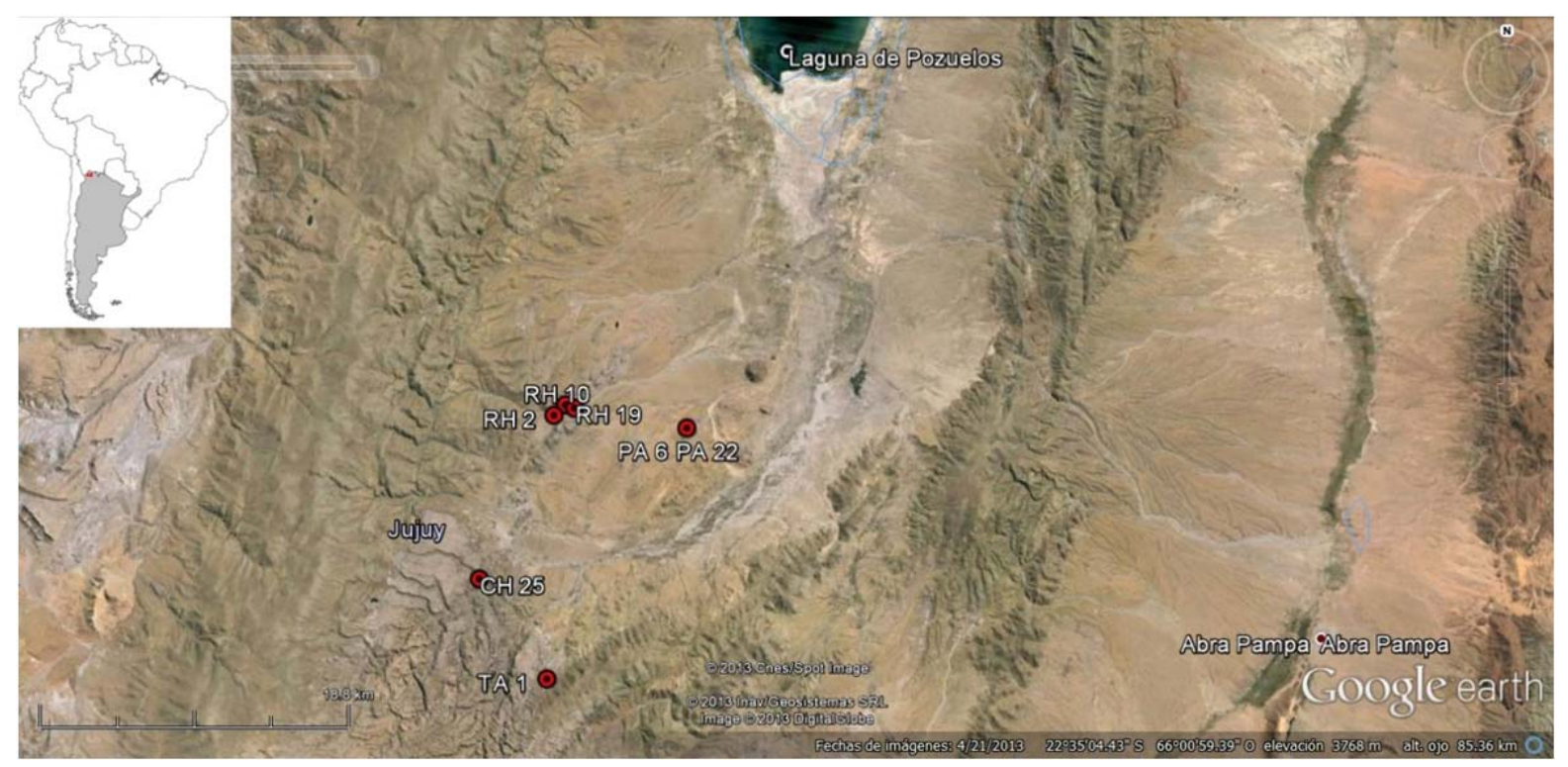


Figura 4.1 Sitios de la cuenca sur de la laguna de Pozuelos de donde se obtuvo el material fragmentario analizado.

\section{Río Herrana:}

Cuatro de las estructuras excavadas son de la localidad arqueológica de Río Herrana, para la cual se han localizado 52 sitios mediante prospección, consistentes en una serie de recintos aislados o adosados en pequeños grupos, que pueden estar asociados a estructuras de cultivo y que se encuentran sobre las laderas de una serie de terrazas que continúan hacia el NE, donde se localiza el Pucará de Rinconada, en la cima de una de estas terrazas. Se ha planteado que este tipo de estructuras asociadas a las áreas productivas configurarían el paisaje rural de pukará (Angiorama 2011). También se observan algunos paneles de arte rupestre y recintos cuadrangulares que podrían corresponder a corrales. El material cerámico de las cuatro estructuras que han sido excavadas por completo en esta localidad fue analizado preliminarmente en una tesina de grado (Pérez Pieroni 2009); pero el análisis fue profundizado aquí.

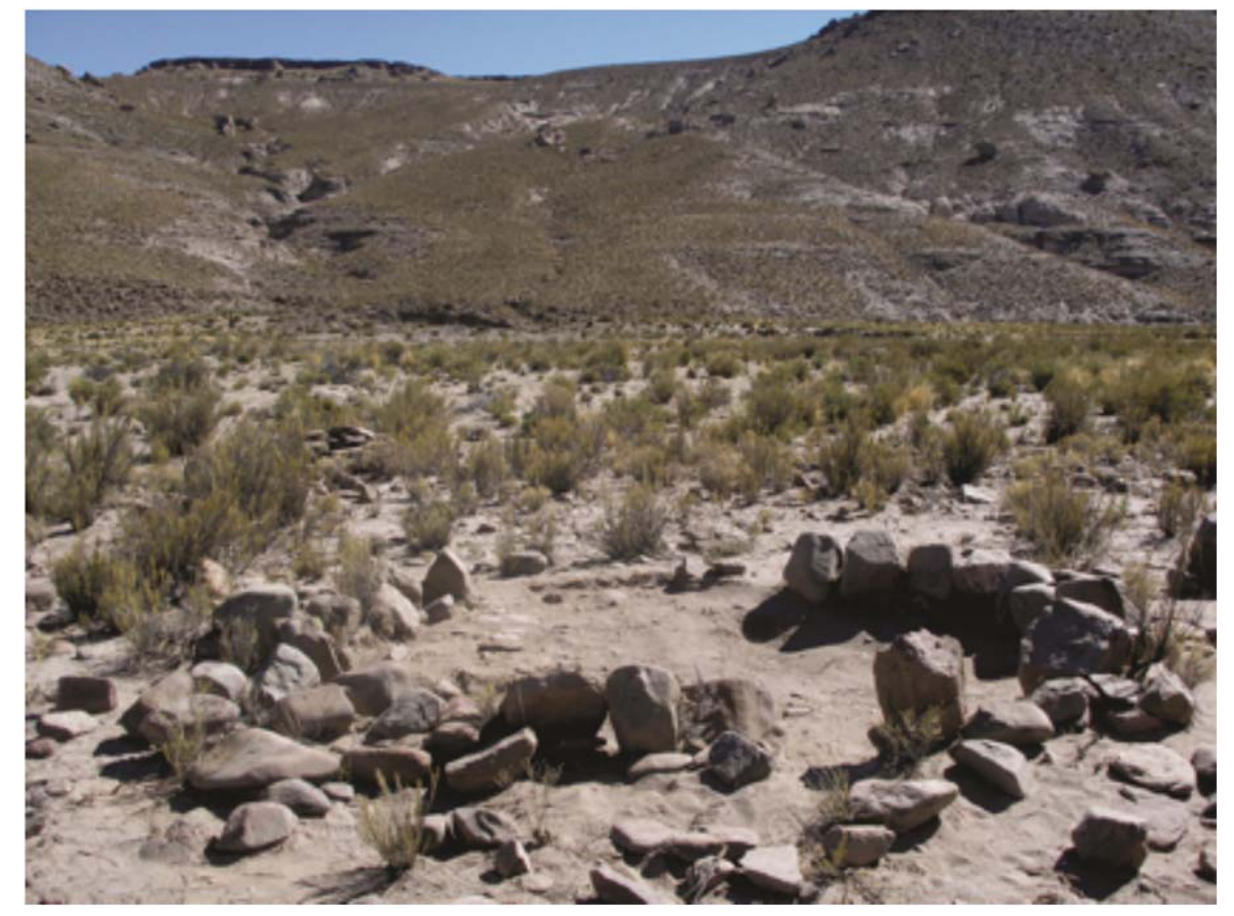

Figura 4.2 Vista de la estructura 1 de RH 2. 
El sitio Río Herrana $2(\mathrm{RH} 2)$ consiste en una única estructura aislada (observable en la Figura 4.2), circular, construida con rocas prismáticas. La excavación completa del recinto permitió diferenciar un único nivel de ocupación, con materiales escasos, consistentes tanto en fragmentos cerámicos, como materiales óseos, líticos y espículas de carbón, que se emplearon para su datación radiocarbónica. Además se detectaron dos rasgos de combustión. Ambos se localizan también en el nivel de ocupación. En base al fechado radiocarbónico, se plantea que este recinto fue ocupado en el S XV (Angiorama 2011).

El material analizado aquí procede de este único nivel y consiste en 65 fragmentos obtenidos en excavación y 53 de recolección superficial en las inmediaciones de la estructura.

El sitio Río Herrana 10 ( $\mathrm{RH} 10$ ) ocupa una amplia superficie en la ladera de una terraza y está integrado por recintos de formas diversas. También se detectaron andenes y canchones de cultivo, recintos de plantas y técnicas constructivas variadas, refugios construidos bajo aleros, acumulaciones de despedres y arte rupestre sobre bloques. Los recintos del sitio fechados hasta ahora, sumados a las características constructivas de las estructuras mencionadas y al arte rupestre registrado, nos permiten suponer que se trata de construcciones que datan de época prehispánica (Angiorama y Pérez Pieroni 2012).

La estructura 1 (Figura 4.3) consiste en un recinto rectangular construido con rocas planas dispuestas horizontalmente, algunas apoyadas sobre rocas grandes. Otras rocas planas alargadas fueron colocadas verticalmente en los accesos del recinto a manera de jambas. Fue construido en momentos prehispánicos tardíos, y remodelado posteriormente en época colonial temprana, luego de un período de abandono. En base a los fechados radiocarbónicos, se plantea que la primera ocupación tuvo lugar entre los s XIV y XV. Las remodelaciones de la estructura original consistieron en el tapiado del vano (visible en la Figura 4.3) y la abertura de uno nuevo orientado en otra dirección, y la ampliación del tamaño de la estructura mediante el desmantelado de uno de los muros y su reemplazo por otro, luego de la prolongación de dos de las paredes restantes. El recinto de época colonial era de planta rectangular, de $4.5 \mathrm{~m}$ por $3 \mathrm{~m}$, con muros de unos $50 \mathrm{~cm}$ de ancho construidos con lajas dispuestas en posición horizontal, con el empleo de argamasa. En algunos sectores, las paredes se conservaron hasta unos $80 \mathrm{~cm}$ altura con respecto al piso de ocupación de época colonial (Angiorama y Pérez Pieroni 2012). 


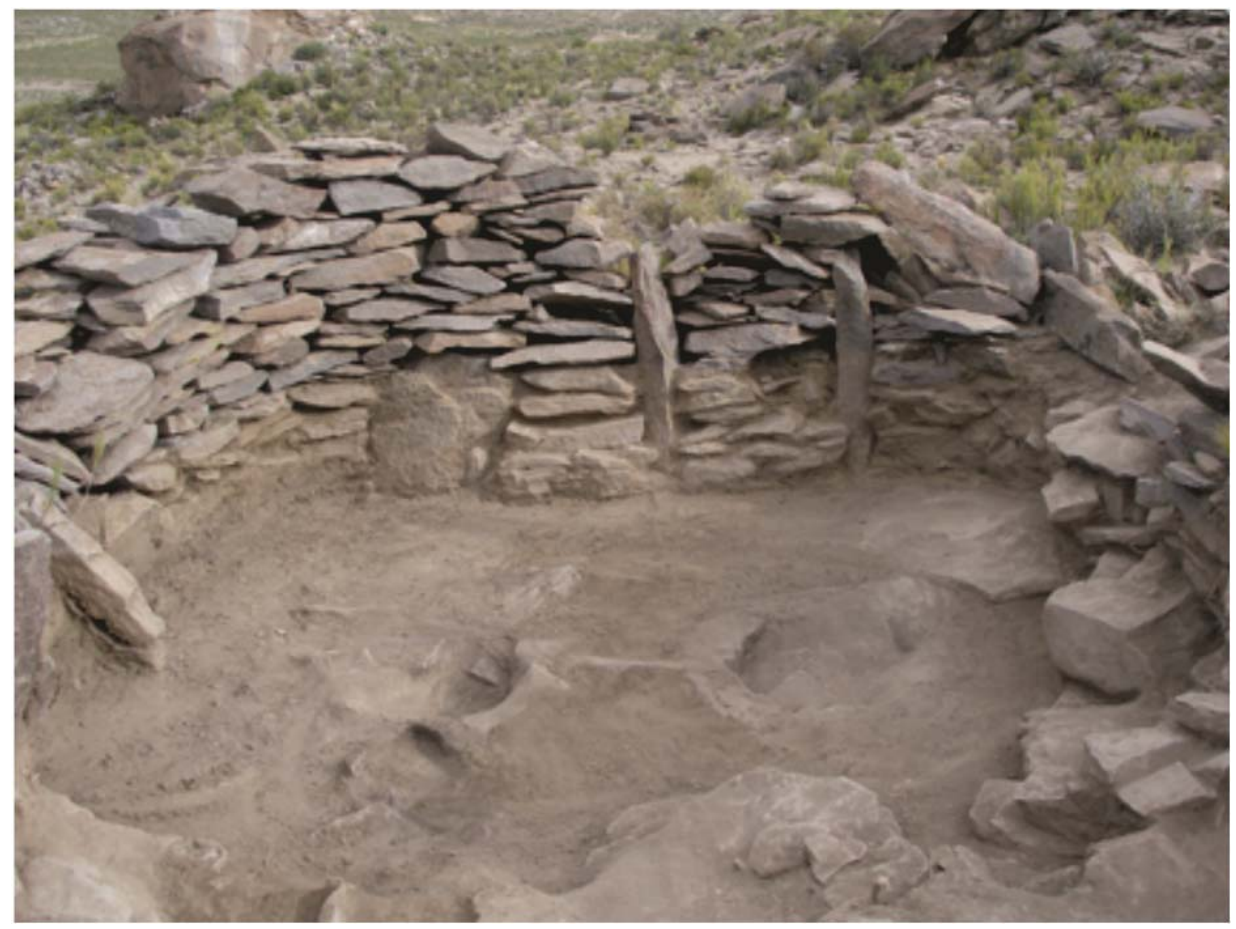

Figura 4.3 Vista de la excavación de RH 10-1. Se observa al fondo el vano con jambas de la primera ocupación que ha sido tapiado en la remodelación de la segunda ocupación, y en el frente a la derecha parte del muro original desmantelado en la ampliación.

El recinto presentaba un vano orientado hacia el este. Junto a él se halló un sector del piso con signos de termoalteración, con ceniza y carbón dispersos en un área de unos $80 \mathrm{~cm}$ de diámetro. En ese rincón se encontró casi todo el material arqueológico del nivel de ocupación colonial, consistente en fragmentos cerámicos y fragmentos de huesos de fauna. A diferencia del nivel de ocupación prehispánico, no se halló en el colonial un fogón formatizado. Del sector del piso termoalterado, del lugar en el que la concentración de carbón era mayor, se tomó una muestra para la realización de un fechado por radiocarbono. El área relativa bajo la curva de calibración indica que existe una probabilidad de 0,70 de que el fechado corresponda al lapso comprendido entre 1649 y 1812 AD (Angiorama y Pérez Pieroni 2012).

El material analizado de esta estructura es tanto el procedente de la primera ocupación como de la segunda, y consiste en 47 fragmentos procedentes de la primer ocupación y 15 de la segunda, como así también de 25 fragmentos en las inmediaciones de la misma. 
El sitio Río Herrana 19 es un conjunto de al menos ocho estructuras de forma circular, muros alargados de contención y otros a manera de andenes, alineaciones de piedra y lajas de gran tamaño paradas. Todo el conjunto ocupa un área extensa, afectado hacia el suroeste por una gran cárcava. La estructura 1 (RH 19-1) (Figura 4.4) es circular, construida con lajas dispuestas en posición vertical. Su excavación completa permitió identificar una única ocupación, con fragmentos cerámicos, incluyendo un fragmento grande correspondiente a una escudilla, materiales líticos (lascas), óseos y espículas de carbón. No se pudo datar la ocupación de este recinto, por falta de materiales. En la excavación de esta estructura se recuperaron 30 fragmentos cerámicos que se analizan aquí, y siete de recolección superficial en sus inmediaciones.

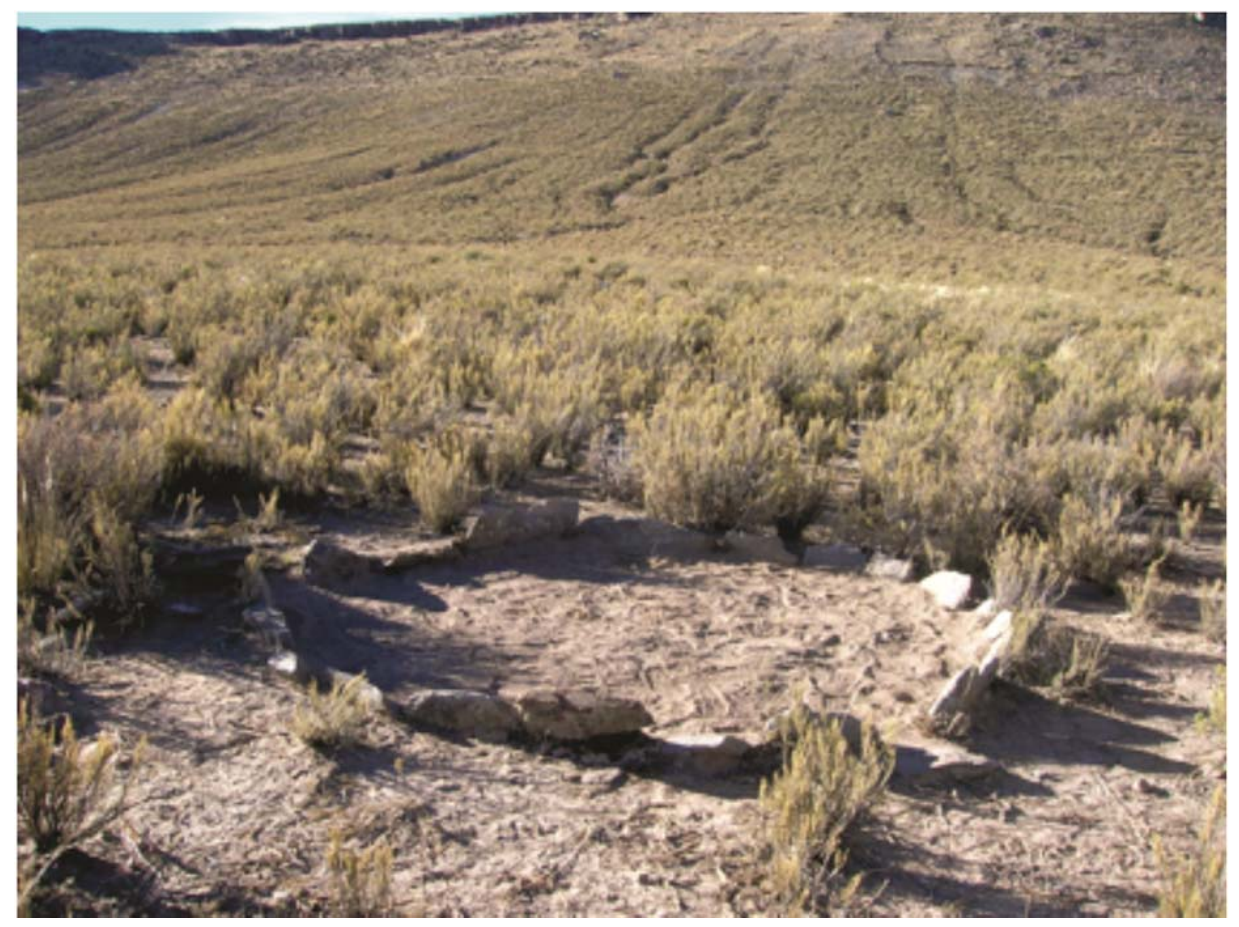

Figura 4.4 Vista de la estructura 1 de RH 19.

La estructura 7 (RH 19-7) (Figura 4.5) también es circular, pero en este caso los muros se construyeron con rocas prismáticas, las cuales estaban muy derrumbadas, lo que dificultó la identificación de los muros. Se definieron dos episodios de ocupación diferentes, el último de los cuales presenta un tabique de división interno (que se observa en la Figura 4.5) y varios rasgos, algunos de combustión difusos, otros con cubetas bien formatizadas y pozos. El primer episodio también presenta numerosos rasgos de combustión, pero sin el tabique interno (Angiorama 2011). Los materiales 
recuperados son abundantes, e incluyen fragmentos cerámicos, materiales líticos, restos óseos, minerales y carbón, con el que se realizaron fechados radiocarbónicos para ambas ocupaciones. La primera habría tenido lugar en el s XIII, mientras que la segunda, en el s XIV (Angiorama com. pers.).

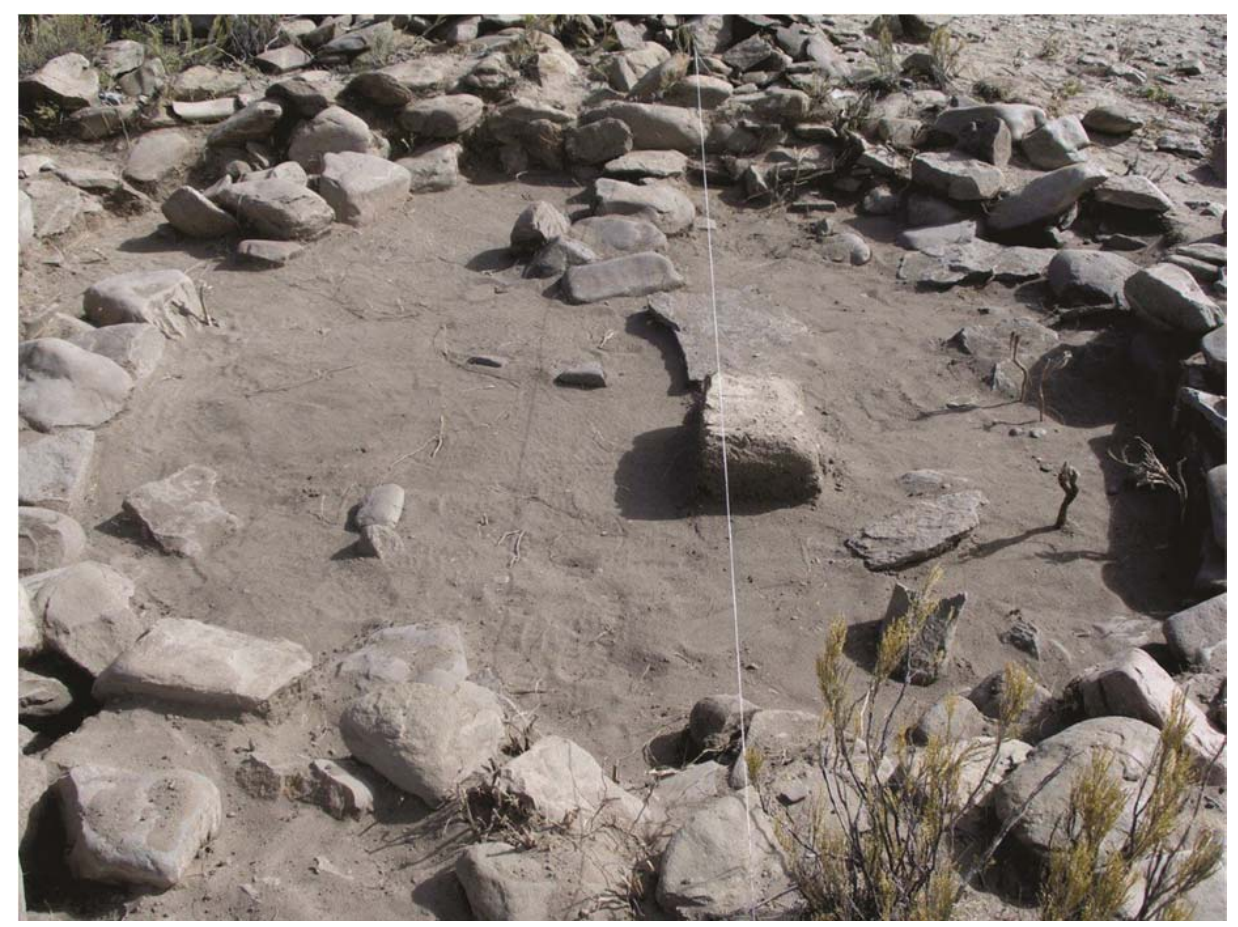

Figura 4.5 Vista de la estructura 7 de RH 19 parcialmente excavada. En el medio se aprecia un tabique de división interno.

De la excavación de la Estructura 7 se recuperaron 439 fragmentos y 12 de la recolección superficial en sus inmediaciones, que se analizan aquí. De los fragmentos procedentes de excavación, 60 corresponden a la primera ocupación de la estructura (Nivel 2), mientras que los restantes 379 son de la segunda (Nivel 1).

\section{Pan de Azúcar:}

La zona alrededor del cerro Pan de Azúcar habría tenido una larga ocupación que, de acuerdo a las evidencias halladas en las prospecciones y excavaciones, como también a las dataciones realizadas, serían tanto de momentos prehispánicos tardíos como coloniales, hallándose incluso puntas de proyectil que podrían datar de momentos arcaicos (Angiorama et al. 2012). La ocupación prehispánica tardía habría consistido en 
estructuras habitacionales, corrales y estructuras para el cultivo, como también en un sitio de ritualidad caravanera en la cima del cerro, consistente en ofrendas de mineral de cobre y otros elementos.

En cambio, para la ocupación colonial, las actividades habrían estado orientadas hacia la minería y metalurgia, dado que se encuentran abundantes escorias en un sector donde además se localizaron dos bases de hornos (PA 1). Además, se localizó otro horno mejor conservado del otro lado del cerro, sin asociación a ninguna estructura (PA 26), que sería del tipo de reverbero, una tecnología de origen europeo (Angiorama et al. 2012). También se registró la presencia de un basurero (sitio Pan de Azúcar 22, PA 22) que consiste en una acumulación de material arqueológico que configura una pequeña lomada parcialmente erosionada por un curso de agua temporario (Figura 4.6). No se encuentra asociado directamente a alguna estructura en particular, pero se emplaza en un sector en el que existen algunas construcciones (recintos y corrales) cuya antigüedad aún no hemos podido establecer, y donde abundan en superficie las evidencias de ocupación prehispánica y, sobre todo, colonial.

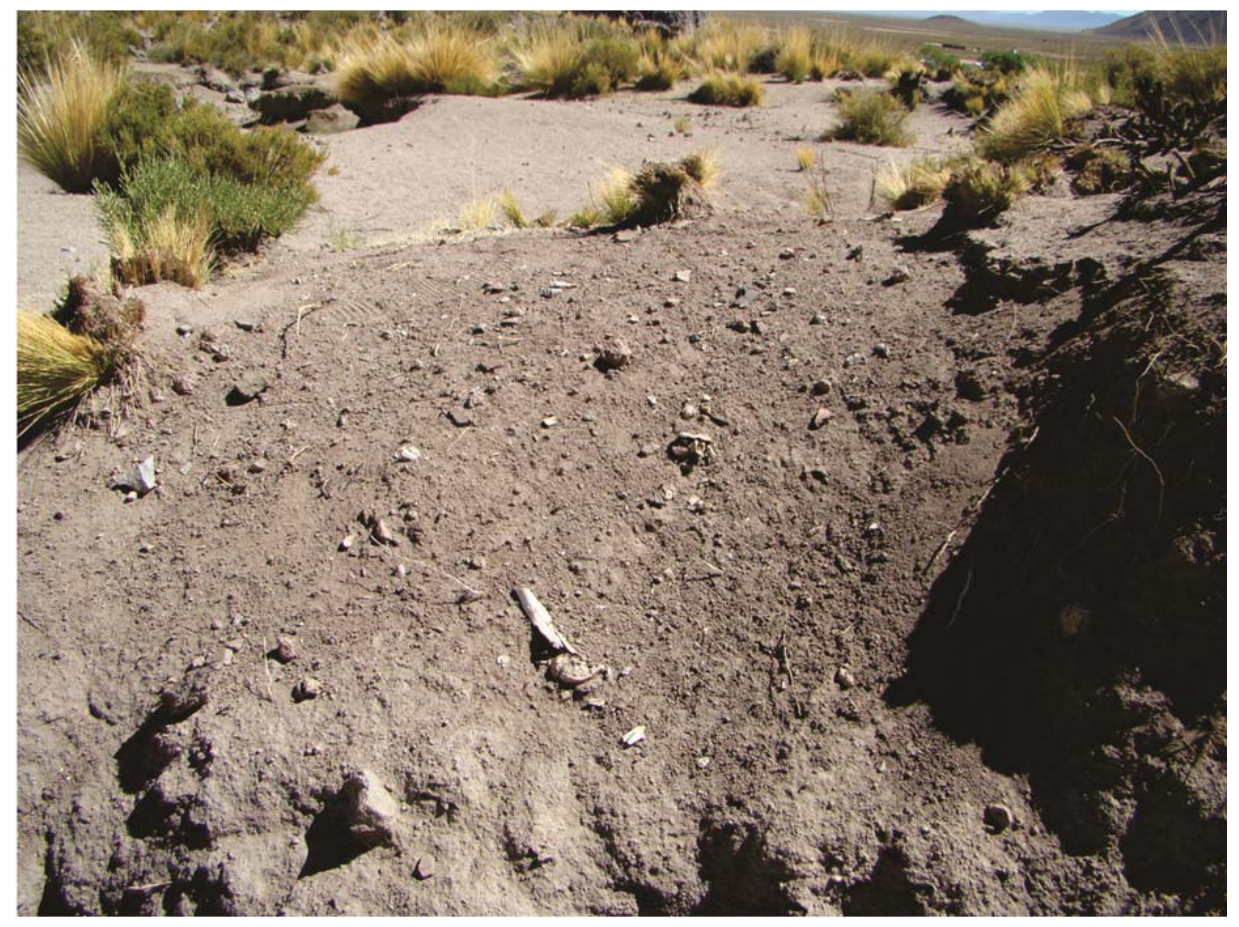

Figura 4.6 Vista del basurero de PA 22.

En este basurero, se realizó un sondeo de $50 \mathrm{~cm}$ de lado, el cual permitió observar que el estrato que contiene los materiales arqueológicos presenta una potencia de unos 
$30 \mathrm{~cm}$, sin niveles estratigráficos diferenciables. La limpieza de parte del perfil originado por el curso de agua nos permitió constatar lo observado en el sondeo y estimar que el basurero se extiende por un área de al menos unos catorce metros de diámetro. La excavación nos permitió recuperar fragmentos cerámicos, huesos de fauna, material lítico tallado, escoria metalúrgica y carbón. Se efectuó un fechado por 14C a partir de una muestra de carbón tomada del techo del nivel con material arqueológico. El área relativa bajo la curva de calibración indica que existe una probabilidad de 0,82 de que el fechado corresponda al lapso comprendido entre 1640 y 1810 AD (Angiorama y Pérez Pieroni 2012).

La muestra de fragmentos analizada aquí correspondiente al sondeo es de 124 fragmentos, además de 22 fragmentos de recolección en la superficie del basurero y cinco de la limpieza de un perfil del mismo junto al cauce.

Por otro lado, se analizó todo el material cerámico obtenido de la excavación de la Estructura 1 de PA 6 (Figura 4.7), una estructura circular sobre un faldeo del cerro Pan de Azúcar, con una única ocupación datada radiocarbónicamente en el siglo XV, sobre el carbón extraído de la excavación del nivel de ocupación (Angiorama com. pers.). La misma se encuentra asociada a otras dos estructuras circulares y a una rectangular y próxima a un área importante de estructuras de cultivo. Las primeras fueron construidas con rocas subesféricas, sin argamasa.

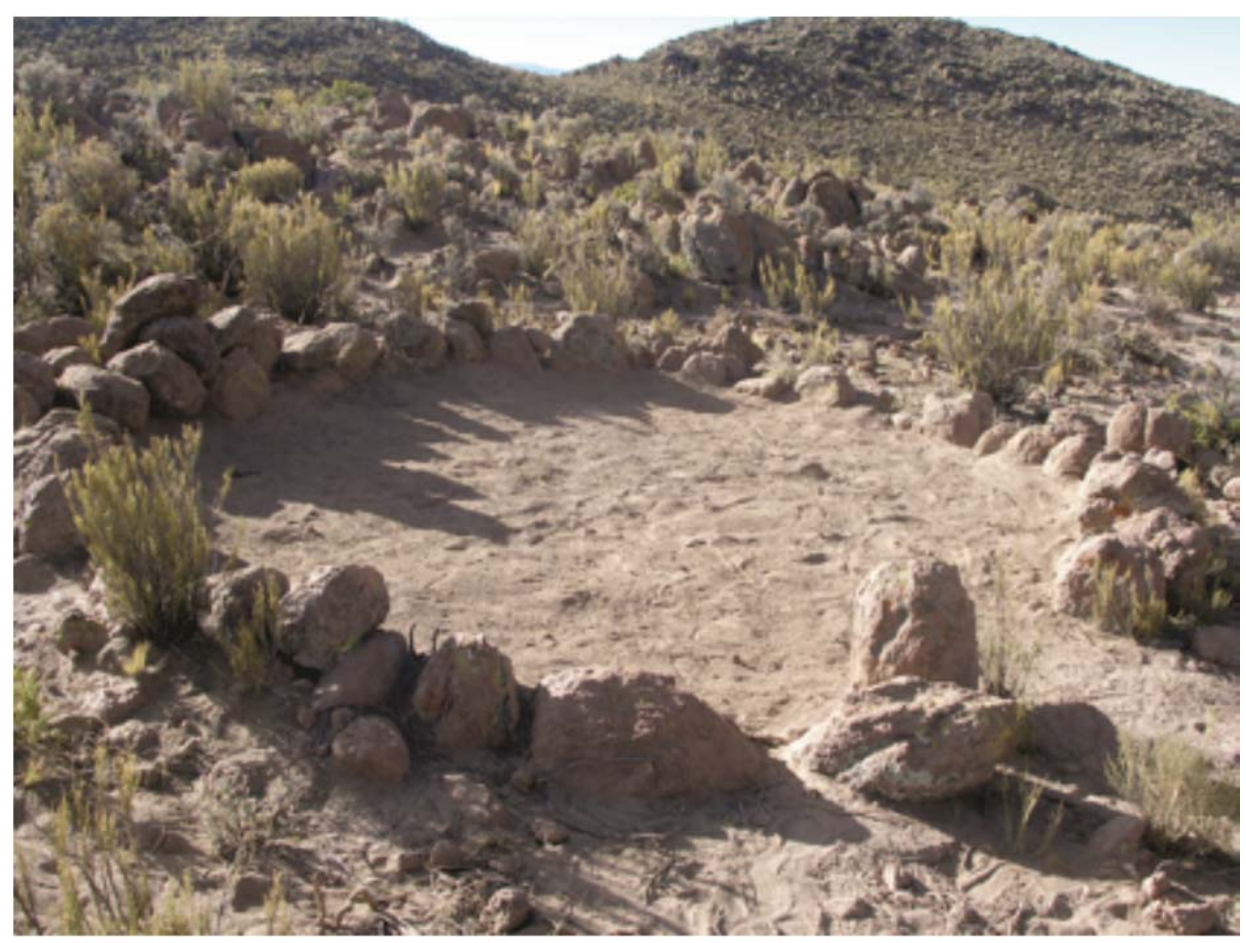


Figura 4.7 Vista de la estructura 1 de PA 6.

De la excavación, se analizaron 124 fragmentos, y 95 de recolección superficial en las inmediaciones de la estructura.

\section{Chajarahuayco 25:}

Chajarahuayco $25(\mathrm{CH} 25)$ se encuentra en la intersección de dos quebradas angostas recorridas por dos cursos de agua permanentes. En este sitio se localizaron cuatro estructuras con características constructivas similares, junto a un complejo de andenes de cultivo que cubren una superficie de media hectárea, irrigados mediante al menos un canal que capta el agua de uno de los cursos de agua mencionados. Los estudios nos indican que las estructuras de cultivo datan de época prehispánica pero fueron reutilizadas durante época colonial (Angiorama y Pérez Pieroni 2012). En el sitio se halló también un horno de fundición metalúrgica de época colonial de más de trescientos años de antigüedad (ver Angiorama y Becerra 2010).

Las dos estructuras mencionadas se excavaron por completo y consisten en recintos domésticos. La Estructura 2 es un recinto de planta cuadrangular construido con rocas subesféricas, sin argamasa, y contaba con un único episodio de ocupación, fechado por C14 en época prehispánica tardía, en el s XV (Angiorama y Pérez Pieroni 2012).

La Estructura 1 de Chajarahuayco 25 ( $\mathrm{CH}$ 25-1) también es un recinto de planta cuadrangular construido con rocas de formas subesféricas, sin el empleo de argamasa (Figura 4.8). En algunos sectores, las paredes se han conservado hasta una altura de unos $50 \mathrm{~cm}$ con respecto al piso de ocupación. El mismo presentaba un vano orientado hacia el sudeste, junto al que se halló un fogón en cubeta de uso reiterado, rodeado por un amplio sector del piso con signos de termoalteración. En los alrededores de la estructura de combustión se encontró casi todo el material arqueológico que se conservó sobre el piso de ocupación (fragmentos cerámicos y fragmentos de huesos de fauna) (Angiorama y Pérez Pieroni 2012). 


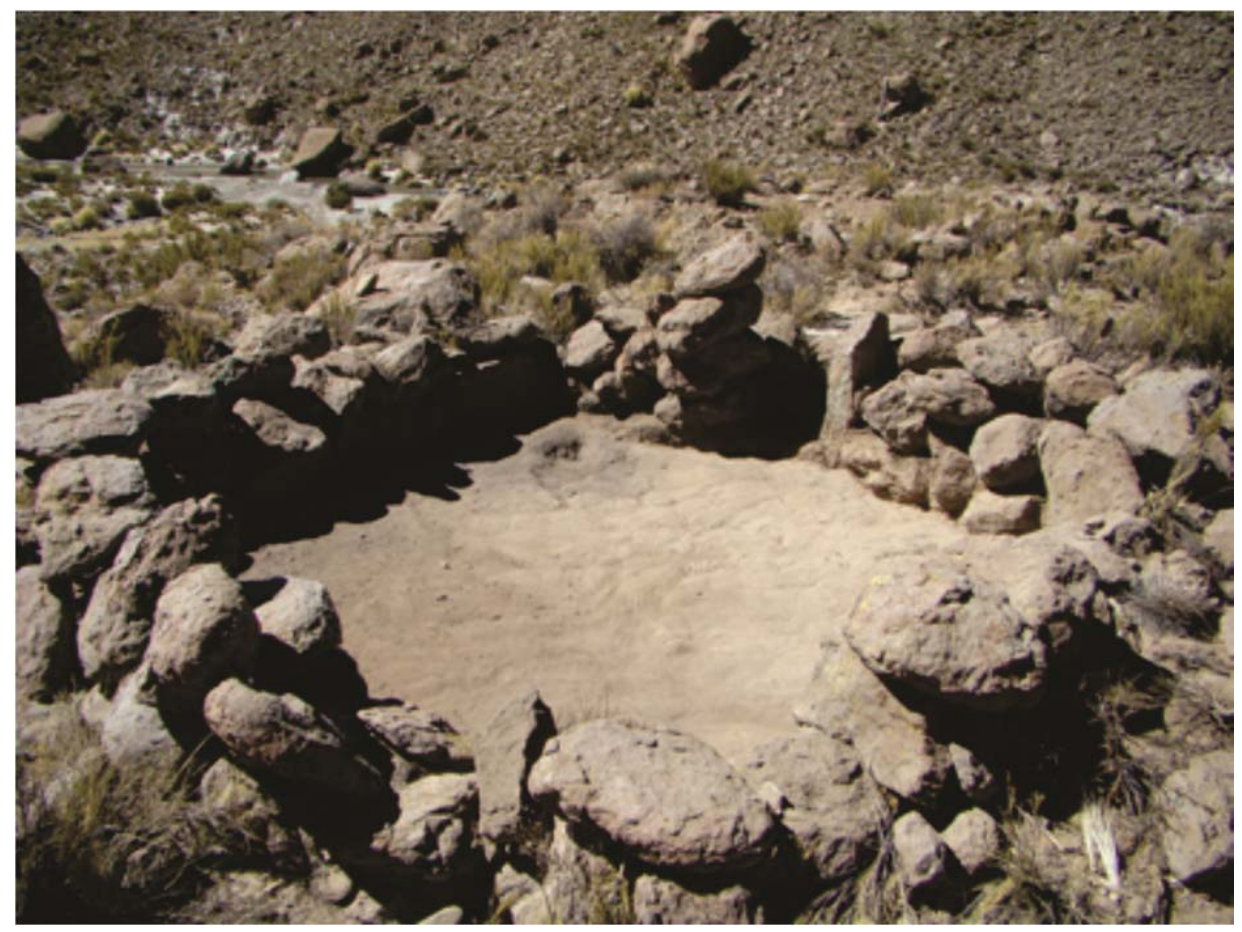

Figura 4.8 Vista de la excavación de la estructura 1 de $\mathrm{CH} 25$. Al fondo se observa el área de fogón junto al vano, y por detrás de la estructura, el cauce temporario que recorre la quebrada de Chajarahuayco.

Del fogón se tomó una muestra para la realización de un fechado por 14C. El resultado fue "moderno". Sin embargo, por varios motivos consideramos como muy probable que la estructura en cuestión haya sido habitada hace más de doscientos años. Por un lado, ya mencionamos la presencia del horno de fundición de época colonial y la evidencia de reutilización de las estructuras de cultivo. Además, esta estructura 1 presenta las mismas características arquitectónicas y estado de conservación que la 2, localizada junto ella, y que fue fechada en el siglo XV, como señalamos antes. Sin embargo, las características de la cerámica que se discutirán más adelante nos hacen suponer que su ocupación no es prehispánica (ver Angiorama y Pérez Pieroni 2012).

La muestra de estas estructuras consiste en 33 fragmentos procedentes de la excavación de la Estructura 1, 16 de recolección superficial en las inmediaciones de la misma; 48 fragmentos de la excavación de la estructura 2 y tres de recolección superficial en sus inmediaciones. 


\section{Tabladitas:}

Al igual que la mayoría de las estructuras aquí analizadas, Tabladitas 1 (TA 1) está localizada en una zona en donde se encuentran otras estructuras aisladas entre áreas de cultivo y corrales. Consiste en un recinto circular con una única ocupación datada sobre carbón recuperado de la excavación en el s. XIV (Angiorama com. pers.), en la cual se encontraron abundantes fragmentos cerámicos, palas líticas completas y fragmentadas y otras evidencias materiales de actividades domésticas.

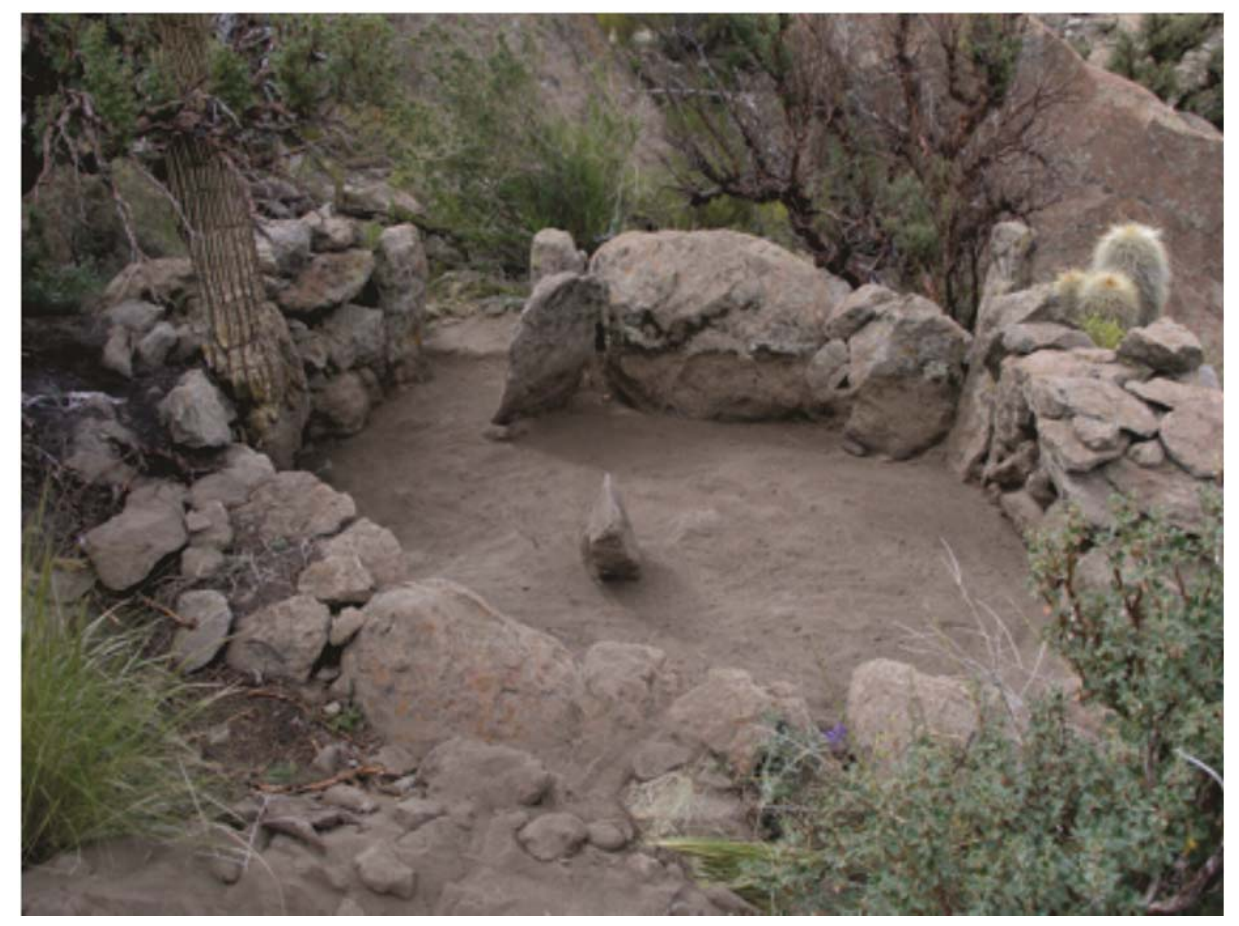

Figura 4.9 Vista de la estructura 1 de TA 1 excavada.

Para este recinto se analizó todo el material de excavación, consistente en 91 fragmentos, y otros nueve fragmentos de recolección superficial en las inmediaciones de la estructura.

Por otro lado, las muestras de la zona de puna próxima a Santa Catalina proceden de dos sitios, cuya localización puede observarse en la Figura 4.10. 


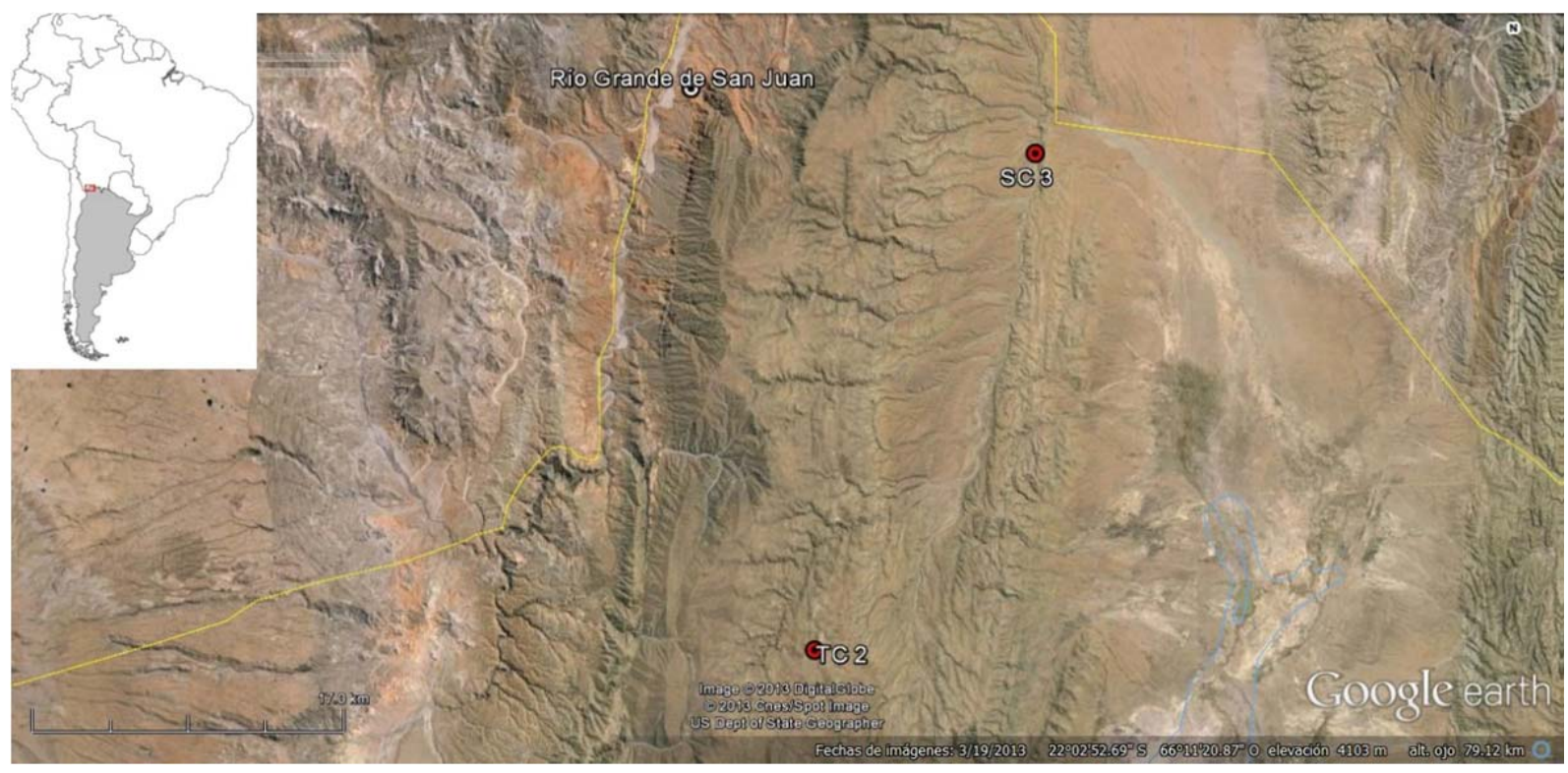

Figura 4.10 Sitios del área de Santa Catalina de donde se obtuvo el material fragmentario analizado.

\section{Santa Catalina:}

En la zona cercana a Santa Catalina, próxima al río San Juan Mayo, y a la frontera con Bolivia, se realizaron tareas de prospección intensiva en sectores vinculados a la actividad minera, que permitieron detectar espacios de ocupación prehispánica, colonial y republicana. Para estos dos últimos momentos la actividad estaba más orientada hacia la minería, como para la zona de Pozuelos. En todos los sitios prospectados, se realizaron recolecciones superficiales indiscriminadas y discriminadas.

El material analizado aquí procede de estas recolecciones superficiales, en dos diferentes sitios que aún no han sido datados, pero que de acuerdo a sus características arquitectónicas y de los materiales en superficie pueden corresponder a momentos prehispánicos tardíos y/o coloniales tempranos. Fueron incluidos, de manera de poder comparar las similitudes y diferencias de las secuencias de manufactura con las de Pozuelos, ya que en la literatura se había planteado que este era un espacio vinculado al estilo Yavi (Krapovickas y Cigliano 1962-63), lo que nos permite contribuir al objetivo de si las diferencias estilísticas en la cerámica se corresponden o no con las tradiciones tecnológicas. 
Santa Catalina 3 sería un pequeño tambo a orillas del río homónimo, con al menos cuatro estructuras asociadas, de morfología circular, y material cerámico Inka provincial y Yavi o Chicha, según lo observado en las tareas de campo y que se aprecian parcialmente en la Figura 4.11. Se analizaron 197 fragmentos procedentes de la recolección superficial del interior de las estructuras y sus alrededores.

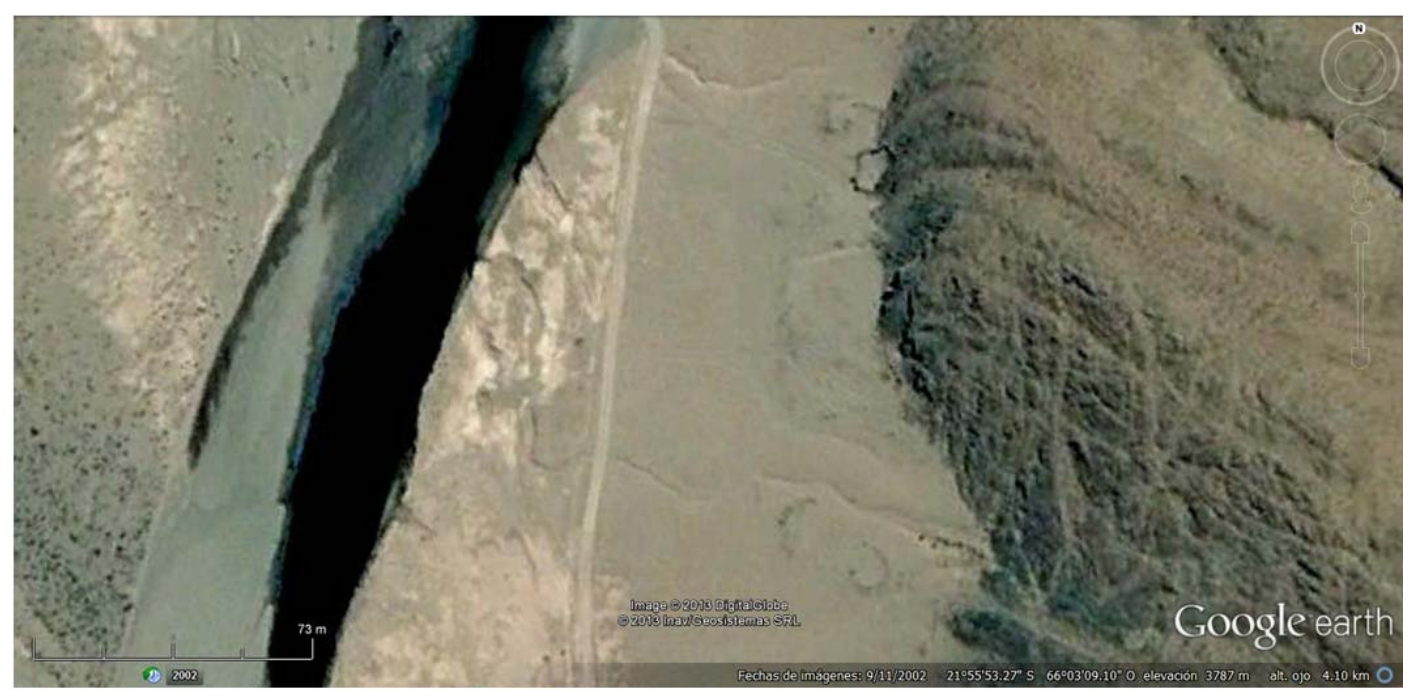

Figura 4.11 Vista aérea del sitio SC 3, donde se aprecian parcialmente las estructuras prospectadas.

\section{Timón Cruz:}

Timón Cruz 2 es un poblado con varios conjuntos de estructuras asociadas entre sí, en la base de una ladera (Figura 4.12). Las estructuras son de diversas morfologías, siendo predominantemente rectangulares, pero hay algunas semicirculares, con muros de lajas con o sin argamasa; y en algunos casos se conservan hastiales en los muros. De acuerdo a la cerámica hallada en superficie, podría haber sido ocupado tanto en momentos prehispánicos tardíos como coloniales. Se identificaron seis conjuntos de estructuras, donde se realizaron recolecciones superficiales de material, y algunos recintos aislados, no asociados a los conjuntos identificados. 


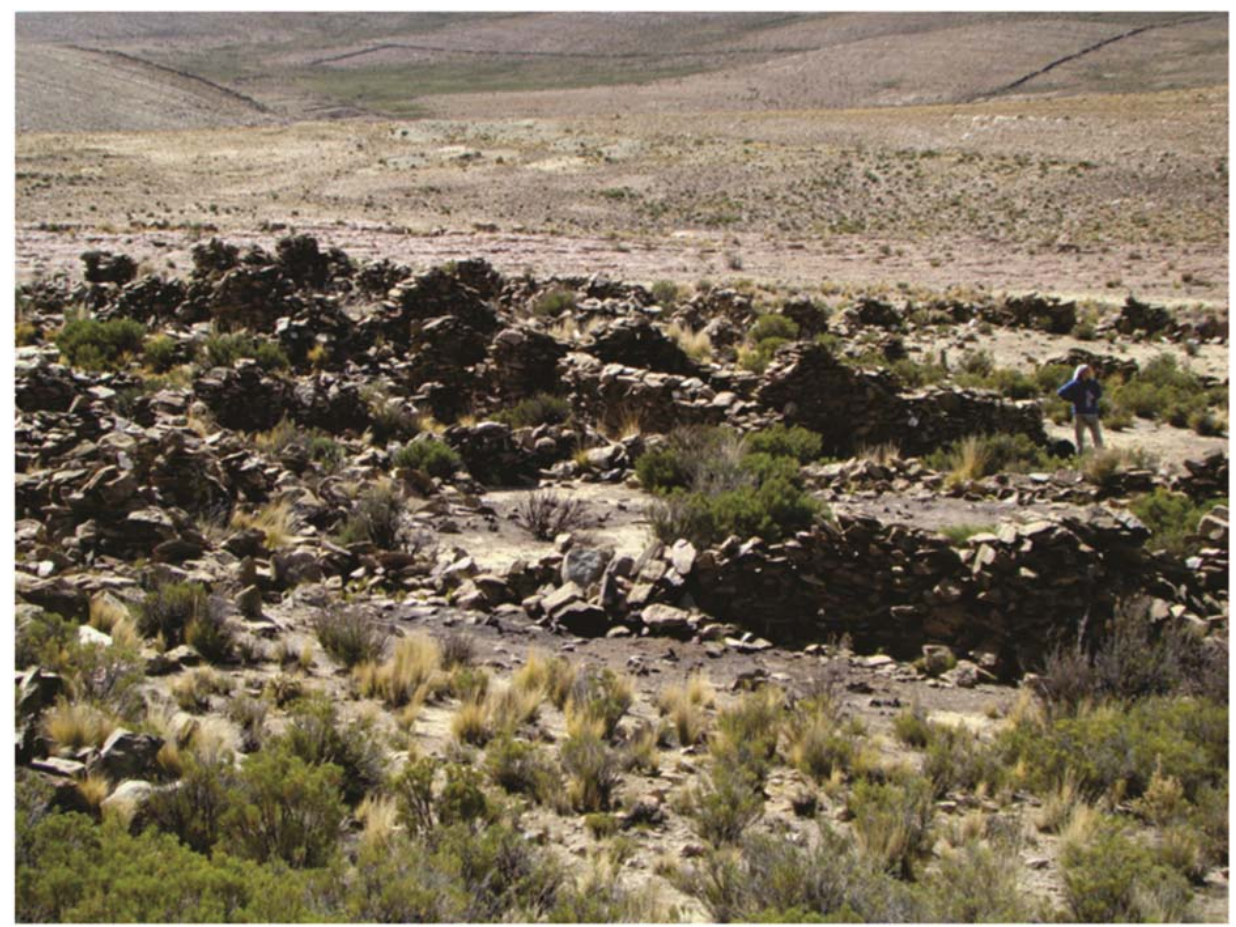

Figura 4.12 Vista parcial del poblado de Timón Cruz 2, donde se aprecian algunas de las estructuras relevadas.

Aquí se analizan 376 fragmentos cerámicos de este sitio, con la siguiente procedencia: 132 fragmentos del conjunto $A$; 80 fragmentos del conjunto $B$; 18 fragmentos del C; 46 del D; 4 del E; 38 del F; mientras que 9 fragmentos se recolectaron de un sector en la Ladera Norte del sitio, y 49 en una porción de terraza externa a las estructuras.

En la Tabla 1 se sintetiza la información sobre la cantidad de fragmentos analizados y su procedencia para el total de los sitios mencionados. 


\begin{tabular}{lcc}
\hline Sitio-Estructura & Nivel o UP & Cantidad de Fgtos \\
\hline RH 2-1 & Ocupación & 65 \\
RH 2-1 & Recol. Superficial & 53 \\
RH 10-1 & Nivel 2 & 47 \\
RH 10-1 & Nivel 1 & 15 \\
RH 10-1 & Recol. Superficial & 25 \\
RH 19-1 & Ocupación & 30 \\
RH 19-1 & Recol. Superficial & 7 \\
RH 19-7 & Nivel 2 & 60 \\
RH 19-7 & Nivel 1 & 379 \\
RH 19-7 & Recol. Superficial & 12 \\
PA 22-Basurero & Sondeo 1 & 124 \\
PA 22-Basurero & Recol. Superficial & 27 \\
PA 6-1 & Ocupación & 124 \\
PA 6-1 & Recol. Superficial & 95 \\
CH 25-1 & Ocupación & 33 \\
CH 25-1 & Recol. Superficial & 16 \\
CH 25-2 & Ocupación & 48 \\
CH 25-2 & Recol. Superficial & 3 \\
TA 1-1 & Ocupación & 91 \\
TA 1-1 & Recol. Superficial & 9 \\
SC 3 & Recol. Superficial & 197 \\
TC 2-1 & Recol. Superficial & 376 \\
\hline TOTAL & & $\mathbf{1 8 3 6}$ \\
\hline & & \\
\hline
\end{tabular}

Tabla 4.1 Cantidades de fragmentos analizados en la muestra por sitio y unidad de procedencia.

\section{Colecciones en museos:}

Además del material fragmentario, se analizaron piezas cerámicas completas de las colecciones depositadas en dos museos y sus fichas de registro correspondientes. Estas piezas proceden de diferentes sectores de la puna cercanos a las áreas de estudio o dentro de la misma, donde fue posible. El objetivo de este relevamiento fue tener una idea más acabada sobre el repertorio de morfologías cerámicas en la puna para el tardío, así como observar otros atributos que son difíciles de ver en material fragmentario: orientación y disposición de huellas y marcas de modelado, disposición de motivos decorativos, dimensiones, etc. Consideramos que el registro de piezas completas es complementario al del material fragmentario, y que ambos nos permiten tener una noción más acabada de las prácticas que conforman las tradiciones tecnológicas. 
En el Instituto Interdisciplinario Tilcara de la Facultad de Filosofía y Letras de la UBA, se relevaron piezas procedentes del sitio Doncellas (o Agua Caliente en Ottonello 1973) y de Queta. Ninguna tiene información de procedencia en las fichas de la colección, salvo la mención del sitio.

La colección Doncellas, excavada por Casanova, como se mencionó, se encuentra depositada tanto en el depósito del referido Instituto como en el Museo Etnográfico en la ciudad de Buenos Aires. No se accedió a las piezas depositadas en este segundo Museo. La colección se conformó en base a las excavaciones llevadas a cabo en la década de 1940 en el área de cementerio de Doncellas exclusivamente, por Casanova, quién abrió aproximadamente 200 enterratorios en uno de los farallones que rodean al sitio (Pérez de Micou 2009). Como señala Ottonello (1973) los entierros de Doncellas se encuentran en dos tipos de estructuras: oquedades naturales cerradas por muros de pirca con argamasa de barro (cuevas tapiadas); o "chullpas", que se encuentran en un único sector del sitio. Los artefactos obtenidos por Casanova serían más de 2500 y proceden según el autor de ambos tipos de tumbas (Casanova 1943). Cabe destacar que el mencionado autor no da mayores detalles sobre los contextos de hallazgo.

Los entierros de este sitio serían de momentos preshipánicos tardíos, ya que los fechados realizados por Pérez de Micou (1996; cito en Pérez de Micou 2009) sobre cuerdas de la Colección Doncellas depositadas en el Museo Etnográfico dieron una edad de 700 años AP. Asimismo, la datación más antigua obtenida en el área de recintos habitacionales, excavado por Alfaro (1988), arroja una antigüedad de 1000 años AP; mientras que la fecha más tardía estaría dada por una moneda hallada por Vigniati con la fecha de 1677 (cito en Ottonello 1973).

Entre los materiales arqueológicos de esta colección, además de piezas cerámicas, se cuentan artefactos sobre madera, textiles de lana, calabazas decoradas, cestería, cordelería, artefactos de metal, etc.

Los materiales cerámicos obtenidos tanto por Casanova como los excavados por Alfaro de Lanzone han sido estudiados previamente. Lafón (1965) emplea los materiales excavados por Casanova para definir su Cultura de Tipo Doncellas. Recientemente, Pérez y Killián Galván (2011) retoman ambas colecciones y en su análisis enfatizan atributos morfo estilísticos, considerándolos reflejo y comunicadores de identidades, que buscan identificar mediante su análisis. Reconocen diferentes categorías morfológicas de recipientes, correspondientes tanto a piezas abiertas como cerradas, tales como 
pucos o escudillas, "vasos chatos", fuentes, vasijas, etc. Asimismo, identifican tipos no decorados y decorados, algunos comparables a lo descrito como cerámica estilo Casabindo, en menor cantidad piezas estilo Yavi, y otros tipos menores, comparables a cerámica inkaica o de la vertiente oriental de los Andes. Los tipos decorados menos frecuentes mencionados se encuentran presentes en las áreas de entierro junto con la cerámica Casabindo, mientras que en el sector de recintos habitacionales son más comunes los materiales estilo Casabindo (Pérez y Killian Galván 2011).

En nuestra muestra se incluyeron 24 piezas cerámicas completas o casi completas de ese sitio. Además se analizaron 41 piezas procedentes de Queta, que también habrían sido excavadas por Casanova en contextos funerarios en la década de 1940, de acuerdo a las fichas de la colección, pero no hay mayores detalles sobre los contextos de hallazgo. Alfaro (1983) refiere haber consultado el informe de los trabajos realizados por Casanova, y describe al sitio como un conglomerado sin defensas, pero tampoco agrega mayor información contextual. En total se relevaron 65 piezas cerámicas del depósito del mencionado Instituto.

Del mismo modo, se analizó la colección de piezas cerámicas excavadas por Eric Boman a comienzos del s. XX en la Puna de Jujuy, en el marco de la misión de CréquiMontfort y Sénéchal de la Grange, y que se encuentran depositadas en el museo Quai Branly, en Paris, Francia. De la misma, 15 piezas o fragmentos cerámicos aparecen con procedencia del Pucará de Rinconada, donde Boman realizó excavaciones en las estructuras mismas del Pukará como en enterratorios en las mesadas adyacentes al mismo (Boman 1908). Sin embargo, a partir de las fichas del museo o de la publicación del autor, no se puede distinguir cuáles proceden de cada uno de estos contextos, salvo para un par de casos que aparecen en las ilustraciones del tomo citado (Boman1908).

Cuatro piezas analizadas proceden de Sayate, en donde este autor excavó grutas funerarias, en las que, además de material cerámico, halló instrumental de madera, como horquetas de atalaje (halladas en todas las tumbas), torteros y cuchillones de madera, restos de vestimenta, fragmentos de arcos y flechas y fragmentos de calabaza (Boman 1908).

Tres objetos (dos torteros y un fragmento de cerámica) proceden de Queta, donde Boman (1908) refiere que relevó los restos de un asentamiento prehispánico en ruinas, en el que observó abundantes fragmentos de alfarería ordinaria. Junto a unos entierros halló dos escudillas ilustradas, que no se localizaron en la colección del museo. 
Otras once piezas completas o casi completas proceden de Sansana, en donde excavó una única tumba de la cual extrajo estos once recipientes. Se trata de un entierro múltiple de dos adultos y un infante, pero el autor no da más datos de asociaciones con otros artefactos (Boman 1908). Este sitio de Sansana, corresponde a lo que posteriormente se denominó Pukará de Cerro Colorado o Cerro Colorado 1 (Krapovickas y Aleksandrowicz 1986-87).

Tres piezas o fragmentos, proceden de Yavi Chico, donde también excavó tumbas, pero no se da mayor información contextual (Boman 1908). Otros dos recipientes incluidos de esta colección no tienen datos de contexto, pero fueron considerados en el análisis dado que uno aparece como procedente de Cochinoca y otro como de la Puna de Jujuy.

En la Tabla 2 se puede observar una síntesis de la procedencia y las cantidades de piezas analizadas. Se debe tener en cuenta que se consideraron tanto recipientes cerámicos completos, como fragmentos y objetos manufacturados en cerámica.

\begin{tabular}{ccccc}
\hline \multicolumn{1}{c}{ Museo } & \multicolumn{1}{c}{ Colección } & Sitio & Excavado por & $\mathbf{N}^{\circ}$ Piezas \\
\hline Instituto Tilcara & Doncellas & Doncellas & Casanova & 24 \\
Instituto Tilcara & Queta & Queta & Casanova & 41 \\
QuaiBranly & Créqui-Montfort y Sénéchal de la Grange & Pucará de Rinconada & Boman & 15 \\
QuaiBranly & Créqui-Montfort y Sénéchal de la Grange & Sayate & Boman & 4 \\
QuaiBranly & Créqui-Montfort y Sénéchal de la Grange & Queta & Boman & 3 \\
QuaiBranly & Créqui-Montfort y Sénéchal de la Grange & Sansana & Boman & 11 \\
QuaiBranly & Créqui-Montfort y Sénéchal de la Grange & Yavi Chico & Boman & 3 \\
QuaiBranly & Créqui-Montfort y Sénéchal de la Grange & Varios & Boman & 2 \\
\hline TOTAL: & & & & $\mathbf{1 0 3}$ \\
\hline
\end{tabular}

Tabla 4.2 Procedencia de las piezas de colecciones en museos analizadas.

\section{Muestras de arena y materias primas actuales:}

Asimismo, se obtuvieron algunas muestras de arena procedentes de los lechos de cursos de agua cercanos a los sitios de Pozuelos cuyas muestras se analizan aquí, a fin de comparar la litología de las mismas con la de las inclusiones no plásticas en la 
cerámica. Debido a que no se encontraron fuentes de arcilla en las prospecciones realizadas, se muestrearon las arenas únicamente.

Se analizaron cuatro muestras, una procedente del lecho del Río Herrana, otra del río Chajarahuayco, otra más del arroyo que pasa junto al sitio Pan de Azúcar 22, y la última de un cauce temporario junto al sitio Fundiciones, cerca de la localidad de Santo Domingo.

En cambio, en la zona de Santa Catalina, los pobladores nos indicaron una fuente de arcilla roja que se usa en la actualidad por los pobladores del centro productor cerámico de Casira, de acuerdo a lo relatado. Asimismo se indicó otra fuente de "pirca", que es la roca lutítica empleada como antiplástico. Se muestrearon ambas a fin de comparar su litología con la de los fragmentos cerámicos analizados, y en una etapa posterior realizar comparaciones químicas de las arcillas.

Asimismo, se obtuvo una muestra del material usado como antiplástico de una alfarera actual de la localidad de Casira, que de acuerdo a lo informado, se obtiene en los cerros próximos al pueblo. 
5.

\section{DE LAS CADENAS OPERATIVAS A LAS TRADICIONES TECNOLÓGICAS: \\ Metodología empleada}

\section{Tradiciones tecnológicas y cadenas operativas en el contexto de la producción cerámica de la puna de Jujuy:}

En función de los conceptos teóricos expuestos en el segundo capítulo, venimos llevando adelante una metodología orientada por la secuencia de procesos de la cadena operativa, que intenta reconstruir la recurrencia de prácticas en esa secuencia, desplegada por los artesanos y artesanas en su interacción con los objetos, como un medio para llegar a las tradiciones tecnológicas. Es decir, intentamos reconstruir aquellas elecciones tecnológicas en la manufactura cerámica que caracterizan al conocimiento particular del grupo de artesanos y artesanas como grupo social.

Dado que no contamos con contextos de manufactura, abordamos a la misma a partir de los materiales ya manufacturados, que consisten en fragmentos cerámicos procedentes de excavación y recolección superficial de diferentes contextos domésticos prehispánicos tardíos y coloniales y en piezas de colección de sitios funerarios y domésticos localizados dentro o muy cerca del área de estudio y que se encuentran depositadas en dos museos diferentes, como hemos detallado en el capítulo previo.

Nuestra metodología de análisis consiste en buscar en los materiales cerámicos de colección y fragmentarios, evidencias de los procedimientos seguidos en las cadenas operativas, de manera de detectar recurrencias en las prácticas que permitan inferir a grupos de artesanos y artesanas que comparten información y modos de hacer. Como destaca Cremonte (2001: 199), la recurrencia de una serie de variables tecnológicas en diferentes conjuntos cerámicos nos puede permitir definir tradiciones tecnológicas que, como señalamos anteriormente, a diferencia de las formas y los diseños, son menos susceptibles de cambios.

A partir de la secuencia de manufactura, esbozada en el Capítulo 2, abordamos a los materiales fragmentarios desde distintas escalas de observación (macroscópica, 
submacroscópica y microscópica) a fin de registrar distintos atributos relacionados a cada uno de los pasos de la secuencia de producción.

Antes de proceder con el análisis, se desplegaron todos los fragmentos correspondientes a cada una de las estructuras y se procedió a remontar los materiales hasta donde fuera posible, con el objetivo de tratar de identificar las piezas originales (Zagorodny 1996). El remontado, a su vez, proporciona áreas mayores para estudiar atributos tecnológicos y estilísticos y permite un control de tipos definidos con anterioridad, ya que se toma como unidad de análisis a la pieza remontada o al conjunto de fragmentos provenientes de una misma pieza. Asimismo, permite determinar el número mínimo de piezas en cada recinto, lo que posibilita analizar la cantidad y distribución de la cerámica en los sitios (Rye 1981, Zagorodny 1996, Wynveldt 2008).

Además, se agruparon los fragmentos que no remontaban, pero que se consideró procedían de una misma pieza porque tenían a simple vista pastas y características superficiales muy semejantes, en grupos o familias de fragmentos (Orton et al 1997). Cada uno representaba una pieza hipotética, que posteriormente se sostuvieron o se reformularon con las observaciones subsiguientes.

Seguidamente, se registraron los atributos de todos los fragmentos, tanto los agrupados como los que no fueron agrupados, y de sus pastas, tanto macroscópicamente como con ayuda de una lupa binocular, y posteriormente se observó una muestra de pastas en corte delgado en microscopio petrográfico. Las observaciones macroscópicas se realizaron tanto a ojo desnudo como con ayuda de una lupa de mano (15x). Para todas las etapas se diseñaron planillas específicas (una para atributos macroscópicos, otra para lupa binocular y otra para microscopio) que pueden observarse en los anexos, junto con sus respectivos códigos analíticos.

A continuación se detallan los atributos contemplados para cada paso de la cadena operativa.

\section{Caracterización de las materias primas y su posible origen y preparado:}

Las materias primas cerámicas consisten en arcillas, materiales empleados como antiplástico, otros minerales que pueden usarse como pigmentos, entre otros. Por lo que caracterizar las mismas a partir de material cerámico fragmentario y poder abordar su 
origen requiere conocer el ambiente geológico y geomorfológico (Cremonte 1996). Con este fin se consultó bibliografía sobre la geología del área de estudio, con especial énfasis en las hojas geológicas disponibles.

Asimismo, se realizaron observaciones en el campo en el área circundante a los sitios de donde proceden los materiales, y se tomaron algunas muestras de arenas para la comparación litológica con las inclusiones no plásticas de los materiales analizados. También se tomaron muestras de materias primas en base a la información provista por la población local, y se obtuvieron otras de los alfareros actuales. La procedencia de todas ellas ha sido descrita en el capítulo anterior.

Para su caracterización, se realizaron observaciones en lupa binocular Motic DM 39C (20 a 40X), semejantes a las realizadas sobre las inclusiones de las pastas cerámicas en fractura fresca, para poder realizar comparaciones. Los atributos contemplados están basados en tablas de descripción sedimentológicas, e incluyeron la granulometría, la selección, el grado de redondez y la litología de los clastos observados hasta el nivel que fue posible. Se emplearon gráficos comparativos publicados en formato de tarjeta por la Primera Reunión Argentina de Sedimentología (1986).

Con respecto al análisis de los materiales cerámicos, sobre los grupos de fragmentos y los fragmentos no agrupados, se seleccionó una muestra para cada sitio, que varió entre el 31 y el $84 \%$ del total, de acuerdo a criterios de selección cualitativos, consistentes en muestrear diferentes porciones morfológicas (borde, base, cuerpo) de las piezas representadas por los grupos de fragmentos (Zagorodny 1996); incluir los fragmentos cuya pertenencia al grupo era dudosa e incorporar a todos los fragmentos que no habían sido agrupados. En el caso de los sitios en donde no se realizaron grupos de fragmentos (PA 22-Basurero; SC 3 y TC 2), se seleccionaron todos, menos aquellos que remontaban. En la Tabla 5.1 se pueden observar las cantidades de fragmentos analizados con lupa por sitio, y el porcentaje del total que representan.

Posteriormente, sobre una fractura fresca de los fragmentos seleccionados para la muestra, y con la lupa binocular, se realizaron diferentes observaciones consignadas en una planilla diseñada para tal fin, en base a los criterios propuestos por Orton et al. (1997), Rye (1981) y Zagorodny (1996). 


\begin{tabular}{|c|c|c|c|}
\hline Sitio-Estructura & Total Fgtos & Muestra Lupa & $\%$ Muestra \\
\hline $\mathrm{RH} 2-1$ & 118 & 37 & $31 \%$ \\
\hline RH 10-1 & 87 & 48 & $55 \%$ \\
\hline RH 19-1 & 37 & 13 & $35 \%$ \\
\hline RH 19-7 & 451 & 171 & $38 \%$ \\
\hline PA 22 -Basurero & 146 & 146 & $100 \%$ \\
\hline PA 6-1 & 219 & 139 & $63 \%$ \\
\hline $\mathrm{CH} 25-1$ & 49 & 41 & $84 \%$ \\
\hline $\mathrm{CH} 25-2$ & 51 & 26 & $51 \%$ \\
\hline TA 1-1 & 100 & 51 & $51 \%$ \\
\hline SC 3 & 197 & 189 & $96 \%$ \\
\hline TC 2-1 & 376 & 364 & $97 \%$ \\
\hline TOTAL: & 1831 & 1225 & $67 \%$ \\
\hline
\end{tabular}

Tabla 5.1 Muestra de fragmentos analizados con lupa binocular por sitio y porcentaje sobre el total.

Para la descripción de las fracturas frescas se tuvieron en cuenta atributos como su aspecto, textura, resistencia a la fractura y regularidad de la misma, presencia de cavidades y tamaño relativo, atmósferas de cocción y color (en notación de la Munsell Soil Colour Chart). Los atributos de las inclusiones contemplaban su densidad, orientación, granulometría, grado de selección, redondez y la identificación mineralógica o litológica de las mismas. Las identificaciones de los minerales y fragmentos de rocas se realizaron hasta el nivel que permitió el uso de esta técnica submacroscópica, la lupa binocular, que en muchos casos es general (ígnea, sedimentaria, y otras categorías generales). Se emplearon gráficos de comparación visual para definir estos atributos, publicados en Orton et al (1997) o en la carta de la Primera Reunión Argentina de Sedimentología (1986).

La caracterización de las pastas también permite observar atributos relacionados a la preparación de las materias primas (presencia de cavidades y orientación de las mismas, distribución de las inclusiones, ambas relacionadas con el amasado), y del modelado (orientación de inclusiones y cavidades, etc.). Asimismo, a partir del color y su distribución se puede inferir la atmósfera de cocción de la pieza (Rye 1981). Igualmente, pueden ser visibles características vinculadas a la construcción de la pieza, tales como uniones, defectos, marcas, etc. (Rye 1981).

Posteriormente, sobre la base de esta clasificación, se seleccionó otra muestra para la realización de cortes delgados para observar en microscopio petrográfico. La petrología cerámica es una subdisciplina que se basa en el empleo de la técnica 
petrográfica (observación de cortes delgados en un microscopio de luz polarizada) y permite la identificación mineralógica de las inclusiones no plásticas presentes en las pastas, a través del examen de sus propiedades ópticas, como así también realizar otras determinaciones cualitativas y cuantitativas referentes a textura, porcentaje de matriz, forma y medidas de las inclusiones y de las cavidades, proporción y relación de Ios distintos constituyentes (Shepard 1968; Sinopoli 1991; Orton et al. 1997, Cremonte 1996, González de Bonaveri et al. 2000). De esta manera, se pueden realizar apreciaciones no sólo sobre la litología de las inclusiones, sino también sobre la preparación de las pastas, la identificación de engobes, pintura y otras coberturas, entre otros atributos de la secuencia de manufactura (Cremonte 1996, González de Bonaveri et al. 2000).

La selección de fragmentos para cortes se realizó con el objeto de muestrear la variabilidad en las pastas observada con la lupa binocular, pero también tratando de abarcar las diferentes morfologías y acabados de superficie reconocidos. Mayormente se escogieron fragmentos de bordes, porque se pueden relacionar a las morfologías reconocidas en el material y se pueden orientar los cortes perpendiculares al plano de la boca, a fin de observar la orientación de las inclusiones, que pueden ser informativas de las técnicas de modelado (Balfet et al 1992), como hemos mencionado. De esta manera, se seleccionaron 50 cortes procedentes de los fragmentos analizados para los sitios de la cuenca sur de Pozuelos, y 20 para los de la zona de Santa Catalina. En la Tabla 5.2 se puede observar la procedencia de los distintos cortes por sitio.

\begin{tabular}{cc}
\hline Sitio & $\mathbf{N}^{\circ}$ Cortes \\
\hline RH 2-1 & 2 \\
RH 10-1 & 5 \\
RH 19-1 & 0 \\
RH 19-7 & 15 \\
PA 22 -Basurero & 7 \\
PA 6-1 & 7 \\
CH 25-1 & 1 \\
CH 25-2 & 5 \\
TA 1-1 & 8 \\
SC 3 & 10 \\
TC 2-1 & 10 \\
\hline TOTAL: & $\mathbf{7 0}$ \\
\hline
\end{tabular}

Tabla 5.2. Cantidad de cortes delgados analizados por sitio. 
Sobre los mismos, se realizaron observaciones de las inclusiones y sus propiedades ópticas, que permiten su identificación mineralógica con mayor precisión. Ello contribuye a estimar la procedencia de los materiales, ya que la mineralogía y la forma de las inclusiones no plásticas, al relacionarlas con la geología local, dan cuenta del origen de las mismas (Rye 1981, Cremonte 1996). De todas formas, el análisis mineralógico no permite determinar la fuente exacta de las materias primas, pero sí nos permite decir si las piezas son o no locales. Hay que tener en cuenta que el proceso de manufactura altera las características de las materias primas originales, mediante procesos de limpieza, de mezcla de distintos materiales o la adición de antiplásticos; por lo que abordar el problema de la procedencia es complejo y puede requerir la utilización de distintas metodologías (Sanhueza et al. 2004).

Sin embargo, intentar inferir la procedencia de las materias primas aporta a la localización de las actividades de producción, a falta de contextos de manufactura detectados hasta la fecha, lo que reviste de importancia ya que el contexto espacial de producción aporta al estudio del contexto social de producción (Costin 2000). Si bien la localización de materias primas no puede relacionarse directamente a la localización de las actividades de producción, a través de estudios etnoarqueológicos se ha señalado que los alfareros frecuentemente emplean las materias primas disponibles localmente (Arnold 1993). Sin embargo, como destacan Arnold et al. (1991), las "fuentes" de procedencia de materias primas pueden ser concebidas en distintos niveles de inclusividad: la región, la comunidad o una mina o cantera individual. Además, la composición de las pastas no refleja simplemente la composición de alguna fuente de materias primas particular, sino que está parcialmente determinada por las prácticas culturales involucradas en la preparación de las pastas (Arnold et al. 1991). Con estas consideraciones en mente, intentamos abordar las pastas y compararlas con la geología local al nivel posible, a fin de aportar a la caracterización de las materias primas como una primera aproximación.

También en esta etapa, la orientación de las inclusiones, las características de la matriz arcillosa, las de las cavidades, la identificación de coberturas, como engobes y pinturas, y otros atributos ayudarán a profundizar las observaciones tecnológicas (Rye 1981, Cremonte 1988).

Los atributos seleccionados para la etapa de microscopía incluyeron características de la matriz, como la textura, el color y su uniformidad; la presencia de pinturas, engobes, vitrificados, etc.; las propiedades de las inclusiones, como la densidad, 
orientación y grado de redondez (en base a las tablas de comparación visual mencionadas anteriormente), y su identificación mineralógica y litológica. Luego se cuantificó el porcentaje de inclusiones, matriz y cavidades mediante análisis composicional o de distribución modal, realizado por point counter (Stoltman 1989; 2001). Se contabilizaron 300 puntos por corte ${ }^{2}$ (Cremonte et al. 2007b), en intervalos de $0.5 \mathrm{~mm}$. Se tomó como límite inferior para la identificación de inclusiones el límite entre arena y limo en la Escala de Wentworth, que es de $0.06 \mathrm{~mm}$ (Carpenter y Feinman 1999; González de Bonaveri et al. 2000; Stoltman 2001). También se midió el tamaño de 100 inclusiones por corte (Cremonte et al. 2007b) y se dividieron las mediciones en la siguiente escala: 1 . muy fino $(0.0625-0.125 \mathrm{~mm})$; 2 . fino $(0.126-0.249)$; 3. medio (0.25$0.499 \mathrm{~mm}$ ); 4. grueso (0.5 a $0.99 \mathrm{~mm}$ ); 5. muy grueso (1 a $1.99 \mathrm{~mm}) ; 6$. grava (mayor a 2 mm) (Stoltman 1989: 149, 1991: 108; Carpenter y Feinman 1999). En base a esta escala se analizó la distribución de las frecuencias de los tamaños, se calculó el rango de tamaños, la media y la moda. Elegimos la media en vez del promedio, porque la misma se ve menos afectada por valores extremos (Drennan 2009).

Las secciones delgadas fueron analizadas, en una primera instancia, con asistencia del Lic. Martín Morosi y de la Lic. Nora Zagorodny en el Centro de Tecnología de Recursos Minerales y Cerámica (CETMIC, CIC - CONICET - UNLP), donde se realizó la identificación petrográfica de las inclusiones y también se tomaron una parte de las fotomicrografías. El conteo de puntos se realizó en el microscopio Karl Zeiss Axioskop (25X a 400X) del Instituto de Arqueología y Museo de la UNT, que tiene adosada una cámara digital Sony al trinóculo, con la cual se tomaron otra parte de las fotomicrografías.

\section{Análisis del modelado y las morfologías:}

En base a las reconstrucciones realizadas en la etapa de remontado se definió la morfología de las piezas originales hasta el nivel que fue posible, en base a la propuesta de clasificación de Balfet et al. (1992), que consiste en una clasificación por grandes categorías definidas según la información de profundidades y diámetros y, secundariamente, de dimensiones. En el caso de las piezas de colección se definieron

\footnotetext{
${ }^{2}$ Exceptuando dos cortes que por haberse hecho a partir de fragmentos muy pequeños, la superficie no permitió realizar 300 conteos. Igualmente, se contaron 190 puntos en uno y 240 en el otro.
} 
las morfologías en base a la misma clasificación, aunque al estar completas la misma pudo ser más particularizada que para el material fragmentario.

En primera instancia establecen una diferencia entre recipientes abiertos (en donde el diámetro máximo coincide con la abertura) y cerrados (presentan, por encima del diámetro máximo del cuerpo, un diámetro inferior, que puede coincidir o no con la abertura). Según su contorno, los recipientes se dividen en recipientes de formas simples (que hacen referencia a un volumen geométrico, como elipsoide, cilindro, cono, esfera, hemisferio, etc.) y recipientes de formas compuestas (que no pueden nombrarse en referencia a un volumen geométrico elemental). Entre estas formas se distingue un perfil continuo o discontinuo, en el primero la división entre segmentos del perfil se hace por puntos de inflexión, y en el segundo, por puntos de intersección o angulares (Balfet et al. 1992).

Por otro lado, sobre las piezas completas pueden hacerse diferentes mediciones que no son posibles para los fragmentos, y que ayudan a caracterizar la forma, tales como el diámetro máximo y mínimo, la altura total, la del cuello, de los diámetros y de los puntos de inflexión y/o intersección; la altura de asas o apéndices. Asimismo, se pudo registrar el tipo de perfil (simple o compuesto, y dentro de este último continuo o discontinuo) (Balfet et al. 1992).

También se midió el espesor máximo y mínimo de las paredes, bordes y bases, que es otro atributo relacionado al modelado, tanto para el material fragmentario como para el material de colección, hasta donde lo permitió la curvatura de las paredes.

En relación al modelado y las huellas resultantes del mismo se observan los patrones de fractura y la orientación de las inclusiones (tanto en fractura fresca en la etapa anterior en lupa binocular, como en relación a las paredes de la pieza), solo para el material fragmentario.

También registramos la presencia y el tipo de huellas y marcas del modelado que muchas veces pueden observarse en las superficies tanto del material fragmentario como de las piezas completas depositadas en los museos y que son resultado de gestos técnicos y, en ocasiones, del uso de herramientas (Rye 1981; Wynveldt 2008; García Roselló 2010). Algunos autores denominan estas marcas como trazas o macro trazas, definiéndolas como "marcas de manufactura presentes en la cerámica y que pueden observarse mediante técnicas macroscópicas" (García Roselló 2010: 290). 
Incluyen tanto marcas y huellas producidas por la acción directa del artesano (marcas de herramientas, huellas, variaciones de espesor, marcas de acabado de superficies, etc.), como aquellas no producidas por los mismos, sino que son evidencias indirectas (fracturas, grietas, etc.) (García Roselló 2010).

Siguiendo a Rye (1981), Wynveldt (2008: 162) y García Roselló (2010, Cap. IV), se tuvieron en cuenta aquellas marcas y huellas relacionadas a la manufactura que no fueron borradas por los pasos subsiguientes, tales como evidencias de rollos y del tipo de unión de los mismos, incluyendo variaciones de espesor; indicios del tipo de inserción de las asas y marcas asociadas a la unión de estos elementos; marcas de utensilios y en qué porción del cuerpo se localizan; improntas digitales y en qué parte del cuerpo se localizan; variaciones de espesor de las paredes y orientación; marcas de unión de segmentos del cuerpo, etc. También se consideraron las evidencias de conductas de manufactura intencionales (Wynveldt 2008), que incluyen acabados de superficie y dirección y orientación de las huellas de acabado, etc. Si bien en el material fragmentario muchas de estas huellas, sus direcciones o distribución son difíciles de observar, en las piezas de colección el registro de las mismas se pudo abordar con mayor detalle.

Cabe señalar que muchas de estas marcas son obliteradas por los pasos subsiguientes de la cadena operativa, como el acabado de superficies, por lo que muchas veces no son visibles o se observan únicamente en las superficies internas de piezas cerradas (Rye 1981).

Asimismo, se observaron atributos morfológicos de bordes, bases y asas. Para los bordes, se reconstruyó el tamaño del diámetro en fragmentos con un arco que permitiese tal reconstrucción (arco igual o mayor al 5\% de la circunferencia), en base al cálculo del radio a partir de la cuerda. Posteriormente, se registró la dirección del borde y la forma del labio.

Para las asas se midió el largo, el ancho y el espesor. Luego se registró su sección, el tipo de inserción y la posición en la pieza. En el caso de los fragmentos de base, se registró su diámetro, la morfología y el tipo de unión de la base con el cuerpo de la pieza. Todas las mediciones mencionadas se realizaron con un calibre con vernier. 


\section{Acabados de superficie y decoración:}

Asimismo, para el material fragmentario y las piezas completas de las colecciones de museo, se registraron los acabados de superficie y la decoración, considerando las técnicas necesarias para producirla, los motivos, la posición de los mismos en la topografía de la pieza, colores, etc. También se señaló si estos acabados de superficie eran asignables o comparables a alguno de los estilos decorativos definidos en la literatura previa.

Al igual que en el caso de las marcas y las huellas, el análisis de la decoración puede ser más detallado sobre piezas completas. En las piezas completas se pueden observar los acabados de superficie y la dirección y orientación de las marcas que se asocian a los mismos, tales como, por ejemplo, caras de pulido, estrías de alisado, etc. Si hay decoración, se pueden registrar los motivos y la posición en la pieza, las asociaciones entre motivos, etc. Muchos de estos atributos no son observables en materiales fragmentarios, o lo son parcialmente, por lo que esta escala de análisis provee información complementaria para reconstruir las cadenas operativas, que se suma a la generada en fragmentos cerámicos de excavación. También se complementan dado que se observan materiales procedentes de diferentes tipos de contextos, dado que, como señalamos en el Capítulo 4, buena parte de las piezas de colección procede de contextos funerarios, mientras que el material fragmentario ha sido obtenido mayormente de la excavación y recolección superficial de contextos probablemente domésticos.

Cabe agregar que para el caso de las piezas de colección también se registró toda la información disponible con respecto a la procedencia (nombre del museo, colección particular en la cual la pieza está registrada o expedición en la que la pieza ha sido recolectada, número de inventario y todo tipo de nomenclatura anterior; sitio de procedencia, y otra información relevante).

\section{Secado, cocción, reparación y reutilización:}

El secado es un paso de la cadena operativa muy delicado, dado que si no se toman los cuidados necesarios puede resultar en fracturas y pérdidas de las piezas modeladas. Sin embargo, es difícil de observar a nivel arqueológico, dado que las piezas no cocidas raramente se conservan en el registro. Por lo que este es un paso de la cadena que no 
pudimos observar desde nuestro material a analizar, aunque se hacen algunas consideraciones al respecto.

El paso posterior al secado consiste en la cocción de las piezas. A pesar de que no se han localizado hasta la fecha contextos de manufactura y cocción, y no podemos estudiar las características de las estructuras empleadas con este fin, abordamos la misma a partir de las evidencias indirectas en el material fragmentario. Si bien no se puede estimar mediante observaciones macroscópicas o microscópicas la temperatura de la cocción, sí se pueden hacer apreciaciones sobre las atmósferas. Para ello, se tuvo en cuenta el registro del color de la superficie externa y de la interna (en notación de la Munsell Soil Colour Chart), y la presencia o no de variaciones de color en fractura fresca (núcleos de cocción, ver Rye 1981), con sus respectivas notaciones. En base a las observaciones de las fracturas, se clasificaron las pastas según su cocción en atmósferas oxidantes completas, incompletas o reductoras, y un cuarto tipo de cocción con valor a nivel regional, como se verá más adelante, que es exterior oxidante e interior reducido.

Sin embargo, debe tenerse en cuenta que las fracturas solo representan una pequeña porción de la pieza y que puede haber variaciones de las atmósferas de cocción a lo largo de la pieza completa, especialmente cuando son cocidas a cielo abierto o en estructuras de cocción muy simples.

Asimismo, se registraron todas las evidencias de reparación o reuso del material cerámico.

\section{La producción alfarera en los s XIX y XX en la puna de Jujuy y el sur del altiplano boliviano:}

Otro interés surgido en la investigación era el de abordar los cambios en la actividad productiva que venimos estudiando después del contacto hispano indígena, qué continuidades y discontinuidades se dan con respecto a momentos prehispánicos y cómo llega este conjunto de prácticas hasta la actualidad.

Sin embargo, al encarar estos problemas nos encontramos con que los documentos históricos para el área desde el momento de las primeras entradas hasta la colonia, no contienen referencias con respecto a la manufactura, distribución o consumo de la alfarería (Gil Montero com. pers.). Probablemente, al ser ésta una práctica 
esencialmente doméstica y cotidiana, haya pasado desapercibida o como poco relevante a los ojos de los conquistadores y funcionarios de la colonia.

A pesar de ello, se encuentran publicados algunos trabajos etnográficos o etnoarqueológicos que refieren a la producción actual de alfarería en la puna jujeña. Ello, sumado a las observaciones que realiza Boman (1908) en su paso por el área, nos llevó a pensar la posibilidad de abordar los cambios que se dieron en la producción cerámica con posterioridad al contacto hispano indígena a partir de las referencias en los documentos de viajeros del siglo XIX y XX y de los registros contemporáneos de investigadores sociales, sumando esta vía al análisis del material cerámico procedente de contextos excavados por nosotros con dataciones coloniales o posteriores al contacto.

Para ello, revisamos la bibliografía a nuestro alcance de estos dos siglos para la puna de Jujuy y el sur del altiplano boliviano, a fin de identificar aspectos relacionados a la producción y consumo de alfarería: obtención de materias primas, manufactura, formas construidas, acabados de superficie, cocción, formas de distribución y consumo de los productos elaborados. También sumamos algunas observaciones realizadas por nosotros en Casira, principal centro productor actual de cerámica en la puna de Jujuy, e informaciones aportadas por pobladores de la puna y otras observaciones realizadas en el campo en las diferentes campañas arqueológicas.

La integración del estudio de fuentes documentales con observaciones etnoarqueológicas (aunque preliminares) y con los datos que provee la arqueología resulta una estrategia muy útil para obtener una visión de largo plazo de la producción cerámica y los cambios producidos en la misma y, por lo tanto, en los grupos sociales que llevan adelante estas prácticas (García Roselló 2007). Siguiendo esta metodología bibliográfica, sumándole la información obtenida desde la arqueología y observaciones etnoarqueológicas (que pueden profundizarse en el futuro), podemos obtener una visión en el largo plazo mucho más rica de la producción cerámica, de su relevancia en los ámbitos domésticos, sus cambios en el tiempo y su rol en la interacción de las poblaciones puneñas; como así también, del impacto sufrido por la conquista inkaica y española en este aspecto de la sociedad local.

Las fuentes empleadas incluyen un relato publicado por Boman (1908) en el tomo II de su obra resultante de su viaje por el norte de Argentina en 1903, como parte de la misión francesa G. de Créqui Montfort - E. Sénéchal de la Grange. En el mismo, el autor 
detalla sus observaciones de la producción llevada adelante por una alfarera de Susques. También incluimos algunas referencias en las obras de Carrillo (1988 [1888]) y De Bonelli (1854). Aunque son muchos los viajeros que pasaron por Jujuy a fines del siglo XIX y comienzos del XX, tan sólo estos autores hacen breves referencias a sus observaciones de la producción cerámica. Asimismo, incluimos una serie de trabajos etnográficos y etnoarqueológicos producidos en la segunda mitad del siglo XX para la puna de Jujuy y nuestras observaciones realizadas en el año 2011 en una visita a Casira, importante centro productor cerámico de la puna de Jujuy, donde entrevistamos brevemente a cuatro olleros.

La información relevada se organizó siguiendo la cadena operativa, al igual que en el caso de la obtenida desde el material arqueológico, con el fin de acercarnos a las diferentes secuencias de manufactura desplegadas por los artesanos, y a través de éstas a las distintas tradiciones tecnológicas que caracterizan a estos grupos y poder realizar comparaciones con las cadenas reconstruidas desde la arqueología. 
6.

\section{LA OBTENCIÓN Y PREPARACIÓN DE LAS MATERIAS PRIMAS}

\section{La geología de la puna:}

Entender las características geológicas y geomorfológicas de la puna, nos permite abordar la obtención de materias primas y por lo tanto la localización de la producción ${ }^{3}$, mediante la comparación de la mineralogía y la litología del área con los conocimientos geológicos y muestreos de materias primas. Por eso, para comenzar este capítulo, hacemos una breve síntesis de la geología local.

La puna es una altiplanicie que se eleva por encima de los $3700 \mathrm{msnm}$, con sus límites dados por la Cordillera Oriental al este y la Cordillera Occidental al oeste (Ramos y Coira 2008). Se caracteriza por tener una red hidrográfica escasa, con cuencas mayormente endorreicas, a excepción del río San Juan Mayo o Grande de San Juan, que es el único vinculado a la cuenca exorreica del río Pilcomayo. Las cuencas endorreicas del norte de la puna incluyen la laguna de Pozuelos y las de Vilama y Pululus (Coira et al. 2004), mientras que hacia el sur se encuentra la cuenca de Miraflores-Guayatayoc.

Dentro de estas cuencas endorreicas, el bolsón que ocupa la laguna de Pozuelos está ubicado entre los departamentos de Rinconada, Yavi y Santa Catalina. El mismo ha sido formado por movimientos orogénicos de fines del Terciario, que dieron origen a los Andes (Tecchi 1991) y es una cuenca intermontana limitada al oeste por la sierra de Rinconada y al este por las de Escaya - Cochinoca (Alonso y Fernández 1996). centro de la depresión está ocupado por la laguna, un cuerpo de agua elongado de orientación meridiana, que fue declarada Monumento Natural en el año 1981, por la gran importancia como hábitat de numerosas aves (Rosas 2008).

\footnotetext{
${ }^{3}$ La localización de la producción se aborda a un nivel regional (Arnold et al. 1991), dado que este tipo de comparación con la geología local no nos permite aproximarnos a las fuentes específicas de materias primas. Por otro lado, buena parte de las formaciones geológicas que se mencionan a continuación se encuentran representadas en todo el ámbito altiplánico. Ver discusión sobre la identificación de fuentes de materias primas en el capítulo anterior.
} 
Las formaciones geológicas que se han definido para la puna son muchas, pero básicamente consisten en rocas sedimentarias de edad ordovícica, con fuerte deformación en el sector occidental; y rocas de origen volcánico, ordovícicas o cenozoicas. Entre las volcánicas, las del último período mencionado son las más abundantes, y están constituidas por estratovolcanes y domos volcánicos andesíticos y dacíticos, y calderas volcánicas asociadas a flujos ignimbríticos (Ramos y Coira 2008: 11).

Las rocas sedimentarias se encuentran muy representadas y ampliamente distribuidas, y exhiben todas las granulometrías. Por ejemplo, las limolitas y lutitas son abundantes en varias formaciones (Formación Acoite, Formación Peña Colorada, Formación Moreta, Formación Tiomayo). Las de la Formación Acoite (Ordovícico) conforman las sierras de Rinconada-Carahuasi, el bloque de Mina Pirquitas-Rosario de Coyaguiama, y tienen algunos afloramientos menores en la cuenca del Grande de San Juan y en Tiomayo. Estas rocas presentan buena estratificación y colores gris verdosos a amarillentos, con bancos de distinta granulometría, de arenosa a limo arcillosa (Coira et al. 2004: 9). En la Formación Acoite, en la sierra de Rinconada, se encuentran vetas de cuarzo con mineralizaciones de oro, sulfuros de $\mathrm{As}, \mathrm{Fe}, \mathrm{Cu}, \mathrm{Pb}, \mathrm{Zn}$ y $\mathrm{Sb}$ y sulfosales de Ag (Coira et al. 2004: 10).

También están representadas las areniscas, tanto en la Formación Acoite, como en el Complejo magmático-sedimentario Cochinoca-Escaya, ambos del Ordovícico; y en las formaciones Peña Colorada, Moreta y Tiomayo, todas de edad Terciaria (Coira et al. 2004).

Otras rocas sedimentarias presentes son los conglomerados, como los de la Formación Moreta (Terciario), que son rojizos, con clastos redondeados a subredondeados de cuarzo, pelitas y areniscas del Ordovícico, y limolitas. Sus afloramientos se encuentran al sur y oeste del cerro pan de Azúcar, y en afloramientos reducidos al sur y norte del pueblo de Rinconada (Coira et al. 2004: 22-23). También están presentes las de la Formación Cabrería (Terciario), que además incluye areniscas, limolitas, ignimbritas y depósitos volcaniclásticos. Sus afloramientos se extienden en la margen occidental de la sierra de Rinconada, desde Mina Eureka al norte hasta la zona de Puertas de San Pedro al sur. Las ignimbritas de esta formación son de composición andesítica, con una matriz con abundantes cristales, cuyos principales minerales son plagioclasa, cuarzo, sanidina, biotita, ortopiroxeno, trazas de hornblenda, etc. (Coira et al. 2004: 24). 
La Formación Tiomayo, además de areniscas, limolitas y arcilitas, presenta conglomerados, tobas e ignimbritas. Sus afloramientos se localizan al oeste de la sierra de Rinconada, mientras que hacia el este, en la cuenca de Pozuelos, aflora hacia el sur, en los bordes de las sierras de Rinconada y Queta. Esta Formación integra las mesadas del Pukará, que se extienden hasta Río Herrana y aflora también en Chajarahuayco. Las ignimbritas de esta formación son blanquecinas, dacíticas, con abundantes fragmentos pumíceos y escasos líticos, dispersos en una matriz vitrocristalina con abundante cuarzo, plagioclasa, sanidina y biotita. Las areniscas y los conglomerados también presentan fragmentos pumíceos, líticos dacíticos, y minerales o litoclastos de la Formación Acoite. Asimismo, hay areniscas cuarzosas (Coira et al. 2004: 30-32).

Del mismo modo, la Formación Puerta de San Pedro (Mioceno Superior-Plioceno) presenta conglomerados, junto con areniscas y aglomerados volcánicos. Aflora en fajas desde el límite con Bolivia hasta la latitud de Orosmayo, en el flanco occidental de la sierra de Rinconada, así como en el sector marginal del valle del río Santa Catalina, particularmente en su margen occidental (Coira et al. 2004: 70).

Los depósitos aluviales y coluviales modernos (Plioceno-Pleistoceno) están integrados por conglomerados, junto con areniscas y limoarcilitas. Se distribuyen en el valle del río Santa Catalina, en el faldeo oriental de la sierra de Rinconada, desde el límite argentino-boliviano hasta Pan de Azúcar, formando depósitos de pie de monte (Coira et al. 2004: 71).

Asimismo, en la puna se encuentran depósitos evaporíticos de importancia, que constituyen los salares de la puna (Ramos y Coira 2008). En la zona de la laguna de Pozuelos se intercalan con limolitas y areniscas finas (Coira et al. 2004).

Otras rocas muy difundidas en el ámbito puneño, como señalamos anteriormente, son las volcánicas. Las más antiguas son las del Complejo magmático-sedimentario Cochinoca-Escaya (Ordovícico), cuyas facies sedimentarias se mencionaron anteriormente. Las magmatitas de esta formación incluyen lavas, hialoclastitas-brechas, sills, diques y cuerpos subvolcánicos, con composiciones mayormente silíceas y básicas subordinadas. Incluyen rocas microporfíricas con fenocristales de plagioclasa, en una matriz clorítica, o bien presentan texturas granulares finas cloríticas. También hay basaltos alcalinos y basanitas, afíricos a pobremente porfíricos. Las rocas dacíticas son las más representadas, conformando los núcleos de las sierras de Quichagua y Queta, y 
son porfíricas, con fenocristales de feldespato alcalino, plagioclasa, cuarzo y biotita, dentro de una matriz microcristalina (Coira et al. 2004: 11-12).

Otras rocas volcánicas son las del Complejo volcánico dómico Casa ColoradaMinuyoc (Mioceno), en donde se incluyen los domos de Casa Colorada y Minuyoc, que son pequeños y de composición dacítica (Coira et al. 2004: 26).

Bajo el nombre Complejo volcánico dómico Lagunas de Pozuelos (Mioceno) se agrupan los cerros de Pan de Azúcar, Cerro León Grande y Chico, Chinchillas, Cerro Redondo y Pórfiro de Poquis, entre otros, compuestas por rocas piroclásticas y lávicas de composición dacítica, de tamaño pequeño y morfologías dómicas. La dacita de la Mina Pan de Azúcar presenta mineralización de plata, plomo y zinc, que ha sido atribuida a la alteración hidrotermal. Las lavas están compuestas por fenocristales de cuarzo, plagioclasa tabular, biotita y ocasionalmente hornblenda en prismas finos, en una matriz afanítica (Coira et al. 2004: 34-35). Las lavas de todos los complejos son muy parecidas (Coira et al. 2004).

Estos fenómenos volcánicos provocaron alteraciones hidrotermales, que modifican las rocas preexistentes en apariencia y composición mineralógica. Además, las volcanitas siempre tienen enclaves metamórficos y de rocas máficas, ricos en biotita y/u hornblenda (Caffe et al. 2008).

La denominación Complejo volcánico Coranzulí agrupa a secuencias piroclásticas y lávicas, de composición andesítico-dacíticas, que conforman el estratovolcán Rachaite, y las secuencias ignimbríticas y lavas dacíticas que se vinculan al centro caldérico del cerro Coranzulí. Este complejo agrupa lo que se conoce como Formación Doncellas, formada por tobas gruesas a brechosas; la Formación Alto Laguna, con ignimbritas, y otras ignimbritas de distintos nombres; todas con afloramientos al sur de nuestra área de estudio (Coira et al. 2004: 46-50).

El Complejo volcánico Vilama-Coruto también está conformado por varias unidades, que incluyen la Ignimbrita Granada, la Ignimbrita Vilama, de composición dacítica, y distintas lavas de composición dacítico andesítica (Coira et al. 2004).

Una síntesis de la geología local, con los afloramientos de los principales tipos de rocas que hemos mencionado en el texto, puede observarse en la Figura 6.1. 


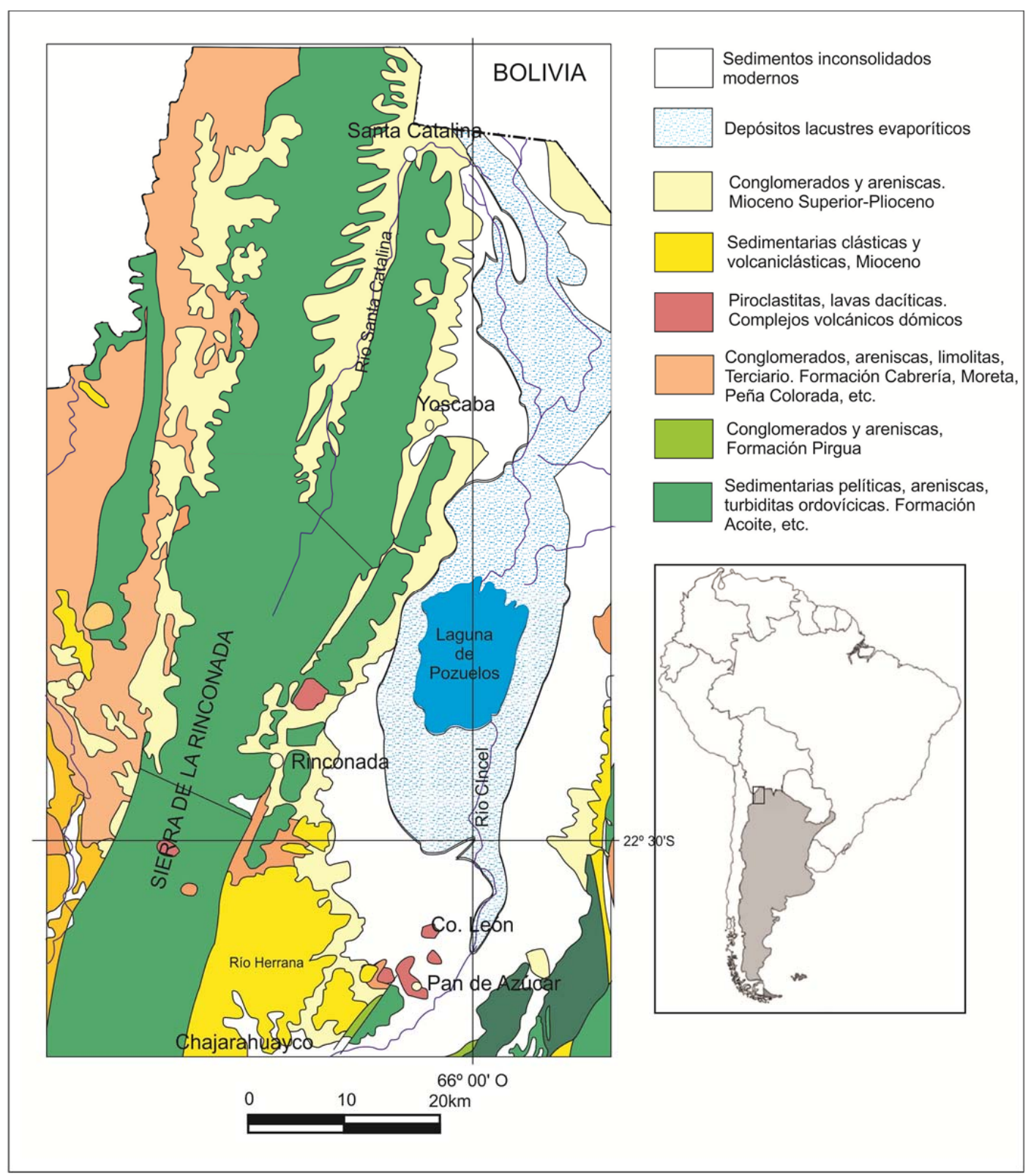

Figura 6.1 Mapa geológico del área de estudio. Dibujado y sintetizado a partir del Mapa Geológico de la Provincia de Jujuy (Coira y Zappettini 2008).

En resumen, vemos que la geología local está básicamente representada por rocas sedimentarias, algunas con deformación, que se presentan en diferentes granulometrías y coloraciones, en afloramientos que abarcan toda el área de estudio y zonas vecinas. Además, también son abundantes las rocas ígneas volcánicas, de composición básicamente andesítica y dacítica. Las rocas metamórficas, por su parte son muy escasas, y se presentan en aureolas de cuerpos dacíticos o en el metamorfismo incipiente de las formaciones sedimentarias más deformadas. 


\section{Clasificación submacroscópica de pastas:}

Para comenzar a comparar la geología local con las inclusiones presentes en la cerámica y realizar una primera aproximación a las materias primas empleadas en la manufactura, realizamos una primera observación de las pastas en lupa binocular. Asimismo, la observación de fracturas frescas por este medio, permite observar otros atributos mencionados en la metodología, algunos vinculados a la cocción, como la presencia de núcleos y la distribución del color y otros al modelado, como la orientación de las inclusiones (descritos en los capítulos próximos).

En base a la identificación de las inclusiones presentes y de ciertos atributos en los que se registraron diferencias, como la textura, la regularidad de la fractura y la densidad, orientación, granulometría y selección de las inclusiones se clasificaron los 1225 fragmentos analizados en la lupa en 9 grupos de pastas (en adelante GP) distintos. Estos son de carácter preliminar, teniendo en cuenta las limitaciones de la lupa binocular, pero sirvieron de base para seleccionar la muestra para los análisis microscópicos subsiguientes.

A continuación se describen las principales características de los grupos de pastas identificados, dejando para capítulos subsiguientes la correlación de los mismos con las morfologías y tratamientos de superficie de las piezas analizadas.

Grupo de pastas 1 (GP 1): está conformado por 112 fragmentos (9.2\% del total). En la Tabla 6.1 se puede observar de qué sitios proceden. Su aspecto es mayormente compacto (73:112), pero puede ser no compacto (39:112), y su textura es predominantemente porosa (95:112), aunque en muchos fragmentos se observa una textura laminar (17:112), dada por la orientación de las micas en la pasta. La superficie de las fracturas es irregular y las cavidades son pequeñas. Las inclusiones son densas (82:112) a muy densas (30:112) (20 a 30\%), con orientación irregular (67:112) a regular parcial (de las micas) (45:112) y selección pobre (66:112) a equilibrada (46:112). Además, las micas son angulosas y los cuarzos, subangulosos a redondeados. La granulometría es variable, con inclusiones de finas a gruesas, pero predominando los tamaños intermedios.

Las inclusiones que pudieron identificarse consisten predominantemente en mineraloclastos de biotita muy abundante, que es lo que permite separar a este grupo 
de fragmentos de los demás. Le sigue el cuarzo traslúcido, y en menor medida minerales félsicos, feldespatos alterados, y litoclastos consistentes en fragmentos de rocas sedimentarias de distintos colores (rojas, marrones, grises).

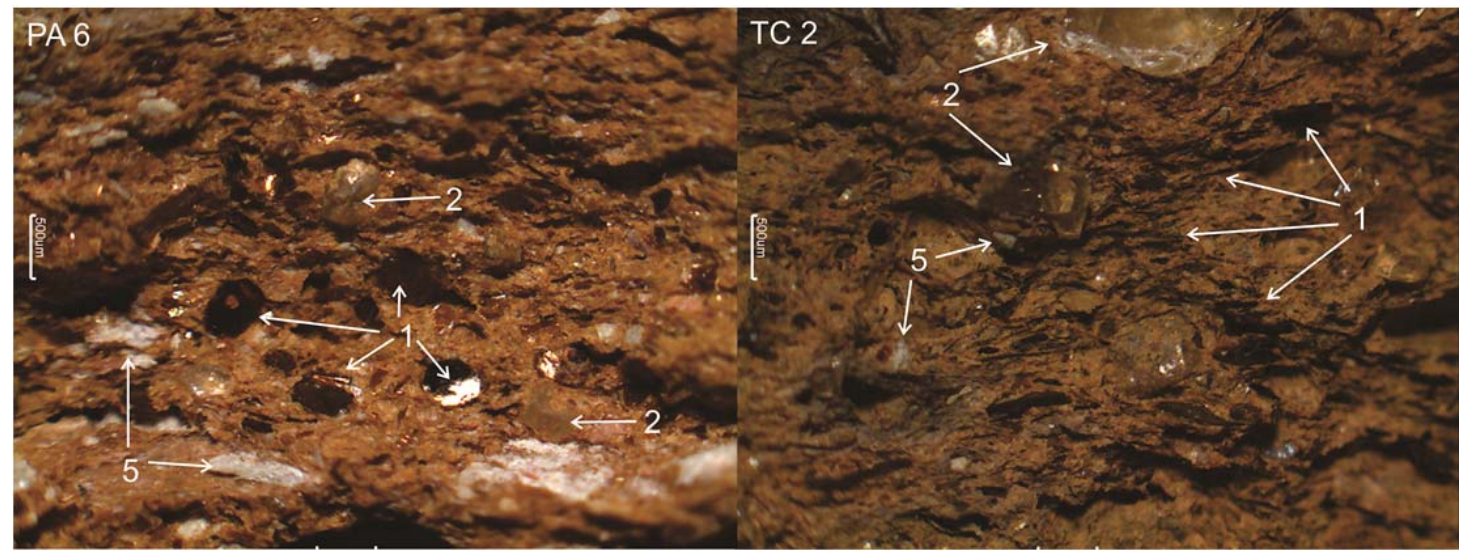

Figura 6.2 Pastas del GP 1 en lupa binocular. La primera fotografía es de un fragmento de PA 6 y la segunda de TC 2. Ref.: 1: biotita; 2: cuarzo, 5: sedimentarias blancas o feldespatos alterados.

Grupo de pastas 2 (GP 2): comprende 146 fragmentos (12\% del total), cuya procedencia se puede observar en la Tabla 6.1. Son fragmentos de textura porosa, con cavidades pequeñas y, en pocos casos, algunas grandes (15:146). Las inclusiones son densas (20\%), con orientación irregular mayormente, con algunos casos de orientación regular parcial (10:146). Su selección es pobre a equilibrada, con algunos fragmentos en los que la selección es buena (31:146), y son de subangulares a subredondeadas y redondeadas, especialmente los cuarzos, que son los que presentan mayor grado de redondez. La granulometría de las inclusiones es variable, de finas a gruesas, aunque predominan los tamaños medianos a finos.

Entre las inclusiones que pudieron identificarse, los mineraloclastos más abundantes son los cuarzos, que es lo que nos condujo a separar estos fragmentos en un grupo. También están presentes las micas (biotita), muchas veces de manera abundante; minerales félsicos indeterminados, feldespatos alterados, y son frecuentes los litoclastos de rocas sedimentarias rojas, marrones y blancas. 


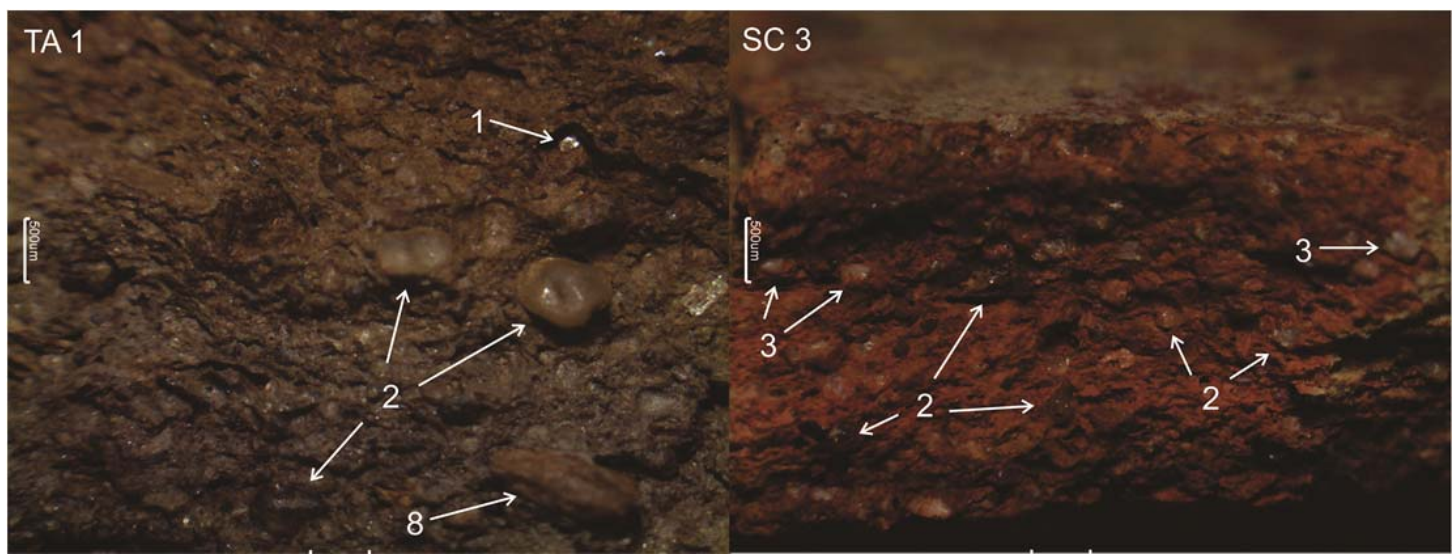

Figura 6.3 Pastas del GP 2 en lupa binocular. La primera fotografía es de un fragmento de TA 1 y la segunda de SC 3. Ref.: 1: biotita; 2: cuarzo; 3: minerales félsicos indeterminados; 8: sedimentaria marrón.

Grupo de pastas 3 (GP 3): comprende 214 fragmentos (17.6\%), cuya procedencia se puede observar en la Tabla 6.1. Su aspecto es compacto y la textura porosa. Presentan cavidades pequeñas (180:214) o pequeñas y grandes (34:214). Por otro lado, la mayoría de los fragmentos son resistentes a la fractura (152:214), probablemente por poseer pastas más compactas que otros grupos. Las inclusiones son densas (20\%), con algunos casos de poco densas a densas (10 a 20\%) (37:214). Muestran una orientación irregular, siendo regular parcial en 17 fragmentos, y selección de pobre a equilibrada. Asimismo, son subangulares a subredondeadas predominantemente, con algunos casos que también tienen inclusiones redondeadas (30:214), que consisten predominantemente en mineraloclastos de cuarzo. Las inclusiones exhiben una granulometría diversa, de finas a gruesas, aunque predominan los tamaños intermedios.

Las inclusiones más características, que permiten separar a estos fragmentos en un grupo, son los litoclastos sedimentarios de color blanco, acompañados en la mayoría de los casos por rosados y/o grises. También se encuentran con frecuencia mineraloclastos de cuarzo traslúcido, biotita, y otros litoclastos sedimentarios rojos y marrones en menor cantidad. Éstos fragmentos fueron clasificados, en su mayoría, de acuerdo a las observaciones macroscópicas, como alfarería muy semejante a lo descrito como "estilo Yavi" (Krapovickas 1973; 1975; Krapovickas et al. 1989). 


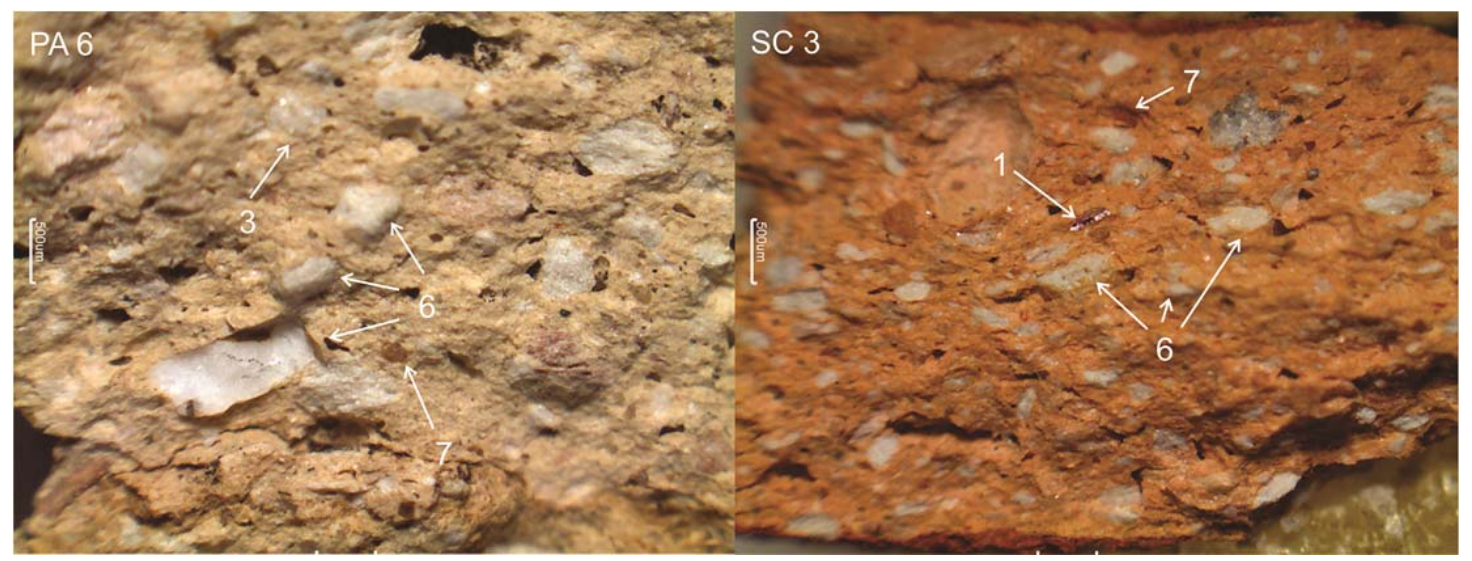

Figura 6.4 Pastas del GP 3 en lupa binocular. La primera fotografía es de un fragmento de PA 6 y la segunda de SC 3. Ref.: 1: biotita; 3: minerales félsicos; 6 : sedimentarias blancas; 7: sedimentarias rojas.

Grupo de pastas 4 (GP 4): este grupo está constituido por 379 fragmentos (31.1\%), cuya procedencia se puede observar en la Tabla 6.1. Su textura es porosa, con dos fragmentos que se presentan con textura laminar, dada por la abundancia de litoclastos sedimentarios que exhiben esa misma característica. Poseen cavidades pequeñas, y algunos fragmentos, pequeñas y grandes (47:379). Las inclusiones son densas (20\%) a muy densas (20 a 30\%), siendo de poco densas a densas (10 a 20\%) en algunos casos (32:379). La orientación es irregular (293:379) a regular parcial (86:379), y la selección es variable, de buena a pobre, predominando la pobre o muy pobre (239:379) y seguido por la equilibrada (113:379) y la buena (27:379). La granulometría de las inclusiones es muy variable, pero predominan las medias y finas.

Los mineraloclastos más abundantes son el cuarzo traslúcido y la mica (biotita). También son frecuentes los litoclastos de rocas sedimentarias rojas, marrones y blancas, y algunos clastos que pueden ser sedimentarias blancas o feldespatos alterados. Otras inclusiones menos frecuentes son posibles litoclastos volcánicos, litoclastos plutónicos, que aparecen muy escasamente, y mineraloclastos de cuarzo o feldespato. Estos fragmentos se agruparon dado que en ellos no predomina ningún tipo de inclusión sobre los otros, como sucede en los grupos anteriores. Este tipo de pastas es el más abundante en todos los sitios de la cuenca sur de Pozuelos, como se observa en la Tabla 6.1. 


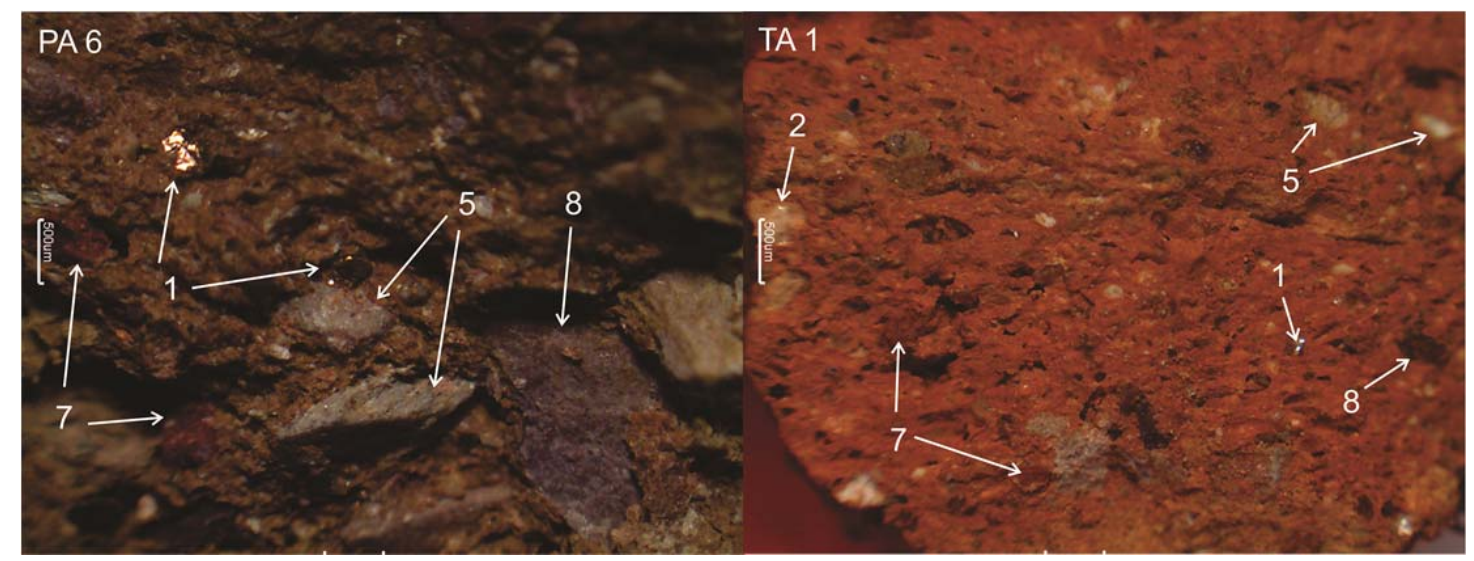

Figura 6.5 Pastas del GP 4 en lupa binocular. La primera fotografía es de un fragmento de PA 6 y la segunda de TA 1. Ref.: 1: biotita; 2: cuarzo; 5: sedimentarias blancas o feldespatos alterados; 7 : sedimentarias rojas; 8: sedimentarias marrones.

Grupo de pastas 5 (GP 5): comprende 134 fragmentos (11\%), cuya procedencia puede observarse en la Tabla 6.1. Su aspecto es compacto y la textura, porosa. Además, la mayor parte de los fragmentos (126:134) son resistentes a la fractura. Presentan cavidades pequeñas y en algunos casos, pequeñas y grandes (36:134). Las inclusiones son poco densas (5 a 10\%), con orientación irregular a regular parcial en algunos fragmentos (14:134). La selección es equilibrada a muy buena, con algunos fragmentos de selección pobre (8:134). La redondez es variable, de angulosa a redondeada, y la granulometría es de fina a media, lo que hace que las inclusiones no sean visibles a simple vista, sin el aumento de la lupa. Estas inclusiones finas y su baja densidad nos llevaron a agrupar estas pastas separadamente de las demás.

Las inclusiones más comunes incluyen mineraloclastos de cuarzo traslúcido, feldespatos alterados, mica fina, cuarzo feldespato y litoclastos de sedimentarias rojas, blancas y grises, sin que predomine ningún tipo en especial. 


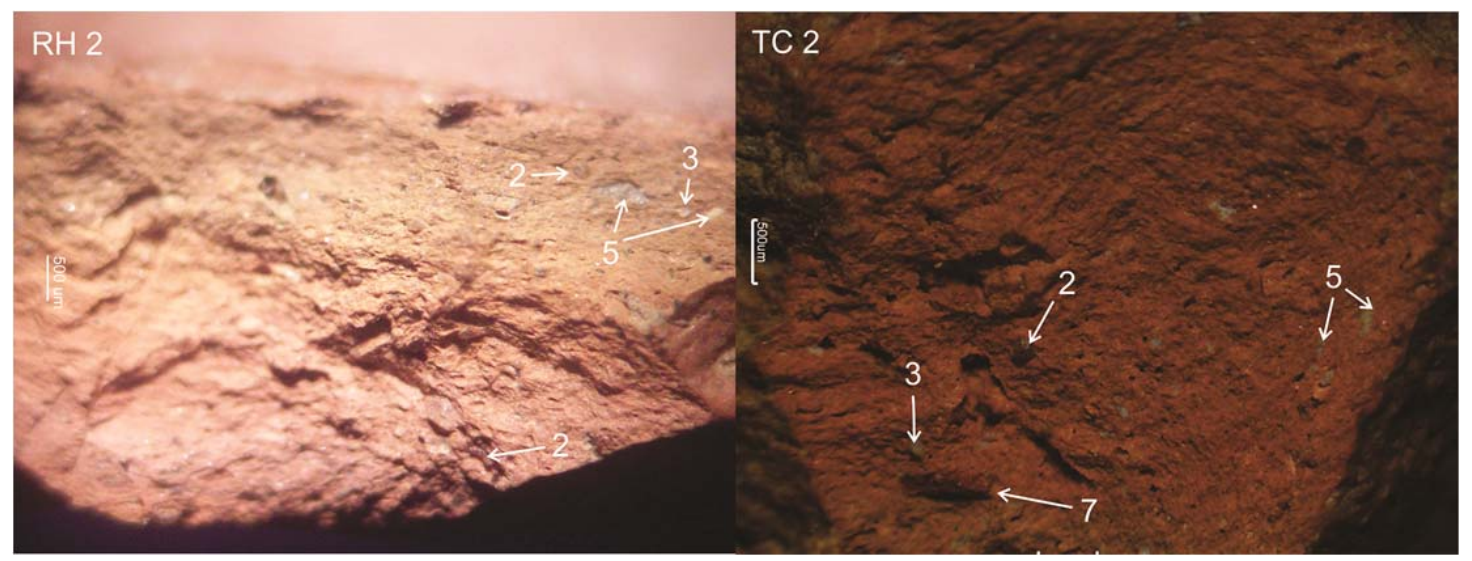

Figura 6.6 Pastas del GP 5 en lupa binocular. La primera fotografía es de un fragmento de RH 2-1 y la segunda de TC 2. Ref.: 2: cuarzo; 3: minerales félsicos; 5: sedimentarias blancas o feldespatos alterados; 7 : sedimentarias rojas.

Grupo de pastas 6 (GP 6): este grupo de pasta consta sólo de cuatro fragmentos (0.3\%) procedentes de la excavación de $\mathrm{CH} 25-1$. Su aspecto es compacto y la textura es porosa a laminar, por la abundancia de mica. Se observan cavidades pequeñas. Las inclusiones son densas (20\%), con orientación regular parcial de las micas, selección pobre y granulometría mayormente gruesa. Son angulosas predominantemente, e incluyen muscovita muy abundante (que es lo que caracteriza al grupo), cuarzo traslúcido y cuarzo blanco, y en menor medida, biotita. Los fragmentos corresponden a una misma pieza cerrada, como se verá más adelante.

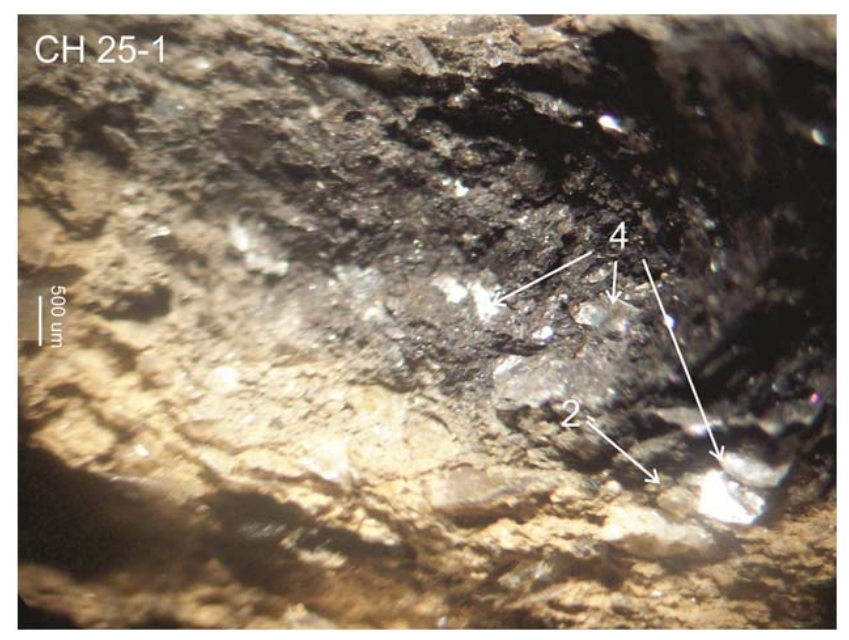

Figura 6.7 Pasta del GP 6 en lupa binocular, del sitio CH 25-1. Ref.: 2: cuarzo; 4: muscovita. 
Grupo de pastas 7 (GP 7): se clasificaron en este grupo 23 fragmentos (1.9\%), todos los cuales proceden de PA 22. Su textura es porosa, con cavidades pequeñas y en 7 ejemplares, algunas grandes. Las inclusiones son densas (20\%) a poco densas (10\%) en algunos casos (4:23), con orientación irregular, y selección pobre (9:23) a equilibrada o buena (14:23). Las inclusiones son subangulosas a subredondeadas mayormente, y predominan las granulometrías medias a finas.

Los mineraloclastos más comunes son de cuarzo traslúcido, seguidos por cuarzos o feldespatos y biotita, y en menor medida feldespatos alterados y cuarzo de color ámbar. También se observan algunos litoclastos plutónicos y cuarcitas, faltando los litoclastos sedimentarios que se observaron en las pastas anteriores. Esta litología llevo a separar a estos fragmentos en un grupo.

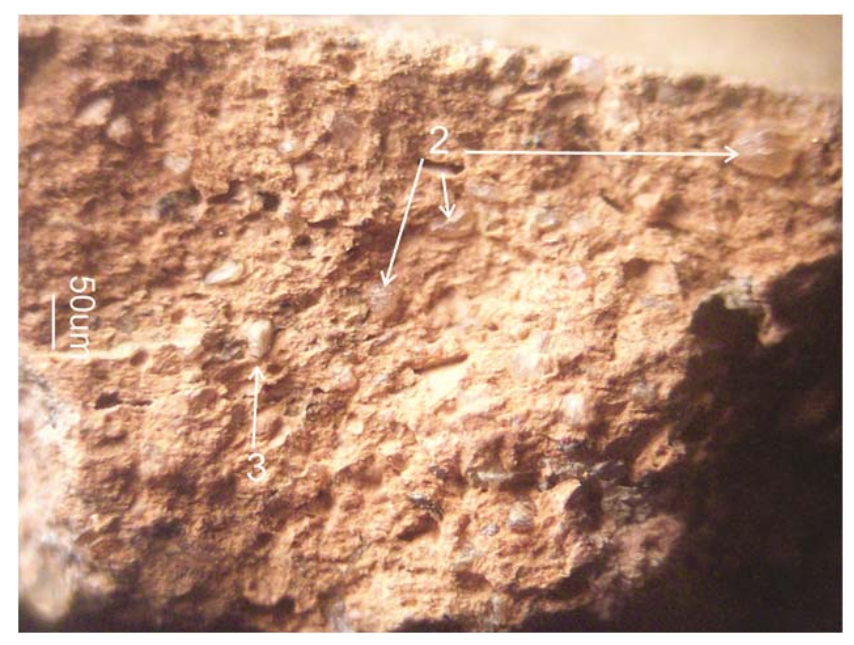

Figura 6.8 Pasta del GP 7 en lupa binocular, del sitio PA 22-Sondeo 1. Ref.: 2: cuarzo; 3: minerales félsicos.

Grupo de pastas 8 (GP 8): consiste en 188 fragmentos (15,4\%), todos procedentes de Santa Catalina 3 y Timón Cruz 2, como se observa en la Tabla 6.1. Su textura es porosa, con cavidades pequeñas y, en algunos casos (27:188), pequeñas y grandes. Las inclusiones son densas (20\%) en general, pero en 20 fragmentos son de poco densas a densas (10 a 20\%). La orientación de las mismas es irregular, aunque en 8 fragmentos es regular parcial. La selección es predominantemente pobre, con algunos fragmentos con selección equilibrada a buena (23:188). Las inclusiones son mayormente de subangulosas a subredondeadas, y su granulometría es variable, aunque predominan los tamaños medios. 
Las inclusiones más abundantes son los litoclastos sedimentarios, de distintos colores (marrones, grises, rojos, blancos). También se observan mineraloclastos en menor cantidad, como cuarzo traslúcido, mica (biotita) muchas veces fina, y cuarzo feldespato. La abundancia de litoclastos sedimentarios, con diferentes colores, nos llevó a agrupar a estos fragmentos. Los separamos del GP 4 por presentar en general pastas más compactas y porque proceden de una zona geográfica distinta que este grupo. Tampoco pudieron agruparse con las del GP 3 porque, si bien predominan los litoclastos sedimentarios, estos no son mayormente blancos o rosados como en ese grupo.

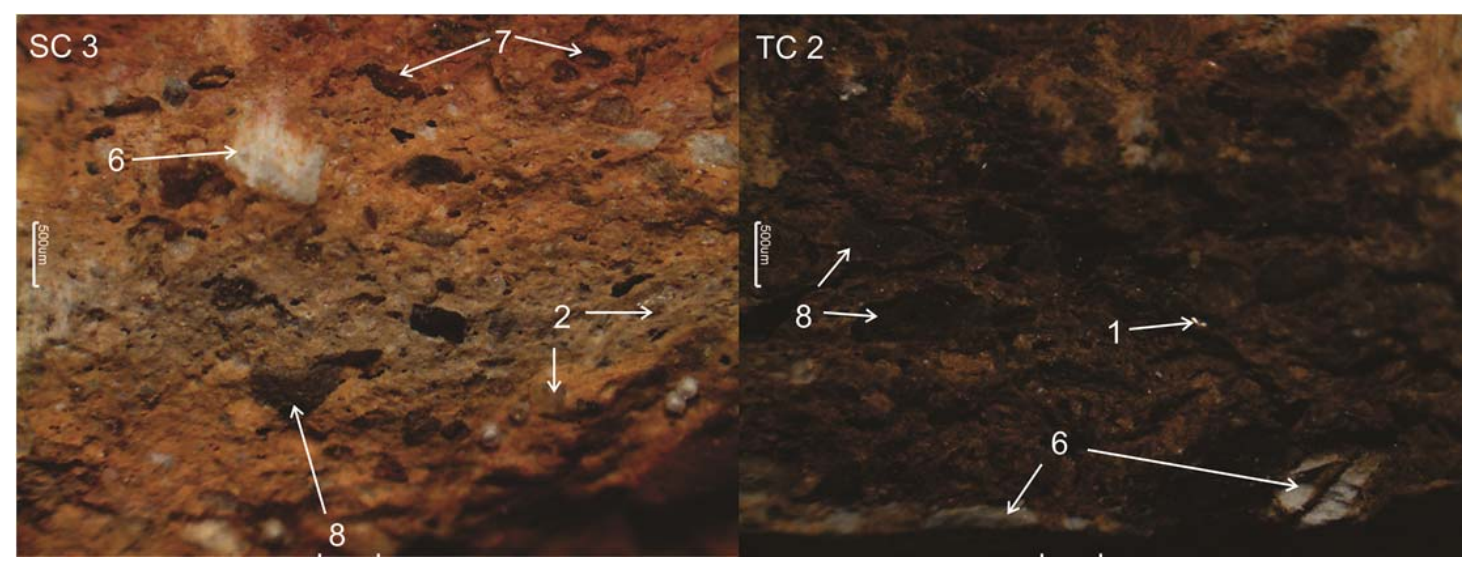

Figura 6.9 Pastas del GP 8 en lupa binocular. La primera fotografía es de un fragmento de SC 3 y la segunda de TC 2. Ref.: 1: biotita; 2: cuarzo; 6: sedimentarias blancas; 7: sedimentarias rojas; 8: sedimentarias marrones.

Grupo de pastas 9 (GP 9): comprende a 19 fragmentos (1.6\%), todos procedentes de SC 3. Presentan textura porosa y cavidades pequeñas. Las inclusiones son mayormente densas (20\%), con tres fragmentos con inclusiones poco densas a densas (10 a 20\%). Su orientación es irregular. La selección es mayormente equilibrada a buena y la granulometría es de media a fina.

Las inclusiones más abundantes son los mineraloclastos de cuarzo, seguidos por posibles litoclastos sedimentarios blancos o feldespatos alterados. En menor cantidad hay litoclastos sedimentarios rojos, mica y unos litoclastos oscuros cuya litología no se pudo identificar con la lupa binocular. Cabe destacar que buena parte de estos fragmentos presenta estrías de modelado con torno $(n=17)$. Esa característica, asociada a la litología de las inclusiones y las diferencias con las pastas del GP 2, que son menos 
compactas, no presentan las inclusiones negras indeterminadas y tienen mayor presencia de mica y litoclastos sedimentarios, llevó a separar estos fragmentos en un nuevo conjunto.

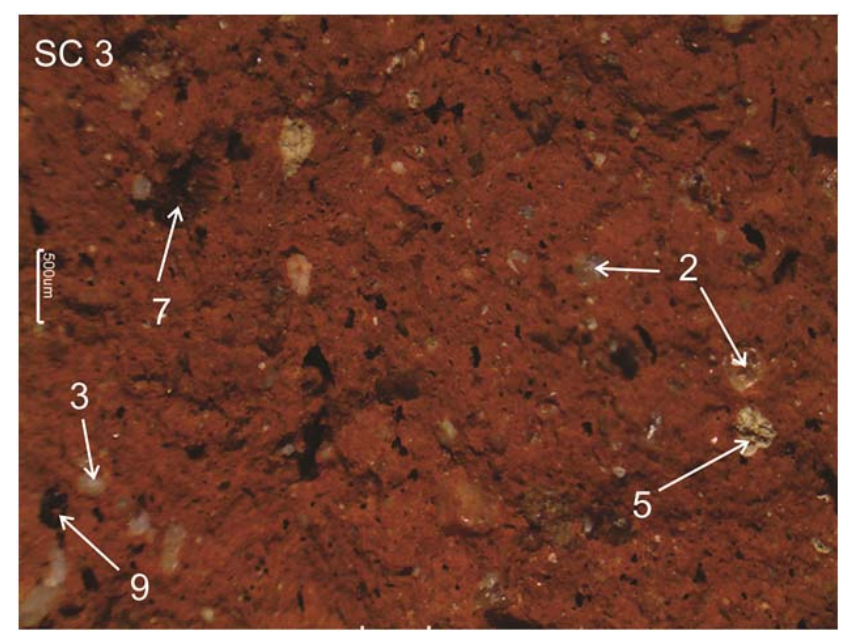

Figura 6.10 Pasta del GP 9 en lupa binocular, del sitio SC 3. Ref.: 2: cuarzo; 3: minerales félsicos; 5: sedimentarias blancas o feldespatos alterados; 7: sedimentarias rojas; 9: litoclastos oscuros indeterminados.

Del total de fragmentos analizados, seis (0.5\%), tres procedentes de PA 22, uno de SC 3 y dos de TC 2, no pudieron ser agrupados en ninguno de los grupos de pastas descritos, porque la litología de las inclusiones no pudo determinarse, o no se asemeja a la de los grupos identificados o no se pudieron observar inclusiones en la lupa, por lo que quedan afuera del análisis de pastas.

En las siguientes tablas se puede observar cómo se distribuyen los grupos de pastas en los diferentes sitios analizados (Tabla 6.1), representado en forma de gráfico de barras en la Figura 6.11, como así también una síntesis de los principales atributos que caracterizan cada GP (Tabla 6.2).

La segunda tabla (Tabla 6.2) permite apreciar que los tipos de inclusiones presentes en los distintos grupos de pastas son bastante homogéneos, destacándose la presencia de mineraloclastos como cuarzo, biotita, minerales félsicos, feldespatos alterados y litoclastos sedimentarios, que presentan diferentes colores a simple vista. A pesar de esta homogeneidad, sí varía la abundancia de estos componentes de grupo en grupo, lo que sumado a otros atributos, como la textura y la densidad, permitieron separar las pastas bajo análisis. Asimismo, hay tipos de inclusiones que solo están presentes en 
algunos tipos de pastas, diferenciándolas de las demás, como la muscovita y los litoclastos oscuros indeterminados.

\begin{tabular}{|c|c|c|c|c|c|c|c|c|c|c|c|c|}
\hline & CH 25-1 & CH 25-2 & PA 6 & PA 22-S1 & RH 2-1 & RH 10-1 & RH 19-1 & RH 19-7 & TA 1 & SC 3 & TC 2 & TOTAL \\
\hline GP 1 & $\begin{array}{c}5 \\
12.2 \%\end{array}$ & $\begin{array}{c}3 \\
11.5 \%\end{array}$ & $\begin{array}{c}7 \\
5.0 \%\end{array}$ & $\begin{array}{c}12 \\
8.4 \%\end{array}$ & $\begin{array}{c}14 \\
37.8 \%\end{array}$ & $\begin{array}{c}13 \\
27.1 \%\end{array}$ & $\begin{array}{c}3 \\
23.1 \%\end{array}$ & $\begin{array}{c}19 \\
11.1 \%\end{array}$ & $\begin{array}{c}4 \\
7.8 \%\end{array}$ & $\begin{array}{c}6 \\
3.2 \%\end{array}$ & $\begin{array}{c}26 \\
7.2 \%\end{array}$ & $\begin{array}{c}112 \\
9.2 \%\end{array}$ \\
\hline GP 2 & $\begin{array}{c}13 \\
31.7 \%\end{array}$ & $\begin{array}{c}9 \\
34.6 \%\end{array}$ & $\begin{array}{c}8 \\
5.8 \%\end{array}$ & $\begin{array}{c}26 \\
18.2 \%\end{array}$ & $\begin{array}{c}2 \\
5.4 \%\end{array}$ & 0 & $\begin{array}{c}1 \\
7.7 \%\end{array}$ & $\begin{array}{c}35 \\
20.5 \%\end{array}$ & $\begin{array}{c}28 \\
54.9 \%\end{array}$ & $\begin{array}{c}9 \\
4.8 \%\end{array}$ & $\begin{array}{c}16 \\
4.4 \%\end{array}$ & $\begin{array}{l}146 \\
12 \%\end{array}$ \\
\hline GP 3 & $\begin{array}{c}1 \\
2.4 \%\end{array}$ & $\begin{array}{c}1 \\
3.8 \%\end{array}$ & $\begin{array}{c}17 \\
12.2 \%\end{array}$ & $\begin{array}{c}3 \\
2.1 \%\end{array}$ & 0 & $\begin{array}{c}1 \\
2.1 \%\end{array}$ & 0 & $\begin{array}{c}19 \\
11.1 \%\end{array}$ & $\begin{array}{c}7 \\
13.7 \%\end{array}$ & $\begin{array}{c}66 \\
35.1 \%\end{array}$ & $\begin{array}{c}99 \\
27.3 \%\end{array}$ & $\begin{array}{c}214 \\
17.6 \%\end{array}$ \\
\hline GP 4 & $\begin{array}{c}17 \\
41.5 \%\end{array}$ & $\begin{array}{c}13 \\
50.0 \%\end{array}$ & $\begin{array}{c}106 \\
76.3 \%\end{array}$ & $\begin{array}{c}76 \\
53.1 \%\end{array}$ & $\begin{array}{c}19 \\
51.4 \%\end{array}$ & $\begin{array}{c}33 \\
68.8 \%\end{array}$ & $\begin{array}{c}7 \\
53.8 \%\end{array}$ & $\begin{array}{c}96 \\
56.1 \%\end{array}$ & $\begin{array}{c}12 \\
23.5 \%\end{array}$ & 0 & 0 & $\begin{array}{c}377 \\
31.1 \%\end{array}$ \\
\hline GP 5 & $\begin{array}{c}1 \\
2.4 \%\end{array}$ & 0 & $\begin{array}{c}1 \\
0.7 \%\end{array}$ & $\begin{array}{c}3 \\
2.1 \%\end{array}$ & $\begin{array}{c}2 \\
5.4 \%\end{array}$ & $\begin{array}{c}1 \\
2.1 \%\end{array}$ & $\begin{array}{c}2 \\
15.4 \%\end{array}$ & $\begin{array}{c}2 \\
1.2 \%\end{array}$ & 0 & $\begin{array}{c}18 \\
9.6 \%\end{array}$ & $\begin{array}{c}103 \\
28.5 \%\end{array}$ & $\begin{array}{l}135 \\
11 \%\end{array}$ \\
\hline GP 6 & $\begin{array}{c}4 \\
9.8 \%\end{array}$ & 0 & 0 & 0 & 0 & 0 & 0 & 0 & 0 & 0 & 0 & $\begin{array}{c}4 \\
0.3 \%\end{array}$ \\
\hline GP 7 & 0 & 0 & 0 & $\begin{array}{c}23 \\
16.1 \%\end{array}$ & 0 & 0 & 0 & 0 & 0 & 0 & 0 & $\begin{array}{c}23 \\
1.9 \%\end{array}$ \\
\hline GP 8 & 0 & 0 & 0 & 0 & 0 & 0 & 0 & 0 & 0 & $\begin{array}{c}70 \\
37.2 \%\end{array}$ & $\begin{array}{c}118 \\
32.6 \%\end{array}$ & $\begin{array}{c}188 \\
15.4 \%\end{array}$ \\
\hline GP 9 & 0 & 0 & 0 & 0 & 0 & 0 & 0 & 0 & 0 & $\begin{array}{c}19 \\
10.1 \% \\
\end{array}$ & 0 & $\begin{array}{c}19 \\
1.6 \% \\
\end{array}$ \\
\hline TOTAL & 41 & 26 & 139 & 143 & 37 & 48 & 13 & 171 & 51 & 188 & 362 & 1219 \\
\hline
\end{tabular}

Tabla 6.1 Distribución de los Grupos de pasta por sitio, en cantidad de fragmentos y porcentajes del total para cada sitio.

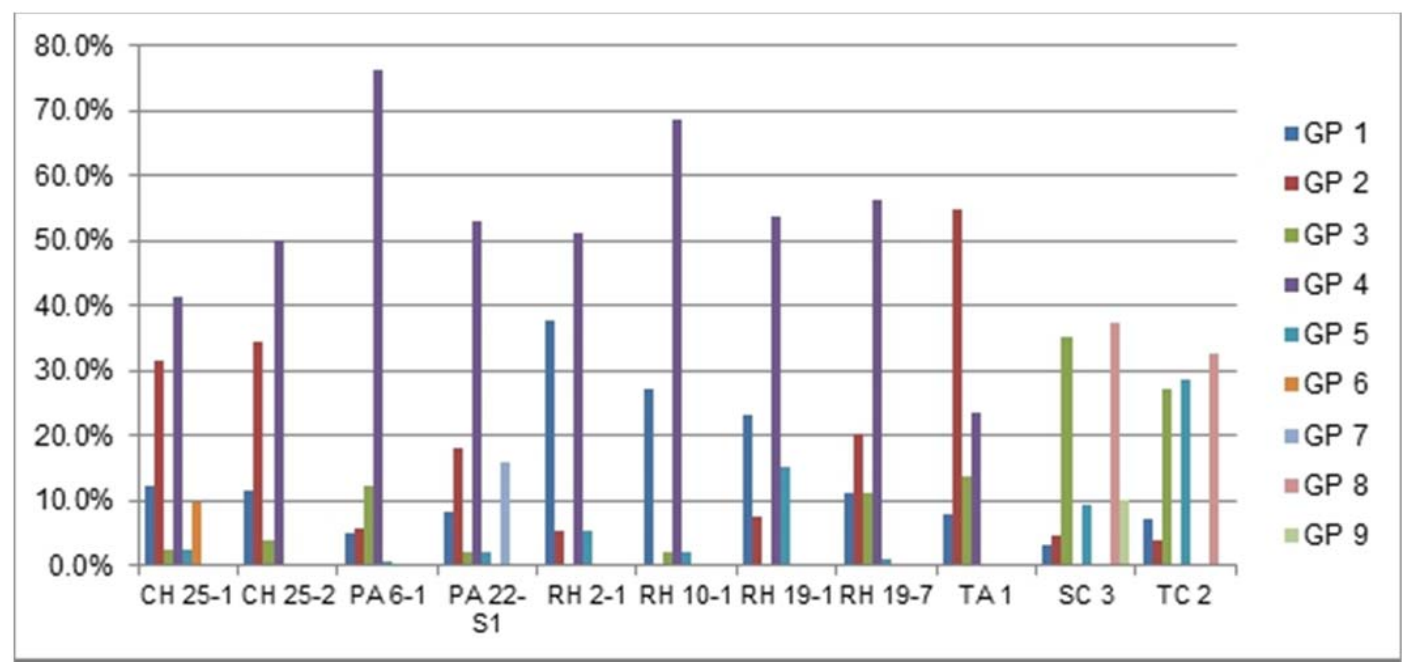

Figura 6.11 Gráfico de barras representando los porcentajes para cada sitio de los GP identificados. 


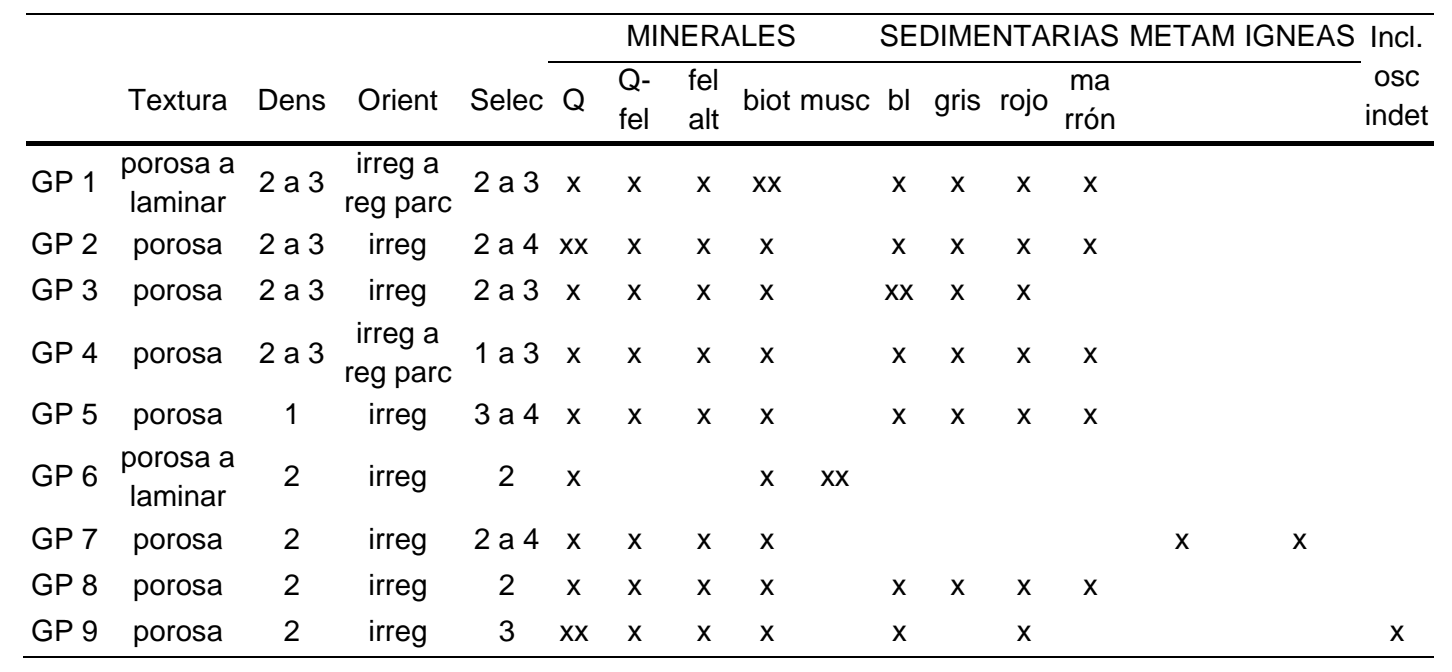

Tabla 6.2 Síntesis de las características principales de cada GP. Ref: Dens: densidad;

Orient: orientación; Selec: selección; Q: cuarzo; fel: feldespato; biot: biotita; musc; muscovita; bl: blanco; incl osc indet: inclusiones oscuras indeterminadas; reg: regular; irreg: irregular; parc: parcial.

Por otro lado, observando la Tabla 6.1 y la Figura 6.11 se nota que los diferentes grupos de pastas se distribuyen diferencialmente en los sitios analizados. Una primera gran distinción, se da entre los sitios de la cuenca sur de Pozuelos y los de la zona de Santa Catalina, lo cual es lógico dado que se trata de dos zonas geográficas separadas de la puna. En los sitios de Pozuelos, predominan los GP 4, 2, y 1, siendo el 4 el más abundante en todos los sitios, excepto en TA 1-1, seguido por los otros dos en diferente orden dependiendo del sitio. En TA 1-1 predomina el GP 2, seguido por el 4. El GP 3 también está presente en casi todos los sitios de Pozuelos, pero en un porcentaje pequeño, aunque en PA 6-1, RH 19-7 y TA1-1 alcanza un porcentaje más considerable, entre el 11 y 14\%. En RH 2-1 y RH 19-1 está completamente ausente. Sin embargo, en los sitios de Santa Catalina, este GP está muy representado, alcanzando un tercio de la muestra.

Otra distinción destacable se da entre los sitios de Pozuelos con fechados prehispánicos y coloniales. En el sitio PA 22-S1 aparece un nuevo grupo de pastas, el GP 7 con litoclastos metamórficos e ígneos y sin sedimentitas (GP 7 de PA 22). Además, en $\mathrm{CH}$ 25-1, que suponemos de época colonial, aparece otro tipo de pasta no presente en los sitios prehispánicos, incluida la estructura 2 del mismo sitio, caracterizado por abundante muscovita (GP 6). Sin embargo, cabe destacar que estos 
tipos representan un porcentaje reducido de la muestra (10 a 16\%), predominando los mismos GP que en los sitios prehispánicos.

En los sitios analizados para la zona de Santa Catalina, también son significativos los GP 5 y 8, aunque su importancia varía entre uno y otro sitio. El GP 5 alcanza un porcentaje importante en TC 2 y mucho menor en SC 3. Por otro lado, el GP 9 solo está presente en este segundo sitio. Además, debe señalarse que este GP incluye fragmentos con estrías de torno, por lo que probablemente se trate de un tipo de pasta poshispánico. Sin embargo, al igual que las pastas poshispánicas de PA 22, este es un tipo minoritario en el total de la muestra del sitio SC 3 (10.1\%).

\section{Las piezas de colección y sus pastas:}

Si bien en las piezas depositadas en los museos no es posible realizar el análisis con lupa binocular que llevamos a cabo sobre el material fragmentario, hemos intentado identificar, en base a observaciones con lupa de mano $(10 \mathrm{x})$ sobre las superficies o en fracturas que en ocasiones presentan estos materiales, grandes categorías de inclusiones para compararlas con las descritas anteriormente, aunque de forma muy general. En la Tabla 6.3 se pueden observar la cantidad de piezas que presentan estas categorías generales de inclusiones, en cada uno de los sitios de donde se extrajeron las piezas relevadas en las colecciones, y los porcentajes correspondientes para cada una de estas categorías sobre el total de piezas de cada sitio. Las piezas que no presentaban inclusiones visibles con lupa no se computaron en la tabla.

Como se puede apreciar, pudieron reconocerse inclusiones como el cuarzo, la mica, inclusiones blancas que pueden ser cuarzo o feldespato, y otras que pueden corresponder a sedimentarias blancas. Asimismo, se observaron otras inclusiones de colores. Al igual que en el análisis con lupa binocular, se registran pastas con abundante cuarzo y/o mica, con cierta importancia en los sitios de Cochinoca, Doncellas, Pucará de

Rinconada, Queta y Sansana. El grupo de pastas que presenta inclusiones de diferentes colores y cuarzo es importante en casi todos los sitios menos Sansana y Doncellas. Las inclusiones de colores a simple vista tienen el aspecto de las sedimentarias rojas, marrones y grises descritas en lupa binocular. También se aprecia que son importantes las pastas con abundantes inclusiones blancas, que consideramos asociado al GP 3, ya que son en todo comparables a las pastas del estilo Yavi. Estas se encuentran presentes en casi todos los sitios analizados menos en Cochinoca. 


\begin{tabular}{|c|c|c|c|c|c|c|c|c|}
\hline & Cochinoca & Doncellas & $\begin{array}{l}\text { Pucará de } \\
\text { Rinconada }\end{array}$ & Queta & Sansana & Sayate & $\begin{array}{c}\text { Yavi } \\
\text { Chico }\end{array}$ & TOTAL \\
\hline \multirow[t]{2}{*}{$Q$ abund } & 0 & 1 & 1 & 4 & 0 & 0 & 0 & 6 \\
\hline & & $5 \%$ & $11.1 \%$ & $10.5 \%$ & & & & $7.5 \%$ \\
\hline \multirow[t]{2}{*}{ Q-mica } & 1 & 3 & 0 & 0 & 1 & 0 & 0 & 5 \\
\hline & $50 \%$ & $15 \%$ & & & $20 \%$ & & & $6.3 \%$ \\
\hline \multirow[t]{2}{*}{ mica abund } & 0 & 2 & 1 & 6 & 0 & 0 & 0 & 9 \\
\hline & & $10 \%$ & $11.1 \%$ & $15.8 \%$ & & & & $11.3 \%$ \\
\hline \multirow[t]{2}{*}{ mica fina } & 0 & 4 & 0 & 3 & 0 & 0 & 0 & 7 \\
\hline & & $20 \%$ & & $7.9 \%$ & & & & $8.8 \%$ \\
\hline \multirow[t]{2}{*}{ Q-mica-incl bl } & 0 & 3 & 0 & 3 & 0 & 0 & 0 & 6 \\
\hline & & $15 \%$ & & $7.9 \%$ & & & & $7.5 \%$ \\
\hline \multirow[t]{2}{*}{ incl colores-Q } & 1 & 1 & 2 & 9 & 0 & 2 & 2 & 17 \\
\hline & $50 \%$ & $5 \%$ & $22.2 \%$ & $23.7 \%$ & & $66.6 \%$ & $66.6 \%$ & $21.3 \%$ \\
\hline \multirow[t]{2}{*}{ mica-incl osc } & 0 & 1 & 0 & 1 & 0 & 0 & 0 & 2 \\
\hline & & $5 \%$ & & $2.6 \%$ & & & & $2.5 \%$ \\
\hline \multirow[t]{2}{*}{ incl bl abund } & 0 & 5 & 3 & 9 & 4 & 1 & 1 & 23 \\
\hline & & $25 \%$ & $33.3 \%$ & $23.7 \%$ & $80 \%$ & $33.3 \%$ & $33.3 \%$ & $28.8 \%$ \\
\hline \multirow[t]{2}{*}{ incl bl-incl osc } & 0 & 0 & 2 & 3 & 0 & 0 & 0 & 5 \\
\hline & & & $22.2 \%$ & $7.9 \%$ & & & & $6.3 \%$ \\
\hline TOTAL & 2 & 20 & 9 & 38 & 5 & 3 & 3 & 80 \\
\hline
\end{tabular}

Tabla 6.3 Tipos de inclusiones observados en piezas de colección en cantidades y porcentaje por sitio. Ref.: Q: cuarzo; abund: abundante; incl: inclusiones; bl: blancas; osc: oscuras.

El tipo de inclusiones identificadas, aún a un nivel tan general, no difiere de aquellas observadas en las pastas del material fragmentario. Lo que si difiere del análisis con lupa es que los tipos de inclusiones identificados no exhiben un patrón claro de distribución en los diferentes sitios. Esto puede deberse a que, además de ser categorías tan generales, se trata de pocas piezas por sitio, por lo que sería necesario ampliar la muestra para observar patrones. En sitios del "área Yavi" como Sansana y Yavi Chico, además de las pastas Yavi, se observan otros tipos de inclusiones. Sin embargo en Sansana predominan las primeras. Por otro lado, el resto de los sitios, que se ubicarían dentro del "área de influencia Casabindo", muestran tipos de inclusiones variados, e incluyen pastas tipo Yavi en un porcentaje importante, salvo Cochinoca, como se mencionó, pero solo pudimos acceder a dos piezas de ese sitio.

Otro factor importante es que la mayoría de estas piezas proceden de contextos funerarios. Quizás ello también influya, aunque en capítulos posteriores, a partir de los 
demás atributos analizados para las piezas de colección, contemplaremos estas diferencias de contexto y del material de cada uno de ellos.

\section{Caracterización petrográfica de las pastas:}

En base a la clasificación preliminar en lupa binocular y las diferencias observadas que se han detallado anteriormente, se seleccionó una muestra de fragmentos para cortes petrográficos, como se describió en la metodología, en el Capítulo 5, a fin de profundizar en la caracterización de las pastas y su comparación con la geología local.

En total, se realizaron 70 cortes delgados, correspondientes a los diferentes grupos de pastas y a los distintos sitios analizados. Sobre la base de la clasificación en lupa, se prefirió cortar fragmentos correspondientes bordes dentro de cada grupo de pastas y de los grupos de fragmentos y fragmentos no agrupados identificados, a fin de orientar los cortes perpendiculares al plano de la boca para obtener información sobre la orientación de las inclusiones (que se discute en el capítulo siguiente) y poder vincular las observaciones de pastas a morfologías concretas. La procedencia, el tipo de pieza al que corresponden, el tipo de pasta y la orientación del corte se sintetizan en la Tabla 6.4 . 


\begin{tabular}{|c|c|c|c|c|c|c|}
\hline $\mathrm{N}^{\circ}$ & Sitio/UP & GF/Fgto $n^{\circ}$ & Fgto & Morfología & G Pasta & Orientación \\
\hline 1 & RH 19-7/102 & 11 & cuerpo & escudilla & 1 & PPB \\
\hline 2 & RH 10-1/N 1 & 6 & cuerpo & indet & 1 & indet \\
\hline 3 & $\mathrm{RH} 2-1 / 401$ & 1 & borde & escudilla & 1 & PPB \\
\hline 4 & $\mathrm{RH} 2-1 / 151$ & 2 & cuerpo & cerrada & 1 & PPB \\
\hline 5 & RH $10-1 /$ N 2 & 2 & cuerpo & escudilla & 1 & indet \\
\hline 6 & RH 19-7/201 & 1 & cuerpo & cerrada & 3 & PPB \\
\hline 7 & RH 19-7/102 & 2 & cuerpo & indet & 3 & PPB \\
\hline 8 & $\mathrm{RH} 19-7 / 100-200$ & 3 & cuerpo & indet & 3 & indet \\
\hline 9 & PA 22-S1/101 & fgto 27 & borde & cerrada & 3 & PPB \\
\hline 10 & RH 19-7/101 & 10 & cuerpo & escudilla & 2 & indet \\
\hline 11 & RH 19-7/R 16 & 13 & borde & escudilla & 2 & PPB \\
\hline 12 & RH 19-7/102 & 16 & borde & abierta & 2 & PPB \\
\hline 13 & RH 19-7/202 & 17 & borde & abierta & 2 & PPB \\
\hline 14 & PA 22-S1/101 & fgto 30 & borde & cerrada & 2 & PPB \\
\hline 15 & RH 19-7/103 & 15 & borde & abierta & 4 & PPB \\
\hline 16 & RH 19-7/202 & fgto 65 & cuerpo & indet & 5 & indet \\
\hline 17 & PA 22-S1/102 & fgto 67 & borde & abierta & 5 & PPB \\
\hline 18 & RH 19-7/102 & 4 & cuerpo & cerrada & 4 & indet \\
\hline 19 & RH 19-7/102 & 5 & borde & abierta & 4 & PPB \\
\hline 20 & RH 19-7/TN4 & 6 & borde & cerrada & 4 & PPB \\
\hline 21 & RH 19-7/103 & 8 & borde & escudilla & 4 & PPB \\
\hline 22 & RH 19-7/101 & 19 & borde & cerrada & 4 & PPB \\
\hline 23 & RH $10-1 /$ N 1 & 1 & cuerpo & escudilla & 4 & PPB \\
\hline 24 & RH 10-1/N 2 & fgto $n^{\circ} 4$ & borde & abierta & 4 & PPB \\
\hline 25 & RH 10-1/N 2 & fgto $n^{0} 5$ & borde & abierta & 4 & PPB \\
\hline 26 & $\mathrm{CH} 25-1 / 102$ & 2 & cuerpo & cerrada & 6 & PPB \\
\hline 27 & PA 22-S1/101 & fgto 32 & pto inflex & cerrada & 7 & PPB \\
\hline 28 & PA 22-S1/103 & fgto 102 & cuerpo & indet & 7 & indet \\
\hline 29 & PA 22-S1/sup & fgto 3 & base & indet & 7 & PPBa \\
\hline 30 & PA 22-S1/102 & fgto 72 & cuerpo & indet & 7 & indet \\
\hline 31 & PA 6-Est $1 / 301$ & 1 & borde & cerrada & 4 & PPB \\
\hline 32 & PA 6-Est $1 / 202$ & 2 & borde & cerrada & 1 & PPB \\
\hline 33 & PA 6-Est 1/202 & 3 & borde & cerrada & 3 & PPB \\
\hline 34 & PA 6-Est $1 / 202$ & 5 & borde & abierta & 4 & PPB \\
\hline 35 & PA 6-Est $1 / 302$ & 6 & borde & abierta & 3 & PPB \\
\hline 36 & PA 6-Est $1 / 202$ & 7 & borde & abierta & 4 & PPB \\
\hline 37 & PA 6-Est 1/Rec sup & fgto 8 & borde & cerrada & 1 & PPB \\
\hline 38 & TA 1- Est1/103 & 1 & borde & cerrada & 2 & PPB \\
\hline 39 & TA 1- Est1/103 & 2 & cuerpo & cerrada & 3 & PPB \\
\hline 40 & TA 1- Est1/103 & 3 & cuerpo & cerrada & 4 & PPB \\
\hline 41 & TA 1- Est1/103 & 4 & pto ang & cerrada & 2 & PPB \\
\hline 42 & TA 1- Est1/103 & 5 & borde & cerrada & 3 & PPB \\
\hline 43 & TA 1- Est1/103 & 6 & borde & abierta & 3 & PPB \\
\hline 44 & TA 1- Est1/103 & 7 & base & abierta & 2 & PPB \\
\hline 45 & TA 1- Est1/103 & Fgto 1 & borde & abierta & 4 & PPB \\
\hline 46 & $\mathrm{CH} 25-2 / 102$ & 1 & base & indet & 2 & PPB \\
\hline 47 & $\mathrm{CH} 25-2 / 102$ & 2 & cuerpo & indet & 1 & indet \\
\hline 48 & $\mathrm{CH} 25-2 / 102$ & 3 & pto inflex & cerrada & 2 & PPB \\
\hline
\end{tabular}




\begin{tabular}{ccccccc}
\hline $\mathbf{N}^{\circ}$ & Sitio/UP & GF/Fgto $\mathbf{n}^{\circ}$ & Fgto & Morfología & G Pasta & Orientación \\
\hline 49 & CH 25-2/102 & 4 & cuerpo & indet & 4 & indet \\
50 & CH 25-2/102 & Fgto 1 & borde & abierta & 2 & PPB \\
51 & SC 3/Rec Sup & Fgto 3 & borde & abierta & 5 & PPB \\
52 & SC 3/Rec Sup & Fgto 5 & cuerpo & abierta & 8 & indet \\
53 & SC 3-Est 2 y 3/Rec Sup & Fgto 24 & borde & abierta & 8 & PPB \\
54 & SC 3/Rec Sup & Fgto 35 & borde & cerrada & 3 & PPB \\
55 & SC 3-Est 1/Rec Sup & Fgto 71 & borde & cerrada & 8 & PPB \\
56 & SC 3/Rec Sup & Fgto 75 & borde & cerrada & 5 & PPB \\
57 & SC 3/Rec Sup & Fgto 99 & borde & cerrada & 3 & PPB \\
58 & SC 3/Rec Sup & Fgto 104 & borde & cerrada & 2 & PPB \\
59 & SC 3/Rec Sup & Fgto 140 & pto inflex & cerrada & 1 & PPB \\
60 & SC 3/Rec Sup & Fgto 189 & cuerpo & indet & 9 & indet \\
61 & TC 2-Conj A/Rec sup & Fgto 1 & borde & cerrada & 8 & PPB \\
62 & TC 2-Conj A/Rec sup & Fgto 2 & borde & abierta & 3 & PPB \\
63 & TC 2-Conj A/Rec sup & Fgto 60 & borde & abierta & 1 & PPB \\
64 & TC 2-Conj B/Rec Sup & Fgto 134 & borde & abierta & 5 & PPB \\
65 & TC 2-Conj B/Rec Sup & Fgto 136 & borde & cerrada & 5 & PPB \\
66 & TC 2-Conj B/Rec Sup & Fgto 137 & borde & cerrada & 1 & PPB \\
67 & TC 2-Conj B/Rec Sup & Fgto 147 & base & indet & 5 & indet \\
68 & TC 2-Conj C/Rec Sup & Fgto 214 & borde & cerrada & 5 & PPB \\
69 & TC 2-Conj D/Rec Sup & Fgto 231 & borde & abierta & 3 & PPB \\
70 & TC 2-Conj D/Rec Sup & Fgto 232 & borde & abierta & 8 & PPB \\
\hline
\end{tabular}

Tabla 6.4 Procedencia, porción del cuerpo, morfología, grupo de pasta y orientación de las secciones delgadas analizadas. Ref: Rec Sup: recolección superficial; pto inflex: punto de inflexión; indet: indeterminado; PPB: perpendicular al plano de la boca.

Por otro lado, en la Tabla 6.5 se vuelcan los resultados del análisis del conteo de puntos, también descrito en la metodología. Los mismos se expresan en porcentajes de los componentes de las pastas para cada corte delgado. 


\section{ว}

\begin{tabular}{|c|c|c|c|c|c|c|c|c|c|c|c|c|c|c|c|c|c|c|c|c|c|c|}
\hline 1 & 1 & 59.5 & 8.0 & 7.7 & 0.0 & 3.2 & 0.0 & 7.1 & 0.0 & 6.4 & 0.0 & 0.0 & 2.6 & 0.0 & 3.9 & 1.3 & 0.3 & 0.0 & 0.0 & 0.0 & 0.0 & 0.0 \\
\hline 2 & 1 & 59.8 & 4.7 & 6.3 & 0.0 & 1.7 & 0.0 & 5.3 & 0.3 & 10.6 & 0.0 & 1.3 & 1.7 & 0.0 & 4.7 & 1.0 & 2.7 & 0.0 & 0.0 & 0.0 & 0.0 & 0.0 \\
\hline 3 & 1 & 56.2 & 4.1 & 3.8 & 0.0 & 2.5 & 0.0 & 5.7 & 1.0 & 1.3 & 0.0 & 0.3 & 15.2 & 0.0 & 9.8 & 0.0 & 0.0 & 0.0 & 0.0 & 0.0 & 0.0 & 0.0 \\
\hline 4 & 1 & 60.9 & 1.6 & 7.6 & 0.0 & 1.6 & 0.0 & 3.6 & 1.3 & 2.3 & 0.0 & 0.3 & 14.1 & 0.0 & 5.6 & 0.7 & 0.3 & 0.0 & 0.0 & 0.0 & 0.0 & 0.0 \\
\hline 5 & 1 & 54.3 & 4.7 & 4.3 & 0.0 & 0.7 & 0.0 & 1.0 & 0.0 & 2.7 & 0.0 & 0.7 & 9.0 & 6.7 & 5.3 & 0.7 & 0.0 & 0.0 & 0.0 & 0.0 & 0.0 & 0.0 \\
\hline 6 & 3 & 69.5 & 3.6 & 2.3 & 0.7 & 0.7 & 0.0 & 1.7 & 0.0 & 0.0 & 0.0 & 0.3 & 6.3 & 1.0 & 13.2 & 0.0 & 0.3 & 0.0 & 0.0 & 0.3 & 0.0 & 0.0 \\
\hline 7 & 3 & 64.6 & 2.3 & 3.0 & 0.3 & 0.0 & 0.0 & 1.7 & 1.3 & 0.0 & 0.0 & 0.3 & 11.3 & 1.0 & 12.9 & 0.7 & 0.7 & 0.0 & 0.0 & 0.0 & 0.0 & 0.0 \\
\hline 8 & 3 & 61.2 & 5.2 & 4.6 & 0.7 & 1.0 & 0.0 & 2.9 & 0.0 & 0.0 & 1.0 & 0.0 & 4.6 & 1.6 & 14.7 & 1.6 & 0.0 & 0.0 & 0.0 & 1.0 & 0.0 & 0.0 \\
\hline 9 & 3 & 62.7 & 7.8 & 2.6 & 1.6 & 2.6 & 0.0 & 0.7 & 0.0 & 0.0 & 0.0 & 0.0 & 1.3 & 3.9 & 11.4 & 0.0 & 0.0 & 0.0 & 2.9 & 0.7 & 1.6 & 0.0 \\
\hline 11 & 2 & 56.7 & 9.6 & 16.6 & 0.5 & 1.1 & 0.0 & 9.6 & 0.0 & 3.2 & 0.0 & 0.5 & 0.0 & 0.0 & 1.6 & 0.0 & 0.0 & 0.0 & 0.0 & 0.0 & 0.5 & 0.0 \\
\hline 12 & 2 & 61.5 & 7.0 & 20.6 & 0.0 & 1.0 & 0.0 & 5.3 & 0.3 & 0.3 & 0.0 & 0.0 & 3.0 & 0.0 & 0.3 & 0.0 & 0.0 & 0.0 & 0.0 & 0.0 & 0.7 & 0.0 \\
\hline 13 & 2 & 62.5 & 4.9 & 13.2 & 0.7 & 1.6 & 0.0 & 9.2 & 1.0 & 1.6 & 0.0 & 1.0 & 0.0 & 2.0 & 0.7 & 0.3 & 1.3 & 0.0 & 0.0 & 0.0 & 0.0 & 0.0 \\
\hline 14 & 2 & 57.4 & 7.4 & 11.4 & 0.6 & 1.5 & 1.9 & 2.8 & 0.3 & 0.0 & 0.3 & 0.0 & 4.3 & 4.3 & 6.8 & 0.0 & 0.0 & 0.0 & 0.0 & 0.9 & 0.0 & 0.0 \\
\hline 15 & 4 & 69.5 & 4.6 & 4.6 & 1.3 & 1.0 & 0.0 & 0.0 & 0.0 & 0.0 & 0.3 & 0.3 & 10.5 & 2.6 & 2.3 & 0.3 & 0.0 & 0.0 & 0.0 & 0.3 & 2.3 & 0.0 \\
\hline 16 & 5 & 80.8 & 2.6 & 3.0 & 0.7 & 1.0 & 0.0 & 0.0 & 0.0 & 0.0 & 0.0 & 0.0 & 6.0 & 0.7 & 2.3 & 1.0 & 0.3 & 0.0 & 0.0 & 0.0 & 1.7 & 0.0 \\
\hline 17 & 5 & 82.2 & 2.9 & 1.2 & 0.0 & 0.8 & 0.0 & 2.1 & 0.0 & 1.2 & 0.0 & 0.0 & 0.0 & 0.0 & 0.0 & 0.0 & 0.0 & 9.5 & 0.0 & 0.0 & 0.0 & 0.0 \\
\hline 18 & 4 & 69.8 & 1.6 & 4.2 & 0.0 & 0.6 & 0.0 & 1.3 & 0.0 & 4.2 & 0.0 & 0.0 & 12.0 & 1.3 & 3.9 & 1.0 & 0.0 & 0.0 & 0.0 & 0.0 & 0.0 & 0.0 \\
\hline 20 & 4 & 73.0 & 3.5 & 3.8 & 0.0 & 0.6 & 0.3 & 2.5 & 0.6 & 0.0 & 0.0 & 0.3 & 8.9 & 0.0 & 2.9 & 0.6 & 0.0 & 0.0 & 1.9 & 0.0 & 1.0 & 0.0 \\
\hline 21 & 4 & 71.0 & 5.0 & 6.0 & 0.7 & 1.3 & 0.0 & 6.7 & 0.7 & 0.3 & 0.0 & 0.0 & 2.7 & 0.7 & 2.7 & 0.0 & 2.3 & 0.0 & 0.0 & 0.0 & 0.0 & 0.0 \\
\hline 22 & 4 & 63.6 & 3.0 & 4.0 & 0.0 & 0.0 & 0.0 & 6.3 & 0.3 & 3.6 & 0.0 & 0.3 & 9.9 & 1.0 & 7.6 & 0.0 & 0.0 & 0.0 & 0.3 & 0.0 & 0.0 & 0.0 \\
\hline 23 & 4 & 60.7 & 2.6 & 10.6 & 0.3 & 0.7 & 0.0 & 9.9 & 1.0 & 2.6 & 0.0 & 0.3 & 5.6 & 0.3 & 3.3 & 0.0 & 0.3 & 0.0 & 1.7 & 0.0 & 0.0 & 0.0 \\
\hline 24 & 4 & 70.2 & 3.2 & 6.3 & 0.0 & 1.0 & 1.0 & 2.5 & 0.3 & 0.0 & 0.0 & 0.0 & 10.8 & 1.0 & 1.3 & 0.0 & 0.6 & 0.0 & 1.3 & 0.0 & 0.6 & 0.0 \\
\hline 25 & 4 & 64.1 & 1.6 & 10.5 & 0.7 & 1.3 & 0.0 & 7.9 & 1.6 & 0.7 & 0.0 & 1.3 & 3.3 & 3.6 & 1.3 & 1.0 & 0.7 & 0.0 & 0.0 & 0.0 & 0.3 & 0.0 \\
\hline 26 & 6 & 65.3 & 2.5 & 8.0 & 3.1 & 1.9 & 0.0 & 0.9 & 0.0 & 1.2 & 11.5 & 0.0 & 0.0 & 0.3 & 0.0 & 0.0 & 0.0 & 0.0 & 2.5 & 0.0 & 2.8 & 0.0 \\
\hline 27 & 7 & 71.4 & 2.2 & 11.1 & 0.3 & 1.0 & 0.0 & 7.0 & 0.6 & 1.3 & 0.0 & 0.0 & 0.3 & 0.0 & 0.3 & 1.0 & 1.0 & 0.0 & 1.3 & 0.0 & 1.3 & 0.0 \\
\hline 28 & 7 & 67.0 & 2.3 & 14.4 & 1.6 & 2.0 & 2.0 & 5.9 & 0.3 & 0.0 & 0.0 & 0.0 & 0.3 & 1.0 & 0.3 & 0.0 & 0.7 & 0.0 & 0.7 & 0.0 & 0.0 & 1.6 \\
\hline 29 & 7 & 61.1 & 3.8 & 9.4 & 2.2 & 0.9 & 0.9 & 4.7 & 0.3 & 0.6 & 0.0 & 0.6 & 4.4 & 0.0 & 2.8 & 0.0 & 0.0 & 0.0 & 0.3 & 0.3 & 0.6 & 6.9 \\
\hline 30 & 7 & 73.4 & 3.8 & 8.0 & 0.0 & 1.0 & 0.3 & 5.8 & 0.3 & 2.9 & 0.0 & 0.0 & 0.0 & 0.6 & 1.0 & 0.0 & 2.2 & 0.0 & 0.0 & 0.3 & 0.3 & 0.0 \\
\hline 31 & 4 & 57.6 & 4.4 & 4.4 & 0.0 & 1.9 & 0.0 & 1.9 & 0.3 & 2.5 & 0.0 & 0.9 & 12.1 & 0.6 & 13.1 & 0.3 & 0.0 & 0.0 & 0.0 & 0.0 & 0.0 & 0.0 \\
\hline 32 & 1 & 70.1 & 3.9 & 2.6 & 0.3 & 0.3 & 0.0 & 1.0 & 0.3 & 9.9 & 0.0 & 0.0 & 4.3 & 0.7 & 5.6 & 0.7 & 0.0 & 0.0 & 0.0 & 0.0 & 0.3 & 0.0 \\
\hline 33 & 3 & 1.7 & 4.5 & 7.1 & 0.0 & 1.0 & 0.0 & 2.9 & 0.0 & 3.2 & 0.0 & 0.6 & 9.1 & 1.6 & 7.5 & 0.6 & 0.0 & 0.0 & 0.0 & 0.0 & 0.0 & 0.0 \\
\hline 34 & 4 & 64.2 & 3.1 & 5.9 & 0.3 & 0.6 & 0.0 & 4.0 & 0.3 & 1.2 & 0.0 & 0.0 & 10.0 & 3.4 & 6.5 & 0.0 & 0.0 & 0.0 & 0.0 & 0.0 & 0.3 & 0.0 \\
\hline 35 & 3 & 72.8 & 3.6 & 0.3 & 0.0 & 0.0 & 0.0 & 0.0 & 0.0 & 0.3 & 0.0 & 0.0 & 3.3 & 2.3 & 16.6 & 0.3 & 0.0 & 0.0 & 0.0 & 0.0 & 0.3 & 0.0 \\
\hline 36 & 4 & 2.7 & 7.6 & 6.6 & 0.0 & 1.0 & 0.0 & 4.6 & 0.3 & 1.7 & 0.0 & 0.0 & 5.9 & 0.0 & 9.6 & 0.0 & 0.0 & 0.0 & 0.0 & 0.0 & 0.0 & 0.0 \\
\hline 40 & 4 & 56.6 & 5.9 & 4.9 & 0.0 & 1.0 & 0.0 & 2.6 & 0.3 & 2.3 & 0.0 & 0.0 & 15.5 & 2.0 & 5.3 & 3.0 & 0.3 & 0.0 & 0.0 & 0.0 & 0.3 & 0.0 \\
\hline 41 & 2 & 58.7 & 4.2 & 16.5 & 0.0 & 0.3 & 0.0 & 3.5 & 0.6 & 3.2 & 0.0 & 0.0 & 1.6 & 0.0 & 0.3 & 1.0 & 0.0 & 0.0 & 0.0 & 0.0 & 0.0 & 0.0 \\
\hline 42 & 3 & 5.9 & 2.0 & 5.9 & 0.7 & 1.3 & 0.0 & 1.3 & 0.0 & 0.0 & 0.0 & 0.0 & 0.0 & 0.7 & 21.6 & 0.0 & 0.0 & 0.0 & 0.0 & 0.0 & 0.7 & 0.0 \\
\hline 43 & 3 & 1.4 & 1.7 & 1.0 & 0.0 & 0.7 & 0.0 & 0.3 & 0.0 & 0.3 & 0.0 & 0.0 & 0.7 & 0.0 & 3.3 & 0.3 & 0.0 & 0.0 & 0.0 & 0.3 & 0.0 & 0.0 \\
\hline 44 & 2 & 61.7 & 6.3 & 10.6 & 1.0 & 2.3 & 0.0 & 2.6 & 0.7 & 0.7 & 0.0 & 0.3 & 4.3 & 1.3 & 6.3 & 1.7 & 0.0 & 0.0 & 0.0 & 0.0 & 0.3 & 0.0 \\
\hline 45 & 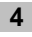 & 73.4 & 4.8 & 4.8 & 0.0 & 0.6 & 0.0 & 5.4 & 0.6 & 1.9 & 0.0 & 0.0 & 3.8 & 0.0 & 1.9 & 1.3 & 1.3 & 0.0 & 0.0 & 0.0 & 0.0 & 0.0 \\
\hline 46 & 2 & 68.8 & 2.3 & 6.3 & 0.7 & 0.3 & 0.0 & 6.6 & 0.7 & 1.6 & 0.0 & 0.3 & 3.6 & 1.0 & 4.6 & 1.0 & 2.0 & 0.0 & 0.0 & 0.0 & 0.3 & 0.0 \\
\hline 47 & 1 & 76.2 & 5.0 & 5.0 & 0.3 & 0.7 & 0.0 & 3.3 & 1.3 & 4.3 & 0.0 & 0.0 & 0.0 & 1.0 & 1.0 & 0.0 & 0.0 & 0.0 & 1.3 & 0.0 & 0.0 & 0.7 \\
\hline 48 & 2 & 9.2 & 3.2 & 10.8 & 0.6 & 1.3 & 0.0 & 5.4 & 1.0 & 1.6 & 0.0 & 0.0 & 4.1 & 1.3 & 7.6 & 1.6 & 1.6 & 0.0 & 0.6 & 0.0 & 0.0 & 0.0 \\
\hline 49 & 4 & 51.4 & 7.0 & 7.6 & 0.0 & 0.6 & 0.0 & 0.6 & 0.6 & 9.2 & 0.3 & 0.3 & 10.2 & 0.0 & 12.1 & 0.0 & 0.0 & 0.0 & 0.0 & 0.0 & 0.0 & 0.0 \\
\hline 50 & 2 & 2.1 & 5.6 & 9.3 & 0.0 & 1.9 & 0.0 & 4.7 & 1.4 & 0.5 & 0.0 & 0.0 & 6.5 & 0.0 & 5.6 & 0.5 & 1.9 & 0.0 & 0.0 & 0.0 & 0.0 & 0.0 \\
\hline 51 & 5 & 84.9 & 3.5 & 4.2 & 1.3 & 0.0 & 0.6 & 1.6 & 0.0 & 0.6 & 0.0 & 0.3 & 0.0 & 0.0 & 1.9 & 0.6 & 0.0 & 0.0 & 0.0 & 0.0 & 0.3 & 0.0 \\
\hline 52 & 8 & 83.1 & 2.3 & 0.3 & 0.7 & 0.0 & 0.0 & 0.3 & 0.0 & 0.0 & 0.0 & 0.0 & 0.7 & 2.3 & 9.1 & 0.7 & 0.0 & 0.0 & 0.0 & 0.7 & 0.0 & 0.0 \\
\hline 53 & 8 & 62.1 & 3.2 & 1.9 & 0.3 & 0.6 & 0.0 & 0.6 & 0.0 & 0.0 & 0.0 & 0.0 & 9.0 & 3.9 & 17.0 & 0.3 & 0.0 & 0.0 & 0.0 & 0.0 & 1.0 & 0.0 \\
\hline 54 & 3 & 74.9 & 2.0 & 1.6 & 1.3 & 0.0 & 0.0 & 0.7 & 0.0 & 0.3 & 0.0 & 0.0 & 6.8 & 0.3 & 10.1 & 0.7 & 1.0 & 0.0 & 0.0 & 0.0 & 0.3 & 0.0 \\
\hline 55 & 8 & 66.0 & 2.0 & 3.6 & 1.7 & 0.0 & 0.0 & 0.0 & 0.0 & 0.3 & 0.0 & 0.0 & 4.3 & 2.0 & 17.2 & 0.3 & 0.0 & 0.0 & 0.0 & 0.0 & 2.6 & 0.0 \\
\hline 56 & 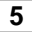 & 3.1 & 1.3 & 0.7 & 0.0 & 0.0 & 0.0 & 0.3 & 0.0 & 0.0 & 0.0 & 0.0 & 0.0 & 0.0 & 4.2 & 0.3 & 0.0 & 0.0 & 0.0 & 0.0 & 0.0 & 0.0 \\
\hline 57 & 3 & 60.9 & 2.6 & 3.9 & 0.3 & 0.0 & 0.0 & 3.6 & 0.0 & 0.7 & 0.0 & 0.3 & 17.1 & 2.3 & 5.9 & 1.0 & 0.3 & 0.0 & 0.0 & 0.0 & 1.0 & 0.0 \\
\hline 58 & 2 & 64.2 & 4.2 & 18.6 & 0.7 & 0.3 & 0.0 & 1.6 & 0.3 & 7.5 & 0.0 & 0.0 & 0.0 & 0.3 & 0.0 & 0.0 & 1.6 & 0.0 & 0.0 & 0.0 & 0.7 & 0.0 \\
\hline 59 & 1 & 2.7 & 3.0 & 3.3 & 0.0 & 1.0 & 0.3 & 15.5 & 0.3 & 12.2 & 0.0 & 0.0 & 0.0 & 0.0 & 0.0 & 1.3 & 0.3 & 0.0 & 0.0 & 0.0 & 0.0 & 0.0 \\
\hline 60 & 9 & 86.3 & 1.6 & 1.6 & 0.0 & 0.0 & 1.6 & 4.1 & 0.0 & 0.3 & 0.0 & 0.3 & 0.0 & 0.0 & 0.0 & 0.0 & 0.0 & 0.0 & 3.5 & 0.0 & 0.6 & 0.0 \\
\hline 61 & 8 & 59.2 & 3.3 & 0.7 & 0.0 & 0.0 & 0.0 & 0.0 & 0.0 & 0.3 & 0.0 & 0.0 & 2.3 & 7.6 & 25.3 & 1.3 & 0.0 & 0.0 & 0.0 & 0.0 & 0.0 & 0.0 \\
\hline 62 & 3 & 72.1 & 3.6 & 2.3 & 0.0 & 0.0 & 0.0 & 0.7 & 0.0 & 0.3 & 0.0 & 0.0 & 9.5 & 0.7 & 10.8 & 0.0 & 0.0 & 0.0 & 0.0 & 0.0 & 0.0 & 0.0 \\
\hline 63 & 1 & 68.0 & 2.3 & 10.4 & 0.3 & 0.0 & 0.0 & 0.0 & 0.0 & 17.2 & 0.0 & 0.0 & 0.0 & 0.0 & 1.6 & 0.0 & 0.0 & 0.0 & 0.3 & 0.0 & 0.0 & 0.0 \\
\hline 64 & 5 & 97.4 & 0.7 & 0.0 & 0.0 & 0.0 & 0.0 & 0.3 & 0.0 & 0.7 & 0.0 & 0.0 & 0.0 & 0.0 & 0.3 & 0.3 & 0.0 & 0.0 & 0.0 & 0.0 & 0.3 & 0.0 \\
\hline 65 & 5 & 84.1 & 6.1 & 1.6 & 1.0 & 0.0 & 0.3 & 0.3 & 0.0 & 0.3 & 0.0 & 0.0 & 0.3 & 0.0 & 4.2 & 0.3 & 0.0 & 0.0 & 0.0 & 0.0 & 1.3 & 0.0 \\
\hline 66 & 1 & 69.6 & 5.5 & 6.8 & 0.3 & 0.6 & 0.0 & 6.8 & 0.3 & 9.1 & 0.0 & 0.3 & 0.0 & 0.0 & 0.0 & 0.0 & 0.6 & 0.0 & 0.0 & 0.0 & 0.0 & 0.0 \\
\hline 67 & 5 & 82.0 & 4.3 & 3.9 & 0.3 & 0.0 & 0.3 & 2.0 & 0.0 & 2.3 & 0.0 & 0.3 & 0.0 & 0.0 & 0.0 & 0.0 & 0.0 & 4.6 & 0.0 & 0.0 & 0.0 & 0.0 \\
\hline 68 & 5 & 89.1 & 1.6 & 2.6 & 0.0 & 0.0 & 0.0 & 1.0 & 0.0 & 0.3 & 0.0 & 0.0 & 0.7 & 0.3 & 3.0 & 0.3 & 0.7 & 0.0 & 0.0 & 0.0 & 0.3 & 0.0 \\
\hline 69 & 3 & 84.6 & 2.6 & 1.0 & 0.0 & 0.0 & 0.0 & 0.0 & 0.0 & 0.0 & 0.0 & 0.0 & 1.0 & 0.7 & 9.2 & 0.0 & 0.0 & 0.0 & 0.0 & 0.0 & 1.0 & 0.0 \\
\hline 70 & 8 & 73.7 & 4.5 & 1.3 & 1.0 & 0.0 & 0.0 & 0.0 & 0.0 & 0.3 & 0.0 & 0.0 & 1.3 & 0.3 & 16.3 & 0.0 & 0.6 & 0.0 & 0.0 & 0.0 & 0.6 & 0.0 \\
\hline
\end{tabular}


Tabla 6.5 Porcentaje de área de cada componente identificado y contabilizado por point counter para los cortes delgados analizados. Ref: Q: cuarzo; ext ond: extinción ondulante; Fel K: feldespato potásico; Fel alt: feldespato alterado; Plag: plagioclasa; Fel MC: feldespato con macla de Carlsbad; polic: policristalino; Metamorf: litoclasto metamórfico.

Del grupo de pastas 1 (GP 1) se analizaron 11 secciones delgadas (Cortes 1, 2, 3, 4, $5,32,37,47,59,63$ y 66). El mismo se había caracterizado por la abundancia de biotita. En el análisis petrográfico, se observa que todos presentan inclusiones densas a muy densas (entre 20 y 40\%) y matriz de estructura lepidoblástica ${ }^{4}$ a pseudolepidoblástica. Los tamaños de las inclusiones son variables, con distribución unimodal en todos los casos y una media promedio de $0.2 \mathrm{~mm}$ y valores de moda que oscilan entre 0.1 y 0.3 $\mathrm{mm}$. Sin embargo, al analizar la mineralogía de las inclusiones, se observa variabilidad dentro de este grupo, identificándose dos subgrupos:

A. Pastas con abundante biotita (4-17\%) (Cortes 1, 2, 32, 37, 47, 59, 63 у 66). Además, presentan mineraloclastos de cuarzo (3-10\%), plagioclasa (1-15\%), litoclastos pelíticos de distinto tipo (0-15\%). Pueden exhibir feldespatos potásicos, anfíboles y litoclastos volcánicos en baja cantidad. En la Figura 6.12 se pueden observar dos fotomicrografías de este tipo de pastas.

B. Pastas con baja cantidad de biotita (1 a 3\%) (Cortes 3, 4 y 5), pero abundante cantidad de litoclastos pelíticos laminares (9-15\%), que en la observación con lupa pudieron haber inducido a su agrupamiento con los cortes anteriores, dado que estos suelen presentar micas que le dan parte de su aspecto laminar. Además, exhiben mineraloclastos de cuarzo (4-8\%), plagioclasas (1-6\%), feldespatos potásicos (1-3\%) y litoclastos pelíticos granulares (6-12\%). Asimismo, pueden presentar bajas cantidades de anfíboles y feldespatos con macla de Carlsbad. Debido a esta composición, los podríamos vincular a los fragmentos del GP 4 (ver más adelante).

\footnotetext{
${ }^{4}$ Término que describe la textura de rocas metamórficas que presentan buena orientación de elementos y en petrografía cerámica se emplea para describir la textura de fondos de pasta con presencia de micas detríticas orientadas (Mottana et al. 1978; Cremonte 1996).
} 


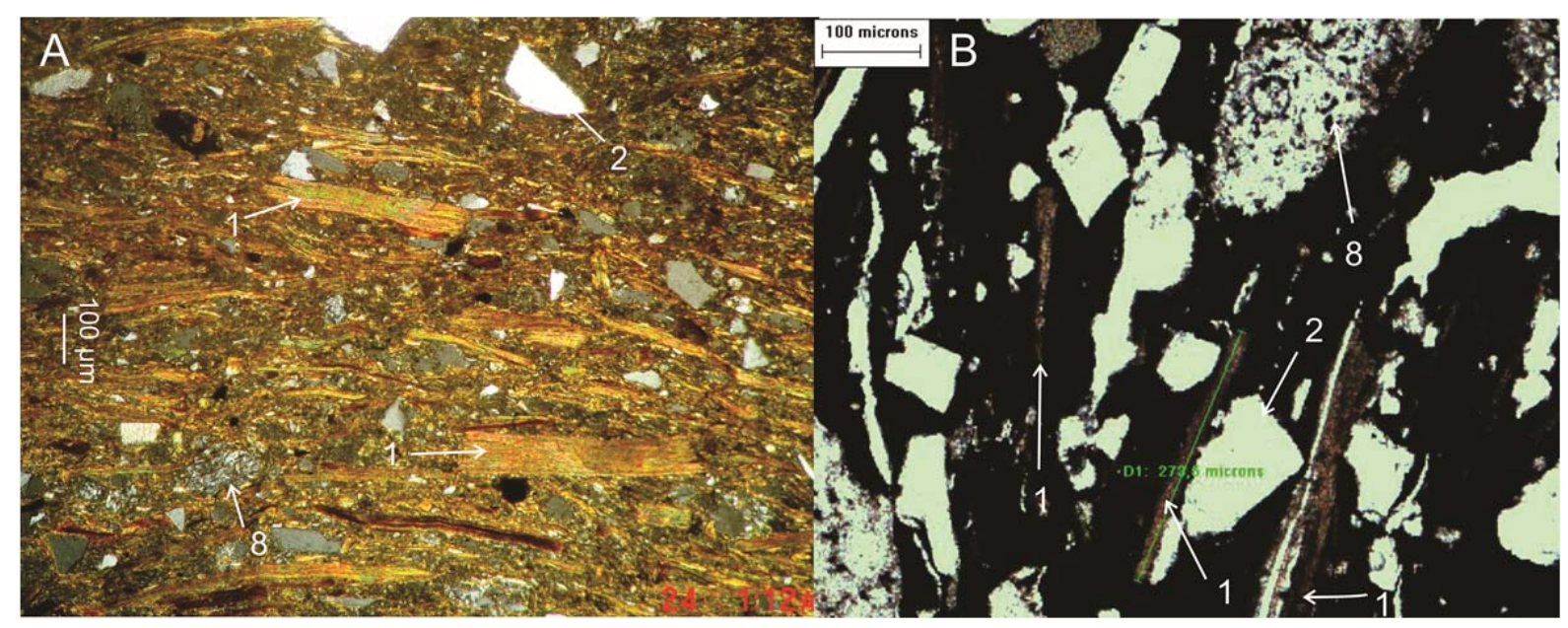

Figura 6.12 Fotomicrografías de secciones delgadas del GP 1, con analizador. A: Corte 63; B: Corte 1. Ref: 1: biotita; 2: cuarzo; 8: pelitas granulares finas.

En cuanto al GP 2, se realizaron 12 secciones delgadas (Cortes 10, 11, 12, 13, 14, 38, 41, 44, 46, 48, 50, 58). Habíamos caracterizado al mismo por la abundancia de cuarzo. A partir del análisis microscópico, pudimos observar que la mayoría presenta matrices con estructura pseudolepidoblástica a lepidoblástica, un porcentaje de cavidades variable (2-10\%) e inclusiones densas a muy densas (26 a 38\%). Las mismas presentan tamaños variables, con distribución unimodal, y una media promedio de 0.2 $\mathrm{mm}$ y las modas presentan valores entre 0.1 y $0.3 \mathrm{~mm}$.

Dentro de las inclusiones observadas, el tipo de mineraloclastos más abundante es el cuarzo (7 a 21\%), como se observó en el análisis submacroscópico, seguido por las plagioclasas (2-10\%) y los litoclastos pelíticos (1-13\%). En menor medida, se observan feldespatos potásicos (1-2\%), biotita (1-8\%), y pueden estar presentes feldespatos con macla de Carlsbad, anfíboles, litoclastos volcánicos y cuarzos policristalinos con extinción ondulante, en porcentajes muy bajos $(<1 \%)$. En la Figura 6.13 se pueden observar dos fotomicrografías de estas pastas. 


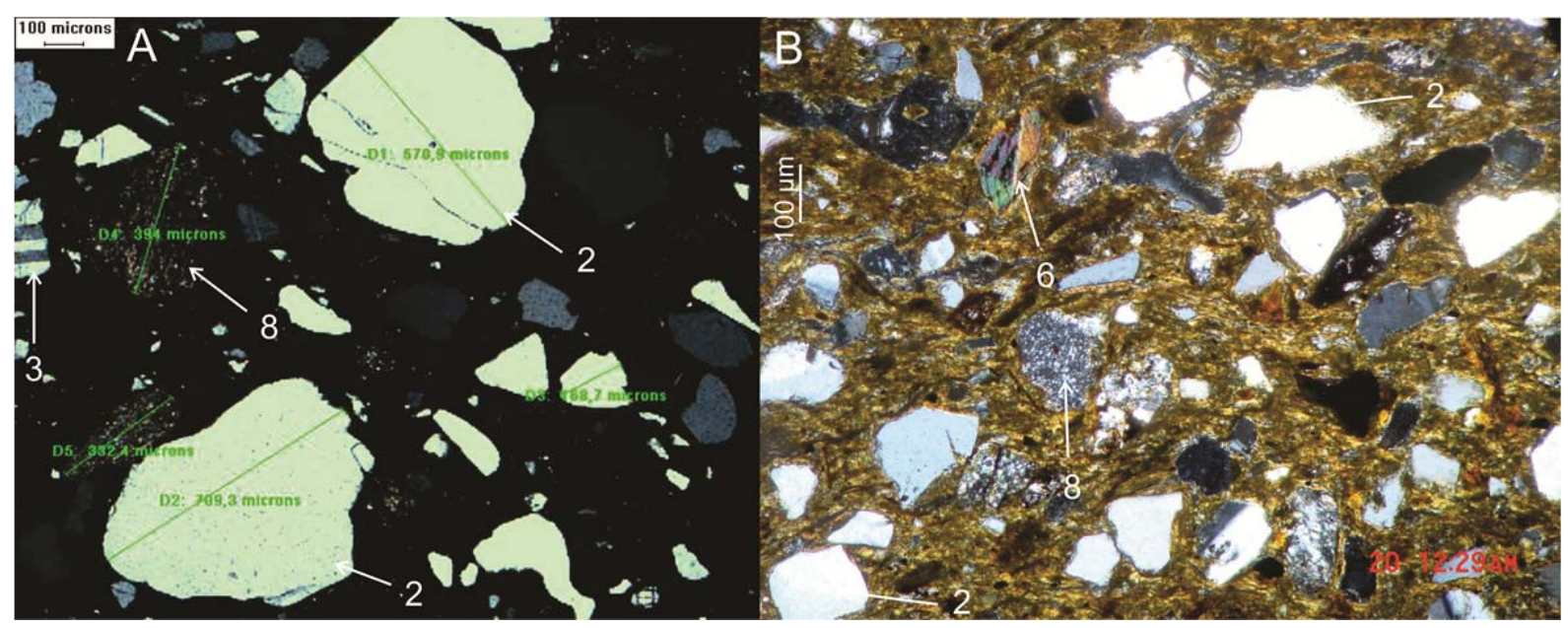

Figura 6.13 Fotomicrografías de secciones delgadas del GP 2, con analizador. A: Corte 12; B: Corte 44. Ref: 2: cuarzo; 3: plagioclasa; 6: anfíbol; 8: pelitas granulares finas.

Para el GP 3, se seleccionaron fragmentos sobre los que se realizaron 13 secciones delgadas (Cortes $6,7,8,9,33,35,39,42,43,54,57,62$ y 69). La mayoría presentan matrices con estructura microgranosa ${ }^{5}$ (en el Corte 57 es pseudolepidoblástica) e inclusiones densas (23 a 37\%), exceptuando dos cortes (43 y 69) que presentan inclusiones poco densas (7-13\%). El porcentaje de cavidades varía entre 2 y $8 \%$. Los tamaños de las inclusiones son muy variables, con medias que van desde 0.1 a $0.4 \mathrm{~mm}$, y la mayoría presentan distribución unimodal, con modas entre 0.06 y $0.25 \mathrm{~mm}$. Pero cuatro fragmentos presentan distribución bimodal, con picos más pequeños en la distribución en tamaños entre 0.5 y $0.75 \mathrm{~mm}$. Este grupo de pastas correspondía a lo que se conoce como estilo Yavi.

Las mismas se caracterizan por la abundancia de litoclastos pelíticos (17 a 25\%), exceptuando los fragmentos con inclusiones poco densas, que si bien sus porcentajes son menores (4 y 11\%), son de igual manera las inclusiones más abundantes. Las pelitas observadas pueden dividirse en varios tipos. Unos son laminares (contienen muscovita fina), otros son granulares finos y otros granulares más gruesos. En casi todos los cortes analizados, los más abundantes son los granulares finos (10 a 22\%), exceptuando dos cortes (Cortes 33 y 57), donde son más abundantes los laminares (9 y $17 \%$ respectivamente). En los cortes con baja densidad de inclusiones los porcentajes son menores, pero se mantiene el predominio de litoclastos pelíticos granulares finos (3 y $9 \%$ ).

\footnotetext{
${ }^{5}$ Fondo de pasta que presenta en parte elementos finos no arcillosos (Cremonte 1996).
} 
Además de los litoclastos pelíticos, se observan mineraloclastos de cuarzo (1 a 7\%) y plagioclasa (1 a 4\%). Pueden estar presentes los feldespatos potásicos, la biotita, los anfíboles y litoclastos de cuarzo policristalino con extinción ondulante, en bajas cantidades. En la Figura 6.14 se pueden observar dos fotomicrografías de estas pastas.

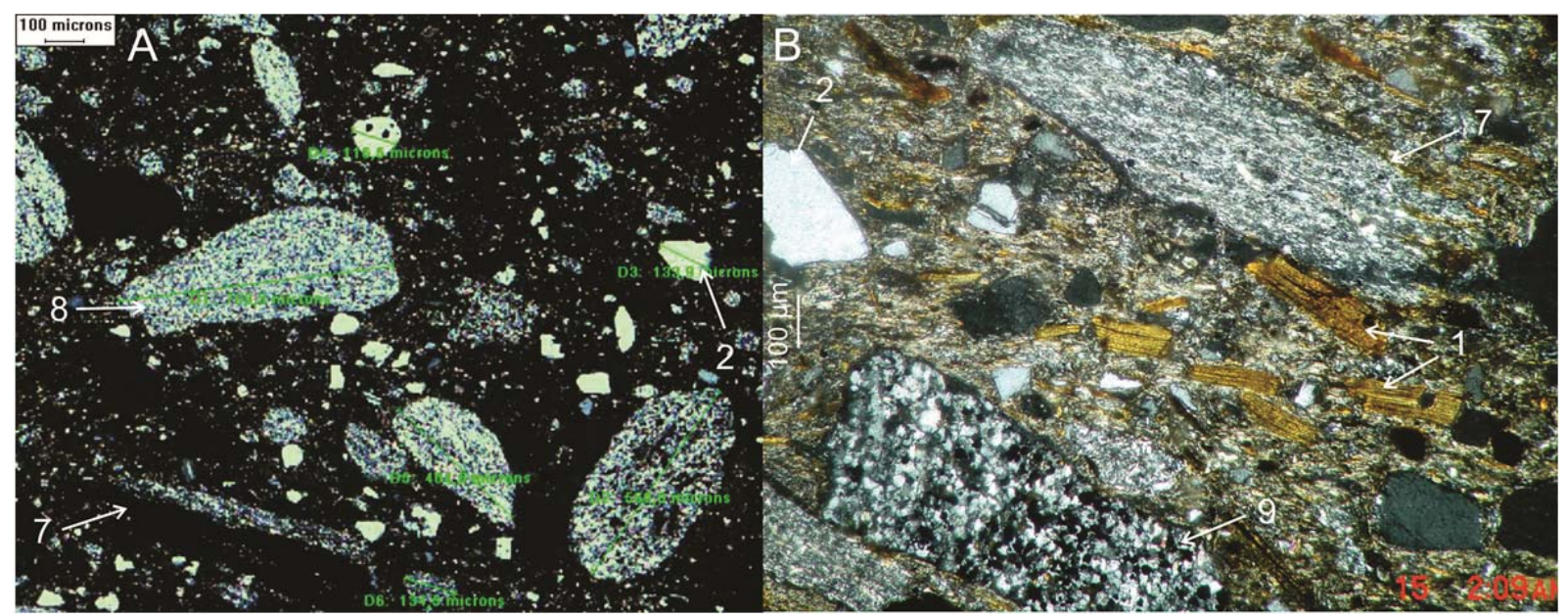

Figura 6.14 Fotomicrografías de secciones delgadas del GP 3, con analizador. A: Corte 8; B: Corte 33. Ref: 1: biotita; 2: cuarzo; 7: pelitas laminares; 8: pelitas granulares finas; 9: pelitas granulares gruesas.

Para el GP 4, se seleccionaron fragmentos sobre los que se confeccionaron 15 secciones delgadas (Cortes 15, 18, 19, 20, 21, 22, 23, 24, 25, 31, 34, 36, 40, 45 y 49). Todos presentan inclusiones densas a muy densas (22 a 42\%) y el porcentaje de cavidades varía entre 2 y $7 \%$. La estructura de la matriz es variable, de microgranosa a lepidoblástica, dependiendo de la abundancia de biotita. Presentan inclusiones de diferentes tamaños, con distribución unimodal en todos los casos, con una media promedio para todos los cortes en $0.2 \mathrm{~mm}$ y modas que se encuentran entre 0.1 y 0.2 $\mathrm{mm}$.

Asimismo, todos presentan el mismo tipo de inclusiones, aunque en proporciones variables. Las pelitas son muy abundantes en todos los cortes (6 hasta 26\%), tanto en sus variedades laminares (3 a 16\%), como granulares finas (1 a 13\%). Las granulares gruesas también están presentes, pero en menor proporción. Entre los mineraloclastos, son abundantes el cuarzo (4 a 11\%) y las plagioclasas (1 a 10\%). Pueden estar presentes los feldespatos potásicos y los anfíboles en bajas cantidades, y la biotita, que en algunos cortes es abundante llegando hasta el 9\%. Eventualmente, aparecen 
litoclastos volcánicos y plutónicos. En la Figura 6.15 se pueden observar fotomicrografías de estas pastas.

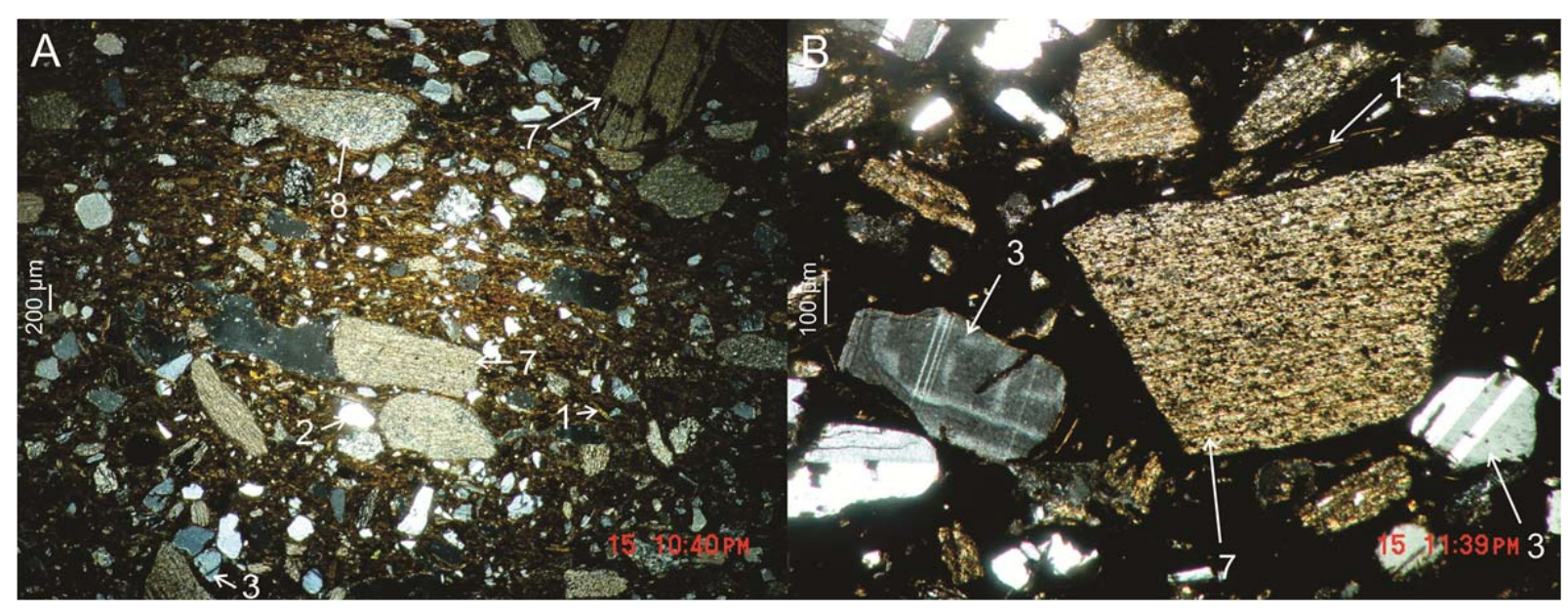

Figura 6.15 Fotomicrografías de secciones delgadas del GP 4, con analizador. A: Corte 34; B: Corte 36. Ref: 1: biotita; 2: cuarzo; 3: plagioclasas; 7: pelitas laminares; 8: pelitas granulares finas.

Ocho cortes corresponden al GP 5 (Cortes 16, 17, 51, 56, 64, 65, 67 y 68), que habíamos caracterizado por presentar inclusiones poco densas. En el análisis petrográfico, observamos que la densidad de las inclusiones es menor al 20\%, pero varía entre 6 y 17\%, con un corte que en el que se contabilizó solo un $2 \%$ de inclusiones (Corte 64). Presentan matriz con estructura microgranosa y una abundancia de cavidades entre 1 y $6 \%$. Los tamaños de las inclusiones tienen distribuciones unimodales, y medias más finas que en los grupos de pastas anteriores (media promedio de $0.1 \mathrm{~mm}$ ), al igual que las modas, que incluyen valores entre 0.06 y 0.12 $\mathrm{mm}$. Al analizar la composición de las inclusiones, podemos distinguir tres variantes o subgrupos dentro de estas pastas:

A. Los cortes 16, 51, 56, 65 y 68 presentan como inclusiones más abundantes litoclastos pelíticos (2 a 9\%), predominantemente de los granulares finos, y mineraloclastos de cuarzo ( 1 a 5\%). Pueden estar presentes en baja cantidad, las plagioclasas, la biotita y los cuarzos policristalinos de extinción ondulante. En la Figura 6.16 A se puede observar una fotomicrografía de este tipo de pastas.

B. Los cortes 17 y 67 presentan como inclusiones más abundantes fragmentos pumíceos. Además se observa cuarzo (1 a 4\%), plagioclasas (2\%) y biotita (1 a 2\%) (ver 
Figura 6.16 B). El corte 17 es de un sitio colonial (PA 22), y además presenta una superficie vitrificada, y el 67 también es de un sitio con una posible ocupación colonial (TC 2), por lo que podría tratarse de un subtipo de momentos coloniales.

C. El corte 64 , que presenta muy escasas inclusiones (2\%), solo presenta plagioclasa, biotita, pelitas granulares finas y cuarzo policristalino con extinción ondulante (Figura 6.16 C).

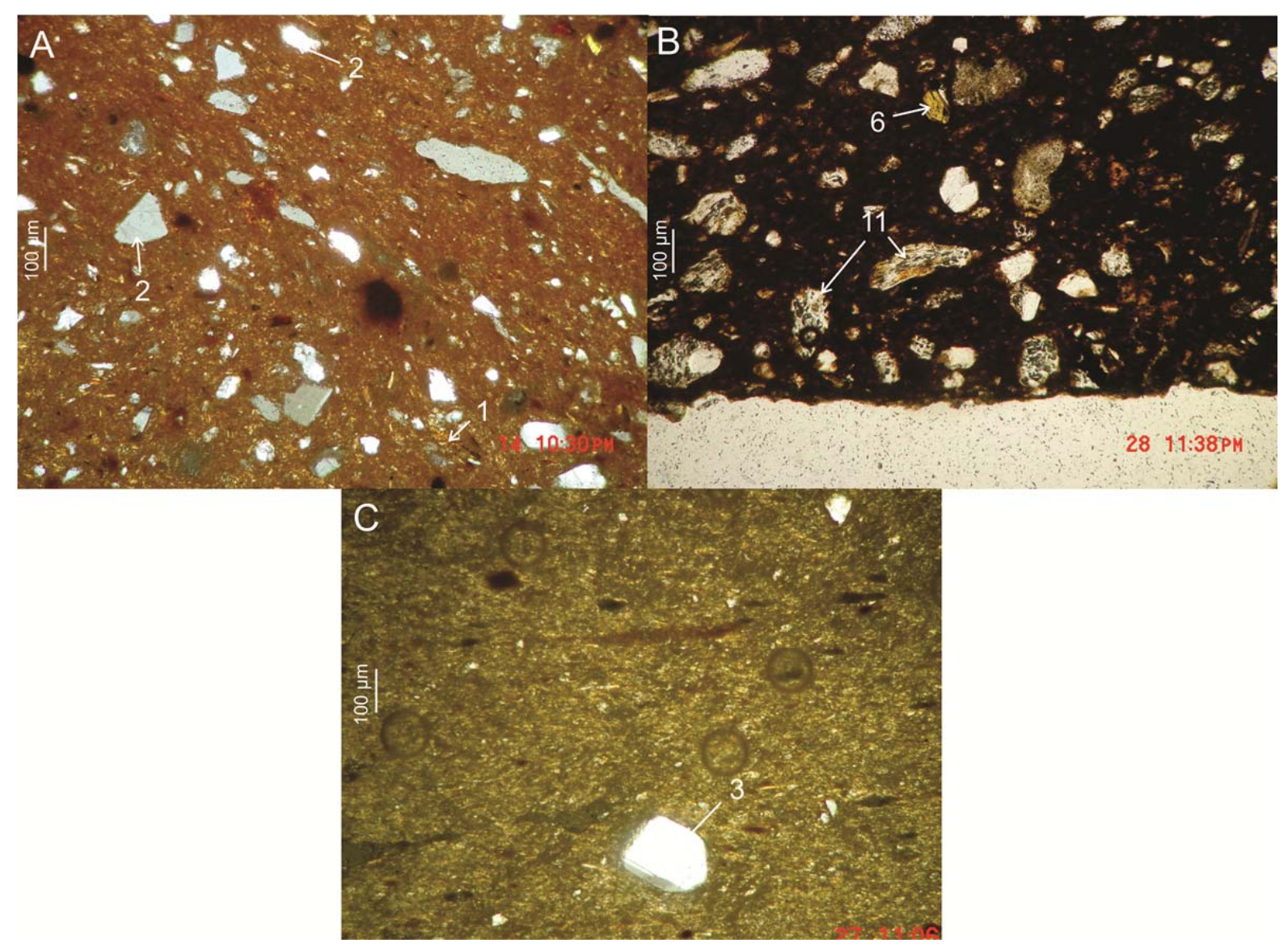

Figura 6.16 Fotomicrografías de secciones delgadas del GP 5, A y C con analizador, B sin analizador. A: Corte 51; B: Corte 67; C: Corte 64. Ref: 1: biotita; 2: cuarzo; 3: plagioclasas; 6: anfíbol; 11: fragmentos pumíceos.

Para el GP 6, solo se realizó un corte (Corte 26), que procede de la estructura 1 de $\mathrm{CH}$ 25. Presenta matriz de estructura lepidoblástica a microgranosa, inclusiones densas (32\%) y algunas cavidades (2,5\%). Las inclusiones presentan una distribución unimodal, con la media y la moda iguales a $0.2 \mathrm{~mm}$. Las inclusiones consisten en muscovita (11.5\%) y cuarzo abundante (8\%), cuarzos con extinción ondulante (3\%) y feldespatos 
potásicos (2\%). También hay litoclastos plutónicos (2.5\%) y de cuarzo policristalino con extinción ondulante (3\%). Las plagioclasas y la biotita son escasas (1\%). En la Figura 6.17 se puede observar una fotomicrografía de este tipo de pastas.

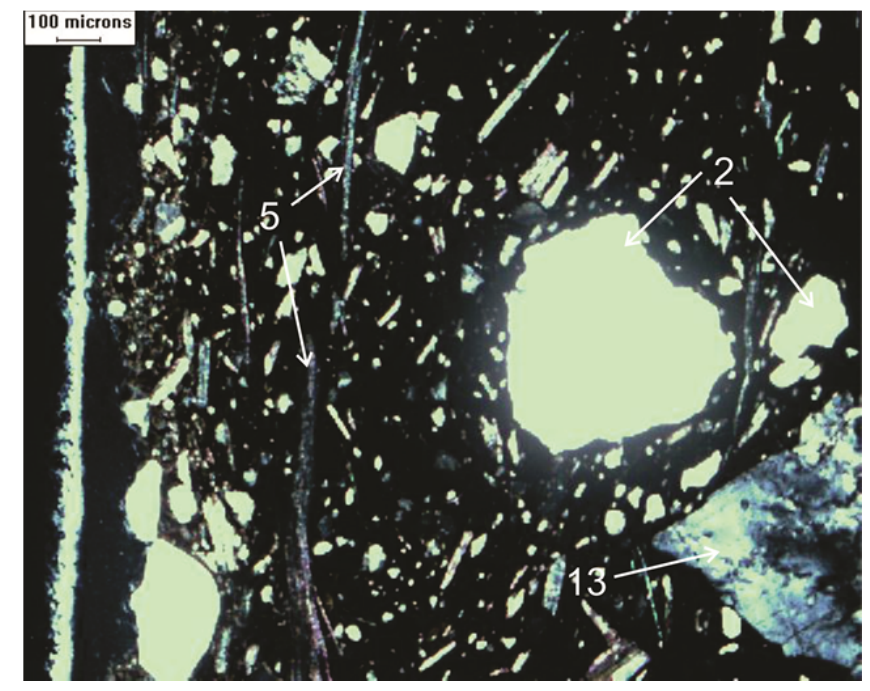

Figura 6.17 Fotomicrografía del Corte 26, con analizador. Referencias: 2: cuarzo; 5: muscovita; 13: cuarzo policristalino con extinción ondulante.

Cuatro cortes corresponden al GP $7(27,28,29$ y 30), procedentes de un sitio colonial (PA 22). Todos presentan estructura pseudolepidoblástica a microgranosa, entre 2 y $4 \%$ de cavidades e inclusiones densas (23 a 35\%). El tamaño de las inclusiones es variable, y presenta distribución unimodal en todos los casos, con media de $0.2 \mathrm{~mm}$ para los cuatro cortes, mientras que las modas están en valores comprendidos entre 0.15 y $0.25 \mathrm{~mm}$.

En todos los casos, el cuarzo es abundante (8 a 14\%), al igual que las plagioclasas (5 a 7\%). Son menos frecuentes los feldespatos potásicos (1-2\%), la biotita (0 a 3\%), los feldespatos con macla de Carlsbad $(<1 \%)$, los litoclastos pelíticos, que en uno de los cortes si son abundantes (Corte 29, 7\%) y los volcánicos (<2\%). Se registraron litoclastos de origen metamórfico, consistentes mayormente en cuarzo policristalino con extinción ondulante y en ocasiones contactos suturados, aunque en porcentajes variables (0.5 a 7\%) para cada corte. En la Figura 6.18 se puede observar una fotomicrografía de una de estas pastas. 


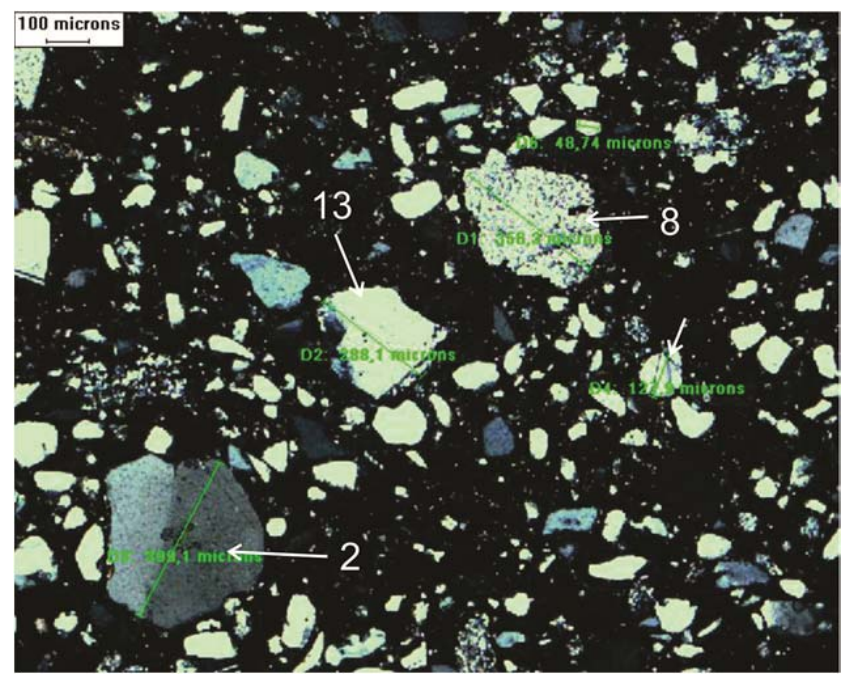

Figura 6.18 Fotomicrografía del Corte 28, con analizador. Referencias: 2: cuarzo; 8: pelita granular fina; 13: cuarzo policristalino con extinción ondulante.

En cuanto al GP 8, se analizaron cinco cortes correspondientes a fragmentos del mismo (Cortes 52, 53, 55, 61 y 70). Presentan estructura microgranosa, y en un caso (Corte 53) pseudolepidoblástica, inclusiones densas a muy densas (15 a 38\%), y cavidades entre 2 y $5 \%$. Las inclusiones presentan tamaños variables, con una media promedio de $0.2 \mathrm{~mm}$, y distribución unimodal en dos cortes (Cortes 53 y 55), y bimodal en los tres restantes, con un pico mayor entre 0.06 y $0.1 \mathrm{~mm}$ y otro más pequeño en $0.75 \mathrm{~mm}$.

Estas pastas, al igual que el GP 3, también se caracterizan por la abundancia de pelitas, aunque en la lupa binocular exhibían diferentes coloraciones, lo que llevó a separarlas en otro grupo. En el análisis microscópico, se observa que las pelitas más abundantes son las granulares finas (9 a 25\%), seguidas por las laminares (1 a 9\%) y las granulares gruesas (0.5 a 8\%). En menor medida, se observan mineraloclastos de cuarzo (1 a 5\%), algunos con extinción ondulante. Pueden estar presentes en baja cantidad (<1\%) plagioclasas y biotita, y litoclastos de cuarzo policristalino con extinción ondulante. En la Figura 6.19 se muestra una fotomicrografía de estas pastas. 


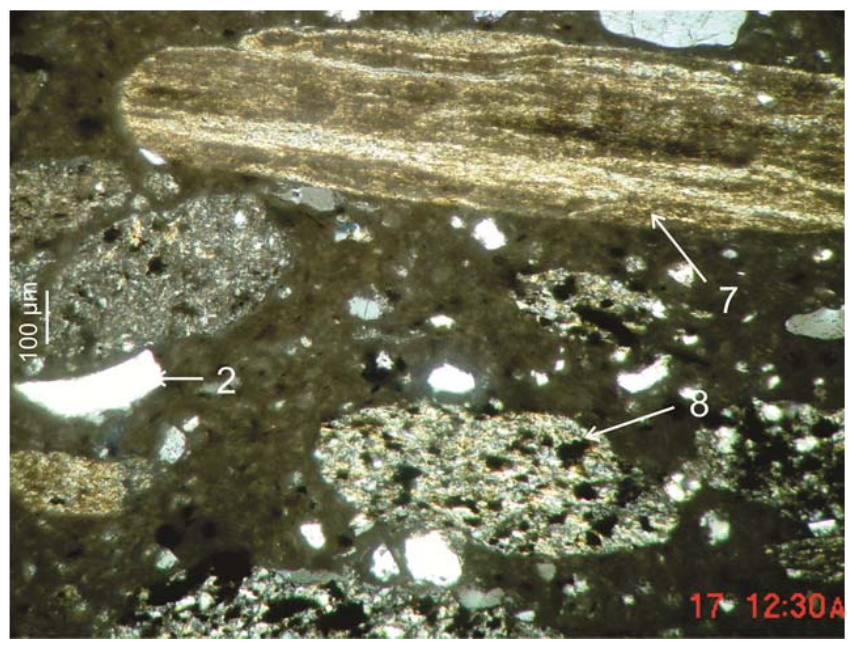

Figura 6.19 Fotomicrografía del Corte 55, con analizador. Referencias: 2: cuarzo; 7 : pelita la minar; 8: pelita granular fina.

Finalmente, para el GP 9 se analizó un único corte (Corte 60), que presenta matriz de estructura microgranosa, algunas cavidades (1.6\%), e inclusiones poco densas (12.1\%). Las mismas presentan tamaños que se distribuyen unimodalmente, con una media de 0.15 y una moda de $0.1 \mathrm{~mm}$.

Las inclusiones más abundantes son las plagioclasas (4\%) y los litoclastos plutónicos (3.5\%), seguidos por el cuarzo (2\%) y feldespatos alterados (2\%), y escasa cantidad $(<1 \%)$ de anfíboles, biotita y cuarzo policristalino con extinción ondulante. La importancia de los litoclastos plutónicos separa a este corte de los demás GP identificados. En la Figura 6.20 se observa una fotomicrografía de este corte.

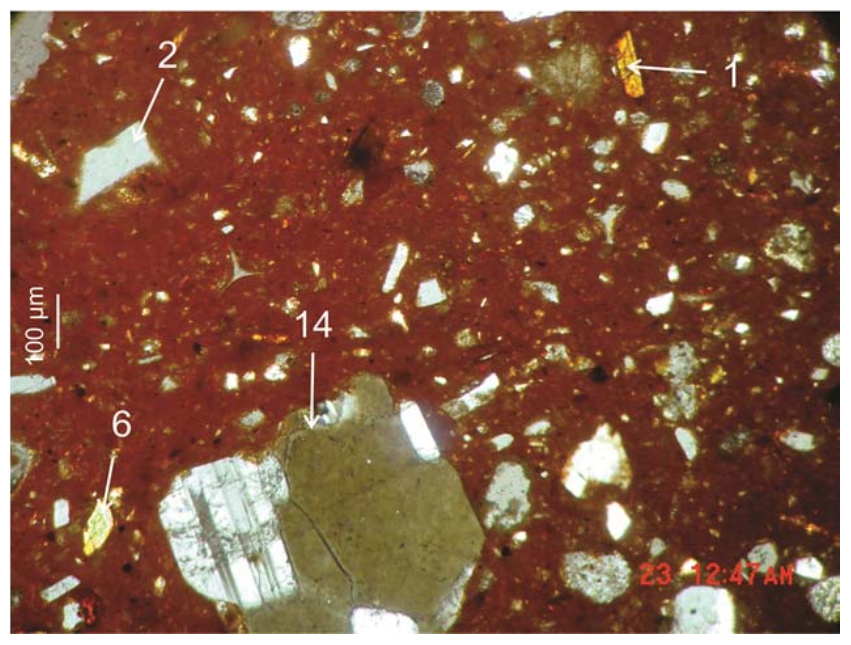


Figura 6.20 Fotomicrografía del Corte 60, con analizador. Referencias: 1: biotita; 2:

cuarzo; 6: anfíbol; 14: litoclasto plutónico.

\section{Caracterización de muestras de arena:}

Sobre las muestras de arena obtenidas en las prospecciones se realizaron tanto observaciones en lupa binocular como en microscopio petrográfico. Las observaciones en lupa incluyeron todas las muestras obtenidas, pero solo se realizaron secciones delgadas sobre tres de ellas, procedentes de los cauces temporarios de Pan de Azúcar, Chajarahuayco y Río Herrana. Esto nos permite comparar las características ópticas de los minerales y litoclastos presentes con las de las pastas cerámicas.

\section{Observaciones en lupa binocular:}

En la Tabla 6.6 se pueden observar las principales características de las arenas del área de Pozuelos analizadas en lupa binocular y en la Figura 6.21 fotos de las mismas.

\begin{tabular}{|c|c|c|c|c|c|c|c|c|c|}
\hline \multirow[b]{2}{*}{ MA } & \multirow[b]{2}{*}{ Gran. } & \multirow[b]{2}{*}{ Selección } & \multirow[b]{2}{*}{ Redondez } & \multicolumn{3}{|c|}{ MINERALES } & \multirow[t]{2}{*}{ SEDIMENTARIAS } & \multicolumn{2}{|c|}{ IGNEAS } \\
\hline & & & & $\mathrm{Q}$ & mica & Q-fel & & Volc & Plut \\
\hline $1-\mathrm{RH}$ & 4 y $5>$ & 1 a 2 & 3 a 5 & $x x$ & $x$ & $x$ & $x$ & $x$ & $x$ \\
\hline $2-\mathrm{CH}$ & 4 y $5>$ & 3 & 2 a 3 & $x x$ & $x x$ & $x$ & $x x$ & $x$ & \\
\hline $3-P A$ & 3 y $4>$ & 1 a 2 & 2 a 4 & $x x$ & $x x$ & $x$ & & $x$ & $x$ \\
\hline 4 - FD & 3 a $5>$ & 1 a 2 & 4 a 5 & $x x$ & $x$ & $x$ & $x$ & & \\
\hline
\end{tabular}

Tabla 6.6 Características submacroscópicas de muestras de arena procedentes de la cuenca sur de la laguna de Pozuelos.

En la tabla se puede apreciar que todas las muestras, menos la de Chajarahuayco (2-CH) presentan una selección pobre, dada por la presencia de elementos gruesos, aunque predominan las granulometrías finas. Al no ser abundantes los elementos gruesos, consideramos que con una separación manual de los mismos, se podría obtener una selección más equilibrada, si se quisiese agregar estas arenas a la arcilla como antiplástico. También se aprecia que el grado de redondez es variable de muestra en muestra, con elementos angulares a redondeados. Estos dos atributos son característicos de sedimentos inmaduros (Jordan et al. 1999) lo que es coherente con 
que las muestras proceden de cauces temporarios, de una zona con baja actividad hídrica.

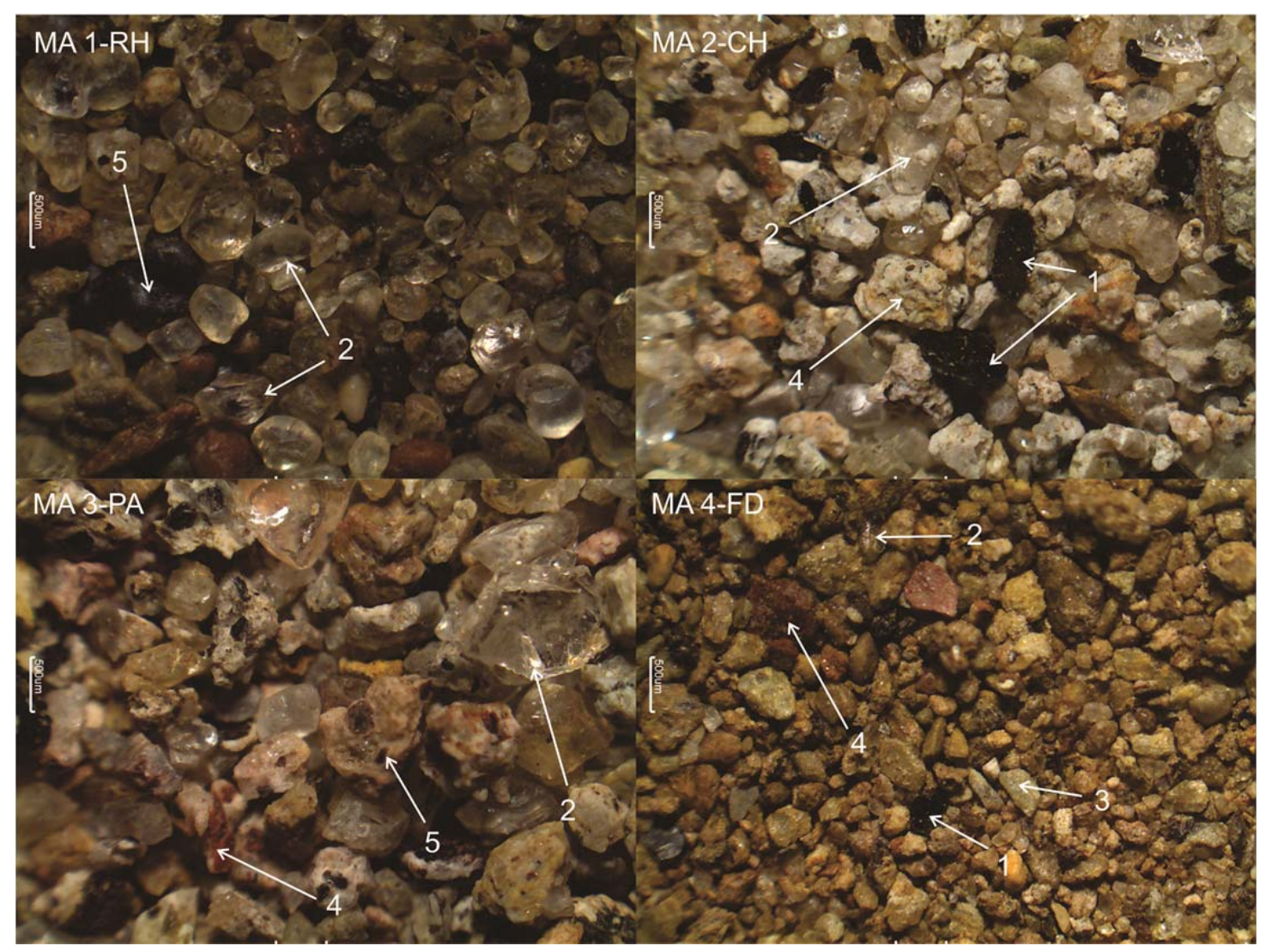

Figura 6.21 Fotografías en lupa binocular de cuatro muestras de arena de la cuenca sur de Pozuelos. Ref: 1: biotita; 2: cuarzo; 3: minerales félsicos; 4: sedimentarias; 5: clastos volcánicos.

Por otro lado, se puede notar que en todas las muestras predomina el cuarzo como mineraloclasto más abundante. Estos cuarzos son traslúcidos, incoloros, de angulosos a subredondeados. Además, hay presencia de biotita, que se exhibe en pequeñas hojuelas hexagonales, y de minerales félsicos indeterminados. Entre los litoclastos, se pudieron identificar los de origen sedimentario, que muestran diferentes colores (rojo, blanco, marrón, amarillo), y que se caracterizan por ser de grano muy fino. También se observan posibles litoclastos volcánicos, algunos de color oscuro, afaníticos, y otros claros, con fenocristales de biotita a simple vista. En muy escasa cantidad, en la muestra de Río Herrana (1-RH) se observaron posibles litoclastos plutónicos. 
También se observaron otras muestras en la lupa, una provista por una ollera de Casira del antiplástico empleado actualmente y que se denomina pirca, y una muestra de una arcilla rojiza y otra blanca (también denominada pirca), provenientes de las proximidades de Santa Catalina, que según un informante de esa población son empleadas en la manufactura actual de cerámica en Casira. Las dos muestras de "pirca" son semejantes y se trata de una roca sedimentaria muy fina, sin fisilidad, fácilmente desagregable, de color marrón muy pálido (10YR 7/4). La muestra de antiplástico de la ollera además contiene algunos clastos sedimentarios más consolidados, blancos y grises, subredondeados.

La muestra de arcilla rojiza está consolidada en agregados difíciles de desarmar, es de color marrón rojizo oscuro $(2,5 \mathrm{YR} 2,5 / 4)$ en fractura fresca y se rompe en terrones irregulares, con caras brillosas. No tiene planos de fisilidad. Como inclusiones se observa mica fina y algunos clastos claros.

La "pirca" color claro que se emplea actualmente como antiplástico, a simple vista tiene el mismo aspecto que las pelitas blancas de la cerámica arqueológica, aunque algunas veces estas pelitas tienen planos de fisilidad (litoclastos pelíticos laminares) no observables en las muestras de "pirca". Sin embargo, para comparar estas muestras de arcilla y "pirca" empleadas en la actualidad con la cerámica arqueológica se hacen necesarios análisis químicos, como la activación neutrónica, y tener en cuenta los efectos de la cocción sobre la composición y el aspecto.

\section{Observaciones en microscopio petrográfico:}

La caracterización de las arenas se profundizó mediante el análisis petrográfico, a fin de comparar la litología de las mismas con las inclusiones cerámicas, como ya se mencionó. Como se trata de arena y no de pastas cerámicas, no se realizó un conteo de puntos como en los cortes cerámicos, dado que no hay matriz ni cavidades, y al estar los clastos del sedimento preparados sobre una resina previo a su pulido (Ponti com. pers.) hay espacios sin minerales que no tienen significación en la cuantificación. Por lo que se contabilizaron 300 clastos por corte, a fin de caracterizar la proporción de cada componente en la arena bajo estudio. Los resultados de esta cuantificación se pueden observar en la Tabla 6.7. 


\begin{tabular}{r|lccc}
\hline \multicolumn{1}{c}{} & $\mathbf{N}^{\circ}$ & 1 & 2 & 3 \\
\cline { 2 - 5 } & Sitio/UP & $\mathrm{RH}$ & $\mathrm{CH}$ & $\mathrm{PA}$ \\
& Redondez & $3 \mathrm{a} 5$ & $2 \mathrm{a} 4$ & $2 \mathrm{a} 4$ \\
& Selección & pobre & equilibrada & pobre \\
\hline MINERALO & Q & $26.1 \%$ & $40.3 \%$ & $24.3 \%$ \\
& Q ext ond & $0.6 \%$ & $1.3 \%$ & $0.3 \%$ \\
& Fel K & $0.6 \%$ & $1.0 \%$ & $0.7 \%$ \\
& Fel Alt & $0.0 \%$ & $0.0 \%$ & $0.3 \%$ \\
& Plagioclasa & $29.3 \%$ & $27.7 \%$ & $26.2 \%$ \\
& Biotita & $6.4 \%$ & $11.3 \%$ & $24.9 \%$ \\
& Anfíbol & $2.5 \%$ & $0.3 \%$ & $0.0 \%$ \\
\hline TARIMEN & Psamita/Arenisca & $4.1 \%$ & $2.7 \%$ & $0.0 \%$ \\
\hline IGNEAS & Pel gran fina & $15.3 \%$ & $5.3 \%$ & $0.0 \%$ \\
\hline & Volcánica & $14.0 \%$ & $10.0 \%$ & $22.9 \%$ \\
& Plutónica & $0.0 \%$ & $0.0 \%$ & $0.3 \%$ \\
& Q pol ext recta & $0.6 \%$ & $0.0 \%$ & $0.0 \%$ \\
\hline METAMORF & & $0.3 \%$ & $0.0 \%$ & $0.0 \%$ \\
\hline
\end{tabular}

Tabla 6.7 Porcentaje de clastos en muestras de arena. Ref.: Q: cuarzo; ext: extinción; ond: ondulante; Fel: feldespato; Alt: alterado; Pel: pelita; gran: granular; pol: policristalino.

Se puede observar, como se destacó en el análisis con lupa binocular, que la selección de clastos de las arenas es pobre a equilibrada. En todas las arenas predominan los cuarzos y las plagioclasas, siendo la de Chajarahuayco más cuarzosa que las otras. Los cuarzos son límpidos, de angulares a redondeados, y las plagioclasas son tabulares, no se encuentran alteradas y en ocasiones presentan zonado, típico de ambientes de origen volcánico. También es importante la presencia de biotita, siendo esta muy abundante en la muestra de Pan de Azúcar. En ocasiones, las biotitas se encuentran alteradas como manchas de óxido. Los feldespatos potásicos son muy escasos, al igual que los anfíboles.

Entre los litoclastos, los más abundantes son los volcánicos, que se caracterizan por presentarse redondeados, de textura ligeramente porfírica, con matriz afanítica y fenocristales pequeños de plagioclasa, cuarzo y biotita. Los litoclastos pelíticos están presentes en las muestras de Río Herrana y de Chajarahuayco, siendo más abundantes en el primero. Dentro de los mismos, son más frecuentes los granulares finos, y no se observaron los laminares que se describieron para los materiales cerámicos. También se observan rocas sedimentarias de grano más grueso, como psamitas o areniscas finas. 
En las fotomicrografías (Figura 6.22) se puede observar el aspecto de los litoclastos volcánicos y pelíticos a nicoles cruzados, y también los distintos mineraloclastos mencionados anteriormente.
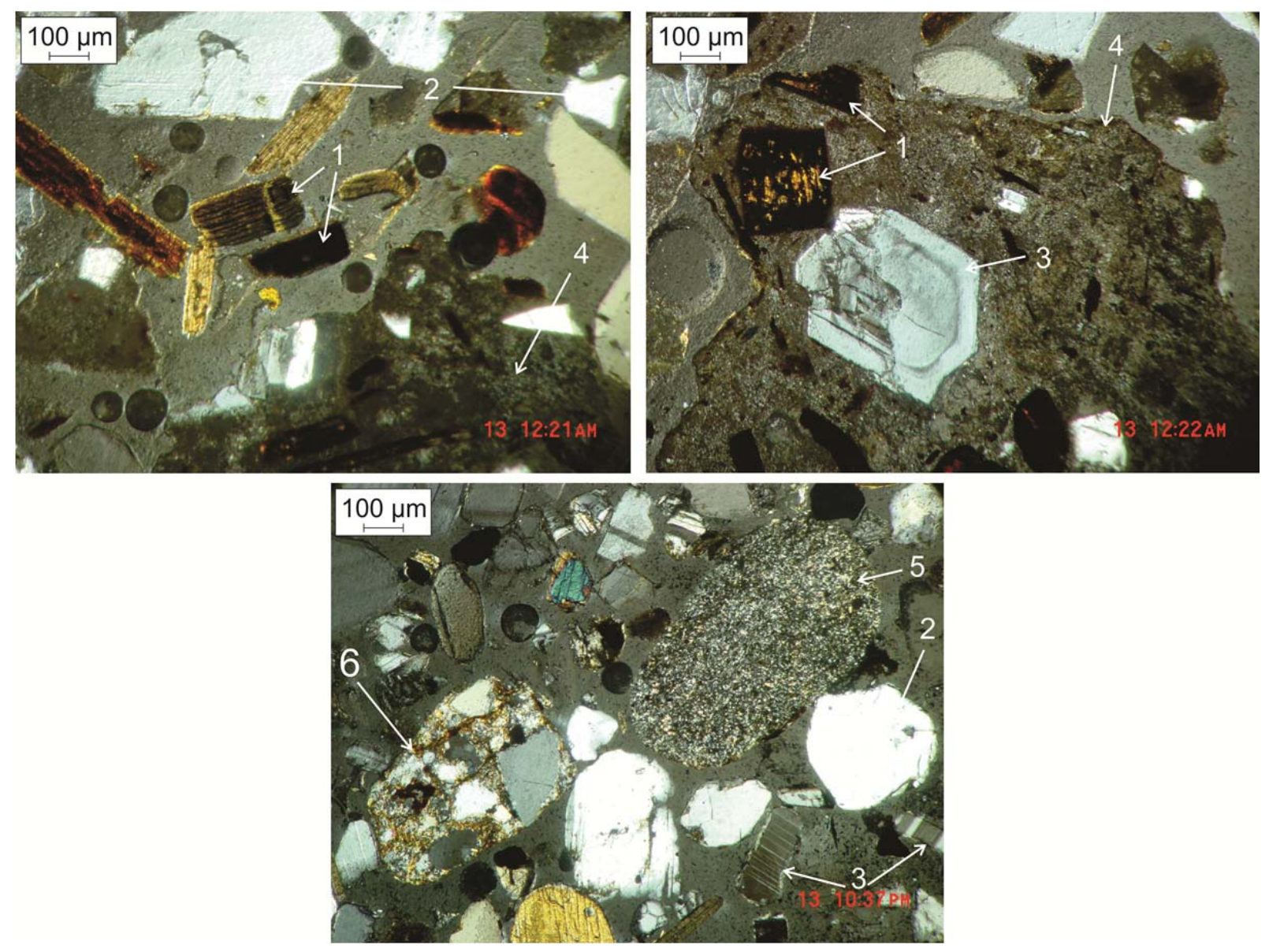

Figura 6.22 Fotomicrografías de los cortes delgados de arenas, con analizador. Las dos de arriba son de la muestra de Pan de Azúcar y la de debajo de Río Herrana. Ref.: 1: biotita, 2: cuarzo, 3: plagioclasa, 4: litoclasto volcánico, 5: pelita granular fina, 6: psamita/arenisca.

En general, las inclusiones de las arenas analizadas son más gruesas que las de las inclusiones en las pastas cerámicas, con rangos de tamaños que llegan hasta los $2 \mathrm{~mm}$ e incluso $5 \mathrm{~mm}$ en la muestra de Río Herrana. Las medias y modas son de 0.38 y 0.35 $\mathrm{mm}$ respectivamente para la muestra $1-\mathrm{RH}$, de 0.3 y $0.3 \mathrm{~mm}$ para la $2-\mathrm{CH}$ y de 0.5 y 0.6 $\mathrm{mm}$ para la 3-PA. Asimismo, las tres muestras exhiben distribuciones unimodales de los tamaños. 
En cuanto a su origen, la presencia de fenocristales de cuarzo, plagioclasa y biotita en los litoclastos volcánicos podría permitir pensar que quizás las arenas se hayan formado a partir de la desintegración de rocas volcánicas, o de ignimbritas (que son sedimentarias de origen volcánico). Por otro lado, la presencia de plagioclasas sin alterar, hablaría de una escasa meteorización química, lo que sumado a la presencia de cuarzos tanto angulares como redondeados, y la selección pobre de estas arenas, estarían indicando sedimentos inmaduros y con poco transporte (Jordan et al. 1999). Esto es lógico, dado que la puna se caracteriza por una baja actividad hídrica, y los cauces de donde se tomaron las muestras de arena son temporarios. Quizás por esta misma razón no se hallaron arcillas, que se forman a partir de la descomposición de feldespatos.

Del análisis de estas secciones delgadas, se puede observar que las muestras de arena estudiadas presentan litoclastos volcánicos abundantes, que no están presentes en esta magnitud en la cerámica de Pozuelos analizada. Sin embargo, cuando se observan estos litoclastos en la cerámica, se presentan de composición muy semejante, con los mismos fenocristales. Los mineraloclastos tienen las mismas características ópticas que los observados en la cerámica, con cuarzos con diferente grado de redondez, bien límpidos y sin inclusiones; plagioclasas como feldespatos más abundantes, muchas veces presentando zonado; y también abundante biotita. Sin embargo, en estas muestras las plagioclasas tienen una proporción mayor que para las pastas cerámicas. Asimismo, se observan litoclastos pelíticos comparables a los descritos para la cerámica, aunque faltan los laminares. Las diferencias entre las distintas muestras de arena puede ser resultado de diferentes cuencas de aporte para cada uno de estos cursos temporarios, con afloramientos de rocas de formaciones variables.

\section{Síntesis y discusión del análisis de pastas:}

En base a las observaciones con lupa binocular, identificamos diferentes grupos de pastas, cuyas observaciones se profundizaron posteriormente con microscópico petrográfico, lo que nos permitió apreciar que, en general, la litología de las pastas bastante uniforme, predominando las inclusiones de mineraloclastos de cuarzo, plagioclasas, biotita, y de litoclastos sedimentarios pelíticos. En menor medida se observaron feldespatos potásicos, muscovita, litoclastos volcánicos, plutónicos, metamórficos y fragmentos pumíceos. 
Los cuarzos son predominantemente claros, redondeados a angulares. En ocasiones presentan extinción ondulante, que puede ser resultado de presiones generadas en condiciones de metamorfismo (Adams et al. 1984). Las plagioclasas son tabulares con maclas polisintéticas y es frecuente observar plagioclasas con zonado, producto de un enfriamiento rápido en su génesis, que son indicadoras de ambientes volcánicos. Los litoclastos sedimentarios pueden ser tanto laminares como granulares, siendo los primeros probablemente resultado de mayor contenido de minerales laminares, como arcilla y muscovita (Adams et al. 1984). A su vez, los granulares presentan una gradación de granos de más finos a más gruesos. Los litoclastos volcánicos son porfíricos, con algunos fenocristales pequeños de plagioclasa (que suelen exhibir zonado) en una matriz afanítica. Mientras que los metamórficos consisten mayormente en cuarzo con extinción ondulante y suturas irregulares. Los fragmentos pumíceos consisten en vidrio vesicular que se aprecia en observaciones sin analizador, en ocasiones con algunos fenocristales de biotita.

Ninguna de estas litologías es discordante de la geología local que, como vimos al comenzar el capítulo, y como se aprecia de la Figura 6.1, consiste mayormente en afloramientos de rocas sedimentarias como lutitas, limolitas y areniscas (Formación Acoite, Formación Peñas Coloradas, Formación Moreta, entre otras tantas), que pueden exhibir algún grado de metamorfismo (sedimentarias ordovícicas de la Formación Acoite) (Coira et al. 2004; Ramos y Coira 2008). También están presentes las rocas volcánicas ordovícicas y, más frecuentemente, cenozoicas, de composición andesítica y dacítica (Ramos y Coira 2008), y las sedimentarias volcaniclásticas, como las ignimbritas y brechas volcánicas. Estas rocas volcánicas o de origen volcánico, exhiben cristaloclastos de plagioclasa, cuarzo y biotita. En algunas rocas sedimentarias de origen volcánico se encuentran frecuentemente fragmentos pumíceos. El cuarzo también es frecuente en forma de vetas en las sedimentitas de la Formación Acoite (Coira et al. 2004).

En cuanto a la variabilidad dentro de las pastas analizadas, la misma puede sintetizarse en algunos agrupamientos más generales. Un grupo de litología uniforme, con variaciones en la proporción de uno u otro elemento, se observa en los GP 1, 2 y 4 y los cortes analizados para los mismos. Las inclusiones pueden ser resultado del agregado de arenas o de la elección de un sedimento arcilloso, con clastos de tamaño arena naturalmente incluidos, dado que se observa la mezcla de mineraloclastos y litologías sedimentarias, con menor aporte de volcánicas (Solá 2007). La granulometría 
es en general fina a media, y no hay una distribución bimodal de tamaños por lo que no se puede hablar de agregado intencional. Los cuarzos pueden estar o no redondeados y las plagioclasas no suelen estar alteradas, lo que sumado a la presencia de biotita (fácilmente alterable) indicaría que se trata de sedimentos inmaduros, que han sufrido escaso transporte (Jordan et al. 1999), lo que, como mencionamos, concuerda con la baja actividad hídrica de la puna y con las características de las muestras de arena obtenidas de los cauces de los cursos temporarios. Este grupo procedería de la cuenca sur de la laguna de Pozuelos.

Si bien las arenas muestreadas en esa área presentan diferente proporción de elementos a los de las pastas, con presencia de litoclastos volcánicos abundantes, no observados en esa magnitud en la cerámica, mayor proporción de plagioclasas y menor contenido de litoclastos pelíticos, a lo que se suma los tamaños de inclusiones en general más gruesos; las características ópticas de los mismos son muy semejantes, al igual que otras propiedades, como la redondez, o la falta de meteorización química, y la distribución unimodal de los tamaños de inclusiones. Debido a esto, consideramos que las observaciones de las arenas permiten apoyar la hipótesis de un origen de las materias primas en sedimentos locales, ya sea de arenas agregadas a la arcilla, o de arcillas con inclusiones tamaño arena naturales, pero de diferentes procedencias, con distintas proporciones en los elementos, y tamaños en general más finos. También la abundancia de litoclastos pelíticos observados en la cerámica puede ser resultado del agregado intencional de rocas sedimentarias molidas, que se redondean más fácilmente que otros tipos de rocas más duras, práctica que se ha observado en tiempos actuales entre las alfareras de la puna Jujeña, como se detallará en el Capítulo 10.

Otro grupo de pastas estaría conformado por los GP 3 y 8, correspondientes mayormente a la zona de Santa Catalina, pero con algunos ejemplares en la zona de Pozuelos. Como dijimos, el GP 3 corresponde a lo que se conoce como cerámica tipo o estilo Yavi y de pastas comparables a otras definidas para este estilo (Cremonte et al. 2007a). El GP 8 presenta características comunes, como mencionamos al discutir su petrografía, pero se diferencia en que las pelitas presentes exhiben diferentes colores al observarlas en lupa binocular. También se pueden incluir a la mayor parte de los fragmentos del GP 5, que si bien presentan baja densidad de inclusiones, las mismas están compuestas por elementos comparables a los GP anteriores, quedando afuera aquellos que presentan inclusiones de fragmentos pumíceos. 
En trabajos previos se ha planteado que estas cerámicas fueron manufacturadas con arcillas que incluyen naturalmente estos elementos (Krapovickas 1975, 1983), aunque al observar las prácticas actuales de los alfareros de Casira (ver Capítulo 10) y analizar en la lupa las inclusiones agregadas en la actualidad, denominadas "pirca", que presentan características semejantes a las de la cerámica prehispánica, se puede plantear que también se pudo haber dado un agregado intencional de este tipo de inclusiones. Quizás la presencia de secciones delgadas con una distribución bimodal de los tamaños para algunos fragmentos del GP 3 (4:14) y del GP 8 (3:5) pueda ser el resultado del agregado intencional de rocas molidas a las arcillas. Por otro lado, estos son los únicos cortes que presentan esta característica, no registrándose distribuciones bimodales en los demás GP identificados. Sin embargo, esta hipótesis requiere profundizarse con mayores análisis, por ejemplo, químicos y petrográficos (los últimos podrían incluir fragmentos experimentales o producidos en la actualidad en Casira).

Los GP 6, 7, 9 y los cortes con fragmentos pumíceos del GP 5 corresponden a fragmentos de sitios con dataciones o materiales poshispánicos y presentan litologías diferentes a los anteriores. Pero debe destacarse que los mismos son poco frecuentes, como se observa en las tablas precedentes. Pueden ser resultado tanto de la introducción de nuevos elementos a los contextos coloniales, muchos de ellos mineros (como PA 22) y que seguramente contaron con la presencia de españoles (Angiorama y Becerra 2010; Pérez Pieroni y Becerra 2010); o ser resultado de nuevas tradiciones productivas en la cerámica.

La litología de los mismos no es discordante con la geología local, porque en la zona se encuentran rocas con fragmentos pumíceos, rocas plutónicas y con bajo grado de metamorfismo, como se ha visto en la primer parte del capítulo. Sin embargo, al ser litologías diferentes a las de los demás grupos de pastas, cabe preguntarse si son elementos alóctonos a los sitios de nuestra zona de estudio o si son resultado de nuevas tradiciones tecnológicas. Quizás, el escaso número de fragmentos en cada uno de estos grupos de pastas, correspondientes muchas veces a una única pieza (como el GP 6 y quizás el GP 9), permite plantear la hipótesis de que se trate de elementos manufacturados en otras zonas de la puna o el altiplano y traídos a los sitios coloniales. Pero profundizar en este planteo también requiere mayores análisis.

Se ha postulado que la relocalización de poblaciones indígenas podría vincularse a la explotación de nuevas materias primas (Ravines 1978, cito en Varela Guarda 2002), lo cual produciría modificaciones en las pastas cerámicas sin implicar cambios en las 
formas y acabados de superficie. Sin embargo, no conocemos para esta porción de la puna de Jujuy reasentamientos de poblaciones locales a partir de las fuentes. Cabe destacar que Varela Guarda (2002) ha identificado un estándar de pasta con abundante muscovita en el Pukará de Turi (Pcia. El Loa, Chile), fechado por TL en 1640 d.C, comparable al Corte 26 aquí descrito. Ello podría ser resultado de elecciones similares en las materias primas después del contacto hispano indígena, por motivos que desconocemos. Esta semejanza en las pastas debería ser profundizada con mayores detalles de su composición y con muestras más amplias.

Para finalizar este capítulo, debemos destacar que los planteos realizados quedan a nivel de hipótesis para trabajos futuros, que mediante el empleo de análisis químicos, puedan determinar el aprovechamiento de fuentes de materias primas locales o no. Sin embargo, la evidencia aquí sintetizada apoya una obtención local a nivel regional, para ambas zonas de la puna analizadas. 


\section{EL MODELADO Y LAS MORFOLOGÍAS}

En este capítulo presentamos aquellas evidencias vinculadas a las técnicas de modelado y las marcas resultantes de las mismas, tanto para los materiales fragmentarios analizados como para las piezas depositadas en las colecciones. Asimismo, exponemos el repertorio morfológico presente en ambos tipos de muestras, dado que consideramos que la morfología elaborada por los artesanos y artesanas estaba vinculada a las técnicas de modelado empleadas.

\section{Las técnicas de modelado y sus atributos en el material fragmentario:}

Como se detalló en la metodología, la primera actividad realizada en el análisis del material fragmentario fue el remontado de fragmentos, junto con el agrupado de aquellos que no remontaban, pero que sin embargo presentaban características muy semejantes y que consideramos que correspondían a una misma pieza. Esto tenía como finalidad trabajar con unidades de análisis que reflejen lo más posible las piezas completas. En la Tabla 7.1 se puede observar el número de grupos de fragmentos (en adelante GF) y de fragmentos que no se pudieron agrupar (en adelante FNA) para cada uno de los sitios analizados. El remontaje y agrupado de fragmentos no pudo llevarse adelante en el basurero de PA 22 ni en los sitios de la zona de Santa Catalina (SC 3 y TC 2), por las características de la obtención de la muestra (ver Capítulo 4). En total, se pudieron remontar o agrupar 747 fragmentos (41\% del total) en 69 grupos que representarían a 69 piezas distintas. El resto de los fragmentos (1084:1831) se analizaron individualmente como FNA. 


\begin{tabular}{|c|c|c|}
\hline & GF & FNA \\
\hline $\mathrm{CH}$ 25-1 Nivel 1 & 3 & 6 \\
\hline CH 25-1 Rec Sup & 1 & 14 \\
\hline CH 25-2 Nivel 1 & 5 & 9 \\
\hline CH 25-2 Rec Sup & 0 & 3 \\
\hline PA 6-1 Nivel 1 & 8 & 5 \\
\hline PA 6-1 Rec Sup & 0 & 95 \\
\hline PA 22 Basurero S1 & 0 & 129 \\
\hline PA 22 Basurero Rec sup & 0 & 22 \\
\hline RH 2-1 Nivel 1 & 8 & 0 \\
\hline RH 2-1 Rec Sup & 0 & 51 \\
\hline RH 10-1 Nivel 1 & 2 & 8 \\
\hline RH 10-1 Nivel 2 & 5 & 3 \\
\hline RH 10-1 Rec Sup & 0 & 25 \\
\hline RH 19-1 Nivel 1 & 5 & 0 \\
\hline RH 19-1 Rec Sup & 0 & 7 \\
\hline RH 19-7 Nivel 1 & 22 & 84 \\
\hline RH 19-7 Nivel 2 & 3 & 9 \\
\hline RH 19-7 Rec sup & 0 & 12 \\
\hline TA 1-1 Nivel 1 & 7 & 20 \\
\hline TA 1-1 Rec Sup & 0 & 9 \\
\hline SC 3 & 0 & 197 \\
\hline TC 2 & 0 & 376 \\
\hline TOTAL & 69 & 1084 \\
\hline
\end{tabular}

Tabla 7.1 Cantidad de grupos de fragmentos (GF) y fragmentos no agrupados (FNA) por sitio y nivel. Ref.: Rec sup: recolección superficial.

Sobre estos grupos de fragmentos y fragmentos no agrupados, hemos registrado marcas y huellas de herramientas o del resultado del modelado. Sin embargo, el registro en este tipo de materiales es muy parcializado, dado que los fragmentos muchas veces conservan porciones pequeñas de las superficies cerámicas originales. Por otro lado, en numerosas ocasiones no se puede orientar el fragmento o saber a qué porción específica de la pieza corresponde, por lo que no se puede determinar la dirección ni la posición de las mismas. Además hay que sumar el hecho de que las técnicas subsiguientes de acabado de la forma y de la superficie suelen enmascarar las huellas de modelado, al igual que las huellas de uso y los procesos posdepositacionales (Rye 1981). Sin embargo, es importante una aproximación en este sentido, dado que, como mencionamos al hablar de la cadena operativa en Capítulo 2, los gestos técnicos vinculados al modelado suelen ser los más estables dentro de las tradiciones tecnológicas. 
Dentro de las marcas observadas, algunas están relacionadas a los acabados de superficie, y serán tratadas en el capítulo siguiente. Aquí sintetizaremos las relacionadas al modelado o técnica de levantado de la pieza.

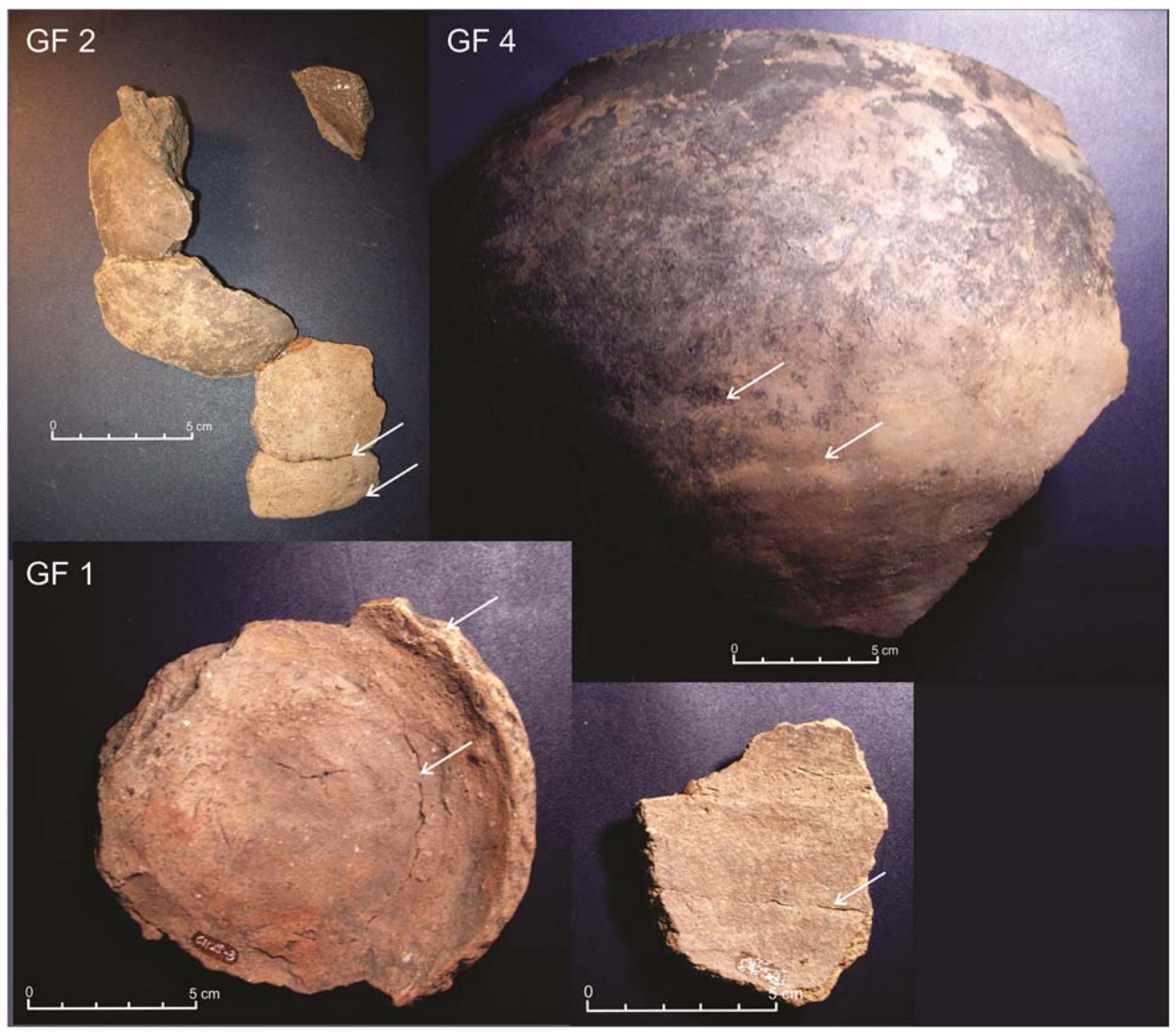

Figura 7.1 Marcas vinculadas al modelado con rollos en grupos de fragmentos y fragmentos no agrupados de $\mathrm{CH}$ 25-1. Las flechas indican la ubicación de las mismas.

En primer lugar, en el sitio $\mathrm{CH}$ 25-1, se registró el modelado por superposición de rollos en tres grupos de fragmentos (GF), que corresponderían a tres piezas diferentes, $y$ en dos fragmentos no agrupados. El grupo de fragmentos 1 (GF 1) presenta variaciones de espesor $u$ ondulaciones horizontales y un patrón de fractura longitudinal cercano a la base, todo lo cual sugiere el modelado por rollos (García Roselló 2010, Rye 1981) $)^{6}$. Las fracturas en facetas más o menos cúbicas del GF 2 también sugieren el modelado por rollos (Rye 1981). El GF 4 presenta variaciones de espesor $u$ ondulaciones horizontales al igual que el GF 1. En un fragmento no agrupado se observan grietas alargadas en la superficie interna, que pueden estar vinculadas a la

\footnotetext{
${ }^{6}$ Las fracturas se suelen asociar a los puntos de mayor fragilidad, por la unión de elementos o juntas. Las longitudinales, escalonadas o en facetas cúbicas se han vinculado mediante trabajos etnográficos al modelado por superposición de rollos (Rye 1981; García Roselló 2010).
} 
unión y alisado de rodetes, como documenta García Roselló (2010) en piezas manufacturadas etnográficamente. En la Figura 7.1 se pueden observar indicadas con flechas estas marcas que evidencian la técnica de modelado mencionada para este sitio. Por su parte, en $\mathrm{CH}$ 25-2, tres grupos de fragmentos exhiben variaciones de espesor horizontales que pueden ser resultado del modelado por rollos.

En PA 6-1, los GF 1 y 2 presentan variaciones de espesor $u$ ondulaciones horizontales, probablemente producidas por el modelado por superposición de rollos, mientras que el GF 4 exhibe evidencias de mala unión de rollos y fracturas producidas probablemente por ese motivo. El GF 6 también presenta variaciones de espesor horizontales, que se pueden apreciar en la Figura 7.2. Por otro lado, el GF 3 exhibe depresiones alargadas de dedos en la superficie interna ${ }^{7}$, lo que se asocia al estirado y arrastrado de arcilla, tanto por el modelado manual como por el estirado de los rollos con los dedos, dejando esas improntas (García Roselló 2010). Otros dos fragmentos no agrupados que remontan también exhiben marcas de arrastre de dedos.

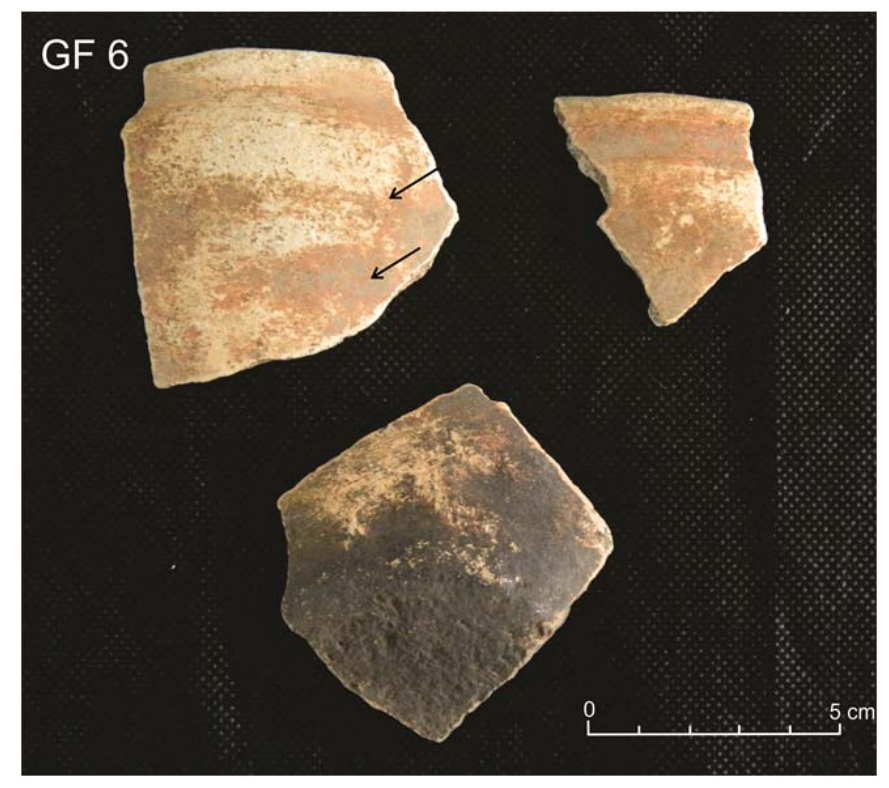

Figura 7.2 Variaciones de espesor u ondulaciones horizontales (indicadas con la flecha) en el GF 6 de PA 6-1.

Para el sondeo de PA 22, 13 fragmentos exhiben evidencias del modelado por superposición de rollos de arcilla. En uno de los mismos se observa el agregado de un

\footnotetext{
${ }^{7}$ Denominadas en la literatura como hendiduras de tipo hemisférico (García Roselló 2010), surcos (Rye 1981), huellas de dedos (Livingstone 2001, cito en García Roselló 2010).
} 
rollo entre la base y el cuerpo (Figura 7.3 A), gesto que se suele realizar para reducir los ángulos en este punto de unión, que son puntos especialmente frágiles, particularmente al momento de la cocción (García Roselló 2010; Peralta com. pers.). En otro fragmento se observa una mala unión de los rollos. En los restantes, se perciben variaciones de espesor verticales que serían por el modelado con rollos (Figura $7.3 \mathrm{~B}$ y C). Por otro lado, cinco fragmentos, exhiben estrías finas paralelas, producidas sobre la arcilla en estado plástico y depresiones longitudinales horizontales, que probablemente estén relacionadas al modelado con uso de torno (Rye 1981; Courty y Roux 1995). En uno de estos fragmentos además se suma la presencia de vitrificado, que es una técnica de acabado introducida por los europeos (Figura 7.3 D).

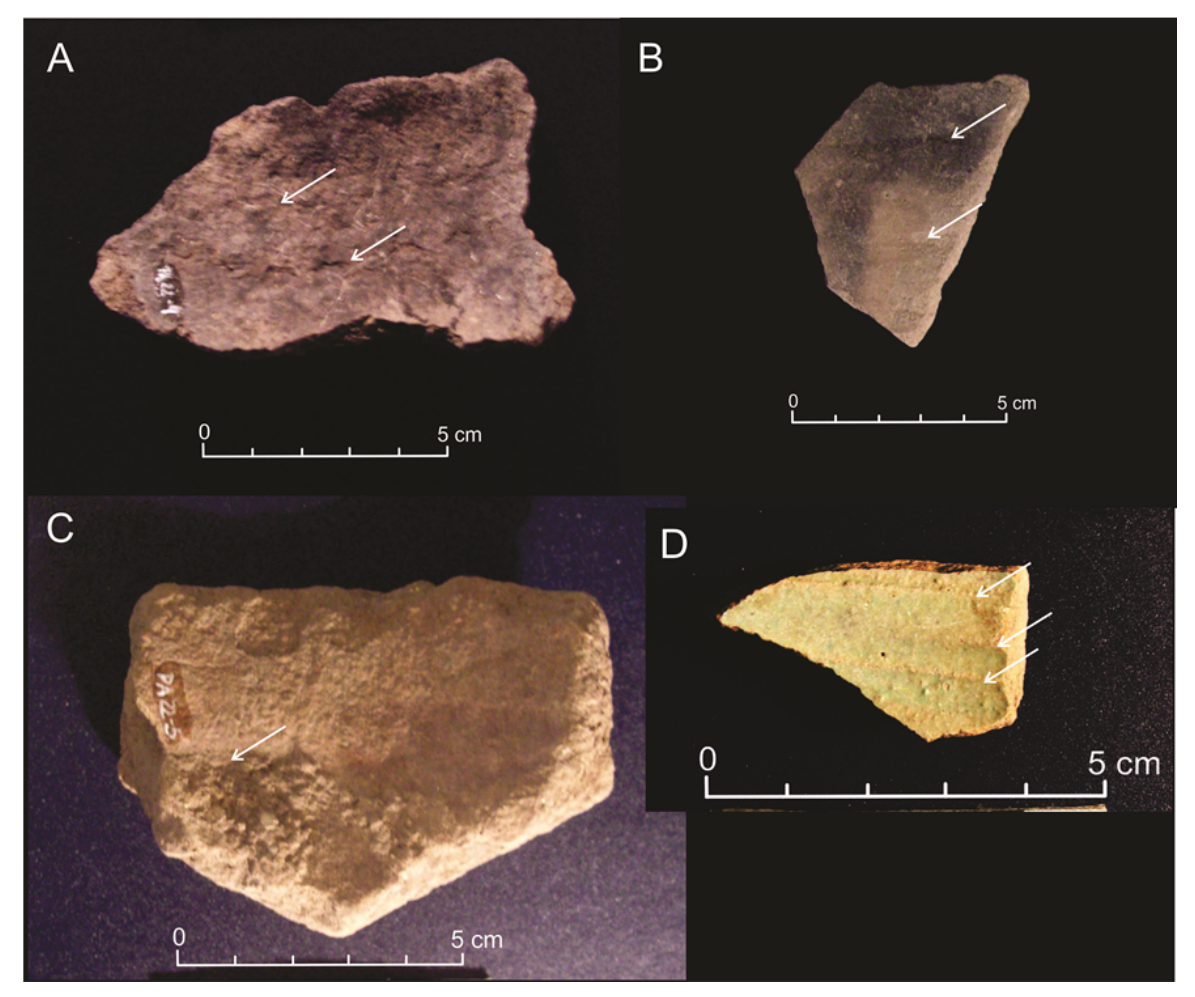

Figura 7.3 Huellas de modelado por superposición de rollos ( $A$, B y C) y de modelado con torno (D) en fragmentos de PA 22-S1. Las flechas indican las uniones y estrías.

En RH 2-1 solo se registraron variaciones de espesor horizontales probablemente vinculadas al modelado por rollos en un grupo de fragmentos (GF 1). En cambio, en RH 10-1 tres grupos de fragmentos (GF 1, 5 y 7) presentan variaciones de espesor horizontales, lo que sumado a las fracturas longitudinales presentes en el GF 1 y 5 , indicarían el modelado por rollos. Los dos primeros son del primer nivel (Nivel 2) de ocupación prehispánica, mientras que el tercero, corresponde al nivel de ocupación 
colonial (Nivel 1). Además, hay tres fragmentos no agrupados que presentan variaciones de espesor horizontales y en un caso fracturas en facetas cúbicas, que corresponderían también al modelado por rollos. Dos pertenecerían al segundo nivel de ocupación, de fechado colonial, y uno de recolección superficial.

Para RH 19-1, tan solo en el GF 1 se observaron evidencias de modelado, consistentes en variaciones de espesor horizontales producidas por la superposición de rollos. Por su parte, en $\mathrm{RH} 19-7$, seis grupos de fragmentos presentan evidencias de modelado con esa misma técnica, cinco del nivel 1 (GF 1, 2, 13, 19 y 20), y uno del segundo nivel (GF 6). Los cinco presentan variaciones de espesor $u$ ondulaciones horizontales, el GF 1 y el 20, fracturas longitudinales y el GF 13 fracturas en facetas cúbicas. EL GF 19, además de variaciones de espesor y fracturas en facetas cúbicas, presenta marcas de dedos en la superficie interna del borde, lo que puede estar vinculado al modelado manual o al estirado de esta sección con los dedos. Además, siete fragmentos no agrupados también habrían pertenecido a piezas modeladas por superposición de rollos, tres corresponden al Nivel 1, dos de los cuales remontan, dos al Nivel 2 y los dos restantes de recolección superficial. Los dos fragmentos que remontan corresponden a un borde que presenta fracturas longitudinales y en facetas cúbicas. Los otros cinco exhiben variaciones de espesor horizontales. Por otro lado, el GF 8 del Nivel 1, presenta variaciones de espesor entre secciones gruesas y delgadas de orientación vertical, patrón que se genera en el modelado manual, por presión con los dedos (Rye 1981). Otro fragmento de recolección superficial también presenta huellas de modelado manual.

En TA 1-1, tres grupos (GF 1, 4 y 6) exhiben evidencias de modelado por rollos. El GF 1 exhibe un reborde o rebaba en la superficie interna por la unión de segmentos, lo que probablemente se deba a que el cuello se modelo sobre el cuerpo mediante superposición de rollos, quizás una vez que el cuerpo adquirió cierta dureza (Figura 7.4). Este tipo de huellas ha sido asociado a la unión de rollos por García Roselló (2010) para colecciones etnográficas. EI GF 4 presenta variaciones de espesor horizontales u ondulaciones en algunas secciones y además otras pequeñas depresiones verticales, probablemente vinculadas al modelado manual, en otras partes de la pieza. Por lo que esta pieza habría sido modelada mediante la superposición de rollos y el modelado manual de algún segmento. El GF 6 exhibe variaciones de espesor por la disposición horizontal de los rollos en el modelado, que se aprecian mejor en la superficie externa (Figura 7.4). Otros dos fragmentos no agrupados que remontan entre sí, presentan variaciones verticales de espesor y fracturas longitudinales, probablemente por el 
modelado por rollos, mientras que un último fragmento de recolección superficial también presenta variaciones de espesor relacionadas a esta técnica de modelado.

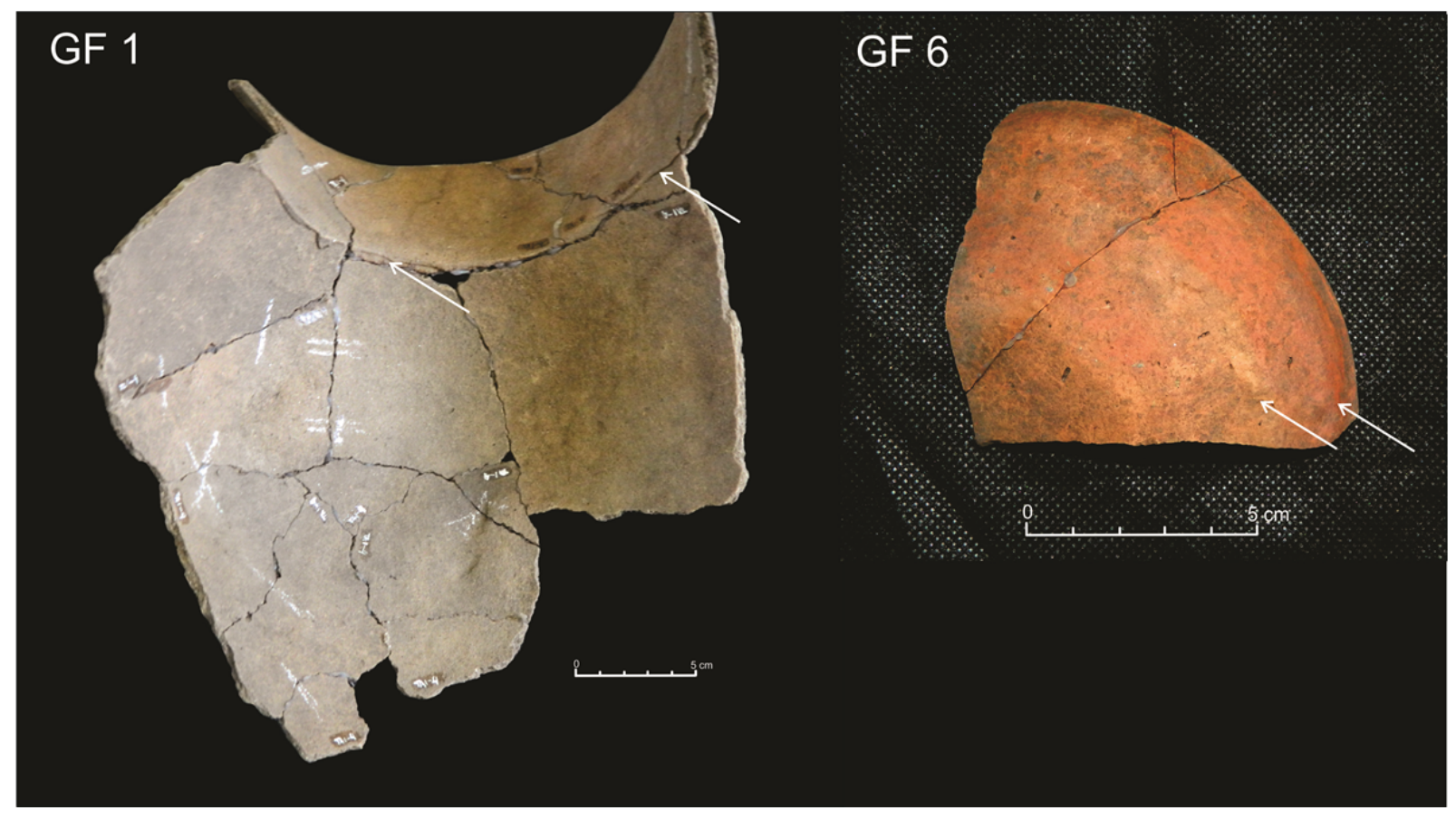

Figura 7.4 Huellas de modelado por superposición de rollos en TA 1-1.

Para los sitios de la zona de Santa Catalina, de los fragmentos recolectados en SC3, cuatro exhiben variaciones de espesor relacionadas al modelado con rollos y dos además exhiben malas uniones entre los mismos. Dos fragmentos, uno de base (Figura 7.5 A) y otro de punto de inflexión, muestran depresiones probablemente producidas por dedos en el modelado. Otros 21 fragmentos exhiben estrías finas y paralelas en la superficie externa, asociadas al modelado por torno (Figura 7.5 B). 


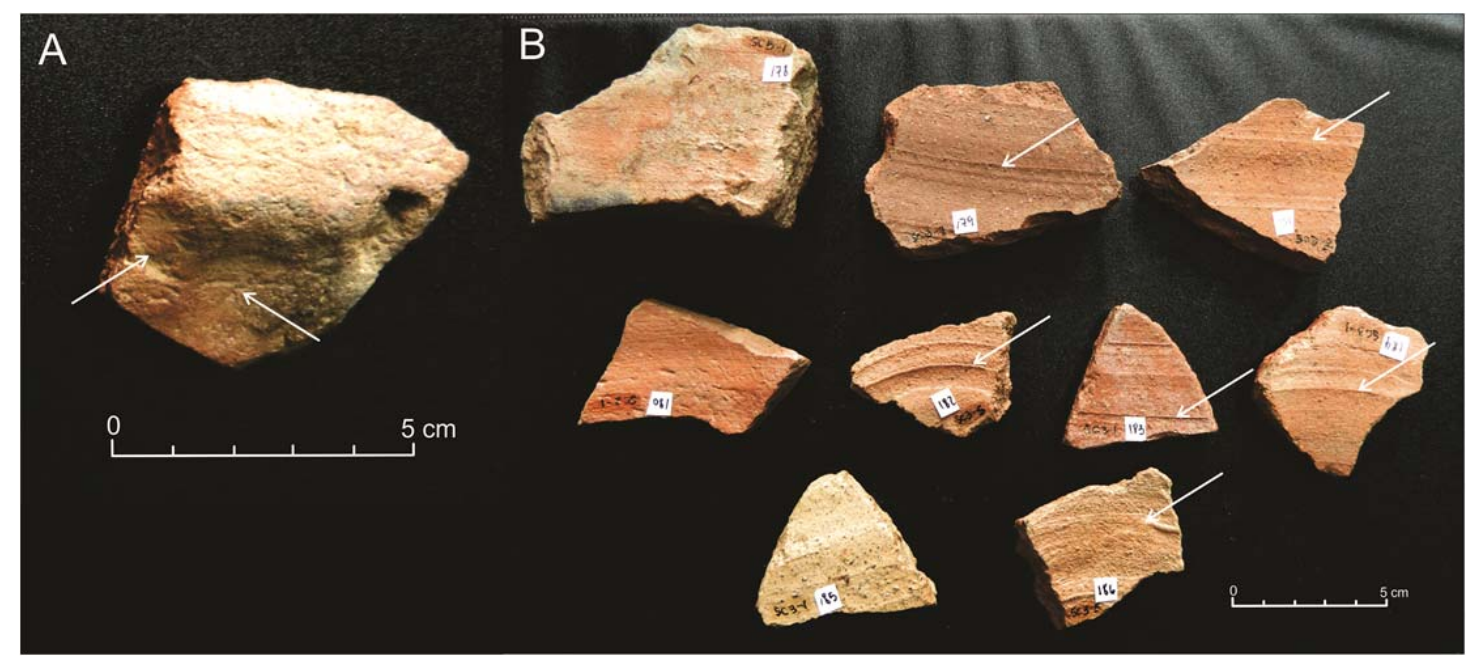

Figura 7.5 Huellas de modelado manual (A) y de modelado con uso de torno (B) en fragmentos de SC 3.

Por último, en TC 2, cinco fragmentos exhiben variaciones de espesor horizontales y en un caso también se observa la mala unión de rollos. Otros dos fragmentos presentan depresiones en la superficie interna, probablemente producidas por el modelado por presionado con los dedos.

En base a las evidencias que hemos descrito, en los siguientes gráficos se puede observar la cantidad de grupos de fragmentos que habrían sido modelados con cada técnica, para los sitios donde pudieron conformarse (Figura 7.6) y para los fragmentos no agrupados (Figura 7.7). Las cantidades fueron trasladadas a porcentajes sobre el total, de manera de que sean comparables, dadas las diferencias en el tamaño de las muestras para los distintos sitios.

Lo primero que se puede notar en los gráficos es que en todos los sitios analizados en los que se pudo determinar la técnica de modelado, tanto de momentos prehispánicos tardíos como coloniales, predomina la superposición de rollos, excepto en SC 3, donde son más abundantes los fragmentos con estrías de torno. Las marcas producidas por el modelado son menos abundantes y las de torno adquieren cierta importancia (pero no más del 10\%) en algunos de los sitios coloniales analizados. 


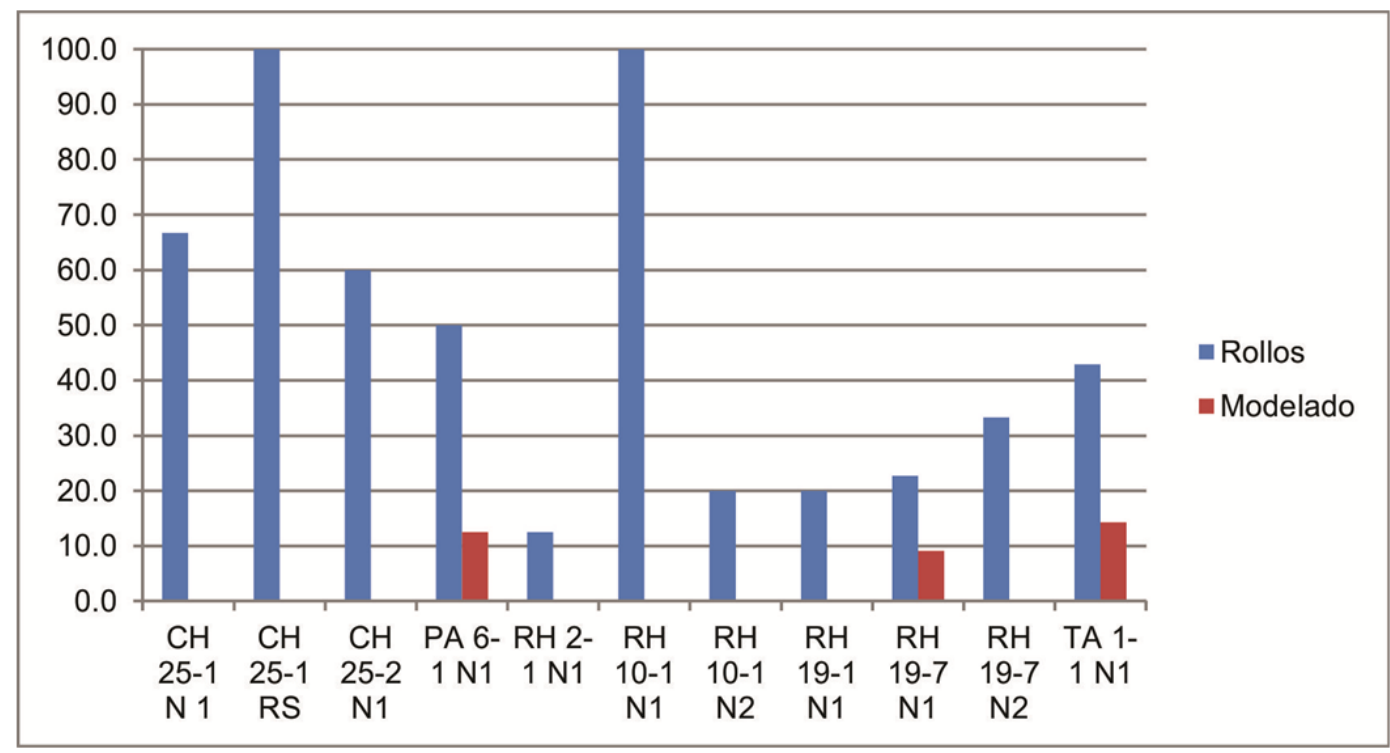

Figura 7.6 Porcentaje de GF modelados por superposición de rollos o por modelado para cada sitio de la muestra. Ref: N: nivel, RS: recolección superficial.

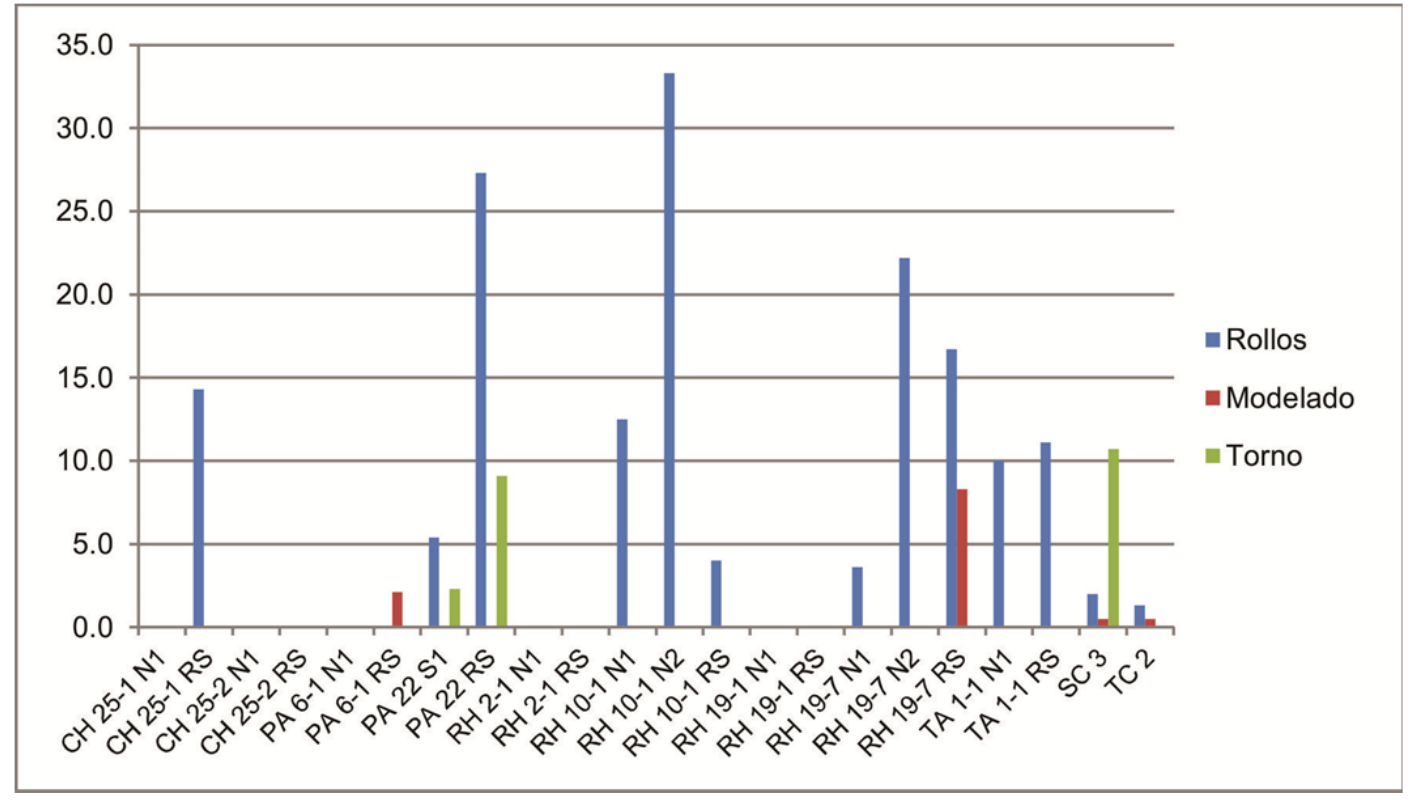

Figura 7.7 Porcentaje de fragmentos no agrupados modelados por superposición de rollos o por modelado para cada sitio de la muestra. Ref: N: nivel, RS: recolección superficial.

Otra observación que se puede hacer es que el porcentaje de determinación de la técnica de modelado en los grupos de fragmentos es significativamente mayor que en los fragmentos no agrupados, lo que puede ser resultado de que al aumentar la cantidad 
de superficie de una pieza por el remontado y agrupado, se incremente la posibilidad de observar evidencias sobre las técnicas empleadas para el modelado.

Como mencionamos anteriormente, las técnicas subsiguientes suelen enmascarar las evidencias del modelado, y hemos observado que en la mayoría de los casos, las mismas se conservan mejor en las superficies internas de piezas cerradas. Por otro lado, muchas veces una misma pieza puede estar modelada por diferentes técnicas, una para cada sección de la pieza (Rye 1981). Debido a que se trata de material fragmentario y a que las técnicas de modelado muchas veces no pueden percibirse, estas diferenciaciones no pudieron observarse en nuestro registro.

\section{Evidencias del modelado en las pastas cerámicas:}

La orientación de las inclusiones también ha sido tomada como un atributo que puede dar información sobre la técnica de modelado. En la literatura previa, se ha destacado el ordenamiento de las inclusiones con respecto a las superficies, observando, por ejemplo, que las mismas se disponen horizontalmente en placas radiográficas de las paredes en piezas modeladas por rollos (Rye 1981). También se tiene en cuenta la orientación en las fracturas, considerándose que la técnica de modelado por rollos puede producir una disposición preferencial horizontal de las inclusiones en fracturas horizontales y verticales (Balfet et al 1991). Asimismo, se ha registrado el ordenamiento de las inclusiones en forma circular en fracturas verticales por este método de modelado (García Roselló 2010). De igual forma, se han identificado otras alineaciones de las inclusiones vinculadas a otras técnicas (ver Rye 1981, Balfet et al. 1991; García Roselló 2010).

Si bien no hemos realizado análisis radiográficos para observar la disposición de las inclusiones con respecto a las superficies, hemos registrado en el análisis con lupa binocular el tipo de alineamiento de las inclusiones en fractura fresca y, en algunos de los sitios analizados, la orientación con respecto a las paredes. Sin embargo, cabe tener en cuenta que las inclusiones presentan una disposición regular cuando son laminares o tabulares, es decir que tienen un eje mayor sobre el que orientarse. Por lo que el porcentaje de fragmentos con elementos regularmente alineados puede estar algo subrepresentado. En la Tabla 7.2 pueden observarse la cantidad de fragmentos con orientación regular parcial e irregular en las fracturas frescas, para cada sitio analizado. Ningún fragmento presentaba un ordenamiento completo o bueno de los elementos. Por 
su parte, la Tabla 7.3 muestra la cantidad de fragmentos con orientación buena, regular parcial e irregular con respecto a las superficies, para los sitios en que se analizó esta variable.

\begin{tabular}{|c|c|c|}
\hline & Reg parcial & Irregular \\
\hline $\mathrm{CH} 25-1$ Nivel 1 & 8 & 17 \\
\hline CH 25-1 Rec Sup & 3 & 13 \\
\hline CH 25-2 Nivel 1 & 2 & 21 \\
\hline CH 25-2 Rec Sup & 0 & 3 \\
\hline PA 6-1 Nivel 1 & 13 & 33 \\
\hline PA 6-1 Rec Sup & 15 & 78 \\
\hline PA 22 Basurero S1 & 30 & 90 \\
\hline PA 22 Basurero Rec sup & 3 & 21 \\
\hline RH 2-1 Nivel 1 & 5 & 9 \\
\hline RH 2-1 Rec Sup & 2 & 21 \\
\hline RH 10-1 Nivel 1 & 6 & 3 \\
\hline RH 10-1 Nivel 2 & 5 & 10 \\
\hline RH 10-1 Rec Sup & 6 & 19 \\
\hline RH 19-1 Nivel 1 & 4 & 3 \\
\hline RH 19-1 Rec Sup & 4 & 2 \\
\hline RH 19-7 Nivel 1 & 27 & 109 \\
\hline RH 19-7 Nivel 2 & 3 & 19 \\
\hline RH 19-7 Rec sup & 3 & 10 \\
\hline TA 1-1 Nivel 1 & 3 & 39 \\
\hline TA 1-1 Rec Sup & 0 & 9 \\
\hline SC 3 & 9 & 180 \\
\hline TC 2 & 32 & 332 \\
\hline TOTAL & 183 & 1041 \\
\hline
\end{tabular}

Tabla 7.2 Orientación de las inclusiones en las fracturas frescas observadas en lupa binocular por sitio.

A partir de la Tabla 7.2 se puede notar que solo una pequeña parte (17.6\%) de los fragmentos observados con lupa presenta una orientación regular parcial de las inclusiones en fractura fresca. Muchos de estos son fragmentos que exhiben abundante mica, que tiende a disponerse horizontalmente ante la presión de los dedos. El porcentaje significativo de alineamiento irregular, puede estar vinculado a distintas técnicas de modelado y a un amasado de la pasta no muy intenso. Rye (1981) lo relaciona al modelado con rollos, mientras que García Roselló (2010) relaciona la orientación de las inclusiones con esa técnica, al igual que Balfet et al. (1991). Por lo que no hay un consenso sobre este atributo y sus implicancias. En la Figura 7.8 se pueden observar dos pastas con orientación regular parcial de los elementos, una de RH 19-7 y otra de TC 2. 


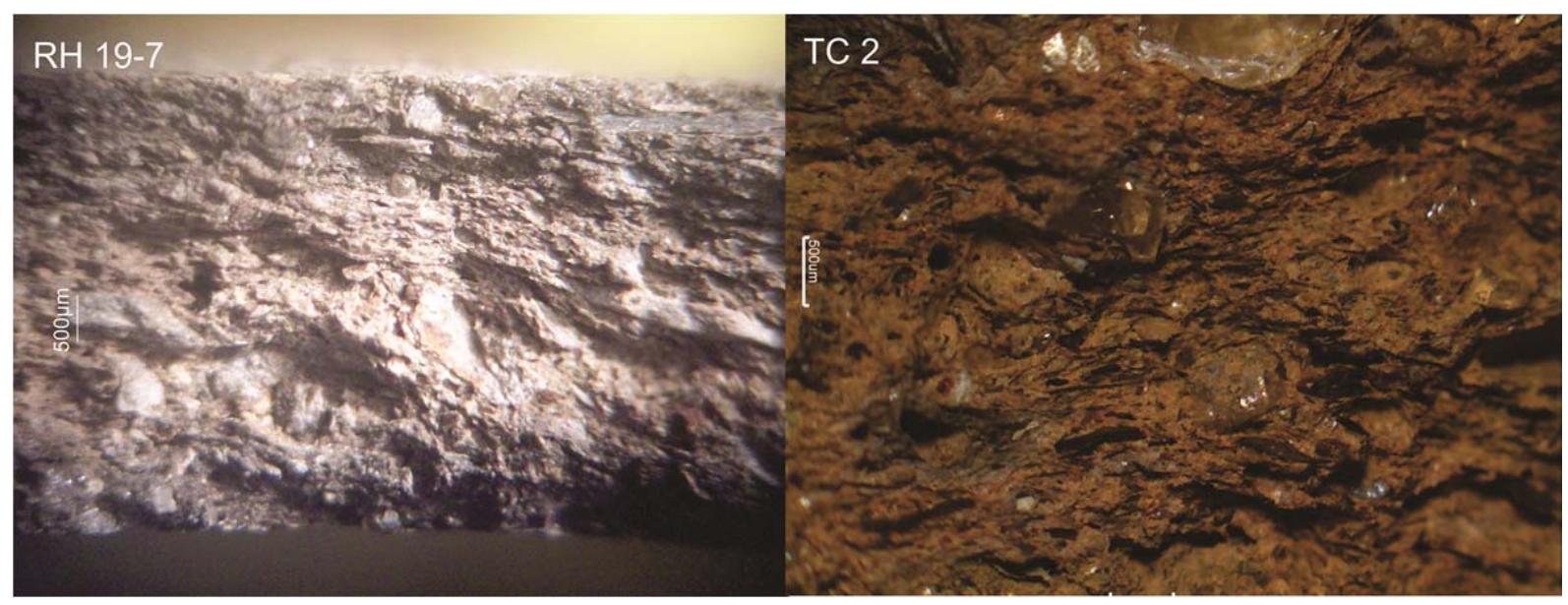

Figura 7.8 Pastas donde se observa la orientación regular parcial de las inclusiones no plásticas tabulares o laminares.

\begin{tabular}{lccc}
\hline & Muy regular & Regular Parcial & Irregular \\
\hline PA 6-1 Nivel 1 & 3 & 10 & 30 \\
PA 6-1 Rec Sup & 0 & 8 & 81 \\
TA 1-1 Nivel 1 & 0 & 16 & 21 \\
TA 1-1 Rec Sup & 0 & 2 & 7 \\
SC 3 & 0 & 8 & 134 \\
TC 2 & 0 & 20 & 235 \\
\hline \multicolumn{1}{r}{ TOTAL } & 3 & 64 & 508 \\
\hline
\end{tabular}

Tabla 7.3 Orientación de las inclusiones con respecto a las superficies observadas en lupa binocular.

En cuanto a la disposición de las inclusiones con respecto a las paredes, en la Tabla 7.3 se observa que un porcentaje aún menor que en el caso anterior exhibe orientación regular parcial (12.6\%). Este tipo de alineación puede vincularse a distintas técnicas de modelado asociadas con la presión de las paredes de manera que provoca la orientación de los elementos laminares o tabulares próximos. Los acabados de superficie también pueden contribuir en este sentido (Rye 1981). Aquí, al igual que anteriormente, el ordenamiento es más manifiesto en aquellos fragmentos que presentan abundante mica.

Sumado a la falta de consenso en la literatura consultada sobre la vinculación de estos atributos a técnicas de modelado concretas, no hemos observado correlaciones 
estrechas entre los fragmentos que exhiben una distribución regular de las inclusiones y los que presentan las evidencias de modelado mencionadas en la sección anterior. Los tres fragmentos que presentan disposición muy regular de las inclusiones (fundamentalmente biotita) con respecto a las superficies en PA 6 si están asociados a otras evidencias de modelado por rollos. Del total de 69 grupos de fragmentos, 24 presentaban evidencias de modelado por superposición de rollos. Dentro de estos, solo seis (20.8\%) (dos de $\mathrm{CH} 25$, uno de PA 6-1, uno de RH 2-1; otro de RH 10-1; y el último de $\mathrm{RH}$ 19-7) presentan orientación regular parcial de las micas en algunas fracturas frescas y tres (12.5\%) (uno de PA 6-1 y dos de TA 1-1) presentan alineamiento parcial de las inclusiones en las superficies. De los fragmentos no agrupados, uno modelado por torno (de PA 22) presenta orientación parcial de las inclusiones en fractura fresca; cuatro (1 de PA 22, 1 de RH 19-7, 2 de TC 2) presentan distribución regular parcial de las inclusiones en la fractura, además de las evidencias de modelado por rollos; y otro (de TC 2) con evidencias de modelado manual también exhibe orientación parcial de las inclusiones.

En el microscopio también se registró la disposición de las inclusiones y las cavidades. Cabe recordar que en 57 de los 70 cortes, los mismos se hicieron de forma perpendicular al plano de la boca, por lo que nos están mostrando secciones verticales de la cerámica. En dos casos (Cortes 1 y 64) se observó una orientación muy buena de las inclusiones en el sentido longitudinal del corte, relacionadas a la presencia de biotita (Corte 1) y a la matriz lepidoblástica con abundante biotita fina (Corte 64). En otros 46 cortes, procedentes de diferentes grupos de pastas, se observa una alineación parcial de los elementos, en algunos casos relacionados a la presencia de micas, o de inclusiones de forma tabular y de grietas y cavidades alargadas. Algunos de estos muestran un arreglo regular cerca de las paredes, y más irregular en el centro, como los cortes 26 y 63. Dos fotomicrografías de estos cortes, con las biotitas y muscovitas orientadas de forma paralela a la pared, se puede observar en la Figura 6.12 y 6.17 del Capítulo 6. Los 21 cortes restantes, también procedentes de diferentes GP, pero mayormente del GP 3 (8:21) y del GP 5 (6:21), y con estructuras generalmente microgranosas de la matriz, presentan las inclusiones y cavidades dispuestas irregularmente.

La orientación vertical de las inclusiones de todos estos cortes puede estar relacionada a la presión ejercida con los dedos en el modelado (pinching) como por la unión y estiramiento de rollos si se ejerce presión manualmente en las paredes. 
También pueden presentarse inclusiones alineadas cerca de la superficie por los acabados que se aplicaron, como un buen alisado o pulido (Rye 1981).

\section{Evidencias de modelado en piezas de colección:}

En el análisis del material de colecciones depositadas en museos, se han registrado marcas semejantes a aquellas descritas para el material fragmentario, que permiten identificar la técnica empleada para el modelado en algunas de las piezas analizadas. En la Tabla 7.4 se pueden observar las cantidades de piezas modeladas por cada técnica para cada uno de los sitios analizados, y el porcentaje del total de cada sitio que representan.

\begin{tabular}{|c|c|c|c|c|}
\hline & Rollos & $\begin{array}{c}\text { Model } \\
\text { manual }\end{array}$ & Indet & TOTAL \\
\hline Doncellas & $\begin{array}{c}12 \\
50 \%\end{array}$ & $\begin{array}{c}3 \\
12.5 \%\end{array}$ & $\begin{array}{c}9 \\
37.5 \%\end{array}$ & 24 \\
\hline Cochinoca & $\begin{array}{c}1 \\
33.3 \%\end{array}$ & 0 & $\begin{array}{c}2 \\
66.7 \%\end{array}$ & 3 \\
\hline Queta & $\begin{array}{c}14 \\
35.9 \%\end{array}$ & $\begin{array}{c}2 \\
5.1 \%\end{array}$ & $\begin{array}{c}23 \\
59 \%\end{array}$ & 39 \\
\hline Rinconada & 0 & 0 & $\begin{array}{c}1 \\
100 \%\end{array}$ & 1 \\
\hline Pucará de Rinconada & $\begin{array}{c}2 \\
13.3 \%\end{array}$ & $\begin{array}{c}2 \\
13.3 \%\end{array}$ & $\begin{array}{c}11 \\
73.3 \%\end{array}$ & 15 \\
\hline Sayate & $\begin{array}{c}1 \\
25 \%\end{array}$ & 0 & $\begin{array}{c}3 \\
75 \%\end{array}$ & 4 \\
\hline Sansana & 0 & $\begin{array}{c}1 \\
9.1 \%\end{array}$ & $\begin{array}{c}10 \\
90.9 \%\end{array}$ & 11 \\
\hline \multirow[t]{2}{*}{ Yavi Chico } & $\begin{array}{c}1 \\
33.3 \\
\end{array}$ & 0 & $\begin{array}{c}2 \\
66.7 \\
\end{array}$ & 3 \\
\hline & $\begin{array}{c}31 \\
31 \%\end{array}$ & $\begin{array}{c}8 \\
8 \% \\
\end{array}$ & $\begin{array}{c}61 \\
61 \% \\
\end{array}$ & 100 \\
\hline
\end{tabular}

Tabla 7.4 Cantidad de piezas de colección por técnica de modelado para cada sitio.

Estos resultados permiten apreciar que para la mayor parte de las piezas analizadas no se pudo identificar la técnica de modelado empleada. Dentro de las que sí, la mayoría han sido modeladas por superposición de rollos de arcilla y, en menor medida, por modelado manual. No se han observado piezas con evidencias de modelado por torno. Dentro de los sitios analizados, aquellas piezas procedentes de Doncellas, seguidas por las de Queta, son las que mayor cantidad de observaciones se pudo realizar sobre las técnicas de modelado. Sin embargo, cabe destacar que la mayoría de los sitios están representados por muy pocas piezas. 
Por otro lado, en la Tabla 7.5, se pueden observar los tipos de huellas que se registraron en las piezas analizadas para cada sitio, mientras que en la Tabla 7.6 se pueden apreciar en que porción del cuerpo aparecen las mismas, observaciones que pudieron hacerse en esta muestra, dado que se trata de piezas completas. En ambos casos, los números tabulados representan las cantidades de piezas sobre las que se registró la huella o marca.

\begin{tabular}{|c|c|c|c|c|c|c|c|}
\hline & $\begin{array}{c}\text { Variac } \\
\text { espesor hor }\end{array}$ & $\begin{array}{c}\text { Variac } \\
\text { esp vert }\end{array}$ & $\begin{array}{c}\text { Marcas } \\
\text { unión rollos }\end{array}$ & $\begin{array}{c}\text { Marcas unión } \\
\text { segmentos }\end{array}$ & $\begin{array}{c}\text { Marcas } \\
\text { dedos }\end{array}$ & $\begin{array}{c}\text { Marcas } \\
\text { recortado }\end{array}$ & $\begin{array}{c}\text { Rollo } \\
\text { terminación }\end{array}$ \\
\hline Doncellas & 11 & 1 & 4 & 4 & 3 & 1 & 2 \\
\hline Cochinoca & 1 & 0 & 0 & 0 & 0 & 0 & 0 \\
\hline Queta & 13 & 2 & 4 & 3 & 1 & 1 & 0 \\
\hline Pucará de Rinconada & 2 & 0 & 0 & 0 & 0 & 0 & 1 \\
\hline Sayate & 1 & 0 & 0 & 1 & 0 & 0 & 0 \\
\hline Sansana & 0 & 1 & 0 & 1 & 1 & 0 & 0 \\
\hline Yavi Chico & 1 & 0 & 0 & 0 & 0 & 0 & 0 \\
\hline TOTAL & 29 & 4 & 8 & 9 & 5 & 2 & 3 \\
\hline
\end{tabular}

Tabla 7.5 Cantidad de piezas por sitio para cada tipo de marca o huella de modelado registradas en piezas de colección.

\begin{tabular}{lccccccc}
\hline & $\begin{array}{c}\text { Variac } \\
\text { espesor hor }\end{array}$ & $\begin{array}{c}\text { Variac esp } \\
\text { vert }\end{array}$ & $\begin{array}{c}\text { Marcas } \\
\text { unión rollos }\end{array}$ & $\begin{array}{c}\text { Marcas unión } \\
\text { segmentos }\end{array}$ & $\begin{array}{c}\text { Marcas } \\
\text { dedos }\end{array}$ & $\begin{array}{c}\text { Marcas } \\
\text { recortado terminación }\end{array}$ \\
\hline Base & 0 & 1 & 2 & 5 & 1 & 1 & 0 \\
Cuerpo & 24 & 3 & 6 & 1 & 4 & 0 & 0 \\
Cuello & 5 & 0 & 1 & 3 & 0 & 0 & 0 \\
Borde & 0 & 0 & 0 & 0 & 0 & 1 & 3 \\
\hline
\end{tabular}

Tabla 7.6 Cantidad de piezas que exhiben las marcas o huellas identificadas en las diferentes porciones morfológicas.

A partir de las tablas se puede apreciar que las principales evidencias del modelado por superposición por rollos son las variaciones de espesor u ondulaciones horizontales, al igual que para el material fragmentario. La mayor parte de las veces las mismas se localizan en el cuerpo de las piezas y en ocasiones en los cuellos de piezas cerradas (Figura 7.9). No se observaron bases modeladas por rodetes. Aunque en varias piezas se observaron patrones de fracturas consistentes con el modelado con rollos, este tipo de huella no es tan relevante en el trabajo con piezas de colección, por presentarse casi todos los materiales completos y en buen estado. En algunas de las piezas se observaron marcas de unión de rollos, que no fueron bien homogeneizadas, localizadas en el cuerpo, y en un par de ocasiones en la unión de la base al cuerpo. 


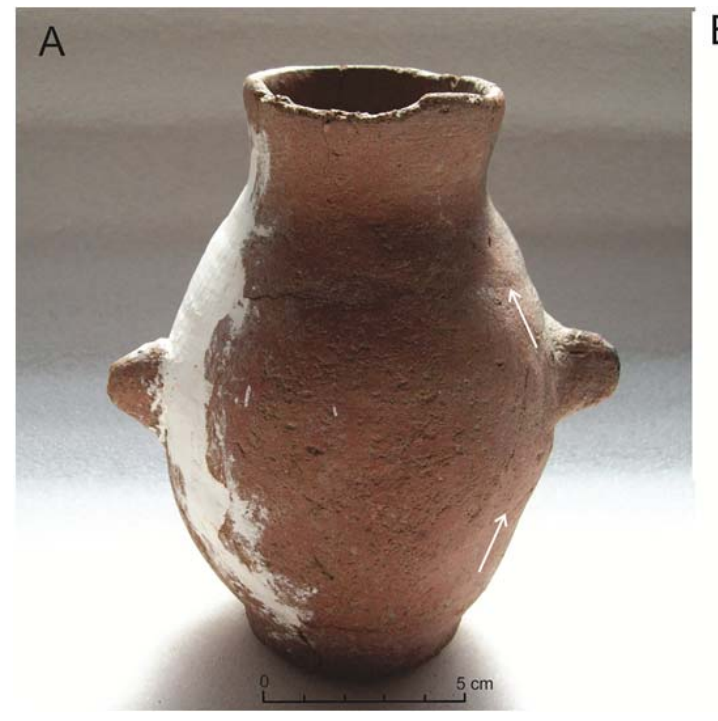

B

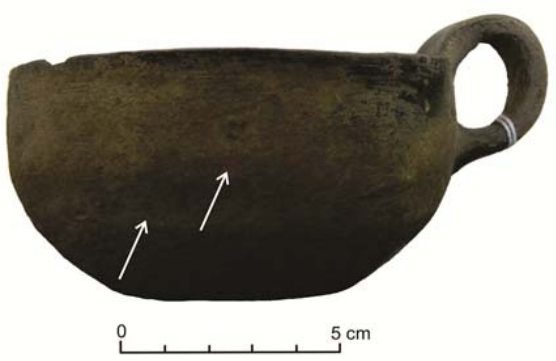

Figura 7.9 Variaciones de espesor y marcas de unión vinculadas al modelado por rollos en piezas de colección. Las mismas se señalan con flechas. A: pieza de Queta depositada en el Instituto Tilcara (IT-2037); B: pieza del Pucará de Rinconada depositada en el Museo Quai Branly (QB-2057).

Por otro lado, también se registraron, en algunas piezas, puntos de unión de segmentos, que seguramente se debe a que fueron modelados por separado o en distintas etapas. La mayoría se observa en la base (Figura 7.10 C), lo que debe ser producto de que la misma se ha modelado en primera instancia y posteriormente se agregan rollos a ese disco para modelar el cuerpo, como se hace en la actualidad (ver Capítulo 10). Las demás uniones de segmentos se observan en la unión del cuello al cuerpo (Figura 7.10 A) o en la porción superior del cuerpo (Figura 7.10 B), todos en piezas cerradas, que pueden ser resultado de que fueron modeladas por partes, dejando secar un poco la porción inferior antes de modelar la superior, como se observa en casos actuales de la zona (ver Capítulo 10) o de otras regiones (por ej., García Roselló 2010), lo que resulta en un secado diferencial que deja uniones visibles. 


\section{IT-Doncellas}

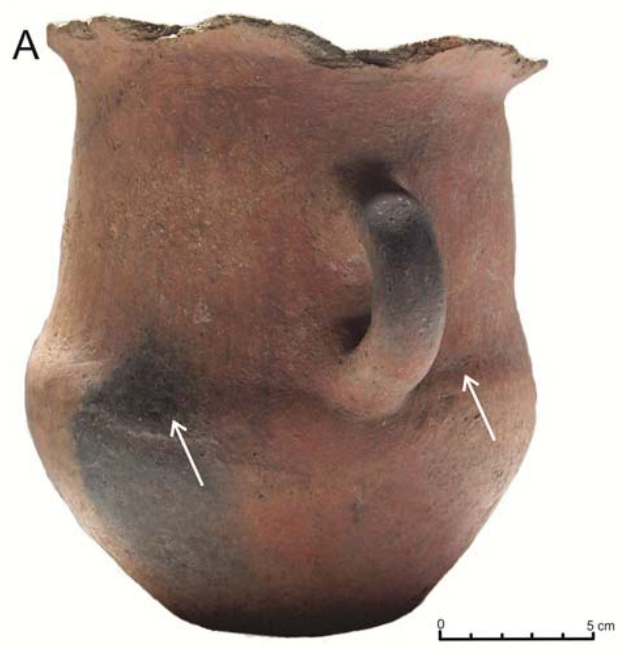

B
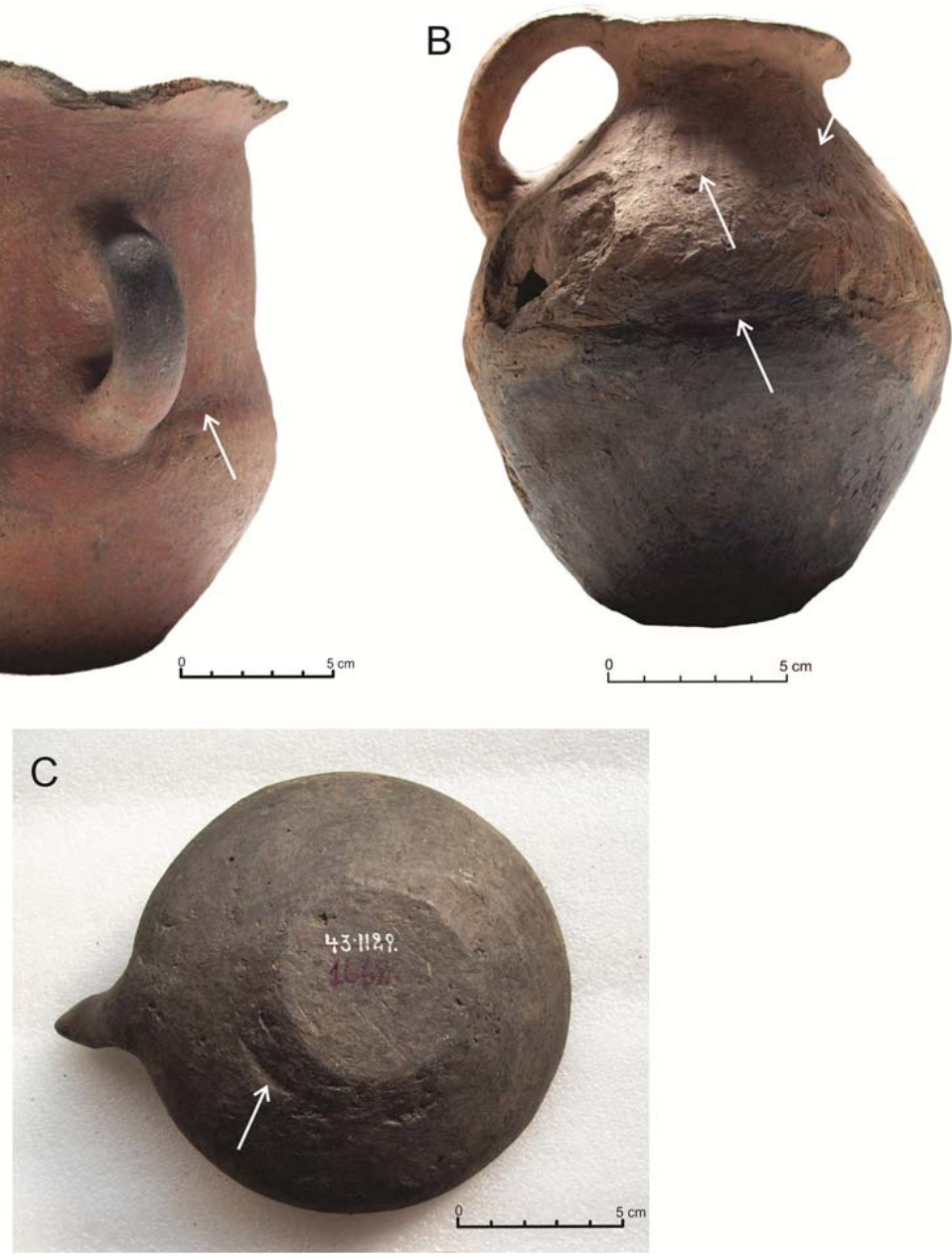

Figura 7.10 Marcas de unión de segmentos en piezas depositadas en el Instituto Tilcara, indicadas por las flechas. A: marca de unión del cuerpo y cuello (IT-1447); B: unión de dos porciones del cuerpo y marcas de dedos en porción superior del cuerpo (IT-1579); C: unión base cuerpo (IT-1662).

También se observaron marcas de dedos y variaciones de espesor verticales en algunas piezas, resultado probablemente del modelado manual. Las mismas se localizan mayormente en el cuerpo (Figura 7.10 B y 7.11) y en ocasiones en las bases (Figura 7.11). 

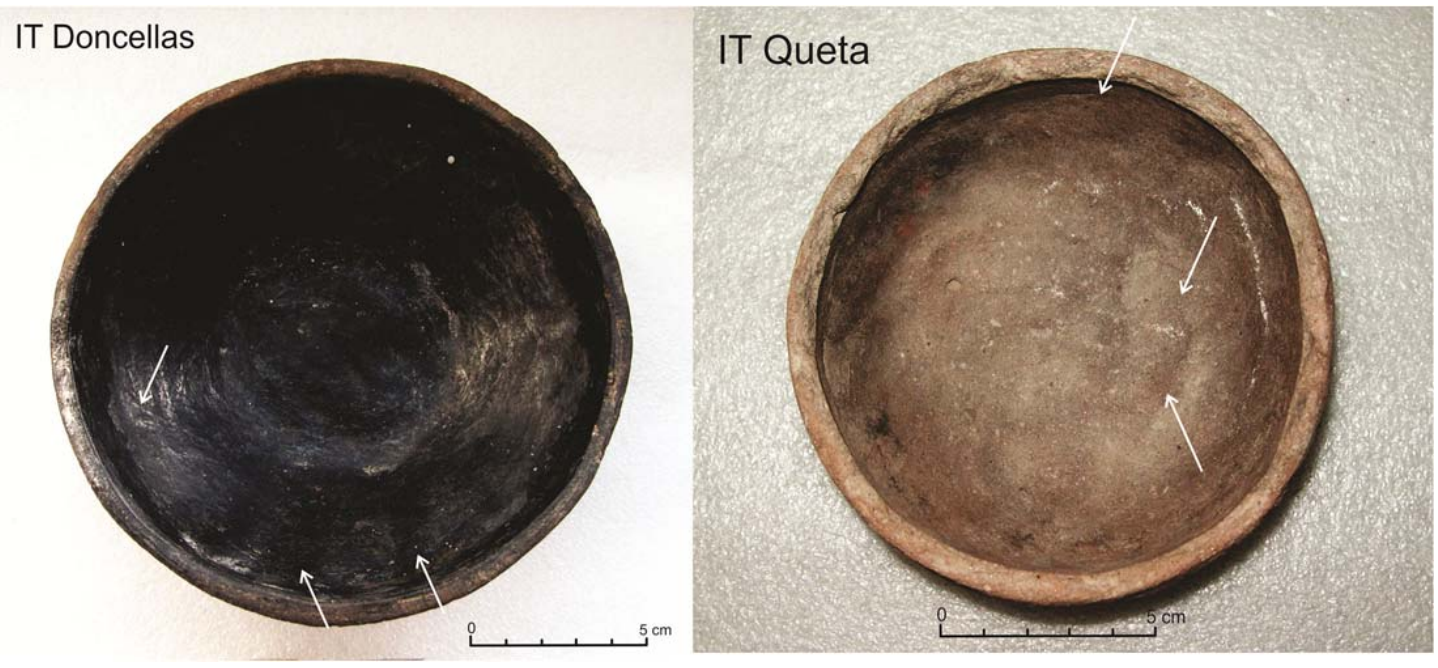

Figura 7.11 Depresiones asociadas a presión de dedos en piezas depositadas en el Instituto Tilcara, señaladas con las flechas (A: IT-1499; B: IT-1968).

Además, en la superficie externa de la base de una pieza (IT 1996) y en el borde de otra (IT 1651) se observaron marcas de recortado, que pueden estar asociadas a la eliminación de sobrantes; y en tres bordes se observó el agregado de un rollo de terminación, que puede ser para engrosar el borde (QB 2055) o en un caso para homogeneizarlo (IT 1651).

\section{Las morfologías presentes en las colecciones:}

De acuerdo a la clasificación de Balfet et al. (1991) se clasificaron las morfologías cerámicas registradas en las colecciones y las que pudieron reconstruirse para el material fragmentario, de acuerdo a la relación de sus dimensiones de diámetros y altura. Primero se separaron dos grandes categorías, que incluyen a las piezas abiertas (diámetro máximo en o cerca de la boca y no presenta restricciones de diámetro) y cerradas (presentan, por encima del diámetro máximo, un diámetro inferior, que puede coincidir o no con la abertura) (Balfet et al. 1991)

Las piezas abiertas se clasifican de acuerdo a la relación del diámetro de la abertura con la altura en las siguientes categorías:

1 Plato: el diámetro máximo es igual o mayor a cinco veces la altura, y es menor a 23 $\mathrm{cm}$ de diámetro. 
2 Fuente: de iguales proporciones al plato, pero el diámetro máximo es mayor a 23 $\mathrm{cm}$.

3 Escudilla (o puco): el diámetro máximo está comprendido entre 2.5 y 5 veces la altura. Pueden ser grandes o pequeñas dependiendo de las dimensiones.

4 Escudilla honda o tazón: el diámetro máximo está comprendido entre 1.5 y 2.5 veces la altura, y es menor a $18 \mathrm{~cm}$.

5 Cuenco: de iguales proporciones que el anterior, pero el diámetro máximo es mayor a $19 \mathrm{~cm}$

6. Escudilla restringida: el diámetro de la abertura está comprendido entre 6 y $12 \mathrm{~cm}$ y es igual o menor a una vez y media la altura.

7. Vaso cubilete o vaso: de iguales proporciones que el anterior, pero el diámetro de la abertura es mayor a $12 \mathrm{~cm}$.

Los recipientes cerrados se clasifican por la relación entre diámetro mínimo y máximo, y del diámetro de la abertura con la altura, en las siguientes categorías:

1 Vasija: el diámetro mínimo es menor o igual a un tercio del diámetro máximo. Además, la altura es igual a una o dos veces el diámetro de la abertura.

2 Tinaja: de las mismas proporciones que la vasija, pero de mayor tamaño y profundidad. La altura es igual a dos a tres veces el diámetro de la abertura.

3 Botella: el diámetro mínimo es menor a un tercio del diámetro máximo.

Una última categoría englobaría a todas aquellas piezas cerámicas consistentes en recipientes que no presentan formas con simetría radial o que no corresponden a recipientes, incluyendo objetos de distinto tipo, como torteros, figurinas, etc.

Siguiendo esta clasificación, en la Tabla 7.7 se pueden observar el número de piezas de cada morfología para las colecciones analizadas. 


\begin{tabular}{|c|c|c|c|c|c|c|c|c|c|c|}
\hline & \multicolumn{5}{|c|}{ ABIERTAS } & \multicolumn{4}{|c|}{ CERRADAS } & \multirow[b]{2}{*}{\begin{tabular}{|c} 
Formas \\
varias
\end{tabular}} \\
\hline & Indet & Escudilla & $\begin{array}{l}\text { Escudilla } \\
\text { honda }\end{array}$ & $\begin{array}{l}\text { Escudilla } \\
\text { restringida }\end{array}$ & Vaso & Indet & Vasija & Tinaja & Botella & \\
\hline Doncellas & 0 & 9 & 2 & 2 & 0 & 0 & 8 & 1 & 2 & 0 \\
\hline Cochinoca & 1 & 1 & 0 & 0 & 0 & 1 & 0 & 0 & 0 & 0 \\
\hline Queta & 0 & 8 & 9 & 1 & 1 & 0 & 12 & 0 & 4 & 5 \\
\hline Rinconada & 0 & 0 & 0 & 0 & 0 & 0 & 1 & 0 & 0 & 0 \\
\hline Pucará de Rinconada & 1 & 1 & 2 & 1 & 0 & 4 & 2 & 0 & 4 & 0 \\
\hline Sayate & 0 & 0 & 1 & 2 & 0 & 1 & 0 & 0 & 0 & 0 \\
\hline Sansana & 0 & 1 & 3 & 0 & 0 & 0 & 5 & 0 & 2 & 0 \\
\hline Yavi Chico & 0 & 0 & 1 & 0 & 0 & 1 & 0 & 0 & 1 & 0 \\
\hline Puna de Jujuy & 0 & 0 & 0 & 0 & 0 & 0 & 0 & 1 & 0 & 0 \\
\hline TOTAL & 2 & 20 & 18 & 6 & 1 & 7 & 28 & 2 & 13 & 5 \\
\hline
\end{tabular}

Tabla 7.7 Cantidad de piezas por categoría morfológica para los sitios representados en las colecciones de museos.

En general, se observa que la proporción de piezas abiertas (47:102) es más o menos equivalente a la de cerradas (50:102). Esa proporción se mantiene en los distintos sitios, exceptuando el Pucará de Rinconada, donde las piezas cerradas (10:15) duplican a las abiertas (5:10), y en Sansana, donde ocurre algo parecido (cuatro abiertas y siete cerradas).

A fin de observar las similitudes y diferencias entre las dos áreas en que tradicionalmente se ha dividido la puna de Jujuy, agrupamos los sitios del sur de la puna (Doncellas, Cochinoca, Queta, Pucará de Rinconada, Rinconada y Sayate), y los del norte, o del área Yavi (Sansana y Yavi Chico) y comparamos las proporciones de piezas. Dado que los sitios del sur son más numerosos y con mayor cantidad de piezas, pasamos las frecuencias a los porcentajes sobre el total de cada área. En la Figura 7.12 se pueden observar los resultados. 


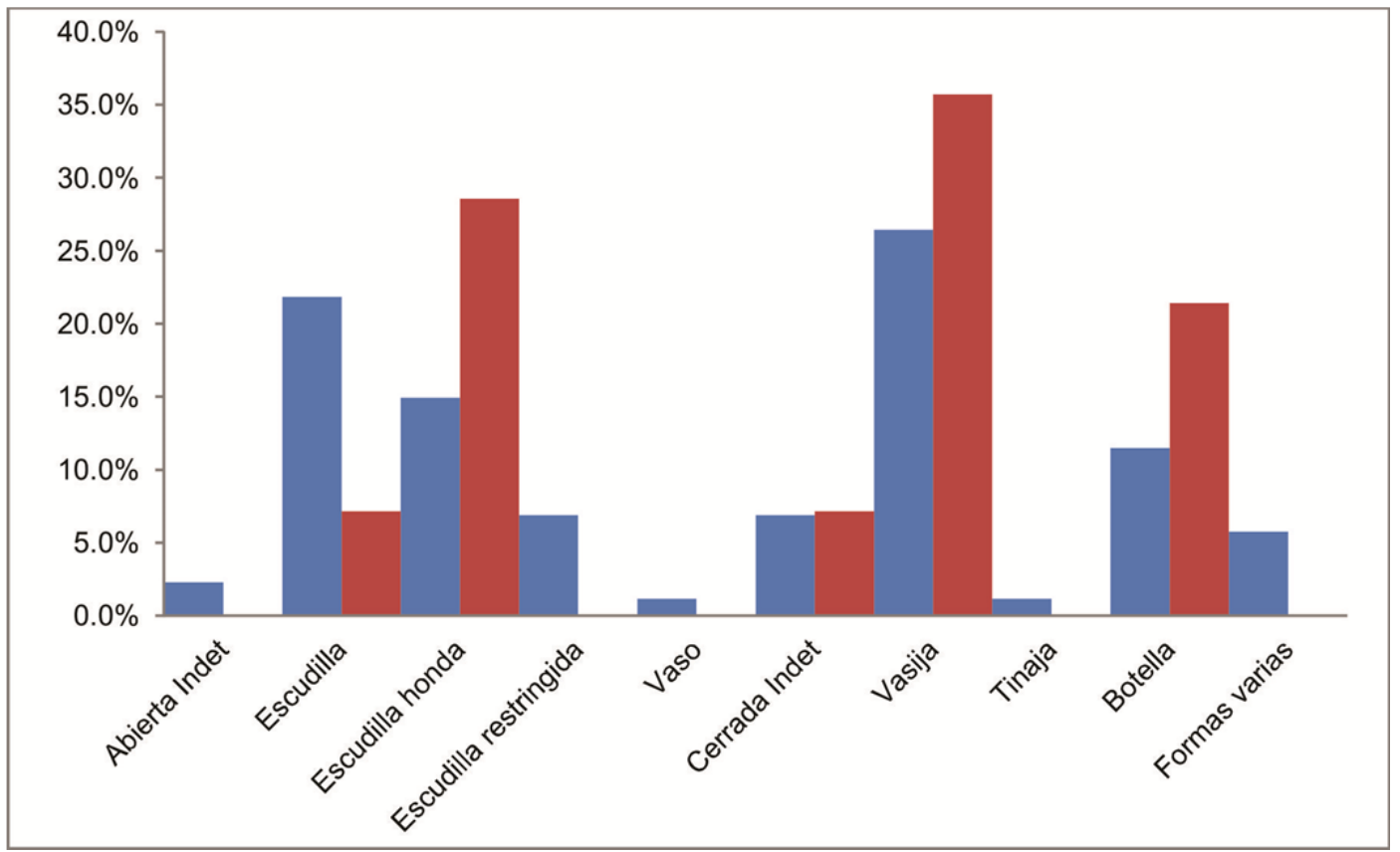

Figura 7.12 Porcentajes de las diferentes morfologías de piezas procedentes de las colecciones para la porción norte de la puna y la porción sur.

A partir del gráfico se puede apreciar que en la puna norte son más frecuentes las morfologías de escudilla honda, vasija y botella; mientras que en la puna sur son más abundantes las escudillas, además de que hay otras morfologías que no están representadas en la puna norte, como las escudillas restringidas, los vasos y las tinajas. Igualmente, debe tenerse en cuenta que la variabilidad para la puna norte puede estar muy reducida por el hecho de que las piezas de esta porción $(n=14)$ son mucho menos que las de la porción sur ( $n=87)$.

Dentro de cada morfología, se observó cierta variabilidad en las dimensiones. Para las escudillas, los diámetros varían entre 8 y $36 \mathrm{~cm}$, pero la mayoría se ubican entre los 12 y $24 \mathrm{~cm}$ (ver Figura 7.13). Las escudillas hondas varían entre 6 y $17 \mathrm{~cm}$ para el diámetro de sus bocas (Figura 7.13). Para las escudillas restringidas o cubiletes, que son menos abundantes, la variabilidad de diámetro máximo es menor (7 a $10 \mathrm{~cm}$ ). 


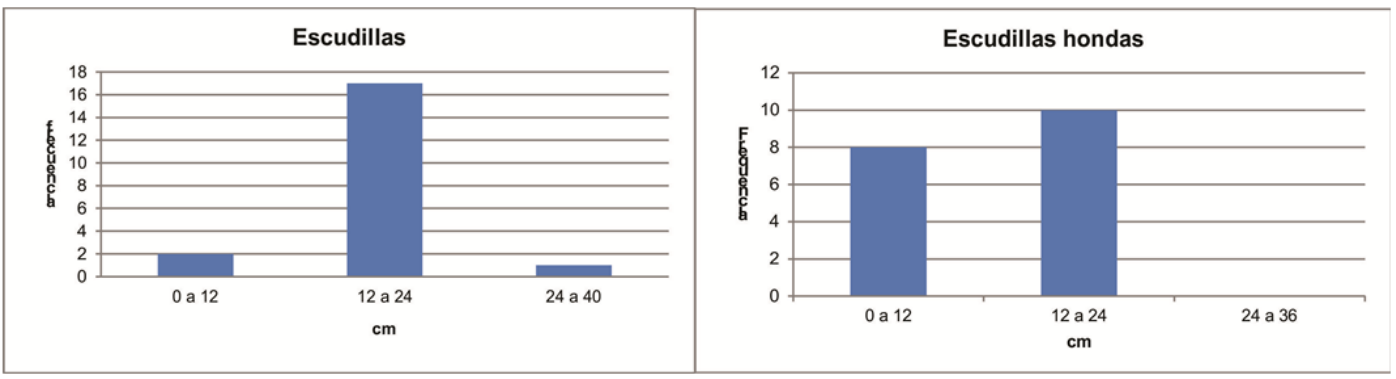

Figura 7.13 Histogramas de frecuencias de tamaños de diámetros para las escudillas y escudillas hondas de las colecciones de museo

Para las vasijas, los diámetros máximos también presentan cierta variabilidad. Dos son miniaturas, procedentes del Pucará de Rinconada, con diámetros de $3.5 \mathrm{~cm}$ (Figura 7.14). El resto presenta diámetros entre 10 y $18 \mathrm{~cm}$, con 17 piezas con diámetro de $10 \mathrm{a}$ $14 \mathrm{~cm}$ y 10 recipientes con diámetros mayores a $14 \mathrm{~cm}$. Las tinajas son solo dos, y con diámetros máximos diferentes, de 15 y $26 \mathrm{~cm}$ cada una. Por definición, son más grandes que las vasijas y con mayor altura en relación al diámetro máximo. Las botellas presentan diámetros entre 8 y $20 \mathrm{~cm}$, con nueve con diámetro máximo menor a $14 \mathrm{~cm}$ y cuatro mayor.
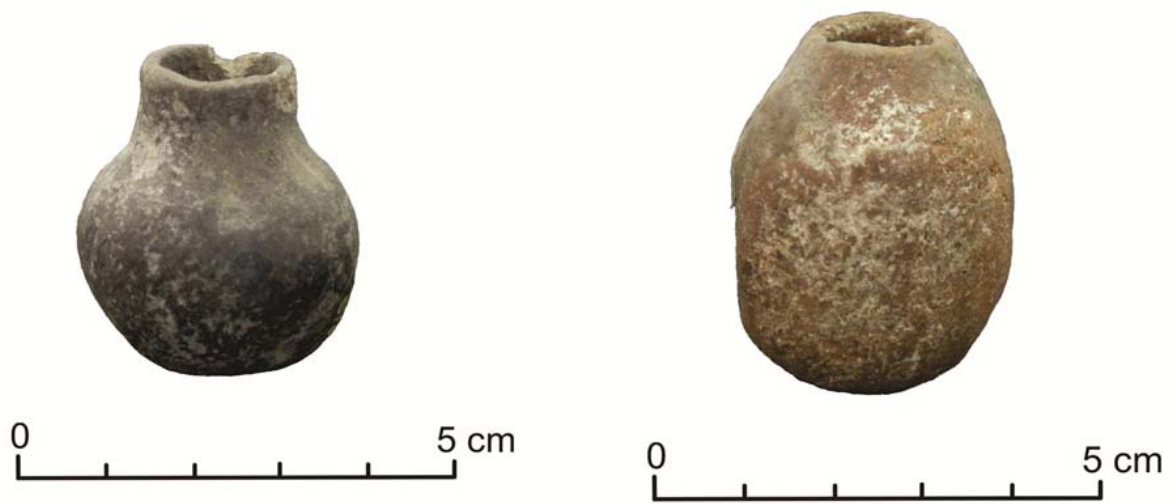

Figura 7.14 Vasijas miniatura procedentes del Pucará de Rinconada, depositadas en el Museo Quai Branly (QB-2063 y QB-2064).

Al analizar la relación entre los diámetros máximos y mínimos de las piezas cerradas analizadas, no observamos una vinculación entre los mismos. En un gráfico de dispersión de puntos, no se observa una correlación estrecha entre ambas variables. 
Las relaciones de diámetro máximo / diámetro mínimo dan valores entre 1.2 y 3.8, con algunos valores extremos que llegan hasta 4.4. En cambio, la vinculación entre la altura y el diámetro máximo es mucho más estrecha, con valores promedio de 1 para la relación diámetro máximo / altura. Por lo que en la construcción de las vasijas, seguro este parámetro tuvo importancia, quizás relacionada a la función. A pesar de la variabilidad de los tamaños, en el gráfico de la Figura 7.15 se puede observar esta relación, aunque hay algunos valores extremos por encima y debajo, que van entre 0.5 y 1.5.

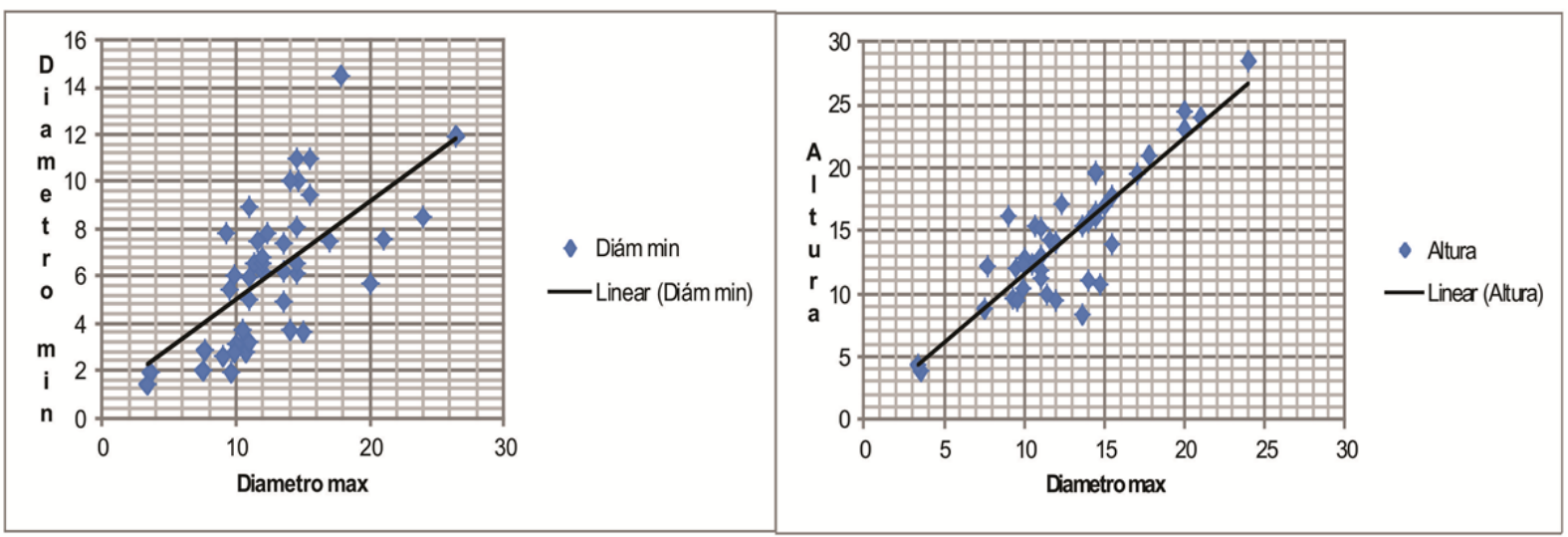

Figura 7.15 Gráficos de dispersión de puntos para las relaciones entre diámetro máximo y mínimo y entre diámetro máximo y altura.

Dentro de las piezas cerradas, también hemos distinguido aquellas que tienen un perfil continuo (puntos de inflexión) de las que tienen perfil discontinuo (puntos de intersección). En la Figura 7.16 A se puede observar una pieza con puntos de inflexión, y en la $B$ con un punto de intersección angular que da origen al cuello. Muchas veces estos puntos coinciden con el comienzo del cuello, en las piezas que lo presentan. Las piezas cerradas con perfil continuo (26:43) son algo más abundantes que las de perfil discontinuo (17:43). Ambos tipos de vasijas están presentes en casi todos los sitios, no habiendo diferencias entre aquellos de la zona norte de la puna y la zona sur. 


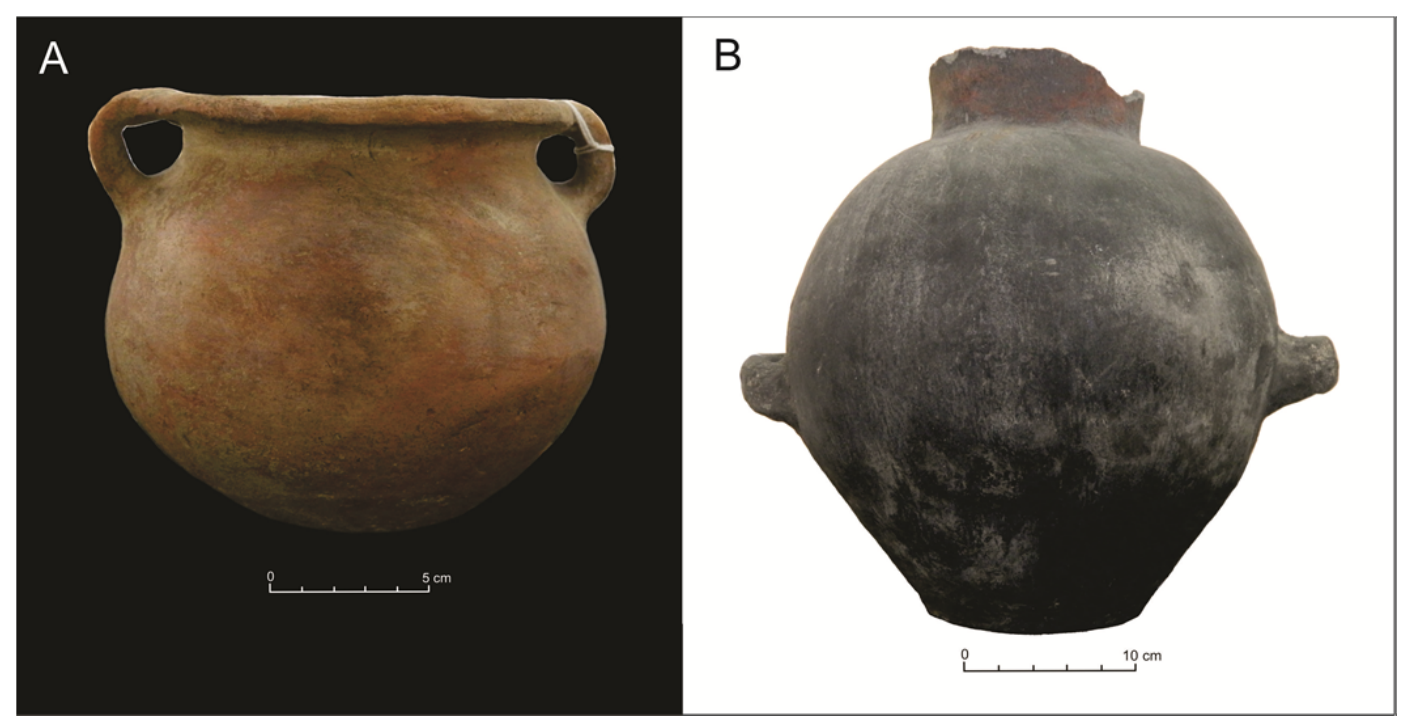

Figura 7.16 Piezas del Museo Quai Branly. A: pieza de perfil continuo, procedente de Sansana (QB-2142); B: pieza de perfil discontinuo, procedencia Puna de Jujuy (QB2478).

Por otro lado, bajo la denominación formas varias se han agrupado diversos objetos que incluyen una figurina ornitomorfa (Figura 7.17 A), un recipiente zoomorfo que no pudo asignarse a ninguna de las categorías anteriores (Figura 7.17 B), una base de una pieza con un asa interna y todo el borde fracturado (Figura $7.17 \mathrm{C}$ ), que no pudo asignarse a ninguna de las morfologías anteriores, y dos torteros a partir de fragmentos cerámicos. Todas estas formas varias proceden de Queta.
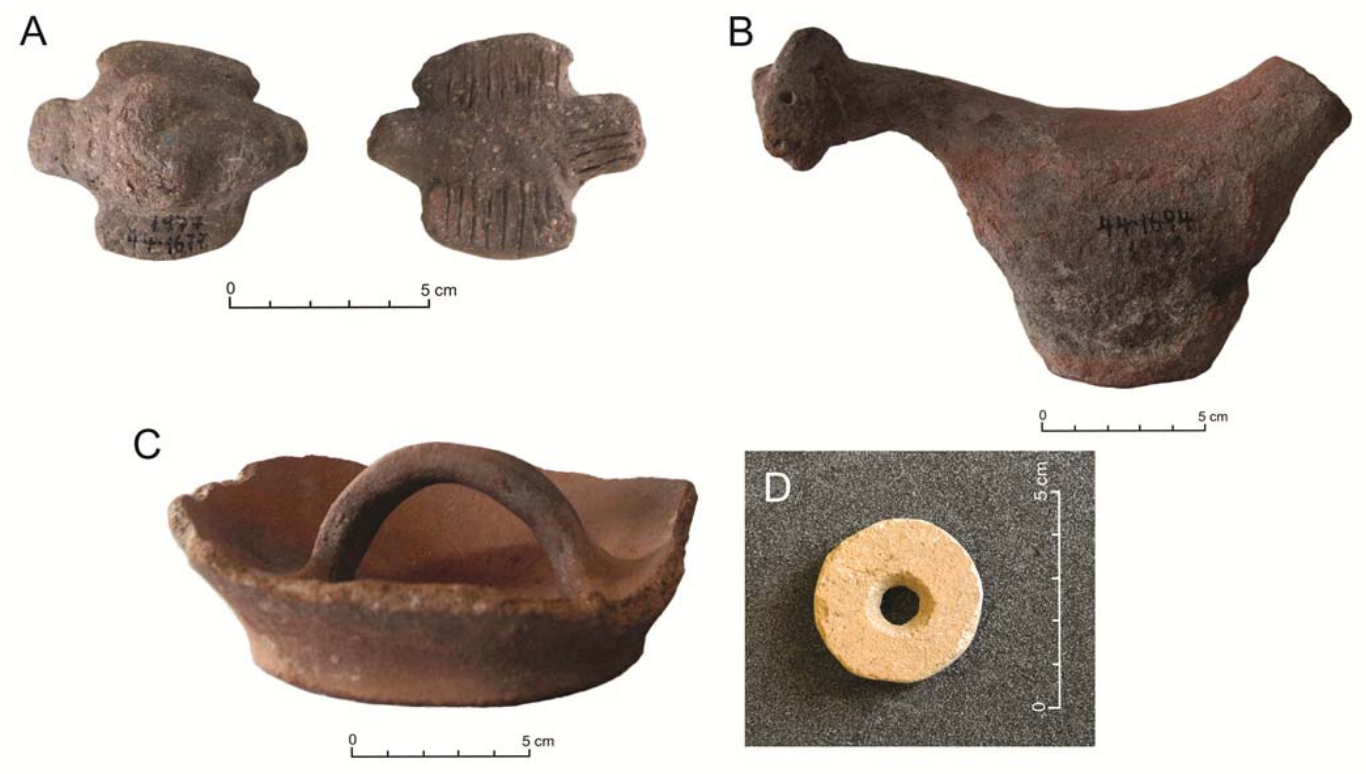
Figura 7.17 Formas varias, procedentes del sitio de Queta. A (IT-1977), B (IT-1999) y C (IT-2000) pertenecen al Instituto Tilcara y D (QB-2085) al Museo Quai Branly.

Algunas de las morfologías relevadas pueden relacionarse a las publicadas en la literatura. Unas pueden asignarse a lo que se ha denominado estilo Casabindo, como la ilustrada en la Figura $7.16 \mathrm{~B}$, correspondientes a piezas subglobulares con cuello cilíndrico ( $n=10)$ (Ottonello 1973; Albeck 2001), a vasijas de boca ancha y asas verticales ( $n=3$ ) (Albeck 2001) como la ilustrada en la Figura 7.18 A, o como los denominados "vasos chatos" $(n=7)$, como el que se muestra en la Figura 7.18 B. Asimismo, son frecuentes los pucos con el interior negro pulido $(n=10)$, que se han documentado junto con la cerámica Casabindo, como mencionamos en los antecedentes (Figura $7.18 \mathrm{C}$ ).

Para las formas varias, piezas zoomorfas comparables a la de la Figura 7.17 B han sido halladas en contextos funerarios de Sorcuyo (o Pueblo Viejo de Tucute) (Casanova 1938, Albeck 1993) y en la excavación de un recinto habitacional del mismo sitio (Albeck 1995-96). Por otro lado, Albeck (1993) menciona la presencia de pucos con asa central interna en la zona de Casabindo, que estarían vinculados a tareas textiles, como el de la Figura $7.17 \mathrm{C}$.
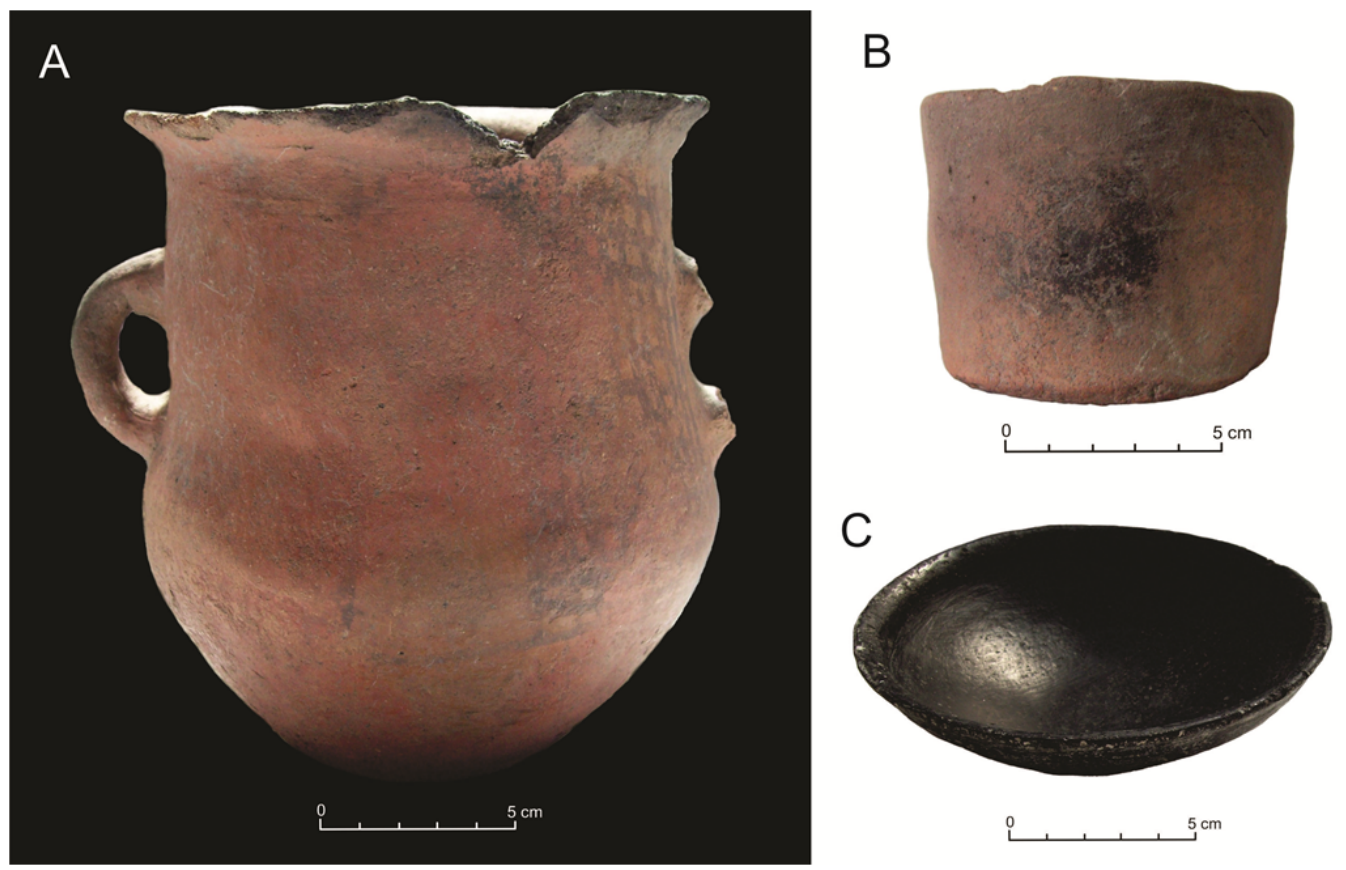
Figura 7.18 Morfologías relacionables al estilo Casabindo, todas procedentes del Instituto Tilcara. A (IT-1447) y C (IT-1437): del sitio Doncellas; B (IT-1994): de Queta.

Otras piezas corresponden a las morfologías definidas para el estilo Yavi $(n=25)$ (Krapovickas 1975; Ávila 2006), como las botellas de cuerpo esférico con asas oblicuas $(n=7)$ como la que se muestra en la Figura 7.19 A, escudillas o pucos $(n=10)$ (Figura 7.19 B), vasijas bajas con punto de intersección angular ( $n=2)$ (Figura 7.19 C); vasijas subglobulares $(n=2)$, y un "pelike" o pieza subglobular de cuello cilíndrico y asas verticales, forma que en la quebrada de Huamahuaca ha sido relacionada a la presencia inka (Ávila 2006).

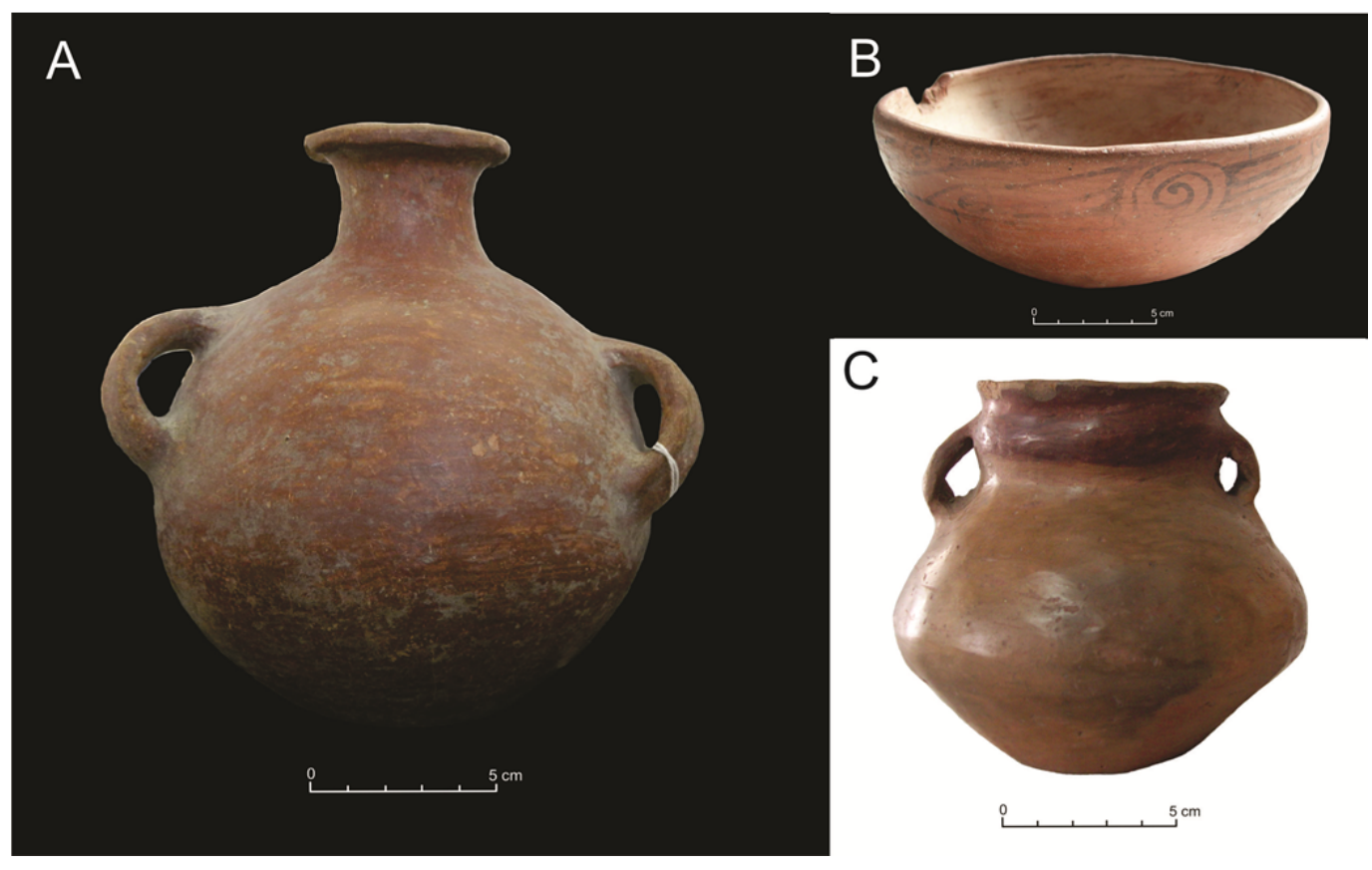

Figura 7.19 Morfologías relacionables al estilo Yavi. A (QB-2140): procedente del sitio Sansana, del museo Quai Branly; B (IT-1800) del sitio Doncellas y C (IT-1965) de Queta, ambas en el Instituto Tilcara.

Incluso otras presentan morfologías vinculadas a la presencia imperial inka, tales como escudillas o pucos con apéndices ornitomorfos $(n=3)$, como el que se ilustra en la Figura 7.20 B; escudillas o pucos con asa cinta lateral $(n=4)$ (Figura 7.20 C), y botellas pequeñas con asa cinta lateral $(n=2)$ como la de la Figura 7.20 A, que corresponden a la forma denominada puchuela o aisana (Bray 2003). Algunas de estas formas presentan características de pasta o decoración vinculables al estilo Yavi (4:8). 
A

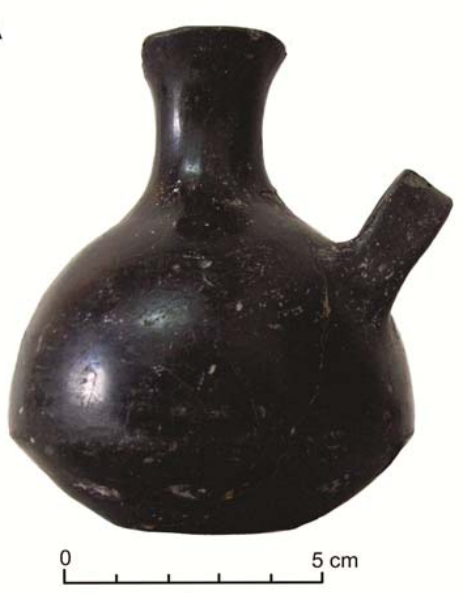

B

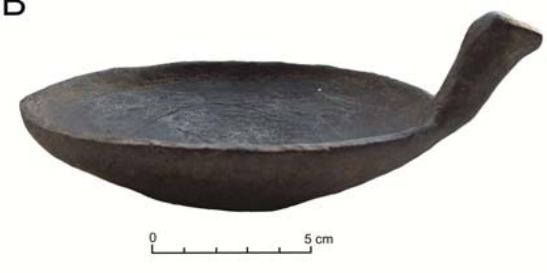

C

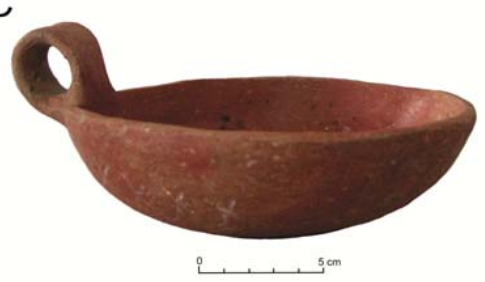

Figura 7.20 Morfologías vinculables a la presencia Inka. Todas proceden del Instituto Tilcara. A (IT-2061) y C (IT 1851) de Queta; B (IT-1662) de Doncellas.

Otras más no son vinculables a estilos de la puna, sino a la quebrada de Humahuaca $(n=2)$, una correspondiente a una escudilla y otra un vaso, comparables a los estilos de la Quebrada por su decoración (como se verá en el próximo Capítulo); y la vertiente oriental de los Andes $(n=2)$, también relacionables a esa región por la decoración (ver Capítulo 8). A su vez, cinco piezas procedentes del Pukará de Rinconada no se relacionan con ninguno de los estilos conocidos, pero sus morfologías permiten pensar que se trate de piezas poshispánicas. Dos corresponden a jarras con pico y asa lateral, una a una botella con asas laterales, otra a otra botella con pico engrosado y otra a una porción de un cuello con un reborde en la mitad del mismo. Para las 29 piezas restantes no se pudo relacionar su morfología con ninguno de los estilos definidos en la literatura.

En la Tabla 7.8 se pueden observar cómo se distribuyen las piezas de los estilos identificados en los distintos sitios presentes en la colección. Se observa que las piezas de morfologías relacionables al estilo Casabindo, incluyendo los vasos chatos, se localizan en los sitios del sur de la puna de Jujuy. Mientras que los pucos con el interior negro pulido, están presentes en ambas zonas. Por otro lado, las piezas estilo Yavi están presentes en casi todos los sitios, tanto del norte como del sur. Las piezas con morfologías relacionables a estilos de momentos inkaicos y a estilos de otras regiones solo están presentes en algunos sitios de la puna sur, y particularmente aquellas relacionables a la quebrada de Humahuaca y el área oriental de los Andes, están solo en Doncellas y el Pukará de Rinconada. Asimismo, las piezas de posible vinculación poshispánica solo se encuentran en ese último sitio. 
A

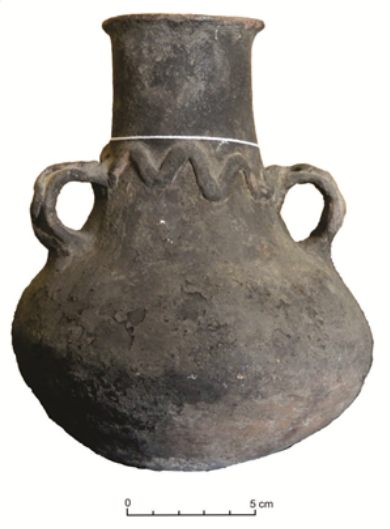

B

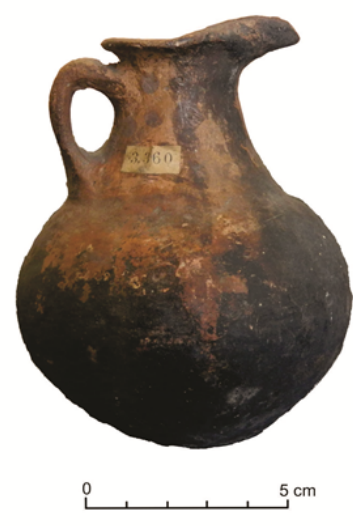

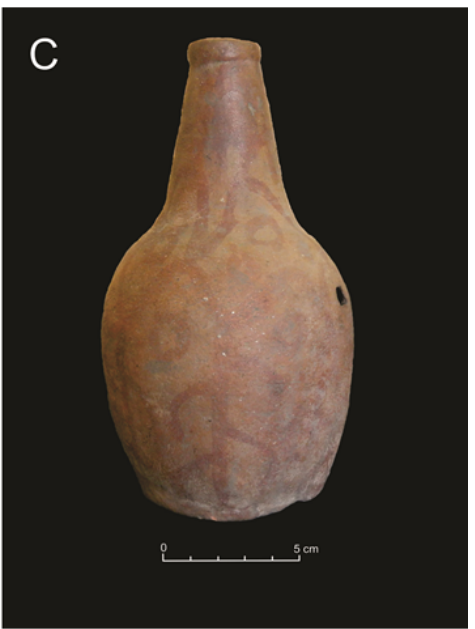

Figura 7.21 Morfologías posiblemente poshispánicas, procedentes del Pucará de Rinconada, del Museo Quai Branly. A: QB-2052; B: QB-2053; C: QB-2055.

\begin{tabular}{lcccccccc}
\hline & Casabindo & $\begin{array}{c}\text { Vasos } \\
\text { chatos }\end{array}$ & PINP & Yavi & $\begin{array}{c}\text { Inka } \\
\text { Pcial }\end{array}$ & Humahuaca & Oriental & Poshispánico \\
\hline Doncellas & 4 & 3 & 3 & 6 & 3 & 1 & 1 & 0 \\
Cochinoca & 0 & 0 & 0 & 0 & 1 & 0 & 0 & 0 \\
Queta & 8 & 2 & 4 & 6 & 4 & 0 & 0 & 0 \\
Rinconada & 0 & 0 & 0 & 1 & 0 & 0 & 0 & 0 \\
Pucará de & 0 & 1 & 1 & 2 & 1 & 1 & 1 & 5 \\
Rinconada & 0 & 1 & 1 & 0 & 0 & 0 & 0 & 0 \\
Sayate & 0 & 0 & 1 & 8 & 0 & 0 & 0 & 0 \\
Sansana & 0 & 0 & 0 & 2 & 0 & 0 & 0 & 0 \\
Yavi Chico & 1 & 0 & 0 & 0 & 0 & 0 & 0 & 0 \\
Puna de Jujuy & 13 & 7 & 10 & 25 & 9 & 2 & 2 & 5 \\
\hline \multicolumn{1}{c}{ TOTAL } & 13 & & & 0 & & & &
\end{tabular}

Tabla 7.8 Cantidad de piezas por sitio asignables a morfologías relacionables a los estilos cerámicos identificados en la literatura. Ref.: PINP: Puco interior negro pulido.

Todas estas morfologías de piezas presentan espesores variables de las paredes, con valores extremos de 1 o $2 \mathrm{~mm}$ a $13 \mathrm{~mm}$. Sin embargo, la media se ubica en los 5 $\mathrm{mm}$. El 92\% de los espesores registrados se ubica entre los 4.5 y los $9.5 \mathrm{~mm}$. No se observan diferencias en los espesores entre las piezas cerradas y las abiertas, presentan medias y modas parecidas, al igual que los valores extremos. En la Figura 7.22 se puede observar un histograma con la distribución de las medidas registradas para los espesores de paredes de todas las muestras. Igualmente, cabe destacar que el 
registro de espesores en las piezas de colección contó con restricciones, dado que en la mayoría de las piezas, que se encuentran completas, con el calibre solo se pudo medir los espesores de bordes y cuellos, mientras que para algunas piezas fragmentadas se pudo registrar la variabilidad de espesores a lo largo del perfil. Por lo que las medidas registradas reflejan parcialmente el universo de espesores para los cuerpos de las piezas analizadas.

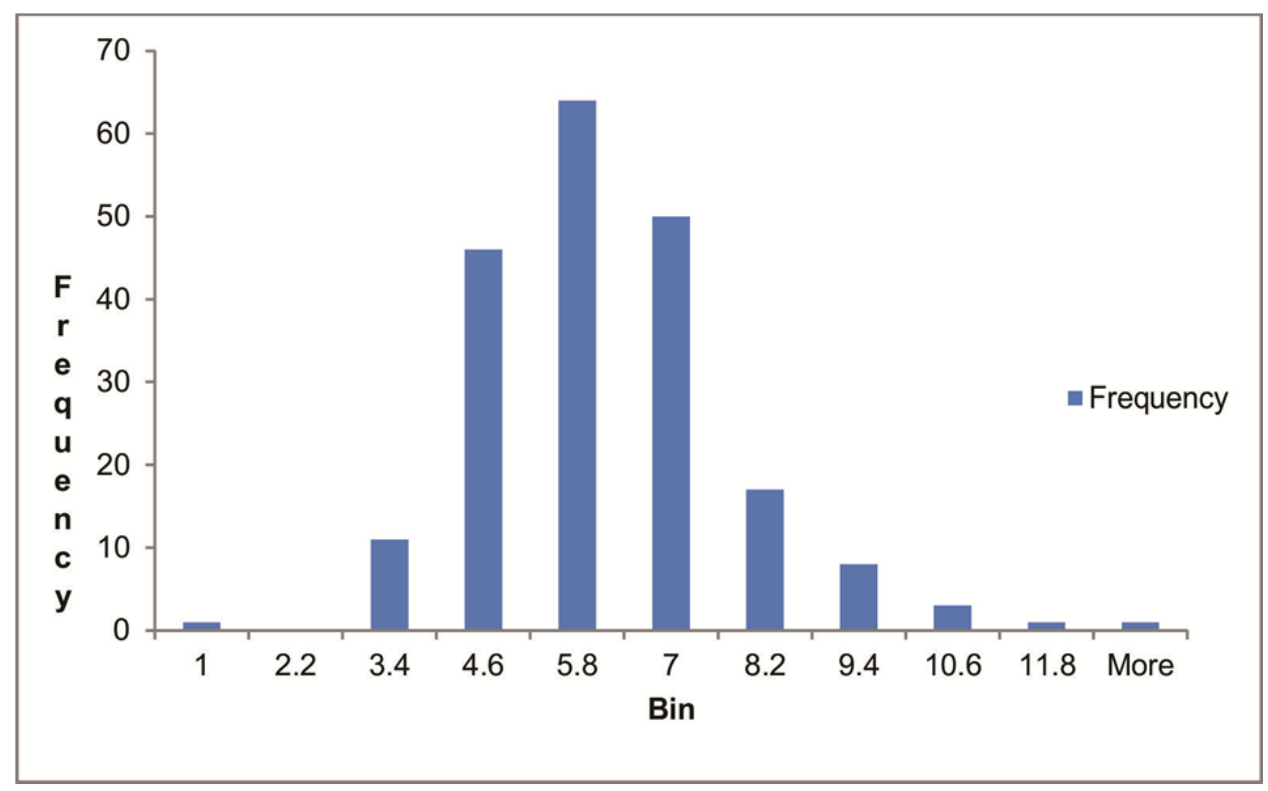

Figura 7.22 Histograma de las frecuencias de espesores (en $\mathrm{mm}$ ) para las piezas depositadas en colecciones.

Morfología de bordes, bases y asas:

Además de clasificar las formas de los perfiles de las piezas completas, se tuvieron en cuenta las morfologías de las distintas porciones, realizándose observaciones sobre los bordes, bases y asas. En primer lugar, los bordes se clasificaron de acuerdo a su dirección (hacia afuera o evertidos, verticales, o hacia adentro o invertidos) y a la forma del labio (plano, redondeado, etc.). Del total de piezas analizadas, en 87 casos (85.3\%) se pudieron clasificar los bordes de esta manera. En la Figura 7.23 se pueden observar las proporciones de los distintos tipos de bordes. 


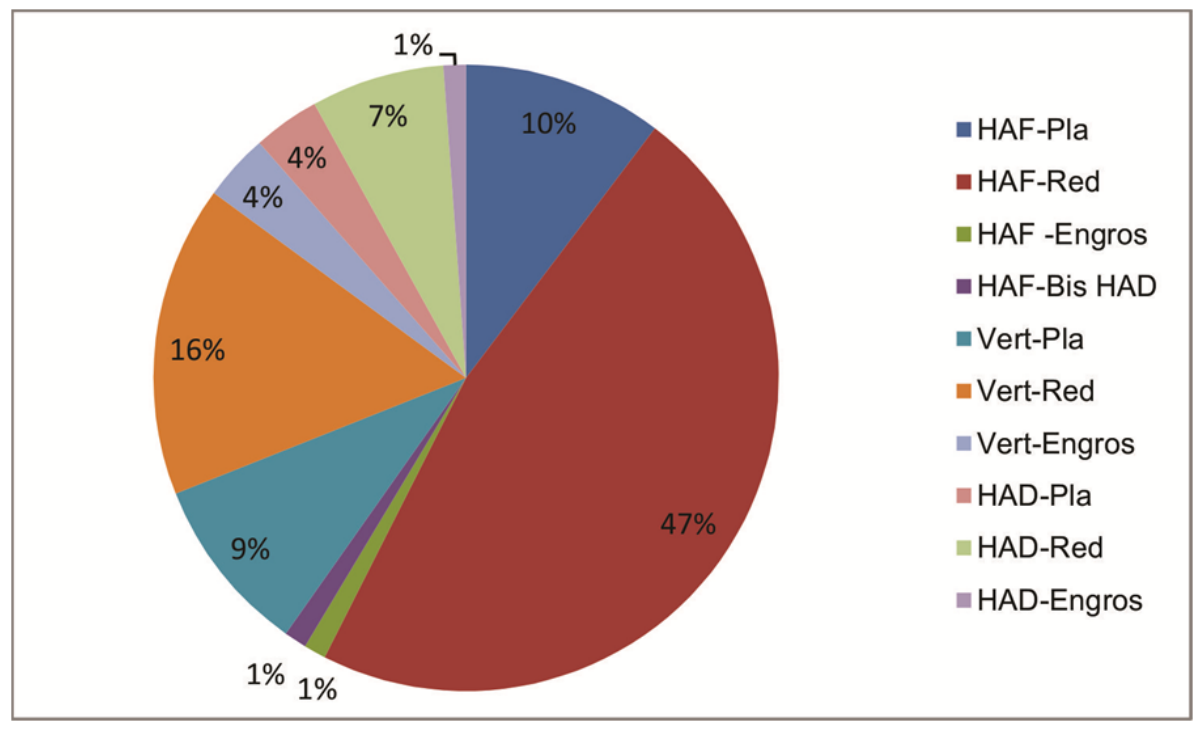

Figura 7.23 Proporción de las diferentes morfologías de bordes identificadas en las piezas de colección. Ref: HAF: hacia afuera; Vert: vertical; HAD: hacia adentro; Pla: plano, Red: redondeado; Engros: engrosado; Bis: Biselado.

Predominan ampliamente los bordes con dirección hacia afuera o evertidos y labio redondeado, seguidos por aquellos también redondeados, pero verticales. En menor cantidad, se registraron bordes con labios planos, de dirección tanto hacia afuera o evertidos, como verticales. Todas las demás morfologías están representadas por pocos ejemplares.

\begin{tabular}{|c|c|c|c|c|c|c|c|c|c|c|}
\hline & HAF-Pla & $\begin{array}{l}\text { HAF- } \\
\text { Red }\end{array}$ & $\begin{array}{c}\text { HAF - } \\
\text { Engros }\end{array}$ & $\begin{array}{c}\text { HAF-Bis } \\
\text { HAD }\end{array}$ & Vert-Pla & $\begin{array}{l}\text { Vert- } \\
\text { Red }\end{array}$ & $\begin{array}{c}\text { Vert- } \\
\text { Engros }\end{array}$ & HAD-Pla & $\begin{array}{l}\text { HAD- } \\
\text { Red }\end{array}$ & $\begin{array}{c}\text { HAD- } \\
\text { Engros }\end{array}$ \\
\hline Doncellas & 3 & 11 & 0 & 1 & 2 & 5 & 0 & 0 & 0 & 0 \\
\hline Cochinoca & 0 & 0 & 0 & 0 & 1 & 1 & 0 & 0 & 0 & 0 \\
\hline Queta & 4 & 15 & 1 & 0 & 4 & 5 & 0 & 2 & 1 & 1 \\
\hline $\begin{array}{l}\text { Pucará de } \\
\text { Rinconada }\end{array}$ & 1 & 8 & 0 & 0 & 0 & 2 & 1 & 1 & 2 & 0 \\
\hline Sayate & 0 & 1 & 0 & 0 & 0 & 0 & 0 & 0 & 0 & 0 \\
\hline Sansana & 0 & 5 & 0 & 0 & 0 & 1 & 2 & 0 & 3 & 0 \\
\hline Yavi Chico & 1 & 1 & 0 & 0 & 1 & 0 & 0 & 0 & 0 & 0 \\
\hline TOTAL & 9 & 41 & 1 & 1 & 8 & 14 & 3 & 3 & 6 & 1 \\
\hline
\end{tabular}

Tabla 7.9 Frecuencias de los distintos tipos de bordes para los diferentes sitios presentes en los materiales depositados en las colecciones de museos. Ref: HAF: hacia afuera; Vert: vertical; HAD: hacia adentro; Pla: plano, Red: redondeado; Engros: engrosado; Bis: Biselado. 
Asimismo, al analizar la distribución de las diferentes formas de bordes en los distintos sitios representados en las colecciones, observamos que en casi todos los sitios predominan los bordes redondeados y evertidos, y que no hay una relación entre los distintos sitios y las formas de bordes. Los sitios con mayor diversidad morfológica son los que cuentan con mayor cantidad de piezas en la muestra (Tabla 7.9).

Al relacionar los tipos morfológicos descritos arriba con los distintos tipos de bordes (Tabla 7.10) también notamos que no hay una vinculación. Las formas de bordes que están presentes en solo uno o dos tipos de vasijas están representadas por pocos ejemplares. De igual manera, los tipos de piezas más abundantes, como las escudillas, escudillas hondas y vasijas, presentan una diversidad amplia de bordes. Sin embargo, en las vasijas hay un claro predominio de bordes redondeados y evertidos, mientras que en las escudillas y escudillas hondas no predomina ningún tipo claramente, sino que los ejemplares de bordes se distribuyen entre las diferentes formas, siendo un poco más frecuentes los redondeados evertidos y verticales.

\begin{tabular}{rccccccccccc}
\hline & HAF-Pla & $\begin{array}{c}\text { HAF- } \\
\text { Red }\end{array}$ & $\begin{array}{c}\text { HAF- } \\
\text { Engros }\end{array}$ & $\begin{array}{c}\text { HAF-Bis } \\
\text { HAD }\end{array}$ & Vert-Pla & $\begin{array}{c}\text { Vert- } \\
\text { Red }\end{array}$ & $\begin{array}{c}\text { Vert- } \\
\text { Engros }\end{array}$ & HAD-Pla & $\begin{array}{c}\text { HAD- } \\
\text { Red }\end{array}$ & $\begin{array}{c}\text { HAD- } \\
\text { Engros }\end{array}$ & TOTAL \\
\hline $\begin{array}{r}\text { Abierta } \\
\text { indet }\end{array}$ & 0 & 0 & 0 & 0 & 0 & 1 & 0 & 0 & 0 & 0 & 1 \\
$\begin{array}{r}\text { Escudilla } \\
\text { Escudilla }\end{array}$ & 3 & 7 & 1 & 1 & 3 & 4 & 1 & 0 & 0 & 0 & 20 \\
$\begin{array}{r}\text { honda } \\
\text { Escudilla }\end{array}$ & 1 & 3 & 0 & 0 & 4 & 4 & 1 & 2 & 2 & 1 & 18 \\
restringida & 0 & 1 & 0 & 0 & 1 & 2 & 0 & 0 & 0 & 0 & 4 \\
Vaso & 0 & 0 & 0 & 0 & 0 & 1 & 0 & 0 & 0 & 0 & 1 \\
$\begin{array}{r}\text { Cerrada } \\
\text { Indet }\end{array}$ & 1 & 4 & 0 & 0 & 0 & 0 & 0 & 0 & 0 & 0 & 5 \\
Vasija & 3 & 15 & 0 & 0 & 0 & 1 & 0 & 1 & 3 & 0 & 23 \\
Tinaja & 0 & 1 & 0 & 0 & 0 & 0 & 0 & 0 & 0 & 0 & 1 \\
Botella & 1 & 10 & 0 & 0 & 0 & 0 & 1 & 0 & 1 & 0 & 13 \\
\hline
\end{tabular}

Tabla 7.10 Frecuencias de los distintos tipos de bordes para las diferentes morfologías de piezas depositadas en las colecciones de museos. Ref: HAF: hacia afuera; Vert: vertical; HAD: hacia adentro; Pla: plano, Red: redondeado; Engros: engrosado; Bis: Biselado.

En cuanto a las bases, la morfología se determinó sobre la parte externa principalmente, dado que en muchas de las piezas cerradas no se puede observar la porción interna. También se clasificó el tipo de unión de las mismas al cuerpo. E repertorio de morfologías para las bases teniendo en cuenta estos dos aspectos, es bastante limitado, con un porcentaje muy alto de piezas con bases con el exterior plano y unión al cuerpo directa (77\%) o inflexa (20\%). El resto de las morfologías presentes 
están representadas por pocas piezas (Figura 7.24). No se observa una relación entre los tipos de bases identificados y las morfologías de las piezas, porque en todas las morfologías predominan las bases planas. Las bases biconvexas y bicóncavas están presentes en piezas abiertas $(n=3)$ y cerradas $(n=1)$, algunas de ellas son las que previamente clasificamos como procedentes probablemente de la vertiente oriental de los Andes, otra corresponde a una escudilla con un apéndice ornitomorfo, y la otra a un puco interior negro pulido.

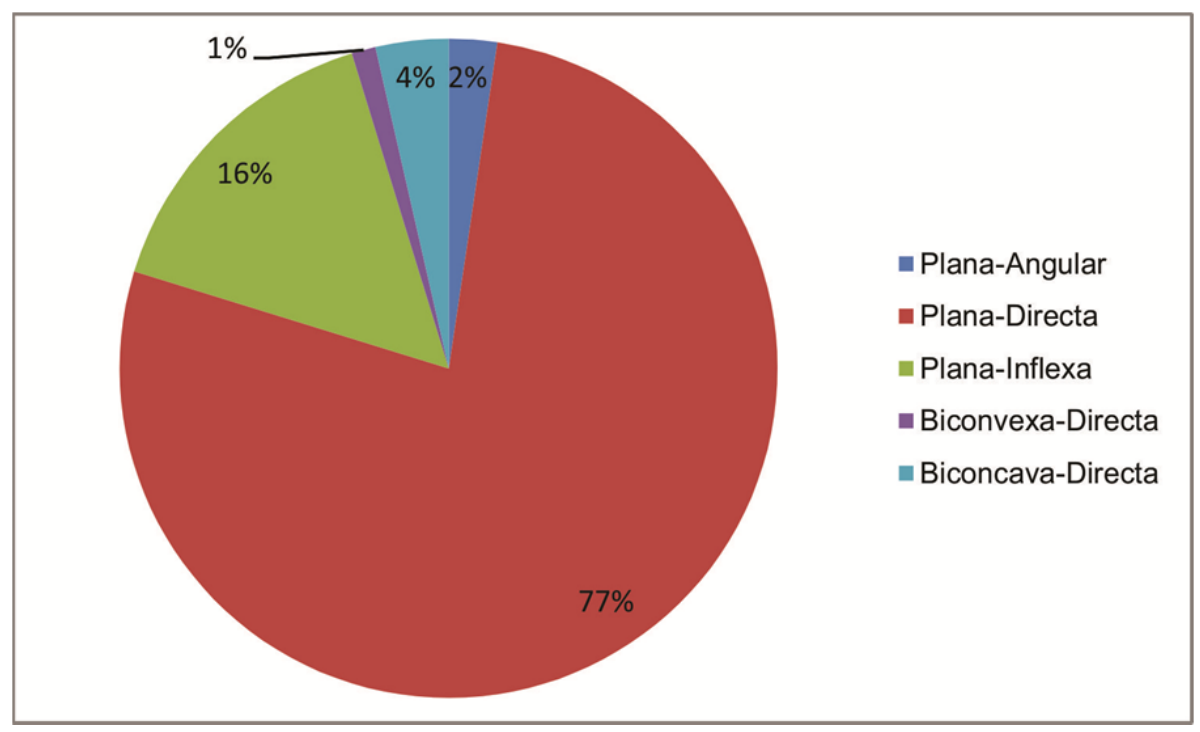

Figura 7.24 Proporción de las diferentes morfologías de bases identificadas en las piezas de colección.

Consideramos que la morfología de las superficies de apoyo puede estar relacionada con las técnicas de manufactura porque, como veremos en el capítulo 10, muchas veces se emplean soportes planos en el modelado que sirven para facilitar las operaciones técnicas, como tornetas, por ejemplo, para girar la pieza, que se emplean en Bolivia y en la localidad actual de Casira, resultando en bases planas. $O$ al modelar una pieza sobre el piso o sobre un textil como observa Boman (1908) también obtendríamos bases planas. Por otro lado, las bases planas también pueden ser resultado de su manufactura por separado, en una primera instancia, seguida luego por la construcción de las paredes sobre las mismas.

Las bases presentan diferentes diámetros, con algunas muy pequeñas $(1,5 \mathrm{~cm})$ hasta otras con $12 \mathrm{~cm}$. Sin embargo, la mayoría (85\%) presenta diámetros comprendidos entre los 4 y los $8,5 \mathrm{~cm}$, con una media en $6,3 \mathrm{~cm}$. 
En cuanto a la morfología de las asas, hemos analizado su sección, posición e inserción. En la Figura 7.25 se pueden observar las proporciones de los distintos tipos de asas, definidos según su posición y su sección. Se observa que para el total de la muestra, predominan las asas colocadas de manera vertical, especialmente aquellas con secciones circulares a subcirculares o planas y subplanas. Las horizontales tipo mamelonares o al pastillaje también son importantes, aunque en menor número, al igual que las horizontales de sección plana o subplana. En general no se observa una correlación entre los tipos de asas identificados y los sitios arqueológicos de donde proceden las muestras, exceptuando las asas horizontales de sección plana o subplana, que corresponden a piezas procedentes únicamente de Doncellas y Queta, que son además los sitios con mayor número de recipientes.

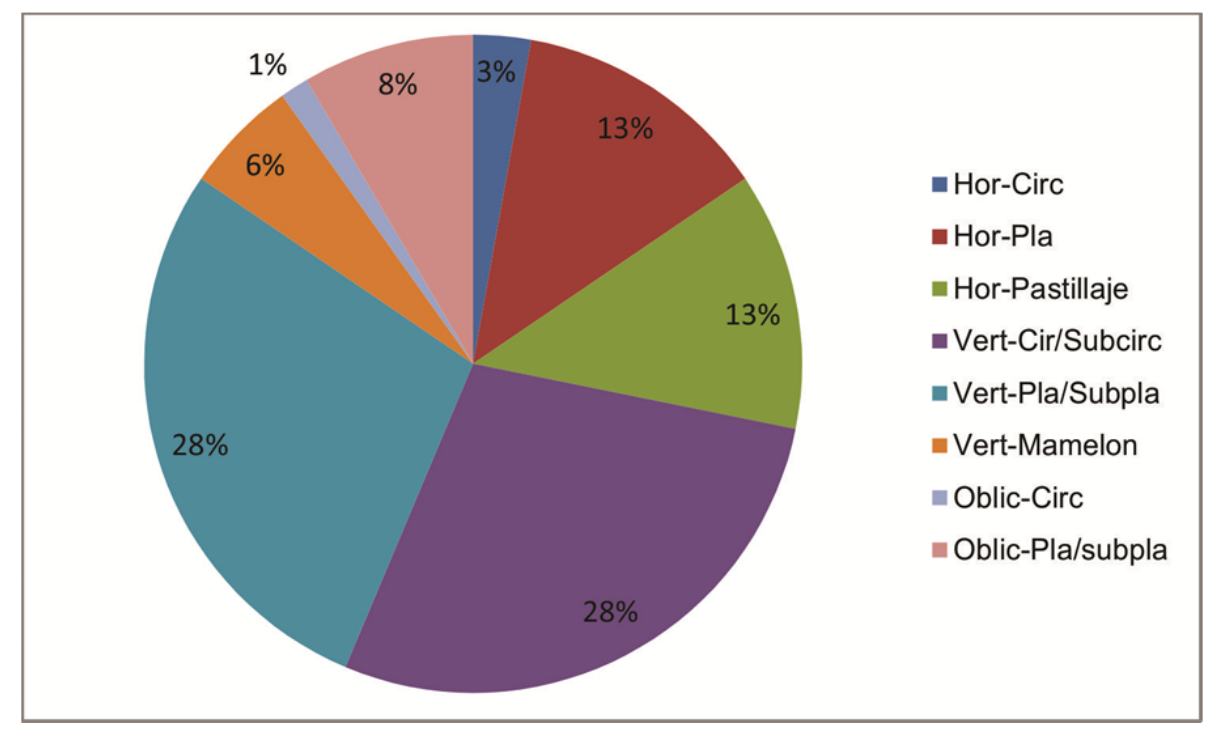

Figura 7.25 Proporción de los diferentes tipos de asas identificadas en el material de colección. Ref: Hor: horizontal; Vert: vertical, Oblic: oblicua, Circ: circular; Pla: plana; Subcirc: subcircular; Subpla: subplana.

Por otro lado, si se observa relación entre la presencia y los tipos de asas y las morfologías de las piezas (Tabla 7.11). Primeramente, las piezas cerradas presentan asas en muchos más casos (47:71) que las abiertas (24:71), lo que resulta lógico, dado que las asas pueden cumplir funciones para el acarreo de las piezas, y como las piezas cerradas suelen ser más grandes, requieren este tipo de aditamentos para su transporte y manipuleo. Además, las asas verticales adheridas (mamelones) solo están presentes 
en piezas cerradas. Las asas oblicuas también están presentes exclusivamente en piezas cerradas, especialmente para las formas de botella.

\begin{tabular}{|c|c|c|c|c|c|c|c|c|c|}
\hline & Hor-Circ & Hor-Pla & $\begin{array}{c}\text { Hor- } \\
\text { Pastillaje }\end{array}$ & $\begin{array}{c}\text { Vert- } \\
\text { Cir/Subcir }\end{array}$ & $\begin{array}{c}\text { Vert- } \\
\text { Pla/Subpl }\end{array}$ & $\begin{array}{c}\text { Vert- } \\
\text { mamelon }\end{array}$ & Jblic-Circ & $\begin{array}{c}\text { Oblic- } \\
\text { Pla/subpla }\end{array}$ & TOTAL \\
\hline Abierta indet & 0 & 0 & 0 & 0 & 1 & 0 & 0 & 0 & 1 \\
\hline Escudilla & 0 & 1 & 3 & 2 & 4 & 0 & 0 & 0 & 10 \\
\hline $\begin{array}{l}\text { Escudilla } \\
\text { honda }\end{array}$ & 0 & 3 & 5 & 1 & 2 & 0 & 0 & 0 & 11 \\
\hline $\begin{array}{l}\text { Escudilla } \\
\text { restringida }\end{array}$ & 0 & 0 & 0 & 2 & 0 & 0 & 0 & 0 & 2 \\
\hline Vaso & 0 & 0 & 0 & 0 & 0 & 0 & 0 & 0 & 0 \\
\hline Cerrada Indet & 0 & 0 & 0 & 2 & 1 & 0 & 0 & 1 & 4 \\
\hline Vasija & 2 & 2 & 1 & 12 & 7 & 1 & 0 & 1 & 26 \\
\hline Tinaja & 0 & 1 & 0 & 0 & 1 & 3 & 0 & 0 & 5 \\
\hline Botella & 0 & 2 & 0 & 1 & 4 & 0 & 1 & 4 & 12 \\
\hline
\end{tabular}

Tabla 7.11 Distribución de los distintos tipos de asas para las diferentes morfologías relevadas. Ref: Hor: horizontal; Vert: vertical, Oblic: oblicua, Circ: circular; Pla: plana; Subcirc: subcircular; Subpla: subplana.

Todos los tipos de asas pueden estar insertas al cuerpo tanto por remaches, como por adhesión, exceptuando las asas al pastillaje o mamelonares, verticales $u$ horizontales, que en todos los casos relevados se encuentran adheridas a las paredes de la pieza. Predominan las asas adheridas simples y las doble remachadas, seguidas por las doble adheridas y las labioadheridas. Los remaches se realizaron por perforación de la pared, que es atravesada por la arcilla del asa, dejando un bulto, más o menos alisado, en la superficie interna. En 10 piezas se observan estos remaches o perforaciones claramente, mientras que en las demás piezas con asas remachadas (12:22) se percibieron bultos al tacto en la superficie interna. En la Figura 7.27 se puede observar una pieza con dos perforaciones donde estuvo colocada el asa remachada, que se fragmento en esas inserciones. 


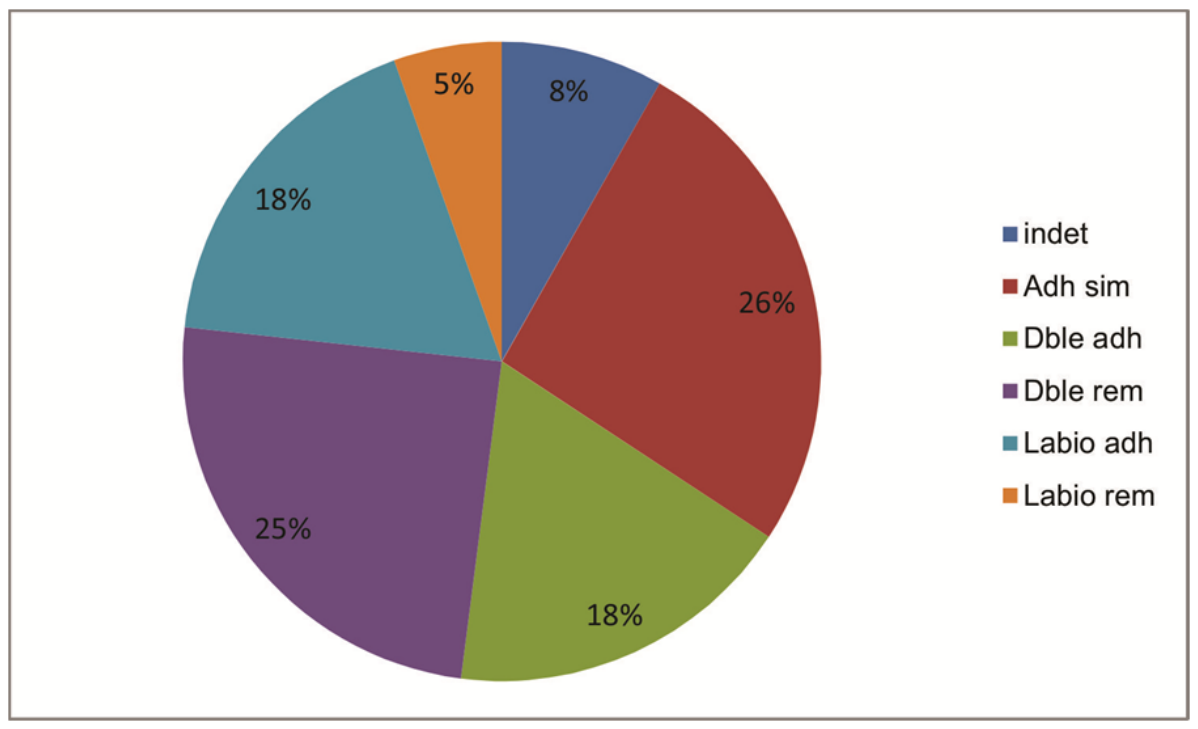

Figura 7.26 Proporción de los diferentes tipos de inserciones de asas identificadas en el material de colección. Ref: Adh: adherida, rem: remachada, sim: simple; Dble: doble.

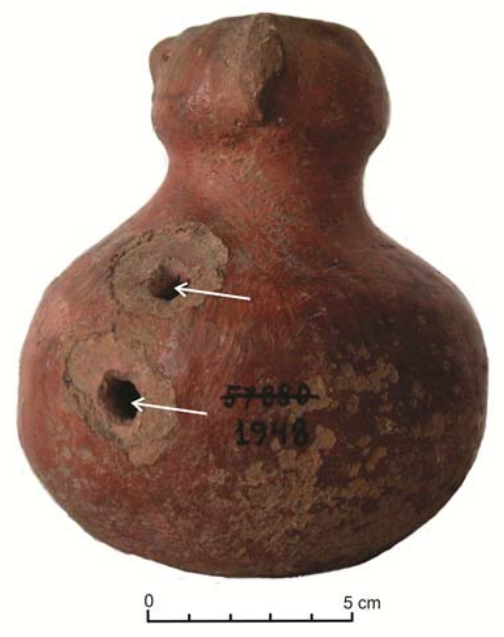

Figura 7.27 Pieza cerámica, tipo botella, con dos perforaciones (indicadas con la flecha) donde estuvo colocada un asa remachada de posición oblicua. Procedente de Rinconada, depositada en el Instituto Tilcara (IT-1948).

Tres piezas correspondientes a escudillas presentan apéndices ornitomorfos, como la ilustrada en la Figura 7.20 B. Además, hay dos piezas que presentan apéndices zoomorfos procedentes de un contexto funerario de Sansana (Boman 1908) (Figura 7.28). Los dos apéndices son tubulares y han sido colocados a la pared de la pieza 
mediante una perforación de la misma. Asimismo, los tubos son huecos por dentro, y en uno de los dos hay una perforación en el otro extremo, donde se encuentra el modelado zoomorfo, que permite que el recipiente pueda usarse para verter líquidos por ese orificio.

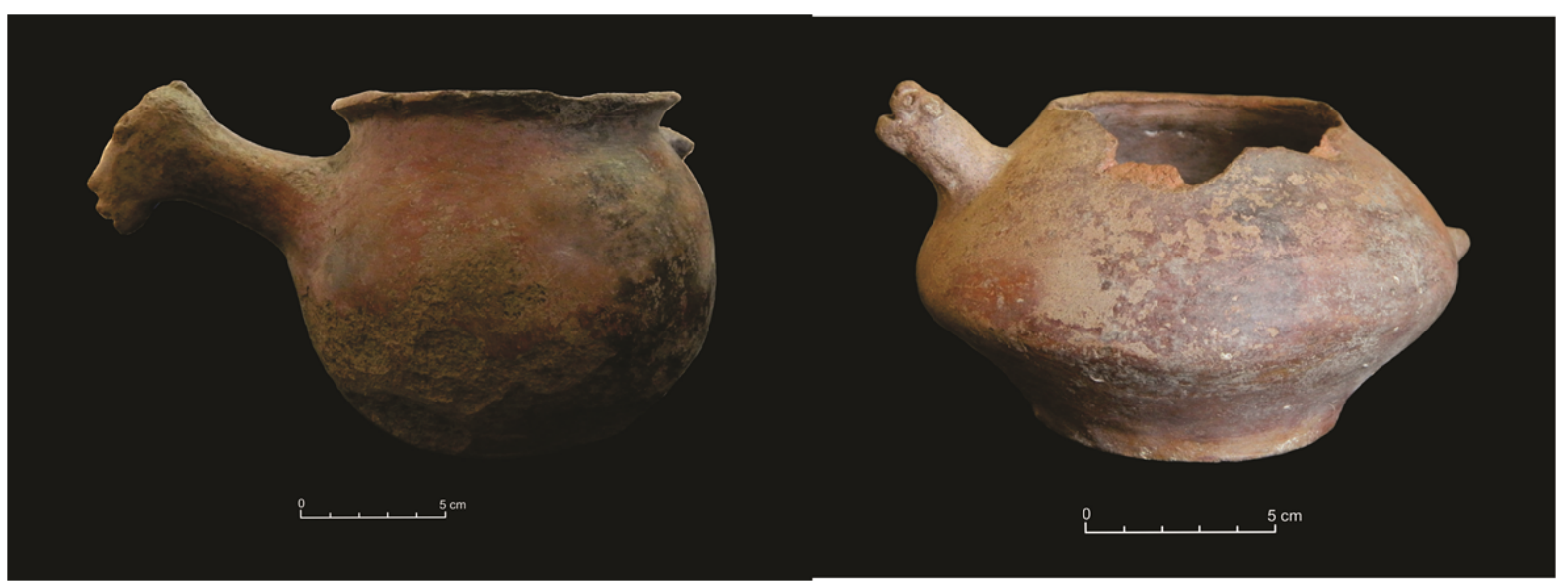

Figura 7.28 Piezas procedentes de Sansana con apéndices modelados zoomorfos, depositadas en el Museo Quai Branly. A: QB-2145; B: QB-2146.

\section{Las morfologías en el material fragmentario:}

En el material fragmentario, el nivel de clasificación de las morfologías no es tan pormenorizado, dada la naturaleza de la muestra. Sin embargo, se pudieron hacer algunas apreciaciones con respecto a las formas, estimando un número mínimo de piezas en base a los grupos de fragmentos y los fragmentos de bordes no agrupados, que permiten hacer algunas consideraciones sobre los perfiles de las piezas. A partir de ello, se determinaron formas generales, como abiertas y cerradas, y dentro de estas, en algunos casos, se pudo precisar si correspondían a categorías más concretas.

Se estimó un número mínimo de 217 piezas para el total de la muestra, de las cuales para 67 (31\%) no se pudo hacer ninguna estimación morfológica. Para el resto, 89 (41\%) corresponden a piezas abiertas y 61 (28\%) a cerradas. Dentro de las piezas abiertas, para algunas se pudo determinar si correspondían a escudillas o escudillas hondas, como una categoría general, y para las cerradas, si correspondían a vasijas o tinajas en general, o a botellas, en base a los diámetros reconstruidos para algunos bordes. La Tabla 7.12 muestra cuántas piezas hay por categoría morfológica para cada 
sitio, diferenciando las distintas ocupaciones y las procedentes de recolección superficial.

\begin{tabular}{lccccccc}
\hline & $\begin{array}{c}\text { Abierta } \\
\text { indet }\end{array}$ & $\begin{array}{c}\text { Escudilla- } \\
\text { Escudilla } \\
\text { honda }\end{array}$ & $\begin{array}{c}\text { Cerrada } \\
\text { Indet }\end{array}$ & $\begin{array}{c}\text { Vasija- } \\
\text { Tinaja }\end{array}$ & Botella & Indeterminadas & TOTAL \\
\hline CH 25-1 N1 & 1 & 1 & 2 & 0 & 0 & 0 & 4 \\
CH 25-1 Rec Sup & 0 & 0 & 0 & 1 & 0 & 0 & 1 \\
CH 25-2 N1 & 1 & 0 & 2 & 0 & 0 & 3 & 6 \\
CH 25-2 Rec Sup & 0 & 0 & 0 & 0 & 0 & 0 & 0 \\
PA 6-1 N1 & 2 & 3 & 3 & 0 & 0 & 2 & 10 \\
PA 6-1 Rec Sup & 3 & 0 & 2 & 0 & 0 & 1 & 6 \\
PA 22-S1 & 3 & 0 & 2 & 0 & 1 & 3 & 9 \\
PA 22-Basurero & 0 & 0 & 2 & 0 & 1 & 0 & 3 \\
Rec sup & 1 & 2 & 1 & 0 & 0 & 3 & 7 \\
RH 2-1 N1 & 0 & 1 & 1 & 0 & 0 & 6 & 8 \\
RH 2-1 Rec sup & 2 & 0 & 2 & 0 & 0 & 0 & 4 \\
RH 10-1 N1 & 2 & 1 & 1 & 0 & 0 & 1 & 5 \\
RH 10-1 N2 & 0 & 0 & 0 & 0 & 0 & 3 & 3 \\
RH 10-1 Rec Sup & 1 & 1 & 0 & 0 & 0 & 3 & 5 \\
RH 19-1 N1 & 2 & 0 & 0 & 0 & 0 & 0 & 2 \\
RH 19-1 Rec Sup & 15 & 1 & 3 & 0 & 0 & 14 & 33 \\
RH 19-7 N1 & 1 & 1 & 1 & 0 & 0 & 2 & 5 \\
RH 19-7 N2 & 1 & 0 & 0 & 0 & 0 & 1 & 2 \\
RH 19-7 Rec Sup & 3 & 1 & 5 & 1 & 0 & 0 & 10 \\
TA 1-1 N1 & 3 & 0 & 1 & 0 & 0 & 0 & 1 \\
TA 1-1 Rec Sup & 0 & 4 & 11 & 0 & 3 & 6 & 44 \\
SC 3 & 20 & 2 & 13 & 0 & 2 & 19 & 49 \\
TC 2 & 13 & 18 & 52 & 2 & 7 & 67 & 217 \\
\hline \multicolumn{1}{c}{ TOTAL } & 71 & 18 & & & & &
\end{tabular}

Tabla 7.12 Cantidad de piezas por tipo morfológico, para cada sitio analizado. Ref: N1: nivel 1; N2: nivel 2; Rec Sup: recolección superficial.

Para el general de la muestra, se observa un predominio de las piezas abiertas sobre las cerradas, como se sintetiza en el gráfico de la Figura 7.29, en porcentajes por sitio. Sin embargo, en algunos sitios predominan las cerradas, correspondientes a ocupaciones coloniales (PA 22-Basurero, $\mathrm{CH} 25-1$ ), y algunos prehispánicos tardíos ( $\mathrm{CH}$ 25-2 y TA 1-1). La segunda ocupación de RH 10-1 (N1), con un fechado colonial, presenta igual proporción de piezas abiertas y cerradas. 


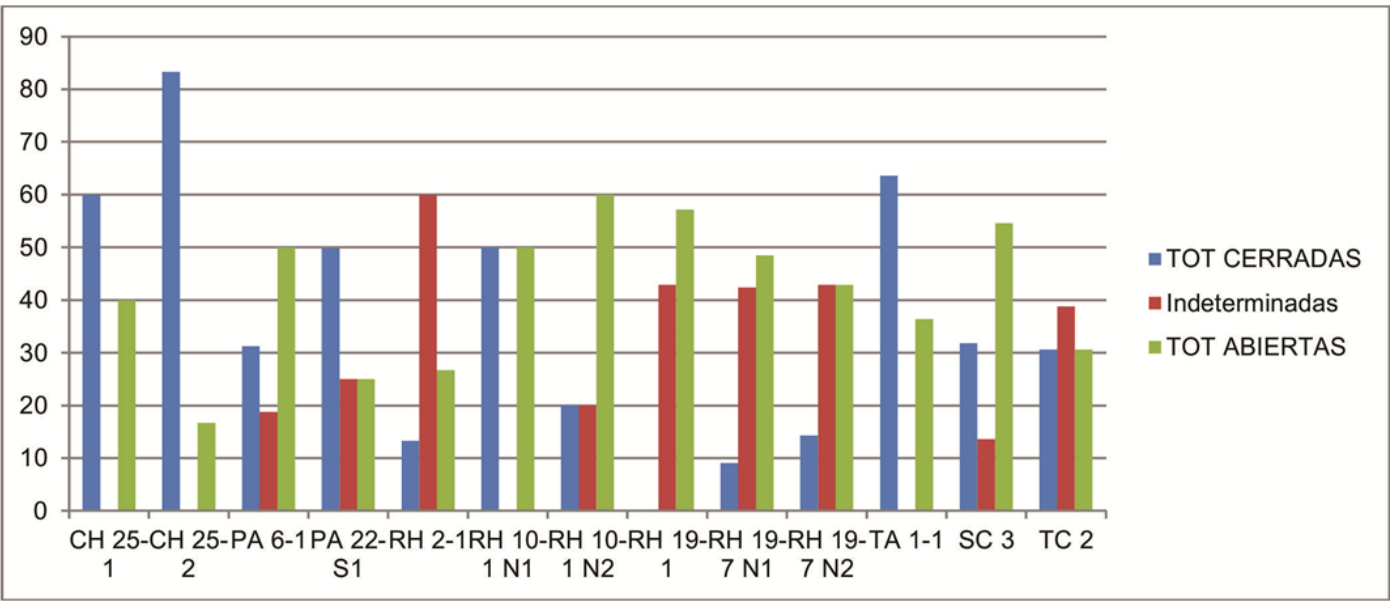

Figura 7.29 Porcentaje de piezas abiertas, cerradas e indeterminadas, por sitio. Ref.:

TOT: total; N1: nivel 1; N2: nivel 2.

Para las piezas abiertas, en la mayoría de los casos (71:89) no se pudo determinar su morfología concreta, pero en 18 casos se pudo apreciar que correspondían a escudillas o escudillas hondas, en base a la reconstrucción de los perfiles parciales, que se observan en las Figuras 7.30 (sur de Pozuelos) y 7.31 (Santa Catalina).

Para ambas zonas se observa que las piezas abiertas presentan una diversidad de tamaños, básicamente observables a partir de los diámetros. En base a la reconstrucción de los diámetros para 40 bordes de piezas diferentes, se observa que los tamaños varían entre 10 y $30 \mathrm{~cm}$, pero la mayor parte de las piezas tienen diámetros comprendidos entre los 12 y $24 \mathrm{~cm}$ (33:40), con un solo ejemplar con diámetro menor a $12 \mathrm{~cm}$, y seis mayor a $24 \mathrm{~cm}$. En general, en todos los sitios analizados se da este predominio de tamaños entre 12 y $24 \mathrm{~cm}$, exceptuando RH 2-1 y RH 10-1 Nivel 2 (donde hay un único borde para el que se pudo reconstruir el diámetro). 


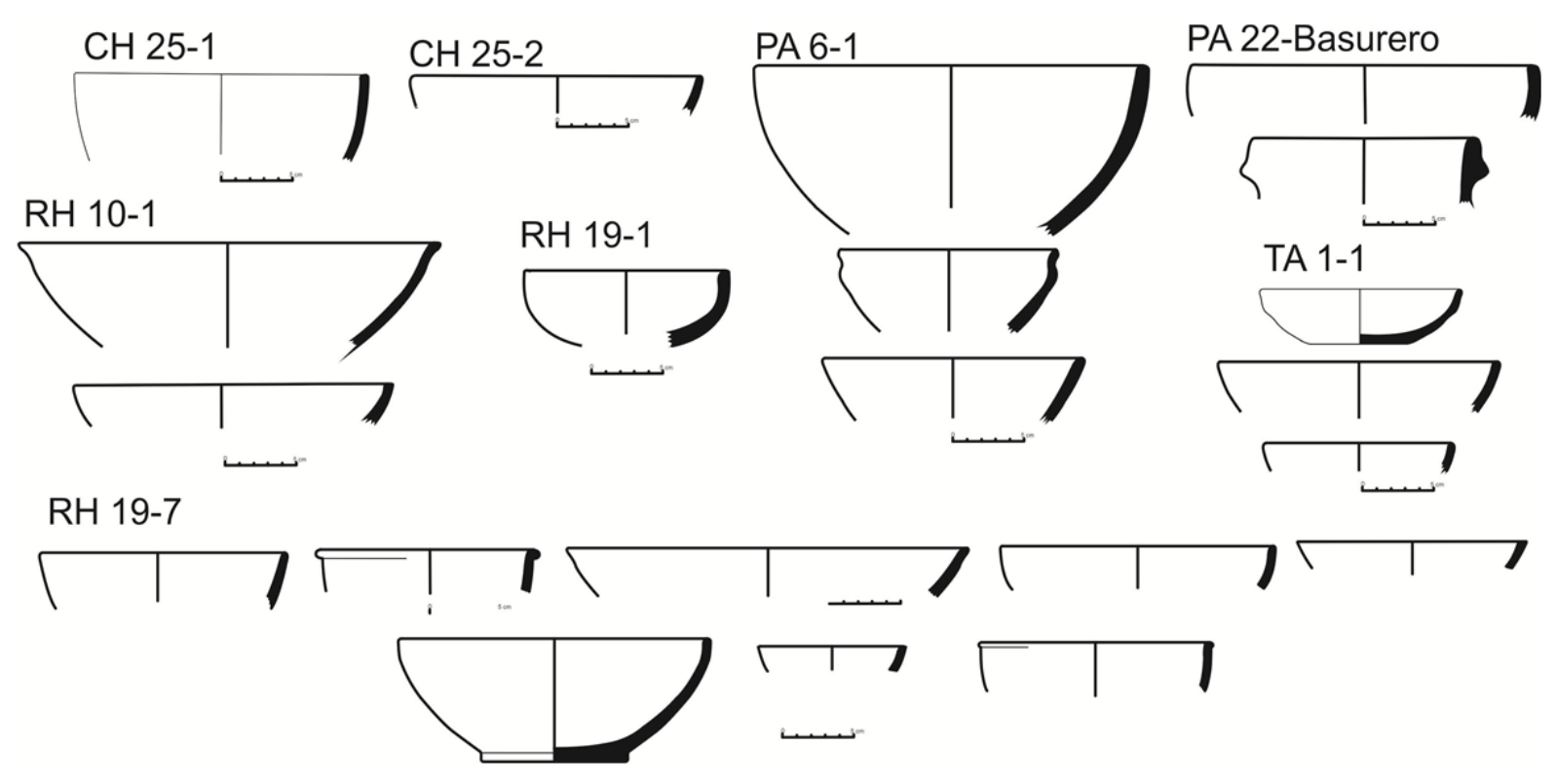

Figura 7.30 Reconstrucciones de perfiles de piezas abiertas de los sitios de la cuenca sur de la laguna de Pozuelos. La escala en todos los casos representa $5 \mathrm{~cm}$.

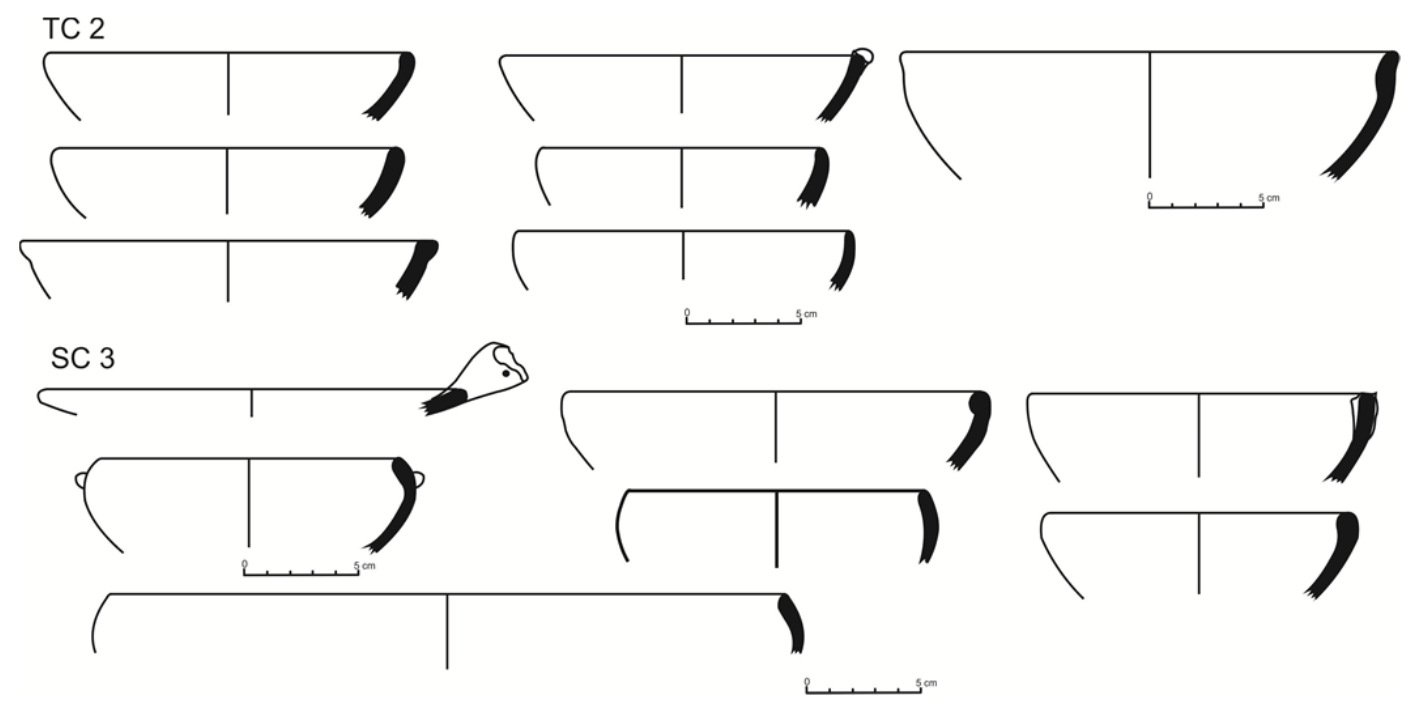

Figura 7.31 Reconstrucciones morfológicas de piezas abiertas de los sitios de la zona de Santa Catalina. La escala en todos los casos representa $5 \mathrm{~cm}$.

Dos fragmentos de bordes de SC 3 presentan apéndices ornitomorfos (Figura 7.32), y uno de TC 2 presenta un apéndice fracturado de sección subcircular adherido al borde, que probablemente correspondió a uno de estos apéndices también, dada la sección y la orientación del mismo. Esta característica permite vincular estas formas abiertas a la presencia imperial inkaica. 


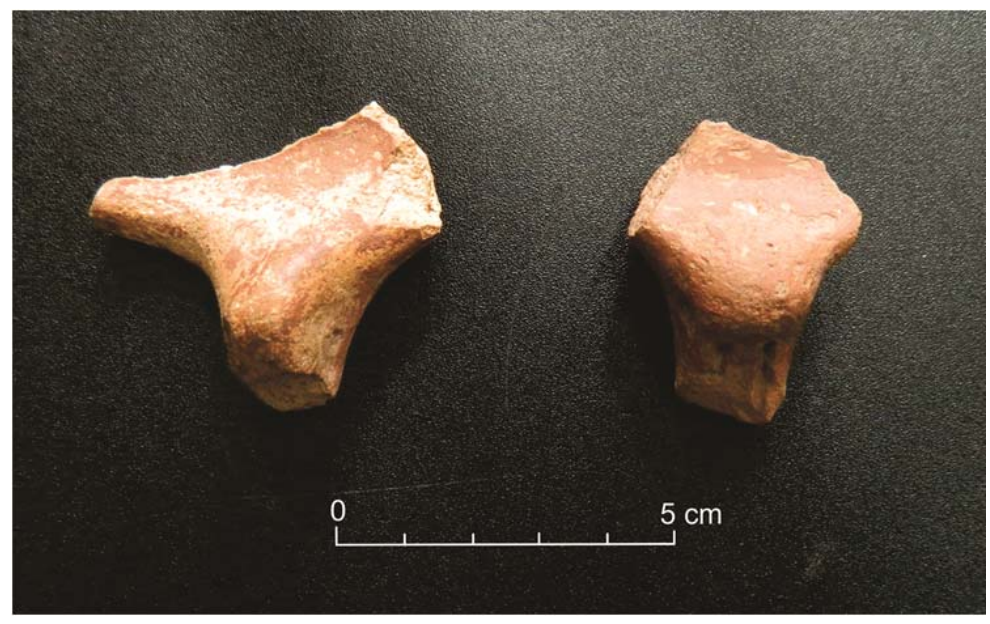

Figura 7.32 Fragmentos de bordes de piezas abiertas, con apéndices ornitomorfos, procedentes de SC 3.

Otra forma abierta de características particulares procede de PA 22-S1 y su perfil se puede observar en el extremo superior derecho de la Figura 7.30. Presenta un reborde modelado a un centímetro y medio del borde, sobre la superficie externa. Esta característica no se repite en ninguna otra pieza analizada y quizás su presencia se deba a que este es un sitio fechado en momentos coloniales.

Para las piezas cerradas también se pudieron reconstruir algunos perfiles parciales en base a los bordes (Figuras 7.33 y 7.34). Sin embargo, en la mayoría de los casos (52:61) no se pueden asignar a un tipo morfológico específico. Para algunas, donde el perfil está más completo, se las pudo asignar a la categoría general vasija-tinaja (2:61) o botella (7:61). La distribución de estas pocas piezas relacionables a botellas por su diámetro de boca muy restringido, es un aspecto a destacar. Dos de ellas proceden del basurero de PA 22 que, como ya mencionamos, es un sitio con un fechado colonial y no están presentes en otros sitios de la cuenca sur de Pozuelos. Las demás proceden de la zona de Santa Catalina (3 de SC 3 y 2 de TC 2). Al igual que para las piezas analizadas en las colecciones de museo, su presencia es más importante en el sector norte de la puna. 

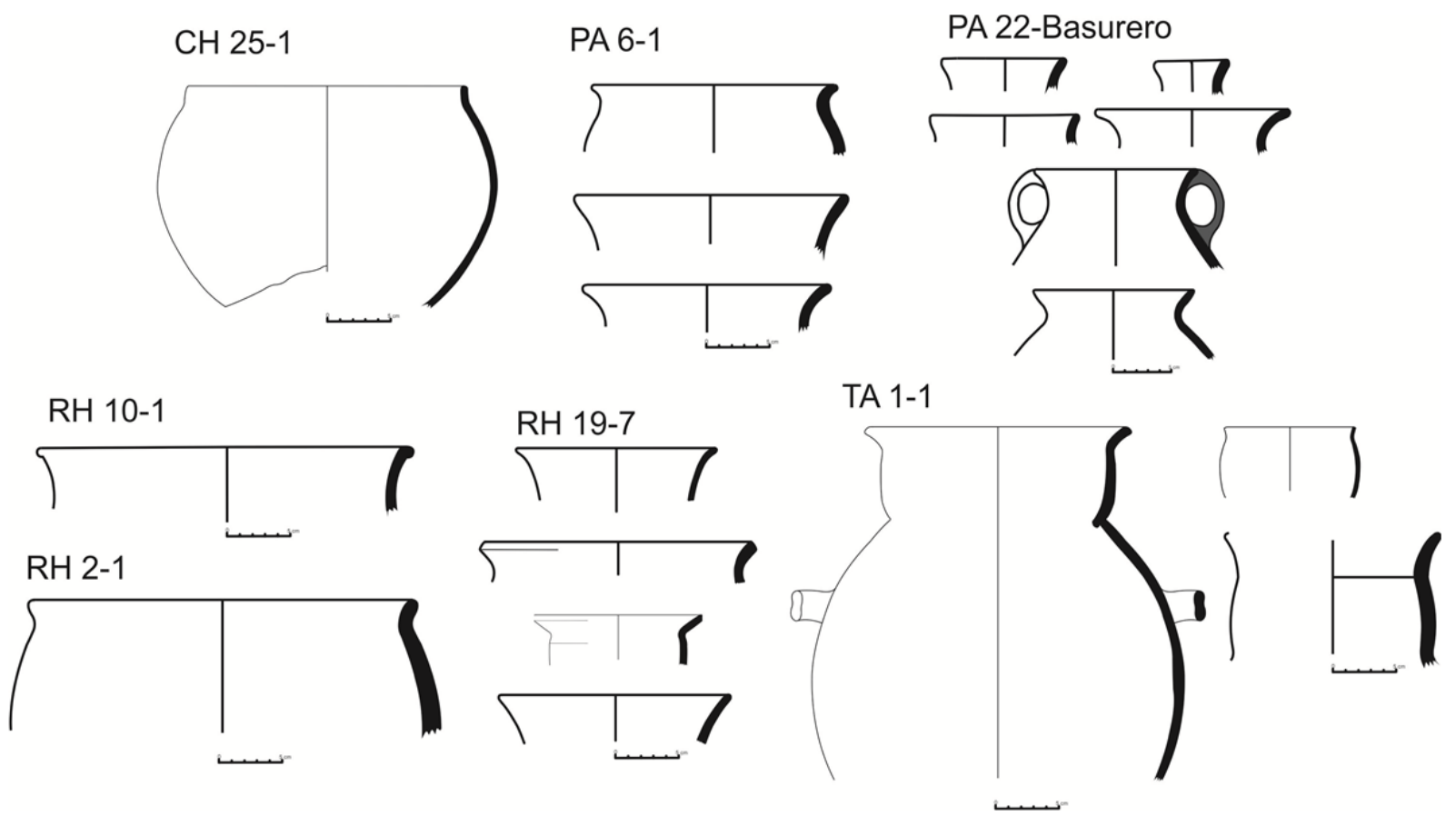

Figura 7.33 Reconstrucciones morfológicas de piezas cerradas de los sitios de la cuenca sur de la laguna de Pozuelos. La escala en todos los casos representa $5 \mathrm{~cm}$.

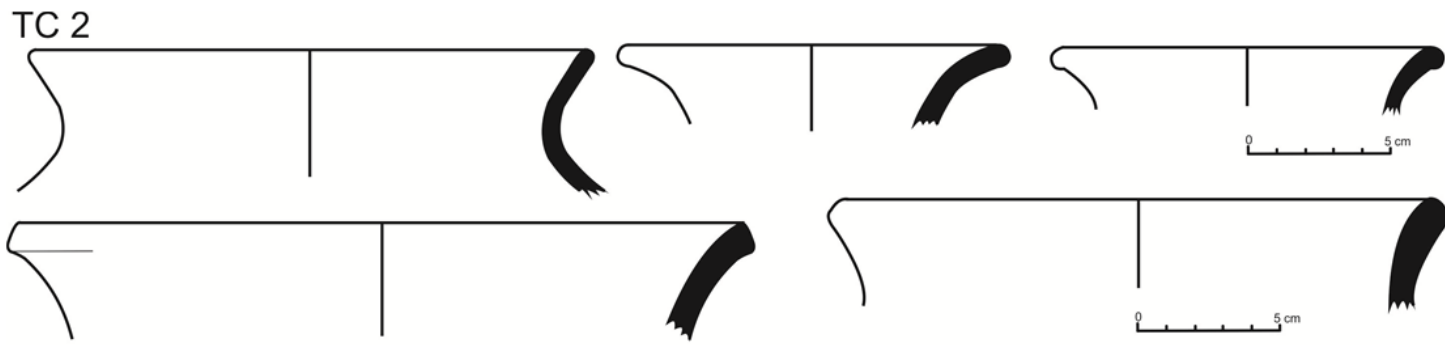

SC 3

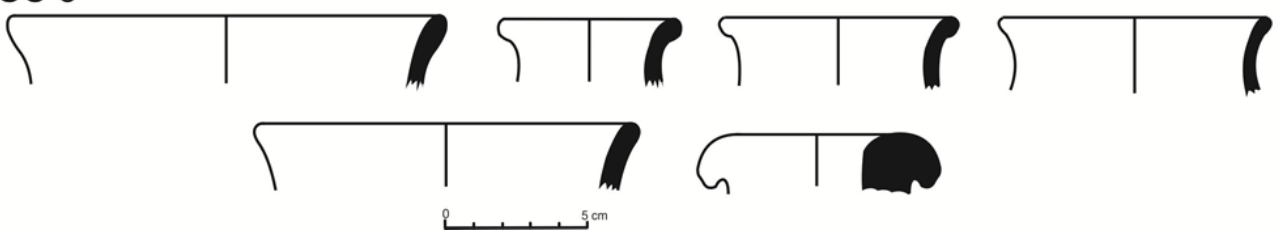

Figura 7.34 Reconstrucciones morfológicas de piezas cerradas de los sitios de la zona de Santa Catalina. La escala en todos los casos representa $5 \mathrm{~cm}$.

En base a las reconstrucciones morfológicas, también se puede notar que varias de las porciones de bordes y cuellos reconstruidas para la zona de Pozuelos (Figura 7.33) probablemente correspondan a cuellos cilíndricos de vasijas de perfil discontinuo, como la ilustrada en la misma figura para TA 1-1 y las que observamos en las colecciones de 
museos y que se han definido como típicas del "área Casabindo" (Albeck 2001). Para la zona de Santa Catalina este tipo de cuellos no están presentes en base a las morfologías reconstruidas.

Uno de los fragmentos de bordes de TC 2 ilustrado en la Figura 7.34 arriba al medio y otro no ilustrado porque no se pudo reconstruir su diámetro, son fuertemente evertidos y de cuellos muy restringidos, lo que hace pensar que posiblemente correspondan a formas tipo aríbalos, asociadas a la presencia Inka.

Si bien en base al material fragmentario no se han podido determinar dimensiones de diámetros máximos y mínimos, para 35 fragmentos de bordes se pudo determinar el diámetro de la abertura. Los tamaños de aberturas muestran un rango muy grande, entre 4 y $31.6 \mathrm{~cm}$, con una media de $18 \mathrm{~cm}$. Los diámetros menores corresponden a las morfologías de botellas de SC 3 y PA 22. En la Figura 7.35 se puede observar un histograma de los diámetros registrados.

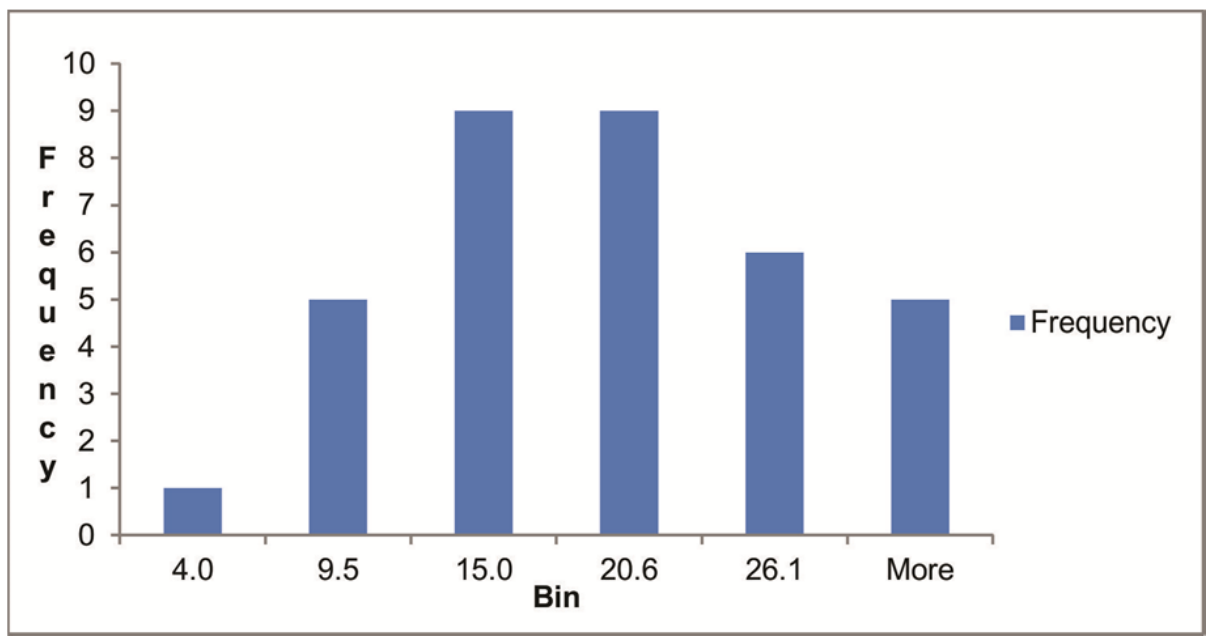

Figura 7.35 Histograma de frecuencias de diámetros reconstruidos para piezas cerradas a partir de fragmentos de bordes.

Por otro lado, el análisis sobre material fragmentario nos permite ver si existen vinculaciones entre las morfologías reconstruidas y los grupos de pastas identificados en el capítulo anterior. No observamos ninguna asociación entre estos atributos. Para cada GP hay una diversidad de morfologías posibles, y los artesanos no emplearon tipos determinados de materias primas para realizar morfologías diferentes, como a veces se observa en contextos etnográficos. En la Tabla 7.13 se puede apreciar el número de piezas de cada morfología identificada para cada GP, teniendo en cuenta los 
grupos de fragmentos y fragmentos de bordes no agrupados. Se observa que casi todos los GP se emplearon para manufacturar piezas abiertas y cerradas, exceptuando aquellos que solo están representados por una única pieza (GP 6 y 9). Los fragmentos que corresponderían a botellas si presentan solo algunos tipos de pastas (GP 3, 5, 7, 8 y 9). Como además la mayoría procede de la zona norte de la puna, al sumar la presencia de estos GP, podemos relacionarlo con el estilo Yavi, no estando presente dentro del estilo Casabindo, ni en los tipos de pastas que hemos identificado para la cuenca sur de Pozuelos.

\begin{tabular}{lccccccc}
\hline & $\begin{array}{c}\text { Abierta } \\
\text { indet }\end{array}$ & $\begin{array}{c}\text { Escudilla- } \\
\text { Escudilla honda }\end{array}$ & Cerrada Indet & Vasija-Tinaja & Botella & Indeterminadas TOTAL \\
\hline GP 1 & 4 & 2 & 5 & 0 & 0 & 13 & 24 \\
GP 2 & 14 & 2 & 7 & 1 & 0 & 5 & 29 \\
GP 3 & 13 & 4 & 14 & 0 & 1 & 11 & 43 \\
GP 4 & 23 & 7 & 11 & 1 & 0 & 21 & 63 \\
GP 5 & 8 & 2 & 4 & 0 & 2 & 5 & 21 \\
GP 6 & 0 & 0 & 1 & 0 & 0 & 0 & 1 \\
GP 7 & 0 & 0 & 0 & 0 & 1 & 0 & 1 \\
GP 8 & 9 & 1 & 7 & 0 & 2 & 9 & 28 \\
GP 9 & 0 & 0 & 0 & 0 & 1 & 0 & 1 \\
\hline
\end{tabular}

Tabla 7.13 Número de piezas para cada morfología reconstruida que presentan los diferentes grupos de pastas identificados previamente.

En cuanto al espesor de las paredes de los fragmentos analizados, la mayor parte de los GF muestran espesores comparables para bordes y cuerpo, con un incremento hacia la base. En la Tabla 7.14 se muestran los espesores promedios de las paredes para cada sitio, donde se observa que en general el promedio es bastante homogéneo, siendo de alrededor de $6 \mathrm{~mm}$ para bordes y cuerpos y de $10 \mathrm{~mm}$ para las bases. Sin embargo, en los sitios de la zona de Santa Catalina el espesor de los fragmentos es en promedio algo mayor que para los de Pozuelos, aunque no sucede lo mismo con las bases.

Al asociar los espesores registrados para los fragmentos de bordes y cuerpos ${ }^{8}$ con los Grupos de pastas (Figura 7.36), se observa que la mayoría de los GP presenta espesores promedio entre 6 y $7 \mathrm{~mm}$. El GP 5, sin embargo, presenta un espesor promedio $(4.9 \mathrm{~mm})$ más fino que los demás, por lo que este tipo de pasta probablemente se empleó para manufacturar piezas de paredes más delgadas, y quizás

${ }^{8}$ Dejamos fuera los fragmentos de bases porque presentan valores más altos y su presencia o ausencia puede entonces afectar el valor del promedio, que es sensible a los valores extremos (Drennan 2009). 
las inclusiones menos densas estén relacionadas a esa necesidad. Asimismo, el GP 9 presenta un espesor promedio mucho más grande $(13.7 \mathrm{~mm})$ que los demás GP. Todos estos fragmentos probablemente correspondan a una misma pieza, manufacturada con torno, de paredes gruesas y cuello muy restringido (ver Figura 7.34 abajo al centro). Quizás haya correspondido a una botija o una morfología semejante, dado que estas eran piezas globulares de cuello restringido empleadas para transportar sustancias alimenticias durante la colonia (Schavelzon 2001).

\begin{tabular}{lccc}
\hline & Borde & Cuerpo & Base \\
\hline CH 25-1 & 6.6 & 5.5 & 13.6 \\
CH 25-2 & 5.3 & 6.2 & 8.2 \\
PA 6-1 & 6.2 & 6.3 & 9.7 \\
PA 22-Basurero & 6 & 6.2 & 9.5 \\
RH 2-1 & 7 & 6.5 & 14.3 \\
RH 10-1 N1 & 6.2 & 6.2 & 9.5 \\
RH 10-1 N2 & 6.2 & 5.6 & 10.5 \\
RH 19-1 & 5.7 & 6.1 & 11.5 \\
RH 19-7 N1 & 5.7 & 6 & 9.2 \\
RH 19-7 N2 & 5.4 & 6 & 10.1 \\
TA 1-1 & 5.2 & 5.7 & 9.9 \\
SC 3 & 7.1 & 7.4 & 9.3 \\
TC 2 & 6.7 & 6.6 & 9.2 \\
\hline
\end{tabular}

Tabla 7.14 Espesor de bordes, cuellos y bases para los fragmentos analizados por sitio.

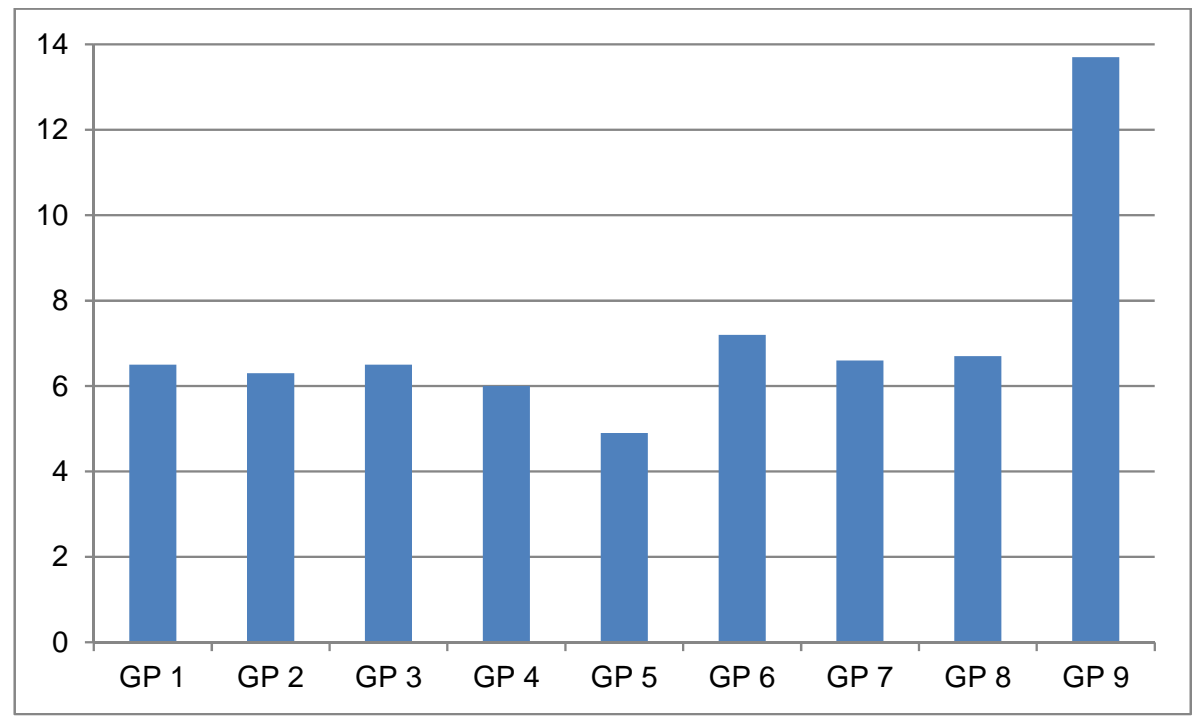

Figura 7.36 Espesor promedio de los fragmentos de bordes y cuerpos para los diferentes Grupos de pastas identificados. 


\section{Morfologías de bordes, bases y asas:}

Al igual que para las piezas de colección, hemos registrado las morfologías de los bordes, bases y asas de los grupos de fragmentos y los fragmentos no agrupados. Los fragmentos de bordes presentan diferentes formas, de acuerdo a su dirección y morfología del labio. Las mismas se grafican en la Figura 7.37. Se observa un claro predominio de los bordes evertidos o hacia afuera y redondeados, seguidos por los verticales y redondeados y los evertidos y planos.

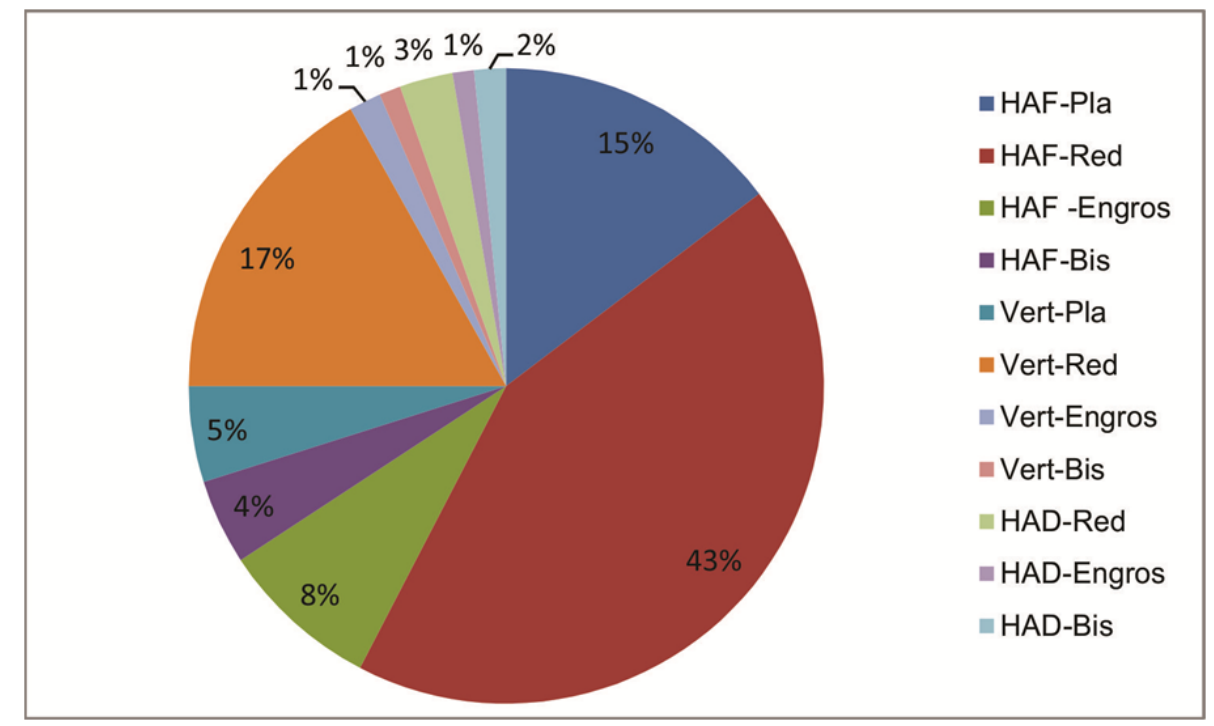

Figura 7.37 Morfologías de bordes del material fragmentario analizado. Ref: HAF. Hacia afuera; Vert: vertical; HAD: hacia adentro; Pla: plano; Red: redondeado; Engros: engrosado; Bis: biselado.

En general, los sitios de la cuenca sur de Pozuelos y los de Santa Catalina muestran los mismos tipos de bordes en proporciones parecidas, aunque en los sitios de Pozuelos los bordes planos son algo más abundantes (25\% contra $14 \%$ en Santa Catalina). En Santa Catalina, los bordes redondeados, con distintas direcciones, alcanzan un $71 \%$ del total, en contraste al $54 \%$ de este tipo de bordes en Pozuelos. Por otro lado, en esa primera zona son algo más abundantes los bordes con dirección hacia adentro o invertidos (8\%) que en la zona de la laguna (3\%).

Al relacionar las morfologías de bordes con las morfologías de las piezas que pudieron identificarse en este material fragmentario (Tabla 7.15), en general se observa 
que no hay una vinculación estrecha entre tipos de bordes y morfologías, al igual que se observó para las piezas de colección. Si se observa que son más frecuentes los bordes evertidos en las piezas cerradas, mientras que en las abiertas abundan más los verticales, que son casi exclusivos de este tipo de piezas, estando presente solo en dos piezas cerradas. Los bordes invertidos o hacia adentro, también son casi exclusivos de las piezas abiertas, habiendo un solo borde correspondiente a una posible pieza cerrada con esa forma. Dentro de las formas abiertas la diversidad morfológica de los bordes es muy amplia, aunque predominan los redondeados, evertidos o verticales. En las cerradas es menos diversa, siendo casi todos los bordes evertidos, y mayormente redondeados. Las formas tipo botellas presentan una proporción importante (4:7) de bordes engrosados.

\begin{tabular}{|c|c|c|c|c|c|c|c|c|c|c|c|}
\hline & $\begin{array}{l}\text { HAF- } \\
\text { Pla }\end{array}$ & $\begin{array}{l}\text { HAF- } \\
\text { Red }\end{array}$ & $\begin{array}{c}\text { HAF - } \\
\text { Engros }\end{array}$ & $\begin{array}{l}\text { HAF- } \\
\text { Bis }\end{array}$ & $\begin{array}{l}\text { Vert- } \\
\text { Pla }\end{array}$ & $\begin{array}{l}\text { Vert- } \\
\text { Red }\end{array}$ & $\begin{array}{c}\text { Vert- } \\
\text { Engros }\end{array}$ & $\begin{array}{c}\text { Vert- } \\
\text { Bis }\end{array}$ & $\begin{array}{l}\text { HAD- } \\
\text { Red }\end{array}$ & $\begin{array}{l}\text { HAD- } \\
\text { Engros }\end{array}$ & $\begin{array}{l}\text { HAD- } \\
\text { Bis }\end{array}$ \\
\hline Abierta indet & 9 & 15 & 7 & 3 & 5 & 19 & 2 & 1 & 4 & 0 & 3 \\
\hline $\begin{array}{l}\text { Escudilla- } \\
\text { Escudilla honda }\end{array}$ & 2 & 5 & 2 & 0 & 1 & 7 & 0 & 1 & 0 & 0 & 0 \\
\hline Cerrada Indet & 7 & 30 & 2 & 1 & 0 & 0 & 0 & 0 & 0 & 1 & 0 \\
\hline Vasija-Tinaja & 1 & 0 & 0 & 0 & 0 & 1 & 0 & 0 & 0 & 0 & 0 \\
\hline Botella & 0 & 3 & 3 & 0 & 0 & 0 & 1 & 0 & 0 & 0 & 0 \\
\hline Indeterminadas & 8 & 26 & 1 & 4 & 3 & 4 & 0 & 0 & 1 & 1 & 0 \\
\hline
\end{tabular}

Tabla 7.15 Tipos de bordes identificados en el material fragmentario para cada morfología reconocida. Ref: HAF. Hacia afuera; Vert: vertical; HAD: hacia adentro; Pla: plano; Red: redondeado; Engros: engrosado; Bis: biselado.

En la Figura 7.38 se ilustran algunos ejemplos de parte de estas morfologías de bordes identificadas. 


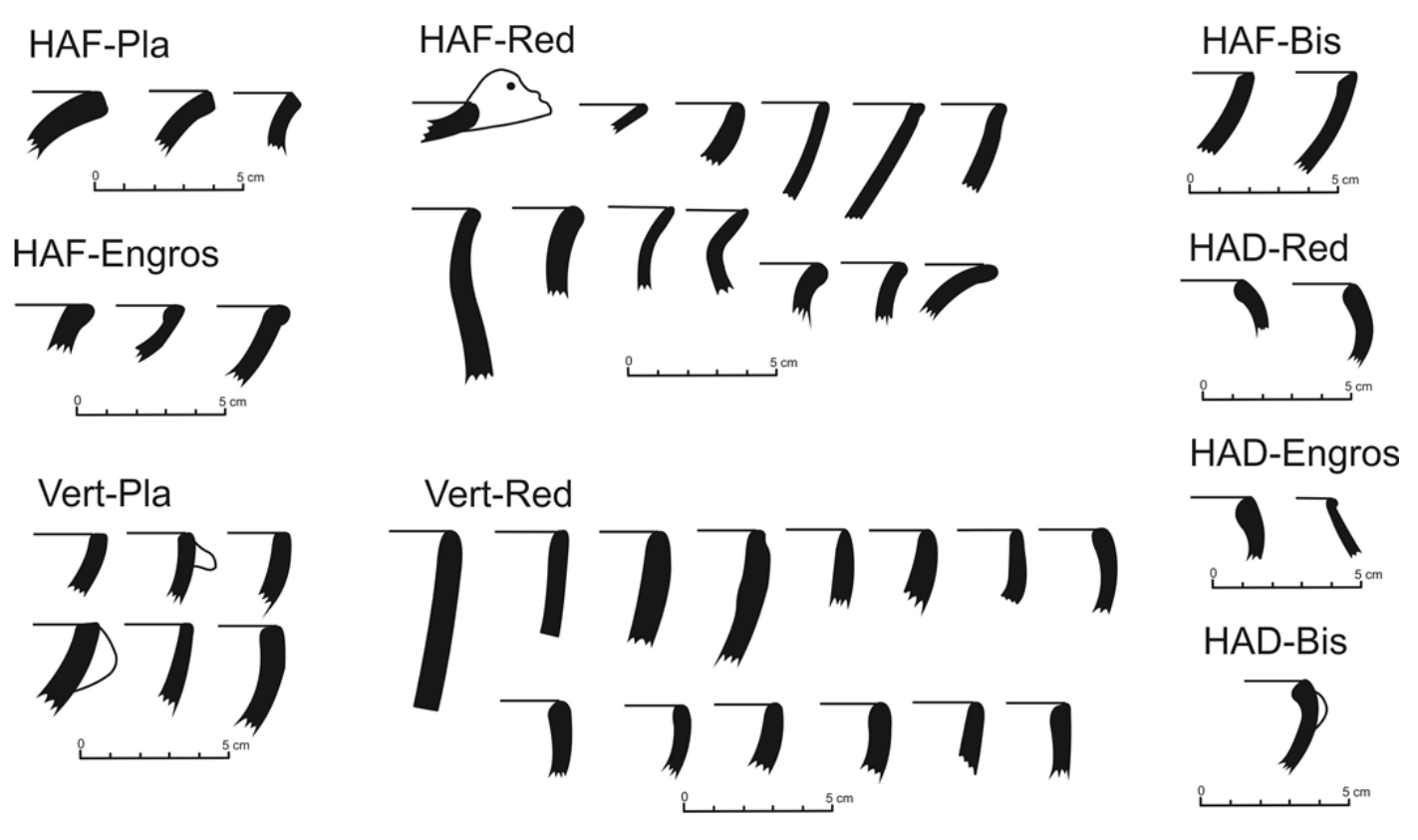

Figura 7.38 Algunos de los tipos de bordes identificados en el material cerámico fragmentario. Ref: HAF. Hacia afuera; Vert: vertical; HAD: hacia adentro; Pla: plano;

Red: redondeado; Engros: engrosado; Bis: biselado.

Con respecto a los fragmentos de base, al considerar la morfología de las mismas y los tipos de unión al cuerpo, vemos que la diversidad de morfologías no es muy amplia. Como se puede apreciar en la Figura 7.39, la mayor parte (41:62) corresponden a bases planocóncavas, con unión al cuerpo directa, seguidas por las plano cóncavas con unión al cuerpo angular. Si, al igual que para las piezas de colección, tenemos en cuenta la morfología externa, vemos que todas las bases menos 2 (de un total de 62) son planas en el exterior. Como señalamos anteriormente, esto debe estar relacionado con las técnicas de modelado y con la superficie empleada para modelar la pieza. Además, puede ser posible que las bases hayan sido modeladas por separado, manualmente, para luego construir el cuerpo sobre la misma, ya que como hemos mencionado, en ocasiones se observan marcas de dedos en este sector de la pieza. Por otro lado, García Roselló (2010) ha señalado que las bases modeladas por separado del cuerpo, pueden presentar una arista en la unión de la base al cuerpo, resultando en bases con uniones angulares. Esta arista también puede recortarse en pasos sucesivos, resultando en uniones directas. En la Figura 7.40 se pueden ver algunos ejemplos de las morfologías de bases relevadas. 


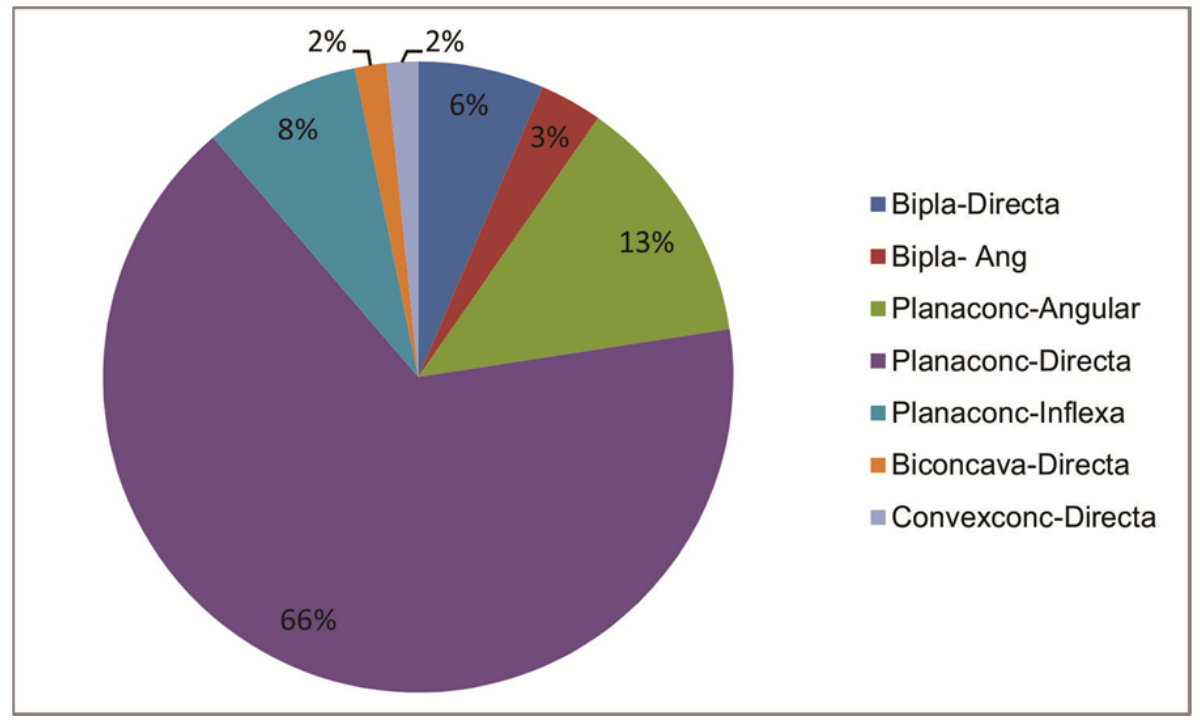

Figura 7.39 Morfologías de bases para el material fragmentario analizado. Ref: Bipla: biplana; Planaconc: plana cóncava; Convexconc: convexo cóncava.

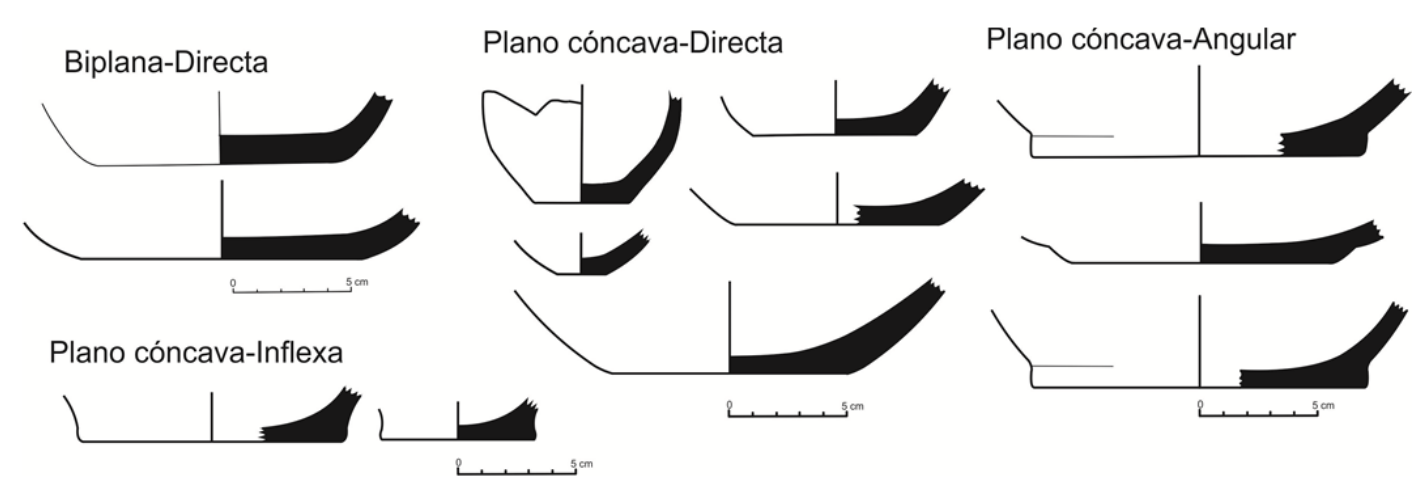

Figura 7.40 Morfologías de fragmentos de bases correspondientes al material fragmentario analizado.

Las formas registradas corresponden tanto a piezas abiertas como a cerradas, no observándose una relación entre los tipos de morfologías de bases con las de las piezas. Además de que para la mayor parte de los fragmentos de bases, no se puede inferir de qué forma de pieza proceden (43:62). Uno de esos fragmentos de bases de TA 1-1, con la pared unida de manera vertical, probablemente corresponda a un vaso chato, única pieza posible de esa morfología registrada en el material fragmentario.

En 51 de los 62 fragmentos de base (82\%) se pudo medir o calcular el diámetro. Los diámetros registrados muestran una variabilidad grande, con un valor mínimo de 2,1 cm 
y un máximo de 24,9. Sin embargo, el $80 \%$ de las mediciones se encuentra entre 5 y 15 $\mathrm{cm}$. El promedio para el tamaño de las bases es igual a $9.2 \mathrm{~cm}$.

Hay un fragmento que posiblemente sea parte de un pie macizo, procedente de TA 11, morfología que no se ha registrado para ninguna de las piezas cerámicas restantes, ni en el material fragmentario, ni en las colecciones de museos (Figura 7.41). Quizás corresponda a alguna forma con pedestal como las registradas por Raffino et al. (1986) en su tipo Inka Provincial ordinario, vinculado a la influencia inka o hispano indígena.

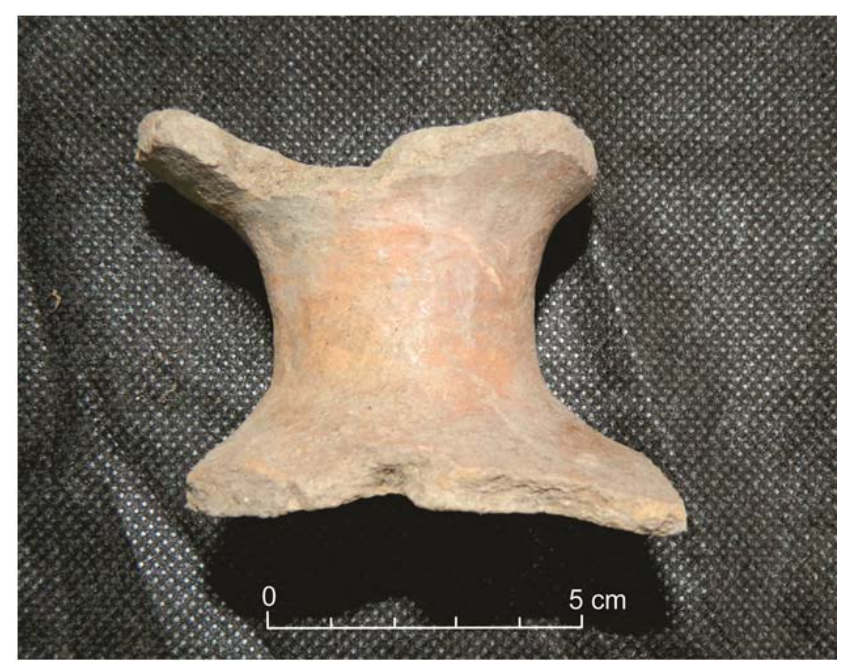

Figura 7.41 Fragmento de pie procedente de Tabladitas 1-1.

Con respecto a las morfologías de las asas, se tuvo en cuenta la posición en la pieza y el tipo de sección, como mencionamos en la metodología. Para la mayor parte de los fragmentos, no se pudo determinar la posición que habrían tenido en la pieza original. Dentro de estas asas de posición indeterminada (42:62), hay igual proporción de fragmentos con sección circular o subcircular (21:42), como con sección plana o subplana (21:42). Para aquellas en que si se pudo determinar la posición, las horizontales (12:62) son más abundantes que las verticales (7:52), y se presentan con sección circular o subcircular como plana o subplana. En dos casos, se trata de asas al pastillaje, sin sección, y corresponden a pequeños apéndices adheridos próximos a los bordes de piezas abiertas, como las observadas entre los materiales de colección. Los dos son fragmentos procedentes de SC 3 . Este rasgo no se ha observado en el material fragmentario del sur de Pozuelos. Un fragmento corresponde a las asas "oblicuas" que Krapovickas (1975) caracteriza como típicas de la cerámica Yavi. 


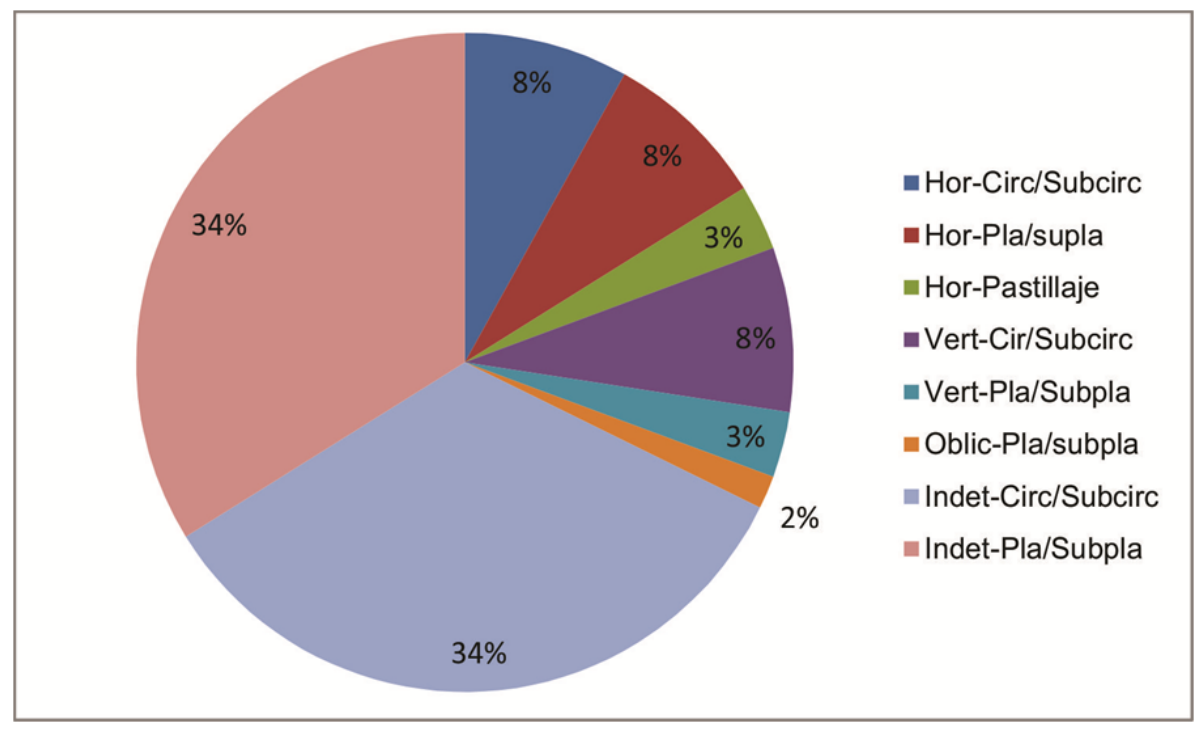

Figura 7.42 Morfologías de los fragmentos de asas para la muestra de material fragmentario analizado. Ref: Hor: horizontal; Vert: vertical; Oblic: oblicua; Indet: indeterminada; Circ: circular; Pla: plana; Subcirc: subcircular; Subpla: subplana.

Para la mayor parte de las asas (51:62) no pudimos inferir de qué tipo de pieza proceden. Solo dos fragmentos de asas corresponden a piezas abiertas, y son las dos asas modeladas al pastillaje mencionadas arriba. Los nueve fragmentos restantes corresponden a piezas cerradas. Al igual que para las piezas de colección, vemos que las asas son más frecuentes en las piezas cerradas, lo cual seguramente está vinculado a su mayor tamaño y la necesidad de sostenerlas o transportarlas.

Con respecto al tipo de inserciones, las mismas se pudieron observar en 44 casos (71\%). La mayoría son asas doble remachadas (21:44), aunque las asas adheridas también son abundantes (18:44). Solo en cinco casos se registraron asas labioadheridas. Tres de las mismas proceden del basurero de PA 22, no hallándose este tipo de asa en otro sitio del área sur de Pozuelos. A pesar de que en los materiales de colección se observan este tipo de asas y han sido documentados en otros sitios del área (Casanova 1938), en el material fragmentario solo aparecen en este sitio colonial. En la Figura 7.43 se pueden observar distintos tipos de inserciones registrados en el material fragmentario. 


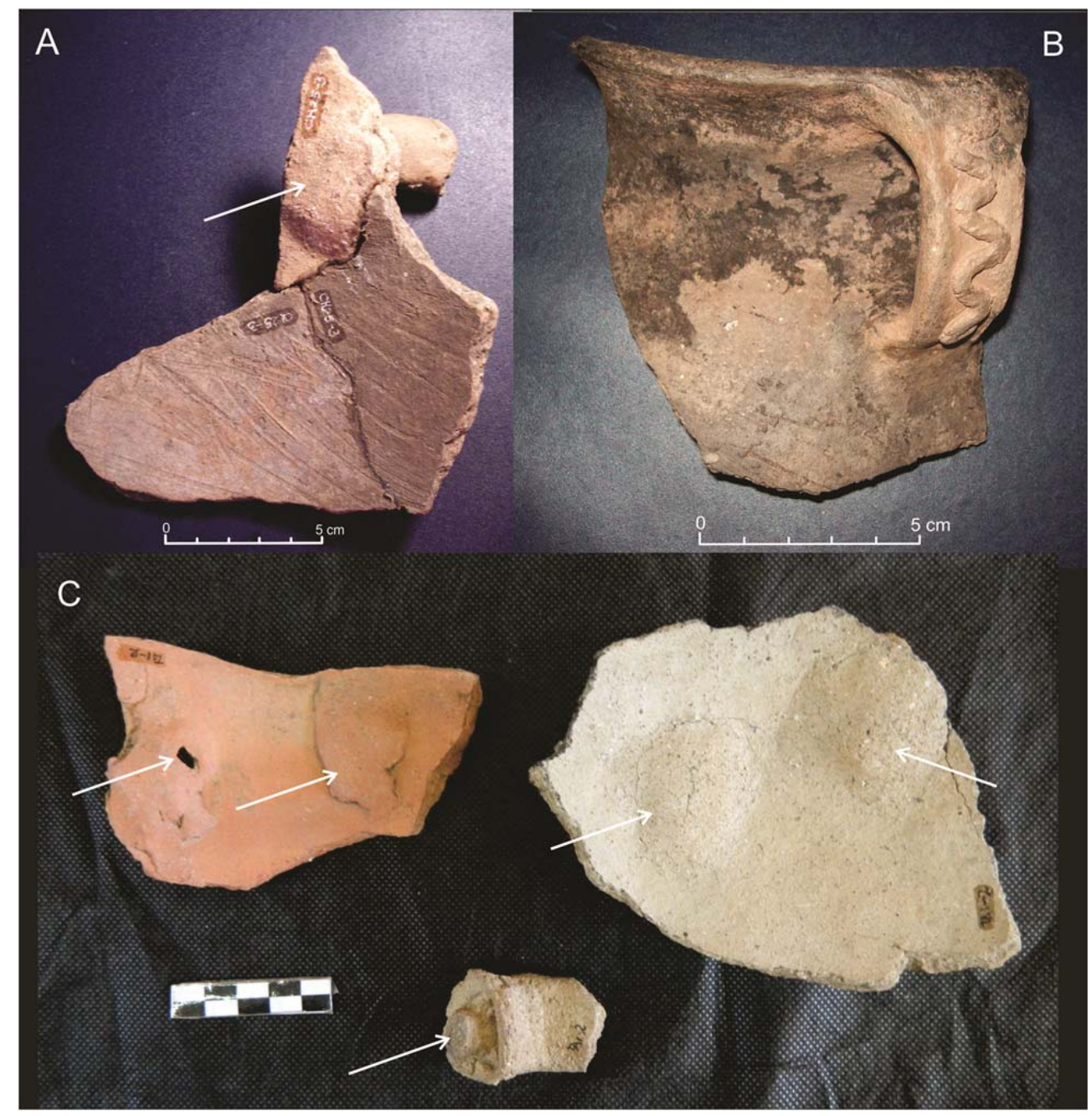

Figura 7.43 Tipos de inserciones de asas registradas en el material fragmentario. A: protuberancia en superficie interna asociada al remachado en fragmento procedente de $\mathrm{CH}$ 25-1. B: Asa labioadherida de PA 22-Basurero. C: remaches de asas en superficie interna en fragmentos de TA 1-1.

\section{Síntesis y conclusiones:}

Para finalizar este capítulo, queremos sintetizar y destacar ciertos puntos del análisis que se llevó adelante para el modelado y las morfologías del material relevado. En primer lugar, debemos recalcar la importancia del remontado en el material fragmentario, que nos permitió obtener superficies más amplias para analizar las marcas y huellas relacionadas al modelado, así como identificar mejor los perfiles de las piezas y sus morfologías. En ese sentido, para más del $40 \%$ de los GF identificados se pudo 
hacer algún tipo de inferencia sobre la técnica de modelado, mientras que para los FNA, solo en un $7 \%$ de los casos analizados. El porcentaje de identificación sobre los GF es similar al de las piezas de colección (39\%), donde además pudo observarse en qué sectores de las piezas se encontraban localizadas las marcas y huellas.

Sobre la base de los grupos de fragmentos, pudimos identificar diferentes huellas y marcas vinculadas a las técnicas de modelado. Fundamentalmente, hemos registrado la presencia de evidencias del modelado por superposición con rollos. Sin embargo, se ha documentado etnográficamente (ver por ejemplo Rye 1981, García Roselló 2010) que la superposición de rollos en realidad es un conjunto de técnicas, variable, dado que se observan diferencias notorias en el diámetro de los rollos, en la forma de unión al rollo anterior, en la superposición mediante anillos o en espiral, etc. Aquí, dadas las características del material y de la falta de una colección de referencia particular sobre el tipo de marcas para cada una de estas variantes, solo podemos destacar que se ha empleado la superposición de rollos, sin mayores precisiones. Sin embargo, queremos remarcar la importancia que tendría realizar tareas experimentales y etnoarqueológicas con poblaciones alfareras actuales para confeccionar una colección de referencia sobre las huellas y marcas asociadas a cada técnica, que permitan profundizar en el análisis de los gestos técnicos de manera más pormenorizada, indicativos de modalidades productivas particulares de cada grupo de artesanos.

También se registraron huellas y marcas asociadas al modelado manual o por presión de dedos, que puede tener lugar tanto para levantar las paredes de una pieza, como para estirar los rollos superpuestos; y estrías y ondulaciones características del levantado con torno. En algunas piezas cerradas, pudieron observarse marcas de unión de segmentos, que probablemente evidencien el modelado de la pieza por partes, con algún tiempo de secado en el medio.

En cuanto a la orientación de las inclusiones observada tanto en lupa como en el microscopio, no se la pudo correlacionar con las técnicas de modelado, no resultando un atributo informativo por ahora. Quizás mediante la aplicación de la técnica radiográfica se puedan realizar más inferencias en este sentido, pero siguiendo a García Roselló (2010), consideramos que el análisis de las marcas y huellas (o macrotrazas) resulta informativo sobre el modelado y más accesible.

Sintetizando las evidencias del modelado, a partir del análisis del material fragmentario y de colección, podemos ver que en ambos sectores de la puna se 
modelaron tanto piezas abiertas (escudillas, escudillas hondas, vasos) como cerradas (vasijas, tinajas, botellas) mediante superposición de rollos básicamente, y en algunos casos mediante el estirado con los dedos de parte de las paredes. Por otro lado, en muchos casos probablemente la base se confeccionó en primer lugar mediante un disco presionado a mano, sobre el cual se modelaron las paredes con rollos, resultando en ocasiones en un punto de unión angular entre la base y el cuerpo.

En algunas piezas cerradas, se modeló primero la mitad inferior y luego la mitad superior. Ya sea que se dejó secar la primer parte para hacer la segunda y/o que se usaron técnicas distintas, el resultado es un punto de unión visible entre ambos segmentos.

Algunas piezas de forma indeterminada, y una posiblemente correspondiente a una botija o pieza cerrada semejante, procedentes de sitios con ocupaciones coloniales, fueron modeladas mediante torneado.

Entre las piezas de colección, que proceden básicamente de contextos funerarios, exceptuando algunas del Pucara de Rinconada ${ }^{9}$, hay una proporción comparable de piezas abiertas y cerradas. Las primeras consisten mayormente en escudillas y escudillas hondas, mientras que entre las segundas predominan las vasijas, seguidas por las botellas. Si bien en los materiales procedentes de sitios del norte de la puna, la diversidad de morfologías es menor que en los del sur, el número de piezas de esa primer procedencia es bastante inferior al de la segunda.

Para el material fragmentario, que procede de la excavación de contextos domésticos (recintos y un basurero), predominan las piezas abiertas sobre las cerradas en casi todos los sitios prehispánicos analizados, aunque no sucede así en sitios con ocupaciones coloniales como PA 22 y CH 25-1. Quizás estas diferencias estén relacionadas a las actividades realizadas en cada sitio.

Entre las escudillas y escudillas hondas, predominan los diámetros entre 12 y $24 \mathrm{~cm}$, tanto para el material fragmentario como para las piezas de colección, aunque se observan piezas más grandes y chicas. Quizás el diámetro esté relacionado a la funcionalidad, pero como no se analizaron las huellas de usos ni la vinculación a las áreas de actividad, es difícil aportar en este sentido. Entre las vasijas de las piezas de

\footnotetext{
${ }^{9}$ Pero que no se puede saber cuáles, dado que la información contextual de las fichas del museo y aquella provista por Boman en su volumen (1908) no lo permiten, exceptuando un par de casos ilustrados en ese tomo.
} 
colección se pudo también apreciar una diversidad de tamaños, pero hay una relación cercana a 1:1 entre el diámetro máximo y la altura de la pieza para aquellas depositadas en colecciones de museos.

Ciertas morfologías entre las piezas de colección corresponden a las definidas previamente para los estilos locales de la puna, mientras que otras serían de zonas geográficas distintas, como la quebrada de Humahuaca o posiblemente la vertiente oriental de los Andes. Estos tipos de piezas no se encuentran entre el material fragmentario, que procede en su totalidad de recintos, considerados habitacionales o domésticos (Angiorama 2011) o de un basurero, cuyos materiales probablemente también correspondan a desechos domésticos (Angiorama y Pérez Pieroni 2012). El hecho de que piezas posiblemente no manufacturadas en la puna se encuentren en contextos funerarios podría indicar que esos contextos estaban vinculados con zonas externas a la puna y que esas piezas tenían un rol en la funebria y no en los espacios domésticos, en donde están ausentes.

Otras presentan atributos morfológicos de momentos inkaicos, aunque corresponderían al estilo Inka provincial (Calderari y Williams 1991), dado que muchas presentan características de las pastas comparables a los tipos Yavi. Las escudillas con apéndices ornitomorfos ("platos pato") se encuentran presentes tanto entre las piezas de colección como entre el material fragmentario. Son escasas en ambos tipos de contextos. Las formas tipo puchuelas con asa lateral solo están presentes en dos casos entre las piezas de colección, al igual que las escudillas con asa lateral. Dos fragmentos de bordes de SC 3 podrían ser parte de aríbalos.

Por otro lado, los fragmentos relacionables a cerámica de momentos inkaicos entre el material fragmentario proceden de SC 3 y TC 2, estando ausentes de la zona sur de la cuenca de Pozuelos, a excepción de un posible fragmento de pie o pedestal, a pesar de que allí se encuentra el Pucará de Rinconada, que habría tenido una ocupación imperial (Ruiz 1996). Sin embargo, entre el material de colección, la totalidad de las piezas con morfología inkaica reconocida proceden de los sitios del sur de la puna, especialmente de Queta y Doncellas, donde se excavaron exclusivamente tumbas. Además, en la quebrada de Queta se encuentra un tambo inkaico asociado al camino imperial que circulaba por esa zona, hacia Moreta y Pozuelos (Raffino et al. 1986).

Otras morfologías del material de colección, procedentes del Pucará de Rinconada, son particulares y no se encuentran en los otros sitios de la puna, tales como jarras con 
pico y asa lateral, una botella con un rollo de refuerzo en el pico y otra con dos asas laterales. Consideramos que pueden ser poshispánicas y ciertos atributos de la decoración que veremos seguidamente pueden reforzar este punto.

Asimismo, las piezas con cuellos restringidos vinculables a botellas aparecen en el norte de la puna (SC 3 y TC 2). Dos ejemplares proceden del basurero de PA 22, y son las únicas para el material fragmentario del sur de Pozuelos, por lo que podrían tener un valor cronológico, siendo asignables a momentos poshispánicos. No sucede lo mismo entre los materiales de colección.

Dentro del material fragmentario, no se observa una relación entre las morfologías de las piezas y los grupos de pastas, sino que con las mismas recetas de pastas se construyeron diferentes formas, tanto abiertas como cerradas. Las botellas si fueron manufacturadas con pastas específicas, que hemos asociado al norte de la puna, en el área de influencia del estilo Yavi.

Lo que se pudo apreciar es que probablemente se prepararon algunas pastas para manufacturar piezas con paredes más delgadas (GP 5) o más gruesas (GP 9), aunque para la mayor parte de los tipos de pastas identificados se emplearon para piezas con espesores promedio más o menos homogéneos entre los distintos sitios.

Tanto entre las piezas de colección como entre el material fragmentario hay una diversidad grande de bordes presentes, aunque predominan los redondeados, evertidos o verticales. Entre el material fragmentario también son importantes los planos y evertidos. No hay una relación directa entre el tipo de borde y la morfología de la pieza, solo que los bordes evertidos son más frecuentes en las piezas cerradas y los verticales en las abiertas. Los invertidos o hacia adentro también son más frecuentes entre piezas abiertas y en el sector norte de la puna de Jujuy. En las botellas son frecuentes los bordes engrosados. Estos tipos de bordes no son diferentes de los que se describen para otros sitios de la puna, como por ejemplo los estudiados para el oeste de la cuenca de Pozuelos (Mamaní 1997), o en los recintos habitacionales del sitio Agua Caliente de Rachaite (Doncellas) (Ottonello 1973), donde se registraron morfologías variadas de bordes, muchos de ellos comparables a los hallados por nosotros.

En cuanto a las formas de las bases, las piezas de colección presentan mayormente bases con el exterior plano y unión al cuerpo directa, y en menor cantidad planas con unión inflexa. Los otros tipos son muy escasos, y están vinculados a piezas de origen 
alóctono. Entre el material fragmentario se da algo parecido, con un predominio de bases planocóncavas, con unión al cuerpo directa, angular o inflexa. Como ya mencionamos, creemos que las bases planas están vinculadas a las características del modelado, seguramente porque se realizó sobre una superficie plana, giratoria o no, y probablemente se modelaron las bases por separado primero y después las paredes por encima.

Entre las asas, predominan las horizontales subplanas y planas. En las piezas de colección estos tipos solo aparecen al sur de la puna. Asimismo entre estos materiales se observan asas mamelonares que no se han registrado entre la muestra de cerámica fragmentaria. Además, las asas son más frecuentes entre las morfologías cerradas, tanto de colección como en el material fragmentario, lo que hemos vinculado a su mayor tamaño y necesidad de transporte y manipuleo. Las mismas pueden estar adheridas a las paredes de la pieza o remachadas. Las asas pequeñas al pastillaje se presentan en piezas abiertas, procedentes del norte la puna, vinculable a la cerámica del estilo Yavi. Dos vasijas, procedentes de un mismo contexto funerario en Sansana, presentan apéndices tubulares huecos de forma zoomorfa, uno perforado en los dos extremos y el otro solo en uno. Las asas oblicuas, al igual que se señala en la literatura previa citada en los antecedentes, están vinculadas a la cerámica de formas y pastas Yavi.

En síntesis, el análisis descrito en este capítulo nos ha permitido abordar los gestos técnicos asociados al modelado y las morfologías producidas, destacando ciertas variaciones y similitudes entre los diferentes contextos y espacios geográficos bajo análisis y relacionándolos con las características de las pastas definidas en el capítulo anterior. En el capítulo siguiente, uniremos esta información con aquella de los acabados de superficie y decoración. 
8.

\section{LOS ACABADOS DE SUPERFICIE Y LA DECORACIÓN}

\section{Acabados de superficie en piezas de colección:}

En este capítulo analizaremos las operaciones que siguen al modelado, y que pueden estar más o menos separadas de esa etapa previa, que refieren al acabado de las superficies y a la aplicación de diferentes técnicas sobre las mismas, que suelen denominarse decoración. Cabe aclarar que consideramos que es difícil separar los atributos decorativos de los acabados de superficie, muchos de estos últimos pueden tener cualidades estéticas y/o funcionales, sin un límite entre ambas. Por lo que en este capítulo tratamos ambos aspectos conjuntamente como parte de un continuo.

Tanto en las piezas depositadas en colecciones de museos, como en el material fragmentario que obtuvimos por excavación y recolección superficial, hemos analizado los tipos de acabados de superficie que se presentan, teniendo en cuenta las siguientes categorías: ordinario (sin tratamiento aparente), alisado (homogeneización de las irregularidades de las superficies), pulido (homogeneización de irregularidades de la superficie mediante la presión con una herramienta dura, tipo un guijarro, para lograr un efecto liso y brilloso $)^{10}$, aplicación de engobe, engobe pulido, aplicación de pintura y corrugado.

En primer lugar, discutiremos estos acabados para las piezas de colección, teniendo en cuenta en piezas de qué sitios se los encuentra y sobre qué morfologías se aplicaron.

En la Tabla 8.1 se pueden observar las piezas de cada tipo morfológico identificado en el capítulo anterior que presentan cada uno de los acabados mencionados. En general, se observa que la mayor parte de las piezas se encuentran alisadas $(27,6 \%)$, pero que son abundantes las piezas con ambas o algunas de sus superficies pulidas (21.4\%), y también son importantes las piezas pintadas (24.5\%). Una parte igualmente

\footnotetext{
${ }^{10}$ No hemos distinguido el pulido del bruñido, porque consideramos que hay un continuo entre ambas, de menor a mayor brillo, y la cocción puede disminuir notablemente el brillo de una pieza que ha sido bruñida, tal como lo hemos observado en nuestra propia práctica de manufactura cerámica.
} 
importante presenta engobe $(24.5 \%)$ y la mayor parte de estas piezas también están pulidas. Un único ejemplar presenta corrugado en el cuello de la pieza (Figura 8.1A), y el mismo procede del sitio Doncellas. Este tipo de tratamiento no ha sido descrito para el material cerámico de la puna de Jujuy, y consideramos que se trata de una pieza de la vertiente oriental de los Andes ${ }^{11}$. Nielsen (1997b: 114) da cuenta de "ollas o cántaros" con corrugados en los cuellos para la Fase Inka de la quebrada de Humahuaca, en el sitio Los Amarillos, por lo que el hallazgo de este recipiente en Doncellas puede estar vinculado a la presencia imperial, lo que se relaciona a otras piezas de morfologías inkaicas presentes en la colección de ese sitio.

\begin{tabular}{|c|c|c|c|c|c|c|c|}
\hline & Ordinario & Alisado & Pulido & Engobe & $\begin{array}{l}\text { Engobe } \\
\text { pulido }\end{array}$ & Pintura & Corrugado \\
\hline Abierta Indet & 0 & 1 & 1 & 0 & 0 & 0 & 0 \\
\hline Escudilla & 1 & 2 & 5 & 2 & 5 & 5 & 0 \\
\hline Escudilla honda & 1 & 4 & 6 & 3 & 1 & 3 & 0 \\
\hline Escudilla restringida & 0 & 4 & 1 & 0 & 0 & 1 & 0 \\
\hline Vaso & 0 & 1 & 0 & 0 & 0 & 0 & 0 \\
\hline Cerrada Indet & 0 & 0 & 1 & 0 & 1 & 5 & 0 \\
\hline Vasija & 0 & 11 & 5 & 0 & 6 & 6 & 1 \\
\hline Tinaja & 0 & 2 & 0 & 0 & 0 & 0 & 0 \\
\hline Botella & 0 & 2 & 2 & 0 & 5 & 4 & 0 \\
\hline TOTAL & 2 & 27 & 21 & 5 & 18 & 24 & 1 \\
\hline
\end{tabular}

Tabla 8.1 Cantidad de piezas de colección por morfología para cada uno de los acabados de superficie identificados.

A

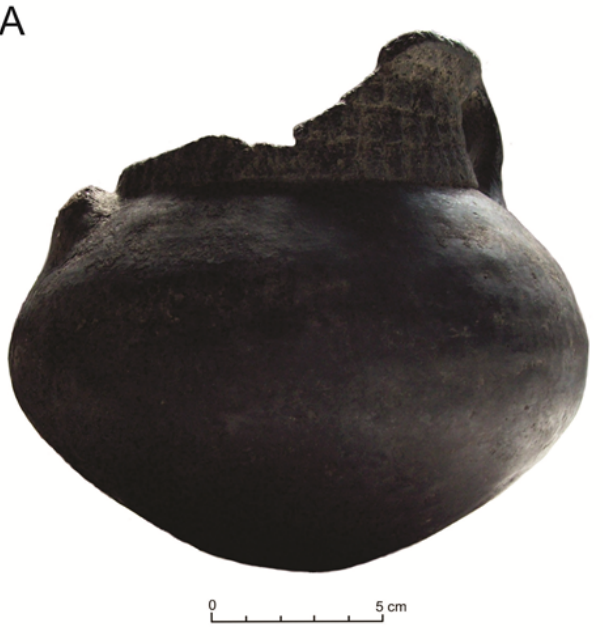

B

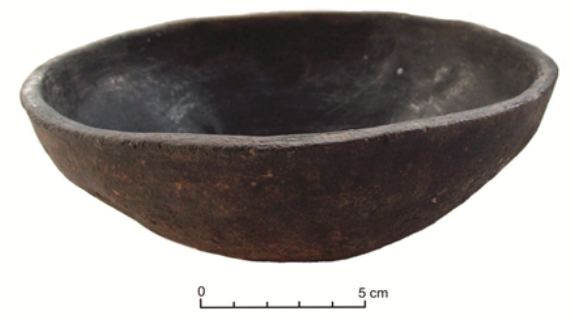

${ }^{11}$ Pérez y Killian (2011) atribuyen esta misma pieza al área de yungas. 
Figura 8.1 Piezas de colección procedentes del sitio Doncellas, depositadas en el Instituto Tilcara. A: Vasija cerámica con corrugado en el cuello (IT-1668). B: Puco interior negro pulido (IT-1499).

Las distintas morfologías de piezas pueden presentar diferentes acabados de superficie, no habiendo en general tipos morfológicos con acabados de superficie específicos. Las escudillas (incluyendo hondas y restringidas), presentan todos los tipos de acabado, habiendo un número importante (12:44) que presentan alguna o ambas de sus superficies pulidas. Muchas están pulidas en el interior y corresponden a lo que se conoce en la literatura como "pucos interior negro pulido" (Figura $8.1 \mathrm{~B}$ ), porque además presentan la superficie interna con cocción reductora. El resto pueden estar alisadas (10:44), varias de las cuales corresponden a escudillas restringidas o vasos que en trabajos previos se han denominado "vasos chatos", ilustrados en el capítulo anterior (Figura 7.18 B); engobadas (11:44) con o sin pulimiento, o pintadas (8:44). Solo dos no presentan ningún tipo de tratamiento.

Las piezas cerradas también presentan diferentes tratamientos. Las vasijas se encuentran mayormente alisadas (11:29), aunque varias tienen las superficies pulidas (5:29), engobadas y pulidas (6:29) o pintadas (6:29). Las únicas dos piezas de la muestra que corresponden a tinajas exhiben sus superficies alisadas, una está ilustrada en la Figura 7.10 B y la otra en la 7.16 B del capítulo anterior. En cambio, las botellas en su mayoría han sido engobadas y pulidas (5:13) o pintadas (4:13), mientras que las restantes poseen las superficies alisadas (2:13) o pulidas (2:13).

Al analizar la distribución por sitio de los distintos acabados de superficie presentes en la colección, se aprecia que las piezas de cada sitio exhiben distintos acabados, no habiendo una distribución diferenciada entre los mismos.

Por otro lado, hemos analizado algunas marcas que se asocian a las técnicas de acabado de superficies, tales como las estrías de alisado y las caras que pueden generarse en la acción de pulir, detallando también su orientación (horizontal, vertical, oblicua, irregular). Además, el material de colección, por tratarse mayormente de piezas completas, nos permite observar en qué porción del cuerpo se localizan las mismas. Cabe señalar que este tipo de gestos se realizan en etapas concretas de la manufactura, con estados particulares de la arcilla. El alisado y el pulido, cuando dejan huellas, han sido realizados con la arcilla aun con humedad. En cambio, otros tratamientos, como la aplicación de engobes y pintura, o el pulido que no deja caras, se 
llevan a cabo con la arcilla seca. Las caras de pulido, como las que hemos registrado, se producen con la arcilla en una etapa cercana al denominado "estado cuero" (García Roselló 2010) (ver Capítulo 9).

En la Tabla 8.2 se muestran los tipos de huellas y su orientación para cada una de las morfologías identificadas. Se observa que en casi todos los tipos morfológicos predominan las estrías de alisado y las caras de pulido horizontales. Las escudillas en general presentan caras de pulido horizontal y/o estrías de alisado con el mismo sentido. En algunos casos, pueden presentarse verticales $u$ oblicuas $y$ excepcionalmente irregulares. En las vasijas se observa una mayor presencia de estrías de alisado verticales y oblicuas, al igual que de caras de pulido también verticales y oblicuas, aunque también aquí predominan las de sentido horizontal. En los dos casos de tinajas solo se observan estrías de alisado, que pueden tener diferentes sentidos. En cambio, en los ejemplares de botellas, predominan las caras de pulido, tanto horizontales como verticales.

\begin{tabular}{lcccccccc}
\hline & \multicolumn{3}{c}{ ESTRÍAS ALISADO } & \multicolumn{5}{c}{ CARAS PULIDO } \\
& Hor & Vert & Oblic & Irreg & Hor & Vert & Oblic & Irreg \\
\hline Abierta Indet & 0 & 0 & 0 & 0 & 0 & 0 & 0 & 0 \\
Escudilla & 3 & 0 & 0 & 1 & 15 & 2 & 1 & 1 \\
Escudilla honda & 10 & 0 & 1 & 0 & 9 & 2 & 3 & 0 \\
Escudilla restringida & 2 & 2 & 0 & 0 & 2 & 1 & 0 & 0 \\
Vaso & 1 & 0 & 0 & 0 & 0 & 0 & 0 & 0 \\
Cerrada Indet & 4 & 0 & 0 & 0 & 2 & 2 & 0 & 0 \\
Vasija & 9 & 2 & 3 & 1 & 13 & 6 & 2 & 1 \\
Tinaja & 0 & 1 & 1 & 1 & 0 & 0 & 0 & 0 \\
Botella & 2 & 0 & 0 & 0 & 7 & 5 & 1 & 0 \\
\hline
\end{tabular}

Tabla 8.2 Distribución de marcas asociadas al alisado y al pulido en las diferentes morfologías de piezas analizadas. Referencias: Hor: horizontal; Vert: vertical; Oblic: oblicua; Irreg: irregular.

Al analizar en qué porción del cuerpo se localizan estas marcas (Tabla 8.3), discriminamos las piezas abiertas en general, de las piezas cerradas en general. Observamos que en las piezas abiertas se registran estrías de alisado en ambas superficies y en el borde, aunque son algo más abundantes en el borde. Las caras de pulido horizontales, verticales y oblicuas son más abundantes en las superficies internas de estas piezas que en las externas, lo que podría indicar un mayor cuidado en el acabado del interior que del exterior. Además, varias de estas piezas son pucos con el 
interior negro pulido, y estos suelen presentar caras de pulido horizontales, básicamente en la superficie interna, que es la que recibió mayor tratamiento.

\begin{tabular}{cccccccccc}
\hline & \multicolumn{3}{c}{ ESTRÍAS ALISADO } & \multicolumn{5}{c}{ CARAS PULIDO } \\
& Hor & Vert & Oblic & Irreg & Hor & Vert & Oblic & Irreg \\
\hline Abiertas & borde & 8 & 0 & 0 & 0 & 2 & 0 & 0 & 0 \\
& sup ext & 6 & 1 & 1 & 0 & 13 & 2 & 2 & 1 \\
sup int & 5 & 1 & 0 & 0 & 22 & 5 & 4 & 0 \\
\hline Cerradas & borde & 8 & 0 & 0 & 0 & 6 & 0 & 0 & 0 \\
& cuello & 4 & 1 & 1 & 0 & 1 & 8 & 0 & 0 \\
cuerpo & 7 & 5 & 4 & 2 & 16 & 6 & 1 & 1 \\
base & 1 & 0 & 0 & 0 & 1 & 0 & 0 & 0 \\
\hline
\end{tabular}

Tabla 8.3 Distribución de marcas asociadas al alisado y al pulido en las diferentes porciones de las piezas abiertas y cerradas analizadas. Referencias: Hor: horizontal; Vert: vertical; Oblic: oblicua; Irreg: irregular; sup: superficie; ext: externa, int: interna.

En el caso de las piezas cerradas, se observa que la mayor parte de las huellas y marcas se localizan en el cuerpo, siendo abundantes también aquellas del borde y cuello, mientras que cerca de la base el registro es mucho menor. Además, se observa que las caras de pulido tienen una tendencia más vertical en el cuello, mientras que cerca del borde y en el cuerpo la orientación es horizontal. Con las estrías de alisado no sucede lo mismo. En la porción del cuerpo se registra la mayor variabilidad de este tipo de marcas.

A su vez, en el capítulo anterior, hemos distinguido dentro de las morfologías analizadas, algunas que corresponden a estilos específicos de los que han sido identificados por los autores previos. En base a estos estilos, quisimos observar si las huellas y sus orientaciones estaban vinculadas a los mismos y si la orientación podía obedecer a gestos técnicos concretos que se vinculen a esos estilos. En la Figura 8.2 se pueden observar la cantidad de registros para cada tipo de huella en las distintas categorías de piezas, en un gráfico de barras. 


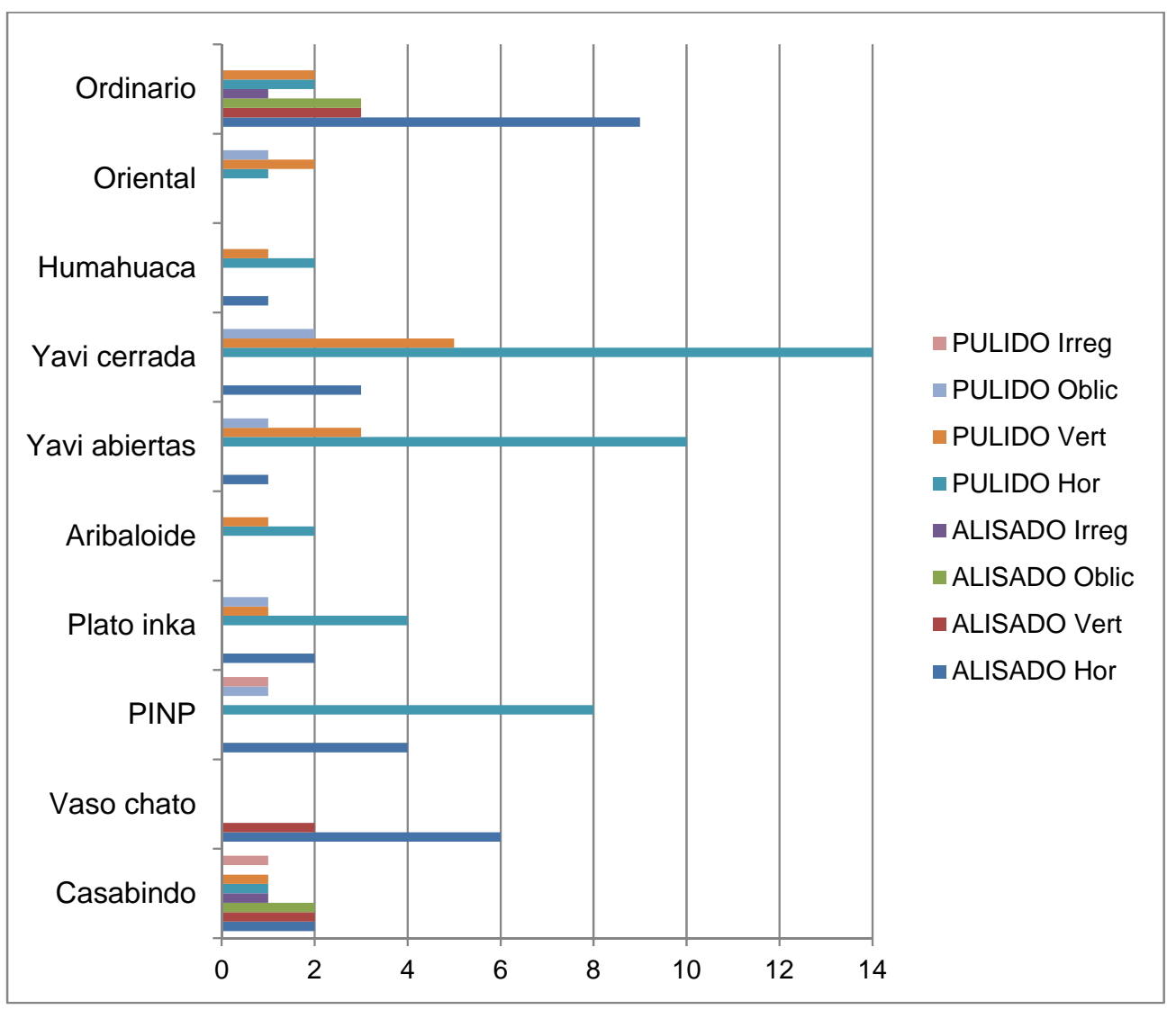

Figura 8.2 Distribución de marcas asociadas al alisado y al pulido en diferentes tipos de piezas asociadas a estilos de la literatura previa. Referencias: PINP: puco interior negro pulido; Irreg: irregular; Oblic: oblicuo; Vert: vertical, Hor: horizontal.

Para los denominados vasos chatos, hemos observado que presentan mayormente estrías de alisado horizontales, que muchas veces se localizan cerca del borde, y en menor cantidad estrías de alisado verticales. Los "pucos interior negro pulido" pueden presentar estrías de alisado horizontales que se localizan mayormente en la superficie externa y cerca del borde, y además presentan caras de pulido horizontales en la superficie interna con mayor frecuencia. Las escudillas con asa lateral o apéndice ornitomorfo, de estilo Inka provincial, también presentan en mayor número marcas de pulido horizontal. En cambio, las piezas denominadas puchuelas muestran pocas marcas, consistentes en marcas de pulido horizontales y verticales.

Las escudillas vinculables al estilo Yavi presentan un predominio de caras de pulido horizontales, seguidas por algunos casos de presencia de estas caras con orientación vertical, que se localizan en las superficies internas. Las piezas cerradas de ese estilo también presentan un predominio de marcas de pulido horizontales, seguidas por las 
verticales, y en menor cantidad, algunas oblicuas. En cambio, en las piezas cerradas que se asocian al estilo Casabindo, las marcas más abundantes están asociadas al alisado y exhiben diferentes orientaciones, sin que predomine ninguna, mientras que las marcas de pulido son escasas y también con diferentes orientaciones. En las piezas no asignables a ningún estilo, u ordinarias, predominan las marcas de alisado horizontales, seguidas por las horizontales y oblicuas, y en algunos casos se observan algunas caras de pulido verticales y horizontales. En la Figura 8.3 se pueden observar ejemplos de estas marcas en algunas de las piezas abiertas analizadas.

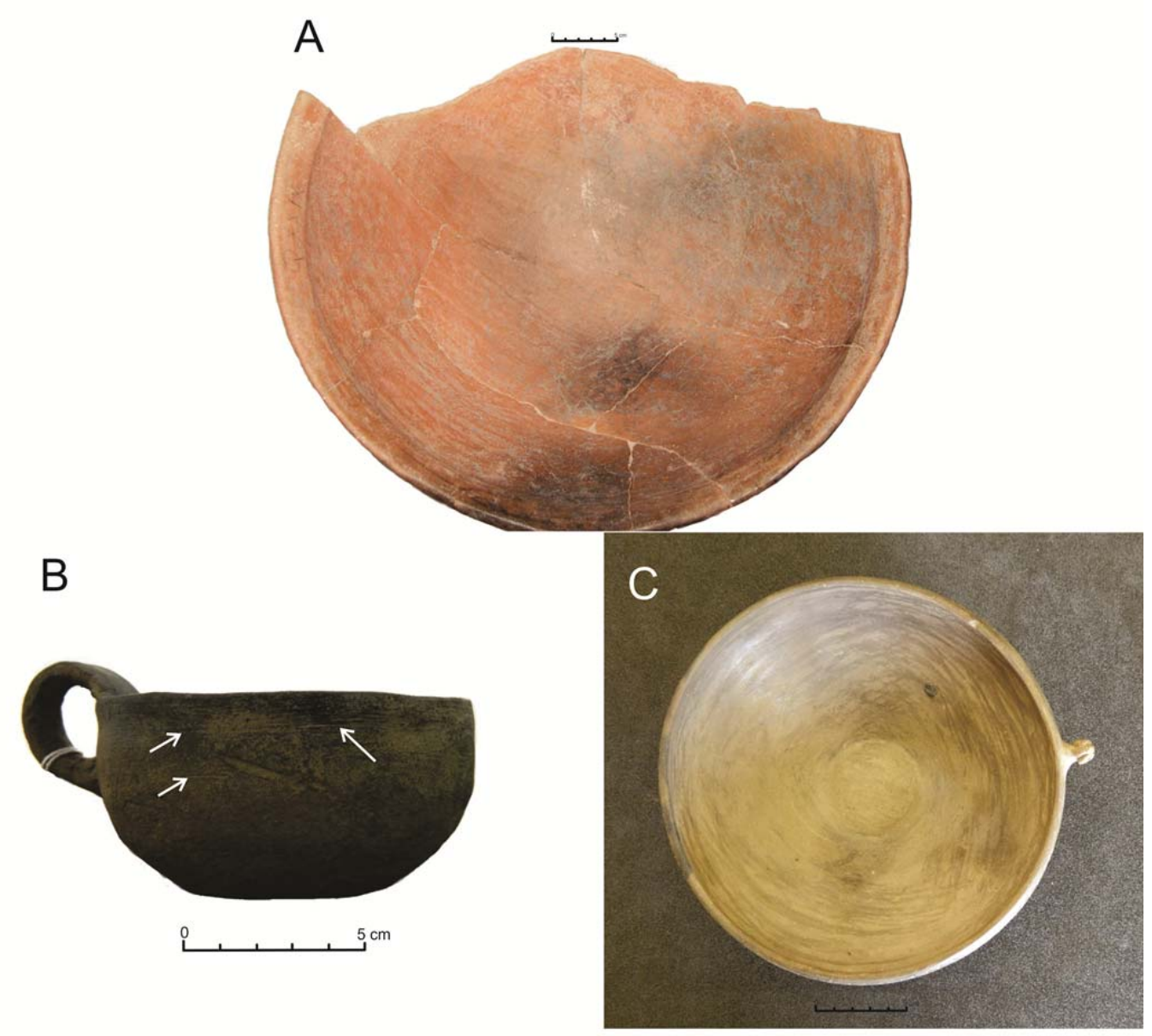

Figura 8.3 Caras de pulido y estrías de alisado en piezas abiertas de las colecciones. A:

Caras de pulido horizontales y verticales en superficie interna de escudilla del sitio Queta, depositada en el Instituto Tilcara (IT-2040); B: escudilla honda con estrías de alisado horizontales cerca del borde (QB-2057); C: caras de pulido horizontales en escudilla (QB-2076); ambas del Pucará de Rinconada, depositadas en el Museo Quai Branly. 
Dentro de los atributos más vinculables a la decoración, o acabados de superficie que involucran aplicación de color a las superficies (pintura o engobe), hemos distinguido aquellas que presentan pintura monocroma, bicolor y tricolor (Figura 8.4). Incluimos también los engobes, porque que suelen tener un color distinto de la pasta, por lo que sirven para otorgarle otro color a la superficie externa, al igual que la pintura. Las piezas sin pintura y engobe representan más de la mitad del total (50:97), mientras que dentro de las pintadas o engobadas, las más abundantes son las monocromas (24:97), seguidas por las bicolores, que también son abundantes (20:97). Las tricolores son mucho más escasas (3:97). En general, todas estas variedades están presentes en todos los sitios. Aunque las tricolores, por ser escasas, solo se encuentran en dos: Queta y Rinconada.

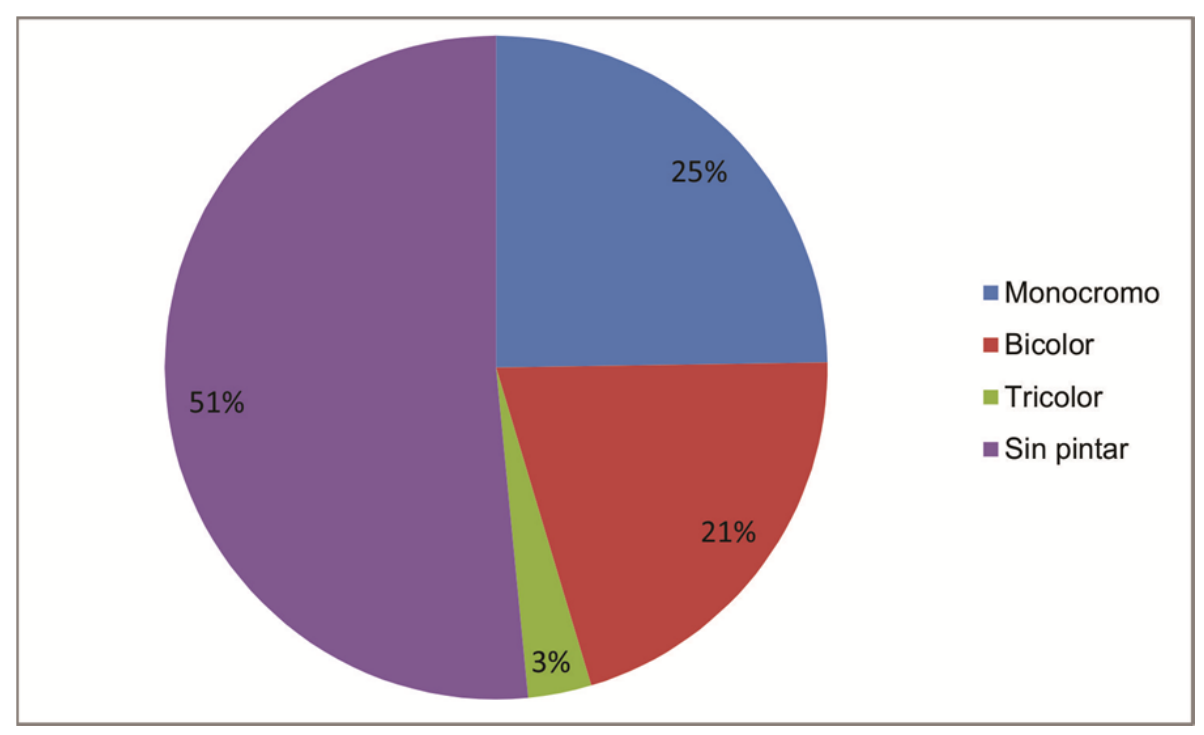

Figura 8.4 Proporción de tipos de pintura-engobe presentes en las piezas de colecciones de museo analizadas.

Dentro de las piezas con decoración monocroma, hay escudillas, escudillas hondas, vasijas y botellas. Para la mayoría (21:24), esta decoración consiste en la aplicación de pintura o engobe de color rojo (10R 4/6, 5/6; 2.5YR 5/6, 6/6), rojo débil (10R 4/4,5/4), rojo claro (10R 6/6) o marrón rojizo (2.5YR 4/4), en una (9:21) o ambas superficies (12:21). En tres piezas del Pukará de Rinconada, la pintura roja forma motivos sobre el fondo de pasta, consistentes en puntos rojos en el cuello y pintura en área en parte del cuerpo en una de las piezas, aunque por el abundante depósito de hollín no se alcanza a observar el motivo completo; líneas curvas rojas en el cuello y parte superior del cuerpo de otra pieza, pero que también presenta manchas negras que ocultan el resto 
de los motivos pintados; y motivos lineales formando un patrón reticulado, con círculos adentro en toda la superficie externa. Dos son formas de jarra con asa lateral y pico y la tercera es tipo botella, y para las tres en el capítulo anterior hemos planteado que consistirían en piezas poshispánicas. El tipo de decoración peculiar, que no aparece en la literatura previa revisada podría reforzar ese punto. En la Figura 8.5 se muestran detalles de la decoración pintada de las dos jarras mencionadas, mientras que la botella y un esquema de los dibujos pintados en ella se pueden ver en la Figura 8.6.

A
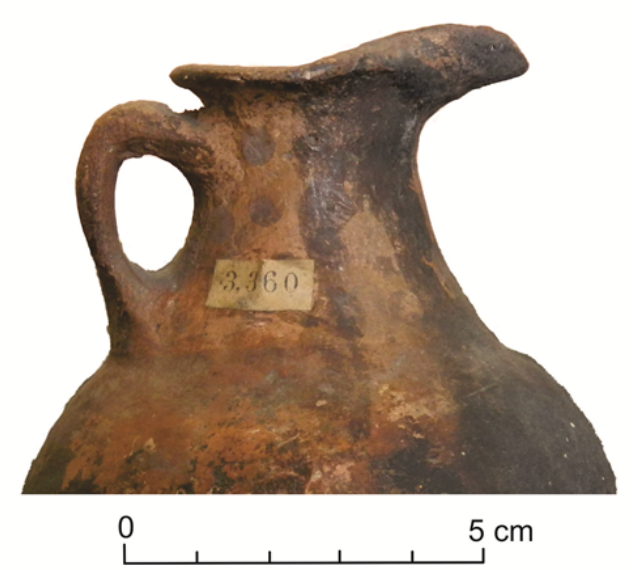

B

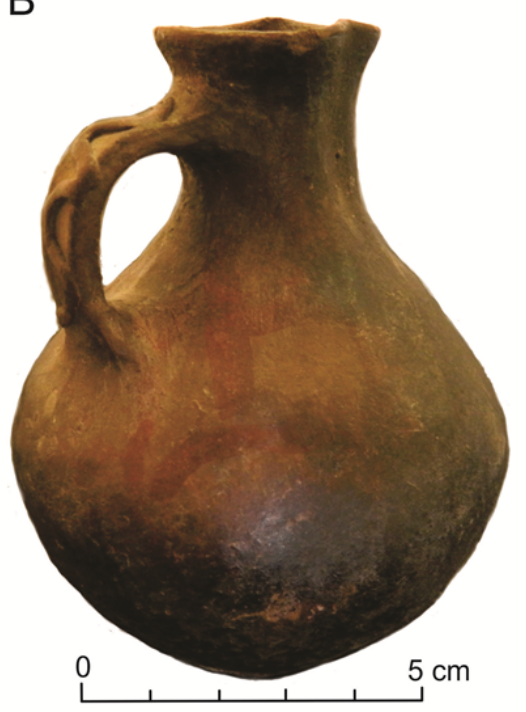

Figura 8.5 Jarras con picos y asa lateral decoradas con pintura roja, del Pucará de Rinconada, depositadas en el Museo Quai Branly. A: QB-2053; B: QB-2054.
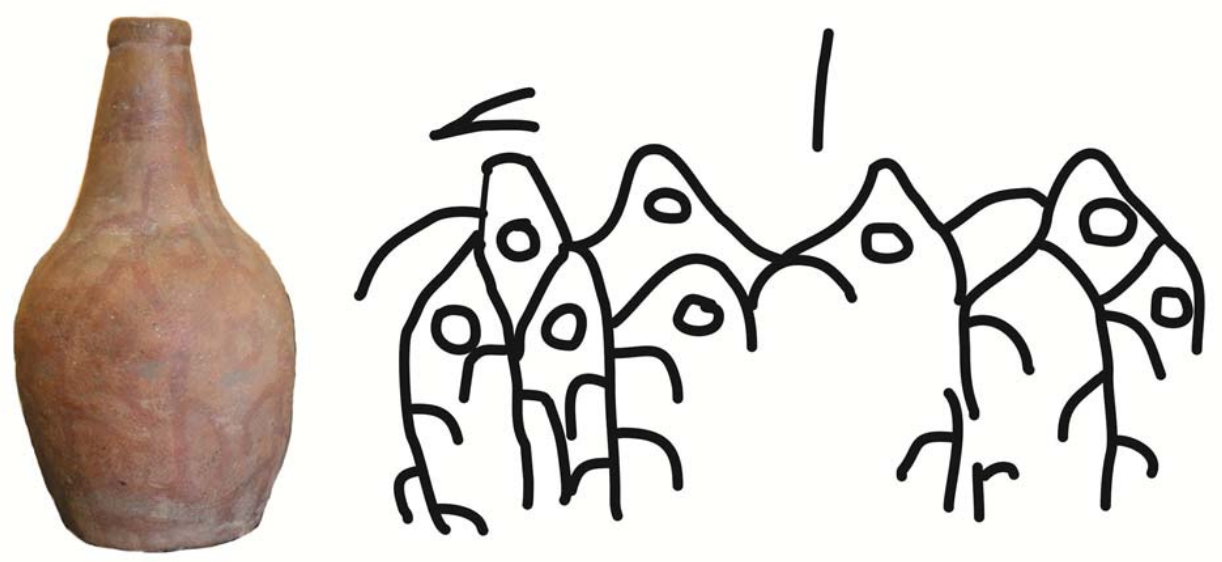
Figura 8.6 Botella decorada con pintura roja, del Pucará de Rinconada, depositada en el Museo Quai Branly (QB-2055).

Las piezas con pintura bicolor corresponden a escudillas, escudillas hondas, cerradas indeterminadas, vasijas y botellas. Presentan motivos en negro ( $N$ 3/, 2.5/; 5YR 2.5/1), negro rojizo (2.5YR 2.5/1), gris rojizo oscuro $(2.5 \mathrm{YR} 3 / 1,4 / 1)$ y gris oscuro (5YR 3/1), sobre pintura o engobe rojo $(2.5 Y R \quad 4 / 6,5 / 6,5 / 8 ; 10 R 4 / 6)$, rojo débil (10R 4/4) o rojo amarillento (5YR 5/6,5/8). En algunos casos la pintura se encuentra muy desleída y solo se percibe débilmente. En dos recipientes, la decoración es relacionable a la del estilo Casabindo, con franjas negras formando motivos de $V$ en la porción superior del cuerpo de piezas globulares con cuello cilíndrico, separado de la porción inferior por una franja negra horizontal a la altura de las asas (Figura $8.7 \mathrm{~A}$ ); o reticulados negros en franjas verticales al costado de las asas en una vasija con cuello cilíndrico y asas verticales, en una pieza que se ilustra en la Figura 7.18 A.
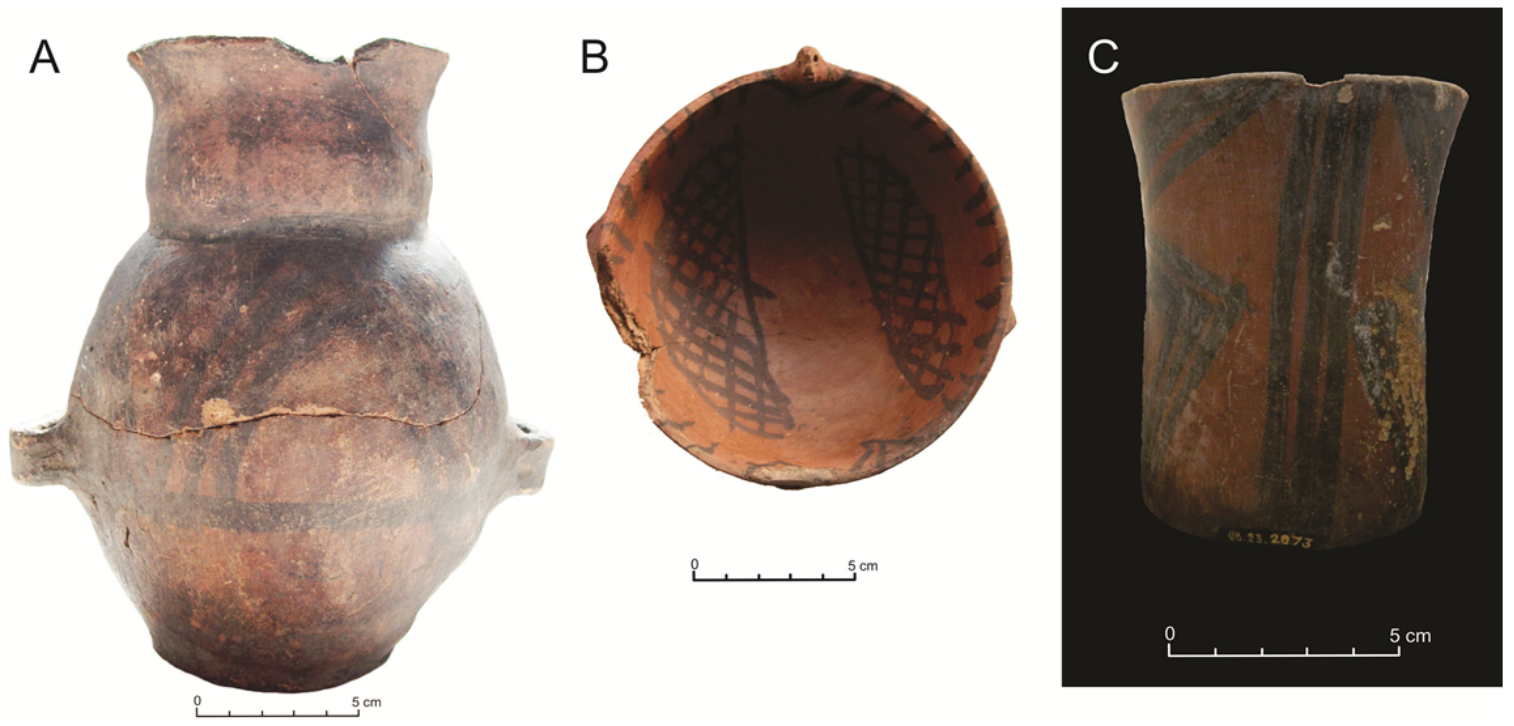

Figura 8.7 Piezas con decoración en negro sobre rojo. A: estilo Casabindo, del sitio Doncellas, depositada en el Instituto Tilcara (IT-1767); B: posible estilo de la quebrada de Humahuaca, del sitio Doncellas, en el Instituto Tilcara (IT-1450); C: estilo AlfarcitoIsla de la quebrada de Humahuaca, procedente del Pucará de Rinconada, en el Museo Quai Branly (QB-2073).

En dos piezas, los motivos en negro sobre rojo, sumado a la morfología, las hacen vinculables a las de la quebrada de Humahuaca. Una es una escudilla honda, del sitio 
Doncellas, con dos motivos ojivales con reticulados en la superficie interna y líneas negras paralelas cruzadas sobre el borde, además de presentar un apéndice modelado pequeño sobre el borde (Figura 8.7 B). Los reticulados semejantes en escudillas o pucos, pero rellenando campos triangulares, han sido documentados en el Período de Desarrollos Regionales de la quebrada de Humahuaca (Nielsen 1997b). La otra es un vaso cilíndrico con líneas negras verticales y en zigzag en grupos de tres, formando un patrón simétrico bilateral (Figura $8.7 \mathrm{C}$ ), procedente del Pucará de Rinconada. Este último correspondería al estilo Alfarcito-Isla de la quebrada, a donde se le ha asignado una cronología de 700 a 1100 d.C. (Nielsen 1997b).

Otras dos escudillas con decoración en negro sobre rojo poseen asas laterales, que hemos relacionado a momentos inkaicos. Una, de Cochinoca, presenta motivos de cruces en el interior y una línea negra todo a lo largo del labio (Figura 8.8 A). Platos con motivos de cruces han sido documentados para el período Inka de la Quebrada de Humahuaca (Nielsen 1997b). La otra, de Queta, presenta dos bandas anulares en la superficie interna, formadas por líneas delgadas paralelas que conforman un campo horizontal donde se disponen otras líneas perpendiculares, y en el labio se observan líneas cortas perpendiculares al mismo (Figura 8.8 B).

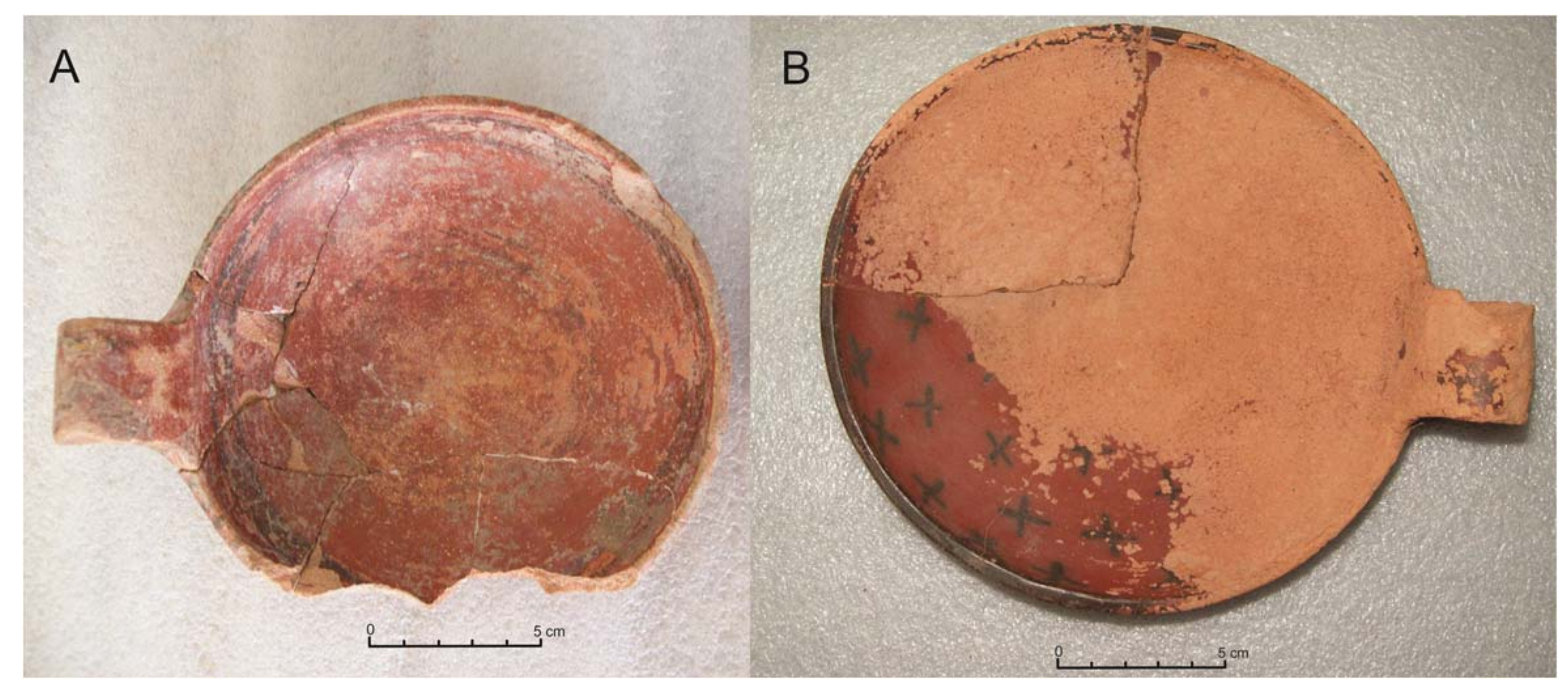

Figura 8.8 Escudillas con asa lateral con decoración en negro sobre rojo, procedentes del Instituto Tilcara. A: del sitio Queta (IT-1990); B: procedente de Cochinoca (IT-1943).

El resto de los recipientes con decoración en negro sobre rojo, corresponden a escudillas, escudillas hondas, piezas cerradas indeterminadas, vasijas y botellas, cuyas pastas y decoración son vinculables a aquellas definidas para el estilo Yavi. Las piezas 
proceden de distintos sitios, como Doncellas, Queta, el Pucará de Rinconada, Yavi Chico y Sansana. En uno de ellos, consistente en una botella de cuerpo esférico, la decoración no es de motivos, sino que se emplearon dos colores de engobe. En varias piezas no se percibe el motivo o se percibe muy poco, porque la pintura se ha borrado parcialmente. En los que sí se puede observar, se aprecian motivos de formas irregulares rellenos con reticulados (por ej. Figura 8.9 A), correspondientes a los motivos que Krapovickas y Aleksandrowicz (1986-87) denominaron "figuras ameboidales"; líneas negras finas o más gruesas, motivos de aves (Figura 8.9 B), espirales, a veces con proyecciones lineales (Figura $8.9 \mathrm{C}$ ), triángulos con proyecciones de espirales (Figura $8.9 \mathrm{C}$ ), etc. Los mismos aparecen en la superficie interna de escudillas o cerca del borde en la superficie externa, en el cuello y cuerpo de vasijas y botellas, y se combinan para formar patrones más o menos complejos. Todos fueron documentados y analizados en la literatura previa (Krapovickas y Aleksandrowicz 1986-87; Krapovickas et al. 1989, Ávila 2006). Una de las piezas es una vasija con una morfología tipo "pelike" (Figura 8.9 A) que ha sido vinculada a la presencia inka (Ávila 2006).

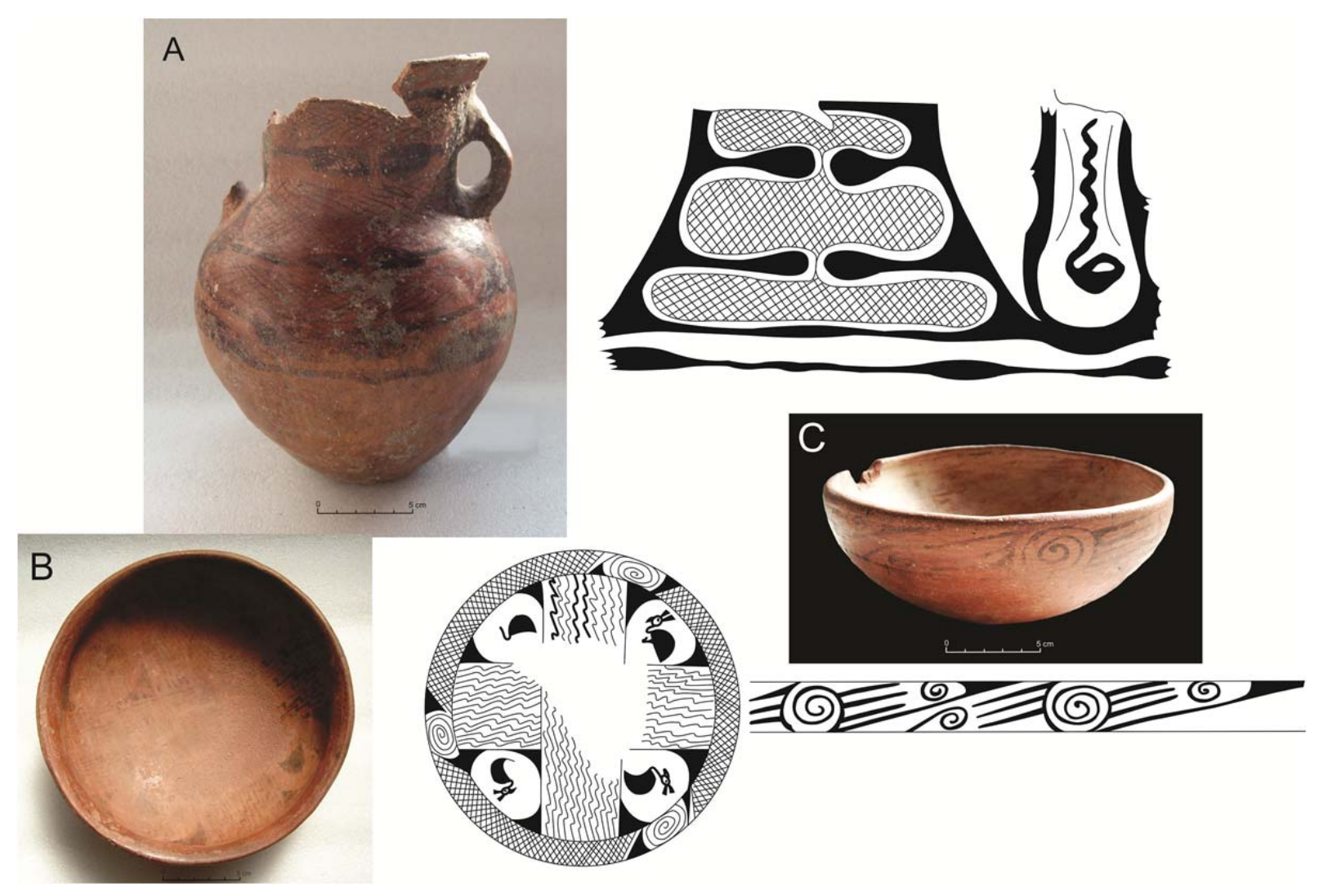

Figura 8.9 Piezas del Instituto Tilcara con decoración en negro sobre rojo, vinculables al estilo Yavi y los dibujos correspondientes a los motivos observados. Todas procedentes de Doncellas. A: IT-1657; B: IT-1672; C: IT-1800. 
Un último recipiente con pintura en negro sobre rojo corresponde a un fragmento de cuello de una pieza cerrada indeterminada, que presenta motivos de manos, procedente de Sayate (Figura 8.10). Motivos comparables han sido descritos para piezas abiertas de la Quebrada de Humahuaca para el período de Desarrollos Regionales local (Nielsen 1997b).

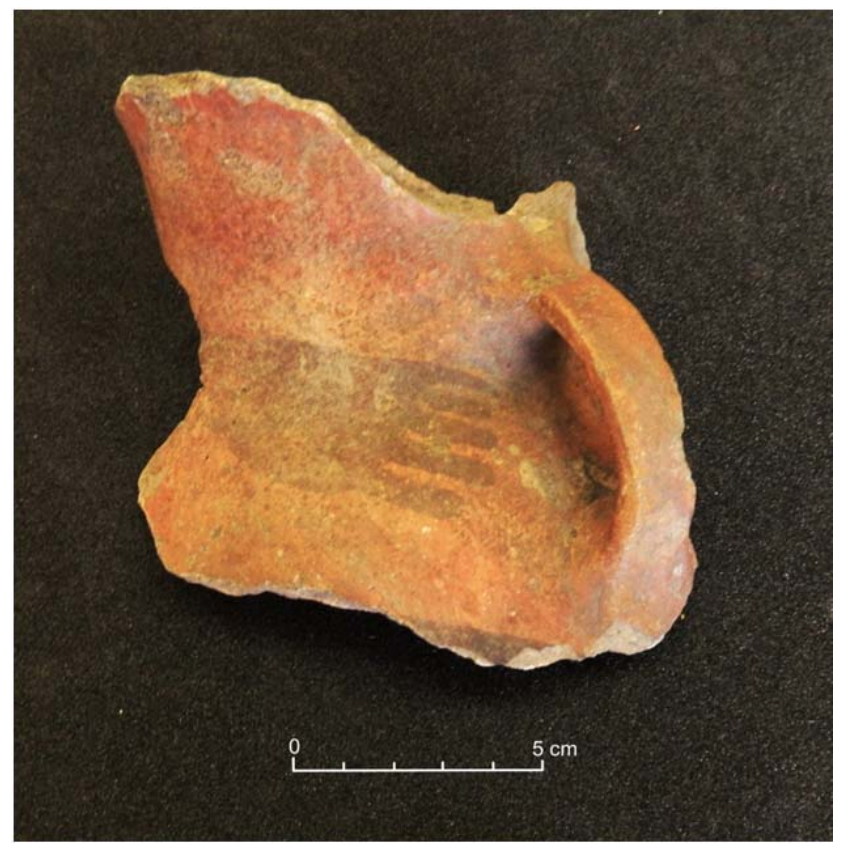

Figura 8.10 Fragmento de cuello de recipiente cerrado, depositado en el Museo Quai Branly (QB-2483), con motivo de mano. Procedente de Sayate.

Las piezas con decoración tricolor son tres, dos vasijas y una botella. Una corresponde a una vasija subglobular de cuello cilíndrico, procedente de Queta, con pintura negra (5YR 3/1) en franjas formando $V$ en la porción superior del cuerpo, dentro de las cuales se observan negativos de círculos, por lo que presuponemos que estuvieron pintados, probablemente en blanco, y se borraron, dado que es un tipo de decoración frecuentemente descrito para este tipo de vasijas en la cerámica del área de Casabindo (Figura 8.11 A). Los círculos son de forma irregular. Las otras dos son piezas vinculables al estilo Yavi, una también de Queta y la otra de Rinconada. La primera presenta engobe de dos colores, uno marrón (7,5YR 5/4) en la porción del cuerpo, y otro rojo (10R 4/3) en el área del cuello, sobre el cual se pintaron motivos de triángulos con proyecciones de espirales en un rojizo más oscuro desleído (10R 3/2) (Figura 8.11 B). La segunda es una botella, también con engobe bicolor marrón rojizo a rojo (2.5YR 4/4 y 4/6), sobre el cual se pintaron en negro ( $\mathrm{N} 3 /$ ) líneas horizontales delimitando dos 
campos tipo franjas, rellenos con líneas perpendiculares y triángulos con proyecciones de espirales. Además sobre el cuello se modeló un rostro (Figura 8.11 C).
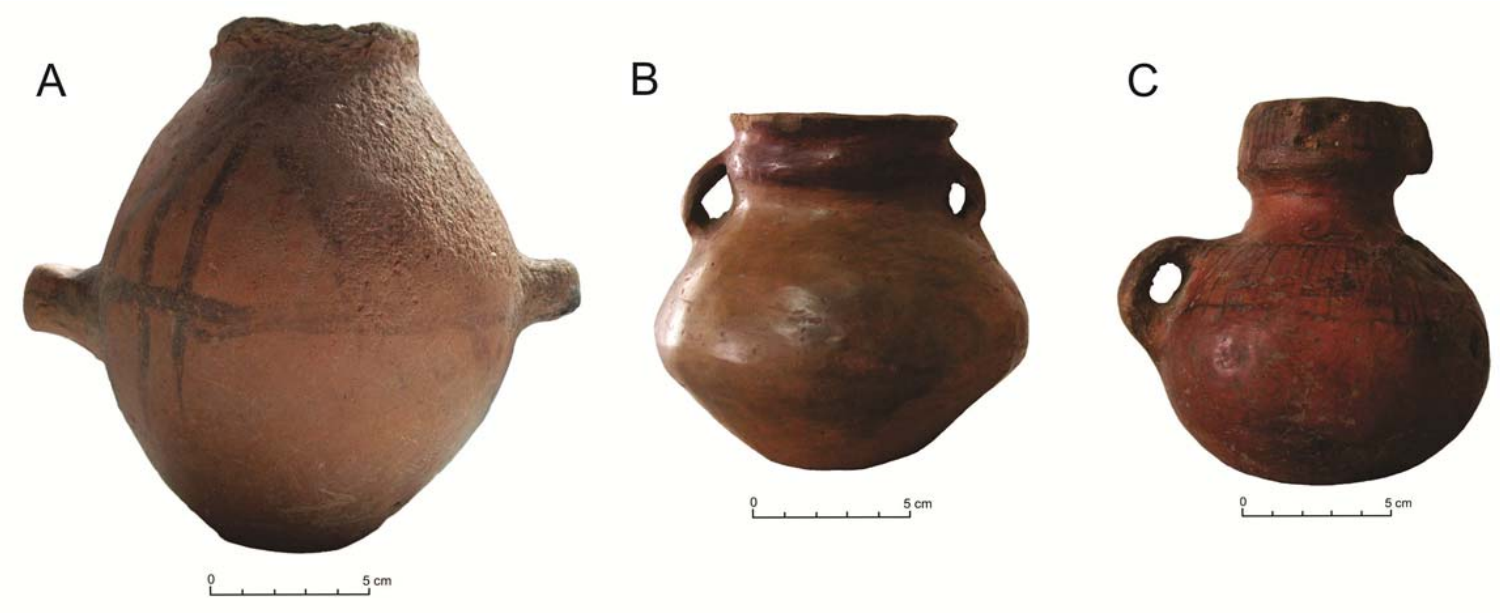

Figura 8.11 Piezas del Instituto Tilcara con decoración tricolor. A: vasija estilo Casabindo, de Queta (IT-1966). B: vasija estilo Yavi, de Queta (IT-1965). C: vasija estilo Yavi, de Rinconada (IT-1948).

En ocho piezas se registraron modificaciones de la superficie por desplazamiento de materia, consistentes básicamente en incisiones. Son tanto escudillas, como vasijas y botellas. Tres son de Doncellas, una un puco Interior negro pulido, con una incisión debajo del borde, otra es la escudilla honda de la Figura $8.7 \mathrm{~B}$, que presenta incisiones formando ojos en el modelado que se encuentra sobre el borde y la tercera es la pieza con el corrugado en el cuello de la Figura $8.1 \mathrm{~A}$, que presenta incisiones perpendiculares en el borde. La botella de la Figura 8.11 C presenta incisiones en el cuello que conforman un rostro.

Una escudilla honda troncocónica del Pucará de Rinconada (Figura 8.12) presenta incisiones formando cruces, colocadas en forma de franja cerca del borde en la superficie externa, además de un apéndice modelado. Este tipo de decoración no se conoce en la literatura previa del área que hemos revisado, y consideramos que probablemente se trate de una pieza de origen no local, quizás de la vertiente oriental de los Andes. 


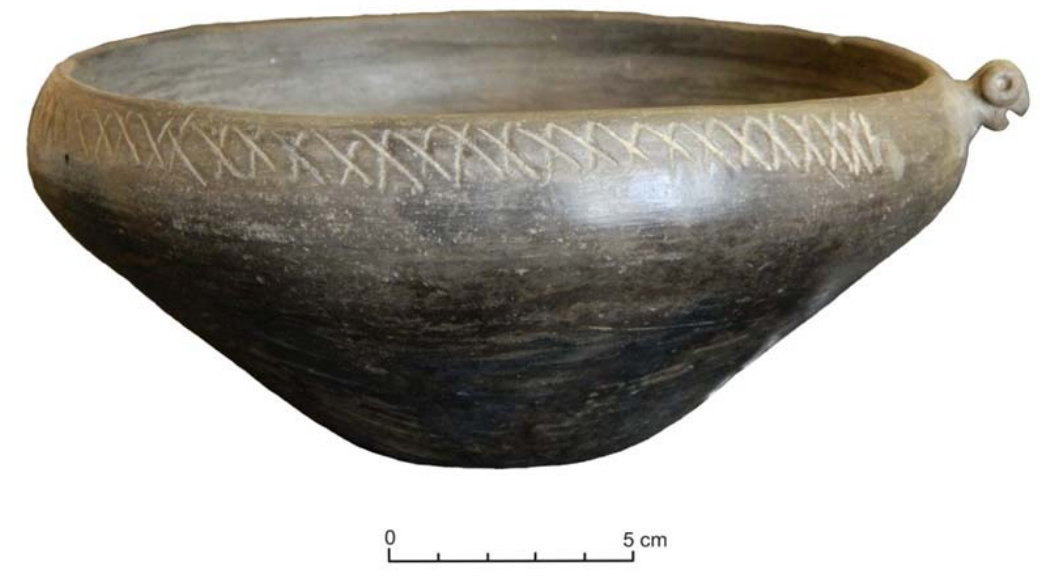

Figura 8.12 Escudilla honda procedente del Pucará de Rinconada, con decoración incisa. Depositada en el Museo Quai Branly (QB-2076).

Otros dos recipientes son de Sansana, uno corresponde a una botella vinculable al estilo Yavi, que presenta un rostro modelado, con incisiones que conforman ojos y boca. El otro corresponde a la segunda pieza ilustrada en la Figura 7.28 del capítulo anterior, en la que mediante incisiones se realizaron ojos y nariz en un apéndice tubular modelado zoomorfo. El último es una botella globular de Yavi Chico, vinculable al estilo Yavi, que, al igual que la anterior, mediante incisiones se conformaron ojos y boca de un rostro en el cuello.

Doce piezas presentan decoración modelada o al pastillaje, algunas ya descritas anteriormente, como la escudilla honda de Doncellas de la Figura 8.7 B, que presenta un pequeño apéndice modelado y la botella de Rinconada, mencionada anteriormente (Figura $8.11 \mathrm{C}$ ) que presenta modelados en la porción del cuello, formando parte del rostro. Otras dos botellas del sitio Yavi Chico, también presentan pastillajes sobre el cuello que conforman parte de un rostro antropomorfo. Otras tres escudillas, dos de Doncellas y una de Queta, presentan apéndices modelados ornitomorfos, una de las cuales puede verse en la Figura 7.20 B, y corresponderían a piezas Inka Provincial.

Una pieza del Pucará de Rinconada del Museo Quai Branly, correspondiente a una botella, que puede observarse en la Figura 7.21 A del capítulo anterior, presenta un pastillaje por debajo del cuello y encima de las asas, colocado de manera horizontal, en forma de zigzag. Sobre las asas se repiten los zigzag al pastillaje. De manera semejante, una de las jarras recobradas del mismo sitio, que se encuentra en la misma 
colección (ya ilustrada en la Figura 8.5 B), presenta un pastillaje similar sobre su asa lateral. Del mismo Pucará procede la escudilla honda mencionada anteriormente (Figura 8.12) que además de la decoración incisa presenta un apéndice zoomorfo adherido al borde.

Las dos vasijas de la Figura 7.28, procedentes de un mismo contexto funerario de Sansana (Boman 1908), presentan apéndices tubulares modelados zoomorfos, uno de los cuales presenta una perforación a la altura de la boca que permitiría verter líquidos del interior de la vasija hacia afuera.

Al analizar en qué porción de las piezas se coloca la decoración (Tabla 8.4) observamos que en las abiertas, que son mayormente escudillas y escudillas hondas, la decoración pintada puede estar tanto en las superficies externas como en las internas. En ocasiones se coloca en la porción interna del borde, característico de piezas del estilo Yavi (Ávila 2006). En las piezas cerradas, la decoración pintada monocroma se ubica mayormente en cuello y cuerpo, dado que suele consistir en una pintura o engobe cubriendo toda la superficie externa, aunque a veces también recubre asas o apéndices y en menor cantidad de casos se extiende hacia la porción interna del borde. Los motivos pintados en negro sobre rojo son frecuentes en cuello y cuerpo, aunque pueden estar también en las asas o en la porción interna del borde. La decoración tricolor es más frecuente en cuerpo y cuello de piezas cerradas, no observándose en las abiertas. La decoración incisa, modelada y al pastillaje es más frecuente en las piezas cerradas y se localiza tanto en el cuerpo como en el cuello y en las asas y apéndices.

\begin{tabular}{lcccccc}
\hline & $\begin{array}{c}\text { Pintura } \\
\text { Monocroma }\end{array}$ & $\begin{array}{c}\text { Pintura } \\
\text { Bicolor }\end{array}$ & $\begin{array}{c}\text { Pintura } \\
\text { Tricolor }\end{array}$ & Inciso & Modelado & Pastillaje \\
\hline PA sup int & 7 & 7 & 0 & 1 & 1 & 1 \\
PA sup ext & 6 & 6 & 0 & 1 & 2 & 0 \\
borde interno & 3 & 8 & 1 & 1 & 0 & 0 \\
cuerpo & 12 & 5 & 3 & 4 & 5 & 3 \\
cuello & 16 & 5 & 4 & 5 & 5 & 4 \\
asas-apéndices & 6 & 4 & 0 & 2 & 7 & 2 \\
\hline
\end{tabular}

Tabla 8.4 Localización de la decoración en las piezas de colección. Referencias: PA: piezas abiertas; sup: superficie; int: interna; ext: externa.

Por otro lado, hemos clasificado como formas varias una figurina ornitomorfa y un recipiente con un apéndice zoomorfo, que no entran en la clasificación morfológica empleada. Ambos proceden de Queta y fueron ilustrados en la Figura 7.17 A y B. La 
figurina representa un ave que en la superficie inferior tiene incisiones paralelas en lo que serían alas y cola. El otro es un recipiente con un orificio en un extremo y en el extremo opuesto un modelado zoomorfo, con dos orejas modeladas y mediante incisiones se realizaron ojos, boca, orificios nasales y una línea que va de oreja a oreja hasta la parte en que se unen cabeza y cuello a modo de bozal. También hay 4 incisiones paralelas y una perpendicular (entre las orejas) que van de la cabeza (entre las orejas) al lomo.

\section{Acabados de superficie en el material fragmentario:}

Al igual que para las piezas de colección, comenzamos analizando los tipos de acabado de superficie que presentan los grupos de fragmentos y los fragmentos no agrupados en los distintos sitios analizados. En la Figura 8.13 se observan cómo se distribuyen los distintos acabados de superficie entre los grupos de fragmentos, que solo fueron posibles de identificar en algunos de los sitios analizados. Se observa el predominio de los fragmentos alisados, seguidos por aquellos que presentan uno o ambas superficies pulidas, y en menor medida los que tienen aplicación de engobes y/o pintura. Una pequeña parte muestra improntas de textil en la superficie externa.

En general, para todos los sitios predominan los grupos de fragmentos con superficies alisadas, exceptuando PA 6 y TA1-1, que en sus niveles de ocupación presentan la misma cantidad de GF alisados que engobados y pulidos; y $\mathrm{RH} 2-1$ en el que sucede lo mismo con los GF pintados. En el nivel 1 de RH 19-7 predominan los GF pulidos. Los fragmentos con improntas textiles son 3 y corresponden a un único GF del primer nivel de RH 10-1, que se ilustra en la Figura 8.14. Este tipo de improntas ha sido mencionado en la literatura, entre los tipos de Yavi Chico, como dentro del denominado Pozuelos con cuarzo (Krapovickas 1975). Krapovickas y Cigliano (1962-63) observan estas improntas en fragmentos de recipientes de gran tamaño y plantean que serían el resultado del uso de telas como base para hacer girar los recipientes mientras se iban modelando. Boman (1908) registra este procedimiento para una alfarera de Cobres, como veremos en el Capítulo 10. 


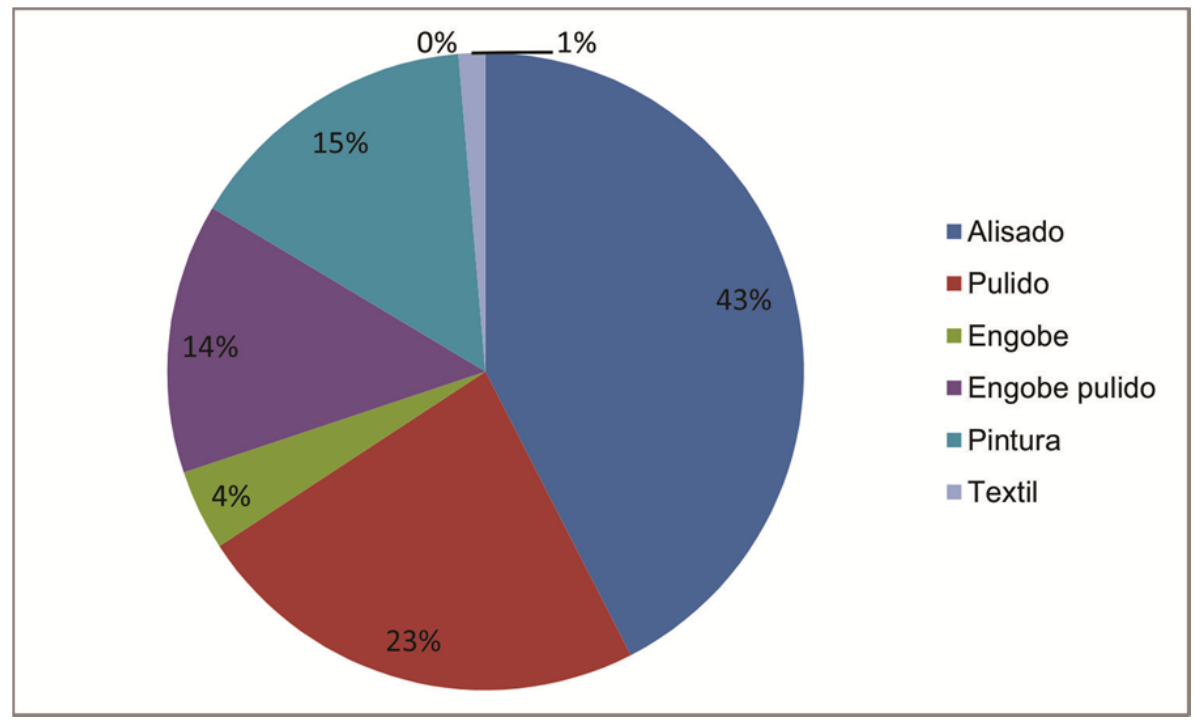

Figura 8.13 Acabados de superficie para los grupos de fragmentos identificados en el material fragmentario.

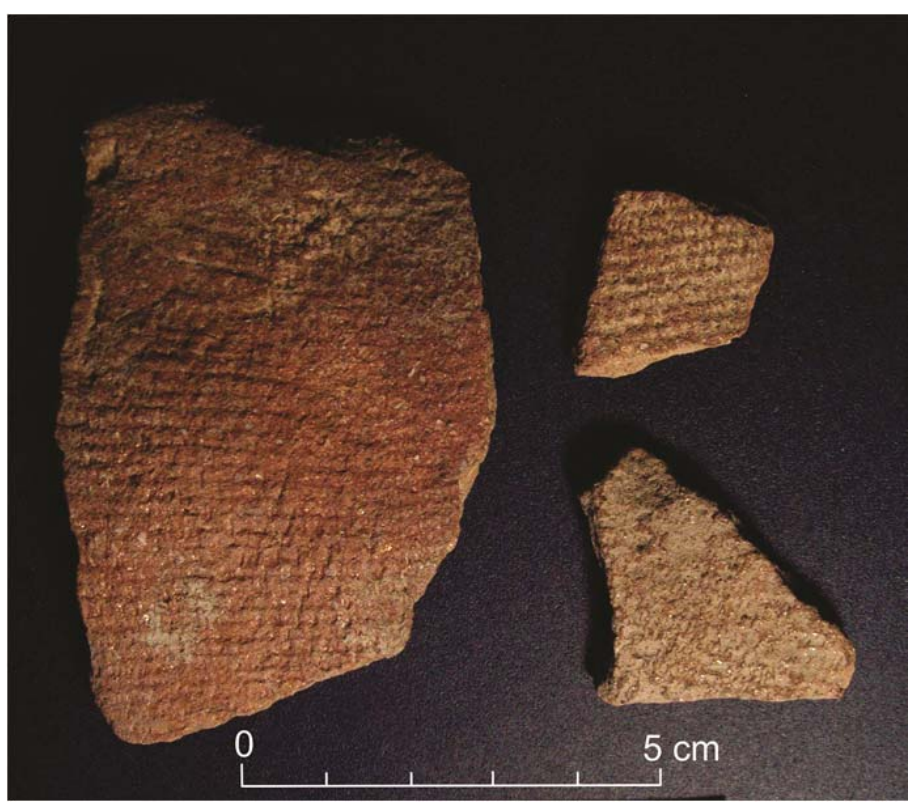

Figura 8.14 Fragmentos con improntas de textil procedentes de RH 10-1 Nivel 1.

Para los fragmentos no agrupados (Figura 8.15) la proporción de fragmentos alisados es mayor que en el caso de los GF, y también aumenta la proporción de fragmentos engobados y pulidos, disminuyendo aquellos solo pulidos. En este caso, este cambio se debe a que entre los fragmentos no agrupados están representados los sitios SC 3 y TC 
2, que tienen una cantidad abundante de fragmentos engobados y pulidos, y en los cuales no se armaron GF, por lo que no sumaban en el gráfico anterior.

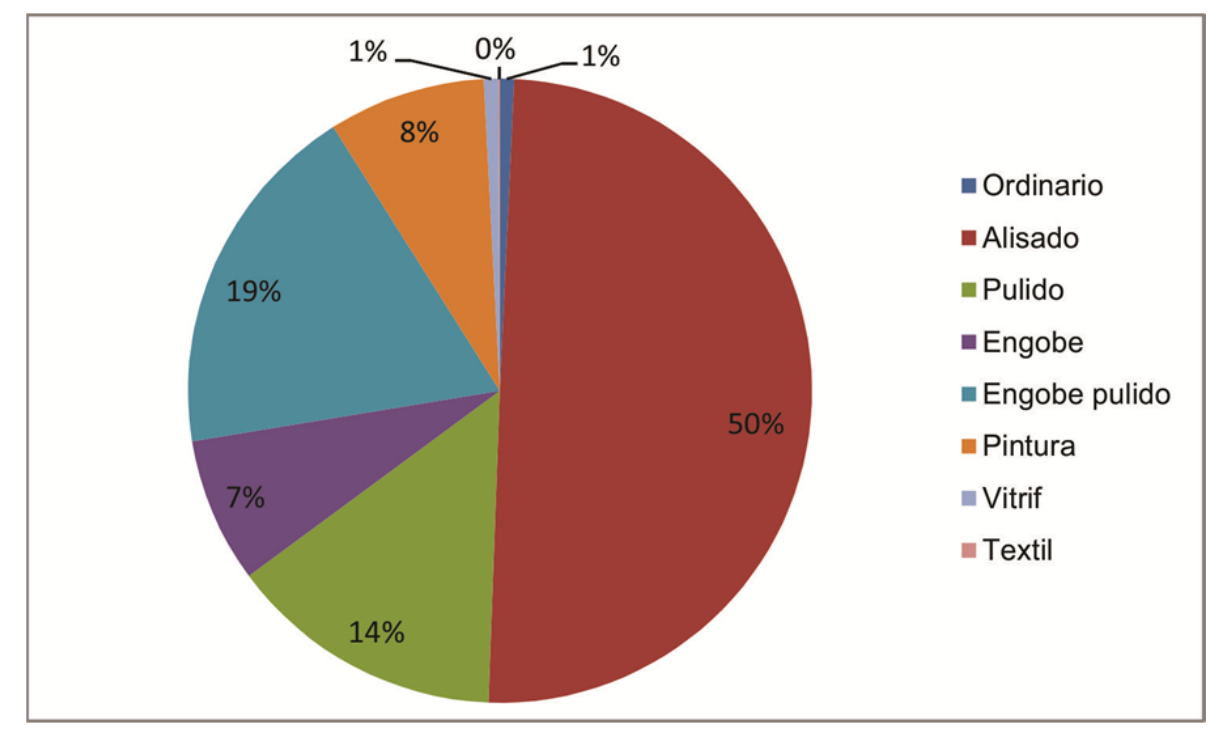

Figura 8.15 Acabados de superficie para los fragmentos no agrupados analizados.

Para los fragmentos no agrupados de los sitios analizados, predominan aquellos alisados, exceptuando los de recolección superficial de RH 2-1 y los de RH 10-1. Como estas recolecciones fueron discriminadas, es decir que se escogían los fragmentos considerados representativos, la proporción de los acabados de superficie en la muestra no estaría representando la de la población real. En SC 3 y TC 2, que poseen mayor abundancia de fragmentos engobados y pintados, se realizaron recolecciones de superficie tanto discriminadas como indiscriminadas. Por lo que si bien no es una muestra que represente fielmente a la población de fragmentos, se acerca mejor a la misma que los sitios de Río Herrana mencionados, y consideramos que si se refleja un cambio en la proporción de fragmentos con estos tipos de acabados de superficie entre esos sitios del norte de la puna, de los de la cuenca sur de la laguna de Pozuelos.

Un único fragmento del primer nivel de $\mathrm{RH}$ 19-7 presenta improntas textiles comparables a las ilustradas arriba. Además, aparecen fragmentos con vitrificado, aunque en bajo número (8:1091), que proceden del basurero de PA 22, de SC 3 y TC 2. La técnica del vitrificado puede vincularse a temporalidades posteriores al contacto hispano indígena. En la Figura 8.16 se pueden observar algunos fragmentos que presentan vitrificado. 


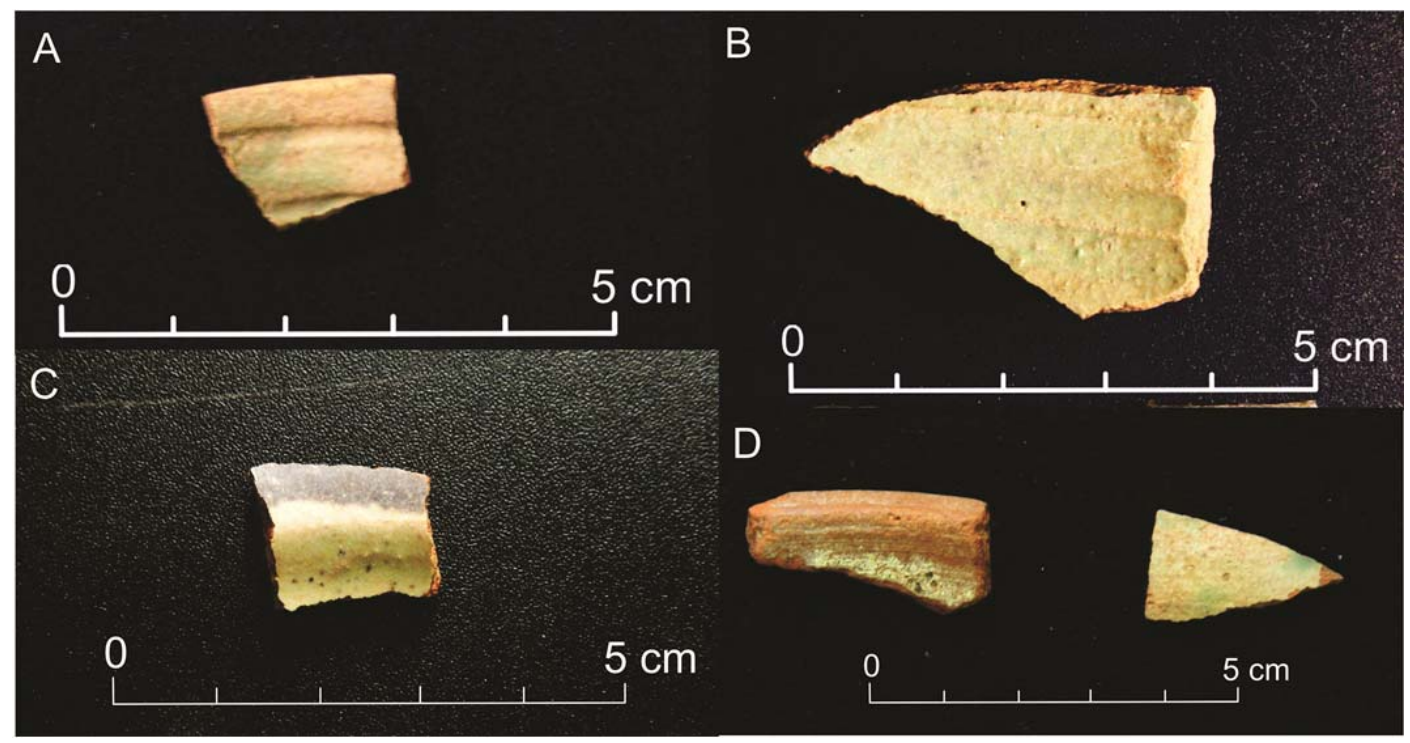

Figura 8.16 Fragmentos con una o ambas superficies vitrificadas. A y B proceden de PA 22; C, de SC 3 y D, de TC 2.

Al analizar en cuales de las morfologías identificadas en el capítulo anterior aparecen los acabados de superficie registrados, tuvimos en cuenta tanto los grupos de fragmentos como los fragmentos no agrupados correspondientes a bordes. Los resultados se pueden observar en la Tabla 8.5, en la cual se aprecia que las piezas alisadas comprenden a todas las morfologías identificadas, pero son más abundantes entre las cerradas. Las dos vasijas identificadas también presentan superficies alisadas. En cambio, las botellas pueden estar alisadas o pulidas, y en menor cantidad engobadas o pintadas. Para las piezas abiertas en general, se observa una proporción mayor de la presencia de superficies pulidas, pero la proporción de piezas engobadas, engobadas y pulidas, y pintadas es apenas un poco mayor que entre las piezas cerradas. Los fragmentos con vitrificado corresponden únicamente a piezas abiertas, mientras que para aquellos con improntas de textil, no se pudo identificar la morfología. La mayor parte de los grupos de fragmentos y fragmentos de bordes cuya morfología no se pudo identificar corresponden a piezas de superficies alisadas. 


\begin{tabular}{|c|c|c|c|c|c|c|c|c|}
\hline & Ordinario & Alisado & Pulido & Engobe & $\begin{array}{l}\text { Engobe } \\
\text { pulido }\end{array}$ & Pintura & Vitrificado & Textil \\
\hline Abierta indet & 1 & 22 & 24 & 6 & 9 & 6 & 3 & 0 \\
\hline $\begin{array}{l}\text { Escudilla-Escudilla } \\
\text { honda }\end{array}$ & 0 & 3 & 7 & 1 & 3 & 2 & 0 & 0 \\
\hline Cerrada Indet & 0 & 26 & 8 & 4 & 9 & 5 & 0 & 0 \\
\hline Vasija-Tinaja & 0 & 2 & 0 & 0 & 0 & 0 & 0 & 0 \\
\hline Botella & 0 & 2 & 2 & 0 & 1 & 1 & 0 & 0 \\
\hline Indeterminadas & 0 & 46 & 1 & 1 & 12 & 9 & 0 & 1 \\
\hline TOTAL & 1 & 101 & 42 & 12 & 34 & 23 & 3 & 1 \\
\hline
\end{tabular}

Tabla 8.5 Distribución de los acabados de superficie entre las diferentes morfologías identificadas.

Al igual que para las piezas de colección, entre los fragmentos de la muestra intentamos registrar las marcas asociadas a los acabados de superficie. Sin embargo, por tratarse de material fragmentario, en la mayoría de los casos no pudimos orientar las marcas registradas, por lo que la identificación de la dirección de las estrías de alisado y las caras de pulido es menor.

Tanto para los grupos de fragmentos como para los fragmentos no agrupados, predominan las estrías de alisado y las caras de pulido con dirección indeterminada y las horizontales. La presencia de caras de pulido es inferior a la de estrías de alisado, lo que seguramente se debe a que los fragmentos con las superficies alisadas son más abundantes. Entre las caras de pulido, la proporción de las verticales es más importante que entre las estrías de alisado. No se observa una distribución diferencial de estas marcas entre los diferentes sitios de la muestra, excepto un incremento de aquellas para las que no se puede identificar su dirección en varios sitios.

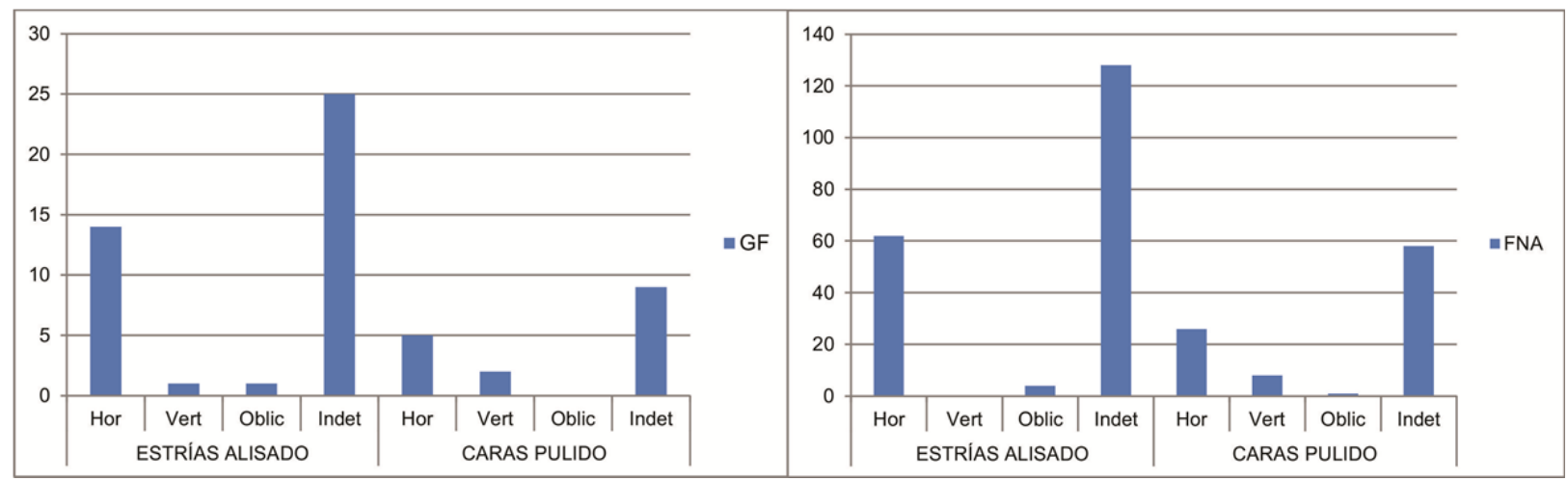

Figura 8.17 Marcas asociadas al alisado y al pulido para los grupos de fragmentos (GF) y fragmentos no agrupados (FNA) de la muestra analizada. Referencias: Hor: horizontal;

Vert: vertical; Oblic: oblicua; Indet: indeterminada. 
Para las diferentes morfologías de piezas (a partir de las GF y fragmentos de bordes), se muestra la distribución de los distintos tipos de marcas en la Tabla 8.6. Entre las piezas cerradas, las marcas más importantes son las estrías de alisado con dirección horizontal, con solo un par de casos de estrías verticales u oblicuas. Algunas presentan caras de pulido, también predominantemente horizontales. Para las botellas, que son muy escasas, son más abundantes las marcas horizontales de pulido $(n=2)$, que las de alisado $(n=1)$. Entre las piezas abiertas también predominan las marcas de alisado horizontales, aunque en un par de casos se observaron algunas verticales. Las caras de pulido son mayormente horizontales.

\begin{tabular}{lcccccccc}
\hline & \multicolumn{4}{c}{ ESTRÍAS ALISADO } & \multicolumn{4}{c}{ CARAS PULIDO } \\
& Hor & Vert & Oblic & Indet & Hor & Vert & Oblic & Indet \\
\hline Abierta indet & 17 & 2 & 0 & 6 & 9 & 0 & 0 & 4 \\
Escudilla-Escudilla & 2 & 0 & 1 & 2 & 4 & 0 & 0 & 3 \\
honda & 12 & 1 & 1 & 7 & 6 & 1 & 0 & 2 \\
Cerrada Indet & 1 & 0 & 0 & 0 & 0 & 0 & 0 & 0 \\
Vasija-Tinaja & 1 & 0 & 0 & 0 & 2 & 0 & 0 & 0 \\
Botella & 9 & 0 & 0 & 12 & 1 & 1 & 0 & 3 \\
Indeterminadas & & & & & & & & \\
\hline
\end{tabular}

Tabla 8.6 Distribución de las marcas asociadas al alisado y al pulido entre las diferentes morfologías de piezas identificadas. Referencias: Hor: horizontal; Vert: vertical; Oblic: oblicua; Indet: indeterminada.

Para profundizar el análisis de las huellas de alisado y pulido, quisimos registrar en qué porciones de las piezas se encuentran presentes. Para ello analizamos en qué tipo de fragmentos aparecen (borde, cuello, cuerpo, base). Como los fragmentos de cuerpo son mucho más abundantes ( $80 \%$ del total) que los de las otras porciones, pasamos las cantidades a porcentajes sobre el total de cada tipo de fragmentos (borde, cuello, cuerpo y base). En la Tabla 8.7 se puede observar que porcentaje de cada porción morfológica presenta cada tipo de marca. En total, se hicieron registros sobre 1008 fragmentos.

Las estrías de alisado horizontales son más frecuentes en los fragmentos de bordes, cuerpos y puntos de inflexión, siendo escasas en las bases. Las pocas estrías oblicuas en cambio aparecen en estas últimas. Sin embargo, se observa que las estrías de alisado indeterminadas son más abundantes en bases y cuerpo, seguramente por la dificultad de orientar estos fragmentos en el análisis. 


\begin{tabular}{ccccccccc}
\hline & \multicolumn{3}{c}{ ESTRÍAS ALISADO } & \multicolumn{3}{c}{ CARAS PULIDO } \\
& Hor & Vert & Oblic & Indet & Hor & Vert & Oblic & Indet \\
\hline borde & $46.7 \%$ & $0.0 \%$ & $0.7 \%$ & $14.8 \%$ & $24.4 \%$ & $5.2 \%$ & $0.0 \%$ & $8.1 \%$ \\
cuerpo & $40.0 \%$ & $0.0 \%$ & $0.0 \%$ & $32.4 \%$ & $9.2 \%$ & $5.6 \%$ & $0.0 \%$ & $12.8 \%$ \\
pto inflex & $38.7 \%$ & $0.0 \%$ & $0.0 \%$ & $22.6 \%$ & $3.2 \%$ & $29.0 \%$ & $0.0 \%$ & $6.5 \%$ \\
base & $20.5 \%$ & $0.0 \%$ & $7.7 \%$ & $41.0 \%$ & $12.8 \%$ & $2.6 \%$ & $2.6 \%$ & $12.8 \%$ \\
\hline
\end{tabular}

Tabla 8.7 Proporción de fragmentos de diferentes porciones de piezas que presentan marcas vinculadas al alisado y al pulido. Referencias: Hor: horizontal; Vert: vertical;

Oblic: oblicua; Indet: indeterminada.

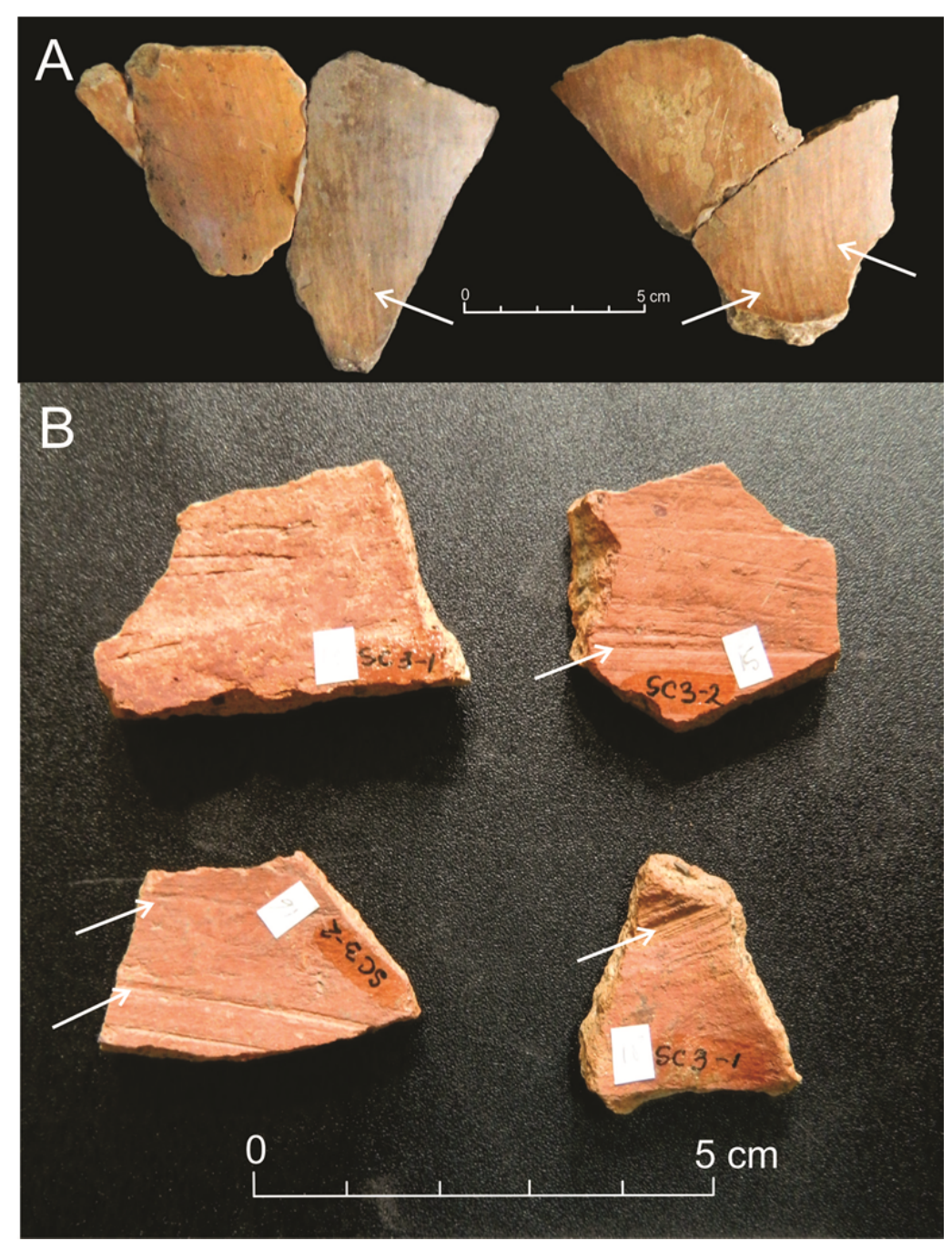

Figura 8.18 Marcas asociadas al pulido y al alisado. A: caras de pulido verticales en fragmentos de cuello procedentes de PA 6-1; B: estrías gruesas de alisado en superficie interna en fragmentos de SC 3. 
Para las caras de pulido, se observa que los bordes muestran mayor cantidad de aquellas con orientación horizontal. En los fragmentos de cuerpo son escasas y son tanto horizontales como verticales. Las caras de pulido verticales son más frecuentes en los fragmentos de puntos de inflexión, que muchas veces corresponden a los cuellos de las piezas, de manera semejante a lo que se observa en las piezas de colección. Entre los fragmentos de bases, se observan mayormente caras de pulido horizontales, con algunas verticales y oblicuas. En la Figura 8.18 se puede observar el aspecto de caras de pulido verticales y estrías de alisado en la superficie interna de dos conjuntos de fragmentos.

En relación a aquellos atributos más vinculados a la decoración de las piezas, o que implican la aplicación de color a la superficie o el desplazamiento o agregado de materia, hemos analizado la presencia de pintura monocroma ${ }^{12}$, bicolor y tricolor, y la presencia de decoración por incisión, modelado y pastillaje, al igual que para las piezas de colección.

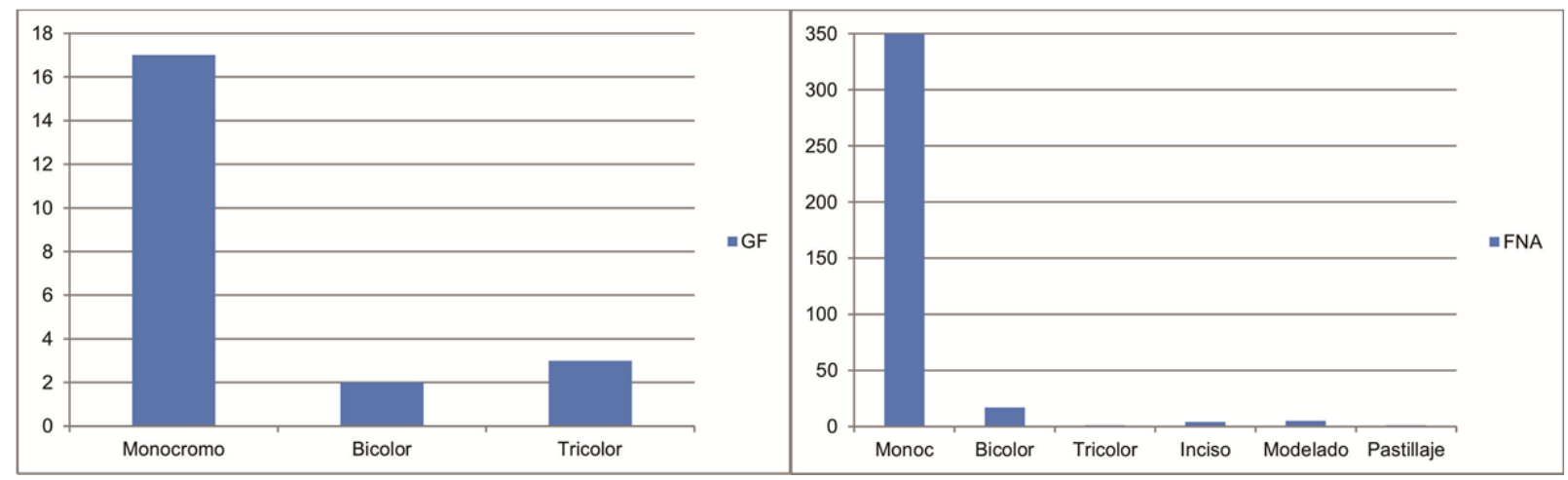

Figura 8.19 Tipos de decoración presentes en los grupos de fragmentos (GF) y fragmentos no agrupados (FNA) de la muestra analizada.

Entre los grupos de fragmentos, solo se registra la presencia de decoración pintada (Figura 8.19), predominando aquellos con pintura o engobe monocromo. En segundo lugar se ubican los que exhiben decoración tricolor, que son tres GF (uno de RH 2-1, otro de RH 19-7 Nivel 1 y el otro de TA 1-1), y consisten básicamente en fragmentos con puntos blancos (5YR 8/1) a marrón muy pálido (10YR 7/3) y franjas negras ( $\mathrm{N} \mathrm{2.5/)}$

\footnotetext{
${ }^{12}$ La decoración pintada también incluye la aplicación de engobes diferentes de la pasta, al igual que en las piezas de colección.
} 
sobre engobe o pintura roja (10R 5/4, 5/6, 5/8) (Figura 8.20). Uno (de RH 2-1) presenta círculos blancos grandes, bien definidos, muy próximos entre sí y con pintura delgada y franjas negras finas de bordes borrosos; el otro tiene círculos irregulares, más espaciados, con pintura blanca más fina y franjas negras anchas, con pintura borrosa. El tercero (de TA 1-1) presenta puntos más pequeños y franjas negras anchas en grupos de 3 , con pintura bien definida. Además, en este último la superficie está mejor acabada que los casos anteriores.

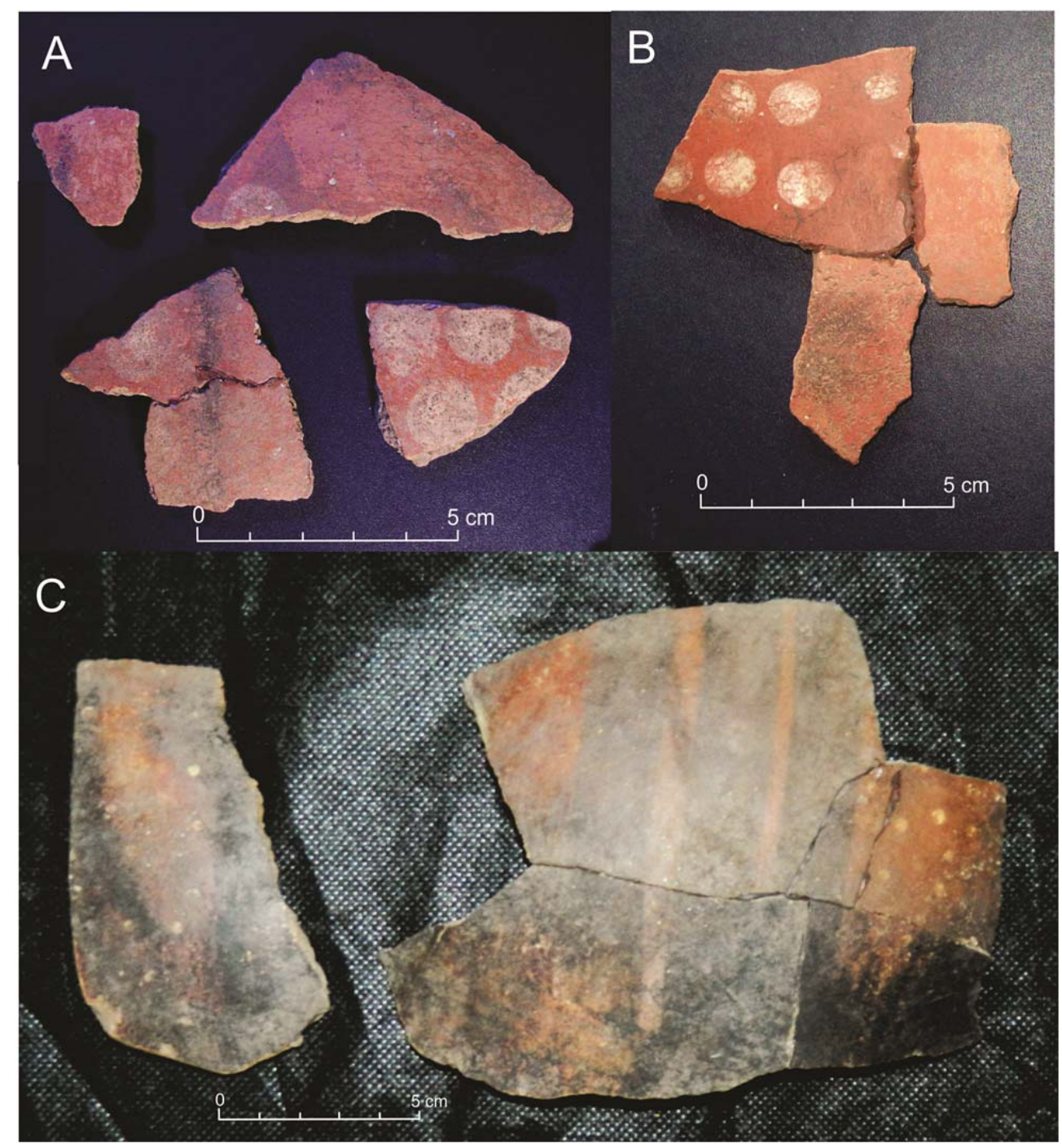

Figura 8.20 Grupos de Fragmentos con decoración pintada tricolor. A: GF de RH 2-1, B: GF procedente de RH 19-7, C: GF de TA 1-1. 
Los bicolores son dos GF de RH 19-7, uno correspondiente a una pieza cerrada Yavi, con motivos en pintura desleída (10R 4/3) consistentes en formas subcirculares rellenas con reticulado y figuras indeterminadas en negro a su alrededor; sobre engobe rojo (10R $4 / 4,5 / 4,5 / 3$ ) (Figura 8.21). El otro presenta franjas perpendiculares gris oscuras (10R $3 / 1$ ) sobre engobe rojo $(10 \mathrm{R} 4 / 4,4 / 6,5 / 6)$. El reticulado que rellena las figuras en la cerámica estilo Yavi es de trazo fino y pintura desleída, mientras que el que observamos en las piezas de colección para piezas que se vincularían al estilo Casabindo es de trazo más grueso y color más oscuro.
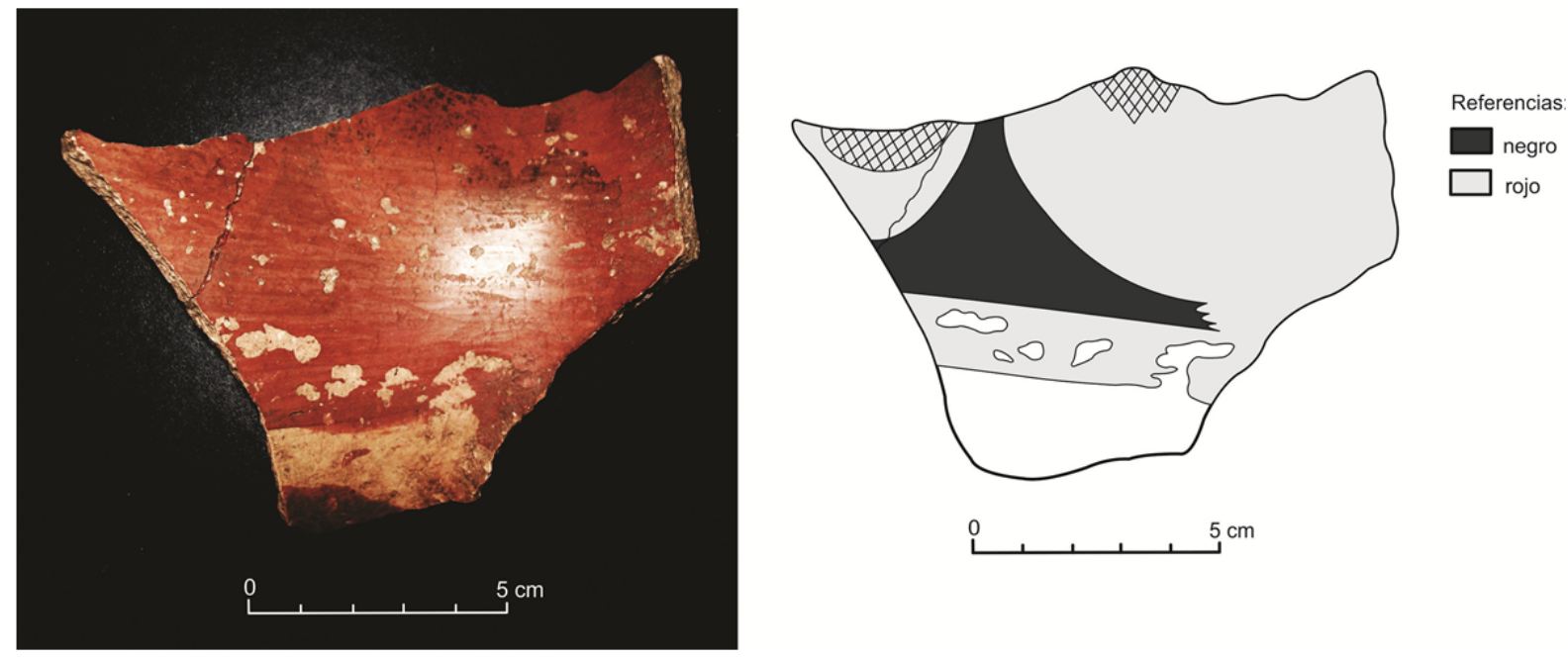

Figura 8.21 Fragmentos pintados del GF 1 de RH 19-7 y dibujo de los motivos.

Entre los fragmentos no agrupados que presentan decoración, los que muestran pintura o engobe monocromo son muy abundantes (350:378). En cambio, los fragmentos con decoración bicolor son más escasos (17:378), y consisten en fragmentos con franjas negras ( $N$ 4/; 7.5YR 2/0) sobre la pasta o engobe rojo (10R 4/6, $4 / 8,5 / 6$ ) (Figura $8.22 \mathrm{~A}$ ) en el cuerpo, mientras que en un fragmento de $\mathrm{RH} 10-1$ la franja se localiza sobre un asa. Un fragmento presenta un pequeño motivo de un camélido en negro sobre el fondo rojo, por lo que correspondería al tipo Inka Pacajes (Figura $8.22 \mathrm{C}$ ), que ha sido localizado en otros sitios, como el sitio Mayu Punku, del oeste de la cuenca de Pozuelos (Mamaní 1997), y en la Quebrada de Humahuaca (Nielsen 1997b). 


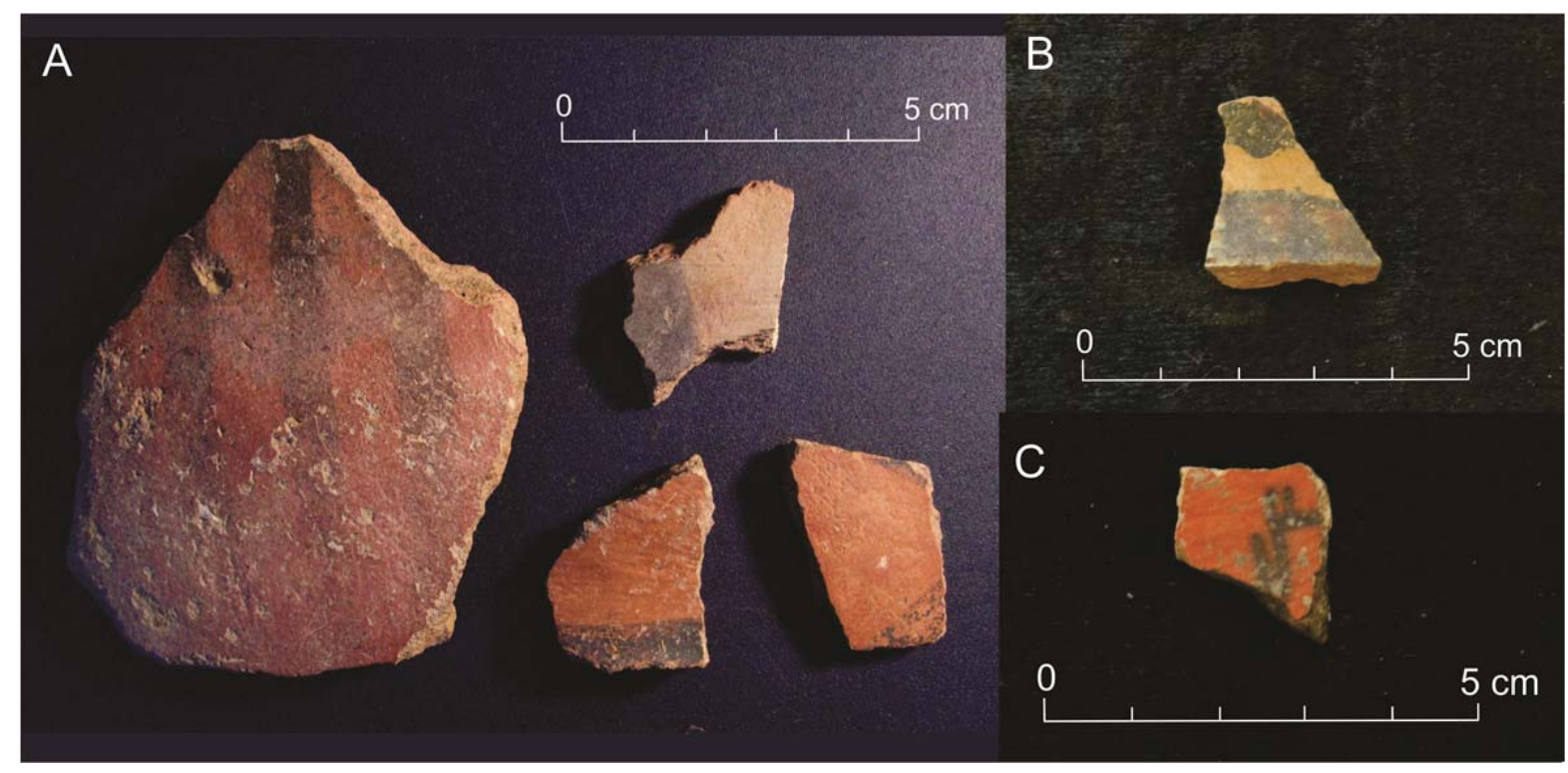

Figura 8.22 Fragmentos no agrupados con decoración en negro sobre rojo y tricolor. A: procedentes de RH 10-1; B: procedente de TC 2.

Hay un único fragmento con decoración tricolor entre los FNA, procedente de TC 2 que exhibe una franja de triángulos negros (10R 2.5/1) y rojos oscuros (10R 3/3) alternados, y otro motivo en negro indistinguible, sobre un fondo marrón claro (5YR 6/4), que podía corresponder al tipo Cusco polícromo (Nielsen com. pers.). El mismo se muestra en la Figura 8.22 B.

Entre los FNA con decoración plástica, la mayor parte de los mismos (9:10) proceden de los sitios del norte de la puna, mientras que estos tipos de decoración no se observan entre los fragmentos del sur de Pozuelos, exceptuando un caso de PA 22. Cuatro de estos fragmentos, todos procedentes de SC 3, presentan incisiones. Dos son los apéndices ornitomorfos de la Figura 7.32, en los que, mediante esa técnica, se formaron los ojos. Los dos restantes son fragmentos de asas, uno con una incisión poco profunda en zigzag y el otro con dos incisiones longitudinales. Los fragmentos con decoración modelada son cinco, dos de SC 3 y tres de TC 2. Los primeros son los mismos dos apéndices recién mencionados, cuya forma ha sido obtenida mediante modelado. Uno es un fragmento de borde al que le falta un apéndice que en el punto de unión tenía sección subcircular. Los otros dos también son fragmentos de bordes, que presentan pequeños relieves triangulares sobresaliendo, atributo que ha sido registrado previamente entre alfarería del estilo Yavi (Ávila 2006). 
Un último fragmento, procedente de recolección superficial del basurero de PA 22 corresponde a un borde con asa labioadherida que presenta un pastillaje en zigzag, y que puede observarse en la Figura 7.43 B. Este tipo de decoración es muy semejante a la observada en las piezas de la colección del Museo Quai Branly, del Pucará de Rinconada, y que estimábamos que podían ser coloniales. Consideramos que la presencia de este tipo de decoración en un único fragmento de todos los analizados para la cuenca sur de Pozuelos en un sitio con una ocupación colonial datada, apoya esa hipótesis.

Al analizar en qué tipos morfológicos de recipientes se registran los atributos decorativos analizados (Tabla 8.8), observamos que son más frecuentes las piezas abiertas pintadas que las cerradas, especialmente en la aplicación de pintura y engobe monocromo. Las piezas con decoración tricolor, correspondientes a los fragmentos con puntos blancos, son cerradas o indeterminadas, no observándose este tipo de decoración en piezas abiertas. Las piezas con incisiones o modelados, que como vimos básicamente se aplican en bordes de algunas piezas del norte de la puna, son todas abiertas, salvo una que es indeterminada. En cambio, el único fragmento que presenta decoración al pastillaje, correspondería a una pieza cerrada indeterminada.

\begin{tabular}{lcccccc}
\hline & Monocromo & Bicolor & Tricolor & Inciso & Modelado & Pastillaje \\
\hline Abierta indet & 20 & 2 & 0 & 1 & 3 & 0 \\
Escudilla-Escudilla honda & 8 & 0 & 0 & 1 & 1 & 0 \\
Cerrada Indet & 15 & 1 & 2 & 0 & 0 & 1 \\
Vasija-Tinaja & 0 & 0 & 0 & 0 & 0 & 0 \\
Botella & 2 & 0 & 0 & 0 & 0 & 0 \\
Indeterminadas & 14 & 0 & 1 & 0 & 1 & 0 \\
\hline
\end{tabular}

Tabla 8.8 Distribución de los tipos de decoración para las distintas morfologías identificadas en el material fragmentario.

Al vincular las morfologías con los acabados de superficie y relacionarlos a la literatura previa, podemos reconocer varias categorías morfo-estilísticas, semejantes a las identificadas en el material de colecciones. Estas incluyen escudillas o pucos con el interior negro y pulido (PINP), piezas del estilo Yavi (tanto abiertas como cerradas o de forma indeterminada), piezas comparables al estilo Casabindo tricolor (Albeck 2001), piezas Inka provinciales (sensu Calderari y Williams 1991), piezas poshispánicas (por la presencia de vitrificado y otro), piezas alisadas o pulidas, no asignables a un estilo particular, tanto abiertas como cerradas; y piezas pintadas o engobadas, abiertas o cerradas, tampoco asimilables a ningún estilo previo. 
Del reconocimiento de estas categorías, surge el interés de analizar, al igual que se hizo para las piezas de colección, si hay una distribución diferencial de las mismas en los diferentes sitios de la muestra analizada. Para contabilizar el número mínimo de piezas de cada categoría, al igual que en el capítulo previo, se tuvieron en cuenta los GF y los FNA correspondientes a bordes. En la Tabla 8.9 se pueden ver las cantidades de piezas por sitio para cada una de las categorías mencionadas.

\begin{tabular}{|c|c|c|c|c|c|c|c|c|c|c|c|c|c|c|}
\hline & $\begin{array}{c}\mathrm{CH} \\
25-1\end{array}$ & $\begin{array}{c}\mathrm{CH} \\
25-2\end{array}$ & $\begin{array}{l}\text { PA } \\
6-1\end{array}$ & $\begin{array}{l}\text { PA } \\
22\end{array}$ & $\begin{array}{l}\mathrm{RH} \\
2-1\end{array}$ & $\begin{array}{c}\mathrm{RH} \\
10-1 \\
\mathrm{~N} 1 \\
\end{array}$ & $\begin{array}{c}\mathrm{RH} \\
10-1 \\
\mathrm{~N} 2 \\
\end{array}$ & $\begin{array}{c}\text { RH } \\
19-1\end{array}$ & $\begin{array}{c}\mathrm{RH} \\
19-7 \\
\mathrm{~N} 1 \\
\end{array}$ & $\begin{array}{c}\mathrm{RH} \\
19-7 \\
\mathrm{~N} 2 \\
\end{array}$ & $\begin{array}{c}\text { TA 1- } \\
1\end{array}$ & Sc 3 & TC 2 & TOTAL \\
\hline PINP & 0 & 0 & 3 & 0 & 2 & 2 & 1 & 1 & 12 & 2 & 1 & 0 & 0 & 24 \\
\hline Yavi cerrada & 0 & 0 & 2 & 0 & 0 & 0 & 0 & 0 & 1 & 0 & 1 & 1 & 1 & 6 \\
\hline Yavi abierta & 0 & 0 & 1 & 0 & 0 & 0 & 0 & 0 & 0 & 0 & 1 & 7 & 4 & 13 \\
\hline Yavi indet & 0 & 0 & 1 & 0 & 0 & 0 & 0 & 0 & 4 & 0 & 0 & 0 & 0 & 5 \\
\hline Casab tric & 0 & 0 & 0 & 0 & 1 & 0 & 0 & 0 & 1 & 0 & 1 & 0 & 0 & 3 \\
\hline Inka pcial & 0 & 0 & 0 & 0 & 0 & 0 & 0 & 0 & 0 & 0 & 0 & 2 & 0 & 2 \\
\hline Poshispánico & 0 & 0 & 0 & 1 & 0 & 0 & 0 & 0 & 0 & 0 & 0 & 2 & 2 & 5 \\
\hline Abierta alis/pul & 2 & 1 & 4 & 2 & 1 & 0 & 2 & 3 & 4 & 0 & 0 & 10 & 5 & 34 \\
\hline $\begin{array}{l}\text { Abierta } \\
\text { pint/eng }\end{array}$ & 0 & 0 & 1 & 0 & 1 & 0 & 1 & 0 & 2 & 0 & 1 & 4 & 4 & 14 \\
\hline $\begin{array}{l}\text { Cerrada } \\
\text { alis/pul }\end{array}$ & 3 & 2 & 3 & 5 & 2 & 2 & 1 & 0 & 1 & 0 & 3 & 10 & 10 & 42 \\
\hline $\begin{array}{l}\text { Cerrada } \\
\text { pint/eng }\end{array}$ & 0 & 0 & 1 & 1 & 0 & 0 & 0 & 0 & 1 & 1 & 1 & 2 & 4 & 11 \\
\hline Indet alis/pul & 0 & 3 & 1 & 3 & 4 & 1 & 5 & 3 & 8 & 4 & 6 & 3 & 11 & 52 \\
\hline Indet pint/eng & 0 & 0 & 0 & 0 & 4 & 0 & 0 & 0 & 0 & 0 & 0 & 2 & 8 & 14 \\
\hline
\end{tabular}

Tabla 8.9 Distribución de las categorías morfo-estilísticas identificadas en los diferentes sitios de la muestra. Ref: N1: nivel 1; N2: nivel 2; PINP: puco interior negro pulido, Indet: indeterminado, Casab: Casabindo, tric: tricolor, alis: alisado, pul: pulido, eng: engobado, pint: pintado.

En todos los sitios analizados, son más frecuentes las piezas abiertas o cerradas, o de morfología indeterminada, que presentan las superficies alisadas o pulidas. En menor medida se observan aquellas con engobe o pintura, también correspondientes a piezas abiertas, cerradas o indeterminadas. En los sitios de la zona de Santa Catalina, las engobadas o pintadas son algo más frecuentes que en los de la cuenca sur de Pozuelos.

Los pucos interior negro pulido (Figura 8.23 A) se encuentran presentes en gran parte de los sitios de la cuenca sur de Pozuelos, aunque no se los encontró en las dos estructuras de Chajarahuayco ni en el basurero de PA 22. Son particularmente abundantes en la segunda ocupación de RH 19-7 (Nivel 1), donde se encontraron varios 
fragmentos de bordes que corresponderían a estos pucos. En los sitios de la zona de Santa Catalina se encuentran ausentes.

En cuanto a las piezas comparables al estilo Yavi (Figura 8.23 B), por su pasta o decoración, se encuentran con mayor frecuencia en los sitios del norte de la puna, lo cual concuerda con que esta zona ha sido considerada dentro del área de influencia de ese estilo. Dentro de estos sitios, son más abundantes las abiertas que las cerradas. En la cuenca sur de Pozuelos, estas piezas solo se localizaron en PA 6-1, en el nivel uno de RH 19-7 y en TA 1-1, estando ausentes en los demás sitios del área. Para estos sitios, son escasos los fragmentos que corresponderían a piezas abiertas de ese estilo, siendo más comunes los de recipientes cerrados o indeterminados.

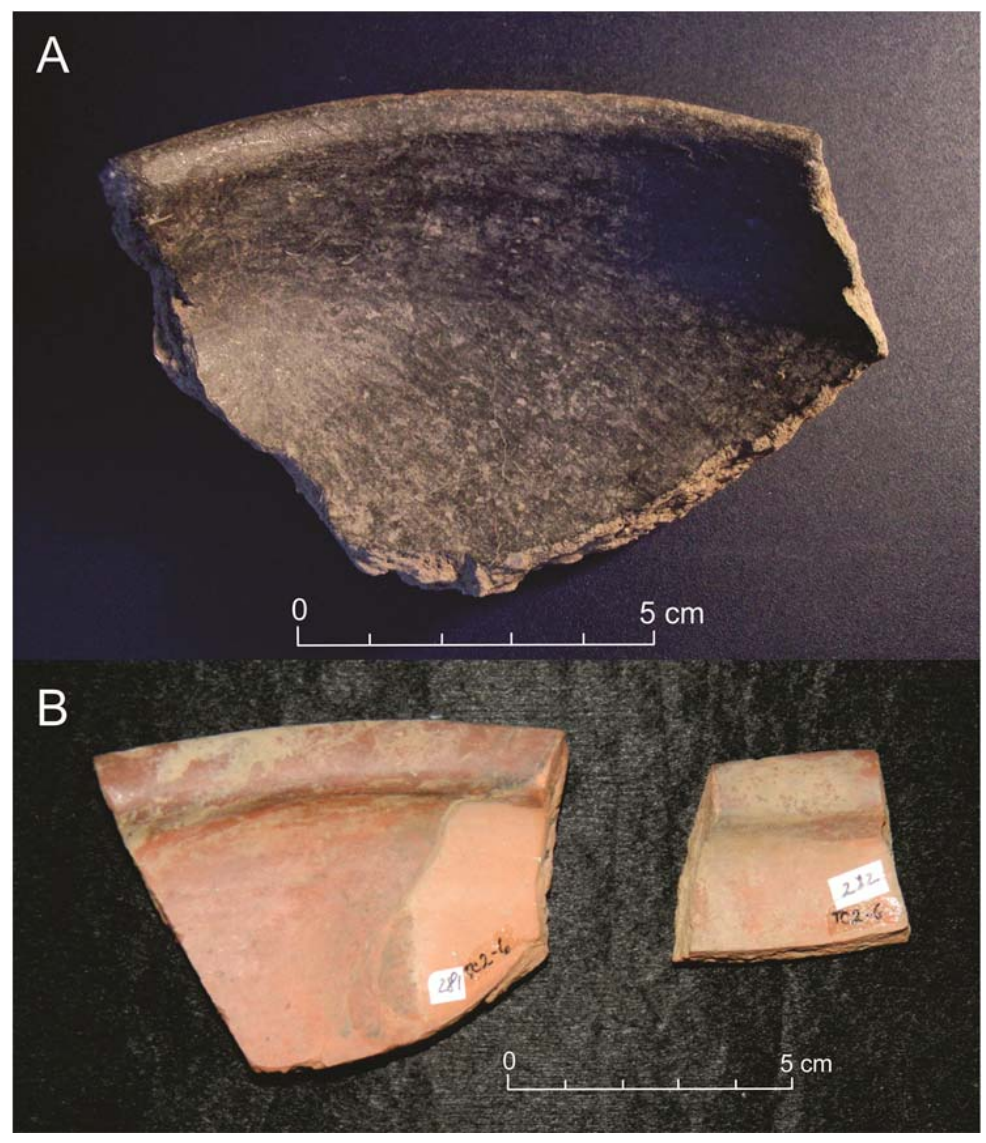

Figura 8.23 Fragmentos correspondientes a piezas abiertas. A: Fragmento de puco interior negro pulido. B: fragmentos de escudilla correspondiente al estilo Yavi.

Las piezas que presentan decoración comparable a la del estilo Casabindo tricolor son escasas, y sólo están presentes en los sitios del sur de Pozuelos, en RH 2-1, RH 19-7 y TA 1-1. Por su parte, aquellas vinculables a Inka provincial también son escasas, 
y solo están presentes en los sitios de la zona de Santa Catalina, donde también debe tenerse en cuenta el fragmento Cusco polícromo y el Inka Pacajes mencionados anteriormente, procedentes de TC 2. A pesar de que el Pucará de Rinconada tendría una ocupación inkaica (Ruiz 1996) y de que entre los recipientes de colección observamos algunos que pueden vincularse a la presencia imperial para la porción sur de la puna que estamos analizando, en los sitios excavados por nosotros, que corresponderían a recintos habitacionales y a un basurero, no hemos encontrado ningún fragmento correspondiente a los estilos asociados al Inka.

Los fragmentos que corresponderían a piezas poshispánicas corresponden a bordes con vitrificado o con estrías de torno. Están presentes en el basurero de PA 22 de la cuenca sur de Pozuelos y en los dos sitios de la zona de Santa Catalina.

En general, se aprecia que en los sitios del norte de la puna las piezas que corresponderían a recipientes decorados (incluyendo también los que presentan pintura y engobe monocromo) son algo más frecuentes que en el sur de la cuenca de Pozuelos, como se puede ver en la Figura 8.24. En esos sitios la proporción de decorados y no decorados es casi igual. En varios de los sitios del sur de Pozuelos, el total de las piezas corresponden a aquellas con superficies alisadas o pulidas, sin decoración, y en los que están presentes las decoradas, son más escasas que las no decoradas.

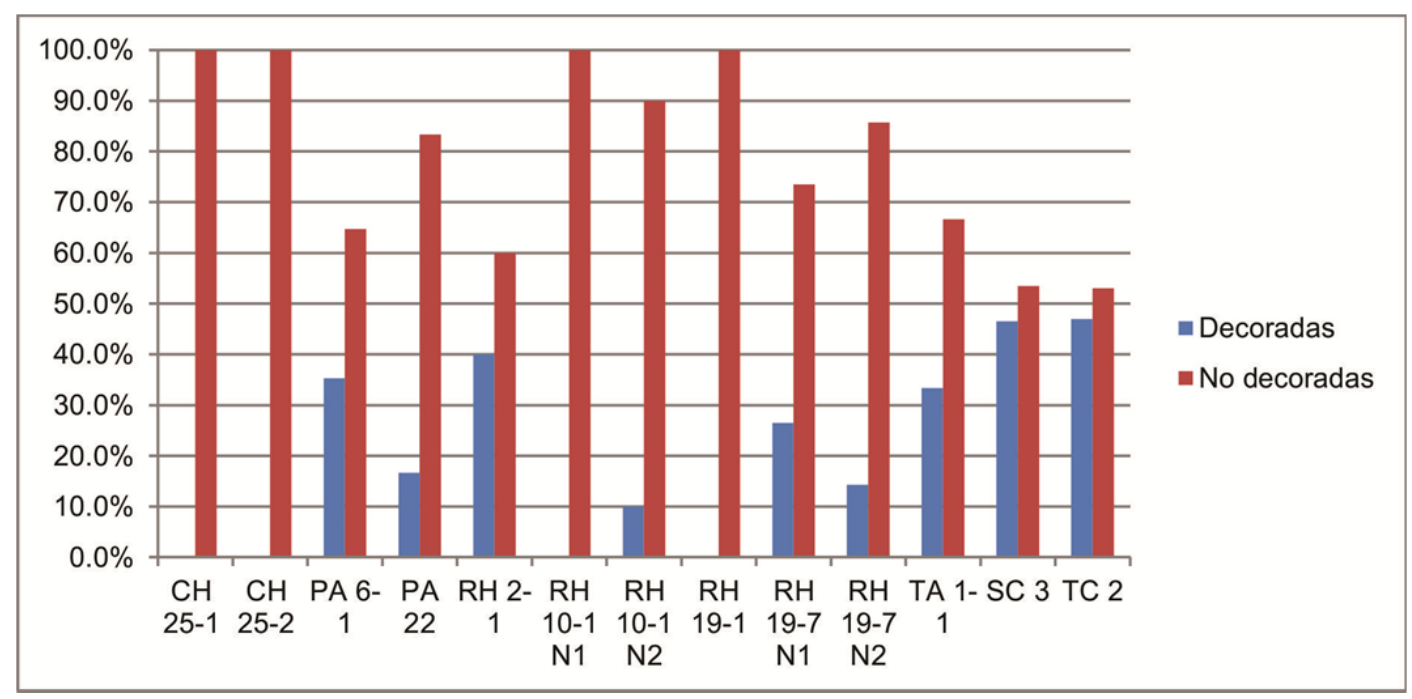

Figura 8.24 Porcentaje de piezas decoradas y no decoradas para cada uno de los sitios analizados de la muestra de material fragmentario. 


\section{La decoración y las pastas:}

Otro aspecto que tuvimos en cuenta en el análisis es la presencia o no de vinculaciones entre los atributos analizados para los acabados de superficie y decoración con los tipos de pastas que hemos identificado en el Capítulo 6. Para eso hemos contabilizado la cantidad de fragmentos de cada GP que presentan los tipos de acabados y decoraciones identificados. Dado que algunos GP tienen muchos fragmentos y otros muy pocos, calculamos los porcentajes de cada acabado para el total de cada tipo de pasta. Los resultados pueden observarse en la Tabla 8.10.

\begin{tabular}{lccccccccc}
\hline & GP 1 & GP 2 & GP 3 & GP 4 & GP 5 & GP 6 & GP 7 & GP 8 & GP 9 \\
\hline Ordinario & $0.0 \%$ & $0.8 \%$ & $0.0 \%$ & $0.9 \%$ & $0.0 \%$ & $0.0 \%$ & $0.0 \%$ & $0.0 \%$ & $0.0 \%$ \\
Alisado & $64.4 \%$ & $69.2 \%$ & $18.2 \%$ & $70.3 \%$ & $16.2 \%$ & $100.0 \%$ & $66.7 \%$ & $52.9 \%$ & $52.6 \%$ \\
Pulido & $14.9 \%$ & $22.0 \%$ & $12.2 \%$ & $10.4 \%$ & $16.9 \%$ & $0.0 \%$ & $25.0 \%$ & $21.5 \%$ & $47.4 \%$ \\
Engobe & $0.0 \%$ & $0.4 \%$ & $10.5 \%$ & $1.6 \%$ & $4.2 \%$ & $0.0 \%$ & $0.0 \%$ & $8.4 \%$ & $0.0 \%$ \\
Engobe pulido & $2.1 \%$ & $1.2 \%$ & $51.0 \%$ & $4.7 \%$ & $55.6 \%$ & $0.0 \%$ & $0.0 \%$ & $13.6 \%$ & $0.0 \%$ \\
Pintura & $5.2 \%$ & $4.0 \%$ & $4.4 \%$ & $8.2 \%$ & $1.4 \%$ & $0.0 \%$ & $8.3 \%$ & $3.1 \%$ & $0.0 \%$ \\
Pintura bicolor & $2.1 \%$ & $0.8 \%$ & $0.0 \%$ & $2.2 \%$ & $3.5 \%$ & $0.0 \%$ & $0.0 \%$ & $0.0 \%$ & $0.0 \%$ \\
Pintura tricolor & $9.8 \%$ & $0.0 \%$ & $3.7 \%$ & $1.5 \%$ & $0.7 \%$ & $0.0 \%$ & $0.0 \%$ & $0.0 \%$ & $0.0 \%$ \\
Vitrificado & $0.0 \%$ & $1.2 \%$ & $0.0 \%$ & $0.1 \%$ & $1.4 \%$ & $0.0 \%$ & $0.0 \%$ & $0.5 \%$ & $0.0 \%$ \\
Textil & $1.5 \%$ & $0.4 \%$ & $0.0 \%$ & $0.0 \%$ & $0.0 \%$ & $0.0 \%$ & $0.0 \%$ & $0.0 \%$ & $0.0 \%$ \\
\hline
\end{tabular}

Tabla 8.10 Porcentajes de fragmentos con los diferentes acabados de superficie identificados para cada uno de los GP.

La mayor parte de las pastas (GP 1, 2, 4, 6, 7, 8 y 9) se emplearon en un porcentaje amplio para elaborar alfarería con las superficies alisadas. EI GP 6 incluye un único recipiente cerrado de superficies alisadas. En Ios GP 1, 2, 4 y 7 el porcentaje de fragmentos alisados abarca entre un 65 y un 70\%, siendo algo menor entre los GP 8 y 9 (53\%). Sin embargo, estos mismos tipos de pastas también están presentes, en porcentajes menores, en fragmentos que exhiben diferentes acabados de superficie, como pulidos, engobados y pulidos, pintados. Por lo que en estos casos, no se requería un tipo de pasta en especial para elaborar piezas decoradas. En el GP 9 el porcentaje de fragmentos pulidos es importante (47\%), mientras que en los demás grupos no alcanza al 25\%. Los fragmentos con engobe y engobe pulido son importantes para el GP 8 (8 y 14\% respectivamente), mientras que en el GP 1 los fragmentos con pintura tricolor llegan hasta un 10\%, porcentaje no observado en otros grupos de pastas.

Los GP 3 y 5 tienen un comportamiento diferente. Para estos grupos de pastas, más del $50 \%$ de los fragmentos presentan engobe pulido, siendo un porcentaje escaso el de 
los fragmentos alisados (16 y 18\% respectivamente), en comparación con los GP mencionados anteriormente. Sin embargo, si comparten con los grupos anteriores la presencia de una diversidad de acabados, que incluyen el pulido y la pintura en las diferentes modalidades identificadas.

Los fragmentos que presentan vitrificado, que son pocos, se presentan con diferentes pastas (GP 2, 4, 5 y 8). En cambio aquellos con improntas textiles, que también son escasos, tienen pastas del GP 1 y 2 . Esto los vincula más a los materiales de la cuenca sur de Pozuelos, donde predominan las pastas de los GP 1 y 2, junto con el 4, como vimos en el capítulo anterior, a pesar de que este tipo de improntas han sido descritas en el "área de influencia Yavi" para el tipo denominado Pozuelos con cuarzo (Krapovickas 1975).

También registramos qué grupos de pastas se presentan en cada una de las categorías mofo-estilísticas que hemos descrito en la sección anterior, contabilizando, de igual manera que lo hicimos antes, el número de grupos de fragmentos y de fragmentos no agrupados correspondientes a bordes para cada una de esas categorías dentro de cada GP. En la Tabla 8.11 se computan estos resultados.

\begin{tabular}{lccccccccc}
\hline & GP 1 & GP 2 & GP 3 & GP 4 & GP 5 & GP 6 & GP 7 & GP 8 & GP 9 \\
\hline PINP & 3 & 7 & 0 & 14 & 0 & 0 & 0 & 0 & 0 \\
Yavi cerrada & 0 & 0 & 6 & 0 & 0 & 0 & 0 & 0 & 0 \\
Yavi abierta & 0 & 0 & 8 & 0 & 4 & 0 & 0 & 1 & 0 \\
Yavi indet & 0 & 0 & 5 & 0 & 0 & 0 & 0 & 0 & 0 \\
Casab tricolor & 1 & 0 & 1 & 1 & 0 & 0 & 0 & 0 & 0 \\
Inka provincial & 0 & 0 & 1 & 0 & 1 & 0 & 0 & 0 & 0 \\
Poshispánico & 0 & 3 & 0 & 0 & 1 & 0 & 0 & 0 & 1 \\
Cerrada alis & 6 & 9 & 5 & 9 & 3 & 1 & 1 & 8 & 0 \\
Abierta alis/pul & 2 & 7 & 6 & 11 & 2 & 0 & 0 & 6 & 0 \\
Abierta pint/eng & 1 & 0 & 2 & 5 & 3 & 0 & 0 & 3 & 0 \\
Indet alis/pul & 11 & 8 & 1 & 21 & 2 & 0 & 0 & 9 & 0 \\
Cerrada pint/eng & 1 & 0 & 2 & 4 & 3 & 0 & 0 & 1 & 0 \\
Indet pint/eng & 1 & 0 & 5 & 3 & 3 & 0 & 0 & 2 & 0 \\
\hline \multicolumn{1}{c}{ TOTAL } & 26 & 34 & 42 & 68 & 22 & 1 & 1 & 30 & 1 \\
\hline
\end{tabular}

Tabla 8.11 Cantidad de piezas de las diferentes categorías morfo-estilísticas para los GP identificados. Ref: PINP: puco interior negro pulido, Indet: indeterminado, Casab: Casabindo, tric: tricolor, alis: alisado, pul: pulido, eng: engobado, pint: pintado.

En la tabla observamos que los GP 1, 2 y 4, que considerábamos en el Capítulo 6 como de composición semejante, aunque con variaciones en las proporciones de los 
componentes, sirvieron para modelar piezas que incluyen los Pucos Interior Negro Pulido y dos de las tres piezas con decoración Casabindo tricolor registradas. Estos tipos morfo-estilísticos definidos solo presentan esas clases de pastas. Además vemos que para estos mismos GP la mayor parte de las piezas identificadas corresponden a piezas cerradas, abiertas e indeterminadas con las superficies alisadas o pulidas. En menor cantidad se observa piezas con engobe o pintura. Además el GP 2 incluye algunas piezas que pueden ser poshispánicas (por la presencia de vitrificado) que presentaban abundante cuarzo, por lo que fueron incluidas en este grupo.

Por lo tanto, podemos apreciar que este conjunto de pastas no se empleó para modelar categorías concretas de piezas, pero si hay ciertas piezas que fueron sólo modeladas con esas pastas. Consideramos que eso puede obedecer a una tradición tecnológica, en la que se emplean ciertas recetas de pasta para elaborar tanto piezas abiertas y cerradas no decoradas como con ciertos acabados de superficie concretos. Si está tradición continúa hasta momentos posteriores al contacto e incluye la aplicación de vitrificados, es algo que consideramos poco probable, dado que los fragmentos que hemos analizado petrográficamente y que presentan vitrificado muestran inclusiones diferentes, como se mencionó en el Capítulo 6.

El GP 3, que considerábamos en el Capítulo 6 como comparable a las pastas descritas para el estilo Yavi, ha sido empleado para manufacturar piezas abiertas, cerradas e indeterminadas relacionables por sus acabados de superficie a ese estilo, como también piezas abiertas, cerradas e indeterminadas alisadas o pulidas, con o sin engobe. Por otro lado, un plato con apéndice ornitomorfo, del estilo Inka provincial, presenta ese mismo tipo de pasta.

Las piezas con acabados de superficie comparables a los del estilo Yavi también fueron manufacturadas, aunque en menor medida, con pastas del GP 5 y 8, que como mencionamos en el Capítulo 6, están relacionadas composicionalmente al GP 3, por lo que también podrían ser parte de una misma tradición tecnológica característica del norte de la puna, aunque con presencia en el sur, con piezas con pastas del GP 3. Además, los GP 5 y 8, al igual que el 3, se emplearon para elaborar piezas abiertas, cerradas e indeterminadas alisadas y pulidas, con o sin engobe. El GP 5 también incluye una pieza inka provincial, que consiste en una escudilla o plato con apéndice ornitomorfo, semejante a la del GP 3, y una pieza poshispánica. Cabe recordar que vimos que ese GP podía dividirse en dos porque habían sido incluidos en él fragmentos que a pesar de tener baja densidad de inclusiones, presentaban diferente composición 
(fragmentos pumíceos). Esos fragmentos poshispánicos, por lo tanto, no serían parte de la tradición tecnológica mencionada.

Por otro lado llama la atención que el GP 3 incluya un grupo de fragmentos que presenta decoración comparable a la del estilo Casabindo tricolor (ilustrado en la Figura $8.20 \mathrm{C}$ ). Es un grupo de fragmentos que presenta franjas negras y pequeños lunares blancos sobre engobe rojo, con pastas totalmente comparables a las del GP 3, incluyendo un corte delgado (Corte 39), que presenta una composición muy semejante a la de los otros cortes de ese GP.

Los GP 6, 7 y 9 incluyen una única pieza cada uno. Para los dos primeros, se trata de piezas cerradas de superficies alisadas, y para el tercero, de una pieza cerrada que podría corresponder a una botija, por las características del borde y el espesor de las paredes, como vimos anteriormente. Los tres GP, y las piezas correspondientes, serían poshispánicos.

La etapa de análisis microscópico también nos permitió realizar observaciones sobre las características de los engobes y vitrificados. Del total de los cortes analizados, trece presentaban engobe. Los engobes aparecen como una capa delgada más oscura que la pasta, bien oxidada, de color rojo oscuro, de espesor homogéneo, sin inclusiones (9:13) con algunas inclusiones muy finas (4:10). Eso puede ser resultado del uso de arcillas puras, sin inclusiones, obtenidas de esa forma o preparadas, a las que se agregó o ya poseían naturalmente óxido de hierro como pigmento.

Un corte (Corte 17) exhibía vitrificado, que en el microscopio se observa como una capa delgada en las superficies, de espesor variable, con algunas inclusiones pequeñas dentro, de color gris. Otro (Corte 64) mostraba una capa diferenciada, delgada y más oxidada que la pasta, con un límite difuso y no neto, como aparece en los engobes, por lo que pensamos que podría corresponder a un auto engobe o ser resultado del pulido que presenta este fragmento. En la Figura 8.25 se puede ver cómo se observa el engobe $(B)$ y el vitrificado $(A)$ en el microscopio petrográfico. 


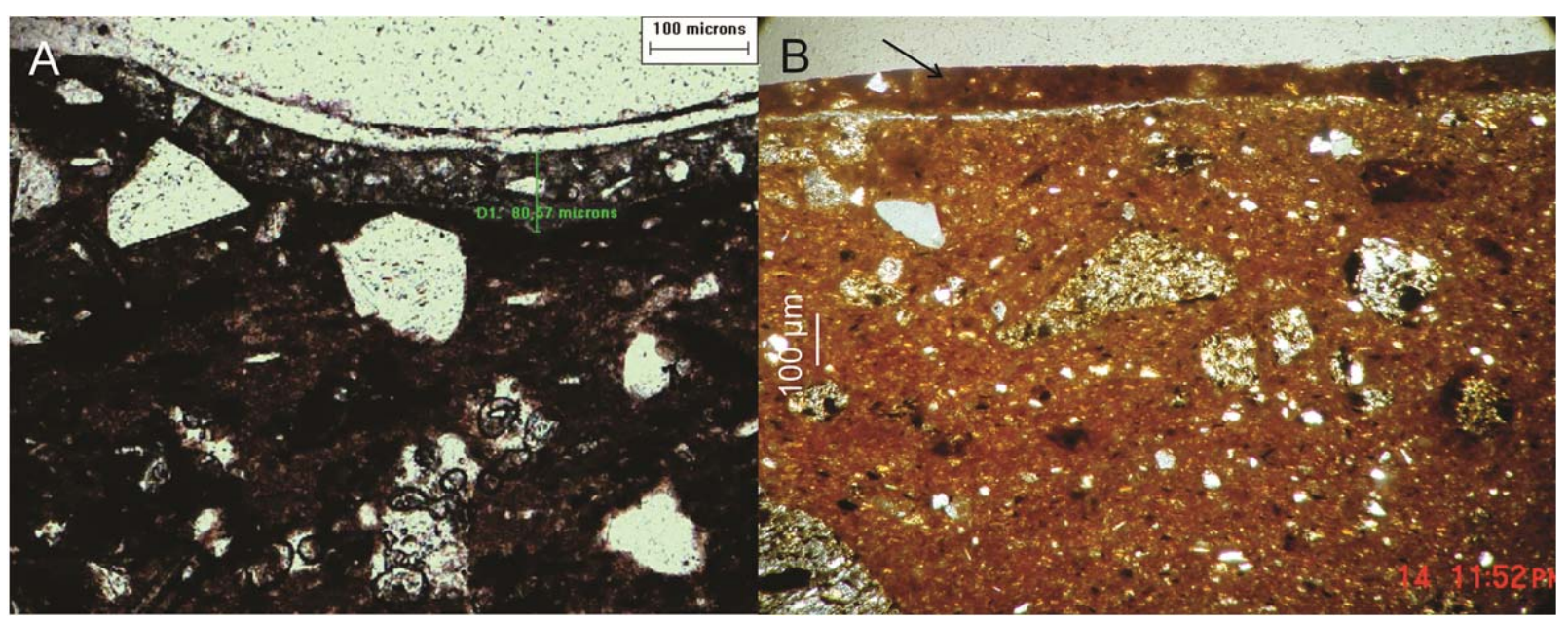

Figura 8.25 Fotomicrografías de secciones delgadas. A: fragmento con vitrificado (señalado en verde) a nicoles paralelos; B: fragmento con engobe rojo (indicado con la flecha) a nicoles cruzados.

\section{Discusión y conclusiones:}

En este capítulo hemos distinguido diferentes tipos de acabados de superficie, que incluyen el alisado, el pulido, el engobe, el engobe pulido, etc., y las marcas que pueden estar asociadas a los mismos. Vimos que tanto en los materiales de colección como en el fragmentario obtenido de excavación y recolección superficial, predominan las piezas con superficies alisadas. Sin embargo, entre las piezas de colección analizadas, cerca de la mitad presenta pintura o engobe; mientras que para el material fragmentario, el porcentaje de grupos de fragmentos o fragmentos no agrupados con esos tratamientos no supera el 34\%. Pero al distinguir los materiales fragmentarios del norte y sur de la puna, hemos observado que en los sitios de Santa Catalina la proporción de fragmentos pintados o engobados es mayor que en la cuenca sur de Pozuelos.

No hay una presencia diferenciada de los distintos tratamientos de superficie entre las morfologías analizadas, tanto en los materiales de colección como en el material fragmentario analizado. Entre las escudillas, los pucos con interior negro tienen su superficie interna pulida en la mayor parte de los casos. Los vasos chatos se presentan alisados, mientras que el resto de las escudillas pueden estar alisadas, aunque más frecuentemente se encuentran engobadas o pintadas, con o sin pulido. Estas piezas abiertas muestran estrías de alisado horizontales, resultado de la homogeneización de las superficies en estado plástico, que frecuentemente se localizan en el borde, como en 
los vasos chatos. Las escudillas pulidas muestran caras en ocasiones, que indicarían que el pulido se llevó a cabo con la arcilla cerca del estado cuero o un poco más seca (García Roselló 2010). Estas caras son mayormente horizontales y se localizan más frecuentemente en las superficies internas, aunque también pueden ser verticales $u$ oblicuas, especialmente en la superficie interna de escudillas del estilo Yavi.

Entre las piezas cerradas, la mayoría se encuentra alisada, aunque entre las vasijas de las piezas de colección hay un número importante de piezas pintadas o engobadas (43\%) y las botellas frecuentemente se encuentran pintadas o engobadas (70\%). Aquellos fragmentos que corresponderían a botellas para el material fragmentario, están mayormente alisadas o pulidas, y en menor cantidad engobadas o pintadas. Entre estos recipientes también predominan las estrías de alisado y las caras de pulido horizontales, aunque son más frecuentes las verticales y oblicuas que en las piezas abiertas, entre los materiales de colección. Entre las botellas, donde predominan las caras de pulido, las mismas pueden ser horizontales o verticales. Las estrías de alisado en el cuerpo son las que exhiben mayor variabilidad en sus direcciones, mientras que las caras de pulido verticales son frecuentes en los cuellos y cerca del borde o en el cuerpo la tendencia es horizontal.

Las piezas con pintura o engobe pueden ser monocromas, que es lo más frecuente ( $25 \%$ del total en las colecciones y entre el 23 y el $32 \%$ en el material fragmentario), e incluyen escudillas, vasijas y botellas. Les siguen las bicolores, que son mucho más frecuentes entre el material de colección (21\%) que para los materiales fragmentarios (2 a $3 \%$ ), correspondientes a escudillas y piezas cerradas. Las tricolores son poco frecuentes ( $3 \%$ entre las de colección y $4 \%$ entre los GF).

En general, se observó que no se empleaban recetas de pastas específicas para elaborar piezas con acabados de superficie particulares, sino que los distintos GP identificados muestran una diversidad de acabados de superficie. Pero los fragmentos alisados son más frecuentes entre los GP 1, 2, 4 y 7, mientras que para los GP 3 y 5 son más abundantes aquellos con engobe pulido. Los primeros GP son más abundantes en la cuenca sur de Pozuelos, mientras que los segundos dos son más frecuentes en la zona de Santa Catalina.

Los recipientes de colección con decoración relacionable a la Casabindo incluyen piezas globulares con líneas negras formando $V$ en la porción superior del cuerpo, con o sin puntos blancos, o con paneles reticulados verticales a los lados de las asas en una 
pieza levemente restringida, pucos con el interior negro pulido y una pieza con una morfología no clasificable, de carácter zoomorfa, comparable a otras descritas para el sitio Sorcuyo o Tucute, como mencionamos en el capítulo anterior, tanto en contextos funerarios como habitacionales (Casanova 1938, Albeck 1993). Entre los materiales fragmentarios, se hallaron 3 GF con decoración de puntos blancos y franjas negras sobre rojo. Todos estos materiales proceden de sitios ubicados en la porción sur de la puna que estamos analizando.

Las piezas con reticulado en negro sobre rojo son comunes en la puna de Jujuy (Casanova 1938; Albeck 2001), a pesar de que en el material fragmentario no hemos encontrado fragmentos reticulados. Los reticulados también son comunes en la quebrada de Humahuaca.

La cerámica tricolor con puntos blancos, denominada "Casabindo tricolor", también se ha denominado como "estilo Peñas Coloradas Grupos A y B", "Queta Tricolor" o "Puna tricolor". A fin de sistematizar la variabilidad presente en todos estos tipos, Zaburlín (2012) ha tenido en cuenta diferentes atributos, que le han permitido realizar una clasificación. La variabilidad presente en los materiales analizados por nosotros es relacionable a los tipos que identifica esta autora. La pieza subglobular del Instituto Tilcara procedente de Queta, el grupo de fragmentos de $\mathrm{RH}$ 2-1 y el de $\mathrm{RH}$ 19-7 presentan características que los hacen comparables al tipo que la autora ha definido como "Casabindo tricolor", del período tardío de la zona de Casabindo. En cambio, el de TA 1-1, con sus puntos pequeños y franjas negras anchas, es comparable al tipo que denomina "Queta tricolor", y que correspondería a momentos de la conquista inka. Todos corresponderían a piezas subglobulares cerradas con cuello cilíndrico (Zaburlín 2012).

Los dos GF con puntos blancos de Río Herrana presentan pastas características del sur de Pozuelos (GP 1 y 4). Sin embargo, el de Tabladitas se asocia muy bien a las pastas del GP 3, características del estilo Yavi, lo cual llama la atención. Quizás este tipo de producción especial, con un estilo decorativo más vinculable a los sitios arqueológicos del sur de la puna, pero una receta de pastas asociable a tradiciones tecnológicas del norte, este relacionada a la presencia imperial que menciona Zaburlín (2012) para este tipo de decoración de puntos más pequeños. Este caso nos ilustra lo que planteábamos en la discusión de los conceptos teóricos de que muchas veces un estilo decorativo puede enmascarar tradiciones tecnológicas diferentes, que pueden ser observables a través del análisis de pastas. 
Los pucos interior negro pulido son frecuentes en los materiales de colección y entre los fragmentos de excavación, para los sitios del sur de la puna. No se observan piezas completas ni fragmentos en sitios del norte de la puna, exceptuando uno procedente del contexto funerario excavado por Boman (1908) en Sansana, como vimos en el capítulo anterior. Además, en los sitios de la cuenca sur de Pozuelos que consideramos coloniales ( $\mathrm{CH}$ 25-1 y PA 22-Basurero) tampoco aparecen, aunque en la segunda ocupación de RH 10-1 hay un GF que probablemente corresponde a una de estas piezas. Entre los materiales fragmentarios, los mismos fueron modelados con pastas de los GP 1, 2 y 4, lo que concuerda con la asociación de estos tipos de pastas a la zona sur de la puna analizada.

Las piezas relacionables al estilo Yavi están presentes en todos los sitios representados por los materiales de colección, e incluyen botellas de cuerpo esférico, con engobe pulido y en ocasiones rostros modelados en el cuello y pintura en el cuerpo de la pieza; escudillas engobadas, con o sin pintura, que si está presente, se ubica en la superficie interna o en una franja cercana al borde en la externa; y vasijas, que pueden presentar decoración, en ocasiones en forma de franja en la superficie interna cercana al borde, o en el cuello en la superficie externa. Dos son polícromas, con pintura negra sobre engobe de dos colores. Los motivos pintados están hechos con líneas delgadas y campos rellenos, todos con pintura negra desleída, y todos han sido reconocidos en la literatura previa (Krapovickas y Aleksandrowicz 1986-87, Ávila 2006). Algunas de estas piezas han sido relevadas previamente por Ávila (2006) y la totalidad corresponden a los patrones morfológicos y decorativos que reconoció para estas piezas para momentos tardíos. Dos piezas de Sansana, que podrían corresponder a este estilo por sus pastas y características del engobe, presentan apéndices modelados zoomorfos tubulares.

Entre el material fragmentario, los fragmentos de este estilo se encuentran en los sitios del norte de la Puna (SC 3 y TC 2) y en algunos de la cuenca sur de Pozuelos (PA 6-1, RH 19-7 y TA 1-1). Un GF de RH 19-7 muestra motivos pintados en negro desleído.

Además, un grupo de fragmentos y un fragmento no agrupado presentan improntas textiles que se asocian al tipo Pozuelos con cuarzo del estilo Yavi, aunque ya ha sido destacado que este tipo tiene una distribución muy amplia, que excedería la ese estilo (Ávila 2009). Estos fragmentos presentan pastas de los GP 1 y 2, que los vincularían más a las tradiciones tecnológicas del sur de la puna que a las del norte. Este tipo de 
impronta puede estar asociado a gestos técnicos del modelado, como el uso de telas para girar la pieza durante ese proceso.

Dos piezas de colección podrían corresponder a estilos de la quebrada de Humahuaca, como hemos visto, una procedente del Pucará de Rinconada y otra de Doncellas. Además, hay otras dos piezas que también sugieren un origen no local, quizás de la vertiente oriental de los Andes, una de Doncellas, con corrugado en el cuello, que puede estar vinculada a la presencia inka, como se ha mencionado; y otra escudilla troncocónica del Pucará de Rinconada, con incisiones y un apéndice modelado. Es de destacar que estas cuatro piezas, que no corresponderían a manufacturas de la puna, se encuentren solo en esos dos sitios, Doncellas y el Pucará de Rinconada.

Las piezas asociables a momentos inkaicos son más frecuentes dentro del material de colección, e incluyen escudillas con asa lateral, una con cruces pintadas en el interior y otra con bandas anulares, también en la superficie interna; escudillas con apéndices ornitomorfos, y formas de botellas pequeñas denominadas puchuela o aisana (Bray 2003), con asa lateral.

Entre los fragmentos no agrupados, se encontraron dos apéndices ornitomorfos, seguramente correspondientes a escudillas o platos; un fragmento con decoración Inka Pacajes y otro Cusco Policromo. Todos proceden de los sitios del norte de la puna (SC 3 у TC 2).

Para el sur de Pozuelos, llama la atención de que en los sitios que hemos excavado no haya ningún fragmento que pueda vincularse a estilos inkaicos, a pesar de que se ha planteado que el Pucará de Rinconada tendría una ocupación de ese momento (Ruiz 1996) y que si se registran materiales de este tipo en las colecciones analizadas, especialmente en los sitios de Doncellas y Queta, además de un ejemplar con procedencia del Pucará. La presencia de esas piezas en contextos funerarios, sumado a la ocupación inka del pukará, y su ausencia en los domésticos rurales podría ser indicativa de que la presencia inka no afectó a la población local rural adyacente al pukará (Angiorama 2012). Si sumamos la ausencia de fragmentos inka en las recolecciones superficiales intensivas que hemos realizado en un área importante de la cuenca sur de Pozuelos (Angiorama 2012) se refuerza esa idea. 
Cuatro piezas con morfología de jarra o botella, procedentes del Pucará de Rinconada, muestran decoración pintada en rojo sobre el fondo de pasta y/o decoración al pastillaje que no ha sido registrado en otros sitios de la puna, ni en la literatura previa, exceptuando un asa de PA 22 que presenta el mismo tipo de motivo serpentiforme al pastillaje. Consideramos que esta presencia en un sitio colonial sumado a la morfología particular de estas piezas, que tienen relación con formas de recipientes (cerámicos o no) europeas, estarían indicando que tienen una temporalidad posterior al ingreso de los españoles al área.

Entre los materiales fragmentarios, aquellos que pueden vincularse a momentos poshispánicos a partir de sus acabados de superficie incluyen fragmentos con vitrificado de PA 22, SC 3 y TC 2. Cabe recordar que son muy poco frecuentes (<2\%) y corresponderían a piezas abiertas, de acuerdo a la morfología de los bordes presentes.

En síntesis, la integración de los análisis de los capítulos previos con el de la decoración nos muestra que una tradición tecnológica o un conjunto de modos de hacer relacionados engloba a las piezas cerradas y abiertas alisadas o pulidas, con los pucos interior negro pulido y algunas piezas de decoración tricolor, que fueron manufacturadas con ciertos tipos de pastas del sur de la cuenca de Pozuelos, y posiblemente de un área mayor. Otra tradición involucra a pastas del estilo Yavi, que además del GP 3 más característico incluye al GP 5 y 8, que sirvieron para hacer piezas abiertas y cerradas, muchas veces engobadas y pulidas, y en ocasiones con pintura negra desleída. También se empelaron estas pastas para realizar algunas piezas de morfología inkaica y una pieza con decoración estilo "Queta tricolor", con puntos blancos.

Además, un conjunto de piezas sería de momentos coloniales, algunas con grupos de pastas específicos y otras de colección sobre las que no se pudieron analizar las pastas pero que presentan morfologías y decoración particulares; y otro conjunto sería de origen no local, quizás algunas vinculadas a la influencia del inka.

Para finalizar, un punto a destacar es que se observa que los estilos decorativos, asociados a los grupos de pastas para el material fragmentario, característicos del norte de la puna se distribuyen en algunos sitios hacia el sur de la misma, tanto en contextos funerarios como en algunos domésticos. Sin embargo, no sucede lo mismo con aquellas piezas con decoración y morfologías que serían características del sur de la puna, asociada a ciertos tipos de pastas en el material fragmentario, que no aparecen en los sitios analizados en el norte de la puna, exceptuando el puco interior negro de Sansana 
ya mencionado. El comportamiento de estos materiales cerámicos pueden estar dando pautas sobre el tipo de interacciones que se generaron entre los grupos sociales que los manufacturaron y usaron, que probablemente fueron diferenciados o resultado de un valor desigual otorgado a los bienes de unos u otros, resultando en una distribución diferencial. Profundizar en este sentido requiere mayores análisis de contextos que involucren otras materialidades además de la cerámica. 


\section{9.}

\section{SECADO Y COCCIÓN. REPARACIÓN Y RECICLADO}

\section{El secado:}

Esta etapa de la manufactura cerámica es sumamente importante (Rye 1981), pero muy difícil de analizar a nivel arqueológico, dado que no quedan evidencias en los recipientes que den pautas sobre el mismo. En base a los atributos que hemos registrado, solo podemos decir que en la manufactura de algunas piezas cerradas hubo un tiempo de secado entre la confección de la porción inferior y la superior, deducido de las marcas de unión de segmentos descritas en el Capítulo 7. Estas incluyen el GF 1 de TA 1-1, consistente en una pieza cerrada de superficies alisadas, que presenta una rebaba en el punto de unión entre el cuerpo y el cuello, y cuatro piezas completas de colección, también cerradas, que muestran un punto de unión entre el cuerpo y el cuello. Consideramos que estas uniones probablemente se deban al modelado posterior del cuello, una vez que el cuerpo adquiere cierta dureza, mediante una etapa de secado de longitud indeterminada, lo que resulta en un secado diferencial de ambas porciones que se observa en estos puntos.

Además, podemos agregar que García Roselló (2010) documenta que ciertas técnicas de modelado y de acabado de superficie se implementan en determinados momentos del secado de la arcilla. Desde que la arcilla está en estado plástico, pueden reconocerse al menos dos etapas de secado, una que implica la pérdida progresiva de agua hasta llegar al estado cuero, en el que adquiere cierta firmeza y pierde sus capacidades plásticas; y otra que va del estado cuero al seco. El modelado solo puede ejecutarse mientras la arcilla está en estado plástico, mientras que los acabados de superficie deben realizarse entre el estado plástico y el de cuero. Una vez seco, el recipiente ya no puede modificarse en su forma ni pueden regularizarse sus superficies sin que se fracture, pero se pueden aplicar los engobes y pinturas (García Roselló 2010). En la Figura 9.1 esquematizamos estos procesos a partir de la información provista por el autor. 


\section{Arcilla plástica}

Arcilla seca

Alisado

Técnicas de desplazamiento de materia

Arcilla en estado cuero

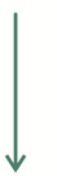

Pulido con caras

Pulido

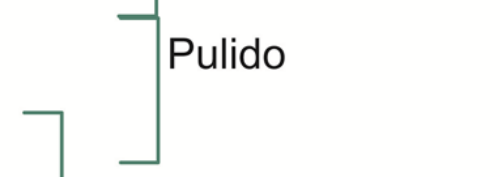

Engobe

Pintura

Figura 9.1 Esquema de los distintos pasos de acabado de superficie y el estado de la arcilla en el que tendrían lugar, en base a la información relevada por García Roselló (2010).

En este sentido, podemos afirmar que las piezas que presentan caras de pulido se pulieron con la arcilla cercana al estado cuero (García Roselló 2010). En todas las categorías morfoestilísticas definidas en los capítulos anteriores que presentan el pulido entre sus acabados de superficie se observan piezas pulidas con o sin caras, por lo que probablemente esa técnica se aplicó en diferentes momentos del proceso. En la Tabla 9.1 podemos ver para las piezas de colección cuántos recipientes de cada categoría presentan pulido con caras y sin caras, mientras que en la 9.2 se vuelca la misma información para el material fragmentario. Las categorías que no presentan ejemplares pulidos no se incluyeron.

\begin{tabular}{lccccccc}
\hline & Casabindo & PIN & $\begin{array}{c}\text { Inka } \\
\text { Pcial }\end{array}$ & Yavi & Humahuaca & Oriental & Indet \\
\hline $\begin{array}{l}\text { Pulido con } \\
\text { caras }\end{array}$ & 4 & 8 & 6 & 23 & 2 & 2 & 8 \\
$\begin{array}{l}\text { Pulido sin } \\
\text { caras }\end{array}$ & 0 & 0 & 0 & 2 & 1 & 0 & 2 \\
\hline
\end{tabular}

Tabla 9.1 Piezas pulidas con o sin caras para las distintas categorías morfoestilísticas reconocidas en el material de colección. Ref: PIN: puco interior negro; Poshisp:

poshispánico; Indet: indeterminado. 


\begin{tabular}{lcccccc}
\hline & Casabindo & PIN & Yavi & Inka & Indet Pul & $\begin{array}{c}\text { Indet } \\
\text { Eng/Pint }\end{array}$ \\
\hline $\begin{array}{l}\text { Pulido con } \\
\text { caras }\end{array}$ & 2 & 12 & 15 & 0 & 5 & 10 \\
Pulido & 1 & 10 & 6 & 2 & 17 & 16 \\
\hline
\end{tabular}

Tabla 9.2 Piezas pulidas con o sin caras para las distintas categorías morfoestilísticas reconocidas en el material fragmentario. Ref: PIN: puco interior negro; Poshisp: poshispánico; Indet: indeterminado; Alis: alisado; Pul: pulido; Eng: engobe; Pint: pintura.

Vemos que las piezas del estilo Casabindo que fueron pulidas presentan caras en la mayoría de los casos, tanto para el material fragmentario como para el de colección, por lo que probablemente está acción se llevó adelante con la arcilla próxima al estado cuero. Los pucos interior negro pulido en las colecciones presentan caras de pulido en todos los casos, mientras que en el material fragmentario solo las presentan cerca de la mitad. Los recipientes asignables al estilo Yavi, tanto abiertos como cerrados, presentan caras de pulido en la mayoría de los casos registrados en las colecciones y en los fragmentos. En cambio, los atribuibles a estilos inkaicos de colección exhiben estas caras en todos los casos, mientras que las del material fragmentario, no. Las piezas de origen no local registradas en las colecciones presentan caras de pulido en mayor número, al igual que las indeterminadas. Entre el material fragmentario, las indeterminadas pulidas mayormente no presentan caras, por lo que probablemente fueron pulidas con la arcilla más secas que en estado cuero, mientras que en las indeterminadas engobadas o pintadas el número de las que no presentan caras es algo mayor a las que sí.

El alisado, a fin de homogeneizar las irregularidades de las superficies debe tener lugar con la arcilla plástica hasta llegar al estado cuero. Este es un paso necesario para todos los recipientes cerámicos y puede irse realizando durante el modelado. En cambio, la pintura y el engobe pueden aplicarse con la arcilla seca (García Roselló 2010).

Fuera de esto, es poco lo que se puede agregar sobre el secado, excepto que seguramente se debieron tener ciertos cuidados para que el mismo no sea muy rápido y se fracturen las piezas, dado el clima extremadamente seco que caracteriza a la puna. 


\section{La cocción de los recipientes cerámicos:}

La cocción de los recipientes también es un aspecto difícil de abordar a partir de los materiales finalizados. Estos no nos permiten precisar qué tipos de estructuras se usaron o qué combustibles. Quizás la falta de hallazgos de estructuras de combustión este dando cuenta de la existencia de cocciones a cielo abierto o en estructuras muy rudimentarias, tal como se hace y se hacía en tiempos recientes en la puna y el altiplano de Bolivia (ver Capítulo 10).

El material analizado y las técnicas a nuestro alcance nos permitieron realizar observaciones sobre el tipo de atmósfera de cocción mediante la observación de fracturas frescas en el material fragmentario ${ }^{13}$. Para las piezas de colección, solo pudimos apreciar los colores de las superficies, que pueden dar algún indicio. Sobre las fracturas frescas hemos registrado la uniformidad del color y la presencia de núcleos, mediante las siguientes categorías: color uniforme, no uniforme neto, con estructura bicapa o tricapa; y no uniforme difuso, con estructura bicapa o tricapa (Figura 9.2). Sobre esta base, hemos distinguido cuatro atmósferas de cocción: oxidante completa, vinculada a colores rojizos y marrones uniformes; oxidante incompleta, con presencia de núcleo o variaciones de color; reductora, con colores grises oscuros y negros; y exterior oxidante e interior reducido, con color no uniforme de estructura bicapa, que consideramos un tipo de cocción con valor local.

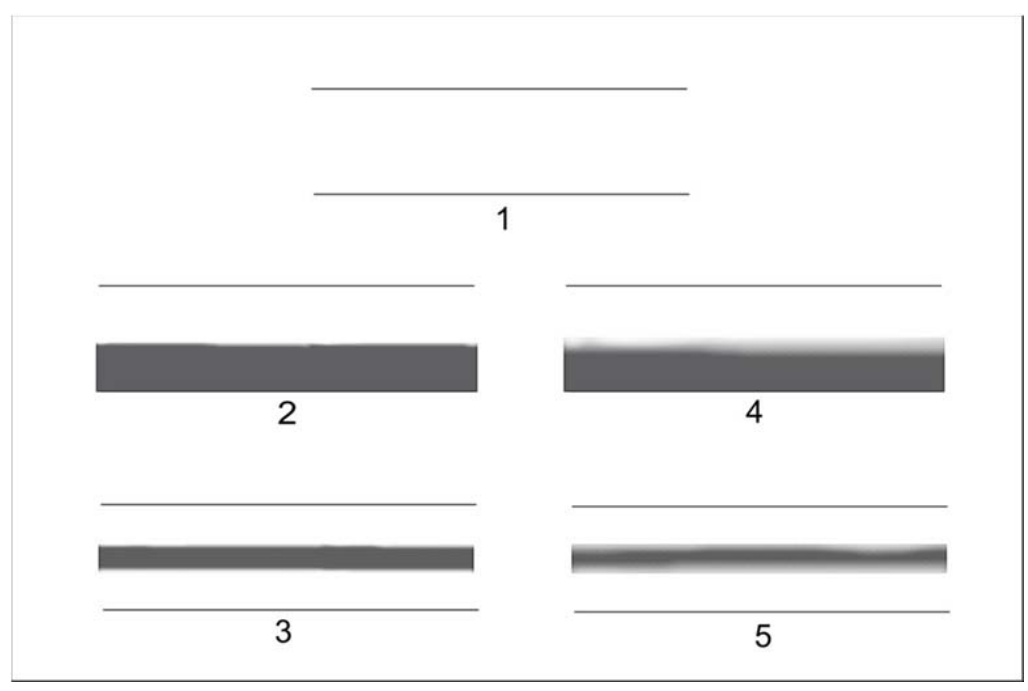

\footnotetext{
${ }^{13}$ Igualmente, cabe señalar que la fractura representa solo una pequeña porción del recipiente completo, por lo que la atmósfera puede variar a lo largo del perfil.
} 
Figura 9.2 Categorías de distribución de color en fracturas frescas (reelaborado de Rye 1981 y de Zagorodny s.f.). 1: Uniforme. 2: No uniforme neto, estructura bicapa y 3: estructura tricapa. 4: No uniforme difuso, estructura bicapa y 4: estructura tricapa.

\section{Observaciones sobre el material fragmentario:}

En el análisis de las variaciones de color entre las fracturas frescas analizadas, en la Figura 9.3 vemos que la mayor parte de las fracturas muestra un color uniforme, seguido por aquellas que presentan color no uniforme, de estructura difusa bicapa y en menor cantidad de estructura difusa tricapa. Los fragmentos que presentan color no uniforme de estructura neta, tanto bicapa como tricapa son muy escasos.

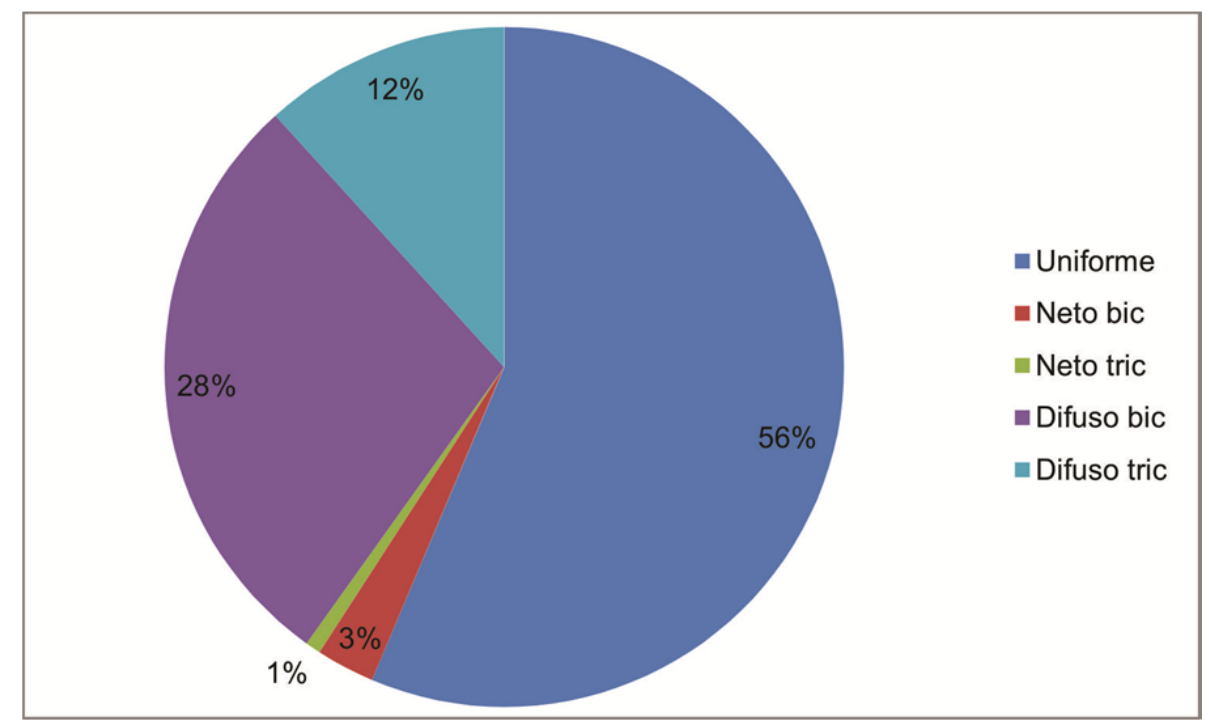

Figura 9.3 Distribución del color para las fracturas frescas analizadas en lupa binocular. Ref.: bic: bicapa; tric: tricapa.

Por otro lado, al analizar cómo se distribuyen los fragmentos con estos tipos de colores entre los distintos sitios analizados, vemos que en todos predominan las fracturas de color uniforme, pero en proporciones variables (Tabla 9.3). En el basurero de Pan de Azúcar, son algo más abundantes las fracturas con color no uniforme difuso bicapa, y en algunos sitios los fragmentos con esa variación de color son casi iguales a los que presentan color uniforme ( $\mathrm{CH}$ 25-2; RH 19-7 Niveles 1 y 2). En algunos sitios las fracturas presentan mayor proporción de color uniforme (especialmente en RH 19-1 y TC 2). 


\begin{tabular}{lccccc}
\hline & Uniforme & Neto bic & Neto tric & Difuso bic & Difuso tric \\
\hline CH 25-1 & $53.7 \%$ & $0.0 \%$ & $0.0 \%$ & $31.7 \%$ & $14.6 \%$ \\
CH 25-2 & $46.2 \%$ & $7.7 \%$ & $0.0 \%$ & $42.3 \%$ & $3.8 \%$ \\
PA 6-1 & $54.7 \%$ & $5.0 \%$ & $0.0 \%$ & $30.9 \%$ & $9.4 \%$ \\
PA 22 Basurero S1 & $39.7 \%$ & $2.7 \%$ & $1.4 \%$ & $40.4 \%$ & $15.8 \%$ \\
RH 2-1 & $56.8 \%$ & $2.7 \%$ & $0.0 \%$ & $35.1 \%$ & $5.4 \%$ \\
RH 10-1 Nivel 1 & $33.3 \%$ & $22.2 \%$ & $0.0 \%$ & $22.2 \%$ & $22.2 \%$ \\
RH 10-1 Nivel 2 & $60.5 \%$ & $5.3 \%$ & $0.0 \%$ & $18.4 \%$ & $15.8 \%$ \\
RH 19-1 & $66.7 \%$ & $0.0 \%$ & $0.0 \%$ & $33.3 \%$ & $0.0 \%$ \\
RH 19-7 Nivel 1 & $41.8 \%$ & $5.9 \%$ & $2.6 \%$ & $38.6 \%$ & $11.1 \%$ \\
RH 19-7 Nivel 2 & $38.9 \%$ & $0.0 \%$ & $0.0 \%$ & $38.9 \%$ & $22.2 \%$ \\
TA 1-1 Nivel 1 & $58.8 \%$ & $0.0 \%$ & $0.0 \%$ & $33.3 \%$ & $7.8 \%$ \\
SC 3 & $58.7 \%$ & $1.1 \%$ & $1.1 \%$ & $22.2 \%$ & $16.9 \%$ \\
TC 2 & $70.1 \%$ & $1.4 \%$ & $0.3 \%$ & $19.2 \%$ & $9.1 \%$ \\
\hline
\end{tabular}

Tabla 9.3 Porcentaje de fracturas frescas con las diferentes variaciones de la distribución de color registrada en lupa binocular por sitio. Ref.: bic: bicapa; tric: tricapa.

También tuvimos en cuenta si las diferentes variaciones en el color de las pastas son más frecuentes en algún grupo de pastas u otro, información que se puede ver volcada porcentualmente en la Tabla 9.4. Las pastas del GP 3 y 5 son las que presentan mayor porcentaje de colores uniformes, mientras que las del 6 y 8 presentan abundantes fragmentos con colores difuso bicapa y, en un porcentaje algo menor, las del 2 y el 4 también. El GP 6 correspondería a una única pieza, por lo que la presencia de fragmentos con color uniforme y difuso bicapa nos permite ver que a lo largo del perfil de una misma pieza se pueden dar variaciones, producto seguramente de atmósferas de cocción poco homogéneas. EI GP 9, probablemente correspondiente a una única pieza, presenta color uniforme en todos los fragmentos.

\begin{tabular}{cccccc}
\hline & Uniforme & Neto bic & Neto tric & Difuso bic Difuso tric \\
\hline GP 1 & $50.5 \%$ & $6.5 \%$ & $0.0 \%$ & $29.0 \%$ & $14.0 \%$ \\
GP 2 & $44.4 \%$ & $2.0 \%$ & $0.7 \%$ & $38.4 \%$ & $14.6 \%$ \\
GP 3 & $72.0 \%$ & $0.5 \%$ & $1.4 \%$ & $17.3 \%$ & $8.9 \%$ \\
GP 4 & $47.9 \%$ & $3.7 \%$ & $0.5 \%$ & $35.4 \%$ & $12.4 \%$ \\
GP 5 & $79.1 \%$ & $3.7 \%$ & $1.5 \%$ & $12.7 \%$ & $3.0 \%$ \\
GP 6 & $50.0 \%$ & $0.0 \%$ & $0.0 \%$ & $50.0 \%$ & $0.0 \%$ \\
GP 7 & $30.4 \%$ & $4.3 \%$ & $4.3 \%$ & $52.2 \%$ & $8.7 \%$ \\
GP 8 & $52.1 \%$ & $1.1 \%$ & $0.0 \%$ & $29.3 \%$ & $17.6 \%$ \\
GP 9 & $100.0 \%$ & $0.0 \%$ & $0.0 \%$ & $0.0 \%$ & $0.0 \%$ \\
\hline
\end{tabular}

Tabla 9.4 Porcentajes de fracturas frescas con las diferentes variaciones de la distribución de color registrada en lupa binocular para cada grupo de pasta. Ref.: bic:

bicapa; tric: tricapa. 
Las variaciones de color son resultado de las atmósferas de cocción, y en base a esa distribución, junto con los colores presentes, determinamos para las fracturas frescas las diferentes atmósferas de cocción mencionadas anteriormente. Para el total de la muestra fragmentaria analizada, podemos ver qué proporción de fragmentos presenta cada una de las atmósferas identificadas en la Figura 9.4. Se observa un predominio importante de las atmósferas oxidantes y, dentro de las mismas, las oxidantes incompletas son algo más abundantes que las completas.

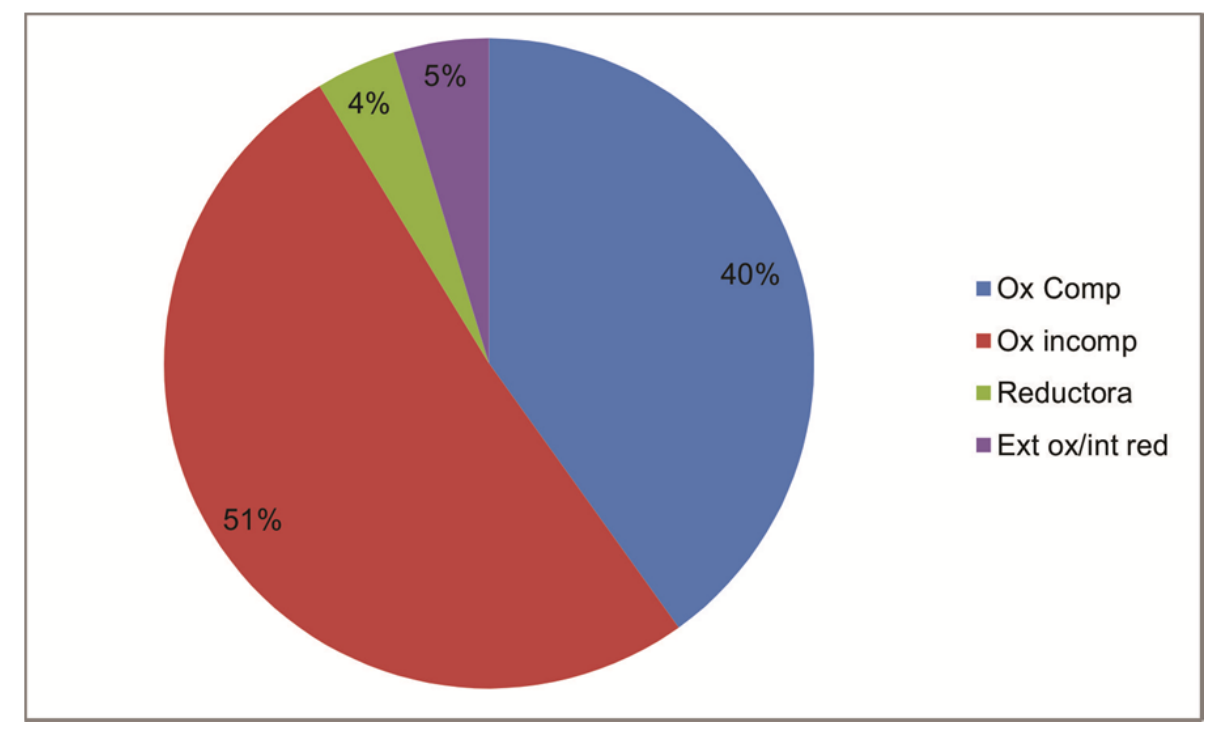

Figura 9.4 Proporción de fracturas frescas con cada uno de los tipos de atmósfera de cocción identificadas. Ref.: Ox: oxidante; comp: completa; incomp: incompleta; Ext: exterior; int: interior; red: reducido.

Estos tipos de cocción muestran variaciones entre los diferentes sitios analizados, que se vuelcan en la Tabla 9.5. En buena parte de los sitios de la cuenca sur de Pozuelos (CH 25-1 y 2; PA 6-1; PA 22-Basurero; RH 19-1; RH 19-7 niveles 1 y 2 y TA 11) predominan los fragmentos correspondientes a piezas cocidas en atmósferas oxidantes incompletas. En cambio, en RH 2-1 y en el nivel 2 de RH 10-1, predominan aquellos correspondientes a piezas cocidas en atmósferas oxidantes completas. En los sitios de Santa Catalina, las fracturas con cocciones oxidantes completas son abundantes, especialmente en TC 2. En todos los sitios de Pozuelos, los fragmentos que presentan el exterior oxidante y el interior reducido (que corresponden mayormente a pucos con el interior negro, como veremos a continuación) muestran un porcentaje variable, adquiriendo cierta importancia en el nivel 1 de RH 10-1, que es la ocupación 
datada en momentos coloniales. En cambio, en los otros dos sitios coloniales de Pozuelos analizados están ausentes, al igual que en los sitios del área de Santa Catalina. Los fragmentos cocidos en atmósfera reductora están presentes en escaso número en todos los sitios.

\begin{tabular}{lcccc}
\hline & Ox Comp & Ox incomp & Reductora & Ext oxlint red \\
\hline CH 25-1 & $24.4 \%$ & $63.4 \%$ & $9.8 \%$ & $2.4 \%$ \\
CH 25-2 & $15.4 \%$ & $80.8 \%$ & $3.8 \%$ & $0.0 \%$ \\
PA 6-1 & $33.1 \%$ & $59.0 \%$ & $1.4 \%$ & $6.5 \%$ \\
PA 22 Basurero & $13.0 \%$ & $76.7 \%$ & $10.3 \%$ & $0.0 \%$ \\
RH 2-1 & $51.4 \%$ & $35.1 \%$ & $5.4 \%$ & $8.1 \%$ \\
RH 10-1 Nivel 1 & $30.0 \%$ & $30.0 \%$ & $10.0 \%$ & $30.0 \%$ \\
RH 10-1 Nivel 2 & $57.9 \%$ & $31.6 \%$ & $2.6 \%$ & $7.9 \%$ \\
RH 19-1 & $30.8 \%$ & $46.2 \%$ & $15.4 \%$ & $7.7 \%$ \\
RH 19-7 Nivel 1 & $24.2 \%$ & $45.8 \%$ & $8.5 \%$ & $21.6 \%$ \\
RH 19-7 Nivel 2 & $33.3 \%$ & $38.9 \%$ & $11.1 \%$ & $16.7 \%$ \\
TA 1-1 & $25.5 \%$ & $68.6 \%$ & $2.0 \%$ & $3.9 \%$ \\
SC 3 & $44.4 \%$ & $54.0 \%$ & $1.6 \%$ & $0.0 \%$ \\
TC 2 & $61.5 \%$ & $37.9 \%$ & $0.5 \%$ & $0.0 \%$ \\
\hline
\end{tabular}

Tabla 9.5 Porcentaje de fracturas frescas que exhiben los diferentes tipos de cocción identificados para cada uno de los sitios analizados. Ref.: Ox: oxidante; comp: completa; incomp: incompleta; Ext: exterior; int: interior; red: reducido.

Otro aspecto a considerar, al igual que lo hicimos con las variaciones de color, es qué relación muestran estas atmósferas de cocción con los grupos de pastas identificados. En la Figura 9.5 se pueden observar las proporciones de las atmósferas de cocción para cada GP en un gráfico de barras. Se observa que los GP 1, 2, 4 y 5 muestran todos los tipos de cocciones identificados, aunque en el GP 5 la cantidad de fragmentos correspondientes a piezas cocidas en atmósferas reductoras o con el exterior oxidante y el interior reducido son muy escasos. Además en los GP 1, 2 y 4 son más frecuentes los fragmentos que muestran colores de atmósferas oxidantes incompletas que completas. En cambio, en los GP 3 y 5, los fragmentos con cocciones oxidantes completas son más abundantes que los que presentan cocciones incompletas. A estas diferencias se suma que en estos GP los fragmentos con exterior oxidado e interior reducido adquieren una importancia algo mayor que en el resto de los GP, en los que no se encuentran presentes o son muy escasos. En el caso del GP 8, hay más fragmentos con cocción oxidante incompleta que completa. 
En el GP 6 los fragmentos con cocción reductora son algo más importantes que en los otros GP, pero como mencionamos anteriormente, todos los fragmentos con este tipo de pasta corresponden a una misma pieza. Estas diferencias, entonces, obedecerían a variaciones en la atmósfera en un mismo evento de cocción, probablemente resultado del contacto directo del recipiente con el combustible. En cambio, para el GP 9, que también correspondería a una misma pieza, la cocción es oxidante completa en todos los fragmentos, lo que mostraría un mejor control de la atmósfera de cocción para este recipiente.

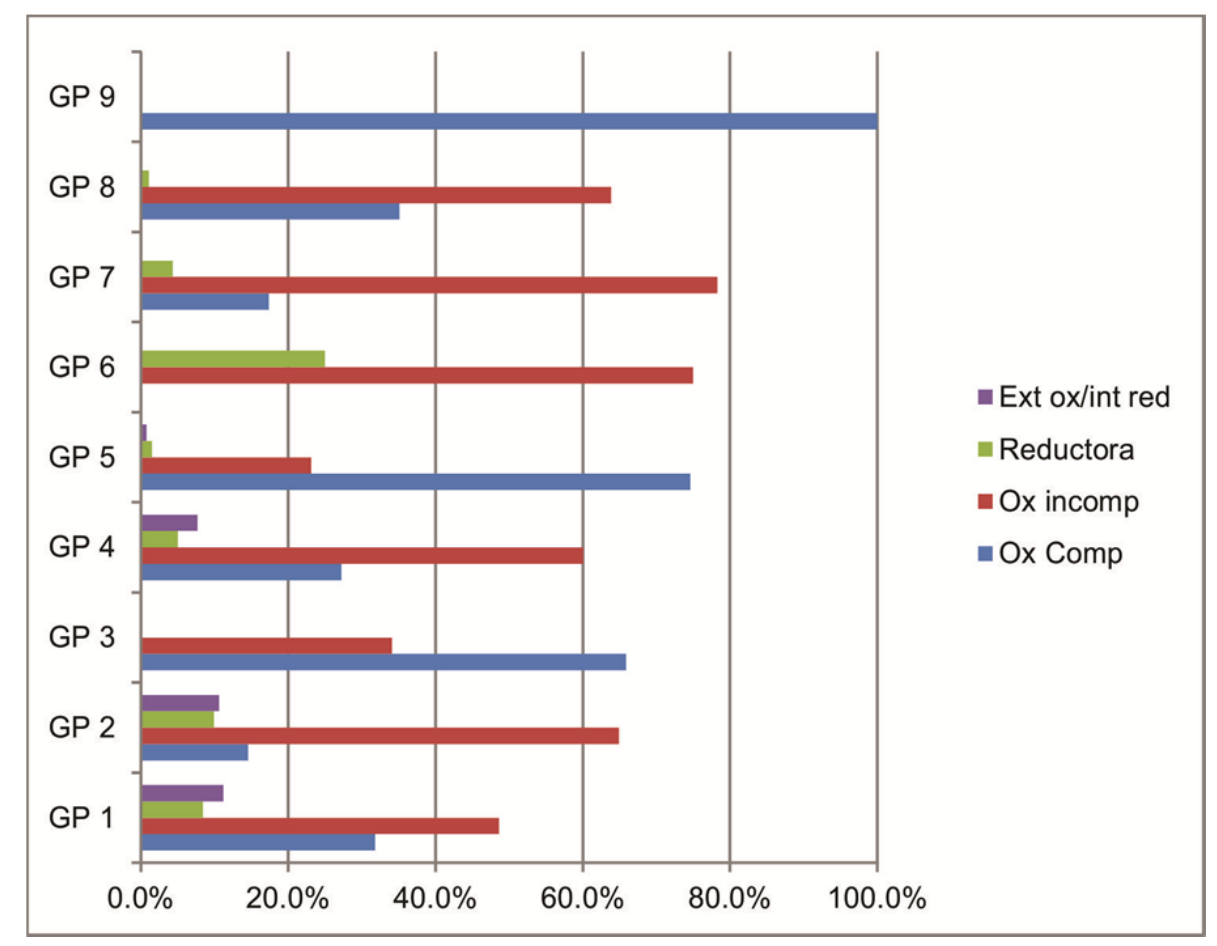

Figura 9.5 Porcentaje de fragmentos que exhiben los diferentes tipos de atmósferas de cocción identificadas para cada grupo de pasta. Ref.: Ox: oxidante; comp: completa; incomp: incompleta; Ext: exterior; int: interior; red: reducido.

Otro punto interesante a analizar en lo referente a la cocción es si existe algún tipo de relación entre los tipos de atmósferas y las categorías morfo-estilísticas que identificamos en los capítulos anteriores. En la Tabla 9.6 se puede ver qué cantidad de piezas, contabilizadas a partir de los grupos de fragmentos y los fragmentos no agrupados correspondientes a bordes, presentan los diferentes tipos de cocción para cada una de estas categorías. A partir de la tabla, podemos ver que los pucos interior negro pulido muestran atmosferas mayormente oxidantes en el exterior y reducidas en el interior. Esto puede deberse a que este tipo de piezas se hayan cocido con el borde 
hacia abajo, resultando en una falta de oxígeno en la parte interna de los mismos, lo que se refuerza porque muchas veces se observa que el color gris oscuro o negro afecta a parte de la superficie externa cercana al borde. Algunos de estos pucos también presentan atmósferas reductoras, lo que en parte también puede ser resultado de que se observaron fracturas frescas cercanas al borde, que presentarían pastas más reducidas por las condiciones mencionadas antes.

\begin{tabular}{lcccc}
\hline & Ox Comp & Ox incomp Reductora Ext ox/int red \\
\hline PINP & 0 & 0 & 6 & 19 \\
Yavi cerrada & 3 & 3 & 0 & 0 \\
Yavi abierta & 9 & 4 & 0 & 0 \\
Yavi indet & 4 & 0 & 0 & 0 \\
Casab tricolor & 2 & 1 & 0 & 0 \\
Inka & 2 & 0 & 0 & 0 \\
Poshisp & 4 & 1 & 0 & 0 \\
Abierta alis/pul & 7 & 20 & 4 & 1 \\
Abierta pint/eng & 6 & 7 & 0 & 0 \\
Cerrada alis & 13 & 25 & 2 & 0 \\
Cerrada Pint-Eng & 7 & 4 & 0 & 0 \\
Indet alis/pul & 16 & 29 & 5 & 2 \\
Indet pint/eng & 10 & 4 & 0 & 0 \\
\hline
\end{tabular}

Tabla 9.6 Cantidad de piezas por categoría morfo-estilística que exhiben los diferentes tipos de cocción identificados. Ref.: Ox: oxidante; comp: completa; incomp: incompleta;

Ext: exterior; int: interior; red: reducido.

Las piezas abiertas y de morfología indeterminada, relacionables al estilo Yavi, muestran predominantemente cocciones en atmósferas oxidantes completas, mientras que para las cerradas, la mitad presenta ese tipo de cocciones, y la otra mitad, oxidantes incompletas. Los fragmentos que corresponderían a momentos inkaicos son los dos fragmentos de borde con apéndices ornitomorfos, de pasta Yavi, que muestran cocciones oxidantes completas.

Aquellos fragmentos de recipientes con decoración comparable a la tricolor de la zona de Casabindo, correspondientes a tres GF, muestran atmósferas de cocción oxidantes completas e incompletas. En cambio, los que corresponderían a piezas poshispánicas, porque presentan vitrificado o estrías de torno, corresponderían en su mayor parte a recipientes cocidos en atmósferas oxidantes completas. 
Entre las piezas que no pueden relacionarse a ningún estilo, las abiertas, cerradas y de morfología indeterminada que presentan las superficies únicamente alisadas o pulidas, muestran un porcentaje elevado (entre 56 y 63\%) de cocciones en atmósferas oxidantes incompletas, y en menor cantidad atmósferas completas (entre 22 y 33\%). Además, algunos fragmentos muestran atmósferas reductoras (entre 5 y 13\%). Las abiertas alisadas también exhiben, en bajo número (3\%), el exterior oxidado y el interior reducido. Por otro lado, las abiertas, cerradas y de morfología indeterminada que presentan pintura o engobe, muestran un porcentaje más importante de cocciones oxidantes completas. Entre las abiertas (46\%) es algo menor que entre las cerradas e indeterminadas (64 y $71 \%$ respectivamente). Entre estos recipientes, además, no hay fragmentos con cocciones reductoras ni con el interior reducido. Creemos que estos resultados pueden estar evidenciando un mayor control en las atmósferas de cocción de los recipientes que presentaban engobe y/o pintura, probablemente para mantener un color uniforme de esos pigmentos.

Observaciones sobre el material de colección:

En el caso de las piezas de colección, en muchas no pudo registrarse el color de la pasta, dado que son piezas completas. Sin embargo, en algunos casos si estaban fracturadas y se pudieron observar algunas variaciones de color. De todas formas, clasificamos la cocción en estos materiales a partir de los colores de superficie y de las fracturas, si se observaban, en tres tipos: oxidante (completa e incompleta), reductora y exterior oxidante e interior reducido. En base a esta clasificación, analizamos su distribución en los diferentes sitios de donde procede el material relevado, y la relación con las distintas categorías morfo-estilísticas de los capítulos previos.

Del total de piezas analizadas, el 78\% (76:97) presentan cocción oxidante (completa o incompleta), mientras que solo el 8\% (8:97) presenta cocción reductora y el 14\% (13:97) restante, presenta el exterior oxidado y el interior reducido. Estas proporciones generales son comparables a aquellas observadas para el material fragmentario.

Por otro lado, entre los diferentes sitios analizados se observan algunas diferencias en las distribuciones de las cocciones. Para los sitios que presentan mayor cantidad de piezas, Doncellas presenta una abundancia de piezas cocidas en atmósfera reductora algo mayor que en los otros sitios, mientras que en Queta son más abundantes las que presentan el exterior oxidante y el interior reducido. El pucará de Rinconada se acerca 
más a las proporciones de la muestra general. Los sitios con pocas piezas presentan mayormente recipientes cocidos en atmósferas oxidantes, excepto Sayate, donde la mitad $(n=2)$ presentan el exterior oxidado y el interior reducido.

\begin{tabular}{lccc}
\hline & $\begin{array}{c}\text { Oxidante } \\
\text { complincomp }\end{array}$ & Reductora & Ext ox/int red \\
\hline Doncellas & 17 & 5 & 2 \\
Cochinoca & $70.8 \%$ & $20.8 \%$ & $8.3 \%$ \\
Queta & 2 & 0 & 0 \\
& $100 \%$ & 1 & 7 \\
Rinconada & 28 & $2.8 \%$ & $19.4 \%$ \\
Pucará de Rinconada & $77.8 \%$ & 0 & 0 \\
Sayate & 1 & 1 & 1 \\
Sansana & $100 \%$ & $6.7 \%$ & $6.7 \%$ \\
Yavi Chico & 13 & 0 & 2 \\
& $26.7 \%$ & 0 & $50 \%$ \\
Puna de Jujuy & $50 \%$ & 0 & 1 \\
\hline
\end{tabular}

Tabla 9.7 Cantidades y porcentajes de piezas para cada tipo de cocción por sitio analizado. Ref.: comp: completa; incomp: incompleta; Ext: exterior; int: interior; ox: oxidante; red: reducido.

Asimismo, dentro de esta muestra de materiales, las diferentes categorías morfoestilísticas presentan determinados tipos de cocciones, como vimos para el material fragmentario. En la Tabla 9.8 se aprecia como los recipientes con morfología o decoración vinculable al estilo Casabindo están cocidos en atmósferas oxidantes, exceptuando un caso, que presenta las superficies reducidas o que han sido expuestas al fuego de manera uniforme con posterioridad a la cocción, quedando todo el recipiente negro (Figura 9.6 A). Los vasos chatos también presentan cocciones oxidantes, completas o incompletas, en mayor cantidad, aunque en un par de casos se observó el exterior oxidado y el interior reducido; como en los pucos interior negro pulido, que mayormente presentan ese tipo de cocción, a veces con los colores negros afectando parte del borde (Figura 9.6 B). Entre las morfologías inkaicas, se observa una incidencia importante de cocciones reducidas, aunque las formas de escudilla presentan más ejemplares cocidos en atmósfera oxidante. Las piezas vinculables al estilo Yavi han sido cocidas en todos los casos en atmósferas oxidantes, completas o incompletas; al igual que aquellas que relacionamos a estilos de la quebrada de Humahuaca y las que podrían ser de cronología poshispánicas. Por otro lado, las relacionables a un origen de la vertiente oriental de los Andes por su decoración plástica presentan cocciones 
reductoras. Entre las que no pudieron ser clasificadas en los estilos anteriores, que son numerosas, la mayor parte presentan cocciones oxidantes, mientras que dos ejemplares, correspondientes a piezas abiertas, presentan el exterior oxidante y el interior reducido.

\begin{tabular}{lccc}
\hline & $\begin{array}{c}\text { Oxidante } \\
\text { complincomp }\end{array}$ & Reductora & Ext ox/int red \\
\hline Casabindo & 12 & 1 & 0 \\
Vaso chato & 5 & 0 & 2 \\
PINP & 0 & 1 & 9 \\
Plato inka & 5 & 2 & 0 \\
Puchuela & 0 & 2 & 0 \\
Yavi abiertas & 10 & 0 & 0 \\
Yavi cerrada & 15 & 0 & 0 \\
Humahuaca & 3 & 0 & 0 \\
Oriental & 0 & 2 & 0 \\
Poshisp & 5 & 0 & 0 \\
Ordinario e Indet & 21 & 0 & 2 \\
\hline
\end{tabular}

Tabla 9.8 Cantidad de recipientes de las colecciones de museo que presentan diferentes atmósferas de cocción, por sitio.
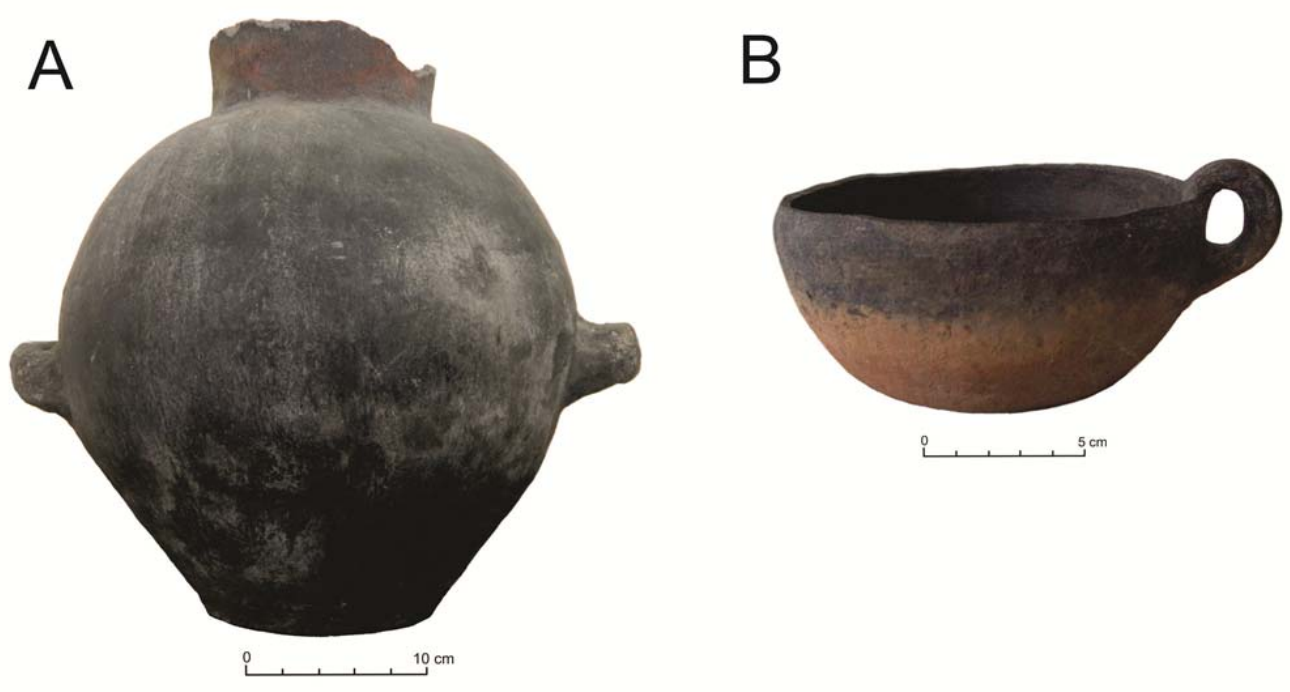

Figura 9.6 Piezas de colección y atmósferas de cocción. A: Pieza de morfología Casabindo del Museo Quai Branly con superficies reducidas, procedencia Puna de Jujuy (IT-2478). B: puco interior negro pulido, procedente de Queta y depositado en el Instituto Tilcara (IT-2057), con parte del borde con colores de atmósferas reductoras. 
Por otro lado, en muchas de las piezas relevadas en las colecciones se observan manchas oscuras, que se relacionan a variaciones en la atmósfera de cocción, posiblemente por estar en contacto con el combustible. Un buen número de las piezas de morfología Casabindo (8:13) presentan estas manchas y entre los vasos chatos, algunos ejemplares también (2:7). Entre las piezas vinculables al estilo Yavi, son más escasos los recipientes que muestran manchas (6:25), al igual que entre los pucos interior negro pulido (1:10). Las morfologías vinculables a momentos inkaicos no presentan manchas, al igual que las piezas que serían de origen no local, aunque aquellas que serían orientales están cocidas en atmósferas reductoras, que son oscuras en su totalidad. Para las piezas que no pudieron clasificarse en las categorías anteriores, algunas presentan manchas de cocción (9:23).

\section{Evidencias de reparación y reciclado:}

Además de los recipientes cerámicos y fragmentos de recipientes analizados, se hallaron algunos objetos manufacturados a partir de fragmentos e indicios de modificaciones y reparaciones en algunos recipientes, tanto en el material fragmentario como entre las piezas de colección, que son acciones posteriores a las de la cadena de manufactura que venimos abordando, pero que tienen que ver con gestos técnicos y con las historias de vida de los recipientes bajo análisis y merecen mencionarse.

Para los materiales que muestran indicios de reparación o reciclado, entre el material fragmentario, en algunos GF y FNA se observaron orificios, de sección cilíndrica o bicónica, ejecutados sobre la pasta ya cocida. Entre los FNA de $\mathrm{CH} 25-2$, un fragmento de borde presenta una perforación cilíndrica de $5 \mathrm{~mm}$ de diámetro. En RH 19-7, un fragmento de cuerpo del GF 9 exhibe un orificio de $5 \mathrm{~mm}$ de diámetro de forma bicónica, mientras que otro de borde del GF 14 muestra un orificio de sección cilíndrica de $4 \mathrm{~mm}$ de diámetro, y un último fragmento no agrupado presenta un orificio de sección bicónica de $6 \mathrm{~mm}$. En la Figura 9.7 A y B se pueden observar dos de estos fragmentos con perforaciones. Las mismas pudieron ser hechas para reparación o para confeccionar torteros, que quizás no llegaron a concluirse, aunque orificios similares con las secciones relevadas, han sido documentados en otros sitios del NOA en la reparación de recipientes que se han fracturado durante o después de la cocción (Balesta y Zagorodny 2002). 


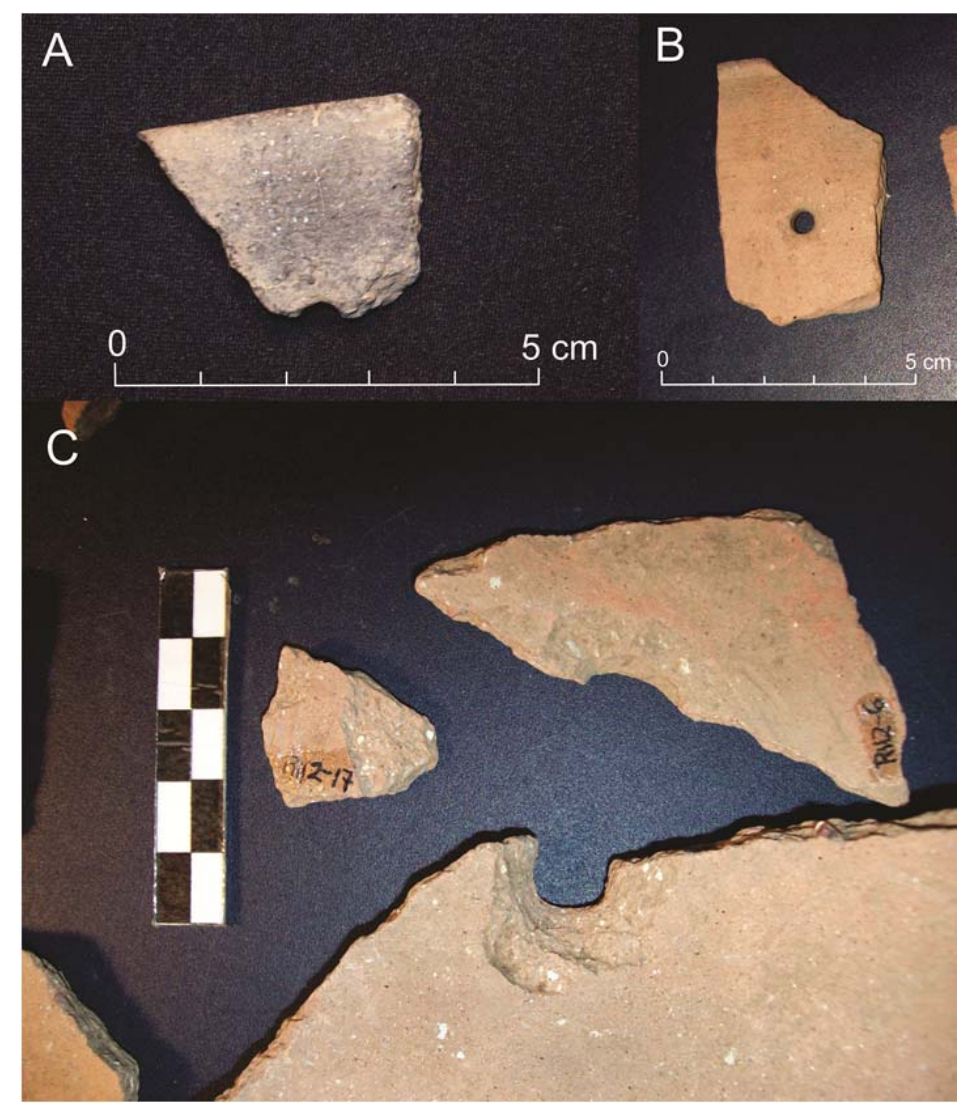

Figura 9.7 Fragmentos con perforaciones. A: fragmento de borde con perforación de $\mathrm{CH}$ 25-2; B: fragmento de borde con perforación de RH 19-7. C: fragmentos perforados de RH 2-1.

Se registraron perforaciones de gran tamaño, que no serían orificios de reparación, tanto en el material fragmentario, como en las piezas de colección analizadas. Tres fragmentos del GF 2 de RH 2-1 (Figura 9.7 C), con decoración tricolor estilo Casabindo, presentan perforaciones circulares de este tipo, que parecen ser intencionales y haber sido practicadas desde la superficie interna hacia la externa, pero cuya función desconocemos. La botella del Pucará de Rinconada, relevada en el Museo Quai Branly, de la Figura 7.21 C también presenta una perforación en la pared, de forma irregular, que puede ser intencional o haber sido ocasionada por procesos posdepositacionales, pero como su estado de conservación es bueno, consideramos que podría haber sido hecha intencionalmente. Una pieza de Sansana, depositada en el mismo Museo, presenta un orificio en la base, de forma irregular (Figura 9.10 C). Quizás ello esté relacionado con la práctica de "matar" piezas, que ha sido documentada en piezas del estilo Yavi con morfología de balde (Krapovickas 1973, Ávila 2006), aunque Krapovickas (1973) describe a estas perforaciones como circulares y con bisel, y la aquí observada 
es de forma irregular. Por otro lado, es la única pieza que presenta este tipo de orificios en la base en toda la muestra analizada.

También se observan fragmentos con bordes trabajados o desgastados sobre la pasta ya cocida, algunos conformando objetos sobre fragmentos reciclados. Un fragmento de PA 22 presenta un borde trabajado, y quizás haya correspondido a una forma circular, como un tortero $u$ otro similar. Otro fragmento de $\mathrm{RH}$ 10-1, correspondiente a un borde, presenta sus extremos trabajados por abrasión, formando un objeto cuadrangular de función indeterminada (Figura 9.8 A). Un fragmento correspondiente al GP 19 de RH 19-7 presenta dos bordes desgastados, formando un ángulo de $90^{\circ}$. En el GF 2 de TA 1-1, que presenta decoración tricolor, uno de los fragmentos, que se observa en la Figura 8.20 hacia la izquierda, presenta dos bordes desgastados por abrasión. En SC 3, un fragmento de borde presenta una de sus fracturas, paralela al borde, desgastada por abrasión o algún proceso similar (Figura 9.8 B). Otro fragmento de cuerpo procedente de TC 2 presenta uno de sus extremos desgastado de manera similar y otro más ha sido trabajado para formar un artefacto de morfología subcircular y plana, con uno de sus bordes más desgastado y en bisel (Figura $9.8 \mathrm{C}$ ).

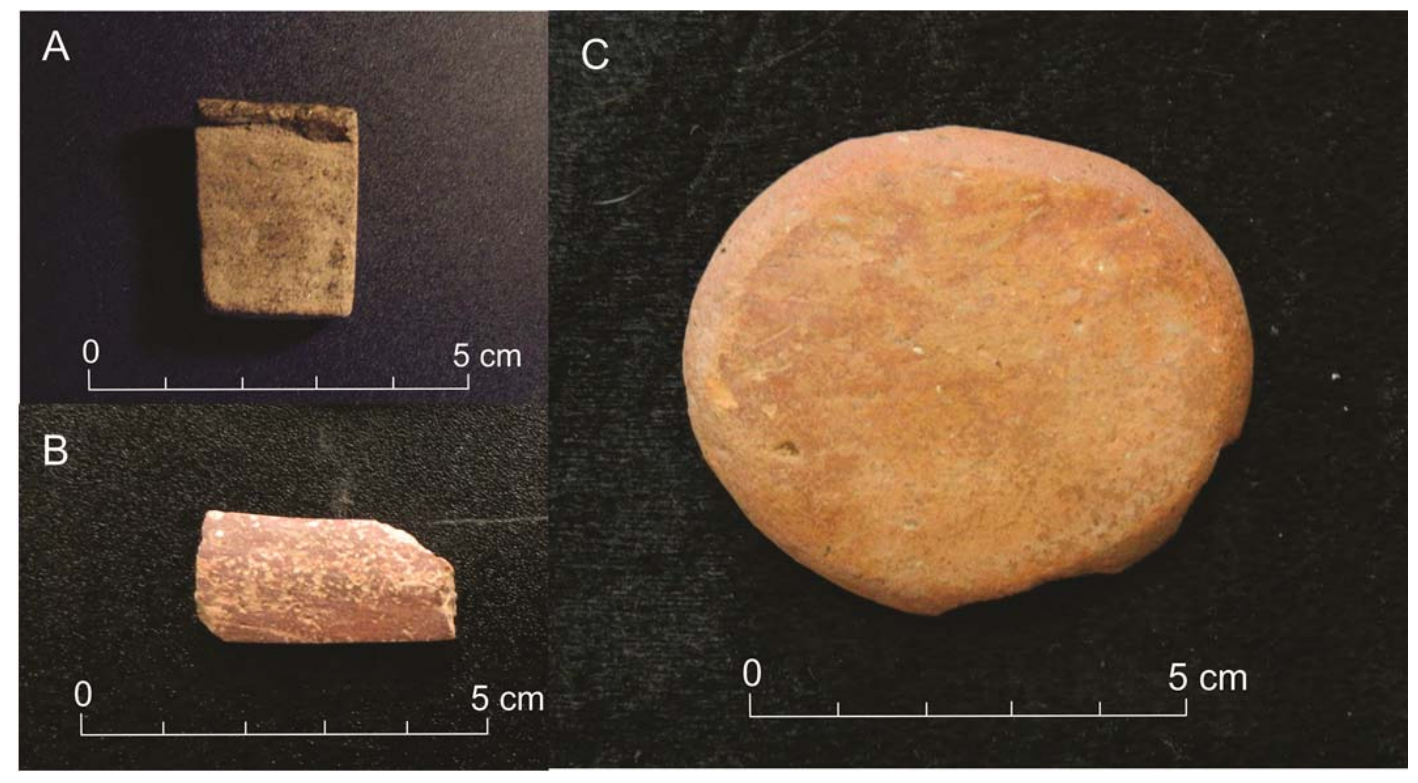

Figura 9.8 Objetos confeccionados sobre fragmentos por desgaste o abrasión de los bordes. A: Procedente de RH 10-1; B: del sitio SC 3 y C: de TC 2. 
Muchos de estos bordes desgastados parecen haber sido empleados sobre otra superficie, como alisadores o con alguna función semejante. Quizás alguno de esos fragmentos se haya empleado en la manufactura cerámica, especialmente el objeto subcircular de TC 2, semejante a otros artefactos arqueológicos empleados como alisadores que se han hallado en contextos de manufactura cerámica en los Andes (Pozzi-Escot et al. 1993) y de morfología similar los que se emplean en la actualidad para alisar el interior de los recipientes durante el modelado, tales como cucharas o calabazas, como veremos en el capítulo siguiente.

En un fragmento, de forma rectangular, del basurero de PA 22 se observó la presencia una perforación subcircular, sobre la pasta fresca de $13 \mathrm{~mm}$ de diámetro, ejecutada desde la superficie interna, cuya función es desconocida.

También se relevaron tres torteros, confeccionados sobre fragmentos cerámicos ya cocidos, por lo que también serían parte del reciclaje del material cerámico. Un fragmento correspondiente a medio tortero procede de TC 2, de aproximadamente $3 \mathrm{~cm}$ de diámetro, con un orificio bicónico de $8 \mathrm{~mm}$ de diámetro (Figura 9.9 A). Otros dos torteros sobre fragmentos proceden de los materiales de colección del sitio Queta $(n=2)$, depositados en el Museo Quai Branly (Figura 9.9 B y C) y que habrían sido recolectados por Boman entre los recintos habitacionales del sitio durante su breve paso por allí (Boman 1908). Se observó que ambos tienen un diámetro aproximado de $4 \mathrm{~cm}$, el primero presenta una perforación cilíndrica y los bordes desprolijos, lo que le da una forma irregular, y el segundo exhibe una perforación bicónica de mayor tamaño.

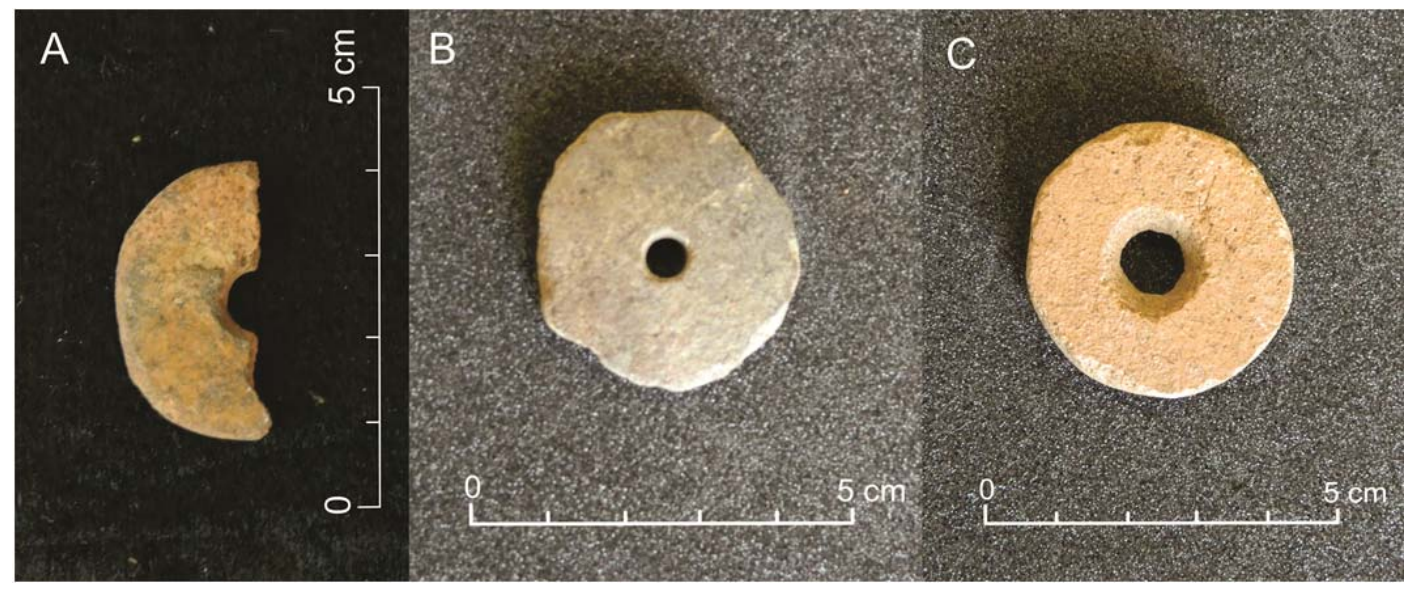

Figura 9.9 Torteros confeccionados sobre fragmentos cerámicos. A: procedente de TC 2, B y C: procedentes del sitio Queta y depositados en el Museo Quai Branly (QB-2084 y QB-2085). 
Algunos recipientes de colección muestran indicios de haber sido reutilizados. Entre las procedentes del sitio Queta, depositadas en el Instituto Interdisciplinario Tilcara, uno corresponde a la porción inferior de una pieza con el borde desgastado, como si una pieza cerrada se hubiese reutilizado para conformar una abierta (Figura 9.10 A). Otro recipiente también corresponde a la porción inferior de una pieza que presenta el borde desgastado y fracturado. Además presenta un orificio en el centro, de 6 a $7 \mathrm{~mm}$ de diámetro también realizado pos cocción (Figura 9.10 B). Quizás se reutilizó la base de una pieza en desuso para hacer esta, que puede ser un "vaso de hilandera" o semejante, como se ha documentado en otros sitios de la puna, atribuyendo estos orificios a la rotación del huso de hilar (Albeck y Ruiz 2003). Otro fragmento de base de un vaso chato del Pucará de Rinconada, depositado en el Museo Quai Branly, presenta un orificio central de $6 \mathrm{~mm}$ de diámetro, quizás con la misma función.
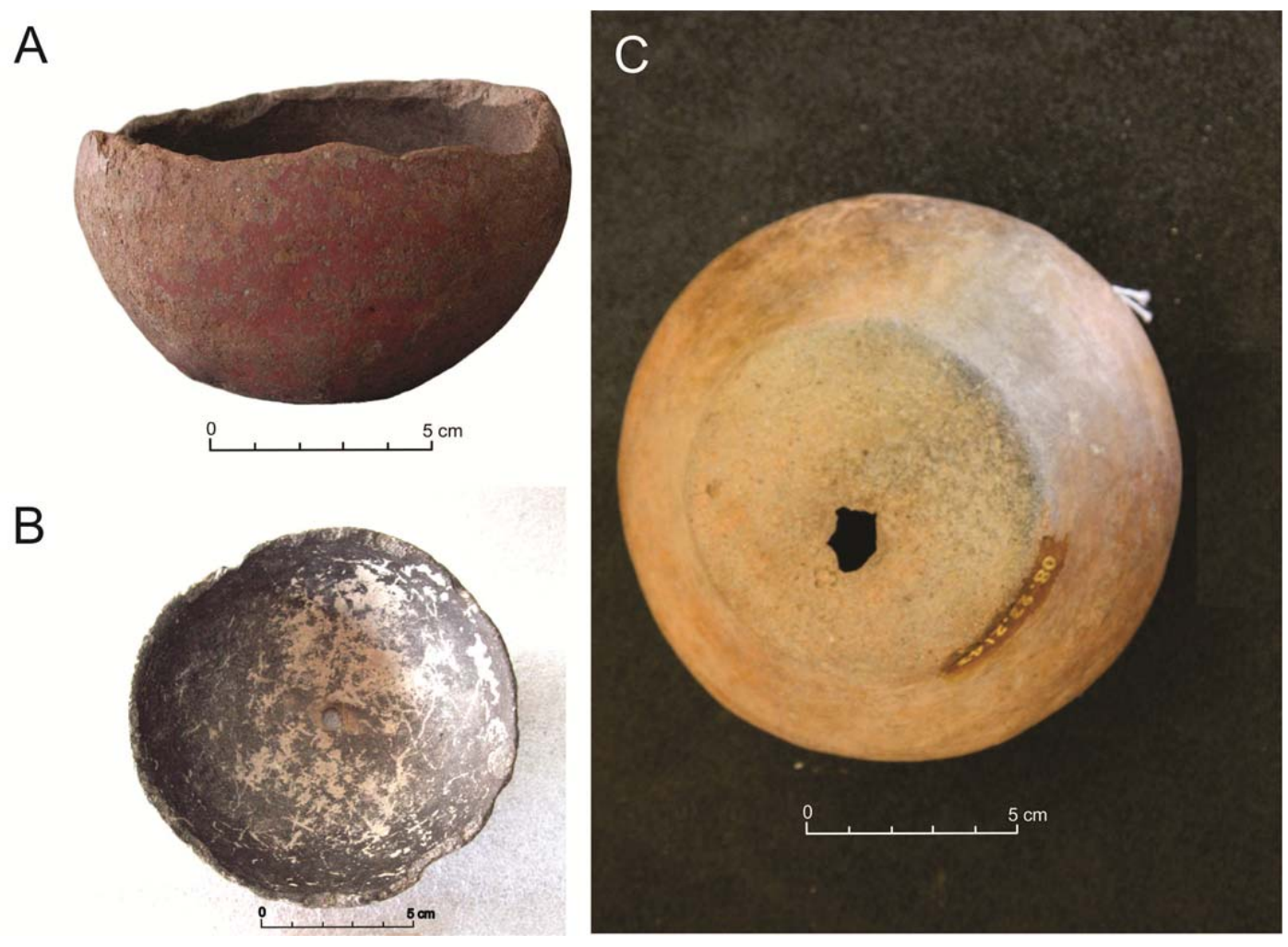

Figura 9.10 Recipientes con indicios de reutilización. A y B: procedentes del sitio Queta y depositados en el Instituto Tilcara (IT-1968 y IT-2030). C: procedente de Sansana y depositada en el Museo Quai Branly (QB-2143). 


\section{Síntesis y discusión:}

En este capítulo hemos visto que los últimos pasos de la secuencia de manufactura son el secado y la cocción de los recipientes. Para los materiales que analizamos, el secado es muy difícil de abordar, y tan solo hemos podido destacar que en algunos recipientes cerrados pudo haber habido un momento de secado entre el modelado de la porción inferior y de la superior, visible en un punto de unión de estas dos secciones.

Por otro lado, hemos mencionado algunas técnicas que pudieron aplicarse en determinados momentos del secado de la arcilla, que puede dividirse en dos etapas fundamentales, una entre el estado plástico y el cuero y otra entre ese y la arcilla completamente seca. El alisado de todos los recipientes analizados debió haber tenido lugar con la arcilla aún plástica, dado que la homogeneización de las superficies requiere el desplazamiento de materia y la extracción de parte de la misma, y suele llevarse a cabo durante el modelado y no como una etapa separada. En cambio el pulido se puede llevar adelante cerca del estado cuero, pudiendo resultar en la presencia de caras si la arcilla presenta humedad. De esta forma, hemos visto que la mayor parte de los recipientes de colección pulidos presentan caras, por lo que este paso debió realizarse con la arcilla en estado cuero o próxima al mismo, mientras que entre los materiales fragmentarios estas caras no son tan comunes, lo cual puede ser resultado de un pulido con la arcilla más seca o del estado fragmentario del material, que dificulta la identificación de marcas. Por otro lado, no se observaron variaciones entre las diferentes categorías morfo-estilísticas identificadas.

Para la cocción de los recipientes representados por el material fragmentario, hemos distinguido diferentes atmósferas de cocción, a partir de las variaciones de color presentes en las fracturas frescas, teniendo en cuenta que la fractura es una pequeña porción del recipiente, y que puede haber variaciones a lo largo del perfil de la pieza, documentadas en algunos casos en el material fragmentario y en las piezas de colección, mediante manchas de cocción. En las piezas de colección no se pudieron analizar fracturas frescas, por lo que las atmósferas de cocción se abordaron a partir de los colores de las superficies.

Hemos observado que en el material fragmentario predominan las cocciones oxidantes, completas o incompletas, predominantemente con colores uniformes, aunque puede haber variaciones de color en las oxidantes incompletas. Las pastas de los GP 2, 4, 6 y 8 presentan mayor porcentaje de colores no uniformes, asociados a una mayor 
presencia de cocciones oxidantes incompletas, que también son más abundantes en el GP 1, mientras que las del 3 y 5 presentan proporciones más importantes de fracturas con colores uniformes, vinculados a cocciones oxidantes completas.

Las cocciones oxidantes completas son más frecuentes en los sitios del norte de la puna, y en algunos de los de la cuenca sur de Pozuelos, y dentro de estos, las piezas comparables al estilo Yavi presentan en mayor frecuencia este tipo de cocciones, al igual que aquellas piezas que serían de cronología poshispánica. Sin embargo, para la mayor parte de los sitios analizados en esa segunda área predominan las cocciones oxidantes incompletas, abarcando a buena parte de las piezas de morfologías abiertas y cerradas, con superficies alisadas o pulidas, que no se clasificaron dentro de ningún estilo. Las piezas pintadas o engobadas, incluyendo aquellas asignables al estilo Casabindo, fueron cocidas en atmósferas mejor controladas, oxidantes completas. Un ejemplar de morfología asignable al estilo Casabindo presenta todas las superficies negras, quizás por cocción reductora o por exposición al fuego después de la cocción.

En los materiales de colección también son más abundantes las cocciones oxidantes, aunque no hemos distinguido entre las completas e incompletas, por las características del material. Además de las piezas asignables al estilo Yavi y Casabindo, las cocidas en atmósfera oxidante incluyen a buena parte de los vasos chatos y a las piezas vinculables a estilos de la quebrada de Humahuaca. En muchos casos, estas piezas presentan manchas de cocción, que dan cuenta de atmósferas poco controladas, quizás por el contacto del combustible y del fuego con los recipientes a cocer. Estas son más frecuentes entre las piezas de morfología Casabindo y aquellas no asignables a ningún estilo, y están presentes entre las piezas del estilo Yavi, aunque en menor proporción.

En base a las evidencias relevadas, consideramos que los recipientes confeccionados con pastas de los GP 3 y 5 , que incluyen morfologías abiertas, cerradas e indeterminadas, muchas asignables a los estilos Yavi, y las piezas del estilo Yavi de las colecciones relevadas, presentan un mayor control de las atmósferas de cocción que el resto del material cocido en atmósfera oxidante. A su vez, aquellos recipientes con engobe o pintura, de estilos indeterminados o con decoración Casabindo tricolor, también muestran un control mayor en la cocción, quizás para que la pintura y el engobe mantengan los colores buscados mediante su aplicación.

Las cocciones con el exterior oxidante y el interior reducido solo se encuentra en la zona sur, vinculadas a los pucos interior negro pulido, con pastas de los GP 1, 2 y 4 en 
el material fragmentario. Algunos vasos chatos de las colecciones de museo también presentan estas cocciones. Este efecto pudo haberse logrado mediante la cocción de los recipientes con la boca hacia abajo. Por otro lado, un número pequeño de pucos con interior negro pulido fueron cocidos en atmósferas reductoras, tanto en el material fragmentario como en las piezas de colección.

Las piezas que corresponderían a morfologías de época inkaica, tanto en el material de colección como en el fragmentario, presentan atmósferas de cocción oxidantes, y en el fragmentario oxidantes completas. Algunas piezas de colección inka provinciales presentan cocciones reductoras, que incluyen a las puchuelas y algunos patos plato. Las cocciones reductoras también están presentes en las piezas de origen oriental relevadas en las colecciones, y en una pequeña proporción del material fragmentario de estilo indeterminado, con superficies alisadas o pulidas.

Durante su historia de vida, los recipientes analizados ya manufacturados han pasado por diferentes usos, que aquí no hemos abordado. Sin embargo, en algunos casos hemos podido registrar modificaciones posteriores sobre la forma que estarían vinculadas a acciones de reparación o reciclado que, de igual manera, involucran gestos técnicos, como distintas formas de perforar y el desgastado de bordes para formatizar algunos fragmentos.

En cuatro casos, dentro del material fragmentario, se observaron orificios que pueden estar vinculados a la reparación de fracturas en los recipientes. Otros recipientes (un GF y dos piezas de colección) presentan perforaciones de gran tamaño, circulares o irregulares, que son de función desconocida.

Siete fragmentos, procedentes de los diferentes sitios analizados, presentan uno o más bordes trabajados por abrasión o algún proceso semejante, que en dos casos dan lugar a objetos con formas concretas (uno cuadrangular y otro subcircular). Quizás alguno haya servido como alisador, en la manufactura cerámica o en alguna otra actividad, resultando en el desgaste que tienen los bordes observados.

Por otro lado, se registraron tres torteros confeccionados a partir de fragmentos y modificaciones sobre algunos recipientes de colección, que incluyen perforaciones en las bases en dos casos, probablemente por su uso como "vaso de hilandera", los que habrían funcionado como soporte para el huso de hilar. Otras modificaciones incluyen el 
trabajado del borde de una pieza fracturada, quizás para reutilizarla como un recipiente abierto.

De los cinco artefactos mencionados que se vinculan a actividades textiles, los torteros proceden todos de áreas de habitación, mientras que los "vasos de hilandera", a los que podemos agregar el recipiente con asa interna ilustrado en la Figura 7.17 C, y que habría sido usado también en la actividad textil (Albeck y Ruiz 2003), proceden de contextos funerarios.

De esta manera, concluimos con el análisis de las cadenas operativas para el material cerámico arqueológico analizado, tanto fragmentario como completo. A continuación, intentaremos abordar como llega este conjunto de prácticas hasta momentos más recientes, mediante el análisis de las cadenas operativas detalladas en fuentes documentales de viajeros y de científicos del siglo $X X$, testimonios de pobladores actuales y observaciones personales. 
10.

\section{LA PRODUCCIÓN ALFARERA EN LOS S XIX Y XX EN LA PUNA DE JUJUY Y EL SUR DEL ALTIPLANO BOLIVIANO}

En base a la revisión bibliográfica de las fuentes que hemos mencionado en la metodología, en este capítulo abordaremos la producción cerámica y sus transformaciones a fines del siglo XIX y durante el XX, partiendo desde la cadena operativa de producción. Posteriormente, comparamos los resultados obtenidos por esta vía con aquellos discutidos en los capítulos anteriores para momentos prehispánicos y coloniales. La ubicación de las localidades mencionadas en este capítulo se puede ver en la Figura 10.1.

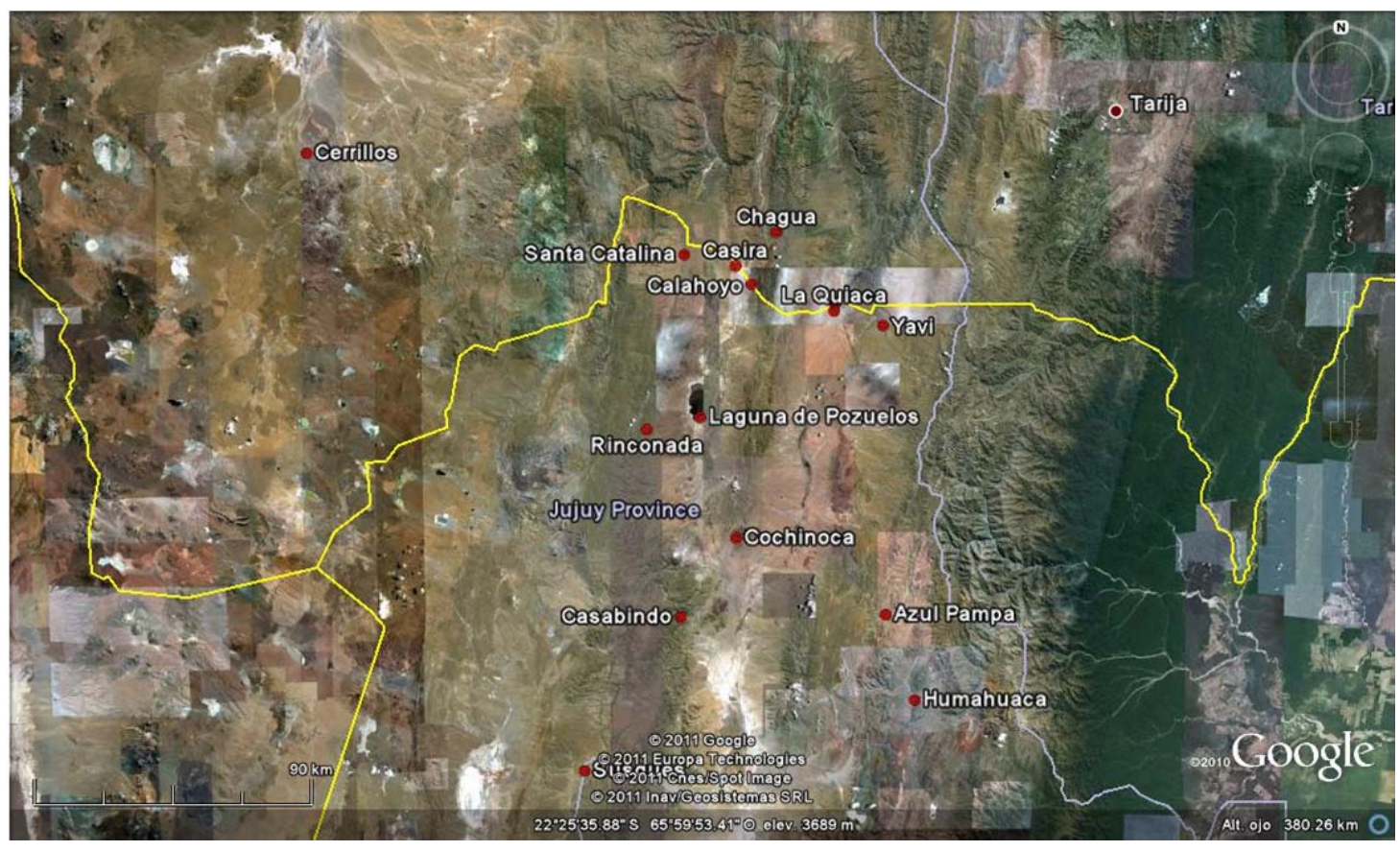

Figura 10.1. Ubicación de las localidades mencionadas en el texto.

Hemos incluido también la porción sur del altiplano boliviano, dado que la frontera entre ambos países es relativamente reciente y, a su vez, permeable, dado que las poblaciones actuales interactúan constantemente, y que en momentos prehispánicos la alfarería del "estilo Yavi" no solo incluía la porción norte de la puna de Jujuy, sino 
también los grandes valles en el sur del actual territorio boliviano y Tarija (Krapovickas 1975; Krapovickas et al. 1989).

\section{Quiénes producen:}

En primer lugar, debemos definir quién son los productores de la cerámica en la puna. Boman observa y relata la producción de una alfarera de Susques, y agrega que, en toda la puna, son las mujeres las que producen la alfarería y que casi todas las "indias" de cierta edad conocen su manufactura, aunque algunas son más habilidosas que otras (Boman 1908).

Las observaciones de los últimos treinta años, etnográficas o etnoarqueológicas, destacan también a la producción cerámica como una actividad predominantemente femenina. En Alto Sapagua (Azul Pampa, Jujuy), García (1988) registró la manufactura de cerámica de la única alfarera que producía en ese momento y que hacía las piezas para consumo de su unidad doméstica principalmente. Para el altiplano boliviano, Sapiencia de Zapata et al. (1997) refieren que las alfareras son mujeres, pero que los ancianos y niños intervienen en el pulido de superficies.

Casira (Departamento Santa Catalina, provincia de Jujuy) es una de las únicas localidades de la puna que se dedica a la producción cerámica actualmente. Según Rodríguez (2002), que realizó tareas etnográficas en la localidad en 1990, la unidad básica de organización del trabajo, tanto para la producción alfarera como para otras actividades productivas, es la unidad doméstica. La mayor parte de los artesanos son mujeres, aunque los hombres participan en el proceso buscando materias primas, leña, etc. Las tareas de modelado y acabado son realizadas, fundamentalmente, por mujeres de distintas edades. Los hombres trabajan, por lo general, con moldes, que son preparados por las mujeres (Rodríguez 2002).

En una visita a Casira en el año 2011, de los cuatro olleros que brevemente entrevistamos dos eran mujeres mientras que los dos restantes eran hombres. Estas personas manifestaron dedicarse a la producción cerámica a tiempo completo y no tener otras actividades productivas. 


\section{Obtención de materias primas:}

Las materias primas suelen obtenerse en las proximidades de la unidad de residencia de la alfarera o a pocos kilómetros, y consisten en arcilla y en alguna roca utilizada como inclusión no plástica o arena. La alfarera observada por Boman (1908) empleaba arcilla y una "roca gnéisica" pulverizada como antiplástico, compuesta de mica, cuarzo y feldespato. Esta roca provenía de una montaña a unos cuantos kilómetros de distancia de Cobres.

Carrillo (1988 [1888]: 165), en su Descripción Brevísima de Jujuy, comenta que en toda la provincia se fabrican vasijas, empleando una materia prima denominada pirca; termino que se utiliza hasta la actualidad para referir al material antiplástico empleado, como documenta por ejemplo García (1988: 35), que la describe como una roca lutítica, que puede exhibir colores azules, grises, negros o rojos, y quién también observa la extracción de materias primas de un cerro en las proximidades de la vivienda de la alfarera. También registra el uso de arena como agregado. Otro dato interesante es que la extracción de materias primas se realiza en el contexto de otras actividades, tales como durante el pastoreo de cabras y ovejas (García 1988).

Los alfareros puneños del río Lagunas (Dpto. Humahuaca, Jujuy) documentados por Fernández (1999) extraen sus materias primas de la sierra, incluyendo la roca que muelen como antiplástico, consistente en una lutita compacta que, al igual que en los casos anteriores, denominan pirca. Una vez extraídas, estas materias primas son secadas con el sol y el viento, para que disminuya su peso. Luego se las coloca en costales y son transportadas hasta la unidad doméstica.

En la porción sur del altiplano boliviano, las fuentes de materias primas suelen estar localizadas dentro de la misma comunidad, pero a veces se obtienen de otras comunidades por trueque o dinero (Sapiencia de Zapata et al. 1997).

En Casira, Rodríguez (2002) documenta una selección de la arcilla según el tamaño y la forma de la vasija que se va a fabricar: para las más grandes se selecciona una más "gruesa", y otra más "fina" para las más chicas. También, distinguen una "arena rojiza" que se emplea como pigmento sobre la pieza ya manufacturada. El autor no explicita la distancia de las fuentes de aprovisionamiento, pero destaca que las arcillas se extraen de vetas en una formación rocosa, con herramientas tales como picos, y la tarea es realizada fundamentalmente por hombres (Rodríguez 2002). 
En una visita realizada por nosotros en el año 2011, una ollera nos comentó que las materias primas son extraídas de los cerros cercanos al pueblo, o de localidades próximas como Santa Catalina (distante a unos cuantos $\mathrm{km}$ ). Allí se extrae una arcilla roja y una pirca blanca (Figura 10.2), que se mezclan para formar el barro empleado para confeccionar los recipientes.

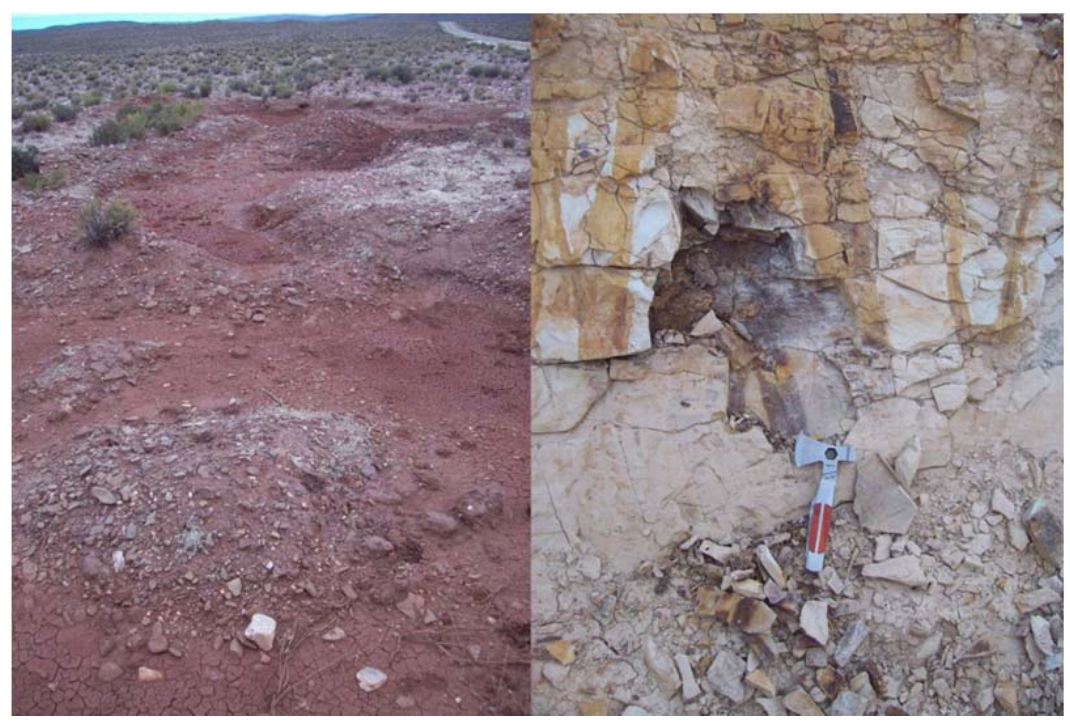

Figura 10.2. Fuentes actuales de materias primas (arcilla roja y pirca blanca) cerca de la localidad de Santa Catalina (Jujuy).

\section{Preparación de materias primas:}

Una vez obtenidas estas materias primas, las mismas deben ser mezcladas y preparadas para su uso. La alfarera observada por Boman (1908) amasaba la arcilla y trabajaba sobre un poncho viejo tendido en el suelo. Esto resulta muy interesante, dado que se conocen fragmentos cerámicos prehispánicos con improntas textiles con una amplia distribución en la puna de Jujuy (Krapovickas 1975; Mamaní 1998), como ya hemos mencionado, y de los que hemos hallado algunos ejemplares, que se han descrito en los capítulos precedentes.

En el caso de los alfareros observados por García (1988) y Fernández (1999), se muele y se mezcla la pirca junto con el barro, agregando o no arena, y se amasa la 
pasta sobre un cuero, dejándola reposar por un tiempo variable. En un caso, la molienda de la pirca se hacía en la cocina, ya que allí estaba el molino plano (García 1988).

En la localidad boliviana de Chagua, las pastas de la cerámica contienen trozos de rocas molidas y granos de lutitas areniscosas (de la Formación Acoite), que según Krapovickas (1975) estuvieron incluidas originalmente en la arcilla de confección.

\section{Modelado:}

Para construir la pieza, en varios casos se observó el modelado manual de la base a partir del estiramiento de un bollo, a la que posteriormente se agregaban rollos sucesivamente, sobre el borde, que se unían por presión de los dedos (Boman 1908, García 1988). En el transcurso del modelado, se alisaba continuamente el exterior y el interior, con instrumentos consistentes en fragmentos de huesos ilíacos y omóplatos de ovejas y llamas juveniles, o con una cuchara de madera (Boman 1908) o metal (García 1988). Las asas eran modeladas por separado y posteriormente adheridas (Boman 1908:478-479). En el caso de la alfarera observada por García (1988), ella empleaba como superficie de apoyo de la pieza bajo ejecución una piedra plana colocada sobre un tarro de lata, que se giraba a modo de torneta. Sobre la misma colocaba arena para que no se pegue la pieza.

En Casira, de manera muy semejante, se emplea una piedra plana como soporte para el modelado, que también cubren con arcilla o arena como antiadherente. Las herramientas empleadas son de madera y están elaboradas por las mismas alfareras, y con ellas se ayudan en la conformación de las paredes y alisan las superficies, manteniéndolas húmedas durante la tarea. El modelado se realiza por superposición de rollos, durante el cual se alisa el interior, mientras que el exterior es acabado al final, sobre una base modelada por estiramiento del bollo, como en los casos anteriores (Rodríguez 2002). Las piezas de mayor tamaño se van confeccionando por partes, ya que requieren un tiempo de secado en distintos momentos. En consecuencia, se suele modelar más de una pieza al mismo tiempo. Sin embargo, las piezas más pequeñas son modeladas de una sola vez (Rodríguez 2002).

En el transcurso de sus viajes en la puna, Boman (1908: 480) observó muchas otras alfareras que, según relata, seguían el mismo procedimiento que la de Cobres. Las variantes consistían en el empleo de distintas rocas y de tiesto molido (inclusiones que 
no hemos observado nunca en la cerámica ni actual ni prehispánica) como antiplásticos. Ninguna alfarera había tratado de adoptar el torno, que sin embargo conocían por haberlo visto en uso por los alfareros de las ciudades. La única tentativa de decoración observada era la decoración de las asas por medio de depresiones transversales u oblicuas, hechas "groseramente" con los dedos.

Otra referencia temprana que tenemos es la de De Bonelli (1854: 117-118), quien, cerca del pueblo de Puna (Departamento de Potosí, Bolivia), describe:

"Me despertó mucho interés observar a los nativos comprometidos en las manufacturas peculiares a esta parte del país. El ingenio con la que los indios se sobreponen a un conjunto de dificultades, era de lo más sorpresivo para mí. Sin herramientas, y solamente con sus manos, trabajan los suelos arcillosos, y modelan vasijas de todos los tamaños; y logran obtener, aunque no sean artículos con gracia, objetos durables" (Traducción personal).

Actualmente, en Casira hemos observado gran número de moldes de yeso entre los alfareros y muchas piezas modeladas por este método (Figura 10.3). También se siguen modelando las piezas por superposición de rollos ("a pulso", según los pobladores locales). Sin embargo, un alfarero manifestó que él produce empleando el torno y que son varios los olleros que producen con torno desde hace aproximadamente 15 años.

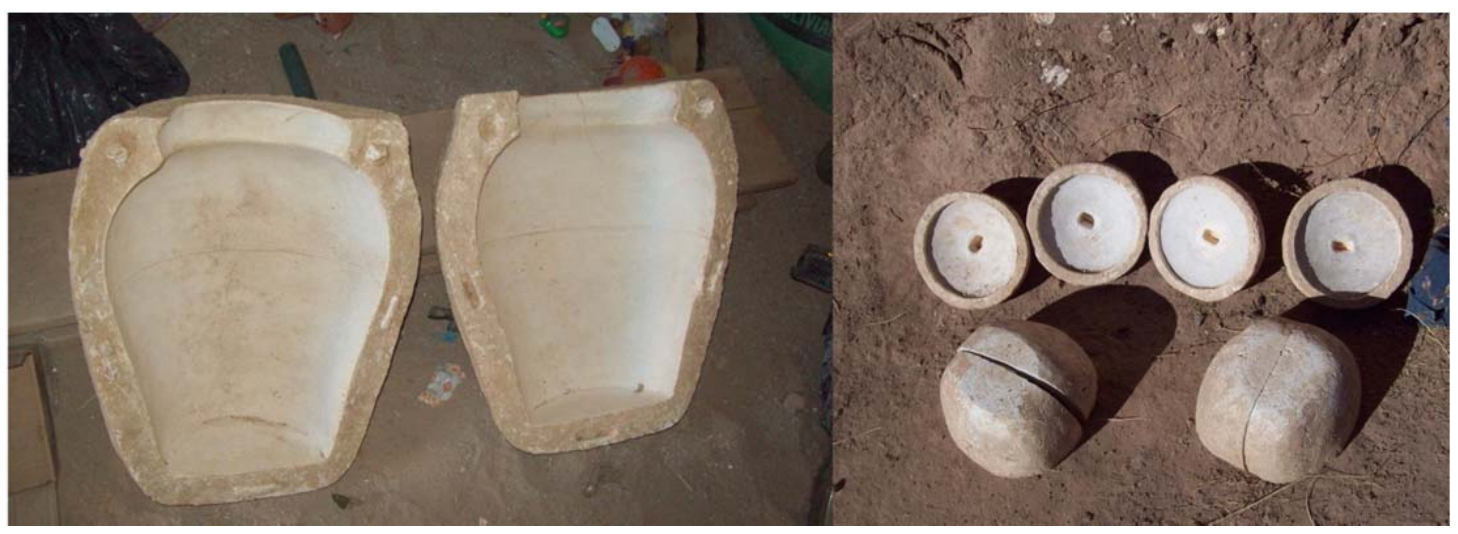

Figura 10.3 Moldes de yeso empleados en la producción cerámica actual de Casira.

Menacho $(2001,2007)$ relevó en Rinconada (Jujuy) piezas cerámicas y sus usos en contextos domésticos actuales de habitantes de esta porción de la puna, y observa que la mayoría exhibe rastros de modelado por superposición de rollos o enrollamiento 
anular. Las superficies presentan un engobe liviano, de la misma coloración de la de la arcilla del cuerpo, sobre el que se alisa la superficie externa.

En la porción sur del altiplano boliviano también se modelan las piezas a mano, por superposición de rollos de arcilla, sobre una especie de torneta giratoria de piedra o arcilla cocida. Las herramientas empleadas para el modelado son piedras planas o lisas y redondas, maderas de distintas formas, pedazos de plástico y metal, entre otros (Sapiencia de Zapata et al. 1997). En la localidad boliviana de Chagua, el modelado también es semejante, se emplea una piedra plana como base, sobre la que se coloca arena como antiadherente y la pieza se levanta por superposición de rollos, sin detallar si la base se confecciona aparte o no. Para alisar y pulir la superficie se emplean piedras adecuadas, metales de desecho como hojas de cuchillo para eliminar sobrantes de la base y fragmentos de madera para alisar el interior, mientras que para "afinar" la boca del recipiente se emplea un trapo que se denomina "suelita", que según los informantes de los autores anteriormente era un pedazo de cuero (Sapiencia de Zapata et al. 1997).

\section{Las morfologías elaboradas:}

En base a las secuencias de modelado descritas, se manufacturan piezas cerámicas de diferente morfología. Por ejemplo, Carrillo (1988 [1888]: 165), menciona algunas de éstas, cuando comenta que:

"Se fabrican en todos los lugares de Jujui vasijas de tierra cocida. Se emplea un ocre mui notable, gris azulado, que llaman en el pais pirca. Ni en formas, i en accesorios decorativos, la industria cerámica està adelantada. Se fabrican ollas, fuentes, platos, yuros, braseros, tazas, candeleros i todos los demàs útiles de un menaje simplicísimo, algunos balaustres para barandas i caños para conductos variados. No conocemos en la actualidad personas que se ocupen del vidriado por el ócsido de plomo, como ecsistían antes. Creemos que esta embrionaria industria ha declinado en manos de las mismas jentes que la han hecho siempre, los indíjenas. I sin embargo, hai en el pais elementos riquísimos, la variedad i mérito de las arcillas es recomendable" (Carrillo 1889: 165).

Las vasijas que Boman (1908: 480) vio ser fabricadas en la puna eran de formas simples y poco variadas, destinadas mayormente a la cocina, de pequeñas 
dimensiones, aproximadamente de 20 a $30 \mathrm{~cm}$ de diámetro de la abertura y de una altura igual. También había piezas más grandes, de aproximadamente 50 a $60 \mathrm{~cm}$ de altura, destinadas a la fermentación de chicha.

De manera similar, la alfarera observada por García (1988: 39) producía ollas (para cocinar) o cántaros (para colocar agua) y candelabros, pero no escudillas. Las ollas de cocina eran de cuerpo globular, cuello bajo y boca restringida. Los cántaros para contener agua eran de cuerpo ancho, boca restringida y base estrecha, con una única asa. Ninguna de las piezas producidas llevaba decoración. Las piezas decoradas se adquirían en Abra Pampa o Susques y no se empleaban para tareas cotidianas. La autora también observó ollas de tamaño más grande y virques que se empleaban en distintas etapas de la elaboración de chicha y que no se exponían al fuego. Algunas de las ollas presentaban cuatro asas. También observó un recipiente abierto para moler maíz, denominado tiesto. Todas estas morfologías también se adquirían fuera de la comunidad por trueque (García 1988).

Entre las morfologías relevadas por Menacho (2007: 155), aquella denominada chuiayuro consiste en recipientes cerrados, con cierta variedad formal, registrándose piezas de forma esférica, subovoide y subrectangular. Se usan exclusivamente para rociar chuia (una de las fases obtenidas en la elaboración de chicha) al rebaño durante la señalada. Destaca que otras sociedades de pastores andinos también utilizan este tipo de artefactos en ceremonias ligadas a la fertilidad del rebaño. Estas piezas son pequeñas y transportables y pueden estar decoradas con modelados zoomorfos de camélidos, ovinos y caprinos, que son los animales a los que se dedica el ritual de la "Señalada".

También registra el uso de platos, consistentes en recipientes abiertos, pequeños y muy transportables, de uso individual, que pueden ser o no de cerámica. En muchos casos se han reemplazado los de cerámica por otros de metal o plástico (García 1988; Nielsen 2000). Los de Rinconada (Jujuy) presentan decoración pintada en rojo en la superficie interna, consistente en líneas curvas o concéntricas de diferente grosor (Menacho 2007: 156).

Para Casira, la importancia y demanda del mercado urbano ha impuesto nuevos diseños y formas, tales como macetas y objetos de adorno (Rodríguez 2002), fenómeno que también se observa en la localidad boliviana de Chagua (Sapiencia de Zapata et al. 1997). Las formas que hemos observado personalmente en Casira incluyen ollas 
globulares con o sin tapa, con dos o cuatro asas, jarras grandes y pequeñas, platos o pucos con o sin asas (dos o cuatro), tazas y platos pequeños para las mismas, candelabros y alcancías en forma de chancho (Figura 10.4). Estas morfologías están orientadas mayormente al mercado externo, no observándose las piezas grandes relacionadas a la producción de chicha local, como ollas y virques. Una de las olleras entrevistadas, de edad mayor, manifestó que sí produce estas piezas eventualmente, aunque en el momento de nuestra visita no tenía ninguna.

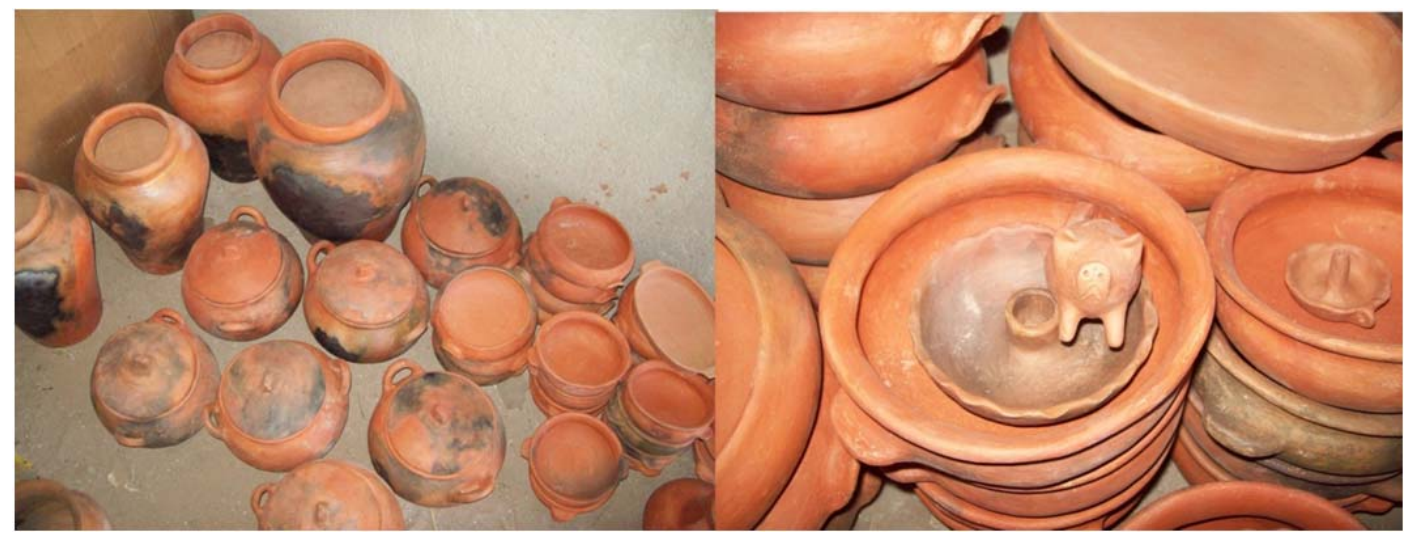

Figura 10.4. Algunas morfologías producidas actualmente en la localidad de Casira.

\section{Acabados de superficie y decoración:}

En la mayoría de los casos, las piezas son simplemente alisadas o pulidas, como en el caso de la alfarera observada por García (1988), que una vez seca la pieza la pulía con una piedra plana, agua y barro. La alfarería decorada se obtenía de otras zonas de la puna, como se mencionó anteriormente.

En Casira, según Rodríguez (2002), el acabado de la superficie externa se completaba al final del modelado, mediante pulido. Finalmente, se la pintaba de color rojizo o anaranjado, con una pintura preparada a tal efecto mezclando arcilla rojiza con agua. Actualmente, se producen mayormente piezas alisadas o pulidas, no observándose otro tipo de acabados de superficie ni decoración, exceptuando piezas formadas con moldes que tienen motivos figurativos en relieve. Sin embargo, en otras localidades de la puna hemos observado piezas con esmaltado de plomo que según los pobladores locales habrían sido manufacturadas en localidades como Casira o en localidades cercanas de Bolivia. Aunque si seguimos la referencia de Carrillo (1889) 
citada arriba, las piezas esmaltadas con plomo habrían dejado de fabricarse antes de su paso por la puna, por las que se encuentran actualmente serían relativamente antiguas.

De las piezas relevadas por Menacho (2007: 153), solo algunas poseen decoración, con flores pintadas en el cuerpo, y son mayormente vasijas empleadas en rituales. La mayoría de las ollas no están decoradas o presentan una decoración muy simple en las asas, con incisiones de puntos o pellizcos modelados en la pasta fresca (Menacho 2007: 154). Otras piezas pequeñas, empleadas para festividades católicas, pueden presentar decoración pintada en varios colores en la superficie externa, en diseños geométricos o paisajes (Menacho 2007: 155).

\section{Secado:}

En la mayoría de los casos no hallamos referencias sobre el secado de las piezas cerámicas previo a su cocción. En el caso de la alfarera observada por García (1988), como mencionamos anteriormente, el pulido de las piezas se realizaba sobre las superficies ya secas. En tanto que Rodríguez (2002) observó que el secado de las piezas tiene lugar dentro de una habitación, hasta el otro día, en el que se la saca al sol para completarlo. Ese mismo autor observa que, en el modelado de las piezas de gran tamaño, puede haber una etapa de secado entre la confección de las distintas partes, como hemos mencionado antes (Rodríguez 2002).

\section{Cocción:}

Una vez secas, las vasijas producidas deben ser sometidas a cocción. Boman (1908) comenta, que las fabricadas por la alfarera que observó se cocían a cielo abierto, cubiertas con excrementos secos de vaca, que se encendían y se dejaban arder hasta que este combustible era completamente consumido por el fuego. El producto terminado tenía una buena cocción y un color rojo ladrillo. Los excrementos eran recolectados del camino que une el valle Calchaquí con Bolivia y que pasa cerca de Cobres (Boman 1908: 479-480).

En Azul Pampa y en Casira, también se empleaba guano de vaca, y además de burro y cabra como combustible (García 1988; Rodríguez 2002). En el primer caso, la estructura de combustión consiste en un pozo excavado, que se encuentra detrás de las 
casas (García 1988). En Casira, para cada cocción se construye una estructura (ver Figura 10.5) en un lugar con buena circulación de aire, lejos de las viviendas, empleando los restos de la que se usó en la cocción anterior. Para las paredes se emplean adobes y fragmentos de vasijas que no se unen con mezcla alguna y que generan paredes no uniformes (Rodríguez 2002).

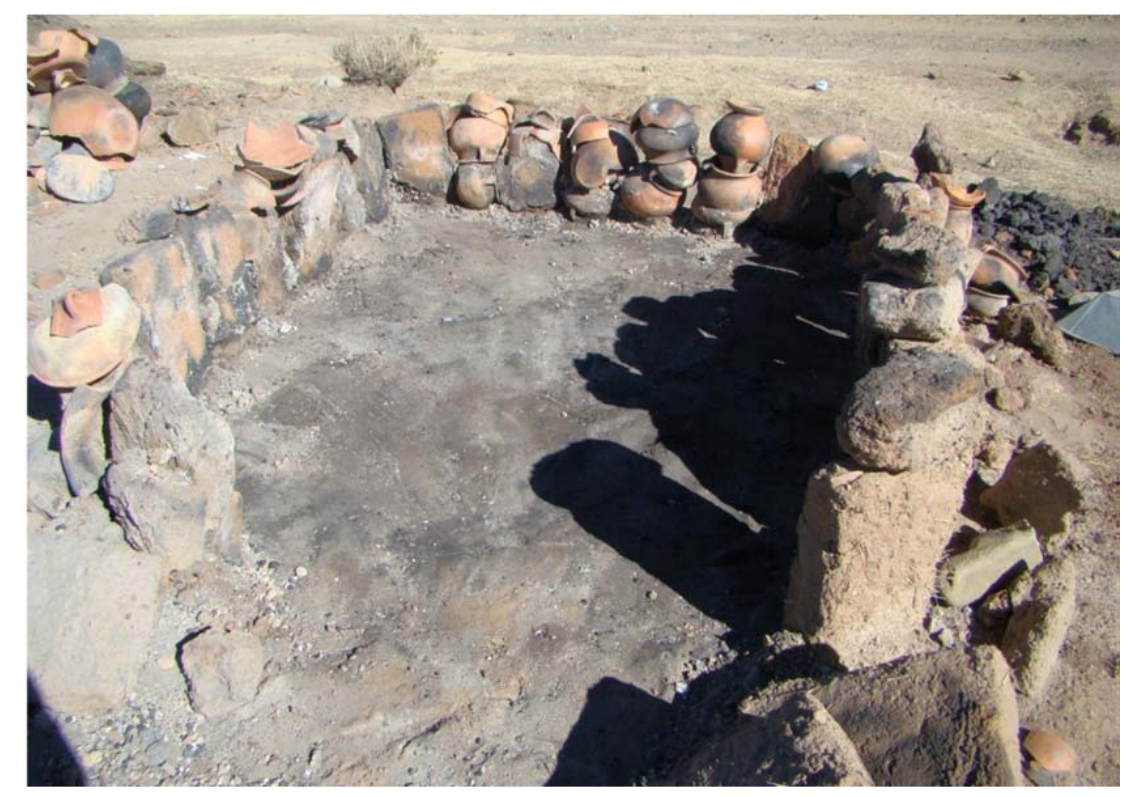

Figura 10.5. Estructura actual para la cocción de piezas cerámicas en Casira, Jujuy.

Para el altiplano de Bolivia, se describen cocciones semejantes, con o sin estructuras, y empleando guano de llama y oveja, y tola (Baccharis sp.) como combustible (Sapiencia de Zapata et al. 1997: 18). Sin embargo, en Chagua, se usa un horno más complejo, con cámara de combustión y otra para colocar las piezas, con leña como combustible (Sapiencia de Zapata et al. 1997: 73).

\section{Tratamientos poscocción:}

Solo Boman (1908) registra el curado de las piezas cerámicas después de la cocción, consistente en ponerles caldo de carnero hirviendo y calentarlas lentamente al fuego, dejando hervir el líquido en las vasijas durante algunas horas. Según el autor, la finalidad de este procedimiento era el de aumentar la solidez de los ceramios. 


\section{Comercialización, intercambio y uso:}

Varios de los autores consultados destacan que la producción alfarera del siglo XX es para uso propio, o para vender a vecinos próximos (Boman 1908; García 1988; Fernández 1999). Las de la alfarera observada por Boman (1908) eran destinadas básicamente para cocción, al igual que las que observó producir García (1988), pero que también se intercambiaban según las necesidades. Además, la autora agrega que toda la comunidad distingue las ollas producidas por una u otra alfarera, mediante pequeñas diferencias.

Para el departamento Rinconada de la puna de Jujuy, Menacho (2001), refiere como las piezas cerámicas son obtenidas por herencia, trueque puerta a puerta, trueque o compra en mercados periódicos y ferias (Casira, Calahoyo, Berque en Bolivia, etc.), encargo directo a productores o compra en centros urbanos. Los artefactos heredados mayormente son aquellos empleados para elaborar y consumir chicha, que tienen una vida útil larga, porque son muy preciadas "afectivamente" (Menacho 2001: 126). Los pobladores también asisten a las ferias y mercados, como la Mancafiesta (La Quiaca, Jujuy) o la feria de Berque (Bolivia). Solo se encargan directamente a los productores las piezas cerámicas denominadas chuyayuro, que se emplea en rituales asociados a la fertilidad del ganado (Menacho 2001: 127). Dentro de nuestras propias investigaciones, Sergio Flores, un poblador de Pan de Azúcar (departamento Rinconada, Jujuy) nos refirió que los pobladores del área adquieren piezas cerámicas manufacturadas en Casira. Asimismo, señaló que las decoraciones de las asas están relacionadas con la artesana que produce esas ollas, pudiendo identificarse las mismas a partir de estas marcas.

En el área de Yavi tampoco se elaboran piezas cerámicas, sino que se adquieren aquellas producidas en la localidad de Chagua (Bolivia), que según Krapovickas (1975), en el momento en que escribió su trabajo era la de mayor venta en La Quiaca y Villazón, y la más utilizada en la puna y regiones vecinas. El autor destaca que en el actual territorio argentino no había producciones alfareras de importancia y que las alfareras que aún producían eran mujeres de edad que conservaban la producción doméstica tradicional (Krapovickas 1975: 299).

En Cerrillos (Lipez, Bolivia), donde actualmente se usan tanto recipientes cerámicos como metálicos, las vasijas relacionadas con la chicha y las ollas grandes para cocinar para muchas personas en las festividades están todas hechas de cerámica (Nielsen 
2000: 231). Estas vasijas no son manufacturadas por los propios pastores, ni lo han sido en el pasado según lo que recuerda la gente, sino que son traídas a lomo de animal de Casira o de otras comunidades alfareras en la Quebrada de Talina (Nielsen 2000: 373).

En todas estas zonas actuales, en las que no producen alfarería, los pobladores adquieren sus recipientes de las ferias, donde son trocados o vendidos por los alfareros. Las ferias del altiplano argentino y boliviano se distribuyen en el año de acuerdo al calendario de producción agrícola ganadero y ceremonial (Karasik 1984). La mayoría de las operaciones de intercambio que tienen lugar en ellas se realizan por trueque, en base a tasas regionales muy estables, según lo que relevó Karasik (1984). Algunas de ellas son: una olla de barro por su contenido en papas; una olla de barro por su contenido en tomates; un platillo de barro por su contenido en ajo (Karasik 1984: 59). Sapiencia de Zapata et al. (1997) también observaron el intercambio de alfarería por su contenido en grano u otro producto agrícola. De manera semejante, Madrazo (1982: 196) registra el uso de distintas morfologías cerámicas como unidades de medida para la venta de grano en el siglo XIX, para Sococha (Bolivia) en la lista de 1820, en la que figuran cien arrenderos pagando por "yuros de semilla" o por "ollas", de maíz o trigo, que tenían un precio fijo.

Las ollas que se producen en Casira se destinan mayormente a la venta en ámbitos rurales o urbanos, habiendo perdido el consumo local la importancia de momentos anteriores. Ello produce cambios en la valoración y significación de la alfarería (Rodríguez 2002). Según Rodríguez (2002: 105) el proceso de mercantilización de esta producción, anteriormente destinada al consumo doméstico de los propios productores o al trueque con otras unidades domésticas, genera transformaciones materiales y simbólicas que afectan el diseño de las piezas, haciendo desaparecer algunas formas usadas tradicionalmente en la zona y aparecer otras.

Los mercados urbanos a los que se destina cada vez más la producción de Casira son los de Salta, Tucumán, Córdoba y Buenos Aires. La venta está mediada fundamentalmente por "acopiadores" o tiene lugar, en menor medida, directamente por productores que viajan a San Salvador de Jujuy o Salta (Rodríguez 2002: 93). En las ferias, los olleros intercambian su producción tanto por productos industrializados, como harina, azúcar, fideos o arroz; como por dinero en efectivo (Rodríguez 2002: 97). También se organiza una feria anual en la misma localidad de Casira, pero, a diferencia de las otras mencionadas, no es una feria de trueque. Los productores venden 
directamente a los acopiadores procedentes de distintas provincias argentinas (Rodríguez 2002: 100).

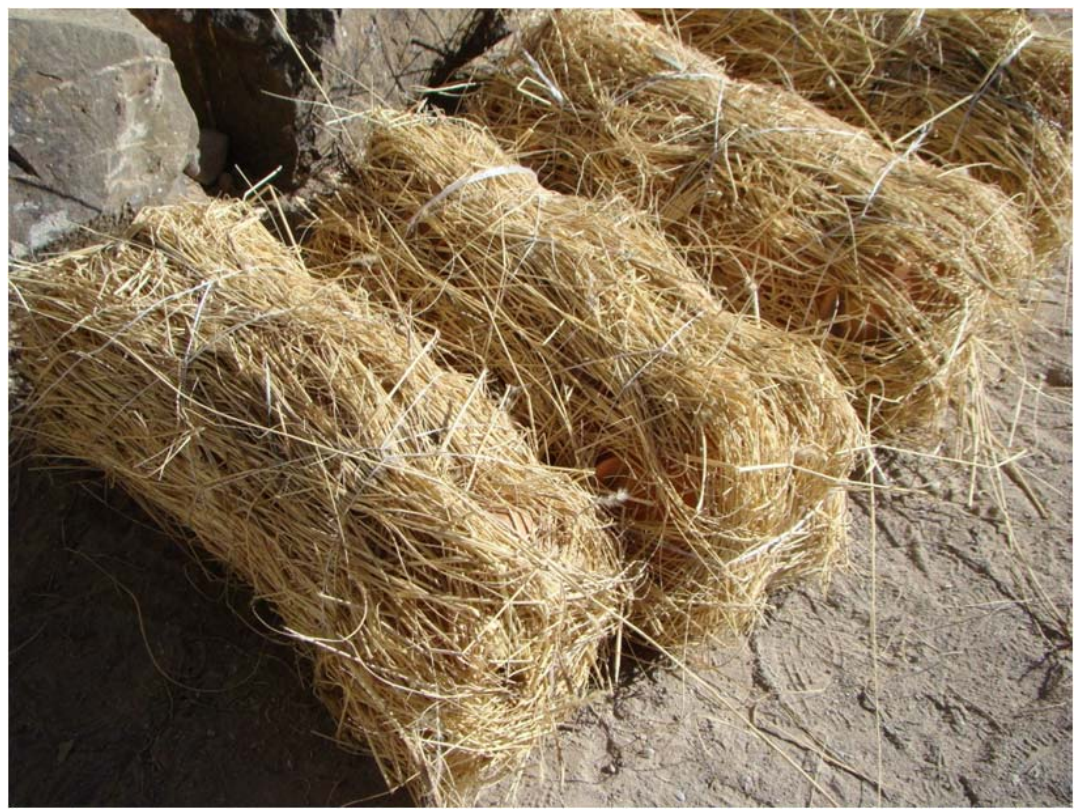

Figura 10.6 Vasijas enfardadas para su traslado y comercialización, en Casira, Jujuy.

Sapiencia de Zapata et al. (1997) manifiestan la misma modalidad de comercialización para los alfareros del altiplano boliviano, que también asisten a ferias en distintos puntos para comercializar su producción, la cual suele intercambiarse por dinero, con el que se adquieren bienes manufacturados necesarios para la subsistencia. En la comunidad Chagua, al igual que en Casira, se produce en grandes cantidades para abastecer la demanda del mercado argentino, y se comercializa mediante el sistema de "acopiadores" o intermediarios. En ferias como la Mancafiesta o en Semana Santa llegan camiones hasta La Quiaca que compran miles de piezas en fardos (Figura 10.6). Los productores de la comunidad trasladan los fardos en lomo de animal y camión, y producen en función del mercado argentino: macetas, fuentes, sartenes, candelabros (Sapiencia de Zapata et al. 1997: 72).

Los artefactos cerámicos así elaborados e intercambiados tienen distintos usos. Algunos son empleados en contextos rituales que implican la preparación y consumo de alimentos y bebidas. Para ello suelen emplearse exclusivamente recipientes cerámicos, que suelen ser de morfologías más variadas y tamaños más grandes que los empleados para otras actividades domésticas (Nielsen 2000; Menacho 2001). Estas vasijas son empleadas para el fermentado, almacenamiento y servicio de chicha, sólo en contextos 
ceremoniales (ritos de paso, celebraciones de santos patrones, inflorada, carnaval) o para entretener fiestas extradomésticas de grupos de trabajo que pueden ayudar en ocasiones especiales (por ej., el techado de la casa) (Nielsen 2000: 307). Para almacenar las piezas se eligen lugares de la casa con poco tránsito, a fin de preservarlas de roturas accidentales, como por ejemplo en los "oratorios" que poseen muchas viviendas rurales de la puna (Menacho 2007).

De manera semejante, las piezas cerámicas usadas para la elaboración de chicha actual en El Perchel (quebrada de Humahuaca, Jujuy), tienen una vida útil larga, algunas con 50 años de antigüedad. Muchas de ellas solo se emplean para este fin y se conservan en espacios protegidos de la casa (Cremonte et al. 2009: 82).

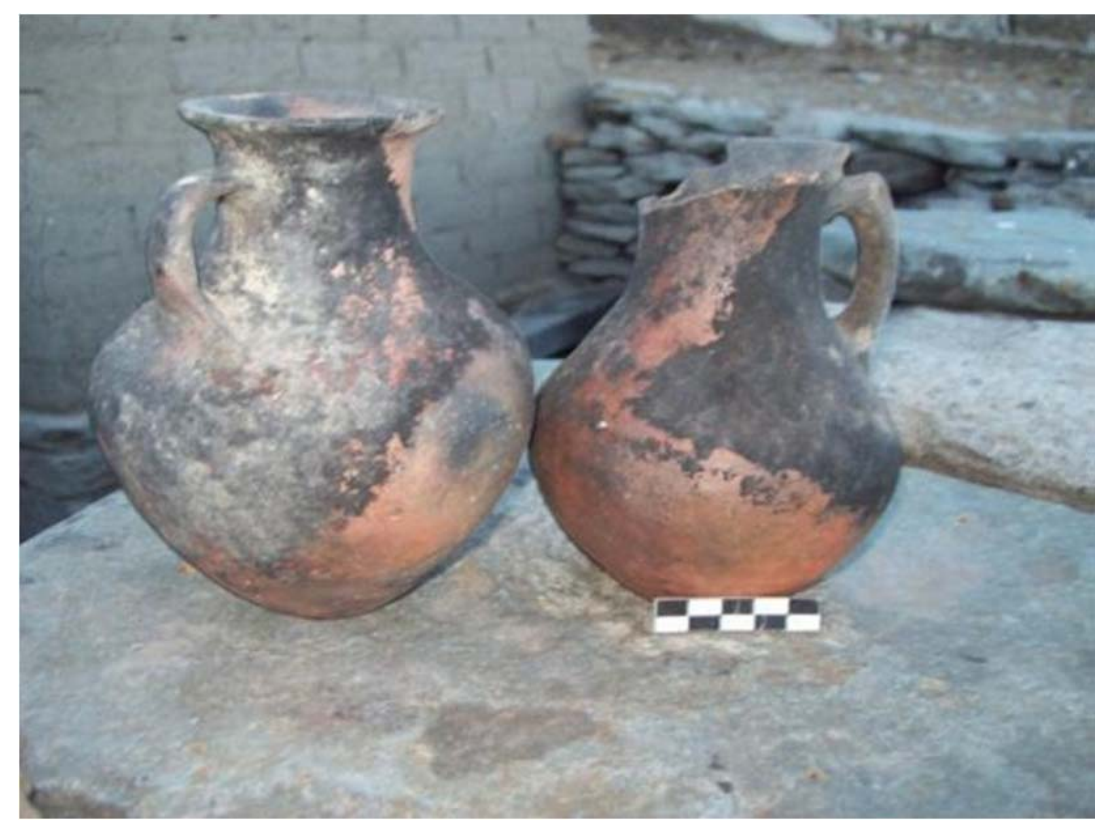

Figura 10.7. Yuros actuales en la cocina externa de una vivienda en la puna de Jujuy.

\section{Síntesis y discusión:}

En base a los resultados de nuestra revisión bibliográfica, se pueden sintetizar ciertas homogeneidades destacables en las cadenas operativas descritas, que probablemente tienen su origen en momentos prehispánicos, de acuerdo a los resultados expuestos en los capítulos anteriores. Sin embargo, estas conclusiones son preliminares y parciales dado las limitaciones impuestas por la bibliografía consultada. 
En primer lugar, la mayoría de las referencias citadas mencionan a las mujeres como las principales productoras de alfarería. Sin embargo, el resto de la unidad doméstica participa en tareas como la extracción o recolección de materias primas, en los acabados de superficie, etc. La evidencia disponible arqueológicamente no nos permite inferir el género de los alfareros en el pasado, pero sería esperable que haya sido una actividad femenina, como lo ha sido casi exclusivamente hasta la actualidad, aunque, al igual que en la actualidad, la unidad doméstica completa podría verse vinculada de una u otra forma en diferentes tareas.

Las materias primas empleadas por las alfareras son extraídas por la unidad doméstica misma, en la mayoría de los casos, de fuentes localizadas en las proximidades de las viviendas. Sin embargo, en algunos pocos casos, las mismas pueden ser adquiridas por compra (Rodríguez 2002). Como antiplástico, se menciona repetidamente el uso de rocas lutíticas (Krapovickas 1975; García 1988; Fernández 1999), denominada pirca por las alfareras desde fines del siglo pasado por lo menos (Carrillo 1988 [1888]; García 1988; Fernández 1999). Estas rocas son molidas para ser agregadas a la arcilla en la conformación de la pasta para modelar, mencionándose varias veces el amasado de la pasta resultante de esta mezcla sobre un cuero o poncho. También se observa la presencia de cuarzo y feldespato en los antiplásticos (Boman 1908; Fernández 1999) o el agregado de arenas (García 1988).

Como hemos visto en el análisis de las pastas cerámicas, en la cerámica prehispánica de la puna de Jujuy es muy frecuente la presencia de rocas sedimentarias pelíticas, tanto en piezas del denominado estilo Yavi (blancas a rosadas) con pastas de los GP 3, 5 y 8, como en fragmentos procedentes de piezas sin decorar y con decoración comparable a la de Casabindo, con pastas de los GP 1, 2 y 4, en donde se observan litoclastos pelíticos de diferentes colores y en diferentes proporciones. También son frecuentes el cuarzo y el feldespato en los materiales analizados por nosotros. Sin embargo, como destaca Krapovickas (1975), es muy frecuente observar mica en las pastas cerámicas prehispánicas, tanto en los tipos por él descritos para el sitio Yavi Chico, como en las pastas observadas por nosotros en la cuenca sur de Pozuelos. También hemos observado dos muestras actuales de pirca, que presentan características macroscópicas semejantes a las inclusiones sedimentarias de la alfarería prehispánica.

En el modelado de las piezas cerámicas, es notable la continuidad observada en distintas fuentes, que mencionan el uso de una base a modo de torneta, sobre la que 
suele colocarse arena o arcilla seca a modo de antiadherente. Sobre la misma se modela la base por ahuecamiento de un bollo, y una vez obtenida la base se van superponiendo rollos de arcilla que se van presionando con los dedos para construir las paredes. Para ello, las alfareras emplean distintas herramientas (cucharas de madera, partes de metal, plástico, piedras de diferentes formas etc.) para ayudarse en la conformación de las paredes, el acabado de las superficies, el recortado de sobrantes, etc.

En nuestras investigaciones, no hemos encontrado herramientas que puedan relacionarse a las mencionadas, exceptuando algunos posibles alisadores mencionados en el capítulo anterior, especialmente el de TC 2 que presenta una morfología comparable a la de la pala de una cuchara, y que tiene una forma muy adecuada para alisar la superficie interna de piezas cerámicas.

Asimismo, hemos observado en los fragmentos cerámicos prehispánicos y coloniales, el modelado por rollos y por ahuecamiento y estirado con los dedos, detectables a través de variaciones de espesor, patrones de fractura e indentaciones en la superficie interna provocadas por la presión con los dedos (Rye 1981), que hemos descrito en detalle en el Capítulo 7. Igualmente, la mayor parte de los fragmentos de bases relevados son planos en el exterior, como se ha visto anteriormente, por lo que las piezas pudieron ser apoyadas sobre una superficie plana para su construcción, ya sea giratoria o no. Además, en algunos casos hemos observado marcas de dedos e indicios de uniones de la base al cuerpo, que podrían estar dando cuenta de que fueron modeladas por separado, antes de la confección de las paredes, al igual que se documenta etnográficamente. Pero no hemos observado la presencia de adherencias en las bases de arena o similares, que deberían ser el resultado del uso de los antiadherentes referidos, exceptuando que después de elaborada la pieza la base sea recortada o sucesivamente trabajada para eliminar estos rastros.

Por otro lado, hemos observado algunas piezas con evidencias de uso de torno y vitrificados en el basurero de Pan de Azúcar 22 y en los sitios del área de Santa Catalina, atributos que no se mencionan para la producción actual. Quizás se hayan importado o trasladado piezas desde otras zonas a la puna en momentos coloniales, o se hayan incorporado procedimientos técnicos, que posteriormente se dejaron de usar. Nos inclinamos más por la primera hipótesis, dado que PA 22 y TC 2 podrían ser centros mineros de cierta importancia, que aparecen mencionados tempranamente en la documentación (Pérez Pieroni y Becerra 2010; Angiorama y Becerra 2012) y que 
seguramente contaban con población española. Por otro lado, el hecho de que el torno y el uso de moldes sean técnicas de modelado de incorporación relativamente reciente en Casira, como hemos visto, es un punto que apoya esta hipótesis. En este caso, consideramos que la incorporación de estas técnicas está relacionada con la orientación de la producción de esta localidad hacia el mercado externo, hacia centros urbanos que demandan gran cantidad de bienes y, por lo tanto, con un incremento en la producción.

La composición de las inclusiones y las técnicas de modelado empleadas son prácticas tecnológicas que podrían estar indicando, en principio, una tradición de manufactura puneña, que tendría sus orígenes al menos en el período tardío de la secuencia prehispánica local. Como vimos en el Capítulo 2, este tipo de pasos suelen ser los que menos modificaciones sufren, siendo las morfologías y los aspectos decorativos los más fácilmente modificables (Rye 1981, Calvo Trias y García Roselló 2011). A esto pueden sumarse las improntas textiles halladas en materiales prehispánicos (Krapovickas 1975; Mamaní 1998), que pueden estar relacionadas al modelado, quizás de modo comparable al que describe Boman (1908).

La mayoría de las alfareras mencionadas en la literatura analizada produce piezas que no presentan decoración o la tienen en grado muy simple. Las superficies son solo pulidas o engobadas y pulidas en la mayoría de los casos. Ello contrasta con la cerámica del estilo Yavi prehispánico (Krapovickas 1975), que presenta una decoración muy profusa en muchas de sus piezas, con una variedad de diseños y configuraciones pictóricas (Ávila 2009). Para esta cerámica se ha postulado una persistencia en el tiempo, incluyendo la conquista inka y su derivación en el estilo Inka Paya, como también el momento del contacto hispano indígena (Krapovickas 1983). Sería interesante intentar abordar las causas que llevaron a la desaparición de estos motivos prehispánicos.

Sin embargo, en muchos casos, las unidades domésticas mencionadas en la literatura relevada poseen algunas piezas con decoración, pero estas son pocas y sólo se usan en contextos rituales, no en las prácticas domésticas de la vida cotidiana. También se menciona que algunas de estas piezas decoradas son de la morfología denominada yuro, morfología que se puede comparar a las de las pequeñas botellas encontradas entre el material arqueológico prehispánico, y que en los ejemplares relacionables al estilo Yavi descritas anteriormente pueden aparecer decoradas, lo que también se ha documentado en otros ejemplares (Ávila 2009). Por lo que se trata de un punto interesante a tener en cuenta para profundizar en el futuro. 
Por otro lado, desde las fuentes consultadas, no se evidencian prácticas productivas diferenciadas entre la porción norte de la puna y el altiplano boliviano sur, y la porción sur de la puna jujeña. Como hemos visto al discutir los antecedentes, para tiempos prehispánicos se observa una diferenciación de los materiales cerámicos entre estas dos áreas, y que han sido relacionadas a grupos étnicos distintos (Krapovickas 1983; Albeck y Ruiz 2003). Nosotros, a lo largo de esta tesis, hemos observado que estas diferencias también se dan a nivel de pastas y de otros atributos analizados. Seguramente el impacto de la conquista, el traslado de poblaciones, las encomiendas, las explotaciones mineras y su consecuente movimiento de personas, entre otros factores contribuyeron a desestructurar a estas poblaciones y como consecuencia ciertos aspectos de las prácticas productivas cerámicas.

Asimismo, dentro de la cocción de la alfarería, se describen estructuras de combustión sencillas a cielo abierto, consistentes en pozos o estructuras construidas para tal fin. Se emplea mayormente bosta de distintos ganados disponibles en la puna, y en ocasiones, el uso de leña. Sólo en Chagua se utilizan hornos de doble cámara para la cocción (Sapiencia de Zapata et al. 1997), lo que probablemente sea una incorporación relativamente reciente, a fin de satisfacer la gran demanda del mercado argentino de objetos tales como macetas, ollas, etc. (Krapovickas 1975; Sapiencia de Zapata et al. 1997). En el capítulo anterior hemos mencionado que hasta la fecha no se han hallado estructuras de combustión para cerámica, pero que su falta puede ser indicativa de cocciones a cielo abierto o en estructuras muy rudimentarias. Si hemos observado un predominio de cocciones oxidantes para el material analizado, frecuentemente incompletas y/o con manchas de cocción, que también pueden indicar poco control de la atmósfera en esta etapa, como ocurre en las cocciones en que el combustible está en contacto con el material cerámico.

En la distribución de las piezas cerámicas, aquellas producidas en el contexto de unidades domésticas son para el uso de la misma, y en ciertos casos, algunas pueden ser trocadas con vecinos. En producciones a mayor escala, se destaca el trueque o venta en ferias, que de acuerdo a las referencias citadas para la contextualización histórica, son un fenómeno colonial. La producción cerámica, junto con las ferias, se articulan al calendario agrícola, ganadero y ritual; muchas veces coincidiendo las ferias con festividades que congregan a gran cantidad de personas desde distintos puntos de la puna (Merlino y Rabey 1978; Buechler 1983). 
Los productores de pueblos como Casira o Chagua producen alfarería en grandes cantidades, que venden a intermediarios o "acopiadores", que posteriormente la comercializan a los grandes centros urbanos (Sapiencia de Zapata 1997; Rodríguez 2002). La demanda de los centros urbanos genera la producción de morfologías que no son tradicionales en la puna y el abandono y la modificación de otras. Esta mercantilización de la producción, que solía ser principalmente doméstica, genera cambios en el valor de la producción, que pasa a ser mayormente de cambio y, además de transformaciones materiales, se producen otras de orden simbólico (Rodríguez 2002).

Sin embargo, cabe mencionar que, como señalan Raffino et al. (2004: 252), Chagua era un centro de producción cerámica chicha desde momentos del imperio inkaico, en donde se producía cerámica utilitaria y otros bienes, que eran distribuidos en una amplia región. Por lo que la concentración de la producción cerámica en algunos de estos centros podría ser anterior a la economía de mercado.

La alfarería en la puna se emplea para fines domésticos, especialmente la preparación de alimentos y a veces para almacenamiento de agua; y para fines rituales. Las morfologías empleadas para estos dos tipos de usos son diferentes (Nielsen 2000; Menacho 2007). En la elaboración, almacenaje y servicio de alimentos y bebidas para rituales, sólo se usan recipientes cerámicos. Muchos de ellos, especialmente los usados para la manufactura y servicio de chicha (virques, yuros, ollas grandes), tienen una vida útil muy larga, pudiendo ser heredados, y son almacenados en lugares especiales de las viviendas para que no sufran roturas (Nielsen 2000; Menacho 2001, 2007; Cremonte et al. 2009). Incluso, muchas de estas piezas son las únicas que presentan decoración en el repertorio cerámico de las unidades domésticas puneñas (Menacho 2007), como ya hemos destacado.

Todo ello hace que estas cerámicas tengan un alto valor material y simbólico para sus propietarios. Sin embargo, este tipo de prácticas es muy difícil de detectar y evaluar arqueológicamente, para momentos prehispánicos y coloniales, y no podemos trasladar las morfologías actuales al pasado, ya que probablemente hayan sufrido modificaciones (Cremonte et al. 2009). En nuestras investigaciones no hemos detectado piezas del tipo virques o yuros, que serían las más conspicuas dentro de las morfologías documentadas actualmente. Sin embargo, entre las vasijas del estilo Yavi, son comunes piezas comparables a los yuros, como mencionamos anteriormente. 
En síntesis, las evidencias de producción cerámica muestran algunas continuidades con las prácticas prehispánicas, especialmente en las técnicas de modelado y en los materiales empleados como antiplásticos. Además, al igual que entre muchas de las alfareras observadas por las referencias citadas, la producción en tiempos prehispánicos debió ser una actividad esencialmente doméstica, organizada en torno a la unidad familiar y para su propio consumo.

Sin embargo, se han producido modificaciones desde la conquista española que incluyen la pérdida de algunas morfologías cerámicas y la inclusión de otras europeas. Algunos recipientes de metal $y$, posteriormente, de plástico han ido reemplazando a algunas ollas y especialmente a los platos para el servicio de alimentos, aunque para uso ritual sólo se usan recipientes cerámicos. También, probablemente se comenzaron a vender las piezas en ferias periódicas en momentos coloniales.

Posteriormente, con la inclusión de nuestra zona a la economía de mercado, se habría intensificado la producción en localidades como Chagua o Casira, introduciendo nuevos medios de producción, como el horno de dos cámaras de Chagua y el torno y los moldes en Casira. Los principales cambios se dieron en la distribución de los materiales, especialmente en que las piezas que adquieren un valor de cambio en dinero, son producidas a gran escala en formas y diseños demandados por los centros urbanos, e intercambiadas a intermediarios. Aunque centros como Chagua tendrían una especialización en la producción cerámica prehispánica (Raffino et al. 2004) También se produce un cambio al generar espacios dentro de la unidad de vivienda especialmente destinados para la producción, permitiendo la continuidad de la misma todo el año y sin el carácter estacional anterior.

Probablemente, ello signifique un impacto profundo en la producción no sólo en los aspectos materiales, sino también en la conceptualización de la producción por las propias comunidades, en su extracción de la práctica doméstica cotidiana y en la transformación de los ciclos agrícolas tradicionales. Seguramente esta intensificación de la producción y la participación de muchas comunidades en las ferias llevó a que la producción doméstica actual de cerámica sea prácticamente inexistente, dado que en todos los lugares en los que hemos consultado a los pobladores actuales en Pozuelos y Santa Catalina, nos comentan que no producen sus propias piezas sino que las adquieren de estos centros. 
A pesar de todos estos cambios, la cerámica manufacturada en la puna sigue sosteniendo algunas pautas tradicionales, y a la par de su venta hacia los centros urbanos, se sigue manteniendo su intercambio por trueque, en un circuito mayor de ferias, unidas a ritualidades y modos de reciprocidad tradicionales. De este modo, la alfarería puneña puede funcionar en diferentes contextos, tanto en formas tradicionales de intercambio y reciprocidad, como en la economía de mercado. 
11.

\section{DE LAS CADENAS OPERATIVAS A LAS TRADICIONES TECNOLÓGICAS \\ Discusión de los resultados}

\section{Cadenas operativas en el material analizado:}

En base a las distintas líneas de evidencia que hemos analizado a lo largo de los diferentes capítulos, ahora podemos sintetizar la información aportada e intentar reconstruir parcialmente las cadenas operativas seguidas en la manufactura de los recipientes de las dos zonas de estudio.

El primer paso que hemos intentado abordar es la obtención y preparación de las materias primas. En primer, lugar clasificamos las pastas en lupa binocular en nueve grupos de pastas o GP, cuya caracterización profundizamos mediante observaciones en microscopio petrográfico. La clasificación se basó principalmente en la composición de las inclusiones. En base a la misma y a su comparación con la geología local, tanto a partir de las publicaciones geológicas disponibles, como de la comparación con las muestras de arena (incluyendo sus características petrográficas) y con materias primas actuales, hemos planteado que probablemente se hayan empleado materias primas locales para la manufactura cerámica, entendiendo lo local a una escala regional.

Algunas pastas (GP 1, 2 y 4), probablemente fueron conformadas a partir de arcillas y arenas locales, o de arcillas con inclusiones naturales de tamaño arena, que presentan inclusiones petrográficamente semejantes a las de las arenas actuales de la cuenca sur de Pozuelos, aunque con diferente proporción y tamaño de los componentes, por lo que debieron ser extraídas de otros lugares con distintas cuencas de aporte. Estas corresponderían a las materias primas empleadas en la zona al sur de la laguna de Pozuelos.

Otras (GP 3, variantes A y C del GP 5 y GP 8) pudieron ser arcillas con agregado de rocas pelíticas molidas (práctica que se observa en la actualidad) o que naturalmente contenían esas inclusiones (Krapovickas 1975) y corresponderían a las materias primas 
con las que se confeccionaron los materiales cerámicos de la porción norte de la puna, representada aquí por los sitios de la zona de Santa Catalina, algunos de los cuales pudieron ser transportados a varios de los sitios analizados en el sur de Pozuelos.

Las pastas restantes (GP 6, 7, 9 y variante B del GP 5) serían poshispánicas, de composición diferente a las anteriores, aunque no discordantes con la geología local. Quizás sean resultado de innovaciones locales o materiales traídos desde otras áreas de la puna, lo que resulta más coherente con su baja proporción en los sitios en los que están presentes y con que las pastas del GP 6 y 9 solo están presentes en una única pieza cada una.

Algunas de estas pastas ya habían sido reconocidas en la literatura anterior, como el GP 3, que corresponde a las pastas del estilo Yavi, caracterizado por Krapovickas (1975) y Cremonte et al. (2007a). Sin embargo, para el resto de la puna no se conocían las características de las pastas, exceptuando las descripciones macroscópicas de Ottonello (1973).

Para las piezas de colección no hemos podido describir sus pastas en profundidad, pero las características de las inclusiones observadas con lupa de mano parecen comparables a las del material fragmentario.

Con estas materias primas, se confeccionaron diferentes recipientes cerámicos, empleando una serie de técnicas de manufactura, que incluyen el modelado por superposición de rollos, el estirado con los dedos o el uso de torno. Predomina el modelado por rollos o rodetes en todos los materiales analizados, tanto fragmentario como de colecciones de museo. Sin embargo, como hemos mencionado, el modelado por rollos es más una serie de técnicas que una sola, y puede haber una amplia variabilidad en las formas de los rollos, de uniones entre ellos, etc. (García Roselló 2010).

También hemos observado que en varias piezas, tanto en el material fragmentario como en el de colección, las bases se confeccionaron por separado, dado que se evidencian las uniones con el cuerpo, y en algunos casos, el modelado manual de las mismas. Asimismo, se registró el modelado por partes de algunas piezas cerradas, que presentan uniones visibles entre su segmento inferior y superior, que pueden ser resultado tanto de un período de secado, como del uso de diferentes técnicas de modelado para cada porción. En otras ocasiones, se pudo observar el modelado 
manual, o estirado de las paredes con las manos, de porciones del cuerpo. Este estirado también pudo haberse producido sobre los rollos luego de aplicados.

Además, se observó el uso de torno, mediante la presencia de estrías características, en algunos materiales fragmentarios de dos sitios que tendrían ocupaciones coloniales (PA 22 y SC 3), pero representan un porcentaje pequeño del total del material.

Las morfologías modeladas mediante estas técnicas incluyen tanto piezas abiertas como cerradas. Para los materiales de colección hemos podido precisar las morfologías, en base a la clasificación de Balfet et al. (1991), mientras que en el material fragmentario en la mayor parte de los casos, solo pudimos señalar la presencia de recipientes abiertos o cerrados. Entre las piezas abiertas, hemos observado la presencia de escudillas, escudillas hondas y restringidas. Entre las cerradas, de vasijas, botellas y algunas tinajas. Además de que se registró una serie de piezas que no entran en las categorías previas y que denominamos formas varias.

Todos los grupos de pastas sirvieron para realizar distintas morfologías, no habiendo una selección manifiesta en las materias primas para realizar determinadas formas. Sin embargo, las pastas del GP 5 sirvieron para modelar piezas con paredes en promedio más delgadas que el resto, y quizás por ello se requería menor densidad de inclusiones.

Por otro lado, las distintas técnicas de modelado registradas también se emplearon para todas las formas observadas, especialmente el modelado por rollos, que se reconoció en todo tipo de morfologías. Sin embargo, las piezas que presentan puntos de unión, que atribuimos al modelado por partes, son todas restringidas. Hemos visto que en la actualidad, en lugares como Casira, las piezas cerradas de gran tamaño se modelan en etapas (Rodríguez 2002).

Estas piezas presentan una diversidad de morfologías de bordes, tanto en el material fragmentario como en el de colecciones, predominando aquellos redondeados, tanto evertidos como verticales. En toda la muestra son más frecuentes los bordes evertidos y redondeados, seguidos por los verticales. Los planos evertidos también son frecuentes, y entre las piezas de colección, los verticales y planos. En la muestra fragmentaria tienen cierta importancia los engrosados. Para toda la muestra, en todos los tipos morfológicos predominan los mismos tipos de bordes. Dentro de las formas abiertas, especialmente entre escudillas y escudillas hondas, la diversidad morfológica de los bordes es muy amplia, aunque predominan los redondeados, evertidos o verticales. En 
las cerradas es menos diversa, siendo casi todos los bordes evertidos, y mayormente redondeados. En las botellas son frecuentes los engrosados.

Las bases son predominantemente planas en todas las formas descritas, tanto para el material de colección como para el fragmentario. Hemos destacado que esto puede vincularse al modelado. Por un lado, puede relacionarse a las huellas y marcas registradas, que indican que en ocasiones fueron modeladas manualmente y posteriormente se construyeron las paredes encima, como hemos observado para el modelado actual de distintos lugares de la puna, en los que primero se modela un disco, sobre el que se elevan las paredes mediante rollos. Por otro, quizás, al igual que en la manufactura moderna relevada, se empleaban superficies planas como bases para confeccionar la pieza, giratorias o no. Además, la mayor parte de las bases presentan uniones al cuerpo directas, o angulares en segundo orden de importancia.

En ocasiones, especialmente entre las piezas cerradas, se colocaron asas, tanto adheridas como remachadas. Entre las piezas de colección, predominan las asas verticales, de sección subcircular, plana o subplana. Las horizontales tipo mamelonares o al pastillaje también son importantes, aunque en menor número, al igual que las horizontales de sección plana o subplana, para piezas globulares de cuello cilíndrico. Algunas escudillas presentan asas labioadheridas o pequeñas asas modeladas al pastillaje. También se relevaron algunos casos, en las colecciones y en el material fragmentario, de asas oblicuas, consideradas características de la alfarería del estilo Yavi (Krapovickas y Aleksandrowicz 1986-87). Además, algunas piezas cerradas y abiertas de colección presentan apéndices zoomorfos (ornitomorfos en las abiertas), modelados y adheridos a la pieza. Dos fragmentos de bordes de recipientes abiertos de la zona de Santa Catalina también presentan apéndices ornitomorfos.

Una vez modeladas, o durante el modelado, se sometió a las piezas a diferentes acabados de superficie, algunos de los cuales presentan características visuales estéticas y que se denominan decoración, aunque hemos mencionado lo difícil de establecer un límite entre lo que es decorativo y lo que no. Las formas abiertas y cerradas, tanto del material de colección como del fragmentario, presentan sus superficies alisadas, pulidas, engobadas (con o sin pulido posterior) o pintadas. Predominan las piezas alisadas, pero entre las abiertas, de colección o las identificadas entre el material fragmentario, son más frecuentes las que presentan al menos una de sus superficies pulidas que entre las cerradas. 
En la mayor parte de las piezas abiertas, las acciones de alisado y pulido se llevan a cabo de manera horizontal, mientras que en las cerradas, si bien predominan las huellas de alisado y pulido horizontales, también están presentes las verticales, oblicuas e irregulares. En los cuellos de las piezas cerradas son comunes las caras de pulido verticales.

La aplicación de engobes o pinturas puede ser monocroma, bicolor o tricolor, siendo más frecuente la primera, a menudo en forma de engobes o capas más finas de pintura, de colores rojos. Le siguen las piezas con pintura bicolor, frecuentemente en negro sobre rojo, ya sea formando franjas de distinta orientación, o como pintura desleída, en diferentes motivos complejos, descritos anteriormente. La pintura tricolor más frecuente es la relacionable al estilo Casabindo (Albeck 2001; Zaburlín 2012), especialmente en el material fragmentario, con lunares blancos entre franjas negras, sobre el fondo de la pasta o engobe rojo, en vasijas globulares. Sin embargo, algunas piezas del estilo Yavi presentan dos colores de engobe y encima pintura desleída negra, relacionables al estilo Yavi polícromo (Krapovickas 1975). Las piezas de colección que procederían de la quebrada de Humahuaca también presentan decoración en negro sobre rojo, al igual que varias de las que han sido clasificadas como inkaicas, y que se relacionan a las del estilo Yavi por sus pastas y acabados de superficie.

También observamos que algunas piezas presentan incisiones, formando rasgos de caras de modelados antropomorfos en botellas del estilo Yavi, u ojos en apéndices ornitomorfos de piezas inkaicas. A su vez, hay decoración incisa en una escudilla honda troncocónica del Pucará de Rinconada y en el borde de la pieza con corrugado en el cuello de Doncellas, para las que hemos deducido una procedencia de áreas hacia el este de los Andes.

La decoración modelada y al pastillaje, además de los cuellos antropomorfos y apéndices ornitomorfos descritos, incluyen las piezas con pastillajes en zigzag del Pucará de Rinconada y de PA 22, que serían de momentos coloniales, y dos recipientes cerrados de Sansana con apéndices zoomorfos tubulares huecos. Otro recipiente de forma no clasificada presenta un modelado zoomorfo con incisiones y también registramos una figurina de ave con algunos rasgos dibujados mediante incisiones.

Varias morfologías y decoraciones, tanto de las colecciones como del material fragmentario, han sido vinculadas a las descritas en la literatura previa, lo que nos llevó a definir categorías morfo-estilísticas y relacionar los atributos observados con ellas. 
Aquellas formas vinculadas al estilo Casabindo incluyen vasijas globulares con cuello cilíndrico, con decoración bicolor, tricolor o sin decoración, vasos chatos y pucos interior negro pulido (Ottonello 1973; Albeck 2001; Albeck y Ruiz 1997). Entre los materiales fragmentarios, presentan pastas de los GP 1, 2 y 4, al igual que buena parte de las piezas abiertas, cerradas e indeterminadas, cuyas morfologías concretas no pudimos precisar, del sur de Pozuelos. Los fragmentos con estos grupos de pastas presentan un porcentaje importante de superficies alisadas o pulidas.

En cambio, otras morfologías, sus pastas y decoraciones, fueron vinculadas a las del estilo Yavi, incluyendo botellas de forma esférica con o sin asas oblicuas, con o sin modelados antropomorfos en el cuello, vasijas, escudillas y escudillas hondas. Algunas presentan engobes característicos y pintura desleída negra (Krapovickas 1975; Krapovickas y Aleksandrowicz 1986-87; Krapovickas et al. 1989; Ávila 2006). En las piezas abiertas que presentan motivos pintados, los mismos se colocan preferentemente en la superficie interior o a modo de franja próxima al borde en la superficie externa. Algunas piezas cerradas también tienen motivos como franja en la porción interna del borde. Entre los fragmentos analizados, este grupo presenta pastas de los GP 3, 5 y 8, y en ellos son más frecuentes los fragmentos engobados y/o pulidos que en el conjunto mencionado anteriormente.

De esta manera, consideramos que estos dos agrupamientos de pastas, con sus categorías morfoestilísticas respectivas, están representando dos tradiciones tecnológicas diferentes de la puna, cada una con sus correspondientes cadenas operativas (ver las figuras más adelante), que sirvieron para manufacturar los recipientes que en la literatura se han asociado a esos dos estilos.

Los fragmentos con improntas textiles se habían clasificado en la bibliografía consultada dentro de los tipos del estilo Yavi. Sin embargo, aquí hemos visto que las pastas que presentan los acercan más a los materiales característicos del área Casabindo, aunque al ser tan escasos los fragmentos con este tipo de impronta, sería necesario ampliar la muestra para realizar mayores comparaciones. Tales improntas pueden ser el resultado de telas como base para el modelado (Boman 1908; Krapovickas y Cigliano 1962-63).

Otro elemento que escapa a las definiciones estilísticas previas, es el grupo de fragmentos con decoración de puntos blancos y líneas negras anchas sobre rojo, que se vincularía a los tipos cerámicos del estilo Casabindo, aunque en este caso presentan 
pastas del GP 3. Zaburlín (2012) vincula estos puntos pequeños al tipo denominado "Queta polícromo", que podría estar asociado a la presencia imperial.

Un pequeño grupo de FNA presenta vitrificado en sus superficies, que puede ser monocromo o bicolor (en un único caso), y corresponden a piezas abiertas en aquellos casos en los que se pudo reconstruir parte de la forma. Este acabado de superficie involucra técnicas introducidas por los europeos en América.

Todas las piezas debieron secarse completamente antes de la cocción, aunque este paso no es posible de abordar con el material bajo estudio. Sin embargo, hemos visto que distintos pasos, como el pulido, o la aplicación de engobes y pinturas, pueden llevarse a cabo en diferentes fases del secado de la arcilla.

Una vez secas, las piezas son sometidas a cocción. Si bien no hemos registrado contextos de manufactura y cocción, quizás la falta de los mismos estén dando cuenta del uso de estructuras efímeras o de cocciones a cielo abierto, como hemos visto que sucede en la actualidad para buena parte de la producción cerámica puneña, habiéndose introducido el horno de doble cámara solo para producciones a gran escala en Bolivia (Sapiencia de Zapata et al. 1997). Sí hemos podido distinguir diferentes tipos de atmósferas cocción, entre las cuales, en la mayor parte del material analizado, tanto de colección como fragmentario, predominan las oxidantes, completas o incompletas. Dentro del material fragmentario, son más abundantes las piezas cocidas en atmósfera oxidante incompleta, que completa.

Para los fragmentos correspondientes a piezas con pastas de los GP 1, 2 y 4, incluyendo las del estilo Casabindo y las que no presentan decoración, predominan las atmósferas oxidantes incompletas, seguidas por las completas. En varias piezas de colección con morfologías asociables a este estilo se observaron manchas de cocción, posiblemente vinculadas a atmósferas variables, oxidantes incompletas. En cambio, los pucos con el interior negro pulido, presentan una coloración particular con el exterior oxidante y el interior reducido, probablemente logrado mediante la colocación de los pucos boca abajo durante la cocción. Algunos muestran cocciones en atmósferas reductoras.

Los fragmentos con pastas de los GP 3, 5 y 8, que incluyen aquellos del estilo Yavi, presentan cocciones oxidantes en casi todos los casos, siendo más frecuentes las completas en los GP 3 y 5, y las incompletas en el 8. Las pastas del GP 3 y del 5, 
además de evidencias de atmósferas más controladas de cocción también presentaban mayor resistencia a la fractura, lo que puede estar asociado a lo anterior, o a que se alcanzaron temperaturas más altas.

Además de los pasos de la cadena operativa analizados, en algunos materiales, se observaron indicios de reparación o reciclado, que serían posteriores a la manufactura. Estos incluyen orificios de reparación y otras perforaciones de función desconocida. También se registró el desgastado de bordes de algunos fragmentos, que en algunos casos han sido formatizados por completo de esta manera, quizás para servir como alisadores, algunos posiblemente en la manufactura cerámica. También se observaron torteros confeccionados sobre fragmentos, el reciclado de la porción inferior de una pieza y el uso de otras dos probablemente como soporte para huso de hilar, que generaron perforaciones en las bases ("vaso de hilandera").

En base a esta síntesis, integrando la información del análisis del material fragmentario y de colección, y siguiendo la propuesta de García Roselló (2010), esquematizamos las cadenas operativas de los materiales analizados, para las diferentes categorías morfo-estilísticas que hemos distinguido en los siguientes gráficos, como una manera de representar la serie de pasos que habrían seguido los artesanos para manufacturar las distintas formas cerámicas presentes. Como intentamos centrarnos en las tradiciones alfareras locales, no consideramos en estos esquemas las piezas que serían de origen no local, presentes en los materiales de colección, que además son escasas y que requerirían un análisis pormenorizado en sus regiones de origen, incluyendo las pastas. Los esquemas que presentamos son hipótesis de las cadenas operativas, que se sustentan en la evidencia registrada. Estas secuencias de pasos representan, a nuestro entender, las elecciones tecnológicas de los artesanos, parte de sus habitus y, por tanto, son una parte de las tradiciones tecnológicas en la manufactura cerámica puneña.

En la siguiente figura (Figura 11.1) vemos el esquema de los pasos que hemos podido reconstruir para las piezas con pastas, formas o decoración que las hacen vinculables al estilo Yavi. 


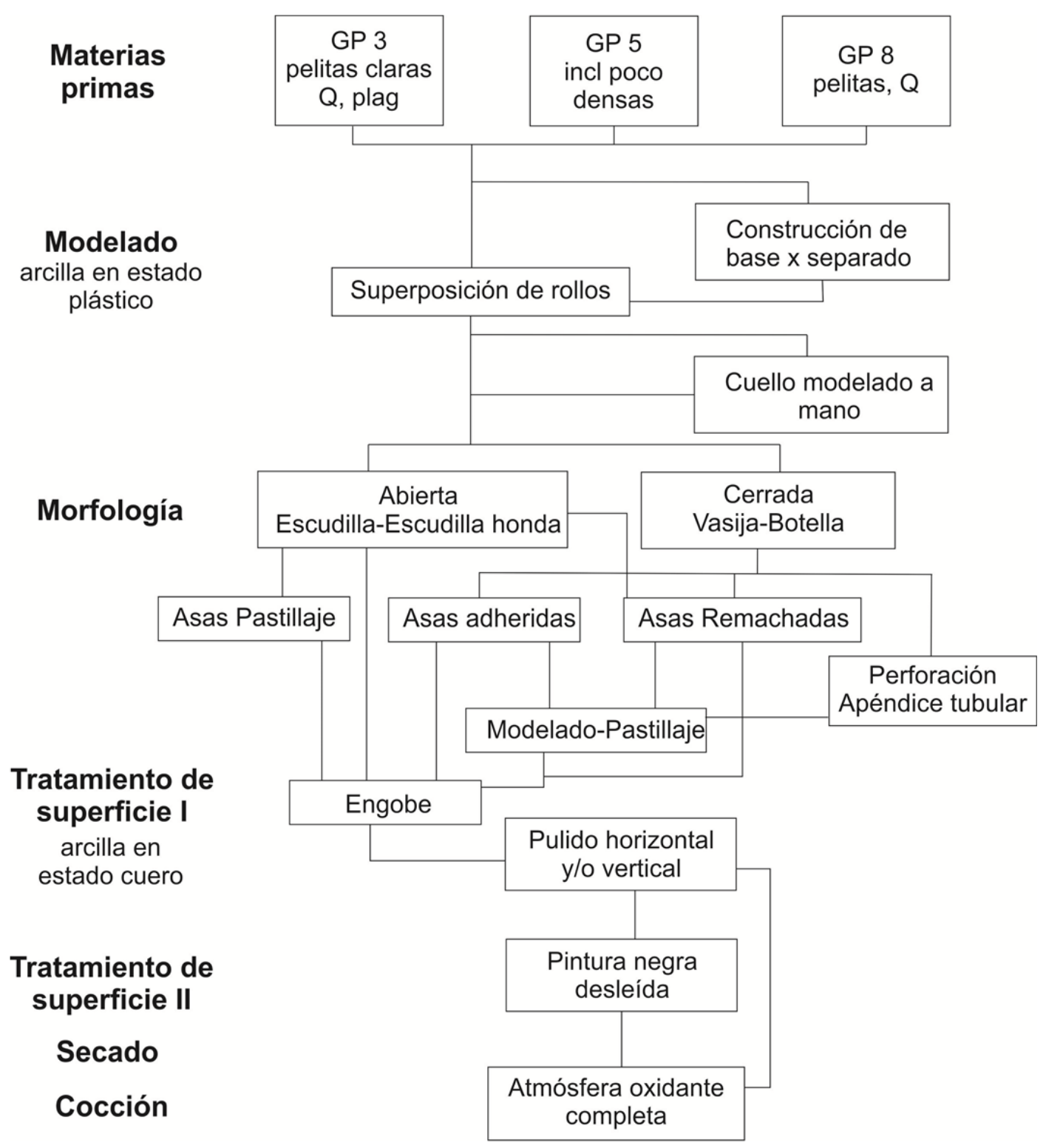

Figura 11.1 Esquema de los pasos reconstruidos en la cadena operativa de los materiales cerámicos de estilo Yavi.

En la Figura 11.2 se muestra la secuencia de pasos reconstruidos para la manufactura de piezas con decoración pintada vinculable a la del estilo Casabindo, que consiste en su totalidad de piezas cerradas y que presentan, en comparación al esquema anterior, menos decisiones u opciones en algunos pasos, en especial en lo referente a la aplicación de asas o en los tipos de acabados de superficie, aunque ello puede deberse a que son pocos ejemplares y de una única clase morfológica. 


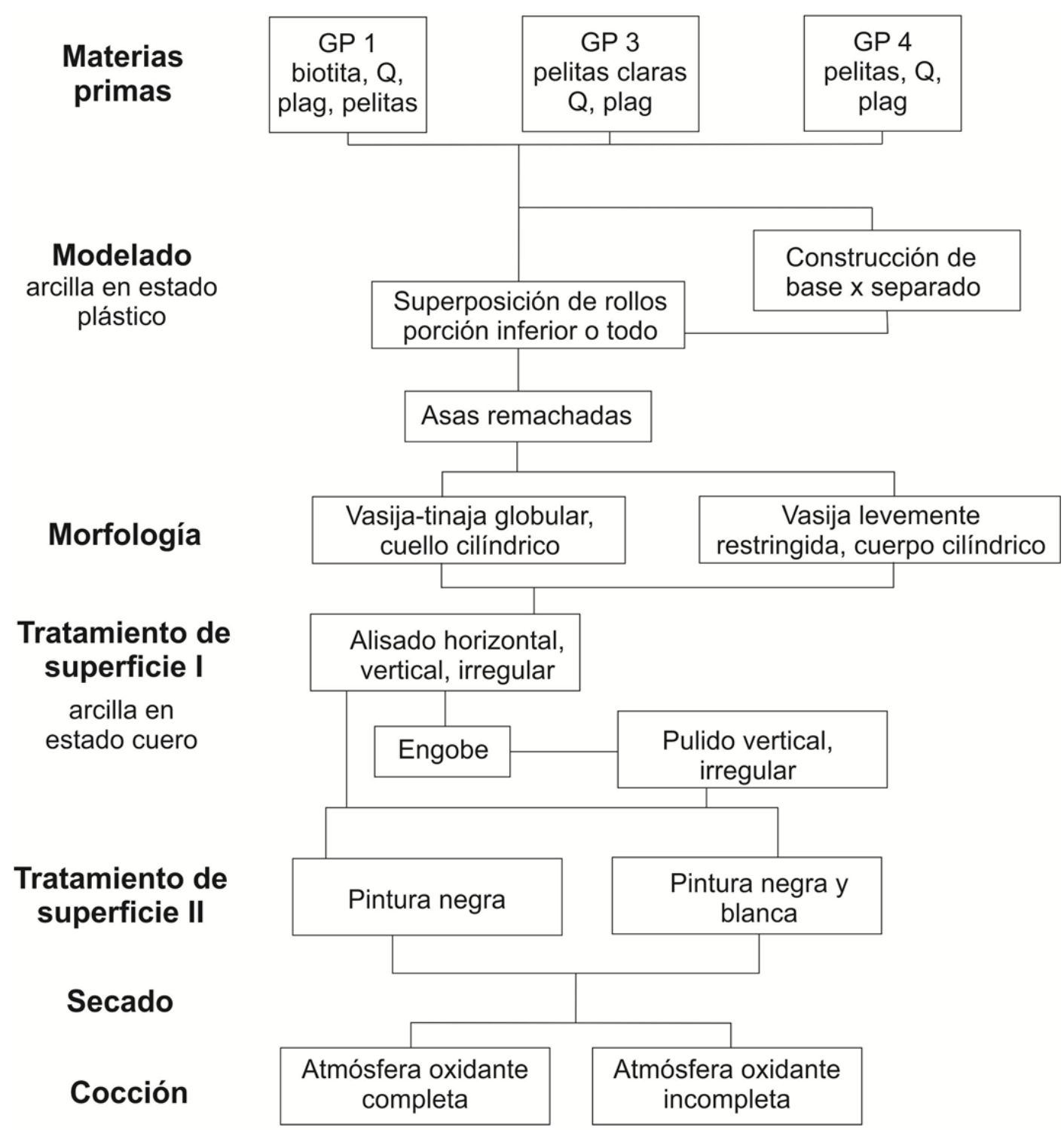

Figura 11.2 Esquema de los pasos reconstruidos en la cadena operativa de los materiales cerámicos de estilo Casabindo pintado.

A continuación, esquematizamos la secuencia de manufactura de los pucos interior negro pulido (Figura 11.3), que destacablemente es bastante homogénea para todos los ejemplares relevados, como se nota en las pocas opciones en cada paso en el diagrama, a pesar de que hay un número importante de piezas dentro de esta categoría. 


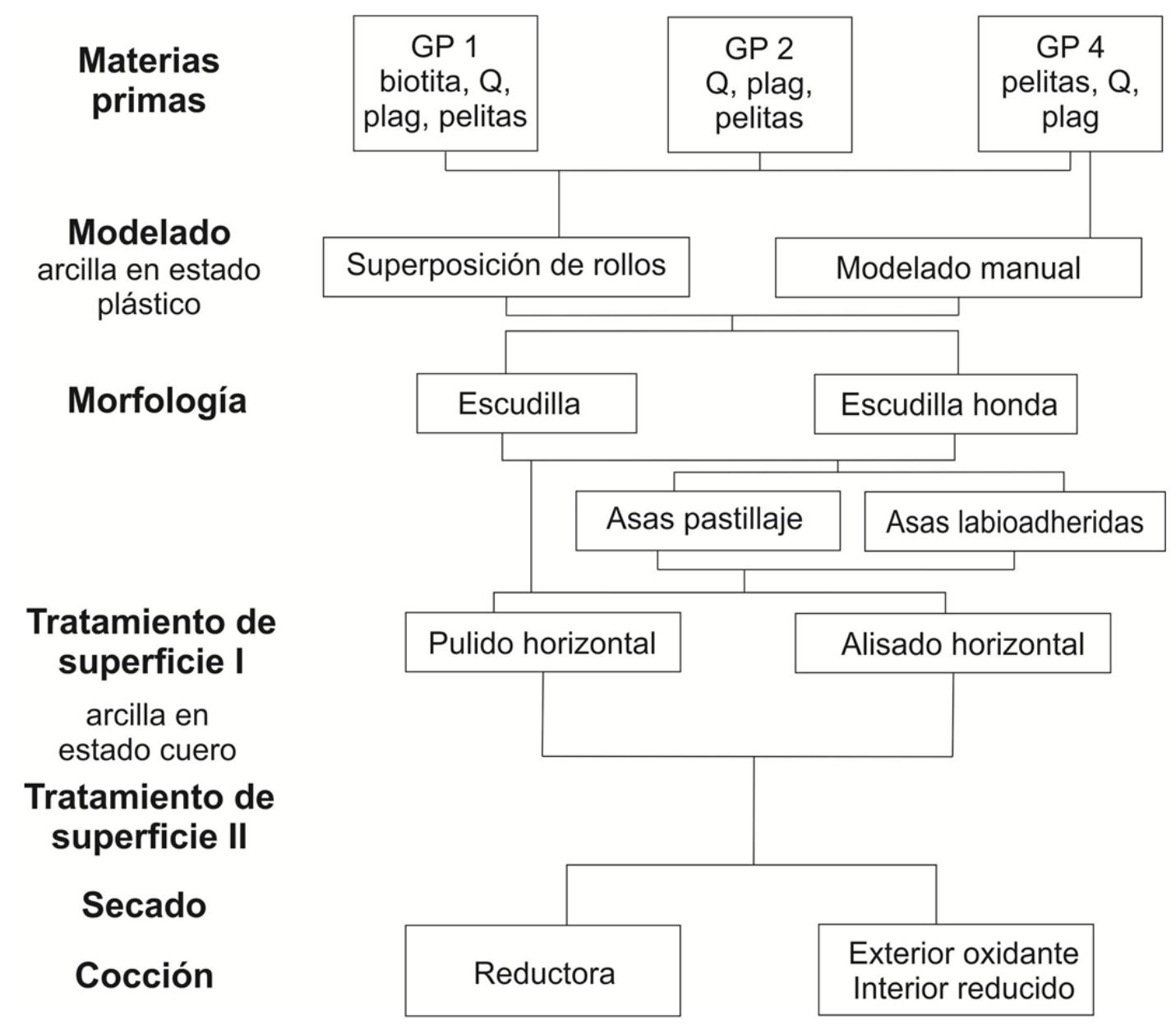

Figura 11.3 Esquema de los pasos reconstruidos en la cadena operativa de los materiales cerámicos clasificados como pucos interior negro pulido.

El siguiente diagrama (Figura 11.4) representa la posible cadena operativa seguida en la manufactura de los vasos chatos. También es una secuencia homogénea, aunque en este caso fueron pocos los ejemplares documentados, y casi todos procedentes de las colecciones de museos. 


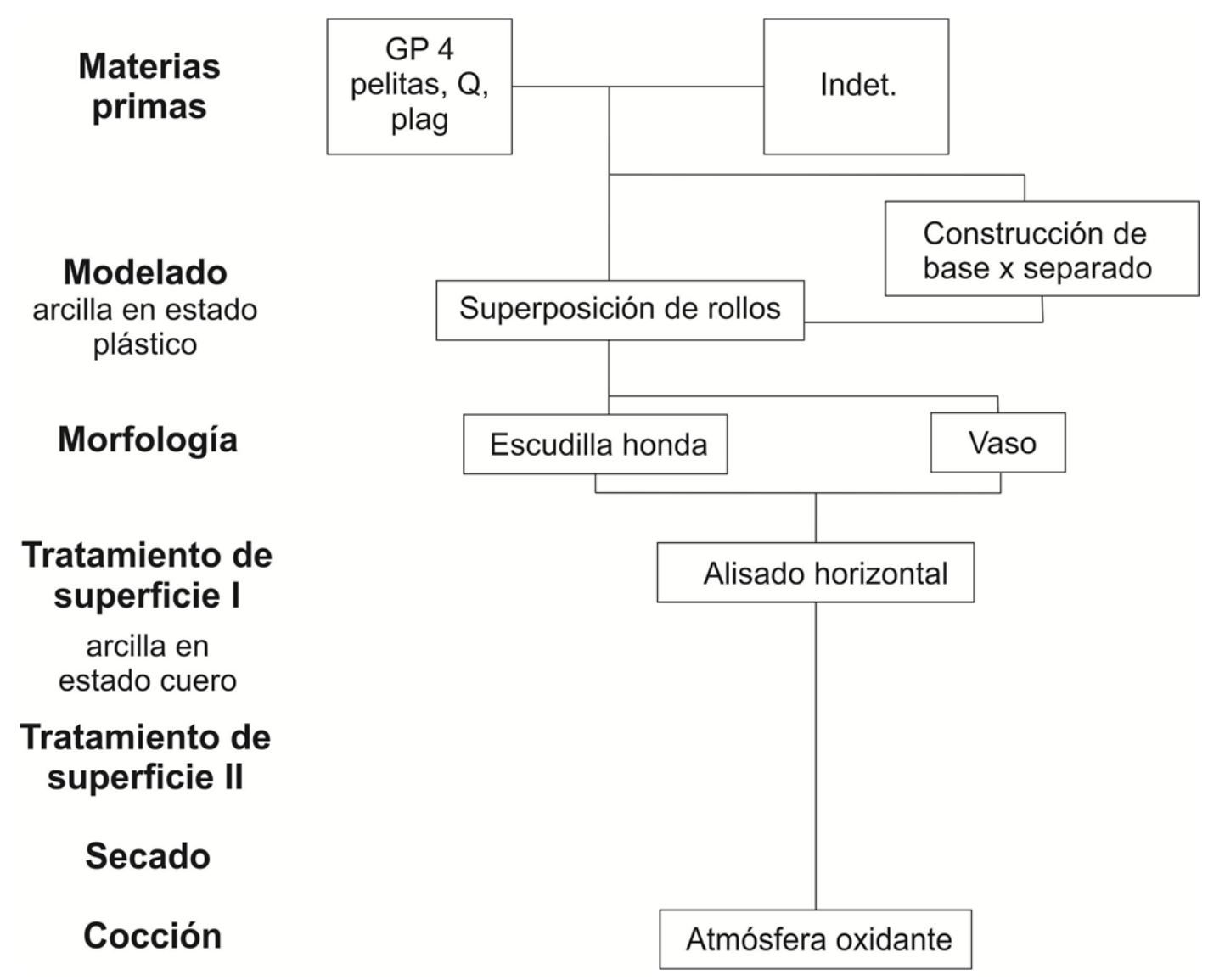

Figura 11.4 Esquema de los pasos reconstruidos en la cadena operativa de los materiales cerámicos clasificados como vasos chatos.

Todos estos últimos tres esquemas corresponden a piezas cuyas morfologías han sido vinculadas a los sitios del sur de la puna y al estilo Casabindo. A continuación, esquematizamos los pasos que se habrían seguido para modelar las piezas cerradas y de forma indeterminada (Figura 11.5) y las piezas abiertas (Figura 11.6), que no se clasificaron como correspondientes a ningún estilo, pero que de acuerdo a los grupos de pastas representados hemos considerado como pertenecientes a una misma tradición tecnológica con el material Casabindo. Estás muestran una diversidad mayor de elecciones en determinados momentos de la secuencia, al contrario de los esquemas precedentes, especialmente para las piezas cerradas. 


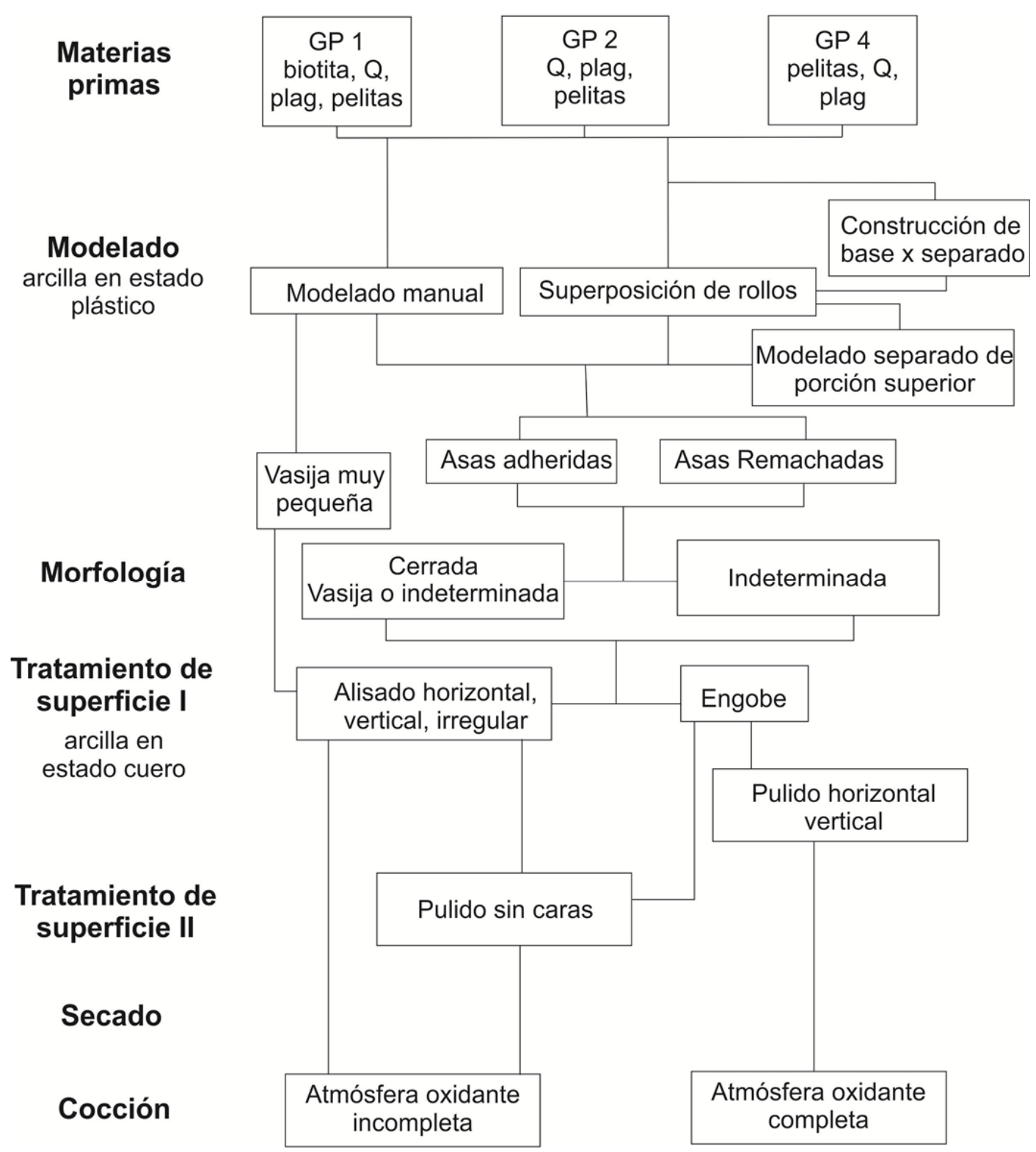

Figura 11.5 Esquema de los pasos reconstruidos en la cadena operativa de los materiales cerámicos cerrados o de forma indeterminada, no clasificados en ningún estilo de la literatura previa. 


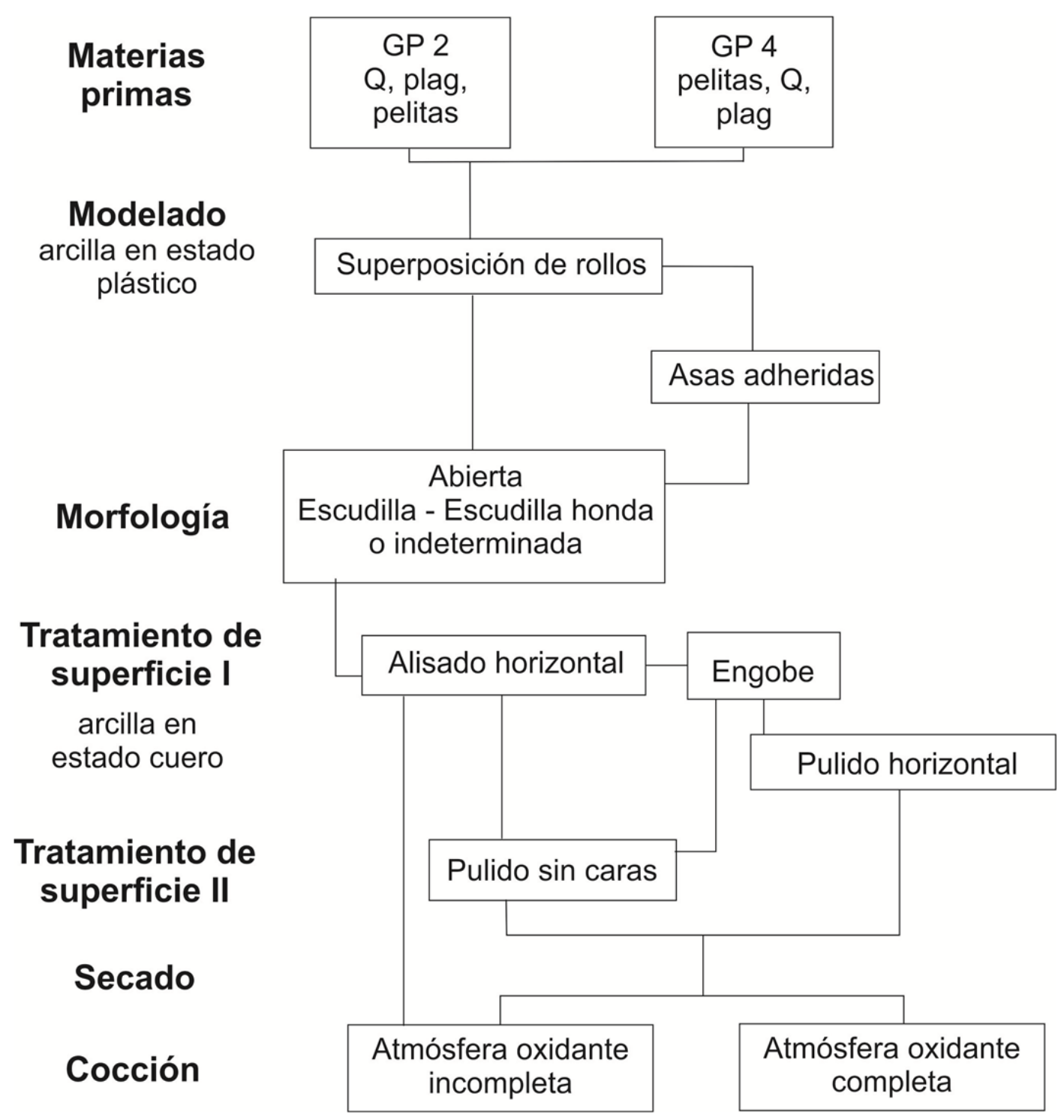

Figura 11.6 Esquema de los pasos reconstruidos en la cadena operativa de los materiales cerámicos de morfología abierta, no clasificados en ningún estilo de la literatura previa.

La siguiente figura (Figura 11.7) busca esquematizar la secuencia de pasos seguida en la manufactura de piezas de morfología inka, tanto fragmentarias como de colección. Aunque algunas de las piezas pueden ser de origen no local, decidimos abordarlas todas juntas, por la imposibilidad de separarlas por su origen, dado que en las de colección no se pudieron analizar las pastas. Probablemente por eso esta sea una secuencia con tantas variaciones $u$ opciones en los distintos pasos analizados, que podría estar representando diferentes tradiciones tecnológicas. 


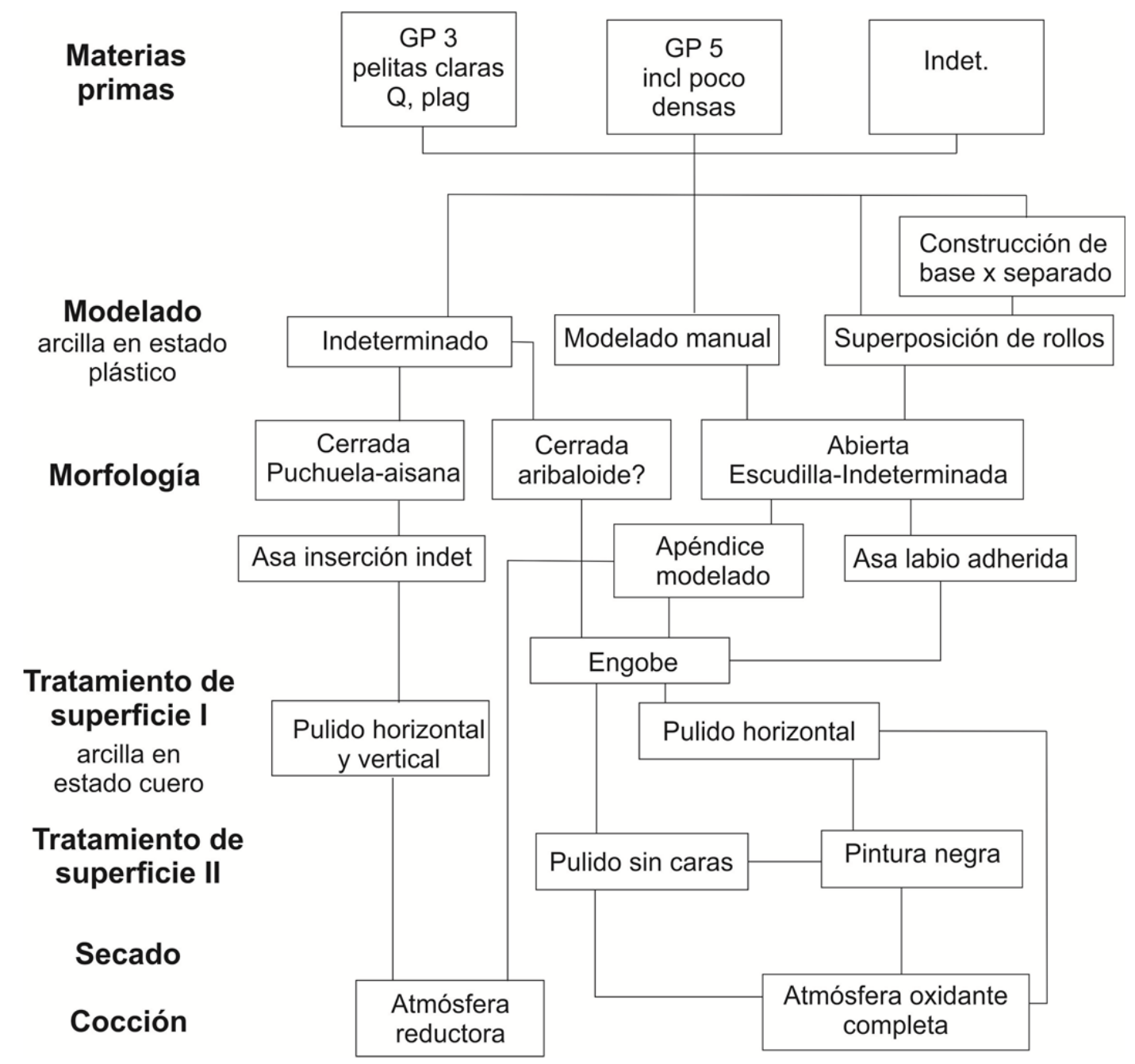

Figura 11.7 Esquema de los pasos reconstruidos en la cadena operativa de los materiales cerámicos clasificables como inkaicos.

Por último, la siguiente secuencia (Figura 11.8) esquematiza la manufactura de piezas que serían de momentos poshispánicos, tanto para el material fragmentario como el de colección. También es una secuencia compleja, con muchas operaciones diferentes en distintas partes de la cadena. Probablemente, muchas de las piezas incorporadas en ella sean de origen no local, como lo hemos discutido previamente, por lo que en realidad estaríamos representando diferentes tradiciones tecnológicas, especialmente para las modeladas con torno o que tienen pastas particulares. Ante la duda, incluimos a todas en el esquema. 


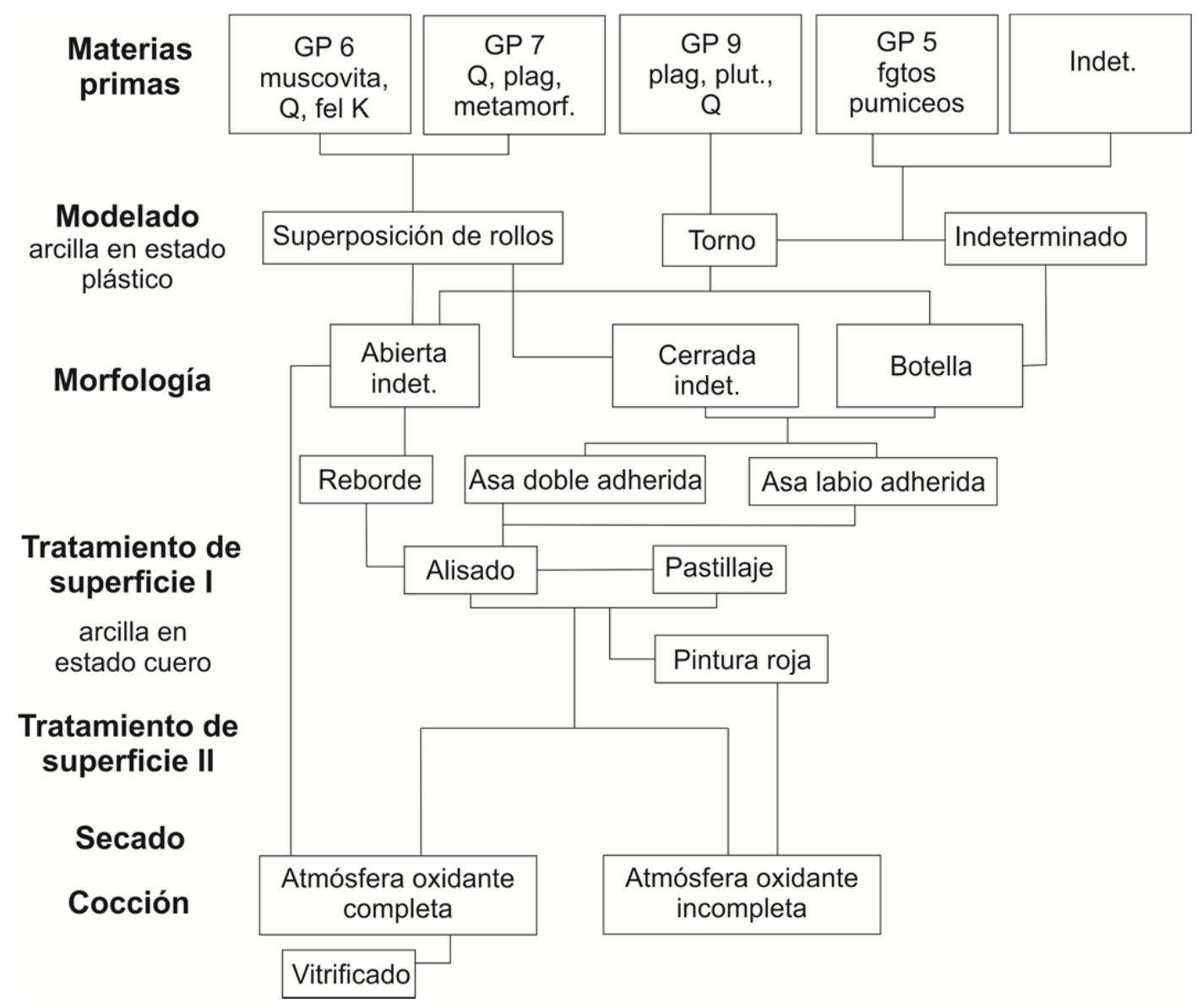

Figura 11.8 Esquema de los pasos reconstruidos en la cadena operativa de los materiales cerámicos clasificables como poshispánicos.

\section{Variaciones contextuales:}

Los materiales abordados en este trabajo proceden de diferentes tipos de contextos, incluyendo recintos habitacionales, un basurero y tumbas. Los contextos fúnebres se encuentran representados por las colecciones de museos, incluyendo los sitios de Queta y Doncellas, donde Casanova excavó exclusivamente tumbas; Sansana, de donde Boman extrajo 11 piezas de un contexto funerario; el Pucará de Rinconada, donde el mismo autor excavó enterratorios en las mesetas que lo rodean, además de los recintos de habitación; y Sayate y Yavi Chico, con algunas piezas procedentes también de inhumaciones. Para el Pucará, en base a la información disponible, solo hemos podido precisar la procedencia de las piezas que el autor publica en su volumen (1908), que son pocas, y consisten en las dos miniaturas de la Figura 7.14 que serían 
de los recintos, y la escudilla restringida o cubilete de la Figura 8.7 C procedente de un entierro en gruta. Para estos contextos, las piezas abiertas son equivalentes en proporción a las cerradas, menos en el Pucará de Rinconada y en Sansana, donde predominan las cerradas.

Además, dentro los contextos funerarios, algunos se localizan en la porción norte de la puna, cercana a la frontera con Bolivia (Sansana, Yavi Chico), mientras que la mayoría corresponden a sitios localizados más al sur, en el área de la laguna de Pozuelos (Pucará de Rinconada, Queta) o en la cuenca de Miraflores-Guayatayoc (Doncellas, Sayate, Cochinoca). Entre estas dos áreas diferentes, hemos observado que para el norte de la puna predominan las morfologías de escudilla honda, vasija y botella, mientras que en la puna sur son más abundantes las escudillas y se registran otras morfologías no representadas en la puna norte, como las escudillas restringidas, los vasos y las tinajas. Además, en Queta se registran aquellas piezas que hemos clasificado como formas varias y que no están presentes en los demás contextos.

Los contextos domésticos o habitacionales están representados en nuestra muestra por el material fragmentario obtenido en el transcurso de nuestras campañas, tanto por excavación como de recolección superficial. En la mayor parte predominan las piezas abiertas sobre las cerradas, exceptuando los sitios TA 1-1 y $\mathrm{CH} 25-2$, con fechados prehispánicos tardíos, y los que pensamos que corresponden a momentos coloniales, como PA 22 y CH 25-1.

Entre los contextos funerarios, representados por las piezas de colección, algo menos de la mitad de los recipientes presentan decoración pintada, ya sea monocroma, como bicolor o tricolor. En cambio, la proporción es menor para el material fragmentario, con 35\% o menos de los GF y FNA decorados. Sin embargo, en el material fragmentario, algunos fragmentos presentan improntas textiles, que no se hallaron entre los materiales de colección, aunque estos son muy escasos. Por otro lado, la porción de la muestra fragmentaria procedente de los sitios del norte de la puna presenta una proporción mayor de decoración que la del sur de la puna.

En cuanto a la distribución de las categorías morfo-estilísticas definidas, los materiales clasificables dentro del estilo Casabindo que hemos descrito se localizan en su totalidad dentro de la porción sur de la puna analizada, tanto para aquellos procedentes de las colecciones de museos como para los fragmentos recuperados por nosotros. Estos incluyen los recipientes y fragmentos con decoración bicolor y tricolor 
con puntos blancos y franjas negras, los pucos interior negro pulido y los vasos chatos, a los que también hemos asociado los recipientes abiertos y cerrados alisados, porque todos presentan pastas de los GP 1, 2 y 4 (en el material fragmentario). Para el caso particular de los pucos interior negro pulido, además hemos observado que son más frecuentes en los contextos habitacionales que en los funerarios, siendo muy abundantes en RH 19-7, como también lo señaló Ottonello (1973) para el sitio Doncellas o Agua Caliente de Rachaite.

En cambio, aquellos relacionables al estilo Yavi, incluyendo piezas abiertas y cerradas con engobes y pintura negra desleída característica, además de la presencia de pastas de los GP 3 y 5 en los materiales fragmentarios, se encuentran tanto en el norte como en el sur. EI GP 8, que también consideramos vinculado a ese estilo, solo está presente en los sitios del norte de la puna. Entre los materiales fragmentarios solo aparecen en algunos contextos, sin embargo en los contextos funerarios representados por los materiales de colección son abundantes. Las formas de botellas corresponderían a este estilo, y entre el material fragmentario, solo se encuentran presentes entre los sitios del norte de la puna, exceptuando aquellas que podrían ser coloniales (de PA 22) y que no corresponden al estilo Yavi. En los materiales de colección también son más frecuentes en esa porción del área de estudio, y las del Pucará de Rinconada serían poshispánicas.

Por otro lado, los contextos funerarios presentan un número de piezas clasificables como inka provincial, que proceden de la porción sur de la puna. Entre el material fragmentario de esa área no hemos relevado este tipo de piezas, pero sí hemos registrado fragmentos vinculables a tipos inkaicos en el norte de la puna, entre los materiales de los sitios del área de Santa Catalina.

Las piezas de posible origen alóctono, clasificadas como procedentes posiblemente de la Quebrada de Humahuaca, o de la vertiente oriental de los Andes, proceden en su totalidad de los contextos funerarios representados en las colecciones.

Por lo tanto, para momentos prehispánicos tardíos registramos diferencias entre las piezas representadas en los contextos funerarios y en los sitios habitacionales, siendo más diversas las formas, decoraciones y orígenes de las primeras. A su vez, en las tumbas son más frecuentes los recipientes decorados, como así también aquellos del estilo Yavi, dentro del sur de la cuenca de Pozuelos. En cambio, en los sitios de Pozuelos son más frecuentes los pucos interior negro pulido que en las tumbas. 
Seguramente estas diferencias estén relacionadas a los distintos usos que se les dieron a los recipientes, íntimamente vinculados a su valor simbólico y su significado dentro de la trama de las relaciones sociales de las que formaron parte; problema sobre el que valdría la pena ahondar mediante otro tipo de análisis que incluyan otras materialidades y sus relaciones.

También observamos diferencias entre los contextos del norte y sur de la puna, con más representación de las formas de botellas entre los primeros, y mayor porcentaje de recipientes decorados para el material fragmentario de la porción norte del área de estudio en comparación con la sur. Consideramos que estas diferencias se relacionan a la mayor presencia del estilo Yavi en el norte de la puna.

Sintetizando estas variaciones contextuales y habiendo visto que para el sur de Pozuelos, la mayor parte de los contextos abordados aquí corresponden a recintos habitacionales asociados a estructuras de cultivo, conformando parte de un paisaje rural (Angiorama 2011), la cerámica encontrada en los mismos debió haber sido parte probablemente de las actividades cotidianas y se debió haber elaborado en las propias unidades domésticas u otras cercanas, pudiendo haberlas intercambiado entre vecinos, como las alfareras observadas por Boman (1908) y García (1988). Distintos autores han destacado el hecho de que la alfarería empleada en contextos domésticos para la preparación y consumo de alimentos frecuentemente es manufacturada localmente (Arnold 1993; Rye 1981; Sinopoli 1991), hipótesis que aquí sostenemos para los materiales de Pozuelos analizados, exceptuando el caso de los fragmentos Yavi, que seguramente fueron manufacturados en la porción norte de la puna.

Los materiales analizados en Santa Catalina proceden de contextos diferentes, uno posiblemente un pequeño tambo y otro un poblado con abundantes estructuras asociadas (ver Capítulo 4). De todas formas, los recipientes analizados pudieron haber funcionado en las actividades cotidianas de las personas que habitaban en estos lugares. Dada la disponibilidad cercana de materias primas, de las que tomamos algunas muestras analizadas en el Capítulo 6, la manufactura pudo haber tenido lugar en estos sitios u otros cercanos. Si sumamos la posible herramienta de alisado de TC 2 , quizás se elaboraban algunos materiales allí a pequeña escala.

En cambio, los recipientes procedentes de los contextos funerarios habrían tenido otro rol en el marco de estos contextos, como acompañamiento de los muertos, junto con otros objetos elaborados en diferentes materias primas. Entre los mismos se 
encuentran diferentes morfologías, materiales que proceden de otras regiones y una mayor representación de las piezas inkaicas. Seguramente, esta representación diferencial de materiales, aunque con elementos en común a los domésticos, habría tenido su significado, difícil de abordar en base a la evidencia relevada.

\section{Variaciones cronológicas:}

Los materiales cerámicos y las evidencias de manufactura actual que abordamos en el transcurso del trabajo representan un lapso cronológico muy amplio, por lo que hemos observado persistencias y cambios en las cadenas operativas y sus resultados a lo largo del tiempo.

Buena parte del material analizado procede de contextos que han sido datados en momentos prehispánicos tardíos, como hemos mencionado en el Capítulo 4, o de sitios en los que se supone una ocupación principal para esa época (básicamente para los materiales de colección). Las dos tradiciones tecnológicas, asociadas a los estilos definidos previamente, que hemos mencionado en la primera sección de este capítulo, tendrían su origen al menos en este período.

Sin embargo, en el conjunto de recipientes completos y fragmentarios, algunos se pueden vincular a la presencia inka. Estos incluyen escudillas con apéndices ornitomorfos, otras con asa lateral, formas de puchuelas o aisanas, un fragmento de estilo Cusco polícromo, otro de estilo Inca Pacajes y dos fragmentos de borde posiblemente correspondientes a formas aribaloides. Las mismas corresponden a piezas inka provincial (sensu Calderari y Williams 1991), ya que en muchos casos se observan características de pasta o acabado de superficie vinculables al estilo Yavi. Las piezas cocidas en atmósfera reductora no se han podido vincular a estilos locales, pero tampoco a procedencias cusqueñas. Quizás estén relacionadas a las otras piezas de cocción reductora que aparecen en las colecciones (que son solo dos), para las que hemos deducido un origen de la vertiente oriental de los Andes, una de las cuales presenta el cuello cilíndrico y corrugado. Como hemos mencionado, piezas similares han sido vinculadas a la presencia inka en la quebrada de Humahuaca (Nielsen 1997b).

Hemos llamado la atención previamente sobre el hecho de que los materiales relacionables a cerámica Inka entre el material fragmentario proceden de SC 3 y TC 2, estando ausentes de la zona sur de la cuenca de Pozuelos (a excepción de un posible 
fragmento de pie o pedestal de TA 1-1), a pesar de que allí se encuentra el Pucará de Rinconada, que habría tenido una ocupación imperial (Ruiz 1996). Sin embargo, entre el material de colección, la totalidad de las piezas con morfología inkaica reconocida proceden de los sitios del sur de la puna, especialmente de Queta y Doncellas, donde se excavaron exclusivamente tumbas. Además, como ya señalamos, en la quebrada de Queta se encuentra un tambo inkaico asociado al camino imperial (Raffino et al. 1986).

En los sitios que presentan ocupaciones datadas en momentos coloniales (PA 22, $\mathrm{RH}$ 10) o que pensamos que pudieron tener una ocupación colonial $(\mathrm{CH} 25-1, \mathrm{TC} 2$, SC $3)$, aparecen materiales cerámicos que se diferencian de los anteriores. Como vimos en el apartado anterior, surgen nuevos grupos de pastas, con composiciones diferentes aunque no discordantes con la de la geología local (cuyas formaciones tienen una amplia distribución regional). La baja proporción de estos elementos en los sitios analizados, que conservan un porcentaje significativo de materiales comparables a los de momentos prehispánicos, nos llevan a plantear que quizás los mismos no sean locales. Algunos quizás hayan sido aportados por españoles o por contacto con ellos, dado que parte de los sitios mencionados corresponden a centros mineros que pudieron tener cierta importancia en época colonial (PA 22 y TC 2) (Angiorama y Becerra 2010).

Por otro lado, también aparecen materiales que presentan indicios de modelado con uso de torno, una técnica introducida en América por los europeos. Sin embargo, al igual que para los grupos de pastas poshispánicos, son escasos los materiales con estas evidencias. Esto nos lleva a plantear la posibilidad de que también sean materiales no locales, a lo que se suma que en el área de estudio el torno es una incorporación muy reciente en la manufactura cerámica (ver Capítulo 10). En todos los sitios con ocupaciones coloniales analizados, para los fragmentos en que se pudo determinar la técnica de modelado, predomina la superposición de rollos, exceptuando SC 3, en donde hay un conjunto de fragmentos con estrías de modelado con torno, pero que mayormente procederían de una misma pieza, con pasta del GP 9.

Otro cambio que se percibe es que para los contextos excavados de estos momentos, las morfologías más abundantes son las cerradas, al contrario de lo que sucede en momentos prehispánicos para la mayor parte de los sitios analizados. Ello debe estar vinculado a los usos que tenían las diferentes piezas y las actividades que se llevaban a cabo en los sitios, aspectos en los que no hemos profundizado. 
Entre las piezas de colección procedentes del Pucará de Rinconada, también hemos registrado cinco que podrían ser de momentos posteriores al contacto hispano indígena, que presentan morfologías correspondientes a botellas, con o sin asas laterales, y jarras con asa lateral y pico. Cuatro presentan pintura roja, formando motivos circulares y lineales, y dos presentan modelados al pastillaje en forma de zigzag. Estos tipos de decoraciones no se encuentran presentes en el resto del material relevado. Otra morfología particular, correspondiente a momentos coloniales, y procedente de PA 22, es una forma abierta con un reborde modelado en la superficie externa. Además en PA 22 tenemos presentes morfologías de botellas, que no se registraron en el material fragmentario de otros sitios de la cuenca sur de Pozuelos, y un fragmento de borde de un recipiente cerrado con asa labioadherida con un pastillaje en zigzag. Por lo que en ambos tipos de muestra analizada se registra la presencia de botellas o jarras para momentos coloniales, que no es una forma presente en los contextos prehispánicos de esta porción de la puna y la aparición de nuevos elementos decorativos. La forma de botella de SC 3 mencionada párrafos atrás, que presentaba estrías de torno y un tipo de pasta particular (GP 9), probablemente corresponda a una botija o similar, con paredes espesas.

Algunos FNA presentan las superficies con vitrificados, como mencionamos arriba, que también sería una técnica introducida por los europeos tras el contacto. Estos fragmentos se localizan en PA 22, SC 3 y TC 2, y son muy escasos.

Estos materiales se enmarcan, como mencionamos en los antecedentes, en un cambio en la orientación de la ocupación del área, centrada fundamentalmente en la explotación minero metalúrgica, a diferencia de la prehispánica, que habría sido básicamente agropastoril (Angiorama 2011). En este contexto, los materiales cerámicos coloniales habrían funcionado en actividades desarrolladas en centros mineros como Pan de Azúcar o posiblemente Timón Cruz, o de otras áreas que habrían seguido funcionando como espacios agrícolas y ganaderos, sin un cambio notable en su cultura material, como Río Herrana 10 o Chajarahuayco 25, aunque este último presenta un horno de fundición, pero también está asociado a andenes de cultivo, que fueron usados en época colonial (Angiorama 2011). En RH 10-1 se observa esta continuidad notablemente, dado que en el segundo nivel, datado en momentos coloniales, se registraron dos grupos de fragmentos, uno correspondiente a un puco interior negro pulido y otro con improntas textiles y otros dos fragmentos con indicios de modelado con rollos. 
Asimismo, algunos de estos contextos coloniales muestran algunos bienes que serían no locales, como los fragmentos con vitrificado y estrías de torno, y grupos de pastas no presentes en los sitios prehispánicos, tales como Pan de Azúcar 22, Timón Cruz 2 y Santa Catalina 3, mientras que en Río Herrana 10 y Chajarahuayco 25 la cerámica sigue siendo muy semejante a la prehispánica. Quizás en los primeros hubo un contacto con españoles o con los grandes centros de población, como Rinconada y Santa Catalina ${ }^{14}$, mientras que en los segundos se daría una continuidad mayor con las poblaciones locales prehispánicas.

En este sentido, llama la atención que algunos de los materiales cerámicos descritos aquí, junto con los fechados radiocarbónicos, sean los únicos elementos que nos permitan distinguir la ocupación colonial de la prehispánica tardía. El resto de la cultura material y las características arquitectónicas de los recintos no se diferencia de las prehispánicas, a excepción posiblemente de los recintos con hastiales de Timón Cruz 2 , faltando por completo otros elementos de origen europeo que suelen encontrarse en otros sitios coloniales del NOA (Angiorama y Pérez Pieroni 2012).

De esta manera, se observa una continuidad notable de las prácticas vinculadas a la obtención de materias primas y al modelado, que llegan incluso hasta la actualidad, aunque las morfologías y la decoración sufrieron variaciones. Este punto ilustra lo que discutíamos en el Capítulo 2 de que los aspectos más estables de las tradiciones tecnológicas son los primeros.

La falta de fuentes documentales que estén hablando de la producción cerámica, de sus artesanos y los cambios producidos por la conquista dificultan el análisis de estas problemáticas para momentos coloniales. Esto hace que el abordaje arqueológico sea la única fuente de información sobre estos temas hasta ahora en esta región del NOA. Sin embargo, consideramos que la ausencia de referencias en las fuentes debe ser resultado justamente de que las actividades de manufactura continuaban siendo prácticas cotidianas, parte de las actividades diarias llevadas adelante por las comunidades agropastoras de la puna y que por lo tanto no tenían relevancia a los ojos de los españoles.

Por su parte, el análisis de la manufactura actual nos muestra que la producción cerámica es una tarea básicamente femenina, aunque la actividad se organiza en base a la unidad familiar. También es una producción esencialmente doméstica, con

${ }^{14}$ SC 3 se localiza muy próximo al poblado Santa Catalina. 
productos que se emplean en el hogar. Consideramos que así pudo ser también en el pasado, aunque con la inserción actual en la economía de mercado, en algunos lugares esta actividad se va tornando en una especialidad de tiempo completo, que se vende en mercados urbanos, mientras que en otros sitios se abandona, para adquirir los productos manufacturados.

Las materias primas empleadas consisten en arcilla con antiplástico agregado de rocas lutíticas y arena, por lo que consideramos que la selección es semejante a la que habría operado en el pasado. También son similares los procesos de modelado, que básicamente consisten en el modelado por estirado de la base y la superposición de rollos de arcilla para conformar las paredes, técnicas que hemos registrado en el material arqueológico analizado. El uso de moldes y torno es una incorporación reciente, originada por la gran demanda del mercado urbano.

Sí se observan cambios en las morfologías modeladas y en sus acabados de superficie. Algunas formas, como escudillas y platos ya no se elaboran, porque se empelan los fabricados con otros materiales, como el metal o el plástico. También se incorporan otras morfologías de origen europeo. Por otro lado, surgen nuevos tipos de recipientes, como resultado de la demanda de los mercados. Las piezas producidas están alisadas o engobadas, pero no presentan decoración. Además, se comenzaron a vender las piezas en ferias periódicas, posiblemente desde momentos coloniales.

Las cocciones actuales son a cielo abierto o en estructuras temporarias de muros realizados con diversos materiales, empleando guano de distintos animales como combustible. Quizás de las mismas maneras se cocieron las piezas en el pasado, resultando en atmósferas oxidantes, muchas veces incompletas y con manchas de cocción, como en las piezas actuales.

De manera similar a las cadenas operativas prehispánicas que esquematizamos previamente, en la siguiente figura (Figura 11.9) mostramos el diagrama para las cadenas operativas actuales, organizadas de acuerdo a los distintos lugares donde se obtuvieron registros e incorporando algunos pasos no observables en el material arqueológico. 


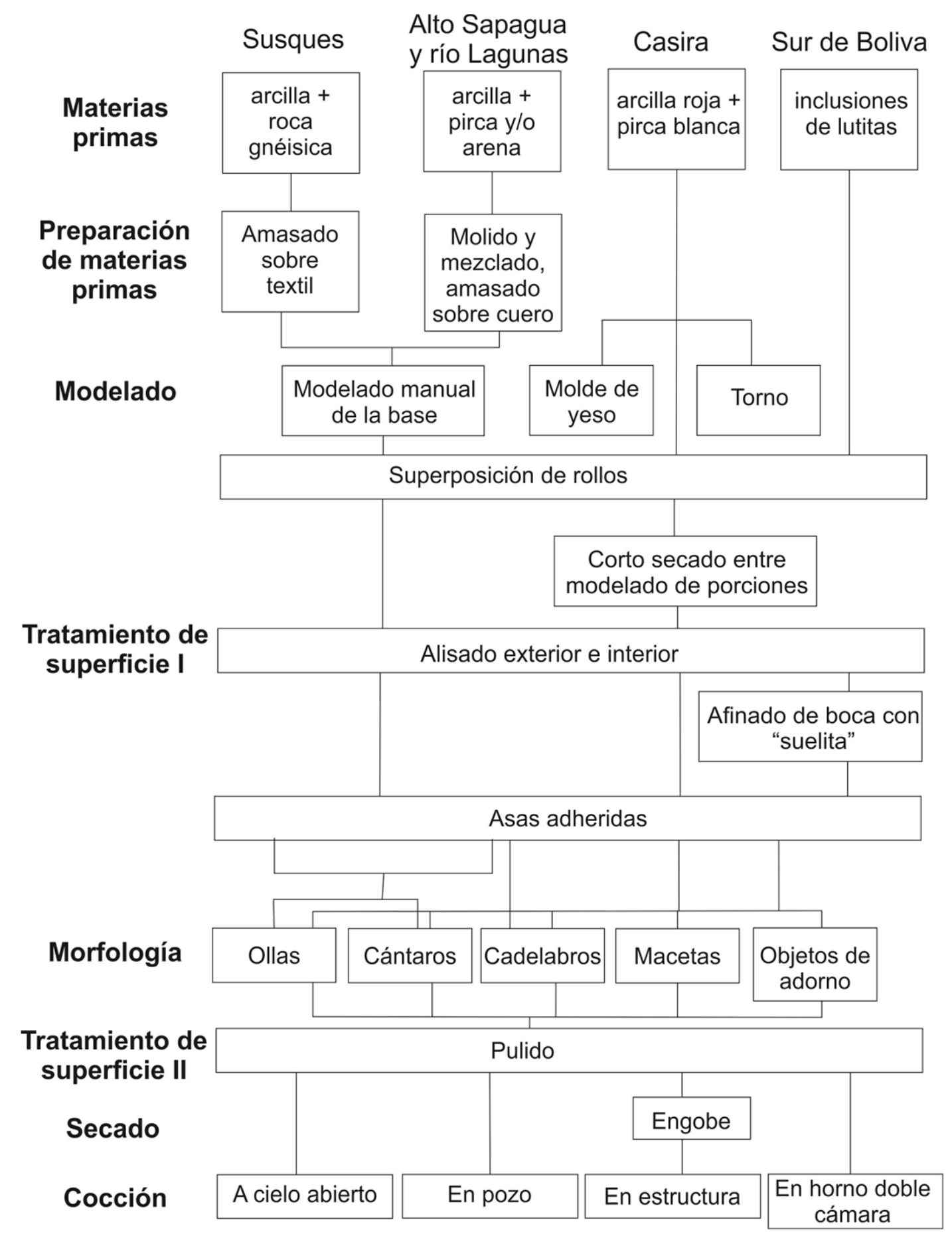

Figura 11.9 Esquema de los pasos reconstruidos en la cadena operativa de los materiales cerámicos para fines del s. XIX y principios del XX en base a la bibliografía consultada.

Consideramos que el análisis de la manufactura de los últimos 150 años nos muestra que las tradiciones tecnológicas puneñas prehispánicas tardías llegan hasta la 
actualidad en algunos aspectos, que justamente están vinculados a aquellos que en la literatura citada en el Capítulo 2 son considerados los más estables, el modelado y la selección de materias primas, modificándose aquellos más visibles, como la morfología y la decoración. Sin embargo, no se evidencian las diferencias entre las producciones del norte de la puna y del sur, como sucede en momentos prehispánicos. Aunque hipotéticamente se puede plantear que la localización de los centros productores a gran escala en la porción norte de la puna y el sur del altiplano de Bolivia puede estar relacionado a una tradición tecnológica previa que involucraba una mayor destreza que las de áreas vecinas, como ya lo hemos destacado para los materiales correspondientes al estilo Yavi, manifiesta por ejemplo en los mejores acabados de superficie y cocciones más controladas con respecto a los del sur la puna analizada.

Las modificaciones más destacables en la manufactura cerámica actual tienen que ver con la inserción en la economía de mercado, la incorporación de técnicas para producir a gran escala, la dedicación a tiempo completo y el cambio en el valor y significado de los materiales cerámicos. Parte del resultado también puede ser la pérdida de las producciones domésticas puneñas, que son reemplazadas por la compra o trueque de piezas cerámicas manufacturadas en estos grandes centros productores.

\section{La tecnología cerámica de Pozuelos y de Santa Catalina en un marco regional:}

A lo largo del desarrollo de los resultados de nuestro trabajo hemos ido relacionando los materiales analizados con los estilos definidos previamente par a la puna de Jujuy, las descripciones de los autores previos, y las relaciones con los materiales de áreas vecinas. Como hemos mencionado numerosas veces, algunos pueden vincularse por su morfología, sus pastas y decoración, con la cerámica del estilo Yavi. Esta tiene una amplia dispersión, que involucra el norte de la puna y el sur del altiplano boliviano como áreas de producción (Krapovickas 1975; Krapovickas et al. 1989; Nielsen 1997a; Beierlein 2009), dispersándose hacia zonas vecinas e incluso ampliándose considerablemente con la conquista inka hacia otras áreas del NOA e incluso el norte de Chile (Williams y Cremonte 1997; Ávila 2006).

Los fragmentos con improntas textiles, como ya hemos mencionado, se incluyen en este estilo, en el tipo denominado Pozuelos con cuarzo (Krapovickas 1975), aunque en los fragmentos que analizamos se presentan pastas que los vinculan más a las piezas del área sur de la puna. Además, ya ha sido destacado que este tipo tiene una 
distribución muy amplia, que excedería la del área Yavi (Ávila 2009), por lo que la caracterización de esta cerámica con granos de cuarzo e improntas debería profundizarse con mayores trabajos a futuro.

Otros han sido vinculados, por su morfología y decoración, a los materiales descritos para la "cultura Agua Caliente" o "estilo Casabindo" (Ottonello 1973; Albeck y Ruiz 1997; Albeck 2001). Entre estos, algunos presentan decoración tricolor, que como mencionamos previamente, ha sido sistematizada por Zaburlín (2012). Los materiales con este tipo de decoración registrados por nosotros son vinculables al tipo que ha definido como "Casabindo tricolor", y que ubica en el período tardío de la zona de Casabindo, al igual que lo hacen los autores previos. En cambio, el de TA 1-1, con sus puntos pequeños y franjas negras anchas, es comparable al tipo que denomina "Queta tricolor", y que correspondería a momentos de la conquista inka, lo que sumado al posible pie registrado en este sitio, podría estar indicando alguna relación con ese imperio en el área de Tabladitas. Ese grupo de fragmentos con puntos pequeños presenta además, como mencionamos, una pasta en todo comparable a la de los tipos Yavi, por lo que lo hace un grupo de fragmentos particular, que nos ilustra que los estilos decorativos pueden estar encubriendo, bajo una apariencia externa homogénea, diferentes modos de hacer.

Los materiales vinculables al estilo Casabindo también incluyen los pucos interior negro pulido, que como hemos visto, presentan diferentes tipos de pastas que los relacionan a las piezas con decoración tricolor y a las sin decorar de superficies alisadas. Ottonello (1973) también registró diferentes tipos de pastas para los pucos con el interior negro, que además están presentes en todos los sitios de habitación donde recolectaron material, disminuyendo su frecuencia en los entierros que excavaron, al igual que señalamos más arriba nosotros al comparar los contextos. Observa algunos con la superficie externa alisada, otros con pintura o engobe rojo. Sin embargo, registra la aplicación de pequeñas asas modeladas o rectangulares, que nosotros no hemos registrado, aunque los materiales de colección si exhibían asas labioadheridas. Este tipo de piezas son frecuentes en la puna, y además han sido registrados en la quebrada de Humahuaca (Nielsen 1997b).

Como ya mencionamos, todos estos materiales en nuestra muestra se localizan en la porción sur de la puna jujeña que hemos analizado. Ya otros autores habían considerado a la zona de Río Herrana y del Pukará de Rinconada y al área de Pan de Azúcar como parte del "área de influencia Casabindo", junto con la cuenca de 
Miraflores-Guayatayoc; mientras que el norte de la cuenca de la laguna, en la subcuenca de Yavi-La Quiaca corresponderían al "área Yavi" en nuestro país (Krapovickas 1983; Albeck 2001, entre otros), como ya hemos mencionado al discutir los antecedentes. Si bien Krapovickas (1983) plantea que el área del río San Juan Mayo habría sido un espacio donde habrían convivido diferentes grupos, el material aquí analizado de Santa Catalina, que se encuentra en la puna cercana a ese valle, es muy uniforme y se corresponde mayormente con el del estilo Yavi, como buena parte de la cerámica que se ha relevado en los últimos años en esa cuenca (Nielsen et al. 2013).

Cabe volver a señalar que hemos observado en el material analizado que los tipos decorativos del estilo Yavi, asociados a sus pastas características, se distribuyen en algunos sitios hacia el sur de la puna, fuera de lo que sería el área de las poblaciones que las produjeron, que han sido vinculadas al grupo etnográfico chicha (Krapovickas 1983), tanto en contextos funerarios como en algunos domésticos. También se ha señalado la dispersión de estos materiales en momentos inkaicos, como ya mencionamos, fuera de la puna. Sin embargo, no sucede lo mismo con aquellas piezas con decoración y morfologías que serían características del sur de la puna, asociada a ciertos tipos de pastas en el material fragmentario, y que no aparecen en los sitios analizados en el norte de la puna, exceptuando un puco interior negro excavado por Boman (1908) en la tumba de Sansana. En cambio, en la quebrada de Humahuaca si se han hallado algunos recipientes con decoración comparable a la de Casabindo y también pucos de interior negro pulido (Albeck 2007). En parte, ello puede ser resultado de que nuestra muestra incluye pocos materiales procedentes de contextos funerarios del norte de la puna (solo Sansana y Yavi Chico). Aunque también, el comportamiento de estos materiales cerámicos pueden estar dando pautas sobre el tipo de interacciones que se generaron entre los grupos sociales que los manufacturaron y usaron, que probablemente fueron diferenciados o resultado de un valor desigual otorgado a los bienes cerámicos o a sus contenidos, resultando en distribuciones disímiles. Profundizar en este sentido requiere mayores análisis de contextos que involucren otras materialidades además de la cerámica.

Los tipos inkaicos registrados también se han hallado en otros sitios de la puna, dado que allí se localizaron varios tambos, asociados al camino imperial, y que son conocidos en momentos coloniales y mencionados en la carta del oidor Matienzo (Raffino et al 1986), a lo que se suma que el Pucará de Rinconada habría sido ocupado por los inkas (Ruiz 1996). Fragmentos con pequeños motivos de camélidos, del tipo Inka Pacajes, como el descrito para TC 2, han sido hallados en sitios como Mayu Punku, del oeste de 
la cuenca de Pozuelos (Mamaní 1997), y en la Quebrada de Humahuaca (Nielsen 1997b).

Previamente hemos llamado la atención sobre el hecho que en los sitios que hemos excavado en la cuenca sur de Pozuelos no haya ningún fragmento que pueda vincularse a estilos inkaicos, a pesar de que se ha planteado que el Pucará de Rinconada tendría una ocupación de ese momento (Ruiz 1996), de que los sitios de Río Herrana se encuentran muy próximos al mismo, y que sí se registran materiales de este tipo en las colecciones analizadas, especialmente en los sitios de Doncellas y Queta, además de un ejemplar con procedencia del Pucará. La presencia de esas piezas en contextos funerarios, sumado a la ocupación inka del pukará, y su ausencia en los domésticos rurales podría ser indicativa de que la ocupación imperial no afectó a la población local rural adyacente (Angiorama 2011). A esto hay que sumar el hecho de que en las recolecciones superficiales intensivas que hemos realizado en un área importante de la cuenca sur de Pozuelos tampoco se han hallado fragmentos asignables a tipos inkaicos (Angiorama 2011).

Por otro lado, muchos de los elementos que se han empleado para definir la ocupación inka en el pukará son arquitectónicos (Alfaro 1969; Ruiz 1996), mientras que los materiales cerámicos que se recuperaron en las excavaciones realizadas por el equipo de Alfaro en recintos domésticos en la cima del Pucará de Rinconada y en contextos funerarios dentro de los mismos, consisten en vasos chatos, pucos interior negro pulido, cerámica ordinaria con asas planas y cerámica decorada en negro sobre rojo con motivos geométricos (Alfaro 1969; Alfaro y Suetta 1970), sin mencionarse materiales inkaicos. Tampoco los hemos registrado en los materiales de colección recuperados por Boman en este sitio, exceptuando una escudilla con asa lateral.

Asimismo, este pukará puede tener una posible ocupación en momentos posteriores al contacto hispano indígena, con incorporación de elementos cerámicos con diferencias a los de momentos anteriores, representados por cuatro piezas con morfología de jarra o botella y un cuello de otra pieza restringida excavadas por Boman con decoración pintada en rojo sobre el fondo de pasta y/o decoración al pastillaje que no ha sido registrado en otros sitios de la puna, ni en la literatura previa, exceptuando un asa de PA 22 que presenta el mismo tipo de motivo serpentiforme al pastillaje y que si cuenta con evidencias de ocupación colonial, incluyendo un fechado radiocarbónico para el sondeo en el basurero (ver Capítulo 4 y Angiorama y Pérez Pieroni 2012). 
Este sería un punto muy interesante para profundizar a fin de comprender la dinámica de las sociedades con posterioridad al contacto, especialmente teniendo en cuenta que Pan de Azúcar fue un centro minero importante según la documentación (Angiorama et al. 2012), por lo que sería relevante abordar si el Pucara de Rinconada tenía alguna vinculación con estas ocupaciones mineras. Asimismo, sería necesario para profundizar en el análisis, conocer la procedencia concreta de esas piezas posiblemente coloniales en el ámbito del pukará, aunque de acuerdo a las descripciones del material extraído de los recintos habitacionales que hace el autor, suponemos que procederían de allí (Boman 1908).

Ciertas morfologías entre las piezas de colección serían de zonas geográficas externas a la puna, como la quebrada de Humahuaca o posiblemente la vertiente oriental de los Andes, y probablemente correspondan a momentos prehispánicos tardíos e inka, como ya hemos discutido oportunamente. Estos tipos de piezas no se encuentran entre el material fragmentario, que procede de contextos domésticos. Si sumamos el hecho de que en los contextos funerarios también se documentan otros tipos de artefactos, que no se encuentran en los contextos domésticos excavados por nosotros hasta la fecha, como las tarabitas u horquetas, que se vinculan a la carga de las llamas (Boman 1908; Albeck 2007) y los vasos de hilandera, relacionados a la actividad textil (Albeck 2007), que son más frecuentes en estos contextos, podemos pensar que las piezas alóctonas registradas estén relacionadas al tráfico caravanero.

Todos estos artefactos recién mencionados estarían asociados a actividades relacionadas a la ganadería, y no se observan hasta ahora en los contextos de habitación. Igualmente, las tarabitas son artefactos de madera, por lo que su ausencia en los recintos habitacionales excavados puede ser resultado de las condiciones de preservación. Sin embargo, los únicos tres torteros registrados, y que también podemos relacionar a actividades textiles, se encontraron entre los recintos. Igualmente, sería un punto interesante a profundizar el hecho de que los artefactos relacionados a la ganadería estén presentes en contextos funerarios y no en los domésticos, que a su vez están frecuentemente asociados directamente a áreas de producción agrícola y en los que hemos hallado numerosas palas líticas (Angiorama 2011), posiblemente relacionadas al trabajo de los campos de cultivo. 


\section{Las tradiciones tecnológicas puneñas: conclusiones}

Para finalizar, en base a las evidencias de las cadenas operativas, la falta de contextos de producción y los atributos del material analizado, junto con las características de la producción actual, que en muchos aspectos muestra continuidad, planteamos como hipótesis que la producción cerámica puneña habría sido básicamente una producción doméstica, que habría involucrado a la unidad familiar en diferentes tareas, en un contexto productivo agropastoril. Esta manufactura no estaría separada de las tareas cotidianas de las unidades domésticas.

Para momentos prehispánicos, se habrían desarrollado dos tradiciones tecnológicas, asociadas a los estilos identificados en la literatura previa, que involucrarían tipos de pastas característicos, técnicas de modelado, con similitudes para toda el área, y morfologías vinculadas a decoraciones características, que fueron reconocidas previamente. Una de ellas se asociaría a lo que se ha clasificado como estilo Casabindo, y que además de piezas globulares de cuello cilíndrico, con decoración bicolor y tricolor, involucraría otras alisadas, piezas abiertas y cerradas alisadas o pulidas, con o sin engobe o pintura roja, vasos chatos y pucos interior negro pulido. Las mismas habrían sido modeladas con pastas con inclusiones de mica, cuarzo, plagioclasas y pelitas en diferente proporción, mediante rollos básicamente y cocidas en diferentes tipos de atmósferas, pero mayormente oxidantes. Esta tradición se ubicaría dentro de nuestra área de estudio en la cuenca sur de la laguna de Pozuelos.

La otra sería la vinculada al estilo Yavi, con botellas esféricas, piezas abiertas y cerradas de superficies pulidas, con o sin engobe y pintura negra desleída, que también habrían sido modeladas con rollos empleando pastas con inclusiones predominantemente pelíticas, densas o poco densas, y cocidas en atmósferas oxidantes completas principalmente. La misma se ubicaría en la porción norte de la puna analizada por nosotros, pero sus materiales habrían llegado, quizás mediante intercambio, a la porción sur de la cuenca de Pozuelos.

Probablemente, la producción de la cerámica estilo Yavi habría involucrado una especialización o destreza algo mayor, manifiesta en las pastas más compactas, con cocciones más controladas, y las superficies mejor acabadas, con mayor frecuencia de pulidos y engobes. Posiblemente debido a ello los inkas habrían empleado poblaciones chichas para producir esta alfarería en Chagua (Raffino et al. 2004) y mitmakunas en otras porciones del NOA habrían seguido manufacturando esta alfarería, intentando 
conservar su tradición tecnológica con materias primas locales (Williams y Cremonte 1997). La influencia inka sobre la manufactura cerámica local también puede estar manifestándose en algunos materiales cerámicos con decoración vinculable a la Casabindo, pero con pastas relacionadas al estilo Yavi.

Posteriormente, en momentos de la conquista, se habrían introducido algunos elementos de origen no local, con diferentes pastas y vitrificados. Sin embargo, las tradiciones de manufactura puneña, con su selección de materias primas y sus técnicas de modelado habrían llegado hasta momentos recientes, en el seno de las unidades familiares rurales, perdiendo algunos elementos, como la decoración o algunas formas. Al insertarse en la economía de mercado, surgirían nuevas transformaciones, como la dedicación a tiempo completo, aunque sin perder la unidad familiar como base de la producción, y la incorporación de nuevas técnicas, como los moldes y el torno, en el marco de una producción a mayor escala, donde la cerámica adquiere nuevos valores.

De esta manera, intentamos aproximarnos y esbozar el desarrollo de la manufactura cerámica en la puna de Jujuy, desde momentos prehispánicos tardíos hasta la actualidad, sus cambios y persistencias, en el contexto de los grupos sociales que las produjeron, mediante las prácticas relacionadas a un saber-cómo concreto, históricamente situadas, y manifestaciones de habitus que, junto con las elecciones tecnológicas, conformaron las tradiciones tecnológicas de estos grupos. 
12.

CONCLUSIONES

Y PERSPECTIVAS FUTURAS

Para finalizar el desarrollo del trabajo, y habiendo discutido y concluido sobre los resultados en el capítulo previo, en esta sección queremos expresar algunas consideraciones sobre el desarrollo de la tesis en sí, sus aportes y perspectivas.

\section{Conclusiones sobre los objetivos y su cumplimiento:}

Al comenzar este trabajo nos planteábamos si los estilos cerámicos que se habían definido tradicionalmente en la puna estaban relacionados a otros aspectos de la secuencia de producción o si encubrían diferentes modos de hacer. A lo largo de los capítulos hemos visto como esos estilos se relacionan a determinadas pastas, técnicas de modelados, tipos de cocción, etc., por lo que tienen una base en cadenas operativas diferenciadas. Pero también vimos cómo hay diferentes puntos en común en las cadenas operativas o cómo en ocasiones la decoración no refleja las prácticas de manufactura. De esta manera, consideramos que el análisis de toda la secuencia de producción enriquece la visión sobre la cerámica en el pasado y sobre las personas que la hacían y la usaban.

Dentro de los objetivos específicos que hemos propuesto, el primero era el de caracterizar las secuencias de procedimientos técnicos empleados en la elaboración de las piezas cerámicas. Con este fin, hemos desarrollado una metodología orientada por la cadena operativa, que nos permitió abordar distintos pasos de la producción. De esta forma, hemos caracterizado las pastas y hecho inferencias sobre las materias primas, hemos abordado las técnicas de modelado mediante el análisis de huellas y marcas y las morfologías resultantes, los acabados de superficie y las atmósferas de cocción. Algunos pasos de la cadena operativa no pudieron ser abordados por las limitaciones propias del material o por la falta de contextos de manufactura. Sin embargo, consideramos que hemos respondido a este objetivo y que este trabajo aporta con la primera caracterización de los procedimientos técnicos desarrollados en la manufactura de cerámica arqueológica de los sectores de la puna jujeña analizados. 
Con respecto al segundo objetivo específico, de abordar los posibles usos de los productos cerámicos en relación a su morfología, las características tecnológicas y los contextos en que fueron recuperados, hemos podido relacionar las morfologías presentes con las características tecnológicas, pero no hemos distinguido diferencias o asociaciones entre formas y atributos tecnológicos concretos que permitan inferir los usos. Por otro lado, la relación de los materiales con los contextos nos permitió observar diferencias de distribución y posiblemente de los significados que adquirieron al estar involucrados en diferentes prácticas, pero no las funciones concretas de los recipientes analizados. Consideramos que el abordaje funcional se vería beneficiado por el análisis de huellas y trazas de uso, de residuos, etc.

El tercer objetivo específico planteado era el de reconocer posibles variaciones a nivel cronológico y espacial para el área de estudio. Consideramos que hemos profundizado a lo largo del trabajo sobre las persistencias y cambios producidos en las cadenas operativas de manufactura cerámica para un lapso cronológico muy amplio. Sobre esa secuencia se podrán modificar y profundizar muchos aspectos, pero creemos que es un primer aporte válido a la manufactura cerámica puneña y su desarrollo histórico. Por otro lado, hemos reconocido variaciones espaciales entre las diferentes zonas bajo análisis para muchos de los pasos de las cadenas operativas, especialmente en los materiales analizados correspondientes a momentos prehispánicos tardíos, que son los más abundantes.

En cuanto al objetivo de identificar las posibles áreas de procedencia de las materias primas empleadas en la manufactura, a nivel regional, a partir del análisis de pastas y la caracterización petrográfica de las inclusiones no plásticas, con la posterior comparación con la geología local, hemos podido plantear la hipótesis de una procedencia y producción local para los materiales analizados, aunque algunas piezas de colección serían alóctonas por sus estilos decorativos, y otros fragmentos poshispánicos probablemente también, en base a los aspectos discutidos en los capítulos previos.

También hemos comparado los materiales estudiados con los de áreas vecinas de la puna y fuera de ella, precisando que algunos pudieron tener su origen fuera del área, aunque la mayor parte serían de procedencia local y parte de tradiciones tecnológicas que abarcarían áreas mayores a las de estudio, relacionándose a los estilos identificados previamente en la literatura. 
De esta manera, consideramos que el desarrollo del trabajo, la metodología escogida y los resultados obtenidos nos han permitido responder a la mayor parte de los aspectos involucrados en los objetivos propuestos, aportando así a la comprensión de la tecnología cerámica puneña, sus tradiciones tecnológicas y sus variaciones temporales y espaciales.

\section{Conclusiones sobre la metodología de análisis:}

La metodología de análisis empleada demostró ser útil en varios aspectos. En primer lugar, el análisis de buena parte de los fragmentos en lupa binocular sobre las fracturas frescas nos permitió realizar una clasificación preliminar de las pastas, que posteriormente se confirmó y se ajustó mediante el análisis petrográfico. Igualmente, la clasificación probablemente podría mejorarse mediante el uso de herramientas estadísticas, como el análisis de agrupamientos (cluster analysis), que clasifiquen los cortes analizados por su similitud y permitan confirmar o no estadísticamente los grupos identificados.

Por otro lado, el remontaje de fragmentos demostró ser muy útil, no solo para obtener perfiles más completos de las piezas y permitir afinar la clasificación morfológica, como ya ha sido señalado anteriormente (Zagorodny 1996), sino que permitieron realizar observaciones más profundas sobre las marcas y huellas asociadas al modelado y al acabado de las superficies, de manera de poder analizar las técnicas y los gestos asociados a ellas. Cabe recordar que sobre el total de grupos de fragmentos pudo identificarse la técnica de modelado para un porcentaje comparable al de las identificaciones realizadas sobre las piezas completas analizadas en las colecciones (aproximadamente 40\%).

Las marcas y huellas de modelado en los recipientes son muy útiles a fin de identificar las técnicas empleadas, pero a menudo son enmascaradas por los pasos subsiguientes de la cadena operativa, por el uso y los procesos posdepositacionales (Rye 1981). Sin embargo, hemos podido registrar algunas tanto en el material fragmentario como en las piezas de colección. Las superficies internas de las piezas cerradas suelen ser las que mejor conservan este tipo de huellas. Por otro lado, la importancia del análisis de estas huellas o macrotrazas ha sido señalada previamente 
(García Roselló 2010) junto con la importancia de acceder a colecciones de referencia etnoarqueológicas y experimentales para poder interpretarlas.

En cambio, el análisis de la orientación de las inclusiones con respecto a las fracturas y a las superficies de los fragmentos, no nos resultó un atributo útil para identificar la técnica de modelado, a lo que se suma la falta de consenso en la literatura sobre el significado de las distintas orientaciones observadas. Además, no observamos una correlación sistemática entre los fragmentos que presentan huellas y marcas de modelado y la orientación de sus inclusiones. Este aspecto podría profundizarse mediante el análisis de placas radiográficas (Rye 1981), que muestren la orientación de todas las inclusiones con relación a las superficies, para los grupos de fragmentos y fragmentos no agrupados que representen porciones significativas de las piezas.

Con respecto al análisis de pastas, si bien las observaciones mediante lupa binocular permitieron realizar una primera clasificación, las observaciones al microscopio reformularon algunos de los grupos identificados y permitieron refinar las caracterizaciones mediante determinaciones mineralógicas y litológicas más precisas, además de permitir realizar un análisis cuantitativo por point counter. La lupa binocular fue muy útil para separar grupos de fragmentos con pastas con características particulares muy conspicuas, como abundancia de biotita, presencia de muscovita, abundancia de pelitas, etc.; y manejar grandes cantidades de fragmentos que luego puedan ser muestreados para su análisis mediante petrografía cerámica. En este sentido, consideramos relevante relacionar ambas escalas de análisis de manera de que se complementen entre sí.

Finalmente, consideramos que la integración de diferentes vías de análisis, que incluyen tanto observaciones macroscópicas como submacroscópicas y microscópicas, efectuadas tanto sobre materiales fragmentarios como en piezas de colección, junto con el análisis de material documental reciente, nos permiten abordar más profundamente los objetivos propuestos, y entender mejor las tradiciones de los alfareros y alfareras, los pasos seguidos en la cadena operativa, y las transformaciones que sufrieron a lo largo del tiempo, tanto con el impacto de la conquista inka, como la española, y también de la inserción de las prácticas productivas en la economía de mercado actual. Las distintas vías son complementarias y permiten hacer observaciones que no se pueden efectuar en otra. Así, por ejemplo, el análisis morfológico y de acabados de superficies, junto con el de huellas de modelado, es más pormenorizado entre los materiales completos de colección. El material fragmentario permite realizar observaciones sobre las pastas que 
no pueden hacerse en las colecciones, y al ser procedentes de contextos excavados, contextualizar mejor el material y vincularlo a dataciones concretas. Además unos y otros proceden de diferentes tipos de contextos. De esta manera, se obtiene información que aporta con diferentes tipos de evidencia a la reconstrucción de las secuencias de producción.

\section{Aportes a las problemáticas y perspectivas futuras:}

Consideramos que este trabajo es una primera contribución a la secuencia de producción de la cerámica de las áreas bajo estudio y un aporte significativo a las de la puna en general. Como mencionamos anteriormente, abordajes tecnológicos de este tipo son muy escasos en la puna jujeña. Sin embargo, este trabajo se inserta en los resultados de autores previos, que han sido fundamentales para comprender la cerámica local y su rol en las relaciones sociales del pasado, por lo que esperamos aquí haber contribuido un poco más al conocimiento de los mismos y de sus historias.

Por otro lado, esperamos que el trabajo aquí elaborado en base al análisis de los materiales de colección y fragmentarios en diferentes escalas de análisis y para distintos momentos cronológicos provea de una buena base de datos comparativa para trabajos posteriores sobre la cerámica local.

Hemos abordado las tradiciones tecnológicas mediante el análisis de las cadenas operativas, planteando hipótesis de las secuencias de procedimientos que pudieron seguirse en su manufactura. Las mismas podrán ser ampliadas, profundizadas y modificadas en el futuro mediante análisis más detallados de diferentes aspectos.

Las caracterizaciones de pastas que aquí se presentan permiten conocer en mayor profundidad las características composicionales de la cerámica puneña, que contaba con pocas contribuciones previas, centradas mayormente en la cerámica Yavi (Krapovickas 1973, 1975; Cremonte et al. 2007a) y algunas descripciones macroscópicas para la porción sur de la puna analizada (Ottonello 1973). Esta contribución, por tanto, es especialmente relevante para la zona de "influencia Casabindo" y permitió agrupar con la cerámica considerada como típica por su decoración, a aquellos materiales no decorados, de superficies alisadas o pulidas, incluyendo vasos chatos y pucos interior negro pulido, que presentan el mismo tipo de pasta. También permite discutir la inclusión de la cerámica con improntas textiles dentro 
de los tipos del estilo Yavi, dado que las características de las pastas las agrupan más a las cerámicas de sur de la puna.

Sin embargo, el análisis composicional de materias primas y, mediante el mismo, el estudio de la localización de la producción cerámica, se vería profundamente beneficiado por la realización de análisis químicos de pastas cerámicas y de materias primas, tales como la activación neutrónica o la fluorescencia de rayos $\mathrm{X}$ (Cremonte et al. 2007b; Orton et al. 1997).

En cuanto al análisis de las huellas de manufactura, a partir de las observaciones que hemos señalado, podemos destacar que una vía importante para profundizar los análisis realizados, sería el desarrollo de tareas experimentales y etnoarqueológicas con poblaciones alfareras actuales para confeccionar una colección de referencia sobre las huellas y marcas asociadas a cada técnica, que permitan profundizar en el análisis de los gestos técnicos de manera más pormenorizada. Estos son sumamente indicativos de modalidades productivas particulares de cada grupo de artesanos y serían un aporte fundamental al análisis de las tradiciones tecnológicas. Por otro lado, la continuidad observada en relación al modelado entre las poblaciones alfareras actuales, como la de Casira, o Chagua, indicarían que estos lugares serían buenos espacios para comenzar estas tareas. Sin embargo, los fuertes cambios que se están produciendo en las prácticas alfareras, como resultado de la gran demanda de mercados urbanos, que se manifiestan en la introducción de nuevas morfologías y nuevas técnicas de modelado, llevarían a la necesidad de que los trabajos etnoarqueológicos se realicen en un futuro cercano. Asimismo, estos trabajos permitirían profundizar en el conocimiento etnoarqueológico de la producción cerámica local y contribuir al saber etnológico y etnoarqueológico general, que ha tenido un desarrollo importante en los Andes (por ej. Arnold 1993; Hosler 1996; Hildebrand y Hagstrum 1999; Druc 2011; entre otros).

Otro aspecto que se podría profundizar en abordajes futuros es el relacionado al uso de los recipientes cerámicos, de manera más concreta al que aquí esbozamos. Como mencionamos arriba, esta problemática se podría trabajar desde el análisis de huellas y trazas de uso y de residuos, que se relacionen a la información generada sobre las formas y con los contextos de procedencia.

Asimismo, en el transcurso del trabajo, hemos mencionado varias problemáticas que surgen del análisis de la cerámica, que podrían profundizarse mediante investigaciones sistemáticas que involucren excavaciones, dataciones y el análisis de otras 
materialidades. Entre ellas, cabe destacar la posibilidad de la ocupación poshispánica del Pucará de Rinconada, la circulación a zonas extensas de la cerámica Yavi, y la circulación restringida de la Casabindo; las diferencias entre los contextos funerarios y los domésticos y su vinculación a las actividades productivas; entre otras tantas.

Otra contribución realizada aquí es la documentación de evidencias cerámicas coloniales, su descripción y análisis tecnológico. No conocemos trabajos similares en contextos rurales de la puna. Por otro lado, la falta de documentación sobre aspectos vinculados a la producción cerámica hacen de este tipo de aportes las únicas evidencias disponibles hasta la fecha en nuestra región sobre las continuidades y cambios sufridos por las prácticas relacionadas a la tecnología cerámica en el área de estudio. En este sentido, sería importante profundizar sobre las modificaciones producidas por la conquista en esta manufactura y también su relación con otras materialidades y el rol de los recipientes cerámicos en los sitios con ocupaciones coloniales y en relación a la transformación en la orientación productiva que se ha observado en la puna, con el fuerte impacto de la minería de metales.

Para concluir, a partir del desarrollo de nuestro trabajo esperamos haber contribuido con nueva información a la comprensión de la dinámica pasada de las poblaciones puneñas, de sus relaciones sociales, su historia y sus transformaciones, desde el análisis de una de las materialidades posibles y centrándonos en la tecnología como acción social, desde las practicas productivas como parte de habitus compartidos. 


\section{BIBLIOGRAFÍA CITADA}

Adams, A. E.; W. S. MacKenzie y C. Guilford. 1984. Atlas of Sedimentary Rocks under the Microscope. Longman Group. Londres.

Albeck, M. E. 1993. Contribución al estudio de los sistemas agrícolas prehispánicos de Casabindo (Puna de Jujuy). Tesis doctoral inédita. Facultad de Ciencias Naturales y Museo, Universidad Nacional de La Plata. MS

Albeck, M. E. 1994. La quebrada de Humahuaca en el intercambio prehispánico. En: Taller de Costa a Selva. Producción e intercambio entre los pueblos agroalfareros de los Andes Centro Sur: 117-132. M. E. Albeck (Ed.). Instituto Interdisciplinario Tilcara, UBA. Buenos Aires.

Albeck, M. E. 1995-96. Áreas de actividad doméstica en Pueblo Viejo de Tucute (Puna de Jujuy). Estudios Atacameños 12: 69-81.

Albeck, M. E. 2001. La puna argentina en los períodos medio y tardío. En: Historia Argentina Prehispánica: 347-388. E. Berberián y A. Nielsen (eds.). Editorial Brujas.

Albeck, M. E. 2007. El Intermedio Tardío: Interacciones económicas y políticas en la Puna de Jujuy. En: Editado por V. Williams, B. Ventura, A. Callegari y H. Yacobaccio; Sociedades Precolombinas Surandinas, pp. 125-145. Buenos Aires.

Albeck, M. E. y S. R. Dip. 1996. El sitio Ojo de Agua de Casabindo. Actas y Memorias del XI Congreso Nacional de Arqueología Argentina (13 parte). Revista del Museo de Historia Natural de San Rafael, Tomo XXV (1/4): 61-70. Mendoza.

Albeck, M. E. y M. S. Ruiz. 1997. Casabindo: las sociedades del período tardío y su vinculación con las áreas aledañas. Estudios Atacameños n 14: 211-222.

Albeck, M. E. y M. S. Ruiz. 2003. El Tardío en la Puna de Jujuy: Poblados, Etnias y Territorios. Cuadernos de la Facultad de Humanidades y Ciencias Sociales. №20. UNJu, S. S. Jujuy.

Albeck, M. E. y S. Palomeque. 2009. Ocupación española de las tierras indígenas de la puna y "raya del Tucumán" durante el temprano período colonial. Memoria Americana 17-2: 173-212.

Albeck, M. E.; H. Mamaní y M. A. Zaburlín. 1995. La cerámica del recinto R-1, Pueblo Viejo de Tucute. Primera parte: función y dispersión de las vasijas. Cuadernos $\mathrm{n}^{\circ}$ 5: 205-220. UNJu. Jujuy.

Albeck, M. E.; M. A. Zaburlin y S. R. Dip. 1999. Etnicidad y arquitectura doméstica en Casabindo. Actas del XII Congreso Nacional de Arqueología Argentina, vol. II: 211-220. La Plata. 
Albeck, M. E.; M. A. Zaburlin y K. A. Menacho. 2007. Espacios productivos y simbólicos. La dominación inca en Casabindo. Actas del XVI Congreso Nacional de Arqueología Argentina, tomo II: 549-554. Jujuy.

Alfaro, L. C. 1969. Exploraciones arqueológicas en la Puna de Jujuy. Antiquitas 8: 7-13. Universidad del Salvador. Buenos Aires.

Alfaro, L. C. 1978. Arte Rupestre en la Cuenca del Río Doncellas (Provincia de Jujuy, República Argentina). Relaciones de la Sociedad Argentina de Antropología XII: 123-146.

Alfaro, L. C. 1983. Investigación arqueológica en la cuenca del río Doncellas (Provincia de Jujuy). Integración de la puna jujeña a los centros cúlticos andinos. Relaciones de la Sociedad Argentina de Antropología, t. XV: 25-47. Buenos Aires.

Alfaro, L y J. Suetta. 1970. Nuevos aportes para el estudio del asentamiento humano en la puna de Jujuy. Revisión del Pucará de Rinconada. Antiquitas 10: 1-10. Universidad del Salvador. Buenos Aires.

Alonso, H y J. Fernández. 1996. Cronología Radiocarbónica de un montículo arqueológico en Pozuelos, Puna de Jujuy, República Argentina. Actas y Memorias del XI Congreso Nacional de Arqueología Argentina (13 parte). Revista del Museo de Historia Natural de San Rafael, Tomo XXV (1/4): 367-382. Mendoza.

Ambrosetti, J. 1902. Antigüedades Calchaquíes. Datos arqueológicos sobre la provincia de Jujuy. Anales de la Sociedad Científica Argentina, tomos LII, LIII y LIV. Buenos Aires.

Angiorama, C. I. 2011. La ocupación del espacio en el sur de Pozuelos (Jujuy, Argentina) durante tiempos prehispánicos y coloniales. Estudios Sociales del NOA 11: 125-142.

Angiorama, C. I. y M. F. Becerra. 2010. Antiguas evidencias de minería y metalurgia en Pozuelos, Santo Domingo y Coyahuayma (Puna de Jujuy, Argentina). Boletín del Museo Chileno de Arte Precolombino 15 (1): 81-104.

Angiorama, C. I. y M. J. Pérez Pieroni. 2012. Primeros estudios sobre manufactura cerámica de contextos coloniales del sur de Pozuelos (puna de Jujuy). Revista de Arqueología Histórica Argentina y Latinoamericana 6: 95-126.

Angiorama, C. I.; M. F. Becerra y M. J. Pérez Pieroni. 2012. Prácticas minerometalúrgicas y vida cotidiana en un centro minero colonial: Pan de Azúcar, Puna de Jujuy (Argentina). Trabajo presentado al 54 Congreso Internacional de Americanistas. Viena, Austria. MS.

Angiorama, C. I.; D. Argañaráz Fochi, M. F. Becerra, E. Del Bel, O. Díaz, M. Giusta, D. Leiton, M. J. Pérez Pieroni, S. Rodríguez Curletto, L. Torres Vega. 2013. El sur de Pozuelos (Puna de Jujuy, Argentina) antes del 1.000 d.c. Primeras evidencias arqueológicas. Trabajo enviado a Revista Comechingonia. MS.

Arnold, D. 1993. Ecology and ceramic production in an Andean Community. Cambridge University Press, Inglaterra. 
Arnold, D; H. Neff y R. Bishop. 1991. Compositional Analysis and "Sources" of Pottery: An Ethnoarcheological Approach. American Anthropologist 93 (1): 70-90.

Ávila, M. F. 2006. Un mundo morado sobre ante. Estudio sobre el estilo cerámico yavi de la puna oriental de Jujuy. Tesis de Licenciatura en Ciencias Antropológicas con Orientación Arqueológica. Facultad de Filosofía y Letras, Universidad de Buenos Aires.

Ávila, M. F. 2005. El estilo alfarero Yavi y su relación con la construcción de entidades culturales. Theoria, vol. 14(1): 85-101.

Ávila, M. F. 2009. Interactuando desde el estilo. Variaciones en la circulación espacial y temporal del estilo alfarero yavi. Estudios Atacameños 37: 29-50.

Baldini, L. y G. Balbarrey. 2004. Análisis de pastas cerámicas tardías del valle calchaquí central (Salta, Argentina). Chungará 36, edición especial: 1069-1080.

Balesta, B. y N. Zagorodny. 2002. La restauración alfarera en la funebria arqueológica. Observación y estudios experimentales sobre la Colección Muñiz Barreto. Bulletin de l'Institut Français d'Études Andines 31(2): 373-395.

Balesta, B. y V. Williams. 2007. El análisis cerámico desde 1936 hasta nuestros días. Relaciones de la Sociedad Argentina de Antropología 32: 169-190.

Balfet, H; M. F. Fauvet-Berthelot y S. Monzón. 1992. Normas para la Descripción de Vasijas Cerámicas. Centre D'Études Mexicaines et Centraméricaines, México D.F.

Beierlein de G., M. 2009. La cerámica prehispánica tardía del Altiplano de Sama y su relación con las regiones vecinas: Una aproximación arqueológica a la complejidad cultural de la macrorregión Noroeste Argentino-Sur de Bolivia. Estudios Atacameños 37: 51-61.

Boman, E. 1908. Antiquités de la Région Andine de la République Argentine et du Désert d'Atacama. Tomo II. Librairie H. Le Soudier. Paris. Imprimerie Nationale.

Bourdieu, P. 1993. El Sentido Práctico. Taurus, Madrid.

Bourdieu, P. 1997. Razones prácticas sobre la teoría de la acción. Anagrama, Barcelona.

Bray, T. L. 2003. Inka Pottery as Culinary Equipment: Food, Feasting, and Gender in Imperial State Design. Latin American Antiquity 14(1): 3-28.

Buechler, J. M. 1983. Trade and market in Bolivia before 1953: an ethnologist in the garden of ethnohistory. Etnohistory 30(2): 107-119.

Caffe, P. J.; B. Coira y S. Mahlburg Kay. 2008. Magmatismo Neógeno temprano de la Puna Jujeña. Geología y Recursos Naturales de la Provincia de Jujuy. Relatorio del XVII Congreso Geológico Argentino, Jujuy. Editado por Coira y Zappettini, pp. 302-312. Asociación Geológica Argentina. 
Calderari, M. y V. Williams. 1991. Reevaluación de los estilos cerámicos incaicos en el Noroeste Argentino. En: El imperio Inka. Actualización y perspectivas y registros arqueológicos y etnohistóricos, Comechingonia Vol. II: 73-96.

Calvo Trias, M. y J. García Roselló. 2011. Tradición, técnica y contactos: un marco de reflexión centrado en la producción cerámica. Rubricatum 5: 1-9.

Carpenter, A. J. y G. M. Feinman. 1999. The Effects of Behaviour on Ceramic Composition: Implications for the Definition of Production Locations. Journal of Archaeological Science 26: 783-796.

Carrillo, J. 1988 [1888]. Descripción Brevísima de Jujuy. Provincia de la República Argentina. Trabajo encomendado por la comisión auxiliar para la exposición de París. En: Descripción de la Provincia de Jujuy. Informes, objetos y datos que presenta el Comisionado Provincial, Senador Nacional D. Eujenio Tello a la Exposición Universal de 1889 en Paris. Reimpreso por la UNJu, Jujuy.

Casanova, E. 1938. Investigaciones arqueológicas en Sorcuyo. Puna de Jujuy. Anales del Museo Argentino de Ciencias Naturales Bernardino Rivadavia XXXIX: 423-456. Buenos Aires.

Casanova, E. 1943. Comunicación acerca del Yacimiento de Doncellas. Boletín de la Sociedad Argentina de Antropología, 5-6: 80-81.

Casanova, E. 1944. Una estólica de la Puna Jujeña. Relaciones de la Sociedad Argentina de Antropología 4: 115-182.

Coira, B.; P. Caffe, A. Ramírez, W. Chayle, A. Díaz, S. Rosas, A. Pérez, B. Pérez, O. Orozco y M. Martínez. 2004. Hoja Geológica 2366-I/2166-III, Mina Pirquitas. 1:250000. Boletín No 269. Servicio Geológico Minero Argentino, Buenos Aires.

Coira, B. y E. O. Zappettini. 2008. Mapa Geológico de la Provincia de Jujuy. Escala 1:500000. Servicio Geológico Minero Argentino, Buenos Aires.

Costin, C. L. 2000. The Use of Ethnoarchaeology for the Archaeological Study of Ceramic Production. Journal of Archaeological Method and Theory 7(4): 377-403.

Courty, M. A. y V. Roux. 1995. Identification of Wheel Throwing on the basis of Ceramic Surface Features and Microfabrics. Journal of Archaeological Science 22: 17-50.

Cremonte, M. B. 1988. Alcances y objetivos de los estudios tecnológicos en la cerámica arqueológica. Anales de Arqueología y Etnología, vol. 38-40: 179-217. Universidad Nacional de Cuyo.

Cremonte, M. B. 1991. Análisis de muestras cerámicas de la quebrada de Humahuaca. Avances en Arqueología, no 1: 7-42. Universidad Nacional de Buenos Aires.

Cremonte, M. B. 1994. Las pastas cerámicas de Potrero Chaquiago, (Catamarca). Producción y movilidad social. Arqueología, n 4: 133-164. Universidad Nacional de Buenos Aires. 
Cremonte, M. B. 1996. De las pastas a los olleros del pasado. Vol. XXV Aniversario Museo Arqueológico Eduardo Casanova, pp. 47-53. Instituto Interdisciplinario Tilcara, FFyL, UBA.

Cremonte, M. B. 2001. Las pastas cerámicas como una contribución a los estudios de identidad. Actas del XIII Congreso Nacional de Arqueología Argentina, tomo II: 199-210. Córdoba.

Cremonte, M. B.; I. L. Botto, A. M. Díaz, R. Viña y M. E. Canafoglia. 2007a. Vasijas YaviChicha: distribución y variabilidad a través del estudio de sus pastas. Actas del XVI Congreso Nacional de Arqueología Argentina, tomo II: 189-193. Jujuy.

Cremonte, M. B.; A. Ramírez y S. M. Peralta. 2007b. Identificación y caracterización de manufacturas cerámicas no locales del Pukara de Volcán. Petrografía de pastas y fluorescencia de rayos. En: Cerámicas arqueológicas. Perspectivas arqueométricas para su análisis e interpretación, editado por M. B. Cremonte y N. Ratto, pp. 49-71. EdiUNJu, Jujuy.

Cremonte, M. B.; C. Otero y M. S. Gheggi. 2009. Reflexiones sobre el consumo de chicha en épocas prehispánicas a partir de un registro actual en Perchel (Dto. Tilcara, Jujuy). Relaciones de la Sociedad Argentina de Antropología XXXIV: 75102.

Debenedetti, S. 1930. Chulpas en las cavernas del río San Juan Mayo. Notas del Museo Etnográfico $\mathrm{n}^{\circ}$ 1: 5-50. Facultad de Filosofía y Letras, UBA, Buenos Aires.

De Bonelli, H. 1854. Travels in Bolivia with a tour across the pampas to Buenos Aires \&c. Vol. 2. The Church Collection at the John Hay Library, Brown University. Londres. Versión digital en: http://www.archive.org/details/travelsinbolivia02debo

De La Fuente, G. A. 2011. Urns, bowls, and ollas: Pottery-making practices and technical identity in the Southern Andes during the Late Period (ca. A.D. 900-A.D. 1450) (Catamarca, Northwestern Argentine Region, Argentina). Latin American Antiquity 22(2): 224-252.

Dobres, M. A. y C. R. Hoffman. 1994. La agencia social y la dinámica de la tecnología prehistórica, Journal of Archaeological Method and Theory 1(3): 211- 258, 1994.

Drennan, R. D. 2009. Statistics for Archaeologists. A Common Sense Approach. Second Edition. Springer, New York.

Druc, I. 2011. Tradiciones alfareras del valle de Cajamarca y cuenca alta del Jequetepeque, Perú. Bulletin de l'Institut Français d'Études Andines 40 (2): 307331.

Fernández, J. 1988-89. Ocupaciones alfareras (2860 \pm 160 años A.P.) en la cueva de Cristóbal, Puna de Jujuy, Argentina. Relaciones de la Sociedad Argentina de Antropología XVII: 139-178.

Fernández, J. 1996. Munitayoc, nuevo sitio con cerámica temprana (1000 a.C.) en la Puna jujeña. Actas y Memorias del XI Congreso Nacional de Arqueología 
Argentina ( $11^{\circ}$ parte). Revista del Museo de Historia Natural de San Rafael, Tomo XXIII (1/4): 51-62. Mendoza.

Fernández, J. 1999. Caracterización mineralógica, petrográfica y granulométrica de arcillas y antiplásticos usados en la alfarería tradicional de la puna jujeña. Relaciones de la Sociedad Argentina de Antropología XXIV: 139-158.

García, L. C. 1988. Etnoarqueología: manufactura de cerámica en Alto Sapagua. En: Arqueología contemporánea argentina: actualidad y perspectivas. Editado por $\mathrm{H}$. Yacobaccio et al., pp. 33-58. Ed. Búsqueda, Buenos Aires.

García, L. C. 1995. Asentamientos formativos y ocupaciones posteriores en cuevas y aleros del área de Azul Pampa (Jujuy). Actas y Memorias del XI Congreso Nacional de Arqueología Argentina (110 Parte). Revista del Museo de Historia Natural de San Rafael. Tomo XXIII (1/2). Mendoza.

García Roselló, J. 2007. La Producción Cerámica Mapuche. Perspectiva Histórica, Arqueológica y Etnográfica. Actas del $6^{\circ}$ Congreso Chileno de Antropología. Tomo II: 1932-1946. Colegio de Antropólogos de Chile. Valdivia.

García Roselló, J. 2010. Análisis traceológico de la cerámica: modelado y espacio social durante el Postalayótico (V-I a.C.) en la península de Santa Ponça (Calvià, Mallorca). Tesis Doctoral. Universitat de les Illes Balears. Departament de Ciències Històriques i Teoria de les Arts. España. MS.

Gell, A. 1992. The Technology of Enchantment and the Enchantment of Technology. En: Anthropology, art, and aesthetics. Editado por W. Walker, pp. 40-67. Clarendon Press, Oxford

Gell, A. 1998. Art and Agency. An Anthropological Theory. Clarendon Press, Oxford.

Giddens, A. 1995. La Constitución de la Sociedad: Bases para la Teoría de la Estructuración. Amorrortu, Buenos Aires.

Gil Montero, R. 2002. Guerras, hombres y ganados en la puna de Jujuy. Comienzos del siglo XIX. Boletín del Instituto de Historia Argentina y Americana "Dr. Emilio Ravignani"; Tercera serie, $\mathrm{n}^{\circ}$ 25: 9-36.

Gil Montero, R. 2004. Caravaneros y transhumantes en los Andes Meridionales. Población y familia indígena en la Puna de Jujuy 1770-1870. Instituto de Estudios Peruanos. Perú.

Gil Montero, R. 2008. La Construcción de Argentina y Bolivia en los Andes Meridionales. Prometeo Libros. Buenos Aires.

González, A. R. 1963. Problemas Arqueológicos de la Puna Argentina. En: A Pedro Bosch Gimpera en el septuagésimo aniversario de su nacimiento, pp. 373-384. México.

González de Bonaveri, M. I., M. M. Frère y P. Solá. 2000. Petrografía de cerámicas arqueológicas de la cuenca del río Salado, Provincia de Buenos Aires. Relaciones de la Sociedad Argentina de Antropología XXV: 207-226. 
Gosselain, O. 1992. Technology and Style: Potters and Pottery Among Bafia of Cameroon. Man, New Series 27 (3): 559-586.

Gosselain, O. 1999. In Pots We Trust: The Processing of Clay and Symbols in SubSaharan Africa. Journal of Material Culture 4(2): 205-230.

Gosselain, O. 2000. Materializing Identities: An African Perspective. Journal of Archaeological Method and Theory 7 (3): 187-217.

Hildebrand, J. A. y Hagstrum, M. B. 1999. New approaches to ceramic use and discard: Cooking pottery from the Peruvian Andes in ethnoarchaeological perspective. Latin American Antiquity 10: 25-46.

Hodder, I. y S. Hutson. 2003. Reading the past. Current approaches to interpretation in archaeology. Cambridge University Press.

Hosler, D. 1996. Technical choices, social categories and meaning among the Andean potters of Las Animas. Journal of Material Culture 1 (1): 63-90.

Ingold, T. 1990 Sociedad, naturaleza y el concepto de tecnología. Archaeological Review from Cambridge 9 (1): 5-17, 1990. Traducción: Andrés Laguens.

Ingold, T. 2000 Making Culture and Weaving the World. En: Matter, Materiality and Modern World, P. M. Graves Brown, ed. Routledge, Londres, pp. 50-71.

Ingold, T. 2008 Tres en uno: cómo disolver las distinciones entre cuerpo, mente y cultura. En: Tecnogénesis. La construcción técnica de las ecologías humanas. Ed. Por Tomás Sánchez Criado, vol. 2: 1-34, AIBR, Madrid.

Jordan, S. C.; C. Schrire Y D. Miller. 1999. Petrography of Locally Produced Pottery from the Dutch Colonial Cape of Good Hope, South Africa. Journal of Archaeological Science 26: 1327-1337.

Karasik, G. 1984. Intercambio tradicional en la puna jujeña. Runa XIV: 51-91.

Keane, W. 2005. Signs Are Not the Garb of Meaning: On the Social Analysis of Material Things. En Materiality, editado por D. Miller, pp. 182-205. Duke University Press, Durham.

Killick, D. 2004. Social Constructionist Approaches to the Study of Technology. World Archaeology 36 (4): 571-578.

Knappett, C. 2002. Photographs, Skeuomorphs and Marionettes: some Thoughts on Mind, Agency and Object. Journal of Material Culture 7 (1): 97-117.

Knappett, C. 2005. Thinking Through Material Culture: An Interdisciplinary Perspective. University of Pennsylvania Press, Philadelphia

Krapovickas, P. 1958-59. Arqueología de la Puna Argentina. Anales de Arqueología y Etnología 14-15:53-113.

Krapovickas, P. 1965. La Cultura de Yavi. Una nueva entidad cultural puneña. Etnia $\mathrm{n}^{\circ}$ 2: 9-10. 
Krapovickas, P. 1968. Subárea de la Puna Argentina. Actas y Memorias del XXXVII Congreso Internacional de Americanistas, tomo 2: 236-271. Buenos Aires.

Krapovickas, P. 1973. Arqueología de Yavi Chico (Provincia de Jujuy, República Argentina). Revista del Instituto de Antropología, n IV: 5-22. Universidad Nacional de Córdoba.

Krapovickas, P. 1975. Algunos tipos cerámicos de Yavi Chico. Actas y trabajos del Primer Congreso Nacional de Arqueología Argentina (Rosario, 1970). Buenos Aires.

Krapovickas, P. 1978. Los Indios de la Puna en el Siglo XVI. Relaciones de la Sociedad Argentina de Antropología, Vol. XII: 71-93. Buenos Aires.

Krapovickas, P. 1983. Las Poblaciones indígenas históricas del sector oriental de la Puna (un intento de correlación entre la información arqueológica y la etnográfica). Relaciones de la Sociedad Argentina de Antropología. Vol. XV. Bs. As. Argentina.

Krapovickas, P. 1984. Montículos y alfarería antropomorfa en el norte de la puna. Novedades del Museo de La Plata, Vol. 1, $n^{\circ}$ 8: 72. La Plata.

Krapovickas, P. 1987-88. Noticia. Nuevos fechados radiocarbónicos para el sector oriental de la puna y la Quebrada de Humahuaca. Runa XVII-XVIII: 207-219.

Krapovickas, P y E. Cigliano. 1962-63. Investigaciones Arqueológicas en el valle del Río Grande de San Juan (Puna Argentina). Anales de Arqueología y Etnología, tomo XVII-XVIII: 71-118.

Krapovickas, P; A. S. Castro; M. M. Pérez Meroni y R. J. Crowder. 1979. La instalación humana en Santa Ana de Abralaite. Sector Oriental de la Puna; Jujuy; Argentina. Relaciones de la Sociedad Argentina de Antropología, Vol. XIII: 27-48.

Krapovickas, P. y S. Aleksandrowicz. 1986-87. Breve visión de la cultura Yavi. Anales de Arqueología y Etnología 41-42: 83-127.

Krapovickas, P; C. P. Pla y S. E. Manuale. 1989. Reconstruyendo el pasado: La Arqueología, la cultura de Yavi y los chichas. Revista Antropología IV (8): 3-11.

Lafón, C. R. 1965. Tiempo y Cultura en la Provincia de Jujuy. Etnía n² 2: 1-5. Olavarría.

Lehmann-Nistche, R. 1904. Catálogo de las antigüedades de la Provincia de Jujuy. Revista del Museo de La Plata, T. XI: 74-120.

Lemonnier, P. 1986. The Study of Material Culture Today: Toward an anthropology of technical systems. Journal of Anthropological Archaeology, vol. 5 (2): 147-186.

Lemonnier, P. 1992. Elements for an Anthropology of Technology. Anthropological Papers No 88: 1-24. Traducción: Andrés Laguens.

Lemonnier, P. 2004. Mythiques chaînes operatoires. Techniques \& Culture 43-44: 2-14.

López, M. A. 2007. Identidad y estilos tecnológicos. Variabilidad de los patrones de secuencias de ejecución de piezas cerámicas consumidas en un sitio de la 
Quebrada de Humahuaca (Jujuy, NOA). Actas del XVI Congreso Nacional de Arqueología Argentina, tomo II: 195-200. Universidad Nacional de Jujuy.

Madrazo, G. 1982. Hacienda y encomienda en los Andes. La Puna argentina bajo el marquesado de Tojo. Siglos XVII a XIX. Fondo Editorial. Buenos Aires.

Mamaní, H. E. 1997. Organización espacial de las sociedades agroalfareras prehispánicas en el sector occidental de la cuenca de Pozuelos (Dep. de Rinconada, Jujuy). Tesina de grado inédita. Universidad Nacional de Jujuy, Jujuy. MS.

Mamaní, H. E. 1998. El paisaje arqueológico en el sector occidental de la cuenca de Pozuelos (Jujuy, Argentina). Los Desarrollos Locales y sus territorios: 257-281. B. Cremonte (ed.) UNJu, Jujuy.

Menacho, K. A. 2001. Etnoarqueología de trayectorias de vida de vasijas cerámicas y modo de vida pastoril. Relaciones de la Sociedad Argentina de Antropología XXVI: 119-144.

Menacho, K. A. 2007. Etnoarqueología y estudios sobre funcionalidad cerámica: aportes a partir de un caso de estudio. Intersecciones en Antropología 8: 149-161.

Merlino, R. y M. Rabey. 1978. El ciclo agrario-ritual en la puna argentina. Relaciones de la Sociedad Argentina de Antropología XII: 47-70.

Mottana, A; R. Crespi y G. Liborio. 1978. Minerales y Rocas. Guías de la Naturaleza. Editorial Grijalbo. Barcelona.

Nielsen, A. E. 1997a. El tráfico caravanero visto desde La Jara. Estudios Atacameños 14: 339-371.

Nielsen, A. E. 1997b. Tiempo y Cultura Material en la Quebrada de Humahuaca. 7001650 d. C. Instituto Interdisciplinario Tilcara, FFyL, UBA.

Nielsen, A. E. 2000. Andean Caravans: an ethnoarchaeology. Tesis Doctoral inédita. Departamento de Antropología, Universidad de Arizona. MS.

Nielsen, A. E.; C. I. Angiorama, J. Maryañski, M. L. López y F. Ávila 2013. La organización del espacio en la subregión San Juan Mayo durante el Periodo de Desarrollos Regionales. Trabajo presentado al XVIII Congreso Nacional de Arqueología Argentina, La Rioja. MS.

Orton, C.; P. Tyers y A. Vince. 1997. La cerámica en arqueología. Editorial Crítica, Barcelona.

Ottonello, M. 1973. Instalación, economía y cambio cultural en el sitio Tardío de Agua Caliente de Rachaite. Publicaciones de la Dirección de Antropología e Historia $n^{o}$ 1: 23-68. San Salvador de Jujuy.

Ottonello, M y P. Krapovickas. 1973. Ecología y arqueología de cuencas en el sector oriental de la Puna, República Argentina. Publicaciones de la Dirección de Antropología e Historia $n^{\circ}$ 1: 3-21. San Salvador de Jujuy. 
Pauketat, T. 2001. Practice and history in archaeology: An emerging paradigm. Anthropological Theory 1 (1): 73-98.

Palamarczuk, E y V. Palamarczuk. 2007 Una muestra de cerámica famabalasto negro grabado. Reflexiones en torno a las interacciones regionales tardías en Yocavil a partir de la petrografía cerámica. Actas del XVI Congreso Nacional de Arqueología Argentina, tomo II: 375-380. Universidad Nacional de Jujuy.

Pérez, M. y V. A. Killian Galván. 2011. Doncellas (Puna Septentrional, Jujuy, Argentina): Nuevos enfoques a partir del estudio cerámico y del análisis paleodietario. Estudios Atacameños 42: 79-100.

Pérez de Micou, C. 2009. Indicios arcaicos en la Colección Doncellas, Jujuy (República Argentina). El "Yacimiento" 26 a la luz de un fechado radiocarbónico (4811 239 AP). Bulletin de l'Institut Français d'Études Andines 38 (1): 75-85.

Pérez Pieroni, M. J. 2009. Análisis tecnológico de materiales cerámicos de la localidad arqueológica de Río Herrana (cuenca sur de la laguna de Pozuelos, puna de Jujuy). Tesina de grado inédita. Facultad de Ciencias Naturales, UNT. MS.

Pérez Pieroni, M. J. y M. F. Becerra. 2010. La localidad de Pan de Azúcar (Jujuy): una primera aproximación a su tecnología cerámica y minero-metalúrgica durante el período colonial. Libro de resúmenes de las Cuartas Jornadas de Jóvenes Investigadores UNT-CONICET. EDUNT, Universidad Nacional de Tucumán.

Pozzi-Escot, D; M. M. Alarcón y C. Vivanco P. 1993. Instrumentos de alfareros de la época Wari. Bulletin de l'Institut Français d'Études Andines 22 (2): 467-496.

Puente, V. 2012. "Atravesando fronteras". Prácticas compartidas e identidades sociales negociadas durante el Tardío prehispánico. Una discusión desde la alfarería ordinaria del valle del Bolsón (Belén, Catamarca). Relaciones de la Sociedad Argentina de Antropología XXXVII (1): 65-87.

Raffino, R. A. 1978. La ocupación Inka en el N. O. Argentino: actualización y perspectivas. Relaciones de la Sociedad Argentina de Antropología n XII: 95-121.

Raffino, R. A.; R. J. Alvis, D. E. Olivera, J. R. Palma. 1986. La instalación inka en la sección andina meridional de Bolivia y extremo boreal de Argentina. En: El imperio Inka: actualización y perspectivas. R. A. Raffino (Ed.). Comechingonia $\mathrm{n}^{\circ}$ especial: 63-129.

Raffino, R. A; C. Vitry y D. Gobbo. 2004. Inkas y Chichas: identidad, transformación y una cuestión fronteriza. Boletín de arqueología PUCP 8: 247-265.

Ramos, V. A. y B. Coira. 2008. Las provincias geológicas de Jujuy. Geología y Recursos Naturales de la Provincia de Jujuy. Relatorio del XVII Congreso Geológico Argentino. S. S. de Jujuy. Editado por Coira y Zappettini, pp. 11-15. Asociación Geológica Argentina.

Ratto, N; A. Feely y R. Plá 2007. La producción alfarera en el Bolsón de Fiambalá (Departamento Tinogasta, Catamarca) y su alcance extra-regional. En Cerámicas 
Arqueológicas. Perspectivas arqueométricas para su análisis e interpretación, editado por M. B. Cremonte y N. Ratto, pp. 123-145. EdiUNJu.

Ratto, N; M. Orgaz y R. Plá 2004. La explotación del alfar de La Troya en el tiempo: casualidad o memoria (Departamento Tinogasta, Catamarca, Argentina). Chungará 36 (2): 351-363.

Rice, P. M. 1987. Pottery Analysis. A Sourcebook. The University of Chicago Press, Chicago.

Rodríguez, J. C. 2002. La Alfarería de Casira. Las Artesanías y el proceso de transformación en su integración a mercados urbanos. EdiUNJu. Universidad Nacional de Jujuy.

Rolandi, D. S. 1974. Un hallazgo de objetos metálicos en el área del río Doncellas (Provincia de Jujuy). Relaciones de la Sociedad Argentina de Antropología $\mathrm{n}^{\circ} \mathrm{VIII}$ : 153-160. Buenos Aires.

Rosas, S. 2008. Sitios de Interés Geológico de la provincia de Jujuy. Geología y Recursos Naturales de la Provincia de Jujuy. Relatorio del XVII Congreso Geológico Argentino, Jujuy. Editado por Coira y Zappettini, pp. 481-491. Asociación Geológica Argentina.

Ruiz, M. 1996. Algunas reflexiones sobre las agrupaciones G-I-K del Pucará de Rinconada, Puna de Jujuy, República Argentina. Vol. XXV Aniversario Museo Arqueológico Dr. Eduardo Casanova: 137-144. Instituto Interdisciplinario Tilcara. Tilcara.

Ruiz, M y M. Albeck. 1997. El Fenómeno Pukara visto desde la Puna Jujeña. Estudios Atacameños 12: 83-95. San Pedro de Atacama. Chile.

Ruiz, M. y D. Chorolque. 2007. Arte Rupestre del Pukara de Rinconada: Una larga historia visual. EdiUNJu. Universidad Nacional de Jujuy, Jujuy.

Rye, O. S. 1981. Pottery Technology. Principles and reconstruction. Taraxacum. Washington D.C., USA.

Sanhueza, L. 2000. Patrón cerámico: hacia la definición de un concepto operativo. Actas del XIV Congreso Nacional de Arqueología Chilena. Contribución Arqueológica 5 (1): 243-257. Copiapó.

Sanhueza, L. 2004. Estilos tecnológicos e identidades sociales durante el periodo alfarero temprano en Chile central: una mirada desde la alfarería. Tesis para obtener el grado de Magíster en Arqueología. Facultad de Ciencias Sociales, Universidad de Chile, Santiago. MS.

Sanhueza, L. y F. Falabella. 2009. Descomponiendo el complejo Llolleo: hacia una propuesta de sus niveles mínimos de integración. Chungara 41: 229-239.

Sanhueza, L.; F. Falabella, E. Fonseca y O. Andonie. 2004. Aplicación de análisis de pastas macroscópicos, petrográficos y de composición de elementos químicos al 
problema de la procedencia de cerámica en el Período Alfarero Temprano de Chile central y Cuyo, Argentina. Estudios Atacameños 28: 121-132.

Sapiencia de Zapata, S.; V. Maceda Rassit y J. Viaña Uzieda. 1997. Inventario de la Cerámica Aymara y Quechua. Producciones "Cima". La Paz, Bolivia.

Schavelzon, D. 2001. Catálogo de cerámicas históricas de Buenos Aires (s. XVI - XX). Formato CD. Buenos Aires, Argentina.

Shepard, A. O. 1985. Ceramics for the Archaeologist. Sith Printing Publication 609. Carnegie Institution of Washington D.C. $12^{\circ}$ edición.

Sica, G. 2010. Del tráfico caravanero a la arriería colonial indígena en Jujuy. Siglos XVII y XVIII. Revista Transporte y Territorio 3: 23-39.

Sica, G. y M. Ulloa. 2007. Jujuy en la colonia. De la fundación de la ciudad a la crisis del orden colonial. En. A. Teruel y M. Lagos (Directores), Jujuy en la Historia. De la colonia al siglo $X X .2^{\mathrm{a}}$ edición, pp. 43-84. EdiUnju. Jujuy.

Sillar, B. y M. S. Tite. 2000. The challenge of 'technological choices' for materials science approaches in archaeology. Archaeometry 42 (1): 2-20.

Sinopoli, C. M. 1991. Approaches to Archaeological Ceramics. Plenum Press. New York.

Solá, P. 2007. La cerámica utilitaria de grupos pastoriles en Susques (Puna argentina). En Cerámicas Arqueológicas. Perspectivas arqueométricas para su análisis e interpretación, editado por M. B. Cremonte y N. Ratto, pp. 73-95. EdiUNJu.

Stoltman, J. B. 1989. A quantitative approach to the petrographic analysis of ceramic thin sections. American Antiquity 54(1): 147-160.

Stoltman, J. B. 1991. Ceramic petrography as a technique for documenting cultural interaction: an example from the upper Mississippi Valley. American Antiquity 56 (1): 103-120.

Stoltman, J. B. 2001. The Role of Petrography in the Study of Archaeological Ceramics. En Earth Sciences and Archaeology, editado por P. Goldberg, V. T. Holliday y C. Reid Ferring, pp. 297-326. Kluwer Academic/Plenum Publishers, New York.

Suetta, J y L. Alfaro. 1979. Excavaciones arqueológicas en el pucará de Rinconada, Pcia. de Jujuy. Actas de las Jornadas de Arqueología del Noroeste Argentino. Universidad del Salvador. Buenos Aires.

Tarragó, M. N. 1977. Relaciones prehispánicas entre San Pedro de Atacama (Norte de Chile) y regiones aledañas: la quebrada de Humahuaca. Estudios Atacameños 5: 50-63. San Pedro de Atacama, Chile.

Tarragó, M. N. 1984. La historia de los pueblos circumpuneños en relación con el Altiplano y los valles meridionales. Estudios Atacameños 7: 116-132.

Tecchi, R. 1991. Los ecosistemas puna y suni en la cuenca de la laguna de Pozuelos. En: La Reserva de la Biosfera Laguna Pozuelos: un ecosistema pastoril en los Andes jujeños, pp. 9-22. García Fernández, J. J. y R. Tecchi (Comp.). 
Varela Guarda, V. 2002. Enseñanzas de alfareros toconceños: tradición y tecnología en la cerámica. Chungará 34 (2): 225-252.

Vignati, M. A. 1938. "Novissima Veterum": Hallazgos en la Puna Jujeña. Revista del Museo de La Plata (Nueva Serie). Tomo I, Sección Antropología: 54-91.

Williams, V y M. B. Cremonte. 1997. Mitmaqkuna o circulación de bienes? Indicadores de la producción cerámica como indicadores étnicos. Un caso de estudio en el Noroeste argentino. En: El Tucumán Colonial y Charcas. Lorandi (Comp.): 75-86. Facultad de Filosofía y Letras, Universidad Nacional de Buenos Aires.

Wynveldt, F. 2008. Tecnología cerámica Belén: caracterización macroscópica y conceptualización en la manufactura alfarera. Intersecciones en Antropología 9: 157-172.

Zaburlín, M. A. 2012. La cerámica tricolor de la Puna jujeña: variabilidad de los motivos con vírgulas y puntos blancos. Arqueología 18: 131-152.

Zagorodny, N. 1995. Estudio ceramológico de un lote de fragmentos provenientes del sitio arqueológico "El Shincal" y zonas aledañas. Catamarca. Hombre y Desierto, $n^{\circ}$ 9. Antofagasta, Chile.

Zagorodny, N. 1996. Un estudio tecnológico sobre la alfarería doméstica en el Temprano. Actas y Memorias del XI Congreso Nacional de Arqueología Argentina ( $11^{\circ}$ Parte). Revista del Museo de Historia Natural de San Rafael (Mendoza), Tomo XXIII (1/4).

Zagorodny, N. s. f. Ficha descriptiva. Laboratorio de Análisis Cerámico. UNLP. M. S. 
ANEXOS 


\section{ANEXO I \\ Código analítico para descripción de material fragmentario macroscópico}

\section{Planillas macroscópicas de descripción de material fragmentario}

\section{CÓDIGO ANALÍTICO PARA DESCRIPCIÓN DE MATERIAL FRAGMENTARIO MACROSCÓPICO:}

- Sitio

- UP

- Porción del cuerpo representada por el fragmento

0. Cuerpo

1. Borde

2. Base

3. Asa

4. Punto de inflexión/intersección

5. Objeto

Manufactura:

- Técnica de levantado

0 . Indeterminado

1. Rollos

2. Modelado

3. Torneado

- Forma (según Balfet et al.)

1. ABIERTAS:

1.1. Plato: $O$ abertura $(<0 ́=23 / 24 \mathrm{~cm})=0$ o $>5 \mathrm{~h}$

1.2. Fuente: $\mathrm{O}$ abertura $(>24 \mathrm{~cm})=0$ ó $>\mathrm{h}$

1.3. Escudilla: $\mathrm{O}$ abertura $(12 \mathrm{a} 22 / 23 \mathrm{~cm})=2.5$ a $5 \mathrm{~h}$

1.4. Escudilla honda o Tazón: $\mathrm{O}$ abertura $(<\mathrm{o}=18 \mathrm{~cm})=1,5$ a $2,5 \mathrm{~h}$

1.5. Cuenco: $O$ abertura $(19$ a $40 \mathrm{~cm})=1,5$ a $2,5 \mathrm{~h}$

1.6. Escudilla restringida o cubilete: $O$ abertura $(6$ a $12 \mathrm{~cm})=0$ ó $<1,5 \mathrm{~h}$

1.7. Vaso cubilete o vaso: $\mathrm{O}$ abertura $(>12 \mathrm{~cm})=0$ o $<1,5 \mathrm{~h}$

\section{CERRADAS:}

2.1. Vasija: O min > ó = 1/3 O máx. h 1 ó 2 O abertura, ó <4

2.2. Tinaja: > tamaño que la vasija, h 2 ó $3 \mathrm{O}$ abertura. 
2.3. Botellón: O min < ó = 1/3 O máx.

3. Formas varias (figurinas, recipientes modelados, etc.)

- Marcas de herramientas en las superficies

0 . No se observan

1. Estrías de alisado

2. Caras de pulido

3. Estrías de modelado

4. Perforaciones varias

5. Marcas digitales

6. Marcas de unión de rollos o segmentos

7. Unión de asas adherida

8. Remache de asas

9. Desgaste o abrasión por reuso

10. Marcas de corte o recorte

- Acabado de la superficie externa
0 . No se observa
1. Ordinario
2. Alisado
3. Pulido
4. Engobado
5. Pintura precocción
6. Pintura poscocción
7. Impronta textil/cestería
8. Corrugado
9. Imbricado
10. Paleteado
11. Vitrificado
12. Esmaltado
13. Deslizamiento de dedos

\section{- Acabado de superficie interna}

Ídem anterior

- Espesor máximo del fragmento (en mm)

- Espesor mínimo del fragmento (en mm)

- Técnicas de decoración por pintura
0. Sin pintar
1. Pintura monocroma
2. Pintura bicolor
3.Pintura tricolor

- Técnicas de decoración por corte/desplazamiento
0 . No se observa
1. Impresión (cestería, textil, etc.)
2. Incisión
3. Estampamiento

Técnicas de decoración por agregado 

0. No se observa
1. Modelado

2. Pastillaje

- Motivos de decoración

- Estilo (si corresponde a algunos de los tipos estilísticos ya definidos en la bibliografía anterior, de manera conspicua)

\section{Cocción}

- Colorles superficie externa (en notación Munsell)

- Color superficie interna (en notación Munsell)

\section{Morfología}

Borde

- Diámetro (en cm)

- Largo del arco (en cm)

- Porcentaje del arco

- Dirección borde

0 . No se observa

1. Hacia afuera

2. Vertical

3. Hacia adentro

\section{- Forma del borde}

0 . No se observa

1. Plano

2. Redondeado

3. Biselado hacia adentro

4. Biselado hacia fuera

5. Doble biselado

6. Engrosado

Asa

- Largo

- Ancho

- Espesor

- Sección asa
0 . No se observa
1. Circular

2. Subcircular

3. Plana

4. Subplana

5. Subtriangular

- Inserción asa

0 . No se observa

1. Adherida simple 
2. Doble adherida

4. Doble remachada

6. Labio remachada

- Posición asa

0 . No se observa

2. Vertical

Base

- Morfología

0 . No se observa

2. Plano convexa

4. Biconvexa

6. Convexo plana

8. Bicóncava

- Unión base
3. Remachada simple

5. Labio adherida

1. Horizontal

3. Oblicua
0 . No se observa
1. Angular

2. Directa

3. Inflexa

1. Biplana

3. Cóncavo convexa

5. Plano cóncava

7. Convexo cóncava

- Diámetro de la base

- Alteraciones posdeposicionales

0 . No se observa

1. Manchas de exposición al fuego

2. Depósitos en superficies

3. Erosión de bordes

4. Erosión de superficies

5. Erosión de pintura

6. Alteración de color

7. Fracturas frescas

- Observaciones

- $\quad \mathbf{N}^{\circ}$ foto

- $\quad N^{\circ}$ ilustración

\section{BIBLIOGRAFÍA:}

Cremonte; M. B. 1991. Análisis de muestras cerámicas de la Quebrada de Humahuaca. Avances en Arqueología, $\mathrm{n}^{\circ}$ 1: 7-42. Universidad Nacional de Buenos Aires.

Espiro E., V. E. 2006. Aportes Para Una Clasificación Tecnológica De Las Cerámicas Pertenecientes Al Primer Milenio De Nuestra Era De La Aldea Piedra Negra, Laguna Blanca, Dpto. Belén, Provincia De Catamarca. Tesis de Licenciatura inédita. Universidad Nacional de Catamarca. 
Orton, C.; P. Tyers y A. Vince. 1997. La cerámica en arqueología. Editorial Crítica, Barcelona.

Primera Convención Nacional de Antropología (Córdoba). 1964. Primera Parte. Cerámica. Publicaciones del Instituto de Antropología 1 (XXVI) Córdoba. 


\begin{tabular}{|c|c|c|c|c|c|c|c|c|c|c|c|c|c|c|c|c|c|c|c|c|c|c|c|c|c|c|c|c|c|c|c|}
\hline \multirow[b]{2}{*}{ Sitio } & \multirow[b]{2}{*}{ UP } & \multirow[b]{2}{*}{ GF } & \multirow[b]{2}{*}{ FNA } & \multirow[b]{2}{*}{ Fgto } & \multicolumn{10}{|c|}{ Manufactura } & \multicolumn{2}{|c|}{ Cocción } & \multicolumn{5}{|c|}{ Borde-labio } & \multicolumn{6}{|c|}{ Asa } & \multicolumn{3}{|c|}{ Base } & \multirow[b]{2}{*}{ Alterac } \\
\hline & & & & & $\begin{array}{l}\begin{array}{l}\text { Tec } \\
\text { lev }\end{array} \\
\end{array}$ & \begin{tabular}{|c} 
For \\
ma
\end{tabular} & $\begin{array}{l}\text { Mar } \\
\text { cas }\end{array}$ & $\begin{array}{l}\text { Sup } \\
\text { ext }\end{array}$ & $\begin{array}{c}\begin{array}{c}\text { Sup } \\
\text { int }\end{array} \\
\end{array}$ & $\begin{array}{l}E s p \\
\max \end{array}$ & $\begin{array}{l}\text { Esp } \\
\text { min }\end{array}$ & \begin{tabular}{|c|}
$\begin{array}{c}\text { Deco } \\
\text { pint }\end{array}$ \\
\end{tabular} & \begin{tabular}{|c|} 
Moti \\
vo \\
\end{tabular} & \begin{tabular}{|c|} 
Esti \\
lo \\
\end{tabular} & Color sup ext & Color sup int & Diam. & $\begin{array}{l}\text { Lrg } \\
\text { arc }\end{array}$ & \begin{tabular}{|c|}
$\%$ \\
arco \\
\end{tabular} & $\mathrm{c}$ & $\begin{array}{l}\text { Fol } \\
\text { ma }\end{array}$ & \begin{tabular}{|l} 
Lar \\
go
\end{tabular} & $\begin{array}{c}\text { An } \\
\text { cho }\end{array}$ & E & cc & $\begin{array}{c}\text { In } \\
\text { serc }\end{array}$ & $\begin{array}{l}\text { Posi } \\
\text { ción }\end{array}$ & $n^{n}$ & \begin{tabular}{|c|}
$\begin{array}{c}\text { or } \\
\text { fol }\end{array}$ \\
\end{tabular} & $\begin{array}{l}\text { runi } \\
\text { ón }\end{array}$ & \\
\hline $\mathrm{CH} 25-$ & 102 & 1 & & 3 & 1 & 2 & 1 & 2 & 2 & 8.3 & 5.2 & 0 & $x$ & $x$ & 5 YR $6 / 4,6 / 3,4 / 1,4 / 2$ & $5 Y R$ 6/3, 5/1, 5/2, 4/1 & $x$ & $x$ & $x$ & $x$ & $x$ & $3,7 \mathrm{fr}$ & 19.5 & 15 & 2 & 1 & 3 & $x$ & $x$ & $x$ & 1 \\
\hline $\mathrm{CH} 25-1$ & 102 & 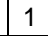 & & 0 & 1 & 2 & 1 & 2 & 2 & 10.3 & 5.5 & 0 & $\mathrm{x}$ & $\mathrm{x}$ & 5 YR $6 / 4,6 / 3,4 / 1,4 / 2$ & $5 / 2,4 / 1$ & 32 & 9.8 & 9.8 & 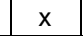 & $\mathrm{x}$ & $\mathrm{x}$ & $\mathrm{x}$ & $x$ & $\mathrm{x}$ & $\mathrm{x}$ & $\mathrm{x}$ & $\mathrm{x}$ & $\mathrm{x}$ & $\mathrm{x}$ & 1 \\
\hline $\mathrm{CH} 25-1$ & 102 & 1 & & 0 & 1 & 2 & 1 & 2 & 2 & 6.7 & 5.5 & 0 & $\mathrm{x}$ & $\mathrm{x}$ & 5 YR $6 / 4,6 / 3,4 / 1,4 / 2$ & $5 Y R$ 6/3, 5/1, 5/2, 4/1 & 32 & 9.8 & 9.8 & $\mathrm{x}$ & $\mathrm{x}$ & $\mathrm{x}$ & $\mathrm{x}$ & $\mathrm{x}$ & $\mathrm{x}$ & $\mathrm{x}$ & $\mathrm{x}$ & $\mathrm{x}$ & $\mathrm{x}$ & $\mathrm{x}$ & 1 \\
\hline $\mathrm{CH} 25-1$ & 102 & 1 & & 2 & 1 & 2 & 1 & 2 & 2 & 14 & 6.1 & 0 & $\mathrm{x}$ & $\mathrm{x}$ & 5 YR $6 / 4,6 / 3,4 / 1,4 / 2$ & $5 Y R \quad 6 / 3,5 / 1,5 / 2,4 / 1$ & $x$ & $\mathrm{x}$ & $\mathrm{x}$ & $\mathrm{x}$ & $\mathrm{x}$ & $\mathrm{x}$ & $\mathrm{x}$ & $\mathrm{x}$ & $\mathrm{x}$ & $\mathrm{x}$ & $\mathrm{x}$ & 10.5 & 1 & 2 & 1 у 3 \\
\hline $\mathrm{CH} 25-1$ & 102 & 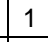 & & 4 & 1 & 2 & 1 & 2 & 2 & 5.6 & 5 & 0 & $x$ & $x$ & 5 YR $6 / 4,6 / 3,4 / 1,4 / 2$ & $5 Y R$ 6/3, 5/1, 5/2, 4/1 & $x$ & $\mathrm{x}$ & $x$ & $x$ & $\mathrm{x}$ & $x$ & $x$ & $x$ & $\mathrm{x}$ & $x$ & $x$ & $x$ & $x$ & $\mathrm{x}$ & 3 \\
\hline $\mathrm{CH} 25-1$ & 102 & 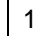 & & 0 & 1 & 2 & 1 & 2 & 2 & 5.6 & 5.1 & 0 & $\mathrm{x}$ & $\mathrm{x}$ & 5 YR $6 / 4,6 / 3,4 / 1,4 / 2$ & $5 Y R$ 6/3, 5/1, 5/2, 4/1 & $x$ & $\mathrm{x}$ & $\mathrm{x}$ & 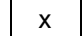 & $\mathrm{x}$ & $\mathrm{x}$ & $\mathrm{x}$ & $\mathrm{x}$ & $\mathrm{x}$ & $\mathrm{x}$ & $\mathrm{x}$ & $\mathrm{x}$ & $\mathrm{x}$ & $\mathrm{x}$ & 1 у 3 \\
\hline $\mathrm{CH} 25-1$ & 102 & 1 & & 0 & 1 & 2 & 1 & 2 & 2 & 6.2 & 4.1 & 0 & $x$ & $x$ & 5 YR 6/4, & $, 5 / 2,4 / 1$ & $x$ & $x$ & $x$ & $\mathrm{x}$ & $\mathrm{x}$ & $x$ & $x$ & $x$ & $\mathrm{x}$ & $x$ & $x$ & $x$ & $x$ & $x$ & 3 \\
\hline $\mathrm{CH} 25-1$ & 102 & 1 & & 0 & 1 & 2 & 1 & 2 & 2 & 6.4 & 5.7 & 0 & $\mathrm{x}$ & $\mathrm{x}$ & 5 YR $6 / 4,6 / 3,4 / 1,4 / 2$ & $1,5 / 2,4 / 1$ & $x$ & $\mathrm{x}$ & $\mathrm{x}$ & $\mathrm{x}$ & $\mathrm{x}$ & $\mathrm{x}$ & $\mathrm{x}$ & $\mathrm{x}$ & $\mathrm{x}$ & $\mathrm{x}$ & $\mathrm{x}$ & $\mathrm{x}$ & $\mathrm{x}$ & $\mathrm{x}$ & 2 у 3 \\
\hline $\mathrm{CH} 25-1$ & 102 & 1 & & 0 & 1 & 2 & $\perp$ & 2 & 2 & 5.7 & 5.7 & 0 & $\mathrm{x}$ & $\mathrm{x}$ & 5 YR 6/4, 6/3, 4 & $5 Y R \quad 6 / 3,5 / 1,5 / 2,4 / 1$ & $x$ & $\mathrm{x}$ & $\mathrm{x}$ & 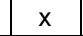 & $\mathrm{x}$ & $\mathrm{x}$ & $\mathrm{x}$ & $x$ & $\mathrm{x}$ & $\mathrm{x}$ & $\mathrm{x}$ & $\mathrm{x}$ & $\mathrm{x}$ & $\mathrm{x}$ & 2 у 3 \\
\hline $\mathrm{CH} 25-1$ & 101 & 1 & & 0 & 1 & 2 & 1 & 2 & 2 & 5.2 & 4.7 & 0 & $x$ & $x$ & 5 YR 6 & $1,5 / 2,4 / 1$ & $x$ & $x$ & $x$ & $x$ & $x$ & $x$ & $x$ & $x$ & $x$ & $x$ & $x$ & $x$ & $x$ & $x$ & 3 \\
\hline $\mathrm{CH} 25-1$ & 101 & o & & 0 & 1 & 2 & 1 & 2 & 2 & 5 & 4.2 & 0 & $\mathrm{x}$ & $\mathrm{x}$ & 5 YR $6 / 4,6 / 3,4 / 1,4 / 2$ & , $5 / 2,4 / 1$ & $x$ & $\mathrm{x}$ & $\mathrm{x}$ & $v$ & $x$ & $\mathrm{x}$ & $\mathrm{x}$ & $\mathrm{x}$ & $\mathrm{x}$ & $\mathrm{x}$ & $\mathrm{x}$ & $\mathrm{x}$ & $\mathrm{x}$ & $\mathrm{x}$ & 3 \\
\hline $\mathrm{CH} 25-1$ & 101 & 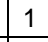 & & 0 & 1 & 2 & 1 & 2 & 2 & 5.6 & 4.5 & 0 & $x$ & $x$ & 5 YR 6/4 & $, 5 / 2,4 / 1$ & $x$ & $x$ & $x$ & $x$ & $x$ & $x$ & $x$ & $x$ & $x$ & $x$ & $x$ & $x$ & $x$ & $x$ & 3 \\
\hline CH 25-1 & 102 & 1 & & 0 & 1 & 2 & 1 & 2 & 2 & 4.5 & 4.1 & 0 & $\mathrm{x}$ & $\mathrm{x}$ & 5 YR $6 / 4,6 / 3,4 / 1,4 / 2$ & $5 Y R$. $6 / 3,5 / 1,5 / 2,4 / 1$ & $x$ & $\mathrm{x}$ & $\mathrm{x}$ & $\mathrm{x}$ & $\mathrm{x}$ & $\mathrm{x}$ & $\mathrm{x}$ & $\mathrm{x}$ & $\mathrm{x}$ & $\mathrm{x}$ & $\mathrm{x}$ & $\mathrm{x}$ & $\mathrm{x}$ & $\mathrm{x}$ & 3 \\
\hline $\mathrm{CH} 25-1$ & 102 & 1 & & 0 & 1 & 2 & 1 & 2 & 2 & 8.5 & 6.5 & 0 & $x$ & $x$ & $4 / 2$ & $5 / 2,4 / 1$ & $x$ & $x$ & $x$ & 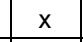 & $x$ & $x$ & $x$ & $\mathrm{x}$ & $x$ & $x$ & $x$ & $x$ & $x$ & $x$ & 4 \\
\hline $\mathrm{CH} 25-1$ & 102 & 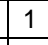 & & 0 & 1 & 2 & 1 & 2 & 2 & 7 & 6.5 & 0 & $x$ & $x$ & $4 / 2$ & $, 5 / 2,4 / 1$ & $x$ & $\mathrm{x}$ & $\mathrm{x}$ & $\mathrm{x}$ & $\mathrm{x}$ & $\mathrm{x}$ & $\mathrm{x}$ & $\mathrm{x}$ & $\mathrm{x}$ & $\mathrm{x}$ & $\mathrm{x}$ & $\mathrm{x}$ & $\mathrm{x}$ & $\mathrm{x}$ & 3 \\
\hline $\mathrm{CH} 25-1$ & 102 & 1 & & 0 & 1 & 2 & 1 & 2 & 2 & 6 & 4.1 & 0 & $\mathrm{x}$ & $\mathrm{x}$ & 5 YR $6 / 4,6$ & $1,5 / 2,4 / 1$ & $x$ & $\mathrm{x}$ & $\mathrm{x}$ & 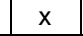 & $\mathrm{x}$ & $\mathrm{x}$ & $\mathrm{x}$ & $x$ & $\mathrm{x}$ & $\mathrm{x}$ & $\mathrm{x}$ & $\mathrm{x}$ & $\mathrm{x}$ & $\mathrm{x}$ & 3 \\
\hline $\mathrm{CH} 25-1$ & 102 & 1 & & 0 & 1 & 2 & 1 & 2 & 2 & 4.5 & 4 & 0 & $\mathrm{x}$ & $x$ & $4 / 2$ & $, 5 / 2,4 / 1$ & $x$ & $\mathrm{x}$ & $x$ & $x$ & $x$ & $x$ & $x$ & $x$ & $x$ & - & & $x$ & $x$ & $\mathrm{x}$ & \\
\hline $\mathrm{CH} 25-1$ & 102 & 1 & & 0 & 1 & 2 & 1 & 2 & 2 & 4.5 & 4.2 & 0 & $\mathrm{x}$ & $\mathrm{x}$ & 5 YR $6 / 4,6 / 3,4$ & $5 Y R \quad 6 / 3,5 / 1,5 / 2,4 / 1$ & $x$ & $\mathrm{x}$ & $\mathrm{x}$ & $\mathrm{x}$ & $\mathrm{x}$ & $\mathrm{x}$ & $\mathrm{x}$ & $\mathrm{x}$ & $\mathrm{x}$ & $\mathrm{x}$ & $\mathrm{x}$ & $\mathrm{x}$ & $\mathrm{x}$ & $\mathrm{x}$ & 3 \\
\hline $\mathrm{CH} 25-1$ & 102 & 1 & & 0 & 1 & 2 & 1 & 2 & 2 & 4.7 & 4.5 & 0 & $x$ & $x$ & $5 \mathrm{YF}$ & $, 5 / 2,4 / 1$ & $x$ & $x$ & $x$ & $x$ & $x$ & $x$ & $x$ & $x$ & $x$ & $x$ & $x$ & $x$ & $x$ & $x$ & 1 y 3 \\
\hline $\mathrm{CH} 25-1$ & 102 & 1 & & 0 & 1 & 2 & 1 & 2 & 2 & 5.5 & 5.4 & 0 & $x$ & $x$ &, $4 / 2$ & $, 5 / 2,4 / 1$ & $x$ & $x$ & $x$ & $x$ & $x$ & $x$ & $x$ & $\mathrm{x}$ & $x$ & 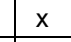 & $x$ & $x$ & $x$ & $x$ & 3 \\
\hline $\mathrm{CH} 25-1$ & 102 & 1 & & 0 & 1 & 2 & 1 & 2 & 2 & 4.3 & 4.1 & 0 & $x$ & $x$ & $4 / 1$ & $1,2,5 / 1$ & $x$ & $x$ & $x$ & $x$ & $x$ & $x$ & $x$ & $x$ & $x$ & $x$ & $x$ & $x$ & $x$ & $x$ & 3 \\
\hline $\mathrm{CH} 25-1$ & 102 & 2 & & 1 & 1 & 2 & 0 & 2 & 2 & 5.2 & 4.8 & 0 & $x$ & $x$ & 5YR $6 / 2,6$ & $1,4 / 1,2,5 / 1$ & indet & 2.7 & indet & $\begin{array}{ll}t & 1 \\
\end{array}$ & 2 & $x$ & $x$ & $x$ & $x$ & $x$ & $x$ & $x$ & $x$ & $x$ & \\
\hline $\mathrm{CH} 25-1$ & 102 & 2 & & 3 & 1 & 2 & 0 & 2 & 2 & 14.6 & 8 & 0 & $\mathrm{x}$ & $\mathrm{x}$ & 5YR 6/2, & , 2,5/1 & $\mathrm{x}$ & $\mathrm{x}$ & $\mathrm{x}$ & $\mathrm{x}$ & $\mathrm{x}$ & indet & tindeti & tindet & 0 & 0 & 1 & $\mathrm{x}$ & $\mathrm{x}$ & $\mathrm{x}$ & 1 \\
\hline $\mathrm{CH} 25-1$ & 102 & 2 & & 0 & 1 & 2 & 0 & 2 & 2 & 8.2 & 6.7 & 0 & $x$ & $x$ & 5YR $6 / 2$, & L, 2,5/1 & $x$ & $x$ & $x$ & $x$ & $x$ & $x$ & $x$ & $x$ & $x$ & $x$ & $x$ & $x$ & $x$ & $x$ & 1 y 3 \\
\hline $\mathrm{CH} 25-1$ & 102 & 2 & & 0 & 1 & 2 & 0 & 2 & 2 & 7.1 & 6 & 0 & $x$ & $x$ & $5 Y R$ 6/2, 6/3, 5/1, 4/1 & 5YR 5/1, 4/1, 2,5/1 & $x$ & $x$ & $x$ & $x$ & $\mathrm{x}$ & $x$ & $x$ & $x$ & $\mathrm{x}$ & $x$ & $x$ & $x$ & $x$ & $x$ & 3 \\
\hline $\mathrm{CH} 25-1$ & 102 & 2 & & 0 & 1 & 2 & 0 & 2 & 2 & 6.5 & 5 & 0 & $x$ & $x$ & 5YR 6/ & $5 Y F$ & $x$ & $x$ & $x$ & 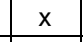 & $x$ & $x$ & $x$ & $x$ & $x$ & $x$ & $x$ & $x$ & $x$ & $x$ & 3 \\
\hline $\mathrm{CH} 25-1$ & 103 & 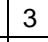 & & 1 & 0 & 1 & $\mathrm{C}$ & 2 & 2 & 6.5 & 5.2 & 0 & $x$ & $\mathrm{x}$ & $5 Y R 5$ & $\mathrm{~N} 3$ / (gris muy osc) & 20 & 4.4 & 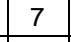 & 2 & 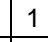 & $x$ & $x$ & $x$ & $x$ & . & 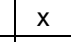 & $x$ & $x$ & $x$ & \\
\hline $\mathrm{CH} 25-1$ & sup & 4 & & 1 & 1 & 2 & 1 & 2 & 2 & 7.3 & 4.2 & 0 & $\mathrm{x}$ & $x$ & $5 / 1$ & 5YR $6 / 4,5$ & 21 & 17.6 & 26.7 & 2 & 2 & $x$ & $x$ & $x$ & $\mathrm{x}$ & $x$ & $x$ & $x$ & $x$ & $x$ & 1 у 2 \\
\hline $\mathrm{CH} 25-1$ & sup & 4 & & 0 & 1 & 2 & 1 & 2 & 2 & 6.2 & 3.5 & 0 & $x$ & $x$ & $5 Y R \quad 6 / 3,5 / 3,2,5 / 1$ & $5 Y R$ 6/4, 5/4, 6/2, 5/1 & $x$ & $x$ & $x$ & v & $x$ & $x$ & $x$ & $x$ & $x$ & $x$ & $x$ & $x$ & $x$ & $x$ & 1 у 2 \\
\hline $\mathrm{CH} 25-1$ & 102 & & 1 & 0 & 0 & 0 & 0 & 5 & 2 & 6 & - & 1 & $\mathrm{x}$ & $\mathrm{x}$ & $5 Y R \quad 6 / 3,10 R$ 5/8 (eng) & $5 Y R$ 5/3 & $\mathrm{x}$ & $\mathrm{x}$ & $\hat{n}$ & $\mathrm{x}$ & $\hat{n}$ & $\mathrm{x}$ & 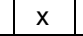 & $x$ & $\hat{A}$ & A & $\mathrm{x}$ & $\mathrm{x}$ & $\mathrm{x}$ & $\mathrm{x}$ & 5 \\
\hline $\mathrm{CH} 25-1$ & 102 & & 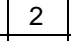 & 0 & 0 & 0 & 0 & $4 \times 3$ & 2 & 3.6 & 3.5 & 1 & $x$ & $x$ & R 4/2, 4/3 (eng) & 13 & $x$ & $x$ & $x$ & . & $x$ & $x$ & - & $x$ & $\lambda$ & $x$ & $x$ & $x$ & $x$ & $x$ & \\
\hline $\mathrm{CH} 25-1$ & 102 & & 3 & 0 & 0 & 0 & 0 & 2 & 0 & 4 & 3.6 & 0 & $x$ & $x$ & 2,5 YR $6 / 4$ & $4 / 1$ & 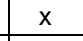 & $x$ & $\mathrm{x}$ & 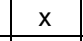 & $x$ & $x$ & $x$ & $x$ & $\mathrm{x}$ & $x$ & $x$ & $x$ & $x$ & $x$ & 4 \\
\hline $\mathrm{CH} 25-1$ & 102 & & 4 & 0 & 0 & 0 & 0 & 2 & 2 & 3.3 & 3 & 0 & $x$ & $x$ & 5 YR $6 / 3$ & $5 Y R$ 6/4 & $x$ & $x$ & $x$ & . & $x$ & $x$ & $x$ & $x$ & $x$ & $x$ & $x$ & $x$ & $x$ & $x$ & 4 \\
\hline $\mathrm{CH} 25-1$ & 103 & & 5 & 0 & 0 & 0 & 0 & 2 & 2 & 6.5 & 5.7 & 0 & $\mathrm{x}$ & $x$ & YR $5 / 3,3 / 1$ & $5 / 3$ & $x$ & $\mathrm{x}$ & $x$ & $x$ & $x$ & $x$ & $x$ & $x$ & $\mathrm{x}$ & $x$ & $x$ & $x$ & $x$ & $x$ & 3 \\
\hline $\mathrm{CH} 25-1$ & sup & & 6 & 2 & 0 & 0 & 0 & 2 & 2 & 14.3 & 9.7 & 0 & $x$ & $x$ & $2,5 Y R$ 4/4, 4/6, 5YR 6/2 & YR $6 / 2,5 / 2$ & $x$ & $x$ & $x$ & $x$ & $x$ & $x$ & $x$ & $x$ & $\mathrm{x}$ & $x$ & $x$ & 11 & 5 & 3 & 3 \\
\hline $\mathrm{CH} 25-1$ & sup & & 7 & 2 & 0 & 0 & 1 & 2 & 2 & 18 & 13 & 0 & $x$ & $x$ & $5 Y R 5 / 3,5 / 4$ & $5 Y R 5 / 4$ & $x$ & $x$ & $x$ & $x$ & $x$ & $x$ & $x$ & $x$ & $x$ & $x$ & $x$ & 18 & 5 & 1 & 3 y 4 \\
\hline $\mathrm{CH} 25-1$ & sup & & 8 & 0 & 0 & 0 & 0 & $4 \times 3$ & 4 & 6.4 & 5.7 & 1 & $\mathrm{x}$ & $\mathrm{x}$ & 10R 5/4, 4/6 (eng) & eng) & $x$ & $\mathrm{x}$ & $\mathrm{x}$ & $\mathrm{x}$ & $\mathrm{x}$ & $\mathrm{x}$ & $\mathrm{x}$ & $\mathrm{x}$ & $\mathrm{x}$ & $\mathrm{x}$ & $\mathrm{x}$ & $\mathrm{x}$ & $x$ & $\mathrm{x}$ & 2 \\
\hline $\mathrm{CH} 25-1$ & sup & & 9 & 0 & 0 & 0 & 0 & $4 \times 3$ & 4 & 5.2 & 4.7 & 1 & $x$ & $x$ & 10R 4/4 (eng) & 5 YR 4/8, 6/6 & - & $\mathrm{x}$ & $x$ & 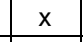 & $x$ & 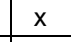 & $x$ & $\mathrm{x}$ & $\hat{n}$ & $x$ & $x$ & 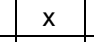 & $\mathrm{x}$ & $\mathrm{x}$ & 4 y 6 \\
\hline $\mathrm{CH} 25-1$ & sup & & 1 & 0 & 0 & 0 & 0 & $4 y^{2}$ & 4 & 5.6 & 5 & 1 & $x$ & $x$ & 10R 4/4 (eng) & $5 Y R$ 6/8, 6/4 & $\hat{\lambda}$ & $x$ & $x$ & . & $x$ & $x$ & $x$ & $x$ & $\lambda$ & $x$ & $x$ & $x$ & $x$ & $x$ & 4 y 6 \\
\hline $\mathrm{CH} 25-1$ & sup & & 1 & 0 & 0 & 0 & 0 & 4 & 4 & 6.2 & 5.5 & 1 & $\mathrm{x}$ & $x$ & 10R 5/6 (eng) & $10 \mathrm{R} 6 / 6$ & $x$ & $x$ & $x$ & X & $x$ & $x$ & $x$ & $x$ & $x$ & $x$ & $x$ & $x$ & $x$ & $x$ & 4 \\
\hline H 25-1 & sup & & 12 & 0 & 0 & 0 & 0 & $5 ?$ & 2 & 6.7 & 6 & 1 & $x$ & $x$ & R 4/6 & $26 / 3$ & $\mathrm{x}$ & $x$ & 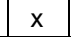 & $\mathrm{x}$ & 入 & $x$ & 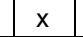 & $x$ & $X$ & $\mathrm{x}$ & x & $x$ & $\mathrm{x}$ & $\mathrm{x}$ & \\
\hline
\end{tabular}




\begin{tabular}{|c|c|c|c|c|c|c|c|c|c|c|c|c|c|c|c|c|c|c|c|c|c|c|c|c|c|c|c|c|c|c|c|}
\hline \multirow[b]{2}{*}{ Sitio } & \multirow[b]{2}{*}{ UP } & \multirow[b]{2}{*}{ GF } & \multirow[b]{2}{*}{ FNA } & \multirow[b]{2}{*}{ Fgto } & \multicolumn{10}{|c|}{ Manufactura } & \multicolumn{2}{|c|}{ Cocción } & \multicolumn{5}{|c|}{ Borde-labio } & \multicolumn{6}{|c|}{ Asa } & \multicolumn{3}{|c|}{ Base } & \multirow[b]{2}{*}{ Alterac } \\
\hline & & & & & $\begin{array}{l}\text { Tec } \\
\text { lev }\end{array}$ & $\begin{array}{l}\text { For } \\
\text { ma }\end{array}$ & $\begin{array}{l}\text { Mar } \\
\text { cas }\end{array}$ & $\begin{array}{l}\text { Sup } \\
\text { ext }\end{array}$ & \begin{tabular}{|c} 
Sup \\
int
\end{tabular} & $\begin{array}{l}\begin{array}{l}\text { Esp } \\
\max \end{array} \\
\end{array}$ & \begin{tabular}{|l} 
Esp \\
min \\
\end{tabular} & $\begin{array}{c}\text { Deco } \\
\text { pint }\end{array}$ & \begin{tabular}{|c|} 
Moti \\
vo \\
\end{tabular} & \begin{tabular}{|c|} 
Esti \\
lo \\
\end{tabular} & Color sup ext & Color sup int & Diam. & $\begin{array}{l}\text { Lrg } \\
\operatorname{arc}\end{array}$ & \begin{tabular}{|c|}
$\%$ \\
arco \\
\end{tabular} & $\mathrm{c}$ & $=\begin{array}{l}\text { For } \\
\text { ma }\end{array}$ & $\begin{array}{c}\text { Lar } \\
\text { go }\end{array}$ & $\begin{array}{l}\begin{array}{c}\text { An } \\
\text { cho }\end{array} \\
\end{array}$ & Esp & Secc & \begin{tabular}{|l} 
In \\
serc \\
\end{tabular} & $\begin{array}{l}\begin{array}{l}\text { Posi } \\
\text { ción }\end{array} \\
\end{array}$ & Diám & \begin{tabular}{|c|}
$\begin{array}{c}\text { Mor } \\
\text { fol }\end{array}$ \\
\end{tabular} & $\begin{array}{l}\text { Uni } \\
\text { ón }\end{array}$ & \\
\hline $\mathrm{CH} 25-1$ & sup & & 13 & 0 & 0 & 0 & 0 & $5 ?$ & 2 & 6.9 & 6 & 1 & $x$ & $x$ & 5YR 5/4, 10R 5/8 (pint) & 5YR 6/2 & $x$ & $x$ & $x$ & $x$ & $x$ & $x$ & $x$ & $x$ & $x$ & $x$ & $x$ & $x$ & $x$ & $x$ & 3 \\
\hline $\mathrm{CH} 25-1$ & sup & & 14 & 1 & 1 & 1 & 1 & 2 & 2 & 12.3 & 7 & 0 & $\mathrm{x}$ & $x$ & $5 Y R 4 / 6,5 / 6$ & $5 Y R 4 / 4,5 / 4$ & indet & $2.4 \mathrm{i}$ & indet & $\begin{array}{l}t \\
\end{array}$ & 5 & $x$ & $x$ & $x$ & $x$ & $x$ & $x$ & $x$ & $x$ & $x$ & 4 \\
\hline $\mathrm{CH} 25-1$ & sup & & 15 & 0 & 1 & 0 & 1 & 2 & 2 & 6.9 & 5.9 & 0 & $x$ & $x$ & 5 YR $5 / 6,5 / 3,5 / 1$ & 2,5 YR $5 / 2$ & $x$ & $x$ & $x$ & $x$ & $x$ & $x$ & $x$ & $x$ & $x$ & $x$ & $x$ & $x$ & $x$ & $x$ & 6 \\
\hline $\mathrm{CH} 25-1$ & sup & & 16 & 0 & 0 & 0 & 0 & 2 & 2 & 7.5 & 5.4 & 0 & $x$ & $x$ & 2,5 YR $5 / 6,6 / 4$ & $2,5 Y R$ 5/4, 5/6 & $x$ & $x$ & $x$ & $x$ & $x$ & $x$ & $x$ & $x$ & $x$ & $x$ & $x$ & $\mathrm{x}$ & $x$ & $x$ & 3 \\
\hline $\mathrm{CH} 25-1$ & sup & & 17 & 0 & 0 & 0 & 0 & 2 & 2 & 6 & 5.2 & 0 & $x$ & $x$ & N4/ (dark gray) & $5 Y R$ 6/3, 5/1 & $x$ & $x$ & $x$ & $x$ & $\mathrm{x}$ & $x$ & $x$ & $x$ & $x$ & $x$ & $x$ & $x$ & $x$ & $x$ & \\
\hline $\mathrm{CH} 25-1$ & sup & & 18 & 0 & 0 & 0 & 0 & 2 & 2 & 6 & 5.4 & 0 & $x$ & $x$ & N4/ (dark gray) & N4/ (dark gray) & $x$ & $x$ & $x$ & $x$ & $x$ & $x$ & $x$ & $x$ & $x$ & $x$ & $x$ & $x$ & $x$ & $x$ & 3 \\
\hline $\mathrm{CH} 25-1$ & sup & & 19 & 0 & 0 & 0 & 0 & 2 & 2 & 5.2 & 4.8 & 0 & $x$ & $x$ & 5YR 6/4 & 5YR 5/4 & $x$ & $\mathrm{x}$ & $\mathrm{x}$ & $x$ & $x$ & $x$ & $x$ & $x$ & $x$ & $x$ & $x$ & $x$ & $x$ & $x$ & 3 \\
\hline $\mathrm{CH} 25-1$ & 102 & & 20 & 0 & 0 & 0 & 1 & 2 & 2 & 6.2 & 4.6 & 0 & $x$ & $x$ & marron rojizo & gris & $x$ & $x$ & $x$ & $x$ & $x$ & $x$ & $x$ & $x$ & $x$ & $x$ & $x$ & $x$ & $x$ & $x$ & 3 \\
\hline
\end{tabular}

\begin{tabular}{|c|c|c|c|c|c|c|c|c|c|c|c|c|c|c|c|c|c|c|c|c|c|c|c|c|c|c|c|c|c|c|c|}
\hline \multirow[b]{2}{*}{ Sitio } & \multirow[b]{2}{*}{ UP } & \multirow[b]{2}{*}{ GF } & \multirow[b]{2}{*}{ FNA } & \multirow[b]{2}{*}{ Fgto } & \multicolumn{10}{|c|}{ Manufactura } & \multicolumn{2}{|c|}{ Cocción } & \multicolumn{5}{|c|}{ Borde-labio } & \multicolumn{6}{|c|}{ Asa } & \multicolumn{3}{|c|}{ Base } & \multirow[b]{2}{*}{ Alterac } \\
\hline & & & & & $\begin{array}{l}\text { Tec } \\
\text { lev }\end{array}$ & $\begin{array}{l}\text { For } \\
\text { ma }\end{array}$ & $\begin{array}{l}\text { Mar } \\
\text { cas }\end{array}$ & \begin{tabular}{|c|} 
Sup \\
ext
\end{tabular} & \begin{tabular}{|c|} 
Sup \\
int
\end{tabular} & \begin{tabular}{|l|} 
Esp \\
max
\end{tabular} & \begin{tabular}{|l|} 
Esp \\
min \\
\end{tabular} & $\begin{array}{c}\text { Deco } \\
\text { pint }\end{array}$ & \begin{tabular}{|c|} 
Moti \\
vo \\
\end{tabular} & \begin{tabular}{|c|}
$\begin{array}{c}\text { Esti } \\
\text { lo }\end{array}$ \\
\end{tabular} & Color sup ext & Color sup int & Diam & $\begin{array}{l}\text { Lrg } \\
\text { arc }\end{array}$ & $\begin{array}{c}\% \\
\text { arco }\end{array}$ & Direc & $\begin{array}{l}\text { For } \\
\text { ma }\end{array}$ & \begin{tabular}{|l|l|} 
Lar & \\
go & c \\
\end{tabular} & $\begin{array}{c}\text { An } \\
\text { cho }\end{array}$ & Esp & Sec & $\begin{array}{l}\text { In } \\
\text { serc }\end{array}$ & $\begin{array}{l}\text { Posi } \\
\text { ción }\end{array}$ & Diám & $\begin{array}{c}\text { Mor } \\
\text { fol } \\
\end{array}$ & $\begin{array}{l}\text { Uni } \\
\text { ón }\end{array}$ & \\
\hline $\mathrm{CH} 25-2$ & 102 & 1 & & 2 & 0 & 0 & 10 & 2 & 2 y 1 & 7 & 5.2 & 0 & $\mathrm{x}$ & $\mathrm{x}$ & $5 Y R 5 / 3,5 / 4,4 / 1,2.5 Y R$ 5/6 & $5 Y R \quad 4 / 1,5 / 2,5 / 3$ & $\mathrm{x}$ & $\mathrm{x}$ & $\mathrm{x}$ & $\mathrm{x}$ & $\mathrm{x}$ & $\mathrm{x}$ & $\mathrm{x}$ & $\mathrm{x}$ & $\mathrm{x}$ & $\mathrm{x}$ & $\mathrm{x}$ & 4.1 & 5 & 2 & 1 y 3 \\
\hline CH 25-2 & 102 & 1 & & 2 & 0 & 0 & 10 & 2 & 3 y 1 & 7.8 & 4.4 & 0 & $\mathrm{x}$ & $\mathrm{x}$ & $5 Y R 5 / 3,5 / 4,4 / 1,2.5 Y R$ 5/6 & $5 Y R \quad 4 / 1,5 / 2,5 / 3$ & $\mathrm{x}$ & $\mathrm{x}$ & $\mathrm{x}$ & $\mathrm{x}$ & $\mathrm{x}$ & $\mathrm{x}$ & $\mathrm{x}$ & $\mathrm{x}$ & $\mathrm{x}$ & $\mathrm{x}$ & $\mathrm{x}$ & 4.1 & 5 & 2 & 1 у 3 \\
\hline $\mathrm{CH} 25-2$ & 102 & 1 & & 0 & 0 & 0 & 0 & 2 & 4 y 1 & 6.4 & 3.6 & 0 & $x$ & $x$ & $5 Y R$ 5/3, 5/4, 4/1, 2,5YR 5/6 & $5 Y R \quad 4 / 1,5 / 2,5 / 3$ & $x$ & $x$ & $\mathrm{x}$ & $x$ & $x$ & $x$ & $x$ & $x$ & $x$ & $x$ & $x$ & $x$ & $x$ & $x$ & 1 y 3 \\
\hline $\mathrm{CH} 25-2$ & 102 & 1 & & 0 & 0 & 0 & 0 & 2 & 5 y 1 & 6.3 & 4.8 & 0 & $x$ & $x$ & $5 Y R$ 5/3, 5/4, 4/1, 2,5YR 5/6 & $5 Y R$ 4/1, 5/2, 5/3 & $x$ & $x$ & $x$ & $x$ & $x$ & $x$ & $x$ & $x$ & $x$ & $x$ & $x$ & $x$ & $x$ & $x$ & 3 \\
\hline $\mathrm{CH} 25-2$ & 102 & 1 & & 0 & 0 & 0 & 0 & 2 & 6 y 1 & 6.6 & 6.4 & 0 & $\mathrm{x}$ & $\mathrm{x}$ & $5 Y R$ 5/3, 5/4, 4/1, 2,5YR 5/6 & $5 Y R \quad 4 / 1,5 / 2,5 / 3$ & $\mathrm{x}$ & $\mathrm{x}$ & $\mathrm{x}$ & $\mathrm{x}$ & $\mathrm{x}$ & $x$ & $\mathrm{x}$ & $\mathrm{x}$ & $\mathrm{x}$ & $\mathrm{x}$ & $\mathrm{x}$ & $\mathrm{x}$ & $\mathrm{x}$ & $\mathrm{x}$ & 3 \\
\hline $\mathrm{CH} 25-2$ & 102 & 1 & & 0 & 0 & 0 & 0 & 2 & 7 y 1 & 3.7 & 2.8 & 0 & $x$ & $x$ & $5 Y R$ 5/3, 5/4, 4/1, 2,5YR 5/6 & $5 Y R \quad 4 / 1,5 / 2,5 / 3$ & $x$ & $x$ & $x$ & $x$ & $x$ & $x$ & $x$ & $x$ & $x$ & $x$ & $x$ & $x$ & $x$ & $x$ & 3 \\
\hline $\mathrm{CH} 25-2$ & 101 & 2 & & 0 & 1 & 0 & 0 & 2 y 3 & 2 & 7.2 & 6.8 & 0 & $\mathrm{x}$ & $\mathrm{x}$ & $5 Y R$ 4/1, 4/2, 5/4 & $5 Y R$ 4/2,6/4, 7,5YR 6/3 & $\mathrm{x}$ & $\mathrm{x}$ & $\mathrm{x}$ & $x$ & $x$ & $\mathrm{x}$ & $\mathrm{x}$ & $x$ & $x$ & $x$ & $\mathrm{x}$ & $\mathrm{x}$ & $\mathrm{x}$ & $x$ & \\
\hline $\mathrm{CH} 25-2$ & 101 & 2 & & 0 & 1 & 0 & 0 & 2 y 3 & 2 & 8.2 & 7.8 & 0 & $x$ & $x$ & $5 Y R$ 4/1, 4/2, 5/4 & $5 Y R$ 4/2,6/4, 7,5YR 6/3 & $x$ & $x$ & $x$ & $x$ & $x$ & $x$ & $x$ & $x$ & $x$ & $x$ & $x$ & $x$ & $x$ & $x$ & \\
\hline $\mathrm{CH} 25-2$ & 102 & 2 & & 0 & 1 & 0 & 0 & 2 y 3 & 2 & 8 & 6.9 & 0 & $\mathrm{x}$ & $\mathrm{x}$ & $5 Y R \quad 4 / 1,4 / 2,5 / 4$ & $5 Y R \quad 4 / 2,6 / 4,7,5 Y R 6 / 3$ & $\mathrm{x}$ & $\mathrm{x}$ & $\mathrm{x}$ & $\mathrm{x}$ & $\mathrm{x}$ & $\mathrm{x}$ & $\mathrm{x}$ & $\mathrm{x}$ & $\mathrm{x}$ & $\mathrm{x}$ & $\mathrm{x}$ & $\mathrm{x}$ & $\mathrm{x}$ & $\mathrm{x}$ & \\
\hline $\mathrm{CH} 25-2$ & 102 & 2 & & 0 & 1 & 0 & 0 & 2 y 3 & 2 & 7 & 6.5 & 0 & $\mathrm{x}$ & $\mathrm{x}$ & $5 Y R$ 4/1, 4/2, 5/4 & $5 Y R$ 4/2,6/4, 7,5YR 6/3 & $\mathrm{x}$ & $\mathrm{x}$ & $\mathrm{x}$ & $\mathrm{x}$ & $\mathrm{x}$ & $\mathrm{x}$ & $\mathrm{x}$ & $\mathrm{x}$ & $\mathrm{x}$ & $\mathrm{x}$ & $\mathrm{x}$ & $\mathrm{x}$ & $\mathrm{x}$ & $\mathrm{x}$ & \\
\hline $\mathrm{CH} 25-2$ & 101 & 2 & & 0 & 1 & 0 & 0 & 2 y 3 & 2 & 7 & 6.1 & 0 & $\mathrm{x}$ & $\mathrm{x}$ & $5 Y R \quad 4 / 1,4 / 2,5 / 4$ & $5 Y R \quad 4 / 2,6 / 4,7,5 Y R$ 6/3 & $\mathrm{x}$ & $\mathrm{x}$ & $\mathrm{x}$ & $\mathrm{x}$ & $\mathrm{x}$ & $x$ & $\mathrm{x}$ & $\mathrm{x}$ & $x$ & $\mathrm{x}$ & $\mathrm{x}$ & $\mathrm{x}$ & $\mathrm{x}$ & $x$ & \\
\hline $\mathrm{CH} 25-2$ & 101 & 2 & & 0 & 1 & 0 & 0 & 2 y 3 & 2 & 8.5 & 6.9 & 0 & $x$ & $x$ & $5 Y R \quad 4 / 1,4 / 2,5 / 4$ & $5 Y R$ 4/2,6/4, 7,5YR 6/3 & $x$ & $x$ & $x$ & $x$ & $x$ & $x$ & $x$ & $x$ & $x$ & $x$ & $x$ & $x$ & $x$ & $x$ & 2 \\
\hline $\mathrm{CH} 25-2$ & 102 & 3 & & 3 & 1 & 2 & 0 & 2 & 2 & 7.1 & 5.9 & 0 & $x$ & $x$ & $5 Y R 3 / 1,4 / 1,4 / 2,5 / 3,5 / 2$ & $5 Y R \quad 4 / 1,5 / 1,5 / 2$ & $x$ & $x$ & $x$ & $x$ & $x$ & $1.3 \mathrm{f}$ & 1.4 & 1.3 & 2 & 1 & 3 & $x$ & $x$ & $x$ & 1 \\
\hline $\mathrm{CH} 25-2$ & 102 & 3 & & 4 & 1 & 2 & 0 & 2 & 2 & 5.7 & 4.9 & 0 & $x$ & $x$ & $5 Y R 3 / 1,4 / 1,4 / 2,5 / 3,5 / 2$ & $5 Y R 4 / 1,5 / 1,5 / 2$ & $x$ & $x$ & $x$ & $x$ & $x$ & $x$ & $x$ & $x$ & $x$ & $x$ & $x$ & $x$ & $x$ & $x$ & 3 \\
\hline $\mathrm{CH} 25-2$ & 102 & 3 & & 4 & 1 & 2 & 0 & 2 & 2 & 6.2 & 5 & 0 & $x$ & $x$ & $5 Y R 3 / 1,4 / 1,4 / 2,5 / 3,5 / 2$ & $5 Y R 4 / 1,5 / 1,5 / 2$ & $x$ & $x$ & $\mathrm{x}$ & $x$ & $x$ & $x$ & $x$ & $x$ & $x$ & $x$ & $x$ & $x$ & $x$ & $x$ & 3 \\
\hline $\mathrm{CH} 25-2$ & 102 & 3 & & 0 & 1 & 2 & 0 & 2 & 2 & 6.3 & 4.7 & 0 & $x$ & $x$ & $5 Y R 3 / 1,4 / 1,4 / 2,5 / 3,5 / 2$ & $5 Y R 4 / 1,5 / 1,5 / 2$ & $x$ & $x$ & $\mathrm{x}$ & $x$ & $x$ & $x$ & $x$ & $x$ & $x$ & $x$ & $x$ & $x$ & $\mathrm{x}$ & $x$ & 3 \\
\hline $\mathrm{CH} 25-2$ & 102 & 3 & & 0 & 1 & 2 & 0 & 2 & 2 & 6.9 & 6.2 & 0 & $\mathrm{x}$ & $\mathrm{x}$ & $5 Y R 3 / 1,4 / 1,4 / 2,5 / 3,5 / 2$ & $5 Y R \quad 4 / 1,5 / 1,5 / 2$ & $\mathrm{x}$ & $\mathrm{x}$ & $\mathrm{x}$ & $\mathrm{x}$ & $\mathrm{x}$ & $\mathrm{x}$ & $\mathrm{x}$ & $\mathrm{x}$ & $\mathrm{x}$ & $\mathrm{x}$ & $\mathrm{x}$ & $\mathrm{x}$ & $\mathrm{x}$ & $\mathrm{x}$ & 1 \\
\hline $\mathrm{CH} 25-2$ & 102 & 3 & & 0 & 1 & 2 & 0 & 2 & 2 & 5.9 & 5 & 0 & $x$ & $x$ & $5 Y R 3 / 1,4 / 1,4 / 2,5 / 3,5 / 2$ & $5 Y R \quad 4 / 1,5 / 1,5 / 2$ & $x$ & $x$ & $x$ & $x$ & $x$ & $x$ & $x$ & $x$ & $x$ & $x$ & $x$ & $x$ & $x$ & $x$ & 3 y 4 \\
\hline $\mathrm{CH} 25-2$ & 102 & 3 & & 0 & 1 & 2 & 0 & 2 & 2 & 5.6 & 4.5 & 0 & $x$ & $x$ & $5 Y R 3 / 1,4 / 1,4 / 2,5 / 3,5 / 2$ & $5 Y R 4 / 1,5 / 1,5 / 2$ & $x$ & $x$ & $x$ & $x$ & $x$ & $x$ & $x$ & $x$ & $\mathrm{x}$ & $\mathrm{x}$ & $x$ & $x$ & $x$ & $x$ & 1 \\
\hline $\mathrm{CH} 25-2$ & 102 & 3 & & 0 & 1 & 2 & 0 & 2 & 2 & 6 & 5.7 & 0 & $x$ & $x$ & $5 Y R 3 / 1,4 / 1,4 / 2,5 / 3,5 / 2$ & $5 Y R \quad 4 / 1,5 / 1,5 / 2$ & $x$ & $x$ & $x$ & $x$ & $x$ & $x$ & $x$ & $x$ & $x$ & $x$ & $x$ & $x$ & $x$ & $x$ & 3 \\
\hline $\mathrm{CH} 25-2$ & 102 & 3 & & 0 & 1 & 2 & 0 & 2 & 2 & 6.2 & 4.8 & 0 & $x$ & $x$ & $5 Y R 3 / 1,4 / 1,4 / 2,5 / 3,5 / 2$ & $5 Y R 4 / 1,5 / 1,5 / 2$ & $x$ & $x$ & $x$ & $x$ & $x$ & $x$ & $x$ & $x$ & $x$ & $x$ & $x$ & $x$ & $x$ & $x$ & 3 \\
\hline $\mathrm{CH} 25-2$ & 102 & 4 & & 2 & 0 & 0 & 1 & 2 & 2 & 13 & 7.3 & 0 & $x$ & $\mathrm{x}$ & 2,5YR 5/4, 5/6, 5YR 5/4, 5/2 & $5 Y R 5 / 3,5 / 2,4 / 2,3 / 1$ & $\mathrm{x}$ & $\mathrm{x}$ & $\mathrm{x}$ & $\mathrm{x}$ & $\mathrm{x}$ & $\mathrm{x}$ & $x$ & $\mathrm{x}$ & $\mathrm{x}$ & $\mathrm{x}$ & $\mathrm{x}$ & 7 & 5 & 2 & 3 у 4 \\
\hline $\mathrm{CH} 25-2$ & 102 & 4 & & 0 & 0 & 0 & 1 & 2 & 2 & 9.6 & 7.2 & 0 & $x$ & $x$ & 2,5YR 5/4, 5/6, 5YR 5/4, 5/2 & $5 Y R$ 5/3, 5/2, 4/2, 3/1 & $x$ & $x$ & $x$ & $x$ & $x$ & $x$ & $x$ & $x$ & $x$ & $x$ & $x$ & $x$ & $x$ & $x$ & 2 \\
\hline $\mathrm{CH} 25-2$ & 102 & 4 & & 0 & 0 & 0 & 0 & 2 & 2 & 8.9 & 5.5 & 0 & $\mathrm{x}$ & $\mathrm{x}$ & 2,5YR 5/4, 5/6, 5YR 5/4, 5/2 & $5 Y R 5 / 3,5 / 2,4 / 2,3 / 1$ & $\mathrm{x}$ & $\mathrm{x}$ & $\mathrm{x}$ & $\mathrm{x}$ & $\mathrm{x}$ & $\mathrm{x}$ & $\mathrm{x}$ & $\mathrm{x}$ & $\mathrm{x}$ & $\mathrm{x}$ & $\mathrm{x}$ & $\mathrm{x}$ & $\mathrm{x}$ & $\mathrm{x}$ & \\
\hline
\end{tabular}




\begin{tabular}{|c|c|c|c|c|c|c|c|c|c|c|c|c|c|c|c|c|c|c|c|c|c|c|c|c|c|c|c|c|c|c|c|}
\hline \multirow[b]{2}{*}{ Sitio } & \multirow[b]{2}{*}{ UP } & \multirow[b]{2}{*}{ GF } & \multirow[b]{2}{*}{ FNA } & \multirow[b]{2}{*}{ Fgto } & \multicolumn{10}{|c|}{ Manufactura } & \multicolumn{2}{|c|}{ Cocción } & \multicolumn{5}{|c|}{ Borde-labio } & \multicolumn{6}{|c|}{ Asa } & \multicolumn{3}{|c|}{ Base } & \multirow[b]{2}{*}{ Alterac } \\
\hline & & & & & $\begin{array}{l}\text { Tec } \\
\text { lev }\end{array}$ & $\begin{array}{l}\text { For } \\
\text { ma }\end{array}$ & $\begin{array}{l}\text { Mar } \\
\text { cas }\end{array}$ & $\begin{array}{l}\text { Sup } \\
\text { ext }\end{array}$ & $\begin{array}{c}\text { Sup } \\
\text { int }\end{array}$ & $\begin{array}{l}\text { Esp } \\
\text { max }\end{array}$ & $\begin{array}{l}\text { Esp } \\
\text { min }\end{array}$ & $\begin{array}{c}\text { Deco } \\
\text { pint }\end{array}$ & $\begin{array}{c}\text { Moti } \\
\text { vo }\end{array}$ & \begin{tabular}{|c|c} 
Esti \\
lo
\end{tabular} & Colo & p int & Diam & $\begin{array}{l}\text { Lrg } \\
\text { arc } \\
\end{array}$ & $\begin{array}{c}\% \\
\text { arco }\end{array}$ & Direc & $\begin{array}{l}\begin{array}{l}\text { For } \\
\text { ma }\end{array} \\
\end{array}$ & $\begin{array}{l}\text { Lar } \\
\text { go }\end{array}$ & $\begin{array}{l}\text { An } \\
\text { cho }\end{array}$ & & & $c \mid \begin{array}{l}\text { In } \\
\text { serc }\end{array}$ & $\begin{array}{l}\begin{array}{l}\text { Posi } \\
\text { ción }\end{array} \\
\end{array}$ & $\begin{array}{ll}\mathrm{si} & \text { Diám } \\
\end{array}$ & n $\begin{array}{c}\text { Mor } \\
\text { fol }\end{array}$ & $\begin{array}{l}\text { Uni } \\
\text { ón }\end{array}$ & \\
\hline $\mathrm{CH} 25-2$ & 102 & 4 & & 0 & 0 & 0 & 0 & 2 & 2 & 9.7 & 9.2 & 0 & $x$ & $x$ & 2,5YR 5/4, 5/6, 5YR 5/4, 5/2 & $5 Y R$ 5/3, 5/2, 4/2, 3/1 & $x$ & $x$ & $x$ & $x$ & $x$ & $x$ & $x$ & $x$ & $x$ & $x$ & $x$ & $x$ & $x$ & $x$ & \\
\hline $\mathrm{CH} 25-2$ & 102 & 4 & & 0 & 0 & 0 & 0 & 2 & 2 & 9.5 & 8.7 & 0 & $x$ & $x$ & 2,5YR 5/4, 5/6, 5YR 5/4, 5/2 & $5 Y R$ 5/3, 5/2, 4/2, 3/1 & $x$ & $x$ & $x$ & $x$ & $x$ & $x$ & $x$ & $\mathrm{x}$ & $x$ & $x$ & $x$ & $x$ & $x$ & $x$ & 3 \\
\hline $\mathrm{CH} 25-2$ & 102 & 4 & & 0 & 0 & 0 & 0 & 2 & 2 & 5.4 & 4.6 & 0 & $x$ & $x$ & 2,5YR 5/4, 5/6, 5YR 5/4, 5/2 & $5 Y R$ 5/3, 5/2, 4/2, 3/1 & $x$ & $x$ & $x$ & $\mathrm{x}$ & $x$ & $x$ & $x$ & $x$ & $x$ & $x$ & $x$ & $x$ & $x$ & $x$ & 3 \\
\hline $\mathrm{CH} 25-2$ & 102 & 4 & & 0 & 0 & 0 & 0 & 2 & 2 & 5.6 & 5.2 & 0 & $\mathrm{x}$ & $x$ & 2,5YR 5/4, 5/6, 5YR 5/4, 5/2 & $5 Y R$ 5/3, 5/2, 4/2, 3/1 & $\mathrm{x}$ & $\mathrm{x}$ & $\mathrm{x}$ & $\mathrm{x}$ & $x$ & $\mathrm{x}$ & $\mathrm{x}$ & $x$ & $x$ & $\mathrm{x}$ & $\mathrm{x}$ & $\mathrm{x}$ & $\mathrm{x}$ & $x$ & 3 \\
\hline $\mathrm{CH} 25-2$ & 102 & 4 & & 0 & 0 & 0 & 0 & 2 & 2 & 5.7 & 5.1 & 0 & $x$ & $x$ & 2,5YR 5/4, 5/6, 5YR 5/4, 5/2 & $5 Y R$ 5/3, 5/2, 4/2, 3/1 & $x$ & $\mathrm{x}$ & $\mathrm{x}$ & $\mathrm{x}$ & $x$ & $x$ & $\mathrm{x}$ & $x$ & $x$ & $\mathrm{x}$ & $\mathrm{x}$ & $\mathrm{x}$ & $x$ & $x$ & 3 y 4 \\
\hline $\mathrm{CH} 25-2$ & 102 & 4 & & 0 & 0 & 0 & 0 & 2 & 2 & 7.2 & 6.3 & 0 & $x$ & $x$ & 2,5YR 5/4, 5/6, 5YR 5/4, 5/2 & $5 Y R$ 5/3, 5/2, 4/2, 3/1 & $x$ & $x$ & $x$ & $x$ & $x$ & $x$ & $x$ & $x$ & $x$ & $x$ & $x$ & $x$ & $x$ & $x$ & 3 \\
\hline $\mathrm{CH} 25-2$ & 102 & 4 & & 0 & 0 & 0 & 0 & 2 & 2 & 5.8 & 4.9 & 0 & $x$ & $x$ & 2,5YR 5/4, 5/6, 5YR 5/4, 5/2 & $5 Y R$ 5/3, 5/2, 4/2, 3/1 & $x$ & $x$ & $x$ & $x$ & $\mathrm{x}$ & $x$ & $x$ & $\mathrm{x}$ & $x$ & $x$ & $\mathrm{x}$ & $\mathrm{x}$ & $\mathrm{x}$ & $\mathrm{x}$ & 3 y 4 \\
\hline $\mathrm{CH} 25-2$ & 102 & 4 & & 0 & 0 & 0 & 0 & 2 & 2 & 6.9 & 6.3 & 0 & $\mathrm{x}$ & $\mathrm{x}$ & 2,5YR 5/4, 5/6, 5YR 5/4, 5/2 & $5 Y R$ S/3, 5/2, 4/2, 3/1 & $\mathrm{x}$ & $\mathrm{x}$ & $\mathrm{x}$ & $\mathrm{x}$ & $\mathrm{x}$ & $\mathrm{x}$ & $\mathrm{x}$ & $\mathrm{x}$ & $\mathrm{x}$ & $\mathrm{x}$ & $\mathrm{x}$ & $\mathrm{x}$ & $\mathrm{x}$ & $\mathrm{x}$ & 3 \\
\hline $\mathrm{CH} 25-2$ & 102 & 5 & & 0 & 1 & 2 & 0 & 2 & 2 & 5.1 & 4 & 0 & $\mathrm{x}$ & $\mathrm{x}$ & 5 YR $5 / 3,5 / 4,4 / 1,2.5 Y R 5 / 6$ & $5 Y R \quad 4 / 1,5 / 2,5 / 3$ & $\mathrm{x}$ & $\mathrm{x}$ & $x$ & $\mathrm{x}$ & $x$ & $\mathrm{x}$ & $\mathrm{x}$ & $x$ & $x$ & $\mathrm{x}$ & $\mathrm{x}$ & $\mathrm{x}$ & $x$ & $\mathrm{x}$ & 3 \\
\hline $\mathrm{CH} 25-2$ & 102 & 5 & & 0 & 1 & 2 & 0 & 2 & 2 & 9.6 & 4.7 & 0 & $x$ & $x$ & $5 Y R 5 / 3,5 / 4,4 / 1,2.5 Y R$ 5/6 & $5 Y R$ 4/1, 5/2, 5/3 & $x$ & $x$ & $x$ & $x$ & $x$ & $x$ & $x$ & $x$ & $x$ & $x$ & $x$ & $x$ & $x$ & $x$ & 3 \\
\hline $\mathrm{CH} 25-2$ & 102 & 5 & & 0 & 1 & 2 & 0 & 2 & 2 & 6.5 & 3.4 & 0 & $x$ & $x$ & 5 YR 5/3, 5/4, 4/1, 2.5 YR 5/6 & $5 Y R$ 4/1, 5/2, 5/3 & $x$ & $x$ & $x$ & $x$ & $x$ & $x$ & $x$ & $x$ & $x$ & $x$ & $x$ & $x$ & $x$ & $x$ & 3 \\
\hline $\mathrm{CH} 25-2$ & 102 & 5 & & 0 & 1 & 2 & 0 & 2 & 2 & 4.8 & 3.2 & 0 & $x$ & $x$ & $5 Y R 5 / 3,5 / 4,4 / 1,2.5$ YR $5 / 6$ & $5 Y R$ 4/1, 5/2, 5/3 & $x$ & $x$ & $x$ & $x$ & $x$ & $x$ & $x$ & $x$ & $x$ & $x$ & $x$ & $x$ & $x$ & $x$ & 3 \\
\hline $\mathrm{CH} 25-2$ & 102 & 5 & & 1 & 1 & 2 & 0 & 2 & 2 & 4 & 3.1 & 0 & $x$ & $x$ & $5 Y R$ 5/3, 5/4, 4/1, 2,5YR 5/6 & $5 Y R$ 4/1, 5/2, 5/3 & $x$ & $x$ & $x$ & $x$ & $x$ & $x$ & $x$ & $x$ & $x$ & $x$ & $x$ & $x$ & $x$ & $x$ & 3 \\
\hline $\mathrm{CH} 25-2$ & 102 & & 1 & 0 & 0 & 1 & $1 \mathrm{y} 4$ & 2 & 2 & 6 & 4.5 & 0 & $x$ & $x$ & $5 Y R$ 5/2, 4/1 & $5 Y R 5 / 2$ & 20 & 3.3 & 5.3 & 2 & 2 & $x$ & $x$ & $x$ & $x$ & $x$ & $x$ & $x$ & $x$ & $x$ & 2 \\
\hline $\mathrm{CH} 25-2$ & 102 & & 2 & 2 & 0 & 0 & 0 & 2 & 2 & 10.7 & 5 & 0 & $x$ & $\mathrm{x}$ & 5YR 5/3 & 5YR 6/3 & $x$ & $\mathrm{x}$ & $x$ & $x$ & $x$ & $x$ & $x$ & $x$ & $x$ & $x$ & $x$ & 6 & 5 & 2 & 3 \\
\hline $\mathrm{CH} 25-2$ & 102 & & 3 & 0 & 0 & 0 & 1 & 2 & 2 & 8.4 & 6.1 & 0 & $x$ & $x$ & 7,5 YR $6 / 3$ & $\mathrm{~N} 3 /, 7,5$ YR $5 / 2$ & $x$ & $x$ & $x$ & $x$ & $x$ & $x$ & $x$ & $x$ & $x$ & $x$ & $x$ & $x$ & $x$ & $x$ & 2 \\
\hline \begin{tabular}{|l|}
$\mathrm{CH} 25-2$ \\
\end{tabular} & 102 & & 5 & 0 & 0 & 0 & 0 & 2 & 2 & 5.4 & 4.7 & 0 & $\mathrm{x}$ & $x$ & $\mathrm{~N} 3 /, 7,5 \mathrm{YR} 6 / 2$ & 7,5 YR $6 / 4$ & $\mathrm{x}$ & $\mathrm{x}$ & $\mathrm{x}$ & $x$ & $x$ & $\mathrm{x}$ & $\mathrm{x}$ & $\mathrm{x}$ & $x$ & $\mathrm{x}$ & $\mathrm{x}$ & $\mathrm{x}$ & $\mathrm{x}$ & $x$ & 1 y 2 \\
\hline \begin{tabular}{|l|}
$\mathrm{CH} 25-2$ \\
\end{tabular} & 102 & & 6 & 0 & 0 & 0 & 4 & 2 & 2 & 6.4 & 5.4 & 0 & $x$ & $x$ & $\mathrm{~N} 3 /, 7,5 \mathrm{YR} 6 / 2$ & 7,5 YR 4/1 & $x$ & $x$ & $x$ & $x$ & $x$ & $x$ & $x$ & $x$ & $x$ & $x$ & $x$ & $x$ & $x$ & $x$ & 2 \\
\hline $\mathrm{CH} 25-2$ & 102 & & 7 & 0 & 0 & 0 & 0 & 2 & 2 & 5.3 & 5.1 & 0 & $x$ & $x$ & $5 Y R$ 6/4 & 5YR 6/2 & $x$ & $x$ & $x$ & $x$ & $x$ & $x$ & $x$ & $x$ & $x$ & $x$ & $x$ & $x$ & $x$ & $x$ & 3 \\
\hline $\mathrm{CH} 25-2$ & 102 & & 8 & 0 & 0 & 0 & 0 & 2 & 2 y 6 & 5.4 & 3.8 & 1 & $x$ & $x$ & 5YR 6/4, 2,5YR 5/6 & $5 Y R 5 / 2$ & $x$ & $x$ & $x$ & $x$ & $x$ & $x$ & $x$ & $x$ & $x$ & $x$ & $x$ & $x$ & $x$ & $x$ & 3 \\
\hline $\mathrm{CH} 25-2$ & 102 & & 9 & 0 & 0 & 0 & 0 & 2 & 2 & 5.2 & 5 & 0 & $x$ & $\mathrm{x}$ & 2,5YR 4/4, 2,5YR 3/1 & $2,5 Y R 3 / 1$ & $x$ & $x$ & $\mathrm{x}$ & $x$ & $x$ & $x$ & $x$ & $x$ & $x$ & $x$ & $x$ & $x$ & $\mathrm{x}$ & $x$ & 3 \\
\hline $\mathrm{CH} 25-2$ & sup & & 10 & 3 & 0 & 0 & 0 & 2 & 2 & 9.4 & 6.5 & 0 & $x$ & yavi? & 2,5 YR $5 / 6$ & 2,5 YR 5/6 & $x$ & $x$ & $x$ & $x$ & $x$ & 1.8 & 22 & 11 & 4 & 1 & 0 & $x$ & $\mathrm{x}$ & $x$ & \\
\hline $\mathrm{CH} 25-2$ & sup & & 11 & 2 & 0 & 0 & 0 & 2 & 2 & 12.4 & 8.7 & 0 & $x$ & yavi? & 2,5 YR $4 / 4$ & 2,5 YR 3/1 & $x$ & $x$ & $x$ & $x$ & $x$ & $x$ & $x$ & $x$ & $x$ & $x$ & $x$ & 5.4 & 5 & 3 & \\
\hline $\mathrm{CH} 25-2$ & sup & & 12 & 0 & 0 & 0 & 0 & 2 & 2 & 12.2 & 7.4 & 0 & $x$ & $x$ & $5 Y R$ 5/3 & N 3/, 5YR 6/2 & $x$ & $x$ & $\mathrm{x}$ & $x$ & $x$ & $x$ & $x$ & $x$ & $x$ & $x$ & $x$ & $x$ & $x$ & $x$ & 2 \\
\hline
\end{tabular}

\begin{tabular}{|c|c|c|c|c|c|c|c|c|c|c|c|c|c|c|c|c|c|c|c|c|c|c|c|c|c|c|c|c|c|c|c|}
\hline \multirow[b]{2}{*}{ Sitio } & \multirow[b]{2}{*}{ UP } & \multirow[b]{2}{*}{ GF } & \multirow[b]{2}{*}{ FNA } & & \multicolumn{10}{|c|}{ Manufactura } & \multicolumn{2}{|l|}{ Cocción } & \multicolumn{5}{|c|}{ Borde-labio } & \multicolumn{6}{|c|}{ Asa } & \multicolumn{3}{|c|}{ Base } & \multirow[b]{2}{*}{ Alterac } \\
\hline & & & & & $\begin{array}{l}\text { Tec } \\
\text { lev }\end{array}$ & $\begin{array}{l}\text { For } \\
\text { ma }\end{array}$ & $\begin{array}{l}\text { Mar } \\
\text { cas }\end{array}$ & $\begin{array}{l}\text { Sup } \\
\text { ext }\end{array}$ & $\begin{array}{c}\text { Sup } \\
\text { int }\end{array}$ & $\begin{array}{l}\text { Esp } \\
\text { max }\end{array}$ & $\begin{array}{l}\text { Esp } \\
\text { min }\end{array}$ & $\begin{array}{c}\text { Deco } \\
\text { pint }\end{array}$ & $\begin{array}{c}\text { Moti } \\
\text { vo }\end{array}$ & $\begin{array}{c}\text { Esti } \\
\text { lo }\end{array}$ & Color sup ext & Color sup int & Diam & $\mid \begin{array}{l}\text { Lrg } \\
\operatorname{arc}\end{array}$ & \begin{tabular}{|c|}
$\%$ \\
arco
\end{tabular} & Direc & $\begin{array}{c}\text { For } \\
\text { ma }\end{array}$ & $\begin{array}{l}\text { Lar } \\
\text { go }\end{array}$ & $\begin{array}{c}\text { An } \\
\text { cho }\end{array}$ & Esp & $\begin{array}{l}\text { Sec } \\
\text { ción }\end{array}$ & \begin{tabular}{|c|} 
In \\
serc
\end{tabular} & $\begin{array}{l}\text { Posi } \\
\text { ción }\end{array}$ & Diám & $\begin{array}{l}\text { Mor } \\
\text { fol }\end{array}$ & $\begin{array}{l}\text { Uni } \\
\text { ón }\end{array}$ & \\
\hline PA 6-1 & 201 & 1 & & 1 & 1 & 2 & 1 & 2 & 2 & 8.7 & 6.1 & 0 & $\mathrm{x}$ & $\mathrm{x}$ & 7,5YR 5/3, 5/4, 4/1, 5YR 5/4 & $7,5 Y R$ 5/3, 5/4, 5/2 & 19,2 & 12,1 & 20 & 1 & 2 & $x$ & $\mathrm{x}$ & $\mathrm{x}$ & $\mathrm{x}$ & $\mathrm{x}$ & $x$ & $\mathrm{x}$ & $\mathrm{x}$ & $\mathrm{x}$ & 3 \\
\hline PA 6-1 & 301 & 1 & & 1 & 1 & 2 & 1 & 2 & 2 & 7.5 & 6.3 & 0 & $x$ & $\mathrm{x}$ & 7,5YR 5/3, 5/4, 4/1, 5YR 5/4 & $7,5 Y R$ 5/3, 5/4, 5/2 & 19,2 & 12,1 & 20 & 1 & 2 & $\mathrm{x}$ & $\mathrm{x}$ & $\mathrm{x}$ & $\mathrm{x}$ & $x$ & $\mathrm{x}$ & $\mathrm{x}$ & $x$ & $\mathrm{x}$ & \\
\hline PA 6-1 & 202 & 1 & & 1 & 1 & 2 & 1 & 2 & 2 & 6.1 & 6 & 0 & $x$ & $x$ & 7,5YR 5/3, 5/4, 4/1, 5YR 5/4 & $7,5 Y R$ 5/3, 5/4, 5/2 & indet & $1,85 \mathrm{i}$ & indet & 1 & 2 & $x$ & $x$ & $x$ & $x$ & $x$ & $x$ & $x$ & $x$ & $x$ & \\
\hline PA 6-1 & 202 & 1 & & 2 & 1 & 2 & 1 & 2 & 2 & 15.5 & 9.9 & 0 & $x$ & $x$ & 7,5YR 5/3, 5/4, 4/1, 5YR 5/4 & $7,5 Y R$ 5/3, 5/4, 5/2 & $\mathrm{x}$ & $\mathrm{x}$ & $\mathrm{x}$ & $\mathrm{x}$ & $\mathrm{x}$ & $\mathrm{x}$ & $\mathrm{x}$ & $\mathrm{x}$ & $\mathrm{x}$ & $\mathrm{x}$ & $\mathrm{x}$ & 12 & 5 & 2 & 3 у 4 \\
\hline PA 6-1 & 202 & 1 & & 2 & 1 & 2 & 1 & 2 & 2 & 16.1 & 9 & 0 & $x$ & $x$ & 7,5YR 5/3, 5/4, 4/1, 5YR 5/4 & $7,5 Y R$ 5/3, 5/4, 5/2 & $x$ & $x$ & $x$ & $x$ & $x$ & $x$ & $x$ & $x$ & $x$ & $x$ & $x$ & 12 & 5 & 2 & 3 y 4 \\
\hline PA 6-1 & 112 & 1 & & 0 & 1 & 2 & 1 & 2 & 2 & 13.4 & 8.7 & 0 & $\mathrm{x}$ & $\mathrm{x}$ & 7,5YR 5/3, 5/4, 4/1, 5YR 5/4 & $7,5 Y R$ 5/3, 5/4, 5/2 & $\mathrm{x}$ & $\mathrm{x}$ & $\mathrm{x}$ & $\mathrm{x}$ & $\mathrm{x}$ & $\mathrm{x}$ & $\mathrm{x}$ & $\mathrm{x}$ & $\mathrm{x}$ & $\mathrm{x}$ & $\mathrm{x}$ & $\mathrm{x}$ & $\mathrm{x}$ & $\mathrm{x}$ & \\
\hline PA 6-1 & 202 & 1 & & 0 & 1 & 2 & 1 & 2 & 2 & 10 & 5.9 & 0 & $\mathrm{x}$ & $\mathrm{x}$ & 7,5YR 5/3, 5/4, 4/1, 5YR 5/4 & $7,5 Y R 5 / 3,5 / 4,5 / 2$ & $\mathrm{x}$ & $\mathrm{x}$ & $\mathrm{x}$ & $\mathrm{x}$ & $\mathrm{x}$ & $\mathrm{x}$ & $\mathrm{x}$ & $\mathrm{x}$ & $\mathrm{x}$ & $\mathrm{x}$ & $\mathrm{x}$ & $\mathrm{x}$ & $\mathrm{x}$ & $\mathrm{x}$ & \\
\hline PA 6-1 & 302 & 1 & & 3 & 1 & 2 & 1 & 2 & 2 & 8.6 & 5.7 & 0 & $\mathrm{x}$ & $\mathrm{x}$ & 7,5YR 5/3, 5/4, 4/1, 5YR 5/4 & $7,5 Y R$ 5/3, 5/4, 5/2 & $\mathrm{x}$ & $\mathrm{x}$ & $\mathrm{x}$ & $\mathrm{x}$ & $x$ & indet & 2,4 & $\mid 1,84$ & 2 & 3 & 0 & $\mathrm{x}$ & $\mathrm{x}$ & $\mathrm{x}$ & 3 \\
\hline
\end{tabular}




\begin{tabular}{|c|c|c|c|c|c|c|c|c|c|c|c|c|c|c|c|c|c|c|c|c|c|c|c|c|c|c|c|c|c|c|c|}
\hline \multirow[b]{2}{*}{ Sitio } & \multirow[b]{2}{*}{ UP } & \multirow[b]{2}{*}{$G F$} & \multirow{2}{*}{\multicolumn{2}{|c|}{ FNA Fgto }} & \multicolumn{10}{|c|}{ Manufactura } & \multicolumn{2}{|l|}{ Cocción } & \multicolumn{5}{|c|}{ Borde-labio } & \multicolumn{6}{|c|}{ Asa } & \multicolumn{3}{|c|}{ Base } & \multirow[b]{2}{*}{ Alterac } \\
\hline & & & & & \begin{tabular}{|l} 
Tec \\
lev \\
\end{tabular} & $\begin{array}{l}\text { For } \\
\text { ma }\end{array}$ & & $\begin{array}{l}\text { Sup } \\
\text { ext }\end{array}$ & $\begin{array}{c}\text { Sup } \\
\text { int }\end{array}$ & $\begin{array}{l}\text { Esp } \\
\text { max }\end{array}$ & $\begin{array}{l}\text { Esp } \\
\text { min } \\
\end{array}$ & $\begin{array}{l}\begin{array}{l}\text { eeco } \\
\text { pint }\end{array} \\
\end{array}$ & \begin{tabular}{|c|} 
Moti \\
vo \\
\end{tabular} & $\begin{array}{c}\text { Esti } \\
\text { lo }\end{array}$ & Colc & Col & Diam & $\begin{array}{l}\text { Lrg } \\
\text { arc }\end{array}$ & $\begin{array}{c}\% \\
\text { arco } \\
\end{array}$ & $c$ & $\begin{array}{l}\text { For } \\
\text { ma }\end{array}$ & $\begin{array}{c}\text { Lar } \\
\text { go }\end{array}$ & $\begin{array}{c}\text { An } \\
\text { cho }\end{array}$ & Esp & $\begin{array}{l}\text { Sec } \\
\text { ción }\end{array}$ & \begin{tabular}{|l} 
In \\
serc \\
\end{tabular} & $\begin{array}{l}\text { Posi } \\
\text { ción }\end{array}$ & Diám & $\begin{array}{c}\text { Mor } \\
\text { fol } \\
\end{array}$ & $\begin{array}{l}\text { Uni } \\
\text { ón }\end{array}$ & \\
\hline PA 6-1 & 201 & 1 & & 4 & 1 & 2 & 1 & 2 & 2 & 6.6 & 5.3 & 0 & $x$ & $x$ & 7,5YR 5/3, 5/4, 4/1, 5YR 5/4 & 7,5 YR $5 / 3,5 / 4,5 / 2$ & $x$ & $x$ & $x$ & $x$ & $x$ & $x$ & $x$ & $x$ & $x$ & $x$ & $x$ & $x$ & $x$ & $x$ & 1 \\
\hline PA 6-1 & 202 & 1 & & 0 & 1 & 2 & 1 & 2 & 2 & 8 & 5.9 & 0 & $\mathrm{x}$ & $x$ & 7,5YR 5/3, 5/4, 4/1, 5YR 5/4 & 7,5 YR $5 / 3,5 / 4,5 / 2$ & $x$ & $x$ & $x$ & $x$ & $x$ & $x$ & $x$ & $x$ & $x$ & $x$ & $x$ & $\mathrm{x}$ & $x$ & $x$ & 1 \\
\hline PA 6-1 & 202 & 1 & & 0 & 1 & 2 & 1 & 2 & 2 & 7.5 & 7.2 & 0 & $x$ & $x$ & 7,5YR 5/3, 5/4, 4/1, 5YR 5/4 & 7,5 YR $5 / 3,5 / 4,5 / 2$ & $x$ & $x$ & $x$ & $x$ & $x$ & $x$ & $x$ & $x$ & $x$ & $x$ & $x$ & $x$ & $x$ & $x$ & 1 \\
\hline PA 6-1 & 202 & 1 & & 0 & 1 & 2 & 1 & 2 & 2 & 7.9 & 5.6 & 0 & $x$ & $x$ & 7,5YR 5/3, 5/4, 4/1, 5YR 5/4 & 7,5 YR 5/3, 5/4, 5/2 & $x$ & $x$ & $x$ & $x$ & $x$ & $x$ & $x$ & $x$ & $x$ & $x$ & $x$ & $x$ & $x$ & $x$ & 1 \\
\hline PA 6-1 & 204 & 1 & & 0 & 1 & 2 & 1 & 2 & 2 & 9 & 6.3 & 0 & $x$ & $x$ & 7,5YR 5/3, 5/4, 4/1, 5YR 5/4 & 7,5 YR $5 / 3,5 / 4,5 / 2$ & $x$ & $x$ & $x$ & $\mathrm{x}$ & $x$ & $x$ & $\mathrm{x}$ & $x$ & $x$ & $x$ & $x$ & $x$ & $x$ & $\mathrm{x}$ & 1 \\
\hline PA 6-1 & 202 & 1 & & 0 & 1 & 2 & 1 & 2 & 2 & 7.7 & 6 & 0 & $\mathrm{x}$ & $\mathrm{x}$ & 7,5YR 5/3, 5/4, 4/1, 5YR 5/4 & $7,5 Y R$ 5/3, 5/4, 5/2 & $\mathrm{x}$ & $\mathrm{x}$ & $\mathrm{x}$ & $\mathrm{x}$ & $\mathrm{x}$ & $\mathrm{x}$ & $\mathrm{x}$ & $x$ & $\mathrm{x}$ & $\mathrm{x}$ & $\mathrm{x}$ & $\mathrm{x}$ & $\mathrm{x}$ & $\mathrm{x}$ & \\
\hline PA 6-1 & 202 & 1 & & 0 & 1 & 2 & 1 & 2 & 2 & 7.6 & 6.6 & 0 & $x$ & $x$ & 7,5YR 5/3, 5/4, 4/1, 5YR 5/4 & 7,5 YR $5 / 3,5 / 4,5 / 2$ & $x$ & $x$ & $x$ & $x$ & $x$ & $\mathrm{x}$ & $x$ & $x$ & $x$ & $x$ & $x$ & $x$ & $x$ & $\mathrm{x}$ & 1 \\
\hline PA 6-1 & 202 & 1 & & 0 & 1 & 2 & 1 & 2 & 2 & 9.8 & 7.4 & 0 & $\mathrm{x}$ & $\mathrm{x}$ & 7,5YR 5/3, 5/4, 4/1, 5YR 5/4 & 7,5 YR $5 / 3,5 / 4,5 / 2$ & $\mathrm{x}$ & $\mathrm{x}$ & $\mathrm{x}$ & $\mathrm{x}$ & $\mathrm{x}$ & $\mathrm{x}$ & $\mathrm{x}$ & $x$ & $\mathrm{x}$ & $\mathrm{x}$ & $\mathrm{x}$ & $\mathrm{x}$ & $\mathrm{x}$ & $\mathrm{x}$ & \\
\hline PA 6-1 & 202 & 1 & & 0 & 1 & 2 & 1 & 2 & 2 & 9.8 & 4.5 & 0 & $x$ & $x$ & 7,5YR 5/3, 5/4, 4/1, 5YR 5/4 & 7,5 YR $5 / 3,5 / 4,5 / 2$ & $x$ & $x$ & $x$ & $x$ & $x$ & $x$ & $x$ & $x$ & $\mathrm{x}$ & $x$ & $x$ & $x$ & $x$ & $x$ & \\
\hline PA 6-1 & 202 & 1 & & 0 & 1 & 2 & 1 & 2 & 2 & 7.2 & 6.1 & 0 & $\mathrm{x}$ & $x$ & 7,5YR 5/3, 5/4, 4/1, 5YR 5/4 & 7,5 YR $5 / 3,5 / 4,5 / 2$ & $x$ & $x$ & $x$ & $\mathrm{x}$ & $x$ & $x$ & $\mathrm{x}$ & $x$ & $x$ & $x$ & $x$ & $x$ & $x$ & $x$ & \\
\hline PA 6-1 & 201 & 1 & & 0 & 1 & 0 & 1 & 2 & 2 & 6.3 & 5 & 0 & $x$ & $x$ & 7,5YR 5/3, 5/4, 4/1, 5YR 5/4 & 7,5 YR $5 / 3,5 / 4,5 / 2$ & $x$ & $x$ & $x$ & $x$ & $x$ & $x$ & $x$ & $x$ & $x$ & $x$ & $x$ & $x$ & $x$ & $x$ & 1 y 4 \\
\hline PA 6-1 & 202 & 1 & & 0 & 1 & 0 & 1 & 2 & 2 & 5.5 & 5 & 0 & $\mathrm{x}$ & $x$ & 7,5YR 5/3, 5/4, 4/1, 5YR 5/4 & 7,5 YR $5 / 3,5 / 4,5 / 2$ & $x$ & $x$ & $x$ & $x$ & $x$ & $x$ & $x$ & $x$ & $x$ & $x$ & $x$ & $\mathrm{x}$ & $x$ & $x$ & 4 \\
\hline PA 6-1 & 102 & 1 & & 0 & 1 & 0 & 1 & 2 & 2 & 6.5 & 3.9 & 0 & $\mathrm{x}$ & $\mathrm{x}$ & 7,5YR 5/3, 5/4, 4/1, 5YR 5/4 & 7,5YR 5/3, 5/4, 5/2 & $\mathrm{x}$ & $x$ & $\mathrm{x}$ & $\mathrm{x}$ & $\mathrm{x}$ & $\mathrm{x}$ & $\mathrm{x}$ & $x$ & $\mathrm{x}$ & $\mathrm{x}$ & $\mathrm{x}$ & $\mathrm{x}$ & $\mathrm{x}$ & $\mathrm{x}$ & \\
\hline PA 6-1 & 301 & 1 & & 0 & 1 & 0 & 1 & 2 & 2 & 6.5 & 4 & 0 & $x$ & $\mathrm{x}$ & 7,5YR 5/3, 5/4, 4/1, 5YR 5/4 & 7,5 YR $5 / 3,5 / 4,5 / 2$ & $\mathrm{x}$ & $x$ & $x$ & $\mathrm{x}$ & $x$ & $x$ & $x$ & $x$ & $x$ & $x$ & $x$ & $x$ & $x$ & $x$ & \\
\hline PA 6-1 & 201 & 1 & & 0 & 1 & 0 & 1 & 2 & 2 & 8.6 & 8 & 0 & $\mathrm{x}$ & $x$ & 7,5YR 5/3, 5/4, 4/1, 5YR 5/4 & 7,5YR 5/3, 5/4, 5/2 & $x$ & $\mathrm{x}$ & $x$ & $\mathrm{x}$ & $x$ & $\mathrm{x}$ & $x$ & $x$ & $\mathrm{x}$ & $x$ & $\mathrm{x}$ & $x$ & $x$ & $\mathrm{x}$ & \\
\hline PA 6-1 & 201 & 1 & & 0 & 1 & 0 & 1 & 2 & 2 & 8.4 & 5.9 & 0 & $x$ & $x$ & 7,5YR 5/3, 5/4, 4/1, 5YR 5/4 & 7,5 YR $5 / 3,5 / 4,5 / 2$ & $x$ & $x$ & $x$ & $x$ & $x$ & $x$ & $x$ & $x$ & $\mathrm{x}$ & $x$ & $x$ & $x$ & $x$ & $x$ & \\
\hline PA 6-1 & 202 & 1 & & 0 & 1 & 0 & 1 & 2 & 2 & 7.1 & 4.6 & 0 & $x$ & $x$ & 7,5YR 5/3, 5/4, 4/1, 5YR 5/4 & 7,5 YR $5 / 3,5 / 4,5 / 2$ & $x$ & $x$ & $x$ & $x$ & $x$ & $x$ & $x$ & $\mathrm{x}$ & $x$ & $x$ & $x$ & $x$ & $x$ & $x$ & 1 y 2 \\
\hline PA 6-1 & 202 & 1 & & 0 & 1 & 0 & 1 & 2 & 2 & 7.1 & 5.8 & 0 & $\mathrm{x}$ & $\mathrm{x}$ & 7,5YR 5/3, 5/4, 4/1, 5YR 5/4 & 7,5 YR $5 / 3,5 / 4,5 / 2$ & $x$ & $x$ & $\mathrm{x}$ & $x$ & $x$ & $x$ & $x$ & $x$ & $\mathrm{x}$ & $x$ & $x$ & $x$ & $\mathrm{x}$ & $\mathrm{x}$ & 1 y 2 \\
\hline PA 6-1 & 202 & 1 & & 0 & 1 & 0 & 1 & 2 & 2 & 8.1 & 6 & 0 & $x$ & $x$ & 7,5YR 5/3, 5/4, 4/1, 5YR 5/4 & 7,5 YR $5 / 3,5 / 4,5 / 2$ & $x$ & $x$ & $x$ & $x$ & $x$ & $x$ & $x$ & $x$ & $x$ & $x$ & $x$ & $x$ & $x$ & $x$ & 1 \\
\hline PA 6-1 & 202 & 1 & & 0 & 1 & 0 & 1 & 2 & 2 & 8.7 & 5.8 & 0 & $\mathrm{x}$ & $\mathrm{x}$ & 7,5YR 5/3, 5/4, 4/1, 5YR 5/4 & 7,5YR 5/3, 5/4, 5/2 & $\mathrm{x}$ & $\mathrm{x}$ & $\mathrm{x}$ & $\mathrm{x}$ & $\mathrm{x}$ & $\mathrm{x}$ & $\mathrm{x}$ & $\mathrm{x}$ & $\mathrm{x}$ & $\mathrm{x}$ & $\mathrm{x}$ & $\mathrm{x}$ & $\mathrm{x}$ & $\mathrm{x}$ & 4 \\
\hline PA 6-1 & 302 & 1 & & 0 & 1 & 0 & 1 & 2 & 2 & 6.7 & 4.6 & 0 & $x$ & $x$ & $7,5 Y R$ 5/3, 5/4, 4/1, 5YR 5/4 & 7,5 YR $5 / 3,5 / 4,5 / 2$ & $x$ & $x$ & $x$ & $x$ & $x$ & $x$ & $x$ & $x$ & $x$ & $x$ & $x$ & $x$ & $x$ & $x$ & \\
\hline PA 6-1 & 102 & 1 & & 0 & 1 & 0 & 1 & 2 & 2 & 7.4 & 5.1 & 0 & $x$ & $x$ & 7,5YR 5/3, 5/4, 4/1, 5YR 5/4 & $7,5 Y R$ 5/3, 5/4, 5/2 & $\mathrm{x}$ & $x$ & $x$ & $x$ & $x$ & $\mathrm{x}$ & $\mathrm{x}$ & $x$ & $\mathrm{x}$ & $x$ & $x$ & $\mathrm{x}$ & $\mathrm{x}$ & $\mathrm{x}$ & \\
\hline PA 6-1 & 202 & 1 & & 0 & 1 & 0 & 1 & 2 & 2 & 7.3 & 6.6 & 0 & $\mathrm{x}$ & $x$ & 7,5YR 5/3, 5/4, 4/1, 5YR 5/4 & 7,5YR 5/3, 5/4, 5/2 & $x$ & $x$ & $x$ & $x$ & $x$ & $\mathrm{x}$ & $x$ & $x$ & $x$ & $x$ & $x$ & $\mathrm{x}$ & $x$ & $\mathrm{x}$ & 3 \\
\hline PA 6-1 & 302 & 1 & & 0 & 1 & 0 & 1 & 2 & 2 & 7.4 & 6.3 & 0 & $x$ & $x$ & 7,5YR 5/3, 5/4, 4/1, 5YR 5/4 & 7,5 YR $5 / 3,5 / 4,5 / 2$ & $x$ & $x$ & $x$ & $x$ & $x$ & $x$ & $x$ & $x$ & $x$ & $x$ & $x$ & $x$ & $x$ & $x$ & \\
\hline PA 6-1 & 202 & 1 & & 0 & 1 & 0 & 1 & 2 & 2 & 6.8 & 5.1 & 0 & $\mathrm{x}$ & $x$ & 7,5YR 5/3, 5/4, 4/1, 5YR 5/4 & 7,5 YR $5 / 3,5 / 4,5 / 2$ & $x$ & $x$ & $x$ & $\mathrm{x}$ & $x$ & $x$ & $x$ & $x$ & $\mathrm{x}$ & $\mathrm{x}$ & $\mathrm{x}$ & $\mathrm{x}$ & $\mathrm{x}$ & $\mathrm{x}$ & \\
\hline PA 6-1 & 202 & 1 & & 0 & 1 & 0 & 1 & 2 & 2 & 7.4 & 7.1 & 0 & $x$ & $x$ & 7,5YR 5/3, 5/4, 4/1, 5YR 5/4 & 7,5 YR $5 / 3,5 / 4,5 / 2$ & $x$ & $x$ & $x$ & $x$ & $x$ & $x$ & $x$ & $x$ & $x$ & $x$ & $x$ & $x$ & $x$ & $x$ & 3 \\
\hline PA 6-1 & 302 & 1 & & 0 & 1 & 0 & 1 & 2 & 2 & 7.2 & 7 & 0 & $x$ & $x$ & 7,5YR 5/3, 5/4, 4/1, 5YR 5/4 & 7,5 YR $5 / 3,5 / 4,5 / 2$ & $x$ & $x$ & $x$ & $x$ & $x$ & $x$ & $x$ & $x$ & $x$ & $x$ & $x$ & $x$ & $x$ & $x$ & \\
\hline PA 6-1 & 101 & 1 & & 0 & 1 & 0 & 1 & 2 & 2 & 6.8 & 5.7 & 0 & $x$ & $\mathrm{x}$ & 7,5YR 5/3, 5/4, 4/1, 5YR 5/4 & 7,5 YR $5 / 3,5 / 4,5 / 2$ & $x$ & $x$ & $\mathrm{x}$ & $\mathrm{x}$ & $\mathrm{x}$ & $\mathrm{x}$ & $x$ & $x$ & $x$ & $x$ & $\mathrm{x}$ & $\mathrm{x}$ & $x$ & $x$ & \\
\hline PA 6-1 & 202 & 1 & & 0 & 1 & 0 & 1 & 2 & 2 & 6.1 & 5.3 & 0 & $x$ & $x$ & 7,5YR 5/3, 5/4, 4/1, 5YR 5/4 & 7,5 YR $5 / 3,5 / 4,5 / 2$ & $x$ & $x$ & $x$ & $x$ & $x$ & $x$ & $x$ & $x$ & $x$ & $x$ & $x$ & $x$ & $x$ & $x$ & 4 \\
\hline PA 6-1 & 202 & 1 & & 0 & 1 & 0 & 1 & 2 & 2 & 6 & 5.9 & 0 & $x$ & $\mathrm{x}$ & 7,5YR 5/3, 5/4, 4/1, 5YR 5/4 & 7,5YR 5/3, 5/4, 5/2 & $x$ & $\mathrm{x}$ & $x$ & $x$ & $\mathrm{x}$ & $x$ & $x$ & $x$ & $x$ & $x$ & $x$ & $x$ & $x$ & $x$ & \\
\hline PA 6-1 & 202 & 1 & & 0 & 1 & 0 & 1 & 2 & 2 & 7.3 & 6.3 & 0 & $x$ & $x$ & 7,5YR 5/3, 5/4, 4/1, 5YR 5/4 & 7,5 YR $5 / 3,5 / 4,5 / 2$ & $x$ & $x$ & $x$ & $\mathrm{x}$ & $x$ & $x$ & $x$ & $x$ & $\mathrm{x}$ & $x$ & $x$ & $x$ & $x$ & $x$ & 3 \\
\hline PA 6-1 & 202 & 1 & & 0 & 1 & 0 & 1 & 2 & 2 & 4.8 & 4.3 & 0 & $x$ & $x$ & 7,5YR 5/3, 5/4, 4/1, 5YR 5/4 & 7,5 YR $5 / 3,5 / 4,5 / 2$ & $x$ & $x$ & $x$ & $x$ & $x$ & $x$ & $x$ & $x$ & $x$ & $x$ & $x$ & $x$ & $x$ & $x$ & 4 \\
\hline PA 6-1 & 112 & 1 & & 0 & 1 & 0 & 1 & 2 & 2 & 6.7 & 5.7 & 0 & $x$ & $x$ & 7,5YR 5/3, 5/4, 4/1, 5YR 5/4 & 7,5 YR $5 / 3,5 / 4,5 / 2$ & $x$ & $x$ & $x$ & $x$ & $x$ & $x$ & $x$ & $x$ & $x$ & $x$ & $x$ & $\mathrm{x}$ & $x$ & $x$ & 4 \\
\hline PA 6-1 & 202 & 1 & & 0 & 1 & 0 & 1 & 2 & 2 & 7.8 & 6.7 & 0 & $x$ & $x$ & 7,5YR 5/3, 5/4, 4/1, 5YR 5/4 & 7,5 YR $5 / 3,5 / 4,5 / 2$ & $x$ & $x$ & $x$ & $x$ & $x$ & $x$ & $x$ & $x$ & $x$ & $x$ & $x$ & $x$ & $x$ & $x$ & \\
\hline PA 6-1 & 202 & 1 & & 0 & 1 & 0 & 1 & 2 & 2 & 6.1 & 5.7 & 0 & $x$ & $x$ & 7,5 YR 5/3,5/4, 4/1, 5YR 5/4 & 7,5 YR $5 / 3,5 / 4,5 / 2$ & $x$ & $x$ & $x$ & $x$ & $x$ & $x$ & $\mathrm{x}$ & $x$ & $x$ & $x$ & $x$ & $x$ & $x$ & $x$ & 3 y 4 \\
\hline PA 6-1 & 202 & 1 & & 0 & 1 & 0 & 1 & 2 & 2 & 7.2 & 6.2 & 0 & $\mathrm{x}$ & $x$ & 7,5YR 5/3, 5/4, 4/1, 5YR 5/4 & 7,5 YR $5 / 3,5 / 4,5 / 2$ & $\mathrm{x}$ & $x$ & $x$ & $\mathrm{x}$ & $x$ & $\mathrm{x}$ & $\mathrm{x}$ & $x$ & $x$ & $x$ & $x$ & $\mathrm{x}$ & $x$ & $x$ & \\
\hline PA 6-1 & 202 & 1 & & 0 & 1 & 0 & 1 & 2 & 2 & 6.2 & 5.9 & 0 & $\mathrm{x}$ & $x$ & 7,5YR 5/3, 5/4, 4/1, 5YR 5/4 & 7,5 YR $5 / 3,5 / 4,5 / 2$ & $\mathrm{x}$ & $\mathrm{x}$ & $\mathrm{x}$ & $x$ & $x$ & $x$ & $x$ & $x$ & $x$ & $x$ & $x$ & $\mathrm{x}$ & $x$ & $x$ & \\
\hline PA 6-1 & 201 & 1 & & 0 & 1 & 0 & 1 & 2 & 2 & 6.6 & 6.3 & 0 & $x$ & $x$ & 7,5YR 5/3, 5/4, 4/1, 5YR 5/4 & 7,5 YR $5 / 3,5 / 4,5 / 2$ & $x$ & $x$ & $x$ & $x$ & $x$ & $x$ & $x$ & $x$ & $x$ & $x$ & $x$ & $x$ & $x$ & $x$ & \\
\hline PA 6-1 & 201 & 1 & & 0 & 1 & 0 & 1 & 2 & 2 & 8.1 & 7.6 & 0 & $x$ & $\mathrm{x}$ & 7,5YR 5/3, 5/4, 4/1, 5YR 5/4 & 7,5 YR $5 / 3,5 / 4,5 / 2$ & $x$ & $x$ & $x$ & $x$ & $x$ & $\mathrm{x}$ & $\mathrm{x}$ & $x$ & $x$ & $x$ & $\mathrm{x}$ & $x$ & $x$ & $x$ & \\
\hline PA 6-1 & 202 & 2 & & 0 & 1 & 2 & 1 & 2 & 2 & 6.4 & 5.3 & 0 & $x$ & $x$ & 5YR 5/4; 2,5YR 5/4 & $5 Y R$ 5/3, 5/4 & 31,6 & 18 & 18,1 & $\mathrm{x}$ & $x$ & $x$ & $x$ & $x$ & $x$ & $x$ & $x$ & $x$ & $x$ & $x$ & 3 \\
\hline PA 6-1 & 202 & 2 & & 4 & 1 & 2 & 1 & 2 & 2 & 8 & 5.6 & 0 & $x$ & $x$ & 5YR 5/4; 2,5YR 5/4 & $5 Y R 5 / 3,5 / 4$ & 31,6 & 18 & 18,1 & $x$ & $x$ & $x$ & $x$ & $x$ & $x$ & $x$ & $x$ & $x$ & $x$ & $x$ & 3 \\
\hline
\end{tabular}




\begin{tabular}{|c|c|c|c|c|c|c|c|c|c|c|c|c|c|c|c|c|c|c|c|c|c|c|c|c|c|c|c|c|c|c|c|c|c|}
\hline \multirow[b]{2}{*}{ Sitio } & \multirow[b]{2}{*}{ UP } & \multirow[b]{2}{*}{ GF } & \multirow[b]{2}{*}{ FNA } & \multirow[b]{2}{*}{ Fgto } & \multicolumn{10}{|c|}{ Manufactura } & \multicolumn{2}{|l|}{ Cocción } & \multicolumn{6}{|c|}{ Borde-labio } & \multicolumn{6}{|c|}{ Asa } & & \multicolumn{3}{|c|}{ Base } & \multirow[b]{2}{*}{ Alterac } \\
\hline & & & & & $\begin{array}{l}\text { Tec } \\
\text { lev } \\
\end{array}$ & $\begin{array}{l}\text { For } \\
\text { ma }\end{array}$ & $\begin{array}{l}\text { Mar } \\
\text { cas }\end{array}$ & $\begin{array}{l}\text { Sup } \\
\text { ext }\end{array}$ & $\begin{array}{c}\text { Sup } \\
\text { int }\end{array}$ & $\begin{array}{l}\text { Esp } \\
\max \end{array}$ & $\begin{array}{l}\text { Esp } \\
\text { min }\end{array}$ & $\begin{array}{c}\text { Deco } \\
\text { pint }\end{array}$ & \begin{tabular}{|c|} 
Moti \\
vo
\end{tabular} & \begin{tabular}{|c|} 
Esti \\
lo
\end{tabular} & Color sup ext & Color sup int & Diam & $\begin{array}{l}\text { Lrg } \\
\text { arc }\end{array}$ & $\begin{array}{c}\% \\
\text { arco }\end{array}$ & Dire & & & \begin{tabular}{l|} 
Lar \\
go
\end{tabular} & \begin{tabular}{|c|}
$\begin{array}{c}\text { An } \\
\text { cho }\end{array}$ \\
\end{tabular} & Esp & p $\begin{array}{l}\text { Sec } \\
\text { ción }\end{array}$ & \begin{tabular}{l|l}
$\mathbf{c}$ & In \\
n & ser \\
\end{tabular} & $\begin{array}{l}\text { Po } \\
\text { ció }\end{array}$ & \begin{tabular}{l|l} 
osi & $\mathrm{Di}$ \\
on
\end{tabular} & Diám & $\begin{array}{c}\text { Mor } \\
\text { fol }\end{array}$ & \begin{tabular}{|l}
$\begin{array}{l}\text { Uni } \\
\text { ón }\end{array}$ \\
\end{tabular} & \\
\hline PA 6-1 & 202 & 2 & & 0 & 1 & 2 & 1 & 2 & 2 & 7.8 & 6 & 0 & $\mathrm{x}$ & $\mathrm{x}$ & 5YR 5/4; 2,5YR 5/4 & $5 Y R 5 / 3,5 / 4$ & 31,6 & 18 & 18,1 & $x$ & & $x$ & $x$ & $x$ & $x$ & $x$ & $x$ & $x$ & $x$ & $x$ & $x$ & $x$ & 3 \\
\hline PA 6-1 & 202 & 2 & & 0 & 1 & 2 & 1 & 2 & 2 & 8.1 & 5.5 & 0 & $x$ & $\mathrm{x}$ & 5YR 5/4; 2,5YR 5/4 & $5 Y R 5 / 3,5 / 4$ & $\mathrm{x}$ & $x$ & $x$ & $x$ & & $x$ & $x$ & $x$ & $x$ & $x$ & $x$ & $x$ & $x$ & $\mathrm{x}$ & $x$ & $x$ & 3 \\
\hline PA 6-1 & 202 & 2 & & 0 & 1 & 2 & 1 & 2 & 2 & indet & indet & 0 & $\mathrm{x}$ & $\mathrm{x}$ & $5 Y R$ 5/4; 2,5YR 5/4 & YR 5/3, 5/4 & $\mathrm{x}$ & $\mathrm{x}$ & $\mathrm{x}$ & $x$ & & $x$ & $x$ & $\mathrm{x}$ & $\mathrm{x}$ & $x$ & $\mathrm{x}$ & $\mathrm{x}$ & $x$ & $\mathrm{x}$ & $x$ & $\mathrm{x}$ & 3 \\
\hline PA 6-1 & 202 & 2 & & 0 & 1 & 2 & 1 & 2 & 2 & 8.1 & 5 & 0 & $\mathrm{x}$ & $x$ & 5YR 5/4; 2,5YR 5/4 & $5 Y R 5 / 3,5 / 4$ & $x$ & $x$ & $x$ & $x$ & & $x$ & $\mathrm{x}$ & $x$ & $x$ & $x$ & $x$ & $x$ & $x$ & $\mathrm{x}$ & $x$ & $x$ & 3 \\
\hline PA 6-1 & 202 & 2 & & 0 & 1 & 2 & 1 & 2 & 2 & 7.5 & 6.4 & 0 & $x$ & $x$ & 5YR 5/4; 2,5YR 5/4 & $5 Y R 5 / 3,5 / 4$ & $\mathrm{x}$ & $\mathrm{x}$ & $\mathrm{x}$ & $x$ & & $x$ & $\mathrm{x}$ & $\mathrm{x}$ & $\mathrm{x}$ & $\mathrm{x}$ & $\mathrm{x}$ & $\mathrm{x}$ & $x$ & $\mathrm{x}$ & $\mathrm{x}$ & $\mathrm{x}$ & 3 \\
\hline PA 6-1 & 202 & 2 & & 0 & 1 & 2 & 1 & 2 & 2 & 6.3 & 5.4 & 0 & $x$ & $x$ & $5 Y R$ 5/4; 2,5YR 5/4 & $5 Y R 5 / 3,5 / 4$ & $x$ & $x$ & $x$ & $\mathrm{x}$ & & $x$ & $x$ & $x$ & $x$ & $x$ & $x$ & $\mathrm{x}$ & $x$ & $\mathrm{x}$ & $x$ & $x$ & 3 \\
\hline PA 6-1 & 202 & 2 & & 0 & 1 & 2 & 1 & 2 & 2 & 6.5 & 6.5 & 0 & $\mathrm{x}$ & $x$ & 5YR 5/4; 2,5YR 5/4 & $5 Y R 5 / 3,5 / 4$ & $\mathrm{x}$ & $\mathrm{x}$ & $\mathrm{x}$ & $x$ & & $x$ & $x$ & $x$ & $x$ & $x$ & $x$ & $x$ & $x$ & $x$ & $x$ & $x$ & 3 \\
\hline PA 6-1 & 202 & 2 & & 0 & 1 & 2 & 1 & 2 & 2 & 6.6 & 6 & 0 & 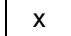 & 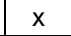 & $5 Y R$ 5/4; 2,5YR 5/4 & $5 / 4$ & $x$ & $\mathrm{x}$ & $\mathrm{x}$ & $x$ & & $x$ & $\mathrm{x}$ & $\mathrm{x}$ & $\mathrm{x}$ & $\mathrm{x}$ & $\mathrm{x}$ & $\mathrm{x}$ & & $\mathrm{x}$ & $x$ & $\mathrm{x}$ & 3 \\
\hline PA 6-1 & 202 & 3 & & 1 & 2 & 2 & $2 \mathrm{y} 5$ & 3 y 4 & $3,4 \mathrm{y} 2$ & 7.8 & 6 & 1 & $\mathrm{x}$ & Yavi & 2,5YR 5/6, 4/4; 5YR 5/4, 5/2 & 2,5YR 5/6,5YR 5/6 & 20,3 & 5,8 & 9.1 & 1 & & 2 & $\mathrm{x}$ & $x$ & $\mathrm{x}$ & $x$ & $x$ & $x$ & $x$ & $\mathrm{x}$ & $x$ & $x$ & \\
\hline PA 6-1 & 202 & 3 & & 1 & 2 & 2 & $2 \mathrm{y} 5$ & 3 y 4 & $3,4 \mathrm{y} 2$ & 7.7 & 6.4 & + & $x$ & Yavi & $2,5 Y R$ 5/6, 4/4; 5YR 5/4, 5/2 & 2,5YR 5/6, 5YR 5/6 & 22,2 & 4,5 & 6,5 & 1 & & 2 & $x$ & $x$ & $x$ & $x$ & $x$ & $x$ & $x$ & $x$ & $x$ & $x$ & 1 \\
\hline PA 6-1 & 204 & 3 & & 4 & 2 & 2 & $2 \mathrm{y} 5$ & 3 y 4 & $3,4 \mathrm{y} 2$ & 8 & 6.3 & 1 & $x$ & Yavi & $2,5 Y R$ 5/6, 4/4; 5YR 5/4, 5/2 & 2,5YR 5/6, 5YR 5/6 & 16,2 & 13 & 25,5 & 5 & & $x$ & $x$ & $x$ & $x$ & $x$ & $x$ & $x$ & $x$ & $x$ & $x$ & $x$ & 1 \\
\hline PA 6-1 & 202 & 3 & & 4 & 2 & 2 & $2 \mathrm{y} 5$ & 3 y 4 & $3,4 y 2$ & 7.2 & 5.4 & 1 & $\mathrm{x}$ & Yavi & 2,5YR 5/6, 4/4; 5 YR 5/4, 5/2 & YYR 5/6 & 16,2 & 13 & 25,5 & 5 & & $x$ & $\mathrm{x}$ & $\mathrm{x}$ & $\mathrm{x}$ & $\mathrm{x}$ & $\mathrm{x}$ & 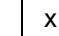 & 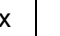 & $\mathrm{x}$ & $x$ & $\mathrm{x}$ & 3 \\
\hline PA 6-1 & Sup & 3 & & 4 & 2 & 2 & $2 \mathrm{y} 5$ & 3 y 4 & $3,4 \mathrm{y} 2$ & 7.3 & 6.9 & 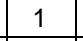 & $\mathrm{x}$ & Yavi & 2,5YR 5/6, 4/4; 5YR 5/4, 5/2 & 2,5YR 5/6, 5YR 5/6 & 16,2 & 13 & 25,5 & \begin{tabular}{|l|l|}
5 & $x$ \\
\end{tabular} & & $x$ & $x$ & $x$ & $x$ & $\mathrm{x}$ & $x$ & $x$ & $x$ & $\mathrm{x}$ & $x$ & $x$ & 3 \\
\hline PA 6-1 & 202 & 3 & & 4 & 2 & 2 & $2 \mathrm{y} 5$ & 3 y 4 & $3,4 y 2$ & 9 & 7.2 & 1 & $x$ & Yavi & 2,5YR 5/6, 4/4; 5YR 5/4, 5/2 & 2,5YR 5/6, 5YR 5/6 & 13,2 & 6,6 & 15,9 & 9 & & $\mathrm{x}$ & $\mathrm{x}$ & $\mathrm{x}$ & $\mathrm{x}$ & $\mathrm{x}$ & $\mathrm{x}$ & $\mathrm{x}$ & $x$ & $\mathrm{x}$ & $x$ & $\mathrm{x}$ & 5 \\
\hline PA 6-1 & 202 & 3 & & 4 & 2 & 2 & $2 \mathrm{y} 5$ & 3 y 4 & $3,4 \mathrm{y} 2$ & 8.5 & 8.3 & 1 & 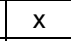 & Yavi & 2,5YR 5/6, 4/4; 5YR 5/4, 5/2 & 2,5YR 5/6, 5YR 5/6 & 13,2 & 6,6 & 15,9 & . & & $x$ & $\mathrm{x}$ & $\mathrm{x}$ & $x$ & $x$ & $x$ & 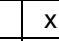 & & $\mathrm{x}$ & $x$ & $\mathrm{x}$ & \\
\hline PA 6-1 & 202 & 3 & & 0 & 2 & 0 & $2 \mathrm{y} 5$ & 3 y 4 & $3,4 \mathrm{y} 2$ & 7 & 5.3 & 1 & $\mathrm{x}$ & Yavi & 2,5YR 5/6, 4/4; 5YR 5/4, 5/2 & 2,5YR 5/6, 5YR 5/6 & $x$ & $\mathrm{x}$ & $x$ & $x$ & & $x$ & $\mathrm{x}$ & $x$ & $x$ & $x$ & $x$ & $x$ & $x$ & $\mathrm{x}$ & $x$ & $\mathrm{x}$ & 3 y 5 \\
\hline PA 6-1 & 202 & 3 & & 0 & 2 & 0 & $2 \mathrm{y} 5$ & 3 y 4 & $3,4 \mathrm{y} 2$ & 7.6 & 5.5 & 1 & $\mathrm{x}$ & Yavi & 2,5YR 5/6, 4/4; 5YR 5/4, 5/2 & $5 Y R$ 5/6 & $\mathrm{x}$ & $\mathrm{x}$ & $x$ & $x$ & & $x$ & $x$ & $x$ & $x$ & $x$ & $x$ & $x$ & $x$ & $x$ & $x$ & $\mathrm{x}$ & 3 y 5 \\
\hline PA 6-1 & 202 & 3 & & 0 & 2 & 0 & $2 \mathrm{y} 5$ & 3 y 4 & $3,4 y 2$ & 6.2 & 5.1 & 1 & $x$ & Yavi & 2,5YR 5/6, 4/4; & $R 5 / 6$ & $\mathrm{x}$ & $\mathrm{x}$ & 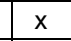 & $x$ & & $x$ & $\mathrm{x}$ & $\mathrm{x}$ & $x$ & $x$ & $x$ & 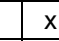 & & $x$ & $x$ & $x$ & \\
\hline PA 6-1 & 202 & 3 & & 4 & 2 & 2 & $2 \mathrm{y} 5$ & 3 y 4 & $3,4 y 2$ & 7.1 & 5.1 & 1 & $\mathrm{x}$ & Yavi & $2,5 Y R$ 5/6, 4/4 & R 5/6 & $\mathrm{x}$ & $\mathrm{x}$ & $\mathrm{x}$ & $\mathrm{x}$ & & $\mathrm{x}$ & $\mathrm{x}$ & $\mathrm{x}$ & $\mathrm{x}$ & $\mathrm{x}$ & $\mathrm{x}$ & $\mathrm{x}$ & & $\mathrm{x}$ & $\mathrm{x}$ & $\mathrm{x}$ & \\
\hline PA 6-1 & 202 & 3 & & 0 & 2 & 2 & $2 \mathrm{y} 5$ & 3 y 4 & $3,4 \mathrm{y} 2$ & 6 & 4.6 & 1 & $\mathrm{x}$ & Yavi & 2,5YR 5/6, 4/4; 5YR 5/4, 5/2 & 2,5 YR 5 & $x$ & $x$ & $\mathrm{x}$ & $\mathrm{x}$ & & $x$ & $\mathrm{x}$ & $x$ & $x$ & $x$ & $x$ & $x$ & $x$ & $\mathrm{x}$ & $x$ & $x$ & 5 \\
\hline PA 6-1 & 202 & 3 & & 0 & 2 & 2 & $2 \mathrm{y} 5$ & 3 y 4 & $3,4 \mathrm{y} 2$ & 8 & 6.9 & 1 & $\mathrm{x}$ & Yavi & 2,5YR 5/6, 4/4; 5YR 5/4, 5/2 & 2,5YR 5/6, 5YR 5/6 & $x$ & $\mathrm{x}$ & $x$ & $\mathrm{x}$ & & $\mathrm{x}$ & $\mathrm{x}$ & $\mathrm{x}$ & $\mathrm{x}$ & $\mathrm{x}$ & $\mathrm{x}$ & 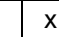 & 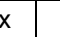 & $x$ & $\mathrm{x}$ & $\mathrm{x}$ & \\
\hline PA 6-1 & 202 & 3 & & 0 & 2 & 2 & $2 \mathrm{y} 5$ & 3 y 4 & $3,4 \mathrm{y} 2$ & 7.9 & 1 & 1 & - & Yavi & 2,5YR 5/6, 4/4; 5YR 5/4, 5/2 & 2,5YR 5/6, 5YR 5/6 & $x$ & $x$ & 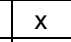 & $x$ & & $x$ & $x$ & $x$ & $x$ & $x$ & $x$ & - & & $\mathrm{x}$ & $x$ & $x$ & \\
\hline PA 6-1 & 302 & 3 & & 0 & 2 & 0 & $2 \mathrm{y} 5$ & 3 y 4 & $3,4 \mathrm{y} 2$ & 6.4 & 5 & 1 & $x$ & Yavi & 2,5YR 5/6, 4/4; 5YR 5/4, 5/2 & 2,5YR 5/6, 5YR 5/6 & $\mathrm{x}$ & $\mathrm{x}$ & $x$ & $x$ & & $x$ & $\mathrm{x}$ & $\mathrm{x}$ & $x$ & $x$ & $x$ & $x$ & $x$ & $\mathrm{x}$ & $x$ & $\mathrm{x}$ & 5 \\
\hline PA 6-1 & 111 & 3 & & 0 & 2 & 0 & $2 \mathrm{y} 5$ & 3 y 4 & $3,4 y 2$ & 6 & 5.5 & 1 & $\mathrm{x}$ & Yavi & 2,5YR 5/6, 4/4; 5 YR 5/4, 5/2 & YYR 5/6 & $\mathrm{x}$ & $\mathrm{x}$ & $\mathrm{x}$ & $\mathrm{x}$ & & $\mathrm{x}$ & $\mathrm{x}$ & $\mathrm{x}$ & $\mathrm{x}$ & $\mathrm{x}$ & $\mathrm{x}$ & 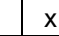 & 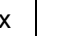 & $\mathrm{x}$ & $\mathrm{x}$ & $\mathrm{x}$ & 5 \\
\hline PA 6-1 & 202 & 3 & & 0 & 2 & 0 & $2 \mathrm{y} 5$ & 3 y 4 & $3,4 y 2$ & 7 & 6.6 & 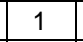 & 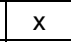 & Yavi & $2,5 Y R$ 5/6, 4/4; 5YR 5/4, 5/2 & 2,5YR 5/6, 5YR 5/6 & $x$ & $\mathrm{x}$ & $\mathrm{x}$ & $x$ & & $x$ & $\mathrm{x}$ & $x$ & $x$ & $x$ & $x$ & $x$ & & $\mathrm{x}$ & $x$ & $x$ & \\
\hline PA 6-1 & 202 & 3 & & 0 & 2 & 0 & $2 \mathrm{y} 5$ & 3 y 4 & $3,4 y 2$ & 6.5 & 5.5 & 1 & $\mathrm{x}$ & Yavi & 2,5YR 5/6, 4/4; 5YR 5/4, 5/2 & 2,5YR 5/6 & $\mathrm{x}$ & $\mathrm{x}$ & $\mathrm{x}$ & $\mathrm{x}$ & & $\mathrm{x}$ & $x$ & $\mathrm{x}$ & $\mathrm{x}$ & $\mathrm{x}$ & $\mathrm{x}$ & $\mathrm{x}$ & $\mathrm{x}$ & $\mathrm{x}$ & $x$ & $\mathrm{x}$ & 3 \\
\hline PA 6-1 & 204 & 3 & & 0 & 2 & 0 & $2 \mathrm{y} 5$ & 3 y 4 & $3,4 \mathrm{y} 2$ & 6.6 & 6.1 & 1 & $\mathrm{x}$ & Yavi & 2,5YR 5/6, 4/4; 5YR 5/4, 5/2 & 5YR 5/6 & $x$ & $x$ & 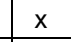 & $\mathrm{x}$ & & $x$ & $\mathrm{x}$ & $x$ & $x$ & $x$ & $x$ & 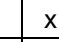 & - & $x$ & $x$ & $x$ & 1 \\
\hline PA 6-1 & 202 & 3 & & 0 & 2 & 0 & $2 \mathrm{y} 5$ & 3 y 4 & $3,4 \mathrm{y} 2$ & 8 & 5 & 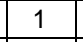 & 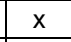 & Yavi & 2,5YR 5/6, 4/4; 5YR 5/4, 5/2 & 2,5YR 5/6, 5YR 5/6 & $\mathrm{x}$ & $x$ & $y$ & $\mathrm{x}$ & & $x$ & $\mathrm{x}$ & $x$ & $x$ & $x$ & $\mathrm{x}$ & - & & $\mathrm{x}$ & $\mathrm{x}$ & $x$ & 3 y 5 \\
\hline PA 6-1 & 202 & 3 & & 0 & 2 & 0 & $2 \mathrm{y} 5$ & 3 y 4 & $3,4 \mathrm{y} 2$ & 6.9 & 6.4 & $\perp$ & X & Yavi & 2,5YR 5/6, 4/4; 5YR 5/4, 5/2 & 2,5YR 5/ & $x$ & $x$ & $\mathrm{x}$ & $x$ & & $x$ & $x$ & $x$ & $x$ & $x$ & $x$ & $\hat{\Lambda}$ & 슨 & $\mathrm{x}$ & $x$ & $x$ & 4 \\
\hline PA 6-1 & 202 & 3 & & 0 & 2 & 0 & $2 \mathrm{y} 5$ & 3 y 4 & $3,4 \mathrm{y} 2$ & indet & indet & 1 & $x$ & Yavi & 2,5YR 5/6, 4/4; 5YR 5/4, 5/2 & 2,5YR 5/6, 5YR 5/6 & $x$ & $x$ & $x$ & $x$ & & $x$ & $x$ & $x$ & $x$ & $x$ & $x$ & $x$ & $x$ & $\mathrm{x}$ & $x$ & $x$ & 4 \\
\hline PA 6-1 & 202 & 3 & & 0 & 2 & 0 & $2 \mathrm{y} 5$ & 3 y 4 & $3,4 y 2$ & 6.9 & 6 & $\perp$ & $x$ & Yavi & 2,5YR 5/6, 4/4; 5YR 5/4, 5/2 & 2,5YR 5/6, 5YR 5/6 & $x$ & $x$ & $x$ & $x$ & & $x$ & $x$ & $x$ & $\mathrm{x}$ & $x$ & $x$ & $x$ & X & $\mathrm{x}$ & $x$ & $x$ & \\
\hline PA 6-1 & 200 & 3 & & 0 & 2 & 0 & $2 \mathrm{y} 5$ & 3 y 4 & $3,4 \mathrm{y} 2$ & 7.4 & 6.1 & 1 & $x$ & Yavi & 2,5YR 5/6, 4/4; 5YR 5/4, 5/2 & 2,5YR 5/6, 5YR 5/6 & $x$ & $x$ & $x$ & $x$ & & $x$ & $x$ & $x$ & $x$ & $x$ & $x$ & 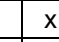 & & $x$ & $x$ & $x$ & 3 y 5 \\
\hline PA 6-1 & 202 & 3 & & 0 & 2 & 0 & $2 \mathrm{y} 5$ & 3 y 4 & $3,4 \mathrm{y} 2$ & 7.3 & 5.6 & 1 & $\mathrm{x}$ & Yavi & 2,5YR 5/6, 4/4; 5YR 5/4, 5/2 & 2,5YR 5/6, 5YR 5/6 & $x$ & $x$ & $\mathrm{x}$ & $\mathrm{x}$ & & $x$ & $\mathrm{x}$ & $x$ & $x$ & $x$ & $x$ & $x$ & $x$ & $\mathrm{x}$ & $x$ & $x$ & \\
\hline PA 6-1 & 204 & 3 & & 0 & 2 & 0 & $2 \mathrm{y} 5$ & 3 y 4 & $3,4 \mathrm{y} 2$ & 6.6 & 5.3 & 1 & $\mathrm{x}$ & Yavi & 2,5YR 5/6, 4/4; 5YR 5/4, 5/2 & 2,5YR 5/6, 5YR 5/6 & $\mathrm{x}$ & $\mathrm{x}$ & $\cdots$ & $\mathrm{x}$ & & $x$ & $\mathrm{x}$ & $\mathrm{x}$ & $\mathrm{x}$ & $\mathrm{x}$ & $\mathrm{x}$ & $\mathrm{x}$ & $x$ & $\mathrm{x}$ & $\mathrm{x}$ & $\mathrm{x}$ & 1 \\
\hline PA 6-1 & 202 & 3 & & 0 & 2 & 0 & $2 \mathrm{y} 5$ & 3 y 4 & $3,4 y 2$ & 7.6 & 6.8 & 1 & $\mathrm{x}$ & Yavi & 2,5YR 5/6, 4/4; 5YR 5/4, 5/2 & 2,5YR 5/6, 5YR 5/6 & $\mathrm{x}$ & $\mathrm{x}$ & $x$ & $\mathrm{x}$ & & $x$ & $\mathrm{x}$ & $\mathrm{x}$ & $\mathrm{x}$ & $\mathrm{x}$ & $\mathrm{x}$ & 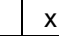 & & $\mathrm{x}$ & $\mathrm{x}$ & $\mathrm{x}$ & \\
\hline PA 6-1 & 202 & 3 & & 0 & 2 & 0 & $2 \mathrm{y} 5$ & 3 y 4 & $3,4 \mathrm{y} 2$ & 6.6 & 6.2 & 1 & $x$ & Yavi & $2,5 Y R$ 5/6, 4/4; 5YR 5/4, 5/2 & 2,5YR 5/6, 5YR 5/6 & $x$ & $x$ & $\mathrm{x}$ & $\mathrm{x}$ & & $x$ & $\mathrm{x}$ & $x$ & $x$ & $x$ & $x$ & 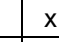 & 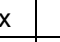 & $\mathrm{x}$ & $x$ & $x$ & \\
\hline PA 6-1 & 202 & 3 & & 0 & 2 & 0 & $2 \mathrm{y} 5$ & 3 y 4 & $3,4 y 2$ & 6 & 4.9 & 1 & $\mathrm{x}$ & Yavi & 2,5YR 5/6, 4/4; 5YR 5/4, 5/2 & 2,5YR 5/6, 5YR 5/6 & $\mathrm{x}$ & $\mathrm{x}$ & $\mathrm{x}$ & $\mathrm{x}$ & & $x$ & $x$ & $\mathrm{x}$ & $\mathrm{x}$ & $\mathrm{x}$ & $\mathrm{x}$ & $x$ & x & $\mathrm{x}$ & $\mathrm{x}$ & $\mathrm{x}$ & 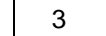 \\
\hline PA 6-1 & 302 & 4 & & 0 & 1 & 2 & $2 \mathrm{y} 6$ & 3 y 4 & 2 & 6.8 & 5.2 & 1 & $x$ & $x$ & 10 R 4/6, 5/6 (eng) & 7,5 YR $5 / 3,5 / 4$ & $\mathrm{x}$ & $x$ & - & $x$ & & $x$ & $\mathrm{x}$ & $x$ & $x$ & $x$ & $x$ & s & त & $x$ & $x$ & $\mathrm{x}$ & 1 y 3 \\
\hline PA 6-1 & 301 & 4 & & 0 & 1 & 2 & $2 \mathrm{y} 6$ & 3 y 4 & 2 & 7.5 & 5.4 & 1 & $x$ & त & 10 R 4/6, 5/6 (eng) & 7,5 YR $5 / 3,5 / 4$ & $x$ & $x$ & $x$ & $\mathrm{x}$ & & $x$ & $\mathrm{x}$ & $x$ & $x$ & $x$ & $x$ & $x$ & $x$ & $x$ & $x$ & $x$ & 1,2 y 3 \\
\hline PA 6-1 & 302 & 4 & & 0 & 1 & 2 & $2 \mathrm{y} 6$ & 3 y 4 & 2 & 5.5 & 4.5 & 1 & $\mathrm{x}$ & $x$ & 10 R 4/6, 5/6 (eng) & R $5 / 3,5 / 4$ & $\mathrm{x}$ & $\mathrm{x}$ & $\mathrm{x}$ & $\mathrm{x}$ & & $x$ & $\mathrm{x}$ & $\mathrm{x}$ & $\mathrm{x}$ & $\mathrm{x}$ & $\mathrm{x}$ & $\mathrm{x}$ & $x$ & $\mathrm{x}$ & $\mathrm{x}$ & $\mathrm{x}$ & \\
\hline PA 6-1 & 302 & 4 & & 0 & 1 & 2 & $2 \mathrm{y} 6$ & 3 y 4 & 2 & 5.5 & 5 & + & $\mathrm{x}$ & $\mathrm{x}$ & 10 R 4/6, 5/6 (eng) & $5 Y R$ 5/3, 5/4 & $x$ & $\mathrm{x}$ & x & $\mathrm{x}$ & & $\mathrm{x}$ & $x$ & $\mathrm{x}$ & $x$ & $x$ & $\mathrm{x}$ & $\mathrm{x}$ & $\mathrm{x}$ & $\mathrm{x}$ & $x$ & $\mathrm{x}$ & \\
\hline
\end{tabular}




\begin{tabular}{|c|c|c|c|c|c|c|c|c|c|c|c|c|c|c|c|c|c|c|c|c|c|c|c|c|c|c|c|c|c|c|c|}
\hline \multirow[b]{2}{*}{ Sitio } & \multirow[b]{2}{*}{ UP } & \multirow[b]{2}{*}{$G F$} & \multirow{2}{*}{\multicolumn{2}{|c|}{ FNA Fgto }} & \multicolumn{10}{|c|}{ Manufactura } & \multicolumn{2}{|c|}{ Cocción } & \multicolumn{5}{|c|}{ Borde-labio } & \multicolumn{6}{|c|}{ Asa } & \multicolumn{3}{|c|}{ Base } & \multirow[b]{2}{*}{ Alterac } \\
\hline & & & & & \begin{tabular}{|l|l} 
Tec \\
lev \\
\end{tabular} & \begin{tabular}{|l|}
$\begin{array}{l}\text { For } \\
\text { ma }\end{array}$ \\
\end{tabular} & $\begin{array}{l}\text { Mar } \\
\text { cas }\end{array}$ & $\begin{array}{l}\text { Sup } \\
\text { ext }\end{array}$ & \begin{tabular}{|c|}
$\begin{array}{c}\text { Sup } \\
\text { int }\end{array}$ \\
\end{tabular} & $\begin{array}{l}\text { Esp } \\
\max \\
\end{array}$ & $\begin{array}{l}\text { Esp } \\
\text { min } \\
\end{array}$ & $\begin{array}{c}\text { Deco } \\
\text { pint }\end{array}$ & \begin{tabular}{|c|} 
Moti \\
vo \\
\end{tabular} & $\begin{array}{c}\text { Esti } \\
\text { lo } \\
\end{array}$ & Color sup ext & Color sup int & Diam & $\begin{array}{l}\text { Lrg } \\
\text { arc }\end{array}$ & $\begin{array}{c}\% \\
\operatorname{arco}\end{array}$ & Direc & $\begin{array}{c}\text { c } \begin{array}{l}\text { For } \\
\text { ma }\end{array} \\
\text {. }\end{array}$ & $\begin{array}{l}\text { Lar } \\
\text { go }\end{array}$ & $\begin{array}{c}\text { An } \\
\text { cho }\end{array}$ & Esp & $p \begin{array}{l}\text { Sec } \\
\text { ción }\end{array}$ & \begin{tabular}{|l|l} 
In \\
serc
\end{tabular} & $\begin{array}{l}\begin{array}{l}\text { Posi } \\
\text { ción }\end{array} \\
\text { ción }\end{array}$ & Diám & $\begin{array}{c}\text { Mor } \\
\text { fol } \\
\end{array}$ & $\begin{array}{l}\text { Uni } \\
\text { ón }\end{array}$ & \\
\hline PA 6-1 & 202 & 4 & & 0 & 1 & 2 & $2 \mathrm{y} 6$ & 3 y 4 & 2 & 6.7 & 5 & 1 & $x$ & $x$ & $10 \mathrm{R} 4 / 6,5 / 6$ (eng) & 7,5 YR $5 / 3,5 / 4$ & $x$ & $x$ & $x$ & $x$ & $x$ & $x$ & $x$ & $x$ & $x$ & $x$ & $x$ & $x$ & $x$ & $x$ & 3 \\
\hline PA 6-1 & 301 & 4 & & 0 & 1 & 2 & $2 \mathrm{y} 6$ & 3 y 4 & 2 & 7.3 & 6 & 1 & $x$ & $x$ & $10 \mathrm{R}$ 4/6, 5/6 (eng) & 7,5 YR $5 / 3,5 / 4$ & $x$ & $x$ & $\mathrm{x}$ & $x$ & $x$ & $x$ & $x$ & $x$ & $x$ & $x$ & $x$ & $x$ & $x$ & $x$ & 1,2 y 3 \\
\hline PA 6-1 & 302 & 4 & & 0 & 1 & 2 & $2 \mathrm{y} 6$ & 3 y 4 & 2 & 6.3 & 5 & 1 & $\mathrm{x}$ & $\mathrm{x}$ & 10 R 4/6, 5/6 (eng) & 7,5 YR $5 / 3,5 / 4$ & $\mathrm{x}$ & $\mathrm{x}$ & $x$ & $\mathrm{x}$ & $\mathrm{x}$ & $x$ & $x$ & $\mathrm{x}$ & $x$ & $x$ & $x$ & $\mathrm{x}$ & $x$ & $\mathrm{x}$ & 1,2 у 3 \\
\hline \begin{tabular}{|l|} 
PA 6-1 \\
\end{tabular} & 302 & 4 & & 0 & 1 & 2 & $2 \mathrm{y} 6$ & 3 y 4 & 2 & 5.5 & 5.5 & 1 & $\mathrm{x}$ & $x$ & 10 R 4/6, 5/6 (eng) & 7,5 YR $5 / 3,5 / 4$ & $x$ & $x$ & $x$ & $\mathrm{x}$ & $x$ & $x$ & $x$ & $x$ & $\mathrm{x}$ & $x$ & $\mathrm{x}$ & $x$ & $x$ & $x$ & 1 y 2,3 \\
\hline PA 6-1 & 302 & 4 & & 0 & 1 & 2 & $2 \mathrm{y} 6$ & 3 y 4 & 2 & 5.9 & 5.2 & 1 & $\mathrm{x}$ & $x$ & $10 \mathrm{R} 4 / 6,5 / 6$ (eng) & 7,5 YR $5 / 3,5 / 4$ & $x$ & $x$ & $x$ & $\mathrm{x}$ & $x$ & $x$ & $x$ & $x$ & $x$ & $x$ & $\mathrm{x}$ & $\mathrm{x}$ & $x$ & $x$ & \\
\hline \begin{tabular}{|l|} 
PA 6-1 \\
\end{tabular} & 202 & 4 & & 0 & 1 & 2 & $2 \mathrm{y} 6$ & 3 y 4 & 2 & 6.4 & 4.3 & 1 & $\mathrm{x}$ & $x$ & $10 \mathrm{R} 4 / 6,5 / 6$ (eng) & 7,5 YR $5 / 3,5 / 4$ & $x$ & $x$ & $x$ & $x$ & $x$ & $x$ & $x$ & $x$ & $x$ & $x$ & $x$ & $x$ & $x$ & $x$ & 3 y 5 \\
\hline PA 6-1 & 202 & 4 & & 0 & 1 & 2 & $2 \mathrm{y} 6$ & 3 y 4 & 2 & 6 & 5 & 1 & $x$ & $x$ & 10 R 4/6, 5/6 (eng) & 7,5 YR $5 / 3,5 / 4$ & $x$ & $x$ & $x$ & $x$ & $x$ & $x$ & $x$ & $x$ & $x$ & $x$ & $x$ & $x$ & $x$ & $x$ & 3 y 5 \\
\hline PA 6-1 & 101 & 4 & & 0 & 1 & 2 & $2 \mathrm{y} 6$ & 3 y 4 & 2 & 5.3 & 5.1 & 1 & $x$ & $x$ & $10 \mathrm{R}$ 4/6, 5/6 (eng) & 7,5 YR $5 / 3,5 / 4$ & $x$ & $x$ & $x$ & $x$ & $x$ & $x$ & $x$ & $x$ & $x$ & $x$ & $x$ & $x$ & $x$ & $x$ & 1 y 2,3 \\
\hline PA 6-1 & 202 & 4 & & 0 & 1 & 2 & $2 \mathrm{y} 6$ & 3 y 4 & 2 & 5.7 & 5.3 & 1 & $x$ & $x$ & 10 R 4/6, 5/6 (eng) & 7,5 YR $5 / 3,5 / 4$ & $x$ & $x$ & $x$ & $x$ & $x$ & $x$ & $x$ & $x$ & $x$ & $x$ & $x$ & $x$ & $x$ & $x$ & 3 y5 \\
\hline PA 6-1 & 103 & 4 & & 0 & 1 & 0 & $2 \mathrm{y} 6$ & 3 y 4 & 2 & 5.5 & 4.5 & 1 & $x$ & $x$ & 10 R 4/6, 5/6 (eng) & 7,5 YR $5 / 3,5 / 4$ & $x$ & $x$ & $x$ & $x$ & $x$ & $x$ & $\mathrm{x}$ & $\mathrm{x}$ & $x$ & $x$ & $x$ & $x$ & $x$ & $x$ & 1 y 2,3 \\
\hline PA 6-1 & 201 & 4 & & 0 & 1 & 0 & $2 \mathrm{y} 6$ & 3 y 4 & 2 & 5.2 & 4 & 1 & $x$ & $x$ & $10 \mathrm{R}$ 4/6, 5/6 (eng) & 7,5 YR $5 / 3,5 / 4$ & $x$ & $x$ & $x$ & $x$ & $x$ & $x$ & $x$ & $x$ & $x$ & $x$ & $x$ & $x$ & $x$ & $x$ & \\
\hline PA 6-1 & 202 & 4 & & 0 & 1 & 0 & $2 \mathrm{y} 6$ & 3 y 4 & 2 & 6.5 & 4.8 & 1 & $x$ & $x$ & $10 \mathrm{R} 4 / 6,5 / 6$ (eng) & 7,5 YR $5 / 3,5 / 4$ & $x$ & $x$ & $x$ & $\mathrm{x}$ & $x$ & $x$ & $x$ & $x$ & $x$ & $x$ & $x$ & $x$ & $x$ & $x$ & 1 \\
\hline PA 6-1 & 200 & 4 & & 0 & 1 & 0 & $2 \mathrm{y} 6$ & 3 y 4 & 2 & 5.1 & 4.9 & 1 & $\mathrm{x}$ & $x$ & $10 \mathrm{R} 4 / 6,5 / 6$ (eng) & 7,5 YR $5 / 3,5 / 4$ & $x$ & $x$ & $x$ & $x$ & $x$ & $x$ & $x$ & $x$ & $x$ & $x$ & $x$ & $x$ & $x$ & $x$ & \\
\hline PA 6-1 & 202 & 5 & & 1 & 0 & 1 & $2 \mathrm{y} 5$ & 2 & 2 & 8 & 6.7 & 0 & $x$ & PIN & $7,5 Y R$ 3/1, 4/1, 4/2, 5/3 & N 3/ & 26,8 & 6,7 & 8 & 2 & 2 & $x$ & $x$ & $x$ & $x$ & $x$ & $x$ & $x$ & $x$ & $x$ & 1 y 2 \\
\hline PA 6-1 & 202 & 5 & & 0 & 0 & 1 & $2 \mathrm{y} 5$ & 2 & 2 & 7.8 & 5.4 & 0 & $x$ & PIN & $7,5 Y R$ 3/1, 4/1, 4/2, 5/3 & $\mathrm{N} 3 /$ & $x$ & $x$ & $x$ & $x$ & $x$ & $x$ & $x$ & $x$ & $x$ & $x$ & $x$ & $x$ & $x$ & $x$ & 1 y 2 \\
\hline PA 6-1 & 112 & 5 & & 0 & 0 & 1 & $2 \mathrm{y} 5$ & 2 & 2 & 6.7 & 6 & 0 & $x$ & PIN & $7,5 Y R$ 3/1, 4/1, 4/2, 5/3 & $\mathrm{N} 3 /$ & $x$ & $x$ & $x$ & $x$ & $x$ & $x$ & $x$ & $x$ & $x$ & $x$ & $x$ & $x$ & $x$ & $x$ & 2 \\
\hline PA 6-1 & 302 & 5 & & 2 & 0 & 1 & $2 \mathrm{y} 5$ & 2 & 2 & 8.8 & 6.9 & 0 & $x$ & PIN & $7,5 Y R$ 3/1, 4/1, 4/2, 5/3 & $\mathrm{N} 3 /$ & $x$ & $x$ & $x$ & $x$ & $x$ & $x$ & $x$ & $x$ & $x$ & $x$ & $x$ & 12 & 5 & 2 & 3 \\
\hline PA 6-1 & 202 & 5 & & 2 & 0 & 1 & $2 \mathrm{y} 5$ & 2 & 2 & 6.8 & 6.5 & 0 & $\mathrm{x}$ & PIN & $7,5 Y R$ 3/1, 4/1, 4/2, 5/3 & $\mathrm{N} 3 /$ & $x$ & $x$ & $x$ & $\mathrm{x}$ & $x$ & $x$ & $x$ & $x$ & $x$ & $x$ & $\mathrm{x}$ & 12 & 5 & 2 & \\
\hline PA 6-1 & 202 & 5 & & 2 & 0 & 1 & $2 \mathrm{y} 5$ & 2 & 2 & 9 & 6.3 & 0 & $\mathrm{x}$ & PIN & $7,5 Y R$ 3/1, 4/1, 4/2, 5/3 & $\mathrm{N} 3 /$ & $x$ & $\mathrm{x}$ & $x$ & $\mathrm{x}$ & $x$ & $x$ & $x$ & $x$ & $x$ & $x$ & $x$ & 12 & 5 & 2 & 3 \\
\hline PA 6-1 & 202 & 5 & & 0 & 0 & 1 & $2 \mathrm{y} 5$ & 2 & 2 & 7 & 6.4 & 0 & $x$ & PIN & 7,5 YR $3 / 1,4 / 1,4 / 2,5 / 3$ & $\mathrm{~N} 3 /$ & $x$ & $x$ & $x$ & $x$ & $x$ & $x$ & $x$ & $x$ & $x$ & $x$ & $x$ & $x$ & $x$ & $x$ & \\
\hline PA 6-1 & 101 & 5 & & 0 & 0 & 1 & $2 \mathrm{y} 5$ & 2 & 2 & 7.5 & 6.4 & 0 & $x$ & PIN & $7,5 Y R$ 3/1, 4/1, 4/2, 5/3 & $\mathrm{N} 3 /$ & $\mathrm{x}$ & $x$ & $x$ & $x$ & $\mathrm{x}$ & $x$ & $\mathrm{x}$ & $\mathrm{x}$ & $x$ & $x$ & $x$ & $x$ & $x$ & $x$ & 3 \\
\hline PA 6-1 & 202 & 6 & & 1 & 1 & 1 & $1 \mathrm{y} 6$ & 2 y 4 & 2 & 8.2 & 5.5 & 1 & $x$ & Yavi & 10R 5/4 (eng), 7,5YR 7/4 & $7,5 Y R 7 / 4$ & 14,9 & 5,1 & 10,9 & 1 & 2 & $x$ & $x$ & $x$ & $x$ & $x$ & $x$ & $x$ & $x$ & $x$ & 5 \\
\hline PA 6-1 & 302 & 6 & & 1 & 1 & 1 & $1 \mathrm{y} 6$ & 2 y 4 & 2 & 6.2 & 5.5 & 1 & $x$ & Yavi & 10R 5/4 (eng), 7,5YR 7/4 & $7,5 Y R$ 7/5 & 16,3 & 4,1 & 8 & 1 & 2 & $x$ & $x$ & $x$ & $x$ & $x$ & $x$ & $x$ & $x$ & $x$ & 5 \\
\hline PA 6-1 & 302 & 6 & & 2 & 1 & 1 & $1 \mathrm{y} 6$ & 2 y 4 & 2 & 13 & 6.4 & 1 & $\mathrm{x}$ & Yavi & 10R 5/4 (eng), 7,5YR 7/4 & 7,5YR 7/6 & $x$ & $x$ & $x$ & $\mathrm{x}$ & $x$ & $x$ & $x$ & $x$ & $\mathrm{x}$ & $x$ & $x$ & 8,6 & 5 & 2 & 1 y 5 \\
\hline PA 6-1 & 202 & 7 & & 1 & 0 & 1 & 2 & 3 & 3 & 5.5 & 4.4 & 0 & $x$ & PINP & $\mathrm{N} 3 /, 5 \mathrm{YR} 4 / 1$ & N 3/; 5YR 5/1 & 17,8 & 4 & 7,2 & 2 & 2 & $x$ & $x$ & $x$ & $x$ & $x$ & $x$ & $x$ & $x$ & $x$ & \\
\hline PA 6-1 & 202 & 7 & & 1 & 0 & 1 & 2 & 3 & 3 & 4.6 & 4.3 & 0 & $x$ & PINP & N 3/, 5YR 4/2 & N 3/; 5YR 5/2 & 17,8 & 4 & 7,2 & 2 & 2 & $x$ & $x$ & $\mathrm{x}$ & $x$ & $x$ & $x$ & $x$ & $x$ & $x$ & \\
\hline PA 6-1 & 202 & 7 & & 0 & 0 & 1 & 2 & 3 & 3 & 5.5 & 5.2 & 0 & $x$ & PINP & $\mathrm{N} 3 /, 5 \mathrm{YR} 4 / 3$ & N 3/; 5YR 5/3 & $x$ & $x$ & $x$ & $x$ & $x$ & $x$ & $x$ & $x$ & $x$ & $x$ & $x$ & $x$ & $x$ & $x$ & \\
\hline PA 6-1 & 201 & 8 & & 0 & 0 & 0 & 2 & 3 y 4 & $3,4 y 2$ & 6.5 & 5.4 & 1 & $\mathrm{x}$ & Yavi & 10R 4/6, 5/6 (eng) & 10R 4/6, 5YR 6/4 & $\mathrm{x}$ & $\mathrm{x}$ & $x$ & $\mathrm{x}$ & $x$ & $x$ & $\mathrm{x}$ & $x$ & $\mathrm{x}$ & $\mathrm{x}$ & $\mathrm{x}$ & $\mathrm{x}$ & $\mathrm{x}$ & $\mathrm{x}$ & 4 \\
\hline PA 6-1 & 301 & 8 & & 0 & 0 & 0 & 2 & 3 y 4 & 3 y 4 & 7 & 6 & 1 & $x$ & Yavi & 10R 4/6, 5/6 (eng) & 10R 4/6, 5YR 6/5 & $x$ & $x$ & $x$ & $x$ & $x$ & $x$ & $x$ & $x$ & $x$ & $x$ & $x$ & $x$ & $x$ & $x$ & \\
\hline PA 6-1 & 202 & & 1 & 1 & 0 & 1 & 1 & 2 y 6 & 2 & 6.7 & 4.7 & 1 & $\mathrm{x}$ & $x$ & 2,5YR 5/6 (pint), 5YR 6/4 & $5 Y R 5 / 3$ & indet & 4 & indet & 2 & 3 & $x$ & $x$ & $x$ & $x$ & $\mathrm{x}$ & $\mathrm{x}$ & $x$ & $x$ & $x$ & 4 y 5 \\
\hline PA 6-1 & 202 & & 2 & 1 & 0 & 1 & 1 & 2 & 3 & 5.3 & 4.9 & 0 & $x$ & $x$ & 7,5 YR $5 / 3$ & 7,5 YR $5 / 3$ & indet & 2 & indet & 2 & 1 & $x$ & $x$ & $x$ & $x$ & $x$ & $x$ & $x$ & $x$ & $x$ & \\
\hline PA 6-1 & 202 & & 3 & 1 & 0 & 0 & 0 & 2 & 2 & 4.8 & 4.6 & 0 & $x$ & $x$ & 7,5YR 5/4 & 7,5YR 5/4 & indet & 1,3 & indet & 1 & 4 & $x$ & $x$ & $x$ & $x$ & $x$ & $x$ & $x$ & $x$ & $x$ & \\
\hline PA 6-1 & 202 & & 4 & 0 & 0 & 1 & 0 & 2 & 3 & 6.7 & 4.9 & 0 & $x$ & $x$ & $5 Y R$ 5/4 & 5YR2,5/1 & $x$ & $x$ & $x$ & $x$ & $x$ & $x$ & $x$ & $x$ & $x$ & $x$ & $x$ & $x$ & $x$ & $x$ & \\
\hline PA 6-1 & 302 & & 5 & 0 & 0 & 0 & 0 & 2 & 2 & 5.8 & 3.8 & 0 & $x$ & $x$ & N 3/ & $5 Y R$ 5/4 & $x$ & $x$ & $x$ & $x$ & $x$ & $x$ & $x$ & $x$ & $x$ & $x$ & $x$ & $x$ & $x$ & $x$ & \\
\hline PA 6-1 & Sup & & 6 & 1 & 0 & 2 & 0 & 2 & 3 y 4 & 7.8 & 5.6 & 1 & $\mathrm{x}$ & Yavi & $5 Y R 5 / 4$ & 2,5YR 5/6 (eng) & 19,2 & 4,1 & 6,8 & 1 & 2 & $x$ & $x$ & $x$ & $x$ & $x$ & $x$ & $x$ & $x$ & $x$ & \\
\hline PA 6-1 & Sup & & 7 & 1 & 0 & 1 & 0 & 2 & 2 & 7.1 & 5 & 0 & $\mathrm{x}$ & $x$ & 2,5 YR $4 / 4$ & 5 Yr 5/1, 5/2 & indet & 3,7 & indet & 1 & 2 & $x$ & $x$ & $x$ & $x$ & $x$ & $x$ & $x$ & $x$ & $x$ & \\
\hline PA 6-1 & Sup & & 8 & 1 & 0 & 2 & 0 & 2 & 2 & 8.6 & 6.2 & 0 & $x$ & $x$ & 7,5 YR $6 / 3$ & 7,5YR 6/3 & indet & 2 & indet & 1 & 2 & $x$ & $x$ & $x$ & $x$ & $x$ & $x$ & $x$ & $x$ & $x$ & 3 \\
\hline PA 6-1 & Sup & & 9 & 1 & 0 & 1 & 1 & 2 & 2 & 4.7 & 4.2 & 0 & $x$ & $x$ & $\mathrm{~N} 4 \mathrm{I}$ & 7,5YR 5/2 & indet & 3,1 & indet & 2 & 1 & $x$ & $x$ & $x$ & $x$ & $x$ & $x$ & $x$ & $x$ & $x$ & \\
\hline PA 6-1 & Sup & & 10 & 1 & 0 & 1 & 0 & 2 & 2 & 6.7 & 6.2 & 0 & $x$ & $x$ & $\mathrm{~N} 3 /$ & N 3/ & indet & 1,8 & indet & 1 & 1 & $x$ & $x$ & $x$ & $x$ & $x$ & $x$ & $x$ & $x$ & $x$ & \\
\hline PA 6-1 & Sup & & 11 & 1 & 0 & 0 & 0 & 3 y 4 & 2 & 8.7 & 6.8 & 1 & $x$ & $x$ & 10R 4/4 (eng); 2,5YR 4/2 & $2,5 Y R 5 / 3$ & indet & 1,5 & indet & 0 & 1 & $x$ & $x$ & $x$ & $x$ & $x$ & $x$ & $x$ & $x$ & $x$ & 5 \\
\hline
\end{tabular}




\begin{tabular}{|c|c|c|c|c|c|c|c|c|c|c|c|c|c|c|c|c|c|c|c|c|c|c|c|c|c|c|c|c|c|c|c|}
\hline \multirow[b]{2}{*}{ Sitio } & \multirow[b]{2}{*}{ UP } & \multirow[b]{2}{*}{$\mathrm{GF}$} & & & \multicolumn{10}{|c|}{ Manufactura } & \multicolumn{2}{|c|}{ Cocción } & \multicolumn{5}{|c|}{ Borde-labio } & \multicolumn{6}{|c|}{ Asa } & \multicolumn{3}{|c|}{ Base } & \multirow[b]{2}{*}{ Alterac } \\
\hline & & & FNA & Fgto & \begin{tabular}{|l} 
Tec \\
lev \\
\end{tabular} & & & Sup & $\begin{array}{c}\text { Sup } \\
\text { int }\end{array}$ & $\begin{array}{l}\text { Esp } \\
\max \end{array}$ & $\begin{array}{l}\text { Esp } \\
\text { min }\end{array}$ & $\begin{array}{l}\begin{array}{l}\text { eeco } \\
\text { pint }\end{array} \\
\end{array}$ & \begin{tabular}{|c|} 
Moti \\
vo \\
\end{tabular} & $\begin{array}{c}\text { Esti } \\
\text { lo }\end{array}$ & Color sup ext & Color sup int & Diam & $\begin{array}{l}\text { Lrg } \\
\text { arc }\end{array}$ & $\begin{array}{c}\% \\
\text { arco }\end{array}$ & Direc & $\begin{array}{l}\text { cor } \\
\text { ma }\end{array}$ & $\begin{array}{l}\text { Lar } \\
\text { go }\end{array}$ & $\begin{array}{c}\text { An } \\
\text { cho }\end{array}$ & \begin{tabular}{l|l} 
& Esp \\
\end{tabular} & $\begin{array}{l}\text { Sec } \\
\text { ción }\end{array}$ & $\begin{array}{l}\text { In } \\
\text { serc }\end{array}$ & $\begin{array}{l}\begin{array}{l}\text { Posi } \\
\text { ción }\end{array} \\
\end{array}$ & Diám & $\begin{array}{c}\text { Mor } \\
\text { fol } \\
\end{array}$ & $\begin{array}{l}\text { Uni } \\
\text { ón }\end{array}$ & \\
\hline PA 6-1 & Sup & & 12 & 2 & 0 & 0 & 10 & 2 & 2 & 13.5 & 7.8 & 0 & $x$ & $x$ & $5 Y R \quad 4 / 4,5 / 4$ & 5YR 5/4 & $x$ & $x$ & $x$ & $x$ & $x$ & $x$ & $x$ & $x$ & $x$ & $x$ & $x$ & 12,8 & 0 & 0 & \\
\hline PA 6-1 & Sup & & 13 & 3 & 0 & 1 & 8 & 2 & 2 & 7.3 & 7 & 0 & $x$ & $x$ & $5 Y R$ 5/3 & $5 Y R$ 6/3 & $x$ & $x$ & $x$ & $x$ & $x$ & 7,4 & 3.2 & \begin{tabular}{|l|l|}
2 & 1,7 \\
\end{tabular} & 2 & 4 & 1 & $x$ & $x$ & $x$ & \\
\hline PA 6-1 & Sup & & 14 & 3 & 0 & 0 & 0 & 2 & 2 & indet & indet & $\begin{array}{ll}\mathrm{t} & 0\end{array}$ & $x$ & $x$ & $5 Y R 5 / 3,5 / 4$ & $x$ & $x$ & $x$ & $x$ & $x$ & $x$ & $5,7 \mathrm{fr}$ & 2.4 & \begin{tabular}{|l|l|}
4 & 1.8 \\
\end{tabular} & 2 & 0 & 0 & $x$ & $x$ & $x$ & \\
\hline PA 6-1 & Sup & & 15 & 4 & 0 & 0 & 0 & 2 & 2 & 6.8 & 5.4 & 0 & $\mathrm{x}$ & $\mathrm{x}$ & $5 Y R 6 / 4$ & $5 Y R 6 / 4$ & $\mathrm{x}$ & $\mathrm{x}$ & $\mathrm{x}$ & $\mathrm{x}$ & $\mathrm{x}$ & $x$ & $\mathrm{x}$ & $\mathrm{x}$ & $\mathrm{x}$ & $x$ & $\mathrm{x}$ & $\mathrm{x}$ & $\mathrm{x}$ & $\mathrm{x}$ & 3 \\
\hline \begin{tabular}{|l|} 
PA 6-1 \\
\end{tabular} & Sup & & 16 & 0 & 2 & 0 & 5 & 2 y 6 & 2 & 9.1 & 5 & 1 & $x$ & $x$ & 10R 4/6 (pint); 5YR 6/4, 5/4 & $5 Y R$ 5/4, 6/4 & $x$ & $\mathrm{x}$ & $\mathrm{x}$ & $x$ & $x$ & $x$ & $\mathrm{x}$ & $x$ & $x$ & $x$ & $\mathrm{x}$ & $x$ & $x$ & $\mathrm{x}$ & 3 y 5 \\
\hline PA 6-1 & Sup & & 17 & 0 & 0 & 0 & 0 & 2 y 6 & 2 & 8.3 & 7 & 1 & $\mathrm{x}$ & $\mathrm{x}$ & $5 Y R 6 / 4,5 / 4$ & $5 Y R$ 5/4, 6/4 & $x$ & $x$ & $x$ & $\mathrm{x}$ & $x$ & $x$ & $x$ & $\mathrm{x}$ & $\mathrm{x}$ & $x$ & $x$ & $x$ & $\mathrm{x}$ & $x$ & 3 y 5 \\
\hline PA 6-1 & Sup & & 18 & 0 & 0 & 0 & 0 & 2 y 4 & 2 & 5.1 & 3 & 1 & $\mathrm{x}$ & $\mathrm{x}$ & 10R 4/4 (eng); 5YR 5/4 & $5 Y R \quad 6 / 4$ & $\mathrm{x}$ & $\mathrm{x}$ & $\mathrm{x}$ & $x$ & $\mathrm{x}$ & $x$ & $x$ & $x$ & $\mathrm{x}$ & $x$ & $x$ & $x$ & $\mathrm{x}$ & $x$ & 5 \\
\hline PA 6-1 & Sup & & 19 & 0 & 0 & 0 & 0 & 2 y 4 & 2 & 4.7 & 3 & 1 & $x$ & $x$ & 10R 4/4 (eng); 5YR 5/4 & $5 Y R 6 / 4$ & $x$ & $x$ & $x$ & $x$ & $x$ & $x$ & $x$ & $x$ & $x$ & $x$ & $x$ & $x$ & $x$ & $x$ & 5 \\
\hline PA 6-1 & Sup & & 20 & 0 & 0 & 0 & 2 & 3 y 4 & 3 & 6.3 & 5 & 1 & $x$ & Yavi & 10R 4/4, 4/6 (eng) & $2,5 Y R$ 5/4, 5/6 & $x$ & $x$ & $x$ & $x$ & $x$ & $x$ & $x$ & $x$ & $x$ & $x$ & $x$ & $x$ & $x$ & $x$ & \\
\hline PA 6-1 & Sup & & 21 & 0 & 0 & 0 & 2 & 3 y 4 & 2 & 5.9 & 5.5 & 1 & $x$ & Yavi & $10 \mathrm{R} 4 / 4,4 / 6$ (eng) & 2,5 YR 5/6 & $x$ & $x$ & $x$ & $x$ & $x$ & $x$ & $x$ & $x$ & $x$ & $x$ & $x$ & $x$ & $x$ & $x$ & \\
\hline PA 6-1 & Sup & & 22 & 0 & 0 & 0 & 0 & 3 y 4 & 3 & 5.5 & 5.2 & 1 & $\mathrm{x}$ & Yavi & 10R 5/4 (eng) & 2,5 YR $6 / 4$ & $\mathrm{x}$ & $x$ & $\mathrm{x}$ & $\mathrm{x}$ & $\mathrm{x}$ & $x$ & $\mathrm{x}$ & $\mathrm{x}$ & $\mathrm{x}$ & $x$ & $\mathrm{x}$ & $\mathrm{x}$ & $\mathrm{x}$ & $\mathrm{x}$ & 3 \\
\hline PA 6-1 & Sup & & 23 & 0 & 2 & 0 & 5 & 2 y 6 & 2 & 8.5 & 4.7 & 1 & $x$ & $x$ & 10R 4/6 (pint); 2,5YR 6/4 & 2,5 YR $5 / 4,6 / 4$ & $x$ & $\mathrm{x}$ & $\mathrm{x}$ & $\mathrm{x}$ & $x$ & $x$ & $x$ & $\mathrm{x}$ & $x$ & $x$ & $x$ & $\mathrm{x}$ & $x$ & $x$ & 3 y 5 \\
\hline PA 6-1 & Sup & & 24 & 0 & 0 & 0 & 0 & 2 & 1 & 7.2 & 5.8 & 0 & $x$ & $x$ & $5 Y R 5 / 3,5 / 4$ & $5 Y R 6 / 3,6 / 4$ & $x$ & $x$ & $x$ & $x$ & $x$ & $x$ & $x$ & $x$ & $x$ & $x$ & $x$ & $x$ & $x$ & $x$ & 3 y 4 \\
\hline PA 6-1 & Sup & & 25 & 0 & 0 & 0 & 0 & 2 & 2 & 9.1 & 6 & 0 & $\mathrm{x}$ & $\mathrm{x}$ & $5 Y R 6 / 4,5 / 4$ & 5YR 6/4 & $x$ & $x$ & $x$ & $\mathrm{x}$ & $\mathrm{x}$ & $x$ & $x$ & $\mathrm{x}$ & $\mathrm{x}$ & $x$ & $\mathrm{x}$ & $\mathrm{x}$ & $\mathrm{x}$ & $x$ & \\
\hline PA 6-1 & Sup & & 26 & 0 & 0 & 0 & 0 & 2 & 2 & 7.5 & 6.4 & 0 & $x$ & $x$ & $5 Y R$ 5/1, 5/2, 5/3 & $5 Y R$ 5/3, 5/4, 4/3 & $x$ & $x$ & $x$ & $x$ & $x$ & $x$ & $x$ & $x$ & $x$ & $x$ & $x$ & $x$ & $x$ & $x$ & \\
\hline PA 6-1 & Sup & & 27 & 0 & 0 & 0 & 0 & 2 & 1 & 6.2 & 4.5 & 0 & $x$ & $x$ & $5 Y R \quad 4 / 3,4 / 1,5 / 3$ & 5YR 5/2 & $x$ & $x$ & $x$ & $x$ & $x$ & $x$ & $x$ & $x$ & $x$ & $x$ & $x$ & $x$ & $x$ & $x$ & \\
\hline PA 6-1 & Sup & & 28 & 0 & 0 & 0 & 0 & 2 & 2 & 7.5 & 6.6 & 0 & $x$ & $x$ & $5 Y R 5 / 4$ & 5YR 6/3 & $x$ & $x$ & $x$ & $x$ & $x$ & $x$ & $x$ & $x$ & $x$ & $x$ & $x$ & $x$ & $x$ & $x$ & 4 \\
\hline PA 6-1 & Sup & & 29 & 0 & 0 & 0 & 0 & 2 & 2 & 5.6 & 4 & 0 & $x$ & $x$ & $5 Y R \quad 4 / 1,5 / 2,5 / 3$ & 5YR 5/3 & $x$ & $x$ & $x$ & $x$ & $x$ & $x$ & $x$ & $x$ & $x$ & $x$ & $x$ & $x$ & $x$ & $x$ & 3 \\
\hline PA 6-1 & Sup & & 30 & 0 & 0 & 0 & 0 & 2 & 2 & 5.7 & 4.1 & 0 & $\mathrm{x}$ & $x$ & $5 Y R$ 5/4, 5/6 & $5 Y R 6 / 3$ & $x$ & $\mathrm{x}$ & $\mathrm{x}$ & $\mathrm{x}$ & $x$ & $x$ & $\mathrm{x}$ & $x$ & $x$ & $x$ & $x$ & $x$ & $x$ & $\mathrm{x}$ & \\
\hline PA 6-1 & Sup & & 31 & 0 & 0 & 0 & 5 & 2 & 2 & 9.1 & 5.6 & 0 & $x$ & $x$ & $5 Y R \quad 6 / 4,5 / 4$ & $5 Y R$ 6/3, 6/4 & $x$ & $x$ & $x$ & $\mathrm{x}$ & $x$ & $x$ & $x$ & $\mathrm{x}$ & $x$ & $x$ & $x$ & $x$ & $x$ & $x$ & 3 \\
\hline PA 6-1 & Sup & & 32 & 0 & 0 & 0 & 0 & 2 & 2 & 8 & 5.2 & 0 & $x$ & $x$ & 7,5 YR $6 / 3,4 / 3$ & 7,5 YR 6/3 & $x$ & $x$ & $x$ & $x$ & $x$ & $x$ & $x$ & $x$ & $x$ & $x$ & $x$ & $x$ & $x$ & $x$ & 3 y 4 \\
\hline PA 6-1 & Sup & & 33 & 0 & 0 & 0 & 1 & 2 & 2 & 7.3 & 4.4 & 0 & $x$ & $x$ & $5 Y R$ 5/4, 6/4 & 5YR 5/4 & $x$ & $x$ & $x$ & $x$ & $x$ & $x$ & $x$ & $x$ & $x$ & $x$ & $x$ & $x$ & $x$ & $x$ & \\
\hline PA 6-1 & Sup & & 34 & 0 & 0 & 0 & 0 & 2 & 2 & 7 & 5.8 & 0 & $x$ & $x$ & $\mathrm{~N} 3 /$ y $4 /$ & 5YR 6/4 & $x$ & $x$ & $x$ & $x$ & $x$ & $x$ & $x$ & $x$ & $x$ & $x$ & $x$ & $x$ & $x$ & $x$ & 1 \\
\hline PA 6-1 & Sup & & 35 & 0 & 0 & 0 & 0 & 2 & 2 & 7.8 & 5.4 & 0 & $x$ & $x$ & 5YR 4/1 & 5YR 6/4 & $x$ & $x$ & $x$ & $x$ & $x$ & $x$ & $x$ & $x$ & $x$ & $x$ & $x$ & $x$ & $x$ & $x$ & 1 \\
\hline PA 6-1 & Sup & & 36 & 0 & 0 & 0 & 0 & 2 & 2 & 9.8 & 6.7 & 0 & $x$ & $\mathrm{x}$ & 2,5YR 4/4, 3/1 & 2,5 YR 5/4 & $x$ & $x$ & $x$ & $x$ & $x$ & $x$ & $x$ & $x$ & $x$ & $x$ & $x$ & $x$ & $x$ & $x$ & 1 \\
\hline PA 6-1 & Sup & & 37 & 0 & 0 & 0 & 0 & 2 & 2 & 8 & 6.5 & 0 & $x$ & $x$ & $5 Y R 5 / 3$ & $5 Y R 5 / 4$ & $x$ & $x$ & $x$ & $x$ & $x$ & $x$ & $x$ & $x$ & $x$ & $x$ & $x$ & $x$ & $x$ & $x$ & 3 y 4 \\
\hline PA 6-1 & Sup & & 38 & 0 & 0 & 0 & 0 & 2 & 2 & 6.3 & 5.1 & 0 & $\mathrm{x}$ & $\mathrm{x}$ & $2,5 Y R$ 5/2, 5/3, 4/3 & $5 Y R$ 5/3 & $x$ & $\mathrm{x}$ & $x$ & $x$ & $x$ & $x$ & $x$ & $\mathrm{x}$ & $\mathrm{x}$ & $x$ & $x$ & $x$ & $x$ & $x$ & 4 \\
\hline PA 6-1 & Sup & & 39 & 0 & 0 & 0 & 0 & 2 & 2 & 6.2 & 5 & 0 & $x$ & $x$ & $5 Y R$ 5/4 & $5 Y R$ 5/2 & $x$ & $x$ & $x$ & $x$ & $x$ & $x$ & $x$ & $x$ & $x$ & $x$ & $x$ & $x$ & $x$ & $x$ & \\
\hline PA 6-1 & Sup & & 40 & 0 & 0 & 0 & 0 & 2 & 2 & 6 & 4.5 & 0 & $\mathrm{x}$ & $x$ & $5 Y R$ 5/2, 5/3 & $5 Y R$ 5/2, 5/3 & $x$ & $x$ & $x$ & $x$ & $x$ & $x$ & $x$ & $x$ & $x$ & $x$ & $\mathrm{x}$ & $x$ & $x$ & $x$ & \\
\hline PA 6-1 & Sup & & 41 & 0 & 0 & 0 & 0 & 2 & 2 & 7.1 & 4.4 & 0 & $x$ & $x$ & 5YR 5/3 & 5YR 5/4 & $x$ & $x$ & $x$ & $x$ & $x$ & $x$ & $x$ & $x$ & $x$ & $x$ & $x$ & $x$ & $x$ & $x$ & \\
\hline PA 6-1 & Sup & & 42 & 0 & 0 & 0 & 0 & 2 & 2 & 7.8 & 6.3 & 0 & $x$ & $x$ & $5 Y R 6 / 3$ & 5YR 6/4 & $x$ & $x$ & $x$ & $x$ & $x$ & $x$ & $x$ & $x$ & $x$ & $x$ & $x$ & $x$ & $x$ & $x$ & 3 \\
\hline PA 6-1 & Sup & & 43 & 0 & 0 & 0 & 0 & 2 & 2 & 5.9 & 5 & 0 & $\mathrm{x}$ & $\mathrm{x}$ & $5 Y R \quad 4 / 2,4 / 3$ & 7,5YR 5/2 & $\mathrm{x}$ & $\mathrm{x}$ & $x$ & $\mathrm{x}$ & $\mathrm{x}$ & $x$ & $\mathrm{x}$ & $\mathrm{x}$ & $\mathrm{x}$ & $x$ & $\mathrm{x}$ & $\mathrm{x}$ & $\mathrm{x}$ & $\mathrm{x}$ & 3 \\
\hline PA 6-1 & Sup & & 44 & 0 & 0 & 0 & 1 & 2 & 2 & 7.4 & 5.6 & 0 & $x$ & $x$ & $5 Y R$ 5/4, 5/3 & 2,5 YR 5/4 & $x$ & $x$ & $x$ & $x$ & $x$ & $x$ & $x$ & $x$ & $x$ & $x$ & $x$ & $x$ & $x$ & $x$ & \\
\hline PA 6-1 & Sup & & 45 & 0 & 0 & 0 & 0 & 2 & 2 & 8 & 5.8 & 0 & $x$ & $x$ & $5 Y R$ 5/3, 5/2 & 2,5 YR 5/4 & $x$ & $x$ & $x$ & $x$ & $x$ & $x$ & $x$ & $x$ & $x$ & $x$ & $x$ & $x$ & $x$ & $x$ & 3 \\
\hline PA 6-1 & Sup & & 46 & 0 & 0 & 0 & 0 & 2 & 2 & 7.8 & 5.3 & 0 & $x$ & $x$ & $5 Y R \quad 4 / 3,5 / 4$ & 5YR 5/4 & $x$ & $x$ & $x$ & $x$ & $x$ & $x$ & $x$ & $x$ & $x$ & $x$ & $x$ & $x$ & $x$ & $x$ & 3 \\
\hline PA 6-1 & Sup & & 47 & 0 & 0 & 0 & 0 & 2 & 2 & 10 & 9 & 0 & $x$ & $x$ & $5 Y R$ 5/3 & $5 Y R 5 / 3$ & $x$ & $x$ & $x$ & $x$ & $x$ & $x$ & $x$ & $x$ & $x$ & $x$ & $x$ & $x$ & $x$ & $x$ & 3 \\
\hline PA 6-1 & Sup & & 48 & 0 & 0 & 0 & 1 & 2 & 2 & 8.3 & 6.6 & 0 & $x$ & $x$ & $5 Y R 6 / 3$ & 5YR 5/4 & $x$ & $x$ & $x$ & $x$ & $x$ & $x$ & $x$ & $x$ & $x$ & $x$ & $x$ & $x$ & $x$ & $x$ & \\
\hline PA 6-1 & Sup & & 49 & 0 & 0 & 0 & 0 & 2 & 2 & 9 & 6.9 & 0 & $x$ & $x$ & 5YR 5/3 & $5 Y R 5 / 3,5 / 2$ & $x$ & $x$ & $x$ & $x$ & $x$ & $x$ & $x$ & $x$ & $x$ & $x$ & $x$ & $x$ & $x$ & $x$ & 3 \\
\hline PA 6-1 & Sup & & 50 & 0 & 0 & 0 & 1 & 2 & 2 & 8 & 5.3 & 0 & $x$ & $x$ & 5YR 5/4 & 5YR 5/3 & $x$ & $x$ & $x$ & $x$ & $x$ & $x$ & $x$ & $x$ & $x$ & $x$ & $x$ & $x$ & $x$ & $x$ & 3 \\
\hline PA 6-1 & Sup & & 51 & 0 & 0 & 0 & 1 & 2 & 2 & 5.6 & 4.2 & 0 & $x$ & $x$ & $\mathrm{~N} 3 /$ & $5 Y R$ 5/1, 5/2 & $x$ & $x$ & $x$ & $x$ & $x$ & $x$ & $x$ & $x$ & $x$ & $x$ & $x$ & $x$ & $x$ & $x$ & 3 \\
\hline PA 6-1 & Sup & & 52 & 0 & 0 & 0 & 0 & 2 & 2 & 5.6 & 4.1 & 0 & $\mathrm{x}$ & $\mathrm{x}$ & $2,5 Y R 5 / 1,4 / 2,4 / 4$ & $5 Y R \quad 4 / 1,5 / 2$ & $\mathrm{x}$ & $x$ & $x$ & $x$ & $x$ & $x$ & $x$ & $x$ & $x$ & $x$ & $x$ & $x$ & $x$ & $x$ & 3 \\
\hline
\end{tabular}




\begin{tabular}{|c|c|c|c|c|c|c|c|c|c|c|c|c|c|c|c|c|c|c|c|c|c|c|c|c|c|c|c|c|c|c|c|c|}
\hline \multirow[b]{2}{*}{ Sitio } & \multirow[b]{2}{*}{ UP } & \multirow[b]{2}{*}{ GF } & & & \multicolumn{10}{|c|}{ Manufactura } & \multicolumn{2}{|c|}{ Cocción } & \multicolumn{5}{|c|}{ Borde-labio } & \multicolumn{7}{|c|}{ Asa } & \multicolumn{3}{|c|}{ Base } & \multirow[b]{2}{*}{ Alterac } \\
\hline & & & FNA & Fgto & \begin{tabular}{|l} 
Tec \\
lev \\
\end{tabular} & & & \begin{tabular}{|l} 
Sup \\
ext
\end{tabular} & $\begin{array}{c}\text { Sup } \\
\text { int }\end{array}$ & $\begin{array}{l}\text { Esp } \\
\text { max }\end{array}$ & $\begin{array}{l}\text { Esp } \\
\text { min } \\
\end{array}$ & $\begin{array}{c}\text { Deco } \\
\text { pint } \\
\end{array}$ & \begin{tabular}{|c|} 
Moti \\
vo \\
\end{tabular} & \begin{tabular}{|c|}
$\begin{array}{c}\text { Esti } \\
\text { lo }\end{array}$ \\
\end{tabular} & Color sup ext & Color sup int & Diam & $\begin{array}{l}\text { Lrg } \\
\text { arc }\end{array}$ & \begin{tabular}{|c|}
$\%$ \\
arco \\
\end{tabular} & Direc & $\begin{array}{l}\text { For } \\
\text { ma }\end{array}$ & $\begin{array}{l}\mathrm{La} \\
\mathrm{go}\end{array}$ & 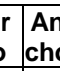 & \begin{tabular}{l|l}
$n$ & Es \\
no & Es \\
\end{tabular} & & \begin{tabular}{l|} 
Sec \\
ción
\end{tabular} & \begin{tabular}{|l|} 
In \\
serc \\
\end{tabular} & $\begin{array}{l}\text { Posi } \\
\text { ción }\end{array}$ & Diám & \begin{tabular}{|c|}
$\begin{array}{c}\text { Mor } \\
\text { fol }\end{array}$ \\
\end{tabular} & \begin{tabular}{|l|} 
Uni \\
ón
\end{tabular} & \\
\hline PA 6-1 & Sup & & 53 & 0 & 0 & 0 & 0 & 2 & 2 & 6.2 & 4.6 & 0 & $x$ & $x$ & $2,5 Y R 5 / 4,5 / 6$ & 2,5 YR $5 / 2$ & $x$ & $x$ & $x$ & $x$ & $x$ & $\mathrm{x}$ & $\mathrm{x}$ & $x$ & $x$ & $x$ & $x$ & $x$ & $x$ & $x$ & $x$ & \\
\hline PA 6-1 & Sup & & 54 & 0 & 0 & 0 & 0 & 2 & 2 & 6.8 & 5.1 & 0 & $x$ & $x$ & 2,5YR 5/4 & 2,5 YR 5/4 & $x$ & $x$ & $x$ & $x$ & $x$ & $x$ & $x$ & $x$ & $x$ & $\mathrm{x}$ & $x$ & $x$ & $x$ & $x$ & $x$ & \\
\hline PA 6-1 & Sup & & 55 & 0 & 0 & 0 & 0 & 2 & 2 & 7.1 & 6.3 & 0 & $x$ & $x$ & 2,5 YR $5 / 1,5 / 2$ & $2,5 Y R 5 / 4$ & $x$ & $x$ & $x$ & $x$ & $x$ & $x$ & $x$ & $x$ & $x$ & $x$ & $x$ & $x$ & $x$ & $x$ & $x$ & \\
\hline PA 6-1 & Sup & & 56 & 0 & 0 & 0 & 0 & 2 & 2 & 6.1 & 4.6 & 0 & $x$ & $x$ & $5 Y R$ 5/2, 5/3 & $5 Y R$ 5/3, 5/4 & $x$ & $x$ & $x$ & $x$ & $x$ & $x$ & $\mathrm{x}$ & $x$ & $x$ & $x$ & $x$ & $x$ & $x$ & $x$ & $x$ & 3 \\
\hline PA 6-1 & Sup & & 57 & 0 & 0 & 0 & 0 & 2 & 2 & 6.3 & 5.5 & 0 & $x$ & $x$ & N 3/; 5YR 5/2 & $5 Y R$ 5/3, 6/3 & $x$ & $x$ & $x$ & $x$ & $x$ & $x$ & $\mathrm{x}$ & $x$ & $x$ & $\mathrm{x}$ & $x$ & $x$ & $x$ & $x$ & $x$ & 1 \\
\hline PA 6-1 & Sup & & 58 & 0 & 0 & 0 & 0 & 2 & 2 & 7.3 & 6.5 & 0 & $x$ & $x$ & $5 Y R$ 4/1, 5/4 & 5YR 5/4 & $x$ & $x$ & $x$ & $x$ & $x$ & $x$ & $x$ & $x$ & $x$ & $x$ & $x$ & $x$ & $x$ & $x$ & $x$ & \\
\hline PA 6-1 & Sup & & 59 & 0 & 0 & 1 & 0 & 2 & 1 & 6.6 & 5.7 & 0 & $\mathrm{x}$ & PINP & 2,5YR 5/6 & $\mathrm{N} 4 /$ & $x$ & $x$ & $x$ & $x$ & $x$ & $x$ & $\mathrm{x}$ & $x$ & $x$ & $x$ & $x$ & $x$ & $x$ & $x$ & $x$ & \\
\hline PA 6-1 & Sup & & 60 & 0 & 0 & 0 & 0 & 1 & 2 & 7.3 & 5.6 & 0 & $x$ & $x$ & $5 Y R$ 6/3 & N 3/ & $x$ & $x$ & $x$ & $x$ & $x$ & $\mathrm{x}$ & $x$ & $x$ & $x$ & $x$ & $x$ & $x$ & $x$ & $x$ & $x$ & 3 y 4 \\
\hline PA 6-1 & Sup & & 61 & 0 & 0 & 0 & 0 & 2 & 2 & 8.2 & 7.7 & 0 & $x$ & $x$ & 5YR 5/4 & 7,5YR 6/3 & $x$ & $x$ & $x$ & $x$ & $x$ & $x$ & $x$ & $x$ & $x$ & $\mathrm{x}$ & $x$ & $x$ & $x$ & $x$ & $x$ & 3 y 4 \\
\hline PA 6-1 & Sup & & 62 & 0 & 0 & 0 & 0 & 2 & 2 & 5.5 & 5 & 0 & $x$ & $x$ & 5YR 5/4 & 5YR 5/2 & $x$ & $x$ & $x$ & $x$ & $x$ & $x$ & $x$ & $x$ & $x$ & $x$ & $x$ & $x$ & $x$ & $x$ & $x$ & \\
\hline PA 6-1 & Sup & & 63 & 0 & 0 & 0 & 0 & 2 & 2 & 8.1 & 7.1 & 0 & $x$ & $x$ & 5YR 4/1 & 5YR 5/4 & $x$ & $x$ & $x$ & $x$ & $x$ & $x$ & $x$ & $x$ & $x$ & $x$ & $x$ & $x$ & $x$ & $x$ & $x$ & 3 \\
\hline PA 6-1 & Sup & & 64 & 0 & 0 & 0 & 0 & 2 & 2 & 5.6 & 5.1 & 0 & $x$ & $x$ & 5YR 5/4 & 5YR 3/1 & $x$ & $x$ & $x$ & $x$ & $x$ & $x$ & $x$ & $x$ & $x$ & $x$ & $x$ & $x$ & $x$ & $x$ & $x$ & \\
\hline \begin{tabular}{|l|} 
PA 6-1 \\
\end{tabular} & Sup & & 65 & 0 & 0 & 0 & 0 & 2 & 2 & 7.7 & 5.5 & 0 & $x$ & $x$ & 5YR 6/4 & $\mathrm{N} \mathrm{4/}$ & $x$ & $x$ & $x$ & $x$ & $x$ & $x$ & $x$ & $x$ & $x$ & $x$ & $x$ & $x$ & $x$ & $x$ & $x$ & 3 \\
\hline PA 6-1 & Sup & & 66 & 0 & 0 & 0 & 0 & 2 & 2 & 6.5 & 5.2 & 0 & $x$ & $x$ & $2,5 Y R \quad 4 / 2,5 / 4$ & $5 Y R 6 / 2$ & $x$ & $x$ & $x$ & $x$ & $x$ & $x$ & $\mathrm{x}$ & $x$ & $x$ & $x$ & $x$ & $x$ & $x$ & $x$ & $x$ & 3 y 4 \\
\hline PA 6-1 & Sup & & 67 & 0 & 0 & 0 & 0 & 2 & 2 & 4.9 & 4.8 & 0 & $x$ & $x$ & 5YR 6/3 & 5YR 6/3 & $x$ & $x$ & $x$ & $x$ & $\mathrm{x}$ & $\mathrm{x}$ & $\mathrm{x}$ & $x$ & $x$ & $\mathrm{x}$ & $x$ & $\mathrm{x}$ & $\mathrm{x}$ & $x$ & $x$ & \\
\hline PA 6-1 & Sup & & 68 & 0 & 0 & 0 & 0 & 2 & 2 & 7.2 & 6.5 & 0 & $x$ & $x$ & 5YR 6/4 & 5YR 6/4 & $x$ & $x$ & $x$ & $x$ & $x$ & $x$ & $x$ & $x$ & $x$ & $x$ & $x$ & $x$ & $x$ & $x$ & $x$ & 3 \\
\hline PA 6-1 & Sup & & 69 & 0 & 0 & 0 & 0 & 2 & 2 & 7 & 6.2 & 0 & $x$ & $x$ & $5 Y R$ 5/4, 5/6 & $5 Y R$ 5/4, 5/6 & $x$ & $x$ & $x$ & $x$ & $x$ & $x$ & $x$ & $x$ & $x$ & $x$ & $x$ & $x$ & $x$ & $x$ & $x$ & 3 \\
\hline PA 6-1 & Sup & & 70 & 0 & 0 & 0 & 0 & 1 & 1 & 6.2 & 5 & 0 & $x$ & $x$ & 5YR 6/4 & 5YR 5/4 & $x$ & $x$ & $x$ & $x$ & $x$ & $x$ & $\mathrm{x}$ & $x$ & $x$ & $x$ & $x$ & $x$ & $x$ & $x$ & $x$ & 3 y 4 \\
\hline PA 6-1 & Sup & & 71 & 0 & 0 & 0 & 0 & 2 & 2 & 5.8 & 5.3 & 0 & $x$ & $x$ & $5 Y R$ 5/3 & $5 Y R$ 5/4 & $x$ & $x$ & $x$ & $x$ & $x$ & $\mathrm{x}$ & $\mathrm{x}$ & $x$ & $x$ & $x$ & $x$ & $x$ & $x$ & $x$ & $x$ & \\
\hline PA 6-1 & Sup & & 72 & 0 & 0 & 0 & 0 & 2 & 2 & 6.3 & 5.3 & 0 & $x$ & $x$ & $5 Y R$ 6/4 & 5YR 6/3 & $x$ & $x$ & $x$ & $x$ & $x$ & $x$ & $x$ & $x$ & $x$ & $\mathrm{x}$ & $x$ & $x$ & $x$ & $x$ & $x$ & \\
\hline PA 6-1 & Sup & & 73 & 0 & 0 & 0 & 0 & 2 & 2 & 6.5 & 5.6 & 0 & $x$ & $x$ & $5 Y R$ 6/4 & $5 Y R$ 6/3 & $x$ & $x$ & $x$ & $x$ & $x$ & $x$ & $x$ & $x$ & $x$ & $x$ & $x$ & $x$ & $x$ & $x$ & $x$ & 3 \\
\hline PA 6-1 & Sup & & 74 & 0 & 0 & 0 & 0 & 2 & 2 & 6.2 & 5.6 & 0 & $x$ & $x$ & 5YR 5/4 & 5YR 5/4 & $x$ & $x$ & $x$ & $x$ & $x$ & $x$ & $x$ & $x$ & $x$ & $\mathrm{x}$ & $x$ & $x$ & $x$ & $x$ & $x$ & 3 y 4 \\
\hline PA 6-1 & Sup & & 75 & 0 & 0 & 0 & 0 & 2 & 2 & 5.8 & 5.3 & 0 & $x$ & $x$ & 5YR 5/2 & 5YR 5/3 & $x$ & $x$ & $x$ & $x$ & $x$ & $x$ & $x$ & $\underline{x}$ & $x$ & $x$ & $x$ & $x$ & $x$ & $x$ & $x$ & 3 \\
\hline PA 6-1 & Sup & & 76 & 0 & 0 & 0 & 0 & 2 & 2 & 6.5 & 5 & 0 & $x$ & $x$ & $5 Y R 5 / 3$ & 2,5 YR 5/4 & $x$ & $x$ & $x$ & $x$ & $x$ & $x$ & $x$ & $x$ & $x$ & $x$ & $x$ & $x$ & $x$ & $x$ & $x$ & 3 y 4 \\
\hline PA 6-1 & Sup & & 77 & 0 & 0 & 0 & 0 & 2 & 1 & 6.6 & 5.4 & 0 & $x$ & $x$ & $5 Y R$ 5/3 & $5 Y R$ 5/4 & $x$ & $x$ & $x$ & $x$ & $x$ & $x$ & $\mathrm{x}$ & $x$ & $x$ & $\mathrm{x}$ & $x$ & $x$ & $x$ & $x$ & $x$ & 3 \\
\hline PA 6-1 & Sup & & 78 & 0 & 0 & 0 & 0 & 2 & 2 & 7.5 & \begin{tabular}{|l|}
6.7 \\
\end{tabular} & 0 & $x$ & $x$ & $5 Y R$ 5/3 & $5 Y$ YR 5/4 & $x$ & $x$ & $x$ & $x$ & $x$ & $\mathrm{x}$ & $\mathrm{x}$ & $\mathrm{x}$ & $x$ & $x$ & $x$ & $x$ & $x$ & $x$ & $x$ & \\
\hline PA 6-1 & Sup & & 79 & 0 & 0 & 0 & 0 & 2 & 2 & 8.1 & 6.8 & 0 & $x$ & $x$ & $5 Y R$ 4/1, 4/2 & 2,5 YR $5 / 6$ & $x$ & $x$ & $x$ & $x$ & $x$ & $x$ & $x$ & $x$ & $x$ & $x$ & $x$ & $x$ & $x$ & $x$ & $x$ & \\
\hline PA 6-1 & Sup & & 80 & 0 & 0 & 0 & 0 & 2 & 2 & 6.3 & 4.2 & 0 & $x$ & $x$ & $5 Y R$ 6/4, 5/4 & $5 Y R 6 / 3$ & $x$ & $x$ & $x$ & $x$ & $x$ & $x$ & $x$ & $x$ & $x$ & $x$ & $x$ & $x$ & $x$ & $x$ & $x$ & \\
\hline PA 6-1 & Sup & & 81 & 0 & 0 & 0 & 0 & 2 & 2 & 5.3 & 4.4 & 0 & $x$ & $x$ & 5YR 5/4 & 5YR 5/4 & $x$ & $x$ & $x$ & $x$ & $x$ & $x$ & $x$ & $x$ & $x$ & $x$ & $x$ & $x$ & $x$ & $x$ & $x$ & 3 \\
\hline PA 6-1 & Sup & & 82 & 0 & 0 & 0 & 0 & 2 & 2 & 7.1 & 5.6 & 0 & $\mathrm{x}$ & $x$ & 5YR 5/4 & $5 Y R$ 5/3 & $x$ & $x$ & $x$ & $\mathrm{x}$ & $x$ & $x$ & $\mathrm{x}$ & $x$ & $x$ & $x$ & $x$ & $x$ & $\mathrm{x}$ & $x$ & $x$ & \\
\hline PA 6-1 & Sup & & 83 & 0 & 0 & 0 & 0 & 2 & 2 & 9.4 & 7 & 0 & $x$ & $x$ & 5YR 5/4 & 5YR 5/3 & $x$ & $x$ & $x$ & $x$ & $x$ & $x$ & $x$ & $x$ & $x$ & $x$ & $x$ & $x$ & $x$ & $x$ & $x$ & 3 \\
\hline PA 6-1 & Sup & & 84 & 0 & 0 & 0 & 0 & 2 & 2 & 6.4 & 5.3 & 0 & $x$ & $x$ & 5 YR 5/3 & 5YR 5/4 & $x$ & $x$ & $x$ & $x$ & $x$ & $x$ & $x$ & $x$ & $x$ & $x$ & $x$ & $x$ & $x$ & $x$ & $x$ & 3 \\
\hline PA 6-1 & Sup & & 85 & 0 & 0 & 0 & 0 & 2 & 2 & 7.7 & 7.4 & 0 & $x$ & $x$ & $5 Y R$ 5/4 & $5 Y R 6 / 3$ & $x$ & $x$ & $x$ & $x$ & $x$ & $x$ & $\mathrm{x}$ & $x$ & $x$ & $x$ & $x$ & $x$ & $x$ & $x$ & $x$ & \\
\hline PA 6-1 & Sup & & 86 & 0 & 0 & 0 & 0 & 2 & 1 & 7.2 & 6.3 & 0 & $x$ & $x$ & $\mathrm{~N} 4 /$ & 5YR 5/3 & $x$ & $x$ & $x$ & $x$ & $x$ & $x$ & $x$ & $x$ & $x$ & $x$ & $x$ & $x$ & $x$ & $x$ & $x$ & 3 \\
\hline PA 6-1 & Sup & & 87 & 0 & 0 & 0 & 0 & 2 & 2 & 7.2 & 4.9 & 0 & $x$ & $x$ & 5YR 5/4 & 5YR 5/4 & $x$ & $x$ & $x$ & $x$ & $x$ & $x$ & $x$ & $x$ & $x$ & $x$ & $x$ & $x$ & $x$ & $x$ & $x$ & \\
\hline PA 6-1 & Sup & & 88 & 0 & 0 & 0 & 0 & 2 & 2 & 8.7 & 6.6 & 0 & $x$ & $x$ & 5YR 4/1 & $5 Y R$ 5/2 & $x$ & $x$ & $x$ & $x$ & $x$ & $x$ & $x$ & $x$ & $x$ & $x$ & $x$ & $x$ & $x$ & $x$ & $x$ & 3 \\
\hline PA 6-1 & Sup & & 89 & 0 & 0 & 0 & 0 & 2 & 2 & 7 & 6 & 0 & $x$ & $x$ & $5 Y R$ 5/2 & $5 Y R$ 5/3 & $x$ & $x$ & $x$ & $x$ & $x$ & $x$ & $x$ & $x$ & $x$ & $x$ & $x$ & $x$ & $x$ & $x$ & $x$ & \\
\hline PA 6-1 & Sup & & 90 & 0 & 0 & 0 & 0 & 2 & 2 & 6 & 4.8 & 0 & $x$ & $x$ & $5 Y R \quad 4 / 2$ & $5 Y R 5 / 3$ & $x$ & $x$ & $x$ & $x$ & $x$ & $x$ & $x$ & $x$ & $x$ & $x$ & $x$ & $x$ & $x$ & $x$ & $x$ & 3 \\
\hline \begin{tabular}{|l|} 
PA 6-1 \\
\end{tabular} & Sup & & 91 & 0 & 0 & 0 & 0 & 2 & 2 & 7.1 & 6.3 & 0 & $x$ & $x$ & 5YR 5/4 & $5 Y R 5 / 3$ & $x$ & $x$ & $x$ & $x$ & $x$ & $x$ & $x$ & $x$ & $x$ & $x$ & $x$ & $x$ & $x$ & $x$ & $x$ & 3 \\
\hline PA 6-1 & Sup & & 92 & 0 & 0 & 0 & 0 & 2 & 2 & 4 & 3.7 & 0 & $x$ & $x$ & $5 Y R$ 5/4 & 5YR 5/1 & $x$ & $x$ & $x$ & $x$ & $x$ & $x$ & $\mathrm{x}$ & $x$ & $x$ & $x$ & $x$ & $x$ & $x$ & $x$ & $x$ & \\
\hline PA 6-1 & Sup & & 93 & 0 & 0 & 0 & 0 & 2 & 2 & 5.4 & 5 & 0 & $x$ & $x$ & 5YR 5/3 & $5 Y R$ 5/3 & $x$ & $x$ & $x$ & $x$ & $x$ & $x$ & $x$ & $x$ & $x$ & $x$ & $x$ & $x$ & $x$ & $x$ & $x$ & \\
\hline
\end{tabular}




\section{Manufactura}

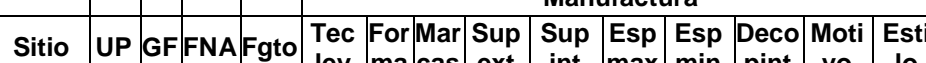

\begin{tabular}{|l|l|l|l|l|l|l|l|l|l|l|l|}
\hline PA 6-1 Sup & 94 & 0 & 0 & 0 & 0 & 2 & 2 & 6 & 4.2 & 0 & $x$ \\
\hline
\end{tabular} \begin{tabular}{llllllll|l|l|l|l|l}
94 & 0 & 0 & 0 & 0 & 2 & 2 & 6 & 4.2 & 0 \\
\hline 95 & 0 & 0 & 0 & 0 & 2 & 2 & 5 & 3.9 & 0 \\
\hline
\end{tabular} PA 6-1 Sup

PA 6-1 Sup

PA 6-1 Sup

PA 6-1 Sup

PA 6-1 Sup

\begin{tabular}{|c|c|c|c|c|c|c|c|c|c}
95 & 0 & 0 & 0 & 0 & 2 & 2 & 5 & 3.9 & 0 \\
\hline 96 & 0 & 0 & 0 & 0 & 1 & 2 & 5.6 & 4.1 & 0 \\
97 & 0 & 0 & 0 & 0 & 2 & 2 & 5.4 & 4.8 & 0 \\
98 & 0 & 0 & 0 & 0 & 2 & 2 & 5.4 & 4.7 & 0 \\
99 & 0 & 0 & 0 & 0 & 2 & 2 & 4.7 & 4.6 & 0 \\
100 & 0 & 0 & 0 & 0 & 2 & 2 & 5.5 & 5.1 & 0
\end{tabular}

\begin{tabular}{c|c|c}
99 & 0 \\
\hline 100 & 0 \\
\hline
\end{tabular}

Cocción 5YR 5/4 5YR 4/3

5YR 5/4 5YR 5/3 5YR 5/3 5YR 5/4 5YR 4/4

\section{Borde-labio}

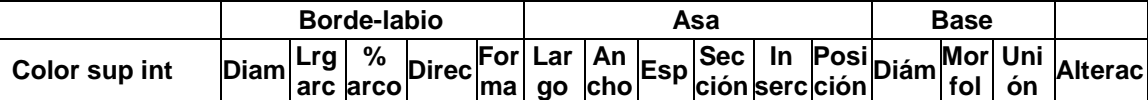

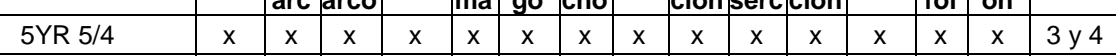
\begin{tabular}{|l|l|l|l|l|l|l|l|l|l|l|l|l|l|l|c|}
\hline 5YR $5 / 2$ & $\mathrm{x}$ & $\mathrm{x}$ & $\mathrm{x}$ & $\mathrm{x}$ & $\mathrm{x}$ & $\mathrm{x}$ & $\mathrm{x}$ & $\mathrm{x}$ & $\mathrm{x}$ & $\mathrm{x}$ & $\mathrm{x}$ & $\mathrm{x}$ & $\mathrm{x}$ & $\mathrm{x}$ & 3 \\
\hline
\end{tabular} \begin{tabular}{|l|l|l|l|l|l|l|l|l|l|l|l|l|l|l|l|} 
5YR 6/2 & $\mathrm{x}$ & $\mathrm{x}$ & $\mathrm{x}$ & $\mathrm{x}$ & $\mathrm{x}$ & $\mathrm{x}$ & $\mathrm{x}$ & $\mathrm{x}$ & $\mathrm{x}$ & $\mathrm{x}$ & $\mathrm{x}$ & $\mathrm{x}$ & $\mathrm{x}$ & $\mathrm{x}$ & $3 \mathrm{y} 4$ \\
\hline
\end{tabular} \begin{tabular}{|l|c|c|c|c|c|c|c|c|c|c|c|c|c|c|c|} 
5YR 5/4 & $x$ & $x$ & $x$ & $x$ & $x$ & $x$ & $x$ & $x$ & $x$ & $x$ & $x$ & $x$ & $x$ & $x$ & 3 \\
\hline
\end{tabular} \begin{tabular}{|l|l|l|l|l|l|l|l|l|l|l|l|l|l|l|l|} 
5YR 5/4 & $\mathrm{x}$ & $\mathrm{x}$ & $\mathrm{x}$ & $\mathrm{x}$ & $\mathrm{x}$ & $\mathrm{x}$ & $\mathrm{x}$ & $\mathrm{x}$ & $\mathrm{x}$ & $\mathrm{x}$ & $\mathrm{x}$ & $\mathrm{x}$ & $\mathrm{x}$ & $\mathrm{x}$ & 3 \\
\hline
\end{tabular} $5 Y R 5 / 4$ 5YR 5/4

Manufactura

Cocción Borde-labio Asa Base

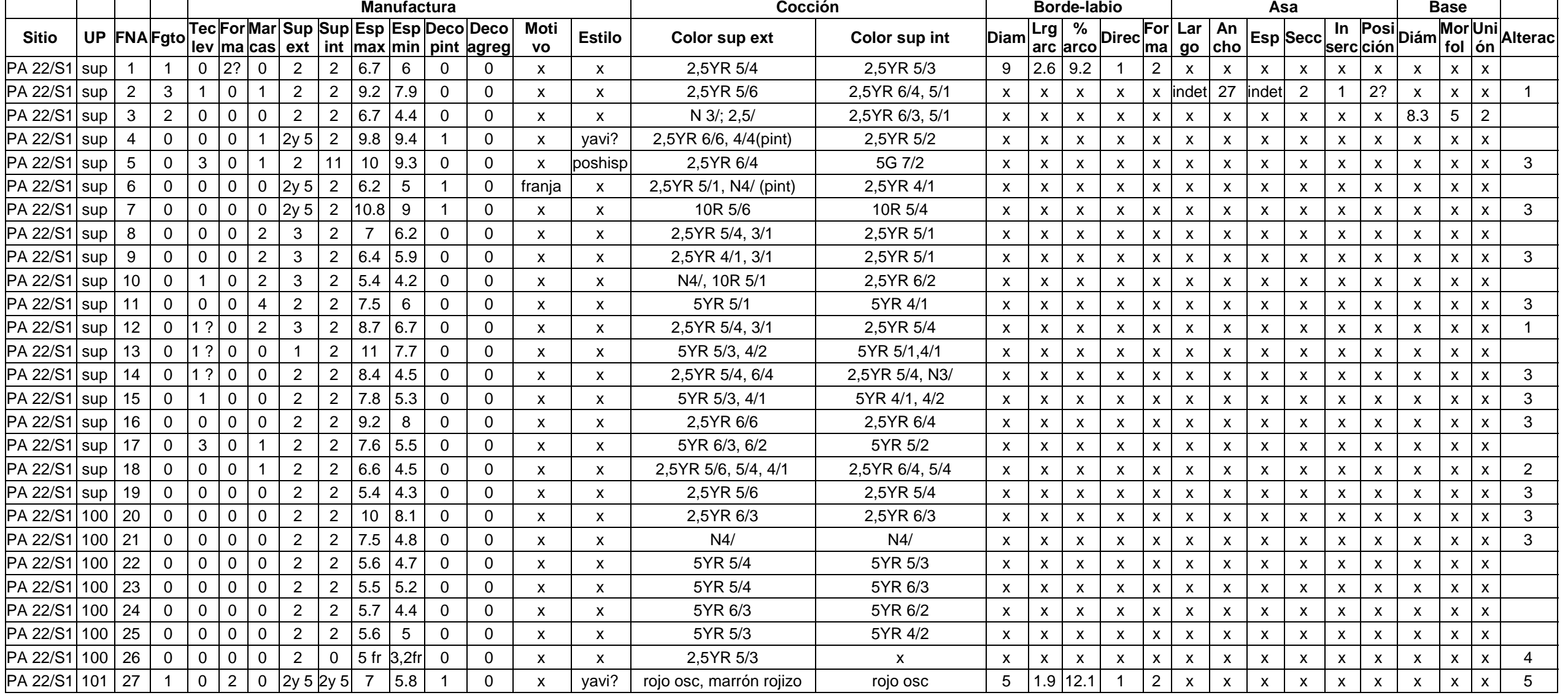

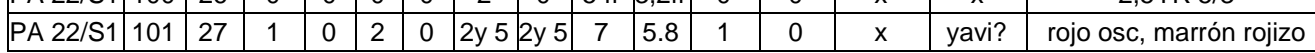




\begin{tabular}{|c|c|c|c|c|c|c|c|c|c|c|c|c|c|c|c|c|c|c|c|c|c|c|c|c|c|c|c|c|c|c|c|}
\hline \multirow[b]{2}{*}{ Sitio } & \multirow[b]{2}{*}{ UP } & \multirow[b]{2}{*}{ FNA } & \multirow[b]{2}{*}{ Fgto } & \multicolumn{11}{|c|}{ Manufactura } & \multicolumn{2}{|c|}{ Cocción } & \multicolumn{5}{|c|}{ Borde-labio } & \multicolumn{6}{|c|}{ Asa } & \multicolumn{3}{|c|}{ Base } & \multirow[b]{2}{*}{ Alterac } \\
\hline & & & & \begin{tabular}{|l|} 
Tec \\
lev \\
\end{tabular} & $\mid \begin{array}{c}\text { For } \\
\text { ma }\end{array}$ & \begin{tabular}{|l|} 
Mar \\
cas
\end{tabular} & $\begin{array}{c}\text { Sup } \\
\text { ext }\end{array}$ & \begin{tabular}{|c|} 
Sup \\
int
\end{tabular} & $\begin{array}{l}\text { Esp } \\
\text { max }\end{array}$ & $\begin{array}{l}\begin{array}{l}\text { Esp } \\
\text { min }\end{array} \\
\end{array}$ & \begin{tabular}{|c|} 
Deco \\
pint
\end{tabular} & \begin{tabular}{|l|} 
Deco \\
agreg
\end{tabular} & $\begin{array}{c}\text { Moti } \\
\text { vo }\end{array}$ & Estilo & Color sup ext & Color sup int & Diam & \begin{tabular}{|l|} 
Lrg \\
arc \\
\end{tabular} & \begin{tabular}{|c|}
$\%$ \\
arco \\
\end{tabular} & Direc ${ }_{n}^{F}$ & \begin{tabular}{|l|}
$\begin{array}{c}\text { For } \\
\text { ma }\end{array}$ \\
\end{tabular} & $\begin{array}{c}\text { Lar } \\
\text { go }\end{array}$ & $\begin{array}{c}\text { An } \\
\text { cho }\end{array}$ & Esp & $\operatorname{secc}$ s & $\begin{array}{l}\text { In } \\
\text { serc }\end{array}$ & $\begin{array}{l}\text { Posi } \\
\text { ción }\end{array} \mid$ & Diám & \begin{tabular}{|c|} 
Mor \\
fol
\end{tabular} & Uni & \\
\hline PA 22/S1 & 101 & 28 & 1 & 1 & 1 & \begin{tabular}{|l|}
1 \\
\end{tabular} & 2 & 2 & 9.6 & \begin{tabular}{|l|}
7 \\
\end{tabular} & 0 & 0 & $x$ & $x$ & gris & marron grisaceo & 23.2 & 4.4 & 6 & 2 & 1 & $x$ & $x$ & $\mathrm{x}$ & $x$ & $x$ & $x$ & $x$ & $x$ & $x$ & 3 \\
\hline PA 22/S1 & 101 & 29 & 1 & 0 & 0 & 0 & 2 & 2 & 7.6 & 6.8 & 0 & 0 & $x$ & $x$ & marron grisáceo & marron grisaceo & indet & 1.7 & indet & 2 & 1 & $x$ & $\mathrm{x}$ & $x$ & $\mathrm{x}$ & $\mathrm{x}$ & $x$ & $x$ & $\mathrm{x}$ & $\mathrm{x}$ & 3 \\
\hline PA 22/S1 & 101 & 30 & 1 & 0 & $2 ?$ & 0 & 2 & 3 & 6.2 & 5.6 & 0 & 0 & $x$ & $x$ & gris claro & gris & 11.2 & 2.2 & 6.25 & 1 & 2 & $x$ & $x$ & $x$ & $x$ & $x$ & $x$ & $x$ & $x$ & $x$ & \\
\hline PA 22/S1 & 101 & 31 & 3 & 0 & 0 & 0 & 2 & $x$ & 8.8 & 7.2 & 0 & 0 & $x$ & $x$ & marrón rojizo & $x$ & $x$ & $x$ & $x$ & $x$ & $x$ & $4 \mathrm{fr}$ & 18 & 8 & 4 & 0 & 0 & $x$ & $x$ & $\mathrm{x}$ & \\
\hline PA 22/S1 & 101 & 32 & 4 & 0 & 2 & 2 & 2 & 3 & 8.5 & 7.4 & 0 & 0 & $x$ & $\mathrm{x}$ & marrón rojizo & gris & $x$ & $x$ & $x$ & $x$ & $\mathrm{x}$ & $\mathrm{x}$ & $x$ & $x$ & $x$ & $x$ & $x$ & $x$ & $x$ & $\mathrm{x}$ & \\
\hline PA 22/S1 & 101 & 33 & 0 & 0 & 0 & 1 & 2 & 2 & 9 & 7.6 & 0 & 0 & $x$ & $x$ & marron & marron & $x$ & $x$ & $x$ & $x$ & $x$ & $x$ & $x$ & $x$ & $x$ & $x$ & $x$ & $x$ & $x$ & $x$ & \\
\hline PA 22/S1 & 101 & 34 & 0 & 0 & 0 & 0 & 2 & 2 & 7.7 & 6 & 0 & 0 & $x$ & $x$ & rojo marrón & gris osc & $x$ & $x$ & $x$ & $x$ & $\mathrm{x}$ & $x$ & $x$ & $x$ & $x$ & $x$ & $x$ & $x$ & $x$ & $\mathrm{x}$ & 3 \\
\hline PA 22/S1 & 101 & 35 & 0 & 0 & 0 & 0 & 2 & 2 & 6.9 & 5.8 & 0 & 0 & $x$ & $x$ & marrón rojizo & marrón rojizo & $x$ & $x$ & $x$ & $x$ & $x$ & $x$ & $x$ & $x$ & $x$ & $x$ & $x$ & $x$ & $x$ & $\mathrm{x}$ & 3 \\
\hline PA 22/S1 & 101 & 36 & 0 & 0 & 0 & 0 & 2 & 2 & 7.5 & 6.4 & 0 & 0 & $x$ & $x$ & rojo marrón & marrón rojizo & $x$ & $x$ & $x$ & $x$ & $x$ & $x$ & $x$ & $x$ & $x$ & $x$ & $x$ & $x$ & $x$ & $\mathrm{x}$ & 3 \\
\hline PA 22/S1 & 101 & 37 & 0 & 0 & 0 & 0 & 2 & 2 & 6.7 & 5 & 0 & 0 & $x$ & $x$ & marron & gris, marrón rojizo & $x$ & $x$ & $x$ & $x$ & $x$ & $x$ & $x$ & $x$ & $x$ & $x$ & $x$ & $x$ & $x$ & $x$ & 3 \\
\hline PA 22/S1 & 101 & 38 & 0 & 0 & 0 & 0 & $2 y 5$ & 2 & 6.6 & 5.7 & 1 & 0 & $x$ & $x$ & rojo, marrón rojizo & marrón rojizo & $x$ & $x$ & $x$ & $x$ & $x$ & $x$ & $x$ & $x$ & $x$ & $x$ & $x$ & $x$ & $x$ & $\mathrm{x}$ & \\
\hline PA 22/S1 & 101 & 39 & 0 & 0 & 0 & 0 & 2 & 2 & 6.7 & 5.5 & 0 & 0 & $x$ & $x$ & marrón rojizo & marrón rojizo & $x$ & $x$ & $x$ & $x$ & $x$ & $x$ & $x$ & $x$ & $x$ & $x$ & $x$ & $x$ & $x$ & $\mathrm{x}$ & 3 \\
\hline PA 22/S1 & 101 & 40 & 0 & 0 & 0 & 0 & 2 & 2 & 4.5 & 4 & 0 & 0 & $x$ & $x$ & marrón rojizo & gris & $x$ & $x$ & $x$ & $x$ & $x$ & $x$ & $x$ & $x$ & $x$ & $x$ & $x$ & $x$ & $x$ & $\mathrm{x}$ & \\
\hline PA 22/S1 & 101 & 41 & 0 & $3 ?$ & 0 & 1 & 2 & 2 & 5.4 & 5 & 0 & 0 & $x$ & $x$ & marrón rojizo & marrón rojizo & $x$ & $x$ & $x$ & $x$ & $x$ & $x$ & $x$ & $x$ & $x$ & $x$ & $x$ & $x$ & $x$ & $\mathrm{x}$ & \\
\hline PA 22/S1 & 101 & 42 & 0 & 0 & 0 & 0 & 2 & 2 & 4 & 3.5 & 0 & 0 & $x$ & $x$ & marrón rojizo & gris osc & $x$ & $x$ & $x$ & $x$ & $\mathrm{x}$ & $x$ & $x$ & $x$ & $x$ & $x$ & $x$ & $x$ & $x$ & $\mathrm{x}$ & \\
\hline PA 22/S1 & 101 & 43 & 0 & 0 & 0 & 0 & 2 & 2 & 5 & 3.9 & 0 & 0 & $x$ & $x$ & gris, marrón rojizo & marrón rojizo & $x$ & $x$ & $x$ & $x$ & $x$ & $x$ & $x$ & $x$ & $x$ & $x$ & $x$ & $x$ & $x$ & $\mathrm{x}$ & \\
\hline PA 22/S1 & 101 & 45 & 0 & 0 & 0 & 1 & 2 & 2 & 4.3 & 3.8 & 0 & 0 & $x$ & $x$ & marrón rojizo & gris osc & $x$ & $x$ & $x$ & $x$ & $\mathrm{x}$ & $x$ & $x$ & $x$ & $x$ & $x$ & $x$ & $x$ & $x$ & $\mathrm{x}$ & \\
\hline PA 22/S1 & 101 & 46 & 0 & $3 ?$ & 0 & 1 & $2 y 5$ & 2 & 5.3 & 4.8 & 1 & 0 & $x$ & $x$ & rojo y marrón rojizo & marrón rojizo & $x$ & $x$ & $x$ & $x$ & $x$ & $x$ & $x$ & $x$ & $x$ & $x$ & $x$ & $x$ & $x$ & $\mathrm{x}$ & 3 \\
\hline PA 22/S1 & 101 & 47 & 0 & 0 & 0 & 0 & 2 & 2 & 5.4 & 5 & 0 & 0 & $x$ & $x$ & marron osc & marron rojizo claro & $x$ & $x$ & $x$ & $x$ & $\mathrm{x}$ & $x$ & $x$ & $x$ & $x$ & $x$ & $x$ & $x$ & $x$ & $\mathrm{x}$ & 3 \\
\hline PA 22/S1 & 101 & 48 & 0 & 0 & 0 & 0 & 2 & 2 & 5.5 & 5 & 0 & 0 & $x$ & $x$ & marrón rojizo & marron & $x$ & $x$ & $x$ & $x$ & $x$ & $x$ & $x$ & $x$ & $x$ & $x$ & $x$ & $x$ & $x$ & $\mathrm{x}$ & \\
\hline PA 22/S1 & 101 & 49 & 0 & 0 & 0 & 0 & 2 & $x$ & $6 \mathrm{fr}$ & $5 \mathrm{fr}$ & 0 & 0 & $x$ & $x$ & marrón rojizo & $x$ & $x$ & $x$ & $x$ & $x$ & $x$ & $x$ & $x$ & $x$ & $x$ & $x$ & $x$ & $x$ & $x$ & $\mathrm{x}$ & 4 \\
\hline PA 22/S1 & 101 & 50 & 0 & 0 & 0 & 1 & 2 & 2 & 6.8 & 6.3 & 0 & 0 & $x$ & $x$ & gris & marrón rojizo & $x$ & $x$ & $x$ & $x$ & $x$ & $x$ & $x$ & $x$ & $x$ & $x$ & $x$ & $x$ & $x$ & $\mathrm{x}$ & 3 \\
\hline PA 22/S1 & 101 & 51 & 0 & 0 & 0 & 0 & 2 & 2 & 8 & 6.5 & 0 & 0 & $x$ & $x$ & gris osc & gris osc & $x$ & $x$ & $x$ & $x$ & $x$ & $x$ & $x$ & $x$ & $x$ & $x$ & $x$ & $x$ & $x$ & $\mathrm{x}$ & \\
\hline PA 22/S1 & 101 & 52 & 0 & 0 & 0 & 0 & 2 & 2 & 7.8 & 7.2 & 0 & 0 & $x$ & $x$ & gris osc & negro & $x$ & $x$ & $x$ & $x$ & $x$ & $x$ & $x$ & $x$ & $x$ & $x$ & $x$ & $x$ & $x$ & $\mathrm{x}$ & 2 \\
\hline PA 22/S1 & 101 & 53 & 0 & 0 & 0 & 0 & 2 & 2 & 5 & 4.1 & 0 & 0 & $x$ & $x$ & rojo y negro (depos) & gris osc & $x$ & $x$ & $x$ & $x$ & $\mathrm{x}$ & $x$ & $x$ & $x$ & $x$ & $x$ & $x$ & $x$ & $x$ & $\mathrm{x}$ & 2 \\
\hline PA 22/S1 & 101 & 54 & 0 & 0 & 0 & 0 & 2 & 2 & 7.6 & 6.9 & 0 & 0 & $x$ & $x$ & gris rojizo & marron grisaceo & $x$ & $x$ & $x$ & $x$ & $x$ & $x$ & $x$ & $x$ & $x$ & $x$ & $x$ & $x$ & $x$ & $x$ & \\
\hline PA 22/S1 & 101 & 55 & 0 & 0 & 0 & 1 & 2 & 2 & 7 & 5.3 & 0 & 0 & $x$ & $x$ & gris claro & gris claro & $x$ & $x$ & $x$ & $x$ & $x$ & $x$ & $x$ & $x$ & $x$ & $x$ & $x$ & $x$ & $x$ & $\mathrm{x}$ & \\
\hline PA 22/S1 & 101 & 56 & 0 & 0 & 0 & 0 & 3 & 2 & 4.7 & 3.1 & 0 & 0 & $x$ & $x$ & gris osc & gris osc & $x$ & $x$ & $x$ & $x$ & $x$ & $x$ & $x$ & $x$ & $x$ & $x$ & $x$ & $x$ & $x$ & $\mathrm{x}$ & 4 \\
\hline PA 22/S1 & 101 & 57 & 0 & 0 & 0 & 9 & 2 & 2 & 6.7 & 6.3 & 0 & 0 & $x$ & $x$ & gris & gris rojizo & $x$ & $x$ & $x$ & $x$ & $x$ & $x$ & $x$ & $x$ & $x$ & $x$ & $x$ & $x$ & $x$ & $\mathrm{x}$ & \\
\hline PA 22/S1 & 101 & 58 & 0 & 0 & 0 & 0 & 3 & 2 & 6 & 5.9 & 0 & 0 & $x$ & $x$ & gris y gris osc & gris & $x$ & $x$ & $x$ & $x$ & $x$ & $x$ & $x$ & $x$ & $x$ & $x$ & $x$ & $x$ & $x$ & $\mathrm{x}$ & 1 \\
\hline PA 22/S1 & 101 & 59 & 0 & 0 & 0 & 0 & 2 & 2 & 6 & 5.3 & 0 & 0 & $x$ & $x$ & marron grisáceo & gris osc & $x$ & $x$ & $x$ & $x$ & $x$ & $x$ & $x$ & $x$ & $x$ & $x$ & $x$ & $x$ & $x$ & $x$ & \\
\hline PA 22/S1 & 101 & 60 & 0 & 0 & 0 & 0 & 2 & 2 & 6.5 & 5.4 & 0 & 0 & $x$ & $x$ & gris osc & gris osc & $x$ & $x$ & $x$ & $x$ & $x$ & $x$ & $x$ & $x$ & $x$ & $x$ & $x$ & $x$ & $x$ & $x$ & \\
\hline PA 22/S1 & 101 & 61 & 0 & 0 & 0 & 0 & 3 & 2 & 7 & 4 & 0 & 0 & $x$ & $x$ & gris & gris & $x$ & $x$ & $x$ & $x$ & $x$ & $x$ & $x$ & $x$ & $\mathrm{x}$ & $x$ & $x$ & $x$ & $x$ & $\mathrm{x}$ & 3 \\
\hline PA 22/S1 & 101 & 65 & 0 & 0 & 0 & 0 & 2 & 2 & 8.5 & 7.3 & 0 & 0 & $x$ & $x$ & marron & gris osc & $x$ & $x$ & $x$ & $x$ & $x$ & $x$ & $x$ & $x$ & $x$ & $x$ & $x$ & $x$ & $x$ & $x$ & 3 \\
\hline PA 22/S1 & 101 & 66 & 0 & 0 & 0 & 0 & 2 & 2 & 7.4 & 7.1 & 0 & 0 & $x$ & $x$ & marron & marron & $x$ & $x$ & $x$ & $x$ & $x$ & $x$ & $x$ & $x$ & $x$ & $x$ & $x$ & $x$ & $x$ & $\mathrm{x}$ & 3 y 4 \\
\hline PA 22/S1 & 102 & 67 & 1 & 0 & 1 & 0 & 12 & 12 & 3.2 & 3 & 0 & 0 & $x$ & poshisp & naranja, blanco & verde claro, blanco & indet & 1.7 & indet & 1 & 2 & $x$ & $x$ & $x$ & $x$ & $x$ & $x$ & $x$ & $x$ & $x$ & \\
\hline PA 22/S1 & 102 & 68 & 1 & 0 & 0 & 0 & 2 & 2 & 6.5 & 5.5 & 0 & 0 & $x$ & $x$ & gris a marron grisáceo & marron rojizo & indet & 1.9 & indet & 1 & 2 & $x$ & $x$ & $x$ & $x$ & $x$ & $x$ & $x$ & $x$ & $\mathrm{x}$ & 2 \\
\hline
\end{tabular}




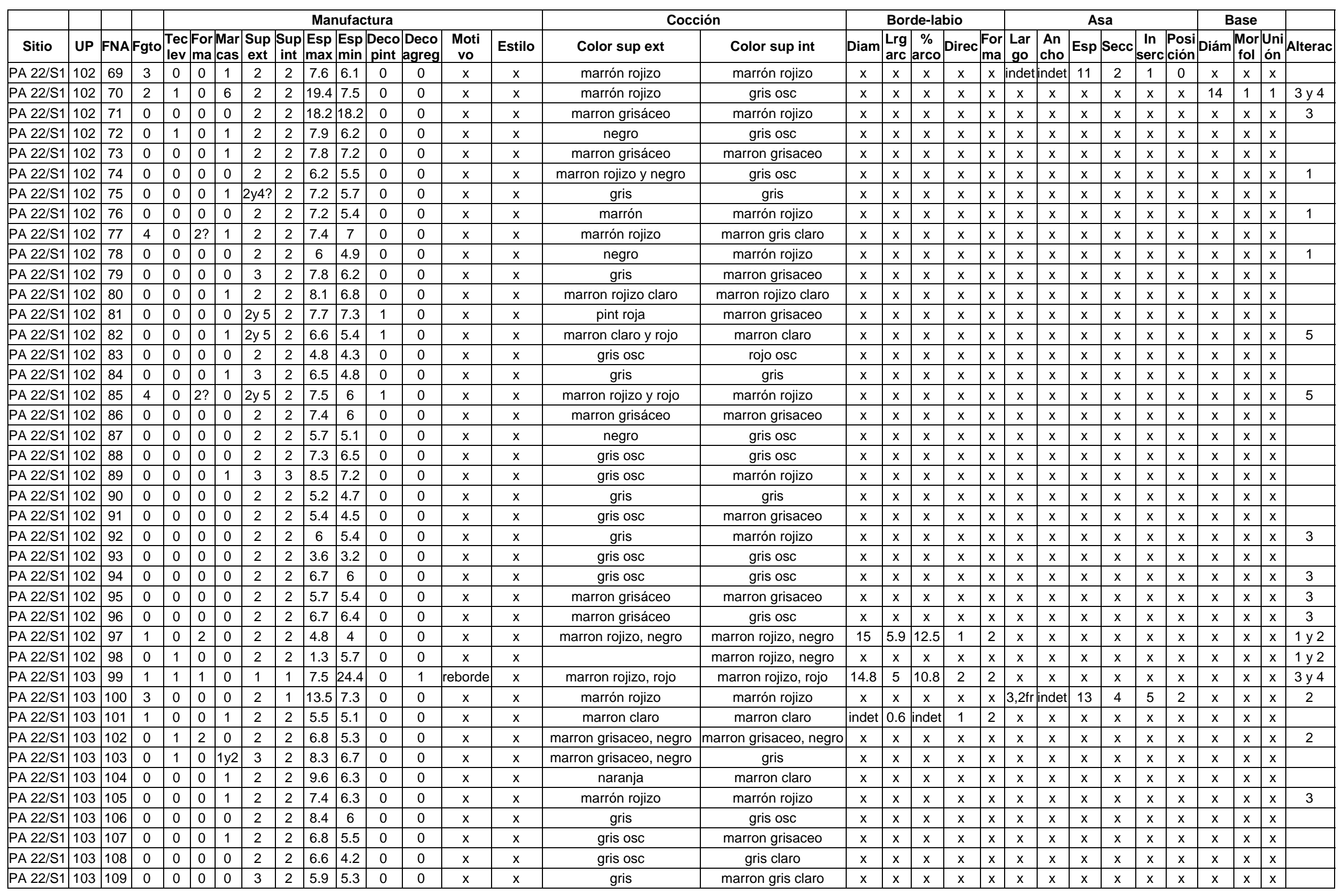




\begin{tabular}{|c|c|c|c|c|c|c|c|c|c|c|c|c|c|c|c|c|c|c|c|c|c|c|c|c|c|c|c|c|c|c|c|}
\hline \multirow[b]{2}{*}{ Sitio } & \multirow[b]{2}{*}{ UP } & \multirow[b]{2}{*}{ FNA } & \multirow[b]{2}{*}{ Fgto } & \multicolumn{11}{|c|}{ Manufactura } & \multicolumn{2}{|c|}{ Cocción } & \multicolumn{5}{|c|}{ Borde-labio } & \multicolumn{6}{|c|}{ Asa } & \multicolumn{3}{|c|}{ Base } & \multirow[b]{2}{*}{ Alterac } \\
\hline & & & & \begin{tabular}{|l|} 
Tec \\
lev
\end{tabular} & & \begin{tabular}{|l|} 
Mar \\
cas
\end{tabular} & $\begin{array}{l}\text { Sup } \\
\text { ext }\end{array}$ & \begin{tabular}{|c|} 
Sup \\
int \\
\end{tabular} & $\begin{array}{l}\text { Esp } \\
\text { max }\end{array}$ & \begin{tabular}{|l|}
$\begin{array}{l}\text { Esp } \\
\text { min }\end{array}$ \\
\end{tabular} & $\begin{array}{c}\text { Deco } \\
\text { pint }\end{array}$ & \begin{tabular}{|l|} 
Deco \\
agreg \\
\end{tabular} & $\begin{array}{c}\text { Moti } \\
\text { vo }\end{array}$ & Estilo & Color sup ext & Color sup int & Diam & \begin{tabular}{|l|} 
Lrg \\
arc \\
\end{tabular} & \begin{tabular}{|c|}
$\%$ \\
arco \\
\end{tabular} & Direc ${ }_{n}^{F}$ & $\begin{array}{l}\text { For } \\
\text { ma }\end{array}$ & $\begin{array}{c}\text { Lar } \\
\text { go }\end{array}$ & $\begin{array}{l}\begin{array}{c}\text { An } \\
\text { cho }\end{array} \\
\end{array}$ & Esp & Secc & \begin{tabular}{|l|l|} 
In \\
serc
\end{tabular} & $\begin{array}{l}\begin{array}{l}\text { Posi } \\
\text { ción }\end{array} \\
\end{array}$ & Diám & $\begin{array}{l}\text { Mor } \\
\text { fol }\end{array}$ & $\begin{array}{l}\text { Uni } \\
\text { ón } \\
\end{array}$ & \\
\hline PA 22/S1 & 103 & 110 & 0 & 0 & 0 & 0 & 2 & 2 & 7.3 & 6.7 & 0 & 0 & $x$ & $x$ & marron grisáceo & marron grisaceo & $x$ & $x$ & $x$ & $x$ & $x$ & $x$ & $x$ & $x$ & $x$ & $x$ & $x$ & $x$ & $x$ & $\mathrm{x}$ & 3 \\
\hline PA 22/S1 & 103 & 111 & 0 & 0 & 0 & 0 & 2 & 2 & 7.3 & 5.6 & 0 & 0 & $x$ & $x$ & marron grisáceo & negro & $x$ & $x$ & $x$ & $x$ & $x$ & $x$ & $x$ & $x$ & $x$ & $x$ & $x$ & $x$ & $x$ & $\mathrm{x}$ & 3 \\
\hline PA 22/S1 & 103 & 112 & 0 & 0 & 0 & 0 & 2 & 2 & 8.5 & 5.9 & 0 & 0 & $x$ & $x$ & marrón rojizo & marrón rojizo & $x$ & $x$ & $x$ & $x$ & $x$ & $x$ & $x$ & $x$ & $x$ & $x$ & $x$ & $x$ & $x$ & $\mathrm{x}$ & 3 \\
\hline PA 22/S1 & 103 & 113 & 0 & 0 & 0 & 0 & 2 & 2 & 7.3 & 5.9 & 0 & 0 & $\mathrm{x}$ & $\mathrm{x}$ & gris osc & gris osc & $x$ & $x$ & $x$ & $x$ & $x$ & $x$ & $x$ & $x$ & $x$ & $x$ & $x$ & $x$ & $x$ & $\mathrm{x}$ & \\
\hline PA 22/S1 & 103 & 114 & 0 & 0 & 0 & 0 & 2 & 2 & 9.3 & 8 & 0 & 0 & $x$ & $x$ & marron grisáceo & marrón rojizo & $x$ & $x$ & $x$ & $x$ & $x$ & $x$ & $x$ & $x$ & $x$ & $x$ & $x$ & $x$ & $x$ & $\mathrm{x}$ & 3 \\
\hline PA 22/S1 & 103 & 115 & 0 & 0 & 0 & 0 & $x$ & 2 & $6 \mathrm{fr}$ & $5,3 \mathrm{fr}$ & 0 & 0 & $x$ & $x$ & $x$ & gris osc & $x$ & $x$ & $x$ & $x$ & $x$ & $x$ & $x$ & $x$ & $x$ & $x$ & $x$ & $x$ & $x$ & $x$ & 4 \\
\hline PA 22/S1 & 103 & 116 & 4 & 0 & 0 & 0 & 2 & 3 & 6.6 & 6.1 & 0 & 0 & $x$ & $x$ & marrón rojizo & gris claro & $x$ & $x$ & $x$ & $x$ & $x$ & $x$ & $x$ & $x$ & $x$ & $x$ & $x$ & $x$ & $x$ & $\mathrm{x}$ & \\
\hline PA 22/S1 & 103 & 117 & 0 & 0 & 0 & 0 & 2 & 2 & 4.5 & 4.2 & 0 & 0 & $x$ & $\mathrm{x}$ & marron grisáceo & gris osc & $x$ & $x$ & $x$ & $x$ & $\mathrm{x}$ & $x$ & $\mathrm{x}$ & $x$ & $x$ & $x$ & $\mathrm{x}$ & $x$ & $x$ & $x$ & \\
\hline PA 22/S1 & 103 & 118 & 0 & 0 & 0 & 0 & 2 & 2 & 5.2 & 4.3 & 0 & 0 & $x$ & $x$ & gris osc & marron grisaceo & $x$ & $x$ & $x$ & $x$ & $x$ & $x$ & $x$ & $x$ & $x$ & $x$ & $x$ & $x$ & $x$ & $\mathrm{x}$ & \\
\hline PA 22/S1 & 103 & 119 & 0 & 0 & 0 & 1 & 2 & 2 & 6.1 & 5.3 & 0 & 0 & $x$ & $x$ & gris claro & marron gris claro & $x$ & $x$ & $x$ & $x$ & $\mathrm{x}$ & $x$ & $x$ & $x$ & $x$ & $x$ & $x$ & $x$ & $x$ & $\mathrm{x}$ & \\
\hline PA 22/S1 & 103 & 120 & 0 & $3 ?$ & 0 & 1 & 2 & 2 & 8 & 7.3 & 0 & 0 & $x$ & $x$ & gris claro & marron rojizo claro & $x$ & $x$ & $x$ & $x$ & $\mathrm{x}$ & $x$ & $x$ & $x$ & $x$ & $x$ & $\mathrm{x}$ & $x$ & $x$ & $\mathrm{x}$ & \\
\hline PA 22/S1 & 103 & 121 & 0 & 0 & 0 & 0 & 2 & 2 & 6 & 5.2 & 0 & 0 & $x$ & $x$ & marron rojizo & marron rojizo & $x$ & $x$ & $x$ & $x$ & $\mathrm{x}$ & $\mathrm{x}$ & $x$ & $x$ & $x$ & $x$ & $\mathrm{x}$ & $x$ & $x$ & $\mathrm{x}$ & 3 \\
\hline PA 22/S1 & 103 & 122 & 0 & 0 & 0 & 0 & 2 & 2 & 5.7 & 4.4 & 0 & 0 & $x$ & $x$ & marron grisáceo & marron grisaceo & $x$ & $x$ & $x$ & $x$ & $x$ & $x$ & $x$ & $x$ & $x$ & $x$ & $x$ & $x$ & $x$ & $\mathrm{x}$ & \\
\hline PA 22/S1 & 103 & 123 & 0 & 0 & 0 & 0 & 2 & 2 & 5.8 & 4.9 & 0 & 0 & $x$ & $x$ & marron rojizo claro & marron gris claro & $x$ & $x$ & $x$ & $x$ & $\mathrm{x}$ & $x$ & $x$ & $x$ & $x$ & $x$ & $x$ & $x$ & $x$ & $\mathrm{x}$ & \\
\hline PA 22/S1 & 103 & 124 & 0 & 0 & 0 & 0 & 2 & 2 & 5.6 & 5 & 0 & 0 & $x$ & $x$ & gris osc & negro & $x$ & $x$ & $x$ & $x$ & $\mathrm{x}$ & $x$ & $\mathrm{x}$ & $x$ & $\mathrm{x}$ & $x$ & $x$ & $x$ & $x$ & $\mathrm{x}$ & \\
\hline PA 22/S1 & 103 & 125 & 0 & 0 & 0 & 0 & 2 & 2 & 7.4 & 7.2 & 0 & 0 & $x$ & $x$ & marron grisáceo & marron grisaceo & $x$ & $x$ & $x$ & $x$ & $x$ & $x$ & $x$ & $x$ & $x$ & $x$ & $x$ & $x$ & $x$ & $\mathrm{x}$ & \\
\hline PA 22/S1 & 103 & 127 & 0 & 0 & 0 & 0 & 2 & 2 & 5.4 & 5.1 & 0 & 0 & $x$ & $x$ & marron rojizo, negro & marrón rojizo & $x$ & $x$ & $x$ & $x$ & $\mathrm{x}$ & $x$ & $x$ & $x$ & $x$ & $x$ & $x$ & $x$ & $x$ & $\mathrm{x}$ & 3 \\
\hline PA 22/S1 & 103 & 128 & 0 & 0 & 0 & 0 & 2 & 2 & 7.7 & 6.7 & 0 & 0 & $x$ & $x$ & marron grisáceo & marron grisáceo & $x$ & $x$ & $x$ & $x$ & $\mathrm{x}$ & $x$ & $x$ & $x$ & $x$ & $x$ & $\mathrm{x}$ & $x$ & $x$ & $x$ & 3 \\
\hline PA 22/S1 & 103 & 129 & 0 & 0 & 0 & 0 & 2 & $x$ & $6,2 \mathrm{fr}$ & $5,4 \mathrm{fr}$ & 0 & 0 & $x$ & $x$ & marrón rojizo & marrón grisáceo & $x$ & $x$ & $x$ & $x$ & $x$ & $x$ & $x$ & $x$ & $x$ & $x$ & $x$ & $x$ & $x$ & $\mathrm{x}$ & 3 y 4 \\
\hline PA 22/S1 & 103 & 130 & 0 & 0 & 0 & 2 & 3 & 2 & 4.8 & 4.2 & 0 & 0 & $x$ & $x$ & marron grisáceo & marron & $x$ & $x$ & $x$ & $x$ & $x$ & $x$ & $x$ & $x$ & $x$ & $x$ & $x$ & $x$ & $x$ & $x$ & \\
\hline PA 22/S1 & 103 & 131 & 0 & 0 & 0 & 1 & 2 & 2 & 5.4 & 4 & 0 & 0 & $x$ & $x$ & gris osc & marron grisáceo & $x$ & $x$ & $x$ & $x$ & $x$ & $x$ & $x$ & $x$ & $x$ & $x$ & $x$ & $x$ & $x$ & $x$ & 4 \\
\hline PA 22/S1 & 103 & 132 & 0 & 0 & 0 & 0 & 2 & 2 & 5 & 3.8 & 0 & 0 & $\mathrm{x}$ & $\mathrm{x}$ & negro & marron grisáceo & $\mathrm{x}$ & $\mathrm{x}$ & $\mathrm{x}$ & $\mathrm{x}$ & $\mathrm{x}$ & $\mathrm{x}$ & $\mathrm{x}$ & $\mathrm{x}$ & $\mathrm{x}$ & $\mathrm{x}$ & $\mathrm{x}$ & $\mathrm{x}$ & $\mathrm{x}$ & $\mathrm{x}$ & \\
\hline PA 22/S1 & 103 & 133 & 0 & 0 & 0 & 0 & 2 & 2 & 7 & 6.2 & 0 & 0 & $x$ & $x$ & egro & gris & $x$ & $x$ & $x$ & $x$ & $\mathrm{x}$ & $x$ & $\mathrm{x}$ & $x$ & $x$ & $x$ & $\mathrm{x}$ & $x$ & $x$ & $x$ & \\
\hline PA 22/S1 & 103 & 134 & 0 & 0 & 0 & 0 & 2 & 2 & 6.3 & 5.8 & 0 & 0 & $x$ & $x$ & gris osc & gris osc & $x$ & $x$ & $x$ & $x$ & $\mathrm{x}$ & $x$ & $\mathrm{x}$ & $x$ & $x$ & $x$ & $\mathrm{x}$ & $x$ & $x$ & $\mathrm{x}$ & \\
\hline PA 22/S1 & 103 & 135 & 0 & 0 & 0 & 0 & 2 & 2 & 5.4 & 3.8 & 0 & 0 & $x$ & $x$ & gris osc & marron rojizo, negro & $x$ & $x$ & $x$ & $x$ & $\mathrm{x}$ & $x$ & $x$ & $x$ & $x$ & $x$ & $\mathrm{x}$ & $x$ & $x$ & $\mathrm{x}$ & \\
\hline PA 22/S1 & 103 & 136 & 0 & 0 & 0 & 1 & 3 & 2 & 5.1 & 4.5 & 0 & 0 & $x$ & $x$ & gris osc & marrón rojizo & $x$ & $x$ & $x$ & $x$ & $\mathrm{x}$ & $x$ & $x$ & $x$ & $x$ & $\mathrm{x}$ & $\mathrm{x}$ & $x$ & $x$ & $\mathrm{x}$ & \\
\hline PA 22/S1 & 103 & 137 & 0 & 0 & 0 & 0 & 3 & $2 y 4$ & 5 & 4.4 & 0 & 0 & $x$ & $x$ & gris osc & rojo claro & $x$ & $x$ & $x$ & $x$ & $x$ & $x$ & $x$ & $x$ & $x$ & $x$ & $x$ & $x$ & $x$ & $\mathrm{x}$ & \\
\hline PA 22/S1 & 103 & 138 & 0 & 0 & 0 & 0 & 2 & 2 & 4.3 & 3.4 & 0 & 0 & $x$ & $x$ & negro & marron grisáceo & $x$ & $x$ & $x$ & $x$ & $\mathrm{x}$ & $x$ & $x$ & $x$ & $x$ & $x$ & $\mathrm{x}$ & $x$ & $x$ & $x$ & 2 \\
\hline PA 22/S1 & 103 & 139 & 0 & 0 & 0 & 0 & 2 & 12 & 4.5 & 3.9 & 0 & 0 & $x$ & poshisp & marron grisáceo & gris claro a blanco & $x$ & $x$ & $x$ & $x$ & $x$ & $x$ & $x$ & $x$ & $x$ & $x$ & $x$ & $x$ & $x$ & $\mathrm{x}$ & \\
\hline PA 22/S1 & 103 & 140 & 0 & 0 & 0 & 0 & $2 y 5$ & 2 & 7.2 & 5.9 & 1 & 0 & $x$ & $x$ & marron rojizo, gris osc, & marrón rojizo & $x$ & $x$ & $x$ & $x$ & $\mathrm{x}$ & $x$ & $x$ & $x$ & $x$ & $x$ & $x$ & $x$ & $x$ & $x$ & 1,3 y 5 \\
\hline PA 22/S1 & 103 & 141 & 0 & 0 & 0 & 0 & 2 y 5 & 2 & 7.3 & 5 & 1 & 0 & $x$ & $x$ & marron claro y rojo & marron claro & $x$ & $x$ & $x$ & $x$ & $\mathrm{x}$ & $x$ & $x$ & $x$ & $x$ & $x$ & $\mathrm{x}$ & $x$ & $x$ & $\mathrm{x}$ & 5 \\
\hline PA 22/S1 & 103 & 142 & 0 & 0 & 0 & 1 & 4 y 3 & 3 & 4.8 & 4 & 1 & 0 & $x$ & $x$ & marron rojizo, rojo osc & marrón rojizo & $x$ & $x$ & $x$ & $x$ & $\mathrm{x}$ & $x$ & $\mathrm{x}$ & $x$ & $\mathrm{x}$ & $x$ & $\mathrm{x}$ & $x$ & $x$ & $\mathrm{x}$ & 5 \\
\hline PA 22/S1 & 103 & 143 & 0 & 0 & 0 & 1 & 3 & 2 & 6.1 & 5 & 0 & 0 & $x$ & $x$ & marrón rojizo & marrón rojizo & $x$ & $x$ & $x$ & $x$ & $\mathrm{x}$ & $x$ & $x$ & $x$ & $x$ & $x$ & $x$ & $x$ & $x$ & $\mathrm{x}$ & \\
\hline PA 22/S2 L & Limp & 146 & 0 & 0 & 0 & 0 & 2 & 2 & 7.5 & 6.8 & 0 & 0 & $x$ & $x$ & marron grisáceo & marrón rojizo & $x$ & $x$ & $x$ & $x$ & $x$ & $x$ & $x$ & $x$ & $x$ & $x$ & $x$ & $x$ & $x$ & $\mathrm{x}$ & \\
\hline PA 22/S2L & Limp & 147 & 0 & 0 & 0 & 0 & 3 y 5 & 2 & 5.3 & 4.1 & 1 & 0 & $x$ & $x$ & marron rojizo y rojo & marrón rojizo & $x$ & $x$ & $x$ & $x$ & $\mathrm{x}$ & $x$ & $x$ & $x$ & $x$ & $x$ & $x$ & $x$ & $x$ & $x$ & 2 y 5 \\
\hline PA 22/S2 L & Limp & 148 & 0 & 0 & 0 & 0 & 2 & 2 & 6.5 & 6 & 0 & 0 & $x$ & $x$ & marron & marron grisáceo & $x$ & $x$ & $x$ & $x$ & $\mathrm{x}$ & $x$ & $x$ & $x$ & $x$ & $x$ & $\mathrm{x}$ & $x$ & $x$ & $\mathrm{x}$ & \\
\hline PA22Bas & sup & 149 & 1 y 3 & 0 & 2 & 1 & 2 & 2 & 9 & 4.1 & 0 & 2 & zigzag & $x$ & marrón grisáceo a negro & marrón rojizo a negro & 13.5 & 10.2 & 24 & 1 & 2 & 6 & 22 & 8 & 3 & 5 & 2 & $x$ & $x$ & $\mathrm{x}$ & 1 у 2 \\
\hline PA22Bas & sup & 150 & 1 & 0 & 2 & 0 & 2 & 2 & 7.6 & 4.4 & 0 & 0 & $x$ & $\mathrm{x}$ & marrón grisáceo a negro & marrón grisáceo & 13.5 & 7.2 & 17 & 1 & 2 & $x$ & $\mathrm{x}$ & $\mathrm{x}$ & $\mathrm{x}$ & $\mathrm{x}$ & $\mathrm{x}$ & $\mathrm{x}$ & $\mathrm{x}$ & $\mathrm{x}$ & 1 y 2 \\
\hline
\end{tabular}




\begin{tabular}{|c|c|c|c|c|c|c|c|c|c|c|c|c|c|c|c|c|c|c|c|c|c|c|c|c|c|c|c|c|c|c|c|}
\hline \multirow[b]{2}{*}{ Sitio } & \multirow[b]{2}{*}{ UP } & \multirow[b]{2}{*}{ GF } & \multirow[b]{2}{*}{ FNA } & \multirow[b]{2}{*}{ Fgto } & \multicolumn{10}{|c|}{ Manufactura } & \multicolumn{2}{|c|}{ Cocción } & \multicolumn{5}{|c|}{ Borde-labio } & \multicolumn{6}{|c|}{ Asa } & \multicolumn{3}{|c|}{ Base } & \multirow[b]{2}{*}{ Alterac } \\
\hline & & & & & $\begin{array}{l}\text { Tec } \\
\text { lev }\end{array}$ & $\begin{array}{l}\text { For } \\
\text { ma }\end{array}$ & $\begin{array}{l}\text { Mar } \\
\text { cas }\end{array}$ & $\begin{array}{l}\text { Sup } \\
\text { ext }\end{array}$ & \begin{tabular}{|c|} 
Sup \\
int
\end{tabular} & $\mid \begin{array}{l}\operatorname{Esp} \\
\max \end{array}$ & $\begin{array}{l}\text { Esp } \\
\text { min }\end{array}$ & $\begin{array}{c}\text { Deco } \\
\text { pint }\end{array}$ & Motivo & Estilo & Color sup ext & Color sup int & Diam & \begin{tabular}{|l|} 
Lrg \\
arc
\end{tabular} & \begin{tabular}{|c|}
$\%$ \\
arco
\end{tabular} & Direc & $\begin{array}{l}\text { For } \\
\text { ma }\end{array}$ & $\begin{array}{l}\text { Lar } \\
\text { go }\end{array}$ & $\begin{array}{c}\text { An } \\
\text { cho }\end{array}$ & Esp & $\begin{array}{l}\text { Sec } \\
\text { ción }\end{array}$ & \begin{tabular}{|l|} 
In \\
serc
\end{tabular} & $\begin{array}{l}\text { Posi } \\
\text { ción }\end{array}$ & i Diám & $\begin{array}{l}\text { Mor } \\
\text { fol }\end{array}$ & $\begin{array}{l}\text { Uni } \\
\text { ón }\end{array}$ & \\
\hline $\mathrm{RH} 2-1$ & sup & 1 & & 1 & 1 & 1 & 2 & 2 & 3 & 6.8 & 5.7 & 0 & $x$ & $x$ & $2.5 Y R$ 4/6, 2.5/4, 3/0 & $2.5 Y R 3 / 0,4 / 0$ & 28 & 86 & 7.8 & 1 & 1 & $x$ & $\mathrm{x}$ & $x$ & $\mathrm{x}$ & $\mathrm{x}$ & $x$ & $x$ & $\mathrm{x}$ & $x$ & 1 y 3 \\
\hline $\mathrm{RH} 2-1$ & 401 & 1 & & 1 & 1 & 1 & 2 & 2 & 3 & 6.8 & 5.7 & 0 & $x$ & $x$ & $2.5 Y R$ 4/6, 2.5/4, 3/0 & $2.5 Y R \quad 3 / 0,4 / 0$ & 28 & 86 & 7.8 & 1 & 1 & $x$ & $x$ & $x$ & $x$ & $x$ & $x$ & $x$ & $x$ & $x$ & 1 y 4 \\
\hline $\mathrm{RH} 2-1$ & 402 & 1 & & 0 & 1 & 1 & 2 & 2 & 3 & 6.8 & 5.7 & 0 & $x$ & $x$ & $2.5 Y R$ 4/6, 2.5/4, 3/0 & $2.5 Y R \quad 3 / 0,4 / 0$ & $x$ & $x$ & $x$ & $x$ & $x$ & $x$ & $x$ & $x$ & $x$ & $x$ & $x$ & $x$ & $x$ & $x$ & 1 \\
\hline $\mathrm{RH} 2-1$ & 301 & 1 & & 0 & 1 & 0 & 2 & 2 & 3 & 6.8 & 5.7 & 0 & $\mathrm{x}$ & $x$ & $2.5 Y R \quad 4 / 6,2.5 / 4,3 / 0$ & $2.5 Y R$ 3/0, 4/1 & $x$ & $x$ & $x$ & $x$ & $x$ & $x$ & $x$ & $x$ & $x$ & $x$ & $x$ & $x$ & $x$ & $x$ & \\
\hline RH 2-1 & 402 & 2 & & 0 & 0 & 2 & $1,2 \mathrm{y} 4$ & $3,4 \mathrm{y} 6$ & $2 \mathrm{y} 6$ & 7.3 & 4 & 3 & \begin{tabular}{c|} 
Fjas \\
lunares
\end{tabular} & Casab & $\begin{array}{c}\text { 10R 5/8,5/6, 10YR7/3, } \\
7.5 \mathrm{YR} 2 / 0 \\
\end{array}$ & 10R5/6, 5YR6/4, 5/4 & $\mathrm{x}$ & $\mathrm{x}$ & $\mathrm{x}$ & $\mathrm{x}$ & $\mathrm{x}$ & $\mathrm{x}$ & $\mathrm{x}$ & $\mathrm{x}$ & $\mathrm{x}$ & $\mathrm{x}$ & $\mathrm{x}$ & $\mathrm{x}$ & $\mathrm{x}$ & $\mathrm{x}$ & \\
\hline $\mathrm{RH} 2-1$ & 152 & 2 & & 0 & 0 & 2 & 1,2 y4 & $3,4 \mathrm{y} 6$ & $2 \mathrm{y} 6$ & 7.3 & 4 & 3 & \begin{tabular}{c|c} 
fjas \\
lunares
\end{tabular} & Casab & $\begin{array}{c}10 \mathrm{R} 5 / 8,5 / 6,10 \mathrm{YR} 7 / 3 \\
7.5 \mathrm{YR} 2 / 0 \\
\end{array}$ & 10R5/6, 5YR6/4, 5/4 & $\mathrm{x}$ & $\mathrm{x}$ & $\mathrm{x}$ & $\mathrm{x}$ & $\mathrm{x}$ & $\mathrm{x}$ & $\mathrm{x}$ & $\mathrm{x}$ & $\mathrm{x}$ & $\mathrm{x}$ & $\mathrm{x}$ & $\mathrm{x}$ & $\mathrm{x}$ & $\mathrm{x}$ & 3 \\
\hline RH 2-1 & 300 & 2 & & 0 & 0 & 0 & $1,2 \mathrm{y} 4$ & $3,4 \mathrm{y} 6$ & $2 \mathrm{y} 6$ & 7.3 & 4 & 3 & \begin{tabular}{c|} 
fjas \\
lunares
\end{tabular} & Casab & $\begin{array}{c}\text { 10R 5/8,5/6, 10YR7/3, } \\
7.5 \mathrm{YR} 2 / 0 \\
\end{array}$ & 10R5/6, 5YR6/4, 5/4 & $\mathrm{x}$ & $\mathrm{x}$ & $\mathrm{x}$ & $\mathrm{x}$ & $\mathrm{x}$ & $\mathrm{x}$ & $\mathrm{x}$ & $\mathrm{x}$ & $\mathrm{x}$ & $\mathrm{x}$ & $\mathrm{x}$ & $\mathrm{x}$ & $\mathrm{x}$ & $\mathrm{x}$ & \\
\hline RH 2-1 & 302 & 2 & & 0 & 0 & 0 & 1,2 y4 & $3,4 \mathrm{y} 6$ & $2 \mathrm{y} 6$ & 7.3 & 4 & 3 & \begin{tabular}{c|} 
fjas \\
lunares
\end{tabular} & Casab & $\begin{array}{r}10 \mathrm{R} 5 / 8,5 \\
7.5 \\
\end{array}$ & 10R5/6, 5YR6/4, 5/4 & $\mathrm{x}$ & $\mathrm{x}$ & $\mathrm{x}$ & $\mathrm{x}$ & $\mathrm{x}$ & $\mathrm{x}$ & $x$ & $\mathrm{x}$ & $x$ & $\mathrm{x}$ & $x$ & $x$ & $\mathrm{x}$ & $\mathrm{x}$ & \\
\hline RH 2-1 & 301 & 2 & & 0 & 0 & 0 & $1,2 \mathrm{y} 4$ & $3,4 \mathrm{y} 6$ & $2 \mathrm{y} 6$ & 7.3 & 4 & 3 & $\begin{array}{c}\text { fjas } \\
\text { lunares }\end{array}$ & Casab & $\begin{array}{c}\text { 10R 5/8,5/6, 10YR7/3, } \\
7.5 \mathrm{YR} 2 / 0 \\
\end{array}$ & 10R5/6, 5YR6/4, 5/4 & $\mathrm{x}$ & $\mathrm{x}$ & $\mathrm{x}$ & $\mathrm{x}$ & $\mathrm{x}$ & $\mathrm{x}$ & $\mathrm{x}$ & $\mathrm{x}$ & $x$ & $\mathrm{x}$ & $x$ & $x$ & $\mathrm{x}$ & $\mathrm{x}$ & 5 \\
\hline RH 2-1 & 301 & 2 & & 0 & 0 & 0 & 1,2 y4 & $3,4 \mathrm{y} 6$ & $2 \mathrm{y} 6$ & 7.3 & 4 & 3 & \begin{tabular}{c|c} 
fjas \\
lunares
\end{tabular} & Casab & $\begin{array}{r}10 \mathrm{R} 5 / 8,5 / 6 \\
7.5 \mathrm{Y} \\
\end{array}$ & 10R5/6, 5YR6/4, 5/4 & $\mathrm{x}$ & $\mathrm{x}$ & $\mathrm{x}$ & $\mathrm{x}$ & $\mathrm{x}$ & $x$ & $\mathrm{x}$ & $x$ & $\mathrm{x}$ & $\mathrm{x}$ & $\mathrm{x}$ & $x$ & $x$ & $\mathrm{x}$ & 5 \\
\hline $\mathrm{RH} 2-1$ & 151 & 2 & & 0 & 0 & 0 & 1,2 y4 & $4 y 6$ & $2 \mathrm{y} 6$ & 7.3 & 4 & 3 & $\begin{array}{c}\text { fjas } \\
\text { lunares }\end{array}$ & Casab & $\begin{array}{c}10 \mathrm{R} 5 / 8,5 / 6,10 \mathrm{YR} 7 / 3, \\
7.5 \mathrm{YR} 2 / 0 \\
\end{array}$ & 10R5/6, 5YR6/4, 5/4 & $\mathrm{x}$ & $\mathrm{x}$ & $\mathrm{x}$ & $x$ & $\mathrm{x}$ & $\mathrm{x}$ & $\mathrm{x}$ & $\mathrm{x}$ & $\mathrm{x}$ & $\mathrm{x}$ & $\mathrm{x}$ & $\mathrm{x}$ & $x$ & $\mathrm{x}$ & 5 \\
\hline RH 2-1 & 302 & 2 & & 0 & 0 & 0 & 1,2 y4 & $3,4 \mathrm{y} 6$ & $2 \mathrm{y} 6$ & 7.3 & 4 & 3 & \begin{tabular}{c|} 
fjas \\
lunares
\end{tabular} & Casab & $\begin{array}{c}\text { 10R 5/8,5/6, 10YR7/3, } \\
7.5 \mathrm{YR} 2 / 0 \\
\end{array}$ & 10R5/6, 5YR6/4, 5/4 & $\mathrm{x}$ & $\mathrm{x}$ & $\mathrm{x}$ & $\mathrm{x}$ & $\mathrm{x}$ & $\mathrm{x}$ & $\mathrm{x}$ & $\mathrm{x}$ & $\mathrm{x}$ & $\mathrm{x}$ & $\mathrm{x}$ & $x$ & $\mathrm{x}$ & $\mathrm{x}$ & 3 \\
\hline $\mathrm{RH} 2-1$ & 302 & 2 & & 0 & 0 & 0 & 1,2 y4 & $3,4 \mathrm{y} 6$ & $2 \mathrm{y} 6$ & 7.3 & 4 & 3 & $\begin{array}{c}\text { fjas } \\
\text { lunares }\end{array}$ & Casab & $\begin{array}{c}\text { 10R 5/8,5/6, 10YR7/3, } \\
7.5 \mathrm{YR} 2 / 0 \\
\end{array}$ & 10R5/6, 5YR6/4, 5/4 & $\mathrm{x}$ & $\mathrm{x}$ & $\mathrm{x}$ & $\mathrm{x}$ & $\mathrm{x}$ & $\mathrm{x}$ & $\mathrm{x}$ & $\mathrm{x}$ & $\mathrm{x}$ & $\mathrm{x}$ & $\mathrm{x}$ & $\mathrm{x}$ & $\mathrm{x}$ & $\mathrm{x}$ & \\
\hline $\mathrm{RH} 2-1$ & 401 & 2 & & 0 & 0 & 0 & 1,2 y4 & $3,4 \mathrm{y} 6$ & $2 \mathrm{y} 6$ & 7.3 & 4 & 3 & \begin{tabular}{|c|} 
fjas \\
lunares
\end{tabular} & Casab & $\begin{array}{c}\text { 10R 5/8,5/6, 10YR7/3, } \\
7.5 \mathrm{YR} 2 / 0\end{array}$ & 10R5/6, 5YR6/4, 5/4 & $x$ & $\mathrm{x}$ & $\mathrm{x}$ & $\mathrm{x}$ & $\mathrm{x}$ & $x$ & $x$ & $x$ & $\mathrm{x}$ & $\mathrm{x}$ & $x$ & $\mathrm{x}$ & $x$ & $\mathrm{x}$ & \\
\hline RH 2-1 & 152 & 2 & & 0 & 0 & 0 & 1,2 y4 & $3,4 \mathrm{y} 6$ & $2 \mathrm{y} 6$ & 7.3 & 4 & 3 & \begin{tabular}{c|} 
fjas \\
lunares
\end{tabular} & Casab & $\begin{array}{c}\text { 10R 5/8,5/6, 10YR7/3, } \\
7.5 \mathrm{YR} 2 / 0 \\
\end{array}$ & 10R5/6, 5YR6/4, 5/4 & $\mathrm{x}$ & $\mathrm{x}$ & $\mathrm{x}$ & $\mathrm{x}$ & $\mathrm{x}$ & $\mathrm{x}$ & $x$ & $\mathrm{x}$ & $x$ & $\mathrm{x}$ & $x$ & $x$ & $\mathrm{x}$ & $\mathrm{x}$ & 3 \\
\hline RH 2-1 & 301 & 2 & & 0 & 0 & 0 & $1,2 \mathrm{y} 4$ & $3,4 \mathrm{y} 6$ & $2 \mathrm{y} 6$ & 7.3 & 4 & 3 & $\begin{array}{c}\text { fjas } \\
\text { lunares }\end{array}$ & Casab & $\begin{array}{c}10 \mathrm{R} 5 / 8,5 / 6,10 \mathrm{YR} 7 / 3, \\
7.5 \mathrm{YR} 2 / 0 \\
\end{array}$ & 10R5/6, 5YR6/4, 5/4 & $\mathrm{x}$ & $\mathrm{x}$ & $\mathrm{x}$ & $\mathrm{x}$ & $\mathrm{x}$ & $\mathrm{x}$ & $x$ & $\mathrm{x}$ & $\mathrm{x}$ & $\mathrm{x}$ & $x$ & $x$ & $\mathrm{x}$ & $\mathrm{x}$ & \\
\hline RH 2-1 & 302 & 2 & & 0 & 0 & 0 & 1,2 y4 & $3,4 \mathrm{y} 6$ & $2 \mathrm{y} 6$ & 7.3 & 4 & 3 & \begin{tabular}{c|c} 
fjas \\
lunares
\end{tabular} & Casab & $\begin{array}{c}\text { 10R 5/8,5/6, 10YR7/3, } \\
7.5 \mathrm{YR} 2 / 0\end{array}$ & 10R5/6, 5YR6/4, 5/4 & $\mathrm{x}$ & $\mathrm{x}$ & $\mathrm{x}$ & $\mathrm{x}$ & $\mathrm{x}$ & $\mathrm{x}$ & $\mathrm{x}$ & $\mathrm{x}$ & $\mathrm{x}$ & $\mathrm{x}$ & $x$ & $\mathrm{x}$ & $\mathrm{x}$ & $\mathrm{x}$ & 3 \\
\hline $\mathrm{RH} 2-1$ & 300 & 2 & & 0 & 0 & 0 & 1,2 y4 & $3,4 \mathrm{y} 6$ & $2 \mathrm{y} 6$ & 7.3 & 4 & 3 & $\begin{array}{c}\text { fjas } \\
\text { lunares }\end{array}$ & Casab & $\begin{array}{c}\text { 10R 5/8,5/6, 10YR7/3, } \\
7.5 \mathrm{YR} 2 / 0 \\
\end{array}$ & 10R5/6, 5YR6/4, 5/4 & $\mathrm{x}$ & $\mathrm{x}$ & $\mathrm{x}$ & $\mathrm{x}$ & $\mathrm{x}$ & $\mathrm{x}$ & $\mathrm{x}$ & $\mathrm{x}$ & $\mathrm{x}$ & $\mathrm{x}$ & $\mathrm{x}$ & $\mathrm{x}$ & $\mathrm{x}$ & $\mathrm{x}$ & \\
\hline $\mathrm{RH} 2-1$ & 201 & 2 & & 0 & 0 & 0 & 1,2 y4 & $3,4 \mathrm{y} 6$ & $2 \mathrm{y} 6$ & 7.3 & 4 & 3 & \begin{tabular}{c|} 
fjas \\
lunares
\end{tabular} & Casab & $\begin{array}{c}\text { 10R 5/8,5/6, 10YR7/3, } \\
7.5 \mathrm{YR} 2 / 0 \\
\end{array}$ & 10R5/6, 5YR6/4, 5/4 & $\mathrm{x}$ & $\mathrm{x}$ & $\mathrm{x}$ & $\mathrm{x}$ & $\mathrm{x}$ & $\mathrm{x}$ & $\mathrm{x}$ & $\mathrm{x}$ & $\mathrm{x}$ & $\mathrm{x}$ & $\mathrm{x}$ & $\mathrm{x}$ & $\mathrm{x}$ & $\mathrm{x}$ & 3 \\
\hline RH 2-1 & 151 & 2 & & 0 & 0 & 0 & 1,2 y4 & $y 6$ & $2 \mathrm{y} 6$ & 7.3 & 4 & 3 & $\begin{array}{c}\text { fjas } \\
\text { lunares }\end{array}$ & Casab & $\begin{array}{c}10 \mathrm{R} 5 / 8,5 / 6,10 \mathrm{YR} 7 / 3, \\
7.5 \mathrm{YR} 2 / 0\end{array}$ & 10R5/6, 5YR & $\mathrm{x}$ & $\mathrm{x}$ & $\mathrm{x}$ & $\mathrm{x}$ & $\mathrm{x}$ & $\mathrm{x}$ & $\mathrm{x}$ & $\mathrm{x}$ & $\mathrm{x}$ & $\mathrm{x}$ & $\mathrm{x}$ & $\mathrm{x}$ & $\mathrm{x}$ & $\mathrm{x}$ & 3 \\
\hline $\mathrm{RH} 2-1$ & 301 & 2 & & 0 & 0 & 0 & 1,2 y4 & $3,4 \mathrm{y} 6$ & $2 \mathrm{y} 6$ & 7.3 & 4 & 3 & \begin{tabular}{c|c} 
fjas \\
lunares
\end{tabular} & Casab & $\begin{array}{c}\text { 10R 5/8,5/6, 10YR7/3, } \\
7.5 \mathrm{YR} 2 / 0\end{array}$ & 10R5/6, 5YR6/4, 5/4 & $\mathrm{x}$ & $x$ & $x$ & $\mathrm{x}$ & $\mathrm{x}$ & $x$ & $x$ & $x$ & $x$ & $\mathrm{x}$ & $x$ & $x$ & $\mathrm{x}$ & $x$ & \\
\hline $\mathrm{RH} 2-1$ & 302 & 2 & & 0 & 0 & 0 & 1,2 y4 & $3,4 \mathrm{y} 6$ & $2 \mathrm{y} 6$ & 7.3 & 4 & 3 & \begin{tabular}{|c|} 
fjas \\
lunares
\end{tabular} & Casab & $\begin{array}{c}\text { 10R 5/8,5/6, 10YR7/3, } \\
7.5 Y R 2 / 0 \\
\end{array}$ & 10R5/6, 5YR6/4, 5/4 & $\mathrm{x}$ & $\mathrm{x}$ & $\mathrm{x}$ & $\mathrm{x}$ & $\mathrm{x}$ & $\mathrm{x}$ & $\mathrm{x}$ & $\mathrm{x}$ & $\mathrm{x}$ & $\mathrm{x}$ & $\mathrm{x}$ & $\mathrm{x}$ & $\mathrm{x}$ & $\mathrm{x}$ & 2 \\
\hline $\mathrm{RH}$ & 402 & 2 & & 0 & 0 & 0 & $1,2 \mathrm{y} 4$ & $y 6$ & $2 \mathrm{y} 6$ & 9.4 & 4 & 3 & \begin{tabular}{c|} 
fjas \\
lunares
\end{tabular} & Casab & $\begin{array}{c}\text { 10R 5/8,5/6, 10YR7/3, } \\
7.5 \mathrm{YR} 2 / 0 \\
\end{array}$ & 10R5/6, 5YR6/4, 5/4 & $\mathrm{x}$ & $\mathrm{x}$ & $\mathrm{x}$ & $\mathrm{x}$ & $\mathrm{x}$ & $\mathrm{x}$ & $x$ & $\mathrm{x}$ & $\mathrm{x}$ & $\mathrm{x}$ & $x$ & $\mathrm{x}$ & $\mathrm{x}$ & $\mathrm{x}$ & \\
\hline
\end{tabular}




\begin{tabular}{|c|c|c|c|c|c|c|c|c|c|c|c|c|c|c|c|c|c|c|c|c|c|c|c|c|c|c|c|c|c|c|c|}
\hline \multirow[b]{2}{*}{ Sitio } & \multirow[b]{2}{*}{ UP } & \multirow[b]{2}{*}{ GF } & \multirow[b]{2}{*}{ FNA } & \multirow[b]{2}{*}{ Fgto } & \multicolumn{10}{|c|}{ Manufactura } & \multicolumn{2}{|c|}{ Cocción } & \multicolumn{5}{|c|}{ Borde-labio } & \multicolumn{6}{|c|}{ Asa } & \multicolumn{3}{|c|}{ Base } & \multirow[b]{2}{*}{ Alterac } \\
\hline & & & & & $\begin{array}{l}\text { Tec } \\
\text { lev }\end{array}$ & $\begin{array}{l}\text { For } \\
\text { ma }\end{array}$ & $\begin{array}{l}\text { Mar } \\
\text { cas }\end{array}$ & $\begin{array}{l}\text { Sup } \\
\text { ext }\end{array}$ & \begin{tabular}{|c|} 
Sup \\
int
\end{tabular} & \begin{tabular}{|l|} 
Esp \\
max
\end{tabular} & \begin{tabular}{|l|} 
Esp \\
min
\end{tabular} & $\begin{array}{c}\text { Deco } \\
\text { pint }\end{array}$ & Motivo & Estilo & Color sup ext & Color sup int & Diam & $\begin{array}{l}\text { Lrg } \\
\text { arc }\end{array}$ & \begin{tabular}{|c|}
$\%$ \\
arco \\
\end{tabular} & Direc & $\begin{array}{l}\text { For } \\
\text { ma }\end{array}$ & $\begin{array}{l}\text { Lar } \\
\text { go }\end{array}$ & $\begin{array}{l}\text { An } \\
\text { cho }\end{array}$ & Esp & $0 \begin{array}{l}\text { Sec } \\
\text { ción }\end{array}$ & \begin{tabular}{l|l} 
In \\
serc
\end{tabular} & \begin{tabular}{l|l} 
& Posi \\
rc & ción \\
\end{tabular} & iám & $\begin{array}{l}n \begin{array}{l}\text { Mor } \\
\text { fol }\end{array} \\
\end{array}$ & $\begin{array}{l}\text { Uni } \\
\text { ón }\end{array}$ & \\
\hline $\mathrm{RH} 2-1$ & 201 & 3 & & 0 & 0 & 0 & 1 & 2 & 2 & 9.4 & 4 & 0 & $x$ & $x$ & $5 Y R 6 / 4>, 5 / 4,3 / 3$ & $5 Y R$ 4/2>, 5/2 & $x$ & $x$ & $x$ & $x$ & $x$ & $x$ & $x$ & $x$ & $x$ & $x$ & $x$ & $x$ & $x$ & $x$ & 6 \\
\hline $\mathrm{RH} 2-1$ & 301 & 3 & & 0 & 0 & 0 & 1 & 2 & 2 & 9.4 & 4 & 0 & $x$ & $x$ & $5 Y R 6 / 4>, 5 / 4,3 / 3$ & $5 Y R \quad 4 / 2>, 5 / 2$ & $x$ & $x$ & $x$ & $x$ & $x$ & $x$ & $x$ & $x$ & $x$ & $x$ & $x$ & $x$ & $x$ & $\mathrm{x}$ & \\
\hline $\mathrm{RH} 2-1$ & 152 & 3 & & 0 & 0 & 0 & 1 & 2 & 2 & 9.4 & 4 & 0 & $x$ & $x$ & $5 Y R$ 6/4>, 5/4, 3/3 & $5 Y R \quad 4 / 2>, 5 / 2$ & $x$ & $x$ & $x$ & $x$ & $x$ & $x$ & $x$ & $x$ & $x$ & $x$ & $x$ & $x$ & $x$ & $x$ & 1 \\
\hline $\mathrm{RH} 2-1$ & 301 & 3 & & 0 & 0 & 0 & 1 & 2 & 2 & 9.4 & 4 & 0 & $\mathrm{x}$ & $\mathrm{x}$ & $5 Y R$ 6/4>, 5/4, 3/3 & $5 Y R \quad 4 / 2>, 5 / 2$ & $\mathrm{x}$ & $\mathrm{x}$ & $\mathrm{x}$ & $\mathrm{x}$ & $\mathrm{x}$ & $x$ & $\mathrm{x}$ & $\mathrm{x}$ & $\mathrm{x}$ & $\mathrm{x}$ & $\mathrm{x}$ & $\mathrm{x}$ & $\mathrm{x}$ & $\mathrm{x}$ & 2 \\
\hline $\mathrm{RH} 2-1$ & 301 & 3 & & 4 & 0 & 0 & 1 & 2 & 2 & 9.4 & 4 & 0 & $x$ & $x$ & $5 Y R 6 / 4>, 5 / 4,3 / 3$ & $5 Y R$ 4/2>, 5/2 & $x$ & $x$ & $x$ & $x$ & $x$ & $x$ & $x$ & $x$ & $x$ & $x$ & $x$ & $x$ & $x$ & $\mathrm{x}$ & 3 \\
\hline $\mathrm{RH} 2-1$ & 401 & 3 & & 4 & 0 & 0 & 1 & 2 & 2 & 9.4 & 4 & 0 & $\mathrm{x}$ & $\mathrm{x}$ & $5 Y R$ 6/4>, 5/4, 3/3 & $5 Y R \quad 4 / 2>, 5 / 2$ & $\mathrm{x}$ & $\mathrm{x}$ & $\mathrm{x}$ & $\mathrm{x}$ & $\mathrm{x}$ & $x$ & $\mathrm{x}$ & $\mathrm{x}$ & $\mathrm{x}$ & $\mathrm{x}$ & $\mathrm{x}$ & $\mathrm{x}$ & $\mathrm{x}$ & $\mathrm{x}$ & 3 \\
\hline $\mathrm{RH} 2-1$ & 100 & 3 & & 0 & 0 & 0 & 1 & 2 & 2 & 9.4 & 4 & 0 & $x$ & $x$ & $5 Y R 6 / 4>, 5 / 4,3 / 3$ & $5 Y R$ 4/2>, 5/2 & $x$ & $x$ & $x$ & $x$ & $x$ & $x$ & $x$ & $x$ & $x$ & $x$ & $x$ & $x$ & $x$ & $\mathrm{x}$ & 3 \\
\hline $\mathrm{RH} 2-1$ & 100 & 3 & & 0 & 0 & 0 & 1 & 2 & 2 & 9.4 & 4 & 0 & $x$ & $x$ & $5 Y R 6 / 4>, 5 / 4,3 / 3$ & $5 Y R$ 4/2>, 5/2 & $x$ & $x$ & $x$ & $x$ & $x$ & $x$ & $x$ & $x$ & $x$ & $x$ & $x$ & $x$ & $x$ & $x$ & 4 \\
\hline $\mathrm{RH} 2-1$ & 100 & 3 & & 0 & 0 & 0 & 1 & 2 & 2 & 9.4 & 4 & 0 & $x$ & $x$ & $5 Y R 6 / 4>, 5 / 4,3 / 3$ & $5 Y R$ 4/2>, 5/2 & $x$ & $x$ & $x$ & $x$ & $x$ & $x$ & $x$ & $x$ & $x$ & $x$ & $x$ & $x$ & $x$ & $\mathrm{x}$ & 4 \\
\hline RH 2-1 & 151 & 3 & & 0 & 0 & 0 & 1 & 2 & 2 & 9.4 & 4 & 0 & $x$ & $x$ & $5 Y R 6 / 4>, 5 / 4,3 / 3$ & 5 YR $4 / 2>, 5 / 2$ & $x$ & $x$ & $x$ & $x$ & $x$ & $x$ & $x$ & $x$ & $x$ & $x$ & $x$ & $x$ & $x$ & $\mathrm{x}$ & \\
\hline $\mathrm{RH} 2-1$ & 152 & 3 & & 0 & 0 & 0 & 1 & 2 & 2 & 9.4 & 4 & 0 & $x$ & $x$ & $5 Y R$ 6/4>, 5/4, 3/3 & $5 Y R \quad 4 / 2>, 5 / 2$ & $x$ & $x$ & $x$ & $x$ & $x$ & $x$ & $x$ & $x$ & $x$ & $x$ & $x$ & $x$ & $x$ & $x$ & 3 y 4 \\
\hline $\mathrm{RH} 2-1$ & 300 & 3 & & 0 & 0 & 0 & 1 & 2 & 2 & 9.4 & 4 & 0 & $x$ & $x$ & $5 Y R$ 6/4>, 5/4, 3/3 & $5 Y R$ 4/2>, 5/2 & $x$ & $x$ & $x$ & $x$ & $x$ & $\mathrm{x}$ & $x$ & $x$ & $x$ & $x$ & $x$ & $x$ & $x$ & $\mathrm{x}$ & 3 \\
\hline $\mathrm{RH} 2-1$ & 400 & 3 & & 0 & 0 & 0 & 1 & 2 & 2 & 9.4 & 4 & 0 & $x$ & $x$ & $5 Y R$ 6/4>, 5/4, 3/3 & $5 Y R \quad 4 / 2>, 5 / 2$ & $x$ & $x$ & $x$ & $x$ & $x$ & $x$ & $x$ & $x$ & $x$ & $x$ & $x$ & $x$ & $x$ & $x$ & 3 y 7 \\
\hline RH 2-1 & 401 & 3 & & 0 & 0 & 0 & 1 & 2 & 2 & 9.4 & 4 & 0 & $x$ & $x$ & $5 Y R$ 6/4>, 5/4, 3/3 & $5 Y R$ 4/2>, 5/2 & $x$ & $x$ & $x$ & $x$ & $x$ & $x$ & $x$ & $x$ & $x$ & $x$ & $x$ & $x$ & $x$ & $x$ & 3 \\
\hline $\mathrm{RH} 2-1$ & 401 & 3 & & 0 & 0 & 0 & 1 & 2 & 2 & 9.4 & 4 & 0 & $x$ & $x$ & $5 Y R$ 6/4>, 5/4, 3/3 & $5 Y R$ 4/2>, 5/2 & $x$ & $x$ & $x$ & $x$ & $\mathrm{x}$ & $x$ & $x$ & $\mathrm{x}$ & $x$ & $x$ & $x$ & $x$ & $\mathrm{x}$ & $\mathrm{x}$ & 3 y 6 \\
\hline $\mathrm{RH} 2-1$ & 401 & 3 & & 0 & 0 & 0 & 1 & 2 & 2 & 9.4 & 4 & 0 & $x$ & $x$ & $5 Y R 6 / 4>, 5 / 4,3 / 3$ & $5 Y R$ 4/2>, 5/2 & $x$ & $x$ & $x$ & $x$ & $x$ & $x$ & $x$ & $x$ & $x$ & $x$ & $x$ & $x$ & $x$ & $\mathrm{x}$ & 3 y 6 \\
\hline $\mathrm{RH} 2-1$ & 301 & 4 & & 0 & 0 & 0 & 1 & 2 & 2 & 12.4 & 5.5 & 0 & $x$ & $x$ & $5 Y R$ 5/2, 7.5YR 4/0, 2/0 & 5YR5/4, 7.5YR3/0 & $x$ & $x$ & $\mathrm{x}$ & $x$ & $\mathrm{x}$ & $x$ & $x$ & $x$ & $x$ & $x$ & $x$ & $x$ & $\mathrm{x}$ & $\mathrm{x}$ & 1 \\
\hline RH 2-1 & 302 & 4 & & 0 & 0 & 0 & 1 & 2 & 2 & 12.4 & 5.5 & 0 & $x$ & $x$ & $5 Y R$ 5/2, 7.5YR 4/0, 2/0 & 5YR5/4, 7.5YR3/0 & $x$ & $x$ & $x$ & $x$ & $x$ & $x$ & $x$ & $x$ & $x$ & $x$ & $x$ & $x$ & $x$ & $x$ & 1 \\
\hline $\mathrm{RH} 2-1$ & 151 & 4 & & 0 & 0 & 0 & 1 & 2 & 2 & 12.4 & 5.5 & 0 & $x$ & $x$ & 5YR 5/2, 7.5YR 4/0, 2/0 & 5YR5/4, 7.5YR3/0 & $x$ & $x$ & $x$ & $x$ & $\mathrm{x}$ & $x$ & $x$ & $x$ & $x$ & $x$ & $x$ & $x$ & $x$ & $\mathrm{x}$ & \\
\hline $\mathrm{RH} 2-1$ & 152 & 4 & & 0 & 0 & 0 & 1 & 2 & 2 & 12.4 & 5.5 & 0 & $x$ & $x$ & $5 Y R$ 5/2, 7.5YR 4/0, 2/0 & 5YR5/4, 7.5YR3/0 & $x$ & $x$ & $x$ & $x$ & $x$ & $x$ & $x$ & $x$ & $x$ & $x$ & $x$ & $x$ & $x$ & $\mathrm{x}$ & 1 y 7 \\
\hline $\mathrm{RH} 2-1$ & 302 & 4 & & 0 & 0 & 0 & 1 & 2 & 2 & 12.4 & 5.5 & 0 & $x$ & $x$ & 5YR 5/2, 7.5YR 4/0, 2/0 & 5YR5/4, 7.5YR3/0 & $x$ & $x$ & $x$ & $\mathrm{x}$ & $x$ & $x$ & $x$ & $x$ & $x$ & $x$ & $x$ & $x$ & $x$ & $\mathrm{x}$ & 1 \\
\hline $\mathrm{RH} 2-1$ & 302 & 4 & & 0 & 0 & 0 & 1 & 2 & 2 & 12.4 & 5.5 & 0 & $x$ & $x$ & 5YR 5/2, 7.5YR 4/0, 2/0 & 5YR5/4, 7.5YR3/0 & $x$ & $x$ & $x$ & $x$ & $\mathrm{x}$ & $\mathrm{x}$ & $x$ & $x$ & $x$ & $x$ & $x$ & $x$ & $x$ & $\mathrm{x}$ & 1 \\
\hline RH 2-1 & 402 & 5 & & 0 & 0 & 0 & 0 & $2 \mathrm{y} 6$ & 2 & 5.4 & 4 & 1 & $\mathrm{x}$ & $x$ & 5YR4/2, 10R4/6, 10YR5/2 & 5YR 5/4, 10YR 6/3 & $\mathrm{x}$ & $x$ & $x$ & $x$ & $x$ & $x$ & $\mathrm{x}$ & $x$ & $\mathrm{x}$ & $x$ & $x$ & $x$ & $x$ & $x$ & 1 \\
\hline $\mathrm{RH} 2-1$ & 402 & 5 & & 0 & 0 & 0 & 0 & $2 \mathrm{y} 6$ & 2 & 5.4 & 4 & 1 & $x$ & $x$ & 5YR4/2, 10R4/6, 10YR5/2 & 5YR 5/4, 10YR 6/3 & $x$ & $\mathrm{x}$ & $\mathrm{x}$ & $x$ & $\mathrm{x}$ & $x$ & $x$ & $\mathrm{x}$ & $x$ & $x$ & $x$ & $x$ & $x$ & $\mathrm{x}$ & 1 \\
\hline $\mathrm{RH} 2-1$ & 402 & 5 & & 0 & 0 & 0 & 0 & $2 \mathrm{y} 6$ & 2 & 5.4 & 4 & 1 & $x$ & $x$ & 5YR4/2, 10R4/6, 10YR5/2 & 5YR 5/4, 10YR 6/3 & $x$ & $x$ & $x$ & $x$ & $x$ & $x$ & $x$ & $x$ & $x$ & $x$ & $x$ & $x$ & $x$ & $\mathrm{x}$ & 1 \\
\hline $\mathrm{RH} 2-1$ & 400 & 5 & & 0 & 0 & 0 & 0 & $2 \mathrm{y} 6$ & 2 & 5.4 & 4 & 1 & $x$ & $x$ & 5YR4/2, 10R4/6, 10YR5/2 & 5YR 5/4, 10YR 6/3 & $x$ & $x$ & $x$ & $x$ & $x$ & $x$ & $x$ & $x$ & $x$ & $x$ & $x$ & $x$ & $x$ & $\mathrm{x}$ & 5 \\
\hline $\mathrm{RH} 2-1$ & 401 & 5 & & 0 & 0 & 0 & 0 & $2 \mathrm{y} 6$ & 2 & 5.4 & 4 & 1 & $x$ & $x$ & 5YR4/2, 10R4/6, 10YR5/2 & 5YR 5/4, 10YR 6/3 & $x$ & $x$ & $x$ & $x$ & $\mathrm{x}$ & $\mathrm{x}$ & $x$ & $\mathrm{x}$ & $x$ & $x$ & $x$ & $x$ & $x$ & $\mathrm{x}$ & 5 \\
\hline $\mathrm{RH} 2-1$ & 151 & 5 & & 0 & 0 & 0 & 0 & $2 \mathrm{y} 6$ & 2 & 5.4 & 4 & 1 & $x$ & $x$ & 5YR4/2, 10R4/6, 10YR5/2 & 5YR 5/4, 10YR 6/3 & $x$ & $x$ & $x$ & $x$ & $x$ & $x$ & $x$ & $x$ & $\mathrm{x}$ & $x$ & $x$ & $x$ & $x$ & $x$ & 5 \\
\hline $\mathrm{RH} 2-1$ & 151 & 5 & & 0 & 0 & 0 & 0 & $2 \mathrm{y} 6$ & 2 & 5.4 & 4 & 1 & $x$ & $x$ & 5YR4/2, 10R4/6, 10YR5/2 & 5YR 5/4, 10YR 6/3 & $x$ & $x$ & $x$ & $x$ & $\mathrm{x}$ & $\mathrm{x}$ & $x$ & $x$ & $x$ & $x$ & $x$ & $x$ & $x$ & $\mathrm{x}$ & 5 \\
\hline $\mathrm{RH} 2-1$ & $\sup$ & 6 & & 1 & 0 & 1 & 2 & 2 & 3 & 6.3 & 5.5 & 0 & $x$ & $x$ & 7.5YR 3/0, 7.5YR 4/0 & 7.5YR $2 / 0$ & 20 & 63 & 8 & 1 & 1 & $x$ & $x$ & $x$ & $x$ & $x$ & $x$ & $x$ & $x$ & $x$ & \\
\hline $\mathrm{RH} 2-1$ & 152 & 6 & & 1 & 0 & 1 & 2 & 2 & 3 & 6.3 & 5.5 & 0 & $x$ & $\mathrm{x}$ & 7.5YR 3/0, 7.5YR 4/0 & $7.5 Y R 2 / 0$ & 20 & 63 & 8 & 1 & 1 & $x$ & $x$ & $x$ & $x$ & $x$ & $x$ & $x$ & $x$ & $x$ & \\
\hline RH 2-1 & 100 & 7 & & 0 & 0 & 1 & 0 & $2 \mathrm{y} 6$ & $2 \mathrm{y} 6$ & 6 & 4.3 & 1 & $x$ & $\mathrm{x}$ & 5YR 5/4, 5YR 6/4 & 10R 5/6, 10R 4/6 & $x$ & $\mathrm{x}$ & $\mathrm{x}$ & $x$ & $\mathrm{x}$ & $x$ & $\mathrm{x}$ & $x$ & $x$ & $x$ & $x$ & $x$ & $x$ & $\mathrm{x}$ & 3 \\
\hline $\mathrm{RH} 2-1$ & 301 & 7 & & 0 & 0 & 1 & 0 & $2 \mathrm{y} 6$ & $2 \mathrm{y} 6$ & 6 & 4.3 & 1 & $x$ & $x$ & $5 Y R$ 5/4, 5YR 6/4 & 10R 5/6, 10R 4/6 & $x$ & $x$ & $x$ & $x$ & $x$ & $x$ & $x$ & $x$ & $x$ & $x$ & $x$ & $x$ & $x$ & $\mathrm{x}$ & 4 \\
\hline RH 2-1 & Sup & 8 & & 0 & 0 & 0 & 1 & 2 & 1 & 12.5 & 7 & 0 & $x$ & $\mathrm{x}$ & 5 YYR 5/3, 5YR 5/4 & $5 Y$ YR 5/2, 4/1 & $\mathrm{x}$ & $\mathrm{x}$ & $\mathrm{x}$ & $x$ & $x$ & $x$ & $\mathrm{x}$ & $x$ & $x$ & $x$ & $x$ & $x$ & $x$ & $x$ & 3 \\
\hline RH 2-1 & 100 & 8 & & 0 & 0 & 0 & 1 & 2 & 1 & 12.5 & 7 & 0 & $x$ & $x$ & $5 Y R$ 5/3, 5YR 5/4 & $5 Y R$ 5/2, 4/1 & $x$ & $x$ & $x$ & $x$ & $x$ & $x$ & $x$ & $x$ & $x$ & $x$ & $x$ & $x$ & $x$ & $x$ & 3 y 4 \\
\hline RH 2-1 & 100 & 8 & & 0 & 0 & 0 & 1 & 2 & 1 & 12.5 & 7 & 0 & $x$ & $\mathrm{x}$ & 5YR 5/3, 5YR 5/4 & $5 Y R$ 5/2, 4/1 & $\mathrm{x}$ & $\mathrm{x}$ & $x$ & $x$ & $x$ & $x$ & $x$ & $x$ & $x$ & $x$ & $x$ & $x$ & $x$ & $x$ & 3 \\
\hline $\mathrm{RH} 2-1$ & 100 & 8 & & 0 & 0 & 0 & 1 & 2 & 1 & 12.5 & 7 & 0 & $x$ & $x$ & $5 Y R$ 5/3, 5YR 5/4 & $5 Y R$ 5/2, 4/1 & $x$ & $x$ & $x$ & $x$ & $x$ & $x$ & $x$ & $x$ & $x$ & $x$ & $x$ & $x$ & $x$ & $\mathrm{x}$ & 3 y 4 \\
\hline $\mathrm{RH} 2-1$ & 100 & 8 & & 0 & 0 & 0 & 1 & 2 & 1 & 12.5 & 7 & 0 & $\mathrm{x}$ & $\mathrm{x}$ & 5YR 5/3, 5YR 5/4 & $5 Y R$ 5/2, 4/1 & $\mathrm{x}$ & $\mathrm{x}$ & $\mathrm{x}$ & $x$ & $x$ & $\mathrm{x}$ & $x$ & $x$ & $x$ & $x$ & $x$ & $x$ & $x$ & $x$ & 3 y 4 \\
\hline
\end{tabular}




\begin{tabular}{|c|c|c|c|c|c|c|c|c|c|c|c|c|c|c|c|c|c|c|c|c|c|c|c|c|c|c|c|c|c|c|c|}
\hline \multirow[b]{2}{*}{ Sitio } & \multirow[b]{2}{*}{ UP } & \multirow[b]{2}{*}{ GF } & \multirow[b]{2}{*}{ FNA } & \multirow[b]{2}{*}{ Fgto } & \multicolumn{10}{|c|}{ Manufactura } & \multicolumn{2}{|c|}{ Cocción } & \multicolumn{5}{|c|}{ Borde-labio } & \multicolumn{6}{|c|}{ Asa } & \multicolumn{3}{|c|}{ Base } & \multirow[b]{2}{*}{ Alterac } \\
\hline & & & & & $\begin{array}{l}\text { Tec } \\
\text { lev }\end{array}$ & \begin{tabular}{|c|} 
For \\
ma \\
\end{tabular} & $\begin{array}{l}\text { Mar } \\
\text { cas }\end{array}$ & \begin{tabular}{|l|} 
Sup \\
ext
\end{tabular} & \begin{tabular}{c|} 
Sup \\
int
\end{tabular} & \begin{tabular}{|l|} 
Esp \\
max
\end{tabular} & $\begin{array}{l}\text { Esp } \\
\text { min }\end{array}$ & $\begin{array}{l}\text { Deco } \\
\text { pint }\end{array}$ & Motivo & Estilo & Color sup ext & Color sup int & Diam & \begin{tabular}{|l|} 
Lrg \\
arc
\end{tabular} & \begin{tabular}{|c|c|}
$\%$ & D \\
arco & \\
\end{tabular} & Direc & $\begin{array}{c}\text { For } \\
\text { ma }\end{array}$ & $\begin{array}{l}\text { Lar } \\
\text { go }\end{array}$ & $\begin{array}{c}\text { An } \\
\text { cho }\end{array}$ & Esp & $\begin{array}{l}\text { Sec } \\
\text { ción }\end{array}$ & \begin{tabular}{|c|} 
In \\
serc
\end{tabular} & $\mid$\begin{tabular}{|} 
Posi \\
ción
\end{tabular} & Diám & $\begin{array}{l}\text { Mor } \\
\text { fol }\end{array}$ & $\begin{array}{l}\text { Uni } \\
\text { ón }\end{array}$ & \\
\hline $\mathrm{RH} 2-1$ & 100 & 8 & & 0 & 0 & 0 & 1 & 2 & 1 & 12.5 & 7 & 0 & $x$ & $x$ & $5 Y R$ 5/3, 5YR 5/4 & $5 Y R$ 5/2, 4/1 & $x$ & $x$ & $x$ & $x$ & $x$ & $x$ & $\mathrm{x}$ & $\mathrm{x}$ & $x$ & $x$ & $x$ & $x$ & $x$ & $x$ & 3 \\
\hline $\mathrm{RH} 2-1$ & 100 & 8 & & 0 & 0 & 0 & 1 & 2 & 1 & 12.5 & 7 & 0 & $x$ & $x$ & $5 Y R$ 5/3, 5YR 5/4 & $5 Y R$ 5/2, 4/1 & $x$ & $x$ & $x$ & $x$ & $x$ & $x$ & $x$ & $x$ & $x$ & $x$ & $x$ & $x$ & $x$ & $x$ & 3 \\
\hline $\mathrm{RH} 2-1$ & Sup & & 1 & 1 & 0 & 2 & 1 & 2 & 2 & 11.5 & 10 & 0 & $x$ & $x$ & $5 Y R$ 5/4 y $6 / 4<$ & $5 Y R$ 5/3 y $6 / 3<$ & 30.6 & 96.1 & 16 & 1 & 2 & $x$ & $x$ & $\mathrm{x}$ & $x$ & $x$ & $x$ & $x$ & $x$ & $x$ & 4 \\
\hline $\mathrm{RH} 2-1$ & Sup & & 2 & 0 & 0 & 2 & 0 & 2 & 2 & 13.5 & 11 & 0 & $x$ & $x$ & $5 Y R$ 5/4 y $6 / 4$ & $5 Y R$ 5/3 y $6 / 3$ & $x$ & $x$ & $x$ & $x$ & $x$ & $x$ & $\mathrm{x}$ & $\mathrm{x}$ & $x$ & $x$ & $x$ & $x$ & $x$ & $x$ & \\
\hline $\mathrm{RH} 2-1$ & Sup & & 3 & 1 & 0 & 0 & 0 & 2 & 2 & 7.5 & 6 & 0 & $x$ & $x$ & 5YR 5/4 & 5YR 5/4 & indet & indet|i & indet & 1 & 1 & $x$ & $x$ & $x$ & $x$ & $x$ & $x$ & $x$ & $x$ & $x$ & 3 \\
\hline $\mathrm{RH} 2-1$ & Sup & & 4 & 1 & 0 & 0 & 0 & 2 & 2 & 8 & 6.3 & 0 & $x$ & $x$ & 5YR 5/6 & 5YR 5/6 & indet & indet & indet & 2 & 1 & $x$ & $x$ & $x$ & $x$ & $x$ & $x$ & $x$ & $x$ & $x$ & 3 \\
\hline $\mathrm{RH} 2-1$ & Sup & & 5 & 1 & 0 & 0 & 0 & 2 & 2 & 8 & 7 & 0 & $x$ & $x$ & 5YR 5/2 & 5YR 5/3 & indet & indet i & indet & 1 & 1 & $\mathrm{x}$ & $x$ & $x$ & $x$ & $x$ & $x$ & $x$ & $x$ & $x$ & 3 \\
\hline $\mathrm{RH} 2-1$ & Sup & & 6 & 1 & 0 & 0 & 0 & $2 \mathrm{y} 6$ & 2 & 7 & 5.5 & 1 & $x$ & $x$ & $5 Y R$ 5/4, 10R 4/6 & 5YR 5/4 & indet & indet i & indet & 0 & 2 & $x$ & $x$ & $\mathrm{x}$ & $x$ & $x$ & $x$ & $x$ & $x$ & $x$ & 3 y 5 \\
\hline $\mathrm{RH} 2-1$ & Sup & & 7 & 1 & 0 & 0 & 0 & $3 y 6$ & $2 \mathrm{y} 6$ & 7.4 & 5.5 & 1 & $x$ & $x$ & 10R 4/6 & 10R 4/6, 5YR 5/4 & indet & indet i & indet & 0 & 2 & $x$ & $x$ & $x$ & $x$ & $x$ & $x$ & $x$ & $x$ & $x$ & 5 \\
\hline $\mathrm{RH} 2-1$ & Sup & & 8 & 1 & 0 & 0 & 0 & $2 \mathrm{y} 6$ & 2 & 6.7 & 4.1 & 1 & $x$ & $x$ & 10R 4/6, 5YR 5/3 & 5 YR 5/3 & indet & indet & indet & 1 & 3 & $x$ & $x$ & $x$ & $x$ & $x$ & $x$ & $x$ & $x$ & $x$ & 5 y 6 \\
\hline $\mathrm{RH} 2-1$ & Sup & & 9 & 2 & 0 & 0 & 0 & 1 & 2 & 20 & 8.5 & 0 & $x$ & $x$ & $2,5 Y R \quad 4 / 6$ & $2.5 Y R$ 5/4 & $x$ & $x$ & $x$ & $x$ & $x$ & $x$ & $x$ & $\mathrm{x}$ & $x$ & $x$ & $x$ & 7a10 & 5 & 3 & 3 \\
\hline $\mathrm{RH} 2-1$ & Sup & & 10 & 3 & 0 & 0 & 0 & 2 & 2 & 9 & 8 & 0 & $x$ & $x$ & 5YR 5/4 & 5YR 5/4 & $x$ & $x$ & $x$ & $x$ & $x$ & 3.6 & 3 & 11 & 4 & 4 & 0 & $x$ & $\mathrm{x}$ & $x$ & 3 y 4 \\
\hline $\mathrm{RH} 2-1$ & sup & & 11 & 0 & 0 & 0 & 2 & 2 & 3 & 8 & 7.3 & 0 & $x$ & $x$ & 5YR 5/4 & 7.5YR 2/0 & $x$ & $x$ & $x$ & $x$ & $x$ & $x$ & $x$ & $x$ & $x$ & $x$ & $x$ & $x$ & $x$ & $x$ & 1,2 y 4 \\
\hline $\mathrm{RH} 2-1$ & Sup & & 12 & 0 & 0 & 0 & 2 & 2 & 3 & 7.6 & 6.8 & 0 & $x$ & $x$ & $5 Y R$ 5/4, 7.5YR 3/2 & $7.5 Y R$ 2/0 y $5 / 2$ & $x$ & $x$ & $x$ & $x$ & $x$ & $x$ & $x$ & $x$ & $x$ & $x$ & $x$ & $x$ & $x$ & $x$ & 1,2 y 4 \\
\hline $\mathrm{RH} 2-1$ & Sup & & 13 & 0 & 0 & 0 & 2 & $2 \mathrm{y} 6$ & 2 & 6.6 & 5 & 1 & $x$ & $x$ & 10R 5/8 & $5 Y R$ 4/4 y $6 / 6$ & $x$ & $x$ & $x$ & $x$ & $x$ & $\mathrm{x}$ & $x$ & $x$ & $x$ & $x$ & $x$ & $x$ & $x$ & $x$ & 3 y 4 \\
\hline $\mathrm{RH} 2-1$ & Sup & & 14 & 0 & 0 & 0 & 1 & $2 \mathrm{y} 6$ & 2 & 8 & 5.6 & 1 & $x$ & $x$ & 10R 4/1 & 5YR 5/6 & $x$ & $x$ & $x$ & $x$ & $x$ & $x$ & $x$ & $x$ & $x$ & $x$ & $x$ & $x$ & $x$ & $x$ & 3 \\
\hline $\mathrm{RH} 2-1$ & Sup & & 16 & 0 & 0 & 0 & 1 & $2 \mathrm{y} 6$ & 2 & 7.5 & 5.6 & 1 & $x$ & $x$ & 10R 4/1 & 5YR 5/4 & $x$ & $x$ & $x$ & $x$ & $x$ & $\mathrm{x}$ & $x$ & $x$ & $x$ & $x$ & $x$ & $x$ & $x$ & $x$ & 3 \\
\hline $\mathrm{RH} 2-1$ & Sup & & 17 & 0 & 0 & 0 & 1 & $2 \mathrm{y} 6$ & 2 & 7 & 5 & 1 & $x$ & $x$ & $10 R 5 / 1$ & 5YR 5/4 & $x$ & $x$ & $x$ & $x$ & $x$ & $\mathrm{x}$ & $x$ & $x$ & $x$ & $x$ & $x$ & $x$ & $\mathrm{x}$ & $x$ & 3 y 4 \\
\hline $\mathrm{RH} 2-1$ & Sup & & 18 & 0 & 0 & 0 & 1 & $2 \mathrm{y} 6$ & 2 & 6.9 & 6 & 1 & $x$ & $x$ & 10R 4/1 & 5YR 5/6 & $x$ & $x$ & $x$ & $x$ & $x$ & $x$ & $\mathrm{x}$ & $x$ & $x$ & $x$ & $x$ & $x$ & $x$ & $x$ & 3 \\
\hline $\mathrm{RH} 2-1$ & Sup & & 19 & 0 & 0 & 0 & 1 & $2 \mathrm{y} 6$ & 2 & 7.7 & 7.2 & 1 & $x$ & $x$ & 10R 4/1 & 5YR 5/6 & $x$ & $x$ & $x$ & $x$ & $x$ & $x$ & $x$ & $x$ & $x$ & $x$ & $x$ & $x$ & $x$ & $x$ & 3 \\
\hline $\mathrm{RH} 2-1$ & Sup & & 20 & 0 & 0 & 0 & 0 & $2 \mathrm{y} 4$ & 2 & 6 & 5.5 & 1 & $x$ & $x$ & $5 Y R 6 / 4,10 R$ 4/6 & 5YR 5/4 & $x$ & $x$ & $x$ & $x$ & $x$ & $\mathrm{x}$ & $x$ & $x$ & $x$ & $x$ & $x$ & $x$ & $x$ & $x$ & 5 \\
\hline $\mathrm{RH} 2-1$ & Sup & & 21 & 0 & 0 & 0 & 0 & $2 \mathrm{y} 4$ & 2 & 5.7 & 5.3 & 1 & $x$ & $x$ & $5 Y R$ 5/4, 10R 4/6 & 5YR 5/4 & $x$ & $x$ & $x$ & $x$ & $x$ & $\mathrm{x}$ & $\mathrm{x}$ & $x$ & $x$ & $x$ & $x$ & $x$ & $x$ & $x$ & 5 \\
\hline $\mathrm{RH} 2-1$ & Sup & & 22 & 0 & 0 & 0 & 0 & $2 \mathrm{y} 4$ & 2 & 6.2 & 5.6 & 1 & $x$ & $x$ & $5 Y R$ 5/4, 10R 4/6 & 5YR 5/4 & $x$ & $x$ & $x$ & $x$ & $x$ & $x$ & $x$ & $\mathrm{x}$ & $x$ & $x$ & $x$ & $x$ & $x$ & $x$ & 5 \\
\hline $\mathrm{RH} 2-1$ & Sup & & 23 & 0 & 0 & 0 & 1 & $2 \mathrm{y} 4$ & 2 & 6.8 & 5 & 1 & $x$ & $x$ & $5 Y R 6 / 4,10 R$ 4/8 & 5YR 5/3 & $x$ & $x$ & $x$ & $x$ & $x$ & $\mathrm{x}$ & $\mathrm{x}$ & $\mathrm{x}$ & $x$ & $x$ & $x$ & $x$ & $x$ & $x$ & 3 y 5 \\
\hline $\mathrm{RH} 2-1$ & Sup & & 24 & 0 & 0 & 0 & 0 & $2 \mathrm{y} 4$ & 2 & 6.6 & 6.3 & 1 & $\mathrm{x}$ & $x$ & $5 Y R$ 5/4, 10R 4/6 & 5YR 5/6 & $\mathrm{x}$ & $\mathrm{x}$ & $\mathrm{x}$ & $x$ & $x$ & $x$ & $\mathrm{x}$ & $\mathrm{x}$ & $\mathrm{x}$ & $\mathrm{x}$ & $x$ & $x$ & $x$ & $\mathrm{x}$ & 3 y 5 \\
\hline $\mathrm{RH} 2-1$ & Sup & & 25 & 0 & 0 & 0 & 0 & $3 y 4$ & 2 & 10.7 & 7 & 1 & $x$ & $x$ & 5YR 5/4, 10R 4/8 & 5YR 5/2 & $x$ & $x$ & $x$ & $x$ & $x$ & $x$ & $x$ & $\mathrm{x}$ & $x$ & $x$ & $x$ & $x$ & $x$ & $x$ & 3 y 5 \\
\hline $\mathrm{RH} 2-1$ & Sup & & 26 & 0 & 0 & 0 & 0 & $3 y 4$ & 2 & 8 & 6.7 & 1 & $x$ & $x$ & 5YR 5/4, 10R 4/6 & 5YR 6/4 & $x$ & $x$ & $x$ & $x$ & $x$ & $\mathrm{x}$ & $\mathrm{x}$ & $x$ & $x$ & $x$ & $x$ & $x$ & $x$ & $x$ & 3 y 5 \\
\hline $\mathrm{RH} 2-1$ & Sup & & 27 & 0 & 0 & 0 & 0 & $2 \mathrm{y} 4$ & 2 & 6.8 & 6 & 1 & $x$ & $x$ & $5 Y R$ 5/4, 10R 4/6 & 5YR 4/4 & $x$ & $x$ & $x$ & $x$ & $x$ & $\mathrm{x}$ & $x$ & $x$ & $x$ & $x$ & $x$ & $x$ & $x$ & $x$ & 3 y 5 \\
\hline $\mathrm{RH} 2-1$ & Sup & & 28 & 0 & 0 & 0 & 0 & $2 \mathrm{y} 4$ & 2 & 6.8 & 6 & 1 & $x$ & $x$ & $5 Y R$ 5/4, 10R 4/6 & 5YR 4/4 & $x$ & $x$ & $x$ & $x$ & $x$ & $\mathrm{x}$ & $\mathrm{x}$ & $x$ & $x$ & $x$ & $x$ & $x$ & $x$ & $x$ & 3 y 5 \\
\hline $\mathrm{RH} 2-1$ & Sup & & 29 & 0 & 0 & 0 & 0 & $2 \mathrm{y} 4$ & 2 & 5.7 & 5.4 & 1 & $x$ & $x$ & $5 Y R 5 / 3,10 R 4 / 6$ & 5YR 5/4 & $x$ & $x$ & $x$ & $x$ & $x$ & $\mathrm{x}$ & $x$ & $x$ & $x$ & $x$ & $x$ & $x$ & $x$ & $x$ & 5 \\
\hline $\mathrm{RH} 2-1$ & Sup & & 30 & 0 & 0 & 0 & 0 & $2 \mathrm{y} 4$ & 2 & 5 & 4.7 & 1 & $x$ & $x$ & 5 YYR 5/3, 10R 4/6 & 5YR 5/4 & $x$ & $x$ & $x$ & $x$ & $x$ & $x$ & $x$ & $x$ & $x$ & $x$ & $x$ & $x$ & $x$ & $x$ & 5 \\
\hline $\mathrm{RH} 2-1$ & Sup & & 31 & 0 & 0 & 0 & 0 & $2 \mathrm{y} 4$ & 2 & 6.2 & 6.2 & 1 & $\mathrm{x}$ & $\mathrm{x}$ & $5 Y R 5 / 3,10 R 4 / 6$ & 5YR 5/4 & $x$ & $x$ & $\mathrm{x}$ & $x$ & $x$ & $x$ & $\mathrm{x}$ & $x$ & $x$ & $x$ & $x$ & $x$ & $x$ & $x$ & 3 y 5 \\
\hline $\mathrm{RH} 2-1$ & Sup & & 32 & 0 & 0 & 0 & 0 & $2 \mathrm{y} 4$ & 2 & 6.5 & 6.5 & 1 & $x$ & $x$ & $5 Y R$ 5/4, 10R 4/6 & 5YR 5/4 & $x$ & $x$ & $x$ & $x$ & $x$ & $x$ & $x$ & $x$ & $x$ & $x$ & $x$ & $x$ & $x$ & $x$ & 3 y 5 \\
\hline $\mathrm{RH} 2-1$ & Sup & & 35 & 0 & 0 & 0 & 0 & $3 y 4$ & 2 & 7 & 6.5 & 1 & $x$ & $x$ & $5 Y R$ 5/4, 10R 4/6 & 5YR 5/4 & $x$ & $x$ & $x$ & $x$ & $x$ & $\mathrm{x}$ & $x$ & $\mathrm{x}$ & $x$ & $x$ & $x$ & $x$ & $x$ & $x$ & 3 y 5 \\
\hline $\mathrm{RH} 2-1$ & Sup & & 36 & 0 & 0 & 0 & 1 & $3 y 4$ & 2 & 7 & 6 & 1 & $x$ & $x$ & 5YR 5/6, 10R 4/6 & 5YR 5/6 & $x$ & $x$ & $x$ & $x$ & $x$ & $\mathrm{x}$ & $\mathrm{x}$ & $x$ & $x$ & $x$ & $x$ & $x$ & $x$ & $x$ & 3 y 5 \\
\hline $\mathrm{RH} 2-1$ & Sup & & 37 & 0 & 0 & 0 & 0 & $3 y 4$ & 2 & 6.7 & 6.3 & 1 & $x$ & $x$ & 10R 4/6 & 5YR 5/3 & $x$ & $x$ & $x$ & $x$ & $x$ & $x$ & $x$ & $x$ & $x$ & $x$ & $x$ & $x$ & $x$ & $x$ & 3 \\
\hline $\mathrm{RH} 2-1$ & Sup & & 38 & 0 & 0 & 0 & 0 & $3 y 4$ & 2 & 6 & 6 & 1 & $\mathrm{x}$ & $\mathrm{x}$ & 10R 4/6 & 5YR 5/4 & $\mathrm{x}$ & $\mathrm{x}$ & $\mathrm{x}$ & $\mathrm{x}$ & $x$ & $\mathrm{x}$ & $\mathrm{x}$ & $\mathrm{x}$ & $\mathrm{x}$ & $x$ & $x$ & $x$ & $x$ & $x$ & 3 \\
\hline $\mathrm{RH} 2-1$ & Sup & & 39 & 0 & 0 & 0 & 0 & $2 \mathrm{y} 4$ & 2 & 5.5 & 5.2 & 1 & $x$ & $x$ & 10R 4/6 & 5YR 5/4 & $x$ & $x$ & $x$ & $x$ & $x$ & $x$ & $x$ & $x$ & $\mathrm{x}$ & $x$ & $x$ & $x$ & $x$ & $x$ & 3 \\
\hline
\end{tabular}




\begin{tabular}{|c|c|c|c|c|c|c|c|c|c|c|c|c|c|c|c|c|c|c|c|c|c|c|c|c|c|c|c|c|c|c|c|}
\hline \multirow[b]{2}{*}{ Sitio } & \multirow[b]{2}{*}{ UP } & \multirow[b]{2}{*}{ GF } & \multirow[b]{2}{*}{ FNA } & \multirow[b]{2}{*}{ Fgto } & \multicolumn{10}{|c|}{ Manufactura } & \multicolumn{2}{|c|}{ Cocción } & \multicolumn{5}{|c|}{ Borde-labio } & \multicolumn{6}{|c|}{ Asa } & \multicolumn{3}{|c|}{ Base } & \multirow[b]{2}{*}{ Alterac } \\
\hline & & & & & $\begin{array}{l}\text { Tec } \\
\text { lev }\end{array}$ & $\begin{array}{l}\text { For } \\
\text { ma }\end{array}$ & $\begin{array}{l}\text { Mar } \\
\text { cas }\end{array}$ & $\begin{array}{c}\text { Sup } \\
\text { ext }\end{array}$ & \begin{tabular}{c|} 
Sup \\
int
\end{tabular} & \begin{tabular}{|l|}
$\operatorname{Esp}$ \\
$\max$
\end{tabular} & \begin{tabular}{|l|} 
Esp \\
min
\end{tabular} & \begin{tabular}{|c|}
$\begin{array}{c}\text { Deco } \\
\text { pint }\end{array}$ \\
\end{tabular} & Motivo & Estilo & Color sup ext & Color sup int & Diam & \begin{tabular}{|l|} 
Lrg \\
arc \\
\end{tabular} & \begin{tabular}{|c|}
$\%$ \\
arco \\
\end{tabular} & Direc & $\begin{array}{l}\text { For } \\
\text { ma }\end{array}$ & $\begin{array}{l}\text { Lar } \\
\text { go }\end{array}$ & $\begin{array}{l}\text { An } \\
\text { cho }\end{array}$ & Esp & $\begin{array}{l}\text { Sec } \\
\text { ción }\end{array}$ & \begin{tabular}{|l|} 
In \\
serc \\
\end{tabular} & $\begin{array}{l}\begin{array}{l}\text { Posi } \\
\text { ción }\end{array} \\
\end{array}$ & Diám & \begin{tabular}{|c|} 
Mor \\
fol
\end{tabular} & $\begin{array}{l}\text { Uni } \\
\text { ón }\end{array}$ & \\
\hline $\mathrm{RH} 2-1$ & Sup & & 40 & 0 & 0 & 0 & 0 & $3 y 4$ & $2 \mathrm{y} 6$ & 5.8 & 4.9 & 1 & $x$ & $x$ & 5YR 5/4, 10R 4/6 & 10R $4 / 6$ & $x$ & $x$ & $x$ & $x$ & $x$ & $x$ & $x$ & $x$ & $x$ & $x$ & $x$ & $x$ & $x$ & $x$ & 4 \\
\hline $\mathrm{RH} 2-1$ & Sup & & 41 & 0 & 0 & 0 & 0 & $3 y 4$ & 2 & 5.7 & 4.8 & 1 & $x$ & $x$ & 10R $4 / 6$ & 5YR 5/4 & $x$ & $x$ & $x$ & $x$ & $x$ & $x$ & $x$ & $x$ & $x$ & $x$ & $x$ & $x$ & $x$ & $\mathrm{x}$ & 3 \\
\hline $\mathrm{RH} 2-1$ & Sup & & 42 & 0 & 0 & 0 & 0 & $3 y 4$ & 2 & 6.3 & 5.5 & 1 & $x$ & $x$ & 10R $4 / 6$ & 5YR 5/4 & $x$ & $x$ & $x$ & $x$ & $x$ & $x$ & $x$ & $x$ & $x$ & $x$ & $x$ & $x$ & $x$ & $x$ & 3 y 4 \\
\hline $\mathrm{RH} 2-1$ & Sup & & 43 & 0 & 0 & 0 & 0 & $3 y 4$ & 2 & 6.5 & 6 & 1 & $x$ & $x$ & 10R $4 / 6$ & 5YR 5/4 & $x$ & $x$ & $x$ & $x$ & $x$ & $x$ & $x$ & $x$ & $x$ & $x$ & $x$ & $x$ & $x$ & $x$ & 3 \\
\hline RH 2-1 & Sup & & 44 & 0 & 0 & 0 & 0 & $2 \mathrm{y} 4$ & $2 \mathrm{y} 4$ & 6.4 & 6 & 1 & $x$ & $x$ & 5YR 5/6, 10R 4/4 & 5YR5/4, 10R 4/4 & $x$ & $x$ & $x$ & $x$ & $x$ & $x$ & $x$ & $x$ & $x$ & $x$ & $x$ & $x$ & $x$ & $x$ & 3 \\
\hline $\mathrm{RH} 2-1$ & Sup & & 45 & 0 & 0 & 0 & 0 & $3 y 4$ & 2 & 5.9 & 5.8 & 1 & $x$ & $x$ & $5 Y R \quad 4 / 4$ & 5YR 5/4 & $x$ & $x$ & $x$ & $x$ & $x$ & $x$ & $x$ & $x$ & $x$ & $x$ & $x$ & $x$ & $x$ & $x$ & 3 \\
\hline $\mathrm{RH} 2-1$ & Sup & & 46 & 0 & 0 & 0 & 0 & $3 y 4$ & $2 \mathrm{y} 6$ & 6.8 & 6 & 1 & $x$ & $x$ & 5YR 4/6 & 10R $4 / 4$ & $x$ & $\mathrm{x}$ & $x$ & $\mathrm{x}$ & $x$ & $x$ & $x$ & $x$ & $\mathrm{x}$ & $x$ & $x$ & $x$ & $\mathrm{x}$ & $\mathrm{x}$ & \\
\hline $\mathrm{RH} 2-1$ & Sup & & 47 & 0 & 0 & 0 & 0 & $3 y 4$ & $2 \mathrm{y} 6$ & 6.7 & 5.9 & 1 & $x$ & $x$ & 5YR 4/6 & 10R 4/4 & $x$ & $x$ & $x$ & $x$ & $x$ & $x$ & $x$ & $x$ & $x$ & $x$ & $x$ & $x$ & $x$ & $x$ & 3 \\
\hline $\mathrm{RH} 2-1$ & Sup & & 48 & 0 & 0 & 0 & 0 & $3 y 4$ & 2 & 5 & 5 & 1 & $x$ & $x$ & 5YR $3 / 3$ & 5YR $3 / 3$ & $x$ & $x$ & $x$ & $x$ & $\mathrm{x}$ & $x$ & $x$ & $x$ & $\mathrm{x}$ & $\mathrm{x}$ & $x$ & $x$ & $x$ & $x$ & 3 \\
\hline RH 2-1 & Sup & & 49 & 0 & 0 & 0 & 0 & $3 y 4$ & 2 & 4 & 4 & 1 & $x$ & $x$ & 7.5YR 4/6 & 5YR 5/2 & $x$ & $x$ & $x$ & $x$ & $x$ & $x$ & $x$ & $x$ & $x$ & $x$ & $x$ & $x$ & $x$ & $x$ & \\
\hline RH 2-1 & Sup & & 50 & 0 & 0 & 0 & 0 & $3 y 4$ & $3 y 4$ & \begin{tabular}{|l|}
5.8 \\
\end{tabular} & 5.8 & 1 & $x$ & $x$ & $2.5 Y R \quad 4 / 4$ & $5 Y R$ 3/3 & $x$ & $x$ & $x$ & $x$ & $x$ & $x$ & $x$ & $x$ & $x$ & $x$ & $x$ & $x$ & $x$ & $x$ & 3 \\
\hline RH 2-1 & Sup & & 51 & 0 & 0 & 0 & 0 & 3 & 3 & 4.5 & 4 & 0 & $x$ & $x$ & $2.5 Y R$ 4/6 & $2.5 Y R$ 4/8 & $x$ & $x$ & $x$ & $x$ & $x$ & $x$ & $x$ & $x$ & $x$ & $x$ & $x$ & $x$ & $x$ & $x$ & \\
\hline
\end{tabular}

\begin{tabular}{|c|c|c|c|c|c|c|c|c|c|c|c|c|c|c|c|c|c|c|c|c|c|c|c|c|c|c|c|c|c|c|c|c|}
\hline \multirow[b]{2}{*}{ Sitio } & \multirow[b]{2}{*}{ UP } & & \multirow[b]{2}{*}{ FNA } & \multirow[b]{2}{*}{ Fgto } & \multicolumn{11}{|c|}{ Manufactura } & \multicolumn{2}{|c|}{ Cocción } & \multicolumn{6}{|c|}{ Borde-labio } & \multicolumn{5}{|c|}{ Asa } & \multicolumn{3}{|c|}{ Base } & \multirow[b]{2}{*}{ Alterac } \\
\hline & & & & & $\begin{array}{l}\text { Tec. } \\
\text { Lev }\end{array}$ & & $\begin{array}{l}\text { Mar } \\
\text { cas }\end{array}$ & $\begin{array}{l}\text { Sup } \\
\text { ext }\end{array}$ & \begin{tabular}{|c|} 
Sup \\
int
\end{tabular} & $\begin{array}{l}\text { Esp } \\
\text { max }\end{array}$ & $\begin{array}{l}\text { Esp } \\
\text { min }\end{array}$ & $\begin{array}{c}\text { Deco } \\
\text { pint }\end{array}$ & \begin{tabular}{|c|} 
Deco \\
corte/desp
\end{tabular} & Motivo & Estilo & Color sup ext & Color sup int & Diam & $\begin{array}{l}\text { Lar } \\
\text { arco }\end{array}$ & \begin{tabular}{|c|}
$\%$ \\
arco
\end{tabular} & \begin{tabular}{|l|} 
Direc \\
ción
\end{tabular} & $\begin{array}{l}\text { For } \\
\text { ma }\end{array}$ & $\begin{array}{l}\text { Lar } \\
\text { go }\end{array}$ & $\begin{array}{c}\text { An } \\
\text { cho }\end{array}$ & Esp & $\begin{array}{l}\text { Sec } \\
\text { ción }\end{array}$ & \begin{tabular}{|c|} 
In \\
serc
\end{tabular} & $\begin{array}{l}\text { Posi } \\
\text { ción }\end{array}$ & Diám & $\begin{array}{c}\text { Mor } \\
\text { fol }\end{array}$ & $\begin{array}{l}\text { Uni } \\
\text { ón }\end{array}$ & \\
\hline $\mathrm{RH} 10-1$ & 102 & 1 & & 2 & 1 & 1 & $1 \mathrm{y} 2$ & 2 & 3 & 11 & 4.8 & 0 & 0 & $x$ & $x$ & 10YR 6/2, 5/1 & 10YR 5/1, 3/1 & $x$ & $x$ & $x$ & $x$ & $x$ & $x$ & $\mathrm{x}$ & $x$ & $\mathrm{x}$ & $x$ & $x$ & 10 & 5 & 2 & 4 \\
\hline $\mathrm{RH} 10-1$ & 102 & 1 & & 2 & 1 & 1 & $1 \mathrm{y} 2$ & 2 & 3 & 11 & 4.8 & 0 & 0 & $x$ & $x$ & 10YR 6/2, 5/2 & 10YR 5/1, 3/2 & $x$ & $x$ & $x$ & $x$ & $\mathrm{x}$ & $x$ & $\mathrm{x}$ & $\mathrm{x}$ & $x$ & $x$ & $x$ & 10 & 5 & 2 & 4 \\
\hline $\mathrm{RH} 10-1$ & 102 & 1 & & 2 & 1 & 1 & $1 \mathrm{y} 2$ & 2 & 3 & 11 & 4.8 & 0 & 0 & $x$ & $x$ & 10YR $6 / 2,5 / 3$ & 10YR 5/1, 3/3 & $x$ & $x$ & $x$ & $x$ & $x$ & $x$ & $x$ & $x$ & $x$ & $x$ & $x$ & 10 & 5 & 0 & 4 \\
\hline $\mathrm{RH} 10-1$ & 102 & 1 & & 0 & 1 & 1 & $1 \mathrm{y} 2$ & 2 & 3 & 11 & 4.8 & 0 & 0 & $x$ & $x$ & 10YR $6 / 2,5 / 4$ & 10YR $5 / 1,3 / 4$ & $x$ & $x$ & $x$ & $x$ & $x$ & $x$ & $x$ & $x$ & $x$ & $x$ & $\mathrm{x}$ & $x$ & $x$ & $x$ & \\
\hline $\mathrm{RH} 10-1$ & 102 & 1 & & 0 & 1 & 0 & $1 \mathrm{y} 2$ & 2 & 3 & 11 & 4.8 & 0 & 0 & $x$ & $x$ & 10YR $6 / 2,5 / 5$ & 10YR 5/1, 3/5 & $x$ & $x$ & $x$ & $x$ & $x$ & $x$ & $x$ & $x$ & $x$ & $x$ & $x$ & $x$ & $x$ & $x$ & 4 \\
\hline RH10-1 & 102 & 1 & & 0 & 1 & 0 & $1 \mathrm{y} 2$ & 2 & 3 & 11 & 4.8 & 0 & 0 & $x$ & $x$ & 10YR $6 / 2,5 / 6$ & $10 Y R$ 5/1, 3/6 & $x$ & $x$ & $x$ & $x$ & $x$ & $x$ & $x$ & $x$ & $x$ & $x$ & $x$ & $x$ & $x$ & $x$ & 4 \\
\hline RH10-1 & 102 & 2 & & 1 & 0 & 1 & 2 & $2 \mathrm{y} 6$ & $3 y 6$ & 6.6 & 6.1 & 1 & 0 & $x$ & $x$ & 10R 5/6 & 10R 5/6 & 30 & 9.2 & 7.5 & 1 & 1 & $x$ & $x$ & $x$ & $x$ & $x$ & $x$ & $x$ & $x$ & $x$ & 4 \\
\hline RH10-1 & 102 & 2 & & 1 & 0 & 1 & 2 & $2 \mathrm{y} 6$ & $3 \mathrm{y} 6$ & 6.6 & 6.1 & 1 & 0 & $x$ & $x$ & 10R 5/6 & 10R 5/6 & 30 & \begin{tabular}{|l|}
9.2 \\
\end{tabular} & 7 & 1 & 1 & $x$ & $x$ & $x$ & $x$ & $x$ & $x$ & $x$ & $x$ & $x$ & 4 \\
\hline RH10-1 & 102 & 2 & & 0 & 0 & 1 & 2 & $2 \mathrm{y} 6$ & $3 \mathrm{y} 6$ & 6.6 & 6.1 & 1 & 0 & $x$ & $x$ & 10R 5/6 & 10R 5/6 & $x$ & $x$ & $x$ & $x$ & $x$ & $x$ & $x$ & $x$ & $x$ & $x$ & $x$ & $x$ & $x$ & $x$ & \\
\hline RH10-1 & 102 & 2 & & 0 & 0 & 1 & 2 & $2 \mathrm{y} 6$ & $3 \mathrm{y} 6$ & 6.6 & \begin{tabular}{|l|}
6.1 \\
\end{tabular} & 1 & 0 & $x$ & $x$ & 10R 5/6 & 10R 5/6 & $x$ & $x$ & $x$ & $x$ & $x$ & $x$ & $x$ & $x$ & $x$ & $x$ & $x$ & $x$ & $x$ & $x$ & \\
\hline RH10-1 & 102 & 2 & & 0 & 0 & 1 & 2 & $2 \mathrm{y} 6$ & $3 \mathrm{y} 6$ & 6.6 & 6.1 & 1 & 0 & $x$ & $x$ & 10R 5/6 & 10R 5/6 & $x$ & $x$ & $x$ & $x$ & $x$ & $x$ & $x$ & $x$ & $x$ & $x$ & $x$ & $x$ & $x$ & $x$ & 4 \\
\hline $\mathrm{RH} 10-1$ & 102 & 2 & & 0 & 0 & 0 & 2 & $2 \mathrm{y} 6$ & $3 \mathrm{y} 6$ & 6.6 & 6.1 & 1 & 0 & $x$ & $x$ & 10R 5/6 & 10R 5/6 & $x$ & $x$ & $x$ & $x$ & $x$ & $x$ & $x$ & $x$ & $x$ & $x$ & $x$ & $x$ & $x$ & $x$ & \\
\hline RH10-1 & 102 & 3 & & 2 & 0 & 0 & 1 & 2 & 2 & 13.2 & 3.2 & 0 & 0 & $x$ & $x$ & 10YR $3 / 1,4 / 1,6 / 4$ & 10YR 4/1,6/2,6/4 & $x$ & $x$ & $x$ & $x$ & $x$ & $x$ & $\mathrm{x}$ & $x$ & $\mathrm{x}$ & $x$ & $\mathrm{x}$ & 11.4 & 5 & 1 & 4 \\
\hline $\mathrm{RH} 10-1$ & 102 & 3 & & 1 & 0 & 0 & 1 & 2 & 2 & 13.2 & 3.2 & 0 & 0 & $x$ & $x$ & 10YR 3/1, 4/1, 6/4 & 10YR $4 / 1,6 / 2,6 / 4$ & indet & indet & indet & 1 & 2 & $x$ & $x$ & $x$ & $x$ & $x$ & $x$ & $x$ & $x$ & $x$ & \\
\hline RH10-1 & 102 & 3 & & 0 & 0 & 0 & 1 & 2 & 2 & 13.2 & 3.2 & 0 & 0 & $x$ & $x$ & 10YR 3/1, 4/1, 6/4 & 10YR 4/1,6/2,6/4 & $x$ & $x$ & $x$ & $x$ & $x$ & $x$ & $x$ & $x$ & $x$ & $x$ & $x$ & $x$ & $x$ & $x$ & 1 y 4 \\
\hline RH10-1 & 102 & 3 & & 0 & 0 & 0 & 1 & 2 & 2 & 13.2 & 3.2 & 0 & 0 & $x$ & $x$ & 10YR 3/1, 4/1, 6/4 & 10YR 4/1,6/2,6/4 & $x$ & $x$ & $x$ & $x$ & $x$ & $x$ & $x$ & $x$ & $x$ & $x$ & $x$ & $x$ & $x$ & $x$ & 1 y 4 \\
\hline $\mathrm{RH} 10-1$ & 102 & 3 & & 0 & 0 & 0 & 1 & 2 & 2 & 13.2 & 3.2 & 0 & 0 & $x$ & $x$ & 10YR 3/1, 4/1, 6/4 & 10YR $4 / 1,6 / 2,6 / 4$ & $x$ & $x$ & $x$ & $x$ & $x$ & $x$ & $x$ & $x$ & $x$ & $x$ & $x$ & $x$ & $x$ & $x$ & \\
\hline $\mathrm{RH} 10-1$ & 102 & 3 & & 0 & 0 & 0 & 1 & 2 & 2 & 13.2 & 3.2 & 0 & 0 & $x$ & $x$ & 10YR 3/1, 4/1, 6/4 & 10YR 4/1,6/2,6/4 & $x$ & $x$ & $x$ & $x$ & $x$ & $x$ & $\mathrm{x}$ & $x$ & $x$ & $x$ & $x$ & $x$ & $x$ & $x$ & 4 \\
\hline
\end{tabular}




\begin{tabular}{|c|c|c|c|c|c|c|c|c|c|c|c|c|c|c|c|c|c|c|c|c|c|c|c|c|c|c|c|c|c|c|c|c|}
\hline \multirow[b]{2}{*}{ Sitio } & \multirow[b]{2}{*}{ UP } & \multirow[b]{2}{*}{ GF $F$} & \multirow[b]{2}{*}{ FNA } & \multirow[b]{2}{*}{ Fgto } & \multicolumn{11}{|c|}{ Manufactura } & \multicolumn{2}{|c|}{ Cocción } & \multicolumn{6}{|c|}{ Borde-labio } & \multicolumn{5}{|c|}{ Asa } & \multicolumn{3}{|c|}{ Base } & \multirow[b]{2}{*}{ Alterac } \\
\hline & & & & & \begin{tabular}{|l|} 
Tec. \\
Lev
\end{tabular} & $\begin{array}{l}\text { For } \\
\text { ma }\end{array}$ & $\begin{array}{l}\text { Mar } \\
\text { cas }\end{array}$ & \begin{tabular}{|c|} 
Sup \\
ext
\end{tabular} & \begin{tabular}{|l|} 
Sup \\
int
\end{tabular} & $\begin{array}{l}\text { Esp } \\
\max \end{array}$ & \begin{tabular}{|l|} 
Esp \\
min
\end{tabular} & $\begin{array}{c}\text { Deco } \\
\text { pint }\end{array}$ & \begin{tabular}{|c|} 
Deco \\
corteldesp
\end{tabular} & Motivo & Estilo & Color sup ext & Color sup int & Diam & $\begin{array}{c}\text { Lar } \\
\text { arco } \\
\end{array}$ & \begin{tabular}{|c|c|}
$\%$ & 0 \\
$a r c o$ & \\
\end{tabular} & \begin{tabular}{|l|} 
Direc \\
ción
\end{tabular} & $\begin{array}{l}\text { For } \\
\text { ma }\end{array}$ & $\begin{array}{l}\text { Lar } \\
\text { go }\end{array}$ & $\begin{array}{c}\text { An } \\
\text { cho }\end{array}$ & Esp & $\begin{array}{l}\text { Sec } \\
\text { ción }\end{array}$ & \begin{tabular}{|l} 
In \\
serc
\end{tabular} & $\begin{array}{l}\text { Posi } \\
\text { ción }\end{array}$ & Diám & n $\begin{array}{c}\text { Mor } \\
\text { fol }\end{array}$ & r Uni & \\
\hline $\mathrm{RH} 10-1$ & 102 & 3 & & 0 & 0 & 0 & 1 & 2 & 2 & 13.2 & 3.2 & 0 & 0 & $x$ & $x$ & 10YR $3 / 1,4 / 1,6 / 4$ & 10YR 4/1,6/2,6/4 & $\mathrm{x}$ & $x$ & $\mathrm{x}$ & $\mathrm{x}$ & $\mathrm{x}$ & $\mathrm{x}$ & $\mathrm{x}$ & $\mathrm{x}$ & $\mathrm{x}$ & $\mathrm{x}$ & $x$ & $\mathrm{x}$ & $x$ & $x$ & 1 y 4 \\
\hline $\mathrm{RH} 10-1$ & 102 & 3 & & 0 & 0 & 0 & 1 & 2 & 2 & 13.2 & 3.2 & 0 & 0 & $x$ & $x$ & 10YR 3/1, 4/1, 6/4 & 10YR 4/1,6/2,6/4 & $x$ & $x$ & $x$ & $x$ & $x$ & $x$ & $x$ & $x$ & $x$ & $x$ & $x$ & $x$ & $x$ & $x$ & 1 y 4 \\
\hline $\mathrm{RH} 10-1$ & 102 & 3 & & 0 & 0 & 0 & 1 & 2 & 2 & 13.2 & 3.2 & 0 & 0 & $x$ & $x$ & 10YR 3/1, 4/1, 6/4 & 10YR 4/1,6/2,6/4 & $\mathrm{x}$ & $x$ & $x$ & $x$ & $x$ & $x$ & $x$ & $x$ & $x$ & $x$ & $\mathrm{x}$ & $\mathrm{x}$ & $x$ & $\mathrm{x}$ & 1 y 4 \\
\hline $\mathrm{RH} 10-1$ & 102 & 3 & & 0 & 0 & 0 & 1 & 2 & 2 & 13.2 & 3.2 & 0 & 0 & $x$ & $x$ & 10YR 3/1, 4/1, 6/4 & 10YR 4/1,6/2,6/4 & $x$ & $x$ & $x$ & $x$ & $x$ & $x$ & $x$ & $x$ & $x$ & $x$ & $x$ & $x$ & $x$ & $x$ & 4 \\
\hline $\mathrm{RH} 10-1$ & 102 & 3 & & 0 & 0 & 0 & 1 & 2 & 2 & 13.2 & 3.2 & 0 & 0 & $x$ & $x$ & 10YR 3/1, 4/1, 6/4 & 10YR 4/1,6/2,6/4 & $x$ & $x$ & $x$ & $x$ & $x$ & $x$ & $x$ & $x$ & $x$ & $x$ & $x$ & $x$ & $x$ & $x$ & 4 \\
\hline $\mathrm{RH} 10-1$ & 102 & 3 & & 0 & 0 & 0 & 1 & 2 & 2 & 13.2 & 3.2 & 0 & 0 & $x$ & $x$ & 10YR $3 / 1,4 / 1,6 / 4$ & 10YR 4/1,6/2,6/4 & $\mathrm{x}$ & $\mathrm{x}$ & $x$ & $x$ & $\mathrm{x}$ & $x$ & $x$ & $x$ & $\mathrm{x}$ & $x$ & $\mathrm{x}$ & $x$ & $\mathrm{x}$ & $x$ & 4 \\
\hline $\mathrm{RH} 10-1$ & 102 & 3 & & 0 & 0 & 0 & 1 & 2 & 2 & 13.2 & 3.2 & 0 & 0 & $x$ & $x$ & 10YR 3/1, 4/1, 6/4 & 10YR 4/1,6/2,6/4 & $x$ & $x$ & $x$ & $x$ & $x$ & $x$ & $x$ & $x$ & $x$ & $x$ & $x$ & $x$ & $x$ & $x$ & 1 y 4 \\
\hline $\mathrm{RH} 10-1$ & 102 & 3 & & 0 & 0 & 0 & 1 & 2 & 2 & 13.2 & 3.2 & 0 & 0 & $x$ & $x$ & 10YR 3/1, 4/1, 6/4 & 10YR 4/1,6/2,6/4 & $x$ & $x$ & $x$ & $x$ & $x$ & $x$ & $x$ & $x$ & $x$ & $x$ & $x$ & $x$ & $x$ & $x$ & 1 y 4 \\
\hline $\mathrm{RH} 10-1$ & 102 & 3 & & 0 & 0 & 0 & 1 & 2 & 2 & 13.2 & 3.2 & 0 & 0 & $x$ & $x$ & 10YR 3/1, 4/1, 6/4 & 10YR 4/1,6/2,6/4 & $x$ & $x$ & $x$ & $x$ & $x$ & $x$ & $x$ & $x$ & $x$ & $x$ & $x$ & $x$ & $x$ & $x$ & 1 \\
\hline $\mathrm{RH} 10-1$ & 102 & 3 & & 0 & 0 & 0 & 1 & 2 & 2 & 13.2 & 3.2 & 0 & 0 & $x$ & $x$ & 10YR 3/1, 4/1, 6/4 & 10YR 4/1,6/2,6/4 & $x$ & $x$ & $x$ & $x$ & $x$ & $x$ & $x$ & $x$ & $x$ & $x$ & $x$ & $x$ & $x$ & $x$ & 4 \\
\hline $\mathrm{RH} 10-1$ & 102 & 3 & & 0 & 0 & 0 & 1 & 2 & 2 & 13.2 & 3.2 & 0 & 0 & $x$ & $x$ & \begin{tabular}{|l|} 
10YR 3/1, 4/1, 6/4 \\
\end{tabular} & 10YR $4 / 1,6 / 2,6 / 4$ & $x$ & $x$ & $x$ & $x$ & $x$ & $x$ & $x$ & $x$ & $x$ & $x$ & $x$ & $x$ & $x$ & $x$ & 1 \\
\hline $\mathrm{RH} 10-1$ & 102 & 3 & & 0 & 0 & 0 & 1 & 2 & 2 & 13.2 & 3.2 & 0 & 0 & $x$ & $x$ & 10YR $3 / 1,4 / 1,6 / 4$ & 10YR $4 / 1,6 / 2,6 / 4$ & $x$ & $x$ & $x$ & $x$ & $x$ & $x$ & $x$ & $x$ & $x$ & $x$ & $x$ & $x$ & $x$ & $x$ & 4 \\
\hline $\mathrm{RH} 10-1$ & 102 & 3 & & 0 & 0 & 0 & 1 & 2 & 2 & 13.2 & 3.2 & 0 & 0 & $x$ & $x$ & 10YR 3/1, 4/1, 6/4 & 10YR 4/1,6/2,6/4 & $x$ & $x$ & $x$ & $x$ & $x$ & $x$ & $x$ & $x$ & $x$ & $x$ & $x$ & $x$ & $x$ & $x$ & 4 \\
\hline $\mathrm{RH} 10-1$ & 102 & 4 & & 4 & 0 & 2 & 1 & $2 \mathrm{y} 6$ & 2 & 9 & 5 & 1 & 0 & $x$ & $x$ & 5YR6/3, 6/4,10R5/6 & $5 Y R$ 6/3, 6/4, 6/1 & 31 & 9.7 & 9 & $x$ & $x$ & $x$ & $x$ & $x$ & $x$ & $x$ & $x$ & $x$ & $x$ & $x$ & 3 \\
\hline $\mathrm{RH} 10-1$ & 102 & 4 & & 4 & 0 & 2 & 1 & 2 & 2 & 9 & 5 & 0 & 0 & $x$ & $x$ & $5 Y R 6 / 3,6 / 4,10 R 5 / 6$ & $5 Y R$ 6/3, 6/4, 6/1 & 31 & 9.7 & 9 & $x$ & $x$ & $x$ & $x$ & $x$ & $x$ & $x$ & $x$ & $x$ & $x$ & $x$ & 3 \\
\hline $\mathrm{RH} 10-1$ & 102 & 4 & & 0 & 0 & 0 & 1 & 2 & 2 & 9 & 5 & 0 & 0 & $x$ & $x$ & 5YR6/3, 6/4,10R5/6 & $5 Y R$ 6/3, 6/4, 6/1 & $x$ & $x$ & $x$ & $x$ & $x$ & $x$ & $x$ & $x$ & $x$ & $x$ & $x$ & $x$ & $x$ & $x$ & 2 \\
\hline $\mathrm{RH} 10-1$ & 102 & 4 & & 0 & 0 & 0 & 1 & 2 & 2 & 9 & 5 & 0 & 0 & $x$ & $x$ & 5YR6/3, 6/4,10R5/6 & $5 Y R \quad 6 / 3,6 / 4,6 / 1$ & $x$ & $x$ & $x$ & $x$ & $x$ & $x$ & $x$ & $x$ & $x$ & $x$ & $x$ & $x$ & $x$ & $x$ & 3 \\
\hline $\mathrm{RH} 10-1$ & 102 & 4 & & 0 & 0 & 0 & 1 & 2 & 2 & 9 & 5 & 0 & 0 & $x$ & $x$ & 5YR6/3, 6/4,10R5/6 & $5 Y R \quad 6 / 3,6 / 4,6 / 1$ & $x$ & $x$ & $x$ & $x$ & $x$ & $x$ & $x$ & $x$ & $x$ & $x$ & $x$ & $x$ & $x$ & $x$ & 3 \\
\hline $\mathrm{RH} 10-1$ & 102 & 4 & & 0 & 0 & 0 & 1 & 2 & 2 & 9 & 5 & 0 & 0 & $x$ & $x$ & $5 Y R 6 / 3,6 / 4,10 R 5 / 6$ & $5 Y R$ 6/3, 6/4, 6/1 & $x$ & $x$ & $x$ & $x$ & $x$ & $x$ & $x$ & $x$ & $x$ & $x$ & $x$ & $x$ & $x$ & $x$ & 6 \\
\hline $\mathrm{RH} 10-1$ & 102 & 5 & & 0 & 1 & 0 & 1 & 2 & 2 & 7.4 & 5.6 & 0 & 0 & $x$ & $x$ & $5 Y R 6 / 3,6 / 4,10 R 5 / 6$ & $5 Y R$ 6/3, 6/4, 6/1 & $x$ & $x$ & $\mathrm{x}$ & $x$ & $x$ & $x$ & $x$ & $x$ & $x$ & $x$ & $x$ & $x$ & $x$ & $x$ & 1 \\
\hline $\mathrm{RH} 10-1$ & 102 & 5 & & 0 & 1 & 0 & 1 & 2 & 2 & 7.4 & 5.6 & 0 & 0 & $x$ & $x$ & 5YR6/3, 6/4,10R5/6 & $5 Y R$ 6/3, 6/4, 6/1 & $x$ & $x$ & $x$ & $x$ & $x$ & $x$ & $x$ & $x$ & $x$ & $x$ & $x$ & $x$ & $x$ & $x$ & 1 \\
\hline $\mathrm{RH} 10-1$ & 202 & 5 & & 0 & 1 & 0 & 1 & 2 & 2 & 7.4 & 5.6 & 0 & 0 & $x$ & $x$ & 5YR6/3, 6/4,10R5/6 & $5 Y R$ 6/3, 6/4, 6/1 & $x$ & $x$ & $x$ & $x$ & $x$ & $x$ & $x$ & $x$ & $x$ & $x$ & $x$ & $x$ & $x$ & $x$ & 1 \\
\hline $\mathrm{RH} 10-1$ & 202 & 6 & & 0 & 0 & 0 & 0 & 7 & 2 & 7.3 & 5.5 & 0 & 1 & $x$ & PcQ & 2,5YR 4/6 & 2,5 YR 4/2, 5/2 & $x$ & $x$ & $x$ & $x$ & $x$ & $x$ & $x$ & $x$ & $x$ & $x$ & $x$ & $x$ & $x$ & $x$ & 3 \\
\hline $\mathrm{RH} 10-1$ & Sup & 6 & & 0 & 0 & 0 & 0 & 7 & 2 & 7.3 & 5.5 & 0 & 1 & $x$ & PcQ & $2,5 Y R \quad 4 / 6$ & $2,5 Y R \quad 4 / 2,5 / 2$ & $x$ & $x$ & $x$ & $x$ & $x$ & $x$ & $x$ & $x$ & $x$ & $x$ & $x$ & $x$ & $x$ & $x$ & 3 \\
\hline $\mathrm{RH} 10-1$ & Sup & 6 & & 0 & 0 & 0 & 0 & 7 & 2 & 7.3 & 5.5 & 0 & 1 & $x$ & PcQ & $2,5 Y R \quad 4 / 6$ & 2,5 YR $4 / 2,5 / 2$ & $x$ & $x$ & $x$ & $x$ & $x$ & $x$ & $x$ & $x$ & $x$ & $x$ & $x$ & $x$ & $x$ & $x$ & 3 \\
\hline $\mathrm{RH} 10-1$ & 102 & 7 & & 1 & 1 & 1 & $1 \mathrm{y} 2$ & 2 & 3 & 10.8 & 4.9 & 0 & 0 & $x$ & $x$ & 10YR 6/2 & 10YR 5/1, 3/1 & 22 & indet & indet & 1 & 2 & $x$ & $x$ & $x$ & $x$ & $x$ & $x$ & $x$ & $x$ & $x$ & \\
\hline $\mathrm{RH} 10-1$ & 202 & 7 & & 2 & 1 & 1 & $1 \mathrm{y} 2$ & 2 & 3 & 10.8 & 4.9 & 0 & 0 & $x$ & $x$ & 10YR 6/2 & 10YR 5/1, 3/1 & $x$ & $x$ & $x$ & $x$ & $x$ & $x$ & $x$ & $x$ & $x$ & $x$ & $x$ & 7 & 5 & 2 & 4 \\
\hline $\mathrm{RH} 10-1$ & 100 & 7 & & 0 & 1 & 01 & $1 \mathrm{y} 2$ & 2 & 3 & 10.8 & 4.9 & 0 & 0 & $x$ & $x$ & 10YR 6/2 & 10YR 5/1, 3/1 & $x$ & $x$ & $x$ & $x$ & $x$ & $x$ & $x$ & $x$ & $x$ & $x$ & $x$ & $x$ & $x$ & $x$ & 4 \\
\hline $\mathrm{RH} 10-1$ & 202 & 7 & & 0 & 1 & 0 & $1 \mathrm{y} 2$ & 2 & 3 & 10.8 & 4.9 & 0 & 0 & $x$ & $x$ & 10YR 6/2 & 10YR 5/1, 3/1 & $x$ & $x$ & $x$ & $x$ & $x$ & $x$ & $x$ & $\mathrm{x}$ & $x$ & $\mathrm{x}$ & $x$ & $x$ & $x$ & $x$ & 4 \\
\hline $\mathrm{RH} 10-1$ & 202 & & 1 & 5 & 0 & 0 & 1 & 2 & 2 & 6.7 & 6 & 0 & 0 & $x$ & $x$ & 7,5 YR 5/2 & $7,5 Y R$ 7/2 & indet $\mathrm{i}$ & indet & indet & 1 & 6 & $x$ & $\mathrm{x}$ & $x$ & $x$ & $x$ & $x$ & $x$ & $x$ & $x$ & \\
\hline $\mathrm{RH} 10-1$ & 102 & & 4 & 1 & 0 & 1 & 0 & 2 & 3 & 5 & 4.1 & 0 & 0 & $x$ & $x$ & 7,5YR 6/6 & 7,5YR 6/4 & indet $\mathrm{i}$ & indet & indet & 1 & 2 & $x$ & $x$ & $x$ & $x$ & $x$ & $x$ & $x$ & $x$ & $x$ & 3 \\
\hline $\mathrm{RH} 10-1$ & 102 & & 5 & 1 & 0 & 1 & 0 & 2 & 2 & 5 & 5 & 0 & 0 & $x$ & $x$ & 7,5YR 6/6 & 7,5YR 6/4 & indet $\mathrm{i}$ & indet i & indet & 1 & 2 & $x$ & $x$ & $x$ & $x$ & $x$ & $x$ & $x$ & $x$ & $x$ & 3 \\
\hline RH10-1 & 100 & & 6 & 1 & 1 & 2 & 1 & 2 & 2 & 8.3 & 6.4 & 0 & 0 & $x$ & $x$ & $7,5 Y R$ 5/4 & $7,5 Y R$ 5/4, 5/0 & 30 & 9.6 & 5.7 & 1 & 6 & $x$ & $x$ & $x$ & $x$ & $x$ & $x$ & $x$ & $x$ & $x$ & 1 \\
\hline $\mathrm{RH} 10-1$ & 100 & & 7 & 3 & 0 & 0 & 1 & 2 & $x$ & $x$ & $x$ & 0 & 0 & $x$ & $x$ & 7,5YR 5/4 & $x$ & $x$ & $x$ & $x$ & $x$ & $\mathrm{x}$ & $5,2 \mathrm{fr}$ & 1.8 & 11.5 & 2 & 0 & 0 & $x$ & $x$ & $x$ & \\
\hline $\mathrm{RH} 10-1$ & 100 & & 8 & 2 & 0 & 0 & 0 & 2 & 2 & 15 & 10 & 0 & 0 & $x$ & $x$ & $5 Y R$ 5/4 & 5YR 5/4 & $x$ & $x$ & $x$ & $x$ & $x$ & $x$ & $x$ & $x$ & $x$ & $x$ & $x$ & 8 & 5 & 1 & \\
\hline
\end{tabular}




\begin{tabular}{|c|c|c|c|c|c|c|c|c|c|c|c|c|c|c|c|c|c|c|c|c|c|c|c|c|c|c|c|c|c|c|c|c|}
\hline \multirow[b]{2}{*}{ Sitio } & \multirow[b]{2}{*}{ UP } & & \multirow[b]{2}{*}{ FNA } & \multirow[b]{2}{*}{ Fgto } & \multicolumn{11}{|c|}{ Manufactura } & \multicolumn{2}{|c|}{ Cocción } & \multicolumn{6}{|c|}{ Borde-labio } & \multicolumn{5}{|c|}{ Asa } & \multicolumn{3}{|c|}{ Base } & \multirow[b]{2}{*}{ Alterac } \\
\hline & & & & & $\begin{array}{l}\text { Tec. } \\
\text { Lev }\end{array}$ & $\begin{array}{l}\text { For } \\
\text { ma }\end{array}$ & $\begin{array}{l}\text { Mar } \\
\text { cas }\end{array}$ & $\begin{array}{c}\text { Sup } \\
\text { ext }\end{array}$ & \begin{tabular}{|c|} 
Sup \\
int
\end{tabular} & $\begin{array}{l}\text { Esp } \\
\max \end{array}$ & $\begin{array}{l}\text { Esp } \\
\text { min }\end{array}$ & $\begin{array}{c}\text { Deco } \\
\text { pint }\end{array}$ & \begin{tabular}{|c|} 
Deco \\
corte/desp
\end{tabular} & Motivo & Estilo & Color sup ext & Color sup int & Diam & $\begin{array}{l}\text { Lar } \\
\text { arco }\end{array}$ & \begin{tabular}{|c|l|}
$\%$ & $D$ \\
$\operatorname{arco}$ & $C$ \\
\end{tabular} & $\begin{array}{l}\text { Direc } \\
\text { ción }\end{array}$ & $\begin{array}{l}\text { For } \\
\text { ma }\end{array}$ & \begin{tabular}{|l|} 
Lar \\
go
\end{tabular} & $\begin{array}{c}\text { An } \\
\text { cho }\end{array}$ & Esp & $\begin{array}{l}\text { Sec } \\
\text { ción }\end{array}$ & $\begin{array}{l}\text { In } \\
\text { serc }\end{array}$ & \begin{tabular}{|l|l|} 
& Posi \\
rc & ción \\
\end{tabular} & Diám & \begin{tabular}{|c|} 
Mor \\
fol
\end{tabular} & $\begin{array}{l}\text { Uni } \\
\text { ón }\end{array}$ & \\
\hline $\mathrm{RH} 10-1$ & 202 & & 9 & 0 & 0 & 0 & 0 & 2 & 3 & 4.5 & 4 & 0 & 0 & $\mathrm{x}$ & $x$ & $5 Y R \quad 4 / 3$ & 7,5 YR $2 / 0$ & $x$ & $x$ & $x$ & $x$ & $x$ & $x$ & $x$ & $x$ & $x$ & $x$ & $x$ & $x$ & $x$ & $\mathrm{x}$ & 3 \\
\hline $\mathrm{RH} 10-1$ & 202 & & 10 & 0 & 0 & 0 & 0 & 2 & 2 & 8.1 & 5.3 & 0 & 0 & $x$ & $x$ & $5 Y R \quad 4 / 3$ & $5 Y R 7 / 3$ & $x$ & $x$ & $x$ & $x$ & $x$ & $x$ & $x$ & $x$ & $x$ & $x$ & $x$ & $x$ & $x$ & $\mathrm{x}$ & 3 \\
\hline $\mathrm{RH} 10-1$ & 102 & & 11 & 0 & 1 & 0 & 1 & 2 & 2 & 7.4 & 4.6 & 0 & 0 & $x$ & $x$ & $5 Y R$ 5/4, 3/1 & $5 Y R$ 5/4 & $x$ & $x$ & $x$ & $x$ & $x$ & $x$ & $x$ & $x$ & $x$ & $x$ & $x$ & $x$ & $x$ & $\mathrm{x}$ & 1 \\
\hline RH 10 & Sup & & 12 & 1 & 0 & 0 & 1 & 2 & 2 & 6.6 & 4.2 & 0 & 0 & $x$ & $x$ & 5YR 5/4 & 5YR 5/4 & indet & indet & indet & 1 & 4 & $x$ & $x$ & $x$ & $x$ & $x$ & $x$ & $x$ & $x$ & $\mathrm{x}$ & \\
\hline RH 10 & Sup & & 13 & 1 & 0 & 0 & 1 & 2 & 2 & 6.1 & 6 & 0 & 0 & $x$ & $x$ & $5 Y R$ 5/3 & $5 Y R$ 5/3 & indet & indet & indet & 1 & 4 & $x$ & $x$ & $x$ & $x$ & $x$ & $x$ & $x$ & $x$ & $\mathrm{x}$ & \\
\hline RH 10 & Sup & & 14 & 1 & 0 & 0 & 1 & 2 & 2 & 6.8 & 5.6 & 0 & 0 & $x$ & $x$ & 5YR 5/6 & 5YR 6/4 & indet & indet & indet & 1 & 2 & $x$ & $x$ & $x$ & $x$ & $x$ & $x$ & $x$ & $x$ & $x$ & 4 \\
\hline RH 10 & Sup & & 16 & 2 & 0 & 0 & 0 & 2 & 3 & 13.7 & 5.3 & 0 & 0 & $x$ & $x$ & 10YR 6/3 & 10YR 4/1 & $x$ & $x$ & $x$ & $x$ & $x$ & $x$ & $x$ & $x$ & $x$ & $x$ & $x$ & 11 & 5 & 2 & 3 y 4 \\
\hline RH 10 & Sup & & 17 & 2 & 0 & 0 & 0 & 2 & 2 & 8.2 & 6.1 & 0 & 0 & $x$ & $x$ & 10YR 5/2 & 10YR 5/1 & $x$ & $x$ & $x$ & $x$ & $x$ & $x$ & $x$ & $x$ & $x$ & $x$ & $x$ & 11 & 5 & 2 & 3 \\
\hline RH 10 & Sup & & 18 & 2 & 1 & 0 & 0 & 2 & 2 & 8.5 & 6.3 & 0 & 0 & $x$ & $x$ & 5YR 6/4 & 5YR 6/6 & $x$ & $x$ & $x$ & $x$ & $x$ & $x$ & $x$ & $x$ & $x$ & $x$ & $x$ & indet & 8 & 2 & 3 \\
\hline RH 10 & Sup & & 19 & 2 & 0 & 0 & 0 & 2 & 2 & 17.6 & 7 & 0 & 0 & $x$ & $x$ & 5YR 6/1 & 5YR 6/4 & $x$ & $x$ & $x$ & $x$ & $x$ & $x$ & $x$ & $x$ & $x$ & $x$ & $x$ & indet & 7 & 3 & \\
\hline RH 10 & Sup & & 20 & 2 & 0 & 0 & 1 & $2 \mathrm{y} 6$ & 2 & 11.6 & 10.2 & 1 & 0 & $x$ & yavi? & 10YR $6 / 1$ y $5 / 1$ & $2,5 Y R \quad 4 / 4$ & $x$ & $x$ & $x$ & $x$ & $x$ & $x$ & $x$ & $x$ & $x$ & $x$ & $x$ & indet & 5 & 2 & \\
\hline RH 10 & Sup & & 21 & 0 & 0 & 0 & 1 & $2 \mathrm{y} 6$ & 2 & 8.3 & 6.2 & 1 & 0 & $x$ & yavi? & 10 YR 8/1 & $2,5 Y R$ 5/4 & $x$ & $x$ & $x$ & $x$ & $x$ & $x$ & $x$ & $x$ & $x$ & $x$ & $x$ & $x$ & $x$ & $\mathrm{x}$ & \\
\hline RH 10 & Sup & & 22 & 3 & 0 & 0 & 2 & 2 & $2 \mathrm{y} 3$ & 9.5 & 6.3 & 0 & 0 & $x$ & $x$ & 2,5 YR $5 / 6$ y $6 / 2$ & 2,5 YR $5 / 6$ y $6 / 2$ & $x$ & $x$ & $x$ & $x$ & $x$ & $3,2 \mathrm{fr}$ & 3 & 15.5 & 52 & 1 & 2 & $x$ & $x$ & $\mathrm{x}$ & 1 \\
\hline RH 10 & Sup & & 23 & 3 & 0 & 0 & 1 & 2 & 2 & 7.6 & 4 & 0 & 0 & $x$ & $x$ & 5YR 5/4 & 5 YR $6 / 2$ & $x$ & $x$ & $x$ & $x$ & $x$ & $x$ & 2 & 9 & 3 & 1 & 2 & $x$ & $x$ & $x$ & \\
\hline RH 10 & Sup & & 25 & 3 & 0 & 0 & 0 & $3 y 6$ & $x$ & $x$ & $x$ & 2 & 0 & franja & Casab & 5YR5/6,4/4;7,5YR2/0 & $x$ & $\mathrm{x}$ & $\mathrm{x}$ & $\mathrm{x}$ & $\mathrm{x}$ & $\mathrm{x}$ & $5,5 \mathrm{fr}$ & 2.6 & 13.5 & \begin{tabular}{|l|l|}
5 & 4
\end{tabular} & 3 & 1 & $\mathrm{x}$ & $\mathrm{x}$ & $\mathrm{x}$ & 6 \\
\hline RH 10 & Sup & & 26 & 3 & 0 & 0 & 0 & $2 \mathrm{y} 6$ & 2 & 6.6 & 6.5 & 2 & 0 & franja & Casab & $\begin{array}{c}\text { 10R4/8, 5YR5/6, } \\
7.5 \mathrm{YR} 2 / 0 \\
\end{array}$ & $x$ & $\mathrm{x}$ & $x$ & $\mathrm{x}$ & $x$ & $\mathrm{x}$ & $4,8 \mathrm{fr}$ & 2,8 & 10 & 3 & 3 & 1 & $\mathrm{x}$ & $\mathrm{x}$ & $\mathrm{x}$ & 6 \\
\hline RH 10 & Sup & & 27 & 3 & 0 & 0 & 0 & $2 \mathrm{y} 6$ & $\mathrm{x}$ & $\mathrm{x}$ & $x$ & 1 & 0 & $x$ & $x$ & 10R5/8, 10R5/4 & $x$ & $\mathrm{x}$ & $x$ & $\mathrm{x}$ & $\mathrm{x}$ & $x$ & $4,4 \mathrm{fr}$ & 2.6 & 13 & 4 & 3 & 1 & $x$ & $x$ & $\mathrm{x}$ & 6 \\
\hline RH 10 & Sup & & 28 & 3 & 0 & 0 & 0 & $3 y 6$ & 2 & 9.6 & 5.1 & 1 & 0 & $x$ & $x$ & 10R 5/8 & $5 Y R$ 6/4 & $x$ & $x$ & $x$ & $x$ & $x$ & $3 \mathrm{fr}$ & 2.5 & 13.5 & \begin{tabular}{|l|l|}
5 & 2 \\
\end{tabular} & 3 & 2 & $x$ & $x$ & $x$ & \\
\hline RH 10 & Sup & & 29 & 0 & 0 & 0 & 1 & $4 \mathrm{y} 6$ & 2 & 11 & 6 & 2 & 0 & lineas & $x$ & 10R4/6, 7,5YR2/0 & $5 Y R$ 5/2 & $x$ & $x$ & $x$ & $x$ & $x$ & $x$ & $x$ & $x$ & $x$ & $x$ & $x$ & $x$ & $x$ & $\mathrm{x}$ & 4 \\
\hline RH 10 & Sup & & 30 & 0 & 0 & 0 & 0 & $4 \mathrm{y} 6$ & 2 & 5.6 & 5.1 & 1 & 0 & franja & $x$ & 10R4/6, 7,5YR2/0 & 5YR 5/6 & $x$ & $x$ & $x$ & $x$ & $x$ & $x$ & $x$ & $x$ & $x$ & $x$ & $x$ & $x$ & $x$ & $x$ & \\
\hline $\mathrm{RH} 10$ & Sup & & 31 & 0 & 0 & 0 & 2 & $3,4 \mathrm{y} 6$ & 2 & 7 & 6 & 2 & 0 & franja & $x$ & 10R4/6, 7,5YR2/0 & $5 Y R 5 / 3$ & $\mathrm{x}$ & $x$ & $x$ & $x$ & $x$ & $\mathrm{x}$ & $x$ & $x$ & $\mathrm{x}$ & $x$ & $x$ & $\mathrm{x}$ & $x$ & $x$ & \\
\hline RH 10 & Sup & & 32 & 0 & 0 & 0 & $1 \mathrm{y} 2$ & $3,4 \mathrm{y} 6$ & 2 & 6 & 4.5 & 2 & 0 & lineas & $x$ & 10R4/6, 7,5YR2/0 & 5YR 5/3 & $\mathrm{x}$ & $x$ & $x$ & $x$ & $x$ & $x$ & $x$ & $x$ & $x$ & $x$ & $x$ & $x$ & $x$ & $x$ & \\
\hline RH 10 & Sup & & 33 & 0 & 0 & 0 & 1 & 4 & 2 & 9.9 & 9 & 1 & 0 & $x$ & $x$ & 10R $4 / 6$ & 5YR 5/3 & $x$ & $x$ & $x$ & $x$ & $x$ & $x$ & $x$ & $x$ & $x$ & $x$ & $x$ & $\mathrm{x}$ & $x$ & $x$ & \\
\hline RH 10 & Sup & & 34 & 0 & 0 & 0 & 0 & 4 & 2 & 7.6 & 7.1 & 1 & 0 & $x$ & $x$ & 10R 4/6 & 5 YR $5 / 3$ & $x$ & $x$ & $x$ & $x$ & $x$ & $x$ & $x$ & $x$ & $x$ & $x$ & $x$ & $x$ & $x$ & $x$ & 4 \\
\hline RH 10 & Sup & & 35 & 0 & 0 & 0 & 0 & 4 & 2 & 5.4 & 7.3 & 1 & 0 & $x$ & $x$ & 10R $4 / 8$ & $5 Y R$ 5/4 & $x$ & $x$ & $x$ & $x$ & $x$ & $x$ & $x$ & $x$ & $x$ & $x$ & $x$ & $x$ & $x$ & $x$ & \\
\hline RH 10 & Sup & & 36 & 0 & 0 & 0 & 2 & $3 y 4$ & 2 & 5 & 4.2 & 1 & 0 & $x$ & $x$ & 10R 5/6 & 5YR 5/3 & $x$ & $x$ & $x$ & $\mathrm{x}$ & $x$ & $x$ & $x$ & $x$ & $x$ & $x$ & $x$ & $x$ & $x$ & $x$ & \\
\hline
\end{tabular}




\begin{tabular}{|c|c|c|c|c|c|c|c|c|c|c|c|c|c|c|c|c|c|c|c|c|c|c|c|c|c|c|c|c|c|c|c|}
\hline \multirow[b]{2}{*}{ Sitio } & \multirow[b]{2}{*}{ UP } & \multirow[b]{2}{*}{ GF } & \multirow[b]{2}{*}{ FNA } & \multirow[b]{2}{*}{ Fgto } & \multicolumn{10}{|c|}{ Manufactura } & \multicolumn{2}{|l|}{ Cocción } & \multicolumn{5}{|c|}{ Borde-labio } & \multicolumn{6}{|c|}{ Asa } & \multicolumn{3}{|c|}{ Base } & \multirow[b]{2}{*}{ Alterac } \\
\hline & & & & & $\begin{array}{l}\text { Tec } \\
\text { lev }\end{array}$ & $\begin{array}{l}\text { For } \\
\text { ma }\end{array}$ & $\begin{array}{l}\text { Mar } \\
\text { cas }\end{array}$ & $\begin{array}{c}\text { Sup } \\
\text { ext }\end{array}$ & $\begin{array}{c}\text { Sup } \\
\text { int }\end{array}$ & $\begin{array}{l}\text { Esp } \\
\max \end{array}$ & $\begin{array}{l}\text { Esp } \\
\text { min }\end{array}$ & $\begin{array}{c}\text { Deco } \\
\text { pint }\end{array}$ & \begin{tabular}{|c} 
Moti \\
vo
\end{tabular} & \begin{tabular}{|c|} 
Es \\
tilo \\
\end{tabular} & Color sup ext & Color sup int & Diam & \begin{tabular}{|l|} 
Lrg \\
arc
\end{tabular} & \begin{tabular}{|c|}
$\%$ \\
arco \\
\end{tabular} & Direc & $\begin{array}{l}\begin{array}{l}\text { For } \\
\text { ma }\end{array} \\
\end{array}$ & $\begin{array}{l}\text { Lar } \\
\text { go }\end{array}$ & $\begin{array}{l}\mathbf{A} \\
\text { cho } \\
\text { cho }\end{array}$ & $\begin{array}{lll} & \text { Esp } \\
\end{array}$ & p $\begin{array}{l}\text { Sec } \\
\text { ción }\end{array}$ & \begin{tabular}{|l} 
In \\
serc \\
\end{tabular} & $\begin{array}{l}\mathrm{Po} \\
\text { sic }\end{array}$ & iám & \begin{tabular}{|c|} 
Mor \\
fol \\
\end{tabular} & \begin{tabular}{|c|} 
Uni \\
ón
\end{tabular} & \\
\hline RH 19-1 & 102 & 1 & & 0 & 1 & 0 & 1 & 2 & 2 & 8.2 & 5.0 & 0 & $x$ & $x$ & $5 Y R$ 5/4, 6/4, 5/2 & $5 Y R$ 5/2, 4/3, 5/4 & $x$ & $x$ & $x$ & $x$ & $x$ & $x$ & $x$ & $x$ & $x$ & $x$ & $x$ & $x$ & $x$ & $x$ & 3 \\
\hline RH 19-1 & 103 & 1 & & 0 & 1 & 0 & 1 & 2 & 2 & 8.2 & 5.0 & 0 & $x$ & $\mathrm{x}$ & $5 Y R$ 5/4, 6/4, 5/2 & 5YR 5/2, 4/3, 5/4 & $x$ & $x$ & $\mathrm{x}$ & $\mathrm{x}$ & $x$ & $x$ & $x$ & $x$ & $\mathrm{x}$ & $x$ & $x$ & $x$ & $x$ & $x$ & 3 \\
\hline RH 19-1 & 100 & 1 & & 0 & 1 & 0 & 1 & 2 & 2 & 8.2 & 5.0 & 0 & $x$ & $x$ & $5 Y R$ 5/4, 6/4, 5/2 & $5 Y R$ 5/2, 4/3, 5/4 & $x$ & $x$ & $x$ & $x$ & $x$ & $x$ & $x$ & $x$ & $x$ & $x$ & $x$ & $x$ & $x$ & $x$ & 3 y 4 \\
\hline RH 19-1 & 100 & 1 & & 0 & 1 & 0 & 1 & 2 & 2 & 8.2 & 5.0 & 0 & $\mathrm{x}$ & $\mathrm{x}$ & $5 Y R 5 / 4,6 / 4,5 / 2$ & $5 Y R$ 5/2, 4/3, 5/4 & $x$ & $\mathrm{x}$ & $\mathrm{x}$ & $\mathrm{x}$ & $\mathrm{x}$ & $\mathrm{x}$ & $\mathrm{x}$ & $\mathrm{x}$ & $\mathrm{x}$ & $\mathrm{x}$ & $\mathrm{x}$ & $\mathrm{x}$ & $\mathrm{x}$ & $\mathrm{x}$ & 3 у 4 \\
\hline RH 19-1 & 100 & 1 & & 0 & 1 & 0 & 1 & 2 & 2 & 8.2 & 5.0 & 0 & $\mathrm{x}$ & $\mathrm{x}$ & $5 Y R 5 / 4,6 / 4,5 / 2$ & $5 Y R$ 5/2, 4/3, 5/4 & $x$ & $\mathrm{x}$ & $\mathrm{x}$ & $\mathrm{x}$ & $x$ & $x$ & $x$ & $\mathrm{x}$ & $\mathrm{x}$ & $\mathrm{x}$ & $\mathrm{x}$ & $\mathrm{x}$ & $\mathrm{x}$ & $x$ & 3 \\
\hline $\mathrm{RH} 19-1$ & 100 & 1 & & 0 & 1 & 0 & 1 & 2 & 2 & 8.2 & 5.0 & 0 & $x$ & $x$ & $5 Y R$ 5/4, 6/4, 5/2 & $5 Y R$ 5/2, 4/3, 5/4 & $x$ & $x$ & $x$ & $x$ & $x$ & $x$ & $x$ & $x$ & $x$ & $x$ & $x$ & $x$ & $x$ & $x$ & 3 \\
\hline RH 19-1 & 100 & 1 & & 0 & 1 & 0 & 1 & 2 & 2 & 8.2 & 5.0 & 0 & $x$ & $x$ & $5 Y R$ 5/4, 6/4, 5/2 & $5 Y R$ 5/2, 4/3, 5/4 & $x$ & $x$ & $x$ & $x$ & $x$ & $x$ & $x$ & $x$ & $x$ & $x$ & $x$ & $x$ & $x$ & $\mathrm{x}$ & 3 \\
\hline RH 19-1 & 100 & 1 & & 0 & 1 & 0 & 1 & 2 & 2 & 8.2 & 5.0 & 0 & $x$ & $x$ & $5 Y R$ 5/4, 6/4, 5/2 & $5 Y R$ 5/2, 4/3, 5/4 & $x$ & $x$ & $x$ & $\mathrm{x}$ & $\mathrm{x}$ & $x$ & $\mathrm{x}$ & $x$ & $x$ & $\mathrm{x}$ & $x$ & $x$ & $\mathrm{x}$ & $x$ & 3 \\
\hline RH 19-1 & 101 & 1 & & 0 & 1 & 0 & 1 & 2 & 2 & 8.2 & 5.0 & 0 & $x$ & $x$ & $5 Y R$ 5/4, 6/4, 5/2 & $5 Y R$ 5/2, 4/3,5/4 & $x$ & $x$ & $x$ & $x$ & $x$ & $x$ & $x$ & $x$ & $x$ & $x$ & $x$ & $x$ & $x$ & $x$ & 3 \\
\hline RH 19-1 & 102 & 1 & & 0 & 1 & 0 & 1 & 2 & 2 & 8.2 & 5.0 & 0 & $x$ & $\mathrm{x}$ & $5 Y R$ 5/4, 6/4, 5/2 & $5 Y R$ 5/2, 4/3, 5/4 & $x$ & $\mathrm{x}$ & $\mathrm{x}$ & $\mathrm{x}$ & $\mathrm{x}$ & $x$ & $\mathrm{x}$ & $\mathrm{x}$ & $\mathrm{x}$ & $\mathrm{x}$ & $\mathrm{x}$ & $\mathrm{x}$ & $\mathrm{x}$ & $\mathrm{x}$ & 3 \\
\hline RH 19-1 & 102 & 2 & & 0 & 0 & 0 & 1 & 2 & 2 & 7.0 & 3.3 & 0 & $\mathrm{x}$ & $\mathrm{x}$ & $5 Y R \quad 4 / 1,4 / 2,5 / 2,7.5 Y R 2 / 0$ & \begin{tabular}{l|l}
0 & $5 Y R \quad 4 / 2,4 / 1$ \\
\end{tabular} & $\mathrm{x}$ & $\mathrm{x}$ & $\mathrm{x}$ & $\mathrm{x}$ & $\mathrm{x}$ & $\mathrm{x}$ & $\mathrm{x}$ & $\mathrm{x}$ & $\mathrm{x}$ & $\mathrm{x}$ & $\mathrm{x}$ & $\mathrm{x}$ & $\mathrm{x}$ & $\mathrm{x}$ & 1 \\
\hline RH 19-1 & 104 & 2 & & 0 & 0 & 0 & 1 & 2 & 2 & 7.0 & 3.3 & 0 & $x$ & $\mathrm{x}$ & $5 Y R \quad 4 / 1,4 / 2,5 / 2,7.5 Y R$ 2/0 & \begin{tabular}{l|l}
0 & $5 Y R \quad 4 / 2,4 / 1$ \\
\end{tabular} & $\mathrm{x}$ & $\mathrm{x}$ & $\mathrm{x}$ & $\mathrm{x}$ & $\mathrm{x}$ & $\mathrm{x}$ & $\mathrm{x}$ & $\mathrm{x}$ & $\mathrm{x}$ & $\mathrm{x}$ & $\mathrm{x}$ & $\mathrm{x}$ & $\mathrm{x}$ & $\mathrm{x}$ & 1 \\
\hline $\mathrm{RH} 19-1$ & 201 & 2 & & 0 & 0 & 0 & 1 & 2 & 2 & 7.0 & 3.3 & 0 & $x$ & $x$ & $5 Y R \quad 4 / 1,4 / 2,5 / 2,7.5 Y R 2 / 0$ & \begin{tabular}{|l|l|}
$0 Y R ~ 4 / 2,4 / 1$ \\
\end{tabular} & $x$ & $x$ & $x$ & $x$ & $x$ & $x$ & $x$ & $x$ & $x$ & $x$ & $x$ & $x$ & $x$ & $\mathrm{x}$ & 1 \\
\hline $\mathrm{RH} 19-1$ & 201 & 2 & & 0 & 0 & 0 & 1 & 2 & 2 & 7.0 & 3.3 & 0 & $x$ & $x$ & $5 Y R \quad 4 / 1,4 / 2,5 / 2,7.5 Y R 2 / 0$ & \begin{tabular}{|l|l|}
$0 Y R ~ 4 / 2,4 / 1$ \\
\end{tabular} & $x$ & $x$ & $x$ & $x$ & $x$ & $x$ & $x$ & $x$ & $x$ & $x$ & $x$ & $x$ & $x$ & $x$ & 1 \\
\hline RH 19-1 & 201 & 2 & & 0 & 0 & 0 & 1 & 2 & 2 & 7.0 & 3.3 & 0 & $\mathrm{x}$ & $\mathrm{x}$ & $5 Y R \quad 4 / 1,4 / 2,5 / 2,7.5 Y R 2 / 0$ & 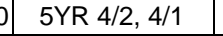 & $\mathrm{x}$ & $\mathrm{x}$ & $\mathrm{x}$ & $\mathrm{x}$ & $\mathrm{x}$ & $\mathrm{x}$ & $\mathrm{x}$ & $\mathrm{x}$ & $\mathrm{x}$ & $\mathrm{x}$ & $\mathrm{x}$ & $\mathrm{x}$ & $\mathrm{x}$ & $\mathrm{x}$ & \\
\hline $\mathrm{RH} 19-1$ & 201 & 2 & & 0 & 0 & 0 & 1 & 2 & 2 & 7.0 & 3.3 & 0 & $x$ & $x$ & $5 Y R$ 4/1, 4/2, 5/2, 7.5YR 2/0 & \begin{tabular}{|l|l|}
0 & $5 Y R ~ 4 / 2,4 / 1$ \\
\end{tabular} & $x$ & $x$ & $x$ & $x$ & $x$ & $x$ & $x$ & $x$ & $x$ & $x$ & $x$ & $x$ & $x$ & $x$ & 1 \\
\hline RH 19-1 & 201 & 2 & & 0 & 0 & 0 & 1 & 2 & 2 & 7.0 & 3.3 & 0 & $\mathrm{x}$ & $\mathrm{x}$ & $5 Y R \quad 4 / 1,4 / 2,5 / 2,7.5 Y R 2 / 0$ & \begin{tabular}{l|l}
0 & $5 Y R$ \\
\end{tabular}$/ 2,4 / 1$ & $x$ & $\mathrm{x}$ & $\mathrm{x}$ & $\mathrm{x}$ & $\mathrm{x}$ & $\mathrm{x}$ & $\mathrm{x}$ & $\mathrm{x}$ & $\mathrm{x}$ & $\mathrm{x}$ & $\mathrm{x}$ & $\mathrm{x}$ & $\mathrm{x}$ & $\mathrm{x}$ & \\
\hline RH 19-1 & 203 & 2 & & 0 & 0 & 0 & 1 & 2 & 2 & 7.0 & 3.3 & 0 & $\mathrm{x}$ & $\mathrm{x}$ & $5 Y R$ 4/1, 4/2, 5/2, 7.5YR 2/0 & 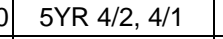 & $\mathrm{x}$ & $\mathrm{x}$ & $\mathrm{x}$ & $\mathrm{x}$ & $\mathrm{x}$ & $\mathrm{x}$ & $\mathrm{x}$ & $\mathrm{x}$ & $\mathrm{x}$ & $\mathrm{x}$ & $\mathrm{x}$ & $\mathrm{x}$ & $\mathrm{x}$ & $x$ & 1 \\
\hline RH 19-1 & 202 & 2 & & 0 & 0 & 0 & 1 & 2 & 2 & 7.0 & 3.3 & 0 & $x$ & $x$ & $5 Y R$ 4/1, 4/2, 5/2, 7.5YR 2/0 & \begin{tabular}{|l|l|}
$0 Y R ~ 4 / 2,4 / 1$ \\
\end{tabular} & $x$ & $x$ & $x$ & $x$ & $x$ & $x$ & $x$ & $x$ & $x$ & $\mathrm{x}$ & $x$ & $x$ & $x$ & $x$ & \\
\hline RH 19-1 & 202 & 2 & & 0 & 0 & 0 & 1 & 2 & 2 & 7.0 & 3.3 & 0 & $\mathrm{x}$ & $\mathrm{x}$ & $5 Y R \quad 4 / 1,4 / 2,5 / 2,7.5 Y R 2 / 0$ & \begin{tabular}{l|l}
0 & $5 Y R$ \\
\end{tabular} & $\mathrm{x}$ & $\mathrm{x}$ & $\mathrm{x}$ & $\mathrm{x}$ & $\mathrm{x}$ & $\mathrm{x}$ & $\mathrm{x}$ & $\mathrm{x}$ & $\mathrm{x}$ & $\mathrm{x}$ & $\mathrm{x}$ & $\mathrm{x}$ & $\mathrm{x}$ & $\mathrm{x}$ & \\
\hline $\mathrm{RH} 19-1$ & 203 & 2 & & 0 & 0 & 0 & 1 & 2 & 2 & 7.0 & 3.3 & 0 & $x$ & $x$ & $5 Y R \quad 4 / 1,4 / 2,5 / 2,7.5 Y R 2 / 0$ & \begin{tabular}{|l|l|}
$0 Y R ~ 4 / 2,4 / 1$ \\
\end{tabular} & $x$ & $x$ & $x$ & $x$ & $x$ & $x$ & $x$ & $x$ & $x$ & $x$ & $x$ & $x$ & $x$ & $x$ & 1 \\
\hline RH 19-1 & 203 & 2 & & 0 & 0 & 0 & 1 & 2 & 2 & 7.0 & 3.3 & 0 & $\mathrm{x}$ & $\mathrm{x}$ & $5 Y R \quad 4 / 1,4 / 2,5 / 2,7.5 Y R 2 / 0$ & \begin{tabular}{l|l}
0 & $5 Y R$ \\
\end{tabular}$/ 2,4 / 1$ & $\mathrm{x}$ & $\mathrm{x}$ & $\mathrm{x}$ & $\mathrm{x}$ & $\mathrm{x}$ & $\mathrm{x}$ & $\mathrm{x}$ & $\mathrm{x}$ & $\mathrm{x}$ & $\mathrm{x}$ & $\mathrm{x}$ & $\mathrm{x}$ & $\mathrm{x}$ & $\mathrm{x}$ & 1 \\
\hline RH 19-1 & 201 & 2 & & 0 & 0 & 0 & 1 & 2 & 2 & 7.0 & 3.3 & 0 & $\mathrm{x}$ & $\mathrm{x}$ & $5 Y R \quad 4 / 1,4 / 2,5 / 2,7.5 Y R 2 / 0$ & \begin{tabular}{l|l}
0 & $5 Y R$ \\
\end{tabular} & $\mathrm{x}$ & $\mathrm{x}$ & $\mathrm{x}$ & $\mathrm{x}$ & $\mathrm{x}$ & $\mathrm{x}$ & $\mathrm{x}$ & $\mathrm{x}$ & $\mathrm{x}$ & $\mathrm{x}$ & $\mathrm{x}$ & $\mathrm{x}$ & $\mathrm{x}$ & $\mathrm{x}$ & \\
\hline RH 19-1 & 201 & 2 & & 0 & 0 & 0 & 1 & 2 & 2 & 7.0 & 3.3 & 0 & $\mathrm{x}$ & $\mathrm{x}$ & $5 Y R \quad 4 / 1,4 / 2,5 / 2,7.5 Y R 2 / 0$ & \begin{tabular}{l|l}
0 & $5 Y R$ \\
\end{tabular}$/ 2,4 / 1$ & $\mathrm{x}$ & $\mathrm{x}$ & $\mathrm{x}$ & $\mathrm{x}$ & $\mathrm{x}$ & $\mathrm{x}$ & $\mathrm{x}$ & $\mathrm{x}$ & $\mathrm{x}$ & $\mathrm{x}$ & $\mathrm{x}$ & $\mathrm{x}$ & $\mathrm{x}$ & $\mathrm{x}$ & \\
\hline RH 19-1 & 102 & 3 & & 1 & 0 & 1 & 0 & 3 & 3 & 7.2 & 4.8 & 0 & $\mathrm{x}$ & $\mathrm{x}$ & $5 Y R 5 / 4,6 / 4$ & $5 Y R 5 / 4,6 / 4$ & indet $\mathrm{i}$ & indet li & indet & 1 & 3 & $\mathrm{x}$ & $\mathrm{x}$ & $\mathrm{x}$ & $\mathrm{x}$ & $\mathrm{x}$ & $\mathrm{x}$ & $\mathrm{x}$ & $\mathrm{x}$ & $\mathrm{x}$ & 3 \\
\hline $\mathrm{RH} 19-1$ & 101 & 3 & & 0 & 0 & 1 & 0 & 3 & 3 & 7.2 & 4.8 & 0 & $x$ & $x$ & $5 Y R 5 / 4,6 / 4$ & $5 Y R 5 / 4,6 / 4$ & $x$ & $x$ & $x$ & $x$ & $x$ & $x$ & $x$ & $x$ & $x$ & $x$ & $x$ & $x$ & $x$ & $\mathrm{x}$ & \\
\hline RH 19-1 & 102 & 5 & & 0 & 0 & 0 & 1 & 3 & 3 & 7.2 & 4.8 & 0 & $x$ & $x$ & $5 Y R \quad 4 / 1,4 / 2,7.5 Y R 2 / 0$ & $5 Y R \quad 4 / 2,4 / 1$ & $x$ & $x$ & $x$ & $x$ & $\mathrm{x}$ & $x$ & $x$ & $x$ & $x$ & $x$ & $x$ & $x$ & $x$ & $\mathrm{x}$ & 3 \\
\hline RH 19-1 & 202 & 5 & & 0 & 0 & 0 & 1 & 3 & 3 & 7.2 & 4.8 & 0 & $x$ & $x$ & $5 Y R$ 4/1, 4/2, 7.5YR 2/0 & $5 Y R 4 / 2,4 / 1$ & $x$ & $x$ & $x$ & $x$ & $x$ & $\mathrm{x}$ & $x$ & $x$ & $x$ & $x$ & $x$ & $x$ & $x$ & $\mathrm{x}$ & 3 \\
\hline RH 19-1 & 203 & 5 & & 0 & 0 & 0 & 1 & 3 & 3 & 7.2 & 4.8 & 0 & $\mathrm{x}$ & $\mathrm{x}$ & $5 Y R$ 4/1, 4/2, 7.5YR 2/0 & $5 Y R 4 / 2,4 / 1$ & $\mathrm{x}$ & $\mathrm{x}$ & $\mathrm{x}$ & $\mathrm{x}$ & $\mathrm{x}$ & $\mathrm{x}$ & $\mathrm{x}$ & $\mathrm{x}$ & $\mathrm{x}$ & $\mathrm{x}$ & $x$ & $\mathrm{x}$ & $\mathrm{x}$ & $\mathrm{x}$ & 3 \\
\hline RH 19-1 & 203 & 4 & & 1 & 0 & 1 & $1 \mathrm{y} 2$ & $2 \mathrm{y} 6$ & 3 & 10.2 & 6.1 & 1 & \begin{tabular}{l|l}
$x$ & $F$ \\
\end{tabular} & PINP & 10R $4 / 6,3 / 1$ & 7.5YR 2/0 & 13 & 40.8 & 25.7 & 2 & 3 & $\mathrm{x}$ & $x$ & $x$ & $x$ & $x$ & $x$ & indet & 8 & 2 & \\
\hline RH 19-1 & Sup & & 1 & 1 & 0 & 1 & 0 & 1 & 1 & 5.0 & 4.7 & 0 & $x$ & $\mathrm{x}$ & $5 Y R$ 5/4, 6/4 & $5 Y R \quad 4 / 1$ & indet $\mathrm{i}$ & indet li & indet & 1 & 6 & $x$ & $\mathrm{x}$ & $\mathrm{x}$ & $\mathrm{x}$ & $\mathrm{x}$ & $x$ & $x$ & $\mathrm{x}$ & $\mathrm{x}$ & 3 \\
\hline RH 19-1 & Sup & & 2 & 1 & 0 & 1 & 0 & 2 & 2 & 7.0 & 6.5 & 0 & $\mathrm{x}$ & $\mathrm{x}$ & 7.5YR 4/0, 3/0 & 7.5YR 3/0 & indet $\mathrm{i}$ & indet ji & Endet & 1 & 6 & $\mathrm{x}$ & $\mathrm{x}$ & $\mathrm{x}$ & $\mathrm{x}$ & $\mathrm{x}$ & $\mathrm{x}$ & $\mathrm{x}$ & $\mathrm{x}$ & $\mathrm{x}$ & 3 \\
\hline RH 19-1 & Sup & & 3 & 2 & 0 & 0 & 0 & 1 & 1 & 14.0 & 9.0 & 0 & $\mathrm{x}$ & $\mathrm{x}$ & $5 Y R$ 5/4, 10R 4/8 & 5YR 5/3 & $x$ & $x$ & $\mathrm{x}$ & $\mathrm{x}$ & $\mathrm{x}$ & $\mathrm{x}$ & $x$ & $\mathrm{x}$ & $x$ & $\mathrm{x}$ & $x$ & 8.6 & 5 & 1 & 4 \\
\hline $\mathrm{RH} 19-1$ & Sup & & 4 & 0 & 0 & 0 & 0 & 2 & 3 & 6.3 & 6.0 & 0 & $x$ & $x$ & 5YR 5/4 & 7.5YR 4/0 & $x$ & $x$ & $x$ & $x$ & $x$ & $\mathrm{x}$ & $x$ & $x$ & $x$ & $x$ & $x$ & $x$ & $x$ & $x$ & 3 \\
\hline $\mathrm{RH} 19-1$ & Sup & & 5 & 0 & 0 & 0 & 0 & 2 & 3 & 6.0 & 6.0 & 0 & $x$ & $x$ & $5 Y R$ 5/4 & 7.5YR 4/0 & $x$ & $x$ & $x$ & $x$ & $x$ & $x$ & $x$ & $x$ & $x$ & $x$ & $x$ & $x$ & $x$ & $x$ & 3 \\
\hline RH 19-1 & Sup & & 6 & 0 & 0 & 0 & 0 & 3y6 & 2 & 6.5 & 5.7 & 1 & $\mathrm{x}$ & $\mathrm{x}$ & 10R $4 / 6,5 / 6$ & $5 Y R 4 / 3$ & $\mathrm{x}$ & $\mathrm{x}$ & $\mathrm{x}$ & $\mathrm{x}$ & $\mathrm{x}$ & $x$ & $\mathrm{x}$ & $\mathrm{x}$ & $\mathrm{x}$ & $\mathrm{x}$ & $\mathrm{x}$ & $\mathrm{x}$ & $\mathrm{x}$ & $\mathrm{x}$ & 3 \\
\hline RH 19-1 & Sup & & 7 & 0 & 0 & 0 & 0 & 6 & 2 & 5.6 & 5.4 & 2 & linea & $\mathrm{x}$ & 10R 5/6, 7.5YR 2/0 & 5YR 5/4 & $\mathrm{x}$ & $\mathrm{x}$ & $\mathrm{x}$ & $\mathrm{x}$ & $x$ & $x$ & $\mathrm{x}$ & $\mathrm{x}$ & $\mathrm{x}$ & $\mathrm{x}$ & $x$ & $x$ & $\mathrm{x}$ & $x$ & 3 \\
\hline
\end{tabular}




\begin{tabular}{|c|c|c|c|c|c|c|c|c|c|c|c|c|c|c|c|c|c|c|c|c|c|c|c|c|c|c|c|c|c|c|c|c|c|}
\hline \multirow[b]{2}{*}{ Sitio } & \multirow[b]{2}{*}{$\begin{array}{c}\mathrm{Ni} \\
\text { vel } \\
\end{array}$} & \multirow[b]{2}{*}{ GF } & \multirow[b]{2}{*}{ FNA } & \multirow[b]{2}{*}{ Fgto } & \multicolumn{11}{|c|}{ Manufactura } & \multicolumn{2}{|c|}{ Cocción } & \multicolumn{5}{|c|}{ Borde-labio } & \multicolumn{7}{|c|}{ Asa } & \multicolumn{3}{|c|}{ Base } & \multirow[b]{2}{*}{ Alterac } \\
\hline & & & & & $\begin{array}{l}\text { Tec } \\
\text { lev }\end{array}$ & $\begin{array}{l}\text { For } \\
\text { ma }\end{array}$ & $\begin{array}{l}\text { Mar } \\
\text { cas }\end{array}$ & \begin{tabular}{|c|} 
Sup \\
ext
\end{tabular} & \begin{tabular}{|c|} 
Sup \\
int
\end{tabular} & $\begin{array}{l}\text { Esp } \\
\max \end{array}$ & \begin{tabular}{|l|} 
Esp \\
min
\end{tabular} & $\begin{array}{l}\text { Deco } \\
\text { pint }\end{array}$ & \begin{tabular}{|c|} 
Deco \\
cor/dsp
\end{tabular} & $\begin{array}{c}\text { Moti } \\
\text { vo }\end{array}$ & Estilo & Color sup ext & Color sup int & Diam & $\begin{array}{l}\text { Lrg } \\
\text { arc } \\
\end{array}$ & \begin{tabular}{|c|}
$\%$ \\
arco \\
\end{tabular} & Dir & $\begin{array}{l}\text { For } \\
\text { ma }\end{array}$ & $\begin{array}{l}\text { Lar } \\
\text { go }\end{array}$ & $\begin{array}{c}\text { An } \\
\text { cho }\end{array}$ & Esp & $p \begin{array}{l}\text { Sec } \\
\text { ción }\end{array}$ & \begin{tabular}{l|l}
$c$ & In \\
n & ser \\
\end{tabular} & \begin{tabular}{l|l}
$\mathrm{r}_{\mathrm{rc}}$ & $\mathrm{P}$ \\
$\mathrm{si}$
\end{tabular} & & iám $\left.\right|_{f} ^{N}$ & $\begin{array}{c}\text { Mor } \\
\text { fol }\end{array}$ & \begin{tabular}{|l|} 
Uni \\
ón \\
\end{tabular} & \\
\hline $\mathrm{RH} 19-7$ & 1 & 1 & & 1 & 1 & 2 & 2 & $2,3 y 4$ & $2,3 y 4$ & 7.4 & 6.1 & 2 & 0 & retic & Yavi & 10R 4/4; 5YR 6/4 & 10R4/4,5/4;5YR7/4,5/4 & 31 & 8.2 & 8.4 & 1 & 2 & $\mathrm{x}$ & $\mathrm{x}$ & $\mathrm{x}$ & $\mathrm{x}$ & $\mathrm{x}$ & 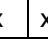 & & $\mathrm{x}$ & $x$ & $\mathrm{x}$ & 5 \\
\hline RH19-7 & 1 & 1 & & 0 & 1 & 2 & 2 & $2,3 y 4$ & $2,3 y 4$ & 6.8 & 6.1 & 2 & 0 & retic & Yavi & 10R 4/4; 5YR 6/4 & 10R4/4,5/4;5YR7/4 5/4 & $x$ & $x$ & $x$ & $x$ & $x$ & $x$ & $x$ & $x$ & $x$ & $x$ & 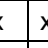 & $x$ & $x$ & $x$ & $x$ & 5 \\
\hline RH19-7 & 1 & 1 & & 0 & 1 & 2 & 2 & $2,3 y 4$ & $2,3 y 4$ & 6.8 & 6.0 & 2 & 0 & retic & Yavi & 10R 4/4; 5YR 6/4 & 10R4/4,5/4;5YR7/4 5/4 & $x$ & $x$ & $x$ & $x$ & $x$ & $x$ & $x$ & $x$ & $x$ & $x$ & 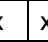 & $x$ & $\mathrm{x}$ & $x$ & $x$ & 5 \\
\hline RH19-7 & 1 & 1 & & 0 & 1 & 2 & 2 & $2,3 y 4$ & $2,3 y 4$ & 6.7 & 6.2 & 2 & 0 & retic & Yavi & 10R 4/4; 5YR 6/4 & 10R4/4,5/4;5YR7/4 5/4 & $x$ & $x$ & $x$ & $x$ & $x$ & $x$ & $x$ & $x$ & $x$ & $x$ & 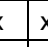 & $x$ & $x$ & $x$ & $x$ & 6 \\
\hline RH19-7 & 1 & 1 & & 0 & 1 & 2 & 2 & $2,3 y 4$ & $2,3 y 4$ & 6.8 & 5.4 & 2 & 0 & retic & Yavi & 10R 4/4; 5YR 6/4 & 10R4/4,5/4;5YR7/4 5/4 & $x$ & $x$ & $x$ & $x$ & $x$ & $x$ & $x$ & $x$ & $x$ & $x$ & 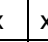 & $x$ & $x$ & $x$ & $x$ & \\
\hline $\mathrm{RH} 19-7$ & 1 & 1 & & 1 & 1 & 2 & 2 & $2,3 y 4$ & $2,3 y 4$ & 7.1 & 6.0 & 2 & 0 & retic & Yavi & 10R 4/4; 5YR 6/4 & 10R4/4, 5/4; 5YR5/4 & indet $\mathrm{i}$ & indet & indet & 1 & 2 & $x$ & $x$ & $x$ & $x$ & $x$ & $x$ & $x$ & $x$ & $x$ & $x$ & 2 \\
\hline RH19-7 & 1 & 1 & & 0 & 1 & 2 & 2 & $2,3 y 4$ & $2,3 \mathrm{y} 4$ & 6.4 & 6.1 & 2 & 0 & retic & Yavi & 10R 4/4; 5YR 6/4 & 10R4/4, 5/4; 5YR5/4 & $x$ & $x$ & $x$ & $\mathrm{x}$ & $x$ & $x$ & $x$ & $x$ & $x$ & $x$ & 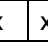 & $x$ & $x$ & $x$ & $x$ & \\
\hline $\mathrm{RH} 19-7$ & 1 & 1 & & 0 & 1 & 2 & 2 & $2,3 y 4$ & $2,3 y 4$ & 9.1 & 6.3 & 2 & 0 & retic & Yavi & 10R 4/4; 5YR 6/4 & 10R4/4, 5/4; 5YR5/4 & $x$ & $x$ & $\mathrm{x}$ & $x$ & $x$ & $x$ & $x$ & $x$ & $x$ & $x$ & $x$ & $x$ & $x$ & $x$ & $x$ & 5 \\
\hline RH19-7 & 1 & 1 & & 0 & 1 & 2 & 2 & $2,3 y 4$ & $2,3 y 4$ & 6.9 & 5.7 & 2 & 0 & retic & Yavi & 10R 4/4; 5YR 6/4 & 10R4/4, 5/4; 5YR5/4 & $x$ & $x$ & $x$ & $x$ & $x$ & $x$ & $x$ & $x$ & $x$ & $x$ & 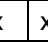 & $x$ & $x$ & $x$ & $x$ & 5 \\
\hline RH19-7 & 1 & 1 & & 0 & 1 & 2 & 2 & $2,3 y 4$ & $2,3 y 4$ & 6.7 & 5.3 & 2 & 0 & retic & Yavi & 10R 4/4; 5YR 6/4 & 10R4/4, 5/4; 5YR5/4 & $x$ & $x$ & $x$ & $x$ & $x$ & $x$ & $x$ & $x$ & $x$ & $x$ & $x$ & $x$ & $x$ & $x$ & $x$ & \\
\hline RH19-7 & 1 & 1 & & 0 & 1 & 2 & 2 & $2,3 y 4$ & $2,3 y 4$ & 7.1 & 6.4 & 2 & 0 & retic & Yavi & 10R 4/4; 5YR 6/4 & 10R4/4, 5/4; 5YR5/4 & $\mathrm{x}$ & $\mathrm{x}$ & $\mathrm{x}$ & $\mathrm{x}$ & $\mathrm{x}$ & $\mathrm{x}$ & $\mathrm{x}$ & $\mathrm{x}$ & $\mathrm{x}$ & $\mathrm{x}$ & $x$ & $x$ & $\mathrm{x}$ & $\mathrm{x}$ & $\mathrm{x}$ & \\
\hline RH19-7 & 1 & 1 & & 0 & 1 & 2 & 2 & $2,3 y 4$ & $2,3 y 4$ & 8.0 & 6.6 & 2 & 0 & retic & Yavi & 10R 4/4; 5YR 6/4 & 10R4/4, 5/4; 5YR5/4 & $x$ & $x$ & $\mathrm{x}$ & $x$ & $x$ & $x$ & $x$ & $x$ & $x$ & $x$ & $x$ & $x$ & $\mathrm{x}$ & $x$ & $\mathrm{x}$ & \\
\hline RH19-7 & 1 & 1 & & 0 & 1 & 2 & 2 & $2,3 y 4$ & $2,3 y 4$ & 7.5 & 6.3 & 2 & 0 & retic & Yavi & 10R 4/4; 5YR 6/4 & 10R4/4, 5/4; 5YR5/4 & $\mathrm{x}$ & $\mathrm{x}$ & $\mathrm{x}$ & $\mathrm{x}$ & $\mathrm{x}$ & $\mathrm{x}$ & $\mathrm{x}$ & $\mathrm{x}$ & $\mathrm{x}$ & $\mathrm{x}$ & $x$ & $x$ & $\mathrm{x}$ & $\mathrm{x}$ & $\mathrm{x}$ & \\
\hline RH19-7 & 1 & 1 & & 1 & 1 & 2 & 2 & $2,3 y 4$ & $2,3 y 4$ & 6.8 & 6.8 & 2 & 0 & retic & Yavi & 10R 4/4; 5YR 6/4 & 10R4/4, 5/4; 5YR5/4 & indet $\mathrm{i}$ & indet & indet & 0 & 2 & $x$ & $x$ & $x$ & $x$ & $x$ & $x$ & $x$ & $\mathrm{x}$ & $x$ & $x$ & \\
\hline RH19-7 & 1 & 1 & & 0 & 1 & 2 & 2 & $2,3 y 4$ & $2,3 y 4$ & 8.9 & 8.0 & 2 & 0 & retic & Yavi & 10R 4/4; 5 YR 6/4 & 10R4/4, 5/4; 5YR5/4 & $x$ & $x$ & $x$ & $x$ & $x$ & $x$ & $x$ & $x$ & $x$ & $x$ & $x$ & $x$ & $x$ & $x$ & $x$ & 5 \\
\hline RH19-7 & 1 & 1 & & 0 & 1 & 2 & 2 & $2,3 y 4$ & $2,3 y 4$ & 8.0 & 5.5 & 2 & 0 & retic & Yavi & 10R 4/4; 5YR 6/4 & 10R4/4, 5/4; 5YR5/4 & $x$ & $x$ & $x$ & $x$ & $x$ & $x$ & $x$ & $\mathrm{x}$ & $x$ & $x$ & $x$ & $x$ & $x$ & $x$ & $x$ & 5 \\
\hline RH19-7 & 1 & 1 & & 0 & 1 & 2 & 2 & $2,3 y 4$ & $2,3 y 4$ & 8.2 & 5.6 & 2 & 0 & retic & Yavi & 10R 4/4; 5YR 6/4 & 10R4/4, 5/4; 5YR5/4 & $\mathrm{x}$ & $\mathrm{x}$ & $\mathrm{x}$ & $\mathrm{x}$ & $\mathrm{x}$ & $\mathrm{x}$ & $\mathrm{x}$ & $\mathrm{x}$ & $\mathrm{x}$ & $\mathrm{x}$ & 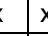 & $x$ & $\mathrm{x}$ & $\mathrm{x}$ & $\mathrm{x}$ & \\
\hline RH19-7 & 1 & 1 & & 0 & 1 & 2 & 2 & $2,3 y 4$ & $2,3 y 4$ & 6.3 & 4.5 & 2 & 0 & retic & Yavi & 10R 4/4; 5YR 6/4 & 10R4/4, 5/4; 5YR5/4 & $x$ & $x$ & $x$ & $x$ & $x$ & $x$ & $x$ & $x$ & $x$ & $x$ & $x$ & $x$ & $x$ & $x$ & $\mathrm{x}$ & 5 \\
\hline RH19-7 & 1 & 1 & & 0 & 1 & 2 & 2 & $2,3 y 4$ & $2,3 y 4$ & 6.7 & 5.3 & 2 & 0 & retic & Yavi & 10R 4/4; 5YR 6/4 & 10R4/4, 5/4; 5YR5/4 & $\mathrm{x}$ & $\mathrm{x}$ & $\mathrm{x}$ & $\mathrm{x}$ & $\mathrm{x}$ & $\mathrm{x}$ & $\mathrm{x}$ & $\mathrm{x}$ & $\mathrm{x}$ & $\mathrm{x}$ & 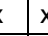 & $x$ & $\mathrm{x}$ & $\mathrm{x}$ & $\mathrm{x}$ & 5 \\
\hline RH19-7 & 1 & 1 & & 0 & 1 & 2 & 2 & $2,3 y 4$ & $2,3 y 4$ & 6.3 & 4.7 & 2 & 0 & retic & Yavi & 10R 4/4; 5YR 6/4 & 10R4/4, 5/4; 5YR5/4 & $x$ & $x$ & $x$ & $x$ & $x$ & $x$ & $x$ & $x$ & $x$ & $x$ & $x$ & $x$ & $\mathrm{x}$ & $x$ & $x$ & 5 \\
\hline RH19-7 & 1 & 1 & & 0 & 1 & 2 & 2 & $2,3 y 4$ & $2,3 y 4$ & indeti & indet & 2 & 0 & retic & Yavi & 10R 4/4; 5YR 6/4 & 10R4/4, 5/4; 5YR5/4 & $x$ & $x$ & $x$ & $x$ & $x$ & $x$ & $x$ & $x$ & $\mathrm{x}$ & $x$ & 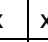 & $x$ & $x$ & $x$ & $x$ & 3 \\
\hline RH19-7 & 1 & 1 & & 0 & 1 & 2 & 2 & $2,3 y 4$ & $2,3 y 4$ & indeti & indet & 2 & 0 & retic & Yavi & 10R 4/4; 5YR 6/4 & 10R4/4, 5/4; 5YR5/4 & $x$ & $x$ & $x$ & $x$ & $x$ & $x$ & $x$ & $x$ & $\mathrm{x}$ & $x$ & $x$ & $x$ & $\mathrm{x}$ & $x$ & $x$ & 3 \\
\hline RH19-7 & 1 & 1 & & 0 & 1 & 2 & 2 & $2,3 y 4$ & $2,3 y 4$ & 6.5 & 5.9 & 2 & 0 & retic & Yavi & 10R 4/4; 5YR 6/4 & 10R4/4, 5/4; 5YR5/4 & $x$ & $x$ & $x$ & $x$ & $x$ & $x$ & $x$ & $x$ & $\mathrm{x}$ & $x$ & $x$ & $x$ & $x$ & $x$ & $x$ & 2 \\
\hline RH19-7 & 1 & 2 & & 0 & 1 & 0 & 2 & $3 y 4$ & $3 y 4$ & 6.2 & 5.0 & 1 & 0 & $\mathrm{x}$ & Yavi & $10 R 5 / 4,4 / 3,4 / 4$ & $5 Y R$ 7/4, 6/4, 6/6 & $\mathrm{x}$ & $\mathrm{x}$ & $\mathrm{x}$ & $\mathrm{x}$ & $\mathrm{x}$ & $x$ & $x$ & $x$ & $\mathrm{x}$ & $\mathrm{x}$ & $x$ & $x$ & $\mathrm{x}$ & $x$ & $\mathrm{x}$ & 5 \\
\hline RH19-7 & 1 & 2 & & 0 & 1 & 0 & 2 & $3 y 4$ & $3 \mathrm{y} 4$ & 6.3 & 5.0 & 1 & 0 & $x$ & Yavi & $10 R 5 / 4,4 / 3,4 / 4$ & $5 Y R 7 / 4,6 / 4,6 / 6$ & $x$ & $x$ & $x$ & $x$ & $\mathrm{x}$ & $x$ & $x$ & $x$ & $x$ & $x$ & $x$ & $x$ & $x$ & $x$ & $x$ & 2 \\
\hline RH19-7 & 1 & 2 & & 0 & 1 & 0 & 2 & $3 y 4$ & $3 y 4$ & 5.0 & 4.6 & 1 & 0 & $x$ & Yavi & $10 R 5 / 4,4 / 3,4 / 4$ & $5 Y R 7 / 4,6 / 4,6 / 6$ & $x$ & $x$ & $x$ & $x$ & $x$ & $x$ & $x$ & $x$ & $\mathrm{x}$ & $x$ & $x$ & $x$ & $x$ & $x$ & $x$ & 5 \\
\hline RH19-7 & 1 & 2 & & 0 & 1 & 0 & 2 & 3y4 & 3y4 & 6.3 & 5.3 & 1 & 0 & $\mathrm{x}$ & Yavi & 10R $5 / 4,4 / 3,4 / 4$ & $5 Y R$ 7/4, 6/4, 6/6 & $\mathrm{x}$ & $\mathrm{x}$ & $\mathrm{x}$ & $\mathrm{x}$ & $\mathrm{x}$ & $\mathrm{x}$ & $\mathrm{x}$ & $\mathrm{x}$ & $\mathrm{x}$ & $\mathrm{x}$ & $x$ & $x$ & $\mathrm{x}$ & $\mathrm{x}$ & $\mathrm{x}$ & 5 \\
\hline RH19-7 & 1 & 2 & & 0 & 1 & 0 & 2 & $3 y 4$ & $3 y 4$ & 7.8 & 5.6 & 1 & 0 & $x$ & Yavi & 10R $5 / 4,4 / 3,4 / 4$ & $5 Y R 7 / 4,6 / 4,6 / 6$ & $x$ & $x$ & $x$ & $x$ & $x$ & $x$ & $x$ & $x$ & $x$ & $x$ & \begin{tabular}{l|l}
$x$ \\
\end{tabular} & $x$ & $x$ & $x$ & $x$ & 2 \\
\hline RH19-7 & 1 & 2 & & 0 & 1 & 0 & 2 & 3y4 & 3y4 & 7.5 & 5.9 & 1 & 0 & $\mathrm{x}$ & Yavi & 10R $5 / 4,4 / 3,4 / 4$ & $5 Y R 7 / 4,6 / 4,6 / 6$ & $\mathrm{x}$ & $\mathrm{x}$ & $\mathrm{x}$ & $\mathrm{x}$ & $\mathrm{x}$ & $\mathrm{x}$ & $\mathrm{x}$ & $x$ & $\mathrm{x}$ & $\mathrm{x}$ & $x$ & $x$ & $\mathrm{x}$ & $x$ & $\mathrm{x}$ & 2 \\
\hline RH19-7 & 1 & 2 & & 0 & 1 & 0 & 2 & 3y4 & 3y4 & 7.5 & 6.0 & 1 & 0 & $\mathrm{x}$ & Yavi & 10R $5 / 4,4 / 3,4 / 4$ & $5 Y R$ 7/4, 6/4, 6/6 & $\mathrm{x}$ & $\mathrm{x}$ & $\mathrm{x}$ & $\mathrm{x}$ & $\mathrm{x}$ & $\mathrm{x}$ & $\mathrm{x}$ & $\mathrm{x}$ & $\mathrm{x}$ & $\mathrm{x}$ & $x$ & $x$ & $\mathrm{x}$ & $\mathrm{x}$ & $\mathrm{x}$ & 5 \\
\hline RH19-7 & 1 & 2 & & 0 & 1 & 0 & 2 & $3 y 4$ & $3 y 4$ & 6.5 & 5.5 & 1 & 0 & $\mathrm{x}$ & Yavi & $10 R 5 / 4,4 / 3,4 / 4$ & $5 Y R \quad 7 / 4,6 / 4,6 / 6$ & $\mathrm{x}$ & $\mathrm{x}$ & $\mathrm{x}$ & $\mathrm{x}$ & $x$ & $x$ & $x$ & $x$ & $\mathrm{x}$ & $\mathrm{x}$ & $x$ & $x$ & $x$ & $x$ & $\mathrm{x}$ & 5 \\
\hline $\mathrm{RH} 19-7$ & 2 & 2 & & 0 & 1 & 0 & 2 & $3 y 4$ & $3 y 4$ & 8.2 & 6.7 & 1 & 0 & $x$ & Yavi & $10 \mathrm{R} 5 / 4,4 / 3,4 / 4$ & $5 Y R 7 / 4,6 / 4,6 / 6$ & $x$ & $x$ & $x$ & $x$ & $x$ & $x$ & $x$ & $x$ & $x$ & $x$ & 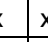 & $x$ & $x$ & $x$ & $x$ & 2 \\
\hline RH19-7 & 1 & 2 & & 0 & 1 & 0 & 2 & $3 y 4$ & 3y4 & 6.0 & 5.8 & 1 & 0 & $\mathrm{x}$ & Yavi & $10 \mathrm{R} 5 / 4,4 / 3,4 / 4$ & $5 Y R \quad 7 / 4,6 / 4,6 / 6$ & $\mathrm{x}$ & $\mathrm{x}$ & $\mathrm{x}$ & $\mathrm{x}$ & $x$ & $x$ & $x$ & $x$ & $\mathrm{x}$ & $\mathrm{x}$ & $x$ & $x$ & $x$ & $x$ & $\mathrm{x}$ & \\
\hline $\mathrm{RH} 19-7$ & 1 & 3 & & 0 & 0 & 0 & 2 & 3y4 & 3y4 & 5.1 & 4.9 & 1 & 0 & $x$ & Yavi & 10R $4 / 3$ y $4 / 4$ & 2.5 YR $6 / 4$ y $6 / 6$ & $\mathrm{x}$ & $\mathrm{x}$ & $\mathrm{x}$ & $\mathrm{x}$ & $x$ & $\mathrm{x}$ & $\mathrm{x}$ & $\mathrm{x}$ & $\mathrm{x}$ & $\mathrm{x}$ & $x$ & $x$ & $\mathrm{x}$ & $x$ & $\mathrm{x}$ & 5 \\
\hline RH19-7 & 1 & 3 & & 0 & 0 & 0 & 2 & $3 y 4$ & $3 y 4$ & 5.1 & 4.8 & 1 & 0 & $x$ & Yavi & $10 \mathrm{R} 4 / 3$ y $4 / 4$ & 2.5 YR $6 / 4$ y $6 / 6$ & $x$ & $x$ & $x$ & $x$ & $x$ & $x$ & $x$ & $x$ & $x$ & $x$ & $x$ & $x$ & $\mathrm{x}$ & $x$ & $x$ & 5 \\
\hline $\mathrm{RH} 19-7$ & 1 & 3 & & 0 & 0 & 0 & 2 & 3y4 & 3y4 & 4.9 & 4.3 & 1 & 0 & $\mathrm{x}$ & Yavi & 10R $4 / 3$ y $4 / 4$ & 2.5 YR $6 / 4$ y $6 / 6$ & $\mathrm{x}$ & $\mathrm{x}$ & $\mathrm{x}$ & $\mathrm{x}$ & $x$ & $\mathrm{x}$ & $x$ & $x$ & $\mathrm{x}$ & $\mathrm{x}$ & $x$ & $x$ & $\mathrm{x}$ & $x$ & $\mathrm{x}$ & 5 \\
\hline RH19-7 & 1 & 3 & & 0 & 0 & 0 & 2 & $3 y 4$ & $3 y 4$ & 4.7 & 4.4 & 1 & 0 & $x$ & Yavi & $10 R$ $4 / 3$ y $4 / 4$ & 2.5 YR $6 / 4$ y $6 / 6$ & $x$ & $x$ & $x$ & $x$ & $x$ & $x$ & $x$ & $x$ & $x$ & $x$ & \begin{tabular}{l|l}
6 \\
6
\end{tabular} & $x$ & $x$ & $x$ & $x$ & 5 \\
\hline RH19-7 & 1 & 3 & & 0 & 0 & 0 & 2 & $3 y 4$ & $3 y 4$ & 5.5 & 4.9 & 1 & 0 & $\mathrm{x}$ & Yavi & $10 R$ $4 / 3$ y $4 / 4$ & 2.5 YR $6 / 4$ y $6 / 6$ & $\mathrm{x}$ & $\mathrm{x}$ & $\mathrm{x}$ & $\mathrm{x}$ & $x$ & $x$ & $x$ & $\mathrm{x}$ & $\mathrm{x}$ & $\mathrm{x}$ & $x$ & $x$ & $\mathrm{x}$ & $x$ & $\mathrm{x}$ & \\
\hline RH19-7 & 1 & 3 & & 0 & 0 & 0 & 2 & 3y4 & 3y4 & 5.3 & 5.1 & 1 & 0 & $\mathrm{x}$ & Yavi & $10 R$ 4/3 y $4 / 4$ & 2.5 YR $6 / 4$ y $6 / 6$ & $\mathrm{x}$ & $\mathrm{x}$ & $\mathrm{x}$ & $\mathrm{x}$ & $\mathrm{x}$ & $\mathrm{x}$ & $\mathrm{x}$ & $\mathrm{x}$ & $\mathrm{x}$ & $\mathrm{x}$ & $\mathrm{k}$ & $x$ & $\mathrm{x}$ & $\mathrm{x}$ & $\mathrm{x}$ & 5 \\
\hline $\mathrm{RH} 19-7$ & 1 & 3 & & 0 & 0 & 0 & 2 & $3 y 4$ & $3 y 4$ & 5.1 & 4.6 & 1 & 0 & $\mathrm{x}$ & Yavi & $10 R \quad 4 / 3$ y $4 / 4$ & 2.5 YR $6 / 4$ y $6 / 6$ & $\mathrm{x}$ & $\mathrm{x}$ & $\mathrm{x}$ & $\mathrm{x}$ & $x$ & $x$ & $x$ & $\mathrm{x}$ & $\mathrm{x}$ & $\mathrm{x}$ & $x$ & $x$ & $\mathrm{x}$ & $x$ & $\mathrm{x}$ & \\
\hline
\end{tabular}




\begin{tabular}{|c|c|c|c|c|c|c|c|c|c|c|c|c|c|c|c|c|c|c|c|c|c|c|c|c|c|c|c|c|c|c|c|c|c|}
\hline \multirow[b]{2}{*}{ Sitio } & \multirow[b]{2}{*}{$\begin{array}{c}\mathrm{Ni} \\
\text { vel }\end{array}$} & \multirow[b]{2}{*}{ GF } & \multirow[b]{2}{*}{ FNA } & \multirow[b]{2}{*}{ Fgto } & \multicolumn{11}{|c|}{ Manufactura } & \multicolumn{2}{|c|}{ Cocción } & \multicolumn{5}{|c|}{ Borde-labio } & \multicolumn{7}{|c|}{ Asa } & \multicolumn{3}{|c|}{ Base } & \multirow[b]{2}{*}{ Alterac } \\
\hline & & & & & $\begin{array}{l}\text { Tec } \\
\text { lev }\end{array}$ & $\begin{array}{l}\text { For } \\
\text { ma }\end{array}$ & $\begin{array}{l}\text { Mar } \\
\text { cas }\end{array}$ & \begin{tabular}{|c|} 
Sup \\
ext
\end{tabular} & \begin{tabular}{|c|} 
Sup \\
int
\end{tabular} & $\begin{array}{l}\text { Esp } \\
\text { max }\end{array}$ & \begin{tabular}{|l|} 
Esp \\
min
\end{tabular} & $\begin{array}{c}\text { Deco } \\
\text { pint }\end{array}$ & $\begin{array}{c}\text { Deco } \\
\text { cor/dsp }\end{array}$ & \begin{tabular}{|c|} 
Moti \\
vo
\end{tabular} & Estilo & Color sup ext & Color sup int & Diam & $\begin{array}{l}\text { Lrg } \\
\text { arc }\end{array}$ & $\begin{array}{c}\% \\
\text { arco }\end{array}$ & Di & I $\begin{array}{l}\begin{array}{l}F o \\
\mathrm{ma}\end{array} \\
\mathrm{a}\end{array}$ & $\begin{array}{l}\text { La } \\
\text { go }\end{array}$ & & $\begin{array}{l}\text { An } \\
\text { ho }\end{array}$ & Esp & $\begin{array}{l}\text { Sec } \\
\text { ción }\end{array}$ & \begin{tabular}{|l|} 
In \\
serc \\
\end{tabular} & $\begin{array}{l}\mathrm{Po} \\
\mathrm{sic}\end{array}$ & Diám & \begin{tabular}{|c|} 
Mor \\
fol
\end{tabular} & $\begin{array}{l}\text { Uni } \\
\text { ón }\end{array}$ & \\
\hline RH19-7 & 1 & 3 & & 0 & 0 & 0 & 2 & $3 y 4$ & $3 y 4$ & 7.3 & 5.6 & 1 & 0 & $x$ & Yavi & $10 R$ $4 / 3$ y $4 / 4$ & 2.5 YR $6 / 4$ y $6 / 6$ & $x$ & $x$ & $x$ & $\mathrm{x}$ & $x$ & $\mathrm{x}$ & & $x$ & $x$ & $x$ & $x$ & $x$ & $x$ & $x$ & $x$ & 5 \\
\hline RH19-7 & 1 & 3 & & 0 & 0 & 0 & 2 & $3 y 4$ & $3 y 4$ & 5.8 & 5.0 & 1 & 0 & $x$ & Yavi & $10 R 4 / 3$ y $4 / 4$ & 2.5 YR $6 / 4$ y $6 / 6$ & $x$ & $\mathrm{x}$ & $x$ & $\mathrm{x}$ & $\mathrm{x}$ & $\mathrm{x}$ & & $\mathrm{x}$ & $\mathrm{x}$ & $x$ & $\mathrm{x}$ & $\mathrm{x}$ & $x$ & $x$ & $\mathrm{x}$ & 5 \\
\hline RH19-7 & 1 & 3 & & 0 & 0 & 0 & 2 & $3 \mathrm{y} 4$ & $3 y 4$ & 7.8 & 6.4 & 1 & 0 & $x$ & Yavi & $10 R \quad 4 / 3$ y $4 / 4$ & 2.5 YR $6 / 4$ y $6 / 6$ & $x$ & $x$ & $x$ & $x$ & $x$ & $x$ & & $x$ & $\mathrm{x}$ & $x$ & $x$ & $x$ & $x$ & $x$ & $x$ & 5 \\
\hline RH19-7 & 1 & 3 & & 0 & 0 & 0 & 2 & $3 y 4$ & $3 y 4$ & 6.7 & 5.5 & 1 & 0 & $x$ & Yavi & $10 R$ $4 / 3$ y $4 / 4$ & 2.5 YR $6 / 4$ y $6 / 6$ & $x$ & $x$ & $x$ & $\mathrm{x}$ & $x$ & $x$ & & $x$ & $x$ & $x$ & $x$ & $x$ & $x$ & $x$ & $x$ & \\
\hline RH19-7 & 1 & 3 & & 0 & 0 & 0 & 2 & $3,4 \mathrm{y} 6$ & 1 & 5.4 & 5.6 & 1 & 0 & $x$ & Yavi & $10 R$ $4 / 3$ y $4 / 4$ & 2.5 YR $6 / 4$ y $6 / 6$ & $x$ & $x$ & $x$ & $x$ & $\mathrm{x}$ & $\mathrm{x}$ & & $x$ & $x$ & $x$ & $x$ & $x$ & $x$ & $x$ & $x$ & \\
\hline RH19-7 & 1 & 4 & & 0 & 0 & 0 & 0 & $3,4 \mathrm{y} 6$ & 1 & 4.8 & 4.3 & 3 & 0 & $\begin{array}{c}\text { fjas y } \\
\text { ptos }\end{array}$ & Casab & 10R4/4,5/6,5YR8/1,N2,5/ & $5 Y R \quad 4 / 2,5 / 4,6 / 2$ & $\mathrm{x}$ & $x$ & $\mathrm{x}$ & $x$ & $\mathrm{x}$ & $x$ & & $\mathrm{x}$ & $\mathrm{x}$ & $x$ & $x$ & $\mathrm{x}$ & $\mathrm{x}$ & $x$ & $\mathrm{x}$ & \\
\hline $\mathrm{RH} 19-7$ & 1 & 4 & & 0 & 0 & 0 & 0 & $3,4 \mathrm{y} 6$ & 1 & 5.0 & 4.7 & 3 & 0 & \begin{tabular}{|c|} 
fjas y \\
ptos
\end{tabular} & Casab & 10R4/4,5/6,5YR8/1,N2,5/ & $5 Y R \quad 4 / 2,5 / 4,6 / 2$ & $x$ & $x$ & $\mathrm{x}$ & $\mathrm{x}$ & $\mathrm{x}$ & $\mathrm{x}$ & & $x$ & $x$ & $x$ & $\mathrm{x}$ & $x$ & $x$ & $x$ & $\mathrm{x}$ & 5 \\
\hline $\mathrm{RH} 19-7$ & 1 & 4 & & 0 & 0 & 0 & 0 & $3,4 \mathrm{y} 6$ & 1 & 4.5 & 4.0 & 3 & 0 & $\begin{array}{c}\text { fjas y } \\
\text { ptos }\end{array}$ & Casab & 10R4/4,5/6,5YR8/1,N2,5/ & $5 Y R \quad 4 / 2,5 / 4,6 / 2$ & $\mathrm{x}$ & $x$ & $\mathrm{x}$ & $\mathrm{x}$ & $\mathrm{x}$ & $\mathrm{x}$ & & $\mathrm{x}$ & $x$ & $x$ & $x$ & $\mathrm{x}$ & $\mathrm{x}$ & $x$ & $\mathrm{x}$ & \\
\hline RH19-7 & 1 & 4 & & 0 & 0 & 0 & 0 & $3,4 y 6$ & 1 & 4.2 & 3.8 & 3 & 0 & \begin{tabular}{|c|} 
fjas y \\
ptos
\end{tabular} & Casab & 10R4/4,5/6,5YR8/1,N2,5/ & $5 Y R \quad 4 / 2,5 / 4,6 / 2$ & $\mathrm{x}$ & $x$ & $\mathrm{x}$ & $\mathrm{x}$ & $\mathrm{x}$ & $\mathrm{x}$ & & $x$ & $x$ & $\mathrm{x}$ & $x$ & $x$ & $\mathrm{x}$ & $x$ & $\mathrm{x}$ & 5 \\
\hline $\mathrm{RH} 19-7$ & 1 & 4 & & 0 & 0 & 0 & 0 & $3,4 y 6$ & 1 & 3.8 & 3.5 & 3 & 0 & $\begin{array}{c}\text { fjas y } \\
\text { ptos }\end{array}$ & Casab & 10R4/4,5/6,5YR8/1,N2,5/ & $5 Y R \quad 4 / 2,5 / 4,6 / 2$ & $\mathrm{x}$ & $x$ & $\mathrm{x}$ & $\mathrm{x}$ & $\mathrm{x}$ & $x$ & & $x$ & $x$ & $\mathrm{x}$ & $x$ & $\mathrm{x}$ & $\mathrm{x}$ & $x$ & $\mathrm{x}$ & 5 \\
\hline RH19-7 & 2 & 4 & & 0 & 0 & 0 & 0 & $3,4 \mathrm{y} 6$ & 1 & 4.1 & 4.1 & 3 & 0 & \begin{tabular}{c|} 
fjas y \\
ptos
\end{tabular} & Casab & 10R4/4,5/6,5YR8/1,N2,5/ & $5 Y R \quad 4 / 2,5 / 4,6 / 2$ & $\mathrm{x}$ & $\mathrm{x}$ & $\mathrm{x}$ & $\mathrm{x}$ & $\mathrm{x}$ & $\mathrm{x}$ & & $x$ & $x$ & $\mathrm{x}$ & $\mathrm{x}$ & $\mathrm{x}$ & $\mathrm{x}$ & $x$ & $x$ & 4 y 5 \\
\hline RH19-7 & 1 & 4 & & 0 & 0 & 0 & 0 & $3,4 \mathrm{y} 6$ & 1 & 5.0 & 4.3 & 3 & 0 & \begin{tabular}{|l|} 
fjas y \\
ptos
\end{tabular} & Casab & 10R4/4,5/6,5YR8/1,N2,5/ & $5 Y R \quad 4 / 2,5 / 4,6 / 2$ & $x$ & $x$ & $x$ & $\mathrm{x}$ & $x$ & $x$ & & $x$ & $x$ & $x$ & $x$ & $x$ & $x$ & $x$ & $x$ & \\
\hline RH19-7 & 1 & 4 & & 0 & 0 & 0 & 0 & $3,4 \mathrm{y} 6$ & 1 & 5.4 & 4.7 & 3 & 0 & $\begin{array}{c}\text { fjas y } \\
\text { ptos }\end{array}$ & Casab & 10R4/4,5/6,5YR8/1,N2,5/ & $5 Y R \quad 4 / 2,5 / 4,6 / 2$ & $x$ & $x$ & $x$ & $x$ & $x$ & $x$ & & $x$ & $\mathrm{x}$ & $\mathrm{x}$ & $x$ & $\mathrm{x}$ & $\mathrm{x}$ & $x$ & $\mathrm{x}$ & \\
\hline $\mathrm{RH} 19-7$ & 1 & 4 & & 0 & 0 & 0 & 0 & $3,4 \mathrm{y} 6$ & 1 & 5.4 & 4.2 & 3 & 0 & \begin{tabular}{|c|} 
fjas y \\
ptos
\end{tabular} & Casab & 10R4/4,5/6,5YR8/1,N2,5/ & $5 Y R \quad 4 / 2,5 / 4,6 / 2$ & $x$ & $x$ & $x$ & $x$ & $x$ & $x$ & & $x$ & $x$ & $x$ & $x$ & $x$ & $x$ & $x$ & $x$ & \\
\hline $\mathrm{RH} 19-7$ & 1 & 4 & & 0 & 0 & 0 & 0 & $3,4 \mathrm{y} 6$ & 1 & 5.0 & 4.2 & 3 & 0 & \begin{tabular}{|c|} 
fjas y \\
ptos
\end{tabular} & Casab & 10R4/4,5/6,5YR8/1,N2,5/ & $5 Y R \quad 4 / 2,5 / 4,6 / 2$ & $x$ & $x$ & $x$ & $\mathrm{x}$ & $x$ & $x$ & & $x$ & $x$ & $x$ & $x$ & $x$ & $x$ & $x$ & $\mathrm{x}$ & 5 \\
\hline RH19-7 & 2 & 5 & & 1 & 0 & 1 & 1 & $2 \mathrm{y} 6$ & $2 \mathrm{y} 6$ & 8 & 4.3 & 1 & 0 & $x$ & $x$ & 10R4/6,5/4,5/8; 5YR 6/6 & 10R4/6,5/4,5YR5/4,6/4 & 15 & 3.3 & 7 & 1 & $2 \mathrm{y} 6$ & $\mathrm{x}$ & & $x$ & $\mathrm{x}$ & $x$ & $x$ & $x$ & $x$ & $x$ & $x$ & 5 \\
\hline RH19-7 & 1 & 5 & & 1 & 0 & 1 & 1 & $2 \mathrm{y} 6$ & $2 \mathrm{y} 6$ & 8.4 & 4.7 & 1 & 0 & $x$ & $x$ & 10R4/6,5/4,5/8; 5YR 6/6 & 10R4/6,5/4,5YR5/4,6/4 & indet & 2.7 & indet & $\begin{array}{ll}t & 1\end{array}$ & $2 \mathrm{y} 6$ & $\mathrm{x}$ & & $x$ & $x$ & $x$ & $x$ & $x$ & $x$ & $x$ & $x$ & 5 \\
\hline RH19-7 & 1 & 5 & & 0 & 0 & 1 & 1 & $2 \mathrm{y} 6$ & $2 \mathrm{y} 6$ & 6.3 & 5.0 & 1 & 0 & $x$ & $x$ & 10R4/6,5/4,5/8; 5YR 6/6 & 10R4/6,5/4,5YR5/4,6/4 & $x$ & $x$ & $x$ & $\mathrm{x}$ & $x$ & $\mathrm{x}$ & & $x$ & $x$ & $x$ & $x$ & $x$ & $x$ & $x$ & $x$ & \\
\hline RH19-7 & 1 & 5 & & 0 & 0 & 1 & 1 & $2 \mathrm{y} 6$ & $2 \mathrm{y} 6$ & 6.5 & 5.3 & 1 & 0 & $x$ & $x$ & 10R4/6,5/4,5/8; 5YR 6/6 & 10R4/6,5/4,5YR5/4,6/4 & $x$ & $x$ & $x$ & $\mathrm{x}$ & $x$ & $\mathrm{x}$ & & $x$ & $x$ & $x$ & $x$ & $x$ & $x$ & $x$ & $x$ & 5 \\
\hline RH19-7 & 1 & 5 & & 0 & 0 & 1 & 1 & $2 \mathrm{y} 6$ & $2 \mathrm{y} 6$ & 6.0 & 5.7 & 1 & 0 & $x$ & $x$ & 10R4/6,5/4,5/8; 5YR 6/6 & 10R4/6,5/4,5YR5/4,6/4 & $x$ & $x$ & $x$ & $x$ & $x$ & $x$ & & $x$ & $x$ & $x$ & $x$ & $x$ & $x$ & $x$ & $x$ & 5 \\
\hline RH19-7 & 1 & 5 & & 0 & 0 & 1 & 1 & $2 \mathrm{y} 6$ & $2 \mathrm{y} 6$ & 7.2 & 5.1 & 1 & 0 & $x$ & $x$ & 10R4/6,5/4,5/8; 5YR 6/6 & 10R4/6,5/4,5YR5/4,6/4 & $x$ & $x$ & $x$ & $x$ & $x$ & $x$ & & $x$ & $x$ & $x$ & $x$ & $x$ & $x$ & $x$ & $x$ & \\
\hline RH19-7 & 1 & 5 & & 0 & 0 & 1 & 1 & $2 \mathrm{y} 6$ & $2 \mathrm{y} 6$ & 6.1 & 5.3 & 1 & 0 & $x$ & $x$ & 10R4/6,5/4,5/8; 5YR 6/6 & 10R4/6,5/4,5YR5/4,6/4 & $x$ & $x$ & $x$ & $x$ & $x$ & $x$ & & $x$ & $x$ & $x$ & $x$ & $x$ & $x$ & $x$ & $x$ & \\
\hline RH19-7 & 1 & 5 & & 2 & 0 & 1 & 1 & $2 \mathrm{y} 6$ & $2 \mathrm{y} 6$ & 9.0 & 6.4 & 1 & 0 & $x$ & $x$ & 10R4/6,5/4,5/8; 5YR 6/6 & 10R4/6,5/4,5YR5/4,6/4 & $x$ & $x$ & $x$ & $x$ & $x$ & $x$ & & $x$ & $x$ & $x$ & $x$ & $x$ & indet & 5 & 2 & \\
\hline RH19-7 & 1 & 5 & & 0 & 0 & 1 & 1 & $2 \mathrm{y} 6$ & $2 \mathrm{y} 6$ & 5.8 & 4.2 & 1 & 0 & $x$ & $x$ & 10R4/6,5/4,5/8; 5YR 6/6 & 10R4/6,5/4,5YR5/4,6/4 & $x$ & $x$ & $x$ & $x$ & $x$ & $x$ & & $x$ & $x$ & $x$ & $x$ & $x$ & $x$ & $x$ & $\mathrm{x}$ & \\
\hline RH19-7 & 1 & 5 & & 0 & 0 & 1 & 1 & $2 \mathrm{y} 6$ & $2 \mathrm{y} 6$ & 4.3 & 4.0 & 1 & 0 & $x$ & $x$ & 10R4/6,5/4,5/8; 5YR 6/6 & 10R4/6,5/4,5YR5/4,6/4 & $x$ & $x$ & $x$ & $x$ & $x$ & $x$ & & $x$ & $x$ & $x$ & $x$ & $x$ & $x$ & $x$ & $x$ & \\
\hline RH19-7 & 2 & 6 & & 1 & 1 & 2 & 1 & $2 \mathrm{y} 6$ & $2 \mathrm{y} 6$ & 5.9 & 5 & 1 & 0 & $x$ & $x$ & 10R4/6,5/4,5/8; 5YR 6/6 & 10R 4/4; 5YR 6/6 & 17.5 & 2.8 & 5 & 1 & 2 & $x$ & & $x$ & $x$ & $x$ & $x$ & $x$ & $x$ & $x$ & $x$ & 5 \\
\hline RH19-7 & 2 & 6 & & 1 & 1 & 2 & 1 & $2 \mathrm{y} 6$ & $2 \mathrm{y} 6$ & 7.2 & 5.3 & 1 & 0 & $x$ & $x$ & 10R4/6,5/4,5/8; 5YR 6/6 & 10R 4/4; 5YR 6/6 & 17.5 & 3.9 & 7 & 1 & 2 & $x$ & & $x$ & $x$ & $x$ & $x$ & $x$ & $x$ & $x$ & $\mathrm{x}$ & 3 y 5 \\
\hline RH19-7 & 2 & 6 & & 1 & 1 & 2 & 1 & $2 \mathrm{y} 6$ & $2 \mathrm{y} 6$ & 5.6 & 4.2 & 1 & 0 & $x$ & $x$ & 10R4/6,5/4,5/8; 5YR 6/6 & 10R 4/4; 5YR 6/6 & indet & 2.1 & indet & $\begin{array}{ll}t \\
\end{array}$ & 2 & $x$ & & $x$ & $x$ & $x$ & $x$ & $x$ & $x$ & $x$ & $x$ & 5 \\
\hline RH19-7 & 2 & 6 & & 0 & 1 & 2 & 1 & $2 \mathrm{y} 6$ & $2 \mathrm{y} 6$ & 6.5 & 5.2 & 1 & 0 & $x$ & $x$ & 10R4/6,5/4,5/8; 5YR 6/6 & 10R 4/4; 5YR 6/6 & $x$ & $x$ & $x$ & $\mathrm{x}$ & $x$ & $x$ & & $x$ & $x$ & $x$ & $x$ & $x$ & $x$ & $x$ & $x$ & 5 y 6 \\
\hline RH19-7 & 1 & 7 & & 1 & 0 & 1 & 0 & $2,4 \mathrm{y} 6$ & $2 \mathrm{y} 4$ & 7.5 & 7.0 & 2 & 0 & franjas & $\mathrm{x}$ & 10R $4 / 4,4 / 6,5 / 6$ y $3 / 1$ & $10 \mathrm{R} 4 / 4,5 / 4$ & indet & 1.8 & indet & $\begin{array}{ll}t \\
t\end{array}$ & 2 & $\mathrm{x}$ & & $x$ & $x$ & $x$ & $x$ & $x$ & $x$ & $x$ & $x$ & 5 \\
\hline RH19-7 & 1 & 7 & & 0 & 0 & 1 & 0 & $2,4 \mathrm{y} 6$ & $2 \mathrm{y} 4$ & 7.6 & 6.6 & 2 & 0 & franjas & $\mathrm{x}$ & 10R $4 / 4,4 / 6,5 / 6$ y $3 / 1$ & $10 \mathrm{R} 4 / 4,5 / 4$ & $x$ & $x$ & $x$ & $\mathrm{x}$ & $x$ & $x$ & & $x$ & $x$ & $x$ & $x$ & $x$ & $x$ & $x$ & $x$ & 5 \\
\hline RH19-7 & 1 & 7 & & 0 & 0 & 1 & 0 & $2,4 \mathrm{y} 6$ & $2 \mathrm{y} 4$ & 8.3 & 7.5 & 2 & 0 & franjas & $x$ & 10R $4 / 4,4 / 6,5 / 6$ y $3 / 1$ & $10 \mathrm{R} 4 / 4,5 / 4$ & $x$ & $x$ & $x$ & $x$ & $x$ & $x$ & & $x$ & $x$ & $x$ & $x$ & $x$ & $x$ & $x$ & $x$ & 5 \\
\hline \begin{tabular}{|l|}
$\mathrm{RH} 19-7$ \\
\end{tabular} & 1 & 7 & & 0 & 0 & 1 & 0 & $2,4 \mathrm{y} 6$ & $2 \mathrm{y} 4$ & 6.9 & 6.8 & 2 & 0 & franjas & $x$ & 10R $4 / 4,4 / 6,5 / 6$ y $3 / 1$ & 10R $4 / 4,5 / 4$ & $x$ & $x$ & $x$ & $x$ & $x$ & $x$ & & $x$ & $x$ & $x$ & $x$ & $x$ & $x$ & $x$ & $x$ & 5 \\
\hline RH19-7 & 1 & 7 & & 0 & 0 & 1 & 0 & $2,4 \mathrm{y} 6$ & $2 \mathrm{y} 4$ & 9.3 & 6.7 & 2 & 0 & franjas & $x$ & 10R $4 / 4,4 / 6,5 / 6$ y $3 / 1$ & 10R $4 / 4,5 / 4$ & $x$ & $x$ & $x$ & $\mathrm{x}$ & $\mathrm{x}$ & $\mathrm{x}$ & & $x$ & $x$ & $x$ & $x$ & $x$ & $x$ & $x$ & $x$ & 3 у 5 \\
\hline
\end{tabular}




\begin{tabular}{|c|c|c|c|c|c|c|c|c|c|c|c|c|c|c|c|c|c|c|c|c|c|c|c|c|c|c|c|c|c|c|c|c|c|}
\hline \multirow[b]{2}{*}{ Sitio } & \multirow[b]{2}{*}{$\begin{array}{c}\mathrm{Ni} \\
\text { vel } \\
\end{array}$} & \multirow[b]{2}{*}{ GF } & \multirow[b]{2}{*}{ FNA } & \multirow[b]{2}{*}{ Fgto } & \multicolumn{11}{|c|}{ Manufactura } & \multicolumn{2}{|c|}{ Cocción } & \multicolumn{5}{|c|}{ Borde-labio } & \multicolumn{6}{|c|}{ Asa } & \multicolumn{4}{|c|}{ Base } & \multirow[b]{2}{*}{ Alterac } \\
\hline & & & & & $\begin{array}{l}\text { Tec } \\
\text { lev }\end{array}$ & $\begin{array}{l}\text { For } \\
\text { ma }\end{array}$ & \begin{tabular}{|l|}
$\begin{array}{l}\text { Mar } \\
\text { cas }\end{array}$ \\
\end{tabular} & \begin{tabular}{|c|}
$\begin{array}{c}\text { Sup } \\
\text { ext }\end{array}$ \\
\end{tabular} & \begin{tabular}{|c|}
$\begin{array}{c}\text { Sup } \\
\text { int }\end{array}$ \\
\end{tabular} & \begin{tabular}{|l|} 
Esp \\
max
\end{tabular} & \begin{tabular}{|l|} 
Esp \\
min
\end{tabular} & $\begin{array}{l}\text { Deco } \\
\text { pint }\end{array}$ & $\begin{array}{c}\text { Deco } \\
\text { corldsp }\end{array}$ & \begin{tabular}{|c|}
$\begin{array}{c}\text { Moti } \\
\text { vo }\end{array}$ \\
\end{tabular} & Estilo & Color sup ext & Color sup int & Diam & \begin{tabular}{|l|} 
Lrg \\
arc \\
\end{tabular} & \begin{tabular}{|c|}
$\%$ \\
arco \\
\end{tabular} & Dir & \begin{tabular}{|l} 
For \\
ma
\end{tabular} & $\begin{array}{l}\text { Lar } \\
\text { go }\end{array}$ & $\begin{array}{c}\text { An } \\
\text { cho }\end{array}$ & Esp & $p \begin{array}{l}\text { Sec } \\
\text { ción }\end{array}$ & \begin{tabular}{l|l}
$c$ & In \\
n & ser \\
\end{tabular} & \begin{tabular}{l|l}
$\mathrm{rc}$ & $\mathrm{P}$ \\
$\mathrm{r}$ & $\mathrm{si}$ \\
\end{tabular} & $\begin{array}{ll} & \\
i c & D i \\
c\end{array}$ & Diám & \begin{tabular}{|c|} 
Mor \\
fol
\end{tabular} & \begin{tabular}{|l|} 
Uni \\
ón \\
\end{tabular} & \\
\hline $\mathrm{RH} 19-7$ & 1 & 7 & & 0 & 0 & 1 & 0 & $2,4 \mathrm{y} 6$ & $2 \mathrm{y} 4$ & 9.0 & 6.5 & 2 & 0 & franjas & $x$ & 10R $4 / 4,4 / 6,5 / 6$ y $3 / 1$ & 10R $4 / 4,5 / 4$ & $x$ & $x$ & $x$ & $\mathrm{x}$ & $x$ & $x$ & $x$ & $x$ & $x$ & $x$ & 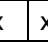 & $x$ & $x$ & $x$ & $x$ & 3 y 5 \\
\hline RH19-7 & 1 & 7 & & 0 & 0 & 1 & 0 & $2,4 \mathrm{y} 6$ & $2 \mathrm{y} 4$ & 10.0 & 5.3 & 2 & 0 & franjas & $x$ & $10 R 4 / 4,4 / 6,5 / 6$ y $3 / 1$ & $10 R 4 / 4,5 / 4$ & $x$ & $x$ & $x$ & $x$ & $x$ & $x$ & $x$ & $x$ & $x$ & $x$ & k & $x$ & $\mathrm{x}$ & $x$ & $x$ & 3 у 5 \\
\hline RH19-7 & 1 & 7 & & 0 & 0 & 1 & 0 & $2,4 \mathrm{y} 6$ & $2 \mathrm{y} 4$ & 8.2 & 7.8 & 2 & 0 & franjas & $x$ & 10R $4 / 4,4 / 6,5 / 6$ y $3 / 1$ & $10 \mathrm{R} 4 / 4,5 / 4$ & $x$ & $x$ & $x$ & $x$ & $x$ & $x$ & $x$ & $x$ & $x$ & $x$ & 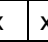 & $x$ & $x$ & $x$ & $x$ & 5 \\
\hline RH19-7 & 1 & 7 & & 0 & 0 & 1 & 0 & $2,4 \mathrm{y} 6$ & $2 \mathrm{y} 4$ & 6.5 & 5.4 & 2 & 0 & franjas & $x$ & $10 R 4 / 4,4 / 6,5 / 6$ y $3 / 1$ & 10R $4 / 4,5 / 4$ & $x$ & $x$ & $x$ & $x$ & $x$ & $x$ & $x$ & $x$ & $x$ & $x$ & $x$ & $x$ & $\mathrm{x}$ & $x$ & $x$ & \\
\hline RH19-7 & 1 & 7 & & 0 & 0 & 1 & 0 & $2,4 \mathrm{y} 6$ & $2 \mathrm{y} 4$ & 5.9 & 4.7 & 2 & 0 & franjas & $x$ & $10 \mathrm{R} 4 / 4,4 / 6,5 / 6$ y $3 / 1$ & $10 \mathrm{R} 4 / 4,5 / 4$ & $x$ & $x$ & $x$ & $x$ & $x$ & $x$ & $x$ & $x$ & $x$ & $x$ & 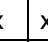 & $x$ & $x$ & $x$ & $x$ & 3 y 5 \\
\hline $\mathrm{RH} 19-7$ & 1 & 7 & & 0 & 0 & 1 & 0 & $2,4 \mathrm{y} 6$ & $2 \mathrm{y} 4$ & 4.5 & 3.7 & 2 & 0 & franjas & $x$ & $10 \mathrm{R} 4 / 4,4 / 6,5 / 6$ y $3 / 1$ & $10 \mathrm{R} 4 / 4,5 / 4$ & $x$ & $x$ & $x$ & $x$ & $x$ & $x$ & $x$ & $x$ & $x$ & $x$ & $x$ & $x$ & $x$ & $x$ & $x$ & 3 \\
\hline RH19-7 & 1 & 7 & & 0 & 0 & 1 & 0 & $2,4 \mathrm{y} 6$ & $2 \mathrm{y} 4$ & 7.0 & 5.5 & 2 & 0 & franjas & $x$ & 10R $4 / 4,4 / 6,5 / 6$ y $3 / 1$ & 10R $4 / 4,5 / 4$ & $x$ & $x$ & $x$ & $\mathrm{x}$ & $x$ & $x$ & $x$ & $x$ & $x$ & $x$ & 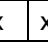 & $x$ & $x$ & $x$ & $x$ & 3 \\
\hline $\mathrm{RH} 19-7$ & 1 & 7 & & 0 & 0 & 1 & 0 & $2,4 \mathrm{y} 6$ & $2 \mathrm{y} 4$ & 5.5 & 5.0 & 2 & 0 & franjas & $\mathrm{x}$ & 10R $4 / 4,4 / 6,5 / 6$ у $3 / 1$ & 10R $4 / 4,5 / 4$ & $x$ & $x$ & $x$ & $x$ & $x$ & $x$ & $x$ & $x$ & $x$ & $x$ & $x$ & $x$ & $\mathrm{x}$ & $x$ & $x$ & 3 \\
\hline RH19-7 & 1 & 8 & & 1 & 2 & 1 & $1,2 \mathrm{y} 3$ & 2 & 3 & 7.1 & 4.0 & 0 & 0 & $x$ & PINP & $5 Y R$ 5/1, 5/3, 6/1, 4/3 & $5 Y R$ 4/1, 4/3 & 22 & 8.8 & 13 & 2 & 2 & $x$ & $x$ & $x$ & $x$ & $x$ & 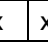 & $x$ & $x$ & $x$ & $x$ & 1 \\
\hline RH19-7 & 1 & 8 & & 2 & 2 & 1 & $1,2 \mathrm{y} 3$ & 2 & 3 & 14.6 & 5.4 & 0 & 0 & $x$ & PINP & 5 YR $5 / 1,5 / 3,6 / 1,4 / 3$ & $5 Y R \quad 4 / 1,4 / 3$ & $x$ & $x$ & $x$ & $x$ & $x$ & $x$ & $x$ & $x$ & $x$ & $x$ & $x$ & \begin{tabular}{l|l}
$\times$ & 9 \\
\end{tabular} & 9.7 & 5 & 1 & 1 \\
\hline RH19-7 & 2 & 8 & & 2 & 2 & 1 & $1,2 \mathrm{y} 3$ & 2 & 3 & 13.2 & 7 & 0 & 0 & $\mathrm{x}$ & PINP & $5 Y R 5 / 1,5 / 3,6 / 1,4 / 3$ & $5 Y R 4 / 1,4 / 3$ & $\mathrm{x}$ & $\mathrm{x}$ & $\mathrm{x}$ & $\mathrm{x}$ & $\mathrm{x}$ & $\mathrm{x}$ & $\mathrm{x}$ & $\mathrm{x}$ & $\mathrm{x}$ & $\mathrm{x}$ & $\mathrm{k}$ & $\times \quad 9$ & 9.7 & 5 & 1 & 1 \\
\hline RH19-7 & 2 & 8 & & 0 & 2 & 1 & $1,2 \mathrm{y} 3$ & 2 & 3 & 7.3 & 5.6 & 0 & 0 & $x$ & PINP & 5 YR $5 / 1,5 / 3,6 / 1,4 / 3$ & $5 Y R \quad 4 / 1,4 / 3$ & $x$ & $x$ & $x$ & $x$ & $x$ & $x$ & $x$ & $x$ & $x$ & $x$ & $x$ & $x$ & $\mathrm{x}$ & $x$ & $\mathrm{x}$ & 1 \\
\hline RH19-7 & 2 & 8 & & 0 & 2 & 1 & $1,2 \mathrm{y} 3$ & 2 & 3 & 7.2 & 6.3 & 0 & 0 & $\mathrm{x}$ & PINP & $5 Y R 5 / 1,5 / 3,6 / 1,4 / 3$ & $5 Y R 4 / 1,4 / 3$ & $\mathrm{x}$ & $\mathrm{x}$ & $\mathrm{x}$ & $\mathrm{x}$ & $\mathrm{x}$ & $\mathrm{x}$ & $\mathrm{x}$ & $\mathrm{x}$ & $\mathrm{x}$ & $\mathrm{x}$ & $x$ & $x$ & $\mathrm{x}$ & $\mathrm{x}$ & $\mathrm{x}$ & 1 \\
\hline RH19-7 & 1 & 8 & & 0 & 2 & 1 & $1,2 \mathrm{y} 3$ & 2 & 3 & 7.3 & 6.2 & 0 & 0 & $x$ & PINP & $5 Y R 5 / 1,5 / 3,6 / 1,4 / 3$ & $5 Y R \quad 4 / 1,4 / 3$ & $x$ & $x$ & $x$ & $x$ & $x$ & $x$ & $x$ & $x$ & $x$ & $x$ & $x$ & $x$ & $x$ & $x$ & $x$ & 1 \\
\hline RH19-7 & 2 & 8 & & 1 & 2 & 1 & $1,2 \mathrm{y} 3$ & 2 & 3 & 6.5 & 6 & 0 & 0 & $x$ & PINP & $5 Y R 5 / 1,5 / 3,6 / 1,4 / 3$ & $5 Y R \quad 4 / 1,4 / 3$ & indet & 1.9 & indet & 2 & 2 & $x$ & $x$ & $x$ & $x$ & $x$ & $x$ & $x$ & $x$ & $x$ & $x$ & 1 \\
\hline RH19-7 & 1 & 8 & & 1 & 2 & 1 & $1,2 \mathrm{y} 3$ & 2 & 3 & 7.2 & 5.9 & 0 & 0 & $x$ & PINP & 5 YR $5 / 1,5 / 3,6 / 1,4 / 3$ & $5 Y R \quad 4 / 1,4 / 3$ & indet: & 1.1 & indet & 2 & 2 & $x$ & $x$ & $\mathrm{x}$ & $x$ & $x$ & $x$ & $x$ & $x$ & $x$ & $x$ & \\
\hline RH19-7 & 1 & 8 & & 0 & 2 & 1 & $1,2 \mathrm{y} 3$ & 2 & 3 & 7.1 & 5.7 & 0 & 0 & $\mathrm{x}$ & PINP & $5 Y R 5 / 1,5 / 3,6 / 1,4 / 3$ & $5 Y R 4 / 1,4 / 3$ & $\mathrm{x}$ & $\mathrm{x}$ & $\mathrm{x}$ & $\mathrm{x}$ & $\mathrm{x}$ & $\mathrm{x}$ & $\mathrm{x}$ & $\mathrm{x}$ & $\mathrm{x}$ & $\mathrm{x}$ & 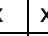 & $x$ & $\mathrm{x}$ & $\mathrm{x}$ & $\mathrm{x}$ & 1 \\
\hline RH19-7 & 2 & 8 & & 0 & 2 & 1 & $1,2 \mathrm{y} 3$ & 2 & 3 & 8.3 & 7.2 & 0 & 0 & $\mathrm{x}$ & PINP & $5 Y R 5 / 1,5 / 3,6 / 1,4 / 3$ & $5 Y R 4 / 1,4 / 3$ & $\mathrm{x}$ & $\mathrm{x}$ & $\mathrm{x}$ & $\mathrm{x}$ & $\mathrm{x}$ & $\mathrm{x}$ & $\mathrm{x}$ & $\mathrm{x}$ & $\mathrm{x}$ & $\mathrm{x}$ & $x$ & $x$ & $\mathrm{x}$ & $\mathrm{x}$ & $\mathrm{x}$ & \\
\hline RH19-7 & 1 & 9 & & 0 & 0 & 1 & $1 \mathrm{y} 4$ & 2 & 3 & 10.0 & 6.3 & 0 & 0 & $\mathrm{x}$ & PINP & $5 Y R$ 5/6, 5/4 y 5/1 & N 3/ y 4/ & $\mathrm{x}$ & $\mathrm{x}$ & $\mathrm{x}$ & $\mathrm{x}$ & $\mathrm{x}$ & $\mathrm{x}$ & $\mathrm{x}$ & $\mathrm{x}$ & $\mathrm{x}$ & $\mathrm{x}$ & 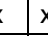 & $x$ & $\mathrm{x}$ & $\mathrm{x}$ & $\mathrm{x}$ & 1 \\
\hline RH19-7 & 2 & 9 & & 0 & 0 & 1 & $1 \mathrm{y} 4$ & 2 & 3 & 7.3 & 6.2 & 0 & 0 & $x$ & PINP & $5 Y R$ 5/6, 5/4 y $5 / 1$ & $\mathrm{~N} 3 /$ y $4 /$ & $x$ & $x$ & $x$ & $x$ & $x$ & $x$ & $x$ & $x$ & $x$ & $x$ & $8 x$ & $x$ & $\mathrm{x}$ & $x$ & $x$ & 1 \\
\hline RH19-7 & 1 & 9 & & 2 & 0 & 1 & $1 \mathrm{y} 4$ & 2 & 3 & 11.0 & 9.5 & 0 & 0 & $x$ & PINP & $5 Y R$ 5/6, 5/4 y $5 / 1$ & $\mathrm{~N} 3 /$ y $4 /$ & $x$ & $x$ & $x$ & $x$ & $x$ & $x$ & $x$ & $x$ & $x$ & $x$ & 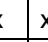 & $\begin{array}{ll}x & \text { in } \\
\end{array}$ & ndet & 5 & 2 & 3 \\
\hline RH19-7 & 1 & 9 & & 0 & 0 & 1 & $1 \mathrm{y} 4$ & 2 & 3 & 9.7 & 8.9 & 0 & 0 & $x$ & PINP & $5 Y R$ 5/6, 5/4 y $5 / 1$ & $\mathrm{~N} 3 /$ y $4 /$ & $x$ & $x$ & $x$ & $x$ & $x$ & $x$ & $x$ & $x$ & $x$ & $x$ & $x$ & $x$ & $x$ & $x$ & $x$ & 3 \\
\hline RH19-7 & 1 & 9 & & 1 & 0 & 1 & $1 \mathrm{y} 4$ & 2 & 3 & 6.6 & 6.1 & 0 & 0 & $x$ & PINP & $5 Y R$ 5/6, 5/4 y 5/1 & $\mathrm{N} 3 /$ y $4 /$ & indet & 2.6 & indet & 2 & 2 & $x$ & $x$ & $x$ & $x$ & $x$ & $x$ & $x$ & $x$ & $x$ & $x$ & 3 \\
\hline RH19-7 & 1 & 9 & & 0 & 0 & 1 & $1 \mathrm{y} 4$ & 2 & 3 & 8.5 & 7.3 & 0 & 0 & $x$ & PINP & $5 Y R 5 / 6,5 / 4$ y $5 / 1$ & $\mathrm{~N} 3 /$ y $4 /$ & $x$ & $x$ & $x$ & $x$ & $x$ & $x$ & $x$ & $x$ & $x$ & $x$ & $x$ & $x$ & $x$ & $x$ & $x$ & 3 \\
\hline RH19-7 & 2 & 9 & & 0 & 0 & 1 & $1 \mathrm{y} 4$ & 2 & 3 & 5.7 & 5.1 & 0 & 0 & $x$ & PINP & $5 Y R 5 / 6,5 / 4$ y $5 / 1$ & $\mathrm{~N} 3 /$ y $4 /$ & $x$ & $x$ & $x$ & $x$ & $x$ & $x$ & $\mathrm{x}$ & $x$ & $x$ & $x$ & 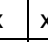 & $x$ & $x$ & $x$ & $x$ & \\
\hline RH19-7 & 1 & 10 & & 1 & 0 & 1 & 1 & 2 & 3 & 6.3 & 5.1 & 0 & 0 & $x$ & PINP & 5YR5/4,3/1;7,5YR5/3,5/2 & N 2,5/, 3/ & indet & 3 & indet & 2 & 2 & $\mathrm{x}$ & $x$ & $x$ & $x$ & $x$ & $x$ & $x$ & $x$ & $x$ & $x$ & 3 \\
\hline RH19-7 & 1 & 10 & & 0 & 0 & 1 & 1 & 2 & 3 & 6.3 & 6.3 & 0 & 0 & $x$ & PINP & 5YR5/4,3/1;7,5YR5/3,5/2 & N 2,5/, 3/ & $x$ & $x$ & $x$ & $x$ & $x$ & $\mathrm{x}$ & $x$ & $x$ & $\mathrm{x}$ & $x$ & k & x & $x$ & $x$ & $x$ & 3 \\
\hline RH19-7 & 1 & 10 & & 2 & 0 & 1 & 1 & 2 & 3 & 12.7 & 9.9 & 0 & 0 & $x$ & PINP & 5YR5/4,3/1;7,5YR5/3,5/2 & N 2,5/, 3/ & $x$ & $x$ & $x$ & $x$ & $x$ & $x$ & $x$ & $x$ & $\mathrm{x}$ & $x$ & $x$ & $x \mid 1$ & 13 & 5 & 2 & 3 \\
\hline RH19-7 & 1 & 10 & & 0 & 0 & 1 & 1 & 2 & 3 & 12.9 & 8.5 & 0 & 0 & $x$ & PINP & 5YR5/4,3/1;7,5YR5/3,5/2 & N 2,5/, 3/ & $x$ & $x$ & $x$ & $x$ & $x$ & $x$ & $x$ & $x$ & $x$ & $x$ & k & $x$ & $x$ & $x$ & $x$ & 3 \\
\hline $\mathrm{RH} 19-7$ & 2 & 10 & & 0 & 0 & 1 & 1 & 2 & 3 & 8.7 & 5.5 & 0 & 0 & $\mathrm{x}$ & PINP & 5YR5/4,3/1;7,5YR5/3,5/2 & N 2,5/, 3/ & $x$ & $\mathrm{x}$ & $x$ & $x$ & $x$ & $x$ & $x$ & $x$ & $x$ & $x$ & $x$ & $x$ & $x$ & $x$ & $x$ & 3 y 4 \\
\hline $\mathrm{RH} 19-7$ & 2 & 10 & & 0 & 0 & 1 & 1 & 2 & 3 & 6.0 & 5.3 & 0 & 0 & $x$ & PINP & 5YR5/4,3/1;7,5YR5/3,5/2 & N 2,5/, 3/ & $x$ & $\mathrm{x}$ & $x$ & $x$ & $x$ & $x$ & $x$ & $x$ & $x$ & $x$ & $x$ & $x$ & $x$ & $x$ & $x$ & 3 \\
\hline $\mathrm{RH} 19-7$ & 1 & 10 & & 0 & 0 & 1 & 1 & 2 & 3 & 6.1 & 4.6 & 0 & 0 & $x$ & PINP & 5YR5/4,3/1;7,5YR5/3,5/2 & N 2,5/, 3/ & $x$ & $\mathrm{x}$ & $\mathrm{x}$ & $x$ & $x$ & $x$ & $x$ & $x$ & $x$ & $x$ & $x$ & $x$ & $x$ & $x$ & $\mathrm{x}$ & 3 \\
\hline RH19-7 & 1 & 10 & & 0 & 0 & 1 & 1 & 2 & 3 & 5.4 & 5.4 & 0 & 0 & $x$ & PINP & 5YR5/4,3/1;7,5YR5/3,5/2 & N 2,5/, 3/ & $x$ & $x$ & $x$ & $x$ & $x$ & $\mathrm{x}$ & $x$ & $x$ & $\mathrm{x}$ & $x$ & $x$ & x & $x$ & $x$ & $x$ & \\
\hline RH19-7 & 1 & 10 & & 0 & 0 & 1 & 1 & 2 & 3 & 8.1 & 5.0 & 0 & 0 & $x$ & PINP & 5YR5/4,3/1;7,5YR5/3,5/2 & N 2,5/, 3/ & $x$ & $x$ & $x$ & $x$ & $x$ & $x$ & $x$ & $x$ & $x$ & $x$ & $x$ & $x$ & $x$ & $x$ & $x$ & 3 \\
\hline RH19-7 & 1 & 10 & & 0 & 0 & 1 & 1 & 2 & 3 & 6.2 & 5.1 & 0 & 0 & $x$ & PINP & 5YR5/4,3/1;7,5YR5/3,5/2 & N 2,5/, 3/ & $x$ & $x$ & $x$ & $x$ & $x$ & $x$ & $x$ & $x$ & $x$ & $x$ & $x$ & $x$ & $x$ & $x$ & $x$ & 3 \\
\hline $\mathrm{RH} 19-7$ & 1 & 11 & & 1 & 0 & 1 & 1 & 2 & 3 & 5.3 & 3.9 & 0 & 0 & $x$ & PINP & $5 Y R 3 / 1,4 / 1,4 / 2,5 / 2$ & $\mathrm{~N} 3 /, 4 / ; 5 Y R$ 5/2 & indet & 2.1 & indet & 1 & 2 & $x$ & $x$ & $x$ & $x$ & $x$ & $x$ & $x$ & $x$ & $x$ & $x$ & 3 \\
\hline $\mathrm{RH} 19-7$ & 1 & 11 & & 2 & 0 & 1 & 1 & 2 & 3 & 14.8 & 9.9 & 0 & 0 & $x$ & PINP & $5 Y R 3 / 1,4 / 1,4 / 2,5 / 2$ & $\mathrm{~N} 3 /, 4 / ; 5 Y R$ 5/2 & $x$ & $x$ & $x$ & $x$ & $x$ & $x$ & $x$ & $x$ & $x$ & $x$ & $x$ & $x$ & 8 & 5 & 2 & 3 \\
\hline RH19-7 & 1 & 11 & & 0 & 0 & 1 & 1 & 2 & 3 & 6.7 & 5.6 & 0 & 0 & $x$ & PINP & $5 Y R 3 / 1,4 / 1,4 / 2,5 / 2$ & $\mathrm{~N} 3 /, 4 / ; 5 Y R$ 5/2 & $x$ & $x$ & $x$ & $x$ & $x$ & $x$ & $x$ & $x$ & $x$ & $\mathrm{x}$ & $x$ & $x$ & $x$ & $x$ & $x$ & 3 \\
\hline $\mathrm{RH} 19-7$ & 1 & 11 & & 0 & 0 & 1 & 1 & 2 & 3 & 5.6 & 4.7 & 0 & 0 & $\mathrm{x}$ & PINP & $5 Y R 3 / 1,4 / 1,4 / 2,5 / 2$ & N 3/, 4/; 5YR 5/2 & $\mathrm{x}$ & $\mathrm{x}$ & $\mathrm{x}$ & $\mathrm{x}$ & $x$ & $\mathrm{x}$ & $\mathrm{x}$ & $\mathrm{x}$ & $\mathrm{x}$ & $\mathrm{x}$ & $x$ & $x$ & $\mathrm{x}$ & $x$ & $\mathrm{x}$ & 3 \\
\hline
\end{tabular}




\begin{tabular}{|c|c|c|c|c|c|c|c|c|c|c|c|c|c|c|c|c|c|c|c|c|c|c|c|c|c|c|c|c|c|c|c|c|}
\hline \multirow[b]{2}{*}{ Sitio } & \multirow[b]{2}{*}{$\begin{array}{c}\mathrm{Ni} \\
\text { vel }\end{array}$} & \multirow[b]{2}{*}{ GF } & \multirow[b]{2}{*}{ FNA } & \multirow[b]{2}{*}{ Fgto } & \multicolumn{11}{|c|}{ Manufactura } & \multicolumn{2}{|c|}{ Cocción } & \multicolumn{5}{|c|}{ Borde-labio } & \multicolumn{6}{|c|}{ Asa } & \multicolumn{3}{|c|}{ Base } & \multirow[b]{2}{*}{ Alterac } \\
\hline & & & & & $\begin{array}{l}\text { Tec } \\
\text { lev }\end{array}$ & $\begin{array}{l}\text { For } \\
\text { ma }\end{array}$ & \begin{tabular}{|l|} 
Mar \\
cas
\end{tabular} & \begin{tabular}{|l|} 
Sup \\
ext
\end{tabular} & $\begin{array}{c}\text { Sup } \\
\text { int }\end{array}$ & $\begin{array}{l}\text { Esp } \\
\text { max }\end{array}$ & \begin{tabular}{|l|} 
Esp \\
min
\end{tabular} & \begin{tabular}{|l} 
Deco \\
pint
\end{tabular} & $\begin{array}{c}\text { Deco } \\
\text { cor/dsp }\end{array}$ & $\begin{array}{c}\text { Moti } \\
\text { vo }\end{array}$ & Estilo & Color sup ext & Color sup int & Diam & $\begin{array}{l}\text { Lrg } \\
\text { arc }\end{array}$ & $\begin{array}{c}\% \\
\text { arco } \\
\end{array}$ & & $\begin{array}{l}\begin{array}{l}\text { For } \\
\text { ma }\end{array} \\
\end{array}$ & $\begin{array}{c}\text { Lar } \\
\text { go }\end{array}$ & $\begin{array}{l}\text { An } \\
\text { cho }\end{array}$ & Esp & $\begin{array}{l}\text { Sec } \\
\text { ción }\end{array}$ & $\begin{array}{l}\text { In } \\
\text { serc }\end{array}$ & & Diám & $\begin{array}{c}\text { Mor } \\
\text { fol }\end{array}$ & $\begin{array}{l}\text { Uni } \\
\text { ón }\end{array}$ & \\
\hline RH19-7 & 1 & 11 & & 0 & 0 & 1 & 1 & 2 & 3 & 4.8 & 4.8 & 0 & 0 & $x$ & PINP & $5 Y R$ 3/1, 4/1, 4/2, 5/2 & $\mathrm{N} 3 /, 4 / ; 5 Y R 5 / 2$ & $x$ & $x$ & $x$ & $x$ & $x$ & $x$ & $x$ & $x$ & $x$ & $x$ & $x$ & $x$ & $\mathrm{x}$ & $x$ & 3 \\
\hline RH19-7 & 1 & 11 & & 0 & 0 & 1 & 1 & 2 & 3 & 5.8 & 5.0 & 0 & 0 & $x$ & PINP & $5 Y R 3 / 1,4 / 1,4 / 2,5 / 2$ & N 3/, 4/; 5YR 5/2 & $x$ & $x$ & $x$ & $\mathrm{x}$ & $x$ & $x$ & $x$ & $x$ & $x$ & $x$ & $x$ & $x$ & $x$ & $x$ & 3 \\
\hline RH19-7 & 1 & 11 & & 0 & 0 & 1 & 1 & 2 & 3 & 7.3 & 4.9 & 0 & 0 & $x$ & PINP & $5 Y R 3 / 1,4 / 1,4 / 2,5 / 2$ & N 3/, 4/; 5YR 5/2 & $x$ & $x$ & $x$ & $x$ & $x$ & $x$ & $x$ & $x$ & $x$ & $x$ & $x$ & $x$ & $x$ & $x$ & 3 \\
\hline RH19-7 & 1 & 11 & & 0 & 0 & 1 & 1 & 2 & 3 & 6.6 & 3.7 & 0 & 0 & $x$ & PINP & $5 Y R 3 / 1,4 / 1,4 / 2,5 / 2$ & $\mathrm{~N} 3 /, 4 / ; 5 Y R 5 / 2$ & $x$ & $x$ & $x$ & $x$ & $x$ & $x$ & $x$ & $x$ & $\mathrm{x}$ & $x$ & $x$ & $x$ & $x$ & $x$ & 3 y 4 \\
\hline RH19-7 & 1 & 11 & & 0 & 0 & 1 & 1 & 2 & 3 & 8.2 & 7.5 & 0 & 0 & $x$ & PINP & $5 Y R 3 / 1,4 / 1,4 / 2,5 / 2$ & $\mathrm{~N} 3 /, 4 / ; 5 Y R 5 / 2$ & $x$ & $x$ & $x$ & $x$ & $x$ & $x$ & $x$ & $x$ & $x$ & $x$ & $x$ & $x$ & $x$ & $x$ & 3 y 4 \\
\hline RH19-7 & 1 & 11 & & 0 & 0 & 1 & 1 & 2 & 3 & 5.7 & 4.2 & 0 & 0 & $x$ & PINP & $5 Y R 3 / 1,4 / 1,4 / 2,5 / 2$ & $\mathrm{~N} 3 /, 4 / ; 5 Y R 5 / 2$ & $x$ & $x$ & $x$ & $x$ & $\mathrm{x}$ & $x$ & $x$ & $x$ & $x$ & $x$ & $x$ & $x$ & $x$ & $x$ & 3 y 4 \\
\hline RH19-7 & 1 & 11 & & 0 & 0 & 1 & 1 & 2 & 3 & 5.3 & 4.7 & 0 & 0 & $x$ & PINP & $5 Y R$ 3/1, 4/1, 4/2, 5/2 & $\mathrm{N} 3 /, 4 / ; 5 Y R 5 / 2$ & $x$ & $x$ & $x$ & $x$ & $x$ & $x$ & $x$ & $x$ & $x$ & $x$ & $x$ & $x$ & $x$ & $x$ & 3 \\
\hline RH19-7 & 1 & 11 & & 0 & 0 & 1 & 1 & 2 & 3 & 8.4 & 7.3 & 0 & 0 & $x$ & PINP & $5 Y R 3 / 1,4 / 1,4 / 2,5 / 2$ & $\mathrm{~N} 3 /, 4 / ; 5 Y R$ 5/2 & $x$ & $x$ & $x$ & $x$ & $x$ & $x$ & $x$ & $x$ & $x$ & $x$ & $x$ & $x$ & $x$ & $x$ & 3 \\
\hline RH19-7 & 1 & 11 & & 0 & 0 & 1 & 1 & 2 & 3 & 6.7 & 5.4 & 0 & 0 & $x$ & PINP & $5 Y R 3 / 1,4 / 1,4 / 2,5 / 2$ & $\mathrm{~N} 3 /, 4 / ; 5 Y R 5 / 2$ & $x$ & $x$ & $x$ & $x$ & $x$ & $x$ & $x$ & $x$ & $x$ & $x$ & $x$ & $x$ & $x$ & $x$ & 3 y 4 \\
\hline RH19-7 & 1 & 11 & & 0 & 0 & 1 & 1 & 2 & 3 & 4.9 & 4.7 & 0 & 0 & $x$ & PINP & $5 Y R 3 / 1,4 / 1,4 / 2,5 / 2$ & $\mathrm{~N} 3 /, 4 / ; 5 Y R 5 / 2$ & $x$ & $x$ & $x$ & $x$ & $x$ & $x$ & $x$ & $x$ & $x$ & $x$ & $x$ & $x$ & $x$ & $x$ & 3 \\
\hline RH19-7 & 1 & 11 & & 0 & 0 & 1 & 1 & 2 & 3 & 4.2 & 4.0 & 0 & 0 & $x$ & PINP & $5 Y R 3 / 1,4 / 1,4 / 2,5 / 2$ & $\mathrm{~N} 3 /, 4 / ; 5 Y R 5 / 2$ & $x$ & $x$ & $x$ & $x$ & $x$ & $x$ & $x$ & $x$ & $x$ & $x$ & $x$ & $x$ & $x$ & $x$ & 3 \\
\hline RH19-7 & 1 & 12 & & 0 & 0 & 1 & $1 \mathrm{y} 2$ & 2 & 3 & 15.0 & 7.7 & 0 & 0 & $x$ & PINP & $5 Y R$ 5/2, 5/3, 5/4, 4/4 & $\mathrm{N} 2,5 /, 3 /, 4 /$ & $x$ & $x$ & $x$ & $x$ & $x$ & $x$ & $x$ & $x$ & $x$ & $x$ & $x$ & $x$ & $x$ & $x$ & 3 \\
\hline RH19-7 & 1 & 12 & & 0 & 0 & 1 & $1 \mathrm{y} 2$ & 2 & 3 & 7.2 & 5.0 & 0 & 0 & $x$ & PINP & $5 Y R$ 5/2, 5/3, 5/4, 4/4 & $\mathrm{N} 2,5 /, 3 /, 4 /$ & $x$ & $x$ & $x$ & $x$ & $x$ & $x$ & $x$ & $x$ & $x$ & $x$ & $x$ & $x$ & $x$ & $x$ & 3 \\
\hline RH19-7 & 1 & 12 & & 0 & 0 & 1 & $1 \mathrm{y} 2$ & 2 & 3 & 6.0 & 5.7 & 0 & 0 & $x$ & PINP & $5 Y R$ 5/2, 5/3, 5/4, 4/4 & $\mathrm{N} 2,5 /, 3 /, 4 /$ & $x$ & $x$ & $x$ & $x$ & $x$ & $x$ & $x$ & $x$ & $x$ & $x$ & $x$ & $x$ & $x$ & $x$ & \\
\hline RH19-7 & 1 & 12 & & 0 & 0 & 1 & $1 \mathrm{y} 2$ & 2 & 3 & 5.8 & 5.4 & 0 & 0 & $x$ & PINP & $5 Y R$ 5/2, 5/3, 5/4, 4/4 & $\mathrm{N} 2,5 /, 3 /, 4 /$ & $x$ & $x$ & $x$ & $x$ & $x$ & $x$ & $x$ & $x$ & $x$ & $x$ & $x$ & $x$ & $x$ & $x$ & \\
\hline RH19-7 & 1 & 12 & & 0 & 0 & 1 & $1 \mathrm{y} 2$ & 2 & 3 & 9.6 & 5.1 & 0 & 0 & $x$ & PINP & $5 Y R$ 5/2, 5/3, 5/4, 4/4 & $\mathrm{N} 2,5 /, 3 /, 4 /$ & $x$ & $x$ & $x$ & $x$ & $x$ & $x$ & $x$ & $x$ & $x$ & $x$ & $x$ & $x$ & $x$ & $x$ & \\
\hline RH19-7 & 1 & 12 & & 0 & 0 & 1 & $1 \mathrm{y} 2$ & 2 & 3 & 7.1 & 4.9 & 0 & 0 & $x$ & PINP & $5 Y R$ 5/2, 5/3, 5/4, 4/4 & $\mathrm{N} 2,5 /, 3 /, 4 /$ & $x$ & $x$ & $x$ & $x$ & $x$ & $x$ & $x$ & $x$ & $x$ & $x$ & $x$ & $x$ & $x$ & $x$ & \\
\hline RH19-7 & 1 & 12 & & 0 & 0 & 1 & $1 \mathrm{y} 2$ & 2 & 3 & 5.3 & 5.1 & 0 & 0 & $x$ & PINP & $5 Y R$ 5/2, 5/3, 5/4, 4/4 & $\mathrm{N} 2,5 /, 3 /, 4 /$ & $x$ & $\mathrm{x}$ & $x$ & $x$ & $x$ & $x$ & $x$ & $x$ & $x$ & $x$ & $x$ & $x$ & $x$ & $x$ & \\
\hline RH19-7 & 2 & 13 & & 1 & 1 & 1 & $1 \mathrm{y} 2$ & 2 & 3 & 5.1 & 4.2 & 0 & 0 & $x$ & PINP & 10YR 4/1, 4/2; N 3/ & N 2,5/, N 3/ & indet & 1.6 & indet & 2 & 2 & $x$ & $x$ & $x$ & $x$ & $x$ & $x$ & $x$ & $x$ & $x$ & \\
\hline RH19-7 & 2 & 13 & & 0 & 1 & 1 & $1 \mathrm{y} 2$ & 2 & 3 & 5.3 & 4.7 & 0 & 0 & $x$ & PINP & 10YR 4/1, 4/2; N 3/ & $\mathrm{N} 2,5 /, \mathrm{N} 3 /$ & $x$ & $x$ & $x$ & $x$ & $x$ & $x$ & $x$ & $x$ & $x$ & $x$ & $x$ & $x$ & $x$ & $x$ & \\
\hline RH19-7 & 2 & 13 & & 1 & 1 & 1 & $1 \mathrm{y} 2$ & 2 & 3 & 5.7 & 4.4 & 0 & 0 & $x$ & PINP & 10YR 4/1, 4/2; N 3/ & $\mathrm{N} 2,5 /, \mathrm{N} 3 /$ & 21 & 5 & 7.6 & 2 & 2 & $x$ & $x$ & $x$ & $x$ & $x$ & $x$ & $x$ & $x$ & $x$ & \\
\hline RH19-7 & 2 & 13 & & 1 & 1 & 1 & $1 \mathrm{y} 2$ & 2 & 3 & 5.7 & 4.5 & 0 & 0 & $x$ & PINP & 10YR 4/1, 4/2; N 3/ & $\mathrm{N} 2,5 /, \mathrm{N} 3 /$ & indet & 2.4 & indet & 2 & 2 & $x$ & $x$ & $x$ & $x$ & $x$ & $x$ & $x$ & $x$ & $x$ & \\
\hline RH19-7 & 1 & 13 & & 1 & 1 & 1 & $1 \mathrm{y} 2$ & 2 & 3 & 4.7 & 4.1 & 0 & 0 & $x$ & PINP & 10YR 4/1, 4/2; N 3/ & $\mathrm{N} 2,5 /, \mathrm{N} 3 /$ & 20 & 3 & 4.7 & 2 & 2 & $x$ & $x$ & $x$ & $x$ & $x$ & $x$ & $x$ & $x$ & $x$ & 3 \\
\hline RH19-7 & 1 & 13 & & 1 & 1 & 1 & $1 \mathrm{y} 2$ & 2 & 3 & 5.4 & 4.1 & 0 & 0 & $x$ & PINP & 10YR 4/1, 4/2; N 3/ & $\mathrm{N} 2,5 /, \mathrm{N} 3 /$ & indet & 1.35 & indet & 2 & 2 & $x$ & $x$ & $x$ & $x$ & $x$ & $x$ & $x$ & $x$ & $x$ & 3 \\
\hline RH19-7 & 1 & 13 & & 0 & 1 & 1 & $1 \mathrm{y} 2$ & 2 & 3 & 5.3 & 4.1 & 0 & 0 & $x$ & PINP & 10YR 4/1, 4/2; N 3/ & $\mathrm{N} 2,5 /, \mathrm{N} 3 /$ & $x$ & $x$ & $x$ & $x$ & $x$ & $x$ & $x$ & $x$ & $x$ & $x$ & $x$ & $x$ & $x$ & $x$ & 3 \\
\hline RH19-7 & 1 & 13 & & 0 & 1 & 1 & $1 \mathrm{y} 2$ & 2 & 3 & 5.2 & 4.6 & 0 & 0 & $x$ & PINP & 10YR 4/1, 4/2; N 3/ & $\mathrm{N} 2,5 /, \mathrm{N} 3 /$ & $x$ & $x$ & $x$ & $x$ & $x$ & $x$ & $x$ & $x$ & $x$ & $x$ & $x$ & $x$ & $x$ & $x$ & \\
\hline RH19-7 & 1 & 13 & & 0 & 1 & 1 & $1 \mathrm{y} 2$ & 2 & 3 & 4.5 & 4.0 & 0 & 0 & $x$ & PINP & 10YR 4/1, 4/2; N 3/ & $\mathrm{N} 2,5 /, \mathrm{N} 3 /$ & $x$ & $x$ & $x$ & $x$ & $x$ & $x$ & $x$ & $x$ & $x$ & $x$ & $x$ & $x$ & $x$ & $x$ & 3 \\
\hline RH19-7 & 1 & 13 & & 0 & 1 & 1 & $1 \mathrm{y} 2$ & 2 & 3 & 5.1 & 4.8 & 0 & 0 & $x$ & PINP & 10YR 4/1, 4/2; N 3/ & $\mathrm{N} 2,5 /, \mathrm{N} 3 /$ & $x$ & $\mathrm{x}$ & $x$ & $x$ & $x$ & $x$ & $x$ & $x$ & $x$ & $x$ & $x$ & $x$ & $x$ & $x$ & \\
\hline RH19-7 & 1 & 14 & & 1 & 0 & 1 & $1,2 \mathrm{y} 4$ & 2 & 3 & 5.5 & 4.7 & 0 & 0 & $x$ & PINP & $5 Y R$ 6/3, 6/4, 5/4 & $\mathrm{N} 4 /, \mathrm{N} 3 /$ & indet & 1 & indet & 1 & $2 \mathrm{y} 6$ & $x$ & $x$ & $x$ & $x$ & $x$ & $x$ & $x$ & $x$ & $x$ & \\
\hline RH19-7 & 1 & 14 & & 0 & 0 & 1 & $1,2 \mathrm{y} 4$ & 2 & 3 & 5.2 & 4.0 & 0 & 0 & $\mathrm{x}$ & PINP & $5 Y R$ 6/3, 6/4, 5/4 & $\mathrm{N} 4 /, \mathrm{N} 3 /$ & $x$ & $x$ & $x$ & $x$ & $\mathrm{x}$ & $x$ & $x$ & $x$ & $x$ & $x$ & $x$ & $x$ & $x$ & $x$ & \\
\hline RH19-7 & 1 & 14 & & 0 & 0 & 1 & $1,2 \mathrm{y} 4$ & 2 & 3 & 5.0 & 4.5 & 0 & 0 & $x$ & PINP & $5 Y R$ 6/3, 6/4, 5/4 & $\mathrm{N} 4 /, \mathrm{N} 3 /$ & $x$ & $x$ & $x$ & $x$ & $x$ & $x$ & $x$ & $x$ & $x$ & $x$ & $x$ & $x$ & $x$ & $x$ & \\
\hline RH19-7 & 1 & 14 & & 0 & 0 & 1 & $1,2 \mathrm{y} 4$ & 2 & 3 & 5.3 & 5.1 & 0 & 0 & $x$ & PINP & $5 Y R$ 6/3, 6/4, 5/4 & $\mathrm{N} \mathrm{4/,} \mathrm{N} \mathrm{3/}$ & $x$ & $x$ & $x$ & $x$ & $x$ & $x$ & $x$ & $x$ & $x$ & $x$ & $x$ & $x$ & $x$ & $x$ & \\
\hline \begin{tabular}{|l|}
$\mathrm{RH} 19-7$ \\
\end{tabular} & 1 & 14 & & 0 & 0 & 1 & $1,2 \mathrm{y} 4$ & 2 & 3 & 7.6 & 4.9 & 0 & 0 & $x$ & PINP & $5 Y R$ 6/3, 6/4, 5/4 & $\mathrm{N} 4 /, \mathrm{N} 3 /$ & $x$ & $x$ & $x$ & $x$ & $x$ & $x$ & $x$ & $x$ & $x$ & $x$ & $x$ & $x$ & $x$ & $x$ & \\
\hline RH19-7 & 2 & 14 & & 0 & 0 & 1 & $1,2 \mathrm{y} 4$ & 2 & 3 & 5.3 & 4.9 & 0 & 0 & $x$ & PINP & $5 Y R$ 6/3, 6/4, 5/4 & $\mathrm{N} 4 /, \mathrm{N} 3 /$ & $x$ & $x$ & $x$ & $x$ & $x$ & $x$ & $x$ & $x$ & $x$ & $x$ & $x$ & $x$ & $x$ & $x$ & \\
\hline RH19-7 & 1 & 14 & & 0 & 0 & 1 & $1,2 \mathrm{y} 4$ & 2 & 3 & 5.1 & 4.2 & 0 & 0 & $x$ & PINP & $5 Y R$ 6/3, 6/4, 5/4 & $\mathrm{N} 4 /, \mathrm{N} 3 /$ & $x$ & $x$ & $x$ & $x$ & $x$ & $x$ & $x$ & $x$ & $x$ & $x$ & $x$ & $x$ & $x$ & $x$ & \\
\hline RH19-7 & 1 & 14 & & 0 & 0 & 1 & $1,2 \mathrm{y} 4$ & 2 & 3 & 5.1 & 4.6 & 0 & 0 & $x$ & PINP & $5 Y R$ 6/3, 6/4, 5/4 & $\mathrm{N} 4 /, \mathrm{N} 3 /$ & $x$ & $\mathrm{x}$ & $x$ & $x$ & $x$ & $x$ & $x$ & $x$ & $x$ & $x$ & $x$ & $x$ & $x$ & $x$ & \\
\hline RH19-7 & 2 & 15 & & 1 & 0 & 1 & 1 & 2 & 3 & 5.7 & 4.1 & 0 & 0 & $x$ & PINP & $5 Y R$ 6/4, 6/6, 5/4, 3/1 & $\mathrm{N} 3 / ; 7,5 Y R$ 6/2, 4/1 & 13 & 4 & 9.8 & 1 & $2 \mathrm{y} 6$ & $x$ & $x$ & $x$ & $x$ & $x$ & $\mathrm{x}$ & $x$ & $x$ & $x$ & \\
\hline RH19-7 & 1 & 15 & & 0 & 0 & 1 & 1 & 2 & 3 & 5.5 & 5.0 & 0 & 0 & $x$ & PINP & 5 YR $6 / 4,6 / 6,5 / 4,3 / 1$ & $\mathrm{~N} 3 / ; 7,5 Y R$ 6/2, 4/1 & $x$ & $x$ & $x$ & $x$ & $x$ & $x$ & $x$ & $x$ & $x$ & $x$ & $\mathrm{x}$ & $x$ & $x$ & $x$ & 4 \\
\hline RH19-7 & 1 & 15 & & 0 & 0 & 1 & 1 & 2 & 3 & 5.4 & 5.0 & 0 & 0 & $x$ & PINP & $5 Y R$ 6/4, 6/6, 5/4, 3/1 & $\mathrm{N} 3 / ; 7,5 Y R$ 6/2, 4/1 & $x$ & $x$ & $x$ & $\mathrm{x}$ & $x$ & $x$ & $x$ & $x$ & $x$ & $x$ & $x$ & $x$ & $x$ & $x$ & 4 \\
\hline
\end{tabular}




\begin{tabular}{|c|c|c|c|c|c|c|c|c|c|c|c|c|c|c|c|c|c|c|c|c|c|c|c|c|c|c|c|c|c|c|c|c|}
\hline \multirow[b]{2}{*}{ Sitio } & \multirow[b]{2}{*}{$\begin{array}{l}\mathrm{Ni} \\
\text { vel } \\
\end{array}$} & \multirow[b]{2}{*}{ GF } & \multirow[b]{2}{*}{ FNA } & \multirow[b]{2}{*}{ Fgto } & \multicolumn{11}{|c|}{ Manufactura } & \multicolumn{2}{|c|}{ Cocción } & \multicolumn{5}{|c|}{ Borde-labio } & \multicolumn{6}{|c|}{ Asa } & \multicolumn{3}{|c|}{ Base } & \multirow[b]{2}{*}{ Alterac } \\
\hline & & & & & $\begin{array}{l}\text { Tec } \\
\text { lev }\end{array}$ & $\begin{array}{l}\text { For } \\
\text { ma }\end{array}$ & $\begin{array}{l}\text { Mar } \\
\text { cas }\end{array}$ & $\begin{array}{c}\text { Sup } \\
\text { ext }\end{array}$ & \begin{tabular}{|c|} 
Sup \\
int
\end{tabular} & $\begin{array}{l}\text { Esp } \\
\text { max }\end{array}$ & $\begin{array}{l}\text { Esp } \\
\text { min }\end{array}$ & $\begin{array}{c}\text { Deco } \\
\text { pint }\end{array}$ & $\begin{array}{c}\text { Deco } \\
\text { cor/dsp }\end{array}$ & \begin{tabular}{|c|}
$\begin{array}{c}\text { Moti } \\
\text { vo }\end{array}$ \\
\end{tabular} & Estilo & sup ext & Color s & Diam & $\begin{array}{l}\text { Lrg } \\
\text { arc }\end{array}$ & $\begin{array}{c}\% \\
\text { arco }\end{array}$ & $0^{\mathrm{Di}}$ & il $\begin{array}{l}\text { Fo } \\
\mathrm{ma}\end{array}$ & \begin{tabular}{|l|l|}
$\mathbf{r}$ & Lar \\
$\mathbf{a}$ & go \\
\end{tabular} & $\begin{array}{c}\begin{array}{c}\text { An } \\
\text { cho }\end{array} \\
\end{array}$ & Esp & $\begin{array}{l}\text { Sec } \\
\text { ción }\end{array}$ & \begin{tabular}{|c|c}
$c$ & In \\
n ser \\
\end{tabular} & \begin{tabular}{l|l}
$\mathbf{r a c}$ & $\mathrm{Po}$ \\
$\mathrm{rc}$ & $\mathrm{sic}$ \\
\end{tabular} & & n $\begin{array}{c}\text { Mor } \\
\text { fol }\end{array}$ & \begin{tabular}{|c} 
Uni \\
ón
\end{tabular} & \\
\hline RH19-7 & 1 & 15 & & 0 & 0 & 1 & 1 & 2 & 3 & 5.6 & 5.1 & 0 & 0 & $\mathrm{x}$ & PINP & $5 Y R$ 6/4, 6/6, 5/4, 3/1 & N 3/; 7,5YR 6/2, 4/1 & $x$ & $\mathrm{x}$ & $x$ & $\mathrm{x}$ & $x$ & $x$ & $x$ & $x$ & $x$ & $x$ & $x$ & $x$ & $\mathrm{x}$ & $x$ & 4 \\
\hline RH19-7 & 1 & 15 & & 0 & 0 & 1 & 1 & 2 & 3 & 5.8 & 5.4 & 0 & 0 & $x$ & PINP & $5 Y R$ 6/4, 6/6, 5/4, 3/1 & N 3/; 7,5YR 6/2, 4/1 & $x$ & $\mathrm{x}$ & $\mathrm{x}$ & $\mathrm{x}$ & $x$ & $\mathrm{x}$ & $\mathrm{x}$ & $x$ & $x$ & $x$ & \begin{tabular}{l|l} 
\\
\end{tabular} & $\mathrm{x}$ & $\mathrm{x}$ & $x$ & 4 \\
\hline RH19-7 & 2 & 15 & & 0 & 0 & 1 & 1 & 2 & 3 & 4.9 & 4.0 & 0 & 0 & $x$ & PINP & $5 Y R$ 6/4, 6/6, 5/4, 3/1 & N 3/; 7,5YR 6/2, 4/1 & $x$ & $\mathrm{x}$ & $\mathrm{x}$ & $\mathrm{x}$ & $\mathrm{x}$ & $\mathrm{x}$ & $\mathrm{x}$ & $x$ & $x$ & $x$ & $x$ & $\mathrm{x}$ & $\mathrm{x}$ & $x$ & \\
\hline RH19-7 & 1 & 16 & & 1 & 0 & 1 & 0 & 2 & 3 & 5.9 & 4.1 & 0 & 0 & $x$ & PIN & 7,5 YR 3/1, 4/1, 5/2 & N 3/; 7,5YR 6/1 & 17 & 2.8 & 5.2 & 2 & 2 & $\mathrm{x}$ & $\mathrm{x}$ & $x$ & $\mathrm{x}$ & $x$ & \begin{tabular}{l|l}
$x$ \\
\end{tabular} & $\mathrm{x}$ & $\mathrm{x}$ & $x$ & 3 y 4 \\
\hline RH19-7 & 1 & 16 & & 0 & 0 & 1 & 0 & 2 & 3 & 5.9 & 5.3 & 0 & 0 & $x$ & PIN & 7,5 YR $3 / 1,4 / 1,5 / 2$ & $\mathrm{~N} 3 / ; 7,5 Y R 6 / 1$ & $x$ & $x$ & $\mathrm{x}$ & $\mathrm{x}$ & $\mathrm{x}$ & $\mathrm{x}$ & $\mathrm{x}$ & $x$ & $x$ & $x$ & \begin{tabular}{l|l}
$x$ \\
\end{tabular} & $x$ & $\mathrm{x}$ & $x$ & 3 y 4 \\
\hline RH19-7 & 1 & 16 & & 1 & 0 & 1 & 0 & 2 & 3 & 6.3 & 4.1 & 0 & 0 & $\mathrm{x}$ & PIN & 7,5 YR $3 / 1,4 / 1,5 / 2$ & N 3/; 7,5YR 6/1 & 16 & 3.7 & 7.4 & 2 & 2 & $\mathrm{x}$ & $\mathrm{x}$ & $\mathrm{x}$ & $x$ & $\mathrm{x}$ & $x$ & $\mathrm{x}$ & $\mathrm{x}$ & $x$ & 3 \\
\hline RH19-7 & 1 & 16 & & 1 & 0 & 1 & 0 & 2 & 3 & 5.2 & 4.5 & 0 & 0 & $\mathrm{x}$ & PIN & 7,5 YR $3 / 1,4 / 1,5 / 2$ & N 3/; 7,5YR 6/1 & 17 & 4.2 & 7.9 & 2 & 2 & $x$ & $x$ & $x$ & $x$ & $x$ & \begin{tabular}{l|l} 
\\
\end{tabular} & $x$ & $x$ & $x$ & 3 \\
\hline RH19-7 & 1 & 16 & & 0 & 0 & 1 & 0 & 2 & 3 & 8.5 & 6.1 & 0 & 0 & $x$ & PIN & 7,5 YR $3 / 1,4 / 1,5 / 2$ & $\mathrm{~N} 3 / ; 7,5 Y R 6 / 1$ & $x$ & $x$ & $\mathrm{x}$ & $\mathrm{x}$ & $\mathrm{x}$ & $x$ & $x$ & $x$ & $x$ & $x$ & \begin{tabular}{l|l} 
\\
\end{tabular} & $\mathrm{x}$ & $x$ & $x$ & \\
\hline RH19-7 & 1 & 17 & & 1 & 0 & 1 & 0 & 2 & 3 & 6.0 & 4.1 & 0 & 0 & $x$ & PINP & $5 Y R$ 5/4, 5/6, 6/4, 6/3 & $\mathrm{N} 3 /, 4 / ; 7,5$ YR $4 / 1$ & indet & 3.1 & indet & $\begin{array}{ll}t & 1 \\
\end{array}$ & 1 & $\mathrm{x}$ & $x$ & $x$ & $x$ & $x$ & \begin{tabular}{l|l}
$x$ \\
\end{tabular} & $x$ & $\mathrm{x}$ & $x$ & \\
\hline RH19-7 & 1 & 17 & & 1 & 0 & 1 & 0 & 2 & 3 & 5.4 & 4.2 & 0 & 0 & $x$ & PINP & $5 Y R$ 5/4, 5/6, 6/4, 6/3 & $\mathrm{N} 3 /, 4 / ; 7,5$ YR $4 / 1$ & indet & 0.6 & indet & \begin{tabular}{l|l}
$t$ & 1 \\
\end{tabular} & 2 & $\mathrm{x}$ & $\mathrm{x}$ & $x$ & $x$ & $x$ & \begin{tabular}{l|l}
$x$ \\
\end{tabular} & $x$ & $\mathrm{x}$ & $x$ & 3 \\
\hline RH19-7 & 1 & 17 & & 0 & 0 & 1 & 0 & 2 & 3 & 5.9 & 5.3 & 0 & 0 & $x$ & PINP & $5 Y R$ 5/4, 5/6, 6/4, 6/3 & $\mathrm{N} 3 /, 4 / ; 7,5$ YR 4/1 & $x$ & $\mathrm{x}$ & $\mathrm{x}$ & $\mathrm{x}$ & $\mathrm{x}$ & $\mathrm{x}$ & $\mathrm{x}$ & $x$ & $x$ & $\mathrm{x}$ & \begin{tabular}{l|l}
$x$ \\
\end{tabular} & $x$ & $\mathrm{x}$ & $x$ & 3 \\
\hline RH19-7 & 1 & 17 & & 0 & 0 & 1 & 0 & 2 & 3 & 9.0 & 7.4 & 0 & 0 & $\mathrm{x}$ & PINP & $5 Y R$ 5/4, 5/6, 6/4, 6/3 & $\mathrm{N} 3 /, 4 / ; 7,5$ YR 4/1 & $\mathrm{x}$ & $x$ & $\mathrm{x}$ & $\mathrm{x}$ & $\mathrm{x}$ & $\mathrm{x}$ & $\mathrm{x}$ & $\mathrm{x}$ & $x$ & $x$ & $x$ & $x$ & $\mathrm{x}$ & $x$ & 3 y 4 \\
\hline RH19-7 & 1 & 17 & & 0 & 0 & 1 & 0 & 2 & 3 & 6.5 & 4.9 & 0 & 0 & $\mathrm{x}$ & PINP & $5 Y R$ 5/4, 5/6, 6/4, 6/3 & $\mathrm{N} 3 /, 4 / ; 7,5$ YR 4/1 & $x$ & $x$ & $\mathrm{x}$ & $\mathrm{x}$ & $\mathrm{x}$ & $\mathrm{x}$ & $\mathrm{x}$ & $x$ & $x$ & $\mathrm{x}$ & \begin{tabular}{l|l}
$x$ \\
\end{tabular} & $x$ & $\mathrm{x}$ & $x$ & 3 y 4 \\
\hline RH19-7 & 1 & 17 & & 0 & 0 & 1 & 0 & 2 & 3 & 8.2 & 7.2 & 0 & 0 & $x$ & PINP & $5 Y R$ 5/4, 5/6, 6/4, 6/3 & N 3/, 4/; 7,5YR 4/1 & $x$ & $x$ & $x$ & $x$ & $x$ & $x$ & $x$ & $x$ & $x$ & $x$ & \begin{tabular}{l|l}
$x$ \\
\end{tabular} & $x$ & $x$ & $x$ & 3 \\
\hline RH19-7 & 1 & 17 & & 0 & 0 & 1 & 0 & 2 & 3 & 5.3 & 4.5 & 0 & 0 & $x$ & PINP & $5 Y R$ 5/4, 5/6, 6/4, 6/3 & $\mathrm{N} 3 /, 4 / ; 7,5$ YR 4/1 & $x$ & $x$ & $\mathrm{x}$ & $x$ & $\mathrm{x}$ & $x$ & $x$ & $x$ & $x$ & $x$ & \begin{tabular}{l|l} 
& $x$
\end{tabular} & $x$ & $x$ & $x$ & 3 \\
\hline RH19-7 & 1 & 17 & & 0 & 0 & 1 & 0 & 2 & 3 & 5.2 & 5.0 & 0 & 0 & $x$ & PINP & $5 Y R$ 5/4, 5/6, 6/4, 6/3 & $\mathrm{N} 3 /, 4 / ; 7,5$ YR 4/1 & $x$ & $x$ & $\mathrm{x}$ & $\mathrm{x}$ & $x$ & $x$ & $x$ & $x$ & $x$ & $x$ & \begin{tabular}{l|l}
$x$ \\
\end{tabular} & $x$ & $x$ & $x$ & 3 \\
\hline RH19-7 & 1 & 18 & & 1 & 0 & 0 & 0 & 2 & 2 & 6.0 & 4.9 & 0 & 0 & $x$ & $x$ & $5 Y R 5 / 3,5 / 4$ & $\mathrm{~N} 4 /$ & indet & 1 & indet & $\begin{array}{ll}t & 1 \\
\end{array}$ & $2 y 6$ & \begin{tabular}{l|l}
6 & $x$ \\
\end{tabular} & $x$ & $x$ & $x$ & $x$ & \begin{tabular}{l|l} 
\\
\end{tabular} & $x$ & $x$ & $x$ & 3 \\
\hline RH19-7 & 1 & 18 & & 1 & 0 & 0 & 0 & 2 & 2 & 7.5 & 5.0 & 0 & 0 & $x$ & $x$ & $5 Y R$ 5/3, 5/4 & $\mathrm{N} 4 /$ & indet & 1.3 & indet & $\begin{array}{ll}t \\
\end{array}$ & $2 y 6$ & \begin{tabular}{l|l}
6 & $x$ \\
\end{tabular} & $x$ & $\mathrm{x}$ & $\mathrm{x}$ & $x$ & \begin{tabular}{l|l}
$x$ \\
\end{tabular} & $\mathrm{x}$ & $x$ & $x$ & 3 \\
\hline RH19-7 & 1 & 18 & & 1 & 0 & 0 & 0 & 2 & 2 & 5.4 & 4.1 & 0 & 0 & $x$ & $x$ & $5 Y R$ 5/3, 5/4 & $\mathrm{N} 4 /$ & indet & 1.1 & indet & $\begin{array}{ll}t & 1\end{array}$ & $2 y 6$ & \begin{tabular}{l|l}
6 & $x$
\end{tabular} & $x$ & $x$ & $x$ & $x$ & \begin{tabular}{l|l} 
& $x$ \\
\end{tabular} & $x$ & $x$ & $x$ & 3 \\
\hline RH19-7 & 1 & 18 & & 1 & 0 & 0 & 0 & 2 & 2 & 5.8 & 4.7 & 0 & 0 & $x$ & $x$ & $5 Y R$ 5/3, 5/4 & $\mathrm{N} 4 \mathrm{I}$ & indet & 1.5 & indet & \begin{tabular}{l|l}
$t$ & 1
\end{tabular} & 2 & $x$ & $x$ & $x$ & $x$ & $x$ & \begin{tabular}{l|l}
$x$ & $x$ \\
\end{tabular} & $x$ & $x$ & $x$ & 3 \\
\hline \begin{tabular}{|l|}
$\mathrm{RH} 19-7$ \\
\end{tabular} & 1 & 18 & & 0 & 0 & 0 & 0 & 2 & 2 & 5.8 & 5.4 & 0 & 0 & $x$ & $x$ & $5 Y R$ 5/3, 5/4 & $\mathrm{N} 4 /$ & $x$ & $x$ & $x$ & $\mathrm{x}$ & $x$ & $x$ & $x$ & $x$ & $x$ & $x$ & \begin{tabular}{l|l} 
& $x$
\end{tabular} & $x$ & $x$ & $x$ & 3 \\
\hline RH19-7 & 1 & 18 & & 0 & 0 & 0 & 0 & 2 & 2 & 5.6 & 5.3 & 0 & 0 & $x$ & $x$ & $5 Y R$ 5/3, 5/4 & $\mathrm{N} 4 /$ & $x$ & $x$ & $x$ & $x$ & $x$ & $x$ & $x$ & $x$ & $x$ & $x$ & \begin{tabular}{l|l} 
& $x$ \\
\end{tabular} & $x$ & $x$ & $x$ & 3 \\
\hline RH19-7 & 1 & 19 & & 1 & $1 \mathrm{y} 2$ & 2 & $1 \mathrm{y} 5$ & 2 & 2 & 7.8 & 4.7 & 1 & 0 & $x$ & $x$ & 5YR4/2,5/4;10R5/4;N3/ & $5 Y R$ 4/2, 5/3, 6/3, 6/4 & 21 & 14.2 & 221.5 & \begin{tabular}{|l|l}
5 & 1 \\
\end{tabular} & 1 & $\mathrm{x}$ & $\mathrm{x}$ & $x$ & $\mathrm{x}$ & $x$ & $x$ & $x$ & $\mathrm{x}$ & $x$ & 2 \\
\hline RH19-7 & 1 & 19 & & 1 & $1 \mathrm{y} 2$ & 2 & $1 \mathrm{y} 5$ & 2 & 2 & 7.2 & 5.5 & 1 & 0 & $x$ & $x$ & 5YR4/2,5/4;10R5/4;N3/ & $5 Y R$ 4/2, 5/3,6/3, 6/4 & 21 & 14.2 & 221.5 & \begin{tabular}{|l|l|}
5 & 1 \\
\end{tabular} & 1 & $x$ & $x$ & $x$ & $x$ & $x$ & $x$ & $\mathrm{x}$ & $x$ & $x$ & 3 \\
\hline RH19-7 & 1 & 19 & & 1 & $1 \mathrm{y} 2$ & 2 & $1 \mathrm{y} 5$ & 2 & 2 & 7.3 & 5.0 & 1 & 0 & $x$ & $x$ & 5YR4/2,5/4;10R5/4;N3/ & $5 Y R$ 4/2, 5/3, 6/3, 6/4 & 21 & 14.2 & 221.5 & \begin{tabular}{|l|l|}
5 & 1 \\
\end{tabular} & 1 & $x$ & $x$ & $x$ & $x$ & $x$ & \begin{tabular}{l|l}
$x$ \\
\end{tabular} & $\mathrm{x}$ & $x$ & $x$ & \\
\hline RH19-7 & 1 & 19 & & 1 & $1 \mathrm{y} 2$ & 2 & $1 \mathrm{y} 5$ & 2 & 2 & 7.5 & 5.0 & 1 & 0 & $x$ & $x$ & 5YR4/2,5/4;10R5/4;N3/ & $5 Y R$ 4/2, 5/3, 6/3, 6/4 & 21 & 14.2 & 221.5 & \begin{tabular}{l|l}
5 & 1 \\
\end{tabular} & 1 & $x$ & $x$ & $x$ & $x$ & $x$ & \begin{tabular}{l|l} 
\\
\end{tabular} & $x$ & $x$ & $x$ & 1 \\
\hline RH19-7 & 1 & 19 & & 1 & $1 \mathrm{y} 2$ & 2 & $1 \mathrm{y} 5$ & 2 & 2 & 7.2 & 5.4 & 1 & 0 & $x$ & $x$ & 5YR4/2,5/4;10R5/4;N3/ & $5 Y R$ 4/2, 5/3, 6/3, 6/4 & 20.2 & 4.4 & 6.9 & 1 & 1 & $x$ & $x$ & $x$ & $x$ & $x$ & \begin{tabular}{l|l}
$x$ \\
\end{tabular} & $x$ & $x$ & $x$ & 3 \\
\hline $\mathrm{RH} 19-7$ & 1 & 19 & & 1 & $1 \mathrm{y} 2$ & 2 & $1 \mathrm{y} 5$ & 2 & 2 & 7.1 & 6.2 & 1 & 0 & $x$ & $x$ & 5YR4/2,5/4;10R5/4;N3/ & $5 Y R$ 4/2, 5/3, 6/3, 6/4 & indet & 3.5 & indet & \begin{tabular}{l|l} 
tt & 1
\end{tabular} & 1 & $x$ & $x$ & $x$ & $x$ & $x$ & \begin{tabular}{l|l} 
\\
\end{tabular} & $x$ & $x$ & $x$ & \\
\hline RH19-7 & 1 & 19 & & 1 & $1 y 2$ & 2 & $1 \mathrm{y} 5$ & 2 & 2 & 6.9 & 5.8 & 1 & 0 & $x$ & $\mathrm{x}$ & 5YR4/2,5/4;10R5/4;N3/ & $5 Y R$ 4/2, 5/3, 6/3, 6/4 & indet & 2.4 & indet & \begin{tabular}{l|l}
$t$ & 1 \\
\end{tabular} & 2 & $x$ & $x$ & $x$ & $\mathrm{x}$ & $x$ & \begin{tabular}{l|l}
$x$ \\
\end{tabular} & $x$ & $x$ & $x$ & \\
\hline RH19-7 & 1 & 19 & & 2 & $1 \mathrm{y} 2$ & 2 & $1 \mathrm{y} 5$ & 2 & 2 & 16.0 & 5.5 & 1 & 0 & $x$ & $\mathrm{x}$ & 5YR4/2,5/4;10R5/4;N3/ & $5 Y R$ 4/2, 5/3, 6/3, 6/4 & $x$ & $\mathrm{x}$ & $\mathrm{x}$ & $\mathrm{x}$ & $\mathrm{x}$ & $\mathrm{x}$ & $\mathrm{x}$ & $\mathrm{x}$ & $\mathrm{x}$ & $x$ & \begin{tabular}{l|l}
$x$ \\
\end{tabular} & \begin{tabular}{l|l}
$\times$ & 14 \\
\end{tabular} & 1 & 1 & \\
\hline RH19-7 & 1 & 19 & & 2 & $1 \mathrm{y} 2$ & 2 & $1 \mathrm{y} 5$ & 2 & 2 & 9.2 & 8.1 & 1 & 0 & $x$ & $x$ & 5YR4/2,5/4;10R5/4;N3/ & $5 Y R$ 4/2, 5/3, 6/3, 6/4 & $x$ & $x$ & $\mathrm{x}$ & $\mathrm{x}$ & $\mathrm{x}$ & $x$ & $x$ & $x$ & $\mathrm{x}$ & $\mathrm{x}$ & \begin{tabular}{l|l}
$x$ \\
\end{tabular} & $x$ indet & 0 & 0 & \\
\hline RH19-7 & 1 & 19 & & 3 & $1 \mathrm{y} 2$ & 2 & $1 \mathrm{y} 5$ & 2 & 2 & 7.5 & 6.2 & 1 & 0 & $x$ & $x$ & 5YR4/2,5/4;10R5/4;N3/ & $5 Y R$ 4/2, 5/3, 6/3, 6/4 & $x$ & $x$ & $\mathrm{x}$ & $x$ & $x$ & $0,8 \mathrm{fr}$ & 13 & 9 & 2 & 3 & \begin{tabular}{l|l}
3 & 0 \\
\end{tabular} & $x$ & $\mathrm{x}$ & $x$ & 3 \\
\hline RH19-7 & 1 & 19 & & 4 & $1 \mathrm{y} 2$ & 2 & $1 \mathrm{y} 5$ & 2 & 2 & 7.0 & 4.6 & 1 & 0 & $x$ & $x$ & 5YR4/2,5/4;10R5/4;N3/ & $5 Y R$ 4/2, 5/3, 6/3, 6/4 & $x$ & $x$ & $x$ & $\mathrm{x}$ & $x$ & $x$ & $x$ & $x$ & $x$ & $x$ & \begin{tabular}{l|l}
$x$ \\
\end{tabular} & $x$ & $x$ & $x$ & \\
\hline RH19-7 & 1 & 19 & & 4 & $1 \mathrm{y} 2$ & 2 & $1 \mathrm{y} 5$ & 2 & 2 & 6.5 & 4.4 & 1 & 0 & $x$ & $x$ & 5YR4/2,5/4;10R5/4;N3/ & $5 Y R$ 4/2, 5/3, 6/3, 6/4 & $x$ & $x$ & $x$ & $\mathrm{x}$ & $x$ & $x$ & $x$ & $x$ & $x$ & $x$ & \begin{tabular}{l|l} 
\\
\end{tabular} & $x$ & $x$ & $x$ & \\
\hline RH19-7 & 1 & 19 & & 0 & $1 y 2$ & 2 & $1 \mathrm{y} 5$ & 2 & 2 & 5.4 & 3.6 & 1 & 0 & $x$ & $x$ & 5YR4/2,5/4;10R5/4;N3/ & $5 Y R$ 4/2, 5/3, 6/3, 6/4 & $x$ & $x$ & $\mathrm{x}$ & $x$ & $x$ & $x$ & $x$ & $x$ & $x$ & $x$ & \begin{tabular}{l|l}
$x$ \\
\end{tabular} & $x$ & $x$ & $x$ & \\
\hline RH19-7 & 1 & 19 & & 0 & $1 \mathrm{y} 2$ & 2 & $1 \mathrm{y} 5$ & 2 & 2 & 5.6 & 4.3 & 1 & 0 & $x$ & $\mathrm{x}$ & 5YR4/2,5/4;10R5/4;N3/ & $5 Y R$ 4/2, 5/3, 6/3, 6/4 & $x$ & $\mathrm{x}$ & $x$ & $\mathrm{x}$ & $\mathrm{x}$ & $\mathrm{x}$ & $\mathrm{x}$ & $\mathrm{x}$ & $\mathrm{x}$ & $x$ & \begin{tabular}{l|l}
$x$ \\
\end{tabular} & $x$ & $x$ & $x$ & \\
\hline RH19-7 & 1 & 19 & & 0 & $1 \mathrm{y} 2$ & 2 & $1 \mathrm{y} 5$ & 2 & 2 & 5.9 & 4.3 & 1 & 0 & $x$ & $x$ & 5YR4/2,5/4;10R5/4;N3/ & $5 Y R$ 4/2, 5/3, 6/3, 6/4 & $x$ & $x$ & $\mathrm{x}$ & $x$ & $x$ & $x$ & $x$ & $x$ & $\mathrm{x}$ & $x$ & \begin{tabular}{l|l}
$x$ \\
\end{tabular} & $x$ & $x$ & $\mathrm{x}$ & \\
\hline RH19-7 & 1 & 19 & & 0 & $1 \mathrm{y} 2$ & 2 & $1 \mathrm{y} 5$ & 2 & 2 & 4.9 & 4.3 & 1 & 0 & $x$ & $x$ & 5YR4/2,5/4;10R5/4;N3/ & $5 Y R$ 4/2, 5/3, 6/3, 6/4 & $x$ & $\mathrm{x}$ & $\mathrm{x}$ & $\mathrm{x}$ & $\mathrm{x}$ & $\mathrm{x}$ & $\mathrm{x}$ & $\mathrm{x}$ & $x$ & $x$ & \begin{tabular}{l|l}
$x$ \\
\end{tabular} & $x$ & $x$ & $\mathrm{x}$ & \\
\hline RH19-7 & 2 & 19 & & 0 & $1 \mathrm{y} 2$ & 2 & $1 \mathrm{y} 5$ & 2 & 2 & 7.3 & 4.2 & 1 & 0 & $x$ & $\mathrm{x}$ & 5YR4/2,5/4;10R5/4;N3/ & $5 Y R$ 4/2, 5/3, 6/3, 6/4 & $x$ & $\mathrm{x}$ & $x$ & $x$ & $x$ & $x$ & $\mathrm{x}$ & $\mathrm{x}$ & $x$ & $x$ & \begin{tabular}{l|l} 
& $x$ \\
\end{tabular} & $x$ & $x$ & $x$ & 1 \\
\hline
\end{tabular}




\begin{tabular}{|c|c|c|c|c|c|c|c|c|c|c|c|c|c|c|c|c|c|c|c|c|c|c|c|c|c|c|c|c|c|c|c|c|}
\hline \multirow[b]{2}{*}{ Sitio } & \multirow[b]{2}{*}{$\begin{array}{c}\mathrm{Ni} \\
\text { vel }\end{array}$} & \multirow[b]{2}{*}{ GF } & \multirow[b]{2}{*}{ FNA } & \multirow[b]{2}{*}{ Fgto } & \multicolumn{11}{|c|}{ Manufactura } & \multicolumn{2}{|c|}{ Cocción } & \multicolumn{5}{|c|}{ Borde-labio } & \multicolumn{6}{|c|}{ Asa } & \multicolumn{3}{|c|}{ Base } & \multirow[b]{2}{*}{ Alterac } \\
\hline & & & & & $\begin{array}{l}\text { Tec } \\
\text { lev }\end{array}$ & $\begin{array}{l}\text { For } \\
\text { ma }\end{array}$ & $\begin{array}{l}\text { Mar } \\
\text { cas }\end{array}$ & \begin{tabular}{|l|} 
Sup \\
ext
\end{tabular} & \begin{tabular}{|c|} 
Sup \\
int
\end{tabular} & $\begin{array}{l}\text { Esp } \\
\text { max }\end{array}$ & \begin{tabular}{|l|} 
Esp \\
min
\end{tabular} & \begin{tabular}{|l} 
Deco \\
pint
\end{tabular} & $\begin{array}{c}\text { Deco } \\
\text { cor/dsp }\end{array}$ & $\begin{array}{c}\text { Moti } \\
\text { vo }\end{array}$ & Estilo & up ext & Color sup int & Diam & $\begin{array}{l}\text { Lrg } \\
\text { arc }\end{array}$ & \begin{tabular}{|c|}
$\%$ \\
arco \\
\end{tabular} & & $\begin{array}{l}\begin{array}{l}\text { For } \\
\text { ma }\end{array} \\
\end{array}$ & $\begin{array}{c}\text { Lar } \\
\text { go }\end{array}$ & $\begin{array}{l}\text { An } \\
\text { cho }\end{array}$ & Esp & $\begin{array}{l}\text { Sec } \\
\text { ción }\end{array}$ & $\begin{array}{l}\text { In } \\
\text { serc }\end{array}$ & & n & $\begin{array}{c}\text { Mor } \\
\text { fol }\end{array}$ & $\begin{array}{l}\text { Uni } \\
\text { ón }\end{array}$ & \\
\hline RH19-7 & 2 & 19 & & 0 & $1 \mathrm{y} 2$ & 2 & $1 \mathrm{y} 5$ & 2 & 2 & 6.2 & \begin{tabular}{|l|l|}
3.4 \\
\end{tabular} & 1 & 0 & $x$ & $x$ & 5YR4/2,5/4;10R5/4;N3/ & $5 Y R \quad 4 / 2,5 / 3,6 / 3,6 / 4$ & $x$ & $x$ & $\mathrm{x}$ & $x$ & $\mathrm{x}$ & $x$ & $x$ & $x$ & $x$ & $x$ & $x$ & $x$ & $\mathrm{x}$ & $x$ & 1 \\
\hline RH19-7 & 2 & 19 & & 0 & $1 \mathrm{y} 2$ & 2 & $1 \mathrm{y} 5$ & 2 & 2 & 8.7 & 7.9 & 1 & 0 & $x$ & $x$ & 5YR4/2,5/4;10R5/4;N3/ & $5 Y R \quad 4 / 2,5 / 3,6 / 3,6 / 4$ & $x$ & $x$ & $x$ & $\mathrm{x}$ & $x$ & $x$ & $x$ & $x$ & $x$ & $\mathrm{x}$ & $x$ & $x$ & $x$ & $\mathrm{x}$ & \\
\hline RH19-7 & 2 & 19 & & 0 & $1 \mathrm{y} 2$ & 2 & $1 \mathrm{y} 5$ & 2 & 2 & 8.4 & 6.6 & 1 & 0 & $x$ & $x$ & 5YR4/2,5/4;10R5/4;N3/ & $5 Y R \quad 4 / 2,5 / 3,6 / 3,6 / 4$ & $x$ & $x$ & $x$ & $x$ & $x$ & $x$ & $x$ & $x$ & $\mathrm{x}$ & $x$ & $x$ & $x$ & $x$ & $x$ & \\
\hline RH19-7 & 1 & 19 & & 0 & $1 \mathrm{y} 2$ & 2 & $1 \mathrm{y} 5$ & 2 & 2 & 5.2 & 3.3 & 1 & 0 & $x$ & $x$ & 5YR4/2,5/4;10R5/4;N3/ & $5 Y R \quad 4 / 2,5 / 3,6 / 3,6 / 4$ & $x$ & $x$ & $x$ & $x$ & $\mathrm{x}$ & $x$ & $x$ & $x$ & $\mathrm{x}$ & $x$ & $\mathrm{x}$ & $x$ & $x$ & $x$ & 1,3 y 5 \\
\hline RH19-7 & 1 & 19 & & 0 & $1 \mathrm{y} 2$ & 2 & $1 \mathrm{y} 5$ & 2 & 2 & 5.1 & 3.8 & 1 & 0 & $x$ & $x$ & 5YR4/2,5/4;10R5/4;N3/ & $5 Y R \quad 4 / 2,5 / 3,6 / 3,6 / 4$ & $x$ & $x$ & $x$ & $x$ & $x$ & $x$ & $x$ & $x$ & $x$ & $x$ & $x$ & $x$ & $x$ & $x$ & 1 y 3 \\
\hline RH19-7 & 1 & 19 & & 0 & $1 \mathrm{y} 2$ & 2 & $1 \mathrm{y} 5$ & 2 & 2 & 7.1 & 5.8 & 1 & 0 & $x$ & $\mathrm{x}$ & 5YR4/2,5/4;10R5/4;N3/ & $5 Y R \quad 4 / 2,5 / 3,6 / 3,6 / 4$ & $x$ & $x$ & $\mathrm{x}$ & $x$ & $x$ & $\mathrm{x}$ & $\mathrm{x}$ & $x$ & $x$ & $x$ & $\mathrm{x}$ & $x$ & $x$ & $x$ & 3 \\
\hline RH19-7 & 1 & 19 & & 0 & $1 \mathrm{y} 2$ & 2 & $1 \mathrm{y} 5$ & 2 & 2 & 6.1 & 5.2 & 1 & 0 & $x$ & $x$ & 5YR4/2,5/4;10R5/4;N3/ & $5 Y R \quad 4 / 2,5 / 3,6 / 3,6 / 4$ & $x$ & $x$ & $x$ & $x$ & $x$ & $x$ & $x$ & $x$ & $x$ & $x$ & $\mathrm{x}$ & $x$ & $x$ & $x$ & 3 \\
\hline RH19-7 & 1 & 19 & & 0 & $1 y_{2}$ & 2 & $1 \mathrm{y} 5$ & 2 & 2 & 4.9 & 4.4 & 1 & 0 & $\mathrm{x}$ & $x$ & 5YR4/2,5/4;10R5/4;N3/ & $5 Y R \quad 4 / 2,5 / 3,6 / 3,6 / 4$ & $x$ & $x$ & $x$ & $x$ & $x$ & $x$ & $x$ & $x$ & $x$ & $x$ & $x$ & $x$ & $x$ & $x$ & 3 \\
\hline RH19-7 & 1 & 19 & & 0 & $1 \mathrm{y} 2$ & 2 & $1 \mathrm{y} 5$ & 2 & 2 & 6.8 & 5.7 & 1 & 0 & $x$ & $x$ & 5YR4/2,5/4;10R5/4;N3/ & $5 Y R \quad 4 / 2,5 / 3,6 / 3,6 / 4$ & $x$ & $x$ & $x$ & $x$ & $x$ & $x$ & $x$ & $x$ & $x$ & $x$ & $x$ & $x$ & $x$ & $x$ & 3 \\
\hline RH19-7 & 1 & 19 & & 0 & $1 \mathrm{y} 2$ & 2 & $1 \mathrm{y} 5$ & 2 & 2 & 6.7 & 4.8 & 1 & 0 & $x$ & $x$ & 5YR4/2,5/4;10R5/4;N3/ & $5 Y R \quad 4 / 2,5 / 3,6 / 3,6 / 4$ & $x$ & $x$ & $x$ & $x$ & $x$ & $x$ & $x$ & $x$ & $x$ & $x$ & $x$ & $x$ & $x$ & $\mathrm{x}$ & 3 \\
\hline RH19-7 & 1 & 19 & & 0 & $1 \mathrm{y} 2$ & 2 & 1y5 & 2 & 2 & 6.5 & 6.1 & 1 & 0 & $x$ & $x$ & 5YR4/2,5/4;10R5/4;N3/ & $5 Y R \quad 4 / 2,5 / 3,6 / 3,6 / 4$ & $x$ & $x$ & $x$ & $x$ & $x$ & $x$ & $\mathrm{x}$ & $x$ & $x$ & $x$ & $\mathrm{x}$ & $x$ & $x$ & $\mathrm{x}$ & 3 \\
\hline RH19-7 & 1 & 19 & & 0 & $1 \mathrm{y} 2$ & 2 & $1 \mathrm{y} 5$ & 2 & 2 & 7.2 & 5.1 & 1 & 0 & $x$ & $x$ & 5YR4/2,5/4;10R5/4;N3/ & $5 Y R \quad 4 / 2,5 / 3,6 / 3,6 / 4$ & $x$ & $x$ & $x$ & $x$ & $x$ & $x$ & $x$ & $x$ & $x$ & $x$ & $\mathrm{x}$ & $x$ & $x$ & $x$ & 1 \\
\hline RH19-7 & 1 & 19 & & 0 & $1 \mathrm{y} 2$ & 2 & $1 \mathrm{y} 5$ & 2 & 2 & 6.5 & 5.3 & 1 & 0 & $x$ & $x$ & 5YR4/2,5/4;10R5/4;N3/ & $5 Y R \quad 4 / 2,5 / 3,6 / 3,6 / 4$ & $x$ & $x$ & $x$ & $x$ & $x$ & $x$ & $x$ & $x$ & $x$ & $x$ & $\mathrm{x}$ & $x$ & $x$ & $x$ & 1 \\
\hline RH19-7 & 1 & 19 & & 0 & $1 \mathrm{y} 2$ & 2 & $1 \mathrm{y} 5$ & 2 & 2 & 8.8 & 5.8 & 1 & 0 & $x$ & $x$ & 5YR4/2,5/4;10R5/4;N3/ & $5 Y R \quad 4 / 2,5 / 3,6 / 3,6 / 4$ & $x$ & $x$ & $x$ & $x$ & $x$ & $x$ & $x$ & $x$ & $x$ & $x$ & $x$ & $x$ & $x$ & $x$ & \\
\hline RH19-7 & 1 & 19 & & 0 & $1 \mathrm{y}^{2}$ & 2 & $1 \mathrm{y} 5$ & 2 & 2 & 7.7 & 4.8 & 1 & 0 & $x$ & $x$ & 5YR4/2,5/4;10R5/4;N3/ & $5 Y R \quad 4 / 2,5 / 3,6 / 3,6 / 4$ & $x$ & $x$ & $x$ & $x$ & $x$ & $x$ & $x$ & $x$ & $x$ & $x$ & $\mathrm{x}$ & $x$ & $x$ & $x$ & \\
\hline RH19-7 & 1 & 19 & & 0 & $1 \mathrm{y} 2$ & 2 & $1 \mathrm{y} 5$ & 2 & 2 & 6.0 & 5.2 & 1 & 0 & $\mathrm{x}$ & $\mathrm{x}$ & 5YR4/2,5/4;10R5/4;N3/ & $5 Y R \quad 4 / 2,5 / 3,6 / 3,6 / 4$ & $\mathrm{x}$ & $\mathrm{x}$ & $x$ & $x$ & $\mathrm{x}$ & $x$ & $x$ & $x$ & $x$ & $x$ & $x$ & $x$ & $\mathrm{x}$ & $\mathrm{x}$ & 1 y 3 \\
\hline RH19-7 & 1 & 19 & & 0 & $1 \mathrm{y}^{2}$ & 2 & $1 \mathrm{y} 5$ & 2 & 2 & 6.0 & 5.4 & 1 & 0 & $x$ & $x$ & 5YR4/2,5/4;10R5/4;N3/ & $5 Y R \quad 4 / 2,5 / 3,6 / 3,6 / 4$ & $x$ & $x$ & $x$ & $x$ & $x$ & $x$ & $x$ & $x$ & $x$ & $x$ & $x$ & $x$ & $x$ & $\mathrm{x}$ & 1 y 3 \\
\hline RH19-7 & 2 & 19 & & 0 & $1 \mathrm{y} 2$ & 2 & $1 \mathrm{y} 5$ & 2 & 2 & 7.1 & 5.2 & 1 & 0 & $\mathrm{x}$ & $\mathrm{x}$ & 5YR4/2,5/4;10R5/4;N3/ & $5 Y R \quad 4 / 2,5 / 3,6 / 3,6 / 4$ & $\mathrm{x}$ & $\mathrm{x}$ & $x$ & $x$ & $\mathrm{x}$ & $x$ & $x$ & $x$ & $x$ & $x$ & $\mathrm{x}$ & $x$ & $\mathrm{x}$ & $\mathrm{x}$ & 1 \\
\hline RH19-7 & 1 & 19 & & 0 & $1 \mathrm{y} 2$ & 2 & $1 \mathrm{y} 5$ & 2 & 2 & 5.2 & 4.7 & 1 & 0 & $x$ & $x$ & 5YR4/2,5/4;10R5/4;N3/ & $5 Y R \quad 4 / 2,5 / 3,6 / 3,6 / 4$ & $x$ & $x$ & $x$ & $x$ & $x$ & $x$ & $x$ & $x$ & $x$ & $x$ & $x$ & $x$ & $x$ & $x$ & 1 \\
\hline RH19-7 & 2 & 19 & & 0 & $1 \mathrm{y} 2$ & 2 & $1 \mathrm{y} 5$ & 2 & 2 & 6.4 & 5.5 & 1 & 0 & $x$ & $x$ & 5YR4/2,5/4;10R5/4;N3/ & $5 Y R \quad 4 / 2,5 / 3,6 / 3,6 / 4$ & $x$ & $x$ & $x$ & $x$ & $x$ & $x$ & $x$ & $x$ & $x$ & $x$ & $x$ & $x$ & $x$ & $x$ & 3 \\
\hline RH19-7 & 1 & 19 & & 0 & $1 \mathrm{y} 2$ & 2 & $1 \mathrm{y} 5$ & 2 & 2 & 6.1 & 5.0 & 1 & 0 & $x$ & $x$ & 5YR4/2,5/4;10R5/4;N3/ & $5 Y R \quad 4 / 2,5 / 3,6 / 3,6 / 4$ & $x$ & $x$ & $x$ & $x$ & $x$ & $x$ & $x$ & $x$ & $x$ & $x$ & $x$ & $x$ & $x$ & $x$ & 3 \\
\hline RH19-7 & 1 & 19 & & 0 & $1 y^{2}$ & 2 & $1 \mathrm{y} 5$ & 2 & 2 & 7.5 & 6.7 & 1 & 0 & $x$ & $x$ & 5YR4/2,5/4;10R5/4;N3/ & $5 Y R \quad 4 / 2,5 / 3,6 / 3,6 / 4$ & $x$ & $x$ & $x$ & $x$ & $x$ & $x$ & $x$ & $x$ & $x$ & $x$ & $x$ & $x$ & $x$ & $x$ & 3 \\
\hline RH19-7 & 1 & 19 & & 0 & $1 \mathrm{y} 2$ & 2 & $1 \mathrm{y} 5$ & 2 & 2 & 8.1 & 7.0 & 1 & 0 & $\mathrm{x}$ & $x$ & 5YR4/2,5/4;10R5/4;N3/ & $5 Y R \quad 4 / 2,5 / 3,6 / 3,6 / 4$ & $x$ & $x$ & $x$ & $x$ & $x$ & $x$ & $x$ & $x$ & $x$ & $x$ & $\mathrm{x}$ & $x$ & $x$ & $\mathrm{x}$ & 3 \\
\hline RH19-7 & 2 & 19 & & 0 & $1 \mathrm{y}^{2}$ & 2 & $1 \mathrm{y} 5$ & 2 & 2 & 6.5 & 5.7 & 1 & 0 & $x$ & $x$ & 5YR4/2,5/4;10R5/4;N3/ & $5 Y R \quad 4 / 2,5 / 3,6 / 3,6 / 4$ & $x$ & $\mathrm{x}$ & $x$ & $x$ & $x$ & $x$ & $x$ & $x$ & $x$ & $x$ & $x$ & $x$ & $\mathrm{x}$ & $\mathrm{x}$ & 3 \\
\hline RH19-7 & 2 & 19 & & 0 & $1 \mathrm{y} 2$ & 2 & $1 \mathrm{y} 5$ & 2 & 2 & 6.7 & 6.0 & 1 & 0 & $x$ & $x$ & 5YR4/2,5/4;10R5/4;N3/ & $5 Y R \quad 4 / 2,5 / 3,6 / 3,6 / 4$ & $x$ & $x$ & $x$ & $x$ & $x$ & $x$ & $x$ & $x$ & $x$ & $x$ & $x$ & $x$ & $x$ & $x$ & 3 \\
\hline RH19-7 & 1 & 19 & & 0 & $1 \mathrm{y}^{2}$ & 2 & $1 \mathrm{y} 5$ & 2 & 2 & 6.7 & 4.2 & 1 & 0 & $x$ & $x$ & 5YR4/2,5/4;10R5/4;N3/ & $5 Y R \quad 4 / 2,5 / 3,6 / 3,6 / 4$ & $x$ & $x$ & $x$ & $x$ & $x$ & $x$ & $x$ & $x$ & $x$ & $x$ & $x$ & $x$ & $x$ & $x$ & 2 \\
\hline RH19-7 & 1 & 19 & & 0 & $1 \mathrm{y} 2$ & 2 & $1 \mathrm{y} 5$ & 2 & 2 & 7.7 & 5.5 & 1 & 0 & $x$ & $x$ & 5YR4/2,5/4;10R5/4;N3/ & $5 Y R \quad 4 / 2,5 / 3,6 / 3,6 / 4$ & $x$ & $x$ & $x$ & $x$ & $x$ & $x$ & $x$ & $x$ & $x$ & $x$ & $x$ & $x$ & $x$ & $x$ & 1 \\
\hline RH19-7 & 1 & 19 & & 0 & $1 \mathrm{y}^{2}$ & 2 & $1 \mathrm{y} 5$ & 2 & 2 & 6.8 & 4.7 & 1 & 0 & $x$ & $x$ & 5YR4/2,5/4;10R5/4;N3/ & $5 Y R \quad 4 / 2,5 / 3,6 / 3,6 / 4$ & $x$ & $x$ & $x$ & $x$ & $\mathrm{x}$ & $x$ & $x$ & $x$ & $x$ & $x$ & $x$ & $x$ & $x$ & $x$ & 1 \\
\hline RH19-7 & 1 & 19 & & 0 & $1 \mathrm{y}^{2}$ & 2 & $1 \mathrm{y} 5$ & 2 & 2 & 6.6 & 5.2 & 1 & 0 & $x$ & $x$ & 5YR4/2,5/4;10R5/4;N3/ & $5 Y R \quad 4 / 2,5 / 3,6 / 3,6 / 4$ & $x$ & $x$ & $x$ & $x$ & $\mathrm{x}$ & $x$ & $x$ & $x$ & $x$ & $x$ & $x$ & $x$ & $\mathrm{x}$ & $\mathrm{x}$ & 1 \\
\hline RH19-7 & 1 & 19 & & 0 & $1 \mathrm{y}^{2}$ & 2 & $1 \mathrm{y} 5$ & 2 & 2 & 5.7 & 4.0 & 1 & 0 & $\mathrm{x}$ & $x$ & 5YR4/2,5/4;10R5/4;N3/ & $5 Y R \quad 4 / 2,5 / 3,6 / 3,6 / 4$ & $\mathrm{x}$ & $\mathrm{x}$ & $x$ & $\mathrm{x}$ & $\mathrm{x}$ & $x$ & $x$ & $x$ & $x$ & $x$ & $x$ & $x$ & $x$ & $\mathrm{x}$ & 1 \\
\hline RH19-7 & 2 & 19 & & 0 & $1 \mathrm{y} 2$ & 2 & $1 \mathrm{y} 5$ & 2 & 2 & 7.7 & 6.5 & 1 & 0 & $x$ & $x$ & 5YR4/2,5/4;10R5/4;N3/ & $5 Y R \quad 4 / 2,5 / 3,6 / 3,6 / 4$ & $x$ & $x$ & $x$ & $\mathrm{x}$ & $x$ & $x$ & $x$ & $x$ & $x$ & $x$ & $x$ & $x$ & $x$ & $x$ & 1 \\
\hline RH19-7 & 1 & 19 & & 0 & $1 \mathrm{y} 2$ & 2 & $1 \mathrm{y} 5$ & 2 & 2 & 6.5 & 3.3 & 1 & 0 & $x$ & $x$ & 5YR4/2,5/4;10R5/4;N3/ & $5 Y R \quad 4 / 2,5 / 3,6 / 3,6 / 4$ & $x$ & $x$ & $x$ & $\mathrm{x}$ & $x$ & $x$ & $x$ & $x$ & $x$ & $x$ & $x$ & $x$ & $x$ & $x$ & 1 \\
\hline RH19-7 & 1 & 19 & & 0 & $1 \mathrm{y} 2$ & 2 & $1 \mathrm{y} 5$ & 2 & 2 & 10.5 & 5.2 & 1 & 0 & $x$ & $x$ & 5YR4/2,5/4;10R5/4;N3/ & $5 Y R \quad 4 / 2,5 / 3,6 / 3,6 / 4$ & $x$ & $x$ & $x$ & $\mathrm{x}$ & $x$ & $x$ & $x$ & $x$ & $x$ & $x$ & $x$ & $x$ & $x$ & $x$ & \\
\hline RH19-7 & 1 & 19 & & 0 & $1 \mathrm{y}^{2}$ & 2 & $1 \mathrm{y} 5$ & 2 & 2 & 7.1 & 5.6 & 1 & 0 & $x$ & $x$ & 5YR4/2,5/4;10R5/4;N3/ & $5 Y R \quad 4 / 2,5 / 3,6 / 3,6 / 4$ & $x$ & $x$ & $x$ & $x$ & $x$ & $x$ & $x$ & $x$ & $x$ & $x$ & $x$ & $x$ & $x$ & $x$ & 1 y 3 \\
\hline RH19-7 & 1 & 19 & & 0 & $1 \mathrm{y}^{2}$ & 2 & $1 \mathrm{y} 5$ & 2 & 2 & 9.4 & 8.2 & 1 & 0 & $x$ & $x$ & 5YR4/2,5/4;10R5/4;N3/ & $5 Y R \quad 4 / 2,5 / 3,6 / 3,6 / 4$ & $x$ & $\mathrm{x}$ & $x$ & $x$ & $x$ & $x$ & $x$ & $x$ & $x$ & $x$ & $x$ & $x$ & $x$ & $x$ & \\
\hline RH19-7 & 1 & 19 & & 0 & $1 \mathrm{y} 2$ & 2 & $1 \mathrm{y} 5$ & 2 & 2 & 7.1 & 5.4 & 1 & 0 & $x$ & $x$ & 5YR4/2,5/4;10R5/4;N3/ & $5 Y R \quad 4 / 2,5 / 3,6 / 3,6 / 4$ & $x$ & $\mathrm{x}$ & $\mathrm{x}$ & $\mathrm{x}$ & $\mathrm{x}$ & $x$ & $x$ & $x$ & $x$ & $x$ & $x$ & $x$ & $\mathrm{x}$ & $x$ & 3 \\
\hline RH19-7 & 1 & 19 & & 0 & $1 \mathrm{y} 2$ & 2 & $1 \mathrm{y} 5$ & 2 & 2 & 7.0 & 5.9 & 1 & 0 & $x$ & $x$ & 5YR4/2,5/4;10R5/4;N3/ & $5 Y R \quad 4 / 2,5 / 3,6 / 3,6 / 4$ & $x$ & $\mathrm{x}$ & $x$ & $\mathrm{x}$ & $x$ & $x$ & $x$ & $x$ & $x$ & $x$ & $x$ & $x$ & $x$ & $x$ & \\
\hline RH19-7 & 2 & 19 & & 0 & $1 \mathrm{y} 2$ & 2 & $1 \mathrm{y} 5$ & 2 & 2 & 6.5 & 5.1 & 1 & 0 & $x$ & $x$ & 5YR4/2,5/4;10R5/4;N3/ & $5 Y R \quad 4 / 2,5 / 3,6 / 3,6 / 4$ & $x$ & $x$ & $x$ & $\mathrm{x}$ & $x$ & $x$ & $x$ & $x$ & $x$ & $x$ & $\mathrm{x}$ & $x$ & $x$ & $x$ & \\
\hline RH19-7 & 1 & 19 & & 0 & $1 \mathrm{y} 2$ & 2 & $1 \mathrm{y} 5$ & 2 & 2 & 9.2 & 7.0 & 1 & 0 & $\mathrm{X}$ & $x$ & 5YR4/2,5/4;10R5/4;N3/ & $5 Y R \quad 4 / 2,5 / 3,6 / 3,6 / 4$ & $x$ & $x$ & $x$ & $x$ & $x$ & $\mathrm{x}$ & $x$ & $x$ & $x$ & $x$ & $x$ & $x$ & $x$ & $x$ & 1 \\
\hline
\end{tabular}




\begin{tabular}{|c|c|c|c|c|c|c|c|c|c|c|c|c|c|c|c|c|c|c|c|c|c|c|c|c|c|c|c|c|c|c|c|c|}
\hline \multirow[b]{2}{*}{ Sitio } & \multirow[b]{2}{*}{$\begin{array}{c}\mathrm{Ni} \\
\mathrm{vel}\end{array}$} & & \multirow[b]{2}{*}{ FNA } & \multirow[b]{2}{*}{ Fgto } & \multicolumn{11}{|c|}{ Manufactura } & \multicolumn{2}{|c|}{ Cocción } & \multicolumn{5}{|c|}{ Borde-labio } & \multicolumn{6}{|c|}{ Asa } & \multicolumn{3}{|c|}{ Base } & \multirow[b]{2}{*}{ Alterac } \\
\hline & & & & & $\begin{array}{l}\text { Tec } \\
\text { lev }\end{array}$ & $\begin{array}{l}\text { For } \\
\text { ma }\end{array}$ & \begin{tabular}{|l} 
Mar \\
cas
\end{tabular} & $\begin{array}{l}\text { Sup } \\
\text { ext }\end{array}$ & \begin{tabular}{|c|}
$\begin{array}{c}\text { Sup } \\
\text { int }\end{array}$ \\
\end{tabular} & \begin{tabular}{|l|} 
Esp \\
max
\end{tabular} & \begin{tabular}{|l|} 
Esp \\
min
\end{tabular} & $\begin{array}{l}\text { Deco } \\
\text { pint }\end{array}$ & $\begin{array}{c}\text { Deco } \\
\text { corldsp }\end{array}$ & \begin{tabular}{|c|}
$\begin{array}{c}\text { Moti } \\
\text { vo }\end{array}$ \\
\end{tabular} & Estilo & Color sup ext & Color sup int & Diam & $\begin{array}{l}\text { Lrg } \\
\text { arc }\end{array}$ & \begin{tabular}{|c|}
$\%$ \\
arco \\
\end{tabular} & Dir & $\begin{array}{l}\text { For } \\
\text { ma }\end{array}$ & \begin{tabular}{|c|} 
Lar \\
go
\end{tabular} & $\begin{array}{c}\text { An } \\
\text { cho }\end{array}$ & Esp & $p \begin{array}{l}\text { Sec } \\
\text { ción }\end{array}$ & \begin{tabular}{l|l}
$\mathbf{c}$ & In \\
n & serc \\
\end{tabular} & \begin{tabular}{l|l}
$\mathrm{rc}$ & $\mathrm{P}$ \\
$\mathrm{r}$ & $\mathrm{si}$ \\
\end{tabular} & $\begin{array}{|ll|}\text { o } & \text { Diám } \\
\text { ic }\end{array}$ & $\begin{array}{c}\text { nor } \\
\text { fol }\end{array}$ & $\begin{array}{l}\text { Uni } \\
\text { i ón }\end{array}$ & \\
\hline $\mathrm{RH} 19-7$ & 1 & 19 & & 0 & $1 y_{2}$ & 2 & $1 \mathrm{y} 5$ & 2 & 2 & 5.8 & 5.5 & 1 & 0 & $\mathrm{x}$ & $\mathrm{x}$ & 5YR4/2,5/4;10R5/4;N3/ & $5 Y R \quad 4 / 2,5 / 3,6 / 3,6 / 4$ & $\mathrm{x}$ & $\mathrm{x}$ & $\mathrm{x}$ & $\mathrm{x}$ & $\mathrm{x}$ & $\mathrm{x}$ & $\mathrm{x}$ & $\mathrm{x}$ & $\mathrm{x}$ & $\mathrm{x}$ & $x$ & $\mathrm{x}$ & $\mathrm{x}$ & $\mathrm{x}$ & 3 \\
\hline RH19-7 & 1 & 19 & & 0 & $1 \mathrm{y} 2$ & 2 & $1 \mathrm{y} 5$ & 2 & 2 & 6.2 & 4.5 & 1 & 0 & $x$ & $\mathrm{x}$ & 5YR4/2,5/4;10R5/4;N3/ & $5 Y R \quad 4 / 2,5 / 3,6 / 3,6 / 4$ & $\mathrm{x}$ & $x$ & $\mathrm{x}$ & $x$ & $x$ & $x$ & $\mathrm{x}$ & $x$ & $x$ & $\mathrm{x}$ & $x$ & $x$ & $\mathrm{x}$ & $x$ & \\
\hline RH19-7 & 1 & 19 & & 0 & $1 \mathrm{y} 2$ & 2 & $1 \mathrm{y} 5$ & 2 & 2 & 6.0 & 4.5 & 1 & 0 & $x$ & $x$ & 5YR4/2,5/4;10R5/4;N3/ & $5 Y R \quad 4 / 2,5 / 3,6 / 3,6 / 4$ & $\mathrm{x}$ & $\mathrm{x}$ & $\mathrm{x}$ & $\mathrm{x}$ & $\mathrm{x}$ & $\mathrm{x}$ & $\mathrm{x}$ & $\mathrm{x}$ & $\mathrm{x}$ & $\mathrm{x}$ & $x$ & $\mathrm{x}$ & $\mathrm{x}$ & $\mathrm{x}$ & 1 y 3 \\
\hline RH19-7 & 1 & 19 & & 0 & $1 \mathrm{y} 2$ & 2 & $1 \mathrm{y} 5$ & 2 & 2 & 7.8 & 6.6 & 1 & 0 & $x$ & $\mathrm{x}$ & 5YR4/2,5/4;10R5/4;N3/ & $5 Y R \quad 4 / 2,5 / 3,6 / 3,6 / 4$ & $\mathrm{x}$ & $\mathrm{x}$ & $\mathrm{x}$ & $x$ & $\mathrm{x}$ & $x$ & $\mathrm{x}$ & $x$ & $x$ & $x$ & $x$ & $x$ & $\mathrm{x}$ & $x$ & 1 \\
\hline RH19-7 & 1 & 19 & & 0 & $1 \mathrm{y} 2$ & 2 & $1 \mathrm{y} 5$ & 2 & 2 & 5.8 & 4.1 & 1 & 0 & $x$ & $\mathrm{x}$ & 5YR4/2,5/4;10R5/4;N3/ & $5 Y R \quad 4 / 2,5 / 3,6 / 3,6 / 4$ & $\mathrm{x}$ & $\mathrm{x}$ & $\mathrm{x}$ & $x$ & $x$ & $x$ & $\mathrm{x}$ & $x$ & $x$ & $x$ & $x$ & $x$ & $x$ & $x$ & \\
\hline $\mathrm{RH} 19-7$ & 1 & 19 & & 0 & $1 \mathrm{y} 2$ & 2 & $1 \mathrm{y} 5$ & 2 & 2 & 10.6 & 8.5 & 1 & 0 & $\mathrm{x}$ & $\mathrm{x}$ & 5YR4/2,5/4;10R5/4;N3/ & $5 Y R \quad 4 / 2,5 / 3,6 / 3,6 / 4$ & $\mathrm{x}$ & $\mathrm{x}$ & $\mathrm{x}$ & $x$ & $\mathrm{x}$ & $\mathrm{x}$ & $\mathrm{x}$ & $x$ & $\mathrm{x}$ & $x$ & $x$ & $x$ & $\mathrm{x}$ & $x$ & 3 \\
\hline RH19-7 & 1 & 19 & & 0 & $1 \mathrm{y} 2$ & 2 & $1 \mathrm{y} 5$ & 2 & 2 & 5.5 & 4.8 & 1 & 0 & $\mathrm{x}$ & $\mathrm{x}$ & 5YR4/2,5/4;10R5/4;N3/ & $5 Y R \quad 4 / 2,5 / 3,6 / 3,6 / 4$ & $\mathrm{x}$ & $\mathrm{x}$ & $\mathrm{x}$ & $\mathrm{x}$ & $\mathrm{x}$ & $\mathrm{x}$ & $\mathrm{x}$ & $\mathrm{x}$ & $\mathrm{x}$ & $\mathrm{x}$ & $x$ & $\mathrm{x}$ & $\mathrm{x}$ & $\mathrm{x}$ & 1 \\
\hline RH19-7 & 1 & 19 & & 0 & $1 \mathrm{y} 2$ & 2 & $1 \mathrm{y} 5$ & 2 & 2 & 6.2 & 5.3 & 1 & 0 & $x$ & $\mathrm{x}$ & 5YR4/2,5/4;10R5/4;N3/ & $5 Y R \quad 4 / 2,5 / 3,6 / 3,6 / 4$ & $\mathrm{x}$ & $\mathrm{x}$ & $\mathrm{x}$ & $x$ & $\mathrm{x}$ & $\mathrm{x}$ & $\mathrm{x}$ & $x$ & $x$ & $x$ & $x$ & $x$ & $\mathrm{x}$ & $x$ & 1 \\
\hline RH19-7 & 1 & 19 & & 0 & $1 \mathrm{y} 2$ & 2 & $1 \mathrm{y} 5$ & 2 & 2 & 5.2 & 4.9 & 1 & 0 & $\mathrm{x}$ & $\mathrm{x}$ & 5YR4/2,5/4;10R5/4;N3/ & $5 Y R \quad 4 / 2,5 / 3,6 / 3,6 / 4$ & $\mathrm{x}$ & $\mathrm{x}$ & $\mathrm{x}$ & $\mathrm{x}$ & $\mathrm{x}$ & $\mathrm{x}$ & $\mathrm{x}$ & $\mathrm{x}$ & $\mathrm{x}$ & $\mathrm{x}$ & $x$ & $\mathrm{x}$ & $\mathrm{x}$ & $\mathrm{x}$ & \\
\hline RH19-7 & 1 & 19 & & 0 & $1 \mathrm{y} 2$ & 2 & $1 \mathrm{y} 5$ & 2 & 2 & 8.4 & 7.2 & 1 & 0 & $x$ & $x$ & 5YR4/2,5/4;10R5/4;N3/ & $5 Y R \quad 4 / 2,5 / 3,6 / 3,6 / 4$ & $x$ & $\mathrm{x}$ & $\mathrm{x}$ & $x$ & $\mathrm{x}$ & $x$ & $\mathrm{x}$ & $x$ & $x$ & $x$ & $x$ & $x$ & $x$ & $x$ & \\
\hline RH19-7 & 1 & 19 & & 0 & $1 \mathrm{y} 2$ & 2 & $1 \mathrm{y} 5$ & 2 & 2 & 5.2 & 4.6 & 1 & 0 & $\mathrm{x}$ & $\mathrm{x}$ & 5YR4/2,5/4;10R5/4;N3/ & $5 Y R \quad 4 / 2,5 / 3,6 / 3,6 / 4$ & $\mathrm{x}$ & $\mathrm{x}$ & $\mathrm{x}$ & $\mathrm{x}$ & $\mathrm{x}$ & $\mathrm{x}$ & $\mathrm{x}$ & $\mathrm{x}$ & $\mathrm{x}$ & $\mathrm{x}$ & $x$ & $\mathrm{x}$ & $\mathrm{x}$ & $\mathrm{x}$ & 1 \\
\hline $\mathrm{RH} 19-7$ & 1 & 19 & & 0 & $1 \mathrm{y} 2$ & 2 & $1 \mathrm{y} 5$ & 2 & 2 & 5.3 & 4.4 & 1 & 0 & $x$ & $x$ & 5YR4/2,5/4;10R5/4;N3/ & $5 Y R \quad 4 / 2,5 / 3,6 / 3,6 / 4$ & $\mathrm{x}$ & $x$ & $\mathrm{x}$ & $x$ & $\mathrm{x}$ & $x$ & $\mathrm{x}$ & $x$ & $x$ & $x$ & $x$ & $x$ & $\mathrm{x}$ & $x$ & 3 \\
\hline RH19-7 & 1 & 19 & & 0 & $1 \mathrm{y} 2$ & 2 & $1 \mathrm{y} 5$ & 2 & 2 & 5.4 & 4.6 & 1 & 0 & $\mathrm{x}$ & $\mathrm{x}$ & 5YR4/2,5/4;10R5/4;N3/ & $5 Y R \quad 4 / 2,5 / 3,6 / 3,6 / 4$ & $\mathrm{x}$ & $\mathrm{x}$ & $\mathrm{x}$ & $\mathrm{x}$ & $\mathrm{x}$ & $\mathrm{x}$ & $\mathrm{x}$ & $\mathrm{x}$ & $\mathrm{x}$ & $\mathrm{x}$ & $x$ & $\mathrm{x}$ & $\mathrm{x}$ & $\mathrm{x}$ & 3 \\
\hline RH19-7 & 1 & 19 & & 0 & $1 \mathrm{y} 2$ & 2 & $1 \mathrm{y} 5$ & 2 & 2 & 5.0 & 4.4 & 1 & 0 & $x$ & $\mathrm{x}$ & 5YR4/2,5/4;10R5/4;N3/ & $5 Y R \quad 4 / 2,5 / 3,6 / 3,6 / 4$ & $\mathrm{x}$ & $\mathrm{x}$ & $\mathrm{x}$ & $\mathrm{x}$ & $\mathrm{x}$ & $\mathrm{x}$ & $\mathrm{x}$ & $\mathrm{x}$ & $\mathrm{x}$ & $\mathrm{x}$ & $x$ & $\mathrm{x}$ & $\mathrm{x}$ & $\mathrm{x}$ & 3 \\
\hline RH19-7 & 2 & 19 & & 0 & $1 y^{2}$ & 2 & $1 \mathrm{y} 5$ & 2 & 2 & 6.3 & 5.2 & 1 & 0 & $\mathrm{x}$ & $\mathrm{x}$ & 5YR4/2,5/4;10R5/4;N3/ & 5YR 4/2, 5/3, 6/3, 6/4 & $\mathrm{x}$ & $\mathrm{x}$ & $\mathrm{x}$ & $\mathrm{x}$ & $\mathrm{x}$ & $\mathrm{x}$ & $\mathrm{x}$ & $\mathrm{x}$ & $\mathrm{x}$ & $\mathrm{x}$ & $x$ & $\mathrm{x}$ & $\mathrm{x}$ & $\mathrm{x}$ & 1 y 3 \\
\hline RH19-7 & 1 & 19 & & 0 & $1 \mathrm{y} 2$ & 2 & $1 \mathrm{y} 5$ & 2 & 2 & 5.8 & 5.5 & 1 & 0 & $x$ & $\mathrm{x}$ & 5YR4/2,5/4;10R5/4;N3/ & $5 Y R \quad 4 / 2,5 / 3,6 / 3,6 / 4$ & $x$ & $x$ & $\mathrm{x}$ & $x$ & $x$ & $x$ & $\mathrm{x}$ & $x$ & $x$ & $x$ & $x$ & $x$ & $x$ & $x$ & \\
\hline RH19-7 & 1 & 19 & & 0 & $1 y^{2}$ & 2 & $1 \mathrm{y} 5$ & 2 & 2 & 5.3 & 4.4 & 1 & 0 & $\mathrm{x}$ & $\mathrm{x}$ & 5YR4/2,5/4;10R5/4;N3/ & 5YR 4/2, 5/3, 6/3, 6/4 & $\mathrm{x}$ & $\mathrm{x}$ & $\mathrm{x}$ & $\mathrm{x}$ & $\mathrm{x}$ & $\mathrm{x}$ & $\mathrm{x}$ & $\mathrm{x}$ & $\mathrm{x}$ & $\mathrm{x}$ & $x$ & $\mathrm{x}$ & $\mathrm{x}$ & $\mathrm{x}$ & \\
\hline RH19-7 & 1 & 19 & & 0 & $1 \mathrm{y} 2$ & 2 & $1 \mathrm{y} 5$ & 2 & 2 & 5.9 & 4.3 & 1 & 0 & $x$ & $\mathrm{x}$ & 5YR4/2,5/4;10R5/4;N3/ & $5 Y R \quad 4 / 2,5 / 3,6 / 3,6 / 4$ & $x$ & $x$ & $\mathrm{x}$ & $x$ & $x$ & $\mathrm{x}$ & $\mathrm{x}$ & $x$ & $\mathrm{x}$ & $x$ & $x$ & $x$ & $\mathrm{x}$ & $x$ & 3 \\
\hline RH19-7 & 1 & 19 & & 0 & $1 \mathrm{y} 2$ & 2 & $1 y 5$ & 2 & 2 & 5.0 & 4.7 & 1 & 0 & $\mathrm{x}$ & $\mathrm{x}$ & 5YR4/2,5/4;10R5/4;N3/ & $5 Y R \quad 4 / 2,5 / 3,6 / 3,6 / 4$ & $\mathrm{x}$ & $\mathrm{x}$ & $\mathrm{x}$ & $\mathrm{x}$ & $\mathrm{x}$ & $\mathrm{x}$ & $\mathrm{x}$ & $\mathrm{x}$ & $\mathrm{x}$ & $\mathrm{x}$ & $x$ & $\mathrm{x}$ & $\mathrm{x}$ & $\mathrm{x}$ & 3 \\
\hline RH19-7 & 1 & 19 & & 0 & $1 \mathrm{y} 2$ & 2 & $1 \mathrm{y} 5$ & 2 & 2 & 5.9 & 4.8 & 1 & 0 & $x$ & $\mathrm{x}$ & 5YR4/2,5/4;10R5/4;N3/ & $5 Y R \quad 4 / 2,5 / 3,6 / 3,6 / 4$ & $\mathrm{x}$ & $x$ & $\mathrm{x}$ & $x$ & $x$ & $x$ & $x$ & $x$ & $x$ & $x$ & $x$ & $x$ & $x$ & $x$ & 3 \\
\hline RH19-7 & 1 & 19 & & 0 & $1 \mathrm{y} 2$ & 2 & $1 \mathrm{y} 5$ & 2 & 2 & 4.0 & 3.5 & 1 & 0 & $x$ & $x$ & 5YR4/2,5/4;10R5/4;N3/ & $5 Y R \quad 4 / 2,5 / 3,6 / 3,6 / 4$ & $x$ & $x$ & $x$ & $x$ & $x$ & $x$ & $x$ & $x$ & $x$ & $x$ & $x$ & $x$ & $x$ & $x$ & 3 \\
\hline RH19-7 & 1 & 19 & & 0 & $1 \mathrm{y} 2$ & 2 & $1 \mathrm{y} 5$ & 2 & 2 & 8.1 & 7.2 & 1 & 0 & $\mathrm{x}$ & $\mathrm{x}$ & 5YR4/2,5/4;10R5/4;N3/ & 5YR 4/2, 5/3, 6/3, 6/4 & $\mathrm{x}$ & $\mathrm{x}$ & $\mathrm{x}$ & $\mathrm{x}$ & $\mathrm{x}$ & $\mathrm{x}$ & $\mathrm{x}$ & $\mathrm{x}$ & $\mathrm{x}$ & $\mathrm{x}$ & $x$ & $\mathrm{x}$ & $\mathrm{x}$ & $\mathrm{x}$ & \\
\hline RH19-7 & 1 & 19 & & 0 & $1 \mathrm{y} 2$ & 2 & $1 \mathrm{y} 5$ & 2 & 2 & 7.5 & 6.7 & 1 & 0 & $x$ & $x$ & 5YR4/2,5/4;10R5/4;N3/ & $5 Y R \quad 4 / 2,5 / 3,6 / 3,6 / 4$ & $x$ & $x$ & $x$ & $x$ & $x$ & $x$ & $x$ & $x$ & $x$ & $x$ & $x$ & $x$ & $x$ & $x$ & 3 \\
\hline RH19-7 & 1 & 19 & & 0 & $1 y_{2}$ & 2 & $1 \mathrm{y} 5$ & 2 & 2 & 5.4 & 4.4 & 1 & 0 & $\mathrm{x}$ & $\mathrm{x}$ & 5YR4/2,5/4;10R5/4;N3/ & $5 Y R$ 4/2, 5/3, 6/3,6/4 & $\mathrm{x}$ & $\mathrm{x}$ & $\mathrm{x}$ & $\mathrm{x}$ & $\mathrm{x}$ & $\mathrm{x}$ & $\mathrm{x}$ & $\mathrm{x}$ & $\mathrm{x}$ & $\mathrm{x}$ & $x$ & $\mathrm{x}$ & $\mathrm{x}$ & $\mathrm{x}$ & 3 \\
\hline RH19-7 & 1 & 19 & & 0 & $1 \mathrm{y} 2$ & 2 & $1 \mathrm{y} 5$ & 2 & 2 & 6.5 & 4.9 & 1 & 0 & $\mathrm{x}$ & $x$ & 5YR4/2,5/4;10R5/4;N3/ & $5 Y R \quad 4 / 2,5 / 3,6 / 3,6 / 4$ & $\mathrm{x}$ & $\mathrm{x}$ & $\mathrm{x}$ & $x$ & $x$ & $x$ & $x$ & $x$ & $x$ & $x$ & $x$ & $x$ & $x$ & $x$ & 3 \\
\hline RH19-7 & 1 & 19 & & 0 & $1 \mathrm{y} 2$ & 2 & $1 \mathrm{y} 5$ & 2 & 2 & 6.3 & 5.3 & 1 & 0 & $x$ & $x$ & 5YR4/2,5/4;10R5/4;N3/ & $5 Y R \quad 4 / 2,5 / 3,6 / 3,6 / 4$ & $\mathrm{x}$ & $x$ & $\mathrm{x}$ & $\mathrm{x}$ & $x$ & $\mathrm{x}$ & $x$ & $x$ & $x$ & $x$ & $x$ & $x$ & $\mathrm{x}$ & $x$ & 3 \\
\hline RH19-7 & 1 & 19 & & 0 & $1 \mathrm{y} 2$ & 2 & $1 \mathrm{y} 5$ & 2 & 2 & 7.0 & 6.8 & 1 & 0 & $x$ & $\mathrm{x}$ & 5YR4/2,5/4;10R5/4;N3/ & $5 Y R \quad 4 / 2,5 / 3,6 / 3,6 / 4$ & $x$ & $x$ & $\mathrm{x}$ & $x$ & $x$ & $x$ & $x$ & $x$ & $\mathrm{x}$ & $x$ & $x$ & $x$ & $x$ & $x$ & 3 \\
\hline RH19-7 & 1 & 20 & & 1 & 1 & 0 & 1 & 2 & 2 & 5.8 & 4.7 & 0 & 0 & $x$ & $\mathrm{x}$ & 5 YR 6/4, 5/2, 5/4, 4/1 & $7,5 Y R \quad 4 / 1,4 / 2,5 / 2,5 / 4$ & $\begin{array}{l}4 \\
49\end{array}$ & 3.6 & 6 & 2 & 2 & $x$ & $x$ & $x$ & $x$ & $x$ & $x$ & $x$ & $x$ & $x$ & \\
\hline RH19-7 & 1 & 20 & & 1 & 1 & 0 & 1 & 2 & 2 & 6.2 & 5.9 & 0 & 0 & $x$ & $x$ & 5 YR 6/4, 5/2, 5/4, 4/1 & 7,5 YR $4 / 1,4 / 2,5 / 2,5 / 4$ & 4 indet & 1.5 & indet & 2 & 2 & $x$ & $x$ & $x$ & $x$ & $x$ & $x$ & $x$ & $x$ & $x$ & \\
\hline $\mathrm{RH} 19-7$ & 1 & 20 & & 3 & 1 & 0 & 1 & 2 & 2 & 21 & 11 & 0 & 0 & $\mathrm{x}$ & $x$ & 5 YR 6/4, 5/2, 5/4, 4/1 & 7,5 YR $4 / 1,4 / 2,5 / 2,5 / 4$ & $\begin{array}{l}4 \times \\
\end{array}$ & $x$ & $\mathrm{x}$ & $x$ & $\mathrm{x}$ & $3.8 \mathrm{fr}$ & $\begin{array}{rl}r & 3.2 \\
\end{array}$ & 1.2 & 4 & 3 & 3 & $x$ & $\mathrm{x}$ & $x$ & 3 \\
\hline $\mathrm{RH} 19-7$ & 1 & 20 & & 0 & 1 & 0 & 1 & 2 & 2 & 6.0 & 4.8 & 0 & 0 & $\mathrm{x}$ & $\mathrm{x}$ & 5 YR 6/4, 5/2, 5/4, 4/1 & 7,5 YR $4 / 1,4 / 2,5 / 2,5 / 4$ & \begin{tabular}{l|l}
4 & $x$ \\
\end{tabular} & $x$ & $\mathrm{x}$ & $x$ & $\mathrm{x}$ & $\mathrm{x}$ & $\mathrm{x}$ & $x$ & $x$ & $x$ & $\underline{x}$ & $\mathrm{x}$ & $\mathrm{x}$ & $x$ & 3 y 4 \\
\hline $\mathrm{RH} 19-7$ & 1 & 20 & & 0 & 1 & 0 & 1 & 2 & 2 & 7.7 & 5.5 & 0 & 0 & $\mathrm{x}$ & $\mathrm{x}$ & 5 YR 6/4, 5/2, 5/4, 4/1 & 7,5 YR 4/1, 4/2, 5/2, 5/4 & $\begin{array}{l}4 \times \\
\end{array}$ & $x$ & $\mathrm{x}$ & $\mathrm{x}$ & $\mathrm{x}$ & $\mathrm{x}$ & $\mathrm{x}$ & $x$ & $\mathrm{x}$ & $x$ & $x$ & $x$ & $\mathrm{x}$ & $\mathrm{x}$ & 3 y 4 \\
\hline RH19-7 & 1 & 20 & & 0 & 1 & 0 & 1 & 2 & 2 & 6.0 & 5.3 & 0 & 0 & $x$ & $x$ & 5 YR 6/4, 5/2, 5/4, 4/1 & 7,5 YR $4 / 1,4 / 2,5 / 2,5 / 4$ & $\begin{array}{l}4 \\
x\end{array}$ & $\mathrm{x}$ & $\mathrm{x}$ & $x$ & $x$ & $x$ & $x$ & $x$ & $x$ & $x$ & $x$ & $x$ & $x$ & $x$ & \\
\hline RH19-7 & 1 & 20 & & 0 & 1 & 0 & 1 & 2 & 2 & 5.6 & 5.1 & 0 & 0 & $x$ & $x$ & 5 YR 6/4, 5/2, 5/4, 4/1 & 7,5 YR $4 / 1,4 / 2,5 / 2,5 / 4$ & \begin{tabular}{l|l}
4 & $x$ \\
\end{tabular} & $\mathrm{x}$ & $\mathrm{x}$ & $x$ & $x$ & $x$ & $x$ & $x$ & $\mathrm{x}$ & $x$ & $x$ & $x$ & $\mathrm{x}$ & $x$ & \\
\hline RH19-7 & 1 & 20 & & 0 & 1 & 0 & 1 & 2 & 2 & 5.4 & 5.2 & 0 & 0 & $x$ & $x$ & 5 YR 6/4, 5/2, 5/4, 4/1 & 7,5 YR $4 / 1,4 / 2,5 / 2,5 / 4$ & $4 \mid x$ & $\mathrm{x}$ & $\mathrm{x}$ & $x$ & $x$ & $x$ & $x$ & $x$ & $x$ & $x$ & $x$ & $x$ & $\mathrm{x}$ & $x$ & \\
\hline $\mathrm{RH} 19-7$ & 1 & 20 & & 0 & 1 & 0 & 1 & 2 & 2 & 6.8 & 6.2 & 0 & 0 & $\mathrm{x}$ & $x$ & 5 YR $6 / 4,5 / 2,5 / 4,4 / 1$ & 7,5 YR $4 / 1,4 / 2,5 / 2,5 / 4$ & $\begin{array}{l}4 \times \\
\end{array}$ & $\mathrm{x}$ & $\mathrm{x}$ & $x$ & $\mathrm{x}$ & $\mathrm{x}$ & $\mathrm{x}$ & $x$ & $x$ & $x$ & $x$ & $x$ & $\mathrm{x}$ & $x$ & 3 \\
\hline $\mathrm{RH} 19-7$ & 1 & 20 & & 0 & 1 & 0 & 1 & 2 & 2 & 6.7 & 5.4 & 0 & 0 & $\mathrm{x}$ & $\mathrm{x}$ & 5 YR 6/4, 5/2, 5/4, 4/1 & 7,5 YR $4 / 1,4 / 2,5 / 2,5 / 4$ & $\begin{array}{l}4 \times \\
\end{array}$ & $\mathrm{x}$ & $\mathrm{x}$ & $x$ & $\mathrm{x}$ & $\mathrm{x}$ & $\mathrm{x}$ & $x$ & $x$ & $x$ & $x$ & $\mathrm{x}$ & $\mathrm{x}$ & $x$ & 3 \\
\hline RH19-7 & 1 & 20 & & 0 & 1 & 0 & 1 & 2 & 2 & 6.3 & 5.4 & 0 & 0 & $x$ & $x$ & 5 YR $6 / 4,5 / 2,5 / 4,4 / 1$ & 7,5 YR $4 / 1,4 / 2,5 / 2,5 / 4$ & \begin{tabular}{l|l}
4 & $x$ \\
\end{tabular} & $\mathrm{x}$ & $x$ & $x$ & $\mathrm{x}$ & $\mathrm{x}$ & $\mathrm{x}$ & $x$ & $x$ & $x$ & $x$ & $x$ & $\mathrm{x}$ & $x$ & 3 y 4 \\
\hline $\mathrm{RH} 19-7$ & 1 & 20 & & 0 & 1 & 0 & 1 & 2 & 2 & 6.8 & 6.2 & 0 & 0 & $\mathrm{x}$ & $\mathrm{x}$ & 5 YR 6/4, 5/2, 5/4, 4/1 & 7,5YR 4/1, 4/2, 5/2, 5/4 & $4 \quad x$ & $\mathrm{x}$ & $\mathrm{x}$ & $x$ & $\mathrm{x}$ & $\mathrm{x}$ & $\mathrm{x}$ & $\mathrm{x}$ & $x$ & $\mathrm{x}$ & $x$ & $\mathrm{x}$ & $\mathrm{x}$ & $x$ & 3 y 4 \\
\hline
\end{tabular}




\begin{tabular}{|c|c|c|c|c|c|c|c|c|c|c|c|c|c|c|c|c|c|c|c|c|c|c|c|c|c|c|c|c|c|c|c|c|}
\hline \multirow[b]{2}{*}{ Sitio } & \multirow[b]{2}{*}{$\begin{array}{c}\mathrm{Ni} \\
\text { vel }\end{array}$} & \multirow[b]{2}{*}{ GF } & \multirow[b]{2}{*}{ FNA } & \multirow[b]{2}{*}{ Fgto } & \multicolumn{11}{|c|}{ Manufactura } & \multicolumn{2}{|c|}{ Cocción } & \multicolumn{5}{|c|}{ Borde-labio } & \multicolumn{6}{|c|}{ Asa } & \multicolumn{3}{|c|}{ Base } & \multirow[b]{2}{*}{ Alterac } \\
\hline & & & & & $\begin{array}{l}\text { Tec } \\
\text { lev }\end{array}$ & $\begin{array}{l}\text { For } \\
\text { ma }\end{array}$ & $\begin{array}{l}\text { Mar } \\
\text { cas }\end{array}$ & $\begin{array}{c}\text { Sup } \\
\text { ext }\end{array}$ & \begin{tabular}{|c|} 
Sup \\
int
\end{tabular} & $\begin{array}{l}\text { Esp } \\
\text { max }\end{array}$ & $\begin{array}{l}\text { Esp } \\
\text { min }\end{array}$ & $\begin{array}{c}\text { Deco } \\
\text { pint }\end{array}$ & $\begin{array}{c}\text { Deco } \\
\text { cor/dsp }\end{array}$ & \begin{tabular}{|c|}
$\begin{array}{c}\text { Moti } \\
\text { vo }\end{array}$ \\
\end{tabular} & Estilo & sup ext & Co & Diam & $\begin{array}{l}\text { Lrg } \\
\text { arc }\end{array}$ & $\begin{array}{c}\% \\
\operatorname{arco} \\
\end{array}$ & & $\begin{array}{l}\text { For } \\
\text { ma }\end{array}$ & \begin{tabular}{|l|} 
Lar \\
go
\end{tabular} & $\begin{array}{c}\begin{array}{c}\text { An } \\
\text { cho }\end{array} \\
\end{array}$ & Esp & $\begin{array}{l}\text { Sec } \\
\text { ción }\end{array}$ & $\begin{array}{l}\text { In } \\
\text { serc }\end{array}$ & $\begin{array}{l}\mathrm{Po} \\
\mathrm{sic}\end{array}$ & & $\begin{array}{c}\text { Mor } \\
\text { fol }\end{array}$ & $\begin{array}{l}\text { Uni } \\
\text { ón }\end{array}$ & \\
\hline RH19-7 & 1 & 20 & & 0 & 1 & 0 & 1 & 2 & 2 & 7.9 & 6.4 & 0 & 0 & $\mathrm{x}$ & $x$ & 5 YR $6 / 4,5 / 2,5 / 4,4 / 1$ & 7,5 YR $4 / 1,4 / 2,5 / 2,5 / 4$ & $\begin{array}{l}4 \quad x \\
\end{array}$ & $\mathrm{x}$ & $\mathrm{x}$ & $x$ & $x$ & $x$ & $x$ & $x$ & $\mathrm{x}$ & $x$ & $x$ & $x$ & $\mathrm{x}$ & $x$ & 4 \\
\hline RH19-7 & 1 & 20 & & 0 & 1 & 0 & 1 & 2 & 2 & 9.3 & 5.2 & 0 & 0 & $x$ & $x$ & 5 YR 6/4, 5/2, 5/4, 4/1 & $7,5 Y R$ 4/1, 4/2, 5/2, 5/4 & \begin{tabular}{l|l}
4 & $x$ \\
\end{tabular} & $\mathrm{x}$ & $\mathrm{x}$ & $x$ & $\mathrm{x}$ & $\mathrm{x}$ & $\mathrm{x}$ & $x$ & $\mathrm{x}$ & $x$ & $\mathrm{x}$ & $x$ & $\mathrm{x}$ & $x$ & 3 y 4 \\
\hline RH19-7 & 2 & 20 & & 0 & 1 & 0 & 1 & 2 & 2 & 8.1 & 6.3 & 0 & 0 & $x$ & $\mathrm{x}$ & 5 YR 6/4, 5/2, 5/4, 4/1 & 7,5 YR $4 / 1,4 / 2,5 / 2,5 / 4$ & \begin{tabular}{l|l}
4 & $x$ \\
\end{tabular} & $\mathrm{x}$ & $\mathrm{x}$ & $x$ & $\mathrm{x}$ & $\mathrm{x}$ & $\mathrm{x}$ & $x$ & $\mathrm{x}$ & $\mathrm{x}$ & $\mathrm{x}$ & $\mathrm{x}$ & $\mathrm{x}$ & $x$ & 4 \\
\hline RH19-7 & 1 & 20 & & 0 & 1 & 0 & 1 & 2 & 2 & 6.1 & 5.3 & 0 & 0 & $x$ & $x$ & 5 YR 6/4, 5/2, 5/4, 4/1 & $7,5 Y R$ 4/1, 4/2, 5/2, 5/4 & \begin{tabular}{l|l}
4 & $x$ \\
\end{tabular} & $\mathrm{x}$ & $\mathrm{x}$ & $x$ & $\mathrm{x}$ & $\mathrm{x}$ & $\mathrm{x}$ & $x$ & $\mathrm{x}$ & $x$ & $\mathrm{x}$ & $\mathrm{x}$ & $\mathrm{x}$ & $x$ & 4 \\
\hline RH19-7 & 2 & 20 & & 0 & 1 & 0 & 1 & 2 & 2 & 5.2 & 4.1 & 0 & 0 & $\mathrm{x}$ & $x$ & 5 YR 6/4, 5/2, 5/4, 4/1 & $7,5 Y R$ 4/1, 4/2, 5/2, 5/4 & \begin{tabular}{l|l}
4 & $x$ \\
\end{tabular} & $x$ & $\mathrm{x}$ & $x$ & $\mathrm{x}$ & $\mathrm{x}$ & $\mathrm{x}$ & $x$ & $x$ & $\mathrm{x}$ & $x$ & $\mathrm{x}$ & $\mathrm{x}$ & $x$ & 1 \\
\hline RH19-7 & 1 & 20 & & 0 & 1 & 0 & 1 & 2 & 2 & 11.7 & 7.9 & 0 & 0 & $\mathrm{x}$ & $\mathrm{x}$ & 5 YR 6/4, 5/2, 5/4, 4/1 & 7,5 YR $4 / 1,4 / 2,5 / 2,5 / 4$ & \begin{tabular}{l|l} 
& $x$ \\
\end{tabular} & $\mathrm{x}$ & $\mathrm{x}$ & $x$ & $\mathrm{x}$ & $\mathrm{x}$ & $\mathrm{x}$ & $\mathrm{x}$ & $x$ & $x$ & $x$ & $\mathrm{x}$ & $\mathrm{x}$ & $x$ & 1 \\
\hline RH19-7 & 1 & 20 & & 0 & 1 & 0 & 1 & 2 & 2 & 7.3 & 6.7 & 0 & 0 & $\mathrm{x}$ & $x$ & 5 YR $6 / 4,5 / 2,5 / 4,4 / 1$ & 7,5 YR $4 / 1,4 / 2,5 / 2,5 / 4$ & \begin{tabular}{l|l}
4 \\
\end{tabular} & $x$ & $\mathrm{x}$ & $x$ & $x$ & $x$ & $\mathrm{x}$ & $\mathrm{x}$ & $\mathrm{x}$ & $x$ & $\mathrm{x}$ & $\mathrm{x}$ & $\mathrm{x}$ & $x$ & 1 y 3 \\
\hline RH19-7 & 1 & 20 & & 0 & 1 & 0 & 1 & 2 & 2 & 5.7 & 4.9 & 0 & 0 & $x$ & $x$ & 5 YR $6 / 4,5 / 2,5 / 4,4 / 1$ & 7,5 YR $4 / 1,4 / 2,5 / 2,5 / 4$ & \begin{tabular}{l|l}
4 \\
\end{tabular} & $\mathrm{x}$ & $\mathrm{x}$ & $x$ & $x$ & $x$ & $x$ & $x$ & $x$ & $\mathrm{x}$ & $x$ & $\mathrm{x}$ & $x$ & $x$ & 3 y 4 \\
\hline RH19-7 & 1 & 20 & & 0 & 1 & 0 & 1 & 2 & 2 & 6.0 & 3.4 & 0 & 0 & $x$ & $x$ & 5 YR 6/4, 5/2, 5/4, 4/1 & $7,5 Y R$ 4/1, 4/2, 5/2, 5/4 & \begin{tabular}{l|l}
4 & $x$ \\
\end{tabular} & $\mathrm{x}$ & $\mathrm{x}$ & $x$ & $x$ & $\mathrm{x}$ & $\mathrm{x}$ & $x$ & $\mathrm{x}$ & $\mathrm{x}$ & $\mathrm{x}$ & $\mathrm{x}$ & $\mathrm{x}$ & $x$ & 1 y 3 \\
\hline RH19-7 & 1 & 20 & & 0 & 1 & 0 & 1 & 2 & 2 & 7.5 & 5.5 & 0 & 0 & $x$ & $x$ & 5 YR 6/4, 5/2, 5/4, 4/1 & $7,5 Y R$ 4/1, 4/2, 5/2, 5/4 & \begin{tabular}{l|l}
4 & $x$ \\
\end{tabular} & $x$ & $\mathrm{x}$ & $x$ & $\mathrm{x}$ & $\mathrm{x}$ & $\mathrm{x}$ & $x$ & $x$ & $\mathrm{x}$ & $x$ & $\mathrm{x}$ & $\mathrm{x}$ & $x$ & 3 \\
\hline RH19-7 & 1 & 20 & & 0 & 1 & 0 & 1 & 2 & 2 & 7.6 & 5.3 & 0 & 0 & $x$ & $\mathrm{x}$ & 5 YR 6/4, 5/2, 5/4, 4/1 & $7,5 Y R$ 4/1, 4/2, 5/2, 5/4 & \begin{tabular}{l|l}
4 & $x$ \\
\end{tabular} & $x$ & $\mathrm{x}$ & $x$ & $\mathrm{x}$ & $\mathrm{x}$ & $\mathrm{x}$ & $x$ & $\mathrm{x}$ & $\mathrm{x}$ & $x$ & $x$ & $\mathrm{x}$ & $x$ & 3 \\
\hline RH19-7 & 1 & 20 & & 0 & 1 & 0 & 1 & 2 & 2 & 7.9 & 6.2 & 0 & 0 & $\mathrm{x}$ & $\mathrm{x}$ & 5 YR 6/4, 5/2, 5/4, 4/1 & 7,5 YR $4 / 1,4 / 2,5 / 2,5 / 4$ & \begin{tabular}{l|l}
4 & $x$ \\
\end{tabular} & $\mathrm{x}$ & $\mathrm{x}$ & $x$ & $\mathrm{x}$ & $\mathrm{x}$ & $\mathrm{x}$ & $\mathrm{x}$ & $\mathrm{x}$ & $x$ & $\mathrm{x}$ & $\mathrm{x}$ & $\mathrm{x}$ & $x$ & 4 \\
\hline RH19-7 & 1 & 20 & & 0 & 1 & 0 & 1 & 2 & 2 & 7.2 & 6.6 & 0 & 0 & $\mathrm{x}$ & $x$ & 5 YR 6/4, 5/2, 5/4, 4/1 & 7,5 YR $4 / 1,4 / 2,5 / 2,5 / 4$ & $\begin{array}{ll}4 \\
\end{array}$ & $x$ & $\mathrm{x}$ & $x$ & $x$ & $\mathrm{x}$ & $\mathrm{x}$ & $x$ & $\mathrm{x}$ & $\mathrm{x}$ & $\mathrm{x}$ & $x$ & $\mathrm{x}$ & $x$ & 3 \\
\hline RH19-7 & 1 & 20 & & 0 & 1 & 0 & 1 & 2 & 2 & 5.3 & 4.6 & 0 & 0 & $x$ & $x$ & 5 YR $6 / 4,5 / 2,5 / 4,4 / 1$ & $7,5 Y R \quad 4 / 1,4 / 2,5 / 2,5 / 4$ & \begin{tabular}{l|l}
4 \\
\end{tabular} & $x$ & $\mathrm{x}$ & $x$ & $x$ & $x$ & $x$ & $x$ & $x$ & $x$ & $x$ & $x$ & $x$ & $x$ & 4 \\
\hline RH19-7 & 1 & 20 & & 0 & 1 & 0 & 1 & 2 & 2 & 5.3 & 4.9 & 0 & 0 & $x$ & $x$ & 5 YR $6 / 4,5 / 2,5 / 4,4 / 1$ & $7,5 Y R$ 4/1, 4/2, 5/2, 5/4 & \begin{tabular}{l|l}
4 & $x$ \\
\end{tabular} & $x$ & $\mathrm{x}$ & $x$ & $x$ & $x$ & $x$ & $x$ & $x$ & $x$ & $x$ & $x$ & $x$ & $x$ & 3 y 4 \\
\hline RH19-7 & 1 & 20 & & 0 & 1 & 0 & 1 & 2 & 2 & 7.4 & 6.1 & 0 & 0 & $x$ & $x$ & 5 YR 6/4, 5/2, 5/4, 4/1 & $7,5 Y R$ 4/1, 4/2, 5/2, 5/4 & \begin{tabular}{l|l}
4 & $x$ \\
\end{tabular} & $x$ & $\mathrm{x}$ & $x$ & $x$ & $x$ & $x$ & $x$ & $x$ & $x$ & $x$ & $\mathrm{x}$ & $x$ & $x$ & 3 y 4 \\
\hline RH19-7 & 1 & 20 & & 0 & 1 & 0 & 1 & 2 & 2 & 6.8 & 6.3 & 0 & 0 & $x$ & $\mathrm{x}$ & 5 YR 6/4, 5/2, 5/4, 4/1 & $7,5 Y R$ 4/1, 4/2, 5/2, 5/4 & \begin{tabular}{l|l}
4 & $x$ \\
\end{tabular} & $x$ & $\mathrm{x}$ & $x$ & $x$ & $x$ & $x$ & $x$ & $x$ & $x$ & $x$ & $x$ & $x$ & $x$ & 1 y 3 \\
\hline RH19-7 & 1 & 20 & & 0 & 1 & 0 & 1 & 2 & 2 & 6.4 & 5.3 & 0 & 0 & $x$ & $\mathrm{x}$ & 5 YR 6/4, 5/2, 5/4, 4/1 & $7,5 Y R$ 4/1, 4/2, 5/2, 5/4 & \begin{tabular}{l|l}
4 & $x$ \\
\end{tabular} & $x$ & $\mathrm{x}$ & $x$ & $\mathrm{x}$ & $x$ & $x$ & $x$ & $x$ & $x$ & $x$ & $\mathrm{x}$ & $x$ & $x$ & 3 \\
\hline RH19-7 & 1 & 20 & & 0 & 1 & 0 & 1 & 2 & 2 & 5.0 & 4.6 & 0 & 0 & $x$ & $x$ & 5 YR 6/4, 5/2, 5/4, 4/1 & 7,5 YR $4 / 1,4 / 2,5 / 2,5 / 4$ & \begin{tabular}{|l|l|}
4 \\
\end{tabular} & $x$ & $\mathrm{x}$ & $\mathrm{x}$ & $\mathrm{x}$ & $x$ & $x$ & $x$ & $x$ & $x$ & $x$ & $x$ & $x$ & $x$ & 3 \\
\hline RH19-7 & 1 & 20 & & 0 & 1 & 0 & 1 & 2 & 2 & 5.3 & 4.7 & 0 & 0 & $x$ & $x$ & 5 YR $6 / 4,5 / 2,5 / 4,4 / 1$ & $7,5 Y R \quad 4 / 1,4 / 2,5 / 2,5 / 4$ & \begin{tabular}{l|l}
4 \\
\end{tabular} & $x$ & $\mathrm{x}$ & $x$ & $\mathrm{x}$ & $x$ & $x$ & $x$ & $x$ & $x$ & $x$ & $x$ & $x$ & $x$ & \\
\hline RH19-7 & 1 & 20 & & 0 & 1 & 0 & 1 & 2 & 2 & 4.5 & 4.3 & 0 & 0 & $x$ & $x$ & 5 YR 6/4, 5/2, 5/4, 4/1 & $7,5 Y R \quad 4 / 1,4 / 2,5 / 2,5 / 4$ & \begin{tabular}{l|l}
4 & $x$ \\
\end{tabular} & $x$ & $\mathrm{x}$ & $x$ & $x$ & $\mathrm{x}$ & $\mathrm{x}$ & $x$ & $x$ & $x$ & $x$ & $x$ & $\mathrm{x}$ & $\mathrm{x}$ & 4 \\
\hline RH19-7 & 1 & 20 & & 0 & 1 & 0 & 1 & 2 & 2 & 6.8 & 6.2 & 0 & 0 & $x$ & $x$ & 5 YR 6/4, 5/2, 5/4, 4/1 & $7,5 Y R$ 4/1, 4/2, 5/2, 5/4 & \begin{tabular}{l|l}
4 & $x$ \\
\end{tabular} & $x$ & $\mathrm{x}$ & $x$ & $x$ & $x$ & $x$ & $x$ & $x$ & $x$ & $x$ & $\mathrm{x}$ & $x$ & $x$ & 3 \\
\hline RH19-7 & 1 & 20 & & 0 & 1 & 0 & 1 & 2 & 2 & 6.1 & 5.9 & 0 & 0 & $x$ & $x$ & 5 YR 6/4, 5/2, 5/4, 4/1 & $7,5 Y R$ 4/1, 4/2, 5/2, 5/4 & \begin{tabular}{l|l}
4 & $x$ \\
\end{tabular} & $x$ & $\mathrm{x}$ & $x$ & $\mathrm{x}$ & $x$ & $x$ & $x$ & $x$ & $x$ & $x$ & $x$ & $x$ & $x$ & \\
\hline RH19-7 & 1 & 20 & & 0 & 1 & 0 & 1 & 2 & 2 & 6.4 & 6.0 & 0 & 0 & $x$ & $x$ & 5 YR 6/4, 5/2, 5/4, 4/1 & $7,5 Y R$ 4/1, 4/2, 5/2, 5/4 & \begin{tabular}{l|l}
4 & $x$ \\
\end{tabular} & $x$ & $\mathrm{x}$ & $x$ & $\mathrm{x}$ & $x$ & $x$ & $x$ & $x$ & $x$ & $x$ & $\mathrm{x}$ & $x$ & $\mathrm{x}$ & 4 \\
\hline RH19-7 & 1 & 20 & & 0 & 1 & 0 & 1 & 2 & 2 & 5.5 & 4.8 & 0 & 0 & $x$ & $x$ & 5 YR 6/4, 5/2, 5/4, 4/1 & $7,5 Y R$ 4/1, 4/2, 5/2, 5/4 & \begin{tabular}{|l|l|}
4 & $x$ \\
\end{tabular} & $x$ & $\mathrm{x}$ & $x$ & $\mathrm{x}$ & $x$ & $x$ & $x$ & $x$ & $x$ & $x$ & $\mathrm{x}$ & $x$ & $\mathrm{x}$ & \\
\hline RH19-7 & 1 & 20 & & 0 & 1 & 0 & 1 & 2 & 2 & 5.3 & 4.8 & 0 & 0 & $x$ & $x$ & 5 YR 6/4, 5/2, 5/4, 4/1 & $7,5 Y R \quad 4 / 1,4 / 2,5 / 2,5 / 4$ & \begin{tabular}{l|l}
4 \\
\end{tabular} & $x$ & $x$ & $x$ & $x$ & $x$ & $x$ & $x$ & $x$ & $x$ & $x$ & $x$ & $x$ & $x$ & 1 \\
\hline RH19-7 & 2 & 20 & & 0 & 1 & 0 & 1 & 2 & 2 & 5.4 & 5.2 & 0 & 0 & $x$ & $x$ & 5 YR 6/4, 5/2, 5/4, 4/1 & $7,5 Y R$ 4/1, 4/2, 5/2, 5/4 & \begin{tabular}{l|l}
4 & $x$ \\
\end{tabular} & $x$ & $x$ & $x$ & $x$ & $x$ & $x$ & $x$ & $x$ & $x$ & $x$ & $x$ & $x$ & $\mathrm{x}$ & \\
\hline $\mathrm{RH} 19-7$ & 1 & 20 & & 0 & 1 & 0 & 1 & 2 & 2 & 7.1 & 6.2 & 0 & 0 & $x$ & $x$ & 5 YR $6 / 4,5 / 2,5 / 4,4 / 1$ & $7,5 Y R \quad 4 / 1,4 / 2,5 / 2,5 / 4$ & \begin{tabular}{|l|l|} 
& $x$
\end{tabular} & $x$ & $x$ & $x$ & $x$ & $x$ & $x$ & $x$ & $x$ & $x$ & $x$ & $x$ & $x$ & $x$ & 3 \\
\hline RH19-7 & 1 & 20 & & 0 & 1 & 0 & 1 & 2 & 2 & 6.0 & 5.2 & 0 & 0 & $x$ & $\mathrm{x}$ & 5 YR 6/4, 5/2, 5/4, 4/1 & $7,5 Y R \quad 4 / 1,4 / 2,5 / 2,5 / 4$ & \begin{tabular}{l|l}
4 & $x$ \\
\end{tabular} & $x$ & $\mathrm{x}$ & $x$ & $\mathrm{x}$ & $x$ & $x$ & $x$ & $x$ & $x$ & $x$ & $x$ & $x$ & $x$ & \\
\hline RH19-7 & 1 & 20 & & 0 & 1 & 0 & 1 & 2 & 2 & 4.5 & 4.4 & 0 & 0 & $x$ & $x$ & 5 YR 6/4, 5/2, 5/4, 4/1 & $7,5 Y R \quad 4 / 1,4 / 2,5 / 2,5 / 4$ & \begin{tabular}{l|l} 
& $x$ \\
\end{tabular} & $\mathrm{x}$ & $\mathrm{x}$ & $\mathrm{x}$ & $x$ & $x$ & $x$ & $\mathrm{x}$ & $x$ & $x$ & $x$ & $x$ & $\mathrm{x}$ & $x$ & 1 \\
\hline RH19-7 & 1 & 20 & & 0 & 1 & 0 & 1 & 2 & 2 & 8.1 & 7.4 & 0 & 0 & $x$ & $x$ & 5 YR 6/4, 5/2, 5/4, 4/1 & $7,5 Y R \quad 4 / 1,4 / 2,5 / 2,5 / 4$ & \begin{tabular}{l|l}
4 & $x$ \\
\end{tabular} & $x$ & $\mathrm{x}$ & $\mathrm{x}$ & $\mathrm{x}$ & $x$ & $x$ & $x$ & $x$ & $x$ & $\mathrm{x}$ & $x$ & $x$ & $\mathrm{x}$ & 3 \\
\hline RH19-7 & 1 & 20 & & 0 & 1 & 0 & 1 & 2 & 2 & 5.7 & 5.4 & 0 & 0 & $x$ & $x$ & 5 YR 6/4, 5/2, 5/4, 4/1 & $7,5 Y R$ 4/1, 4/2, 5/2, 5/4 & \begin{tabular}{l|l}
4 \\
\end{tabular} & $x$ & $\mathrm{x}$ & $\mathrm{x}$ & $x$ & $x$ & $x$ & $x$ & $\mathrm{x}$ & $x$ & $x$ & $\mathrm{x}$ & $\mathrm{x}$ & $x$ & \\
\hline RH19-7 & 1 & 20 & & 0 & 1 & 0 & 1 & 2 & 2 & 6.4 & 6.0 & 0 & 0 & $x$ & $x$ & 5 YR 6/4, 5/2, 5/4, 4/1 & $7,5 Y R \quad 4 / 1,4 / 2,5 / 2,5 / 4$ & \begin{tabular}{l|l}
4 \\
\end{tabular} & $x$ & $x$ & $\mathrm{x}$ & $x$ & $x$ & $x$ & $x$ & $x$ & $x$ & $x$ & $x$ & $x$ & $\mathrm{x}$ & \\
\hline RH19-7 & 1 & 20 & & 0 & 1 & 0 & 1 & 2 & 2 & 10.9 & 7.4 & 0 & 0 & $x$ & $x$ & 5 YR 6/4, 5/2, 5/4, 4/1 & $7,5 Y R \quad 4 / 1,4 / 2,5 / 2,5 / 4$ & \begin{tabular}{l|l}
4 \\
\end{tabular} & $x$ & $\mathrm{x}$ & $x$ & $x$ & $x$ & $x$ & $x$ & $x$ & $x$ & $x$ & $x$ & $x$ & $x$ & 3 \\
\hline RH19-7 & 1 & 20 & & 0 & 1 & 0 & 1 & 2 & 2 & 5.6 & 5.4 & 0 & 0 & $x$ & $x$ & 5 YR 6/4, 5/2, 5/4, 4/1 & $7,5 Y R \quad 4 / 1,4 / 2,5 / 2,5 / 4$ & \begin{tabular}{l|l}
4 & $x$ \\
\end{tabular} & $x$ & $\mathrm{x}$ & $x$ & $x$ & $x$ & $x$ & $x$ & $x$ & $x$ & $x$ & $x$ & $x$ & $\mathrm{x}$ & 3 y 4 \\
\hline RH19-7 & 1 & 20 & & 0 & 1 & 0 & 1 & 2 & 2 & 5.3 & 4.9 & 0 & 0 & $x$ & $\mathrm{x}$ & 5 YR $6 / 4,5 / 2,5 / 4,4 / 1$ & $7,5 Y R$ 4/1, 4/2, 5/2,5/4 & \begin{tabular}{l|l}
4 & $x$ \\
\end{tabular} & $\mathrm{x}$ & $\mathrm{x}$ & $\mathrm{x}$ & $\mathrm{x}$ & $\mathrm{x}$ & $\mathrm{x}$ & $x$ & $x$ & $\mathrm{x}$ & $x$ & $x$ & $x$ & $\mathrm{x}$ & 1 \\
\hline RH19-7 & 1 & 20 & & 0 & 1 & 0 & 1 & 2 & 2 & 5.8 & 4.7 & 0 & 0 & $x$ & $x$ & 5 YR 6/4, 5/2, 5/4, 4/1 & $7,5 Y R \quad 4 / 1,4 / 2,5 / 2,5 / 4$ & \begin{tabular}{|l|l|}
4 & $x$ \\
\end{tabular} & $x$ & $\mathrm{x}$ & $\mathrm{x}$ & $\mathrm{x}$ & $x$ & $x$ & $x$ & $x$ & $x$ & $x$ & $x$ & $x$ & $\mathrm{x}$ & 3 \\
\hline RH19-7 & 1 & 20 & & 0 & 1 & 0 & 1 & 2 & 2 & 6.4 & 6.0 & 0 & 0 & $x$ & $x$ & 5 YR 6/4, 5/2, 5/4, 4/1 & $7,5 Y R$ 4/1, 4/2, 5/2, 5/4 & \begin{tabular}{l|l}
4 & $x$ \\
\end{tabular} & $x$ & $x$ & $\mathrm{x}$ & $\mathrm{x}$ & $\mathrm{x}$ & $\mathrm{x}$ & $\mathrm{x}$ & $x$ & $x$ & $\mathrm{x}$ & $x$ & $x$ & $\mathrm{x}$ & \\
\hline RH19-7 & 2 & 21 & & 1 & 0 & 0 & 1 & 2 & 2 & 5.7 & 5.2 & 0 & 0 & $x$ & $x$ & 5YR3/1,5/4; 7,5YR 5/3 & 5YR4/1,5/4;7,5YR5/3 & indet & 1.8 & indet & 1 & 2 & $x$ & $x$ & $\mathrm{x}$ & $x$ & $x$ & $x$ & $x$ & $\mathrm{x}$ & $x$ & 1 y 3 \\
\hline
\end{tabular}




\begin{tabular}{|c|c|c|c|c|c|c|c|c|c|c|c|c|c|c|c|c|c|c|c|c|c|c|c|c|c|c|c|c|c|c|c|}
\hline \multirow[b]{2}{*}{ Sitio } & \multirow[b]{2}{*}{$\begin{array}{c}\mathrm{Ni} \\
\text { vel }\end{array}$} & \multirow[b]{2}{*}{ GF } & FNA & \multicolumn{11}{|c|}{ Manufactura } & \multicolumn{2}{|c|}{ Cocción } & \multicolumn{5}{|c|}{ Borde-labio } & \multicolumn{6}{|c|}{ Asa } & \multicolumn{3}{|c|}{ Base } & \multirow[b]{2}{*}{ Alterac } \\
\hline & & & Fgto & $\begin{array}{l}\text { Tec } \\
\text { lev }\end{array}$ & $\begin{array}{l}\text { For } \\
\text { ma }\end{array}$ & $\begin{array}{l}\text { Mar } \\
\text { cas }\end{array}$ & $\begin{array}{l}\text { Sup } \\
\text { ext }\end{array}$ & $\begin{array}{c}\text { Sup } \\
\text { int }\end{array}$ & $\begin{array}{l}\text { Esp } \\
\text { max }\end{array}$ & $\begin{array}{l}\text { Esp } \\
\text { min }\end{array}$ & $\begin{array}{c}\text { Deco } \\
\text { pint }\end{array}$ & $\begin{array}{c}\text { Deco } \\
\text { cor/dsp }\end{array}$ & \begin{tabular}{|c|} 
Moti \\
vo
\end{tabular} & Estilo & Color sup ext & Color sup int & Diam & $\begin{array}{l}\text { Lrg } \\
\text { arc }\end{array}$ & \begin{tabular}{|c|}
$\%$ \\
arco
\end{tabular} & Dir & $\begin{array}{l}\text { For } \\
\text { ma }\end{array}$ & $\begin{array}{l}\text { Lar } \\
\text { go }\end{array}$ & $\begin{array}{c}\text { An } \\
\text { cho }\end{array}$ & Esp & $\begin{array}{l}\text { Sec } \\
\text { ción }\end{array}$ & $\begin{array}{l}\text { In } \\
\text { serc }\end{array}$ & $\begin{array}{l}P o \\
\text { sic }\end{array}$ & Diám & $\begin{array}{c}\text { Mor } \\
\text { fol }\end{array}$ & $\begin{array}{l}\text { Uni } \\
\text { ón }\end{array}$ & \\
\hline RH19-7 & 1 & 21 & 1 & 0 & 0 & 1 & 2 & 2 & 6.0 & 4.3 & 0 & 0 & $x$ & $x$ & 5YR3/1,5/4; 7,5YR 5/3 & 5YR4/1,5/4;7,5YR5/3 & indet & 2.4 & indet & 1 & 2 & $x$ & $\mathrm{x}$ & $x$ & $\mathrm{x}$ & $x$ & $x$ & $\mathrm{x}$ & $x$ & $x$ & \\
\hline RH19-7 & 1 & 21 & 3 & 0 & 0 & 1 & 2 & 2 & 10.6 & 9.8 & 0 & 0 & $x$ & $x$ & 5YR3/1,5/4; 7,5YR 5/3 & 5YR4/1,5/4;7,5YR5/3 & $x$ & $\mathrm{x}$ & $\mathrm{x}$ & $x$ & $x$ & $2,5 \mathrm{fr}$ & 1.6 & 1 & 2 & 3 & 0 & $x$ & $\mathrm{x}$ & $x$ & 1 y 3 \\
\hline RH19-7 & 1 & 21 & 0 & 0 & 0 & 1 & 2 & 2 & 6.2 & 3.9 & 0 & 0 & $x$ & $\mathrm{x}$ & 5YR3/1,5/4; 7,5YR 5/3 & 5YR4/1,5/4;7,5YR5/3 & $x$ & $\mathrm{x}$ & $\mathrm{x}$ & $x$ & $x$ & $x$ & $x$ & $x$ & $x$ & $x$ & $x$ & $x$ & $\mathrm{x}$ & $x$ & 1 \\
\hline RH19-7 & 1 & 21 & 0 & 0 & 0 & 1 & 2 & 2 & 5.9 & 3.8 & 0 & 0 & $x$ & $x$ & 5YR3/1,5/4; 7,5YR 5/3 & 5YR4/1,5/4;7,5YR5/3 & $\mathrm{x}$ & $x$ & $\mathrm{x}$ & $x$ & $x$ & $x$ & $x$ & $x$ & $x$ & $x$ & $x$ & $x$ & $\mathrm{x}$ & $x$ & 1 \\
\hline RH19-7 & 1 & 21 & 0 & 0 & 0 & 1 & 2 & 2 & 7.1 & 6.0 & 0 & 0 & $\mathrm{x}$ & $x$ & 5YR3/1,5/4; 7,5YR 5/3 & 5YR4/1,5/4;7,5YR5/3 & $\mathrm{x}$ & $x$ & $\mathrm{x}$ & $x$ & $x$ & $\mathrm{x}$ & $x$ & $\mathrm{x}$ & $x$ & $x$ & $x$ & $x$ & $\mathrm{x}$ & $x$ & 3 \\
\hline RH19-7 & 1 & 21 & 0 & 0 & 0 & 1 & 2 & 2 & 4.5 & 3.8 & 0 & 0 & $x$ & $x$ & 5YR3/1,5/4; 7,5YR 5/3 & 5YR4/1,5/4;7,5YR5/3 & $\mathrm{x}$ & $x$ & $\mathrm{x}$ & $x$ & $x$ & $x$ & $x$ & $\mathrm{x}$ & $x$ & $x$ & $x$ & $x$ & $\mathrm{x}$ & $x$ & 3 \\
\hline RH19-7 & 1 & 21 & 0 & 0 & 0 & 1 & 2 & 2 & 8.4 & 5.9 & 0 & 0 & $x$ & $x$ & 5YR3/1,5/4; 7,5YR 5/3 & 5YR4/1,5/4;7,5YR5/3 & $\mathrm{x}$ & $x$ & $\mathrm{x}$ & $x$ & $x$ & $x$ & $x$ & $\mathrm{x}$ & $\mathrm{x}$ & $x$ & $x$ & $x$ & $x$ & $x$ & 3 \\
\hline RH19-7 & 1 & 21 & 0 & 0 & 0 & 1 & 2 & 2 & 8.0 & 5.3 & 0 & 0 & $x$ & $x$ & 5YR3/1,5/4; 7,5YR 5/3 & 5YR4/1,5/4;7,5YR5/3 & $x$ & $x$ & $\mathrm{x}$ & $x$ & $x$ & $\mathrm{x}$ & $x$ & $x$ & $x$ & $x$ & $x$ & $x$ & $\mathrm{x}$ & $x$ & 3 \\
\hline RH19-7 & 1 & 21 & 0 & 0 & 0 & 1 & 2 & 2 & 8.0 & 4.3 & 0 & 0 & $x$ & $x$ & 5YR3/1,5/4; 7,5YR 5/3 & 5YR4/1,5/4;7,5YR5/3 & $x$ & $\mathrm{x}$ & $\mathrm{x}$ & $x$ & $\mathrm{x}$ & $\mathrm{x}$ & $\mathrm{x}$ & $x$ & $x$ & $x$ & $x$ & $\mathrm{x}$ & $\mathrm{x}$ & $x$ & 3 \\
\hline RH19-7 & 1 & 21 & 0 & 0 & 0 & 1 & 2 & 2 & 6.8 & 6.1 & 0 & 0 & $x$ & $x$ & 5YR3/1,5/4; 7,5YR 5/3 & 5YR4/1,5/4;7,5YR5/3 & $\mathrm{x}$ & $\mathrm{x}$ & $\mathrm{x}$ & $x$ & $x$ & $x$ & $x$ & $\mathrm{x}$ & $x$ & $x$ & $x$ & $x$ & $\mathrm{x}$ & $x$ & \\
\hline RH19-7 & 1 & 21 & 0 & 0 & 0 & 1 & 2 & 2 & 6.1 & 5.4 & 0 & 0 & $x$ & $\mathrm{x}$ & 5YR3/1,5/4; 7,5YR 5/3 & 5YR4/1,5/4;7,5YR5/3 & $x$ & $\mathrm{x}$ & $\mathrm{x}$ & $x$ & $\mathrm{x}$ & $\mathrm{x}$ & $\mathrm{x}$ & $x$ & $\mathrm{x}$ & $\mathrm{x}$ & $x$ & $x$ & $\mathrm{x}$ & $x$ & 3 \\
\hline RH19-7 & 1 & 21 & 0 & 0 & 0 & 1 & 2 & 2 & 4.6 & 3.9 & 0 & 0 & $\mathrm{x}$ & $x$ & 5YR3/1,5/4; 7,5YR 5/3 & 5YR4/1,5/4;7,5YR5/3 & $x$ & $x$ & $\mathrm{x}$ & $x$ & $\mathrm{x}$ & $x$ & $x$ & $x$ & $\mathrm{x}$ & $x$ & $x$ & $x$ & $\mathrm{x}$ & $x$ & 3 \\
\hline RH19-7 & 1 & 21 & 0 & 0 & 0 & 1 & 2 & 2 & 5.6 & 5.4 & 0 & 0 & $\mathrm{x}$ & $x$ & 5YR3/1,5/4; 7,5YR 5/3 & 5YR4/1,5/4;7,5YR5/3 & $x$ & $\mathrm{x}$ & $\mathrm{x}$ & $x$ & $\mathrm{x}$ & $x$ & $\mathrm{x}$ & $x$ & $\mathrm{x}$ & $\mathrm{x}$ & $x$ & $x$ & $\mathrm{x}$ & $x$ & 3 \\
\hline RH19-7 & 1 & 22 & 0 & 0 & 0 & 1 & 2 & 2 & 6.5 & 4.6 & 0 & 0 & $x$ & $x$ & $5 Y R 5 / 3,4 / 1,4 / 3,2.5 / 1$ & $5 Y R$ 5/2, 4/1, 4/2, 3/1 & $x$ & $x$ & $x$ & $x$ & $x$ & $x$ & $x$ & $x$ & $x$ & $x$ & $x$ & $x$ & $x$ & $x$ & 1 \\
\hline RH19-7 & 1 & 22 & 0 & 0 & 0 & 1 & 2 & 2 & 5.7 & 4.5 & 0 & 0 & $x$ & $x$ & $5 Y R$ 5/3, 4/1, 4/3, 2.5/1 & $5 Y R$ 5/2, 4/1, 4/2, 3/1 & $x$ & $x$ & $\mathrm{x}$ & $x$ & $x$ & $x$ & $x$ & $x$ & $x$ & $x$ & $x$ & $x$ & $x$ & $x$ & 1 \\
\hline RH19-7 & 2 & 22 & 0 & 0 & 0 & 1 & 2 & 2 & 6.3 & 3.8 & 0 & 0 & $x$ & $x$ & $5 Y R$ 5/3, 4/1, 4/3, 2.5/1 & $5 Y R$ 5/2, 4/1, 4/2, 3/1 & $x$ & $x$ & $\mathrm{x}$ & $x$ & $x$ & $x$ & $x$ & $x$ & $x$ & $x$ & $x$ & $x$ & $x$ & $x$ & 3 \\
\hline RH19-7 & 2 & 22 & 0 & 0 & 0 & 1 & 2 & 2 & 5.1 & 4.5 & 0 & 0 & $x$ & $\mathrm{x}$ & $5 Y R$ 5/3, 4/1, 4/3, 2.5/1 & $5 Y R$ 5/2, 4/1, 4/2, 3/1 & $x$ & $x$ & $\mathrm{x}$ & $x$ & $x$ & $x$ & $x$ & $x$ & $x$ & $x$ & $x$ & $x$ & $x$ & $x$ & 3 \\
\hline RH19-7 & 2 & 22 & 0 & 0 & 0 & 1 & 2 & 2 & 6.0 & 3.5 & 0 & 0 & $x$ & $x$ & $5 Y R$ 5/3, 4/1, 4/3, 2.5/1 & $5 Y R$ 5/2, 4/1, 4/2, 3/1 & $x$ & $\mathrm{x}$ & $\mathrm{x}$ & $x$ & $x$ & $x$ & $x$ & $x$ & $\mathrm{x}$ & $x$ & $x$ & $x$ & $x$ & $x$ & 1 y 3 \\
\hline RH19-7 & 2 & 22 & 0 & 0 & 0 & 1 & 2 & 2 & 4.5 & 4.0 & 0 & 0 & $x$ & $x$ & 5 YR $5 / 3,4 / 1,4 / 3,2.5 / 1$ & $5 Y R$ 5/2, 4/1, 4/2, 3/1 & $x$ & $\mathrm{x}$ & $\mathrm{x}$ & $x$ & $x$ & $x$ & $\mathrm{x}$ & $x$ & $\mathrm{x}$ & $x$ & $x$ & $x$ & $x$ & $x$ & 1 y 3 \\
\hline RH19-7 & 1 & 22 & 0 & 0 & 0 & 1 & 2 & 2 & 6.3 & 4.4 & 0 & 0 & $\mathrm{x}$ & $\mathrm{x}$ & $5 Y R$ 5/3, 4/1, 4/3, 2.5/1 & $5 Y R$ 5/2, 4/1, 4/2, 3/1 & $\mathrm{x}$ & $\mathrm{x}$ & $\mathrm{x}$ & $x$ & $x$ & $x$ & $\mathrm{x}$ & $x$ & $x$ & $x$ & $x$ & $x$ & $x$ & $x$ & 1 \\
\hline RH19-7 & 2 & 22 & 0 & 0 & 0 & 1 & 2 & 2 & 5.6 & 4.9 & 0 & 0 & $x$ & $x$ & $5 Y R$ 5/3, 4/1, 4/3, 2.5/1 & $5 Y R$ 5/2, 4/1, 4/2, 3/1 & $x$ & $x$ & $\mathrm{x}$ & $x$ & $x$ & $\mathrm{x}$ & $x$ & $x$ & $x$ & $x$ & $x$ & $x$ & $x$ & $x$ & 1 \\
\hline RH19-7 & 1 & 22 & 0 & 0 & 0 & 1 & 2 & 2 & 5.5 & 4.2 & 0 & 0 & $x$ & $\mathrm{x}$ & $5 Y R$ 5/3, 4/1, 4/3, 2.5/1 & $5 Y R$ 5/2, 4/1, 4/2, 3/1 & $\mathrm{x}$ & $\mathrm{x}$ & $\mathrm{x}$ & $x$ & $x$ & $x$ & $x$ & $x$ & $\mathrm{x}$ & $x$ & $x$ & $\mathrm{x}$ & $x$ & $x$ & 1 \\
\hline RH19-7 & 2 & 22 & 0 & 0 & 0 & 1 & 2 & 2 & 4.8 & 4.1 & 0 & 0 & $x$ & $x$ & $5 Y R$ 5/3, 4/1, 4/3, 2.5/1 & $5 Y R$ 5/2, 4/1, 4/2, 3/1 & $x$ & $x$ & $\mathrm{x}$ & $x$ & $\mathrm{x}$ & $x$ & $x$ & $x$ & $\mathrm{x}$ & $x$ & $x$ & $x$ & $x$ & $x$ & \\
\hline RH19-7 & 2 & 22 & 0 & 0 & 0 & 1 & 2 & 2 & 4.3 & 3.8 & 0 & 0 & $x$ & $x$ & $5 Y R$ 5/3, 4/1, 4/3, 2.5/1 & $5 Y R$ 5/2, 4/1, 4/2, 3/1 & $x$ & $x$ & $\mathrm{x}$ & $x$ & $\mathrm{x}$ & $\mathrm{x}$ & $x$ & $x$ & $\mathrm{x}$ & $x$ & $x$ & $\mathrm{x}$ & $x$ & $x$ & \\
\hline RH19-7 & 2 & 23 & 3 & 0 & 0 & 1 & 2 & 2 & 12.4 & 5.2 & 0 & 0 & $x$ & $x$ & $2,5 Y R 5 / 6,5 / 4,4 / 4,4 / 3$ & $2,5 Y R 5 / 6,5 / 4$ & $x$ & $x$ & $\mathrm{x}$ & $x$ & $\mathrm{x}$ & inde & tindet & tindet & 1 & 3 & 1 & $x$ & $x$ & $x$ & \\
\hline RH19-7 & 2 & 23 & 0 & 0 & 0 & 1 & 2 & 2 & 4.5 & 4.0 & 0 & 0 & $x$ & $x$ & $2,5 Y R$ 5/6, 5/4, 4/4, 4/3 & $2,5 Y R$ 5/6, 5/4 & $x$ & $x$ & $\mathrm{x}$ & $x$ & $x$ & $x$ & $x$ & $x$ & $x$ & $x$ & $x$ & $x$ & $x$ & $x$ & 2 \\
\hline RH19-7 & 2 & 23 & 0 & 0 & 0 & 1 & 2 & 2 & 5.0 & 4.4 & 0 & 0 & $x$ & $x$ & $2,5 Y R$ 5/6, 5/4, 4/4, 4/3 & 2,5 YR $5 / 6,5 / 4$ & $x$ & $x$ & $x$ & $x$ & $x$ & $x$ & $x$ & $x$ & $x$ & $x$ & $x$ & $x$ & $x$ & $x$ & 2 \\
\hline RH19-7 & 2 & 23 & 0 & 0 & 0 & 1 & 2 & 2 & 7.6 & 5.2 & 0 & 0 & $x$ & $x$ & $2,5 Y R 5 / 6,5 / 4,4 / 4,4 / 3$ & $2,5 Y R$ 5/6, 5/4 & $x$ & $x$ & $\mathrm{x}$ & $x$ & $x$ & $x$ & $x$ & $x$ & $x$ & $x$ & $x$ & $x$ & $x$ & $x$ & \\
\hline RH19-7 & 2 & 23 & 0 & 0 & 0 & 1 & 2 & 2 & 7.1 & 4.9 & 0 & 0 & $x$ & $\mathrm{x}$ & $2,5 Y R 5 / 6,5 / 4,4 / 4,4 / 3$ & $2,5 Y R$ 5/6, 5/4 & $\mathrm{x}$ & $x$ & $\mathrm{x}$ & $x$ & $\mathrm{x}$ & $x$ & $x$ & $x$ & $\mathrm{x}$ & $x$ & $x$ & $\mathrm{x}$ & $x$ & $\mathrm{x}$ & \\
\hline RH19-7 & 2 & 23 & 0 & 0 & 0 & 1 & 2 & 2 & 5.8 & 4.4 & 0 & 0 & $x$ & $\mathrm{x}$ & $2,5 Y R$ 5/6, 5/4, 4/4, 4/3 & $2,5 Y R$ 5/6, 5/4 & $\mathrm{x}$ & $\mathrm{x}$ & $\mathrm{x}$ & $x$ & $\mathrm{x}$ & $\mathrm{x}$ & $\mathrm{x}$ & $x$ & $\mathrm{x}$ & $x$ & $x$ & $\mathrm{x}$ & $\mathrm{x}$ & $x$ & 2 \\
\hline RH19-7 & 1 & 24 & 0 & 0 & 0 & 1 & 2 & 2 & 8.3 & 6.2 & 0 & 0 & $x$ & $x$ & 10R5/6; 7,5YR5/3,3/1 & $7,5 Y R$ 5/3, 5/2, 4/1 & $x$ & $x$ & $\mathrm{x}$ & $x$ & $\mathrm{x}$ & $x$ & $x$ & $x$ & $x$ & $\mathrm{x}$ & $x$ & $x$ & $x$ & $x$ & 1 \\
\hline RH19-7 & 1 & 24 & 0 & 0 & 0 & 1 & 2 & 2 & 8.2 & 7.6 & 0 & 0 & $\mathrm{x}$ & $x$ & 10R5/6; 7,5YR5/3,3/1 & 7,5 YR $5 / 3,5 / 2,4 / 1$ & $x$ & $x$ & $\mathrm{x}$ & $x$ & $x$ & $x$ & $x$ & $x$ & $x$ & $x$ & $x$ & $x$ & $\mathrm{x}$ & $x$ & 1 \\
\hline RH19-7 & 1 & 24 & 0 & 0 & 0 & 1 & 2 & 2 & 8.2 & 5.6 & 0 & 0 & $x$ & $x$ & 10R5/6; 7,5YR5/3,3/1 & 7,5 YR $5 / 3,5 / 2,4 / 1$ & $x$ & $x$ & $x$ & $x$ & $x$ & $x$ & $x$ & $x$ & $x$ & $x$ & $x$ & $x$ & $x$ & $x$ & 1 \\
\hline RH19-7 & 1 & 24 & 0 & 0 & 0 & 1 & 2 & 2 & 6.8 & 5.9 & 0 & 0 & $x$ & $x$ & 10R5/6; 7,5YR5/3,3/1 & 7,5YR 5/3, 5/2, 4/1 & $x$ & $x$ & $x$ & $x$ & $x$ & $x$ & $x$ & $x$ & $x$ & $x$ & $x$ & $x$ & $x$ & $x$ & 1 \\
\hline RH19-7 & 1 & 25 & 0 & 0 & 0 & 0 & 2 & 2 & 7.9 & 5.4 & 0 & 0 & $x$ & $\mathrm{x}$ & 7,5YR5/3, 4/2, 4/1, 3/1 & $7,5 Y R 5 / 2,5 / 3,4 / 1$ & $\mathrm{x}$ & $x$ & $x$ & $x$ & $\mathrm{x}$ & $\mathrm{x}$ & $x$ & $x$ & $\mathrm{x}$ & $x$ & $x$ & $\mathrm{x}$ & $x$ & $x$ & 1 y 3 \\
\hline RH19-7 & 1 & 25 & 0 & 0 & 0 & 0 & 2 & 2 & 9.7 & 6.8 & 0 & 0 & $x$ & $x$ & 7,5YR5/3, 4/2, 4/1, 3/1 & $7,5 Y R$ 5/2, 5/3, 4/1 & $x$ & $x$ & $\mathrm{x}$ & $x$ & $x$ & $x$ & $x$ & $x$ & $x$ & $\mathrm{x}$ & $x$ & $x$ & $x$ & $x$ & 3 \\
\hline RH19-7 & 1 & 25 & 0 & 0 & 0 & 0 & 2 & 2 & 9.0 & 6.3 & 0 & 0 & $\mathrm{x}$ & $x$ & $7,5 Y R 5 / 3,4 / 2,4 / 1,3 / 1$ & 7,5 YR $5 / 2,5 / 3,4 / 1$ & $x$ & $\mathrm{x}$ & $\mathrm{x}$ & $x$ & $x$ & $x$ & $\mathrm{x}$ & $\mathrm{x}$ & $x$ & $x$ & $x$ & $\mathrm{x}$ & $x$ & $x$ & 1 y 3 \\
\hline RH19-7 & 1 & 25 & 0 & 0 & 0 & 0 & 2 & 2 & 8.4 & 7.7 & 0 & 0 & $\mathrm{x}$ & $\mathrm{x}$ & $7,5 Y R 5 / 3,4 / 2,4 / 1,3 / 1$ & 7,5 YR $5 / 2,5 / 3,4 / 1$ & $\mathrm{x}$ & $\mathrm{x}$ & $\mathrm{x}$ & $x$ & $x$ & $x$ & $x$ & $\mathrm{x}$ & $\mathrm{x}$ & $x$ & $\mathrm{x}$ & $\mathrm{x}$ & $x$ & $x$ & 3 \\
\hline
\end{tabular}




\begin{tabular}{|c|c|c|c|c|c|c|c|c|c|c|c|c|c|c|c|c|c|c|c|c|c|c|c|c|c|c|c|c|c|c|c|c|}
\hline \multirow[b]{2}{*}{ Sitio } & \multirow[b]{2}{*}{\begin{tabular}{c|}
$\mathbf{N i}$ \\
vel
\end{tabular}} & \multirow[b]{2}{*}{ GF } & \multirow[b]{2}{*}{ FNA } & \multirow[b]{2}{*}{ Fgto } & \multicolumn{11}{|c|}{ Manufactura } & \multicolumn{2}{|c|}{ Cocción } & \multicolumn{5}{|c|}{ Borde-labio } & \multicolumn{6}{|c|}{ Asa } & \multicolumn{3}{|c|}{ Base } & \multirow[b]{2}{*}{ Alterac } \\
\hline & & & & & $\begin{array}{l}\text { Tec } \\
\text { lev }\end{array}$ & $\begin{array}{l}\text { For } \\
\text { ma }\end{array}$ & \begin{tabular}{|l|} 
Mar \\
cas \\
\end{tabular} & \begin{tabular}{|c|} 
Sup \\
ext
\end{tabular} & \begin{tabular}{|c} 
Sup \\
int
\end{tabular} & $\begin{array}{l}\text { Esp } \\
\text { max }\end{array}$ & $\begin{array}{l}\text { Esp } \\
\text { min }\end{array}$ & $\begin{array}{c}\text { Deco } \\
\text { pint }\end{array}$ & $\begin{array}{c}\text { Deco } \\
\text { cor/dsp }\end{array}$ & \begin{tabular}{|c|} 
Moti \\
vo \\
\end{tabular} & Estilo & Color sup ext & Color sup int & Diam & \begin{tabular}{|l|} 
Lrg \\
arc \\
\end{tabular} & \begin{tabular}{|c|}
$\%$ \\
arco \\
\end{tabular} & & $\begin{array}{l}\text { For } \\
\text { ma }\end{array}$ & \begin{tabular}{|l|} 
Lar \\
go
\end{tabular} & $\begin{array}{c}\text { An } \\
\text { cho }\end{array}$ & Esp & $\begin{array}{l}\text { Sec } \\
\text { ción }\end{array}$ & \begin{tabular}{|l} 
In \\
serc \\
\end{tabular} & $\begin{array}{l}\text { Po } \\
\text { sic }\end{array}$ & Diám & $\begin{array}{l}\text { Mor } \\
\text { fol } \\
\end{array}$ & $\begin{array}{c}\text { Uni } \\
\text { ón }\end{array}$ & \\
\hline RH19-7 & 1 & & 1 & 1 & 1 & 0 & 2 & $3 y 4$ & 2 & 8.5 & 6.6 & 1 & 0 & $x$ & Yavi & 10R $4 / 4,3 / 1$ & 2,5 YR $6 / 6$ & 17 & 5.4 & 10.1 & \begin{tabular}{|l|l}
3 & 2 \\
\end{tabular} & $2 \mathrm{y} 6$ & $x$ & $x$ & $x$ & $\mathrm{x}$ & $x$ & $x$ & $x$ & $x$ & $x$ & 1 \\
\hline RH19-7 & 1 & & 2 & 1 & 1 & 0 & 2 & $3 y 4$ & 2 & 8.8 & 5.7 & 1 & 0 & $x$ & Yavi & 10R $4 / 4$ & $2,5 Y R$ 6/6 & 17 & 5.4 & 10.1 & \begin{tabular}{|l|l|}
3 & 2 \\
\end{tabular} & $2 \mathrm{y} 6$ & $x$ & $x$ & $x$ & $x$ & $x$ & $x$ & $x$ & $x$ & $\mathrm{x}$ & \\
\hline \begin{tabular}{|l|}
$\mathrm{RH} 19-7$ \\
\end{tabular} & 1 & & 3 & 1 & 0 & 2 & 1 & $3 \mathrm{y} 6$ & $3 \mathrm{y} 6$ & 6.3 & 5.1 & 1 & 0 & $x$ & $x$ & 10R 5/6 & 10R 5/6, 4/6 & 13 & 7.3 & 17.9 & 1 & 2 & $x$ & $x$ & $x$ & $x$ & $x$ & $x$ & $x$ & $x$ & $x$ & \\
\hline RH19-7 & 1 & & 4 & 1 & 0 & 1 & 0 & $2 \mathrm{y} 6$ & 3 & 6.2 & 4.8 & 1 & 0 & $x$ & PINP & 10R $4 / 4$ & 10R 3/1 & 28 & 5.6 & 6.4 & 1 & 3 & $x$ & $x$ & $x$ & $x$ & $x$ & $x$ & $x$ & $x$ & $x$ & 2 \\
\hline RH19-7 & 1 & & 5 & 1 & 0 & 1 & 1 & 2 & 2 & 6.4 & 5.2 & 0 & 0 & $x$ & $x$ & 7,5YR 5/3, 3/1 & 7,5YR 4/1 & 19 & 3.6 & 6 & 2 & 2 & $x$ & $x$ & $x$ & $x$ & $x$ & $x$ & $x$ & $x$ & $x$ & 3 \\
\hline RH19-7 & 1 & & 6 & 1 & 0 & 1 & 0 & 2 & 2 & 6.0 & 5.3 & 0 & 0 & $x$ & $x$ & 7,5 YR $6 / 4,4 / 1$ & 7,5 YR $6 / 2$ & indet & 2.1 & indet & 1 & 2 & $x$ & $x$ & $x$ & $x$ & $x$ & $x$ & $x$ & $x$ & $x$ & 3 \\
\hline RH19-7 & 1 & & 7 & 1 & 0 & 1 & 1 & 2 & 3 & 5.3 & 4.7 & 0 & 0 & $x$ & PINP & $5 Y R$ 5/4 & $\mathrm{N} 3 /$ & 16 & 3.2 & 6.4 & 1 & 1 & $x$ & $x$ & $x$ & $x$ & $\mathrm{x}$ & $x$ & $x$ & $x$ & $\mathrm{x}$ & \\
\hline RH19-7 & 2 & & 8 & 1 & 0 & 1 & 1 & 2 & 3 & 5.7 & 4.5 & 0 & 0 & $x$ & PINP & 7,5 YR $5 / 4$ & 7,5YR 5/1, 4/1 & 10 & 2.3 & 7.3 & 1 & 1 & $x$ & $x$ & $x$ & $x$ & $x$ & $x$ & $x$ & $x$ & $x$ & \\
\hline \begin{tabular}{|l|}
$\mathrm{RH} 19-7$ \\
\end{tabular} & 1 & & 9 & 1 & 0 & 1 & 1 & 2 & 2 & 6.0 & 4.6 & 0 & 0 & $x$ & $x$ & 7,5YR 3/1 & 7,5 YR 5/2 & indet & 2.3 & indet & 2 & 2 & $x$ & $x$ & $x$ & $x$ & $x$ & $x$ & $x$ & $x$ & $x$ & \\
\hline RH19-7 & 1 & & 10 & 1 & 0 & 1 & 0 & 2 & 3 & 5.7 & 5.2 & 0 & 0 & $x$ & PINP & $5 Y R 4 / 4, N 3 /$ & $\mathrm{N} 3 /, \mathrm{N} 4 /$ & indet & 1.2 & indet & 1 & 1 & $x$ & $x$ & $x$ & $x$ & $x$ & $x$ & $x$ & $x$ & $x$ & 3 \\
\hline RH19-7 & 1 & & 11 & 1 & 0 & 0 & 0 & 2 & 2 & 6.5 & 5.0 & 0 & 0 & $x$ & $x$ & $2,5 Y R 5 / 6$ & $2,5 Y R 5 / 3$ & indet & 1.8 & indet & 1 & 1 & $x$ & $x$ & $x$ & $x$ & $\mathrm{x}$ & $x$ & $x$ & $x$ & $x$ & \\
\hline $\mathrm{RH} 19-7$ & 1 & & 12 & 1 & 0 & 0 & 0 & 2 & 2 & 5.5 & 5.2 & 0 & 0 & $\mathrm{x}$ & $\mathrm{x}$ & 7,5YR 6/3, 3/1 & 7,5YR 4/1 & indet & 1.8 & indet & 1 & 2 & $\mathrm{x}$ & $x$ & $\mathrm{x}$ & $\mathrm{x}$ & $\mathrm{x}$ & $x$ & $\mathrm{x}$ & $\mathrm{x}$ & $\mathrm{x}$ & \\
\hline RH19-7 & 1 & & 13 & 1 & 0 & 0 & 0 & 2 & 2 & 5.2 & 4.4 & 0 & 0 & $x$ & $x$ & 10YR 4/1 & 10YR 5/1 & indet & 1.4 & indet & 1 & 2 & $x$ & $x$ & $x$ & $x$ & $\mathrm{x}$ & $x$ & $x$ & $x$ & $x$ & \\
\hline RH19-7 & 1 & & 14 & 1 & 0 & 0 & 0 & 2 & 3 & 4.6 & 4.4 & 0 & 0 & $x$ & $x$ & $5 Y R$ 5/4, 3/1 & $\mathrm{N} 3 /$ & indet & 1.5 & indet & 1 & 2 & $x$ & $x$ & $x$ & $x$ & $x$ & $x$ & $x$ & $x$ & $x$ & \\
\hline RH19-7 & 1 & & 15 & 3 & 0 & 0 & 0 & $2 \mathrm{y} 6$ & $x$ & 7.6 & 6.9 & 1 & 0 & $x$ & Yavi & $2,5 Y R$ 6/4, 10R 4/6 & $x$ & $x$ & $x$ & $x$ & $x$ & $\mathrm{x}$ & 3.7 & 10 & 7.6 & 1 & 2 & 0 & $x$ & $x$ & $x$ & \\
\hline RH19-7 & 1 & & 16 & 3 & 0 & 0 & 0 & $2 \mathrm{y} 6$ & $x$ & 11.8 & 11.5 & 1 & 0 & $x$ & $x$ & 5YR 5/3, 5/2; 10R 4/6 & $x$ & $x$ & $x$ & $x$ & $x$ & $\mathrm{x}$ & $3,6 \mathrm{fr}$ & 20 & 11.7 & \begin{tabular}{l|l}
77 & 2
\end{tabular} & 0 & 0 & $x$ & $x$ & $x$ & \\
\hline RH19-7 & 1 & & 17 & 3 & 0 & 0 & 0 & 2 & $x$ & 10.5 & 9.3 & 0 & 0 & $x$ & $x$ & $5 Y R$ 4/1, 4/2 & $x$ & $x$ & $x$ & $x$ & $x$ & $x$ & $2,3 \mathrm{fr}$ & 15 & 10 & 2 & 0 & 0 & $x$ & $x$ & $\mathrm{x}$ & \\
\hline RH19-7 & 1 & & 18 & 3 & 0 & 0 & 0 & 2 & $\mathrm{x}$ & 11 & 9.7 & 0 & 0 & $\mathrm{x}$ & $\mathrm{x}$ & 5YR 5/4 & $\mathrm{x}$ & $\mathrm{x}$ & $\mathrm{x}$ & $\mathrm{x}$ & $\mathrm{x}$ & $\mathrm{x}$ & $2 \mathrm{fr}$ & 14 & 10.5 & 5 & 0 & 0 & $\mathrm{x}$ & $\mathrm{x}$ & $\mathrm{x}$ & \\
\hline RH19-7 & 1 & & 19 & 2 & 0 & 0 & 0 & 2 & 2 & 10.0 & 7.1 & 0 & 0 & $x$ & $x$ & 5YR 5/6; 7,5YR 5/6 & 7,5YR 5/6, 4/1 & $x$ & $x$ & $x$ & $x$ & $x$ & $x$ & $x$ & $x$ & $x$ & $x$ & $x$ & 10 & 5 & 2 & 3 \\
\hline RH19-7 & 1 & & 20 & 1 & 0 & 0 & 0 & 2 & 2 & 6.2 & 4.9 & 0 & 0 & $x$ & $x$ & $2,5 Y R$ 5/6 & $5 Y R 5 / 3$ & indet & 3.5 & indet & 0 & 2 & $x$ & $x$ & $x$ & $x$ & $x$ & $x$ & $x$ & $x$ & $x$ & \\
\hline RH19-7 & 1 & & 21 & 4 & 0 & 0 & 6 & 7 & 2 & 9.1 & 2.8 & 0 & 1 & $x$ & $x$ & $5 Y R 5 / 3$ & 5YR 6/4 & $x$ & $x$ & $x$ & $x$ & $x$ & $x$ & $x$ & $x$ & $x$ & $x$ & $x$ & $x$ & $x$ & $x$ & 3 \\
\hline RH19-7 & 1 & & 22 & 0 & 0 & 0 & $2 \mathrm{y} 1$ & $3 y 4$ & 2 & 7.2 & 5.8 & 1 & 0 & $x$ & Yavi & 5YR 4/3, 2,5/1 & $7,5 Y R$ T/3 & $x$ & $x$ & $x$ & $x$ & $x$ & $x$ & $x$ & $x$ & $x$ & $x$ & $x$ & $x$ & $x$ & $x$ & 1 \\
\hline RH19-7 & 2 & & 23 & 0 & 1 & 0 & 1 & $2 \mathrm{y} 6$ & 2 & 9.2 & 4.9 & 1 & 0 & $x$ & $x$ & 10R 4/6, 5YR 5/3 & 5YR 5/4 & $x$ & $x$ & $x$ & $x$ & $x$ & $x$ & $x$ & $x$ & $x$ & $\mathrm{x}$ & $x$ & $x$ & $x$ & $x$ & 5 \\
\hline RH19-7 & 1 & & 24 & 0 & 0 & 0 & 0 & $2 \mathrm{y} 6$ & 2 & 5.1 & 3.7 & 1 & 0 & $x$ & $x$ & 10R 4/8; 5YR 5/4 & 5YR 6/4 & $x$ & $x$ & $x$ & $x$ & $x$ & $x$ & $x$ & $x$ & $x$ & $x$ & $x$ & $x$ & $x$ & $x$ & 3 y 5 \\
\hline RH19-7 & 1 & & 25 & 0 & 0 & 0 & 0 & $2 \mathrm{y} 6$ & 2 & 4.4 & 3.8 & 1 & 0 & $x$ & $x$ & 10R 4/8; 5YR 5/4 & 5YR 6/4 & $x$ & $x$ & $x$ & $x$ & $x$ & $x$ & $x$ & $x$ & $x$ & $x$ & $x$ & $x$ & $x$ & $x$ & 3 y 5 \\
\hline RH19-7 & 1 & & 26 & 0 & 0 & 0 & 0 & $3 \mathrm{y} 6$ & 2 & 6.4 & 5.6 & 1 & 0 & $x$ & $x$ & $5 Y R$ 5/2, 4/1 & 5YR 5/4 & $x$ & $x$ & $x$ & $x$ & $x$ & $x$ & $x$ & $x$ & $x$ & $x$ & $x$ & $x$ & $x$ & $x$ & \\
\hline RH19-7 & 1 & & 27 & 0 & 0 & 0 & 0 & $3 \mathrm{y} 6$ & 2 & 6.0 & 5.4 & 1 & 0 & $x$ & $x$ & 5YR 5/2 & 5YR 5/4 & $x$ & $x$ & $x$ & $x$ & $x$ & $x$ & $x$ & $x$ & $x$ & $x$ & $x$ & $x$ & $x$ & $x$ & \\
\hline RH19-7 & 1 & & 28 & 0 & 0 & 0 & 0 & $2 \mathrm{y} 6$ & 2 & 5.1 & 4.0 & 1 & 0 & $x$ & $x$ & $5 Y R$ 3/1, 5/3 & 5YR 5/1 & $x$ & $x$ & $x$ & $x$ & $x$ & $x$ & $x$ & $x$ & $x$ & $x$ & $x$ & $x$ & $x$ & $x$ & 5 \\
\hline RH19-7 & 1 & & 29 & 0 & 1 & 0 & 6 & $3 y 4$ & 2 & 5.8 & 4.1 & 1 & 0 & $x$ & $x$ & 10R $4 / 4$ & $2,5 Y R$ 6/6 & $x$ & $x$ & $x$ & $x$ & $x$ & $x$ & $x$ & $x$ & $x$ & $x$ & $x$ & $x$ & $x$ & $x$ & \\
\hline RH19-7 & 1 & & 30 & 0 & 0 & 0 & 0 & $3 y 4$ & 2 & 5.6 & 4.1 & 1 & 0 & $\mathrm{x}$ & $x$ & $2,5 Y R$ 4/6 & $2,5 Y R$ 5/6 & $x$ & $x$ & $x$ & $x$ & $x$ & $\mathrm{x}$ & $x$ & $x$ & $x$ & $x$ & $x$ & $x$ & $\mathrm{x}$ & $x$ & \\
\hline RH19-7 & 1 & & 31 & 0 & 0 & 0 & 0 & $3 y 4$ & 2 & 5.2 & 4.1 & 1 & 0 & $\mathrm{x}$ & $x$ & 10R 4/6; 2,5YR 6/6 & 2,5 YR $5 / 6$ & $\mathrm{x}$ & $\mathrm{x}$ & $\mathrm{x}$ & $x$ & $x$ & $\mathrm{x}$ & $x$ & $x$ & $\mathrm{x}$ & $\mathrm{x}$ & $x$ & $\mathrm{x}$ & $\mathrm{x}$ & $\mathrm{x}$ & 5 \\
\hline RH19-7 & 1 & & 32 & 0 & 0 & 0 & 1 & 2 & 1 & 6.5 & 5.7 & 0 & 0 & $\mathrm{x}$ & $\mathrm{x}$ & $7,5 Y R \quad 4 / 2$ & 7,5YR 4/3, 6/3 & $\mathrm{x}$ & $\mathrm{x}$ & $\mathrm{x}$ & $x$ & $x$ & $\mathrm{x}$ & $x$ & $x$ & $\mathrm{x}$ & $\mathrm{x}$ & $x$ & $\mathrm{x}$ & $\mathrm{x}$ & $\mathrm{x}$ & 6 \\
\hline RH19-7 & 1 & & 33 & 0 & 0 & 0 & 1 & 2 & 1 & 6.2 & 6.0 & 0 & 0 & $x$ & $x$ & 7,5YR 5/3 & 7,5 YR 4/3 & $x$ & $x$ & $x$ & $x$ & $x$ & $x$ & $x$ & $x$ & $x$ & $x$ & $x$ & $x$ & $x$ & $x$ & \\
\hline RH19-7 & 1 & & 34 & 0 & 0 & 0 & 0 & 2 & 1 & 6.2 & 5.8 & 0 & 0 & $x$ & $x$ & 7,5 YR $5 / 3$ & 7,5 YR 4/3 & $x$ & $x$ & $x$ & $x$ & $x$ & $x$ & $x$ & $x$ & $x$ & $x$ & $x$ & $x$ & $x$ & $x$ & \\
\hline RH19-7 & 1 & & 35 & 0 & 0 & 0 & 0 & 2 & 2 & 5.2 & 4.8 & 0 & 0 & $x$ & $x$ & 7,5YR 4/1, 5/2 & $7,5 Y R$ 4/1 & $x$ & $x$ & $x$ & $x$ & $x$ & $x$ & $x$ & $x$ & $\mathrm{x}$ & $\mathrm{x}$ & $x$ & $x$ & $x$ & $x$ & 3 \\
\hline RH19-7 & 1 & & 36 & 0 & 0 & 0 & 0 & 2 & 2 & 5.3 & 4.7 & 0 & 0 & $x$ & $x$ & $7,5 Y R \quad 4 / 2,5 / 2$ & 7,5 YR $5 / 2$ & $x$ & $x$ & $x$ & $x$ & $x$ & $x$ & $x$ & $x$ & $x$ & $x$ & $x$ & $x$ & $x$ & $x$ & 3 \\
\hline RH19-7 & 2 & & 37 & 0 & 0 & 0 & 0 & 2 & 2 & 10.0 & 8.9 & 0 & 0 & $x$ & $x$ & 7,5YR 5/4, 5/3, 5/1 & $7,5 Y R$ 4/1 & $x$ & $x$ & $x$ & $x$ & $x$ & $x$ & $x$ & $x$ & $\mathrm{x}$ & $x$ & $x$ & $x$ & $x$ & $\mathrm{x}$ & 3 \\
\hline RH19-7 & 2 & & 38 & 0 & 0 & 0 & 0 & 2 & 2 & 10.3 & 9.7 & 0 & 0 & $x$ & $x$ & 7,5YR 5/3, 5/1 & $7,5 Y R$ 4/1 & $x$ & $x$ & $x$ & $x$ & $x$ & $x$ & $x$ & $x$ & $x$ & $\mathrm{x}$ & $x$ & $x$ & $x$ & $\mathrm{x}$ & 3 \\
\hline RH19-7 & 1 & & 39 & 0 & 0 & 0 & 4 & 2 & 3 & 13.2 & 5.0 & 0 & 0 & $x$ & $x$ & 5YR 5/4 & $7,5 Y R$ 5/1 & $x$ & $x$ & $x$ & $x$ & $x$ & $x$ & $x$ & $x$ & $x$ & $x$ & $x$ & $x$ & $x$ & $\mathrm{x}$ & 3 y 4 \\
\hline
\end{tabular}




\begin{tabular}{|c|c|c|c|c|c|c|c|c|c|c|c|c|c|c|c|c|c|c|c|c|c|c|c|c|c|c|c|c|c|c|c|c|}
\hline \multirow[b]{2}{*}{ Sitio } & \multirow[b]{2}{*}{$\begin{array}{c}\mathrm{Ni} \\
\text { vel }\end{array}$} & & \multirow[b]{2}{*}{ FNA } & \multirow[b]{2}{*}{ Fgto } & \multicolumn{11}{|c|}{ Manufactura } & \multicolumn{2}{|c|}{ Cocción } & \multicolumn{5}{|c|}{ Borde-labio } & \multicolumn{6}{|c|}{ Asa } & \multicolumn{3}{|c|}{ Base } & \multirow[b]{2}{*}{ Alterac } \\
\hline & & & & & $\begin{array}{l}\text { Tec } \\
\text { lev }\end{array}$ & $\begin{array}{l}\text { For } \\
\text { ma }\end{array}$ & \begin{tabular}{|l|} 
Mar \\
cas
\end{tabular} & \begin{tabular}{|l|} 
Sup \\
ext
\end{tabular} & \begin{tabular}{|c|} 
Sup \\
int
\end{tabular} & $\begin{array}{l}\text { Esp } \\
\text { max }\end{array}$ & \begin{tabular}{|l|}
$\begin{array}{c}\text { Esp } \\
\text { min }\end{array}$ \\
\end{tabular} & \begin{tabular}{|c|}
$\begin{array}{c}\text { Deco } \\
\text { pint }\end{array}$ \\
\end{tabular} & \begin{tabular}{|c|}
$\begin{array}{c}\text { Deco } \\
\text { corldsp }\end{array}$ \\
\end{tabular} & $\begin{array}{c}\text { Moti } \\
\text { vo }\end{array}$ & Estilo & Color sup ext & Color sup int & Diam & \begin{tabular}{|l|} 
Lrg \\
arc \\
\end{tabular} & \begin{tabular}{|c|}
$\%$ \\
arco \\
\end{tabular} & Dir & $\begin{array}{l}\text { For } \\
\text { ma }\end{array}$ & $\begin{array}{l}\text { Lar } \\
\text { go }\end{array}$ & $\begin{array}{c}\text { An } \\
\text { cho }\end{array}$ & Esp & $\begin{array}{l}\text { Sec } \\
\text { ciór }\end{array}$ & \begin{tabular}{|l|l}
$n$ & In \\
ser
\end{tabular} & \begin{tabular}{l|l} 
& $P o$ \\
rc & sic \\
\end{tabular} & Diám & $\begin{array}{c}\text { Mor } \\
\text { fol }\end{array}$ & $\begin{array}{c}\text { Uni } \\
\text { ón }\end{array}$ & \\
\hline RH19-7 & 2 & & 40 & 0 & 1 & 0 & 1 & 2 & 2 & 8.6 & 6.1 & 0 & 0 & $\mathrm{x}$ & $\mathrm{x}$ & 7,5YR 4/2, 4/3, 3/1 & 7,5YR 5/4 & $\mathrm{x}$ & $\mathrm{x}$ & $\mathrm{x}$ & $\mathrm{x}$ & $x$ & $\mathrm{x}$ & $\mathrm{x}$ & $\mathrm{x}$ & $\mathrm{x}$ & $\mathrm{x}$ & $x$ & $\mathrm{x}$ & $\mathrm{x}$ & $\mathrm{x}$ & \\
\hline RH19-7 & 2 & & 41 & 0 & 0 & 0 & 0 & 2 & 2 & 7.8 & 5.7 & 0 & 0 & $\mathrm{x}$ & $\mathrm{x}$ & 7,5YR 5/2, 5/3 & 7,5YR 5/3 & $\mathrm{x}$ & $\mathrm{x}$ & $\mathrm{x}$ & $\mathrm{x}$ & $x$ & $\mathrm{x}$ & $x$ & $\mathrm{x}$ & $\mathrm{x}$ & $\mathrm{x}$ & $x$ & $\mathrm{x}$ & $\mathrm{x}$ & $\mathrm{x}$ & \\
\hline RH19-7 & 1 & & 42 & 0 & 0 & 0 & 0 & 2 & 2 & 7.0 & 5.5 & 0 & 0 & $x$ & $x$ & $5 Y R 5 / 4,4 / 1$ & $5 Y R$ 5/6, 5/4 & $x$ & $x$ & $x$ & $x$ & $x$ & $x$ & $x$ & $x$ & $x$ & $x$ & $x$ & $x$ & $x$ & $x$ & \\
\hline RH19-7 & 1 & & 43 & 0 & 0 & 0 & 0 & 2 & 3 & 5.2 & 4.1 & 0 & 0 & $\mathrm{x}$ & $x$ & $5 Y R 5 / 4,6 / 4,4 / 1$ & N 3/ & $\mathrm{x}$ & $\mathrm{x}$ & $x$ & $x$ & $\mathrm{x}$ & $\mathrm{x}$ & $\mathrm{x}$ & $\mathrm{x}$ & $\mathrm{x}$ & $\mathrm{x}$ & $x$ & $\mathrm{x}$ & $\mathrm{x}$ & $\mathrm{x}$ & 1 \\
\hline RH19-7 & 1 & & 44 & 0 & 0 & 0 & 0 & 2 & 3 & 5.0 & 3.8 & 0 & 0 & $x$ & $x$ & 7,5 YR 4/1, 4/2 & N 3/ & $x$ & $x$ & $x$ & $x$ & $x$ & $x$ & $x$ & $x$ & $x$ & $x$ & $x$ & $x$ & $x$ & $x$ & 3 \\
\hline RH19-7 & 1 & & 45 & 0 & 0 & 0 & 0 & 2 & 3 & 8.5 & 7.9 & 0 & 0 & $x$ & $x$ & $\mathrm{~N} \mathrm{4/y} 3 /$ & $\mathrm{N} 3 /$ & $x$ & $x$ & $x$ & $x$ & $x$ & $x$ & $x$ & $x$ & $x$ & $x$ & $x$ & $x$ & $x$ & $x$ & 3 \\
\hline RH19-7 & 1 & & 46 & 0 & 0 & 0 & 0 & 0 & 3 & 11.3 & 10.6 & 0 & 0 & $x$ & $x$ & 5YR 5/4 & N 3/ & $x$ & $x$ & $x$ & $x$ & $x$ & $x$ & $x$ & $x$ & $x$ & $x$ & $x$ & $x$ & $x$ & $x$ & 3 y 4 \\
\hline RH19-7 & 1 & & 47 & 0 & 0 & 0 & 0 & 2 & 3 & 5.2 & 4.1 & 0 & 0 & $x$ & $x$ & $5 Y R 5 / 4,6 / 4$ & N 2,5/ & $x$ & $x$ & $x$ & $x$ & $x$ & $x$ & $x$ & $x$ & $x$ & $x$ & $x$ & $x$ & $x$ & $x$ & \\
\hline RH19-7 & 1 & & 48 & 0 & 0 & 0 & 0 & 2 & 3 & 4.5 & 4.3 & 0 & 0 & $x$ & $x$ & $10 \mathrm{R} 4 / 4,4 / 6$ & N 3/ & $x$ & $x$ & $x$ & $x$ & $x$ & $x$ & $x$ & $x$ & $x$ & $x$ & $x$ & $x$ & $x$ & $x$ & \\
\hline RH19-7 & 1 & & 49 & 0 & 0 & 0 & 0 & 2 & 3 & 5.4 & 4.9 & 0 & 0 & $x$ & $x$ & N 3/ & N 3/ & $x$ & $x$ & $x$ & $x$ & $x$ & $\mathrm{x}$ & $x$ & $x$ & $x$ & $x$ & $x$ & $x$ & $x$ & $x$ & \\
\hline RH19-7 & 1 & & 50 & 0 & 0 & 0 & 0 & 2 & 3 & 5.7 & 5.4 & 0 & 0 & $x$ & $x$ & 5YR 4/2 & 5 YR 4/1 & $x$ & $x$ & $x$ & $x$ & $x$ & $x$ & $x$ & $\mathrm{x}$ & $x$ & $x$ & $x$ & $x$ & $x$ & $x$ & \\
\hline RH19-7 & 2 & & 51 & 0 & 0 & 0 & 0 & 2 & 2 & 7.0 & 5.5 & 0 & 0 & $x$ & $x$ & 7,5 YR 5/2 & 5YR 5/4 & $x$ & $x$ & $x$ & $x$ & $x$ & $\mathrm{x}$ & $x$ & $x$ & $x$ & $x$ & $x$ & $x$ & $x$ & $x$ & 3 y 4 \\
\hline RH19-7 & 1 & & 52 & 0 & 0 & 0 & 0 & 2 & 2 & 9.1 & 7.3 & 0 & 0 & $x$ & $x$ & 7,5 YR $5 / 3,5 / 1$ & 7,5YR3/1 & $x$ & $x$ & $x$ & $x$ & $x$ & $\mathrm{x}$ & $x$ & $\mathrm{x}$ & $\mathrm{x}$ & $x$ & $x$ & $x$ & $x$ & $x$ & 3 \\
\hline RH19-7 & 1 & & 53 & 0 & 0 & 0 & 0 & 2 & 2 & 6.8 & 5.2 & 0 & 0 & $x$ & $x$ & 7,5YR 4/2, 4/1 & 7,5YR 4/1 & $x$ & $x$ & $x$ & $x$ & $x$ & $\mathrm{x}$ & $\mathrm{x}$ & $\mathrm{x}$ & $x$ & $x$ & $x$ & $x$ & $x$ & $x$ & \\
\hline RH19-7 & 1 & & 54 & 0 & 0 & 0 & 0 & 2 & 3 & 7.8 & 7.6 & 0 & 0 & $x$ & $x$ & 7,5YR 5/3 & 7,YR 5/3 & $x$ & $x$ & $x$ & $x$ & $x$ & $\mathrm{x}$ & $x$ & $x$ & $x$ & $x$ & $x$ & $x$ & $x$ & $x$ & 3 \\
\hline RH19-7 & 1 & & 55 & 0 & 0 & 0 & 0 & 2 & 2 & 6.0 & 4.7 & 0 & 0 & $x$ & $x$ & 7,5YR 5/2 & 7,5YR 4/1 & $x$ & $x$ & $x$ & $x$ & $x$ & $x$ & $x$ & $\mathrm{x}$ & $x$ & $x$ & $x$ & $x$ & $x$ & $x$ & 3 \\
\hline RH19-7 & 1 & & 56 & 0 & 0 & 0 & 1 & 2 & $2 \mathrm{y} 4$ & 6.5 & 5.3 & 1 & 0 & $x$ & $x$ & 7,5YR 5/3 & 7,5YR 7/3, 5/3 & $x$ & $x$ & $x$ & $x$ & $x$ & $\mathrm{x}$ & $x$ & $\mathrm{x}$ & $x$ & $x$ & $x$ & $x$ & $x$ & $x$ & 5 \\
\hline RH19-7 & 1 & & 57 & 0 & 0 & 0 & 1 & 2 & 2 & 7.5 & 5.4 & 0 & 0 & $x$ & $x$ & 7,5YR 5/3 & 7,5YR 5/6 & $x$ & $x$ & $x$ & $x$ & $x$ & $x$ & $x$ & $\mathrm{x}$ & $x$ & $x$ & $x$ & $x$ & $x$ & $x$ & \\
\hline RH19-7 & 2 & & 58 & 0 & 0 & 0 & 0 & 2 & 2 & 6.9 & 4.5 & 0 & 0 & $x$ & $\mathrm{x}$ & 7,5YR 5/3, 4/2, 4/1 & 7,5 YR $5 / 3$ & $\mathrm{x}$ & $x$ & $x$ & $x$ & $\mathrm{x}$ & $\mathrm{x}$ & $x$ & $x$ & $x$ & $x$ & $x$ & $x$ & $x$ & $x$ & \\
\hline RH19-7 & 1 & & 59 & 0 & 0 & 0 & 0 & 2 & 2 & 6.9 & 5.4 & 0 & 0 & $x$ & $x$ & 5YR 4/2 & 5YR 4/2 & $x$ & $x$ & $x$ & $x$ & $x$ & $\mathrm{x}$ & $\mathrm{x}$ & $x$ & $\mathrm{x}$ & $x$ & $x$ & $x$ & $x$ & $x$ & \\
\hline RH19-7 & 1 & & 60 & 0 & 0 & 0 & 0 & 2 & 3 & 7.1 & 6.8 & 0 & 0 & $x$ & $x$ & N 3/; 5YR 6/2 & $\mathrm{N} 4 /$ & $x$ & $x$ & $x$ & $x$ & $x$ & $\mathrm{x}$ & $x$ & $\mathrm{x}$ & $x$ & $x$ & $x$ & $x$ & $x$ & $x$ & 3 y 4 \\
\hline RH19-7 & 1 & & 61 & 0 & 0 & 0 & 0 & 2 & 2 & 5.6 & 3.4 & 0 & 0 & $x$ & $x$ & 5YR 5/3 & 5YR 4/1 & $x$ & $x$ & $x$ & $x$ & $x$ & $\mathrm{x}$ & $x$ & $\mathrm{x}$ & $x$ & $x$ & $x$ & $x$ & $x$ & $x$ & 3 \\
\hline RH19-7 & 1 & & 62 & 0 & 0 & 0 & 0 & 2 & 2 & 8.5 & 7.8 & 0 & 0 & $x$ & $x$ & 5YR 6/4 & 5YR 5/6 & $x$ & $x$ & $x$ & $x$ & $x$ & $\mathrm{x}$ & $x$ & $\mathrm{x}$ & $x$ & $x$ & $x$ & $x$ & $x$ & $x$ & \\
\hline RH19-7 & 1 & & 63 & 0 & 0 & 0 & 0 & 2 & 2 & 8.1 & 7.2 & 0 & 0 & $x$ & $x$ & 5YR 5/4 & 5YR 5/1 & $x$ & $x$ & $x$ & $x$ & $\mathrm{x}$ & $x$ & $\mathrm{x}$ & $x$ & $x$ & $x$ & $x$ & $x$ & $x$ & $x$ & 3 \\
\hline RH19-7 & 1 & & 64 & 0 & 0 & 0 & 0 & 2 & 2 & 4.8 & 3.8 & 0 & 0 & $x$ & $x$ & 5YR 5/1 y $5 / 2$ & 5YR 5/3 & $x$ & $x$ & $x$ & $x$ & $x$ & $x$ & $\mathrm{x}$ & $\mathrm{x}$ & $x$ & $x$ & $x$ & $x$ & $x$ & $x$ & 3 \\
\hline RH19-7 & 1 & & 65 & 0 & 0 & 0 & 2 & 2 & 3 & 5.0 & 4.6 & 0 & 0 & $x$ & $x$ & $5 Y R$ 5/4, 5/2 & $5 Y R 5 / 3,4 / 1$ & $x$ & $x$ & $x$ & $x$ & $x$ & $x$ & $\mathrm{x}$ & $x$ & $x$ & $x$ & $x$ & $x$ & $x$ & $x$ & \\
\hline RH19-7 & 1 & & 66 & 0 & 0 & 0 & 1 & 2 & 2 & 5.0 & 4.4 & 0 & 0 & $x$ & $x$ & $5 Y R$ 5/2 y $4 / 1$ & 5YR 6/4 & $x$ & $x$ & $x$ & $x$ & $x$ & $x$ & $x$ & $x$ & $x$ & $x$ & $x$ & $x$ & $x$ & $x$ & \\
\hline RH19-7 & 1 & & 67 & 0 & 0 & 0 & 0 & 3 & 2 & 5.7 & 4.2 & 0 & 0 & $x$ & $x$ & 5YR 2,5/1 & $5 Y R 4 / 1$ & $x$ & $x$ & $x$ & $x$ & $x$ & $x$ & $x$ & $x$ & $x$ & $x$ & $x$ & $x$ & $x$ & $x$ & \\
\hline RH19-7 & 1 & & 68 & 0 & 0 & 0 & 0 & 1 & 2 & 10.8 & 7.0 & 0 & 0 & $x$ & $x$ & 5YR $2 /, 5 / 1$ & 5YR 5/4 & $x$ & $x$ & $x$ & $x$ & $x$ & $x$ & $x$ & $x$ & $x$ & $x$ & $x$ & $x$ & $x$ & $x$ & 1 у 2 \\
\hline RH19-7 & 1 & & 69 & 0 & 0 & 0 & 0 & 2 & 2 & 7.9 & 7.5 & 0 & 0 & $x$ & $x$ & 5YR 5/3 & 5YR 4/2 & $x$ & $x$ & $x$ & $x$ & $x$ & $\mathrm{x}$ & $\mathrm{x}$ & $\mathrm{x}$ & $x$ & $x$ & $x$ & $x$ & $x$ & $x$ & 3 \\
\hline RH19-7 & 1 & & 70 & 0 & 0 & 0 & 0 & 2 & 2 & 7.0 & 5.9 & 0 & 0 & $x$ & $\mathrm{x}$ & $5 Y R$ 5/2, 5/3 & $5 Y R$ 6/3, 4/1 & $x$ & $x$ & $x$ & $x$ & $x$ & $\mathrm{x}$ & $x$ & $x$ & $x$ & $x$ & $x$ & $x$ & $x$ & $x$ & 3 \\
\hline RH19-7 & 1 & & 71 & 0 & 0 & 0 & 0 & 2 & 2 & 6.8 & 5.7 & 0 & 0 & $x$ & $x$ & 5YR 5/4 & 5YR 6/2 & $x$ & $x$ & $x$ & $x$ & $x$ & $x$ & $x$ & $x$ & $x$ & $x$ & $x$ & $x$ & $x$ & $x$ & 3 \\
\hline RH19-7 & 1 & & 72 & 0 & 0 & 0 & 0 & 2 & 2 & 5.8 & 5.0 & 0 & 0 & $x$ & $x$ & 5YR 6/3 & 5YR 6/4 & $x$ & $x$ & $x$ & $x$ & $x$ & $x$ & $x$ & $x$ & $x$ & $x$ & $x$ & $x$ & $x$ & $x$ & 3 \\
\hline RH19-7 & 1 & & 73 & 0 & 0 & 0 & 0 & 2 & 3 & 7.0 & 5.9 & 0 & 0 & $x$ & $x$ & 5YR 5/3 & 5YR 5/1 & $x$ & $\mathrm{x}$ & $\mathrm{x}$ & $x$ & $\mathrm{x}$ & $\mathrm{x}$ & $\mathrm{x}$ & $\mathrm{x}$ & $\mathrm{x}$ & $\mathrm{x}$ & $\mathrm{x}$ & $\mathrm{x}$ & $\mathrm{x}$ & $\mathrm{x}$ & 3 \\
\hline RH19-7 & 2 & & 74 & 0 & 0 & 0 & 0 & 2 & 2 & 5.8 & 4.6 & 0 & 0 & $x$ & $x$ & 5YR 2,5/1 & $5 Y R 4 / 2,5 / 1$ & $\mathrm{x}$ & $\mathrm{x}$ & $\mathrm{x}$ & $\mathrm{x}$ & $\mathrm{x}$ & $\mathrm{x}$ & $\mathrm{x}$ & $x$ & $\mathrm{x}$ & $x$ & $x$ & $x$ & $x$ & $x$ & \\
\hline RH19-7 & 1 & & 75 & 0 & 0 & 0 & 0 & 3 & 2 & 6.4 & 5.2 & 0 & 0 & $x$ & $x$ & $5 Y R$ 5/4, 5/1 & $5 Y R 5 / 3$ & $x$ & $x$ & $x$ & $x$ & $x$ & $x$ & $x$ & $x$ & $x$ & $x$ & $x$ & $x$ & $x$ & $x$ & 3 \\
\hline RH19-7 & 1 & & 76 & 0 & 0 & 0 & 0 & 2 & 3 & 7.4 & 6.0 & 0 & 0 & $x$ & $x$ & 2,5 YR 5/6 & 2,5YR 5/1 & $x$ & $x$ & $x$ & $x$ & $x$ & $x$ & $x$ & $x$ & $x$ & $x$ & $x$ & $x$ & $x$ & $x$ & 3 y 4 \\
\hline RH19-7 & 1 & & 77 & 0 & 0 & 0 & 1 & 2 & 2 & 6.4 & 5.8 & 0 & 0 & $x$ & $x$ & $5 Y R$ 5/3 & 5YR 5/2 & $x$ & $x$ & $x$ & $x$ & $\mathrm{x}$ & $x$ & $x$ & $x$ & $x$ & $x$ & $x$ & $x$ & $x$ & $x$ & \\
\hline RH19-7 & 1 & & 78 & 0 & 0 & 0 & 1 & 2 & 2 & 8.2 & 5.5 & 0 & 0 & $x$ & $x$ & $5 Y R 3 / 1$ & 5YR 4/1 & $\mathrm{x}$ & $x$ & $\mathrm{x}$ & $x$ & $\mathrm{x}$ & $x$ & $\mathrm{x}$ & $x$ & $x$ & $\mathrm{x}$ & $x$ & $x$ & $x$ & $x$ & \\
\hline
\end{tabular}




\begin{tabular}{|c|c|c|c|c|c|c|c|c|c|c|c|c|c|c|c|c|c|c|c|c|c|c|c|c|c|c|c|c|c|c|c|c|}
\hline \multirow[b]{2}{*}{ Sitio } & \multirow[b]{2}{*}{$\begin{array}{c}\mathrm{Ni} \\
\text { vel }\end{array}$} & \multirow{2}{*}{\multicolumn{2}{|c|}{ FNA }} & \multirow[b]{2}{*}{ Fgto } & \multicolumn{11}{|c|}{ Manufactura } & \multicolumn{2}{|c|}{ Cocción } & \multicolumn{5}{|c|}{ Borde-labio } & \multicolumn{6}{|c|}{ Asa } & \multicolumn{3}{|c|}{ Base } & \multirow[b]{2}{*}{ Alterac } \\
\hline & & & & & $\begin{array}{l}\text { Tec } \\
\text { lev }\end{array}$ & $\begin{array}{l}\text { For } \\
\text { ma }\end{array}$ & $\begin{array}{l}\text { Mar } \\
\text { cas }\end{array}$ & $\begin{array}{l}\text { Sup } \\
\text { ext }\end{array}$ & $\begin{array}{c}\text { Sup } \\
\text { int }\end{array}$ & $\begin{array}{l}\text { Esp } \\
\text { max }\end{array}$ & \begin{tabular}{|l} 
Esp \\
min
\end{tabular} & $\begin{array}{c}\text { Deco } \\
\text { pint }\end{array}$ & \begin{tabular}{|l|}
$\begin{array}{c}\text { Deco } \\
\text { corldsp }\end{array}$ \\
\end{tabular} & \begin{tabular}{|c|} 
Moti \\
vo \\
\end{tabular} & Estilo & Color sup ext & Color sup int & Diam & $\begin{array}{l}\text { Lrg } \\
\text { arc } \\
\end{array}$ & \begin{tabular}{|c|}
$\%$ \\
arco
\end{tabular} & Dir & $\begin{array}{l}\begin{array}{l}\text { For } \\
\text { ma }\end{array} \\
\end{array}$ & \begin{tabular}{|l} 
Lar \\
go
\end{tabular} & $\begin{array}{l}\begin{array}{c}\text { An } \\
\text { cho }\end{array} \\
\end{array}$ & Esp & $\begin{array}{l}\text { Sec } \\
\text { ción }\end{array}$ & $\begin{array}{l}\text { In } \\
\text { serc }\end{array}$ & \begin{tabular}{l|l} 
Po \\
sic
\end{tabular} & c Diám & $\begin{array}{c}\text { Mor } \\
\text { fol }\end{array}$ & $\begin{array}{c}\text { Uni } \\
\text { ón }\end{array}$ & \\
\hline RH19-7 & 1 & & 79 & 0 & 0 & 0 & 1 & 2 & 2 & 9.7 & 8.1 & 0 & 0 & $x$ & $x$ & $5 Y R \quad 4 / 2$ & 5YR 4/1 & $x$ & $x$ & $x$ & $x$ & $x$ & $x$ & $x$ & $x$ & $x$ & $x$ & $x$ & $x$ & $x$ & $x$ & \\
\hline RH19-7 & 1 & & 80 & 0 & 0 & 0 & 0 & 2 & 2 & 6.4 & 4.9 & 0 & 0 & $x$ & $x$ & 5YR 6/4 & 5YR 5/4 & $x$ & $x$ & $x$ & $x$ & $x$ & $x$ & $x$ & $x$ & $x$ & $x$ & $x$ & $x$ & $x$ & $x$ & \\
\hline RH19-7 & 1 & & 81 & 0 & 0 & 0 & 0 & 2 & 2 & 8.0 & 7.2 & 0 & 0 & $x$ & $x$ & 5YR 5/4 & 5YR $2,5 / 1$ & $x$ & $x$ & $x$ & $x$ & $x$ & $x$ & $x$ & $x$ & $x$ & $x$ & $x$ & $x$ & $x$ & $x$ & 4 \\
\hline RH19-7 & 1 & & 82 & 0 & 0 & 0 & 0 & 2 & 2 & 6.5 & 5.7 & 0 & 0 & $x$ & $x$ & $5 Y R$ 6/6, 5/3 & 5YR 5/6 & $x$ & $x$ & $x$ & $x$ & $x$ & $x$ & $x$ & $x$ & $x$ & $x$ & $x$ & $x$ & $x$ & $x$ & \\
\hline RH19-7 & 1 & & 83 & 0 & 0 & 0 & 1 & 2 & 2 & 6.4 & 5.7 & 0 & 0 & $x$ & $x$ & $5 Y R 5 / 3,4 / 1$ & 5YR 5/2 & $x$ & $x$ & $x$ & $x$ & $x$ & $x$ & $x$ & $x$ & $x$ & $x$ & $x$ & $x$ & $x$ & $x$ & \\
\hline RH19-7 & 1 & & 84 & 0 & 0 & 0 & 0 & 2 & 2 & 5.2 & 4.1 & 0 & 0 & $x$ & $x$ & 5YR 4/1 & 4YR 6/3 & $x$ & $x$ & $\mathrm{x}$ & $x$ & $x$ & $x$ & $x$ & $x$ & $x$ & $x$ & $x$ & $x$ & $x$ & $x$ & \\
\hline RH19-7 & 1 & & 85 & 0 & 0 & 0 & 0 & 2 & 2 & 3.6 & 3.2 & 0 & 0 & $x$ & $x$ & $2,5 Y R$ 5/6, 6/6 & 2,5 YR $5 / 6$ & $x$ & $x$ & $x$ & $x$ & $x$ & $x$ & $x$ & $x$ & $x$ & $x$ & $x$ & $x$ & $x$ & $x$ & \\
\hline RH19-7 & 1 & & 86 & 0 & 0 & 0 & 0 & 2 & 2 & 6.4 & 5.4 & 0 & 0 & $x$ & $x$ & 5YR 5/6 & $5 Y R$ 5/3 & $x$ & $x$ & $x$ & $x$ & $x$ & $x$ & $x$ & $x$ & $x$ & $x$ & $x$ & $x$ & $x$ & $x$ & \\
\hline RH19-7 & 1 & & 87 & 0 & 0 & 0 & 0 & 2 & 3 & 4.7 & 4.7 & 0 & 0 & $x$ & $x$ & $5 Y R$ 5/3 & 5YR 5/1 & $x$ & $x$ & $x$ & $x$ & $x$ & $x$ & $x$ & $x$ & $x$ & $x$ & $x$ & $x$ & $x$ & $x$ & \\
\hline RH19-7 & 1 & & 88 & 0 & 0 & 0 & 0 & 0 & 2 & 8.6 & $5 \mathrm{fr}$ & 0 & 0 & $x$ & $x$ & $5 Y R$ 6/4, 4/1 & $5 Y R$ 5/1, 4/1 & $x$ & $x$ & $x$ & $x$ & $x$ & $x$ & $x$ & $x$ & $x$ & $x$ & $x$ & $x$ & $x$ & $x$ & 3 y 4 \\
\hline RH19-7 & 1 & & 89 & 0 & 0 & 0 & 0 & 2 & 2 & 9.0 & 4.8 & 0 & 0 & $x$ & $x$ & $5 Y R$ 5/3 & $5 Y R$ 6/2 & $x$ & $x$ & $x$ & $x$ & $x$ & $x$ & $x$ & $x$ & $x$ & $x$ & $x$ & $x$ & $x$ & $x$ & \\
\hline RH19-7 & 1 & & 90 & 0 & 0 & 0 & 0 & 2 & 2 & 6.0 & 5.8 & 0 & 0 & $x$ & $x$ & 5YR 5/2 & 5YR 5/2 & $x$ & $x$ & $x$ & $x$ & $x$ & $x$ & $x$ & $x$ & $x$ & $x$ & $x$ & $x$ & $x$ & $x$ & \\
\hline RH19-7 & 1 & & 91 & 0 & 0 & 0 & 0 & 2 & 2 & 4.3 & \begin{tabular}{|l|}
3.9 \\
\end{tabular} & 0 & 0 & $x$ & $x$ & 2,5 YR $5 / 6$ & 2,5 YR 5/6 & $x$ & $x$ & $x$ & $x$ & $x$ & $x$ & $x$ & $x$ & $x$ & $x$ & $x$ & $x$ & $x$ & $x$ & 3 \\
\hline \begin{tabular}{|l|}
$\mathrm{RH} 19-7$ \\
\end{tabular} & 1 & & 92 & 0 & 0 & 0 & 0 & 2 & 2 & 6.6 & 5.1 & 0 & 0 & $x$ & $x$ & 2,5 YR 4/2 & 2,5 YR $4 / 2$ & $x$ & $x$ & $x$ & $x$ & $x$ & $x$ & $x$ & $x$ & $x$ & $x$ & $x$ & $x$ & $x$ & $x$ & \\
\hline RH19-7 & 1 & & 93 & 0 & 0 & 0 & 0 & 0 & 3 & $5 \mathrm{fr}$ & $5 \mathrm{fr}$ & 0 & 0 & $x$ & $x$ & 2,5 YR $5 / 2$ & $2,5 Y R$ 3/1 & $x$ & $x$ & $x$ & $x$ & $x$ & $x$ & $x$ & $x$ & $x$ & $x$ & $x$ & $x$ & $x$ & $x$ & 3 y 4 \\
\hline RH19-7 & Sup & & 94 & 1 & 0 & 1 & 1 & 2 & 3 & 6.3 & 4.1 & 0 & 0 & $x$ & PINP & $5 Y R 6 / 3,4 / 1$ & N 3/ & 16 & 3.8 & 7.5 & 2 & 6 & $x$ & $x$ & $x$ & $x$ & $x$ & $x$ & $x$ & $x$ & $x$ & 2 y 3 \\
\hline RH19-7 & Sup & & 95 & 1 & 1 & 0 & 0 & 2 & 2 & 6.4 & 4.9 & 0 & 0 & $x$ & $x$ & $5 Y R 5 / 4,4 / 4$ & 5YR 5/4 & indet & 2.2 & indet & 1 & 2 & $x$ & $x$ & $x$ & $x$ & $x$ & $x$ & $x$ & $x$ & $x$ & 3 \\
\hline RH19-7 & Sup & & 96 & 3 & 0 & 0 & $1 \mathrm{y} 2$ & 3 & 2 & $x$ & $x$ & 1 & 0 & $x$ & Yavi & 10R $4 / 3$ & $5 Y R 6 / 4$ & $x$ & $x$ & $x$ & $x$ & $x$ & $4.7 \mathrm{fr}$ & 2.7 & 13 & 4 & 0 & 0 & $x$ & $x$ & $x$ & \\
\hline RH19-7 & Sup & & 97 & 3 & 0 & 0 & $1 \mathrm{y} 2$ & 3 & 2 & $x$ & $x$ & 1 & 0 & $x$ & Yavi & 10R $4 / 4$ & 5YR 6/4 & $x$ & $x$ & $x$ & $x$ & $x$ & $3 \mathrm{fr}$ & 2.6 & 11 & 4 & 0 & 0 & $x$ & $x$ & $x$ & \\
\hline RH19-7 & Sup & & 98 & 3 & 0 & 0 & 0 & $2,3 y 4$ & $2 \mathrm{y} 4$ & 9.3 & 6.7 & 1 & 0 & $x$ & Yavi & $2,5 Y R$ 6/6; 10R 4/4 & 2,5YR6/6,6/8;10R4/4 & $x$ & $x$ & $x$ & $x$ & $x$ & $1.5 \mathrm{fr}$ & 2.4 & 14 & 4 & 1 & 0 & $x$ & $x$ & $x$ & 5 \\
\hline RH19-7 & Sup & & 99 & 2 & 2 & 0 & 5 & $2 \mathrm{y3}$ & 1 & 8.3 & 6.1 & 0 & 0 & $x$ & Yavi & $10 \mathrm{R} 3 / 4,4 / 4$ & 10R 5/6, 4/6 & $x$ & $x$ & $x$ & $x$ & $x$ & $x$ & $x$ & $x$ & $x$ & $x$ & $x$ & 5 & 5 & 2 & \\
\hline RH19-7 & Sup & & 100 & 2 & 0 & 0 & 0 & $2,3 y 4$ & 2 & 6.3 & 4.1 & 1 & 0 & $x$ & $x$ & $10 R 5 / 6,6 / 6$ & $5 Y R 6 / 4$ & $x$ & $x$ & $x$ & $x$ & $x$ & $x$ & $x$ & $x$ & $x$ & $x$ & $x$ & 4.4 & 5 & 2 & \\
\hline RH19-7 & Sup & & 101 & 0 & 1 & 0 & 1 & $2 \mathrm{y} 4$ & 2 & 7.8 & 5.8 & 1 & 0 & $x$ & Yavi & $2,5 Y R$ 6/4, 10R 4/4 & 2,5 YR $6 / 6$ & $x$ & $x$ & $x$ & $x$ & $x$ & $x$ & $x$ & $x$ & $\mathrm{x}$ & $x$ & $x$ & $x$ & $\mathrm{x}$ & $x$ & 3 \\
\hline RH19-7 & Sup & & 102 & 0 & 0 & 0 & 0 & $2 \mathrm{y} 4$ & 2 & 8.5 & 6.4 & 1 & 0 & $x$ & $x$ & 5YR 4/4; 10R 4/6 & $5 Y R 5 / 4$ & $x$ & $x$ & $x$ & $x$ & $x$ & $x$ & $x$ & $x$ & $x$ & $x$ & $x$ & $x$ & $x$ & $x$ & \\
\hline RH19-7 & Sup & & 103 & 0 & 0 & 0 & 0 & $3,4 \mathrm{y} 6$ & 2 & 4.9 & 4.7 & 2 & 0 & $x$ & $x$ & 10R 4/4, 4/6; N $3 /$ & 2,5 YR $6 / 4$ & $x$ & $x$ & $\mathrm{x}$ & $x$ & $x$ & $x$ & $x$ & $x$ & $x$ & $x$ & $x$ & $x$ & $x$ & $x$ & 5 \\
\hline RH19-7 & Sup & & 104 & 0 & 0 & 1 & 0 & 2 & 3 & 5.9 & 4.7 & 0 & 0 & $x$ & PINP & 2,5 YR $4 / 1,3 / 4,5 / 3$ & $2,5 Y R$ 4/1, 5/1, 4/3 & $x$ & $x$ & $\mathrm{x}$ & $x$ & $x$ & $x$ & $x$ & $x$ & $x$ & $x$ & $x$ & $x$ & $x$ & $x$ & 4 \\
\hline RH19-7 & Sup & & 105 & 0 & 0 & 0 & 0 & 2 & 3 & 5.5 & 4.9 & 0 & 0 & $x$ & $x$ & 2,5 YR $6 / 4,5 / 2$ & $\mathrm{~N} \mathrm{4/}$ & $x$ & $x$ & $x$ & $x$ & $x$ & $x$ & $x$ & $x$ & $x$ & $x$ & $x$ & $x$ & $x$ & $x$ & 7 \\
\hline
\end{tabular}

\begin{tabular}{|c|c|c|c|c|c|c|c|c|c|c|c|c|c|c|c|c|c|c|c|c|c|c|c|c|c|c|c|c|c|c|c|c|}
\hline \multirow[b]{2}{*}{ Sitio } & \multirow[b]{2}{*}{ UP } & \multirow[b]{2}{*}{$\mathrm{FN}^{\circ}$} & \multirow[b]{2}{*}{ Fgto } & \multicolumn{12}{|c|}{ Manufactura } & \multicolumn{2}{|c|}{ Cocción } & \multicolumn{5}{|c|}{ Borde-labio } & \multicolumn{6}{|c|}{ Asa } & \multicolumn{3}{|c|}{ Base } & \multirow[b]{2}{*}{ Alterac } \\
\hline & & & & $\begin{array}{l}\text { Tec } \mathrm{F} \\
\text { lev }\end{array}$ & $\begin{array}{c}\text { For } \\
\text { ma }\end{array}$ & $\begin{array}{l}\text { Mar } \\
\text { cas }\end{array}$ & Sup & $\begin{array}{c}\text { Sup } \\
\text { int }\end{array}$ & $\begin{array}{l}\text { Esp } \\
\max \end{array}$ & $\begin{array}{l}\text { Esp } \\
\text { min }\end{array}$ & $\begin{array}{c}\text { Deco } \\
\text { pint }\end{array}$ & \begin{tabular}{|l|} 
Deco \\
corldsp
\end{tabular} & \begin{tabular}{|l|} 
Deco \\
agreg
\end{tabular} & Motivo & Estilo & Color sup ext & Color sup int & Diam & $\mid \begin{array}{l}\text { Lrg } \\
\operatorname{arc}\end{array}$ & \begin{tabular}{|c|c|}
$\%$ \\
arco
\end{tabular} & Direc & $\begin{array}{c}\text { cor } \\
\text { ma }\end{array}$ & $\begin{array}{l}\text { Lar } \\
\text { go }\end{array}$ & $\begin{array}{c}\text { An } \\
\text { cho }\end{array}$ & Esp $\begin{array}{l}S \\
c\end{array}$ & \begin{tabular}{|l|} 
Sec \\
ción
\end{tabular} & $\begin{array}{l}\text { In } \\
\text { serc }\end{array}$ & $\begin{array}{l}\text { Posi } \\
\text { ción }\end{array}$ & Diám & $\begin{array}{c}\text { Mor } \\
\text { fol }\end{array}$ & $\begin{array}{l}\text { Uni } \\
\text { ón }\end{array}$ & \\
\hline SC 3 & Sup & 1 & 1 & 0 & 1 & 0 & $3 y 4$ & $3 y 4$ & 21.5 & 4.8 & 1 & 2 & 1 & ornitomorf & Yavi-inka & 10R4/4; 2,5YR6/6 & 10R $5 / 6$ & 17,9 & 5,2 & 9,3 & 1 & 2 & $2,7 \mathrm{fr}$ & 2,1 & 2,2 & $x$ & 5 & 1 & $x$ & $x$ & $x$ & 5 \\
\hline $\mathrm{SC} 3$ & Sup & 2 & 1 & 0 & 1 & 0 & $3 y_{4}^{3}$ & $3 y 4$ & 18.5 & 6.7 & 1 & 2 & 1 & ornitomorf & Yavi-inka & 10R4/4; 2,5YR5/4 & 10R4/4; 2,5YR5/4 & 4 indet & 3,1 & indet & 1 & 2 & $2,9 \mathrm{fr}$ & 2,3 & 1.5 & $\mathrm{x}$ & 5 & 1 & $x$ & $\mathrm{x}$ & $\mathrm{x}$ & 4 у 5 \\
\hline SC 3 & Sup & 3 & 1 & 0 & 1 & 2 & $3 y^{4} 3$ & $3 y 4$ & 7 & 5.8 & 1 & 0 & 0 & $\mathrm{x}$ & Yavi & $2,5 Y R \quad 4 / 3,4 / 4$ & $2,5 Y R \quad 4 / 4$ & 17,9 & 4,1 & 7,3 & 2 & $2 \mathrm{y} 6$ & $\mathrm{x}$ & $\mathrm{x}$ & $\mathrm{x}$ & $x$ & $\mathrm{x}$ & $\mathrm{x}$ & $\mathrm{x}$ & $\mathrm{x}$ & $\mathrm{x}$ & \\
\hline SC 3-1 & Int & 4 & 1 & 0 & 1 & 73 & $3 y_{4}$ & $3 y 4$ & 12 & 5.8 & 1 & 0 & 0 & $x$ & $x$ & $2,5 Y R \quad 4 / 3,4 / 4$ & 10R $4 / 6$ & 14,7 & 4,2 & 9,1 & 2 & 2 & indet & 2.9 & indet & 0 & 5 & 0 & $\mathrm{x}$ & $\mathrm{x}$ & $x$ & \\
\hline $\mathrm{SC} 3$ & Sup & 5 & 0 & 0 & 1 & 033 & $3 y^{4}$ & $3 y 4$ & 5.7 & 4.6 & 1 & 0 & 0 & $x$ & $x$ & $2,5 Y R$ 4/4 & $2,5 Y R \quad 4 / 4$ & $x$ & $x$ & $x$ & $x$ & $x$ & $x$ & $x$ & $x$ & $x$ & $x$ & $x$ & $\mathrm{x}$ & $x$ & $x$ & \\
\hline
\end{tabular}




\section{Manufactura}

Cocción

Borde-labio

Asa

Base

\begin{tabular}{|c|c|c|c|c|c|c|c|c|c|c|c|c|c|c|c|c|c|c|c|c|c|c|c|c|c|c|c|c|c|c|c|c|c|}
\hline \multirow[b]{2}{*}{ Sitio } & \multirow[b]{2}{*}{ UP } & \multirow[b]{2}{*}{$\mathrm{FN}^{\circ}$} & & \multicolumn{12}{|c|}{ Manufactura } & \multicolumn{2}{|c|}{ Cocción } & \multicolumn{5}{|c|}{ Borde-labio } & \multicolumn{7}{|c|}{ Asa } & \multicolumn{3}{|c|}{ Base } & \multirow[b]{2}{*}{ Alterac } \\
\hline & & & Fgto & $\begin{array}{l}\text { Tec } \\
\text { lev } \\
\end{array}$ & $\begin{array}{l}\text { For } \\
\text { ma }\end{array}$ & $\begin{array}{l}\text { Mar } \\
\text { cas }\end{array}$ & $\begin{array}{l}\text { Sup } \\
\text { ext }\end{array}$ & \begin{tabular}{|l} 
Sup \\
int
\end{tabular} & \begin{tabular}{|l|} 
Esp \\
max
\end{tabular} & \begin{tabular}{|l|} 
Esp \\
min \\
\end{tabular} & \begin{tabular}{|c|} 
Deco \\
pint \\
\end{tabular} & \begin{tabular}{|c|} 
Deco \\
cor/dsp
\end{tabular} & \begin{tabular}{|l|} 
Deco \\
agreg
\end{tabular} & Motivo & Estilo & Color sup ext & Colo & Diam & $\begin{array}{l}\text { Lrg } \\
\text { arc }\end{array}$ & \begin{tabular}{|c|c|}
$\%$ \\
arco
\end{tabular} & Direc & $\begin{array}{l}\text { For } \\
\text { ma }\end{array}$ & $\begin{array}{l}\text { Lar } \\
\text { go }\end{array}$ & $\begin{array}{c}\text { An } \\
\text { cho }\end{array}$ & Esp & p $\begin{array}{l}\text { Sec } \\
\text { ción }\end{array}$ & \begin{tabular}{l|l}
$c$ & In \\
n ser \\
\end{tabular} & & $\begin{array}{l}\text { iosi } \\
\text { ión } \\
\end{array}$ & Diám & \begin{tabular}{|c|} 
Mor \\
fol \\
\end{tabular} & $\begin{array}{l}\text { Uni } \\
\text { ón }\end{array}$ & \\
\hline $\mathrm{SC} 3$ & Sup & 6 & 0 & 0 & 1 & 2 & $3 y 4$ & $3 y 4$ & 6.1 & 5.6 & 1 & 0 & 0 & $x$ & $x$ & $2,5 Y R$ 4/3 & $2,5 Y R \quad 4 / 3$ & $x$ & $x$ & $x$ & $x$ & $x$ & $x$ & $x$ & $x$ & $x$ & $x$ & & $x$ & $x$ & $x$ & $x$ & 4 \\
\hline SC3-4 & Ext & 7 & 0 & 0 & 0 & 2 & $3 y 4$ & $3 y 4$ & 6 & 5.4 & 1 & 0 & 0 & $x$ & $x$ & 10R $4 / 3$ & $2,5 Y R \quad 4 / 4$ & $x$ & $x$ & $x$ & $x$ & $x$ & $x$ & $x$ & $x$ & $x$ & $x$ & & $x$ & $x$ & $x$ & $x$ & \\
\hline $\mathrm{SC} 3$ & Sup & 8 & 0 & 0 & 1 & 0 & $3 y 4$ & $3 y 4$ & 6.8 & 4.9 & 1 & 0 & 0 & $\mathrm{x}$ & $\mathrm{x}$ & 10R $4 / 6$ & 10R4/6; 2,5YR5/6 & $\mathrm{x}$ & $x$ & $\mathrm{x}$ & $x$ & $\mathrm{x}$ & $x$ & $\mathrm{x}$ & $\mathrm{x}$ & $x$ & $\mathrm{x}$ & $x$ & $x$ & $x$ & $x$ & $x$ & 5 \\
\hline SC 3 & Sup & 9 & 0 & 0 & 0 & 2 & $3 y 4$ & $3 y 4$ & 6.3 & 6 & 1 & 0 & 0 & $x$ & $x$ & 2,5YR 5/6 & 2,5 YR 5/6 & $x$ & $x$ & $x$ & $x$ & $x$ & $x$ & $x$ & $x$ & $x$ & $x$ & $x$ & $x$ & $x$ & $x$ & $x$ & \\
\hline $\mathrm{SC} 3$ & Sup & 10 & 0 & 0 & 1 & 0 & $3 y 4$ & $3 y 4$ & 4.3 & 3.1 & 1 & 0 & 0 & $x$ & $x$ & $2,5 Y R$ 3/3 & $2,5 Y R \quad 4 / 3$ & $x$ & $x$ & $x$ & $x$ & $x$ & $x$ & $x$ & $x$ & $x$ & $x$ & $x$ & $x$ & $x$ & $x$ & $x$ & 5 \\
\hline $\mathrm{SC} 3$ & Sup & 11 & 2 & 0 & 0 & 0 & $3 y 4$ & 4 & 8.5 & 3.9 & 1 & 0 & 0 & $x$ & Yavi & 10R4/6; 2,5YR5/6 & 10R4/6; 2,5YR5/6 & $x$ & $x$ & $x$ & $x$ & $x$ & $x$ & $x$ & $x$ & $x$ & $x$ & $x$ & $x$ & 6,9 & 5 & 2 & 5 \\
\hline SC3-4 & Ext & 12 & 3 & 0 & 0 & 2 & 4 & 4 & 9.6 & 6 & 1 & 0 & 0 & $x$ & $x$ & $2,5 Y R$ 5/6, 4/6 & $2,5 Y R \quad 3 / 3,4 / 4$ & $x$ & $x$ & $x$ & $x$ & $\mathrm{x}$ & $1,2 \mathrm{fr}$ & 2,3 & 1,6 & 2 & 1 & 0 & 0 & $x$ & $x$ & $x$ & 5 \\
\hline $\mathrm{SC} 3$ & Sup & 13 & 0 & 0 & 0 & 1 & 4 & 4 & 8.1 & 6.6 & 1 & 0 & 0 & $x$ & $x$ & $2,54 / 4,5 / 6$ & $2,5 Y R \quad 6 / 6,4 / 6$ & $x$ & $x$ & $x$ & $x$ & $x$ & $x$ & $x$ & $x$ & $x$ & $x$ & & $x$ & $x$ & $x$ & $x$ & 5 \\
\hline SC 3-1 & Int & 14 & 0 & 0 & 0 & 0 & $3 y 4$ & $3 y 4$ & 9 & 6 & 1 & 0 & 0 & $x$ & $x$ & 2,5YR 5/6 & 2,5 YR 5/6 & $x$ & $x$ & $x$ & $x$ & $x$ & $x$ & $x$ & $x$ & $x$ & $x$ & $x$ & $x$ & $x$ & $x$ & $x$ & 5 \\
\hline SC 3-1 & Int & 15 & 0 & 0 & 0 & 1 & 4 & 4 & 7.7 & 5.9 & 1 & 0 & 0 & $x$ & $x$ & $2,5 Y R$ 4/6 & $2,5 Y R \quad 4 / 6$ & $x$ & $x$ & $x$ & $x$ & $x$ & $x$ & $x$ & $x$ & $x$ & $x$ & $x$ & $x$ & $x$ & $x$ & $x$ & 5 \\
\hline SC 3-1 & Int & 16 & 0 & 0 & 0 & 1 & 4 & 4 & 7 & 5.7 & 1 & 0 & 0 & $x$ & $x$ & $2,5 Y R$ 4/6, 5/8 & $2,5 Y R \quad 4 / 4$ & $x$ & $x$ & $x$ & $x$ & $x$ & $x$ & $x$ & $x$ & $x$ & $x$ & $x$ & $x$ & $x$ & $x$ & $x$ & 5 \\
\hline SC 3-1 & Int & 17 & 0 & 0 & 0 & 1 & 4 & 4 & 6.7 & 5 & 1 & 0 & 0 & $x$ & $x$ & $2,5 Y R \quad 4 / 6$ & 2,5 YR $4 / 6$ & $x$ & $x$ & $\mathrm{x}$ & $x$ & $x$ & $x$ & $x$ & $\mathrm{x}$ & $x$ & $\mathrm{x}$ & $x$ & $x$ & $x$ & $x$ & $x$ & 5 \\
\hline $\mathrm{SC} 3$ & Sup & 18 & 0 & 0 & 0 & 1 & 4 & 4 & 7.2 & 6 & 1 & 0 & 0 & $x$ & $x$ & $2,5 Y R \quad 4 / 4,5 / 4$ & 2,5 YR 4/6 & $x$ & $x$ & $x$ & $x$ & $x$ & $x$ & $x$ & $x$ & $x$ & $x$ & $x$ & $x$ & $x$ & $x$ & $x$ & 5 \\
\hline SC 3 & Sup & 19 & 0 & 0 & 0 & 1 & 4 & 4 & 8 & 5.4 & 1 & 0 & 0 & $x$ & $x$ & $2,5 Y R \quad 4 / 4$ & 2,5 YR $4 / 4$ & $x$ & $x$ & $x$ & $x$ & $x$ & $x$ & $x$ & $x$ & $x$ & $x$ & $x$ & $x$ & $x$ & $x$ & $x$ & 5 \\
\hline SC3-4 & Ext & 20 & 0 & 0 & 0 & 1 & 4 & 4 & 6.8 & 5.7 & 1 & 0 & 0 & $x$ & $x$ & $2,5 Y R$ 4/6 & 2,5 YR 5/4 & $x$ & $x$ & $x$ & $\mathrm{x}$ & $\mathrm{x}$ & $x$ & $\mathrm{x}$ & $x$ & $x$ & $x$ & $x$ & $x$ & $x$ & $x$ & $x$ & 5 \\
\hline SC 3-1 & Int & 21 & 0 & 0 & 0 & 1 & 4 & 4 & 5.8 & 4.7 & 1 & 0 & 0 & $x$ & $x$ & 10R $4 / 6$ & 10R 5/6 & $x$ & $x$ & $x$ & $x$ & $x$ & $x$ & $x$ & $x$ & $x$ & $x$ & $x$ & $x$ & $x$ & $x$ & $x$ & 5 \\
\hline S $3-2 y 3$ & 3 Sup & 22 & 1 & 0 & 1 & 2 & $3 y 4$ & 6 & 5.7 & 4.2 & 1 & 0 & 0 & $\mathrm{x}$ & Yavi & 10R $4 / 4,3 / 1$ & $2,5 Y R 5 / 2,10 R 3 / 1$ & 13 & 3,5 & 8,6 & 3 & 2 & 1,8 & 0,76 & $0,4 !$ & \begin{tabular}{l|l}
5 & 0 \\
\end{tabular} & 1 & & 1 & $x$ & $x$ & $x$ & 5 \\
\hline 3-2y3 & 3 Sup & 23 & 0 & 0 & 1 & 2 & $3 y 4$ & 6 & 4.7 & 3.4 & 1 & 0 & 0 & $x$ & Yavi & 10R $4 / 4,3 / 2$ & $2,5 Y R$ 5/2, 4/4 & $x$ & $x$ & $x$ & $x$ & $x$ & $x$ & $x$ & $x$ & $x$ & $x$ & $x$ & $x$ & $x$ & $x$ & $x$ & 5 \\
\hline SC 3 & Sup & 24 & 1 & 0 & 1 & 2 & 4 & 4 & 6.8 & 4.3 & 1 & 0 & 0 & $x$ & Yavi & 2,5 YR 5/6, 4/6 & 2,5 YR $4 / 4,5 / 4$ & indet & 2,9 & indet & 3 & 3 & 1,2 & 1,1 & 0,4 & 0 & 1 & & 0 & $x$ & $x$ & $x$ & 5 \\
\hline $\mathrm{SC} 3$ & Sup & 25 & 1 & 0 & 1 & 9 & 4 & 2 & 6.3 & 4.4 & 1 & 0 & 0 & $x$ & Yavi & 10R $4 / 4$ & $2,5 Y R$ 5/6 & indet & 2,5 & indet & 3 & 3 & $x$ & $x$ & $x$ & $x$ & $x$ & $x$ & $x$ & $x$ & $x$ & $x$ & 5 \\
\hline SC 3 & Sup & 26 & 1 & 0 & 1 & 2 & $3 y 4$ & 2 & 6.5 & 5 & 1 & 0 & 0 & $\mathrm{x}$ & $x$ & $10 \mathrm{R} 4 / 6$ & 5YR 5/2 & indet & 1,4 & indet & 3 & 2 & $\mathrm{x}$ & $x$ & $\mathrm{x}$ & $x$ & $x$ & $x$ & $x$ & $x$ & $x$ & $x$ & \\
\hline SC 3-1 & Ext & 27 & 1 & 0 & 1 & 0 & $3 y 4$ & 2 & 6.5 & 4.5 & 1 & 0 & 0 & $x$ & Yavi & 2,5YR5/6, 10R4/6 & $2,5 Y R 6 / 3$ & indet & 1 & indet & 3 & 2 & $x$ & $x$ & $x$ & $x$ & $x$ & & $x$ & $x$ & $x$ & $x$ & 5 \\
\hline SC 3-1 & Ext & 28 & 1 & 0 & 1 & 0 & 4 & 2 & 6.5 & 4.6 & 1 & 0 & 0 & $x$ & Yavi & 10R $4 / 4$ & 1,5 YR $6 / 4$ & indet & $2,2 i$ & indet & 2 & 2 & $x$ & $x$ & $x$ & $x$ & $x$ & & $x$ & $x$ & $x$ & $x$ & 5 \\
\hline SC 3-1 & Ext & 29 & 1 & 0 & 1 & 0 & 4 & 4 & 6.5 & 3.8 & 1 & 0 & 0 & $x$ & $x$ & 2,5 YR $4 / 3,5 / 3$ & 2,5 YR $4 / 3$ & indet & 2,4 & indet & 2 & 2 & $x$ & $x$ & $x$ & $x$ & $x$ & & $x$ & $x$ & $x$ & $x$ & 5 \\
\hline SC 3-1 & Ext & 30 & 0 & 0 & 0 & 1 & $3 y 4$ & 2 & 7.5 & 5.6 & 1 & 0 & 0 & $x$ & Yavi & 10R4/4; 2,5YR5/6 & 2,5 YR 5/6 & $x$ & $x$ & $x$ & $x$ & $x$ & $x$ & $x$ & $\mathrm{x}$ & $x$ & $x$ & $x$ & $x$ & $x$ & $x$ & $x$ & 5 \\
\hline SC 3 & Sup & 31 & 0 & 0 & 0 & 1 & $3 y 4$ & 2 & 6 & 4.8 & 1 & 0 & 0 & $x$ & Yavi & 10R4/6; 2,5YR5/6 & 2,5 YR 5/6 & $x$ & $x$ & $x$ & $x$ & $x$ & $x$ & $x$ & $\mathrm{x}$ & $x$ & $x$ & $x$ & $x$ & $x$ & $\mathrm{x}$ & $x$ & 5 \\
\hline $\mathrm{SC} 3$ & Sup & 32 & 0 & 0 & 0 & 1 & $3 y 4$ & 2 & 6.5 & 5.6 & 1 & 0 & 0 & $x$ & Yavi & 10R4/4; 2,5YR5/6 & $2,5 Y R$ 5/6 & $x$ & $x$ & $x$ & $x$ & $x$ & $x$ & $x$ & $x$ & $x$ & $x$ & $x$ & $x$ & $x$ & $x$ & $x$ & 5 \\
\hline SC 3-1 & Int & 33 & 0 & 0 & 0 & 0 & $3 y 4$ & 2 & 5.8 & 4.6 & 1 & 0 & 0 & $x$ & Yavi & 10R4/4; 2,5YR5/6 & 2,5YR 5/6 & $x$ & $x$ & $x$ & $\mathrm{x}$ & $x$ & $x$ & $x$ & $x$ & $x$ & $x$ & $x$ & $x$ & $x$ & $x$ & $x$ & 5 \\
\hline $\mathrm{SC} 3$ & Sup & 34 & 1 & 0 & 2 & 0 & $2 \mathrm{y} 6$ & $2 \mathrm{y} 6$ & 9.4 & 7 & 1 & 0 & 0 & $x$ & $x$ & $2,5 Y R \quad 4 / 4,5 / 6$ & $5 Y R 5 / 4,4 / 3$ & indet & 2,3 i & indet & 1 & 2 & $x$ & $x$ & $x$ & $x$ & $x$ & & $x$ & $x$ & $x$ & $x$ & 5 \\
\hline S $3-2 y 3$ & 3 Sup & 35 & 1 & 0 & 2 & 2 & 2 & $3 y 4$ & 7 & 5.4 & 1 & 0 & 0 & $x$ & Yavi & $2,5 Y R \quad 4 / 2,5 / 6$ & 10R $4 / 4$ & 14,8 & 4,7 & 10,1 & 1 & 2 & $x$ & $\mathrm{x}$ & $\mathrm{x}$ & $\mathrm{x}$ & $\mathrm{x}$ & & $\mathrm{x}$ & $\mathrm{x}$ & $\mathrm{x}$ & $x$ & 1 \\
\hline $\mathrm{SC} 3$ & Sup & 36 & 1 & 0 & 0 & 0 & $3 y 4$ & 2 & 6 & 4.7 & 1 & 0 & 0 & $\mathrm{x}$ & $\mathrm{x}$ & $2,5 Y R \quad 4 / 4$ & 2,5 YR $4 / 3$ & indet & 2,1 i & indet & 1 & 2 & $x$ & $x$ & $\mathrm{x}$ & $x$ & $x$ & & $x$ & $\mathrm{x}$ & $x$ & $x$ & \\
\hline SC 3 & Sup & 37 & 2 & 0 & 0 & 2 & $3 y 4$ & 3 & 11.5 & 6.6 & 1 & 0 & 0 & $x$ & $x$ & 2,5 YR $4 / 4,5 / 5$ & 2,5 YR $4 / 3$ & $x$ & $x$ & $x$ & $x$ & $x$ & $x$ & $x$ & $x$ & $x$ & $x$ & $x$ & $x$ & 5 & 5 & 2 & \\
\hline SC $3-2 y 3$ & 3 Sup & 38 & 2 & 0 & 0 & 0 & 4 & 2 & 10.7 & 6 & 1 & 0 & 0 & $x$ & $x$ & 2,5YR4/4, 5YR6/6 & 7,5YR 6/4 & $x$ & $x$ & $x$ & $x$ & $x$ & $x$ & $x$ & $x$ & $x$ & $x$ & $x$ & $x$ & 8,5 & 5 & 3 & 5 \\
\hline $\mathrm{SC} 3$ & Sup & 39 & 0 & 1 & 0 & 0 & $3 y 4$ & 2 & 6.2 & 3.9 & 1 & 0 & 0 & $x$ & $x$ & $2,5 Y R$ 5/4, 4/3 & $2,5 Y R \quad 5 / 3,5 / 4$ & $x$ & $x$ & $x$ & $x$ & $x$ & $x$ & $x$ & $x$ & $x$ & $x$ & $x$ & $x$ & $x$ & $x$ & $x$ & 4 \\
\hline $\mathrm{SC} 3$ & Sup & 40 & 0 & 1 & 0 & 0 & $3 y 4$ & 2 & 6.5 & 4.3 & 1 & 0 & 0 & $x$ & $x$ & $2,5 Y R$ 5/4, 4/3 & $2,5 Y R$ 5/3, 5/4 & $\mathrm{x}$ & $x$ & $x$ & $x$ & $x$ & $x$ & $x$ & $x$ & $x$ & $x$ & $x$ & $x$ & $x$ & $x$ & $x$ & \\
\hline SC 3-1 & Int & 41 & 0 & 0 & 0 & 0 & $3 y 4$ & 2 & 6.1 & 4.5 & 1 & 0 & 0 & $x$ & $x$ & $2,5 Y R$ 5/4, 4/4 & $2,5 Y R$ 5/4 & $x$ & $x$ & $x$ & $x$ & $x$ & $x$ & $x$ & $x$ & $x$ & $x$ & & $x$ & $x$ & $x$ & $x$ & \\
\hline $\mathrm{SC} 3$ & Sup & 42 & 0 & 0 & 0 & 0 & $3 y 4$ & 2 & 6.4 & 4.3 & 1 & 0 & 0 & $x$ & $x$ & $2,5 Y R$ 5/4, 4/4 & 2,5 YR 5/4 & $x$ & $x$ & $x$ & $x$ & $x$ & $x$ & $x$ & $x$ & $x$ & $x$ & & $x$ & $x$ & $x$ & $x$ & 4 \\
\hline $\mathrm{SC} 3$ & Sup & 43 & 0 & 0 & 0 & 0 & $3 y 4$ & 2 & 7 & 6.8 & 1 & 0 & 0 & $\mathrm{x}$ & $x$ & 10R $4 / 4$ & 5YR 5/3 & $x$ & $x$ & $\mathrm{x}$ & $x$ & $x$ & $x$ & $x$ & $\mathrm{x}$ & $x$ & $x$ & $x$ & $x$ & $x$ & $x$ & $x$ & 3 \\
\hline - $3-2 y^{3}$ & 3 Sup & 44 & 0 & 0 & 0 & 0 & $3 y 4$ & 2 & 5.7 & 4.7 & 1 & 0 & 0 & $x$ & $x$ & 10R $4 / 3$ & 5YR 6/4 & $x$ & $x$ & $x$ & $x$ & $x$ & $x$ & $x$ & $x$ & $x$ & $x$ & $x$ & $x$ & $\mathrm{x}$ & $x$ & $x$ & \\
\hline C $3-2 y 3$ & 3 Sup & 45 & 0 & 0 & 0 & 0 & $3 y 4$ & 2 & 5.9 & 5.6 & 1 & 0 & 0 & $x$ & $x$ & $10 \mathrm{R} 4 / 3$ & 5YR 6/4 & $x$ & $x$ & $x$ & $x$ & $x$ & $x$ & $x$ & $x$ & $x$ & $x$ & & $x$ & $x$ & $x$ & $x$ & \\
\hline $\mathrm{SC} 3$ & Sup & 46 & 0 & 0 & 0 & 1 & $3 y 4$ & 2 & 6.4 & 5.4 & 1 & 0 & 0 & $x$ & $x$ & 10R $4 / 6$ & $5 Y R$ 5/4 & $x$ & $x$ & $x$ & $x$ & $x$ & $x$ & $x$ & $x$ & $x$ & $\mathrm{x}$ & & $x$ & $x$ & $x$ & $x$ & \\
\hline
\end{tabular}




\section{Manufactura}

Cocción

Borde-labio

Asa

Base

\begin{tabular}{|c|c|c|c|c|c|c|c|c|c|c|c|c|c|c|c|c|c|c|c|c|c|c|c|c|c|c|c|c|c|c|c|c|}
\hline \multirow[b]{2}{*}{ Sitio } & \multirow[b]{2}{*}{ UP } & \multirow[b]{2}{*}{$\mathrm{FN}^{\circ}$} & & \multicolumn{12}{|c|}{ Manufactura } & \multicolumn{2}{|c|}{ Cocción } & \multicolumn{5}{|c|}{ Borde-labio } & \multicolumn{6}{|c|}{ Asa } & \multicolumn{3}{|c|}{ Base } & \multirow[b]{2}{*}{ Alterac } \\
\hline & & & Fgto & $\begin{array}{l}\text { Tec } \\
\text { lev }\end{array}$ & $\begin{array}{l}\text { For } \\
\text { ma }\end{array}$ & \begin{tabular}{|l|} 
Mar \\
cas
\end{tabular} & $\begin{array}{l}\text { Sup } \\
\text { ext }\end{array}$ & \begin{tabular}{|c|} 
Sup \\
int
\end{tabular} & $\begin{array}{l}\text { Esp } \\
\text { max }\end{array}$ & $\begin{array}{l}\text { Esp } \\
\text { min } \\
\end{array}$ & $\begin{array}{c}\text { Deco } \\
\text { pint }\end{array}$ & \begin{tabular}{|c} 
Deco \\
cor/dsp
\end{tabular} & \begin{tabular}{|l|} 
Deco \\
agreg
\end{tabular} & Motivo & Estilo & Color sup ext & Color sup int & Diam & $\mid \begin{array}{l}\operatorname{Lrg} \\
\operatorname{arc}\end{array}$ & \begin{tabular}{|c|}
$\%$ \\
$\operatorname{arco}$
\end{tabular} & Direc & $\begin{array}{l}\begin{array}{l}\text { For } \\
\text { ma }\end{array} \\
\end{array}$ & \begin{tabular}{c|} 
Lar \\
go \\
\end{tabular} & \begin{tabular}{|c|}
$\begin{array}{c}\text { an } \\
\text { cho }\end{array}$ \\
\end{tabular} & Esp & $\begin{array}{l}\text { Sec } \\
\text { ción }\end{array}$ & \begin{tabular}{|c|} 
In \\
serc
\end{tabular} & $\begin{array}{l}\text { Posi } \\
\text { ción }\end{array}$ & Diám & $\begin{array}{l}\text { Mor } \\
\text { fol }\end{array}$ & $\begin{array}{c}\text { Uni } \\
\text { ón }\end{array}$ & \\
\hline $\mathrm{SC} 3$ & Sup & 47 & 0 & 0 & 0 & 0 & $3 y 4$ & 2 & 6 & 5.8 & 1 & 0 & 0 & $\mathrm{x}$ & $x$ & 10R $4 / 6$ & $2,5 Y R$ 5/4 & $\mathrm{x}$ & $\mathrm{x}$ & $\mathrm{x}$ & $\mathrm{x}$ & $\mathrm{x}$ & $\mathrm{x}$ & $\mathrm{x}$ & $\mathrm{x}$ & $\mathrm{x}$ & $\mathrm{x}$ & $\mathrm{x}$ & $\mathrm{x}$ & $\mathrm{x}$ & $x$ & 3 \\
\hline $\mathrm{SC} 3$ & Sup & 48 & 0 & 0 & 0 & 0 & $3 y 4$ & 2 & 6.5 & 6 & 1 & 0 & 0 & $x$ & $x$ & 10R $4 / 6$ & 2,5 YR $5 / 6$ & $\mathrm{x}$ & $\mathrm{x}$ & $\mathrm{x}$ & $\mathrm{x}$ & $\mathrm{x}$ & $\mathrm{x}$ & $\mathrm{x}$ & $x$ & $\mathrm{x}$ & $x$ & $\mathrm{x}$ & $\mathrm{x}$ & $\mathrm{x}$ & $x$ & \\
\hline SC 3-1 & Int & 49 & 0 & 0 & 0 & 1 & 4 & 2 & 7.8 & 6.9 & 1 & 0 & 0 & $x$ & $x$ & 10R $4 / 4$ & 2,5 YR $5 / 6$ & $x$ & $x$ & $x$ & $x$ & $x$ & $x$ & $x$ & $x$ & $x$ & $x$ & $x$ & $x$ & $x$ & $\mathrm{x}$ & 5 \\
\hline SC 3-1 & Int & 50 & 0 & 0 & 0 & 0 & $3 y 4$ & 2 & 5.4 & 4.2 & 1 & 0 & 0 & $\mathrm{x}$ & $\mathrm{x}$ & 10R $4 / 4$ & 5YR 5/3 & $\mathrm{x}$ & $\mathrm{x}$ & $\mathrm{x}$ & $\mathrm{x}$ & $\mathrm{x}$ & $x$ & $\mathrm{x}$ & $\mathrm{x}$ & $\mathrm{x}$ & $\mathrm{x}$ & $\mathrm{x}$ & $\mathrm{x}$ & $\mathrm{x}$ & $x$ & \\
\hline $\mathrm{SC} 3$ & Sup & 51 & 0 & 0 & 0 & 0 & 4 & 2 & 6.8 & 5.5 & 1 & 0 & 0 & $x$ & $x$ & 2,5 YR $4 / 4$ & 2,5YR 5/6 & $\mathrm{x}$ & $\mathrm{x}$ & $\mathrm{x}$ & $\mathrm{x}$ & $\mathrm{x}$ & $\mathrm{x}$ & $\mathrm{x}$ & $\mathrm{x}$ & $\mathrm{x}$ & $\mathrm{x}$ & $\mathrm{x}$ & $\mathrm{x}$ & $\mathrm{x}$ & $x$ & \\
\hline $\mathrm{SC} 3$ & Sup & 52 & 0 & 0 & 0 & 0 & 4 & 2 & 7.4 & 6.2 & 1 & 0 & 0 & $x$ & $x$ & $2,5 Y R$ 4/4 & YR 6/4 & $x$ & $x$ & $x$ & $x$ & $x$ & $x$ & $x$ & $x$ & $x$ & $x$ & $x$ & $x$ & $x$ & $x$ & 5 \\
\hline SC3-4 & Ext & 53 & 0 & 0 & 0 & 0 & $3 y 4$ & 2 & 7.5 & 5.1 & 1 & 0 & 0 & $x$ & $x$ & 10R $4 / 4$ & 5YR $6 / 6$ & $x$ & $x$ & $x$ & $x$ & $x$ & $x$ & $x$ & $x$ & $x$ & $x$ & $x$ & $x$ & $x$ & $x$ & 5 \\
\hline SC3-4 & Ext & 54 & 0 & 0 & 0 & 0 & $3 y 4$ & 2 & 4.9 & 4.2 & 1 & 0 & 0 & $\mathrm{x}$ & $\mathrm{x}$ & 10R $4 / 6$ & $5 Y R 4 / 2$ & $\mathrm{x}$ & $\mathrm{x}$ & $\mathrm{x}$ & $\mathrm{x}$ & $\mathrm{x}$ & $\mathrm{x}$ & $\mathrm{x}$ & $\mathrm{x}$ & $\mathrm{x}$ & $\mathrm{x}$ & $\mathrm{x}$ & $\mathrm{x}$ & $\mathrm{x}$ & $x$ & \\
\hline $\mathrm{SC} 3$ & Sup & 55 & 0 & 0 & 0 & 0 & 4 & 2 & 7 & 6.2 & 1 & 0 & 0 & $x$ & $x$ & $2,5 Y R$ 4/4 & 2,5 YR 5/6 & $x$ & $x$ & $x$ & $x$ & $x$ & $x$ & $x$ & $x$ & $x$ & $x$ & $x$ & $x$ & $x$ & $\mathrm{x}$ & 5 \\
\hline SC 3-1 & Int & 56 & 0 & 0 & 0 & 1 & $3 y 4$ & 2 & \begin{tabular}{|l|}
9.5 \\
\end{tabular} & \begin{tabular}{|l|}
6.8 \\
\end{tabular} & 1 & 0 & 0 & $x$ & $x$ & 10R4/6; 2,5YR5/6 & 2,5YR 5/4 & $x$ & $x$ & $x$ & $x$ & $\mathrm{x}$ & $x$ & $\mathrm{x}$ & $x$ & $x$ & $x$ & $x$ & $x$ & $x$ & $\mathrm{x}$ & 3 y 5 \\
\hline $\mathrm{SC} 3$ & Sup & 57 & 0 & 0 & 0 & 1 & $3 y 4$ & 2 & 6.9 & 4.8 & 1 & 0 & 0 & $x$ & $x$ & 10R $4 / 6,4 / 4$ & 5YR 5/4 & $x$ & $x$ & $x$ & $x$ & $x$ & $x$ & $x$ & $x$ & $x$ & $x$ & $x$ & $x$ & $x$ & $\mathrm{x}$ & 5 \\
\hline SC3-4 & Ext & 58 & 0 & 0 & 0 & 0 & $3 y 4$ & 2 & 7.8 & 7.2 & 1 & 0 & 0 & $x$ & $x$ & 10R4/6; 2,5YR5/6 & 5YR 5/6 & $x$ & $x$ & $x$ & $x$ & $x$ & $x$ & $x$ & $x$ & $x$ & $x$ & $x$ & $x$ & $x$ & $x$ & 3 y 5 \\
\hline $\mathrm{SC} 3$ & Sup & 59 & 0 & 0 & 0 & 0 & $3 y 4$ & 2 & 6.8 & 4.6 & 1 & 0 & 0 & $x$ & $x$ & 2,5YR4/3; 5YR5/4 & $5 Y R 5 / 3,5 / 4$ & $\mathrm{x}$ & $x$ & $x$ & $\mathrm{x}$ & $x$ & $\mathrm{x}$ & $x$ & $x$ & $x$ & $x$ & $x$ & $x$ & $x$ & $\mathrm{x}$ & 5 \\
\hline $\mathrm{SC} 3$ & Sup & 60 & 0 & 0 & 0 & 0 & $3 y 4$ & 2 & 5.9 & 4.5 & 1 & 0 & 0 & $\mathrm{x}$ & $x$ & 2,5YR4/3; 5YR5/4 & $5 Y R$ 5/3, 5/4 & $x$ & $x$ & $x$ & $x$ & $x$ & $x$ & $x$ & $x$ & $x$ & $x$ & $x$ & $x$ & $x$ & $x$ & 5 \\
\hline $\mathrm{SC} 3$ & Sup & 61 & 0 & 0 & 0 & 1 & 4 & 2 & 5.8 & 4.5 & 1 & 0 & 0 & $\mathrm{x}$ & $x$ & 2,5 YR $4 / 4,5 / 6$ & 7,5 YR $5 / 3$ & $x$ & $x$ & $x$ & $\mathrm{x}$ & $x$ & $\mathrm{x}$ & $\mathrm{x}$ & $\mathrm{x}$ & $x$ & $x$ & $x$ & $x$ & $x$ & $\mathrm{x}$ & 5 \\
\hline SC 3-1 & Int & 62 & 0 & 0 & 0 & 0 & 4 & 4 & 6.7 & 4.7 & 1 & 0 & 0 & $x$ & $x$ & 2,5 YR $5 / 6,4 / 6$ & 2,5YR5/4; 5YR5/3 & $x$ & $x$ & $x$ & $x$ & $x$ & $x$ & $x$ & $x$ & $x$ & $x$ & $x$ & $x$ & $x$ & $x$ & 4 y 5 \\
\hline $\mathrm{SC} 3$ & Sup & 63 & 0 & 0 & 0 & 0 & 4 & 2 & 7.1 & 6.6 & 1 & 0 & 0 & $x$ & $x$ & $2,5 Y R \quad 4 / 4$ & 7,5 YR $6 / 4$ & $x$ & $x$ & $x$ & $x$ & $x$ & $x$ & $x$ & $x$ & $x$ & $x$ & $x$ & $x$ & $x$ & $x$ & 5 \\
\hline SC3-4 & Ext & 64 & 0 & 0 & 0 & 0 & 4 & 2 & 7 & 5.6 & 1 & 0 & 0 & $x$ & $x$ & 2,5YR3/3; 5YR5/4 & 2,5 YR $5 / 6$ & $x$ & $x$ & $x$ & $x$ & $x$ & $x$ & $x$ & $x$ & $x$ & $x$ & $x$ & $x$ & $x$ & $\mathrm{x}$ & 5 \\
\hline SC 3-1 & Int & 65 & 0 & 0 & 0 & 0 & 4 & 2 & 3.6 & 3 & 1 & 0 & 0 & $x$ & $x$ & $2,5 Y R \quad 4 / 3,5 / 4$ & $2,5 Y R 5 / 4$ & $x$ & $x$ & $x$ & $x$ & $x$ & $x$ & $x$ & $x$ & $x$ & $x$ & $x$ & $x$ & $x$ & $x$ & 3 y 5 \\
\hline SC 3-1 & Int & 66 & 0 & 0 & 0 & 0 & 4 & 2 & 9.4 & 8.4 & 1 & 0 & 0 & $\mathrm{x}$ & $\mathrm{x}$ & $5 Y R \quad 4 / 6$ & 5YR 5/6 & $\mathrm{x}$ & $x$ & $x$ & $\mathrm{x}$ & $x$ & $\mathrm{x}$ & $x$ & $x$ & $x$ & $x$ & $x$ & $x$ & $x$ & $x$ & \\
\hline $\mathrm{SC} 3$ & Sup & 67 & 1 & 0 & 1 & 2 & 2 & 3 & 6.4 & 4.4 & 0 & 0 & 0 & $\mathrm{x}$ & Yavi & 7,5 YR 5/3 & $5 Y R$ 5/4, 5/6 & 13 & 3,4 & 8,3 & 2 & 2 & $x$ & $x$ & $x$ & $x$ & $x$ & $x$ & $x$ & $x$ & $x$ & 4 \\
\hline $\mathrm{SC} 3$ & Sup & 68 & 1 & 0 & 1 & 2 & 2 & 3 & 7.8 & 5.6 & 0 & 0 & 0 & $x$ & $x$ & $5 Y R$ 5/4 & $5 Y R 5 / 4,4 / 4$ & indet & 3 & indet & 2 & 2 & $x$ & $x$ & $x$ & $x$ & $x$ & $x$ & $x$ & $x$ & $x$ & 4 \\
\hline SC 3-1 & Ext & 69 & 1 & 0 & 1 & 2 & 2 & 3 & 6.6 & 4 & 0 & 0 & 0 & $x$ & $x$ & 5YR 4/1,4/2,5/1 & $5 Y R$ 4/1, 4/2 & 29,6 & 4 & 6,2 & 3 & 3 & $x$ & $x$ & $x$ & $x$ & $x$ & $x$ & $x$ & $x$ & $x$ & 4 \\
\hline SC 3-2y3 & 3 Sup & 70 & 1 & 0 & 1 & 2 & 3 & 3 & 6.1 & 4.6 & 0 & 0 & 0 & $x$ & $x$ & $5 Y R \quad 4 / 2,4 / 3$ & $5 Y R 4 / 3$ & indet & 1,3 & indet & 3 & 2 & $x$ & $x$ & $x$ & $x$ & $x$ & $x$ & $x$ & $x$ & $x$ & \\
\hline SC 3-1 & Int & 71 & 1 & 0 & 2 & 1 & 2 & 3 & 6.6 & 6 & 0 & 0 & 0 & $x$ & $x$ & $5 Y R$ 6/3, 6/4 & $5 Y R$ 6/4, 5/4 & indet 2 & 2,3 i & indet & 1 & 2 & $x$ & $x$ & $x$ & $x$ & $x$ & $x$ & $x$ & $x$ & $\mathrm{x}$ & \\
\hline SC 3-1 & Ext & 72 & 4 & 0 & 0 & 0 & 2 & 3 & 8.6 & 5.4 & 0 & 0 & 0 & $x$ & $x$ & $5 Y R \quad 4 / 3,4 / 4$ & $5 Y R$ 5/4 & $x$ & $x$ & $x$ & $x$ & $x$ & $x$ & $x$ & $x$ & $x$ & $x$ & $x$ & $x$ & $x$ & $x$ & \\
\hline SC 3-1 & Int & 73 & 1 & 0 & 2 & 2 & 2 & 3 & 5 & 4.1 & 0 & 0 & 0 & $x$ & $x$ & 2,5 YR 5/6, 5/2 & 2,5YR4/6, 4/3, 4/1 & \begin{tabular}{l|l}
6 & 3
\end{tabular} & 3,9 & 20,7 & 1 & $2 \mathrm{y} 6$ & $\mathrm{x}$ & $x$ & $x$ & $x$ & $x$ & $x$ & $x$ & $x$ & $\mathrm{x}$ & 1 \\
\hline $\mathrm{SC} 3$ & Ext & 74 & 1 & 0 & 2 & 0 & 2 & 3 & 5.2 & 4.5 & 0 & 0 & 0 & $\mathrm{x}$ & $\mathrm{x}$ & 2,5 YR $4 / 6,4 / 3$ & 2,5 YR $4 / 6,4 / 2$ & $8 \mid 2$ & 2,5 & 10 & 1 & $2 \mathrm{y} 6$ & $x$ & $\mathrm{x}$ & $\mathrm{x}$ & $x$ & $x$ & $\mathrm{x}$ & $\mathrm{x}$ & $x$ & $\mathrm{x}$ & \\
\hline $\mathrm{SC} 3$ & Ext & 75 & 1 & 0 & 2 & 1 & 3 & 2 & \begin{tabular}{|l|}
3.9 \\
\end{tabular} & 3 & 0 & 0 & 0 & $x$ & $x$ & 2,5 YR $5 / 6$ & 2,5 YR $5 / 6,5 / 8$ & 9,3 & 3,1 & 10.6 & 1 & 2 & $x$ & $x$ & $x$ & $x$ & $x$ & $x$ & $x$ & $x$ & $x$ & \\
\hline SC 3-1 & Ext & 76 & 1 & 0 & 2 & 0 & 3 & 2 & 5.5 & 5.3 & 0 & 0 & 0 & $x$ & $x$ & $2,5 Y R$ 5/4 & $2,5 Y R 5 / 3$ & indet & 0,6 & indet & 1 & 4 & $x$ & $x$ & $x$ & $\mathrm{x}$ & $x$ & $x$ & $x$ & $x$ & $x$ & \\
\hline $\mathrm{SC} 3$ & Sup & 77 & 2 & 0 & 1 & 0 & 3 & 2 & 12.6 & 6.7 & 0 & 0 & 0 & $x$ & Yavi? & 5YR6/6; 7,5YR6/6 & $5 Y R$ 6/6 & $x$ & $x$ & $x$ & $x$ & $x$ & $x$ & $x$ & $x$ & $x$ & $x$ & $x$ & 9,8 & 5 & 2 & \\
\hline $\mathrm{SC} 3$ & Sup & 78 & 2 & 0 & 1 & 0 & 3 & 3 & 11.5 & 7.3 & 0 & 0 & 0 & $x$ & Yavi? & 2,5 YR $5 / 6$ & 2,5 YR 5/6 & $x$ & $x$ & $x$ & $\mathrm{x}$ & $x$ & $x$ & $x$ & $x$ & $x$ & $x$ & $x$ & indet & 5 & 2 & \\
\hline SC 3-1 & Int & 79 & 0 & 0 & 0 & 0 & 3 & 2 & 9 & \begin{tabular}{|l|}
8.5 \\
\end{tabular} & 0 & 0 & 0 & $x$ & Yavi & $2,5 Y R$ 6/8 & $2,5 Y R$ 6/8 & $x$ & $x$ & $x$ & $x$ & $x$ & $x$ & $x$ & $x$ & $x$ & $x$ & $x$ & $x$ & $x$ & $x$ & \\
\hline SC 3-1 & Int & 80 & 0 & 0 & 0 & 0 & 3 & 2 & 8.9 & 8.4 & 0 & 0 & 0 & $x$ & Yavi & 2,5 YR $6 / 8$ & 2,5 YR $6 / 8$ & $x$ & $x$ & $x$ & $x$ & $x$ & $x$ & $x$ & $x$ & $x$ & $x$ & $x$ & $x$ & $x$ & $x$ & \\
\hline SC 3-1 & Int & 81 & 0 & 0 & 0 & 0 & 3 & 2 & \begin{tabular}{|l|}
8.9 \\
\end{tabular} & 8.8 & 0 & 0 & 0 & $\mathrm{x}$ & Yavi & $2,5 Y R 6 / 8$ & 2,5 YR $6 / 8$ & $x$ & $x$ & $x$ & $x$ & $x$ & $x$ & $x$ & $x$ & $x$ & $x$ & $x$ & $x$ & $x$ & $x$ & \\
\hline SC 3 & Sup & 82 & 0 & 0 & 0 & 1 & 3 & 2 & 11.5 & 9.8 & 0 & 0 & 0 & $\mathrm{x}$ & $x$ & 2,5 YR $4 / 4,3 / 1$ & 5YR 5/3 & $x$ & $x$ & $\mathrm{x}$ & $\mathrm{x}$ & $x$ & $x$ & $\mathrm{x}$ & $x$ & $x$ & $x$ & $\mathrm{x}$ & $x$ & $x$ & $x$ & 3 \\
\hline $\mathrm{SC} 3$ & Sup & 83 & 0 & 0 & 0 & 0 & 3 & 2 & 6.2 & 4.2 & 0 & 0 & 0 & $x$ & $x$ & 5YR 5/4 & 5YR 5/4 & $x$ & $x$ & $x$ & $x$ & $x$ & $x$ & $x$ & $x$ & $x$ & $x$ & $x$ & $x$ & $x$ & $x$ & \\
\hline $\mathrm{SC} 3$ & Sup & 84 & 0 & 0 & 0 & 2 & 3 & 2 & 9 & 8.3 & 0 & 0 & 0 & $\mathrm{x}$ & $\mathrm{x}$ & 7,5YR $6 / 4,5 / 4$ & 2,5 YR $6 / 8$ & $x$ & $x$ & $x$ & $x$ & $x$ & $x$ & $x$ & $x$ & $x$ & $x$ & $x$ & $x$ & $x$ & $x$ & \\
\hline SC3-4 & Ext & 85 & 0 & 0 & 0 & 0 & 3 & 2 & \begin{tabular}{|l|}
8.4 \\
\end{tabular} & 4.4 & 0 & 0 & 0 & $x$ & $x$ & 5YR 5/4 & $5 Y R$ 5/3 & $x$ & $x$ & $x$ & $x$ & $x$ & $x$ & $x$ & $x$ & $x$ & $x$ & $x$ & $x$ & $x$ & $x$ & 1 \\
\hline SC3-4 & Int & 86 & 0 & 0 & 0 & 1 & 3 & 2 & 8 & 4.9 & 0 & 0 & 0 & $x$ & $x$ & $5 Y R$ 5/4 & 5YR 5/4 & $x$ & $x$ & $x$ & $x$ & $x$ & $x$ & $x$ & $x$ & $\mathrm{x}$ & $x$ & $x$ & $x$ & $x$ & $x$ & \\
\hline SC 3 & Sup & 87 & 0 & 0 & 0 & 1 & 3 & 2 & \begin{tabular}{|l|}
7.6 \\
\end{tabular} & 5.5 & 0 & 0 & 0 & $x$ & $x$ & $5 Y R$ 5/4 & $2,5 Y R$ 6/6 & $x$ & $x$ & $x$ & $x$ & $x$ & $x$ & $x$ & $x$ & $x$ & $x$ & $x$ & $x$ & $x$ & $x$ & \\
\hline
\end{tabular}




\section{Manufactura}

Cocción

Borde-labio

Asa

Base

\begin{tabular}{|c|c|c|c|c|c|c|c|c|c|c|c|c|c|c|c|c|c|c|c|c|c|c|c|c|c|c|c|c|c|c|c|c|}
\hline \multirow[b]{2}{*}{ Sitio } & \multirow[b]{2}{*}{ UP } & \multirow[b]{2}{*}{$\mathrm{FN}^{\circ}$} & & \multicolumn{12}{|c|}{ Manufactura } & \multicolumn{2}{|c|}{ Cocción } & \multicolumn{5}{|c|}{ Borde-labio } & \multicolumn{6}{|c|}{ Asa } & \multicolumn{3}{|c|}{ Base } & \multirow[b]{2}{*}{ Alterac } \\
\hline & & & Fgto & $\begin{array}{l}\text { Tec } \\
\text { lev }\end{array}$ & \begin{tabular}{|l|} 
For \\
ma
\end{tabular} & \begin{tabular}{|l|} 
Mar \\
cas
\end{tabular} & $\begin{array}{l}\text { Sup } \\
\text { ext }\end{array}$ & \begin{tabular}{|c|} 
Sup \\
int
\end{tabular} & \begin{tabular}{l|} 
Esp \\
$\max$
\end{tabular} & \begin{tabular}{|l|} 
Esp \\
min
\end{tabular} & \begin{tabular}{|c|} 
Deco \\
pint \\
\end{tabular} & \begin{tabular}{|c} 
Deco \\
cor/dsp
\end{tabular} & \begin{tabular}{|l|} 
Deco \\
agreg
\end{tabular} & Motivo & Estilo & Color sup ext & Color sup int & Diam & $\begin{array}{l}\text { Lrg } \\
\text { arc }\end{array}$ & \begin{tabular}{|c|}
$\%$ \\
$\operatorname{arco}$
\end{tabular} & Direc & $\begin{array}{l}\text { For } \\
\text { ma }\end{array}$ & \begin{tabular}{c|} 
Lar \\
go \\
\end{tabular} & \begin{tabular}{|c|}
$\begin{array}{c}\text { An } \\
\text { cho }\end{array}$ \\
\end{tabular} & Esp & \begin{tabular}{|l|} 
Sec \\
ción
\end{tabular} & $\begin{array}{l}\text { In } \\
\text { serc }\end{array}$ & $\begin{array}{l}\text { Posi } \\
\text { ción }\end{array}$ & Diám & $\begin{array}{c}\text { Mor } \\
\text { fol } \\
\end{array}$ & $\begin{array}{l}\text { Uni } \\
\text { ón }\end{array}$ & \\
\hline SC3-4 & Ext & 88 & 0 & 0 & 0 & 0 & 3 & 2 & 6 & 5 & 0 & 0 & 0 & $x$ & $x$ & 5YR 5/4 & 5YR 4/1 & $x$ & $x$ & $x$ & $x$ & $x$ & $x$ & $x$ & $x$ & $x$ & $x$ & $x$ & $x$ & $x$ & $x$ & 1 \\
\hline SC 3-1 & Ext & 89 & 0 & 0 & 1 & 2 & 3 & 3 & 6.2 & 5.9 & 0 & 0 & 0 & $x$ & $\mathrm{x}$ & 5YR 6/6 & 5YR 6/6 & $\mathrm{x}$ & $x$ & $\mathrm{x}$ & $\mathrm{x}$ & $\mathrm{x}$ & $\mathrm{x}$ & $x$ & $x$ & $\mathrm{x}$ & $\mathrm{x}$ & $\mathrm{x}$ & $x$ & $\mathrm{x}$ & $x$ & \\
\hline SC 3-1 & Int & 90 & 0 & 0 & 0 & 0 & 3 & 2 & 8.7 & 8 & 0 & 0 & 0 & $x$ & $x$ & 2,5 YR $6 / 8$ & 2,5 YR $6 / 8$ & $x$ & $x$ & $x$ & $x$ & $x$ & $x$ & $x$ & $x$ & $x$ & $x$ & $x$ & $x$ & $x$ & $x$ & \\
\hline SC3-4 & Ext & 91 & 0 & 0 & 0 & 0 & 3 & 2 & 6.6 & 5.5 & 0 & 0 & 0 & $\mathrm{x}$ & $\mathrm{x}$ & 7,5YR 5/4, 4/1 & 2,5 YR $6 / 8$ & $\mathrm{x}$ & $\mathrm{x}$ & $\mathrm{x}$ & $\mathrm{x}$ & $\mathrm{x}$ & $\mathrm{x}$ & $\mathrm{x}$ & $\mathrm{x}$ & $\mathrm{x}$ & $\mathrm{x}$ & $x$ & $\mathrm{x}$ & $\mathrm{x}$ & $x$ & 1 \\
\hline SC 3-1 & Int & 92 & 0 & 0 & 0 & 1 & 3 & 2 & 7.7 & 7.3 & 0 & 0 & 0 & $x$ & $x$ & 5YR 4/2 & 5 YY $6 / 6$ & $x$ & $x$ & $x$ & $x$ & $x$ & $x$ & $x$ & $x$ & $x$ & $\mathrm{x}$ & $x$ & $x$ & $x$ & $x$ & 1 \\
\hline C $3-2 y 3$ & Sup & 93 & 0 & 0 & 0 & 1 & 3 & 2 & 6.3 & 5.8 & 0 & 0 & 0 & $\mathrm{x}$ & $x$ & $5 Y R$ 5/3, 4/1 & 7,5 YR $7 / 4$ & $x$ & $x$ & $\mathrm{x}$ & $x$ & $x$ & $\mathrm{x}$ & $\mathrm{x}$ & $\mathrm{x}$ & $x$ & $x$ & $x$ & $x$ & $\mathrm{x}$ & $x$ & 1 \\
\hline SC 3 & Sup & 94 & 1 & 0 & 1 & 0 & $2 \mathrm{y} 4$ & 2 & 10.5 & 7.6 & 1 & 0 & 0 & $x$ & $x$ & 2,5YR3/1,5/6,4/6 & 5 YR $6 / 4$ & indet & 4,6 & indet & 1 & 1 & 2,3 & 2,7 & 1 & $x$ & 1 & 1 & $x$ & $x$ & $x$ & 1 \\
\hline $\mathrm{SC} 3$ & Sup & 95 & 1 & 3 & 1 & 1 & 2 & 2 & 8.3 & 4.6 & 0 & 0 & 0 & $x$ & poshisp & $5 Y R 5 / 4,4 / 3$ & $2,5 Y R \quad 4 / 4$ & 13 & 4,5 & 11 & 1 & $2 \mathrm{y} 6$ & $x$ & $x$ & $x$ & $x$ & $x$ & $x$ & $x$ & $x$ & $x$ & 4 \\
\hline $\mathrm{SC} 3$ & Sup & 96 & 1 & 0 & 1 & 0 & 2 & 2 & 8.5 & 4.2 & 0 & 0 & 0 & $x$ & $x$ & 5YR 5/4 & $2,5 Y R$ 5/6 & indet & 3 & indet & 1 & 2 & $x$ & $x$ & $x$ & $x$ & $x$ & $x$ & $x$ & $x$ & $x$ & \\
\hline $\mathrm{SC} 3$ & Sup & 97 & 1 & 0 & 0 & 0 & 2 & 2 & 14.8 & 6 & 0 & 0 & 0 & $x$ & $x$ & 5YR 5/2 & 5YR 5/2 & indet & 5,2 i & indet & 1 & 2 & indet & 4,2 & 1,5 & 4 & 5 & 2 & $x$ & $x$ & $x$ & \\
\hline $\mathrm{SC} 3$ & Sup & \begin{tabular}{|l|l|}
98 \\
\end{tabular} & 1 & 0 & 2 & 1 & 2 & 2 & 8.2 & 7.3 & 0 & 0 & 0 & $x$ & $x$ & 5YR 6/4 & $2,5 Y R$ 4/6 & indet & 3,4 & indet & 1 & 2 & $x$ & $x$ & $x$ & $x$ & $x$ & $x$ & $x$ & $x$ & $x$ & \\
\hline SC 3 & Sup & 99 & 1 & 0 & 2 & 0 & $2 \mathrm{y} 4$ & $2 \mathrm{y} 4$ & 7 & 5.7 & 1 & 0 & 0 & $x$ & $x$ & 5YR6/4; 2,5YR5/6 & $2,5 Y R$ 5/6 & 13 & 4,1 & 10 & 1 & 2 & $x$ & $x$ & $x$ & $x$ & $\mathrm{x}$ & $x$ & $x$ & $x$ & $x$ & 5 \\
\hline $\mathrm{SC} 3$ & Sup & 100 & 1 & 0 & 1 & 0 & 2 & 2 & 7.6 & 5 & 0 & 0 & 0 & $x$ & $x$ & 2,5 YR 4/4 & $2,5 Y R$ 5/6 & indet & $3,7 \mathrm{i}$ & indet & 2 & 2 & $x$ & $x$ & $x$ & $x$ & $x$ & $x$ & $x$ & $x$ & $x$ & \\
\hline $\mathrm{SC} 3$ & Sup & 101 & 1 & 0 & 1 & 0 & 2 & 2 & 6.3 & 3.8 & 0 & 0 & 0 & $x$ & $x$ & YR 5/3 & $2,5 Y R 5 / 6,4 / 3$ & indet & $2,9 \mathrm{i}$ & indet & 2 & 1 & 1,6 & 1,3 & 1,1 & 0 & 1 & 1 & $x$ & $x$ & $x$ & \\
\hline $\mathrm{SC} 3$ & Sup & 102 & 1 & 0 & 1 & 0 & 2 & 2 & 6.5 & 4.8 & 0 & 0 & 0 & $x$ & $x$ & $2,5 Y R \quad 4 / 6$ & $2,5 Y R \quad 4 / 2$ & indet & 2,9 & indet & 2 & 1 & $x$ & $x$ & $x$ & $x$ & $x$ & $x$ & $x$ & $x$ & $x$ & \\
\hline $\mathrm{SC} 3$ & Sup & 103 & 1 & 0 & 2 & 0 & 2 & 2 & 8 & 6.5 & 0 & 0 & 0 & $x$ & $x$ & 2,5 YR 5/6 & 2,5 YR $5 / 6$ & indet & 2,7 i & indet & 1 & 1 & $x$ & $x$ & $x$ & $x$ & $x$ & $x$ & $x$ & $x$ & $x$ & 3 \\
\hline $\mathrm{SC} 3$ & Sup & 104 & 1 & 0 & 2 & 0 & 2 & 2 & 7.9 & 6 & 0 & 0 & 0 & $x$ & $x$ & $5 Y R 4 / 1$ & $5 Y R$ 4/1, 4/2 & indet & 2,1 i & indet & 1 & 2 & $x$ & $x$ & $x$ & $x$ & $x$ & $x$ & $x$ & $x$ & $x$ & 3 \\
\hline SC 3 & Sup & 105 & 1 & 0 & 1 & 0 & 2 & 2 & 6.9 & 5 & 0 & 0 & 0 & $x$ & $x$ & $5 Y R \quad 4 / 1,4 / 4$ & $5 Y R$ 4/1, 4/3 & indet & 2,7 i & indet & 1 & 1 & $x$ & $x$ & $x$ & $x$ & $x$ & $x$ & $x$ & $x$ & $x$ & \\
\hline SC $3-2 y 3$ & Sup & 106 & 1 & 0 & 1 & 0 & 2 & 2 & 7 & 6 & 0 & 0 & 0 & $x$ & $x$ & $5 Y R \quad 4 / 3$ & 5YR 5/4 & indet & 2,6 i & indet & 2 & 2 & $x$ & $x$ & $x$ & $x$ & $x$ & $x$ & $x$ & $x$ & $x$ & 4 \\
\hline SC3-4 & Int & 107 & 1 & 0 & 0 & 0 & $2 \mathrm{y} 6$ & $2 \mathrm{y} 6$ & 12 & 10 & 1 & 0 & 0 & $x$ & $x$ & $2,5 Y R \quad 4 / 6,5 / 6$ & $2,5 Y R \quad 4 / 6,6 / 6$ & indet & $2,9 \mathrm{i}$ & indet & 2 & 2 & $x$ & $x$ & $x$ & $x$ & $x$ & $x$ & $x$ & $x$ & $x$ & 3 y 4 \\
\hline C $3-2 y 3$ & Sup & 108 & 1 & 0 & 2 & 1 & 2 & 2 & 5.7 & 4.5 & 0 & 0 & 0 & $x$ & $x$ & 5YR 4/3 & 5YR 4/3 & indet & 2,4 & indet & 1 & 2 & $x$ & $x$ & $x$ & $x$ & $x$ & $x$ & $x$ & $\mathrm{x}$ & $x$ & \\
\hline $\mathrm{SC} 3$ & Sup & 109 & 1 & 0 & 2 & 0 & 2 & 2 & 9 & 6.5 & 0 & 0 & 0 & $x$ & $x$ & $2,5 Y R$ 5/6 & $2,5 Y R$ 5/6 & indet & 2,7 & indet & 1 & 2 & $x$ & $x$ & $x$ & $x$ & $x$ & $x$ & $x$ & $x$ & $x$ & 3 \\
\hline SC 3-1 & Ext & 110 & 1 & 0 & 1 & 0 & 2 & 3 & 7 & 6 & 0 & 0 & 0 & $x$ & $x$ & 2,5 YR $5 / 6$ & $2,5 Y R$ 5/6 & indet & 3 & indet & 1 & 2 & $x$ & $x$ & $x$ & $x$ & $x$ & $x$ & $x$ & $x$ & $x$ & \\
\hline SC $3-2 y 3$ & Sup & 111 & 1 & 0 & 0 & 0 & 2 & 2 & 6.2 & 5.8 & 0 & 0 & 0 & $x$ & $x$ & 5YR 4/3 & 5YR 4/4 & indet & $1,7 \mathrm{i}$ & indet & 1 & 2 & $x$ & $x$ & $x$ & $x$ & $\mathrm{x}$ & $x$ & $x$ & $x$ & $x$ & \\
\hline SC 3 & Sup & 112 & 1 & 0 & 0 & 0 & 2 & 2 & 10 & 9 & 0 & 0 & 0 & $x$ & $x$ & 2,5 YR 5/4 & 5YR 6/4 & indet & 1,6 & indet & 2 & 1 & $x$ & $x$ & $x$ & $x$ & $x$ & $x$ & $x$ & $x$ & $x$ & 3 \\
\hline SC 3-1 & Int & 113 & 0 & 0 & 0 & 2 & 3 & 2 & 7.7 & 7.2 & 0 & 0 & 0 & $x$ & $x$ & $5 Y R \quad 4 / 2,4 / 3$ & $2,5 Y R$ 5/6 & $x$ & $x$ & $x$ & $x$ & $x$ & $x$ & $x$ & $x$ & $x$ & $\mathrm{x}$ & $x$ & $x$ & $x$ & $x$ & \\
\hline SC 3-1 & Int & 114 & 0 & 0 & 0 & 0 & 3 & 2 & \begin{tabular}{|l|}
8.7 \\
\end{tabular} & 6.5 & 0 & 0 & 0 & $x$ & $x$ & 2,5 YR $4 / 3,4 / 4$ & 2,5 YR 5/6 & $x$ & $x$ & $x$ & $x$ & $x$ & $x$ & $x$ & $x$ & $x$ & $x$ & $x$ & $x$ & $x$ & $x$ & 3 \\
\hline SC 3-1 & Ext & 115 & 0 & 0 & 0 & 0 & 3 & 3 & 8.6 & 6.8 & 0 & 0 & 0 & $x$ & $x$ & $5 Y R$ 5/3, 4/1 & 5YR 4/2 & $x$ & $x$ & $x$ & $x$ & $x$ & $x$ & $x$ & $x$ & $x$ & $x$ & $\mathrm{x}$ & $x$ & $x$ & $x$ & \\
\hline $\mathrm{SC} 3$ & Sup & 116 & 0 & 0 & 0 & 0 & 3 & 2 & \begin{tabular}{|l|}
8.1 \\
\end{tabular} & 6.3 & 0 & 0 & 0 & $x$ & $x$ & 5YR 6/4 & 5 YR $4 / 3$ & $x$ & $x$ & $x$ & $x$ & $x$ & $x$ & $x$ & $x$ & $x$ & $x$ & $x$ & $x$ & $x$ & $x$ & \\
\hline SC3-4 & Ext & 117 & 0 & 0 & 0 & 0 & 3 & 2 & 5.9 & 4.8 & 0 & 0 & 0 & $x$ & $x$ & $2,5 Y R$ 5/6 & $2,5 Y R$ 5/3 & $x$ & $x$ & $x$ & $\mathrm{x}$ & $x$ & $x$ & $x$ & $x$ & $x$ & $x$ & $x$ & $x$ & $x$ & $x$ & \\
\hline SC 3-1 & Int & 118 & 0 & 0 & 0 & 1 & 3 & 2 & 5.1 & 4.1 & 0 & 0 & 0 & $x$ & $x$ & 7,5 YR $4 / 2,4 / 3$ & 7,5 YR $6 / 4$ & $x$ & $x$ & $x$ & $\mathrm{x}$ & $x$ & $x$ & $x$ & $x$ & $x$ & $x$ & $x$ & $x$ & $x$ & $x$ & \\
\hline SC 3-1 & Int & 119 & 0 & 0 & 0 & 0 & 3 & 2 & 6.2 & 3.4 & 0 & 0 & 0 & $x$ & $x$ & $5 Y R$ 5/4, 6/4 & 5YR 5/2 & $x$ & $x$ & $x$ & $x$ & $x$ & $x$ & $x$ & $x$ & $x$ & $x$ & $x$ & $x$ & $x$ & $x$ & \\
\hline SC 3-1 & Ext & 120 & 0 & 0 & 0 & 0 & 3 & 2 & 9.3 & 7.9 & 0 & 0 & 0 & $x$ & $x$ & $5 Y R 4 / 4$ & $5 Y R$ 5/3 & $x$ & $x$ & $x$ & $x$ & $x$ & $x$ & $x$ & $x$ & $x$ & $x$ & $x$ & $x$ & $x$ & $x$ & \\
\hline SC3-4 & Ext & 121 & 0 & 0 & 0 & 0 & 3 & 3 & 7.7 & 5.3 & 0 & 0 & 0 & $x$ & $x$ & $5 Y R 5 / 4$ & 5YR 5/3 & $x$ & $x$ & $x$ & $x$ & $x$ & $x$ & $x$ & $x$ & $x$ & $x$ & $x$ & $x$ & $x$ & $x$ & \\
\hline SC3-4 & Int & 122 & 0 & 0 & 0 & 0 & 3 & 2 & 7.1 & 6.3 & 0 & 0 & 0 & $x$ & $\mathrm{x}$ & 5YR 4/2 & 5YR 5/6 & $x$ & $x$ & $x$ & $x$ & $x$ & $x$ & $x$ & $x$ & $x$ & $x$ & $x$ & $x$ & $x$ & $x$ & \\
\hline SC 3-1 & Int & 123 & 0 & 0 & 0 & 0 & 3 & 2 & 6.7 & 4.2 & 0 & 0 & 0 & $x$ & $x$ & $2,5 Y R$ 5/6 & 2,5 YR $5 / 6$ & $x$ & $x$ & $x$ & $x$ & $x$ & $x$ & $x$ & $x$ & $x$ & $x$ & $x$ & $x$ & $x$ & $x$ & \\
\hline SC 3-1 & Int & 124 & 0 & 0 & 0 & 0 & 3 & 2 & 5.2 & 5 & 0 & 0 & 0 & $x$ & $x$ & $\mathrm{~N} 3 /$ & 2,5 YR 5/6 & $x$ & $x$ & $x$ & $x$ & $x$ & $x$ & $x$ & $x$ & $x$ & $x$ & $x$ & $x$ & $x$ & $x$ & \\
\hline SC3-4 & Ext & 125 & 0 & 0 & 0 & 0 & 3 & 2 & 6.8 & 6.4 & 0 & 0 & 0 & $x$ & $x$ & $5 Y R 4 / 4$ & 2,5 YR $5 / 6$ & $x$ & $x$ & $x$ & $x$ & $x$ & $x$ & $x$ & $x$ & $x$ & $x$ & $x$ & $x$ & $x$ & $x$ & \\
\hline SC 3-2y3 & Sup & 126 & 0 & 0 & 1 & 0 & 11 & \begin{tabular}{|l|l|}
11 \\
\end{tabular} & 4.8 & 3.5 & 2 & 0 & 0 & franja & shisp & $5 Y 7 / 3$ & $5 Y 7 / 3,3 / 1$ & $x$ & $x$ & $x$ & $x$ & $x$ & $x$ & $x$ & $x$ & $x$ & $x$ & $x$ & $x$ & $x$ & $x$ & \\
\hline SC3-4 & Ext & 127 & 3 & 0 & 0 & 0 & 2 & 2 & 11.2 & 10 & 0 & 0 & 0 & $\mathrm{x}$ & $x$ & $2,5 Y R$ 5/4 & $2,5 Y R$ 5/4 & $x$ & $x$ & $x$ & $x$ & $x$ & $4,3 \mathrm{fr}$ & 2,3 & 1,1 & 2 & 0 & 0 & $x$ & $x$ & $x$ & \\
\hline SC3-4 & Int & 128 & 3 & 0 & 0 & 0 & 2 & 2 & 12.3 & 7.4 & 0 & 0 & 0 & $x$ & $x$ & 7,5YR 6/4, 5/1 & 7,5 YR $6 / 4,6 / 3$ & $x$ & $x$ & $x$ & $x$ & $x$ & $3,5 \mathrm{fr}$ & 2,2 & 1,2 & 4 & 0 & 0 & $x$ & $x$ & $x$ & \\
\hline
\end{tabular}




\section{Manufactura}

Cocción

Borde-labio

Asa

Base

\begin{tabular}{|c|c|c|c|c|c|c|c|c|c|c|c|c|c|c|c|c|c|c|c|c|c|c|c|c|c|c|c|c|c|c|c|c|}
\hline & & & & \multicolumn{12}{|c|}{ Manufactura } & \multicolumn{2}{|c|}{ Cocción } & \multicolumn{5}{|c|}{ Borde-labio } & \multicolumn{6}{|c|}{ Asa } & \multicolumn{3}{|c|}{ Base } & \multirow[b]{2}{*}{ Alterac } \\
\hline Sitio & UP & $\mathbf{F}$ & Fgto & \begin{tabular}{|l|}
$\begin{array}{l}\text { Tec } \\
\text { lev }\end{array}$ \\
\end{tabular} & $\begin{array}{l}\text { For } \\
\text { ma }\end{array}$ & $\begin{array}{l}\text { Mar } \\
\text { cas }\end{array}$ & \begin{tabular}{|l|} 
Sup \\
ext
\end{tabular} & \begin{tabular}{|c|} 
Sup \\
int
\end{tabular} & $\begin{array}{l}\text { Esp } \\
\text { max }\end{array}$ & $\begin{array}{l}\text { Esp } \\
\text { min } \\
\end{array}$ & $\begin{array}{c}\begin{array}{c}\text { Deco } \\
\text { pint }\end{array} \\
\end{array}$ & $\begin{array}{c}\text { Deco } \\
\text { cor/dsp }\end{array}$ & \begin{tabular}{|l} 
Deco \\
pagreg
\end{tabular} & Motivo & Estilo & Color sup ext & Color sup int & Diam & \begin{tabular}{|l|} 
Lrg \\
arc \\
\end{tabular} & \begin{tabular}{|c|c|}
$\%$ & $D$ \\
$\operatorname{arco}$ & $\mathrm{D}$ \\
\end{tabular} & Direc & $\begin{array}{l}\mathrm{Fo} \\
\mathrm{ma}\end{array}$ & $\begin{array}{c}\text { Lar } \\
\text { go }\end{array}$ & $\begin{array}{l}\text { An } \\
\text { cho }\end{array}$ & Esp & $\begin{array}{l}\text { Sec } \\
\text { ción }\end{array}$ & $\begin{array}{l}\text { In } \\
\text { serc }\end{array}$ & $\begin{array}{l}\text { Posi } \\
\text { ción }\end{array}$ & Diám & $\begin{array}{c}\text { Mor } \\
\text { fol }\end{array}$ & $\begin{array}{l}\text { Uni } \\
\text { ón }\end{array}$ & \\
\hline SC $3-2 y 3$ & 3 Sup & 129 & 3 & 0 & 0 & 0 & 2 & 2 & 12.3 & 7.9 & 0 & 0 & 0 & $\mathrm{x}$ & $\mathrm{x}$ & $2,5 Y R$ 5/4, 5/6 & $2,5 Y R$ 5/4 & $x$ & $x$ & $x$ & $x$ & $x$ & $3,4 \mathrm{fr}$ & 2 & 9 & 4 & 0 & 0 & $x$ & $x$ & $x$ & \\
\hline SC 3 & Sup & 130 & 3 & 0 & 0 & 0 & 2 & 2 & 6.5 & 5.9 & 0 & 0 & 0 & $\mathrm{x}$ & $\mathrm{x}$ & $10 \mathrm{R} 5 / 6$ & 10R $5 / 6$ & $\mathrm{x}$ & $\mathrm{x}$ & $\mathrm{x}$ & $\mathrm{x}$ & $\mathrm{x}$ & $3,2 \mathrm{fr}$ & 1,3 & 0,6 & 2 & 2 & 0 & $\mathrm{x}$ & $\mathrm{x}$ & $x$ & \\
\hline SC 3-1 & Int & 131 & 3 & 0 & 0 & 0 & 2 & 2 & 7 & 7 & 0 & 1 & 0 & zigzag & $\mathrm{x}$ & 2,5 YR $6 / 6$ & 2,5 YR $6 / 6$ & $x$ & $x$ & $x$ & $x$ & $x$ & $2,7 \mathrm{fr}$ & 2 & 0,7 & 4 & 0 & 0 & $x$ & $x$ & $x$ & \\
\hline SC3-4 & Int & 132 & 3 & 0 & 0 & 0 & 2 & 2 & 9 & 8.4 & 0 & 1 & 1 & lineas & $x$ & 5YR 6/4 & 5YR 6/4 & $x$ & $x$ & $x$ & $x$ & $x$ & $2,9 \mathrm{fr}$ & 2,4 & 0,8 & 3 & 0 & 0 & $x$ & $x$ & $x$ & \\
\hline SC $3-2 y 3$ & Sup & 133 & 3 & 0 & 0 & 0 & 2 & $2 \mathrm{y} 6$ & 8 & 7 & 1 & 0 & 0 & $x$ & $\mathrm{x}$ & 2,5YR4/4, 5YR6/6 & $5 Y R 6 / 6$ & $x$ & $x$ & $\mathrm{x}$ & $x$ & $x$ & $1,4 \mathrm{fr}$ & 2,8 & 1 & 3 & 1 & 0 & $x$ & $x$ & $x$ & 3 \\
\hline SC 3-1 & Int & 134 & 3 & 0 & 0 & 0 & 2 & 2 & 11 & 7 & 0 & 0 & 0 & $\mathrm{x}$ & $\mathrm{x}$ & $5 Y R$ 5/3, 5/2 & 2,5 YR $5 / 6$ & $\mathrm{x}$ & $x$ & $\mathrm{x}$ & $\mathrm{x}$ & $\mathrm{x}$ & inde & 3,1 & indet & 2 & 1 & 0 & $\mathrm{x}$ & $\mathrm{x}$ & $x$ & \\
\hline SC 3-1 & Int & 135 & 3 & 0 & 0 & 0 & $2 \mathrm{y} 6$ & $2 \mathrm{y} 6$ & 25 & 12 & 1 & 0 & 0 & $x$ & $\mathrm{x}$ & 2,5 YR $5 / 6,4 / 4$ & $2,5 Y R$ 5/6, 4/4 & $x$ & $x$ & $x$ & $x$ & $x$ & $3,1 \mathrm{fr}$ & $2,7 \mathrm{fr}$ & 1,2 & 4 & 0 & 0 & $x$ & $x$ & $x$ & \\
\hline SC 3 & Sup & 136 & 3 & 0 & 0 & 1 & 2 & 2 & 6.4 & 4.6 & 0 & 0 & 0 & $x$ & $x$ & 5YR 5/4 & $5 Y R \quad 4 / 2$ & $x$ & $x$ & $\mathrm{x}$ & $x$ & $x$ & $1,3 \mathrm{fr}$ & 1,6 & 1,4 & 1 & 1 & 0 & $x$ & $x$ & $x$ & \\
\hline SC 3 & Sup & 137 & 2 & 1 & 0 & 6 & 2 & 2 & 18.5 & 7.7 & 0 & 0 & 0 & $x$ & $x$ & $5 Y R$ 4/1, 4/2 & 5YR 5/4 & $x$ & $x$ & $x$ & $x$ & $x$ & $x$ & $x$ & $x$ & $x$ & $\mathrm{x}$ & $x$ & 12.2 & 5 & 2 & 3 \\
\hline SC3-4 & Ext & 138 & 2 & 0 & 0 & 6 & 2 & 2 & 9.6 & 4.9 & 0 & 0 & 0 & $x$ & $x$ & 5YR 5/4 & 5YR 5/4 & $x$ & $\mathrm{x}$ & $x$ & $x$ & $x$ & $x$ & $x$ & $x$ & $x$ & $\mathrm{x}$ & $x$ & 8,4 & 5 & 2 & \\
\hline SC 3 & Sup & 139 & 2 & 2 & 0 & 5 & 2 & 2 & 14.2 & 8.4 & 0 & 0 & 0 & $\mathrm{x}$ & $x$ & $5 Y R$ 5/1,5/2,5/3 & $5 Y R$ 5/4 & $x$ & $x$ & $x$ & $x$ & $x$ & $x$ & $x$ & $x$ & $x$ & $\mathrm{x}$ & $x$ & indet & 5 & 2 & 3 \\
\hline SC 3 & Sup & 140 & 4 & 2 & 2 & 5 & 2 & 1 & 9.8 & 7 & 0 & 0 & 0 & $x$ & $x$ & 5YR 6/4 & $5 Y R$ 6/3 & $x$ & $x$ & $x$ & $x$ & $x$ & $x$ & $x$ & $x$ & $x$ & $\mathrm{x}$ & $x$ & $x$ & $x$ & $x$ & \\
\hline SC 3-1 & Int & 141 & 0 & 0 & 0 & 0 & 2 & 3 & 11.3 & 7.2 & 0 & 0 & 0 & $x$ & $x$ & $2,5 Y R$ S/6,4/1,4/2 & 2,5 YR 5/6 & $x$ & $x$ & $x$ & $x$ & $x$ & $x$ & $x$ & $x$ & $x$ & $\mathrm{x}$ & $x$ & $x$ & $x$ & $x$ & \\
\hline SC3-4 & Int & 142 & 0 & 0 & 0 & 0 & 2 & 2 & 7 & 5.6 & 0 & 0 & 0 & $x$ & $x$ & $5 Y R$ 6/3, 6/4 & $5 Y R$ 5/4 & $x$ & $x$ & $x$ & $x$ & $x$ & $x$ & $x$ & $x$ & $x$ & $\mathrm{x}$ & $x$ & $x$ & $x$ & $x$ & \\
\hline SC 3-1 & Int & 143 & 0 & 0 & 0 & 0 & 2 & 2 & 10.2 & 7.4 & 0 & 0 & 0 & $x$ & $\mathrm{x}$ & $5 Y R$ 5/4 & $5 Y R 5 / 3$ & $x$ & $x$ & $x$ & $x$ & $x$ & $x$ & $x$ & $x$ & $x$ & $\mathrm{x}$ & $x$ & $x$ & $x$ & $x$ & \\
\hline SC3-4 & Int & 144 & 0 & 1 & 0 & 6 & 2 & 2 & 9 & 5.8 & 0 & 0 & 0 & $x$ & $x$ & 5YR 5/6 & $2,5 Y R$ 5/2, 5/3 & $x$ & $x$ & $x$ & $x$ & $x$ & $x$ & $x$ & $x$ & $x$ & $\mathrm{x}$ & $\mathrm{x}$ & $x$ & $x$ & $x$ & \\
\hline SC3-4 & Ext & 145 & 0 & 0 & 0 & 0 & 2 & 2 & 8 & 5.1 & 0 & 0 & 0 & $x$ & $x$ & $5 Y R$ 4/1, 3/1 & $2,5 Y R$ 5/4, 5/6 & $x$ & $\mathrm{x}$ & $x$ & $x$ & $x$ & $x$ & $x$ & $x$ & $x$ & $\mathrm{x}$ & $x$ & $x$ & $x$ & $x$ & \\
\hline SC 3-1 & Ext & 146 & 0 & 0 & 0 & 0 & 2 & 2 & 5.7 & 5.7 & 0 & 0 & 0 & $x$ & $x$ & 2,5 YR $4 / 1,4 / 2$ & $5 Y R$ 5/4 & $x$ & $x$ & $x$ & $x$ & $x$ & $x$ & $x$ & $x$ & $x$ & $\mathrm{x}$ & $x$ & $x$ & $x$ & $x$ & \\
\hline SC 3-1 & Ext & 147 & 0 & 0 & 0 & 0 & 2 & 2 & 6.9 & 5.2 & 0 & 0 & 0 & $x$ & $x$ & $5 Y R$ 5/6 & $2,5 Y R$ T/6 & $x$ & $x$ & $x$ & $x$ & $x$ & $x$ & $x$ & $x$ & $x$ & $\mathrm{x}$ & $x$ & $x$ & $x$ & $x$ & \\
\hline SC 3-1 & Int & 148 & 0 & 0 & 0 & 0 & 2 & 2 & 6.4 & 5.3 & 0 & 0 & 0 & $x$ & $\mathrm{x}$ & $5 Y R 5 / 4,4 / 4$ & 5YR 5/6 & $x$ & $\mathrm{x}$ & $x$ & $x$ & $x$ & $x$ & $x$ & $x$ & $x$ & $\mathrm{x}$ & $\mathrm{x}$ & $\mathrm{x}$ & $x$ & $x$ & \\
\hline SC 3-1 & Int & 149 & 0 & 0 & 0 & 0 & 2 & 2 & 8.1 & 7 & 0 & 0 & 0 & $x$ & $x$ & 2,5 YR $5 / 1,5 / 3$ & $2,5 Y R \quad 4 / 1,4 / 2$ & $x$ & $\mathrm{x}$ & $x$ & $x$ & $x$ & $x$ & $x$ & $x$ & $x$ & $\mathrm{x}$ & $x$ & $x$ & $x$ & $x$ & \\
\hline SC 3 & Sup & 150 & 0 & 0 & 0 & 0 & 2 & 2 & 6.1 & 5.5 & 0 & 0 & 0 & $x$ & $x$ & 2,5YR3/1,4/6,5/4 & 5YR 5/4 & $x$ & $x$ & $x$ & $\mathrm{x}$ & $x$ & $x$ & $x$ & $x$ & $x$ & $\mathrm{x}$ & $x$ & $x$ & $x$ & $x$ & 1 \\
\hline SC 3-1 & Int & 151 & 0 & 0 & 0 & 0 & 2 & 2 & 7.2 & 5.1 & 0 & 0 & 0 & $x$ & $x$ & $5 Y R 4 / 3$ & 5YR 4/2 & $x$ & $x$ & $x$ & $x$ & $x$ & $x$ & $x$ & $x$ & $x$ & $\mathrm{x}$ & $x$ & $x$ & $x$ & $x$ & 3 \\
\hline SC 3-1 & Int & 152 & 0 & 0 & 0 & 0 & 2 & 2 & 10.2 & 8.5 & 0 & 0 & 0 & $x$ & $\mathrm{x}$ & $2,5 Y R$ 4/4, 3/1 & 5YR 4/1 & $x$ & $x$ & $x$ & $\mathrm{x}$ & $x$ & $x$ & $x$ & $x$ & $x$ & $\mathrm{x}$ & $x$ & $x$ & $x$ & $x$ & \\
\hline SC $3-2 y^{3}$ & Sup & 153 & 0 & 0 & 0 & 0 & 2 & 2 & 7.5 & 7 & 0 & 0 & 0 & $x$ & $x$ & 5YR 5/6 & 5YR 4/6 & $x$ & $x$ & $x$ & $x$ & $x$ & $x$ & $x$ & $x$ & $x$ & $\mathrm{x}$ & $\mathrm{x}$ & $x$ & $x$ & $x$ & \\
\hline SC $3-2 y 3$ & Sup & 154 & 0 & 0 & 0 & 1 & 2 & 2 & 7 & 5.3 & 0 & 0 & 0 & $x$ & $x$ & $5 Y R$ 3/1, 4/2 & $5 Y R$ 6/1, 6/2 & $x$ & $\mathrm{x}$ & $x$ & $x$ & $x$ & $x$ & $x$ & $x$ & $x$ & $x$ & $x$ & $x$ & $x$ & $x$ & \\
\hline SC 3 & Sup & 155 & 0 & 0 & 0 & 0 & 2 & 2 & 6 & 4.8 & 0 & 0 & 0 & $x$ & $\mathrm{x}$ & $5 Y R \quad 4 / 3,5 / 3$ & $5 Y R$ 5/4 & $x$ & $x$ & $x$ & $\mathrm{x}$ & $x$ & $x$ & $x$ & $x$ & $x$ & $\mathrm{x}$ & $\mathrm{x}$ & $x$ & $x$ & $x$ & \\
\hline SC 3-1 & Int & 156 & 0 & 0 & 0 & 0 & 2 & 2 & 5.9 & 4.6 & 0 & 0 & 0 & $x$ & $x$ & $5 Y R$ 5/3 & 2,5YR 5/6 & $x$ & $\mathrm{x}$ & $x$ & $x$ & $x$ & $x$ & $x$ & $x$ & $x$ & $\mathrm{x}$ & $x$ & $x$ & $x$ & $x$ & 3 \\
\hline SC 3-1 & Int & 157 & 0 & 0 & 0 & 0 & 2 & 2 & 6.1 & \begin{tabular}{|l|}
4.4 \\
\end{tabular} & 0 & 0 & 0 & $x$ & $x$ & 5YR 5/2 & 2,5 YR 5/6 & $x$ & $x$ & $x$ & $x$ & $x$ & $x$ & $x$ & $x$ & $x$ & $\mathrm{x}$ & $x$ & $x$ & $x$ & $x$ & \\
\hline SC3-4 & Int & 158 & 0 & 0 & 0 & 0 & 2 & 2 & 5.4 & 4.5 & 0 & 0 & 0 & $x$ & $x$ & $2,5 Y R$ 5/6 & 2,5 YR 5/6 & $x$ & $x$ & $x$ & $x$ & $x$ & $x$ & $x$ & $x$ & $x$ & $\mathrm{x}$ & $x$ & $x$ & $x$ & $x$ & 3 \\
\hline SC 3-1 & Ext & 159 & 0 & 0 & 0 & 0 & 0 & \begin{tabular}{|l|l}
2 & 1 \\
\end{tabular} & $11.2 \mathrm{fr}$ & $11.2 \mathrm{fr}$ & 0 & 0 & 0 & $x$ & $x$ & 2,5 YR 5/6 & 2,5 YR $5 / 6$ & $x$ & $x$ & $x$ & $x$ & $x$ & $x$ & $x$ & $x$ & $x$ & $\mathrm{x}$ & $x$ & $x$ & $x$ & $x$ & 3 y 4 \\
\hline SC 3-1 & Ext & 160 & 0 & 0 & 0 & 0 & 2 & 2 & 11 & 7.2 & 0 & 0 & 0 & $x$ & $x$ & 2,5YR 5/6 & 2,5YR 5/4 & $x$ & $x$ & $x$ & $x$ & $x$ & $x$ & $x$ & $x$ & $x$ & $\mathrm{x}$ & $x$ & $x$ & $x$ & $x$ & \\
\hline SC 3-1 & Int & 161 & 0 & 0 & 0 & 0 & $3 y 4$ & 2 & 11.3 & 8.5 & 1 & 0 & 0 & $x$ & $x$ & 2,5 YR $4 / 4$ & 2,5 YR 5/6 & $\mathrm{x}$ & $x$ & $x$ & $x$ & $x$ & $x$ & $x$ & $\mathrm{x}$ & $x$ & $x$ & $\mathrm{x}$ & $x$ & $x$ & $x$ & 3 \\
\hline SC 3-1 & Int & 162 & 0 & 0 & 0 & 0 & 2 & 2 & 7 & 6.9 & 0 & 0 & 0 & $x$ & $x$ & 2,5YR4/1,5/2,5/4 & $2,5 Y R$ 4/1 & $x$ & $\mathrm{x}$ & $x$ & $x$ & $x$ & $x$ & $x$ & $x$ & $x$ & $\mathrm{x}$ & $\mathrm{x}$ & $x$ & $x$ & $x$ & \\
\hline SC 3-1 & Int & 163 & 0 & 0 & 0 & 0 & 2 & 2 & 6.2 & 5 & 0 & 0 & 0 & $x$ & $x$ & 5YR 5/4 & $5 Y R$ 6/3 & $x$ & $x$ & $x$ & $x$ & $x$ & $\mathrm{x}$ & $x$ & $x$ & $x$ & $\mathrm{x}$ & $x$ & $x$ & $x$ & $x$ & \\
\hline SC 3-1 & Int & 164 & 0 & 0 & 0 & 0 & 2 & 2 & 5.2 & 4.4 & 0 & 0 & 0 & $x$ & $x$ & 5YR 4/4 & 5YR 5/4 & $x$ & $\mathrm{x}$ & $x$ & $\mathrm{x}$ & $x$ & $\mathrm{x}$ & $x$ & $x$ & $x$ & $\mathrm{x}$ & $\mathrm{x}$ & $x$ & $x$ & $x$ & \\
\hline SC 3-1 & Ext & 165 & 0 & 0 & 0 & 0 & 2 & 2 & 7.5 & 5.5 & 0 & 0 & 0 & $x$ & $x$ & $2,5 Y R$ 5/6 & $2,5 Y R$ 5/6 & $x$ & $x$ & $x$ & $x$ & $x$ & $x$ & $x$ & $x$ & $x$ & $\mathrm{x}$ & $x$ & $x$ & $x$ & $x$ & 3 \\
\hline SC 3 & Sup & 166 & 0 & 0 & 0 & 0 & $2 \mathrm{y} 6$ & 2 & 9 & \begin{tabular}{|l|}
8.4 \\
\end{tabular} & 1 & 0 & 0 & $\mathrm{x}$ & $\mathrm{x}$ & 2,5YR4/4; 5YR6/4 & $5 Y R 6 / 4,6 / 6$ & $x$ & $x$ & $x$ & $x$ & $x$ & $x$ & $x$ & $x$ & $x$ & $x$ & $\mathrm{x}$ & $x$ & $x$ & $x$ & \\
\hline SC 3-1 & Int & 167 & 0 & 0 & 0 & 0 & 2 & 2 & 6.7 & 4.5 & 0 & 0 & 0 & $x$ & $x$ & 2,5 YR $4 / 4,3 / 1$ & $5 Y R 5 / 2$ & $x$ & $\mathrm{x}$ & $x$ & $x$ & $x$ & $x$ & $x$ & $x$ & $x$ & $\mathrm{x}$ & $\mathrm{x}$ & $x$ & $x$ & $x$ & \\
\hline SC 3-1 & Ext & 168 & 0 & 0 & 0 & 0 & 2 & 2 & 6.7 & 6 & 0 & 0 & 0 & $x$ & $x$ & 2,5 YR $5 / 4$ & 2,5 YR 5/4 & $\mathrm{x}$ & $x$ & $x$ & $\mathrm{x}$ & $\mathrm{x}$ & $x$ & $x$ & $\mathrm{x}$ & $x$ & $\mathrm{x}$ & $\mathrm{x}$ & $\mathrm{x}$ & $x$ & $x$ & \\
\hline SC3-4 & Ext & 169 & 0 & 0 & 0 & 0 & 2 & 2 & 6 & 3.3 & 0 & 0 & 0 & $x$ & $x$ & 5YR $2,5 / 1$ & 5YR $2,5 / 1$ & $x$ & $x$ & $x$ & $x$ & $x$ & $x$ & $x$ & $x$ & $x$ & $x$ & $x$ & $x$ & $x$ & $x$ & \\
\hline
\end{tabular}




\section{Manufactura}

Cocción

Borde-labio

Asa

Base

\begin{tabular}{|c|c|c|c|c|c|c|c|c|c|c|c|c|c|c|c|c|c|c|c|c|c|c|c|c|c|c|c|c|c|c|c|c|}
\hline \multirow[b]{2}{*}{ Sitio } & \multirow[b]{2}{*}{ UP $\mathrm{F}$} & \multirow{2}{*}{\multicolumn{2}{|c|}{$\mathrm{FN}^{\circ}$ Fgto }} & \multicolumn{12}{|c|}{ Manufactura } & \multicolumn{2}{|c|}{ Cocción } & \multicolumn{5}{|c|}{ Borde-labio } & \multicolumn{6}{|c|}{ Asa } & \multicolumn{3}{|c|}{ Base } & \multirow[b]{2}{*}{ Alterac } \\
\hline & & & & $\begin{array}{l}\text { Tec } \\
\text { lev }\end{array}$ & \begin{tabular}{|l|} 
For \\
ma \\
\end{tabular} & $\begin{array}{l}\text { Mar } \\
\text { cas }\end{array}$ & $\begin{array}{l}\text { Sup } \\
\text { ext }\end{array}$ & $\begin{array}{c}\text { Sup } \\
\text { int }\end{array}$ & \begin{tabular}{|l|} 
Esp \\
$\max$ \\
\end{tabular} & \begin{tabular}{|l|} 
Esp \\
min \\
\end{tabular} & $\begin{array}{c}\text { Deco } \\
\text { pint } \\
\end{array}$ & \begin{tabular}{|c|} 
Deco \\
corldsp
\end{tabular} & \begin{tabular}{|l|} 
Deco \\
agreg
\end{tabular} & Motivo & Estilo & Color sup ext & up int & Diam & $\begin{array}{l}\text { Lrg } \\
\operatorname{arc}\end{array}$ & \begin{tabular}{|c|}
$\%$ \\
arco \\
\end{tabular} & Direc & $\begin{array}{l}\text { For } \\
\text { ma }\end{array}$ & $\begin{array}{l}\text { Lar } \\
\text { go }\end{array}$ & \begin{tabular}{|c|} 
An \\
cho
\end{tabular} & Esp & \begin{tabular}{l|} 
Sec \\
ción
\end{tabular} & \begin{tabular}{|l|} 
In \\
serc \\
\end{tabular} & $\begin{array}{l}\text { Posi } \\
\text { ción }\end{array}$ & Diám & $\begin{array}{l}\text { Mor } \\
\text { fol }\end{array}$ & $\begin{array}{c}\text { Uni } \\
\text { ón }\end{array}$ & \\
\hline SC3-4 & Ext & 170 & 0 & 0 & 0 & 0 & 2 & 2 & 6.8 & 5 & 0 & 0 & 0 & $x$ & $x$ & 5YR 4/1, 4/2 & 5YR 6/4 & $\mathrm{x}$ & $x$ & $x$ & $x$ & \begin{tabular}{l|l}
$x$ \\
\end{tabular} & $\mathrm{x}$ & $\mathrm{x}$ & $\mathrm{x}$ & $x$ & $x$ & $x$ & $\mathrm{x}$ & $x$ & $x$ & 3 \\
\hline SC 3-1 & Int & 171 & 0 & 0 & 0 & 0 & 2 & 2 & 6 & 5.5 & 0 & 0 & 0 & $x$ & $x$ & 2,5YR 5/6 & 5YR 5/3 & $x$ & $x$ & $x$ & $x$ & $x$ & $x$ & $x$ & $x$ & $x$ & $x$ & $x$ & $x$ & $x$ & $x$ & \\
\hline SC 3-1 & Ext & 172 & 0 & 0 & 0 & 0 & 2 & 2 & 5.8 & 4.5 & 0 & 0 & 0 & $x$ & $x$ & $5 Y R$ 5/4 & 5YR 5/4 & $x$ & $x$ & $x$ & 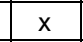 & $x$ & $x$ & $x$ & $\mathrm{x}$ & $x$ & $x$ & $x$ & $x$ & $x$ & $x$ & \\
\hline SC3-4 & Int & 173 & 0 & 0 & 0 & 0 & 2 & 2 & 5 & 3.7 & 0 & 0 & 0 & $x$ & $x$ & $2,5 Y R$ 5/6 & 5YR 5/1 & $x$ & $x$ & $x$ & $x$ & $x$ & $x$ & $x$ & $x$ & $x$ & $x$ & $x$ & $x$ & $x$ & $x$ & \\
\hline SC3-4 & Ext & 174 & 0 & 0 & 0 & 0 & 2 & 2 & 10.8 & 9 & 0 & 0 & 0 & $x$ & $x$ & 5YR 5/4 & 5YR 5/4 & $x$ & $x$ & $x$ & $x$ & $x$ & $x$ & $x$ & $x$ & $x$ & $x$ & $x$ & $x$ & $x$ & $x$ & 3 \\
\hline SC 3-1 & Int & 175 & 0 & 0 & 0 & 0 & 2 & 2 & 7.7 & 7.5 & 0 & 0 & 0 & $x$ & $x$ & 5YR 5/4 & 5YR 6/4 & $x$ & $x$ & $x$ & $x$ & $x$ & $x$ & $x$ & $x$ & $x$ & $x$ & $x$ & $x$ & $x$ & $x$ & \\
\hline SC 3-1 & Ext & 176 & 0 & 0 & 0 & 0 & 2 & 2 & 7.3 & 6.8 & 0 & 0 & 0 & $x$ & $x$ & $2,5 Y R$ 5/6 & $2,5 Y R$ 5/4 & $x$ & $x$ & $x$ & $x$ & $x$ & $x$ & $x$ & $x$ & $x$ & $x$ & $x$ & $x$ & $x$ & $\mathrm{x}$ & 3 \\
\hline SC 3-1 & Ext & 177 & 0 & 0 & 0 & 0 & 2 & 2 & 7.3 & 6.4 & 0 & 0 & 0 & $x$ & $x$ & $5 Y R 6 / 4$ & $5 Y R$ 5/4 & $x$ & $x$ & $x$ & $x$ & $x$ & $x$ & $x$ & $x$ & $x$ & $x$ & $x$ & $x$ & $x$ & $x$ & 3 \\
\hline SC 3 & Sup & 178 & 0 & 3 & 0 & 1 & $2 \mathrm{y} 6$ & 2 & 30 & 29 & 1 & 0 & 0 & $x$ & \begin{tabular}{|l|} 
poshisp \\
\end{tabular} & 10YR 6/3 & 2,5YR 5/6 & $x$ & $x$ & $x$ & $x$ & $x$ & $x$ & $x$ & $x$ & $x$ & $x$ & $x$ & $x$ & $x$ & $\mathrm{x}$ & \\
\hline $\mathrm{SC} 3$ & Sup & 179 & 0 & 3 & 0 & 1 & $2 \mathrm{y} 6$ & 2 & 13 & 11.1 & 1 & 0 & 0 & $x$ & poshisp & 10YR 5/3 & 2,5 YR 4/4 & $x$ & $x$ & $x$ & $x$ & $x$ & $x$ & $x$ & $x$ & $x$ & $x$ & $x$ & $x$ & $x$ & $\mathrm{x}$ & \\
\hline SC 3 & Sup & 180 & 0 & 3 & 0 & 1 & $2 \mathrm{y} 6$ & 2 & 10.5 & 9.5 & 1 & 0 & 0 & $x$ & poshisp & 10YR $6 / 3$ & $2,5 Y R$ 5/6 & $x$ & $x$ & $x$ & $x$ & $x$ & $x$ & $x$ & $x$ & $x$ & $x$ & $x$ & $x$ & $x$ & $x$ & \\
\hline SC 3-1 & Int & 181 & 0 & 3 & 0 & 1 & 2 & 2 & 12 & 10.9 & 0 & 0 & 0 & $x$ & \begin{tabular}{|l|} 
poshisp \\
\end{tabular} & $7,5 Y R$ 5/4 & 2,5YR 5/6 & $x$ & $x$ & $x$ & $x$ & $x$ & $x$ & $x$ & $x$ & $x$ & $x$ & $x$ & $x$ & $x$ & $x$ & \\
\hline SC3-4 & Int & 182 & 0 & 3 & 0 & 1 & 2 & 2 & 14.7 & 12.8 & 0 & 0 & 0 & $x$ & poshisp & $2,5 Y R$ 5/6 & $2,5 Y R$ 5/6 & $x$ & $x$ & $x$ & $x$ & $x$ & $\mathrm{x}$ & $x$ & $x$ & $x$ & $x$ & $x$ & $x$ & $x$ & $x$ & 3 \\
\hline SC 3 & Sup & 183 & 0 & 3 & 0 & 1 & $2 \mathrm{y} 6$ & 2 & 12.6 & 10.6 & 1 & 0 & 0 & $x$ & poshisp & 10YR6/4;7,5YR5/4 & $2,5 Y R$ 5/4 & $x$ & $x$ & $x$ & $x$ & $x$ & $x$ & $x$ & $x$ & $x$ & $x$ & $x$ & $x$ & $x$ & $x$ & \\
\hline SC 3 & Sup & 184 & 0 & 3 & 0 & 1 & $2 \mathrm{y} 6$ & 2 & 14.3 & 11 & 1 & 0 & 0 & $x$ & poshisp & 10YR 6/4 & $2,5 Y R$ 5/6 & $x$ & $x$ & $x$ & $x$ & $x$ & $x$ & $x$ & $x$ & $x$ & $x$ & $x$ & $x$ & $x$ & $\mathrm{x}$ & 3 \\
\hline $\mathrm{SC} 3$ & Sup & 185 & 0 & 3 & 0 & 1 & $2 \mathrm{y} 6$ & 2 & 19 & \begin{tabular}{|l|}
14.7 \\
\end{tabular} & 1 & 0 & 0 & $x$ & poshisp & $5 Y 7 / 3$ & 10YR 6/4 & $x$ & $x$ & $x$ & $x$ & $x$ & $\mathrm{x}$ & $x$ & $x$ & $x$ & $\mathrm{x}$ & $\mathrm{x}$ & $x$ & $x$ & $\mathrm{x}$ & \\
\hline SC3-4 & Int & 186 & 0 & 3 & 0 & 1 & 2 & 2 & 16.6 & 14.2 & 0 & 0 & 0 & $x$ & poshisp & $5 Y R 5 / 4$ & 5YR 6/4 & $x$ & $x$ & $x$ & $x$ & $x$ & $x$ & $x$ & $x$ & $x$ & $x$ & $x$ & $x$ & $x$ & $x$ & 3 y 4 \\
\hline C $3-2 y 3$ & Sup & 187 & 0 & 3 & 0 & 1 & 2 & 2 & 13.6 & 12.2 & 0 & 0 & 0 & $x$ & poshisp & 7,5YR6/4;5YR5/4 & $2,5 Y R$ 5/6 & $x$ & $x$ & $x$ & $x$ & $x$ & $x$ & $\mathrm{x}$ & $x$ & $x$ & $x$ & $x$ & $x$ & $x$ & $\mathrm{x}$ & \\
\hline $\mathrm{SC} 3$ & Sup & 188 & 0 & 3 & 0 & 1 & $2 \mathrm{y} 6$ & 2 & 14.1 & 11.6 & 1 & 0 & 0 & $x$ & poshisp & 10YR $7 / 3$ & $2,5 Y R 5 / 6$ & $x$ & $x$ & $x$ & $x$ & $\mathrm{x}$ & $x$ & $x$ & $x$ & $x$ & $x$ & $x$ & $x$ & $x$ & $x$ & \\
\hline $\mathrm{SC} 3$ & Sup & 189 & 0 & 3 & 0 & 1 & $2 \mathrm{y} 6$ & 2 & 10.6 & 9.4 & 1 & 0 & 0 & $x$ & poshisp & $5 Y 7 / 3$ & $2,5 Y R$ 5/6 & $x$ & $x$ & $x$ & $x$ & $x$ & $x$ & $x$ & $x$ & $x$ & $x$ & $x$ & $x$ & $x$ & $\mathrm{x}$ & \\
\hline $\mathrm{SC} 3$ & Sup. & 190 & 0 & 3 & 0 & 1 & $2 \mathrm{y} 6$ & 2 & 14 & 10.7 & 1 & 0 & 0 & $x$ & poshisp & 10YR 6/3 & $2,5 Y R$ 5/6 & $x$ & $x$ & $x$ & $\mathrm{x}$ & $x$ & $x$ & $x$ & $x$ & $x$ & $x$ & $x$ & $x$ & $x$ & $x$ & 3 \\
\hline $\mathrm{SC} 3$ & Sup & 191 & 0 & 3 & 0 & 1 & $2 \mathrm{y} 6$ & 2 & 12 & 10.7 & 1 & 0 & 0 & $x$ & \begin{tabular}{|l|} 
poshisp \\
\end{tabular} & 10YR 6/4 & 2,5YR 4/6 & $x$ & $x$ & $x$ & $x$ & $x$ & $x$ & $x$ & $x$ & $x$ & $x$ & $x$ & $x$ & $x$ & $x$ & \\
\hline C $3-2 y 3$ & Sup & 192 & 0 & 3 & 0 & 1 & 2 & 2 & 14.6 & 13.8 & 0 & 0 & 0 & $\mathrm{x}$ & poshisp & 2,5YR 5/6 & $2,5 Y R \quad 4 / 6$ & $x$ & $\mathrm{x}$ & $x$ & $x$ & $\mathrm{x}$ & $\mathrm{x}$ & $x$ & $x$ & $\mathrm{x}$ & $\mathrm{x}$ & $\mathrm{x}$ & $x$ & $\mathrm{x}$ & $\mathrm{x}$ & \\
\hline SC 3-1 & Ext & 193 & 0 & 3 & 0 & 1 & 2 & 2 & \begin{tabular}{|l|}
12.4 \\
\end{tabular} & 12 & 0 & 0 & 0 & $x$ & \begin{tabular}{|l|} 
poshisp \\
\end{tabular} & $2,5 Y R$ 5/6 & $2,5 Y R$ 5/6 & $x$ & $x$ & $x$ & $\mathrm{x}$ & $x$ & $x$ & $x$ & $x$ & $x$ & $x$ & $x$ & $x$ & $x$ & $x$ & \\
\hline SC 3-1 & Ext & 194 & 0 & 3 & 0 & 1 & 2 & 2 & 17.7 & 17.4 & 0 & 0 & 0 & $x$ & poshisp & 2,5YR 5/4 & $2,5 Y R \quad 4 / 6$ & $x$ & $x$ & $x$ & $x$ & $x$ & $x$ & $\mathrm{x}$ & $x$ & $x$ & $x$ & $x$ & $x$ & $x$ & $x$ & 3 \\
\hline SC 3-1 & Int & 195 & 0 & 3 & 0 & 1 & 2 & 2 & 11 & 7.6 & 0 & 0 & 0 & $x$ & \begin{tabular}{|l|} 
poshisp \\
\end{tabular} & 5YR 6/4 & $2,5 Y R$ 5/4 & $x$ & $x$ & $x$ & $x$ & $x$ & $x$ & $\mathrm{x}$ & $x$ & $x$ & $x$ & $x$ & $x$ & $x$ & $x$ & \\
\hline SC3-4 & Ext & 196 & 0 & 3 & 0 & 1 & 2 & 2 & 7.6 & 7.2 & 0 & 0 & 0 & $x$ & poshisp & $5 Y R 5 / 4$ & 5YR 5/4 & $x$ & $x$ & $x$ & $x$ & $x$ & $x$ & $x$ & $x$ & $x$ & $x$ & $x$ & $x$ & $x$ & $x$ & \\
\hline $5 \mathrm{C} 3$ & Sup 1 & 197 & 1 & (a) & 2 & 1 & 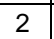 & 2 & 2 & 5 & 0 & 0 & 0 & $x$ & poshisp & Indet & 2,5YR 5/6 & 4 & $3,3 \mid 2$ & 26,2 & 2 & $2 \mathrm{y} 6$ & $x$ & $x$ & $x$ & $x$ & $x$ & $x$ & $x$ & -1 & $\mathrm{x}$ & 3 \\
\hline
\end{tabular}

\begin{tabular}{|c|c|c|c|c|c|c|c|c|c|c|c|c|c|c|c|c|c|c|c|c|c|c|c|c|c|c|c|c|c|c|c|}
\hline \multirow[b]{2}{*}{ Sitio } & \multirow[b]{2}{*}{ UP } & \multirow[b]{2}{*}{$\mathrm{FN}^{\circ}$} & \multirow[b]{2}{*}{ Fgto } & \multicolumn{11}{|c|}{ Manufactura } & \multicolumn{2}{|c|}{ Cocción } & \multicolumn{5}{|c|}{ Borde-labio } & \multicolumn{6}{|c|}{ Asa } & \multicolumn{3}{|c|}{ Base } & \multirow[b]{2}{*}{ Alterac } \\
\hline & & & & $\begin{array}{l}\text { Tec } \\
\text { lev }\end{array}$ & $\begin{array}{l}\text { For } \\
\text { ma }\end{array}$ & $\begin{array}{l}\text { Mar } \\
\text { cas }\end{array}$ & \begin{tabular}{|l} 
Sup \\
ext
\end{tabular} & \begin{tabular}{|c|}
$\begin{array}{c}\text { Sup } \\
\text { int }\end{array}$ \\
\end{tabular} & $\left|\begin{array}{l}\text { Esp } \\
\max \end{array}\right|$ & $\begin{array}{l}\text { Esp } \\
\min \end{array}$ & $\begin{array}{c}\text { Deco } \\
\text { pint }\end{array}$ & \begin{tabular}{|l|} 
Deco \\
agreg \\
\end{tabular} & \begin{tabular}{|c}
$\begin{array}{c}\text { Moti } \\
\text { vo }\end{array}$ \\
\end{tabular} & Estilo & Color sup ext & Color sup int & Diam & \begin{tabular}{|l|} 
Lrg \\
arc \\
\end{tabular} & \begin{tabular}{|c|}
$\%$ \\
arco \\
\end{tabular} & Direc & $\begin{array}{l}\text { For } \\
\text { ma }\end{array}$ & $\begin{array}{l}\text { Lar } \\
\text { go }\end{array}$ & $\begin{array}{c}\text { An } \\
\text { cho }\end{array}$ & Esp & $\begin{array}{l}\text { Sec } \\
\text { ción }\end{array}$ & \begin{tabular}{|c|} 
In \\
serc
\end{tabular} & $\begin{array}{l}\text { Posi } \\
\text { ción }\end{array}$ & Diám & $\begin{array}{c}\text { Mor } \\
\text { fol }\end{array}$ & $\begin{array}{c}\text { Uni } \\
\text { ón }\end{array}$ & \\
\hline TC 2 & Conj A & 1 & 1 & 0 & 2 & 1 & 2 & 3 & 9.2 & 7.5 & 0 & 0 & $x$ & $x$ & $5 Y R 5 / 3,5 / 4$ & $5 Y R$ 5/3, 4/3 & 18.2 & 5.4 & 9.4 & 1 & $1 \mathrm{y} 6$ & $x$ & $x$ & $x$ & $x$ & $x$ & $x$ & $x$ & $x$ & $x$ & \\
\hline TC 2 & Conj A & 2 & 1 & 0 & 1 & 2 & 3 & 3 & 7.9 & 6.9 & 0 & 1 & $x$ & Yavi & $2.5 Y R$ 5/6 & $2.5 Y R$ 5/6 & indet & 2.3 & indet & 1 & 2 & $x$ & $x$ & $x$ & $x$ & $x$ & $x$ & $x$ & $x$ & $x$ & \\
\hline TC 2 & Conj $\mathrm{A}$ & 3 & 1 & 0 & 0 & 2 & 3 & $3 y 6$ & 5.0 & 4.8 & 1 & 0 & $\mathrm{x}$ & $\mathrm{x}$ & 2.5YR 5/6 & 2.5 YR 5/6, 4/4 & indet & 0.7 & indet & t 1 & 2 & $\mathrm{x}$ & $\mathrm{x}$ & $\mathrm{x}$ & $\mathrm{x}$ & $\mathrm{x}$ & $\mathrm{x}$ & $\mathrm{x}$ & $\mathrm{x}$ & $\mathrm{x}$ & \\
\hline TC 2 & Conj A & 4 & 2 & 0 & 0 & $1 \mathrm{y} 2$ & 3 & 2 & 20.9 & 10.4 & 0 & 0 & $\mathrm{x}$ & $\mathrm{x}$ & 2.5 YR $3 / 3,3 / 1$ & 7.5YR 5/3 & $\mathrm{x}$ & $\mathrm{x}$ & $\mathrm{x}$ & $\mathrm{x}$ & $\mathrm{x}$ & $x$ & $x$ & $x$ & $\mathrm{x}$ & $\mathrm{x}$ & $\mathrm{x}$ & 4.5 & 1 & 2 & 1 \\
\hline \begin{tabular}{|l|l|} 
TC 2 \\
\end{tabular} & Conj A & 5 & 0 & 0 & 0 & 1 & 3 & 2 & 6.0 & 4.2 & 0 & 0 & $x$ & $x$ & $2.5 Y R \quad 4 / 4,5 / 6$ & 2.5 YR $5 / 3$ & $\mathrm{x}$ & $x$ & $x$ & $x$ & $x$ & $x$ & $x$ & $x$ & $x$ & $x$ & $x$ & $x$ & $x$ & $x$ & 3 \\
\hline TC 2 & Conj A & 6 & 0 & 0 & 0 & 0 & 3 & 2 & 6.5 & 5.1 & 0 & 0 & $x$ & $x$ & $5 Y R$ 4/1, 4/2 & 5YR 5/4 & $x$ & $x$ & $x$ & $x$ & $x$ & $x$ & $x$ & $x$ & $x$ & $x$ & $x$ & $x$ & $x$ & $x$ & 1 \\
\hline TC 2 & Conj A & 7 & 0 & 1 & 0 & 1 & 3 & 2 & 8.5 & 5.0 & 0 & 0 & $x$ & $\mathrm{x}$ & 5YR 4/1 & $5 Y R 5 / 4$ & $\mathrm{x}$ & $\mathrm{x}$ & $\mathrm{x}$ & $x$ & $\mathrm{x}$ & $x$ & $x$ & $x$ & $\mathrm{x}$ & $\mathrm{x}$ & $\mathrm{x}$ & $\mathrm{x}$ & $\mathrm{x}$ & $\mathrm{x}$ & 1 \\
\hline TC 2 & Conj $\mathrm{A}$ & 8 & 0 & 0 & 0 & 0 & 3 & 3 & 8.0 & 7.4 & 0 & 0 & $x$ & $x$ & $2.5 Y R \quad 4 / 4$ & $2.5 Y R \quad 4 / 6$ & $x$ & $x$ & $x$ & $x$ & $x$ & $x$ & $x$ & $x$ & $x$ & $x$ & $x$ & $x$ & $x$ & $x$ & \\
\hline TC 2 & Conj A & 9 & 0 & 0 & 0 & 2 & 3 & 3 & 8.6 & 5.4 & 0 & 0 & $\mathrm{x}$ & $x$ & 2.5 YR $5 / 8$ & 2.5 YR $5 / 6$ & $\mathrm{x}$ & $\mathrm{x}$ & $x$ & $x$ & $x$ & $\mathrm{x}$ & $x$ & $x$ & $\mathrm{x}$ & $\mathrm{x}$ & $x$ & $x$ & $\mathrm{x}$ & $\mathrm{x}$ & \\
\hline
\end{tabular}




\begin{tabular}{|c|c|c|c|c|c|c|c|c|c|c|c|c|c|c|c|c|c|c|c|c|c|c|c|c|c|c|c|c|c|c|c|}
\hline \multirow[b]{2}{*}{ Sitio } & \multirow[b]{2}{*}{ UP } & \multirow[b]{2}{*}{$\mathrm{FN}^{\circ}$} & \multirow[b]{2}{*}{ Fgto } & \multicolumn{11}{|c|}{ Manufactura } & \multicolumn{2}{|c|}{ Cocción } & \multicolumn{5}{|c|}{ Borde-labio } & \multicolumn{6}{|c|}{ Asa } & \multicolumn{3}{|c|}{ Base } & \multirow[b]{2}{*}{ Alterac } \\
\hline & & & & $\begin{array}{l}\text { Tec } \\
\text { lev }\end{array}$ & $\begin{array}{l}\text { For } \\
\text { ma }\end{array}$ & $\begin{array}{l}\text { Mar } \\
\text { cas }\end{array}$ & $\begin{array}{l}\text { Sup } \\
\text { ext }\end{array}$ & $\begin{array}{c}\text { Sup } \\
\text { int }\end{array}$ & $\begin{array}{l}\text { Esp } \\
\text { max }\end{array}$ & $\begin{array}{l}\text { Esp } \\
\min \end{array}$ & $\begin{array}{l}\text { Deco } \\
\text { pint }\end{array}$ & $\begin{array}{l}\text { Deco } \\
\text { agreg }\end{array}$ & $\begin{array}{c}\text { Moti } \\
\text { vo }\end{array}$ & Estilo & Color sup ext & Color sup int & Diam & $\begin{array}{l}\text { Lrg } \\
\text { arc }\end{array}$ & $\begin{array}{c}\% \\
\text { arco }\end{array}$ & Direc & $\begin{array}{l}\begin{array}{l}\text { For } \\
\text { ma }\end{array} \\
\end{array}$ & $\begin{array}{l}\text { Lar } \\
\text { go }\end{array}$ & $\begin{array}{c}\text { An } \\
\text { cho }\end{array}$ & Esp & $\begin{array}{l}\text { Sec } \\
\text { ción }\end{array}$ & $\begin{array}{l}\text { In } \\
\text { serc }\end{array}$ & $\begin{array}{l}\text { Posi } \\
\text { ción }\end{array}$ & \begin{tabular}{l|l} 
niám \\
\end{tabular} & n $\begin{array}{l}\text { Mor } \\
\text { fol }\end{array}$ & 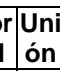 & \\
\hline TC 2 & Conj A & 10 & 0 & 0 & 0 & 0 & 3 & 2 & 7.9 & 7.4 & 0 & 0 & $\mathrm{x}$ & $x$ & 5YR 4/3 & 5YR 5/4 & $\mathrm{x}$ & $\mathrm{x}$ & $x$ & $x$ & $x$ & $\mathrm{x}$ & $\mathrm{x}$ & $\mathrm{x}$ & $\mathrm{x}$ & $x$ & $x$ & $\mathrm{x}$ & $x$ & $\mathrm{x}$ & 3 \\
\hline TC 2 & Conj A & 11 & 0 & 0 & 0 & 0 & 3 & 2 & 5.0 & 4.1 & 0 & 0 & $\mathrm{x}$ & $\mathrm{x}$ & 2.5 YR 5/6 & 2.5 YR 5/6 & $x$ & $x$ & $x$ & $x$ & $x$ & $x$ & $x$ & $x$ & $x$ & $x$ & $x$ & $x$ & $x$ & $x$ & \\
\hline TC 2 & Conj A & 12 & 0 & 0 & 0 & 1 & 3 & 2 & 6.4 & 5.5 & 0 & 0 & $x$ & $x$ & 2.5 YR 5/6 & 5YR 6/4 & $x$ & $x$ & $x$ & $x$ & $x$ & $x$ & $x$ & $x$ & $x$ & $x$ & $x$ & $x$ & $x$ & $x$ & \\
\hline TC 2 & Conj A & 13 & 0 & 0 & 0 & 9 & 3 & 3 & 6.5 & 4.8 & 0 & 0 & $x$ & $x$ & 5YR 4/2 & $5 Y R$ 5/3 & $\mathrm{x}$ & $x$ & $\mathrm{x}$ & $x$ & $x$ & $\mathrm{x}$ & $x$ & $\mathrm{x}$ & $x$ & $\mathrm{x}$ & $\mathrm{x}$ & $x$ & $x$ & $\mathrm{x}$ & \\
\hline TC 2 & Conj A & 14 & 0 & 0 & 0 & 2 & $3 y 4$ & 2 & 7.5 & 7.3 & 1 & 0 & $\mathrm{x}$ & Yavi & 2.5YR 5/6 & 2.5YR 5/6 & $\mathrm{x}$ & $\mathrm{x}$ & $\mathrm{x}$ & $\mathrm{x}$ & $\mathrm{x}$ & $\mathrm{x}$ & $\mathrm{x}$ & $\mathrm{x}$ & $\mathrm{x}$ & $\mathrm{x}$ & $\mathrm{x}$ & $\mathrm{x}$ & $\mathrm{x}$ & $\mathrm{x}$ & \\
\hline TC 2 & Conj A & 15 & 0 & 0 & 0 & $1 \mathrm{y} 2$ & 3 & 2 & 6.0 & 5.7 & 0 & 0 & $\mathrm{x}$ & $\mathrm{x}$ & 2.5 YR 5/6 & 2.5 YR 5/6 & $x$ & $\mathrm{x}$ & $x$ & $x$ & $x$ & $\mathrm{x}$ & $x$ & $\mathrm{x}$ & $\mathrm{x}$ & $x$ & $x$ & $x$ & $x$ & $\mathrm{x}$ & 3 \\
\hline TC 2 & Conj A & 16 & 0 & 0 & 0 & 0 & 3 & 2 & 5.4 & 5.0 & 0 & 0 & $x$ & $x$ & $5 Y R \quad 4 / 4,4 / 1$ & 2.5 YR 5/6 & $x$ & $x$ & $x$ & $x$ & $x$ & $x$ & $x$ & $x$ & $x$ & $x$ & $x$ & $x$ & $x$ & $x$ & 3 \\
\hline TC 2 & Conj A & 17 & 0 & 0 & 0 & 0 & 3 & 2 & 4.5 & 3.9 & 0 & 0 & $x$ & $x$ & 5YR 5/6 & 5YR 5/6 & $\mathrm{x}$ & $x$ & $\mathrm{x}$ & $x$ & $\mathrm{x}$ & $x$ & $x$ & $x$ & $\mathrm{x}$ & $x$ & $\mathrm{x}$ & $\mathrm{x}$ & $\mathrm{x}$ & $\mathrm{x}$ & \\
\hline TC 2 & Conj A & 18 & 0 & 0 & 0 & 0 & 3 & 2 & 5.6 & 4.6 & 0 & 0 & $\mathrm{x}$ & $x$ & 5YR 5/6 & 5YR 5/\& & $\mathrm{x}$ & $\mathrm{x}$ & $x$ & $x$ & $x$ & $x$ & $\mathrm{x}$ & $\mathrm{x}$ & $x$ & $x$ & $\mathrm{x}$ & $x$ & $x$ & $x$ & \\
\hline TC 2 & Conj A & 19 & 0 & 0 & 0 & 0 & 3 & 3 & 7.2 & 5.5 & 0 & 0 & $x$ & Yavi & $5 Y R 4 / 4$ & 5YR 5/4 & $\mathrm{x}$ & $\mathrm{x}$ & $\mathrm{x}$ & $x$ & $x$ & $\mathrm{x}$ & $x$ & $x$ & $x$ & $\mathrm{x}$ & $x$ & $x$ & $\mathrm{x}$ & $x$ & 3 \\
\hline TC 2 & Conj A & 20 & 0 & 0 & 0 & 0 & 3 & 2 & 8.4 & 6.8 & 0 & 0 & $x$ & $x$ & 5YR 3/2 & 5YR 5/4 & $x$ & $x$ & $x$ & $x$ & $x$ & $x$ & $x$ & $x$ & $x$ & $x$ & $x$ & $x$ & $x$ & $x$ & \\
\hline TC 2 & Conj A & 21 & 0 & 0 & 0 & 0 & 3 & 2 & 5.3 & 5.3 & 0 & 0 & $\mathrm{x}$ & Yavi & 2.5YR 5/6 & 2.5YR 5/6 & $\mathrm{x}$ & $\mathrm{x}$ & $\mathrm{x}$ & $\mathrm{x}$ & $x$ & $\mathrm{x}$ & $\mathrm{x}$ & $\mathrm{x}$ & $\mathrm{x}$ & $x$ & $\mathrm{x}$ & $\mathrm{x}$ & $\mathrm{x}$ & $\mathrm{x}$ & \\
\hline TC 2 & Conj A & 22 & 1 & 0 & 2 & 0 & 2 & $3 y 4$ & 10.5 & 6.3 & 1 & 0 & $x$ & Yavi & 5YR 6/6 & $2.5 Y R \quad 4 / 4$ & indet & 2.3 & indet & $\begin{array}{ll}t & 1 \\
\end{array}$ & 2 & indet & tindet & tindet & $\begin{array}{ll}0 \\
\end{array}$ & 0 & $x$ & $x$ & $x$ & $x$ & 1 \\
\hline TC 2 & Conj A & 23 & 1 & 0 & 1 & 0 & $3 y 4$ & $3 y 4$ & 7.8 & 7.3 & 1 & 0 & $x$ & $x$ & $2.5 Y R$ 4/4 & 2.5YR 4/4 & indet & 1.5 & indet & $\begin{array}{l}\mathrm{t} \\
2\end{array}$ & 2 & $x$ & $x$ & $x$ & $x$ & $x$ & $x$ & $x$ & $x$ & $x$ & 3 \\
\hline TC 2 & Conj A & 24 & 1 & 0 & 0 & 0 & 2 & $3 \mathrm{y} 6$ & 6.8 & 6.3 & 1 & 0 & $x$ & $x$ & 2.5YR 5/6 & 2.5 YR 4/6 & indet & 1.3 & indet & $\begin{array}{ll}t & 1 \\
\end{array}$ & 2 & $x$ & $x$ & $x$ & $x$ & $x$ & $x$ & $x$ & $x$ & $x$ & \\
\hline TC 2 & Conj A & 25 & 2 & 0 & 0 & 0 & 2 & 3 & 10.7 & 7.6 & 0 & 0 & $x$ & $x$ & $2.5 Y R$ 5/6 & $2.5 Y R$ 4/6 & $x$ & $x$ & $x$ & $x$ & $x$ & $x$ & $x$ & $x$ & $x$ & $x$ & $x$ & indet & $\begin{array}{ll}t & 5 \\
\end{array}$ & 2 & 3 \\
\hline TC 2 & Conj A & 26 & 0 & 0 & 0 & 0 & $2 y 4$ & 2 & 10.2 & 7.6 & 1 & 0 & $\mathrm{x}$ & $\mathrm{x}$ & $5 Y R$ 5/4, 6/6 & $5 Y R 6 / 2$ & $\mathrm{x}$ & $\mathrm{x}$ & $\mathrm{x}$ & $\mathrm{x}$ & $x$ & $\mathrm{x}$ & $\mathrm{x}$ & $\mathrm{x}$ & $\mathrm{x}$ & $\mathrm{x}$ & $\mathrm{x}$ & $\mathrm{x}$ & $\mathrm{x}$ & $x$ & 1 y 5 \\
\hline TC 2 & Conj A & 27 & 0 & 0 & 0 & 0 & $2 \mathrm{y} 4$ & 2 & 7.3 & 6.5 & 1 & 0 & $x$ & $x$ & 2.5YR 4/4 & 2.5 YR $6 / 6$ & $x$ & $x$ & $x$ & $x$ & $x$ & $x$ & $x$ & $x$ & $x$ & $x$ & $x$ & $x$ & $x$ & $x$ & \\
\hline TC 2 & Conj A & 28 & 0 & 0 & 0 & 1 & $3 y 4$ & 2 & 6.6 & 6.0 & 1 & 0 & $x$ & Yavi & 2.5 YR 4/6 & 2.5 YR 5/6 & $x$ & $x$ & $x$ & $x$ & $x$ & $x$ & $x$ & $x$ & $x$ & $x$ & $x$ & $x$ & $x$ & $x$ & \\
\hline TC 2 & Conj A & 29 & 0 & 0 & 0 & 0 & 3y4 & 2 & 6.8 & 6.0 & 1 & 0 & $\mathrm{x}$ & $\mathrm{x}$ & 10R $4 / 4$ & 2.5YR 6/6 & $\mathrm{x}$ & $\mathrm{x}$ & $\mathrm{x}$ & $\mathrm{x}$ & $x$ & $\mathrm{x}$ & $\mathrm{x}$ & $\mathrm{x}$ & $\mathrm{x}$ & $\mathrm{x}$ & $\mathrm{x}$ & $\mathrm{x}$ & $x$ & $\mathrm{x}$ & \\
\hline TC 2 & Conj A & 30 & 0 & 0 & 0 & 2 & $3 y 4$ & 2 & 6.4 & 5.8 & 1 & 0 & $x$ & $x$ & $10 \mathrm{R} 4 / 4$ & 2.5 YR 5/6 & $x$ & $x$ & $x$ & $x$ & $x$ & $x$ & $x$ & $x$ & $x$ & $x$ & $x$ & $x$ & $x$ & $x$ & \\
\hline TC 2 & Conj A & 31 & 0 & 0 & 0 & 0 & $3 y 4$ & 2 & 5.3 & 5.0 & 1 & 0 & $x$ & $x$ & 10R $4 / 4$ & 2.5YR 5/6 & $x$ & $x$ & $x$ & $x$ & $x$ & $x$ & $x$ & $x$ & $x$ & $x$ & $x$ & $x$ & $x$ & $x$ & 1 \\
\hline TC 2 & Conj A & 32 & 0 & 0 & 0 & 2 & $3 y 4$ & 2 & 5.3 & 4.5 & 1 & 0 & $x$ & $x$ & 5YR 4/4 & $5 Y R \quad 4 / 3,3 / 1$ & $x$ & $x$ & $x$ & $x$ & $x$ & $x$ & $x$ & $x$ & $x$ & $x$ & $x$ & $x$ & $x$ & $x$ & 1 \\
\hline TC 2 & Conj A & 33 & 0 & 0 & 0 & 0 & $2 \mathrm{y} 4$ & 2 & 8.7 & 7.5 & 1 & 0 & $x$ & Yavi & 2.5YR4/6;7.5YR6/4 & $7.5 Y R 7 / 3$ & $x$ & $x$ & $x$ & $x$ & $x$ & $x$ & $x$ & $x$ & $x$ & $x$ & $x$ & $x$ & $x$ & $x$ & 5 \\
\hline TC 2 & Conj A & 34 & 0 & 0 & 1 & 0 & $3 y 4$ & $3,4 \mathrm{y} 6$ & 7.5 & 5.0 & 2 & 0 & lineas & Yavi & $10 \mathrm{R} 4 / 6$ & 10R 4/6, 4/2(pint) & $x$ & $x$ & $x$ & $x$ & $x$ & $x$ & $x$ & $x$ & $x$ & $x$ & $x$ & $x$ & $x$ & $x$ & \\
\hline TC 2 & Conj A & 35 & 0 & 0 & 0 & 2 & 3y4 & 2 & 8.0 & 6.2 & 1 & 0 & $\mathrm{x}$ & Yavi & 10R $4 / 6$ & 5YR 7/6 & $\mathrm{x}$ & $\mathrm{x}$ & $\mathrm{x}$ & $\mathrm{x}$ & $\mathrm{x}$ & $\mathrm{x}$ & $\mathrm{x}$ & $\mathrm{x}$ & $\mathrm{x}$ & $\mathrm{x}$ & $\mathrm{x}$ & $\mathrm{x}$ & $\mathrm{x}$ & $\mathrm{x}$ & 3 \\
\hline TC 2 & Conj A & 36 & 0 & 0 & 0 & 0 & $3 y 4$ & $3 y 4$ & 6.8 & 5.8 & 1 & 0 & $x$ & $x$ & $2.5 Y R$ 4/4 & $2.5 Y R$ 4/6 & $x$ & $x$ & $x$ & $x$ & $x$ & $x$ & $x$ & $x$ & $x$ & $x$ & $x$ & $x$ & $x$ & $x$ & \\
\hline TC 2 & Conj A & 37 & 0 & 0 & 0 & 0 & $2 \mathrm{y} 4$ & 2 & 7.0 & 6.9 & 1 & 0 & $\mathrm{x}$ & $x$ & $2.5 Y R \quad 4 / 4,5 / 6$ & $2.5 Y R$ 5/6 & $\mathrm{x}$ & $\mathrm{x}$ & $\mathrm{x}$ & $\mathrm{x}$ & $x$ & $\mathrm{x}$ & $\mathrm{x}$ & $\mathrm{x}$ & $\mathrm{x}$ & $\mathrm{x}$ & $\mathrm{x}$ & $\mathrm{x}$ & $\mathrm{x}$ & $\mathrm{x}$ & 3 y 5 \\
\hline TC 2 & Conj A & 38 & 0 & 0 & 0 & 0 & 3y4 & 3 & 6.7 & 6.2 & 1 & 0 & $\mathrm{x}$ & Yavi & 10R4/8;5YR6/6 & 7.5YR 6/4 & $\mathrm{x}$ & $\mathrm{x}$ & $\mathrm{x}$ & $\mathrm{x}$ & $\mathrm{x}$ & $x$ & $x$ & $\mathrm{x}$ & $\mathrm{x}$ & $\mathrm{x}$ & $\mathrm{x}$ & $\mathrm{x}$ & $\mathrm{x}$ & $\mathrm{x}$ & 5 \\
\hline TC 2 & Conj A & 39 & 0 & 0 & 0 & 0 & $2 \mathrm{y} 4$ & 2 & 6.4 & 5.6 & 1 & 0 & $x$ & Yavi & $10 \mathrm{R} 4 / 6$ & 2.5 YR 5/6 & $x$ & $x$ & $x$ & $x$ & $x$ & $x$ & $x$ & $x$ & $x$ & $x$ & $x$ & $x$ & $x$ & $x$ & 5 \\
\hline TC 2 & Conj A & 40 & 0 & 0 & 0 & $1 \mathrm{y} 2$ & $3 y 4$ & 2 & 6.6 & 6.3 & 1 & 0 & $x$ & $x$ & $2.5 Y R$ 4/4 & $2.5 Y R$ 5/6 & $x$ & $x$ & $x$ & $x$ & $x$ & $x$ & $x$ & $x$ & $x$ & $x$ & $x$ & $x$ & $x$ & $x$ & \\
\hline TC 2 & Conj A & 41 & 0 & 0 & 0 & 0 & $3 y 4$ & 2 & 6.8 & 5.5 & 1 & 0 & $x$ & $x$ & $2.5 \mathrm{YR} 4 / 6$ & $2.5 Y R 5 / 6$ & $x$ & $x$ & $x$ & $x$ & $x$ & $x$ & $x$ & $x$ & $x$ & $x$ & $x$ & $x$ & $x$ & $x$ & \\
\hline TC 2 & Conj A & 42 & 0 & 0 & 0 & 0 & $3 y 4$ & 2 & 6.0 & 5.4 & 1 & 0 & $x$ & $x$ & $2.5 Y R \quad 4 / 3$ & 2.5 YR $6 / 6$ & $x$ & $x$ & $x$ & $x$ & $x$ & $x$ & $x$ & $x$ & $x$ & $x$ & $x$ & $x$ & $x$ & $x$ & \\
\hline TC 2 & Conj A & 43 & 0 & 0 & 0 & 1 & $3 y 4$ & $3 y 4$ & 8.6 & 7.6 & 1 & 0 & $x$ & $x$ & $2.5 Y R$ 4/6 & 2.5YR 4/4 & $x$ & $x$ & $x$ & $x$ & $x$ & $x$ & $x$ & $x$ & $x$ & $x$ & $x$ & $x$ & $x$ & $x$ & \\
\hline TC 2 & Conj A & 44 & 0 & 0 & 0 & 2 & 3 & $3,4 \mathrm{y} 6$ & 9.0 & 8.1 & 2 & 0 & linea & $x$ & $2.5 Y R$ 4/4 & 2.5 YR $4 / 6,6 / 2$ & $x$ & $x$ & $x$ & $x$ & $x$ & $x$ & $x$ & $x$ & $x$ & $x$ & $x$ & $x$ & $x$ & $x$ & \\
\hline TC 2 & Conj A & 45 & 0 & 0 & 0 & 0 & $2 y 4$ & $2 y 4$ & 8.5 & 6.1 & 1 & 0 & $\mathrm{x}$ & Yavi & $2.5 Y R \quad 4 / 4$ & $2.5 Y R \quad 4 / 4,5 / 6$ & $\mathrm{x}$ & $\mathrm{x}$ & $\mathrm{x}$ & $\mathrm{x}$ & $x$ & $\mathrm{x}$ & $\mathrm{x}$ & $\mathrm{x}$ & $\mathrm{x}$ & $x$ & $\mathrm{x}$ & $\mathrm{x}$ & $\mathrm{x}$ & $\mathrm{x}$ & 3 у 5 \\
\hline TC 2 & Conj A & 46 & 0 & 0 & 0 & 0 & 2 & 3 & 6.3 & 5.6 & 0 & 0 & $x$ & $x$ & 5YR 3/1 & 5YR 4/6 & $x$ & $x$ & $x$ & $x$ & $x$ & $x$ & $x$ & $x$ & $x$ & $x$ & $x$ & $x$ & $x$ & $x$ & 1 \\
\hline TC 2 & Conj A & 47 & 0 & 0 & 0 & 0 & $3 y 4$ & 2 & 8.2 & 8.0 & 1 & 0 & $x$ & $x$ & $2.5 Y R \quad 4 / 2$ & $2.5 Y R \quad 4 / 4$ & $x$ & $x$ & $x$ & $x$ & $x$ & $x$ & $x$ & $x$ & $x$ & $x$ & $x$ & $x$ & $x$ & $x$ & 3 \\
\hline TC 2 & Conj A & 48 & 0 & 0 & 0 & 0 & 3 & 3 & 6.2 & 5.5 & 0 & 0 & $\mathrm{x}$ & $\mathrm{x}$ & 2.5YR 5/8 & 2.5YR 5/8 & $\mathrm{x}$ & $\mathrm{x}$ & $\mathrm{x}$ & $\mathrm{x}$ & $\mathrm{x}$ & $\mathrm{x}$ & $\mathrm{x}$ & $\mathrm{x}$ & $\mathrm{x}$ & $\mathrm{x}$ & $\mathrm{x}$ & $\mathrm{x}$ & $\mathrm{x}$ & $\mathrm{x}$ & \\
\hline TC 2 & Conj A & 49 & 0 & 0 & 0 & 0 & $3 y 4$ & 3 & 6.3 & 5.8 & 1 & 0 & $\mathrm{x}$ & $\mathrm{x}$ & 10R $4 / 4$ & 2.5YR 5/3 & $\mathrm{x}$ & $\mathrm{x}$ & $\mathrm{x}$ & $\mathrm{x}$ & $\mathrm{x}$ & $\mathrm{x}$ & $\mathrm{x}$ & $\mathrm{x}$ & $\mathrm{x}$ & $\mathrm{x}$ & $\mathrm{x}$ & $\mathrm{x}$ & $\mathrm{x}$ & $\mathrm{x}$ & 5 \\
\hline TC 2 & Conj A & 50 & 0 & 0 & 0 & 0 & 3y4 & 3y4 & 6.7 & 6.4 & 1 & 0 & $\mathrm{x}$ & $\mathrm{x}$ & $2.5 Y R \quad 4 / 6$ & 2.5YR 4/6 & $\mathrm{x}$ & $\mathrm{x}$ & $\mathrm{x}$ & $\mathrm{x}$ & $x$ & $\mathrm{x}$ & $\mathrm{x}$ & $\mathrm{x}$ & $\mathrm{x}$ & $x$ & $\mathrm{x}$ & $\mathrm{x}$ & $x$ & $\mathrm{x}$ & 3 \\
\hline
\end{tabular}




\begin{tabular}{|c|c|c|c|c|c|c|c|c|c|c|c|c|c|c|c|c|c|c|c|c|c|c|c|c|c|c|c|c|c|c|c|}
\hline \multirow[b]{2}{*}{ Sitio } & \multirow[b]{2}{*}{ UP } & \multirow[b]{2}{*}{$\mathrm{FN}^{\circ}$} & \multirow[b]{2}{*}{ Fgto } & \multicolumn{11}{|c|}{ Manufactura } & \multicolumn{2}{|c|}{ Cocción } & \multicolumn{5}{|c|}{ Borde-labio } & \multicolumn{6}{|c|}{ Asa } & \multicolumn{3}{|c|}{ Base } & \multirow[b]{2}{*}{ Alterac } \\
\hline & & & & $\begin{array}{l}\text { Tec } \\
\text { lev }\end{array}$ & $\begin{array}{l}\text { For } \\
\text { ma }\end{array}$ & $\begin{array}{l}\text { Mar } \\
\text { cas }\end{array}$ & $\begin{array}{l}\text { Sup } \\
\text { ext }\end{array}$ & $\begin{array}{c}\text { Sup } \\
\text { int }\end{array}$ & $\begin{array}{l}\text { Esp } \\
\text { max }\end{array}$ & \begin{tabular}{|l|l} 
& Esp \\
& min \\
\end{tabular} & $\begin{array}{l}\text { Deco } \\
\text { pint }\end{array}$ & $\begin{array}{l}\text { Deco } \\
\text { agreg }\end{array}$ & \begin{tabular}{|c} 
Moti \\
vo
\end{tabular} & Estilo & Color sup ext & Color sup int & Diam & $\begin{array}{l}\text { Lrg } \\
\text { arc }\end{array}$ & $\begin{array}{c}\% \\
\text { arco }\end{array}$ & Direc & $\begin{array}{l}\begin{array}{l}\text { For } \\
\text { ma }\end{array} \\
\end{array}$ & $\begin{array}{l}\text { Lar } \\
\text { go }\end{array}$ & $\begin{array}{c}\text { An } \\
\text { cho }\end{array}$ & Esp & $\begin{array}{l}\text { Sec } \\
\text { ción }\end{array}$ & $\begin{array}{l}\text { In } \\
\text { serc }\end{array}$ & $\begin{array}{l}\begin{array}{l}\text { Posi } \\
\text { ción }\end{array} \\
\end{array}$ & $\begin{array}{ll}\text { niám } \\
\end{array}$ & $\mathrm{m} \begin{array}{c}\text { Mor } \\
\text { fol }\end{array}$ & $\begin{array}{l}\text { Uni } \\
\text { ón }\end{array}$ & \\
\hline TC 2 & Conj A & 51 & 0 & 0 & 0 & 0 & $3 y 4$ & 2 & 7.2 & 7.2 & 1 & 0 & $x$ & $x$ & 10R 4/4; 2.5YR 5/6 & $2.5 Y R$ 5/6 & $\mathrm{x}$ & $\mathrm{x}$ & $\mathrm{x}$ & $\mathrm{x}$ & $\mathrm{x}$ & $\mathrm{x}$ & $x$ & $x$ & $x$ & $\mathrm{x}$ & $x$ & $\mathrm{x}$ & $\mathrm{x}$ & $x$ & 5 \\
\hline TC 2 & Conj A & 52 & 0 & 0 & 0 & 0 & $3 y 4$ & 3y4 & 6.0 & 4.8 & 1 & 0 & $\mathrm{x}$ & $\mathrm{x}$ & 2.5YR 4/4 & 2.5YR 4/4 & $\mathrm{x}$ & $\mathrm{x}$ & $\mathrm{x}$ & $\mathrm{x}$ & $\mathrm{x}$ & $\mathrm{x}$ & $\mathrm{x}$ & $\mathrm{x}$ & $\mathrm{x}$ & $\mathrm{x}$ & $\mathrm{x}$ & $\mathrm{x}$ & $\mathrm{x}$ & $\mathrm{x}$ & \\
\hline TC 2 & Conj A & 53 & 0 & 0 & 0 & 0 & $3 y 4$ & 2 & 5.7 & 5.0 & 1 & 0 & $x$ & $x$ & 5YR 3/1 & 2.5 YR $5 / 6$ & $x$ & $x$ & $x$ & $x$ & $x$ & $x$ & $x$ & $x$ & $x$ & $\mathrm{x}$ & $x$ & $x$ & $x$ & $x$ & 3 \\
\hline TC 2 & Conj A & 54 & 0 & 0 & 0 & 0 & $3 y 4$ & 2 & 4.6 & 4.3 & 1 & 0 & $\mathrm{x}$ & $x$ & 10R $4 / 6$ & 10R $4 / 6$ & $\mathrm{x}$ & $\mathrm{x}$ & $x$ & $x$ & $x$ & $\mathrm{x}$ & $x$ & $x$ & $x$ & $x$ & $\mathrm{x}$ & $\mathrm{x}$ & $\mathrm{x}$ & $x$ & \\
\hline TC 2 & Conj A & 55 & 0 & 0 & 0 & 0 & $3 y 4$ & 2 & 6.6 & 6.3 & 1 & 0 & $x$ & $x$ & $2.5 Y R \quad 4 / 6$ & $2.5 Y R 5 / 6$ & $x$ & $x$ & $x$ & $x$ & $x$ & $x$ & $x$ & $x$ & $\mathrm{x}$ & $x$ & $x$ & $x$ & $x$ & $x$ & 4 \\
\hline TC 2 & Conj A & 56 & 0 & 0 & 0 & 0 & $3 y 4$ & 2 & 6.5 & 6.5 & 1 & 0 & $\mathrm{x}$ & $\mathrm{x}$ & 2.5 YR $4 / 6$ & $2.5 Y R 4 / 3$ & $x$ & $\mathrm{x}$ & $\mathrm{x}$ & $x$ & $x$ & $\mathrm{x}$ & $\mathrm{x}$ & $\mathrm{x}$ & $\mathrm{x}$ & $\mathrm{x}$ & $\mathrm{x}$ & $\mathrm{x}$ & $\mathrm{x}$ & $x$ & \\
\hline TC 2 & Conj A & 57 & 1 & 0 & 1 & 1 & 11 & 11 & 9.8 & 6.4 & 1 & 0 & $x$ & Poshisp & 10YR 7/3; 5G 7/ & 10YR 7/3 & indet & 3.3 & indet & $\begin{array}{ll}t & 1 \\
\end{array}$ & $1 \mathrm{y} 6$ & $x$ & $x$ & $x$ & $x$ & $x$ & $x$ & $x$ & $x$ & $x$ & 3 \\
\hline TC 2 & Conj A & 58 & 0 & 0 & 0 & 0 & 11 & 11 & 3.7 & 3.4 & 1 & 0 & $x$ & Poshisp & 5GY8/; 2.5YR5/4 & $2.5 Y R$ 5/4 & $x$ & $x$ & $x$ & $x$ & $x$ & $x$ & $x$ & $x$ & $x$ & $x$ & $x$ & $x$ & $x$ & $x$ & \\
\hline TC 2 & Conj A & 59 & 1 & 0 & 2 & 2 & 2 & 2 & 7.0 & 5.8 & 0 & 0 & $x$ & $x$ & N3/; 7.5YR 5/3 & $5 Y R \quad 4 / 2,5 / 4$ & 19.4 & 8.5 & 14 & 1 & 2 & $x$ & $x$ & $x$ & $x$ & $x$ & $x$ & $x$ & $x$ & $x$ & 1 у 2 \\
\hline TC 2 & Conj A & 60 & 1 & 0 & 1 & 0 & 2 & 2 & 8.6 & 7.8 & 0 & 0 & $x$ & $x$ & $2.5 Y R$ 5/4, 5/6 & $2.5 Y R 5 / 4,5 / 6$ & indet & 2.8 & indet & $\begin{array}{ll}t & 2 \\
\end{array}$ & 2 & $x$ & $x$ & $x$ & $x$ & $x$ & $x$ & $x$ & $x$ & $x$ & 1 y 3 \\
\hline TC 2 & Conj A & 61 & 1 & 0 & 2 & 1 & 2 & 2 & 7.3 & 5.5 & 0 & 0 & $\mathrm{x}$ & $x$ & N3/, 4/ & 5YR 5/4 & indet & 2.1 & indet & $\begin{array}{ll}t & 1\end{array}$ & 2 & $\mathrm{x}$ & $x$ & $x$ & $x$ & $x$ & $x$ & $x$ & $x$ & $x$ & \\
\hline TC 2 & Conj A & 62 & 1 & 0 & 2 & 0 & 2 & 2 & 7.2 & 6.0 & 0 & 0 & $x$ & $x$ & 5YR 5/4 & 5YR 5/4 & indet & 2.3 & indet & $\begin{array}{ll}t & 1 \\
\end{array}$ & 2 & $\mathrm{x}$ & $x$ & $x$ & $x$ & $x$ & $x$ & $x$ & $x$ & $x$ & \\
\hline TC 2 & Conj A & 63 & 1 & 0 & 0 & 0 & 2 & 2 & 7.4 & 6.0 & 0 & 0 & $x$ & $x$ & $5 Y R \quad 4 / 3$ & 5YR 5/4 & indet & 1.5 & indet & $\begin{array}{ll}t & 1 \\
\end{array}$ & 1 & $x$ & $x$ & $x$ & $x$ & $x$ & $x$ & $x$ & $x$ & $x$ & \\
\hline TC 2 & Conj A & 64 & 1 & 0 & 0 & 0 & 2 & 2 & 8.1 & 7.0 & 0 & 0 & $\mathrm{x}$ & $\mathrm{x}$ & $5 Y R$ 5/2, 5/4 & $2.5 Y R \quad 4 / 1,4 / 4$ & indet & 2.6 & indet & $t \mid \begin{array}{ll}t & 1\end{array}$ & 2 & $\mathrm{x}$ & $\mathrm{x}$ & $\mathrm{x}$ & $\mathrm{x}$ & $\mathrm{x}$ & $\mathrm{x}$ & $\mathrm{x}$ & $\mathrm{x}$ & $x$ & 4 \\
\hline TC 2 & Conj A & 65 & 1 & 0 & 0 & 0 & 2 & 2 & 6.5 & 6.0 & 0 & 0 & $x$ & $x$ & 5YR 5/6 & 5YR 5/6 & indet & 2.1 & indet & $\begin{array}{ll}t & 1 \\
\end{array}$ & 2 & $\mathrm{x}$ & $x$ & $x$ & $x$ & $x$ & $x$ & $x$ & $x$ & $x$ & \\
\hline TC 2 & Conj A & 66 & 1 & 0 & 0 & 0 & 2 & 2 & 7.4 & 5.6 & 0 & 1 & $x$ & $x$ & 5YR 4/1 & 5YR 3/1 & indet & 1.9 & indet & $\begin{array}{ll}t & 1 \\
\end{array}$ & 2 & $x$ & $x$ & $x$ & $x$ & $x$ & $x$ & $x$ & $x$ & $x$ & 3 \\
\hline TC 2 & Conj A & 67 & 4 & 0 & 2 & 1 & 2 & 2 & 12.3 & 9.5 & 0 & 0 & $\mathrm{x}$ & $\mathrm{x}$ & 2.5 YR $5 / 3,5 / 6,4 / 1$ & $2.5 Y R$ 5/6 & $\mathrm{x}$ & $\mathrm{x}$ & $\mathrm{x}$ & $\mathrm{x}$ & $x$ & $\mathrm{x}$ & $\mathrm{x}$ & $\mathrm{x}$ & $\mathrm{x}$ & $\mathrm{x}$ & $\mathrm{x}$ & $\mathrm{x}$ & $\mathrm{x}$ & $x$ & 3 \\
\hline TC 2 & Conj A & 68 & 2 & 0 & 0 & 6 & 2 & 2 & 14.6 & 7.3 & 0 & 0 & $\mathrm{x}$ & $\mathrm{x}$ & 7.5YR5/3,5/4;2.5YR5/4 & 7.5YR 5/3, 5/4 & $\mathrm{x}$ & $\mathrm{x}$ & $\mathrm{x}$ & $\mathrm{x}$ & $\mathrm{x}$ & $\mathrm{x}$ & $\mathrm{x}$ & $\mathrm{x}$ & $\mathrm{x}$ & $\mathrm{x}$ & $\mathrm{x}$ & 11.9 & \begin{tabular}{l|l}
9 & 1 \\
\end{tabular} & 2 & \\
\hline TC 2 & Conj A & 69 & 2 & 0 & 0 & 0 & 2 & 2 & 11.5 & 10.0 & 0 & 0 & $\mathrm{x}$ & $\mathrm{x}$ & $2.5 Y R \quad 4 / 3,4 / 4$ & $2.5 Y R 5 / 3,5 / 4$ & $\mathrm{x}$ & $\mathrm{x}$ & $\mathrm{x}$ & $\mathrm{x}$ & $x$ & $\mathrm{x}$ & $\mathrm{x}$ & $\mathrm{x}$ & $\mathrm{x}$ & $\mathrm{x}$ & $\mathrm{x}$ & 8.2 & 1 & 2 & 3 \\
\hline TC 2 & Conj A & 70 & 3 & 0 & 0 & 0 & 2 & 0 & $8 \mathrm{fr}$ & $8 \mathrm{fr}$ & 0 & 0 & $\mathrm{x}$ & $\mathrm{x}$ & $5 Y R 5 / 3,5 / 4$ & $\mathrm{x}$ & $\mathrm{x}$ & $\mathrm{x}$ & $\mathrm{x}$ & $\mathrm{x}$ & $x$ & $4,1 \mathrm{fr}$ & 2.6 & 19 & 2 & 3 & 0 & $\mathrm{x}$ & $\mathrm{x}$ & $x$ & 3 \\
\hline TC 2 & Conj A & 71 & 3 & 0 & 0 & 1 & 2 & 0 & 9 & 8.8 & 0 & 0 & $x$ & $x$ & $2.5 Y R$ 5/6, 4/6, 4/2 & $x$ & $x$ & $x$ & $x$ & $x$ & $x$ & $3,8 \mathrm{fr}$ & \begin{tabular}{|l|}
2.6 \\
\end{tabular} & 9 & 4 & 0 & 0 & $x$ & $x$ & $x$ & \\
\hline TC 2 & Conj A & 72 & 3 & 0 & 0 & 0 & 2 & 2 & 8.8 & 6 & 0 & 0 & $\mathrm{x}$ & $x$ & $5 Y R$ 6/4, 5/4 & $5 Y R 6 / 6$ & $\mathrm{x}$ & $\mathrm{x}$ & $\mathrm{x}$ & $\mathrm{x}$ & $x$ & $1 \mathrm{fr}$ & $2.4 \mathrm{fr}$ & \begin{tabular}{l|l} 
& 8
\end{tabular} & 4 & 1 & 0 & $\mathrm{x}$ & $\mathrm{x}$ & $x$ & 3 \\
\hline TC 2 & Conj A & 73 & 3 & 0 & 0 & 0 & 2 & 0 & 6 & 5.2 & 0 & 0 & $x$ & $x$ & $5 Y R \quad 4 / 4,4 / 2$ & $\mathrm{x}$ & $\mathrm{x}$ & $\mathrm{x}$ & $\mathrm{x}$ & $\mathrm{x}$ & $x$ & $1,9 \mathrm{fr}$ & 2.5 & 5 & 3 & 0 & 0 & $\mathrm{x}$ & $\mathrm{x}$ & $x$ & \\
\hline TC 2 & Conj A & 74 & 0 & 0 & 0 & 0 & 2 & 2 & 7.7 & 6.7 & 0 & 0 & $x$ & $x$ & $5 Y R$ 4/2, 4/1 & 5YR 5/4 & $x$ & $x$ & $x$ & $x$ & $x$ & $x$ & $x$ & $x$ & $x$ & $x$ & $x$ & $x$ & $x$ & $x$ & 1 \\
\hline TC 2 & Conj A & 75 & 0 & 1 & 0 & 6 & 2 & 2 & 9.5 & 7.7 & 0 & 0 & $\mathrm{x}$ & $\mathrm{x}$ & $5 Y R 5 / 3,5 / 4$ & $5 Y R$ 5/4 & $\mathrm{x}$ & $\mathrm{x}$ & $\mathrm{x}$ & $\mathrm{x}$ & $x$ & $\mathrm{x}$ & $\mathrm{x}$ & $\mathrm{x}$ & $\mathrm{x}$ & $x$ & $\mathrm{x}$ & $\mathrm{x}$ & $\mathrm{x}$ & $x$ & \\
\hline TC 2 & Conj A & 76 & 0 & 0 & 0 & 0 & 2 & 2 & 9.6 & 7.4 & 0 & 0 & $x$ & $x$ & 2,5YR 5/6 & 2,5YR 6/8 & $x$ & $x$ & $x$ & $x$ & $x$ & $x$ & $x$ & $x$ & $x$ & $x$ & $x$ & $x$ & $x$ & $x$ & 3 \\
\hline TC 2 & Conj A & 77 & 0 & 0 & 0 & 0 & 2 & 2 & 9.1 & 5.7 & 0 & 0 & $\mathrm{x}$ & $x$ & 7,5 YR $5 / 2,5 / 3$ & 7,5 YR $5 / 3$ & $x$ & $\mathrm{x}$ & $\mathrm{x}$ & $\mathrm{x}$ & $x$ & $\mathrm{x}$ & $\mathrm{x}$ & $x$ & $\mathrm{x}$ & $x$ & $\mathrm{x}$ & $x$ & $\mathrm{x}$ & $x$ & \\
\hline TC 2 & Conj A & 78 & 0 & 0 & 0 & 0 & 2 & 2 & 9.5 & 8.1 & 0 & 0 & $x$ & $x$ & 5YR 5/4 & 2,5 YR 5/6 & $x$ & $x$ & $x$ & $x$ & $x$ & $x$ & $x$ & $x$ & $x$ & $x$ & $x$ & $x$ & $x$ & $x$ & 3 \\
\hline TC 2 & Conj A & 79 & 0 & 0 & 0 & 0 & 2 & 2 & 10.2 & 6.9 & 0 & 0 & $x$ & $x$ & $2.5 Y R$ 5/6, 3/1 & $2.5 Y R$ 5/6 & $x$ & $x$ & $x$ & $x$ & $x$ & $x$ & $x$ & $x$ & $x$ & $x$ & $x$ & $x$ & $x$ & $x$ & 1 y 3 \\
\hline TC 2 & Conj A & 80 & 0 & 0 & 0 & 0 & 2 & 2 & 12.0 & 9.9 & 0 & 0 & $\mathrm{x}$ & $\mathrm{x}$ & $2.5 Y R$ 5/6 & $2.5 Y R$ 5/1 & $\mathrm{x}$ & $\mathrm{x}$ & $\mathrm{x}$ & $\mathrm{x}$ & $x$ & $\mathrm{x}$ & $\mathrm{x}$ & $\mathrm{x}$ & $\mathrm{x}$ & $\mathrm{x}$ & $\mathrm{x}$ & $\mathrm{x}$ & $\mathrm{x}$ & $x$ & 3 \\
\hline TC 2 & Conj A & 81 & 0 & 0 & 0 & 0 & 2 & 2 & 7.7 & 6.5 & 0 & 0 & $x$ & Yavi & $2.5 Y R$ 5/3, 5/4 & $2.5 Y R$ 5/2 & $x$ & $x$ & $x$ & $x$ & $x$ & $x$ & $x$ & $x$ & $x$ & $x$ & $x$ & $x$ & $x$ & $x$ & \\
\hline TC 2 & Conj A & 82 & 0 & 0 & 0 & 0 & 2 & 2 & 9.5 & 6.9 & 0 & 0 & $x$ & Yavi & $2.5 Y R$ 5/6 & $2.5 Y R$ G/6 & $x$ & $x$ & $x$ & $x$ & $x$ & $x$ & $x$ & $x$ & $x$ & $x$ & $x$ & $x$ & $x$ & $x$ & \\
\hline TC 2 & Conj A & 83 & 0 & 0 & 0 & 0 & 2 & 2 & 7.0 & 5.2 & 0 & 0 & $\mathrm{x}$ & $x$ & 2.5 YR 5/6 & 5YR 5/6 & $x$ & $\mathrm{x}$ & $\mathrm{x}$ & $x$ & $x$ & $\mathrm{x}$ & $x$ & $x$ & $x$ & $\mathrm{x}$ & $\mathrm{x}$ & $x$ & $x$ & $x$ & \\
\hline TC 2 & Conj A & 84 & 0 & 0 & 0 & 0 & 2 & 2 & 10.5 & 7.5 & 0 & 0 & $x$ & $x$ & $2.5 Y R 5 / 6$ & 5YR 5/1 & $x$ & $x$ & $x$ & $x$ & $x$ & $x$ & $x$ & $x$ & $x$ & $x$ & $x$ & $x$ & $x$ & $x$ & 3 \\
\hline TC 2 & Conj A & 85 & 0 & 0 & 0 & 0 & 2 & 2 & 7.3 & 7.3 & 0 & 0 & $x$ & $x$ & 2.5 YR $4 / 4$ & 2.5 YR $5 / 6$ & $x$ & $x$ & $\mathrm{x}$ & $x$ & $x$ & $x$ & $x$ & $x$ & $x$ & $x$ & $x$ & $x$ & $x$ & $x$ & 3 у 4 \\
\hline TC 2 & Conj A & 86 & 0 & 0 & 0 & 0 & 2 & 2 & 7.9 & 7.0 & 0 & 0 & $x$ & $x$ & $5 Y R$ 5/3 & $2.5 Y R$ 5/6 & $x$ & $x$ & $x$ & $x$ & $x$ & $x$ & $x$ & $x$ & $x$ & $x$ & $x$ & $x$ & $x$ & $x$ & \\
\hline TC 2 & Conj A & 87 & 0 & 0 & 0 & 0 & 2 & 2 & 7.5 & 6.2 & 0 & 0 & $x$ & $x$ & $5 Y R \quad 4 / 2$ & $2.5 Y R$ 5/7 & $x$ & $x$ & $x$ & $x$ & $x$ & $x$ & $x$ & $x$ & $x$ & $x$ & $x$ & $x$ & $x$ & $x$ & \\
\hline TC 2 & Conj A & 88 & 0 & 0 & 0 & 0 & 2 & 2 & 7.1 & 5.7 & 0 & 0 & $x$ & $\mathrm{x}$ & $5 Y R$ 4/3 & $5 Y R$ 5/4 & $x$ & $\mathrm{x}$ & $x$ & $x$ & $x$ & $\mathrm{x}$ & $\mathrm{x}$ & $\mathrm{x}$ & $\mathrm{x}$ & $x$ & $\mathrm{x}$ & $\mathrm{x}$ & $\mathrm{x}$ & $x$ & \\
\hline TC 2 & Conj A & 89 & 0 & 0 & 0 & 0 & 2 & 0 & 8.6 & 7.0 & 0 & 0 & $x$ & $x$ & $5 Y R \quad 4 / 3$ & 5YR 5/3 & $x$ & $x$ & $x$ & $x$ & $x$ & $x$ & $x$ & $x$ & $x$ & $x$ & $x$ & $x$ & $\mathrm{x}$ & $x$ & 3 y 4 \\
\hline TC 2 & Conj A & 90 & 0 & 0 & 0 & 0 & 2 & 2 & 7.2 & 5.7 & 0 & 0 & $x$ & $x$ & $5 Y R$ 5/4, 4/4 & $5 Y R 4 / 3$ & $x$ & $x$ & $x$ & $x$ & $x$ & $x$ & $x$ & $x$ & $x$ & $x$ & $x$ & $x$ & $x$ & $x$ & \\
\hline TC 2 & Conj A & 91 & 0 & 0 & 0 & 0 & 2 & 1 & 8.0 & 6.2 & 0 & 0 & $\mathrm{x}$ & $x$ & $5 Y R \quad 4 / 1,4 / 2$ & 5YR 5/6 & $\mathrm{x}$ & $\mathrm{x}$ & $\mathrm{x}$ & $x$ & $x$ & $\mathrm{x}$ & $\mathrm{x}$ & $\mathrm{x}$ & $\mathrm{x}$ & $\mathrm{x}$ & $\mathrm{x}$ & $x$ & $\mathrm{x}$ & $x$ & 3 \\
\hline
\end{tabular}




\begin{tabular}{|c|c|c|c|c|c|c|c|c|c|c|c|c|c|c|c|c|c|c|c|c|c|c|c|c|c|c|c|c|c|c|c|}
\hline \multirow[b]{2}{*}{ Sitio } & \multirow[b]{2}{*}{ UP } & \multirow[b]{2}{*}{$\mathrm{FN}^{\circ}$} & \multirow[b]{2}{*}{ Fgto } & \multicolumn{11}{|c|}{ Manufactura } & \multicolumn{2}{|c|}{ Cocción } & \multicolumn{5}{|c|}{ Borde-labio } & \multicolumn{6}{|c|}{ Asa } & \multicolumn{3}{|c|}{ Base } & \multirow[b]{2}{*}{ Alterac } \\
\hline & & & & \begin{tabular}{|l|} 
Tec \\
lev
\end{tabular} & \begin{tabular}{|c|} 
For \\
ma
\end{tabular} & $\begin{array}{l}\text { Mar } \\
\text { cas }\end{array}$ & \begin{tabular}{|l|} 
Sup \\
ext
\end{tabular} & $\begin{array}{c}\text { Sup } \\
\text { int }\end{array}$ & $\begin{array}{l}\mid \begin{array}{l}\text { Esp } \\
\max \end{array} \\
\end{array}$ & \begin{tabular}{|l|}
$\begin{array}{c}\text { Esp } \\
\text { min }\end{array}$ \\
\end{tabular} & $\begin{array}{l}\text { Deco } \\
\text { pint }\end{array}$ & \begin{tabular}{|l|} 
Deco \\
agreg
\end{tabular} & \begin{tabular}{|c|}
$\begin{array}{c}\text { Moti } \\
\text { vo }\end{array}$ \\
\end{tabular} & Estilo & Color sup ext & Color sup int & Diam & \begin{tabular}{|l|} 
Lrg \\
arc
\end{tabular} & \begin{tabular}{|c|}
$\%$ \\
arco \\
\end{tabular} & Direc & $\begin{array}{l}\begin{array}{l}\text { For } \\
\text { ma }\end{array} \\
\end{array}$ & $\begin{array}{l}\text { Lar } \\
\text { go }\end{array}$ & $\begin{array}{c}\text { An } \\
\text { cho }\end{array}$ & Esp & $\begin{array}{l}\text { Sec } \\
\text { ción }\end{array}$ & $\begin{array}{c}\text { In } \\
\text { serc }\end{array}$ & $\begin{array}{l}\text { Posi } \\
\text { ción } \\
\end{array}$ & Diám & $\begin{array}{c}\begin{array}{c}\text { Mor } \\
\text { fol }\end{array} \\
\end{array}$ & $\begin{array}{l}\text { Uni } \\
\text { ón }\end{array}$ & \\
\hline TC 2 & Conj A & 92 & 0 & 0 & 0 & 0 & 2 & 2 & 5.7 & 4.6 & 0 & 0 & $\mathrm{x}$ & Yavi & 2.5 YR 5/6 & $2.5 Y R$ 6/6 & $\mathrm{x}$ & $x$ & $\mathrm{x}$ & $\mathrm{x}$ & $\mathrm{x}$ & $\mathrm{x}$ & $\mathrm{x}$ & $\mathrm{x}$ & $\mathrm{x}$ & $\mathrm{x}$ & $\mathrm{x}$ & $\mathrm{x}$ & $x$ & $\mathrm{x}$ & \\
\hline TC 2 & Conj A & 93 & 0 & 0 & 0 & 0 & 0 & 2 & 8.5 & 8.0 & 0 & 0 & $\mathrm{x}$ & $\mathrm{x}$ & $5 Y R 4 / 3$ & 5YR 5/3 & $\mathrm{x}$ & $x$ & $\mathrm{x}$ & $\mathrm{x}$ & $\mathrm{x}$ & $\mathrm{x}$ & $\mathrm{x}$ & $\mathrm{x}$ & $\mathrm{x}$ & $\mathrm{x}$ & $\mathrm{x}$ & $\mathrm{x}$ & $x$ & $x$ & 3 y 4 \\
\hline TC 2 & Conj A & 94 & 0 & 0 & 0 & 0 & 2 & 2 & 5.9 & 4.0 & 0 & 0 & $x$ & $x$ & 5YR 3/1 & $5 Y R 4 / 4$ & $x$ & $x$ & $x$ & $x$ & $x$ & $x$ & $x$ & $x$ & $x$ & $x$ & $x$ & $x$ & $x$ & $x$ & \\
\hline TC 2 & Conj A & 95 & 0 & 0 & 0 & 0 & 2 & 2 & 7.5 & 6.6 & 0 & 0 & $\mathrm{x}$ & $x$ & $5 Y R$ 5/3, N3/ & 5YR 6/4 & $\mathrm{x}$ & $x$ & $x$ & $x$ & $\mathrm{x}$ & $\mathrm{x}$ & $\mathrm{x}$ & $x$ & $x$ & $\mathrm{x}$ & $\mathrm{x}$ & $x$ & $\mathrm{x}$ & $\mathrm{x}$ & 3 \\
\hline TC 2 & Conj $\mathrm{A}$ & 96 & 2 & 0 & 0 & 0 & 2 & 2 & 9.0 & 7.5 & 0 & 0 & $x$ & $\mathrm{x}$ & 2.5 YR $4 / 3$ & 5YR 5/3 & $x$ & $x$ & $\mathrm{x}$ & $x$ & $\mathrm{x}$ & $\mathrm{x}$ & $\mathrm{x}$ & $x$ & $x$ & $\mathrm{x}$ & $\mathrm{x}$ & indet & 5 & 2 & 3 \\
\hline TC 2 & Conj A & 97 & 0 & 0 & 0 & 0 & 2 & 2 & 8.0 & 8.0 & 0 & 0 & $x$ & $x$ & $5 Y R \quad 4 / 3$ & $5 Y R 5 / 4$ & $x$ & $\mathrm{x}$ & $x$ & $x$ & $x$ & $x$ & $x$ & $x$ & $x$ & $x$ & $x$ & $x$ & $x$ & $x$ & 3 \\
\hline TC 2 & Conj A & 98 & 0 & 0 & 0 & 1 & $2 \mathrm{y} 6$ & 2 & 6.0 & 5.1 & 1 & 0 & $x$ & $x$ & 10R 4/6, 7,5YR 5/3 & 7,5YR 6/4 & $x$ & $x$ & $x$ & $x$ & $x$ & $x$ & $x$ & $x$ & $x$ & $x$ & $x$ & $x$ & $x$ & $\mathrm{x}$ & 5 \\
\hline TC 2 & Conj $\mathrm{A}$ & 99 & 0 & 0 & 0 & 0 & 2 & 2 & 6.7 & 6.0 & 0 & 0 & $x$ & $x$ & $5 Y R$ 5/3 & 5YR 5/2 & $x$ & $x$ & $x$ & $x$ & $x$ & $x$ & $x$ & $x$ & $x$ & $x$ & $x$ & $x$ & $x$ & $x$ & 3 \\
\hline TC 2 & Conj A & 100 & 0 & 0 & 0 & 0 & 2 & 2 & 9.5 & 8.0 & 0 & 0 & $x$ & $x$ & 2,5 YR 5/6, 6/6 & $5 Y R$ 5/4 & $x$ & $x$ & $x$ & $x$ & $x$ & $x$ & $x$ & $x$ & $x$ & $x$ & $x$ & $x$ & $x$ & $x$ & 3 \\
\hline TC 2 & Conj A & 101 & 0 & 0 & 0 & 0 & 2 & 2 & 8.7 & 8.0 & 0 & 0 & $x$ & $x$ & 2,5YR 5/1 & 2,5 YR $6 / 6$ & $x$ & $x$ & $x$ & $x$ & $x$ & $x$ & $x$ & $x$ & $x$ & $x$ & $x$ & $x$ & $x$ & $x$ & 3 y 4 \\
\hline TC 2 & Conj A & 102 & 0 & 0 & 0 & 0 & 2 & 2 & 6.5 & 5.0 & 0 & 0 & $x$ & $x$ & 2,5 YR 5/6 & 2,5YR 6/7 & $x$ & $x$ & $x$ & $x$ & $x$ & $x$ & $x$ & $x$ & $x$ & $x$ & $x$ & $x$ & $x$ & $\mathrm{x}$ & \\
\hline TC 2 & Conj A & 103 & 0 & 0 & 0 & 0 & 2 & 2 & 8.9 & 8.6 & 0 & 0 & $\mathrm{x}$ & $\mathrm{x}$ & /R 5/6 & 5YR 5/6 & $\mathrm{x}$ & $x$ & $\mathrm{x}$ & $\mathrm{x}$ & $\mathrm{x}$ & $\mathrm{x}$ & $\mathrm{x}$ & $\mathrm{x}$ & $x$ & $\mathrm{x}$ & $\mathrm{x}$ & $x$ & $x$ & $\mathrm{x}$ & 3 \\
\hline TC 2 & Conj A & 104 & 0 & 0 & 0 & 0 & 2 & 2 & 8.0 & 8.0 & 0 & 0 & $x$ & $x$ & $2,5 Y R$ 5/6 & $2,5 Y R$ 5/6 & $x$ & $x$ & $x$ & $x$ & $x$ & $x$ & $x$ & $x$ & $x$ & $x$ & $x$ & $x$ & $x$ & $x$ & 3 y 4 \\
\hline TC 2 & Conj A & 105 & 0 & 0 & 0 & 0 & 2 & 2 & 6.6 & 5.8 & 0 & 0 & $\mathrm{x}$ & $x$ & 2,5YR 5/4 & 2,5YR 5/6 & $\mathrm{x}$ & $x$ & $\mathrm{x}$ & $\mathrm{x}$ & $\mathrm{x}$ & $\mathrm{x}$ & $\mathrm{x}$ & $\mathrm{x}$ & $x$ & $\mathrm{x}$ & $\mathrm{x}$ & $\mathrm{x}$ & $x$ & $\mathrm{x}$ & \\
\hline TC 2 & Conj A & 106 & 0 & 0 & 0 & 0 & 2 & 2 & 5.1 & 5.0 & 0 & 0 & $\mathrm{x}$ & $x$ & 2,5 YR $5 / 4$ & 2,5YR 5/6 & $x$ & $x$ & $x$ & $x$ & $x$ & $x$ & $x$ & $x$ & $x$ & $\mathrm{x}$ & $x$ & $x$ & $x$ & $\mathrm{x}$ & \\
\hline TC 2 & Conj A & 107 & 0 & 0 & 0 & 0 & 2 & 2 & 5.7 & 5.0 & 0 & 0 & $x$ & $x$ & $2,5 Y R$ 5/3, 5/4, 4/1 & $2,5 Y R$ 5/6 & $x$ & $x$ & $x$ & $x$ & $x$ & $\mathrm{x}$ & $x$ & $x$ & $x$ & $x$ & $x$ & $x$ & $x$ & $x$ & \\
\hline TC 2 & Conj A & 108 & 0 & 0 & 0 & 0 & 2 & 2 & 8.2 & 7.3 & 0 & 0 & $x$ & $x$ & 7,5 YR 4/2 & 5YR 5/4 & $x$ & $x$ & $x$ & $x$ & $x$ & $x$ & $x$ & $x$ & $\mathrm{x}$ & $x$ & $\mathrm{x}$ & $x$ & $x$ & $x$ & \\
\hline TC 2 & Conj A & 109 & 0 & 0 & 0 & 0 & 2 & 2 & 6.0 & 5.6 & 0 & 0 & $x$ & $x$ & 5YR 5/4 & 5YR 5/4 & $x$ & $x$ & $x$ & $x$ & $x$ & $x$ & $x$ & $x$ & $x$ & $x$ & $x$ & $x$ & $x$ & $x$ & \\
\hline TC 2 & Conj A & 110 & 0 & 0 & 0 & 0 & 2 & 2 & 6.5 & 5.4 & 0 & 0 & $x$ & $x$ & $5 Y R$ 5/4, 4/1 & $5 Y R$ 5/3 & $x$ & $x$ & $x$ & $x$ & $x$ & $x$ & $x$ & $x$ & $x$ & $x$ & $x$ & $x$ & $x$ & $x$ & 1 \\
\hline TC 2 & Conj A & 111 & 0 & 0 & 0 & 0 & 2 & 2 & 10.3 & 9.0 & 0 & 0 & $\mathrm{x}$ & $x$ & 5YR 5/4 & 5YR 4/4 & $\mathrm{x}$ & $x$ & $\mathrm{x}$ & $x$ & $x$ & $\mathrm{x}$ & $\mathrm{x}$ & $x$ & $x$ & $\mathrm{x}$ & $\mathrm{x}$ & $x$ & $x$ & $\mathrm{x}$ & 3 \\
\hline TC 2 & Conj A & 112 & 0 & 0 & 0 & 0 & 2 & 2 & 6.7 & 5.8 & 0 & 0 & $x$ & $x$ & 2,5 YR 5/6 & 2,5 YR 4/3 & $x$ & $x$ & $x$ & $x$ & $x$ & $x$ & $x$ & $x$ & $x$ & $x$ & $x$ & $x$ & $x$ & $x$ & \\
\hline TC 2 & Conj A & 113 & 1 & 0 & 0 & 0 & 2 & 2 & 8.4 & 5.5 & 0 & 0 & $x$ & $x$ & $2,5 Y R$ 4/4 & 2,5YR 5/6 & indet & 1 & indet & $\begin{array}{l}\mathrm{t} \\
\end{array}$ & 2 & $x$ & $x$ & $x$ & $x$ & $x$ & $x$ & $x$ & $x$ & $x$ & 3 \\
\hline TC 2 & Conj A & 114 & 0 & 0 & 0 & 0 & 2 & 2 & 7.7 & 7.2 & 0 & 0 & $x$ & $x$ & 2,5YR 5/6 & 5YR 5/4 & $x$ & $x$ & $x$ & $x$ & $x$ & $x$ & $x$ & $x$ & $x$ & $x$ & $x$ & $x$ & $x$ & $x$ & 3 \\
\hline TC 2 & Conj $\mathrm{A}$ & 115 & 0 & 0 & 0 & 0 & 2 & 2 & 5.0 & 4.7 & 0 & 0 & $x$ & $x$ & $5 Y R \quad 4 / 2,5 / 4$ & $5 Y R \quad 4 / 4,5 / 4$ & $x$ & $x$ & $x$ & $x$ & $x$ & $x$ & $x$ & $x$ & $x$ & $x$ & $x$ & $x$ & $x$ & $x$ & \\
\hline TC 2 & Conj A & 116 & 0 & 0 & 0 & 0 & 2 & 2 & 7.5 & 7.0 & 0 & 0 & $x$ & $x$ & 2,5 YR 4/2 & 2,5YR 5/4 & $x$ & $x$ & $x$ & $x$ & $x$ & $x$ & $x$ & $x$ & $x$ & $x$ & $x$ & $x$ & $x$ & $x$ & 3 \\
\hline TC 2 & Conj A & 117 & 0 & 0 & 0 & 0 & 2 & 2 & 6.0 & 5.5 & 0 & 0 & $\mathrm{x}$ & $\mathrm{x}$ & 2,5YR 5/4 & 2,5YR 5/6 & $\mathrm{x}$ & $x$ & $\mathrm{x}$ & $\mathrm{x}$ & $\mathrm{x}$ & $\mathrm{x}$ & $\mathrm{x}$ & $\mathrm{x}$ & $\mathrm{x}$ & $\mathrm{x}$ & $\mathrm{x}$ & $\mathrm{x}$ & $x$ & $\mathrm{x}$ & \\
\hline TC 2 & Conj A & 118 & 0 & 0 & 0 & 0 & 2 & 2 & 7.8 & 6.7 & 0 & 0 & $x$ & $x$ & 5YR 5/3 & 2,5 YR 5/6 & $x$ & $x$ & $x$ & $x$ & $x$ & $x$ & $x$ & $x$ & $x$ & $x$ & $x$ & $x$ & $x$ & $x$ & 3 \\
\hline TC 2 & Conj A & 119 & 0 & 0 & 0 & 0 & 2 & 2 & 7.9 & 7.0 & 0 & 0 & $x$ & $x$ & 2,5YR 5/4 & 2,5YR 5/6 & $\mathrm{x}$ & $x$ & $x$ & $x$ & $x$ & $\mathrm{x}$ & $x$ & $x$ & $x$ & $\mathrm{x}$ & $x$ & $x$ & $\mathrm{x}$ & $x$ & 3 \\
\hline TC 2 & Conj A & 120 & 0 & 0 & 0 & 0 & 2 & 2 & 8.5 & 7.9 & 0 & 0 & $\mathrm{x}$ & $x$ & 2,5YR 5/6 & 2,5YR 5/6 & $\mathrm{x}$ & $x$ & $\mathrm{x}$ & $x$ & $x$ & $x$ & $x$ & $x$ & $x$ & $\mathrm{x}$ & $\mathrm{x}$ & $x$ & $x$ & $x$ & 3 \\
\hline TC 2 & Conj A & 121 & 0 & 0 & 0 & 0 & 2 & 2 & 5.3 & 5.1 & 0 & 0 & $x$ & $x$ & 2,5 YR 5/4 & 2,5YR 5/4 & $x$ & $x$ & $x$ & $x$ & $x$ & $x$ & $x$ & $x$ & $x$ & $x$ & $x$ & $x$ & $x$ & $x$ & 3 \\
\hline TC 2 & Conj A & 122 & 0 & 0 & 0 & 0 & 2 & 2 & 6.3 & 5.4 & 0 & 0 & $x$ & $x$ & 2,5 YR 5/6 & $2,5 Y R$ 5/6 & $x$ & $x$ & $x$ & $x$ & $x$ & $x$ & $x$ & $x$ & $x$ & $x$ & $x$ & $x$ & $x$ & $x$ & \\
\hline TC 2 & Conj A & 123 & 0 & 0 & 0 & 1 & 2 & 2 & 3.8 & 3.5 & 0 & 0 & $x$ & $x$ & $5 Y R$ 5/1, 6/3 & $5 Y R 6 / 3$ & $x$ & $x$ & $x$ & $x$ & $x$ & $x$ & $x$ & $x$ & $x$ & $x$ & $x$ & $x$ & $x$ & $x$ & \\
\hline TC 2 & Conj A & 124 & 0 & 0 & 0 & 0 & 2 & 2 & 7.2 & 5.9 & 0 & 0 & $x$ & $x$ & $5 Y R 5 / 3$ & $5 Y R$ 5/3 & $x$ & $x$ & $x$ & $x$ & $x$ & $x$ & $x$ & $x$ & $x$ & $x$ & $x$ & $x$ & $x$ & $x$ & \\
\hline TC 2 & Conj A & 125 & 0 & 0 & 0 & 0 & 2 & 2 & 5.9 & 5.1 & 0 & 0 & $x$ & $x$ & 2,5YR 5/6 & 2,5YR 5/6 & $x$ & $x$ & $x$ & $x$ & $x$ & $x$ & $x$ & $x$ & $x$ & $x$ & $x$ & $x$ & $x$ & $x$ & 3 \\
\hline TC 2 & Conj A & 126 & 0 & 0 & 0 & 0 & 2 & 2 & 4.5 & 3.8 & 0 & 0 & $x$ & $x$ & 2,5 YR 5/6 & $2,5 Y R$ 5/6 & $x$ & $x$ & $x$ & $x$ & $x$ & $x$ & $x$ & $x$ & $x$ & $x$ & $x$ & $x$ & $x$ & $x$ & \\
\hline TC 2 & Conj A & 127 & 0 & 0 & 0 & 0 & 2 & 2 & 5.7 & 5.6 & 0 & 0 & $\mathrm{x}$ & $\mathrm{x}$ & $\mathrm{N} 3 /$ & 2,5YR 5/4 & $\mathrm{x}$ & $x$ & $\mathrm{x}$ & $\mathrm{x}$ & $\mathrm{x}$ & $\mathrm{x}$ & $\mathrm{x}$ & $x$ & $\mathrm{x}$ & $\mathrm{x}$ & $\mathrm{x}$ & $\mathrm{x}$ & $\mathrm{x}$ & $\mathrm{x}$ & 3 \\
\hline TC 2 & Conj $\mathrm{A}$ & 128 & 0 & 0 & 0 & 0 & 2 & 2 & 6.0 & 5.8 & 0 & 0 & $x$ & $\mathrm{x}$ & 2,5YR 5/6 & 2,5YR 5/6 & $\mathrm{x}$ & $x$ & $x$ & $\mathrm{x}$ & $\mathrm{x}$ & $\mathrm{x}$ & $\mathrm{x}$ & $x$ & $\mathrm{x}$ & $x$ & $\mathrm{x}$ & $\mathrm{x}$ & $\mathrm{x}$ & $\mathrm{x}$ & 3 \\
\hline TC 2 & Conj A & 129 & 0 & 0 & 0 & 0 & 2 & 2 & 8.6 & 7.9 & 0 & 0 & $x$ & $x$ & $5 Y R$ 5/2, 6/3 & $5 Y R 6 / 4$ & $x$ & $x$ & $x$ & $x$ & $x$ & $x$ & $x$ & $x$ & $x$ & $x$ & $x$ & $x$ & $x$ & $x$ & 3 \\
\hline TC 2 & Conj A & 130 & 0 & 0 & 0 & 0 & 2 & 2 & 6.5 & 5.9 & 0 & 0 & $\mathrm{x}$ & $\mathrm{x}$ & 5YR 5/3 & 5YR 6/2 & $\mathrm{x}$ & $x$ & $\mathrm{x}$ & $\mathrm{x}$ & $\mathrm{x}$ & $\mathrm{x}$ & $\mathrm{x}$ & $\mathrm{x}$ & $\mathrm{x}$ & $\mathrm{x}$ & $\mathrm{x}$ & $\mathrm{x}$ & $x$ & $\mathrm{x}$ & \\
\hline TC 2 & Conj A & 131 & 0 & 0 & 0 & 0 & 2 & 2 & 7.1 & 6.9 & 0 & 0 & $x$ & $\mathrm{x}$ & $5 Y R 5 / 3,6 / 4$ & 2,5YR 5/6 & $x$ & $\mathrm{x}$ & $x$ & $x$ & $x$ & $\mathrm{x}$ & $\mathrm{x}$ & $x$ & $\mathrm{x}$ & $x$ & $\mathrm{x}$ & $\mathrm{x}$ & $\mathrm{x}$ & $\mathrm{x}$ & 3 \\
\hline TC 2 & Conj A & 132 & 0 & 0 & 0 & 0 & 2 & 2 & 5.0 & 4.7 & 0 & 0 & $x$ & $x$ & 5YR 4/3 & $5 Y R$ 5/3 & $\mathrm{x}$ & $x$ & $\mathrm{x}$ & $x$ & $x$ & $\mathrm{x}$ & $\mathrm{x}$ & $\mathrm{x}$ & $x$ & $\mathrm{x}$ & $\mathrm{x}$ & $x$ & $x$ & $x$ & \\
\hline
\end{tabular}




\begin{tabular}{|c|c|c|c|c|c|c|c|c|c|c|c|c|c|c|c|c|c|c|c|c|c|c|c|c|c|c|c|c|c|c|c|}
\hline \multirow[b]{2}{*}{ Sitio } & \multirow[b]{2}{*}{ UP } & \multirow[b]{2}{*}{$\mathrm{FN}^{\circ}$} & \multirow[b]{2}{*}{ Fgto } & \multicolumn{11}{|c|}{ Manufactura } & \multicolumn{2}{|c|}{ Cocción } & \multicolumn{5}{|c|}{ Borde-labio } & \multicolumn{6}{|c|}{ Asa } & \multicolumn{3}{|c|}{ Base } & \multirow[b]{2}{*}{ Alterac } \\
\hline & & & & $\begin{array}{l}\text { Tec } \\
\text { lev }\end{array}$ & $\begin{array}{l}\text { For } \\
\text { ma }\end{array}$ & $\begin{array}{l}\text { Mar } \\
\text { cas }\end{array}$ & $\begin{array}{c}\text { Sup } \\
\text { ext }\end{array}$ & \begin{tabular}{|c} 
Sup \\
int
\end{tabular} & $\begin{array}{l}\text { Esp } \\
\text { max }\end{array}$ & \begin{tabular}{|l|l|} 
& Esp \\
min
\end{tabular} & $\begin{array}{l}\text { Deco } \\
\text { pint }\end{array}$ & $\begin{array}{l}\text { Deco } \\
\text { agreg }\end{array}$ & \begin{tabular}{|c|} 
Moti \\
vo
\end{tabular} & Estilo & Color sup ext & Color sup int & Diam & $\begin{array}{l}\text { Lrg } \\
\text { arc }\end{array}$ & $\begin{array}{c}\% \\
\text { arco }\end{array}$ & Direc & $\begin{array}{l}\begin{array}{l}\text { For } \\
\text { ma }\end{array} \\
\end{array}$ & $\begin{array}{l}\text { Lar } \\
\text { go }\end{array}$ & $\begin{array}{c}\text { An } \\
\text { cho }\end{array}$ & Esp & $\begin{array}{l}\text { Sec } \\
\text { ción }\end{array}$ & $\begin{array}{l}\text { In } \\
\text { serc }\end{array}$ & $\begin{array}{l}\begin{array}{l}\text { Posi } \\
\text { ción }\end{array} \\
\end{array}$ & Diám & $n \begin{array}{l}\text { Mor } \\
\text { fol }\end{array}$ & $\begin{array}{l}\mid \begin{array}{l}\text { Uni } \\
\text { ín }\end{array} \\
\end{array}$ & \\
\hline TC 2 & Conj B & 133 & 1 & 0 & 1 & 2 & 3 & 3 & 5.7 & 5.0 & 0 & 0 & $\mathrm{x}$ & Yavi & $5 Y R$ 6/6 & 5YR 6/6 & 15.6 & 6.2 & 12.7 & 1 & 2 & $\mathrm{x}$ & $\mathrm{x}$ & $\mathrm{x}$ & $\mathrm{x}$ & $x$ & $\mathrm{x}$ & $\mathrm{x}$ & $x$ & $x$ & \\
\hline TC 2 & Conj B & 134 & 1 & 0 & 1 & 2 & 3 & 3 & 6.3 & 4.9 & 0 & 0 & $x$ & Yavi & 5YR 6/6 & 5YR 6/6 & 15.6 & 6.2 & 12.7 & 1 & 2 & $x$ & $x$ & $x$ & $x$ & $x$ & $x$ & $x$ & $x$ & $x$ & \\
\hline TC 2 & Conj B & 135 & 1 & 0 & 2 & 2 & $2 \mathrm{y} 4$ & $3 y 4$ & 7.0 & 6.3 & 1 & 0 & $x$ & $x$ & $10 \mathrm{R} 4 / 4,3 / 1$ & 10R $5 / 6,5 / 8$ & 13.5 & 3.6 & 8.5 & 1 & 2 & $x$ & $x$ & $x$ & $x$ & $x$ & $x$ & $x$ & $x$ & $x$ & 1 \\
\hline TC 2 & Conj B & 136 & 1 & 0 & 2 & $1 y^{2}$ & $2 \mathrm{y} 4$ & $3 y 4$ & 9.1 & 7.0 & 1 & 0 & $\mathrm{x}$ & $\mathrm{x}$ & 10R $5 / 4$ & 10R $5 / 6$ & indet & 3.5 & indet & $t \mid \begin{array}{ll}t & 1\end{array}$ & 1 & $\mathrm{x}$ & $\mathrm{x}$ & $\mathrm{x}$ & $\mathrm{x}$ & $\mathrm{x}$ & $\mathrm{x}$ & $\mathrm{x}$ & $\mathrm{x}$ & $\mathrm{x}$ & \\
\hline TC 2 & Conj B & 137 & 1 & 0 & 2 & 0 & 2 & $3 y 4$ & 8.6 & 5.5 & 1 & 0 & $\mathrm{x}$ & $\mathrm{x}$ & $5 Y R 5 / 3$ & 2,5YR 3/3 & 13.2 & 3.8 & 9.2 & 1 & $2 \mathrm{y} 6$ & $\mathrm{x}$ & $\mathrm{x}$ & $\mathrm{x}$ & $\mathrm{x}$ & $\mathrm{x}$ & $\mathrm{x}$ & $\mathrm{x}$ & $\mathrm{x}$ & $\mathrm{x}$ & 3 \\
\hline TC 2 & Conj B & 138 & 1 & 0 & 1 & 2 & $3 y 4$ & 3 & 7.0 & 5.0 & 1 & 1 & $\mathrm{x}$ & $\mathrm{x}$ & $2,5 Y R \quad 4 / 3,4 / 4$ & 5YR 6/4 & 15.5 & 4.3 & 8.8 & 2 & 2 & indet & \begin{tabular}{l|l|} 
& 1.9 \\
\end{tabular} & 12 & 2 & 1 & 2 & $\mathrm{x}$ & $x$ & $x$ & \\
\hline TC 2 & Conj B & 139 & 1 & 0 & 2 & 2 & $2 \mathrm{y} 4$ & $3 y 4$ & 6.5 & 4.7 & 1 & 0 & $\mathrm{x}$ & $\mathrm{x}$ & 2,5 YR 4/4 & 2,5 YR 4/4 & indet & 2.8 & indet & $\begin{array}{ll}t & 1 \\
\end{array}$ & 2 & $x$ & $x$ & $x$ & $x$ & $x$ & $x$ & $x$ & $x$ & $x$ & \\
\hline TC 2 & Conj B & 140 & 1 & 0 & 1 & 0 & $3 y 4$ & 2 & 6.6 & 5.3 & 1 & 2 & $\mathrm{x}$ & $\mathrm{x}$ & 2,5YR 4/4 & 2,5YR 5/6 & indet & 2.3 & indet & $\begin{array}{l}t \quad 1 \\
\end{array}$ & 2 & 1 & 0.6 & 0.15 & 50 & 1 & 1 & $\mathrm{x}$ & $\mathrm{x}$ & $x$ & 3 \\
\hline TC 2 & Conj B & 141 & 1 & 0 & 0 & 0 & $2 \mathrm{y} 4$ & $3 y 4$ & 5.8 & 4.6 & 1 & 0 & $\mathrm{x}$ & $x$ & 2,5YR 5/6 & 2,5YR 4/6 & indet & 1.9 & indet & $\begin{array}{l}\mathrm{t} \\
1\end{array}$ & 2 & $\mathrm{x}$ & $\mathrm{x}$ & $\mathrm{x}$ & $x$ & $\mathrm{x}$ & $\mathrm{x}$ & $x$ & $x$ & $x$ & \\
\hline TC 2 & Conj B & 142 & 1 & 0 & 0 & 0 & $2 \mathrm{y} 4$ & $3 y 4$ & 6.0 & 5.6 & 1 & 0 & $x$ & $x$ & 2,5 YR $4 / 3$ & 2,5 YR 4/6 & indet & 2.2 & indet & \begin{tabular}{l|l}
$t$ & 1 \\
\end{tabular} & 2 & $\mathrm{x}$ & $x$ & $x$ & $x$ & $\mathrm{x}$ & $x$ & $\mathrm{x}$ & $x$ & $x$ & \\
\hline TC 2 & Conj B & 143 & 1 & 0 & 0 & 0 & 2 & $3 y 4$ & 5.9 & 5.0 & 1 & 0 & $x$ & $x$ & 2,5 YR $4 / 3$ & 2,5 YR 4/6 & indet & 1.1 & indet & $\begin{array}{ll}t & 1 \\
\end{array}$ & 2 & $x$ & $x$ & $x$ & $x$ & $x$ & $x$ & $x$ & $x$ & $x$ & \\
\hline TC 2 & Conj B & 144 & 1 & 0 & 0 & 0 & 3y4 & 2 & 5.3 & 4.5 & 1 & 0 & $\mathrm{x}$ & $x$ & 10R $5 / 6$ & 10R $4 / 6$ & indet & 1 & indet & $t \quad 2$ & 2 & $\mathrm{x}$ & $\mathrm{x}$ & $\mathrm{x}$ & $\mathrm{x}$ & $\mathrm{x}$ & $\mathrm{x}$ & $\mathrm{x}$ & $x$ & $\mathrm{x}$ & \\
\hline TC 2 & Conj B & 145 & 2 & 0 & 1 & 2 & $2 \mathrm{y} 4$ & $3 y 4$ & 8.7 & 5.7 & 1 & 0 & $x$ & $x$ & 2,5YR 4/4, 4/2; N 3/ & 2,5 YR $5 / 6,4 / 6$ & $x$ & $x$ & $x$ & $x$ & $x$ & $x$ & $x$ & $x$ & $x$ & $x$ & $x$ & 6.4 & 5 & 2 & 1 \\
\hline TC 2 & Conj B & 146 & 2 & 0 & 0 & 1 & $3 y 4$ & 2 & 19.0 & 12.4 & 1 & 0 & $x$ & $x$ & 2,5 YR 4/4 & $5 Y R$ 5/2, 5/3 & $x$ & $x$ & $x$ & $x$ & $x$ & $x$ & $x$ & $x$ & $x$ & $x$ & $x$ & 14.6 & 5 & 2 & 6 \\
\hline TC 2 & Conj B & 147 & 2 & 0 & 0 & 0 & 3y4 & 2 & 9.3 & 6.0 & 1 & 0 & $\mathrm{x}$ & $x$ & $2,5 Y R \quad 4 / 4$ & $5 Y R$ 5/2, 5/3 & $\mathrm{x}$ & $\mathrm{x}$ & $\mathrm{x}$ & $\mathrm{x}$ & $x$ & $\mathrm{x}$ & $\mathrm{x}$ & $\mathrm{x}$ & $\mathrm{x}$ & $\mathrm{x}$ & $\mathrm{x}$ & 6.4 & 5 & 2 & 6 \\
\hline TC 2 & Conj B & 148 & 2 & 0 & 0 & 0 & $3 y 4$ & 2 & 7.1 & 5.5 & 1 & 0 & $x$ & $x$ & $2,5 Y R \quad 4 / 4$ & $5 Y R$ 5/3 & $x$ & $\mathrm{x}$ & $x$ & $x$ & $x$ & $x$ & $x$ & $x$ & $x$ & $x$ & $x$ & 2.1 & 5 & 2 & \\
\hline TC 2 & Conj B & 149 & 2 & 2 & 0 & 5 & 3y4 & 1 & 10.0 & 4.7 & 1 & 0 & $x$ & $x$ & $2,5 Y R \quad 4 / 4$ & $5 Y R$ 5/3, 5/4 & $\mathrm{x}$ & $x$ & $x$ & $x$ & $x$ & $x$ & $x$ & $\mathrm{x}$ & $x$ & $\mathrm{x}$ & $\mathrm{x}$ & 3.1 & 5 & 2 & \\
\hline TC 2 & Conj B & 150 & 2 & 0 & 1 & 2 & $3 y 4$ & $3 y 4$ & 9.8 & 7.1 & 1 & 0 & $x$ & $x$ & 10R $4 / 6$ & 10R $4 / 6$ & $x$ & $x$ & $x$ & $x$ & $x$ & $x$ & $\mathrm{x}$ & $x$ & $x$ & $x$ & $x$ & 4.6 & 5 & 2 & 4 \\
\hline TC 2 & Conj B & 151 & 3 & 0 & 0 & 2 & $3 y 4$ & 2 & 8.5 & 7 & 1 & 0 & $x$ & $x$ & 2,5YR 4/4 & 5YR 5/4 & $x$ & $x$ & $x$ & $\mathrm{x}$ & $x$ & $4,5 \mathrm{fr}$ & 2.5 & 9 & 4 & 0 & 3 & $x$ & $\mathrm{x}$ & $x$ & \\
\hline TC 2 & Conj B & 152 & 3 & 0 & 0 & 0 & 3y4 & 2 & 11.7 & 8.6 & 1 & 0 & $\mathrm{x}$ & $x$ & 10R $4 / 6$ & 5YR 5/4 & $\mathrm{x}$ & $\mathrm{x}$ & $x$ & $x$ & $x$ & $3,6 \mathrm{fr}$ & 3.8 & 11 & 4 & 0 & 0 & $x$ & $x$ & $x$ & 4 y 5 \\
\hline TC 2 & Conj B & 153 & 4 & 0 & 2 & $2 \mathrm{y} 13$ & $3 y 4$ & 2 & 11.6 & 7.5 & 1 & 0 & $x$ & $x$ & 2,5 YR 4/6, 5/6 & $5 Y R \quad 4 / 1,4 / 2$ & $x$ & $x$ & $x$ & $x$ & $x$ & $x$ & $x$ & $x$ & $x$ & $x$ & $x$ & $x$ & $x$ & $x$ & 1 \\
\hline TC 2 & Conj B & 154 & 4 & 0 & 2 & 2 & $3 y 4$ & $3 y 4$ & 7.1 & 6.8 & 1 & 0 & $x$ & Yavi & $2,5 Y R$ 4/6, 5/6 & 2,5 YR $4 / 1,4 / 2$ & $x$ & $x$ & $x$ & $x$ & $x$ & $x$ & $x$ & $x$ & $x$ & $x$ & $x$ & $x$ & $x$ & $x$ & 6 \\
\hline TC 2 & Conj B & 155 & 4 & 0 & 2 & 2 & 3y4 & 2 & 9.0 & 7.0 & 1 & 0 & $x$ & $x$ & 2,5 YR $4 / 2$ & 2,5YR 5/6 & $\mathrm{x}$ & $\mathrm{x}$ & $\mathrm{x}$ & $x$ & $x$ & $\mathrm{x}$ & $x$ & $x$ & $x$ & $\mathrm{x}$ & $\mathrm{x}$ & $x$ & $\mathrm{x}$ & $x$ & \\
\hline TC 2 & Conj B & 156 & 4 & 0 & 2 & 2 & $3 y 4$ & 2 & 9.0 & 8.0 & 1 & 0 & $x$ & $x$ & 2,5 YR $4 / 2$ & $2,5 Y R$ 5/6 & $x$ & $x$ & $x$ & $x$ & $x$ & $x$ & $x$ & $x$ & $x$ & $x$ & $x$ & $x$ & $x$ & $x$ & \\
\hline TC 2 & Conj B & 157 & 0 & 0 & 0 & $1 \mathrm{y} 2$ & $3,4 \mathrm{y} 6$ & 2 & 7.0 & 6.5 & 2 & 0 & espiral & Yavi & 2,5 YR $5 / 4$ & 2,5YR 4/1, 3/1 & $x$ & $x$ & $x$ & $x$ & $x$ & $x$ & $x$ & $x$ & $x$ & $x$ & $x$ & $x$ & $\mathrm{x}$ & $\mathrm{x}$ & 1 y 5 \\
\hline TC 2 & Conj B & 158 & 0 & 0 & 0 & 0 & 3y4 & $2 \mathrm{y} 4$ & 9.5 & 6.5 & 1 & 0 & $\mathrm{x}$ & $\mathrm{x}$ & 10R $4 / 6$ & 10R $4 / 6$ & $\mathrm{x}$ & $\mathrm{x}$ & $\mathrm{x}$ & $\mathrm{x}$ & $\mathrm{x}$ & $\mathrm{x}$ & $\mathrm{x}$ & $\mathrm{x}$ & $\mathrm{x}$ & $\mathrm{x}$ & $\mathrm{x}$ & $\mathrm{x}$ & $x$ & $\mathrm{x}$ & \\
\hline TC 2 & Conj B & 159 & 0 & 0 & 0 & 1 & $3 y 4$ & 2 & 6.0 & 5.0 & 1 & 0 & $x$ & $x$ & 10R $4 / 4,4 / 6$ & 2,5 YR $5 / 4,5 / 6$ & $x$ & $x$ & $x$ & $x$ & $x$ & $x$ & $x$ & $x$ & $x$ & $x$ & $x$ & $x$ & $x$ & $x$ & 6 \\
\hline TC 2 & Conj B & 160 & 0 & 1 & 0 & 1 & 3y4 & 2 & 7.8 & 5.3 & 1 & 0 & $x$ & $x$ & $5 Y R 4 / 3$ & $5 Y R$ 6/1, 6/2 & $\mathrm{x}$ & $x$ & $\mathrm{x}$ & $x$ & $x$ & $x$ & $x$ & $x$ & $x$ & $\mathrm{x}$ & $\mathrm{x}$ & $x$ & $x$ & $x$ & \\
\hline TC 2 & Conj B & 161 & 0 & 0 & 0 & 1 & $3 y 4$ & 2 & 7.7 & 6.5 & 1 & 0 & $\mathrm{x}$ & $\mathrm{x}$ & 2,5YR 4/4 & 5YR 5/4 & $\mathrm{x}$ & $\mathrm{x}$ & $\mathrm{x}$ & $\mathrm{x}$ & $\mathrm{x}$ & $\mathrm{x}$ & $\mathrm{x}$ & $\mathrm{x}$ & $x$ & $\mathrm{x}$ & $x$ & $x$ & $x$ & $x$ & \\
\hline TC 2 & Conj B & 162 & 0 & 0 & 0 & 0 & $3 y 4$ & 2 & 8.5 & 6.7 & 1 & 0 & $x$ & $x$ & 10R $4 / 4$ & 2,5 YR $6 / 3$ & $x$ & $x$ & $x$ & $x$ & $x$ & $x$ & $x$ & $x$ & $x$ & $x$ & $x$ & $x$ & $x$ & $x$ & 2 \\
\hline TC 2 & Conj B & 163 & 0 & 0 & 0 & 0 & $3 y 4$ & 2 & 8.5 & 6.7 & 1 & 0 & $x$ & $x$ & 10R $4 / 4$ & 2,5 YR $6 / 3$ & $x$ & $x$ & $x$ & $x$ & $x$ & $x$ & $x$ & $x$ & $x$ & $x$ & $x$ & $x$ & $x$ & $x$ & 2 \\
\hline TC 2 & Conj B & 164 & 0 & 0 & 0 & 2 & $3 y 4$ & 2 & 8.7 & 4.9 & 1 & 0 & $x$ & $x$ & 10R $4 / 4$ & 5YR 6/4 & $x$ & $x$ & $x$ & $x$ & $x$ & $x$ & $x$ & $x$ & $x$ & $x$ & $x$ & $x$ & $x$ & $x$ & 5 \\
\hline TC 2 & Conj B & 165 & 0 & 0 & 0 & 2 & $3 y 4$ & 2 & 8.7 & 4.9 & 1 & 0 & $x$ & $x$ & 10R $4 / 4$ & 5YR 6/4 & $x$ & $x$ & $x$ & $x$ & $x$ & $x$ & $x$ & $x$ & $x$ & $x$ & $x$ & $x$ & $x$ & $x$ & 5 \\
\hline TC 2 & Conj B & 166 & 0 & 0 & 0 & 2 & $3 y 4$ & 2 & 8.7 & 6.0 & 1 & 0 & $x$ & $x$ & $10 \mathrm{R} 4 / 6$ & 2,5YR 5/6 & $x$ & $x$ & $x$ & $x$ & $x$ & $x$ & $x$ & $x$ & $x$ & $x$ & $x$ & $x$ & $x$ & $x$ & \\
\hline TC 2 & Conj B & 167 & 0 & 0 & 0 & 2 & $3 y 4$ & 2 & 8.0 & 6.5 & 1 & 0 & $x$ & Yavi & 10R $4 / 6$ & 2,5 YR 5/6 & $x$ & $x$ & $x$ & $x$ & $x$ & $x$ & $x$ & $x$ & $x$ & $x$ & $x$ & $x$ & $x$ & $x$ & \\
\hline TC 2 & Conj B & 168 & 0 & 0 & 0 & 2 & 3y4 & 2 & 8.0 & 6.5 & 1 & 0 & $\mathrm{x}$ & Yavi & 10R $4 / 6$ & 2,5 YR $5 / 6$ & $\mathrm{x}$ & $\mathrm{x}$ & $\mathrm{x}$ & $\mathrm{x}$ & $x$ & $\mathrm{x}$ & $\mathrm{x}$ & $\mathrm{x}$ & $x$ & $x$ & $\mathrm{x}$ & $\mathrm{x}$ & $x$ & $x$ & \\
\hline TC 2 & Conj B & 169 & 0 & 0 & 0 & 0 & $3 y 4$ & 2 & 6.8 & 6.0 & 1 & 0 & $x$ & $x$ & $10 R 4 / 4$ & 2,5 YR $5 / 6$ & $x$ & $x$ & $x$ & $x$ & $x$ & $x$ & $x$ & $x$ & $x$ & $x$ & $x$ & $x$ & $x$ & $x$ & \\
\hline TC 2 & Conj B & 170 & 0 & 0 & 0 & 0 & $3 y 4$ & 2 & 8.5 & 7.6 & 1 & 0 & $x$ & $x$ & 2,5 YR $4 / 3,3 / 3$ & 2,5 YR 5/6 & $x$ & $x$ & $x$ & $x$ & $x$ & $x$ & $x$ & $x$ & $x$ & $x$ & $x$ & $x$ & $x$ & $x$ & \\
\hline TC 2 & Conj B & 171 & 0 & 0 & 0 & 2 & 3y4 & 2 & 9.2 & 7.4 & 1 & 0 & $\mathrm{x}$ & $\mathrm{x}$ & 2,5YR 4/4 & 2,5YR 6/4 & $\mathrm{x}$ & $\mathrm{x}$ & $\mathrm{x}$ & $\mathrm{x}$ & $\mathrm{x}$ & $\mathrm{x}$ & $\mathrm{x}$ & $\mathrm{x}$ & $\mathrm{x}$ & $x$ & $\mathrm{x}$ & $\mathrm{x}$ & $x$ & $\mathrm{x}$ & \\
\hline TC 2 & Conj B & 172 & 0 & 0 & 0 & 0 & $3 y 4$ & 2 & 9.0 & 5.7 & 1 & 0 & $x$ & $\mathrm{x}$ & 2,5YR 3/1. 3/2 & 2,5 YR $6 / 3$ & $\mathrm{x}$ & $\mathrm{x}$ & $\mathrm{x}$ & $\mathrm{x}$ & $\mathrm{x}$ & $\mathrm{x}$ & $\mathrm{x}$ & $\mathrm{x}$ & $\mathrm{x}$ & $\mathrm{x}$ & $\mathrm{x}$ & $\mathrm{x}$ & $\mathrm{x}$ & $\mathrm{x}$ & 1 \\
\hline TC 2 & Conj B & 173 & 0 & 0 & 0 & $1 \mathrm{y} 2$ & 3y4 & 2 & 5.2 & 4.7 & 1 & 0 & $\mathrm{x}$ & $\mathrm{x}$ & 10R $4 / 6$ & 2,5 YR $5 / 4$ & $\mathrm{x}$ & $\mathrm{x}$ & $\mathrm{x}$ & $\mathrm{x}$ & $x$ & $\mathrm{x}$ & $\mathrm{x}$ & $\mathrm{x}$ & $\mathrm{x}$ & $\mathrm{x}$ & $\mathrm{x}$ & $\mathrm{x}$ & $\mathrm{x}$ & $x$ & \\
\hline
\end{tabular}




\begin{tabular}{|c|c|c|c|c|c|c|c|c|c|c|c|c|c|c|c|c|c|c|c|c|c|c|c|c|c|c|c|c|c|c|c|}
\hline \multirow[b]{2}{*}{ Sitio } & \multirow[b]{2}{*}{ UP } & \multirow[b]{2}{*}{$\mathrm{FN}^{\mathrm{o}}$} & \multirow[b]{2}{*}{ Fgto } & \multicolumn{11}{|c|}{ Manufactura } & \multicolumn{2}{|c|}{ Cocción } & \multicolumn{5}{|c|}{ Borde-labio } & \multicolumn{6}{|c|}{ Asa } & \multicolumn{3}{|c|}{ Base } & \multirow[b]{2}{*}{ Alterac } \\
\hline & & & & $\begin{array}{l}\text { Tec } \\
\text { Iev }\end{array}$ & $\begin{array}{l}\text { For } \\
\text { ma }\end{array}$ & $\begin{array}{l}\text { Mar } \\
\text { cas }\end{array}$ & \begin{tabular}{|c|} 
Sup \\
ext
\end{tabular} & $\begin{array}{c}\text { Sup } \\
\text { int }\end{array}$ & $\begin{array}{l}\text { Esp } \\
\max \end{array}$ & $\begin{array}{l}\text { Esp } \\
\min \end{array}$ & $\begin{array}{l}\text { Deco } \\
\text { pint }\end{array}$ & $\begin{array}{l}\text { Deco } \\
\text { agreg }\end{array}$ & \begin{tabular}{|c|}
$\begin{array}{c}\text { Moti } \\
\text { vo }\end{array}$ \\
\end{tabular} & Estilo & Color sup ext & Color sup int & Diam & $\begin{array}{l}\text { Lrg } \\
\text { arc }\end{array}$ & \begin{tabular}{|c|}
$\%$ \\
arco
\end{tabular} & Direc & $\begin{array}{l}\begin{array}{l}\text { For } \\
\text { ma }\end{array} \\
\end{array}$ & $\begin{array}{l}\text { Lar } \\
\text { go }\end{array}$ & $\begin{array}{c}\text { An } \\
\text { cho }\end{array}$ & Esp & $\begin{array}{l}\text { Sec } \\
\text { ción }\end{array}$ & $\begin{array}{c}\text { In } \\
\text { serc }\end{array}$ & $\begin{array}{l}\text { Posi } \\
\text { ción }\end{array}$ & Diám & $\begin{array}{c}\text { Mor } \\
\text { fol }\end{array}$ & $\begin{array}{c}\text { Uni } \\
\text { ón }\end{array}$ & \\
\hline TC 2 & Conj B & 174 & 0 & 0 & 0 & 0 & $3 y 4$ & 2 & 8.4 & 6.5 & 1 & 0 & $x$ & $x$ & 2,5YR 4;6 & 2,5YR 5/6 & $\mathrm{x}$ & $\mathrm{x}$ & $\mathrm{x}$ & $\mathrm{x}$ & $\mathrm{x}$ & $\mathrm{x}$ & $\mathrm{x}$ & $\mathrm{x}$ & $\mathrm{x}$ & $\mathrm{x}$ & $\mathrm{x}$ & $\mathrm{x}$ & $\mathrm{x}$ & $\mathrm{x}$ & 5 \\
\hline TC 2 & Conj B & 175 & 0 & 0 & 0 & 0 & $3 y 4$ & 2 & 6.6 & 5.4 & 1 & 0 & $\mathrm{x}$ & $\mathrm{x}$ & 2,5 YR $4 / 3$ & $5 Y R 7 / 6,6 / 4$ & $\mathrm{x}$ & $\mathrm{x}$ & $x$ & $\mathrm{x}$ & $x$ & $\mathrm{x}$ & $\mathrm{x}$ & $\mathrm{x}$ & $\mathrm{x}$ & $x$ & $\mathrm{x}$ & $\mathrm{x}$ & $\mathrm{x}$ & $\mathrm{x}$ & \\
\hline TC 2 & Conj B & 176 & 0 & 0 & 0 & $1 \mathrm{y} 2$ & $3 y 4$ & 2 & 5.0 & 4.8 & 1 & 0 & $x$ & $x$ & 2,5 YR 4/4 & 2,5 YR 5/6 & $x$ & $x$ & $x$ & $x$ & $x$ & $x$ & $x$ & $x$ & $x$ & $x$ & $x$ & $x$ & $x$ & $x$ & \\
\hline TC 2 & Conj B & 177 & 0 & 0 & 0 & 0 & $3 y 4$ & 2 & 6.0 & 5.5 & 1 & 0 & $\mathrm{x}$ & $\mathrm{x}$ & 2,5YR 4/6 & 5YR 7/6 & $\mathrm{x}$ & $\mathrm{x}$ & $\mathrm{x}$ & $\mathrm{x}$ & $\mathrm{x}$ & $\mathrm{x}$ & $\mathrm{x}$ & $\mathrm{x}$ & $\mathrm{x}$ & $\mathrm{x}$ & $\mathrm{x}$ & $\mathrm{x}$ & $\mathrm{x}$ & $\mathrm{x}$ & \\
\hline TC 2 & Conj B & 178 & 0 & 0 & 0 & 0 & 3y4 & 2 & 5.8 & 5.5 & 1 & 0 & $\mathrm{x}$ & $\mathrm{x}$ & 10R $4 / 6$ & $2,5 Y R$ 5/1, 5/2 & $\mathrm{x}$ & $\mathrm{x}$ & $\mathrm{x}$ & $\mathrm{x}$ & $x$ & $\mathrm{x}$ & $\mathrm{x}$ & $\mathrm{x}$ & $\mathrm{x}$ & $x$ & $\mathrm{x}$ & $\mathrm{x}$ & $\mathrm{x}$ & $\mathrm{x}$ & \\
\hline TC 2 & Conj B & 179 & 0 & 0 & 0 & 0 & $3 y 4$ & 2 & 6.4 & 5.8 & 1 & 0 & $x$ & $x$ & 2,5 YR $5 / 6$ & 2,5 YR $5 / 6$ & $x$ & $x$ & $x$ & $x$ & $x$ & $x$ & $x$ & $x$ & $x$ & $x$ & $x$ & $x$ & $x$ & $x$ & \\
\hline TC 2 & Conj B & 180 & 0 & 0 & 0 & 0 & 3y4 & 2 & 7.2 & 6.3 & 1 & 0 & $\mathrm{x}$ & $\mathrm{x}$ & 2,5YR 4/3 & $5 Y R 6 / 4$ & $\mathrm{x}$ & $\mathrm{x}$ & $\mathrm{x}$ & $\mathrm{x}$ & $\mathrm{x}$ & $\mathrm{x}$ & $\mathrm{x}$ & $\mathrm{x}$ & $\mathrm{x}$ & $\mathrm{x}$ & $\mathrm{x}$ & $\mathrm{x}$ & $\mathrm{x}$ & $\mathrm{x}$ & \\
\hline TC 2 & Conj B & 181 & 0 & 0 & 0 & 0 & $3 y 4$ & 2 & 7.1 & 6.0 & 1 & 0 & $\mathrm{x}$ & $\mathrm{x}$ & 2,5YR 4/4 & 2,5YR 6/6 & $\mathrm{x}$ & $\mathrm{x}$ & $\mathrm{x}$ & $\mathrm{x}$ & $\mathrm{x}$ & $\mathrm{x}$ & $\mathrm{x}$ & $\mathrm{x}$ & $\mathrm{x}$ & $\mathrm{x}$ & $\mathrm{x}$ & $\mathrm{x}$ & $\mathrm{x}$ & $\mathrm{x}$ & \\
\hline TC 2 & Conj B & 182 & 0 & 0 & 0 & 0 & $3 y 4$ & 2 & 6.3 & 6.0 & 1 & 0 & $x$ & $x$ & 10R $4 / 4$ & 2,5YR 5/6 & $x$ & $x$ & $x$ & $x$ & $x$ & $x$ & $x$ & $x$ & $x$ & $x$ & $x$ & $x$ & $x$ & $x$ & \\
\hline TC 2 & Conj B & 183 & 0 & 0 & 0 & 0 & $3 y 4$ & 2 & 4.7 & 3.9 & 1 & 0 & $x$ & $x$ & 2,5 YR $5 / 6$ & 2,5 YR $5 / 6$ & $x$ & $x$ & $x$ & $x$ & $x$ & $x$ & $x$ & $x$ & $x$ & $x$ & $x$ & $x$ & $x$ & $x$ & \\
\hline TC 2 & Conj B & 184 & 0 & 0 & 0 & 0 & $3,4 \mathrm{y} 6$ & $3 y 4$ & 6.4 & 5.9 & 3 & 0 & $\begin{array}{l}\text { Trián } \\
\text { gulos }\end{array}$ & $\begin{array}{l}\text { Cusco } \\
\text { Polic? }\end{array}$ & 10R 2,5/1, 3/3; 5YR6/4 & $10 \mathrm{R} 3 / 3$ & $x$ & $x$ & $x$ & $x$ & $x$ & $x$ & $x$ & $x$ & $x$ & $\mathrm{x}$ & $x$ & $x$ & $x$ & $x$ & \\
\hline TC 2 & Conj B & 185 & 1 & 0 & 2 & 2 & 3 & 2 & 8.5 & 5.5 & 0 & 0 & $x$ & $x$ & $5 Y R 5 / 4,5 / 3$ & $5 Y R \quad 4 / 1,4 / 2$ & indet & 1.4 & indet & 1 & 2 & $x$ & $x$ & $x$ & $x$ & $x$ & $x$ & $x$ & $x$ & $x$ & 1 \\
\hline TC 2 & Conj B & 186 & 0 & 0 & 0 & $1 y^{2}$ & 3 & 2 & 8.5 & 6.0 & 0 & 0 & $\mathrm{x}$ & $x$ & 2,5YR 5/6 & 2,5YR 5/4 & $\mathrm{x}$ & $\mathrm{x}$ & $x$ & $x$ & $x$ & $x$ & $x$ & $x$ & $x$ & $x$ & $x$ & $x$ & $x$ & $x$ & \\
\hline TC 2 & Conj B & 187 & 0 & 0 & 0 & 1 & 3 & 2 & 7.5 & 6.0 & 0 & 0 & $x$ & $x$ & $5 Y R$ 5/2, 6/2 & $5 Y R$ 5/1, 5/2 & $\mathrm{x}$ & $x$ & $\mathrm{x}$ & $x$ & $x$ & $\mathrm{x}$ & $x$ & $x$ & $x$ & $x$ & $\mathrm{x}$ & $\mathrm{x}$ & $x$ & $x$ & 2 \\
\hline TC 2 & Conj B & 188 & 0 & 0 & 0 & 2 & 3 & 2 & 7.3 & 6.6 & 0 & 0 & $\mathrm{x}$ & $\mathrm{x}$ & 2,5YR 5/6 & 2,5YR 5/6 & $\mathrm{x}$ & $\mathrm{x}$ & $\mathrm{x}$ & $\mathrm{x}$ & $x$ & $\mathrm{x}$ & $\mathrm{x}$ & $\mathrm{x}$ & $\mathrm{x}$ & $\mathrm{x}$ & $\mathrm{x}$ & $\mathrm{x}$ & $\mathrm{x}$ & $\mathrm{x}$ & \\
\hline TC 2 & Conj B & 189 & 0 & 0 & 0 & 2 & 3 & 2 & 7.4 & 6.5 & 0 & 0 & $\mathrm{x}$ & $\mathrm{x}$ & 2,5YR 5/8 & 2,5YR 5/6 & $\mathrm{x}$ & $\mathrm{x}$ & $\mathrm{x}$ & $\mathrm{x}$ & $x$ & $\mathrm{x}$ & $\mathrm{x}$ & $\mathrm{x}$ & $\mathrm{x}$ & $\mathrm{x}$ & $\mathrm{x}$ & $\mathrm{x}$ & $x$ & $\mathrm{x}$ & \\
\hline TC 2 & Conj B & 190 & 0 & 0 & 0 & 2 & 2 & 3 & 8.1 & 7.0 & 0 & 0 & $\mathrm{x}$ & $x$ & 5YR 5/3 & 5YR 5/4 & $\mathrm{x}$ & $\mathrm{x}$ & $\mathrm{x}$ & $\mathrm{x}$ & $\mathrm{x}$ & $\mathrm{x}$ & $\mathrm{x}$ & $x$ & $\mathrm{x}$ & $\mathrm{x}$ & $\mathrm{x}$ & $\mathrm{x}$ & $\mathrm{x}$ & $x$ & 2 \\
\hline TC 2 & Conj B & 191 & 1 & 0 & 2 & 1 & 2 & 2 & 11.0 & 9.2 & 0 & 0 & $x$ & $x$ & $5 Y R$ 5/2, 5/4 & 2,5 YR $4 / 4,4 / 6$ & 25.5 & 4.7 & 5.9 & 1 & 1 & $x$ & $x$ & $x$ & $x$ & $x$ & $x$ & $x$ & $x$ & $x$ & 2 \\
\hline TC 2 & Conj B & 192 & 1 & 0 & 2 & 0 & 2 & 2 & 11.9 & 9.7 & 0 & 0 & $\mathrm{x}$ & $\mathrm{x}$ & $2,5 Y R$ 4/2, 5/6 & $2,5 Y R \quad 4 / 2,5 / 6$ & 20.6 & 4.2 & 6.5 & 1 & 1 & $\mathrm{x}$ & $\mathrm{x}$ & $\mathrm{x}$ & $\mathrm{x}$ & $\mathrm{x}$ & $\mathrm{x}$ & $\mathrm{x}$ & $\mathrm{x}$ & $\mathrm{x}$ & 2 y 6 \\
\hline TC 2 & Conj B & 193 & 1 & 0 & 0 & 0 & 2 & 2 & 6.2 & 5.5 & 0 & 0 & $x$ & $x$ & 5YR 5/4 & 5YR 4/4 & indet & 4.5 & indet & 1 & 2 & $1 \mathrm{fr}$ & 3.2 & 9 & 4 & 1 & 2 & $\mathrm{x}$ & $\mathrm{x}$ & $\mathrm{x}$ & 2 \\
\hline TC 2 & Conj B & 194 & 1 & 0 & 0 & 0 & 2 & 2 & 6 & 5.7 & 0 & 0 & $x$ & $x$ & 5YR 5/4 & 5YR 5/4 & indet & 3.9 & indet & 1 & 2 & $1 \mathrm{fr}$ & 3.2 & 10 & 4 & 1 & 2 & $x$ & $\mathrm{x}$ & $x$ & \\
\hline TC 2 & Conj B & 195 & 1 & 0 & 0 & 0 & 2 & 2 & 7.8 & 5.2 & 0 & 0 & $\mathrm{x}$ & $\mathrm{x}$ & 2,5YR 5/6 & 5YR 5/1 & indet & 1.7 & indet & 1 & 2 & $\mathrm{x}$ & $\mathrm{x}$ & $\mathrm{x}$ & $\mathrm{x}$ & $\mathrm{x}$ & $\mathrm{x}$ & $\mathrm{x}$ & $\mathrm{x}$ & $\mathrm{x}$ & 2 \\
\hline TC 2 & Conj B & 196 & 1 & 0 & 0 & 0 & 2 & 2 & 6.1 & 5.9 & 0 & 0 & $x$ & $x$ & 2,5YR 4/6 & $2.5 Y R \quad 4 / 6$ & indet & 1.8 & indet & 0 & 2 & $x$ & $x$ & $x$ & $x$ & $x$ & $x$ & $x$ & $x$ & $x$ & 3 \\
\hline TC 2 & Conj B & 197 & 2 & 0 & 0 & 2 & 2 & 2 & 16.6 & 6.1 & 0 & 0 & $\mathrm{x}$ & $\mathrm{x}$ & $5 Y R$ 5/4, 4/4 & $5 Y R \quad 4 / 1,4 / 2$ & $\mathrm{x}$ & $\mathrm{x}$ & $\mathrm{x}$ & $\mathrm{x}$ & $\mathrm{x}$ & $\mathrm{x}$ & $\mathrm{x}$ & $\mathrm{x}$ & $\mathrm{x}$ & $\mathrm{x}$ & $\mathrm{x}$ & 13.2 & 5 & 1 & 1 \\
\hline TC 2 & Conj B & 198 & 2 & 0 & 0 & 0 & 2 & 2 & 10.9 & 7.2 & 0 & 0 & $x$ & $x$ & 5YR 5/4 & 5YR 5/2 & $x$ & $x$ & $x$ & $x$ & $x$ & $x$ & $x$ & $x$ & $x$ & $x$ & $x$ & indet & $\begin{array}{l}\mathrm{t} \\
\end{array}$ & 2 & \\
\hline TC 2 & Conj B & 199 & 3 & 0 & 0 & 0 & 2 & 2 & 9.5 & 8.2 & 0 & 0 & $x$ & $x$ & 5YR 5/4 & 5 YR 5/2, 5/1 & $x$ & $x$ & $x$ & $x$ & $x$ & $3,8 \mathrm{fr}$ & $\begin{array}{r}r 3 \\
\end{array}$ & 9 & 3 & 0 & 0 & $x$ & $x$ & $x$ & 3 \\
\hline TC 2 & Conj B & 200 & 3 & 0 & 0 & 0 & 2 & 2 & 13 & 12.5 & 0 & 0 & $\mathrm{x}$ & $\mathrm{x}$ & $5 Y R 5 / 4,5 / 3,4 / 1$ & 5YR 5/2 & $\mathrm{x}$ & $\mathrm{x}$ & $\mathrm{x}$ & $\mathrm{x}$ & $\mathrm{x}$ & $4,3 \mathrm{fr}$ & $\begin{array}{rl}r & 1.3 \\
\end{array}$ & 13 & 2 & 0 & 0 & $\mathrm{x}$ & $\mathrm{x}$ & $\mathrm{x}$ & \\
\hline TC 2 & Conj B & 201 & 3 & 0 & 0 & 0 & 2 & 2 & 10 & 7.5 & 0 & 0 & $x$ & $x$ & $2,5 \mathrm{YR} 4 / 4$ & 5YR 3/1 & $x$ & $x$ & $x$ & $x$ & $x$ & $1,1 \mathrm{fr}$ & \begin{tabular}{r|r}
$r$ & 2.6 \\
\end{tabular} & 13 & 2 & 1 & 0 & $x$ & $x$ & $x$ & 3 \\
\hline TC 2 & Conj B & 202 & 5 & 0 & 3 & 0 & 2 & 2 & 9 & 8.5 & 0 & 0 & $x$ & $x$ & 5YR 5/4 & 5YR 5/4 & 3.7 & 5.4 & 47 & $x$ & $x$ & $x$ & $x$ & $x$ & $x$ & $x$ & $x$ & $x$ & $x$ & $x$ & \\
\hline TC 2 & Conj B & 203 & 0 & 0 & 0 & 0 & 2 & 2 & 9.3 & 6.5 & 0 & 0 & $\mathrm{x}$ & $\mathrm{x}$ & 2,5YR 5/6 & 2,5YR 6/6 & $\mathrm{x}$ & $\mathrm{x}$ & $\mathrm{x}$ & $\mathrm{x}$ & $\mathrm{x}$ & $\mathrm{x}$ & $\mathrm{x}$ & $\mathrm{x}$ & $\mathrm{x}$ & $\mathrm{x}$ & $\mathrm{x}$ & $\mathrm{x}$ & $\mathrm{x}$ & $\mathrm{x}$ & \\
\hline TC 2 & Conj B & 204 & 0 & 1 & 0 & 0 & 2 & 2 & 8.2 & 4.9 & 0 & 0 & $x$ & $x$ & 2,5 YR $5 / 2,5 / 3,4 / 1$ & 2,5YR 5/6: 5YR6/4 & $x$ & $x$ & $x$ & $x$ & $x$ & $x$ & $x$ & $x$ & $x$ & $x$ & $x$ & $x$ & $\mathrm{x}$ & $x$ & 1 \\
\hline TC 2 & Conj B & 205 & 0 & 0 & 0 & 0 & 2 & 2 & 10.1 & 8.6 & 0 & 0 & $x$ & $x$ & $5 Y R$ 4/1, 3/1 & $2,5 Y R \quad 4 / 4$ & $x$ & $x$ & $x$ & $x$ & $x$ & $x$ & $x$ & $x$ & $x$ & $x$ & $x$ & $x$ & $x$ & $x$ & 1 \\
\hline TC 2 & Conj B & 206 & 0 & 0 & 0 & 0 & 2 & 2 & 6.7 & 5.0 & 0 & 0 & $\mathrm{x}$ & $\mathrm{x}$ & 2,5 YR 5/1, 4/1 & 2,5YR 5/6 & $\mathrm{x}$ & $\mathrm{x}$ & $\mathrm{x}$ & $\mathrm{x}$ & $\mathrm{x}$ & $\mathrm{x}$ & $\mathrm{x}$ & $\mathrm{x}$ & $\mathrm{x}$ & $\mathrm{x}$ & $\mathrm{x}$ & $\mathrm{x}$ & $\mathrm{x}$ & $\mathrm{x}$ & 1 \\
\hline TC 2 & Conj B & 207 & 0 & 0 & 0 & 0 & 2 & 2 & 7.0 & 5.5 & 0 & 0 & $x$ & $x$ & $2,5 Y R$ 5/1, 5/4 & 2,5YR 5/6 & $x$ & $x$ & $x$ & $x$ & $x$ & $x$ & $x$ & $x$ & $x$ & $\mathrm{x}$ & $x$ & $x$ & $x$ & $x$ & 1 \\
\hline TC 2 & Conj B & 208 & 0 & 0 & 0 & 0 & 2 & 2 & 8.6 & 8.4 & 0 & 0 & $\mathrm{x}$ & $\mathrm{x}$ & 7,5YR 3/1, 4/1 & 2,5YR 4/6 & $\mathrm{x}$ & $\mathrm{x}$ & $\mathrm{x}$ & $\mathrm{x}$ & $\mathrm{x}$ & $\mathrm{x}$ & $\mathrm{x}$ & $\mathrm{x}$ & $\mathrm{x}$ & $\mathrm{x}$ & $\mathrm{x}$ & $\mathrm{x}$ & $\mathrm{x}$ & $\mathrm{x}$ & 1 \\
\hline TC 2 & Conj B & 209 & 0 & 0 & 0 & 0 & 2 & 2 & 7.8 & 6.2 & 0 & 0 & $\mathrm{x}$ & $\mathrm{x}$ & 7,5YR 5/2, 5/3 & 7,5YR 5/1, 5/2 & $\mathrm{x}$ & $\mathrm{x}$ & $\mathrm{x}$ & $\mathrm{x}$ & $\mathrm{x}$ & $\mathrm{x}$ & $\mathrm{x}$ & $\mathrm{x}$ & $x$ & $\mathrm{x}$ & $x$ & $x$ & $x$ & $\mathrm{x}$ & \\
\hline TC 2 & Conj B & 210 & 0 & 0 & 0 & 0 & 2 & 2 & 6.3 & 6.0 & 0 & 0 & $x$ & $x$ & 5YR 6/4 & 2,5 YR 4/6 & $x$ & $x$ & $x$ & $x$ & $x$ & $x$ & $x$ & $x$ & $x$ & $x$ & $x$ & $x$ & $x$ & $x$ & \\
\hline TC 2 & Conj B & 211 & 0 & 0 & 0 & 0 & 2 & 2 & 6.6 & 5.6 & 0 & 0 & $\mathrm{x}$ & $\mathrm{x}$ & 2,5YR 5/6 & 5YR 5/4 & $\mathrm{x}$ & $\mathrm{x}$ & $\mathrm{x}$ & $\mathrm{x}$ & $\mathrm{x}$ & $\mathrm{x}$ & $\mathrm{x}$ & $\mathrm{x}$ & $\mathrm{x}$ & $\mathrm{x}$ & $\mathrm{x}$ & $\mathrm{x}$ & $\mathrm{x}$ & $\mathrm{x}$ & \\
\hline TC 2 & Conj B & 212 & 0 & 0 & 0 & 0 & 2 & 2 & 6.7 & 5.4 & 0 & 0 & $x$ & $x$ & $5 Y R$ 5/2, 5/4 & $2,5 Y R \quad 4 / 4$ & $x$ & $x$ & $x$ & $x$ & $x$ & $x$ & $x$ & $x$ & $x$ & $x$ & $x$ & $x$ & $x$ & $x$ & 6 \\
\hline TC 2 & Conj C & 213 & 1 & 0 & 2 & 0 & 2 & 3 & 7.8 & 7.1 & 0 & 0 & $\mathrm{x}$ & $\mathrm{x}$ & 5YR 6/4 & 2,5YR 5?6 & indet & 2.5 & indet & 1 & 1 & $\mathrm{x}$ & $\mathrm{x}$ & $\mathrm{x}$ & $\mathrm{x}$ & $\mathrm{x}$ & $\mathrm{x}$ & $\mathrm{x}$ & $\mathrm{x}$ & $\mathrm{x}$ & 3 \\
\hline
\end{tabular}




\begin{tabular}{|c|c|c|c|c|c|c|c|c|c|c|c|c|c|c|c|c|c|c|c|c|c|c|c|c|c|c|c|c|c|c|c|}
\hline \multirow[b]{2}{*}{ Sitio } & \multirow[b]{2}{*}{ UP } & \multirow[b]{2}{*}{$\mathrm{FN}^{\circ}$} & \multirow[b]{2}{*}{ Fgto } & \multicolumn{11}{|c|}{ Manufactura } & \multicolumn{2}{|c|}{ Cocción } & \multicolumn{5}{|c|}{ Borde-labio } & \multicolumn{6}{|c|}{ Asa } & \multicolumn{3}{|c|}{ Base } & \multirow[b]{2}{*}{ Alterac } \\
\hline & & & & $\begin{array}{l}\text { Tec } \\
\text { lev }\end{array}$ & $\begin{array}{l}\text { For } \\
\text { ma }\end{array}$ & $\begin{array}{l}\text { Mar } \\
\text { cas }\end{array}$ & $\begin{array}{l}\text { Sup } \\
\text { ext }\end{array}$ & $\begin{array}{c}\text { Sup } \\
\text { int }\end{array}$ & $\begin{array}{l}\text { Esp } \\
\text { max }\end{array}$ & $\begin{array}{l}\text { Esp } \\
\min \end{array}$ & $\begin{array}{l}\text { Deco } \\
\text { pint }\end{array}$ & $\begin{array}{l}\text { Deco } \\
\text { agreg }\end{array}$ & \begin{tabular}{|c|} 
Moti \\
vo
\end{tabular} & Estilo & Color sup ext & Color sup int & Diam & $\begin{array}{l}\text { Lrg } \\
\text { arc }\end{array}$ & \begin{tabular}{c|}
$\%$ \\
$a r c o$
\end{tabular} & Direc & $\begin{array}{l}\begin{array}{l}\text { For } \\
\text { ma }\end{array} \\
\end{array}$ & $\begin{array}{c}\text { Lar } \\
\text { go }\end{array}$ & $\begin{array}{c}\text { An } \\
\text { cho }\end{array}$ & Esp & $\begin{array}{l}\begin{array}{l}\text { Sec } \\
\text { ción }\end{array} \\
\end{array}$ & $\begin{array}{c}\text { In } \\
\text { serc }\end{array}$ & \begin{tabular}{|l|l}
$n$ & Posi \\
rc & ción \\
\end{tabular} & Diám & n $\begin{array}{c}\text { Mor } \\
\text { fol }\end{array}$ & $\begin{array}{c}\text { Uni } \\
\text { ón }\end{array}$ & \\
\hline TC 2 & Conj C & 214 & 1 & 0 & 2 & 0 & 2 & 2 & 7.8 & 5.9 & 0 & 0 & $x$ & $x$ & 2,5YR 5/4 & $2,5 Y R$ T/4 & indet & 3 & indet & 1 & 1 & $\mathrm{x}$ & $x$ & $x$ & $\mathrm{x}$ & $\mathrm{x}$ & $\mathrm{x}$ & $\mathrm{x}$ & $\mathrm{x}$ & $\mathrm{x}$ & \\
\hline TC 2 & Conj C & 215 & 2 & 0 & 0 & 0 & 2 & 2 & 7.6 & 5.0 & 0 & 0 & $\mathrm{x}$ & $\mathrm{x}$ & $2,5 Y R$ 5/4, 5/2 & $7,5 Y R$ 5/2, 5/3 & $\mathrm{x}$ & $\mathrm{x}$ & $\mathrm{x}$ & $\mathrm{x}$ & $\mathrm{x}$ & $\mathrm{x}$ & $\mathrm{x}$ & $x$ & $\mathrm{x}$ & $\mathrm{x}$ & $\mathrm{x}$ & 6.6 & 5 & 2 & 3 y 4 \\
\hline TC 2 & Conj C & 216 & 0 & 0 & 0 & 1 & $2 \mathrm{y} 6$ & 2 & 8.7 & 6.5 & 1 & 0 & $\mathrm{x}$ & Yavi & 2,5YR 6/6; 10R 4/6 & $5 Y R 6 / 6$ & $\mathrm{x}$ & $\mathrm{x}$ & $\mathrm{x}$ & $\mathrm{x}$ & $x$ & $x$ & $\mathrm{x}$ & $x$ & $\mathrm{x}$ & $\mathrm{x}$ & $\mathrm{x}$ & $\mathrm{x}$ & $\mathrm{x}$ & $x$ & 5 \\
\hline TC 2 & Conj C & 217 & 0 & 0 & 0 & 1 & $3 \mathrm{y} 6$ & 2 & 6.5 & 4.0 & 1 & 0 & $\mathrm{x}$ & $\mathrm{x}$ & 2,5YR 5/6, 4/6 & 5YR 5/4 & $x$ & $\mathrm{x}$ & $\mathrm{x}$ & $\mathrm{x}$ & $x$ & $x$ & $x$ & $x$ & $x$ & $\mathrm{x}$ & $\mathrm{x}$ & $\mathrm{x}$ & $\mathrm{x}$ & $x$ & 5 \\
\hline TC 2 & Conj C & 218 & 0 & 0 & 0 & $1 \mathrm{y} 2$ & 3 & 2 & 6.1 & 5.4 & 0 & 0 & $x$ & $x$ & $2,5 Y R$ 5/6 & $2,5 Y R$ 5/6 & $x$ & $x$ & $x$ & $x$ & $x$ & $x$ & $x$ & $x$ & $x$ & $x$ & $x$ & $x$ & $x$ & $x$ & \\
\hline TC 2 & Conj C & 219 & 0 & 0 & 0 & 2 & 3 & 3 & 6.3 & 5.9 & 0 & 0 & $\mathrm{x}$ & $\mathrm{x}$ & 2,5YR 4/6 & 2,5YR 4/6 & $x$ & $\mathrm{x}$ & $x$ & $x$ & $x$ & $x$ & $x$ & $x$ & $\mathrm{x}$ & $\mathrm{x}$ & $\mathrm{x}$ & $\mathrm{x}$ & $\mathrm{x}$ & $x$ & 3 \\
\hline TC 2 & Conj C & 220 & 0 & 0 & 0 & 0 & $3 y 4$ & 2 & 6.0 & 5.4 & 1 & 0 & $x$ & $x$ & 2,5 YR 4/4 & 2,5 YR 5/6 & $x$ & $x$ & $x$ & $x$ & $x$ & $x$ & $x$ & $x$ & $x$ & $x$ & $x$ & $x$ & $x$ & $x$ & 3 \\
\hline TC 2 & Conj C & 221 & 0 & 0 & 0 & 0 & 3 & 3 & 6.5 & 5.0 & 0 & 0 & $x$ & $x$ & 2,5 YR $4 / 6$ & 5YR 5/4 & $\mathrm{x}$ & $x$ & $\mathrm{x}$ & $x$ & $x$ & $x$ & $x$ & $x$ & $x$ & $x$ & $\mathrm{x}$ & $x$ & $\mathrm{x}$ & $x$ & \\
\hline TC 2 & Conj C & 222 & 0 & 0 & 0 & 0 & $3 y 4$ & 2 & 6.3 & 5.6 & 1 & 0 & $x$ & $x$ & 10R 4/4 & 2,5 YR $6 / 6$ & $x$ & $x$ & $x$ & $x$ & $x$ & $x$ & $x$ & $x$ & $x$ & $x$ & $x$ & $x$ & $x$ & $x$ & 5 \\
\hline TC 2 & Conj C & 223 & 0 & 0 & 0 & 0 & $3 y 4$ & 2 & 6.7 & 5.9 & 1 & 0 & $x$ & $x$ & $2,5 Y R$ 4/6 & $2,5 Y R$ 4/6 & $x$ & $x$ & $x$ & $x$ & $x$ & $x$ & $x$ & $x$ & $x$ & $x$ & $x$ & $x$ & $x$ & $x$ & \\
\hline TC 2 & Conj C & 224 & 0 & 0 & 0 & 0 & 3 & 2 & 13.0 & 9.3 & 0 & 0 & $\mathrm{x}$ & $x$ & 2,5 YR $5 / 6$ & 2,5 YR 5/6 & $x$ & $x$ & $x$ & $x$ & $x$ & $x$ & $x$ & $x$ & $x$ & $x$ & $\mathrm{x}$ & $x$ & $x$ & $x$ & \\
\hline TC 2 & Conj C & 225 & 0 & 0 & 0 & 0 & 2 & 2 & 7.8 & 5.8 & 0 & 0 & $x$ & $x$ & 5YR 6/6 & 2,5 YR 5/6 & $x$ & $x$ & $x$ & $x$ & $x$ & $x$ & $x$ & $x$ & $x$ & $x$ & $x$ & $x$ & $x$ & $x$ & 3 \\
\hline TC 2 & Conj C & 226 & 0 & 0 & 0 & 0 & 2 & 2 & 8.0 & 6.5 & 0 & 0 & $x$ & $x$ & 5YR 6/4 & $5 Y R 7 / 6$ & $x$ & $x$ & $x$ & $x$ & $x$ & $x$ & $x$ & $x$ & $x$ & $x$ & $x$ & $x$ & $x$ & $x$ & 3 y 4 \\
\hline TC 2 & Conj C & 227 & 0 & 0 & 0 & 0 & 2 & 2 & 7.5 & 6.4 & 0 & 0 & $\mathrm{x}$ & $\mathrm{x}$ & $5 Y R 6 / 6$ & 5YR 6/6 & $x$ & $\mathrm{x}$ & $x$ & $x$ & $x$ & $x$ & $x$ & $x$ & $x$ & $\mathrm{x}$ & $\mathrm{x}$ & $x$ & $\mathrm{x}$ & $x$ & 3 \\
\hline TC 2 & Conj C & 228 & 0 & 0 & 0 & 0 & 2 & 2 & 5.4 & 4.8 & 0 & 0 & $x$ & $x$ & 2,5 YR 4/3 & 5YR 5/4 & $x$ & $x$ & $x$ & $x$ & $x$ & $x$ & $x$ & $x$ & $x$ & $x$ & $x$ & $x$ & $x$ & $x$ & 3 \\
\hline TC 2 & Conj C & 229 & 0 & 0 & 0 & 0 & 2 & 2 & 7.2 & 6.8 & 0 & 0 & $x$ & $x$ & $2,5 Y R \quad 4 / 3$ & 2,5YR 5/6 & $x$ & $x$ & $x$ & $x$ & $x$ & $x$ & $x$ & $x$ & $x$ & $x$ & $x$ & $x$ & $x$ & $x$ & \\
\hline TC 2 & Conj C & 230 & 0 & 0 & 0 & 0 & 2 & 2 & 5.7 & 4.8 & 0 & 0 & $x$ & $x$ & 5YR 5/6 & 5YR 5/6 & $\mathrm{x}$ & $x$ & $\mathrm{x}$ & $x$ & $x$ & $x$ & $x$ & $x$ & $x$ & $x$ & $\mathrm{x}$ & $x$ & $x$ & $x$ & \\
\hline TC 2 & Conj D & 231 & 1 & 0 & 1 & 0 & 2 & 3 & 7.0 & 5.0 & 0 & 0 & $x$ & $x$ & 2,5YR 4/6 & 2,5YR 5/6 & 14.8 & 5 & 10.8 & 1 & 2 & $x$ & $x$ & $x$ & $x$ & $x$ & $x$ & $\mathrm{x}$ & $\mathrm{x}$ & $\mathrm{x}$ & \\
\hline TC 2 & Conj D & 232 & 1 & 0 & 1 & 0 & 3 & 3 & 6.0 & 4.1 & 0 & 0 & $x$ & $x$ & 5YR 4/4 & $5 Y R$ 5/1, 5/2 & 12.2 & 3.2 & 8.5 & 2 & 2 & $x$ & $x$ & $x$ & $x$ & $\mathrm{x}$ & $\mathrm{x}$ & $x$ & $\mathrm{x}$ & $x$ & \\
\hline TC 2 & Conj D & 233 & 1 & 0 & 1 & 0 & 3 & 0 & 7.5 & 5.2 & 0 & 0 & $\mathrm{x}$ & $\mathrm{x}$ & 2,5YR 5/6 & 2,5 YR $5 / 6$ & indet & 3.2 & indet & 2 & 2 & $x$ & $x$ & $x$ & $\mathrm{x}$ & $\mathrm{x}$ & $\mathrm{x}$ & $\mathrm{x}$ & $\mathrm{x}$ & $x$ & 3 y 4 \\
\hline TC 2 & Conj D & 234 & 1 & 0 & 1 & 0 & 2 & 3 & 8.0 & 5.5 & 0 & 0 & $x$ & $x$ & $2,5 Y R 6 / 6$ & $2,5 Y R$ 6/4 & indet & 2.2 & indet & 2 & 2 & $x$ & $x$ & $x$ & $x$ & $x$ & $x$ & $x$ & $x$ & $x$ & \\
\hline TC 2 & Conj D & 235 & 1 & 0 & 0 & 0 & $3 y 6$ & $3 y 6$ & 8.8 & 6.0 & 1 & 0 & $\mathrm{x}$ & $\mathrm{x}$ & 2,5 YR $5 / 8,6 / 8$ & $2,5 Y R$ 5/8, $6 / 8$ & indet & 2.4 & indet & 0 & 1 & $x$ & $\mathrm{x}$ & $x$ & $\mathrm{x}$ & $\mathrm{x}$ & $\mathrm{x}$ & $\mathrm{x}$ & $\mathrm{x}$ & $x$ & 5 \\
\hline TC 2 & Conj D & 236 & 3 & 0 & 0 & 0 & $2 \mathrm{y} 6$ & 2 & 11 & 5 & 1 & 0 & $\mathrm{x}$ & $\mathrm{x}$ & 2,5YR 6/4, 5/6 (pint?) & $5 Y R 6 / 4$ & $\mathrm{x}$ & $\mathrm{x}$ & $\mathrm{x}$ & $\mathrm{x}$ & $\mathrm{x}$ & 2.9 & 3.1 & 13 & 4 & 1 & 0 & $\mathrm{x}$ & $\mathrm{x}$ & $\mathrm{x}$ & 4 y 5 \\
\hline TC 2 & Conj D & 237 & 3 & 0 & 0 & 0 & 2 & 2 & 8.5 & 5 & 0 & 0 & $x$ & $x$ & $2,5 Y R$ 4/3. 4/4 & $2,5 Y R 5 / 6$ & $x$ & $x$ & $x$ & $x$ & $x$ & 0.9 & 2.7 & 10 & 4 & 3 & 0 & $x$ & $x$ & $x$ & 3 \\
\hline TC 2 & Conj D & 238 & 0 & 0 & 0 & 1 & $3 y 6$ & 2 & 8.8 & 6.0 & 2 & 0 & lineas & $x$ & 2,5YR 4/4, 3/1 (pint) & $2,5 Y R 5 / 6$ & $x$ & $x$ & $x$ & $x$ & $x$ & $x$ & $x$ & $x$ & $x$ & $x$ & $x$ & $x$ & $x$ & $x$ & 4 \\
\hline TC 2 & Conj D & 239 & 0 & 0 & 0 & 0 & $2 \mathrm{y} 4$ & 2 & 7.2 & 5.6 & 1 & 0 & $\mathrm{x}$ & $\mathrm{x}$ & 5YR 7/4 & 2,5YR 5/6 & $\mathrm{x}$ & $\mathrm{x}$ & $\mathrm{x}$ & $\mathrm{x}$ & $\mathrm{x}$ & $\mathrm{x}$ & $\mathrm{x}$ & $\mathrm{x}$ & $\mathrm{x}$ & $\mathrm{x}$ & $\mathrm{x}$ & $\mathrm{x}$ & $\mathrm{x}$ & $\mathrm{x}$ & \\
\hline TC 2 & Conj D & 240 & 0 & 0 & 0 & 2 & $3 y 4$ & 2 & 7.9 & 7.0 & 1 & 0 & $\mathrm{x}$ & $\mathrm{x}$ & 2,5 YR $4 / 6$ & 2,5 YR $5 / 6$ & $\mathrm{x}$ & $\mathrm{x}$ & $\mathrm{x}$ & $\mathrm{x}$ & $x$ & $x$ & $x$ & $x$ & $\mathrm{x}$ & $\mathrm{x}$ & $\mathrm{x}$ & $\mathrm{x}$ & $\mathrm{x}$ & $x$ & 5 \\
\hline TC 2 & Conj D & 241 & 0 & 0 & 0 & 2 & $3 y 4$ & 2 & 8.3 & 7.0 & 1 & 0 & $x$ & $x$ & 2,5 YR $4 / 6$ & 2,5 YR $6 / 4$ & $x$ & $x$ & $x$ & $x$ & $x$ & $x$ & $x$ & $x$ & $x$ & $x$ & $x$ & $x$ & $x$ & $x$ & \\
\hline TC 2 & Conj D & 242 & 0 & 0 & 0 & 2 & $3 y 4$ & $3 y 4$ & 5.3 & 5.0 & 1 & 0 & $x$ & $x$ & $2,5 Y R \quad 4 / 6$ & $2,5 Y R \quad 4 / 3$ & $x$ & $x$ & $x$ & $x$ & $x$ & $x$ & $x$ & $x$ & $x$ & $x$ & $x$ & $x$ & $x$ & $x$ & \\
\hline TC 2 & Conj D & 243 & 0 & 0 & 0 & 0 & $3 y 4$ & $3 y 4$ & 9.8 & 6.4 & 1 & 0 & $\mathrm{x}$ & $\mathrm{x}$ & 2,5 YR $4 / 4$ & 2,5YR 4/6 & $\mathrm{x}$ & $\mathrm{x}$ & $\mathrm{x}$ & $\mathrm{x}$ & $x$ & $x$ & $x$ & $x$ & $x$ & $\mathrm{x}$ & $\mathrm{x}$ & $\mathrm{x}$ & $\mathrm{x}$ & $x$ & 5 \\
\hline TC 2 & Conj D & 244 & 0 & 0 & 0 & 0 & $3 y 4$ & 2 & 6.8 & 6.3 & 1 & 0 & $x$ & $x$ & 2,5 YR 4/4 & 2,5 YR 5/6 & $x$ & $x$ & $x$ & $x$ & $x$ & $x$ & $x$ & $x$ & $x$ & $x$ & $x$ & $x$ & $x$ & $x$ & \\
\hline TC 2 & Conj D & 245 & 0 & 0 & 0 & $1 \mathrm{y} 2$ & $3 y 4$ & 2 & 10.7 & 9.3 & 1 & 0 & $x$ & $x$ & 5YR 3/1 & $5 Y R 6 / 6$ & $x$ & $x$ & $x$ & $x$ & $x$ & $x$ & $x$ & $x$ & $x$ & $x$ & $x$ & $x$ & $x$ & $x$ & \\
\hline TC 2 & Conj D & 246 & 0 & 0 & 0 & 1 & $3 y 4$ & 2 & 7.5 & 5.8 & 1 & 0 & $\mathrm{x}$ & $\mathrm{x}$ & $5 Y R 5 / 6,3 / 2$ & $5 Y R 6 / 6$ & $\mathrm{x}$ & $\mathrm{x}$ & $\mathrm{x}$ & $\mathrm{x}$ & $x$ & $x$ & $x$ & $\mathrm{x}$ & $x$ & $\mathrm{x}$ & $\mathrm{x}$ & $\mathrm{x}$ & $x$ & $x$ & 5 \\
\hline TC 2 & Conj D & 247 & 0 & 0 & 0 & 0 & $3 y 6$ & 2 & 6.9 & 6.0 & 1 & 0 & $x$ & $x$ & $2,5 Y R$ 5/6, 3/2 & $2,5 Y R 5 / 6$ & $x$ & $x$ & $x$ & $x$ & $x$ & $x$ & $x$ & $x$ & $x$ & $x$ & $x$ & $x$ & $x$ & $x$ & 3 y 5 \\
\hline TC 2 & Conj D & 248 & 0 & 0 & 0 & 0 & $3 y 4$ & 2 & 12.6 & 7.3 & 1 & 0 & $\mathrm{x}$ & $x$ & 2,5 YR $4 / 3,5$ YR $5 / 3$ & 2,5 YR $6 / 6$ & $\mathrm{x}$ & $\mathrm{x}$ & $\mathrm{x}$ & $\mathrm{x}$ & $x$ & $x$ & $x$ & $x$ & $\mathrm{x}$ & $\mathrm{x}$ & $\mathrm{x}$ & $\mathrm{x}$ & $\mathrm{x}$ & $x$ & 5 \\
\hline TC 2 & Conj D & 249 & 0 & 0 & 0 & 0 & 2 & 2 & 8.1 & 7.0 & 0 & 0 & $\mathrm{x}$ & $\mathrm{x}$ & 5YR 5/4 & $5 Y R 5 / 3$ & $x$ & $\mathrm{x}$ & $x$ & $x$ & $x$ & $x$ & $x$ & $x$ & $x$ & $x$ & $x$ & $x$ & $x$ & $x$ & \\
\hline TC 2 & Conj D & 250 & 4 & 0 & 2 & 0 & 2 & 2 & 5.8 & 4.4 & 0 & 0 & $x$ & $x$ & 2,5 YR $5 / 6$ & 2,5 YR $6 / 6$ & $x$ & $x$ & $x$ & $x$ & $x$ & $x$ & $x$ & $x$ & $x$ & $x$ & $x$ & $x$ & $x$ & $x$ & \\
\hline TC 2 & Conj D & 251 & 0 & 0 & 0 & 0 & 2 & 2 & 6.4 & 5.9 & 0 & 0 & $x$ & $\mathrm{x}$ & 2,5 YR $4 / 4$ & 2,5YR 5/6 & $x$ & $\mathrm{x}$ & $\mathrm{x}$ & $x$ & $x$ & $x$ & $x$ & $x$ & $\mathrm{x}$ & $\mathrm{x}$ & $\mathrm{x}$ & $\mathrm{x}$ & $\mathrm{x}$ & $x$ & \\
\hline TC 2 & Conj D & 252 & 0 & 0 & 0 & 0 & $2 \mathrm{y} 6$ & 2 & 5.0 & 4.3 & 1 & 0 & $\mathrm{x}$ & $x$ & 2,5YR 5/6; 10R 4/4 & 2,5YR 6/6 & $x$ & $x$ & $x$ & $x$ & $x$ & $x$ & $x$ & $x$ & $\mathrm{x}$ & $x$ & $x$ & $x$ & $x$ & $x$ & \\
\hline TC 2 & Conj D & 253 & 4 & 0 & 2 & 2 & $3 y 4$ & 2 & 5.8 & 4.5 & 1 & 0 & $x$ & $x$ & 5YR 6/8 & $5 Y R$ 5/3. 5/4 & $x$ & $x$ & $x$ & $x$ & $x$ & $x$ & $x$ & $x$ & $x$ & $x$ & $x$ & $x$ & $x$ & $x$ & \\
\hline TC 2 & Conj D & 254 & 0 & 0 & 0 & 0 & 2 & 2 & 9.4 & 8.2 & 0 & 0 & $\mathrm{x}$ & $x$ & 2,5YR 5/6 & $5 Y R 6 / 6$ & $\mathrm{x}$ & $\mathrm{x}$ & $\mathrm{x}$ & $x$ & $x$ & $x$ & $x$ & $x$ & $\mathrm{x}$ & $\mathrm{x}$ & $\mathrm{x}$ & $x$ & $\mathrm{x}$ & $x$ & \\
\hline
\end{tabular}




\begin{tabular}{|c|c|c|c|c|c|c|c|c|c|c|c|c|c|c|c|c|c|c|c|c|c|c|c|c|c|c|c|c|c|c|c|}
\hline \multirow[b]{2}{*}{ Sitio } & \multirow[b]{2}{*}{ UP } & \multirow[b]{2}{*}{$\mathrm{FN}^{\circ}$} & \multirow[b]{2}{*}{ Fgto } & \multicolumn{11}{|c|}{ Manufactura } & \multicolumn{2}{|c|}{ Cocción } & \multicolumn{5}{|c|}{ Borde-labio } & \multicolumn{6}{|c|}{ Asa } & \multicolumn{3}{|c|}{ Base } & \multirow[b]{2}{*}{ Alterac } \\
\hline & & & & \begin{tabular}{|l|} 
Tec \\
lev
\end{tabular} & \begin{tabular}{|c|} 
For \\
ma
\end{tabular} & $\begin{array}{l}\text { Mar } \\
\text { cas }\end{array}$ & \begin{tabular}{|l|} 
Sup \\
ext
\end{tabular} & \begin{tabular}{|c|} 
Sup \\
int
\end{tabular} & $\begin{array}{l}\mid \begin{array}{l}\text { Esp } \\
\max \end{array} \\
\end{array}$ & \begin{tabular}{|l|}
$\begin{array}{c}\text { Esp } \\
\text { min }\end{array}$ \\
\end{tabular} & $\begin{array}{l}\text { Deco } \\
\text { pint }\end{array}$ & \begin{tabular}{|l|} 
Deco \\
agreg
\end{tabular} & \begin{tabular}{|c|}
$\begin{array}{c}\text { Moti } \\
\text { vo }\end{array}$ \\
\end{tabular} & Estilo & Color sup ext & Color sup int & Diam & $\begin{array}{l}\text { Lrg } \\
\text { arc }\end{array}$ & \begin{tabular}{c|}
$\%$ \\
$\operatorname{arco}$ \\
\end{tabular} & Direc & $\begin{array}{l}\begin{array}{l}\text { For } \\
\text { ma }\end{array} \\
\end{array}$ & $\begin{array}{l}\text { Lar } \\
\text { go }\end{array}$ & $\begin{array}{c}\text { An } \\
\text { cho }\end{array}$ & Esp & $\begin{array}{l}\text { Sec } \\
\text { ción }\end{array}$ & \begin{tabular}{|c|c} 
In \\
serc \\
\end{tabular} & \begin{tabular}{|l|l|}
$\begin{array}{l}\text { Posi } \\
\text { ción }\end{array}$ \\
\end{tabular} & Diám & \begin{tabular}{|c|}
$\begin{array}{c}\text { Mor } \\
\text { fol }\end{array}$ \\
\end{tabular} & $\begin{array}{c}\text { Uni } \\
\text { ón } \\
\end{array}$ & \\
\hline TC 2 & Conj D & 255 & 0 & 0 & 0 & 0 & $2 \mathrm{y} 4$ & 2 & 7.0 & 6.3 & 1 & 0 & $\mathrm{x}$ & $\mathrm{x}$ & 2,5YR 4/4, 4/1 & 2,5YR 4/4 & $\mathrm{x}$ & $\mathrm{x}$ & $\mathrm{x}$ & $\mathrm{x}$ & $\mathrm{x}$ & $\mathrm{x}$ & $\mathrm{x}$ & $\mathrm{x}$ & $\mathrm{x}$ & $\mathrm{x}$ & $\mathrm{x}$ & $\mathrm{x}$ & $\mathrm{x}$ & $\mathrm{x}$ & \\
\hline TC 2 & Conj D & 256 & 0 & 0 & 0 & 0 & 2 & 2 & 7.6 & 6.6 & 0 & 0 & $x$ & $x$ & 2,5 YR 5/6, 6/6 & 2,5YR 5/6 & $x$ & $x$ & $x$ & $x$ & $x$ & $x$ & $x$ & $x$ & $x$ & $x$ & $x$ & $x$ & $x$ & $x$ & 3 \\
\hline TC 2 & Conj D & 257 & 0 & 0 & 0 & 0 & 2 & 2 & 6.2 & 5.0 & 0 & 0 & $x$ & $x$ & 2,5 YR $6 / 8$ & $2,5 Y R$ 6/8 & $x$ & $x$ & $x$ & $x$ & $x$ & $x$ & $x$ & $x$ & $x$ & $x$ & $x$ & $x$ & $x$ & $x$ & \\
\hline TC 2 & Conj D & 258 & 0 & 0 & 0 & 0 & 3y4 & 2 & 7.8 & 6.0 & 1 & 0 & $\mathrm{x}$ & $\mathrm{x}$ & $2,5 Y R \quad 4 / 4$ & 2,5YR 5/6 & $\mathrm{x}$ & $\mathrm{x}$ & $\mathrm{x}$ & $\mathrm{x}$ & $\mathrm{x}$ & $\mathrm{x}$ & $x$ & $x$ & $\mathrm{x}$ & $\mathrm{x}$ & $\mathrm{x}$ & $\mathrm{x}$ & $\mathrm{x}$ & $\mathrm{x}$ & 5 \\
\hline TC 2 & Conj D & 259 & 0 & 0 & 0 & 0 & 3y4 & 2 & 8.0 & 6.5 & 1 & 0 & $\mathrm{x}$ & $\mathrm{x}$ & 2,5YR 4/4 & 2,5YR 5/6 & $\mathrm{x}$ & $\mathrm{x}$ & $\mathrm{x}$ & $\mathrm{x}$ & $\mathrm{x}$ & $\mathrm{x}$ & $\mathrm{x}$ & $\mathrm{x}$ & $\mathrm{x}$ & $\mathrm{x}$ & $\mathrm{x}$ & $\mathrm{x}$ & $\mathrm{x}$ & $\mathrm{x}$ & 5 \\
\hline TC 2 & Conj D & 260 & 0 & 0 & 0 & 0 & $3 y 4$ & 2 & 7.0 & 6.5 & 1 & 0 & $x$ & $x$ & 2,5 YR 4/4 & $5 Y R 6 / 4$ & $x$ & $x$ & $x$ & $x$ & $x$ & $x$ & $x$ & $x$ & $x$ & $x$ & $x$ & $x$ & $x$ & $x$ & 4 \\
\hline TC 2 & Conj D & 261 & 0 & 0 & 0 & 0 & $3 y 4$ & $3 y 4$ & 6.0 & 5.4 & 1 & 0 & $x$ & $\mathrm{x}$ & 2,5 YR 4/4 & $2,5 Y R \quad 4 / 4$ & $x$ & $x$ & $x$ & $x$ & $x$ & $x$ & $x$ & $x$ & $x$ & $x$ & $x$ & $x$ & $x$ & $x$ & 5 \\
\hline TC 2 & Conj D & 262 & 0 & 0 & 0 & 0 & 2 & 2 & 8.0 & 8.0 & 0 & 0 & $x$ & $x$ & 2,5YR 5/4 & $2,5 Y R$ 5/6 & $x$ & $x$ & $x$ & $x$ & $x$ & $x$ & $x$ & $x$ & $x$ & $x$ & $x$ & $x$ & $x$ & $x$ & 4 \\
\hline TC 2 & Conj D & 263 & 0 & 0 & 0 & 0 & 2 & 2 & 6.6 & 5.3 & 0 & 0 & $x$ & $x$ & $4 / 3$ & $5 / 4$ & $x$ & $x$ & $x$ & $x$ & $x$ & $x$ & $x$ & $x$ & $x$ & $x$ & $x$ & $x$ & $x$ & $x$ & \\
\hline TC 2 & Conj D & 264 & 0 & 0 & 0 & 0 & 2 & 2 & 6.8 & 5.2 & 0 & 0 & $x$ & $x$ & 2,5 YR 5/6 & 2,5 YR 5/6 & $x$ & $x$ & $x$ & $x$ & $x$ & $x$ & $x$ & $x$ & $x$ & $x$ & $x$ & $x$ & $x$ & $x$ & \\
\hline TC 2 & Conj D & 265 & 0 & 0 & 0 & 0 & 2 & 2 & 5.8 & 5.0 & 0 & 0 & $x$ & $x$ & 5YR 6/8 & $5 Y R 6 / 8$ & $x$ & $x$ & $x$ & $x$ & $x$ & $x$ & $x$ & $x$ & $x$ & $x$ & $x$ & $x$ & $x$ & $x$ & \\
\hline TC 2 & Conj D & 266 & 0 & 0 & 0 & 0 & 3 & 2 & 6.2 & 4.9 & 0 & 0 & $x$ & $x$ & $/ 3$ & $5 / 4$ & $x$ & $x$ & $x$ & $x$ & $x$ & $x$ & $x$ & $x$ & $x$ & $x$ & $x$ & $x$ & $x$ & $\mathrm{x}$ & \\
\hline TC 2 & Conj D & 267 & 0 & 0 & 0 & 0 & 2 & 2 & 5.8 & 3.3 & 0 & 0 & $x$ & $x$ & $2,5 Y R \quad 4 / 6$ & 2,5 YR 4/6 & $x$ & $x$ & $x$ & $x$ & $x$ & $x$ & $x$ & $x$ & $x$ & $x$ & $x$ & $x$ & $x$ & $x$ & \\
\hline TC 2 & Conj D & 268 & 0 & 0 & 0 & 0 & 3 & 2 & 7.2 & 5.8 & 0 & 0 & $\mathrm{x}$ & $\mathrm{x}$ & 2,5YR 5/6 & $2,5 Y R$ 6/4 & $\mathrm{x}$ & $\mathrm{x}$ & $\mathrm{x}$ & $\mathrm{x}$ & $\mathrm{x}$ & $\mathrm{x}$ & $\mathrm{x}$ & $\mathrm{x}$ & $\mathrm{x}$ & $\mathrm{x}$ & $\mathrm{x}$ & $\mathrm{x}$ & $\mathrm{x}$ & $\mathrm{x}$ & \\
\hline TC 2 & Conj D & 269 & 0 & 0 & 0 & 0 & 3 & 2 & 5.2 & 4.0 & 0 & 0 & $x$ & $x$ & $\mathrm{R} 5 / 6$ & 2,5YR 5/6 & $x$ & $x$ & $x$ & $x$ & $x$ & $x$ & $x$ & $x$ & $x$ & $x$ & $x$ & $x$ & $x$ & $x$ & \\
\hline TC 2 & Conj D & 270 & 0 & 0 & 0 & 0 & 2 & 2 & 8.7 & 7.0 & 0 & 0 & $x$ & $x$ & 5YR 5/4 & $5 Y R 6 / 4$ & $x$ & $x$ & $x$ & $x$ & $x$ & $x$ & $x$ & $x$ & $x$ & $x$ & $x$ & $x$ & $x$ & $x$ & 4 \\
\hline TC 2 & Conj D & 271 & 0 & 0 & 0 & 0 & $3 y 4$ & 2 & 8.0 & 7.2 & 1 & 0 & $\mathrm{x}$ & $\mathrm{x}$ & 2,5 YR $4 / 3$ & $5 Y R$ 5/3 & $\mathrm{x}$ & $\mathrm{x}$ & $\mathrm{x}$ & $\mathrm{x}$ & $\mathrm{x}$ & $x$ & $\mathrm{x}$ & $\mathrm{x}$ & $\mathrm{x}$ & $\mathrm{x}$ & $\mathrm{x}$ & $\mathrm{x}$ & $\mathrm{x}$ & $\mathrm{x}$ & \\
\hline TC 2 & Conj D & 272 & 0 & 0 & 0 & 0 & 2 & 2 & 5.1 & 3.9 & 0 & 0 & $x$ & $\mathrm{x}$ & 2,5YR 5/6 & 2,5YR 5/6 & $x$ & $x$ & $x$ & $x$ & $x$ & $x$ & $x$ & $x$ & $x$ & $x$ & $x$ & $x$ & $x$ & $x$ & \\
\hline TC 2 & Conj D & 273 & 0 & 0 & 0 & 0 & 2 & 2 & 6.0 & 4.3 & 0 & 0 & $x$ & $x$ & 2,5YR 5/6 & $2,5 Y R$ 4/4 & $x$ & $x$ & $x$ & $x$ & $x$ & $x$ & $x$ & $x$ & $x$ & $x$ & $x$ & $x$ & $x$ & $x$ & 4 \\
\hline TC 2 & Conj D & 274 & 0 & 0 & 0 & 0 & 2 & 2 & 7.0 & 6.8 & 0 & 0 & $\mathrm{x}$ & $\mathrm{x}$ & 2,5YR 5/6 & 5YR 5/4 & $\mathrm{x}$ & $x$ & $\mathrm{x}$ & $\mathrm{x}$ & $\mathrm{x}$ & $\mathrm{x}$ & $\mathrm{x}$ & $\mathrm{x}$ & $\mathrm{x}$ & $x$ & $\mathrm{x}$ & $\mathrm{x}$ & $\mathrm{x}$ & $\mathrm{x}$ & 3 \\
\hline TC 2 & Conj D & 275 & 0 & 0 & 0 & 0 & $3 y 4$ & 2 & 5.3 & 5.0 & 1 & 0 & $x$ & $\mathrm{x}$ & OR $4 / 4$ & $5 Y R 7 / 6$ & $x$ & $x$ & $x$ & $x$ & $x$ & $x$ & $x$ & $x$ & $x$ & $x$ & $x$ & $x$ & $x$ & $x$ & \\
\hline TC 2 & Conj D & 276 & 0 & 0 & 0 & 0 & $3 y 4$ & 2 & 6.6 & 5.4 & 1 & 0 & $x$ & $x$ & 10R $4 / 4$ & $5 Y R$ 5/3 & $x$ & $x$ & $x$ & $x$ & $x$ & $x$ & $x$ & $x$ & $x$ & $x$ & $x$ & $x$ & $x$ & $x$ & \\
\hline TC 2 & Conj E & 277 & 0 & 0 & 0 & 0 & 2 & 2 & 5.0 & 4.0 & 0 & 0 & $x$ & $x$ & 2,5YR 4/4 & 2,5YR 5/4 & $x$ & $x$ & $x$ & $x$ & $x$ & $x$ & $x$ & $x$ & $x$ & $x$ & $x$ & $x$ & $x$ & $x$ & 2 \\
\hline TC 2 & Conj E & 278 & 0 & 0 & 0 & 0 & 2 & 2 & 5.5 & 4.0 & 0 & 0 & $x$ & $\mathrm{x}$ & $2,5 Y R \quad 4 / 4$ & $2,5 Y R$ 5/4 & $x$ & $x$ & $x$ & $x$ & $x$ & $x$ & $x$ & $x$ & $x$ & $x$ & $x$ & $x$ & $x$ & $x$ & 2 \\
\hline TC 2 & Conj E & 279 & 0 & 0 & 0 & 0 & 2 & 2 & 5.5 & 5.2 & 0 & 0 & $x$ & $x$ & $2,5 Y R$ 4/4 & 2,5YR 5/4 & $x$ & $x$ & $x$ & $x$ & $x$ & $x$ & $x$ & $x$ & $x$ & $x$ & $x$ & $x$ & $x$ & $x$ & 2 \\
\hline TC 2 & Conj E & 280 & 0 & 0 & 0 & 0 & 2 & 2 & 4.0 & 3.6 & 0 & 0 & $\mathrm{x}$ & $\mathrm{x}$ & 2,5YR 4/4 & 2,5YR 5/4 & $\mathrm{x}$ & $\mathrm{x}$ & $\mathrm{x}$ & $\mathrm{x}$ & $\mathrm{x}$ & $\mathrm{x}$ & $\mathrm{x}$ & $\mathrm{x}$ & $\mathrm{x}$ & $\mathrm{x}$ & $\mathrm{x}$ & $\mathrm{x}$ & $\mathrm{x}$ & $\mathrm{x}$ & 2 \\
\hline TC 2 & Conj $\mathrm{F}$ & 281 & 1 & 0 & 1 & 0 & $3 y 4$ & $3 y 4$ & 8.1 & 5.6 & 1 & 0 & $x$ & Yavi & $2,5 Y R$ 4/1, 4/2, 3/1 & $2,5 Y R 3 / 4,4 / 6,6 / 6$ & 21.3 & 8 & 12 & 1 & $2 \mathrm{y} 6$ & $x$ & $x$ & $x$ & $x$ & $x$ & $x$ & $x$ & $x$ & $x$ & 1 y 6 \\
\hline TC 2 & Conj F & 282 & 1 & 0 & 1 & 2 & 3y4 & $3 y 4$ & 8.2 & 5.6 & 1 & 0 & $\mathrm{x}$ & Yavi & $2,5 Y R \quad 4 / 4$ & $2,5 Y R$ 3/4, 5/6 & indet & 3 & indet & 1 & $2 \mathrm{y} 6$ & $\mathrm{x}$ & $\mathrm{x}$ & $\mathrm{x}$ & $\mathrm{x}$ & $x$ & $\mathrm{x}$ & $\mathrm{x}$ & $\mathrm{x}$ & $\mathrm{x}$ & 2 \\
\hline TC 2 & Conj $\mathrm{F}$ & 283 & 1 & 0 & 1 & 2 & 2 & $3 y 4$ & 5.2 & 4.4 & 1 & 0 & $\mathrm{x}$ & $\mathrm{x}$ & 2,5YR 5/6 & $2,5 Y R \quad 4 / 4$ & 14.5 & 3.5 & 7.7 & 2 & 2 & $\mathrm{x}$ & $x$ & $x$ & $x$ & $\mathrm{x}$ & $\mathrm{x}$ & $\mathrm{x}$ & $\mathrm{x}$ & $x$ & 4 \\
\hline TC 2 & Conj F & 284 & 1 & 0 & 0 & 0 & 2 & 2 & 5.0 & 4.5 & 0 & 0 & $x$ & $\mathrm{x}$ & $5 Y R 5 / 4$ & 2,5 YR $5 / 4$ & indet & $2.1 \mathrm{i}$ & indet & 1 & 2 & $x$ & $x$ & $x$ & $x$ & $x$ & $x$ & $x$ & $x$ & $x$ & 3 \\
\hline TC 2 & Conj F & 285 & 2 & 0 & 0 & 0 & 3 & 2 & 9.8 & 4.1 & 0 & 0 & $x$ & $x$ & 2,5 YR 5/6, 6/4 & 2,5 YR $6 / 6$ & $x$ & $x$ & $x$ & $x$ & $x$ & $x$ & $x$ & $x$ & $x$ & $x$ & $x$ & 7.5 & 5 & 2 & 3 y 4 \\
\hline TC 2 & Conj $\mathrm{F}$ & 286 & 3 & 0 & 0 & 0 & $2 \mathrm{y} 6$ & 2 & 7 & 5 & 1 & 0 & $\mathrm{x}$ & $\mathrm{x}$ & $10 R \quad 4 / 4$ & 2,5YR 4/1, 4/2, 5/3 & $\mathrm{x}$ & $\mathrm{x}$ & $\mathrm{x}$ & $\mathrm{x}$ & $\mathrm{x}$ & $1,7 \mathrm{fr}$ & 2.3 & 13 & 2 & 1 & 0 & $\mathrm{x}$ & $\mathrm{x}$ & $x$ & 5 \\
\hline TC 2 & Conj $\mathrm{F}$ & 287 & 3 & 0 & 0 & 0 & 2 & 2 & 6.6 & 4.7 & 0 & 0 & $\mathrm{x}$ & Yavi & YR 5/3, 5/4 & 2,5YR 5/6 & $\mathrm{x}$ & $\mathrm{x}$ & $\mathrm{x}$ & $\mathrm{x}$ & $\mathrm{x}$ & $2,3 \mathrm{fr}$ & 2.9 & 13 & 4 & 1 & 0 & $\mathrm{x}$ & $\mathrm{x}$ & $\mathrm{x}$ & \\
\hline TC 2 & Conj F & 288 & 5 & 0 & 3 & 0 & 2 & 2 & 12 & 6 & 0 & 0 & $x$ & $x$ & 2,5YR 5/6, 4/6 & 2,5 YR 5/6 & $x$ & $x$ & $x$ & $x$ & $x$ & 6.5 & 5.5 & $x$ & $x$ & $x$ & $x$ & $x$ & $x$ & $x$ & 2 \\
\hline TC 2 & Conj F & 289 & 0 & 0 & 0 & 1 & 2 & 2 & 6.0 & 4.2 & 0 & 0 & $x$ & $x$ & 2,5 YR 5/6, 4/6 & $5 Y R 4 / 2,4 / 3$ & $x$ & $x$ & $x$ & $x$ & $x$ & $x$ & $x$ & $x$ & $x$ & $x$ & $x$ & $x$ & $x$ & $x$ & 6 \\
\hline TC 2 & Conj $\mathrm{F}$ & 290 & 0 & 0 & 0 & 1 & 2 & 2 & 6.3 & 4.2 & 0 & 0 & $\mathrm{x}$ & $\mathrm{x}$ & 2,5YR 5/6, 4/6 & $5 Y R \quad 4 / 2,4 / 3,5 / 4$ & $\mathrm{x}$ & $\mathrm{x}$ & $\mathrm{x}$ & $\mathrm{x}$ & $\mathrm{x}$ & $\mathrm{x}$ & $\mathrm{x}$ & $\mathrm{x}$ & $\mathrm{x}$ & $\mathrm{x}$ & $\mathrm{x}$ & $\mathrm{x}$ & $\mathrm{x}$ & $\mathrm{x}$ & 6 \\
\hline TC 2 & Conj F & 291 & 0 & 0 & 0 & 1 & 2 & 2 & 4.4 & 4.3 & 0 & 0 & $x$ & $x$ & 2,5 YR $5 / 6,4 / 6$ & $5 Y R \quad 4 / 2,4 / 3$ & $x$ & $x$ & $x$ & $x$ & $x$ & $x$ & $x$ & $x$ & $x$ & $x$ & $x$ & $x$ & $x$ & $x$ & 6 \\
\hline TC 2 & Conj F & 292 & 0 & 0 & 0 & 0 & $2 \mathrm{y} 4$ & 2 & 10.0 & 7.8 & 1 & 0 & $x$ & $x$ & 2,5YR 5/6, 4/3 (eng) & 2,5YR 5/6 & $x$ & $x$ & $x$ & $x$ & $x$ & $x$ & $x$ & $x$ & $x$ & $x$ & $x$ & $x$ & $x$ & $x$ & 5 \\
\hline TC 2 & Conj $\mathrm{F}$ & 293 & 0 & 0 & 0 & 0 & $2 \mathrm{y} 4$ & 2 & 8.4 & 7.6 & 1 & 0 & $\mathrm{x}$ & $\mathrm{x}$ & 2,5YR 5/6, 4/3 (eng) & 2,5YR 5/6 & $\mathrm{x}$ & $\mathrm{x}$ & $\mathrm{x}$ & $\mathrm{x}$ & $\mathrm{x}$ & $\mathrm{x}$ & $\mathrm{x}$ & $\mathrm{x}$ & $\mathrm{x}$ & $\mathrm{x}$ & $\mathrm{x}$ & $\mathrm{x}$ & $\mathrm{x}$ & $\mathrm{x}$ & 5 \\
\hline TC 2 & Conj F & 294 & 0 & 2 & 0 & 2 & 3y4 & 1 & 12.7 & 6.4 & 1 & 0 & $\mathrm{x}$ & Yavi & 2,5 YR $4 / 3$ & 2,5 YR $5 / 4$ & $\mathrm{x}$ & $\mathrm{x}$ & $\mathrm{x}$ & $\mathrm{x}$ & $\mathrm{x}$ & $\mathrm{x}$ & $\mathrm{x}$ & $\mathrm{x}$ & $\mathrm{x}$ & $\mathrm{x}$ & $\mathrm{x}$ & $\mathrm{x}$ & $\mathrm{x}$ & $\mathrm{x}$ & \\
\hline TC 2 & Conj $\mathrm{F}$ & 295 & 0 & 1 & 0 & $1 \mathrm{y} 2$ & 3y4 & 2 & 10.0 & 6.0 & 1 & 0 & $\mathrm{x}$ & $\mathrm{x}$ & $2,5 Y R \quad 4 / 6$ & 2,5 YR $5 / 6,6 / 4$ & $x$ & $\mathrm{x}$ & $\mathrm{x}$ & $\mathrm{x}$ & $\mathrm{x}$ & $\mathrm{x}$ & $\mathrm{x}$ & $x$ & $\mathrm{x}$ & $\mathrm{x}$ & $\mathrm{x}$ & $\mathrm{x}$ & $\mathrm{x}$ & $x$ & 6 \\
\hline
\end{tabular}




\begin{tabular}{|c|c|c|c|c|c|c|c|c|c|c|c|c|c|c|c|c|c|c|c|c|c|c|c|c|c|c|c|c|c|c|c|}
\hline \multirow[b]{2}{*}{ Sitio } & \multirow[b]{2}{*}{ UP } & \multirow[b]{2}{*}{$\mathrm{FN}^{\circ}$} & \multirow[b]{2}{*}{ Fgto } & \multicolumn{11}{|c|}{ Manufactura } & \multicolumn{2}{|c|}{ Cocción } & \multicolumn{5}{|c|}{ Borde-labio } & \multicolumn{6}{|c|}{ Asa } & \multicolumn{3}{|c|}{ Base } & \multirow[b]{2}{*}{ Alterac } \\
\hline & & & & \begin{tabular}{|l|} 
Tec \\
lev
\end{tabular} & $\begin{array}{l}\text { For } \\
\text { ma }\end{array}$ & $\begin{array}{l}\text { Mar } \\
\text { cas }\end{array}$ & \begin{tabular}{|c|} 
Sup \\
ext
\end{tabular} & \begin{tabular}{|c|} 
Sup \\
int
\end{tabular} & $\begin{array}{l}\text { Esp } \\
\max \end{array}$ & \begin{tabular}{|l|} 
Esp \\
min
\end{tabular} & $\begin{array}{c}\text { Deco } \\
\text { pint }\end{array}$ & $\begin{array}{l}\text { Deco } \\
\text { agreg }\end{array}$ & \begin{tabular}{|c|}
$\begin{array}{c}\text { Moti } \\
\text { vo }\end{array}$ \\
\end{tabular} & Estilo & Color sup ext & Color sup int & Diam & $\begin{array}{l}\text { Lrg } \\
\text { arc }\end{array}$ & $\begin{array}{c}\% \\
\text { arco } \\
\end{array}$ & Direc & $\begin{array}{l}\text { For } \\
\text { ma }\end{array}$ & $\begin{array}{c}\text { Lar } \\
\text { go }\end{array}$ & $\begin{array}{c}\text { An } \\
\text { cho }\end{array}$ & Esp & $\begin{array}{l}\text { Sec } \\
\text { ción }\end{array}$ & $\begin{array}{l}\text { In } \\
\text { serc }\end{array}$ & $\mid \begin{array}{l}\text { Posi } \\
\text { ción }\end{array}$ & Diám & $\begin{array}{c}\text { Mor } \\
\text { fol }\end{array}$ & $\begin{array}{c}\text { Uni } \\
\text { ón }\end{array}$ & \\
\hline TC 2 & Conj F & 296 & 0 & 0 & 0 & 0 & $2 \mathrm{y} 4$ & 1 & 7.2 & 4.1 & 1 & 0 & $\mathrm{x}$ & $\mathrm{x}$ & 10R 4/4; 2,5YR 5/6 & $5 Y R 6 / 4$ & $\mathrm{x}$ & $\mathrm{x}$ & $\mathrm{x}$ & $\mathrm{x}$ & $\mathrm{x}$ & $\mathrm{x}$ & $\mathrm{x}$ & $\mathrm{x}$ & $\mathrm{x}$ & $\mathrm{x}$ & $\mathrm{x}$ & $\mathrm{x}$ & $\mathrm{x}$ & $\mathrm{x}$ & 5 \\
\hline TC 2 & Conj $\mathrm{F}$ & 297 & 0 & 0 & 0 & 1 & $3 y 4$ & 2 & 9.0 & 6.3 & 1 & 0 & $\mathrm{x}$ & $\mathrm{x}$ & $10 R \quad 4 / 6$ & $5 Y R 6 / 4$ & $\mathrm{x}$ & $\mathrm{x}$ & $\mathrm{x}$ & $\mathrm{x}$ & $\mathrm{x}$ & $\mathrm{x}$ & $\mathrm{x}$ & $\mathrm{x}$ & $\mathrm{x}$ & $\mathrm{x}$ & $\mathrm{x}$ & $\mathrm{x}$ & $\mathrm{x}$ & $\mathrm{x}$ & 5 \\
\hline TC 2 & Conj F & 298 & 0 & 0 & 0 & 0 & 2 & 2 & 8.0 & 5.9 & 0 & 0 & $x$ & $x$ & 2,5 YR 5/4, 5/6 & $5 Y R 5 / 3$ & $x$ & $x$ & $x$ & $x$ & $x$ & $x$ & $x$ & $x$ & $x$ & $x$ & $x$ & $x$ & $x$ & $x$ & \\
\hline TC 2 & Conj F & 299 & 0 & 0 & 0 & 0 & 2 & 2 & 10.1 & 6.8 & 0 & 0 & $\mathrm{x}$ & $\mathrm{x}$ & 2,5YR 5/6, 4/2 & 2,5YR 5/4, 5/6 & $\mathrm{x}$ & $\mathrm{x}$ & $\mathrm{x}$ & $\mathrm{x}$ & $\mathrm{x}$ & $\mathrm{x}$ & $\mathrm{x}$ & $\mathrm{x}$ & $\mathrm{x}$ & $\mathrm{x}$ & $\mathrm{x}$ & $\mathrm{x}$ & $\mathrm{x}$ & $\mathrm{x}$ & \\
\hline TC 2 & Conj $\mathrm{F}$ & 300 & 0 & 0 & 0 & 0 & 2 & 2 & 7.0 & 6.3 & 0 & 0 & $\mathrm{x}$ & $\mathrm{x}$ & 2,5YR 5/6 & 5YR 5/4 & $\mathrm{x}$ & $\mathrm{x}$ & $\mathrm{x}$ & $\mathrm{x}$ & $\mathrm{x}$ & $\mathrm{x}$ & $\mathrm{x}$ & $\mathrm{x}$ & $\mathrm{x}$ & $\mathrm{x}$ & $\mathrm{x}$ & $\mathrm{x}$ & $\mathrm{x}$ & $\mathrm{x}$ & \\
\hline TC 2 & Conj F & 301 & 0 & 0 & 0 & 0 & $3 y 4$ & 2 & 9.6 & 9.0 & 1 & 0 & $x$ & $x$ & 2,5YR 4/6 & 5YR 4/1 & $x$ & $x$ & $x$ & $x$ & $x$ & $x$ & $x$ & $x$ & $x$ & $x$ & $x$ & $x$ & $x$ & $x$ & 3 \\
\hline TC 2 & Conj F & 302 & 0 & 0 & 0 & 0 & 3у4 4 & $2 \mathrm{y} 6$ & 7.2 & 5.7 & 1 & 0 & $\mathrm{x}$ & $\mathrm{x}$ & 10R $4 / 6$ & 2,5YR5/6; 5YR 7/6 & $\mathrm{x}$ & $\mathrm{x}$ & $\mathrm{x}$ & $\mathrm{x}$ & $\mathrm{x}$ & $\mathrm{x}$ & $\mathrm{x}$ & $\mathrm{x}$ & $\mathrm{x}$ & $\mathrm{x}$ & $\mathrm{x}$ & $\mathrm{x}$ & $\mathrm{x}$ & $\mathrm{x}$ & \\
\hline TC 2 & Conj $\mathrm{F}$ & 303 & 0 & 0 & 0 & 0 & 3y4 & 2 & 7.7 & 7.2 & 1 & 0 & $\mathrm{x}$ & Yavi & 10R $4 / 6$ & 2,5YR 5/4 & $\mathrm{x}$ & $\mathrm{x}$ & $\mathrm{x}$ & $\mathrm{x}$ & $\mathrm{x}$ & $\mathrm{x}$ & $\mathrm{x}$ & $\mathrm{x}$ & $\mathrm{x}$ & $\mathrm{x}$ & $\mathrm{x}$ & $\mathrm{x}$ & $\mathrm{x}$ & $\mathrm{x}$ & \\
\hline TC 2 & Conj F & 304 & 0 & 0 & 0 & 0 & 3 & 2 & 7.8 & 6.8 & 0 & 0 & $x$ & $x$ & 10R 5/6 & 10R $5 / 6$ & $x$ & $\mathrm{x}$ & $x$ & $x$ & $x$ & $x$ & $x$ & $x$ & $\mathrm{x}$ & $x$ & $x$ & $x$ & $x$ & $x$ & \\
\hline TC 2 & Conj F & 305 & 0 & 0 & 0 & 0 & $3 y 4$ & 2 & 7.0 & 6.2 & 1 & 0 & $x$ & $x$ & 5YR 2.5/1 & 2,5YR 5/6 & $\mathrm{x}$ & $\mathrm{x}$ & $\mathrm{x}$ & $\mathrm{x}$ & $\mathrm{x}$ & $\mathrm{x}$ & $\mathrm{x}$ & $\mathrm{x}$ & $\mathrm{x}$ & $\mathrm{x}$ & $\mathrm{x}$ & $\mathrm{x}$ & $\mathrm{x}$ & $\mathrm{x}$ & \\
\hline TC 2 & Conj F & 306 & 0 & 0 & 0 & 0 & 3y4 & 2 & 7.2 & 4.9 & 1 & 0 & $\mathrm{x}$ & $\mathrm{x}$ & $5 Y R$ 5/1, 4/1 & 2,5YR 5/6 & $\mathrm{x}$ & $\mathrm{x}$ & $\mathrm{x}$ & $\mathrm{x}$ & $\mathrm{x}$ & $\mathrm{x}$ & $\mathrm{x}$ & $\mathrm{x}$ & $\mathrm{x}$ & $\mathrm{x}$ & $\mathrm{x}$ & $\mathrm{x}$ & $\mathrm{x}$ & $\mathrm{x}$ & \\
\hline TC 2 & Conj F & 307 & 0 & 0 & 0 & 0 & 2 & 2 & 7.3 & 7.2 & 0 & 0 & $x$ & $x$ & 7,5YR 5/3 & 7,5YR 3/1 & $x$ & $x$ & $x$ & $x$ & $x$ & $x$ & $x$ & $x$ & $x$ & $x$ & $x$ & $x$ & $x$ & $x$ & \\
\hline TC 2 & Conj $\mathrm{F}$ & 308 & 0 & 0 & 0 & 0 & 2 & 2 & 8.0 & 6.5 & 0 & 0 & $\mathrm{x}$ & $x$ & 5YR 5/4 & 2,5YR 5/6 & $\mathrm{x}$ & $\mathrm{x}$ & $\mathrm{x}$ & $\mathrm{x}$ & $\mathrm{x}$ & $\mathrm{x}$ & $\mathrm{x}$ & $x$ & $\mathrm{x}$ & $\mathrm{x}$ & $\mathrm{x}$ & $\mathrm{x}$ & $\mathrm{x}$ & $\mathrm{x}$ & \\
\hline TC 2 & Conj F & 309 & 0 & 0 & 0 & 0 & 3 & 2 & 7.0 & 5.1 & 0 & 0 & $\mathrm{x}$ & $\mathrm{x}$ & 2,5YR 4/4 & 2,5YR 5/4 & $\mathrm{x}$ & $\mathrm{x}$ & $\mathrm{x}$ & $\mathrm{x}$ & $\mathrm{x}$ & $\mathrm{x}$ & $\mathrm{x}$ & $\mathrm{x}$ & $\mathrm{x}$ & $\mathrm{x}$ & $\mathrm{x}$ & $\mathrm{x}$ & $\mathrm{x}$ & $\mathrm{x}$ & \\
\hline TC 2 & Conj $\mathrm{F}$ & 310 & 0 & 0 & 0 & 0 & 2 & $2 \mathrm{y} 4$ & 4.6 & 3.8 & 1 & 0 & franja & $\mathrm{x}$ & 2,5YR 5/6 & 2,5YR5/6; 10R 4/6 & $\mathrm{x}$ & $\mathrm{x}$ & $\mathrm{x}$ & $\mathrm{x}$ & $\mathrm{x}$ & $\mathrm{x}$ & $\mathrm{x}$ & $\mathrm{x}$ & $\mathrm{x}$ & $\mathrm{x}$ & $\mathrm{x}$ & $\mathrm{x}$ & $\mathrm{x}$ & $\mathrm{x}$ & 3 \\
\hline TC 2 & Conj F & 311 & 0 & 0 & 0 & 0 & 2 & $2 \mathrm{y} 4$ & 4.7 & 3.8 & 1 & 0 & franja & $\mathrm{x}$ & 2,5YR 5/6 & 2,5YR5/6; 10R 4/6 & $\mathrm{x}$ & $\mathrm{x}$ & $\mathrm{x}$ & $\mathrm{x}$ & $\mathrm{x}$ & $\mathrm{x}$ & $\mathrm{x}$ & $\mathrm{x}$ & $\mathrm{x}$ & $\mathrm{x}$ & $\mathrm{x}$ & $\mathrm{x}$ & $\mathrm{x}$ & $\mathrm{x}$ & 3 \\
\hline TC 2 & Conj F & 312 & 0 & 0 & 0 & 0 & $3 y 4$ & 2 & 4.6 & 3.6 & 1 & 0 & $x$ & $x$ & 10R $4 / 4$ & 2,5YR 4/6 & $\mathrm{x}$ & $\mathrm{x}$ & $\mathrm{x}$ & $\mathrm{x}$ & $\mathrm{x}$ & $\mathrm{x}$ & $\mathrm{x}$ & $\mathrm{x}$ & $\mathrm{x}$ & $\mathrm{x}$ & $\mathrm{x}$ & $\mathrm{x}$ & $\mathrm{x}$ & $\mathrm{x}$ & 2 \\
\hline TC 2 & Conj F & 313 & 0 & 0 & 0 & 0 & 3 & 2 & 5.7 & 5.2 & 0 & 0 & $x$ & $x$ & 2,5YR 5/6 & 2,5 YR $5 / 3$ & $x$ & $x$ & $x$ & $x$ & $x$ & $x$ & $x$ & $x$ & $x$ & $x$ & $x$ & $x$ & $x$ & $x$ & \\
\hline TC 2 & Conj F & 314 & 0 & 0 & 0 & 0 & 3y4 & 2 & 9.4 & 7.9 & 1 & 0 & $\mathrm{x}$ & $\mathrm{x}$ & 2,5 YR $4 / 4$ & $5 Y R 6 / 6$ & $\mathrm{x}$ & $\mathrm{x}$ & $\mathrm{x}$ & $\mathrm{x}$ & $\mathrm{x}$ & $\mathrm{x}$ & $\mathrm{x}$ & $\mathrm{x}$ & $\mathrm{x}$ & $\mathrm{x}$ & $\mathrm{x}$ & $\mathrm{x}$ & $\mathrm{x}$ & $\mathrm{x}$ & 5 \\
\hline TC 2 & Conj F & 315 & 0 & 0 & 0 & 0 & $3 y 4$ & $3,4 \mathrm{y} 6$ & 5.4 & 4.5 & 2 & 0 & $\begin{array}{c}\begin{array}{c}\text { Came } \\
\text { lido }\end{array} \\
\end{array}$ & $\begin{array}{c}\text { inka } \\
\text { pacajes }\end{array}$ & 10R $4 / 6$ & 10R 4/6, 2,5/1 & $\mathrm{x}$ & $\mathrm{x}$ & $\mathrm{x}$ & $\mathrm{x}$ & $\mathrm{x}$ & $\mathrm{x}$ & $\mathrm{x}$ & $\mathrm{x}$ & $\mathrm{x}$ & $\mathrm{x}$ & $\mathrm{x}$ & $\mathrm{x}$ & $\mathrm{x}$ & $\mathrm{x}$ & \\
\hline TC 2 & Conj F & 316 & 0 & 0 & 0 & 0 & 3 & 2 & 8.3 & 7.4 & 0 & 0 & $x$ & $x$ & 2,5YR 5/6 & 2,5YR 5/6 & $x$ & $x$ & $x$ & $x$ & $x$ & $x$ & $x$ & $x$ & $x$ & $x$ & $x$ & $x$ & $x$ & $x$ & \\
\hline TC 2 & Conj F & 317 & 0 & 0 & 0 & 0 & 3y4 & 2 & 7.5 & 6.2 & 1 & 0 & $\mathrm{x}$ & $\mathrm{x}$ & 10R $4 / 4$ & 2,5YR 5/6 & $\mathrm{x}$ & $\mathrm{x}$ & $\mathrm{x}$ & $\mathrm{x}$ & $\mathrm{x}$ & $\mathrm{x}$ & $\mathrm{x}$ & $\mathrm{x}$ & $\mathrm{x}$ & $\mathrm{x}$ & $\mathrm{x}$ & $\mathrm{x}$ & $\mathrm{x}$ & $\mathrm{x}$ & \\
\hline TC 2 & Conj $\mathrm{F}$ & 318 & 0 & 0 & 0 & 0 & 11 & 2y11 & 6.0 & 4.8 & 1 & 0 & $\mathrm{x}$ & Poshisp & $5 Y R 8 / 4$ & $5 Y 8 / 4 ; 2,5 Y R$ 5/6 & $\mathrm{x}$ & $\mathrm{x}$ & $\mathrm{x}$ & $\mathrm{x}$ & $\mathrm{x}$ & $\mathrm{x}$ & $\mathrm{x}$ & $\mathrm{x}$ & $\mathrm{x}$ & $\mathrm{x}$ & $\mathrm{x}$ & $\mathrm{x}$ & $\mathrm{x}$ & $\mathrm{x}$ & \\
\hline TC 2 & Terraza & 319 & 1 & 0 & 1 & 1 & 11 & 11 & 10.0 & 6.4 & 2 & 0 & $\mathrm{x}$ & Poshisp & $5 Y R \quad 4 / 4 ; 5 Y 7 / 2$ & 5YR8/2,5/2;5YR4/4 & 18 & 4.9 & 8.8 & 1 & $1 \mathrm{y} 6$ & $\mathrm{x}$ & $\mathrm{x}$ & $\mathrm{x}$ & $\mathrm{x}$ & $\mathrm{x}$ & $\mathrm{x}$ & $\mathrm{x}$ & $\mathrm{x}$ & $\mathrm{x}$ & 5 \\
\hline TC 2 & Terraza & 320 & 1 & 0 & 2 & 0 & 2 & 3 & 7.8 & 5.8 & 0 & 0 & $x$ & $x$ & 2,5YR 5/6 & $2,5 Y R \quad 4 / 4$ & indet & 2.2 & indet & $\begin{array}{l}t \\
1\end{array}$ & 2 & $x$ & $x$ & $x$ & $x$ & $x$ & $x$ & $x$ & $x$ & $x$ & \\
\hline TC 2 & Terraza & 321 & 1 & 0 & 0 & 0 & 3y4 & $3 y 4$ & 6.0 & 5.5 & 1 & 0 & $\mathrm{x}$ & $\mathrm{x}$ & 2,5YR 5/6 & 2,5YR 4/6 & indet & 2.2 & indet & $\begin{array}{l}\mathrm{t} \\
\end{array}$ & 2 & $\mathrm{x}$ & $\mathrm{x}$ & $\mathrm{x}$ & $\mathrm{x}$ & $\mathrm{x}$ & $\mathrm{x}$ & $\mathrm{x}$ & $\mathrm{x}$ & $\mathrm{x}$ & 3 \\
\hline TC 2 & Terraza & 322 & 1 & 0 & 0 & 0 & 2 & 2 & 5.9 & 5.1 & 0 & 0 & $\mathrm{x}$ & $\mathrm{x}$ & $5 Y R$ 5/4 & $5 Y R 4 / 4$ & indet & 2.2 & indet & $t \mid 1$ & 2 & $\mathrm{x}$ & $\mathrm{x}$ & $\mathrm{x}$ & $\mathrm{x}$ & $\mathrm{x}$ & $\mathrm{x}$ & $\mathrm{x}$ & $\mathrm{x}$ & $\mathrm{x}$ & \\
\hline TC 2 & Terraza & 323 & 2 & 0 & 0 & 1 & 3 & 2 & 9.0 & 6.8 & 0 & 0 & $x$ & $x$ & 5YR 4/4 & 5YR 4/3 & $x$ & $\mathrm{x}$ & $x$ & $x$ & $x$ & $x$ & $x$ & $x$ & $x$ & $x$ & $x$ & 5 & 5 & 2 & 3 \\
\hline TC 2 & Terraza & 324 & 3 & 0 & 0 & 0 & $3 y 4$ & 2 & 11 & 9.3 & 1 & 0 & $x$ & $x$ & 10R $4 / 4$ & 2,5YR 5/6 & $x$ & $x$ & $x$ & $x$ & $x$ & $3,4 \mathrm{fr}$ & 2.8 & 10 & 4 & 0 & 0 & $x$ & $x$ & $x$ & \\
\hline TC 2 & Terraza & 325 & 5 & 0 & 3 & 0 & 2 & 2 & 6.8 & 6.7 & 0 & 0 & $\mathrm{x}$ & $\mathrm{x}$ & 5YR 5/4 & 5YR 5/4 & 3 & 3.2 & 36 & $\mathrm{x}$ & $\mathrm{x}$ & $\mathrm{x}$ & $\mathrm{x}$ & $\mathrm{x}$ & $\mathrm{x}$ & $\mathrm{x}$ & $\mathrm{x}$ & $\mathrm{x}$ & $\mathrm{x}$ & $\mathrm{x}$ & \\
\hline TC 2 & Terraza & 326 & 5 & 0 & 3 & 0 & 2 & 2 & 7 & 6.4 & 0 & 0 & $\mathrm{x}$ & $\mathrm{x}$ & 5YR 5/4 & 5YR 5/4 & 3 & 2.1 & 22 & $\mathrm{x}$ & $x$ & $\mathrm{x}$ & $\mathrm{x}$ & $\mathrm{x}$ & $\mathrm{x}$ & $\mathrm{x}$ & $\mathrm{x}$ & $\mathrm{x}$ & $\mathrm{x}$ & $\mathrm{x}$ & \\
\hline TC 2 & Terraza & 327 & 0 & 0 & 0 & 1 & $3 y 4$ & 2 & 6.1 & 5.0 & 1 & 0 & $x$ & $\mathrm{x}$ & 10R $4 / 6$ & $2,5 Y R \quad 4 / 3$ & $x$ & $\mathrm{x}$ & $x$ & $x$ & $x$ & $x$ & $x$ & $\mathrm{x}$ & $x$ & $x$ & $x$ & $x$ & $x$ & $x$ & \\
\hline TC 2 & Terraza & 328 & 0 & 0 & 0 & 0 & 3 & 2 & 11.2 & 5.8 & 0 & 0 & $\mathrm{x}$ & $\mathrm{x}$ & $5 Y R$ 4/1, 4/2 & 7,5 YR 5/2, 5/3 & $\mathrm{x}$ & $\mathrm{x}$ & $\mathrm{x}$ & $\mathrm{x}$ & $\mathrm{x}$ & $\mathrm{x}$ & $\mathrm{x}$ & $\mathrm{x}$ & $\mathrm{x}$ & $\mathrm{x}$ & $\mathrm{x}$ & $\mathrm{x}$ & $\mathrm{x}$ & $\mathrm{x}$ & 3 \\
\hline TC 2 & Terraza & 329 & 0 & 0 & 0 & 0 & 2 & 2 & 8.0 & 5.1 & 0 & 0 & $x$ & $x$ & 10R 4/6, 5/6 & 2,5YR 5/6 & $x$ & $\mathrm{x}$ & $x$ & $x$ & $x$ & $x$ & $x$ & $x$ & $x$ & $x$ & $x$ & $x$ & $x$ & $\mathrm{x}$ & \\
\hline TC 2 & Terraza & 330 & 0 & 0 & 0 & 0 & 3y6 & 2 & 7.9 & 6.6 & 1 & 0 & $\mathrm{x}$ & Yavi & 10R 5/6 & $5 Y R 6 / 6$ & $\mathrm{x}$ & $\mathrm{x}$ & $\mathrm{x}$ & $\mathrm{x}$ & $\mathrm{x}$ & $\mathrm{x}$ & $\mathrm{x}$ & $\mathrm{x}$ & $\mathrm{x}$ & $\mathrm{x}$ & $\mathrm{x}$ & $\mathrm{x}$ & $\mathrm{x}$ & $\mathrm{x}$ & \\
\hline TC 2 & Terraza & 331 & 0 & 0 & 0 & 0 & 3 & 2 & 8.2 & 7.5 & 0 & 0 & $\mathrm{x}$ & $\mathrm{x}$ & 2,5 YR 4/2, 4/3 & $\mathrm{N} 4 /, 3 /$ & $\mathrm{x}$ & $\mathrm{x}$ & $\mathrm{x}$ & $\mathrm{x}$ & $\mathrm{x}$ & $\mathrm{x}$ & $\mathrm{x}$ & $\mathrm{x}$ & $\mathrm{x}$ & $\mathrm{x}$ & $\mathrm{x}$ & $\mathrm{x}$ & $\mathrm{x}$ & $\mathrm{x}$ & 3 \\
\hline TC 2 & Terraza & 332 & 0 & 0 & 0 & 1 & 3y4 & 2 & 6.5 & 4.9 & 1 & 0 & $\mathrm{x}$ & $\mathrm{x}$ & $2,5 Y R 3 / 1,4 / 4$ & 5YR 5/4 & $\mathrm{x}$ & $\mathrm{x}$ & $\mathrm{x}$ & $\mathrm{x}$ & $\mathrm{x}$ & $\mathrm{x}$ & $\mathrm{x}$ & $\mathrm{x}$ & $\mathrm{x}$ & $\mathrm{x}$ & $\mathrm{x}$ & $\mathrm{x}$ & $\mathrm{x}$ & $\mathrm{x}$ & \\
\hline TC 2 & Terraza & 333 & 0 & 0 & 0 & 0 & $3 y 4$ & 2 & 7.5 & 6.4 & 1 & 0 & $x$ & $x$ & 2,5YR 4/4 & 2,5YR 5/6 & $x$ & $x$ & $x$ & $x$ & $x$ & $x$ & $x$ & $x$ & $\mathrm{x}$ & $\mathrm{x}$ & $x$ & $\mathrm{x}$ & $x$ & $x$ & 3 y 5 \\
\hline TC 2 & Terraza & 334 & 0 & 0 & 0 & 0 & $3,4 \mathrm{y} 6$ & 2 & 7.3 & 5.3 & 2 & 0 & indet & $x$ & 10R 4/6, 2,5/1 & 5YR 4/4 & $x$ & $x$ & $x$ & $x$ & $x$ & $x$ & $x$ & $x$ & $x$ & $x$ & $x$ & $x$ & $x$ & $\mathrm{x}$ & 5 \\
\hline TC 2 & Terraza & 335 & 0 & 0 & 0 & 2 & 3y4 & 2 & 7.9 & 6.1 & 1 & 0 & $\mathrm{x}$ & $\mathrm{x}$ & 2,5 YR 4/2 & 2,5YR 5/6 & $\mathrm{x}$ & $\mathrm{x}$ & $\mathrm{x}$ & $\mathrm{x}$ & $\mathrm{x}$ & $\mathrm{x}$ & $\mathrm{x}$ & $\mathrm{x}$ & $\mathrm{x}$ & $\mathrm{x}$ & $\mathrm{x}$ & $\mathrm{x}$ & $\mathrm{x}$ & $\mathrm{x}$ & \\
\hline
\end{tabular}




\begin{tabular}{|c|c|c|c|c|c|c|c|c|c|c|c|c|c|c|c|c|c|c|c|c|c|c|c|c|c|c|c|c|c|c|c|}
\hline \multirow[b]{2}{*}{ Sitio } & \multirow[b]{2}{*}{ UP } & \multirow[b]{2}{*}{$\mathrm{FN}^{\circ}$} & \multirow[b]{2}{*}{ Fgto } & \multicolumn{11}{|c|}{ Manufactura } & \multicolumn{2}{|c|}{ Cocción } & \multicolumn{5}{|c|}{ Borde-labio } & \multicolumn{6}{|c|}{ Asa } & \multicolumn{3}{|c|}{ Base } & \multirow[b]{2}{*}{ Alterac } \\
\hline & & & & $\begin{array}{l}\text { Tec } \\
\text { lev }\end{array}$ & $\begin{array}{l}\text { For } \\
\text { ma }\end{array}$ & $\begin{array}{l}\text { Mar } \\
\text { cas }\end{array}$ & $\begin{array}{l}\text { Sup } \\
\text { ext }\end{array}$ & $\begin{array}{c}\text { Sup } \\
\text { int }\end{array}$ & $\begin{array}{l}\text { Esp } \\
\text { max }\end{array}$ & $\begin{array}{l}\text { Esp } \\
\min \end{array}$ & $\begin{array}{l}\text { Deco } \\
\text { pint }\end{array}$ & $\begin{array}{l}\text { Deco } \\
\text { agreg }\end{array}$ & \begin{tabular}{|c|} 
Moti \\
vo
\end{tabular} & Estilo & Color sup ext & Color sup int & Diam & $\begin{array}{l}\text { Lrg } \\
\text { arc }\end{array}$ & $\begin{array}{c}\% \\
\text { arco } \\
\end{array}$ & Direc & $\begin{array}{l}\begin{array}{l}\text { For } \\
\text { ma }\end{array} \\
\end{array}$ & $\begin{array}{c}\text { Lar } \\
\text { go }\end{array}$ & $\begin{array}{c}\text { An } \\
\text { cho }\end{array}$ & Esp & $\begin{array}{l}\text { Sec } \\
\text { ción }\end{array}$ & $\begin{array}{l}\text { In } \\
\text { serc }\end{array}$ & $\begin{array}{l}\begin{array}{l}\text { Posi } \\
\text { ción }\end{array} \\
\end{array}$ & \begin{tabular}{l|l} 
niám \\
\end{tabular} & $n \begin{array}{c}\text { Mor } \\
\text { fol }\end{array}$ & $\begin{array}{l}\mid \begin{array}{l}\text { Uni } \\
\text { ín }\end{array} \\
\end{array}$ & \\
\hline TC 2 & Terraza & 336 & 0 & 0 & 0 & 0 & $3 y 4$ & 2 & 7.0 & 6.7 & 1 & 0 & $\mathrm{x}$ & $\mathrm{x}$ & 2,5YR 5/6 & 2,5YR 5/6 & $\mathrm{x}$ & $\mathrm{x}$ & $x$ & $\mathrm{x}$ & $x$ & $x$ & $x$ & $\mathrm{x}$ & $\mathrm{x}$ & $x$ & $\mathrm{x}$ & $\mathrm{x}$ & $\mathrm{x}$ & $x$ & \\
\hline TC 2 & Terraza & 337 & 0 & 0 & 0 & 0 & 3y4 & 2 & 5.8 & 5.1 & 1 & 0 & $\mathrm{x}$ & $\mathrm{x}$ & 10R $4 / 6$ & 2,5YR 5/6 & $\mathrm{x}$ & $\mathrm{x}$ & $\mathrm{x}$ & $\mathrm{x}$ & $\mathrm{x}$ & $\mathrm{x}$ & $x$ & $\mathrm{x}$ & $\mathrm{x}$ & $\mathrm{x}$ & $\mathrm{x}$ & $\mathrm{x}$ & $\mathrm{x}$ & $\mathrm{x}$ & \\
\hline TC 2 & Terraza & 338 & 0 & 0 & 0 & 0 & 3y4 & 2 & 6.0 & 5.5 & 1 & 0 & $\mathrm{x}$ & $x$ & 2,5YR 5/6 & 2,5YR 4/4 & $\mathrm{x}$ & $\mathrm{x}$ & $\mathrm{x}$ & $x$ & $x$ & $x$ & $x$ & $\mathrm{x}$ & $\mathrm{x}$ & $\mathrm{x}$ & $\mathrm{x}$ & $\mathrm{x}$ & $\mathrm{x}$ & $\mathrm{x}$ & \\
\hline TC 2 & Terraza & 339 & 0 & 0 & 0 & 0 & 3y4 & 2 & 6.0 & 4.6 & 1 & 0 & $\mathrm{x}$ & $\mathrm{x}$ & 10R $4 / 6$ & 2,5YR 5/6 & $\mathrm{x}$ & $\mathrm{x}$ & $\mathrm{x}$ & $\mathrm{x}$ & $x$ & $\mathrm{x}$ & $x$ & $\mathrm{x}$ & $\mathrm{x}$ & $\mathrm{x}$ & $\mathrm{x}$ & $\mathrm{x}$ & $\mathrm{x}$ & $\mathrm{x}$ & 5 \\
\hline TC 2 & Terraza & 340 & 0 & 0 & 0 & 0 & 6 & 2 & 6.5 & 5.2 & 1 & 0 & indet & $\mathrm{x}$ & $2,5 Y R 3 / 1,5 / 6$ & $5 Y R$ 4/4 & $\mathrm{x}$ & $\mathrm{x}$ & $\mathrm{x}$ & $\mathrm{x}$ & $\mathrm{x}$ & $\mathrm{x}$ & $\mathrm{x}$ & $\mathrm{x}$ & $\mathrm{x}$ & $\mathrm{x}$ & $\mathrm{x}$ & $\mathrm{x}$ & $\mathrm{x}$ & $\mathrm{x}$ & 5 \\
\hline TC 2 & Terraza & 341 & 0 & 0 & 0 & 0 & $3 y 4$ & 2 & 6.4 & 6.0 & 1 & 0 & $\mathrm{x}$ & $\mathrm{x}$ & 2,5 YR $4 / 4$ & 5YR 6/6 & $x$ & $\mathrm{x}$ & $x$ & $x$ & $x$ & $x$ & $x$ & $\mathrm{x}$ & $\mathrm{x}$ & $x$ & $\mathrm{x}$ & $x$ & $x$ & $x$ & \\
\hline TC 2 & Terraza & 342 & 0 & 0 & 0 & 0 & 3y4 & 2 & 6.6 & 5.4 & 1 & 0 & $x$ & $x$ & 10R $4 / 4$ & 5YR 5/4 & $\mathrm{x}$ & $x$ & $\mathrm{x}$ & $x$ & $x$ & $x$ & $x$ & $x$ & $x$ & $x$ & $x$ & $\mathrm{x}$ & $x$ & $x$ & 3 \\
\hline TC 2 & Terraza & 343 & 0 & 0 & 0 & 0 & 3 & 2 & 5.8 & 5.4 & 0 & 0 & $x$ & $\mathrm{x}$ & 2,5YR 4/4 & 5YR 5/2 & $\mathrm{x}$ & $x$ & $\mathrm{x}$ & $x$ & $\mathrm{x}$ & $x$ & $\mathrm{x}$ & $x$ & $\mathrm{x}$ & $x$ & $\mathrm{x}$ & $\mathrm{x}$ & $\mathrm{x}$ & $x$ & 3 \\
\hline TC 2 & Terraza & 344 & 0 & 0 & 0 & 0 & 3 & 2 & 6.6 & 5.3 & 0 & 0 & $\mathrm{x}$ & $x$ & 2,5YR 4/4 & 2,5YR 5/4 & $\mathrm{x}$ & $\mathrm{x}$ & $x$ & $x$ & $x$ & $x$ & $x$ & $x$ & $x$ & $\mathrm{x}$ & $\mathrm{x}$ & $x$ & $x$ & $x$ & \\
\hline TC 2 & Terraza & 345 & 0 & 0 & 0 & 0 & $3 y 4$ & 2 & 5.3 & 4.9 & 1 & 0 & $x$ & $x$ & 2,5 YR $4 / 3$ & 2,5 YR $5 / 6$ & $\mathrm{x}$ & $\mathrm{x}$ & $\mathrm{x}$ & $x$ & $x$ & $x$ & $x$ & $x$ & $x$ & $\mathrm{x}$ & $x$ & $x$ & $x$ & $x$ & \\
\hline TC 2 & Terraza & 346 & 0 & 0 & 0 & 0 & 3 & 2 & 7.3 & 5.8 & 0 & 0 & $x$ & $x$ & 2,5 YR 4/4 & 5YR 5/4 & $x$ & $x$ & $x$ & $x$ & $x$ & $x$ & $x$ & $x$ & $x$ & $x$ & $x$ & $x$ & $x$ & $x$ & 3 \\
\hline TC 2 & Terraza & 347 & 0 & 0 & 0 & 0 & $2 y 4$ & 2 & 5.6 & 4.7 & 1 & 0 & $\mathrm{x}$ & $x$ & 10R 4/4; 2,5YR 5/6 & 2,5YR 5/6 & $\mathrm{x}$ & $\mathrm{x}$ & $\mathrm{x}$ & $\mathrm{x}$ & $x$ & $\mathrm{x}$ & $\mathrm{x}$ & $\mathrm{x}$ & $\mathrm{x}$ & $\mathrm{x}$ & $\mathrm{x}$ & $\mathrm{x}$ & $\mathrm{x}$ & $\mathrm{x}$ & 5 \\
\hline TC 2 & Terraza & 348 & 0 & 0 & 0 & 0 & $3 y 4$ & 2 & 6.2 & 5.2 & 1 & 0 & $x$ & $x$ & 2,5 YR 4/4 & 2,5 YR $5 / 6$ & $x$ & $x$ & $x$ & $x$ & $x$ & $x$ & $x$ & $x$ & $x$ & $x$ & $x$ & $x$ & $x$ & $x$ & 5 \\
\hline TC 2 & Terraza & 349 & 0 & 0 & 0 & 0 & $3 y 4$ & 2 & 6.0 & 5.9 & 1 & 0 & $x$ & $x$ & 2,5 YR 4/4 & 5YR 5/4 & $x$ & $x$ & $x$ & $x$ & $x$ & $x$ & $x$ & $x$ & $x$ & $x$ & $x$ & $x$ & $x$ & $x$ & 3 \\
\hline TC 2 & Terraza & 350 & 0 & 0 & 0 & 0 & 2 & 2 & 8.2 & 7.0 & 0 & 0 & $\mathrm{x}$ & $\mathrm{x}$ & $2,5 Y R$ 5/4, 4/1 & 2,5YR 5/4 & $\mathrm{x}$ & $\mathrm{x}$ & $\mathrm{x}$ & $\mathrm{x}$ & $\mathrm{x}$ & $\mathrm{x}$ & $\mathrm{x}$ & $\mathrm{x}$ & $\mathrm{x}$ & $\mathrm{x}$ & $\mathrm{x}$ & $\mathrm{x}$ & $\mathrm{x}$ & $\mathrm{x}$ & \\
\hline TC 2 & Terraza & 351 & 0 & 0 & 0 & 0 & 2 & 2 & 9.0 & 6.6 & 0 & 0 & $x$ & $x$ & 5YR 5/4 & 5YR 5/4 & $x$ & $x$ & $x$ & $x$ & $x$ & $x$ & $x$ & $x$ & $x$ & $x$ & $x$ & $x$ & $x$ & $x$ & \\
\hline TC 2 & Terraza & 352 & 0 & 0 & 0 & 0 & 2 & 2 & 6.5 & 5.8 & 0 & 0 & $\mathrm{x}$ & $\mathrm{x}$ & $5 Y R 4 / 2$ & $2,5 Y R$ 6/6 & $\mathrm{x}$ & $\mathrm{x}$ & $\mathrm{x}$ & $\mathrm{x}$ & $x$ & $\mathrm{x}$ & $\mathrm{x}$ & $\mathrm{x}$ & $\mathrm{x}$ & $\mathrm{x}$ & $\mathrm{x}$ & $\mathrm{x}$ & $\mathrm{x}$ & $x$ & 3 \\
\hline TC 2 & Terraza & 353 & 0 & 0 & 0 & 0 & 2 & 2 & 6.7 & 5.5 & 0 & 0 & $x$ & $x$ & 2,5YR 5/6 & 2,5YR 5/6 & $x$ & $x$ & $x$ & $x$ & $x$ & $x$ & $x$ & $x$ & $x$ & $x$ & $x$ & $x$ & $x$ & $x$ & 3 \\
\hline TC 2 & Terraza & 354 & 0 & 0 & 0 & 0 & 2 & 2 & 6.7 & 6.5 & 0 & 0 & $x$ & $x$ & $5 Y R$ 5/1, 5/2 & 5YR 5/4 & $x$ & $x$ & $x$ & $x$ & $x$ & $x$ & $x$ & $x$ & $x$ & $x$ & $x$ & $x$ & $x$ & $x$ & \\
\hline TC 2 & Terraza & 355 & 0 & 0 & 0 & 0 & 2 & 2 & 6.4 & 6.1 & 0 & 0 & $\mathrm{x}$ & $\mathrm{x}$ & 5YR 5/4 & $5 Y R 4 / 2$ & $\mathrm{x}$ & $\mathrm{x}$ & $\mathrm{x}$ & $\mathrm{x}$ & $x$ & $x$ & $x$ & $\mathrm{x}$ & $\mathrm{x}$ & $\mathrm{x}$ & $\mathrm{x}$ & $\mathrm{x}$ & $\mathrm{x}$ & $\mathrm{x}$ & \\
\hline TC 2 & Terraza & 356 & 0 & 0 & 0 & 0 & 2 & 2 & 6.9 & 6.0 & 0 & 0 & $x$ & $x$ & N 2,5/ & 2,5YR 6/4 & $x$ & $x$ & $x$ & $x$ & $x$ & $x$ & $x$ & $x$ & $x$ & $x$ & $x$ & $x$ & $x$ & $x$ & 3 \\
\hline TC 2 & Terraza & 357 & 0 & 0 & 0 & 0 & 2 & 2 & 7.5 & 6.3 & 0 & 0 & $x$ & $x$ & 2,5YR 5/6 & 2,5YR 5/6 & $x$ & $x$ & $x$ & $x$ & $x$ & $x$ & $x$ & $x$ & $x$ & $x$ & $x$ & $x$ & $x$ & $x$ & \\
\hline TC 2 & Terraza & 358 & 0 & 0 & 0 & 0 & 2 & 2 & 6.4 & 4.8 & 0 & 0 & $\mathrm{x}$ & $\mathrm{x}$ & 2,5YR 5/6 & 2,5YR 5/6 & $\mathrm{x}$ & $\mathrm{x}$ & $\mathrm{x}$ & $x$ & $x$ & $x$ & $x$ & $x$ & $x$ & $\mathrm{x}$ & $x$ & $x$ & $x$ & $x$ & \\
\hline TC 2 & Terraza & 359 & 0 & 0 & 0 & 0 & 2 & 2 & 6.5 & 5.9 & 0 & 0 & $x$ & $x$ & 2,5 YR 5/6 & 2,5 YR $5 / 6$ & $x$ & $x$ & $x$ & $x$ & $x$ & $x$ & $x$ & $x$ & $x$ & $x$ & $x$ & $x$ & $x$ & $x$ & \\
\hline TC 2 & Terraza & 360 & 0 & 0 & 0 & 0 & 2 & 2 & 5.3 & 5.0 & 0 & 0 & $x$ & $x$ & 2,5 YR $5 / 6$ & 2,5 YR $6 / 6$ & $x$ & $x$ & $x$ & $x$ & $x$ & $x$ & $x$ & $x$ & $x$ & $x$ & $x$ & $x$ & $x$ & $\mathrm{x}$ & \\
\hline TC 2 & Terraza & 361 & 0 & 0 & 0 & 0 & 2 & 2 & 7.3 & 7.3 & 0 & 0 & $\mathrm{x}$ & $\mathrm{x}$ & 2,5YR 5/4 & 2,5YR 5/4 & $\mathrm{x}$ & $\mathrm{x}$ & $\mathrm{x}$ & $\mathrm{x}$ & $\mathrm{x}$ & $x$ & $x$ & $\mathrm{x}$ & $\mathrm{x}$ & $\mathrm{x}$ & $\mathrm{x}$ & $\mathrm{x}$ & $\mathrm{x}$ & $\mathrm{x}$ & \\
\hline TC 2 & Terraza & 362 & 0 & 0 & 0 & 0 & 2 & 2 & 10.7 & 8.6 & 0 & 0 & $x$ & $x$ & 2,5YR 5/4 & 2,5YR 5/4 & $x$ & $x$ & $x$ & $x$ & $x$ & $x$ & $x$ & $x$ & $x$ & $x$ & $x$ & $x$ & $x$ & $x$ & \\
\hline TC 2 & Terraza & 363 & 0 & 0 & 0 & 0 & 2 & 2 & 6.4 & 5.0 & 0 & 0 & $x$ & $x$ & 5YR 5/2 & $5 Y R \quad 4 / 4$ & $\mathrm{x}$ & $x$ & $\mathrm{x}$ & $x$ & $x$ & $x$ & $x$ & $x$ & $x$ & $\mathrm{x}$ & $x$ & $x$ & $x$ & $x$ & \\
\hline TC 2 & Terraza & 364 & 0 & 0 & 0 & 0 & 3y4 & 2 & 5.5 & 4.5 & 1 & 0 & $\mathrm{x}$ & $\mathrm{x}$ & 2,5 YR 4/4 & $2,5 Y R \quad 4 / 4$ & $\mathrm{x}$ & $\mathrm{x}$ & $\mathrm{x}$ & $x$ & $x$ & $x$ & $x$ & $x$ & $x$ & $\mathrm{x}$ & $x$ & $x$ & $x$ & $x$ & 3 \\
\hline TC 2 & Terraza & 365 & 0 & 0 & 0 & 0 & 2 & 2 & 5.3 & 4.5 & 0 & 0 & $x$ & $x$ & 2,5 YR $4 / 3$ & 2,5 YR 5/6 & $x$ & $x$ & $x$ & $x$ & $x$ & $x$ & $x$ & $x$ & $x$ & $x$ & $x$ & $x$ & $x$ & $x$ & \\
\hline TC 2 & Terraza & 366 & 0 & 0 & 0 & 1 & $3 y 4$ & 2 & 5.7 & 5.4 & 1 & 0 & $x$ & $x$ & 5YR 4/3 & 5YR 4/3 & $x$ & $x$ & $x$ & $x$ & $x$ & $x$ & $x$ & $x$ & $x$ & $x$ & $x$ & $x$ & $x$ & $x$ & 3 \\
\hline TC 2 & Terraza & 367 & 0 & 0 & 0 & 0 & 2 & 2 & 5.5 & 4.8 & 0 & 0 & $x$ & $x$ & 5YR 4/4 & 5YR 5/4 & $x$ & $\mathrm{x}$ & $\mathrm{x}$ & $\mathrm{x}$ & $\mathrm{x}$ & $x$ & $x$ & $\mathrm{x}$ & $x$ & $\mathrm{x}$ & $x$ & $\mathrm{x}$ & $x$ & $x$ & 3 \\
\hline TC 2 & Ladera N & 368 & 2 & 0 & 0 & 2 & $3 y 4$ & 2 & 10.7 & 8.0 & 1 & 0 & $x$ & $\mathrm{x}$ & $10 \mathrm{R} 4 / 6$ & 2,5YR 5/6 & $x$ & $x$ & $x$ & $\mathrm{x}$ & $x$ & $x$ & $x$ & $\mathrm{x}$ & $x$ & $x$ & $x$ & indet & \begin{tabular}{|l|l|}
$\mathrm{t}$ & 5 \\
\end{tabular} & 2 & \\
\hline TC 2 & Ladera N & 369 & 4 & 0 & 2 & 0 & $2 \mathrm{y} 6$ & $2 \mathrm{y} 6$ & 9.6 & 8.0 & 1 & 0 & $x$ & $x$ & $7,5 \mathrm{R} 3 / 1$ & 7,5YR 3/1 & $x$ & $x$ & $x$ & $x$ & $x$ & $x$ & $x$ & $x$ & $x$ & $x$ & $x$ & $x$ & $x$ & $x$ & 5 \\
\hline TC 2 & Ladera N & 370 & 0 & 0 & 0 & 0 & 3 & 2 & 7.5 & 6.1 & 0 & 0 & $x$ & $x$ & 2,5 YR $4 / 3,4 / 4$ & $5 Y R$ 5/2, 5/3 & $x$ & $x$ & $x$ & $x$ & $x$ & $x$ & $x$ & $x$ & $x$ & $x$ & $x$ & $x$ & $x$ & $x$ & \\
\hline TC 2 & Ladera N & v 371 & 0 & 0 & 0 & 1 & $2 y 4$ & 2 & 11.3 & 8.6 & 1 & 0 & $x$ & $x$ & 10R $4 / 6$ & 2,5YR 5/6 & $\mathrm{x}$ & $\mathrm{x}$ & $\mathrm{x}$ & $\mathrm{x}$ & $x$ & $x$ & $x$ & $\mathrm{x}$ & $x$ & $x$ & $\mathrm{x}$ & $\mathrm{x}$ & $x$ & $x$ & 5 \\
\hline TC 2 & Ladera N & 372 & 0 & 0 & 0 & 0 & $2 \mathrm{y} 4$ & $3 y 4$ & 7.9 & 6.5 & 1 & 0 & $x$ & $x$ & $10 \mathrm{R} 4 / 6$ & 2,5 YR $3 / 2$ & $x$ & $x$ & $x$ & $x$ & $x$ & $x$ & $x$ & $x$ & $x$ & $x$ & $x$ & $x$ & $\mathrm{x}$ & $x$ & 5 \\
\hline TC 2 & Ladera N & 373 & 0 & 0 & 0 & 2 & $3 y 4$ & $3 y 4$ & 10.7 & 9.4 & 1 & 0 & $x$ & $x$ & 2,5 YR 5/8 & 2,5 YR 4/6 & $x$ & $x$ & $x$ & $x$ & $x$ & $x$ & $x$ & $x$ & $x$ & $x$ & $x$ & $x$ & $x$ & $x$ & \\
\hline TC 2 & Ladera N & v 374 & 0 & 0 & 0 & 0 & 3 & 3 & 7.2 & 5.5 & 0 & 0 & $\mathrm{x}$ & $\mathrm{x}$ & 10R $4 / 6$ & $2,5 Y R \quad 4 / 4$ & $\mathrm{x}$ & $\mathrm{x}$ & $\mathrm{x}$ & $\mathrm{x}$ & $\mathrm{x}$ & $x$ & $x$ & $\mathrm{x}$ & $\mathrm{x}$ & $x$ & $\mathrm{x}$ & $\mathrm{x}$ & $\mathrm{x}$ & $\mathrm{x}$ & \\
\hline TC 2 & Ladera N & N 375 & 0 & 0 & 0 & 0 & $3 y 4$ & 3y4 & 6.9 & 5.5 & 1 & 0 & $\mathrm{x}$ & $\mathrm{x}$ & 2,5YR 4/6 & 2,5YR 4/6 & $\mathrm{x}$ & $x$ & $\mathrm{x}$ & $x$ & $\mathrm{x}$ & $x$ & $\mathrm{x}$ & $\mathrm{x}$ & $\mathrm{x}$ & $x$ & $x$ & $\mathrm{x}$ & $\mathrm{x}$ & $x$ & \\
\hline TC 2 & Ladera N & N 376 & 0 & 0 & 0 & 0 & 3y4 & 3y4 & 8.1 & 7.2 & 1 & 0 & $\mathrm{x}$ & $x$ & 2,5YR 5/8 & 2,5YR 5/ & $x$ & $\mathrm{x}$ & $\mathrm{x}$ & $x$ & $x$ & $x$ & $x$ & $x$ & $x$ & $x$ & $\mathrm{x}$ & $x$ & $\mathrm{x}$ & $x$ & \\
\hline
\end{tabular}




\title{
ANEXO II \\ Código analítico para descripción de materiales depositados en colecciones de museo
}

\author{
Planilla de descripción de materiales de colección
}

\section{CÓDIGO ANALÍTICO PARA DESCRIPCIÓN DE MATERIALES DEPOSITADOS EN COLECCIONES DE MUSEO:}

\section{PROCEDENCIA:}

1.1 Colección: nombre del museo, colección particular en la cual la pieza está registrada o expedición en la que la pieza ha sido recolectada.

1.2 $\mathrm{N}^{\circ}$ de inventario: número de inventario con el cual se identifica a cada una de las piezas en cada museo. Registrar también todo tipo de nomenclatura anterior.

\subsection{Sitio}

\section{MANUFACTURA:}

\subsection{Técnica de levantado:}
0 . Indeterminado
1. Rollos
2. Modelado
3. Torneado

2.2 Marcas de herramientas y del modelado en las superficies:

2.2.1 Evidencias técnicas por problemas en la manufactura:

1. variaciones de espesor:

1.1 hor por modelado con rollos; 1.2 por modelado manual

2. estrías unión asa

3. remaches de asas

4. marcas unión:

4.1 de segmentos del cuerpo; 4.2 de rollos

5. manchas de cocción

6. de recortado: 
6.1 de borde; 6.2 de base

7. marcas de dedos

8. grietas de secado

9. marcas de corte o incisiones de función desconocida.

10. asimetrías en la altura de distintas partes del cuerpo

11. rollo de refuerzo (en borde, pto inflex, etc.)

12. perforación en pasta fresca:

12.1 para agregado de apéndice.

\subsubsection{Evidencias de conductas de manufactura intencionadas y} reparación:

1. estrías alisado:

1.1 horizontales; 1.2 verticales; 1.3 oblicuas; 1.4 irregulares

2. marcas de pulido:

2.1 horizontales; 2.2 verticales; 2.3 oblicuas; 2.4 irregulares

3. desgastado de borde para reciclado

4. perforación

\subsection{Acabado de la superficie externa:}

0 . No se observa

2. Alisado

4. Engobado

6. Pintura poscocción

8. Corrugado

10. Paleteado

12. Esmaltado
1. Ordinario

3. Pulido

5. Pintura precocción

7. Impronta textil/cestería

9. Imbricado

11. Vitrificado

13. Arrastre de dedos

2.4 Acabado de la superficie interna: ídem anterior.

\section{MORFOLOGÍA:}

3.1 Forma (según Balfet et al.) Distinguir recipientes 1. abiertos y 2. cerrados.

1.1. Plato: $O$ abertura $(<o ́=23 / 24 \mathrm{~cm})=$ ó $>5 \mathrm{~h}$

1.2. Fuente: $\mathrm{O}$ abertura $(>24 \mathrm{~cm})=$ ó $>5 \mathrm{~h}$

1.3. Escudilla: $O$ abertura $(12$ a $22 / 23 \mathrm{~cm})=2.5$ a $5 \mathrm{~h}$

1.4. Escudilla honda o Tazón: $O$ abertura $(<$ ó $=18 \mathrm{~cm})=1,5$ a 2,5h

1.5. Cuenco: O abertura $(19$ a $40 \mathrm{~cm})=1,5$ a $2,5 \mathrm{~h}$ 
1.6. Escudilla restringida o cubilete: $O$ abertura $(6$ a 12 cm) $=0$ < $1,5 \mathrm{~h}$

1.7. Vaso cubilete o vaso: $\mathrm{O}$ abertura $(>12 \mathrm{~cm})=0$ ó $<1,5 \mathrm{~h}$

2.1. Vasija: O min > ó = 1/3 O máx. h 1 ó 2 O abertura, ó <4

2.2. Tinaja: > tamaño que la vasija, h 2 ó 3 O abertura.

2.3. Botellón: $O$ min < ó = 1/3 O máx.

3. Formas varias (figurinas, recipientes modelados, etc.)

3.2 Diámetro de la boca (en $\mathrm{cm}$ )

3.3 Diámetro máximo (en $\mathrm{cm}$ )

3.4 Diámetro mínimo (en cm)

3.5 Diámetro de la base (en cm)

3.6 Altura total $(\mathrm{en} \mathrm{cm})$

3.7 Altura del cuello (en $\mathrm{cm}$ )

Altura de puntos de inflexión/intersección (en cm)

Altura de los diámetros máx. y min

Altura de las asas

3.8 Perfil: 1. Forma simple

2. Forma compuesta

2.1 perfil continuo (puntos de inflexión)

2.2 perfil discontinuo (puntos de intersección)

3.9 Espesor de las paredes: medio, máximo y mínimo

\subsection{Borde:}

3.10.1 Dirección:

0 . No se observa

1. Hacia afuera

2. Vertical

3. Hacia adentro

\subsubsection{Forma:}

0 . No se observa

1. Plano

2. Redondeado

3. Biselado hacia adentro

4. Biselado hacia afuera

5. Doble biselado

6. Engrosado 


\subsection{Asa:}

3.11.1 Número: cantidad de asas

3.11.2 Largo (en cm)

3.11.3 Ancho (en cm)

3.11.4 Espesor (en cm)

\subsubsection{Sección asa:}

0 . No se observa

1. Circular

2. Subcircular

3. Plana

4. Subplana

5. Subtriangular

\subsubsection{Inserción asa:}

0 . No se observa

1. Adherida simple

2. Doble adherida

3. Remachada simple

4. Doble remachada

5. Labio adherida

6. Labio remachada

\subsubsection{Posición asa:}
0 . No se observa
1. Horizontal
2. Vertical
3. Oblicua

\subsection{Base:}

\subsubsection{Morfología:}

0 . No se observa

1. Biplana

2. Plana convexa

3. Cóncava convexa

4. Biconvexa

5. Plano cóncava

6. Convexo plana

7. Convexo cóncava

8. Bicóncava

3.12.2 Unión base:

0 . No se observa

1. Angular

2. Directa

3. Inflexa

3.12.3 Espesor base (en cm)

\section{DECORACIÓN:}

\subsection{Soporte:}


1. Superficie interna

2. Superficie externa (piezas abiertas)

3. Cuerpo

4.Cuello

5. Borde interno

6. Asas o apéndices

7. Labio

4.2 Técnicas de decoración por pintura:

0. Sin pintar

1. Pintura monocroma

2. Pintura bicolor

3. Pintura tricolor

4.3 Técnicas de decoración por corte/desplazamiento:

0 . No se observa

1. Impresión (cestería, textil, etc.)

2. Incisión

3. Estampamiento

4. Corrugado

4.4 Técnicas de decoración por agregado:

0 . No se observa

1. Modelado

2. Pastillaje

\subsection{Motivos de decoración}

4.6 Estilo: si corresponde a alguno de los tipos estilísticos ya definidos en la bibliografía, de manera conspicua.

\section{COCCIÓN:}

5.1 Color superficie externa (en notación Munsell).

5.2 Color superficie interna (en notación Munsell).

5.3 Color pasta (en notación Munsell)

\section{ALTERACIONES POSDEPOSICIONALES:}

0 . No se observa

1. Manchas de exposición al fuego

2. Depósitos en superficies

3. Erosión de bordes

4. Erosión de superficies

5. Erosión de pintura

6. Desgaste de la base (y nivel)

7. Desgaste interno (y nivel)

8. Desgaste del borde (y nivel).

9. Fragmentación varia (borde, asas, cuerpo, etc.)

\section{NN DE FOTO}




\section{Nº DE ILUSTRACIÓN}

\section{OBSERVACIONES}

\section{BIBLIOGRAFÍA:}

Ávila, M. F. 2006. Un mundo morado sobre ante. Estudio sobre el estilo cerámico yavi de la puna oriental de Jujuy. Tesis de Licenciatura en Ciencias Antropológicas con Orientación Arqueológica. Facultad de Filosofía y Letras, Universidad de Buenos Aires.

Cremonte, M. B. 1991. Análisis de muestras cerámicas de la Quebrada de Humahuaca. Avances en Arqueología, nº 1: 7-42. Universidad Nacional de Buenos Aires.

Espiro E., V. E. 2006. Aportes Para Una Clasificación Tecnológica De Las Cerámicas Pertenecientes Al Primer Milenio De Nuestra Era De La Aldea Piedra Negra, Laguna Blanca, Dpto. Belén, Provincia De Catamarca. Tesis de Licenciatura inédita. Universidad Nacional de Catamarca.

Orton, C.; P. Tyers y A. Vince. 1997. La cerámica en arqueología. Editorial Crítica, Barcelona.

Primera Convención Nacional de Antropología (Córdoba). 1964. Primera Parte. Cerámica. Publicaciones del Instituto de Antropología 1 (XXVI) Córdoba. 


\begin{tabular}{|c|c|c|c|c|c|c|c|c|c|c|c|c|c|c|c|c|c|c|c|c|c|c|c|c|c|c|c|c|c|c|c|c|c|}
\hline \multirow[b]{2}{*}{\begin{tabular}{|l|}
$\mathrm{Mu}$ \\
seo
\end{tabular}} & \multirow[b]{2}{*}{\begin{tabular}{|l|}
$N^{\circ}$ \\
Inv \\
\end{tabular}} & \multirow[b]{2}{*}{ Sitio } & \multicolumn{19}{|c|}{ Manufactura } & \multicolumn{2}{|c|}{ Borde } & \multicolumn{7}{|c|}{ Asa } & \multicolumn{3}{|c|}{ Base } \\
\hline & & & $\begin{array}{l}\text { Tec } \\
\text { lev } \\
\end{array}$ & \begin{tabular}{|c|}
$M$ \\
manuf
\end{tabular} & $M$ intenc & \begin{tabular}{|c|} 
Sup \\
ext
\end{tabular} & \begin{tabular}{|c|} 
Sup \\
int
\end{tabular} & $\begin{array}{l}\text { For } \\
\text { ma }\end{array}$ & $\begin{array}{l}\text { Diám } \\
\text { boca }\end{array}$ & $\begin{array}{c}\text { Diám } \\
\text { max }\end{array}$ & $\begin{array}{c}\text { Diám } \\
\text { min }\end{array}$ & \begin{tabular}{|l|} 
Diam \\
base
\end{tabular} & Altura & \begin{tabular}{|c|} 
Alt \\
cuello
\end{tabular} & \begin{tabular}{|c|}
$\begin{array}{c}\text { Alt ptos } \\
\text { int/infl }\end{array}$ \\
\end{tabular} & \begin{tabular}{|l|} 
Alt d \\
max
\end{tabular} & \begin{tabular}{|c|} 
Alt d \\
min
\end{tabular} & $\begin{array}{c}\text { Alt } \\
\text { asas }\end{array}$ & Perfil & \begin{tabular}{|l|} 
Esp \\
$\max$
\end{tabular} & $\begin{array}{l}\text { Esp } \\
\text { min }\end{array}$ & Direc & $\begin{array}{l}\text { For } \\
\text { ma }\end{array}$ & $\mathrm{N}^{\circ}$ & $\begin{array}{l}\text { Lar } \\
\text { go }\end{array}$ & \begin{tabular}{|c|}
$\begin{array}{c}\text { An } \\
\text { cho }\end{array}$ \\
\end{tabular} & Esp & Secc & \begin{tabular}{|l|} 
In \\
serc
\end{tabular} & c $\begin{array}{l}\begin{array}{l}\text { Posi } \\
\text { ción }\end{array} \\
\text {. }\end{array}$ & Esp & \begin{tabular}{|c|}
$\begin{array}{c}\text { Mor } \\
\text { fol }\end{array}$ \\
\end{tabular} & $\begin{array}{l}\text { Uni } \\
\text { ón } \\
\end{array}$ \\
\hline IT & 1437 & Doncellas & 1 & 1.1 & $2.1,2.4$ & 3 & 3 & 1.3 & 13.2 & $x$ & $x$ & 5.9 & 3.8 & $\mathrm{x}$ & $\mathrm{x}$ & $\mathrm{x}$ & $x$ & $x$ & 1 & 4.2 & 4.2 & 1 & 3 & 0 & $\mathrm{x}$ & $\mathrm{x}$ & $x$ & $x$ & $x$ & $\mathrm{x}$ & 5 & 5 & 2 \\
\hline IT & 1439 & Doncellas & 0 & 0 & 2.1 & 2 & 3 & 1.3 & 18.5 & $x$ & $x$ & indet & 7.5 & $x$ & $x$ & $x$ & $x$ & 5.5 & 1 & 4.5 & 4.5 & 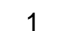 & 2 & 1 & 3.5 & 0.8 & 7 & 0 & 1 & 1 & indet & 5 & 0 \\
\hline IT & 1447 & Doncellas & 1,0 & $2,4.1$ & $1,2.1,2.4$ & 3 y 6 & 2 & 2.1 & 13.5 & 14.5 & 11 & 7.3 & 16 & 7.3 & 7.3/14.8 & 6.5 & 14.8 & 7 & 2.2 & 5.2 & 4 & 1 & 0 & 2 & 5.1 & 1.8 & 12 & 1 & 4 & 2 & 12 & 5 & 2 \\
\hline IT & 1450 & Doncellas & 0 & 0 & $1.1,2.1$ & 2 y 6 & 3 y 6 & 1.4 & 12 & $x$ & $x$ & 4.4 & 5.8 & $x$ & $x$ & $x$ & $x$ & 3.8 & 1 & 6.3 & 4 & 2 & 1 & 2 & 1.8 & 0.6 & 5 & 0 & 1 & 1 & 6 & 5 & 2 \\
\hline IT & 1471 & Cochinoca & 1 & 3,5 & 2.2 & 3 & 1 & 2 & 0 & 15 & 0 & 9.2 & $13 \mathrm{fr}$ & 0 & 0 & 9.5 & 0 & 3.5 & 2 & 8 & 6.5 & $x$ & $x$ & 2 & 6 & 2 & 8.5 & 4 & 4 & 3 & 10 & 5 & 2 \\
\hline IT & 1499 & Doncellas & 2,1 & 1.2 & 2.1 & 2 & 3 & 1.3 & 14.5 & $x$ & $x$ & 5.5 & 4.9 & $x$ & $x$ & $x$ & $x$ & $x$ & 1 & 5.5 & 5.5 & 2 & 1 & $\mathrm{x}$ & $x$ & $x$ & $x$ & $x$ & $x$ & $x$ & 8 & 1 & 2 \\
\hline IT & 1502 & Doncellas & 1,0 & 4.2 & $2.2,2.1,2.3$ & 3 y 4 & $3 y 4,2$ & 2.3 & 6 & 15 & 3.6 & 7.7 & 16.9 & 13 & 13 & 6.5 & $\mid 14.6$ & 5 & 2.1 & 8.2 & 4.3 & 1 & 2 & 2 & 5.8 & 1.7 & 7 & 4 & 2 & 3 & 6.2 & 5 & 2 \\
\hline $\mathrm{IT}$ & 1577 & Doncellas & 1 & 1.1 & $1.1,1.2$ & 2 & 2 & 1.6 & 7.3 & $x$ & $x$ & 6.7 & $x$ & $x$ & $x$ & $x$ & $x$ & $x$ & 1 & 7.4 & 4.7 & 2 & 2 & $\mathrm{x}$ & $x$ & $x$ & $x$ & $x$ & $x$ & $x$ & 10 & 5 & 2 \\
\hline IT & 1579 & Doncellas & 2,0 & $1.2,4.1,5$ & 1.4 & 2 a 1 & 0 & 2.2 & 6.5 & 14.5 & 6.1 & 6.5 & 16.5 & 14 & 14 & 8.5 & 15 & 11 & 2.1 & 5 & 5 & 1 & 2 & 1 & 6 & 2.5 & 13 & 4 & 5 & 2 & 15 & 1 & 2 \\
\hline IT & 1651 & Doncellas & 2,1 & \begin{tabular}{|c|}
$1.2,2$, \\
$4.2,6.1$ \\
\end{tabular} & 1.4 & 2 & 2 & 1.3 & 7.7 & $\mathrm{x}$ & $\mathrm{x}$ & 4.2 & 2.4 & $\mathrm{x}$ & $x$ & $\mathrm{x}$ & $\mathrm{x}$ & $x$ & 1 & 6.2 & 6.2 & 1 & 1 & 1 & 3.4 & 0.8 & 17 & 2 & 5 & 2 & 5 & 5 & 1 \\
\hline IT & 1657 & Doncellas & 1 & 0 & 2.1,2.2,2.3 & $3,4 y 6$ & $3,4,6$ & 2.1 & 11 & 14.5 & 8.1 & 5.8 & 19.5 & 14 & $14 / 18.5$ & 8.5 & 14 & 12.5 & 2.2 & 6 & 3.5 & 1 & 2 & 2 & 5 & 1.8 & 9 & 4 & 4 & 2 & 9 & 5 & 2 \\
\hline IT & 1659 & Doncellas & 0 & 2,5 & 2.1 & 3 & 2 & 2.3 & 4.3 & 10.7 & 2.8 & 4.5 & 15.3 & 9.2 & $2,9.2$ & 6 & 12.5 & 5.5 & 2.2 & 4.3 & 4.3 & 1 & 2 & 1 & 5.6 & 4.9 & 7.9 & 3 & 2 & 1 i & indet & 1 & 2 \\
\hline IT & 1660 & Doncellas & 0 & 2,5 & $2.2,2.1$ & 1 y 3 & 2 y 3 & 2.1 & 14 & 15.5 & 11 & 7.8 & 17.7 & 10.5 & 10.5 & 5.7 & 14.5 & 7.6 & 2.1 & 6.5 & 6.5 & 1 & 2 & 2 & 7 & 2 & 10 & 4 & 4 & 2 & 7 & 5 & 1a 3 \\
\hline IT & 1661 & Doncellas & 0 & 0 & 0 & 2 & 2 & 2.1 & 6 & 9.9 & 6 & 5.8 & 10.4 & $x$ & 6 & 3.5 & 8.3 & 5 & 2.1 & 5 & 4 & $x$ & $x$ & 1 & 5.4 & 2.1 & 9 & 4 & 5 & 2 & 5 & 5 & 2 \\
\hline IT & 1662 & Doncellas & 1 & 4.2 & 2.1 & 3 & 3 & 1.3 & 12.9 & $x$ & $x$ & 5.3 & 2.8 & $x$ & $x$ & $x$ & $x$ & $x$ & 1 & 4.9 & 3.8 & 1 & 1 & 1 & 3.6 & 1.7 & 16 & $x$ & 5 & 2 & 4 & 5 & 2 \\
\hline IT & 1665 & Doncellas & 0 & 7 & 2.1 & 3 y 4 & 3 y 4 & 1.3 & 15.6 & $x$ & $x$ & 7.5 & 6.2 & $x$ & $x$ & $x$ & $x$ & $x$ & 1 & 4.2 & 4.2 & 1 & 2 & $\mathrm{x}$ & $x$ & $x$ & $x$ & $x$ & $x$ & $x$ & 8 & 5 & 2 \\
\hline IT & 1668 & Doncellas & 1 & 4.1 & $2.1,2.2$ & 3 & 3 & 2.1 & 11.4 & 15.5 & 9.4 & indet & 13.9 & 10 & 10 & 0 & 10 & 9.3 & 2.2 & 6.7 & 4.5 & 1 & 2 & 2 & 4.6 & 2 & 5 & 3 & 6 & 2 & 6.7 & 8 & 2 \\
\hline IT & 1672 & Doncellas & 0 & 8 & 2.1 & $3,4 \mathrm{y} 6$ & $3,4 \mathrm{y} 6$ & 1.3 & 17.5 & $x$ & $x$ & 6.9 & 6 & $x$ & $x$ & $x$ & $x$ & $x$ & 1 & 6.5 & 6.5 & $\perp$ & 2 & $x$ & $x$ & $x$ & $x$ & $x$ & $x$ & $x$ & 5 & 5 & 2 \\
\hline IT & 1673 & Doncellas & 1 & 4.2 & 2.1 y 2.2 & 3 y 4 & $3,4 \mathrm{y} 6$ & 1.3 & 14.7 & 6.5 & 4.3 & $x$ & $x$ & $x$ & $x$ & $x$ & $x$ & 3.4 & 1 & 6 & 6 & 2 & 2 & 2 & 2 & 0.8 & 4 & $x$ & 1 & 1 & 5 & 5 & 2 \\
\hline IT & 1765 & Doncellas & 0 & 9 & 2.2 & 3 y 4 & 2 & 2.1 & 17.8 & 17.8 & 14.5 & 4.3 & 21 & 3.5 & 3.5 & 4.8 & 8.6 & 2.3 & 2.1 & 4 & 4 & 1 & 1 & 2 & 3.7 & 1.2 & 9 & 1 & 4 & 2 & 5 & 5 & 2 \\
\hline IT & 1767 & Doncellas & 1 & 4.2 & 1.1,1.2,1.3 & 2 y 6 & 2 & 2.1 & 9 & 12.3 & 7.8 & 7.5 & 17.1 & 12.5 & $12.5 / 14.8$ & 7.5 & 12.5 & 5.5 & 2.2 & 5.1 & 4.1 & 1 & 2 & 2 & 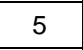 & 1.7 & 7.5 & 3 & 4 & 1 & 6 & 5 & 3 \\
\hline IT & 1768 & Doncellas & 1 & 1.1 & 1.1 & 2 & 2 & 1.4 & 7.7 & $x$ & $x$ & 6.6 & 5.3 & $x$ & $x$ & $x$ & $x$ & $x$ & 1 & 7.6 & 2.7 & 2 & 2 & $x$ & $x$ & $x$ & $x$ & $x$ & $x$ & $x$ & 5 & 5 & 2 \\
\hline IT & 1784 & Doncellas & 1 & 1.1 & 1 & 2 & 2 & 1.6 & 7.1 & $x$ & $x$ & 6.1 & 5.4 & $x$ & $x$ & $x$ & $x$ & $x$ & 1 & 4.6 & 2.7 & 2 & 2 & $x$ & $x$ & $x$ & $x$ & $x$ & $x$ & $x$ & 9 & 5 & 2 \\
\hline IT & 1798 & Doncellas & 1 & 2 & $1.1,1.3$ & 2 & 2 & 2.1 & 9.2 & 11.6 & 7.5 & 6.1 & 14.2 & 12.8 & 9.1 & 5.4 & 12.8 & 8.4 & 2.1 & 6.8 & 6 & 1 & 2 & 2 & 4.6 & 1.5 & 8 & 2 & 2 & 2 & 1.5 & 5 & 2 \\
\hline IT & 1800 & Doncellas & 0 & 0 & $1.1,2.1$ & $3,4 \mathrm{y} 6$ & 2 & 1.3 & 17.7 & $x$ & $x$ & 6.1 & 6. & $\mathrm{x}$ & $x$ & $x$ & $x$ & $x$ & 1 & 5.6 & 4.7 & 2 & 2 & $\mathrm{x}$ & $x$ & $x$ & $x$ & $x$ & $x$ & $x$ & 8 & 5 & 2 \\
\hline IT & 1850 & Queta & 0 & 0 & 0 & 2 a 1 & 2 a 1 & 1.4 & 12.8 & $x$ & $x$ & 7.5 & 8.6 & $x$ & x & $x$ & $x$ & $x$ & 1 & 9 & 8 & $\perp$ & 2 & $\mathrm{x}$ & $x$ & $x$ & $x$ & $x$ & $x$ & $x$ & 20 & 5 & 3 \\
\hline IT & 1851 & Queta & 1 & $1.1,2$ & $2.1,2.4$ & 3 y 4 & 3 y 4 & 1.3 & 15.4 & $x$ & $x$ & 6 & 4.6 & $x$ & $x$ & $x$ & $x$ & $x$ & 1 & 5.8 & 5.8 & $\angle$ & 1 & 1 & 4.3 & 2.9 & 8 & 3 & 5 & 2 & 5 & 5 & 2 \\
\hline IT & 1852 & Queta & 0 & 5 & 1.1 & 2 a 1 & 4 & 1.4 & 14.1 & $x$ & $x$ & 6.7 & 10 & $x$ & $x$ & $x$ & $x$ & 6.8 & $\perp$ & 8 & 5 & 2 & $1 \mathrm{a} 2$ & 2 & 4.2 & 1.8 & 9 & 2 a 4 & 4 & 1 & 8 & 5 & 3 \\
\hline IT & 1943 & Cochinoca & 0 & 0 & 0 & 2 y 4 & $2,4 \mathrm{y} 6$ & 1.3 & 15.1 & $x$ & $x$ & 4.3 & 5 & $x$ & A & A & $x$ & 4.5 & $\perp$ & 5 & 5 & 2 & 1 & 1 & 3.3 & 3 & 6 & 3 & 5 & 2 & 5 & 5 & 2 \\
\hline IT & 1948 & Rinconada & 0 & 3,5 & 2.1 & $3,4 \mathrm{y} 6$ & 2 & 2.1 & 4.5 & 11 & 5 & 6.7 & 11.8 & 7.3 & 7.3 & 3.7 & 7.8 & 3.5 & 2.2 & 6 & 6 & 3 & 1 & 2 & 4.1 & \begin{tabular}{|l|}
1.6 \\
\end{tabular} & 10 & 1 & 4 & 2 & 6 & indet & 2 \\
\hline IT & 1965 & Queta & 0 & 5 & 2.1 & 3 y 4 & 2 y 4 & 2.1 & 6.9 & 11.4 & 6.5 & 5.5 & 10 & 7.2 & $\begin{array}{c}6.7,7.8 \\
8.7 \\
\end{array}$ & 4 & \begin{tabular}{|c|}
$7.2 \mathrm{y}$ \\
9.5 \\
\end{tabular} & 6.7 & 2.1 & 4 & 4 & 1 & 2 & 2 & $\begin{array}{c}3.3 \mathrm{y} \\
2.3 \\
\end{array}$ & 1.2 & 6 & 4 & 2 & 2 & 5 & 5 & 2 \\
\hline IT & 1966 & Queta & 0 & $2,6.2$ & 0 & 2 y 6 & 2 & 2.1 & 0 & 13.5 & 6.2 & 5.8 & $16,4 \mathrm{fr}$ & 14.5 & 14.5 & 7.5 & 14.5 & 6.8 & 2.2 & 7 & 6 & $x$ & $x$ & 2 & 5.9 & 2 & 14 & 2 & 4 & 2 & 8 & 5 & 2 \\
\hline IT & 1967 & Queta & 0 & 5 & 2.2 & 3 y 4 & 3 y 4 & 2.3 & 4 & 7.7 & 2.9 & 4 & 12.1 & 8.7 & 7.5 & 4.5 & \begin{tabular}{|l|}
10.5 \\
\end{tabular} & 4.5 & 2.1 & 5 & 4 & 1 & 2 & 2 & 3.5 & 1.4 & 7 & 4 & 0 & 2 & 8 & indet & 2 \\
\hline IT & 1968 & Queta & 2,1 & $4.2,7$ & $1.1,3$ & 2 y 4 & 2 & 1.4 & 10.2 & 10.9 & $x$ & 6.2 & 6 & $x$ & $x$ & 4.5 & $x$ & $x$ & 1 & 7 & 5.5 & 1 & 2 & $\mathrm{x}$ & $x$ & $x$ & $x$ & $x$ & $x$ & $x$ & 10 & 5 & 2 \\
\hline
\end{tabular}




\begin{tabular}{|c|c|c|c|c|c|c|c|c|c|c|c|c|c|c|c|c|c|c|c|c|c|c|c|c|c|c|c|c|c|c|c|c|c|}
\hline \multirow[b]{2}{*}{$\begin{array}{l}\mathrm{Mu} \\
\text { seo }\end{array}$} & \multirow[b]{2}{*}{$\begin{array}{c}N^{\circ} \\
\text { Inv }\end{array}$} & \multirow[b]{2}{*}{ Sitio } & \multicolumn{19}{|c|}{ Manufactura } & \multicolumn{2}{|c|}{ Borde } & \multicolumn{7}{|c|}{ Asa } & \multicolumn{3}{|c|}{ Base } \\
\hline & & & $\begin{array}{l}\text { Tec } \\
\text { lev }\end{array}$ & $\begin{array}{c}\mathrm{M} \\
\text { manuf }\end{array}$ & $M$ intenc & \begin{tabular}{|c|} 
Sup \\
ext
\end{tabular} & $\begin{array}{c}\text { Sup } \\
\text { int }\end{array}$ & $\begin{array}{l}\text { For } \\
\text { ma }\end{array}$ & $\begin{array}{l}\text { Diám } \\
\text { boca }\end{array}$ & $\begin{array}{c}\text { Diám } \\
\text { max }\end{array}$ & $\begin{array}{c}\text { Diám } \\
\text { min }\end{array}$ & $\begin{array}{l}\text { Diam } \\
\text { base }\end{array}$ & Altura & $\begin{array}{c}\text { Alt } \\
\text { cuello }\end{array}$ & \begin{tabular}{|c|} 
Alt ptos \\
int/infl
\end{tabular} & \begin{tabular}{|l|} 
Alt d \\
max
\end{tabular} & $\begin{array}{c}\text { Alt d d } \\
\text { min }\end{array}$ & $\begin{array}{c}\text { Alt } \\
\text { asas }\end{array}$ & Perfil & $\left|\begin{array}{l}E s p \\
\max \end{array}\right|$ & $\begin{array}{l}\text { Esp } \\
\text { min }\end{array}$ & Direc & $c\left|\begin{array}{l}\text { For } \\
\text { ma }\end{array}\right|$ & $\mathrm{N}^{\circ}$ & $\begin{array}{l}\text { Lar } \\
\text { go }\end{array}$ & $\begin{array}{c}\text { An } \\
\text { cho }\end{array}$ & Esp & Secc & $\begin{array}{l}\text { In } \\
\text { serc }\end{array}$ & $\begin{array}{l}\text { Posi } \\
\text { ción }\end{array}$ & Esp & $\begin{array}{c}\text { Mor } \\
\text { fol }\end{array}$ & $\begin{array}{l}\text { Uni } \\
\text { ón } \\
\end{array}$ \\
\hline IT & 1977 & Queta & 0 & 0 & 0 & 2 & 2 & 3 & $x$ & $x$ & $x$ & $x$ & $x$ & $x$ & $x$ & $x$ & $x$ & $x$ & $x$ & $x$ & $x$ & $x$ & $x$ & $x$ & $6.6 \mathrm{fr}$ & 5.2 & 2.5 & $x$ & $x$ & $x$ & $x$ & $x$ & $x$ \\
\hline IT 1 & 1980 & Queta & 0 & 4.1 & 1.1 & 2 & 2 & 2.1 & 7.2 & 14.5 & 6.5 & 7.3 & 19.6 & 16 & 17.8 & 8.5 & \begin{tabular}{|l|}
17.8 \\
\end{tabular} & 10.5 & 2.2 & 6.3 & 6.3 & 1 & 2 & 2 & 3.2 & 1.5 & 2 & 0 & 1 & 2 & 12 & 5 & 2 \\
\hline IT & 1987 & Queta & 1 & $4.1,10$ & $1.1,1.2,1.3$ & 2 & 2 & 2.1 & $9.5 \mathrm{fr}$ & 24 & 8.5 & 9 & 28.5 & 24 & 24 & 12 & 26 & $11,5 / 15$ & 2.2 & 7 & 5 & 1 & $x$ & 2 & 2.2 y 8 & $2.6 \mathrm{y} 2$ & 1.6 & 0 y 2 & 1 y 4 & 42 y 1 & 1.5 & 5 & 2 \\
\hline IT & 1990 & Queta & 0 & 0 & 2.1 & 3 y 43 & $3,4 \mathrm{y} 6$ & 1.3 & 14.5 & $x$ & $x$ & 5.8 & 4 & $x$ & $x$ & $x$ & $x$ & 3.5 & 1 & 6 & 4.8 & 2 & 2 & 1 & 4 & 1.5 & indet & 3 & 5 & 2 & 5 & 5 & 2 \\
\hline $\begin{array}{ll}\text { IT } 1 \\
\text {. }\end{array}$ & 1994 & Queta & 0 & 5 & 1.1 & 2 & 2 & 1.7 & 6.9 & $x$ & $x$ & 6.1 & 5 & $x$ & $x$ & $x$ & $x$ & $x$ & 1 & 7.5 & 3 & 2 & 2 & $\mathrm{x}$ & $x$ & $x$ & $x$ & $x$ & $x$ & $x$ & 5 & 5 & 2 \\
\hline IT & 1995 & Queta & 0 & 0 & 1.1 & 2 & 2 & 1.4 & 9.2 & 9.6 & $x$ & 4.2 & 5.3 & $x$ & $x$ & $x$ & $x$ & 4.2 y 3 & 1 & 7.7 & 4.7 & 3 & 1 & 2 & 0.9 & 1.4 & 30 & 0 y 4 & 1 & $1 \mathrm{y} 0$ & 7 & 5 & 2 \\
\hline IT & 1996 & Queta & 0 & $4.1,5$ & $2.1,2.2$ & 2 & 2 & 2.3 & 6.4 & 20 & 5.7 & 8.5 & 24.5 & 21.7 & $7.5 / 21.7$ & 12.7 & 22.8 & 11 & 2.2 & 6 & 4 & 1 & 1 & 1 & 5.5 & 2 & 10 & 4 & 0 & 2 & 15 & 0 & 3 \\
\hline IT & 1998 & Queta & 0 & 5 & 0 & 2 & 2 & 2.1 & 9.2 & 17 & 7.5 & 6.3 & 19.5 & 15.5 & 15.5 & 9 & 17 & 9.8 & 2.2 & 5 & 5 & 1 & 2 & 2 & 3.5 & 3 & 15 & 0 & 1 & 2 & 15 & 5 & 2 \\
\hline IT & 1999 & Queta & 0 & $4.1,5$ & 0 & 2 & 0 & 3 & 3 & 7.2 & $x$ & 5 & 10 & $x$ & $x$ & $x$ & $x$ & $x$ & 3 & 5 & 4.5 & 2 & 2 & $x$ & $x$ & $x$ & $x$ & $x$ & $x$ & $x$ & $x$ & 0 & 2 \\
\hline IT & 2000 & Queta & 0 & 5 & 1.4 & 2 & 2 & 3 & $x$ & $16 \mathrm{fr}$ & $x$ & 11 & $5 \mathrm{fr}$ & $x$ & $x$ & $x$ & $x$ & 1 & 1 & 8.5 & 6.7 & $x$ & $x$ & 1 & 9.2 & 2.5 & 11 & 3 & 2 & 0 & 10 & 5 & 3 \\
\hline IT & 2003 & Queta & 2 & 0 & $1.1,6.1$ & 2 & 2 & 1.4 & 6.4 & $x$ & $x$ & 5.6 & 2.9 & $x$ & $x$ & $x$ & $x$ & $x$ & 1 & 7 & 5.5 & 1 & 1 & $\mathrm{x}$ & $x$ & $x$ & $x$ & $x$ & $x$ & $x$ & 3 & 5 & 3 \\
\hline IT & 2005 & Queta & 0 & 0 & 2.1 & 3 y 4 & 3 y 4 & 1.3 & 18.8 & $x$ & $x$ & 8 & 6.5 & $x$ & $x$ & $x$ & $x$ & $x$ & 1 & 6 & 5.8 & 2 & 2 & $x$ & $x$ & $x$ & $x$ & $x$ & $x$ & $x$ & 7 & 5 & 2 \\
\hline IT & 2006 & Queta & 1 & 1.1 & 2.1 y 2.2 & 3 y 4 & 3 y 4 & 2.1 & 5.7 & 10.5 & 3.7 & 4.3 & 12.3 & 8.8 & 8.8 & 5 & 10 & 5 & 2.1 & 5 & 5 & 1 & 2 & 2 & 4 & 1.3 & 6 & 4 & 4 & 3 & 8 & 1 & 2 \\
\hline IT & 2013 & Queta & 0 & 0 & 2.1 & 2 & 3 & 1.3 & 15.5 & $x$ & $x$ & 7.5 & 6.5 & $y$ & $x$ & $x$ & $x$ & $x$ & 1 & 5 & 4.4 & 1 & 2 & $x$ & $x$ & $x$ & $x$ & $x$ & $x$ & $x$ & 5 & 5 & 2 \\
\hline IT 2 & 2029 & Queta & 1 & $1.1,3$ & 1.1 & 1 & 2 & 1.3 & 14.0 & $x$ & $x$ & 7.6 & 5.7 & $x$ & $x$ & $x$ & $x$ & 1.3 & 1 & 9 & 6 & 1 & 2 & 1 & 5 & 1.9 & 13 & 2 a 4 & 6 & 2 & 6 & 5 & 3 \\
\hline IT & 2030 & Queta & 0 & 0 & 3 y 4 & 2 & 2 & 1.3 & 11.0 & $x$ & $x$ & 6.9 & 3.8 & $x$ & $x$ & $x$ & $x$ & $x$ & 1 & 6 & 4 & 1 & 2 & $x$ & $x$ & $x$ & $x$ & $x$ & $x$ & $x$ & 5 & 5 & 3 \\
\hline IT & 2036 & Queta & 1 & $4.1,5$ & 2.1 & 2 & 2 & 2.1 & 8.7 & 21 & 7.6 & 9.7 & 24 & 19 & 19 & 10 & 21.5 & 7.7 & 2.2 & 7.5 & 4.7 & 1 & 1 & 2 & 6 & 2.6 & 20 & 2 & 0 & 2 & 10 & 1 & 2 \\
\hline IT & 2037 & Queta & 1 & 5 & 0 & 2 & 2 & 2.1 & 6.5 & 11 & 5.9 & 6 & 15.2 & 12.8 & 12.8 & 6.8 & 13.2 & 8 & 2.1 & 5 & 5 & 1 & 2 & 2 & 2.5 & 1.2 & 17 & 0 & 1 & 2 & 10 & 5 & 3 \\
\hline IT & 2040 & Queta & 1 & 3,5 & $21,2.2$ & 3 y 43 & $3,4 \mathrm{y} 6$ & 1.3 & 36.3 & $x$ & $x$ & 10.7 & 14.5 & $x$ & $x$ & $x$ & $x$ & 8.5 & 1 & 7.6 & 6.5 & 1 & $2 \mathrm{y} 6$ & 1 & 9 & 2.3 & 10 & 4 & 4 & 1 & 8 & 5 & 3 \\
\hline IT & 2042 & Queta & 1 & 4.2 & $1.1,2.1$ & 2 & 3 & 1.4 & 17 & $x$ & $x$ & 6.3 & 7.8 & $x$ & $x$ & $x$ & $x$ & 6.3 & 1 & 8 & 4.5 & 2 & 1 & 2 & 1 & 1.4 & 5 & 0 & 1 & 1 & 11 & 1 & 2 \\
\hline IT & 2050 & Queta & 0 & 0 & 0 & 3 y 4 & 3 y 4 & 2.3 & 9.4 & 20 & 5.7 & 9.4 & 23 & 18 & 17.5 & 8.5 & 18 & 9 & 2.1 & 5.5 & 5 & 1 & 2 & 2 & 7.3 & 1.8 & 11 & 2 a 4 & 0 & 3 & 5 & 0 & 2 \\
\hline IT & 2051 & Queta & 0 & 5,9 & 1.1 y 1.4 & 2 & 2 & 2.1 & 7 & 12 & 6.2 & 5 & 14 & 12 & 11 & 6.6 & 12 & 5.8 & 2.1 & 5 & 5 & 1 & 1 & 2 & 2.3 & 2 & 15 & 0 & 1 & 1 & 10 & 5 & 2 \\
\hline IT & 2057 & Queta & 0 & 2,3 & 1.1 y 2.1 & 2 & 3 & 1.4 & 12.2 & 12.7 & $x$ & 8.1 & 5.4 & $x$ & $x$ & $x$ & $x$ & 2.1 & 1 & 5.5 & 4.3 & 3 & 1 & 1 & 4.2 & 1.3 & 11 & 2 & 6 & 2 & 6 & 5 & 2 \\
\hline IT & 2058 & Queta & 1 & 1.1 & 1.1 & 2 & 2 & 1.6 & 6.9 & $x$ & $x$ & 5.7 & 5.7 & $x$ & $x$ & $x$ & $x$ & $x$ & 1 & 5 & 3 & 2 & 1 & $\mathrm{x}$ & $x$ & $x$ & $x$ & $x$ & $x$ & $x$ & 5 & 5 & 3 \\
\hline IT & 2059 & Queta & 1 & 4.2 & 1 & 3 y 4 & $2,3 y 4$ & 2.1 & 8.8 & 9.5 & 5.4 & 5.7 & 12 & 7 & 7 & 3.5 & 9.2 & 6.8 & 2.1 & 5.6 & 3.6 & 1 & 2 & 2 & 4.7 & 1.1 & 8 & 2 a 4 & 2 & 2 & 5 & 5 & 2 \\
\hline IT & 2060 & Queta & 1 & 4.2 & $2.1,2.2$ & $3,4 \mathrm{y}^{3} 3$ & $3,4 \mathrm{y} 6$ & 1.4 & 16.5 & 17.2 & $x$ & 6.5 & 7 & $x$ & $x$ & 6 & $x$ & 6.5 & 1 & 10 & 5 & 3 & $3 y 6$ & 2 & 1 & 2.2 & 6 & $x$ & 1 & 1 & 5 & 5 & 2 \\
\hline IT & 2061 & Queta & 0 & 0 & $2.1,2.2$ & 3 & 2 y 3 & 2.3 & 2.7 & 7.5 & 2 & 3.5 & 8.8 & 5.4 & 1.7 y 5.4 & 1.7 & 7.1 & 4 & 2.2 & 3 & 3 & 1 & 2 & 1 & 2.4 & 3 & 5 & 4 & 2 & 1 & 5 & 0 & 2 \\
\hline IT & 2067 & Queta & 0 & 0 & $1,2.1,2.4$ & 3 y 4 & 3 y 4 & 1.3 & 14.0 & $x$ & $x$ & 4 & 5 & $x$ & $x$ & $x$ & $x$ & 4.5 & 1 & 9 & 4 & 1 & 2 & 1 & 3.2 & 1.3 & 19 & 2 & 5 & $x$ & 9 & 8 & 2 \\
\hline QB & 1949 & Sayate & 0 & 1 & 0 & 1 & 1 & 1.4 & 12.8 & $x$ & $x$ & 6.9 & 5.5 & 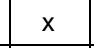 & $x$ & $x$ & $x$ & 0 & 1 & 10 & 6 & 1 & 2 & 1 & 5.8 & 3 & 10 & 4 & 5 & 2 & indet & 5 & 2 \\
\hline QB & 1950 & Sayate & 0 & 0 & 2.1 & 2 & 3 & 1.6 & indet & $x$ & $x$ & 6.8 & $8.5 \mathrm{fr}$ & $x$ & $x$ & $x$ & $x$ & 2 & 1 & 7 & 6 & $x$ & $x$ & 1 & 5.8 & 1.5 & 11 & 1 & 2 & 2 & 10 & 1 & 2 \\
\hline QB & 1951 & Sayate & 0 & 4.1 & 1.2 & 2 & 2 & 1.6 & indet & $x$ & $x$ & 6.3 & $5.6 \mathrm{fr}$ & $x$ & $x$ & $x$ & $x$ & $x$ & 1 & 7 & 3 & $x$ & $x$ & 0 & $x$ & $x$ & $x$ & $x$ & $x$ & $x$ & 8 & 5 & 2 \\
\hline QB & 2052 & Rinconada & 1 & $4.2,10$ & 1.1 & 2 & 2 & 2.3 & 5.84 & 13.6 & 4.9 & 5.6 & 15.4 & 7.4 & 7.4 & 4.1 & 11.4 & 6.7 & 2.1 & 5.4 & 5.4 & 1 & 2 & 2 & 3.9 & 18.7 & 5.5 & 3 & 2 & 2 & indet & 1 & 2 \\
\hline
\end{tabular}




\section{Manufactura}

Borde

Asa

Base

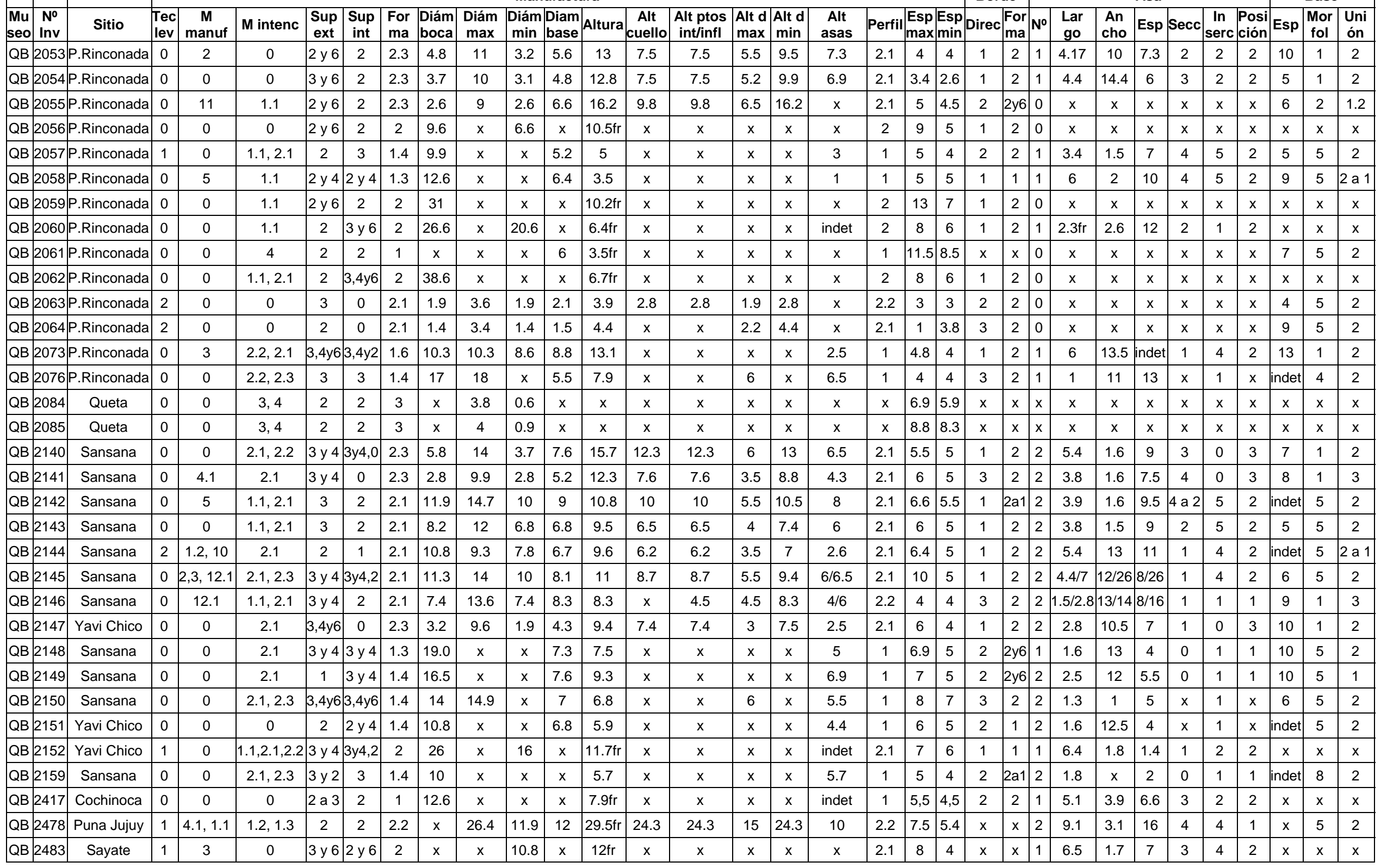


Continuación:

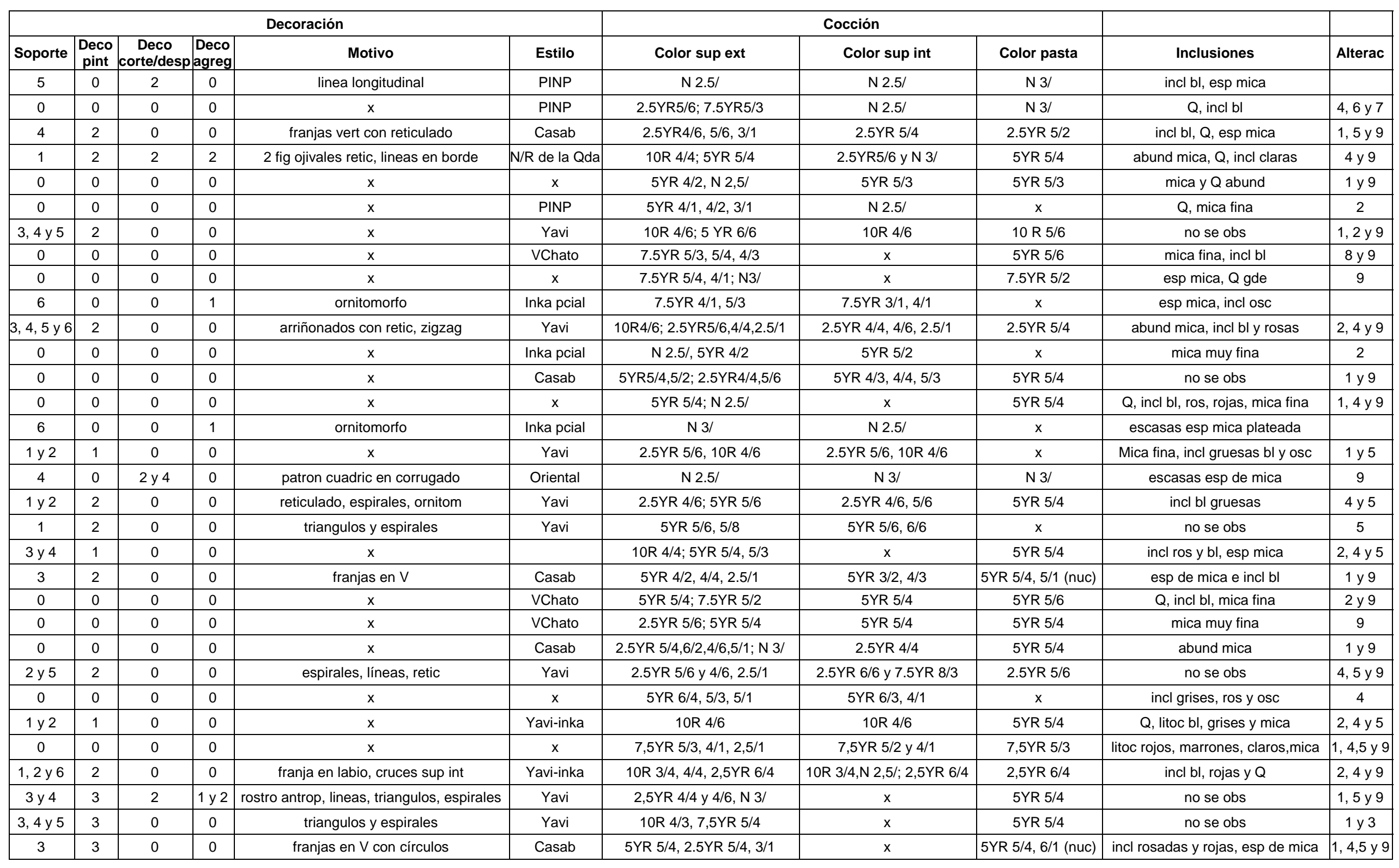




\begin{tabular}{|c|c|c|c|c|c|c|c|c|c|c|}
\hline \multicolumn{6}{|c|}{ Decoración } & \multicolumn{3}{|c|}{ Cocción } & \multirow[b]{2}{*}{ Inclusiones } & \multirow[b]{2}{*}{ Altera } \\
\hline Soporte & $\begin{array}{c}\text { Deco } \\
\text { pint }\end{array}$ & \begin{tabular}{|c|} 
Deco \\
corte/desp
\end{tabular} & \begin{tabular}{|l|} 
Deco \\
agreg
\end{tabular} & Motivo & Estilo & Color sup ext & Color sup int & Color pasta & & \\
\hline 3,4 y 5 & 1 & 0 & 0 & $x$ & $x$ & $2.5 Y R 4 / 4,3 / 1$ & 2.5 YR $4 / 4$ & $5 Y R 5 / 4$ & mica abund & 1,4 y 9 \\
\hline 2 & 1 & 0 & 0 & $x$ & $x$ & 10R 4/4, 5YR 4/2, 5/3, 3/1 & $5 Y R$ 4/1, 4/2, 3/1 & $5 Y R 5 / 3$ & mica abund, incl rojas, bl y $\mathrm{Q}$ & 1,5 y 8 \\
\hline 3 & 0 & 2 & 1 & ornitomorfo & $x$ & $5 Y R 4 / 1$ y $3 / 1$ & $5 Y R \quad 4 / 1$ y $3 / 1$ & $x$ & incl osc, claras y Q & 9 \\
\hline 0 & 0 & 0 & 0 & $x$ & Casab & $5 Y R 6 / 4,5 / 4$ & 5YR 6/4 & 5YR 5/4 & incl finas claras & 4 \\
\hline 0 & 0 & 0 & 0 & $x$ & Casab & 2,5 YR $5 / 3,5 / 4$ & 2,5 YR $5 / 3$ & 2,5 YR $5 / 4$ & mica, litoc claros y rojos & 4 y 9 \\
\hline 1 y 6 & 2 & 0 & 0 & bandas concentricas & Yavi-inka & 10R 4/6, 2,5YR $4 / 3$ & $10 \mathrm{R} 4 / 6,2,5 \mathrm{YR} 5 / 4, \mathrm{~N} 3 /$ & $2,5 Y R$ 6/6, 6/4, 5/6 & incl bl y rosas & 4,5 y 9 \\
\hline 0 & 0 & 0 & 0 & $x$ & VChato & $5 Y R$ 5/3, 5/4, 4/1, 3/1 & $5 Y R 5 / 3,4 / 1$ & $2,5 Y R 5 / 4$ & mica fina abund, incl claras y $\mathrm{Q}$ & 1 y 9 \\
\hline 0 & 0 & 0 & 0 & $\mathrm{x}$ & PINP & 2,5 YR $5 / 4,5 / 6$ & $\mathrm{~N} 3 /$ & $\mathrm{x}$ & mica fina y litoc claros & 9 \\
\hline 0 & 0 & 0 & 0 & $x$ & $\mathrm{x}$ & 2,5 YR $5 / 4,4 / 3,4 / 4,4 / 2$ & 2,5 YR $5 / 4$ & 2,5 YR $5 / 4$ & abund $\mathrm{Q}$, mica, incl bl y rojas & 9 \\
\hline 0 & 0 & 0 & 0 & $x$ & Casab & $5 Y R$ 5/4, 5/3; N 3/ & $5 Y R 5 / 4$ & 5YR 5/4 y N3/ & abund $Q$, incl claras y osc & 4 y 9 \\
\hline 6 & 0 & 2 & 1 & cabeza camélido con bozal & $\mathrm{x}$ & $5 Y R$ 5/2, 5/1, 4/1, 5/4 & $x$ & 2,5 YR $5 / 4$ & abund Q, incl bl y rojas, poca mica & 4 \\
\hline 0 & 0 & 0 & 0 & $x$ & $x$ & $5 Y R$ 5/3, 5/4, 4/3, 4/1, 3/1 & 5YR 4/3, 4/1, & $5 Y R 5 / 4$ & incl bl, Q, mica fina & 1 y 9 \\
\hline 0 & 0 & 0 & 0 & $x$ & $x$ & $5 Y R 5 / 3,5 / 4$ & $\mathrm{~N} 3 /$ & $x$ & abund Q, incl bl y rojas, poca mica & 0 \\
\hline 1 y 2 & 1 & 0 & 0 & $x$ & Yavi & 10R $5 / 4$ y $5 / 6$ & 10R $5 / 4$ y $5 / 6$ & 2.5 YR $5 / 6$ & incl bl y grises & 2 y 4 \\
\hline 0 & 0 & 0 & 0 & $x$ & PINP & $5 Y R 5 / 3,5 / 4$ & $\mathrm{~N} 3 /$ & $x$ & Q, mica fina, incl marrones & 9 \\
\hline 0 & 0 & 0 & 0 & $x$ & $x$ & $5 Y R 5 / 2,5 / 3$ & $5 Y R 4 / 3,3 / 2$ & $5 Y R 4 / 2$ & mica fina y escasa & 9 \\
\hline 0 & 0 & 0 & 0 & $x$ & $x$ & $5 Y R$ 4/3, 4/2; 10YR 4/4 & $5 Y R 4 / 3$ & $5 Y R 4 / 3$ & Q, mica, litoc claros & 1,8 y 9 \\
\hline 0 & 0 & 0 & 0 & $x$ & $x$ & $5 Y R 5 / 3,5 / 4$ & $\mathrm{~N} 2,5 /$ a N 4/ & N 3/ a $5 Y R$ 5/2 & abund mica fina, $\mathrm{Q}$ & 2 y 9 \\
\hline 0 & 0 & 0 & 0 & $x$ & Casab & : 5YR 5/4; 2,5 YR 5/6 & $2.5 \mathrm{YR} 5 / 4$ & $2.5 Y R 5 / 6, \mathrm{~N} 3 /$ & $\begin{array}{c}\text { incl bl, rosadas, rojas, mica fina y } \\
\mathrm{Q}\end{array}$ & 9 \\
\hline 0 & 0 & 0 & 0 & $x$ & Casab & $2.5 Y R \quad 4 / 4,5 / 4$ & $2.5 Y R 5 / 4$ & 2.5 YR $5 / 6$ & incl rosadas, finas bl y mica & 1 y 9 \\
\hline 1 & 2 & 0 & 0 & espirales & Yavi & 2,5 YR 5/6, 5/8 & 2,5 YR 5/6, 5/8 & $2,5 Y R 5 / 4$ & incl bl, pasta compacta & 1 y 9 \\
\hline 0 & 0 & 0 & 0 & $x$ & PINP & $5 Y R$ 3/1, 3/2, 4/1, 4/2, 4/4 & N 2,5/ & $x$ & esp finas mica & 1,2 y 9 \\
\hline 3,4 y 5 & 1 & 0 & 0 & $x$ & Yavi & 10R 4/6; 2,5YR 5/4, 4/1 & 10R 4/6; 2,5 YR 5/4 & 2,5YR 5/6 & incl claras & 4 y 9 \\
\hline 0 & 0 & 0 & 0 & $x$ & Casab & 2,5 YR $6 / 4,5 / 6$ & $\mathrm{x}$ & $x$ & incl bl y rojas & 4 \\
\hline 0 & 0 & 0 & 0 & $x$ & PINP & 5YR 5/4, N4/ & $\mathrm{N} 2,5 /$ & $x$ & incl marrones y mica & 0 \\
\hline 0 & 0 & 0 & 0 & $x$ & VChato & $5 Y R$ 5/4, 5/2 & N 3/ & $x$ & mica fina y abund, $Q$ & 9 \\
\hline 3 y 4 & 1 & 0 & 0 & $x$ & $x$ & $10 \mathrm{R} 4 / 6$ & $10 \mathrm{R} 4 / 6$ & $5 Y R 6 / 2$ & abund mica & 4 \\
\hline 1,2 y 5 & 2 & 0 & 0 & linea long y reticulado & Yavi & 10R 4/4, 4/6; 2,5YR 5/4, 5/6 & 10R 4/4; 2,5 YR 5/4 & $x$ & incl bl, rosas y mica fina & 5 \\
\hline 0 & 0 & 0 & 0 & $x$ & $\mathrm{x}$ & 5YR 4/4, 3/1, 2.5/1; N 2,5/ & $5 Y R$ 4/4, 3/1 & $\mathrm{x}$ & mica fina, $\mathrm{Q}$ e incl claras & 1 y 9 \\
\hline 3 y 6 & 2 & 0 & 0 & franjas hor y en campos triang & Casab & 10R 5/6, 3/1; 5YR 6/4 & 5YR 5/4 & $5 Y R 5 / 4$ & incl bl, rojas y $\mathrm{Q}$ & 5 y 9 \\
\hline 0 & 0 & 0 & 0 & $x$ & PINP & $5 Y R$ 5/4, 4/1, 4/2, 3/1 & 5YR 2,5/1 & 5YR 5/4, 5YR 3/1 & $\mathrm{Q}$, incl bl, moradas y mica & 4 y 9 \\
\hline 0 & 0 & 0 & 0 & $x$ & $\mathrm{x}$ & $5 Y R 6 / 4,4 / 1$ & 5YR 6/6 & $\mathrm{x}$ & no se obs & 9 \\
\hline
\end{tabular}




\begin{tabular}{|c|c|c|c|c|c|c|c|c|c|c|}
\hline \multicolumn{6}{|c|}{ Decoración } & \multicolumn{3}{|c|}{ Cocción } & \multirow[b]{2}{*}{ Inclusiones } & \multirow[b]{2}{*}{ Alterac } \\
\hline Soporte & $\begin{array}{c}\text { Deco } \\
\text { pint }\end{array}$ & $\begin{array}{c}\text { Deco } \\
\text { corte/desp }\end{array}$ & \begin{tabular}{|l|} 
Deco \\
agreg
\end{tabular} & Motivo & Estilo & Color sup ext & Color sup int & Color pasta & & \\
\hline 0 & 0 & 0 & 0 & $x$ & VChato & $5 Y R 5 / 4,4 / 1$ & N3/ & $5 Y R$ 5/4, 3/1 & incl marrones, claras, Q y mica & 9 \\
\hline 4 y 6 & 0 & 0 & 2 & zigzag & Poshisp? & $\mathrm{N} 3 /, 2.5 / ; 5 \mathrm{YR} 4 / 2$ & $5 Y R \quad 4 / 2$ & $x$ & no se obs & 1 y 2 \\
\hline 4 & 1 & 0 & 0 & puntos y áreas pint & Poshisp? & N 2.5/; 5YR 4/2, 5/3; 2.5YR4/4 & $5 Y R 5 / 3$ & $x$ & no se obs & 1 y 2 \\
\hline 3,4 y 6 & 1 & 0 & 2 & lineas curvas pint, zigzag pastillaje & Poshisp? & $5 Y R 3 / 2,4 / 2,5 / 3 ;$ N 2.5/ & $5 Y R 5 / 3$ & $x$ & no se obs & 1 \\
\hline 3 y 4 & 1 & 0 & 0 & lineas en patron complejo retic & Poshisp? & 5YR 5/4, 10R 5/6 & 5YR 5/4 & $x$ & abund mica plateada & 6 y 9 \\
\hline 4 & 1 & 0 & 1 & reborde a $1 / 2$ cuello & Poshisp? & 10R 5/6; 10R 4/2, N 3/ & 10R $4 / 2$ & 5 YR $5 / 3$ & algunas incl Q & 1 y 9 \\
\hline 0 & 0 & 0 & 0 & $x$ & PINP & $5 Y R$ 5/4, 5/3, 3/1 & N 2.5/ & $x$ & no se obs & 9 \\
\hline 1 y 2 & 1 & 0 & 0 & $x$ & Inka pcial & $2.5 Y R$ 5/6, 5/4 & $2.5 Y R 5 / 6,5 / 4$ & $x$ & incl bl y mica & 9 \\
\hline 4 & 1 & 0 & 0 & $x$ & $\mathrm{x}$ & 10R 6/6, 5YR 6/4 & $5 Y R 5 / 3$ & $5 Y R 5 / 4$ & incl bl, rojas, moradas, mica y $\mathrm{Q}$ & 4 y 9 \\
\hline 5 & 2 & 0 & 0 & espiral? Y tres lineas q salen de él & Yavi & $5 Y R 6 / 6$ & $5 Y R 6 / 6,6 / 3$ & 2.5 YR $6 / 6$ & incl claras y marrones & 5 y 9 \\
\hline 0 & 0 & 0 & 0 & $x$ & VChato & 5YR 5/4 & 5YR 5/3 & 5YR 5/4 & incl bl, osc, Q & 3 y 9 \\
\hline 5 & 2 & 0 & 0 & franja hor reticulada & Yavi? & 2.5 YR $5 / 6$ & 10R 5/6, 2.5YR 3/1 & $x$ & abund incl bl & 9 \\
\hline 0 & 0 & 0 & 0 & $x$ & $x$ & $5 Y R$ 2.5/1, 3/2 & $x$ & $5 Y R 4 / 2$ & incl bl y osc & 3 y 4 \\
\hline 2 & 2 & 0 & 0 & fjas vert y en zigzag de a 3 & Alfarcito-Isla & 10R 5/6, 2.5 YR 6/4 & 2.5 YR $5 / 2$ & 2.5 YR $6 / 4$ & incl bl y osc & 4 y 9 \\
\hline 2 y 6 & 0 & 2 & 1 & cruces inc, apend zoomorf & Oriental & $7.5 Y R$ 5/3, 4/2, N 3/ & 7.5 YR $5 / 2,4 / 1$ & $x$ & no se obs & 0 \\
\hline$x$ & 0 & 0 & 0 & $x$ & $x$ & $5 Y R 5 / 3,5 / 1$ & 5YR 5/4 & $5 Y R 5 / 4$ & alg incl osc y mica & 1 \\
\hline$x$ & 0 & 0 & 0 & $x$ & $x$ & 2.5 YR $6 / 4$ & 2.5 YR $6 / 3,4 / 1$ & $2.5 Y R 6 / 3,4 / 1$ & incl osc y rojas & 0 \\
\hline 3 y 4 & 1 & 0 & 0 & $x$ & Yavi & 10R 5/6 & $x$ & $5 Y R 6 / 6$ & incl blancas & 2 y 8 \\
\hline 3 y 4 & 1 & 2 & 2 & model antropomorf en cuello & Yavi & 10R 5/6 & $5 Y R 6 / 6$ & $5 Y R 6 / 6$ & no se obs & 5 \\
\hline 3 y 4 & 1 & 0 & 0 & $x$ & $x$ & $5 Y R 6 / 6,5 / 4$ & $5 Y R$ 5/4 & $x$ & no se obs & 2 \\
\hline 0 & 0 & 0 & 0 & $x$ & Yavi & $5 Y R 5 / 4,4 / 2,6 / 6$ & 5 YR $6 / 6$ & $5 Y R 5 / 4$ & no se obs & 2 y 9 \\
\hline 0 & 0 & 0 & 0 & $x$ & $x$ & 2.5 YR $5 / 4,5 / 2$ & 2.5 YR $5 / 4,5 / 2$ & 2.5 YR $5 / 4$ & no se obs & 9 \\
\hline 3,4 y 6 & 1 & 0 & 1 & apéndice tubular con model zoomorf & Yavi & 10R 5/6, 3/1; 5YR 6/6 & $5 Y R 6 / 6,5 / 2$ & $5 Y R 6 / 6$ & incl grises y marrones & 1,4 y 9 \\
\hline 3,4 y 6 & 1 & 2 & 1 & apéndice tubular con model zoomorf & Yavi & $10 \mathrm{R} 5 / 4,5 / 2,4 / 1$ & $5 Y R 5 / 2,5 / 3$ & $5 Y R 5 / 4$ & incl claras & 4,5 y 9 \\
\hline 3 y 4 & 2 & 2 & 1 & rostro cuello, lineas y espirales en fja & Yavi & 2.5 YR $5 / 4,5 / 6$ & $x$ & $x$ & algunas incl bl & 0 \\
\hline 5 & 2 & 0 & 0 & reticulado & Yavi & 10R 4/4, 2.5YR 5/6 & 2.5 YR $6 / 6$ & 2.5 YR $5 / 6$ & abund incl bl & 4 y 9 \\
\hline 1 & 1 & 0 & 0 & $x$ & Yavi & $2.5 Y R$ 5/6, 5/2, 4/1 & 2.5 YR $6 / 6$ & $5 Y R 5 / 4$ & no se obs & 2 y 9 \\
\hline 2,5 & 2 & 0 & 0 & fja negra ondul, lineas negras de a 3 & Yavi & $5 Y R$ 5/6, 4/6; 3/1 & $5 Y R 5 / 6,4 / 6$ & $x$ & no se obs & 5 \\
\hline 0 & 0 & 0 & 0 & $x$ & PINP & $5 Y R$ 6/4, 4/1, 3/1 & $5 Y R$ 3/1 a N3/ & $x$ & Q y mica & 0 \\
\hline 0 & 0 & 0 & 0 & $x$ & $x$ & $5 Y R$ 5/2, 5/3 & 5YR 5/2 & $5 Y R 4 / 2$ & no se obs & 2 y 9 \\
\hline 0 & 0 & 0 & 0 & $x$ & Casab & $5 Y R 3 / 1$, N3/, N 2.5/ & N3/, 5YR 3/1 & $5 Y R \quad 4 / 2$ & no se obs & 1,2 y 9 \\
\hline 4 & 2 & 0 & 0 & motivo tipo mano & $x$ & 2.5 YR $5 / 6,4 / 1$ & 2.5 YR $5 / 4$ & $2.5 Y R 5 / 4,4 / 4$ & abund incl bl & 4 y 9 \\
\hline
\end{tabular}




\section{ANEXO III \\ Código analítico para descripción de fracturas frescas en lupa binocular}

Planillas de descripción de fracturas frescas

CÓDIGO ANALÍTICO PARA DESCRIPCIÓN DE FRACTURAS FRESCAS EN LUPA BINOCULAR:

- Sitio y estructura

- UP

- $\quad N^{\circ}$ grupo

- $\quad N^{\circ}$ de fragmento especial

\section{Fractura}

- Aspecto general

$\begin{array}{ll}\text { 1. compacto } & \text { 2. no compacto }\end{array}$

- Textura
1. laminar
2. porosa
3. floja

- Resistencia
1. resistente
2. quebradiza
3. deleznable

- Regularidad
1. irregular
2. regular recta
3.regular concoidea

\section{Cavidades}

1. grandes cavidades

2. pequeñas cavidades

\section{Cocción}
1. oxidante completa 2. oxidante incompleta
3. reductora
4. exterior oxidante, interior reducido
5. primero oxidante después reducida

Color (más la notación Munsell)
1. uniforme
2. no uniforme neto - estructura bicapa 
3. no uniforme neto - estructura tricapa 4. no uniforme difuso - estructura bicapa 5. no uniforme difuso - estructura tricapa

\section{$\underline{\text { Inclusiones }}$}

- Inclusiones

$\begin{array}{ll}\text { 1. se observan a ojo desnudo } & \text { 2. solo se observan bajo lupa }\end{array}$

- Densidad

$\begin{array}{lll}\text { 1. poco denso }(5 \text { a } 10 \%) & \text { 2. denso }(20 \%) & \text { 3. muy denso }(30 \%)\end{array}$

- Orientación
1. irregular
2. regular parcial
3. regular total

- Granulometría
1. Muy grueso
2. Grueso
3. Mediano
4. Fino
5. Muy fino

- Grado de selección
1. Muy pobre
2. Pobre
3. Moderada
4. Buena
5. Muy buena

- Redondez
1. Muy anguloso
2. Anguloso
3. Subanguloso
4. Subredondeado
5. Redondeado
6. Muy redondeado

- Tipo de inclusiones
0 . Indeterminado
1. Mineral
2. Lítico
3. Tiesto molido

- Composición

Especies que se presentan en mayor porcentaje

Componentes aislados o singulares

- Grupo de pasta (número)

\section{Bibliografía usada:}

Orton, C.; P. Tyers y A. Vince. 1997. La cerámica en arqueología. Editorial Crítica, Barcelona.

Rye, O. S. 1981. Pottery Technology. Principles and reconstruction. Taraxacum. Washington D.C., USA.

Zagorodny, N. I. s. f. Ficha descriptiva. Laboratorio de Análisis Cerámico. UNLP. M. S. 


\begin{tabular}{|c|c|c|c|c|c|c|c|c|c|c|c|c|c|c|c|c|c|c|c|c|c|}
\hline \multirow[b]{2}{*}{$\begin{array}{c}\text { Sitio y } \\
\text { est }\end{array}$} & \multirow[b]{2}{*}{ UP } & \multirow[b]{2}{*}{ GF } & \multirow[b]{2}{*}{ FNA } & \multicolumn{4}{|c|}{ Fractura } & \multirow[b]{2}{*}{$\begin{array}{l}\mathrm{Ca} \\
\text { vid }\end{array}$} & \multirow{2}{*}{\multicolumn{2}{|c|}{$\begin{array}{l}\text { Coc Co } \\
\text { ción lor }\end{array}$}} & \multirow[b]{2}{*}{ Not color } & \multicolumn{7}{|c|}{ Inclusiones } & \multicolumn{2}{|c|}{ Composic } & \multirow[b]{2}{*}{ GP } \\
\hline & & & & $\begin{array}{c}\text { Aspec } \\
\text { to }\end{array}$ & \begin{tabular}{|l|l|}
$c$ & $\begin{array}{l}\text { Tex } \\
\text { tura }\end{array}$ \\
\end{tabular} & $\begin{array}{l}\text { Resis } \\
\text { tenc. }\end{array}$ & $\begin{array}{lll}\text { Re } \\
\text { ul }\end{array}$ & & & & & Incl & Dens & $\begin{array}{c}\text { Orien } \\
\text { tac }\end{array}$ & $\begin{array}{l}\text { Orient } \\
\text { pared }\end{array}$ & Granul & & $\begin{array}{c}\mathrm{Re} \\
\mathrm{don}\end{array}$ & comp mayor & comp aislados & \\
\hline $\mathrm{CH} 25-1$ & 102 & 1 & & 2 & 2 & 2 & 1 & 2 & 2 & 4 & $5 Y R$ 5/3, 3/1 & 1 & 2 & 1 & & 2 y $3>, 1$ & 2 & $3 a 4$ & Q trasl; sed rojas, grises y bl & mica, fel alt & 2 \\
\hline $\mathrm{CH} 25-1$ & 102 & 1 & & 2 & 2 & 1 & 1 & 2 & 1 & 1 & 2,5 YR $4 / 4$ & 1 & 2 & 1 & & 2 y $3>, 1$ y 5 & 2 & $3 a 4$ & Q trasl,sed bl y grises, mica & sed rojas, fel alt & 2 \\
\hline $\mathrm{CH} 25-1$ & 102 & 1 & & 2 & 2 & 1 & 2 & 2 & 1 & 1 & 5YR 5/4 & 1 & 3 & 2 & & 3 y 4 & 3 & $2 \mathrm{a} 5$ & mica abund, Q trasl, sed bl & sed rojas, fel alt & 2 \\
\hline $\mathrm{CH} 25-1$ & 102 & 1 & & 2 & 2 & 2 & 1 & 2 & 2 & 4 & $5 Y R$ 4/3, 4/1 & 1 & 2 & 2 & & 3 y $4>, 2$ & 2 & $3 a 4$ & Q trasl, sed grises, marrones, mica & fel alt, sed rojas & 2 \\
\hline $\mathrm{CH} 25-1$ & 101 & 1 & & 2 & 2 & 2 & 1 & 2 & 2 & 4 & $2,5 Y R \quad 4 / 4,4 / 1$ & 1 & 3 & 2 & & 3 y 4 & 3 & $2 \mathrm{a} 3$ & mica, Q trasl & sed bl, fel alt & 2 \\
\hline $\mathrm{CH} 25-1$ & 101 & 1 & & 2 & 2 & 2 & 1 & 2 & 2 & 4 & $5 Y R \quad 4 / 4,4 / 1$ & 1 & 2 & 2 & & 1 y $2>$ & 3 & $2 \mathrm{a} 3$ & mica abund, Q trasl & sed bl, grises, fel alt & 2 \\
\hline $\mathrm{CH} 25-1$ & 102 & 1 & & 2 & 2 & 2 & 1 & 2 & 3 & 1 & gris marrón osc & 1 & 2 & 2 & & 2 y 5 & 2 & $2 a 3$ & Q trasl, mica, sed marrones & sed grises y rojas, fel alt & 2 \\
\hline $\mathrm{CH} 25-1$ & 102 & 1 & & 2 & 2 & 1 & 2 & 2 & 2 & 1 & marrón & 1 & 2 & 1 & & 2 y 4 & 3 & $2 \mathrm{a} 3$ & Q trasl, mica, sed rojas & sed grises, fel alt & 2 \\
\hline $\mathrm{CH} 25-1$ & 102 & 1 & & 2 & 2 & 2 & 1 & 2 & 2 & 5 & marrón rojizo, gris osc & 1 & 2 & 1 & & 3 y 4,5 & 3 & $2 \mathrm{a} 3$ & Q trasl, mica & sed grises, fel alt & 2 \\
\hline $\mathrm{CH} 25-1$ & 102 & 1 & & 1 & 2 & 1 & 1 & 2 & 2 & 4 & marrón claro, gris & 1 & 2 & 1 & & 3 y $4>, 2$ & 2 & 2 & Q trasl, mica, sed bl & fel alt, sed rojas & 2 \\
\hline $\mathrm{CH} 25-1$ & 102 & 1 & & 2 & 2 & 2 & 1 & 2 & 2 & 4 & rojo marrón a grisáceo & 1 & $2 \mathrm{a} 3$ & 1 & & 4 y $5>, 2$ & 3 & $3 a 4$ & Q trasl, mica & fel alt & 2 \\
\hline $\mathrm{CH} 25-1$ & 102 & 1 & & 2 & 2 & 3 & 1 & 2 & 2 & 1 & marrón grisáceo osc & 1 & $2 a 3$ & 1 & & 3 y $4>, 5$ & 3 & $3 a 4$ & Q trasl, mica, sed marrones & sed grises, fel alt & 2 \\
\hline $\mathrm{CH} 25-1$ & 102 & 1 & & 2 & 2 & 2 & 1 & 2 & 1 & 1 & rojo marrón & 1 & $2 \mathrm{a} 3$ & 1 & & 4 y $5>, 3$ & 3 & $2 \mathrm{a} 3$ & mica, Q trasl & fel alt, Q-fel & 2 \\
\hline $\mathrm{CH} 25-1$ & 102 & 1 & & 2 & 2 & 2 & 1 & 2 & 2 & 1 & marron gris claro & 1 & 2 & 1 & & 4 y $5>, 1$ & 2 & $3 a 4$ & mica, Q trasl & fel alt, sed bl y marrones, Q-fel & 2 \\
\hline $\mathrm{CH} 25-1$ & 102 & 2 & & 2 & 1 & 2 & 1 & 2 & 3 & 1 & N3/ & 1 & 2 & 2 & & 1 y $2>, 5$ & 2 & $1 a 2$ & muscovita muy abund, Q trasl & biotita & 6 \\
\hline $\mathrm{CH} 25-1$ & 102 & 2 & & 2 & 2 & 2 & 1 & 2 & 2 & 1 & 5YR 5/4 & 1 & 2 & 1 & & 1 y $2>, 4$ & 2 & $1 \mathrm{a} 2$ & muscovita muy abund, Q trasl & biotita, Q bl & 6 \\
\hline $\mathrm{CH} 25-1$ & 102 & 2 & & 2 & 1 & 2 & 1 & 2 & 2 & 4 & $5 Y R$ 6/4, 3/1 & 1 & $2 \mathrm{a} 3$ & 2 & & 1 y $2>, 5$ & 2 & $1 \mathrm{a} 2$ & muscovita muy abund, $\mathrm{Q}$ trasl, $\mathrm{Q}$ bl & biotita & 6 \\
\hline $\mathrm{CH} 25-1$ & 103 & 3 & & 1 & 2 & 1 & 1 & 2 & 4 & 4 & $5 Y R$ 5/2, N3/ & 1 & 2 & 1 & & 2 y $3>$ & 4 & $3 a 5$ & sed rojas y marrones, mica, $\mathrm{Q}$ trasl & sed grises y bl, fel alt & 4 \\
\hline $\mathrm{CH} 25-1$ & Sup & 4 & & 1 & 2 & 1 & 1 & $2 \mathrm{y} 1$ & 2 & 4 & 2,5YR 5/4, N5/ & 1 & $1 \mathrm{a} 2$ & 1 & & 1 y $2>, 5$ & 2 & $2 a 4$ & sed rojas y marrones, $\mathrm{Q}$ trasl & mica, Q-fel & 4 \\
\hline $\mathrm{CH} 25-1$ & Sup & 4 & & 1 & 2 & 1 & 1 & $2 \mathrm{y} 1$ & 2 & 5 & 2,5YR 5/4 (nuc), N5/ & 1 & 2 & 1 & & 1 y $2>, 4$ y 5 & 2 & $2 \mathrm{a} 4$ & sed rojas, marrones y grises & Q trasl, Q-fel, mica & 4 \\
\hline $\mathrm{CH} 25-1$ & 102 & & 1 & 1 & 2 & 1 & 1 & 2 & 1 & 1 & 2,5 YR $5 / 4$ & 1 & 2 & 1 & & 3 y $4>, 5$ & 3 & $2 \mathrm{a} 4$ & Q trasl, mica, sed rojas & Q-fel, fel alt, sed grises & 4 \\
\hline $\mathrm{CH} 25-1$ & 102 & & 2 & 1 & 2 & 1 & 1 & $2 \mathrm{y} 1$ & 2 & 1 & 5YR 5/4 & 2 & 1 & 1 & & 4 y 5 & 4 & $2 a 3$ & Q trasl, mica & sed gris, Q-fel & 5 \\
\hline $\mathrm{CH} 25-1$ & 102 & & 3 & 2 & 2 & 1 & 1 & $2 \mathrm{y} 1$ & 2 & 4 & $2,5 Y R$ 5/4, 5/1 & 1 & 2 & 1 & & 2 y $3>$ & 2 & $3 a 4$ & Q trasl, biotita, Q-fel, sed rojas & sed grises & 4 \\
\hline $\mathrm{CH} 25-1$ & 102 & & 4 & 2 & 2 & 1 & 1 & $2 \mathrm{y} 1$ & 1 & 1 & 2,5 YR $5 / 4$ & 1 & 2 & 1 & & 2 y $3>$ & 2 & $3 a 4$ & Q trasl, biotita,sed rojas y moradas & fel alt, sed grises & 4 \\
\hline $\mathrm{CH} 25-1$ & 103 & & 5 & 2 & 2 & 2 & 2 & $2 \mathrm{y} 1$ & 2 & 4 & $2,5 Y R \quad 4 / 4,3 / 1$ & 1 & $2 a 3$ & 1 & & 4 y 5 & 4 & $4 a 5$ & mica, Q trasl, sed rojas & Q-fel, fel alt & 4 \\
\hline $\mathrm{CH} 25-1$ & Sup & & 6 & 2 & 2 & 2 & 1 & $2 \mathrm{y} 1$ & 2 & 5 & $5 Y R$ 5/4, 5/2 & 1 & 2 & 2 & & 4 y $5>, 1$ y 2 & 2 & $3 a 4$ & mica, Q trasl, sed rojas y bl & fel alt, sed grises & 4 \\
\hline $\mathrm{CH} 25-1$ & Sup & & 7 & 1 & 2 & 1 & 1 & 2 & 1 & 1 & $5 Y R 5 / 3$ & 1 & 2 & 1 & & 4 y $5>, 2$ & 3 & $3 a 4$ & Q trasl, mica, sed rojas y bl & sed marron, Q-fel & 4 \\
\hline $\mathrm{CH} 25-1$ & Sup & & 8 & 1 & 2 & 1 & 1 & 2 & 2 & 1 & 5YR 4/1 & 1 & 2 & 1 & & $1,2,3$ & 2 & $2 \mathrm{a} 3$ & sed bl, rojas, Q-fel & fel alt & 4 \\
\hline $\mathrm{CH} 25-1$ & Sup & & 9 & 1 & 2 & 1 & 2 & $2 \mathrm{y} 1$ & 2 & 5 & $5 Y R$ 5/3, 5/1 & 1 & 2 & 1 & & 4 y $5>, 1$ & 2 & $3 a 4$ & sed rojas y bl, grises & Q-fel, fel alt & 4 \\
\hline $\mathrm{CH} 25-1$ & Sup & & 10 & 1 & 2 & 1 & 1 & 2 & 1 & 5 & 2,5YR 5/6, 5YR 5/4 & 1 & 2 & 2 & & 2 y $3>, 5$ & 2 & $2 \mathrm{a} 5$ & sed rojas, sed bl o fel alt & mica fina, Q-fel & 4 \\
\hline $\mathrm{CH} 25-1$ & Sup & & 11 & 1 & 2 & 1 & 1 & 2 & 1 & 1 & 2,5 YR $6 / 6$ & 1 & 2 & 2 & & $4>1$ y 5 & 2 & $3 a 4$ & sed bl y rosas o fel alt, sed rojas & Q trasl & 3 \\
\hline $\mathrm{CH} 25-1$ & Sup & & 12 & 2 & 2 & 1 & 1 & 2 & 2 & 4 & $5 Y R$ 5/4, 5/2 & 1 & 2 & 1 & & 2 y $3>, 4$ & 3 & $3 a 4$ & mica, Q trasl, sed rojas y bl o fel alt & Q-fel & 4 \\
\hline $\mathrm{CH} 25-1$ & Sup & & 13 & 2 & 2 & 2 & 1 & 2 & 2 & 1 & 5YR $4 / 3$ & 1 & $2 \mathrm{a} 3$ & 1 & & 1 y $2>, 5$ y 6 & 1 & $3 a 4$ & sed rojas, Q trasl, mica & sed claras, fel alt, Q-fel & 4 \\
\hline $\mathrm{CH} 25-1$ & Sup & & 16 & 1 & 2 & 1 & 2 & 2 & 1 & 1 & $2,5 Y R$ T/6 & 1 & 2 & 1 & & 4 y $5>, 2$ & 3 & $3 a 4$ & sed rojas, rosas, bl, Q trasl, mic & fel alt, roca negra afanit & 4 \\
\hline $\mathrm{CH} 25-1$ & Sup & & 17 & 2 & 2 & 2 & 1 & 2 & 3 & 1 & N3/ & 1 & $2 \mathrm{a} 3$ & 1 & & 4 y $5>, 3$ & 3 & $3 a 4$ & Q trasl, mica, sed marrones & roca volc afan, Q-fel & 2 \\
\hline $\mathrm{CH} 25-1$ & Sup & & 18 & 2 & 2 & 2 & 2 & 2 & 3 & 1 & N3/ & 1 & 3 & 1 & & 4 y 5 & 4 & $3 a 4$ & Q trasl, mica, sed marrones & fel alt, Q fel & 2 \\
\hline
\end{tabular}




\begin{tabular}{|c|c|c|c|c|c|c|c|c|c|c|c|c|c|c|c|c|c|c|c|c|c|}
\hline \multirow[t]{2}{*}{$\mathrm{CH} 25-1$} & \multirow[t]{2}{*}{ Sup } & & \multirow[t]{2}{*}{19} & 2 & 2 & 2 & 2 & \multirow[t]{2}{*}{2} & \multirow[t]{2}{*}{1} & \multirow[t]{2}{*}{1} & \multirow[t]{2}{*}{$2,5 Y R$ 5/4 } & 1 & 2 & 1 & & 4 y $5>, 3$ & & $2 \mathrm{a} 3$ & Q trasl, mica, sed rojas y bl & fel alt, Q-fel & \multirow[b]{3}{*}{ GF } \\
\hline & & & & \multicolumn{4}{|c|}{ Fractura } & & & & & \multicolumn{7}{|c|}{ Inclusiones } & \multicolumn{2}{|c|}{ Composic } & \\
\hline $\begin{array}{c}\text { Sitio y } \\
\text { est }\end{array}$ & UP & GF & FNA & $\begin{array}{c}\text { Aspec } \\
\text { to }\end{array}$ & \begin{tabular}{|l|l|}
$c$ & $\begin{array}{l}\text { Tex } \\
\text { tura }\end{array}$ \\
\end{tabular} & \begin{tabular}{|l} 
Resis \\
tenc.
\end{tabular} & $\begin{array}{l}\mathbf{R e} \\
\text { gul }\end{array}$ & $\begin{array}{l}\mathrm{Ca} \\
\text { vid } \\
\end{array}$ & $\begin{array}{l}\text { Coc } \\
\text { ción }\end{array}$ & $\begin{array}{l}\text { Co } \\
\text { lor }\end{array}$ & Not color & Incl & Dens & $\begin{array}{c}\text { Orien } \\
\text { tac }\end{array}$ & $\begin{array}{l}\text { Orient } \\
\text { pared }\end{array}$ & Granul & $\begin{array}{l}\text { Se } \\
\text { lec }\end{array}$ & $\begin{array}{l}\mathrm{Re} \\
\mathrm{don}\end{array}$ & comp mayor & comp aislados & \\
\hline $\mathrm{CH} 25-1$ & 102 & & 20 & 1 & 2 & 2 & 1 & 2 & 2 & 1 & marrón rojizo & 1 & 2 & 1 & & 2 y $3>, 1$ & 1 & $2 \mathrm{a} 3$ & sed rojas, Q trasl, mica & sed bl y grises, fel alt & 4 \\
\hline $\mathrm{CH} 25-2$ & 102 & 1 & & 2 & 2 & 1 & 1 & 2 & 2 & 4 & $\mathrm{~N} 3 /, 5 \mathrm{YR} 4 / 3$ & 1 & 2 & 1 & & 2 y $3>, 4$ y 5 & 3 & $2 a 3$ & Q trasl, sed marrones y grises, mica & Q-fel, fel alt & 2 \\
\hline $\mathrm{CH} 25-2$ & 102 & 1 & & 2 & 2 & 1 & 1 & 2 & 2 & 4 & $5 Y R 5 / 2$ y $5 / 4$ & 1 & 2 & 1 & & 3 y $4>, 2$ y 5 & 3 & $2 a 3$ & Q trasl, sed marrones, mica & sed bl, Q-fel, fel alt & 2 \\
\hline $\mathrm{CH} 25-2$ & 101 & 2 & & 1 & 2 & 1 & 1 & 2 & 2 & 2 & 10R $5 / 6,3 / 1$ & 1 & 2 & 1 & & 4 y $5>$ & 3 & $3 a 4$ & mica, Q trasl, sed bl o fel alt & Q-fel, sed rojas & 1 \\
\hline $\mathrm{CH} 25-2$ & 101 & 2 & & 1 & 2 & 1 & 1 & 2 & 2 & 1 & $10 R 5 / 4$ & 1 & 2 & 1 & & 4 y $5>, 3$ & 3 & $3 a 4$ & mica, Q trasl, sed bl o fel alt & Q- fel, sed rojas & 1 \\
\hline $\mathrm{CH} 25-2$ & 101 & 2 & & 1 & 2 & 1 & 1 & $2 \mathrm{y} 1$ & 2 & 4 & $10 R 5 / 3,5 / 1$ & 1 & 2 & 1 & & 4 y $5>, 3$ & 3 & $3 a 4$ & mica, Q trasl, sed bl o fel alt & Q-fel, sed marrones & 1 \\
\hline $\mathrm{CH} 25-2$ & 102 & 3 & & 2 & 2 & 2 & 1 & 2 & 2 & 1 & 5YR 4/2 & 1 & 2 & 1 & & 3 y $4>, 2$ y 5 & 3 & $3 a 4$ & Q trasl, sed bl o fel alt, mica & sed marrones y grises & 2 \\
\hline $\mathrm{CH} 25-2$ & 102 & 3 & & 2 & 2 & 2 & 1 & 2 & 2 & 1 & $5 Y R 4 / 2$ & 1 & 2 & 1 & & 3 y $4>, 2$ y 5 & 3 & $3 a 4$ & Q trasl, mica, sed grises y bl & sed rojas y marrones & 2 \\
\hline $\mathrm{CH} 25-2$ & 102 & 3 & & 2 & 2 & 2 & 1 & 2 & 2 & 4 & $5 Y R$ 4/1, 4/2 & 1 & 2 & 1 & & 3 y $4>, 5$ & 3 & $3 a 4$ & Q trasl, mica, sed bl o fel alt & sed marrones y grises & 2 \\
\hline $\mathrm{CH} 25-2$ & 102 & 4 & & 2 & 2 & 2 & 1 & 2 & 2 & 1 & 5YR 4/2 & 1 & 2 & 1 & & 4 y $5>, 2$ y 3 & 3 & $3 a 4$ & Q trasl, mica, sed grises y bl & sed rojas, Q-fel, roca volc afan & 4 \\
\hline $\mathrm{CH} 25-2$ & 102 & 4 & & 2 & 2 & 2 & 1 & 2 & 2 & 1 & $5 Y R 4 / 2$ & 1 & 2 & 1 & & 2 y $3>, 4$ y 5 & 2 & $3 a 4$ & mica, Q trasl, sed grises y bl & sed rojas y marrones, fel alt & 4 \\
\hline $\mathrm{CH} 25-2$ & 102 & 4 & & 2 & 2 & 1 & 1 & 2 & 2 & 4 & $5 Y R \quad 4 / 3,4 / 1$ & 1 & 2 & 1 & & 1 y $2>, 4$ y 5 & 2 & $2 \mathrm{a} 3$ & mica, sed grises y bl & sed rojas, Q trasl, Q-fel & 4 \\
\hline $\mathrm{CH} 25-2$ & 102 & 4 & & 2 & 2 & 2 & 1 & 2 & 2 & 1 & 5YR 4/2 & 1 & 2 & 1 & & 4 y $5>, 1$ y 2 & 3 & $2 \mathrm{a} 3$ & mica, sed grises y bl, Q trasl & Q-fel, sed marr y rojas, fel alt & 4 \\
\hline $\mathrm{CH} 25-2$ & 102 & 5 & & 2 & 2 & 2 & 1 & 2 & 1 & 1 & 2,5YR 4/1 & 1 & 2 & 1 & & 2 y $3>, 1$ y 4 & 2 & $2 \mathrm{a} 3$ & sed bl, Q trasl, mica & sed marrones y rojas, fel alt & 4 \\
\hline $\mathrm{CH} 25-2$ & 102 & 5 & & 2 & 2 & 2 & 1 & 2 & 2 & 4 & 2,5 YR $4 / 8$ y $4 / 4$ & 1 & 2 & 1 & & 2 y $3>, 1$ y 4 & 2 & $2 \mathrm{a} 3$ & Q trasl, sed bl, fel alt, mica & sed marrones y rojas & 4 \\
\hline $\mathrm{CH} 25-2$ & 102 & & 2 & 2 & 2 & 2 & 1 & 2 & 2 & 1 & 5YR 4/3 & 1 & 2 & 1 & & 4 y $5>, 3$ y 2 & 3 & $3 a 4$ & Q trasl, mica, sed bl o fel alt & sed rojas, Q-fel, sed grises & 2 \\
\hline $\mathrm{CH} 25-2$ & 102 & & 3 & 2 & 2 & 1 & 1 & 2 & 2 & 4 & $5 Y R$ 5/3,4/1 & 1 & 2 & 1 & & 2 y $3>, 1$ y 4 & 2 & $3 a 4$ & Q trasl, sed grises, mica & sed bl o fel alt, sed rojas, Q-fel & 2 \\
\hline $\mathrm{CH} 25-2$ & 102 & & 4 & 2 & 2 & 2 & 1 & 2 & 2 & 4 & $5 Y R \quad 4 / 3,4 / 1$ & 1 & 2 & 2 & & 2 y $3>, 4$ y 5 & 3 & $2 \mathrm{a} 3$ & mica, Q trasl, sed rojas y marrones & sed bl o fel alt, sed grises & 4 \\
\hline $\mathrm{CH} 25-2$ & 102 & & 5 & 2 & 2 & 2 & 1 & $2 \mathrm{y} 1$ & 2 & 4 & 7,5 YR $5 / 2,3 / 1$ & 1 & 2 & 2 & & 1 y $2>, 3$ & 2 & $3 a 4$ & sed grises y marrones, $\mathrm{Q}$ trasl, mica & sed ros y bl ofel alt, rojas, Q-fel & 4 \\
\hline $\mathrm{CH} 25-2$ & 102 & & 6 & 1 & 2 & 2 & 1 & 2 & 2 & 5 & $\mathrm{~N} 3 /, \mathrm{N} \mathrm{4/ \text {(nuc) }}$ & 2 & $1 \mathrm{a} 2$ & 1 & & 4 y $5>, 2$ y 3 & 2 & $3 a 4$ & $\mathrm{Q}$ trasl, sed grises, mica & sed bl o fel alt & 4 \\
\hline $\mathrm{CH} 25-2$ & 102 & & 7 & 2 & 2 & 1 & 1 & 2 & 1 & 1 & 5YR 5/4 & 1 & 2 & 1 & & 4 y $5>, 1$ y 2 & 2 & $3 a 4$ & Q trasl, sed rojas y marrones, mica & sed grises, bl y rosas ofel alt, & 4 \\
\hline $\mathrm{CH} 25-2$ & 102 & & 8 & 1 & 2 & 1 & 1 & 2 & 1 & 1 & 7,5 YR $5 / 3$ & 1 & 2 & 1 & & 2 y $3>, 4$ y 5 & 3 & $3 a 4$ & sed bl y grises, $\mathrm{Q}$ trasl, mica & fel alt, sed rojas & 4 \\
\hline $\mathrm{CH} 25-2$ & 102 & & 9 & 2 & 2 & 2 & 1 & 2 & 2 & 4 & 2,5 YR 4/6 & 1 & 2 & 1 & & 2 y $3>, 4$ & 3 & $3 a 4$ & sed grises y marrones. Q trasl & sed bl o fel alt, Q-fel, mica & 4 \\
\hline $\mathrm{CH} 25-2$ & Sup & & 10 & 1 & 2 & 1 & 1 & 2 & 1 & 1 & 2,5 YR $5 / 8$ & 2 & 1 & 1 & & 4 y $5>, 1$ & 2 & $3 a 4$ & sed bl y rosas o fel alt, Q trasl & sed grises, mica, sed rojas & 3 \\
\hline $\mathrm{CH} 25-2$ & Sup & & 11 & 2 & 2 & 1 & 1 & 2 & 2 & 2 & $2,5 Y R$ 4/6, 3/1 & 1 & 2 & 1 & & 3 y $4>, 1$ y 2 & 2 & $3 a 4$ & sed bl o fel alt, sed rojas & sed grises, mica, Q trasl, cuarc & 4 \\
\hline $\mathrm{CH} 25-2$ & Sup & & 12 & 2 & 2 & 2 & 1 & 2 & 2 & 4 & $5 Y R$ 5/4, N3/ & 1 & 2 & 1 & & 4 y $5>, 3$ & 4 & $4 a 5$ & Q trasl, sed bl o fel alt & mica, Q-fel, sed rojas & 2 \\
\hline PA6-1 & 201 & 1 & & 1 & 2 & 2 & 1 & 2 & 2 & 5 & 5YR 3/1, 3/2 (nuc) & 1 & 2 & 2 & 2 & 1 y 2,4 y 5 & 1 & $2 \mathrm{a} 4$ & mica, sed rojas y bl & $\mathrm{Q}$, sed grises & 4 \\
\hline PA6-1 & 202 & 1 & & 1 & 2 & 2 & 1 & 2 & 2 & 4 & $5 Y R \quad 4 / 3,4 / 1$ & 1 & $2 \mathrm{a} 3$ & 2 & 1 & 2 y $3>, 5$ & 2 & $2 \mathrm{a} 4$ & mica, sed grises y rojas & $\mathrm{Q}$, sed bl & 4 \\
\hline PA6-1 & 202 & 1 & & 1 & 2 & 2 & 1 & 2 & 2 & 4 & $5 Y R \quad 4 / 3,4 / 1$ & 1 & 2 & 1 & 1 & 1 y 2,4 & 2 & $2 \mathrm{a} 4$ & mica, sed rojas y bl & $\mathrm{Q}$, sed grises & 4 \\
\hline PA6-1 & 302 & 1 & & 1 & 2 & 2 & 1 & 2 & 2 & 5 & 5YR 5/4;2,5YR 5/6(nuc) & 1 & 2 & 1 & 2 & 2 y $3>, 5$ & 2 & $2 \mathrm{a} 4$ & mica, sed rojas y bl & Q, sed grises & 4 \\
\hline PA6-1 & 202 & 1 & & 1 & 2 & 2 & 1 & $2 \mathrm{y} 1$ & 2 & 4 & N 3/, 5YR 5/3 & 1 & 2 & 1 & 1 & 4 y $5>, 2$ & 2 & $2 \mathrm{a} 4$ & mica, sed grises y bl & $\mathrm{Q}$, sed rojas & 4 \\
\hline PA6-1 & 202 & 1 & & 1 & 2 & 2 & 1 & 2 & 2 & 4 & $5 Y R 5 / 3,4 / 1$ & 1 & 2 & 2 & 1 & 4 y $5>, 2$ & 2 & $2 \mathrm{a} 4$ & mica, sed grises y bl & $\mathrm{Q}$, sed rojas & 4 \\
\hline PA6-1 & 102 & 1 & & 1 & 2 & 2 & 1 & 2 & 2 & 5 & 5YR 4/1, 4/3 (nuc) & 1 & 2 & 2 & 2 & 4 y $5>, 2$ & 3 & $3 a 4$ & mica, sed grises y bl & $\mathrm{Q}$, sed rojas & 4 \\
\hline PA6-1 & 201 & 1 & & 1 & 2 & 2 & 1 & $2 \mathrm{y} 1$ & 2 & 4 & $5 Y R \quad 4 / 2,3 / 1$ & 1 & 2 & 2 & 1 & 4 y $5>, 2$ & 3 & $2 \mathrm{a} 4$ & mica, sed grises y bl & $\mathrm{Q}$, sed rojas & 4 \\
\hline PA6-1 & 202 & 1 & & 1 & 2 & 2 & 1 & 2 & 2 & 2 & N 3/, 5YR 5/2 & 1 & 2 & 2 & 2 & 1 y 2,4 y 5 & 1 & $2 \mathrm{a} 4$ & mica, sed grises y bl & $\mathrm{Q}$, sed rojas & 4 \\
\hline
\end{tabular}




\begin{tabular}{|c|c|c|c|c|c|c|c|c|c|c|c|c|c|c|c|c|c|c|c|c|c|}
\hline PA6-1 & 201 & 1 & & 1 & 2 & 2 & 1 & 2 & 2 & 2 & $5 Y R \quad 4 / 2,5 / 3$ & 1 & 2 & 1 & 2 & 1 y $2>$ & 1 & $2 \mathrm{a} 4$ & mica, sed rojas y bl & $\mathrm{Q}$, sed grises & 4 \\
\hline PA6-1 & 201 & 1 & & 1 & 2 & 2 & 1 & 2 & 1 & 1 & $5 Y R$ 5/4 & 1 & $2 a 3$ & 1 & 1 & 1 y $2>$ & 1 & $2 \mathrm{a} 4$ & mica, sed rojas a moradas & $\mathrm{Q}$, sed bl & 4 \\
\hline & & & & \multicolumn{4}{|c|}{ Fractura } & & & & & \multicolumn{7}{|c|}{ Inclusiones } & \multicolumn{2}{|c|}{ Composic } & \\
\hline $\begin{array}{c}\text { Sitio y } \\
\text { est }\end{array}$ & UP & GF & FNA & $\begin{array}{c}\text { Aspec } \\
\text { to }\end{array}$ & $\begin{array}{l}\text { Tex } \\
\text { tura }\end{array}$ & $\begin{array}{l}\text { Resis } \\
\text { tenc. }\end{array}$ & $\begin{array}{l}\mathbf{R e} \\
\text { gul }\end{array}$ & \begin{tabular}{|l|} 
Ca \\
vid \\
\end{tabular} & $\begin{array}{l}\text { Coc } \\
\text { ción }\end{array}$ & $\begin{array}{l}\text { Co } \\
\text { lor }\end{array}$ & Not color & Incl & Dens & $\begin{array}{c}\text { Orien } \\
\text { tac }\end{array}$ & $\begin{array}{l}\text { Orient } \\
\text { pared }\end{array}$ & Granul & $\begin{array}{l}\text { Se } \\
\text { lec }\end{array}$ & $\begin{array}{l}\mathrm{Re} \\
\mathrm{don}\end{array}$ & comp mayor & comp aislados & GP \\
\hline PA6-1 & 202 & 1 & & 1 & 2 & 2 & 1 & 2 & 2 & 4 & N3/, 5YR 4/1 & 1 & 2 & 1 & 1 & 4 y $5>, 2$ & 2 & $2 \mathrm{a} 4$ & mica, sed bl y grises & $\mathrm{Q}$, sed rojas & 4 \\
\hline PA6-1 & 302 & 1 & & 1 & 2 & 2 & 1 & 2 & 1 & 1 & $5 Y R 5 / 4$ & 1 & 2 & 1 & 1 & 1 y 2,4 y 5 & 1 & 2a4 & mica, sed bl y rojas a moradas & $\mathrm{Q}$, sed grises & 4 \\
\hline PA6-1 & 302 & 1 & & 1 & 2 & 2 & 1 & 2 & 1 & 1 & 5YR 5/4 & 1 & 2 & 1 & 1 & 1 y 2,4 y 5 & 1 & $2 \mathrm{a} 4$ & mica, sed bl y rojas a moradas & $\mathrm{Q}$, sed grises & 4 \\
\hline PA6-1 & 202 & 2 & & 1 & 2 & 2 & 1 & 2 & 1 & 1 & 5YR 4/4 & 1 & 2 & 1 & 3 & 1 y $2>, 3$ y 4 & 2 & $2 \mathrm{a} 4$ & mica muy abund, Q & sed bl y rojas & 1 \\
\hline PA6-1 & 202 & 2 & & 1 & 2 & 2 & 1 & 2 & 1 & 1 & 5YR 4/4 & 1 & 2 & 1 & 3 & 1 y $2>, 3$ y 4 & 2 & $2 \mathrm{a} 4$ & mica muy abund, sed bl, Q & sed rojas y grises & 1 \\
\hline PA6-1 & 202 & 2 & & 1 & 2 & 2 & 1 & 2 & 1 & 1 & 5YR 4/4 & 1 & 2 & 1 & 3 & 1 y $2>, 3$ y 4 & 2 & $2 \mathrm{a} 4$ & mica muy abund, sed bl, Q & sed rojas y grises & 1 \\
\hline PA6-1 & 202 & 3 & & 1 & 2 & 2 & 1 & 2 & 1 & 1 & 7,5YR 5/3 & 1 & 2 & 1 & 0 & 2 у $3>, 4$ & 2 & $3 a 4$ & sed bl abund y rojas, mica & Q, fel alt? & 3 \\
\hline PA6-1 & 202 & 3 & & 1 & 2 & 2 & 1 & 2 & 2 & 4 & 7,5YR 5/2; 5YR 5/4 & 1 & 2 & 1 & 1 & 2 y $3>, 4$ & 2 & 2a4 & sed bl abund, mica, sed rojas & Q, fel alt? & 3 \\
\hline PA6-1 & 202 & 3 & & 1 & 2 & 1 & 1 & 2 & 2 & 1 & 7,5YR 5/3 & 1 & 2 & 1 & 1 & 2 y $3>, 4$ & 2 & $2 \mathrm{a} 4$ & sed bl abund, mica, sed rojas & $\mathrm{Q}$, fel alt? & 3 \\
\hline PA6-1 & 202 & 3 & & 1 & 2 & 2 & 1 & 2 & 2 & 1 & 7,5YR 4/1 & 1 & 2 & 1 & 1 & 2 y $3>, 4$ & 2 & $2 \mathrm{a} 4$ & sed bl abund, sed rojas, mica & Q, fel alt? & 3 \\
\hline PA6-1 & 202 & 3 & & 1 & 2 & 2 & 1 & 2 & 2 & 4 & 7,5YR 4/3, 4/1 & 1 & 2 & 2 & 1 & 3 y $4>, 2$ & 3 & $2 \mathrm{a} 4$ & sed bl y grises abund, mica, sed rojas & Q, fel alt? & 3 \\
\hline PA6-1 & 202 & 3 & & 1 & 2 & 2 & 1 & 2 & 1 & 1 & $7,5 Y R$ 5/4 & 1 & 2 & 1 & 1 & 2 y $3>, 4$ & 2 & $2 \mathrm{a} 4$ & sed bl abund, sed rojas, mica & Q, fel alt? & 3 \\
\hline PA6-1 & 302 & 3 & & 1 & 2 & 2 & 1 & 2 & 1 & 1 & 7,5 YR $5 / 3$ & 1 & 2 & 1 & 1 & 2 y $3>, 4$ & 2 & $3 a 4$ & sed bl abund, sed rojas, mica & Q, fel alt? & 3 \\
\hline PA6-1 & 202 & 3 & & 1 & 2 & 2 & 1 & 2 & 2 & 1 & $7,5 Y R \quad 4 / 2$ & 1 & 2 & 1 & 1 & 2 y $3>$ & 2 & $3 a 4$ & sed bl abund, mica, sed grises y rojas & Q, fel alt? & 3 \\
\hline PA6-1 & 202 & 3 & & 1 & 2 & 2 & 1 & $2 \mathrm{y} 1$ & 1 & 1 & $7,5 Y R 5 / 3$ & 1 & 2 & 1 & 0 & 2 y $3>, 4$ & 2 & $2 \mathrm{a} 4$ & sed bl abund, sed rojas, mica & $\mathrm{Q}$, fel alt? & 3 \\
\hline PA6-1 & 302 & 4 & & 1 & 2 & 1 & 1 & 2 & 2 & 1 & $5 Y R 4 / 3$ & 1 & 2 & 1 & 0 & 3 y $4>$ & 3 & $3 a 4$ & sed bl, mica, Q & sed rojas, Q-fel & 4 \\
\hline PA6-1 & 302 & 4 & & 1 & 2 & 1 & 1 & 2 & 2 & 4 & $5 Y R$ 4/3, 3/1 & 1 & 2 & 1 & 1 & 3. y $4>, 2$ & 3 & $3 a 4$ & sed bl, mica, Q & sed rojas & 4 \\
\hline PA6-1 & 301 & 4 & & 1 & 2 & 1 & 1 & $2 \mathrm{y} 1$ & 2 & 4 & $5 Y R 5 / 3,4 / 2$ & 1 & 2 & 1 & 2 & 3 y $4>$ & 3 & $3 a 4$ & mica, sed bl, Q & sed rojas & 4 \\
\hline PA6-1 & 111 & 4 & & 1 & 2 & 1 & 1 & 2 & 2 & 1 & 5YR $4 / 3$ & 1 & 2 & 1 & 1 & 3 y $4>$ & 3 & $3 a 4$ & sed bl, mica, Q & sed rojas, Q-fel & 4 \\
\hline PA6-1 & 302 & 4 & & 1 & 2 & 2 & 1 & 2 & 2 & 1 & $5 Y R \quad 4 / 3$ & 1 & 2 & 1 & 2 & 3 y $4>, 2$ & 3 & $3 a 4$ & sed bl, mica, Q & sed rojas & 4 \\
\hline PA6-1 & 103 & 4 & & 1 & 2 & 1 & 1 & 2 & 2 & 1 & $5 Y R 4 / 3$ & 1 & 2 & 1 & 1 & 4 y $5>$ & 4 & $3 a 4$ & sed bl, mica, Q & sed rojas & 4 \\
\hline PA6-1 & 202 & 5 & & 1 & 2 & 1 & 1 & 2 & 4 & 4 & $5 Y R \quad 4 / 3, N 2,5 /$ & 1 & 2 & 1 & 1 & 2 у $3>, 4$ & 2 & $3 a 4$ & sed bl y grises, mica, $\mathrm{Q}$ & sed rojas & 4 \\
\hline PA6-1 & 202 & 5 & & 1 & 2 & 1 & 1 & 2 & 4 & 4 & $5 Y R$ 3/2; N 2,5/ & 1 & 2 & 2 & 1 & 3 y $4>$ & 3 & $3 a 4$ & sed bl y grises, mica, $\mathrm{Q}$ & sed rojas y marrones & 4 \\
\hline PA6-1 & 202 & 5 & & 1 & 2 & 1 & 1 & 2 & 4 & 5 & $5 Y R$ 3/2, 4/3; N 2,5/ & 1 & 2 & 1 & 2 & 3 y $4>, 2$ & 2 & $3 a 4$ & sed bl y grises, mica, $\mathrm{Q}$ & sed rojas & 4 \\
\hline PA6-1 & 202 & 6 & & 1 & 2 & 1 & 1 & $2 \mathrm{y} 1$ & 1 & 1 & 10YR $7 / 4$ & 1 & $2 a 3$ & 1 & 1 & 2 y $3>$ & 3 & $3 a 4$ & sed bl muy abund, sed rosas y rojas & Q-fel, Q, mica fina & 3 \\
\hline PA6-1 & 202 & 7 & & 1 & 2 & 1 & 1 & 2 & 3 & 1 & N 2,5/ & 1 & 2 & 2 & 1 & 3 y $4>, 2$ & 2 & $3 a 4$ & sed grises, Q, mica & $x$ & 4 \\
\hline PA6-1 & 201 & 8 & & 1 & 2 & 1 & 1 & 2 & 2 & 5 & 7,5YR 6/4, 7/3 (nuc) & 1 & 2 & 2 & 1 & 3 y $4>, 2$ & 2 & $2 \mathrm{a} 4$ & sed bl abund, mica, $\mathrm{Q}$ & sed rojas, Q-fel & 3 \\
\hline PA6-1 & 202 & & 1 & 1 & 2 & 2 & 1 & 2 & 1 & 1 & 5YR 5/4 & 1 & 2 & 2 & 2 & 4 y $5>, 1$ y 2 & 2 & $3 a 4$ & mica, sed moradas, $\mathrm{Q}$ & sed bl y rojas & 4 \\
\hline PA6-1 & 202 & & 2 & 1 & 2 & 2 & 1 & 2 & 2 & 1 & $5 Y R$ 5/2 & 2 & 2 & 1 & 1 & 3 y $4>, 2$ & 2 & $3 a 4$ & mica, sed grises, $\mathrm{Q}$ & sed bl y rojas & 4 \\
\hline PA6-1 & 202 & & 3 & 1 & 2 & 2 & 1 & 2 & 1 & 1 & 5YR 5/4 & 2 & 2 & 1 & 1 & 3 у $4>, 5$ & 3 & $3 a 5$ & mica abund, $\mathrm{Q}$ & sed bl y rojas & 1 \\
\hline PA6-1 & 202 & & 4 & 1 & 2 & 1 & 1 & 2 & 4 & 2 & $5 Y R$ 5/4; N 2,5/ & 2 & 2 & 2 & 1 & 2 y $3>, 4$ & 3 & $3 a 4$ & sed bl a grises, mica, $\mathrm{Q}$ & $x$ & 4 \\
\hline PA6-1 & sup & & 7 & 1 & 2 & 1 & 1 & 2 & 1 & 1 & $5 Y R 5 / 4$ & 2 & 2 & 1 & 1 & 4 y $5>, 3$ & 4 & $3 a 4$ & sed grises y bl, Q, mica & sed rojas & 4 \\
\hline PA6-1 & sup & & 8 & 1 & 2 & 2 & 1 & 2 & 1 & 1 & $5 Y R 5 / 4$ & 1 & 2 & 1 & 2 & 3 y $4>$ & 3 & $2 \mathrm{a} 4$ & mica abund, sed grises y bl & $\mathrm{Q}$, sed rojas & 1 \\
\hline PA6-1 & sup & & 9 & 1 & 2 & 2 & 1 & 2 & 3 & 1 & N 2,5/ & 2 & 1 & 1 & 1 & 4 y $5>$ & 4 & $2 \mathrm{a} 4$ & $\mathrm{Q}$, sed grises, mica & sed rojas & 5 \\
\hline
\end{tabular}




\begin{tabular}{|c|c|c|c|c|c|c|c|c|c|c|c|c|c|c|c|c|c|c|c|c|c|}
\hline PA6-1 & sup & & 10 & 1 & 2 & 1 & 1 & $2 \mathrm{y} 1$ & 4 & 4 & $5 Y R$ 5/2; N 2,5/ & 1 & $2 \mathrm{a} 3$ & 1 & 1 & 3 y $4>, 2$ & 2 & $3 \mathrm{a} 4$ & Q, sed grises y bl, mica & sed rojas & 4 \\
\hline PA6-1 & sup & & 11 & 1 & 2 & 1 & 1 & $2 \mathrm{y} 1$ & 1 & 1 & 5YR 5/4 & 1 & $2 \mathrm{a} 3$ & 2 & 1 & 2 y $3>$ & 2 & $3 a 4$ & $\mathrm{Q}$, mica, sed bl & sed rojas, Q-fel & 4 \\
\hline PA6-1 & sup & & 12 & 1 & 2 & 2 & 1 & 2 & 1 & 1 & 5YR 5/4 & 1 & $2 \mathrm{a} 3$ & 1 & 1 & 3 y $4>, 2$ & 2 & $2 \mathrm{a} 4$ & mica abund, sed bl, Q & sed rojas, marrones y grises & 1 \\
\hline & & & & \multicolumn{4}{|c|}{ Fractura } & & & & & \multicolumn{7}{|c|}{ Inclusiones } & \multicolumn{2}{|c|}{ Composic } & \\
\hline $\begin{array}{c}\text { Sitio y } \\
\text { est }\end{array}$ & UP & GF & FNA & $\begin{array}{c}\text { Aspec } \\
\text { to }\end{array}$ & $\left|\begin{array}{l|}T e x \\
\text { tura }\end{array}\right|$ & $\begin{array}{l}\text { Resis } \\
\text { tenc. }\end{array}$ & $\begin{array}{l}\mathbf{R e} \\
\text { gul }\end{array}$ & $\begin{array}{l}\text { Ca } \\
\text { vid }\end{array}$ & $\begin{array}{l}\text { Coc } \\
\text { ción }\end{array}$ & $\begin{array}{l}\text { Co } \\
\text { Ior }\end{array}$ & Not color & Incl & Dens & $\begin{array}{c}\text { Orien } \\
\text { tac }\end{array}$ & $\begin{array}{l}\text { Orient } \\
\text { pared }\end{array}$ & Granul & \begin{tabular}{|l|}
$\mathrm{Se}$ \\
lec
\end{tabular} & \begin{tabular}{c|}
$\mathbf{R e}$ \\
don
\end{tabular} & comp mayor & comp aislados & GP \\
\hline PA6-1 & sup & & 13 & 1 & 2 & 2 & 1 & 2 & 2 & 4 & $5 Y R \quad 4 / 2,3 / 1$ & 1 & 2 & 1 & 2 & 1 y $2>, 3$ & 1 & $2 \mathrm{a} 4$ & sed bl, grises y rojas, mica, Q & $x$ & 4 \\
\hline PA6-1 & sup & & 14 & 1 & 2 & 1 & 1 & 2 & 1 & 1 & $2,5 Y R \quad 4 / 4$ & 1 & $2 \mathrm{a} 3$ & 1 & 1 & 3 y $4>, 2$ & 2 & $3 a 5$ & sed bl y grises, mica, $\mathrm{Q}$ & sed rojas, Q-fel & 4 \\
\hline PA6-1 & sup & & 15 & 1 & 2 & 2 & 1 & 2 & 1 & 1 & 5YR 5/4 & 1 & 2 & 2 & 2 & 3 y $4>, 1$ y 2 & 1 & $2 \mathrm{a} 4$ & mica, sed bl, grises y rojas, $Q$ & $\mathrm{x}$ & 4 \\
\hline PA6-1 & sup & & $16 / 17$ & 1 & 2 & 2 & 1 & 2 & 2 & 5 & $5 Y R 5 / 4,6 / 3$ (nuc) & 1 & 2 & 2 & 1 & 3 y $4>, 1$ y 2 & 1 & $3 a 4$ & sed bl, rojas y moradas, mica, $\mathrm{Q}$ & $x$ & 4 \\
\hline PA6-1 & sup & & $18 / 19$ & 1 & 2 & 1 & 1 & 2 & 1 & 1 & $2,5 Y R$ 5/6 & 2 & 2 & 1 & 1 & 3 y $4>$ & 3 & $3 a 4$ & sed grises y bl abund & mica fina, $Q$, sed rojas & 3 \\
\hline PA6-1 & sup & & 20 & 1 & 2 & 1 & 1 & 2 & 1 & 1 & $2,5 Y R$ 5/6 & 2 & 2 & 1 & 0 & 3 y $4>, 2$ & 3 & $3 a 4$ & sed grises abund, sed bl, mica fina & sed rojas, Q & 3 \\
\hline PA6-1 & sup & & 21 & 1 & 2 & 1 & 1 & 2 & 2 & 5 & 2,5YR 5/6, 5/3 (nuc) & 2 & 2 & 1 & 0 & 3 y $4>, 2$ & 3 & $3 a 4$ & sed grises abund, sed bl, mica fina & sed rojas, Q & 3 \\
\hline PA6-1 & sup & & 22 & 1 & 2 & 1 & 2 & 2 & 1 & 1 & $2,5 Y R$ 5/6 & 2 & 2 & 2 & 0 & 3 y $4>, 2$ & 3 & $3 a 4$ & sed grises abund, sed bl, mica fina & sed rojas, Q & 3 \\
\hline PA6-1 & sup & & 23 & 1 & 2 & 2 & 1 & 2 & 1 & 5 & $5 Y R 5 / 4,6 / 3$ (nuc) & 1 & 2 & 1 & 1 & 3 y $4>, 2$ & 3 & $3 a 4$ & sed bl, rojas y moradas, mica, $\mathrm{Q}$ & $x$ & 4 \\
\hline PA6-1 & sup & & 24 & 1 & 2 & 1 & 1 & 2 & 2 & 4 & $5 Y R$ 5/4, 6/4 & 1 & 2 & 1 & 1 & 3 y $4>, 1$ y 2 & 1 & $3 a 4$ & sed bl, rojas y moradas, mica, Q & fel alt? & 4 \\
\hline PA6-1 & sup & & 25 & 1 & 2 & 1 & 1 & 2 & 1 & 1 & 5YR 5/4 & 1 & 2 & 1 & 1 & 3 y $4>, 1$ y 2 & 1 & $3 a 4$ & sed bl y rojas, mica, $\mathrm{Q}$ & Q-fel & 4 \\
\hline PA6-1 & sup & & 26 & 1 & 2 & 2 & 1 & $2 \mathrm{y} 1$ & 1 & 1 & $2,5 Y R$ 5/6 & 1 & 2 & 1 & 1 & 3 у $4>, 2$ & 2 & $3 a 4$ & mica, sed bl y rojas, Q & Q-fel & 4 \\
\hline PA6-1 & sup & & 27 & 1 & 2 & 2 & 1 & 2 & 2 & 1 & $2,5 Y R 3 / 1$ & 1 & 2 & 1 & 1 & 4 y $5>, 3$ & 4 & $2 \mathrm{a} 4$ & mica, Q, sed grises y marrones & Q-fel, fel alt? & 4 \\
\hline PA6-1 & sup & & 29 & 1 & 2 & 1 & 1 & 2 & 2 & 1 & 5YR $4 / 2$ & 1 & 2 & 2 & 1 & 3 y $4>, 1$ y 2 & 1 & $3 a 4$ & mica, sed bl, grises y rojas, $\mathrm{Q}$ & Q-fel & 4 \\
\hline PA6-1 & sup & & 30 & 1 & 2 & 2 & 1 & 2 & 2 & 4 & $5 Y R 6 / 4,4 / 2$ & 1 & 2 & 1 & 1 & 4 у $5>, 2$ у 3 & 2 & $3 a 4$ & mica, sed bl y rojas, $Q$ & fel alt? & 4 \\
\hline PA6-1 & sup & & 31 & 1 & 2 & 1 & 1 & 2 & 2 & 4 & $\mathrm{~N} 4 / 1,5 \mathrm{YR} 5 / 3$ & 1 & 2 & 1 & 1 & 4 y $5>$ & 4 & $3 a 4$ & mica, sed bl y grises, $\mathrm{Q}$ & sed rojas & 4 \\
\hline PA6-1 & sup & & 32 & 1 & 2 & 2 & 1 & 2 & 2 & 4 & $5 Y R$ 3/2, 4/1 & 1 & 2 & 2 & 1 & 3 y $4>, 1$ y 2 & 2 & $3 a 4$ & $\mathrm{Q}$, mica, sed bl y rojas & fel alt? & 4 \\
\hline PA6-1 & sup & & 33 & 1 & 2 & 1 & 1 & 2 & 2 & 4 & $5 Y R 5 / 4,4 / 2$ & 1 & 2 & 1 & 1 & 3 y $4>, 2$ & 2 & $3 a 4$ & mica, sed bl y rojas, $Q$ & Q-fel & 4 \\
\hline PA6-1 & sup & & 34 & 1 & 2 & 1 & 1 & 2 & 2 & 4 & $5 Y R$ 5/3, N3/ & 1 & 2 & 1 & 2 & 4 y $5>, 2$ & 3 & $3 a 4$ & mica, sed bl y grises, $Q$ & sed rojas, Q-fel & 4 \\
\hline PA6-1 & sup & & 35 & 1 & 2 & 1 & 1 & 2 & 2 & 2 & N 4/, 5YR 5/4 & 1 & $2 \mathrm{a} 3$ & 1 & 2 & 3 y $4>, 1$ y 2 & 2 & $2 \mathrm{a} 4$ & mica abund, sed bl, Q & sed rojas & 1 \\
\hline PA6-1 & sup & & 36 & 1 & 2 & 1 & 1 & 2 & 1 & 1 & 5YR 5/4 & 1 & 2 & 1 & 1 & 3 y $4>, 1$ y 2 & 2 & $3 a 4$ & mica, sed bl, rosadas y rojas, $\mathrm{Q}$ & sed moradas, Q-fel & 4 \\
\hline PA6-1 & sup & & 37 & 1 & 2 & 1 & 1 & 2 & 2 & 4 & $5 Y R$ 5/4, 3/2 & 1 & 2 & 1 & 1 & 3 y $4>, 2$ & 2 & $3 a 4$ & mica, sed bl, moradas y rojas, Q & fel alt? & 4 \\
\hline PA6-1 & sup & & 38 & 1 & 2 & 1 & 1 & 2 & 2 & 1 & $5 Y R 4 / 2$ & 1 & 2 & 2 & 1 & 3 у $4>, 1$ у 2 & 2 & $3 a 4$ & mica, sed grises y rojas, $Q$ & Q-fel & 4 \\
\hline PA6-1 & sup & & 39 & 1 & 2 & 1 & 1 & 2 & 1 & 1 & 5YR 5/4 & 1 & 2 & 1 & 1 & 2 y $3>, 4$ & 2 & $3 a 4$ & mica, sed bl y grises, $\mathrm{Q}$ & sed rojas, Q-fel & 4 \\
\hline PA6-1 & sup & & 40 & 1 & 2 & 1 & 1 & 2 & 2 & 4 & $5 Y R$ 5/4, 4/2 & 1 & 2 & 1 & 1 & 1 y $2>, 4$ & 2 & $3 a 4$ & mica, sed bl y grises, Q & sed rojas, fel alt? & 4 \\
\hline PA6-1 & sup & & 41 & 1 & 2 & 1 & 1 & 2 & 2 & 1 & 5YR $4 / 2$ & 1 & 2 & 1 & 1 & 3 y $4>, 2$ & 2 & $3 a 4$ & mica, Q, sed bl y rojas & Q-fel & 4 \\
\hline PA6-1 & sup & & 42 & 1 & 2 & 1 & 1 & 2 & 2 & 4 & $5 Y R$ 5/2, 5/4 & 1 & 2 & 1 & 1 & 2 y $3>, 1$ & 2 & $2 \mathrm{a} 4$ & mica, sed bl y rojas, $\mathrm{Q}$ & fel alt? & 4 \\
\hline PA6-1 & sup & & 43 & 1 & 2 & 2 & 1 & 2 & 2 & 1 & $5 Y R 3 / 2$ & 1 & $2 \mathrm{a} 3$ & 2 & 1 & 3 y $4>, 2$ & 2 & $3 a 4$ & mica, Q, sed grises y rojas & Q-fel & 4 \\
\hline PA6-1 & sup & & 44 & 1 & 2 & 1 & 1 & 2 & 1 & 1 & 5YR 5/4 & 1 & 2 & 1 & 1 & 3 y $4>, 2$ & 2 & $3 a 4$ & mica, $Q$, sed bl y rojas & Q-fel & 4 \\
\hline PA6-1 & sup & & 45 & 1 & 2 & 1 & 1 & 2 & 2 & 4 & $5 Y R 3 / 2,4 / 4$ & 1 & 2 & 1 & 1 & 3 y $4>$ & 3 & $3 a 5$ & Q abund, mica, sed bl y rojas & Q-fel & 2 \\
\hline PA6-1 & sup & & 48 & 1 & 2 & 1 & 1 & 2 & 2 & 1 & $7,5 Y R$ 5/4 & 1 & 2 & 1 & 1 & 3 y $4>, 1$ y 2 & 1 & $3 a 4$ & mica, Q, sed rojas y bl & Q-fel & 4 \\
\hline PA6-1 & sup & & 49 & 1 & 2 & 2 & 1 & 2 & 2 & 1 & 7,5 YR 3/1 & 1 & 2 & 1 & 1 & 3 y $4>, 2$ & 2 & $3 a 4$ & mica, $Q$, sed grises y rojas & Q-fel & 4 \\
\hline PA6-1 & sup & & 50 & 1 & 2 & 2 & 1 & 2 & 1 & 1 & 5YR 5/4 & 1 & 2 & 2 & 1 & 2 у $3>, 1$ & 2 & $3 a 4$ & mica, sed bl y rojas, $Q$ & sed moradas, Q-fel & 4 \\
\hline
\end{tabular}




\begin{tabular}{|c|c|c|c|c|c|c|c|c|c|c|c|c|c|c|c|c|c|c|c|c|c|}
\hline PA6-1 & sup & & 51 & 1 & 2 & 1 & 1 & 2 & 2 & 4 & $\mathrm{~N} 3 /, 7,5$ YR $5 / 4$ & 1 & 2 & 1 & 2 & 3 y $4>, 2$ & 2 & $3 \mathrm{a} 4$ & mica abund, sed bl y rojas, $Q$ & Q-fel & 4 \\
\hline PA6-1 & sup & & 52 & 1 & 2 & 1 & 1 & 2 & 2 & 4 & $5 Y R$ 4/2, N 3/ & 1 & 2 & 1 & 1 & 3 y $4>, 2$ & 2 & $3 a 4$ & mica, sed grises y rojas, $\mathrm{Q}$ & & 4 \\
\hline PA6-1 & sup & & 53 & 1 & 2 & 1 & 1 & 2 & 1 & 1 & 5YR 5/4 & 1 & 2 & 1 & 1 & 4 y $5>, 2$ & 2 & $3 a 4$ & mica, sed bl y rojas, Q & Q-fel & 4 \\
\hline PA6-1 & sup & & 54 & 1 & 2 & 1 & 1 & 2 & 1 & 1 & $2,5 Y R$ 6/6 & 1 & 2 & 1 & 1 & 4 y $5>, 3$ & 2 & $3 a 4$ & sed bl, rojas y marrones, Q & mica fina, Q-fel & 4 \\
\hline & & & & \multicolumn{4}{|c|}{ Fractura } & & & & & \multicolumn{7}{|c|}{ Inclusiones } & \multicolumn{2}{|c|}{ Composic } & \\
\hline $\begin{array}{c}\text { Sitio y } \\
\text { est }\end{array}$ & UP & GF & FNA & $\begin{array}{c}\text { Aspec } \\
\text { to }\end{array}$ & \begin{tabular}{|l|} 
Tex \\
tura
\end{tabular} & \begin{tabular}{|l|} 
Resis \\
tenc.
\end{tabular} & $\begin{array}{l}\mathbf{R e} \\
\text { gul }\end{array}$ & $\begin{array}{l}\text { Ca } \\
\text { vid }\end{array}$ & $\begin{array}{l}\text { Coc } \\
\text { ción }\end{array}$ & $\begin{array}{l}\text { Co } \\
\text { Ior } \\
\end{array}$ & Not color & Incl & Dens & $\begin{array}{c}\text { Orien } \\
\text { tac }\end{array}$ & $\begin{array}{l}\text { Orient } \\
\text { pared }\end{array}$ & Granul & \begin{tabular}{|l|} 
Se \\
lec
\end{tabular} & \begin{tabular}{|l|}
$\mathbf{R e}$ \\
don \\
\end{tabular} & comp mayor & comp aislados & GP \\
\hline PA6-1 & sup & & 55 & 1 & 2 & 1 & 1 & 2 & 2 & 4 & 10R $4 / 2,5 / 6$ & 1 & 2 & 1 & 1 & 3 y $4>, 2$ & 2 & $3 a 4$ & mica, sed bl y rojas, $Q$ & Q-fel & 4 \\
\hline PA6-1 & sup & & 56 & 1 & 2 & 1 & 1 & 2 & 2 & 1 & $5 Y R$ 5/3 & 1 & 2 & 1 & 1 & 3 y $4>, 2$ & 2 & $3 a 4$ & mica, $Q$, sed bl & sed rojas, Q-fel & 4 \\
\hline PA6-1 & sup & & 57 & 1 & 2 & 1 & 1 & 2 & 2 & 4 & $\mathrm{~N} 3 /, 7,5 \mathrm{YR} 5 / 4$ & 1 & 2 & 1 & 1 & 4 y $5>, 2$ & 2 & $3 a 4$ & sed bl y rojas, mica, $\mathrm{Q}$ & Q-fel, posible plutónica roja & 4 \\
\hline PA6-1 & sup & & 58 & 1 & 2 & 2 & 1 & 2 & 1 & 1 & $5 Y R$ 5/6 & 1 & 2 & 1 & 1 & 4 y $5>, 1$ y 2 & 1 & $3 a 4$ & Q, mica, sed bl y rojas & Q-fel & 4 \\
\hline PA6-1 & sup & & 59 & 1 & 2 & 1 & 1 & 2 & 4 & 2 & $5 Y R$ 5/4, N 2,5/ & 1 & 2 & 1 & 1 & 4 y $3>, 2$ & 3 & $3 a 4$ & Q, mica, sed bl, rojas y moradas & Q-fel & 4 \\
\hline PA6-1 & sup & & 60 & 1 & 2 & 2 & 1 & 2 & 4 & 4 & 7,5YR 5/4, N3/ & 1 & 2 & 1 & 1 & 4 y $5>, 2$ & 2 & $3 a 4$ & $\mathrm{Q}$, sed bl, grises y rojas, mica & Q-fel & 4 \\
\hline PA6-1 & sup & & 61 & 1 & 2 & 2 & 1 & 2 & 2 & 4 & $7,5 Y R \quad 4 / 1,5 / 2$ & 1 & 2 & 1 & 1 & 3 y $4>, 1$ y 2 & 2 & $3 a 4$ & sed bl, marrones y rojas, $\mathrm{Q}$, mica & Q-fel, fel alt? & 4 \\
\hline PA6-1 & sup & & 62 & 1 & 2 & 1 & 1 & 2 & 2 & 1 & 7,5 YR 3/1 & 1 & 2 & 1 & 2 & 4 y $5>, 3$ & 3 & $3 a 4$ & Q, mica, sed bl, grises y rojas & Q-fel & 4 \\
\hline PA6-1 & sup & & 63 & 1 & 2 & 1 & 1 & 2 & 2 & 4 & 2,5YR 5/6, 5YR 5/4 & 1 & 2 & 1 & 1 & 4 y $3>, 2$ & 2 & $3 a 4$ & $\mathrm{Q}$, mica, sed rojas y bl & Q-fel, fel alt? & 4 \\
\hline PA6-1 & sup & & 64 & 1 & 2 & 1 & 1 & $2 \mathrm{y} 1$ & 2 & 5 & 5YR 5/4, N 3/ (nuc) & 1 & 2 & 1 & 0 & 2 y $3>, 4$ & 2 & $3 a 4$ & sed grises, Q, Q-fel & sed rojas & 4 \\
\hline PA6-1 & sup & & 65 & 1 & 2 & 1 & 1 & 2 & 4 & 4 & 7,5YR 5/3, N 3/ & 1 & 2 & 1 & 1 & 3 y $4>, 1$ y 2 & 1 & $3 a 4$ & mica, sed bl y grises & sed rojas, Q & 4 \\
\hline PA6-1 & sup & & 66 & 1 & 2 & 1 & 1 & 2 & 2 & 4 & $2,5 Y R$ 5/4, 4/2 & 1 & 2 & 1 & 1 & 2 y $3>, 4$ & 2 & $3 a 4$ & mica, $Q$, sed bl y grises & sed rojas, Q-fel & 4 \\
\hline PA6-1 & sup & & 68 & 1 & 2 & 1 & 1 & $2 \mathrm{y} 1$ & 1 & 1 & 5YR 5/4 & 1 & 2 & 1 & 1 & 3 y $4>, 1$ y 2 & 2 & $3 a 5$ & mica, sed bl y rojas, Q & Q-fel & 4 \\
\hline PA6-1 & sup & & 69 & 1 & 2 & 1 & 1 & 2 & 2 & 5 & 2,5 YR $6 / 6,5 / 1$ & 1 & 2 & 1 & 1 & 2 у $3>, 4$ & 2 & $3 a 4$ & Q muy abund, mica & sed bl, Q-fel & 2 \\
\hline PA6-1 & sup & & 70 & 1 & 2 & 1 & 1 & $2 \mathrm{y} 1$ & 1 & 1 & 5YR 5/4 & 1 & 2 & 1 & 1 & 3 y $4>$ & 3 & $3 a 4$ & mica, sed bl y rojas, Q & Q-fel & 4 \\
\hline PA6-1 & sup & & 71 & 1 & 2 & 1 & 1 & 2 & 2 & 1 & $7,5 Y R$ 5/3 & 1 & 2 & 1 & 1 & 3 y $4>, 2$ & 2 & $3 a 4$ & mica, Q, sed bl y rojas & sed moradas, Q-fel & 4 \\
\hline PA6-1 & sup & & 72 & 1 & 2 & 2 & 1 & 2 & 2 & 1 & 7,5YR 4/4 & 2 & 2 & 1 & 1 & 3 у $4>, 1$ y 2 & 1 & $3 a 4$ & Q, mica, sed rojas & sed bl, Q-fel & 4 \\
\hline PA6-1 & sup & & 73 & 1 & 2 & 2 & 1 & 2 & 1 & 1 & 5YR 5/4 & 1 & 2 & 1 & 1 & 3 y $4>, 2$ & 2 & $3 a 4$ & mica, $Q$, sed bl y rojas & Q-fel & 4 \\
\hline PA6-1 & sup & & 74 & 2 & 2 & 2 & 1 & 2 & 1 & 1 & $2,5 Y R \quad 4 / 6$ & 1 & $2 \mathrm{a} 3$ & 1 & 1 & 3 y $4>, 2$ & 2 & $3 a 5$ & Q muy abund, sed bl y rojas & mica fina, Q-fel & 2 \\
\hline PA6-1 & sup & & 75 & 1 & 2 & 1 & 1 & 2 & 1 & 1 & $2,5 Y R$ 5/6 & 1 & 2 & 1 & 1 & 2 y $3>, 4$ & 2 & $3 a 4$ & $\mathrm{Q}$, sed bl y rojas & mica fina, Q-fel & 4 \\
\hline PA6-1 & sup & & 76 & 1 & 2 & 1 & 1 & 2 & 2 & 1 & $5 Y R \quad 4 / 3$ & 1 & 2 & 1 & 1 & 3 y $4>, 2$ & 2 & $3 a 4$ & mica, $Q$, sed bl y rojas & sed moradas, Q-fel & 4 \\
\hline PA6-1 & sup & & 77 & 1 & 2 & 2 & 1 & 2 & 2 & 1 & $5 Y R$ 5/2 & 1 & 2 & 1 & 1 & 3 y $4>, 2$ & 2 & $3 a 4$ & mica, sed bl y rojas, $Q$ & Q-fel & 4 \\
\hline PA6-1 & sup & & 78 & 1 & 2 & 2 & 1 & $2 \mathrm{y} 1$ & 1 & 1 & 5YR 5/4 & 1 & 2 & 1 & 1 & 3 y $4>, 1$ y 2 & 2 & $3 a 4$ & mica, $Q$, sed bl y rojas & sed rosas, Q-fel & 4 \\
\hline PA6-1 & sup & & 79 & 1 & 2 & 2 & 1 & 2 & 2 & 5 & $2,5 Y R$ 5/6, 4/2 (nuc) & 1 & 2 & 1 & 1 & 3 y $4>, 1$ y 2 & 2 & $3 a 4$ & sed bl, marrones y rojas, mica & Q, Q-fel & 4 \\
\hline PA6-1 & sup & & 80 & 1 & 2 & 2 & 1 & 2 & 2 & 1 & $5 Y R 5 / 3$ & 1 & 2 & 1 & 1 & 3 y $4>, 2$ & 2 & $3 a 4$ & mica, Q, sed bl y rojas & Q-fel & 4 \\
\hline PA6-1 & sup & & 81 & 1 & 2 & 2 & 1 & 2 & 1 & 1 & 5YR 5/6 & 1 & 2 & 1 & 1 & 2 y $3>, 1$ & 2 & $3 a 4$ & mica, $Q$, sed bl y rojas & Q-fel & 4 \\
\hline PA6-1 & sup & & 82 & 1 & 2 & 2 & 2 & 2 & 1 & 1 & 5YR 5/4 & 1 & 2 & 2 & 1 & 3 y $4>, 2$ & 3 & $3 a 4$ & mica, Q, sed bl y moradas & sed rojas, Q-fel & 4 \\
\hline PA6-1 & sup & & 83 & 1 & 2 & 2 & 1 & 2 & 1 & 1 & 5YR 5/4 & 1 & $2 \mathrm{a} 3$ & 1 & 1 & 3 y $4>, 2$ & 3 & $3 a 4$ & Q abund, sed bl y rojas & Q-fel, mica & 2 \\
\hline PA6-1 & sup & & 84 & 1 & 2 & 2 & 1 & 2 & 2 & 4 & $5 Y R \quad 4 / 3,6 / 4$ & 1 & 2 & 1 & 1 & 3 y $4>, 2$ & 2 & $3 a 4$ & Q, mica, sed bl y rojas & Q-fel & 4 \\
\hline PA6-1 & sup & & 87 & 1 & 2 & 2 & 1 & 2 & 1 & 1 & 5YR 5/4 & 1 & 2 & 1 & 1 & 3 y $4>, 1$ y 2 & 1 & $3 a 5$ & Q abund, sed bl y rojas & Q-fel, mica & 2 \\
\hline PA6-1 & sup & & 88 & 1 & 2 & 1 & 1 & $2 \mathrm{y} 1$ & 2 & 2 & N 3/, 2,5YR 4/4 & 1 & 2 & 1 & 1 & 2 у $3>, 4$ & 2 & $3 a 5$ & Q, sed bl y rojas & mica, Q-fel & 4 \\
\hline PA6-1 & sup & & 89 & 1 & 2 & 1 & 1 & 2 & 2 & 1 & 5 YR $5 / 3$ & 1 & 2 & 1 & 1 & 3 y $4>, 2$ & 2 & $3 a 4$ & mica, sed bl y rojas, $Q$ & Q-fel & 4 \\
\hline
\end{tabular}




\begin{tabular}{|c|c|c|c|c|c|c|c|c|c|c|c|c|c|c|c|c|c|c|c|c|c|}
\hline PA6-1 & sup & & 90 & 1 & 2 & 2 & 1 & 2 & 2 & 4 & $5 Y R$ 5/4, 4/1 & 1 & 2 & 2 & 1 & 2 y $3>, 4$ & 2 & $3 a 4$ & mica, sed bl y rojas, Q & Q-fel & 4 \\
\hline PA6-1 & sup & & 91 & 1 & 2 & 2 & 1 & 2 & 2 & 5 & 5YR 5/3, N3/ (nuc) & 1 & 2 & 1 & 2 & 3 y $4>, 2$ & 2 & $3 a 4$ & mica, sed bl y rojas, $\mathrm{Q}$ & Q-fel & 4 \\
\hline PA6-1 & sup & & 92 & 1 & 2 & 2 & 1 & 2 & 1 & 1 & 2,5 YR 5/6 & 1 & 2 & 2 & 1 & 3 y $4>, 1$ y 2 & 2 & $3 a 4$ & mica, sed bl y rojas & $\mathrm{Q}$, fel alt? & 4 \\
\hline PA6-1 & sup & & 93 & 1 & 2 & 1 & 1 & 2 & 2 & 1 & $5 Y R$ 5/3 & 1 & 2 & 2 & 1 & 3 y $4>, 2$ & 2 & $3 a 4$ & mica, sed bl y rojas, Q & Q-fel & 4 \\
\hline PA6-1 & sup & & 94 & 1 & 2 & 1 & 1 & 2 & 2 & 1 & 5YR 5/3 & 1 & 2 & 1 & 1 & 3 y $4>$ & 3 & $3 a 4$ & mica, $Q$, sed bl y rojas & Q-fel & 4 \\
\hline & & & & \multicolumn{4}{|c|}{ Fractura } & & & & & \multicolumn{7}{|c|}{ Inclusiones } & \multicolumn{2}{|c|}{ Composic } & \\
\hline $\begin{array}{c}\text { Sitio y } \\
\text { est }\end{array}$ & UP & GF & FNA & $\begin{array}{c}\text { Aspec } \\
\text { to }\end{array}$ & \begin{tabular}{|l|} 
Tex \\
tura \\
\end{tabular} & \begin{tabular}{|l|} 
Resis \\
tenc.
\end{tabular} & \begin{tabular}{l|}
$\operatorname{Re}$ \\
gul \\
\end{tabular} & \begin{tabular}{|l|l|} 
Ca & $C$ \\
vid & $c$ \\
\end{tabular} & $\begin{array}{l}\text { Coc } \\
\text { ción }\end{array}$ & $\begin{array}{l}\text { Co } \\
\text { lor }\end{array}$ & Not color & Incl & Dens & \begin{tabular}{|c|}
$\begin{array}{c}\text { Orien } \\
\text { tac }\end{array}$ \\
\end{tabular} & $\begin{array}{l}\text { Orient } \\
\text { pared }\end{array}$ & Granul & \begin{tabular}{l|} 
Se \\
lec
\end{tabular} & \begin{tabular}{|c|}
$\mathbf{R e}$ \\
don \\
\end{tabular} & comp mayor & comp aislados & GP \\
\hline PA6-1 & sup & & 95 & 1 & 2 & 2 & 1 & 2 & 2 & 4 & 2,5YR 5/4; 5YR 4/3 & 1 & 2 & 1 & 1 & 3 y $4>, 2$ & 2 & $3 a 5$ & Q abund, mica, sed rojas & sed bl o fel alt & 2 \\
\hline PA6-1 & sup & & 96 & 1 & 2 & 2 & 1 & 2 & 2 & 4 & 2,5YR 4/4, N3/ & 1 & 2 & 1 & 1 & 4 y $5>$ & 4 & $3 a 5$ & $\mathrm{Q}$, mica, sed bl y rojas & Q-fel & 4 \\
\hline PA6-1 & sup & & 97 & 1 & 2 & 1 & 1 & 2 & 2 & 1 & $5 Y R$ 5/3 & 1 & 2 & 1 & 1 & 4 y $5>$ & 4 & $3 a 4$ & mica, sed bl y rojas, Q & Q-fel & 4 \\
\hline PA6-1 & sup & & 98 & 1 & 2 & 2 & 1 & 2 & 1 & 1 & $2,5 Y R$ 5/6 & 1 & 2 & 1 & 1 & 3 y $4>$ & 3 & $3 a 4$ & Q abund, sed bl & sed rojas, mica, Q-fel & 4 \\
\hline PA6-1 & sup & & 99 & 1 & 2 & 1 & 1 & 2 & 2 & 1 & 5YR 6/4 & 1 & 2 & 2 & 1 & 3 y $4>$ & 3 & $3 a 4$ & Q, mica, sed bl y rojas & Q-fel & 4 \\
\hline PA6-1 & sup & & 100 & 1 & 2 & 1 & 1 & 2 & 2 & 4 & 5YR 4/3, 2,5YR 5/6 & 1 & 2 & 1 & 1 & 2 y $3>$ & 2 & $3 a 4$ & Q, sed bl y rojas, mica & Q-fel & 4 \\
\hline PA 22 & Sup & & 1 & 1 & 2 & 1 & 1 & $2 \mathrm{y} 1$ & 1 & 1 & $5 Y R 6 / 4$ & 1 & $1 \mathrm{a} 2$ & 1 & & 4 y $5>, 3$ & 4 & $2 \mathrm{a} 4$ & Q trasl, biotita fina, Q-fel & fel alt & 7 \\
\hline PA 22 & Sup & & 2 & 2 & 2 & 2 & 1 & 2 & 2 & 5 & 2,5YR5/6, 5YR5/3, 4/1 & 1 & 2 & 1 & & 1 y $2>, 5$ & 2 & $2 a 3$ & sed rojas y marrones, sed bl o fel alt & Q-fel, mica fina & 4 \\
\hline PA 22 & Sup & & 3 & 1 & 2 & 1 & 1 & 2 & 2 & 4 & $5 Y R 5 / 2, N 3 /$ & 1 & 2 & 1 & & 2 y $3>, 5$ & 3 & $3 a 4$ & Q trasl, fel alt, Q ambar & fgto roca osc afanit, Q-fel & 7 \\
\hline PA 22 & Sup & & 4 & 1 & 2 & 1 & 1 & 2 & 2 & 4 & 2,5 YR $6 / 6,6 / 2$ & 1 & 1 & 1 & & 1 y 2,4 y 5 & 2 & $2 a 3$ & Q trasl, Q-fel bl, fel alt o sed bl & & 7 \\
\hline PA 22 & Sup & & 5 & 1 & 2 & 1 & 2 & 2 & 1 & 1 & $2,5 Y R 6 / 6$ & 1 & 2 & 1 & & 4 y $5>, 2$ y 3 & 3 & $3 a 4$ & Q trasl, Q-fel, fel alt, sed rojas & biotita fina & 4 \\
\hline PA 22 & Sup & & 7 & 1 & 2 & 1 & 12 & $2 \mathrm{y} 1$ & 1 & 1 & 5YR 6/4 & 1 & 2 & 1 & & 4 y $5>, 2$ & 3 & $3 a 4$ & Q trasl, Q-fel, fel alt & biotita fina & 7 \\
\hline PA22 S1 & Sup & & 8 & 1 & 2 & 1 & 1 & $2 \mathrm{y} 1$ & 2 & 5 & $5 Y R 6 / 4,5 / 1$ & 1 & 2 & 2 & & 4 y $5>, 2$ & 2 & $2 a 3$ & mica muy abund, $\mathrm{Q}$ trasl & fel alt, sed rojas & 1 \\
\hline PA 22 & Sup & & 9 & 1 & 2 & 1 & 1 & $2 \mathrm{y} 1$ & 2 & 4 & $5 Y R 5 / 4,4 / 1$ & 1 & 2 & 1 & & 4 y $5>, 2$ & 2 & $2 \mathrm{a} 4$ & Q trasl, sed rojas y marrones & fel alt, mica fina & 2 \\
\hline PA 22 & Sup & & 10 & 1 & 2 & 2 & 1 & 2 & 3 & 1 & 5YR 3/1 & 1 & 2 & 1 & & 1 y $2>, 3$ y 4 & 3 & $2 a 3$ & Q trasl, Q ambar, sed marrones & fgto roca osc afanit, Q-fel & 4 \\
\hline PA22 S1 & Sup & & 11 & 2 & 1 & 2 & 1 & 2 & 3 & 1 & $5 Y R 4 / 1$ & 1 & $2 \mathrm{a} 3$ & 2 & & 3 y $4>, 2$ & 3 & $2 \mathrm{a3}$ & mica muy abund, Q trasI & fel alt, volc? & 1 \\
\hline PA 22 & Sup & & 12 & 1 & 2 & 1 & 1 & 2 & 2 & 4 & 2,5 YR $6 / 6,5 / 2$ & 1 & 2 & 1 & & $5>, 1$ y 2 & 1 & $3 a 4$ & Q trasl, fel alt o sed bl & fel bl, fgtos rocas grises & 7 \\
\hline PA 22 & Sup & & 13 & 1 & 2 & 1 & 1 & 2 & 5 & 5 & $5 Y R$ 5/3, 3/1 & 1 & 2 & 1 & & 2 y $3>, 5$ & 3 & $3 a 4$ & Q tras, mica & sed rojas, fel alt & 2 \\
\hline PA 22 & Sup & & 14 & 1 & 2 & 1 & 1 & 2 & 2 & 4 & $2,5 Y R 5 / 4, N 3 /$ & 1 & 2 & 1 & & 1 y $2>, 5$ & 2 & $3 a 5$ & sed grises, marrones y rojas, $\mathrm{Q}$ trasI & mica, fel alt, Q-fel & 4 \\
\hline PA 22 & Sup & & 15 & 1 & 2 & 1 & 1 & $2 \mathrm{y} 1$ & 1 & 1 & $5 Y R 5 / 3$ & 1 & 2 & 1 & & 4 y $5>, 3$ & 3 & $3 a 4$ & sed rojas y marrones, Q trasl, mica & fel alt, Q-fel & 4 \\
\hline PA 22 & Sup & & 16 & 1 & 2 & 1 & 1 & 2 & 2 & 1 & $5 Y R 4 / 1$ & 1 & 2 & 1 & & 2 y $3>$ & 3 & $3 a 4$ & sed grises grandes, marrones y rojas & Q trasl, fel alt, Q-fel & 4 \\
\hline PA 22 & Sup & & 17 & 1 & 2 & 2 & 1 & 2 & 2 & 1 & $5 Y R 6 / 3$ & 1 & 2 & 1 & & 2 у $3>, 1,5$ & 2 & $2 \mathrm{a} 4$ & Q trasl muy abund, Q-fel & fel alt, sed rojas y bl, mica & 2 \\
\hline PA 22 & Sup & & 18 & 1 & 2 & 2 & 2 & 2 & 2 & 5 & $2,5 Y R$ 6/4, 5/1 & 1 & 2 & 1 & & 2 y $3>$ & 3 & $3 a 4$ & sed marrones, bl y rojas, Q trasl & mica fina & 4 \\
\hline PA 22 & Sup & & 19 & 1 & 2 & 2 & 1 & 2 & 2 & 1 & 2,5 YR 4/2 & 1 & 2 & 1 & & 4 y $5>, 2$ & 3 & $3 a 4$ & sed rojas,Q trasl, fel alt & Q fel, mica fina & 4 \\
\hline PA22 S1 & 100 & & 20 & 1 & 2 & 1 & 2 & 2 & 2 & 1 & $2,5 Y R 6 / 4$ & 1 & $2 \mathrm{a} 3$ & 1 & & 4 y $5>$ & 4 & $2 \mathrm{a} 3$ & $\mathrm{Q}$ trasl muy abund, sed rojas, mica & fel alt, sed grises y claras & 2 \\
\hline PA22 S1 & 100 & & 21 & 1 & 2 & 1 & 1 & 2 & 3 & 1 & $\mathrm{~N} 2,5 /$ & 1 & 2 & 1 & & 2 y $3>$ & 3 & $2 a 3$ & Q ambar, Q trasl, biotita & fel alt, Q-fel & 7 \\
\hline PA22 S1 & 100 & & 22 & 2 & 2 & 2 & 1 & 2 & 2 & 1 & $5 Y R$ 5/1 & 1 & 2 & 1 & & $5>, 3$ & 4 & $3 a 4$ & Q trasl, biotita & fel alt, cuarc gris & 7 \\
\hline PA22 S1 & 100 & & 23 & 2 & 2 & 2 & 1 & 2 & 2 & 4 & $5 Y R 5 / 4,5 / 2$ & 1 & 2 & 1 & & 4 y $5>, 3$ & 3 & $3 \mathrm{a} 4$ & Q trasl, Q-fel & fel alt, Q ambar, biotita fina & 7 \\
\hline PA22 S1 & 100 & & 26 & 2 & 1 & 2 & 1 & 2 & 2 & 2 & $2,5 Y R$ 5/4, 5/1 & 1 & $2 a 3$ & 2 & & 3,4 y $5>$ & 3 & $2 a 3$ & mica muy abund, Q trasl & sed rojas, fel alt & 1 \\
\hline PA22 S1 & 101 & & 27 & 1 & 2 & 2 & 1 & 2 & 1 & 1 & $2,5 Y R 6 / 8$ & 1 & 2a3 & 1 & & 4 y $3>$ & 4 & $2 \mathrm{a} 3$ & Q-fel bl, sed bl o fel alt, Q trasl & sed rojas y marrones,mica & 3 \\
\hline PA22 S1 & 101 & & 28 & 1 & 2 & 2 & 1 & 2 & 2 & 4 & 5YR 5/4, N 2,5/ & 1 & 2 & 1 & & 1 y $2>, 4$ y 5 & 2 & $3 a 4$ & Q trasl, mica, sed marrones y rojas & Q-fel & 2 \\
\hline
\end{tabular}




\begin{tabular}{|c|c|c|c|c|c|c|c|c|c|c|c|c|c|c|c|c|c|c|c|c|c|}
\hline \multirow[b]{2}{*}{\begin{tabular}{|c|}
$\begin{array}{c}\text { Sitio y } \\
\text { est }\end{array}$ \\
\end{tabular}} & \multirow[b]{2}{*}{ UP } & \multirow[b]{2}{*}{ GF } & \multirow[b]{2}{*}{ FNA } & \multicolumn{4}{|c|}{ Fractura } & \multirow[b]{2}{*}{$\begin{array}{l}\text { Ca } \\
\text { vid }\end{array}$} & \multirow{2}{*}{\multicolumn{2}{|c|}{$\begin{array}{l}\text { Coc Co } \\
\text { ción lor }\end{array}$}} & \multirow[b]{2}{*}{ Not color } & \multicolumn{7}{|c|}{ Inclusiones } & \multicolumn{2}{|l|}{ Composic } & \multirow[b]{2}{*}{ GP } \\
\hline & & & & $\begin{array}{c}\text { Aspec } \\
\text { to }\end{array}$ & $\begin{array}{l}\text { Tex } \\
\text { tura }\end{array}$ & $\begin{array}{l}\text { Resis } \\
\text { tenc. }\end{array}$ & $\begin{array}{l}\mathrm{Re} \\
\text { gul }\end{array}$ & & & & & Incl & Dens & 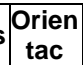 & $\left|\begin{array}{l}\text { Orient } \\
\text { pared }\end{array}\right|$ & Granul & $\begin{array}{l}\text { Se } \\
\text { lec }\end{array}$ & $\begin{array}{l}\mathrm{Re} \\
\mathrm{don}\end{array}$ & comp mayor & comp aislados & \\
\hline PA22 S1 & 101 & & 29 & 1 & 2 & 1 & 1 & 2 & 1 & 1 & 5YR 5/4 & 1 & 2 & 1 & & 2 y $3>, 4$ & 3 & $2 \mathrm{a} 3$ & Q trasl, mica, Q-fel & sed bl o fel alt & 2 \\
\hline PA22 S1 & 101 & & 30 & 2 & 2 & 1 & 1 & 2 & 3 & 1 & $5 Y R$ 2,5/1 & 1 & 2 & 2 & & 4 y $5>, 1$ & 2 & $2 \mathrm{a} 3$ & Q trasl, Q ambar, mica & sed marrones, fel alt & 2 \\
\hline PA22 S1 & 101 & & 31 & 1 & 2 & 2 & 1 & 2 & 2 & 1 & 5YR 3/1 & 1 & $1 \mathrm{a} 2$ & 1 & & 4 y $5>$ & 4 & $2 a 3$ & mica, Q trasl & sed marrones, roca osc afan & 4 \\
\hline PA22 S1 & 101 & & 32 & 2 & 2 & 2 & 1 & 2 & 1 & 1 & $5 Y R$ 5/6 & 1 & 2 & 1 & & 4 y 5 & 4 & $4 a 5$ & Q trasl, biotita, fel alt & cuarcita marrón & 7 \\
\hline PA22 S1 & 101 & & 33 & 1 & 2 & 1 & 2 & 2 & 2 & 4 & 2,5 YR 5/6, N 3/ & 1 & 2 & 1 & & 4 y $5>, 3$ & 4 & $2 \mathrm{a} 3$ & Q trasl, mica, Q-fel & fel alt, sed marrones y rojas & 2 \\
\hline PA22 S1 & 101 & & 34 & 1 & 2 & 1 & 1 & 2 & 2 & 5 & 2,5 YR 5/3, 6/6, 3/1 & 1 & 2 & 1 & & 4 y $5>$ & 4 & $3 a 4$ & Q trasl, Q-fel, biotita, fel alt & $x$ & 7 \\
\hline PA22 S1 & 101 & & 35 & 2 & 2 & 1 & 1 & 2 & 2 & 5 & 5YR 5/4, 6/3 (nuc) & 1 & 2 & 1 & & 4 y $5>, 1$ y 2 & 2 & $2 \mathrm{a} 4$ & Q trasl, Q. fel, sed bl o fel alt, mica & sed marrones y rojas, fgto plut & 2 \\
\hline PA22 S1 & 101 & & 36 & 1 & 2 & 1 & 1 & 2 & 2 & 4 & 2,5 YR $5 / 8,4 / 1$ & 1 & 2 & 1 & & 4 y $5>, 3$ y 2 & 2 & $2 \mathrm{a} 3$ & Q trasl, biotita, fel alt & Q fel, cuarc roja & 7 \\
\hline PA22 S1 & 101 & & 37 & 2 & 2 & 2 & 1 & 2 & 1 & 1 & 2,5 YR $4 / 4$ & 1 & 2 & 1 & & 4 y $5>, 3$ & 3 & $2 \mathrm{a} 3$ & mica, Q trasl, sed rojas y rosas & sed bl o fel alt & 4 \\
\hline PA22 S1 & 101 & & 38 & 2 & 2 & 1 & 1 & 2 & 1 & 1 & $5 Y R 5 / 4$ & 2 & 2 & 2 & & 4 y $5>, 1$ y 2 & 2 & $2 \mathrm{a} 3$ & Q trasl, Q-fel, sed rojas & fel alt, mica fina & 4 \\
\hline PA22 S1 & 101 & & 39 & 1 & 2 & 1 & 2 & 2 & 1 & 1 & 2,5 YR $5 / 6$ & 1 & 1 & 1 & & 4 y $5>$ & 4 & $3 a 4$ & Q trasl, mica, Q-fel & sed rojas, fel alt, & 5 \\
\hline PA22 S1 & 101 & & 40 & 2 & 2 & 2 & 1 & $2 \mathrm{y} 1$ & 5 & 4 & 2,5 YR $3 / 1,3 / 2$ & 1 & 2 & 1 & & 2 y $3>, 1$ y 5 & 2 & $2 \mathrm{a} 3$ & sed marrones y grises, $\mathrm{Q}$ trasl, mica & fel alt & 4 \\
\hline PA22 S1 & 101 & & 41 & 2 & 2 & 1 & 1 & 2 & 2 & 5 & $5 Y R$ 5/4, 5/2 (nuc) & 2 & 2 & 1 & & 2 y $3>, 4$ & 2 & $3 a 4$ & sed marrones y grises, $\mathrm{Q}$ trasl & mica fina, fel alt & 4 \\
\hline PA22 S1 & 101 & & 42 & 2 & 2 & 1 & 1 & 2 & 2 & 4 & $2,5 Y R$ 5/6, 4/1 & 1 & 2 & 2 & & 3 y $4>, 5$ & 3 & $3 a 4$ & Q trasl, sed marrones y rojas, mica & sed grises, Q-fel, fel alt & 4 \\
\hline PA22 S1 & 101 & & 43 & 1 & 2 & 1 & 1 & 2 & 2 & 4 & $2,5 Y R \quad 4 / 3,3 / 1$ & 1 & 2 & 2 & & 2 y $3>, 1$ & 3 & $2 \mathrm{a} 3$ & sed marrones, Q trasl, mica & fel alt, sed rojas y bl & 4 \\
\hline PA22 S1 & 101 & & 44 & 2 & 2 & 2 & 1 & 2 & 2 & 1 & $2,5 Y R 5 / 4$ & 2 & 2 & 1 & & 2 y $3>, 4$ y 5 & 2 & $2 a 3$ & sed marrones, Q trasl & Q-fel, sed grises, mica fina & 4 \\
\hline PA22 S1 & 101 & & 46 & 2 & 2 & 2 & 1 & $2 \mathrm{y} 1$ & 2 & 4 & 2,5 YR $5 / 4,5 / 1$ & 1 & 2a3 & 1 & & $5>, 4$ y 3 & 4 & $3 a 4$ & biotita, Q trasl, & Q-fel, volc grises & 7 \\
\hline PA22 S1 & 101 & & 47 & 2 & 2 & 3 & 1 & $2 \mathrm{y} 1$ & 2 & 4 & 2,5YR 5/6, 3/1 & 1 & $2 \mathrm{a} 3$ & 1 & & 3 y $4>, 2$ & 2 & $3 a 4$ & Q trasl, biotita, Q-fel & sed bl o fel alt & 7 \\
\hline PA22 S1 & 101 & & 48 & 1 & 2 & 2 & 1 & 2 & 3 & 5 & N 2,5/, 5/ (nuc) & 2 & $1 \mathrm{a} 2$ & 1 & & 4 y $5>$ & 4 & $3 a 4$ & Q trasl, sed bl o fel alt & mica fina & 2 \\
\hline PA22 S1 & 101 & & 49 & 1 & 2 & 2 & 1 & 2 & 2 & 3 & $5 Y R$ 6/3, 3/1 & 1 & 2 & 1 & & 4 y $5>$ & 4 & $3 a 4$ & Q trasl, Q-fel, biotita & $x$ & 7 \\
\hline PA22 S1 & 101 & & 50 & 1 & 2 & 1 & 1 & 2 & 2 & 5 & 2,5YR 5/6, 6/1 (nuc) & 1 & 2 & 1 & & 4 y $5>, 3$ & 3 & $3 a 4$ & Q trasl, mica, sed marrones & fel alt, Q-fel, sed rojas & 4 \\
\hline PA22 S1 & 101 & & 51 & 2 & 2 & 2 & 1 & 2 & 3 & 1 & N 2,5/ & 1 & 2 & 1 & & 1 y $2>, 4$ & 2 & $3 a 4$ & sed marrones a gris osc & Q trasl, mica fina,sed bl o fel alt & 4 \\
\hline PA22 S1 & 101 & & 52 & 1 & 2 & 2 & 1 & 2 & 2 & 1 & $5 Y R 3 / 2$ & 1 & 2 & 1 & & 2 y $3>, 1$ & 2 & $3 a 4$ & Q trasl, sed marrones y grises & mica fina, Q-fel, fel alt,sed roj & 4 \\
\hline PA22 S1 & 101 & & 53 & 2 & 2 & 1 & 1 & 2 & 2 & 4 & 2,5 YR $4 / 4,4 / 1$ & 1 & 2 & 1 & & 4 y $5>, 1$ y 2 & 2 & $2 \mathrm{a} 3$ & sed marrones, Q trasl, mica & sed rojas, fel alt & 4 \\
\hline PA22 S1 & 101 & & 54 & 2 & 2 & 1 & 1 & $2 \mathrm{y} 1$ & 2 & 4 & $2,5 Y R$ 5/4, 3/1 & 1 & 2 & 1 & & 3 y $4>, 1$ y 2 & 2 & $2 \mathrm{a} 3$ & Q trasl, biotita & Q-fel & 7 \\
\hline PA22 S1 & 101 & & 55 & 1 & 1 & 1 & 2 & 2 & 2 & 5 & $5 Y R \quad 4 / 4,5 / 1$ (nuc) & 2 & 2 & 2 & & 3 y $4>$ & 3 & $2 \mathrm{a} 3$ & sed marrones, Q trasl, mica & sed gris, Q-fel & 4 \\
\hline PA22 S1 & 101 & & 56 & 1 & 1 & 2 & 1 & 2 & 3 & 5 & 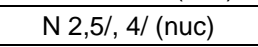 & 1 & $1 \mathrm{a} 2$ & 2 & & 4 y $5>, 2$ & 3 & 2a3 & sed marrones a gris osc, Q trasl & mica fina, Q-fel & 4 \\
\hline PA22 S1 & 101 & & 57 & 2 & 2 & 2 & 1 & $2 \mathrm{y} 1$ & 2 & 1 & 5YR 4/1 & 1 & 2 & 1 & & 2 y $3>$ & 3 & $3 a 4$ & sed marrones y grises, $\mathrm{Q}$ trasl,mica & fel alt, roca negra afanit & 4 \\
\hline PA22 S1 & 101 & & 58 & 2 & 2 & 2 & 1 & 2 & 2 & 1 & $5 Y R 3 / 1$ & 2 & 2 & 2 & & 2 y $3>, 4$ & 3 & $2 \mathrm{a} 3$ & sed marrones y grises, $\mathrm{Q}$ trasl & mica fina, sed bl o fel alt & 4 \\
\hline PA22 S1 & 101 & & 59 & 1 & 2 & 2 & 1 & 2 & 2 & 4 & $5 Y R 4 / 2,5 / 1$ & 2 & 2 & 1 & & 4 y $5>, 2$ & 2 & $3 a 4$ & Q trasl, sed marrones, mica fina & fel alt, sed rojas,roca osc afan & 4 \\
\hline PA22 S1 & 101 & & 60 & 2 & 2 & 1 & 1 & 2 & 3 & 1 & $\mathrm{~N} 3 /$ & 1 & 2 & 1 & & 1 y $2>, 3$ y 4 & 2 & $2 \mathrm{a} 3$ & Q trasl, mica & sed marrones, Q-fel, Q ambar & 2 \\
\hline PA22 S1 & 101 & & 61 & 2 & 2 & 1 & 1 & 2 & 3 & 1 & N 3/ & 2 & 2 & 2 & & 1 y $2>$ & 3 & $3 a 4$ & sed marrones y grises, Q-fel & mica fina, $Q$ trasl & 4 \\
\hline PA22 S1 & 101 & & 62 & 1 & 2 & 1 & 1 & 2 & 2 & 4 & $5 Y R$ 5/2, 3/1 & 2 & 2 & 1 & & 4 y $5>, 2$ & 3 & $3 a 4$ & Q trasl, sed rojas y marrones & sed bl o fel alt, mica fina & 4 \\
\hline PA22 S1 & 101 & & 65 & 2 & 2 & 2 & 2 & 2 & 2 & 4 & $5 Y R$ 4/3, 2,5/1 & 1 & 2 & 1 & & 3 y $4>, 2$ & 3 & $3 a 4$ & mica, Q trasl, sed marrones & Q-fel & 2 \\
\hline PA22 S1 & 101 & & 66 & 2 & 2 & 2 & 1 & 2 & 2 & 4 & $5 Y R$ 4/3, 3/1 & 1 & $2 \mathrm{a} 3$ & 1 & & 4 y $5>$ & 3 & $2 \mathrm{a} 3$ & mica muy abund & Q trasl, fel alt & 1 \\
\hline PA22 S1 & 102 & & 67 & 1 & 2 & 2 & 1 & 2 & 1 & 1 & 10R 5/6 & 2 & 1 & 1 & & 5 & 4 & 2a3 & Q trasl, mica, Q-fel & fel alt, sed claras? & 5 \\
\hline
\end{tabular}




\begin{tabular}{|c|c|c|c|c|c|c|c|c|c|c|c|c|c|c|c|c|c|c|c|c|c|}
\hline \multirow[b]{2}{*}{$\begin{array}{c}\text { Sitio y } \\
\text { est }\end{array}$} & \multirow[b]{2}{*}{ UP } & \multirow[b]{2}{*}{ GF } & \multirow[b]{2}{*}{ FNA } & \multicolumn{4}{|c|}{ Fractura } & \multirow[b]{2}{*}{\begin{tabular}{|l|l} 
Ca \\
lid
\end{tabular}} & \multirow{2}{*}{\multicolumn{2}{|c|}{\begin{tabular}{|l|l|} 
Coc Co \\
ción \\
Ior
\end{tabular}}} & \multirow[b]{2}{*}{ Not color } & \multicolumn{7}{|c|}{ Inclusiones } & \multicolumn{2}{|l|}{ Composic } & \multirow[b]{2}{*}{ GP } \\
\hline & & & & $\begin{array}{c}\text { Aspec } \\
\text { to } \\
\end{array}$ & $\begin{array}{l}\text { Tex } \\
\text { tura }\end{array}$ & $\begin{array}{l}\text { Resis } \\
\text { tenc. }\end{array}$ & $\begin{array}{l}\mathrm{Re} \\
\text { gul }\end{array}$ & & & & & Incl & Dens & \begin{tabular}{|c|}
$\begin{array}{c}\text { Orien } \\
\text { tac }\end{array}$ \\
\end{tabular} & $\begin{array}{l}\text { Orient } \\
\text { pared }\end{array}$ & Granul & & \begin{tabular}{|c|}
$R e$ \\
don \\
\end{tabular} & comp mayor & comp aislados & \\
\hline PA22 S1 & 102 & & 68 & 2 & 2 & 2 & 1 & $2 \mathrm{y} 1$ & 2 & 1 & $2,5 Y R \quad 4 / 2$ & 1 & 2 & 1 & & 2 y $3>$ & 2 & $3 a 4$ & sed claras, rosas y rojas, mica, Q trasl & fel alt, Q-fel & 4 \\
\hline PA22 S1 & 102 & & 69 & 1 & 2 & 1 & 1 & 2 & 2 & 1 & $5 Y R 5 / 4$ & 1 & 2 & 1 & & 4 y $5>$ & 4 & $3 a 4$ & Q trasl, sed rojas, rosas, bl o fel alt & sed marrones y grises, mica & 4 \\
\hline PA22 S1 & 102 & & 70 & 2 & 2 & 1 & 1 & 2 & 2 & 4 & $5 Y R \quad 4 / 3,2,5 / 1$ & 1 & 2 & 2 & & $2>, 1$ y 3 & 3 & $2 a 3$ & sed marrones y grises, $\mathrm{Q}$ trasl, mica & fel alt, Q fel & 4 \\
\hline PA22 S1 & 102 & & 71 & 2 & 2 & $x$ & 1 & 2 & 2 & 4 & 5 YR $5 / 3,4 / 1$ & 1 & $2 \mathrm{a} 3$ & 1 & & 4 y $5>, 1$ y 2 & 2 & $2 \mathrm{a} 3$ & Q trasl, mica, Q-fel & fel alt, sed marrones & 4 \\
\hline PA22 S1 & 102 & & 72 & 1 & 2 & 2 & 1 & 2 & 3 & 1 & N 2,5/ & 1 & $1 \mathrm{a} 2$ & 1 & & 3 y $4>, 2$ & 3 & $2 a 3$ & Q trasl, Q ambar, biotita, sed marrones & Q fel, fel alt & 4 \\
\hline PA22 S1 & 102 & & 73 & 2 & 2 & 2 & 1 & 2 & 3 & 1 & N 2,5/ & 1 & 2 & 1 & & 4 y $5>, 1$ y 2 & 2 & $3 a 4$ & Q trasl, mica, sed marrones & fel alt, Q-fel & 4 \\
\hline PA22 S1 & 102 & & 74 & 2 & 2 & 2 & 1 & 2 & 2 & 4 & $5 Y R$ 4/3, 3/1 & 1 & 2 & 2 & & 2 y $3>, 1$ & 3 & $2 a 3$ & sed marrones, $\mathrm{Q}$ trasl, mica fina & Q-fel & 4 \\
\hline PA22 S1 & 102 & & 75 & 1 & 2 & 1 & 1 & $2 \mathrm{y} 1$ & 3 & 5 & $\mathrm{~N} 4 /, 6 /$ (nuc) & 1 & 2 & 2 & & 2 y $3>, 1$ y 5 & 2 & $2 \mathrm{a} 3$ & sed claras, mica, Q trasl & Q- fel, fel alt, sed rojas & 4 \\
\hline PA22 S1 & 102 & & 76 & 2 & 2 & 1 & 1 & 2 & 1 & 1 & 2,5 YR $4 / 6$ & 1 & 2 & 2 & & 4 y $5>, 3$ y 2 & 3 & $2 \mathrm{a3}$ & sed marrones y grises, $\mathrm{Q}$ trasl, mica & fel alt & 4 \\
\hline PA22 S1 & 102 & & 77 & 2 & 2 & 1 & 1 & 2 & 2 & 4 & $5 Y R$ 6/2, N 3/ & 1 & 2 & 1 & & 4 y $5>, 3$ y 4 & 2 & $2 a 3$ & Q trasl, mica & fel alt, sed grises & 2 \\
\hline PA22 S1 & 102 & & 78 & 2 & 2 & 2 & 1 & $2 \mathrm{y} 1$ & 5 & 5 & 10R 5/4 (nuc), 3/1 & 1 & 2 & 1 & & 4 y $5>, 3$ & 3 & $2 \mathrm{a} 3$ & mica abund, Q trasl & sed rojas y grises, fel alt & 1 \\
\hline PA22 S1 & 102 & & 79 & 1 & 2 & 1 & 2 & 2 & 2 & 4 & $2,5 Y R$ 5/1, N 3/ & 1 & 2 & 1 & & 3 y $4>, 2$ & 3 & $3 a 4$ & Q trasl, Q-fel, biotita & fgto roca plut con $\mathrm{Q}$ & 7 \\
\hline PA22 S1 & 102 & & 80 & 1 & 2 & 1 & 1 & 2 & 2 & 5 & $5 Y R \quad 4 / 2,6 / 4, N 3 /$ & 1 & 2 & 2 & & 1 y $2>, 3$ y 4 & 2 & $3 a 4$ & sed marrones, grises, rojas, bl & mica, Q trasl & 4 \\
\hline PA22 S1 & 102 & & 81 & 2 & 2 & 2 & 1 & 2 & 2 & 4 & $2,5 Y R$ 5/4, 5/1 & 1 & 2 & 1 & & 2 y $3>, 4$ y 5 & 2 & $2 \mathrm{a} 3$ & Q trasl, biotita, sed grises & sed bl o fel alt & 2 \\
\hline PA22 S1 & 102 & & 82 & 1 & 2 & 1 & 1 & $2 \mathrm{y} 1$ & 1 & 1 & 5YR 7/4 & 1 & 2 & 1 & & 4 y $5>, 2$ y 3 & 3 & $3 a 4$ & sed bl o fel alt, Q trasl & sed rojas y rosas,mica & 3 \\
\hline PA22 S1 & 102 & & 83 & 1 & 2 & 2 & 1 & 2 & 2 & 4 & $2,5 Y R$ 4/8, N 3/ & 2 & 2 & 1 & & 4 y $5>$ & 4 & $3 a 4$ & Q trasl, sed bl o fel alt & mica, sed rojas, Q-fel & 4 \\
\hline PA22 S1 & 102 & & 85 & 2 & 2 & 1 & 1 & 2 & 2 & 1 & 2,5YR 4/1 & 1 & $1 \mathrm{a} 2$ & 2 & & 2 y $3>, 1$ y 5 & 2 & $2 a 3$ & sed marrones, Q trasl & mica, volc gris, fel alt & 4 \\
\hline PA22 S1 & 102 & & 86 & 2 & 2 & 2 & 1 & 2 & 2 & 5 & $5 Y R$ 3/1, 4/2 (nuc) & 1 & 2 & 2 & & 2 y $3>$ & 3 & $2 a 3$ & sed marrones y grises, mica & $\mathrm{Q}$ trasl, sed rojas & 4 \\
\hline PA22 S1 & 102 & & 87 & 2 & 2 & 2 & 1 & 2 & 2 & 4 & $5 Y R \quad 4 / 2,2,5 / 1$ & 2 & $1 \mathrm{a} 2$ & 2 & & 2 y $3>$ & 3 & $2 a 3$ & sed marrones y grises, $\mathrm{Q}$ trasl, mica & fel alt, sed rojas & 4 \\
\hline PA22 S1 & 102 & & 88 & 2 & 2 & 2 & 1 & 2 & 2 & 1 & 5YR 5/4 & 2 & 2 & 2 & & 3 y $2>, 4$ & 2 & $2 \mathrm{a3}$ & Q trasl, sed marrones, rojas, mica, Q-fel & roca ignea clara con min osc & 4 \\
\hline PA22 S1 & 102 & & 89 & 2 & 2 & 1 & 1 & 2 & 5 & 5 & $5 Y R$ 5/2, 3/1 & 1 & 2 & 1 & & 2 y $3>, 4$ y 5 & 2 & $3 a 4$ & Q trasl, sed marrones y grises, Q-fel & mica & 4 \\
\hline PA22 S1 & 102 & & 90 & 2 & 2 & 2 & 1 & 2 & 2 & 4 & $5 Y R \quad 4 / 2,2,5 / 1$ & 1 & 2 & 1 & & 1 y $2>, 3$ y 4 & 2 & $2 a 3$ & sed marrones y grises, Q trasl, Q-fel & mica & 4 \\
\hline PA22 S1 & 102 & & 91 & 1 & 2 & 2 & 2 & 2 & 2 & 1 & 2,5 YR 3/1 & 1 & $1 \mathrm{a} 2$ & 2 & & 3 y $4>$ & 3 & $3 a 4$ & sed marrones y grises & mica fina, $\mathrm{Q}$ trasl & 4 \\
\hline PA22 S1 & 102 & & 92 & 2 & 2 & 1 & 2 & 2 & 2 & 4 & $2,5 Y R$ 6/4, N 3/ & 1 & 2 & 1 & & 4 y $5>$ & 4 & $3 a 5$ & Q trasl, mica & sed marr,fel alt,roca osc afan & 4 \\
\hline PA22 S1 & 102 & & 93 & 2 & 2 & 1 & 1 & 2 & 2 & 4 & $2,5 Y R$ 5/6, N 5/ & 1 & 2 & 2 & & 2 y $3>, 4$ y 5 & 2 & $3 a 4$ & Q trasl, sed marrones y rojas, & fel alt o sed bl, mica & 4 \\
\hline PA22 S1 & 102 & & 94 & 2 & 2 & 1 & 1 & 2 & 2 & 4 & $2,5 Y R$ 3/1, N 2,5/ & 2 & 2 & 1 & & 3 y $4>, 2$ & 3 & $3 a 4$ & sed marrones, Q trasl, mica & roca osc afan & 4 \\
\hline PA22 S1 & 102 & & 95 & 2 & 2 & 1 & 1 & 2 & 2 & 1 & $2,5 Y R \quad 4 / 1$ & 1 & 2 & 1 & & 2 y $3>, 1$ y 4 & 2 & $3 a 4$ & $\mathrm{Q}$ trasl, mica, sed marrones & Q-fel & 2 \\
\hline PA22 S1 & 102 & & 96 & 2 & 2 & 1 & 1 & 2 & 2 & 4 & $5 Y R$ 4/4, 2,5/1 & 1 & 2 & 1 & & 2 y $3>, 4$ & 2 & $3 a 4$ & mica abund, Q trasl, Q-fel & fel alt, plut bl y neg? & 1 \\
\hline PA22 S1 & 103 & & 99 & 2 & 2 & 1 & 1 & $2 \mathrm{y} 1$ & 2 & 1 & $7,5 Y R$ 5/4 & 1 & 2 & 1 & & 4 y $5>, 1$ y 2 & 2 & $3 a 4$ & Q trasl, sed bl o fel alt, mica & sed rojas, Q-fel & 4 \\
\hline PA22 S1 & 103 & & 100 & 2 & 2 & 1 & 1 & 2 & 2 & 1 & $5 Y R$ 5/3 & 1 & 2 & 1 & & 4 y $5>$ & 2 & $3 a 4$ & Q trasl, fel alt o sed bl, mica & Q-fel, sed rojas & 4 \\
\hline PA22 S1 & 103 & & 101 & 2 & 2 & 1 & 1 & 2 & 1 & 1 & 5YR 5/4 & 1 & 2 & 1 & & 3 y $4>$ & 3 & $2 \mathrm{a} 3$ & sed marrones y grises, $\mathrm{Q}$ trasl, mica & Q-fel, fel alt, sed rojas & 4 \\
\hline PA22 S1 & 103 & & 102 & 1 & 2 & 1 & 1 & 2 & 2 & 5 & 5YR 5/6, 5/3 (nuc) & 1 & $1 \mathrm{a} 2$ & 1 & & 2 y $3>, 4$ & 3 & $2 \mathrm{a} 3$ & sed marrones y grises, Q trasl & mica, fel alt & 4 \\
\hline PA22 S1 & 103 & & 103 & 1 & 2 & 2 & 1 & 2 & 2 & 4 & $2,5 Y R$ 4/2, N 3/ & 1 & 2 & 1 & & 4 y $5>$ & 4 & $4 a 5$ & Q trasl, mica & fel alt, sed bl y rojas, Q-fel & 2 \\
\hline PA22 S1 & 103 & & 106 & 2 & 2 & 1 & 1 & 2 & 3 & 2 & $\mathrm{~N} 2,5 /, 2,5 \mathrm{YR} 3 / 1$ & 1 & 2 & 1 & & 4 y $5>, 1$ & 2 & $3 a 4$ & sed marrones, Q trasl, mica & sed bl y rojas & 4 \\
\hline PA22 S1 & 103 & & 107 & 2 & 2 & 2 & 1 & 2 & 3 & 1 & $\mathrm{~N} 2,5 /$ & 1 & 2 & 1 & & 2 y $3>, 4$ & 3 & $2 \mathrm{a} 3$ & sed marrones y grises, mica & fel alt o sed bl, Q trasl & 4 \\
\hline PA22 S1 & 103 & & 108 & 2 & 2 & 2 & 1 & 2 & 2 & 4 & $\mathrm{~N} 2,5 /, 5 \mathrm{YR} 4 / 2$ & 1 & 2 & 2 & & 4 y $5>, 1$ y 2 & 2 & $2 a 3$ & sed marrones, grises y rojas, Q trasI & fel alt, Q-fel, mica & 4 \\
\hline
\end{tabular}




\begin{tabular}{|c|c|c|c|c|c|c|c|c|c|c|c|c|c|c|c|c|c|c|c|c|c|}
\hline \multirow[b]{2}{*}{\begin{tabular}{|c|}
$\begin{array}{c}\text { Sitio y } \\
\text { est }\end{array}$ \\
\end{tabular}} & \multirow[b]{2}{*}{ UP } & \multirow[b]{2}{*}{ GF } & \multirow[b]{2}{*}{ FNA } & \multicolumn{4}{|c|}{ Fractura } & \multirow[b]{2}{*}{\begin{tabular}{l|l} 
Ca \\
vid
\end{tabular}} & \multirow{2}{*}{\multicolumn{2}{|c|}{\begin{tabular}{ll|} 
Coc & Co \\
ción & lor \\
\end{tabular}}} & \multirow[b]{2}{*}{ Not color } & \multicolumn{7}{|c|}{ Inclusiones } & \multicolumn{2}{|c|}{ Composic } & \multirow[b]{2}{*}{ GP } \\
\hline & & & & $\begin{array}{c}\text { Aspec } \\
\text { to }\end{array}$ & \begin{tabular}{l|} 
Tex \\
tura
\end{tabular} & \begin{tabular}{|l|} 
Resis \\
tenc.
\end{tabular} & $\begin{array}{l}\mathbf{R e} \\
\text { gul }\end{array}$ & & & & & Incl & Dens & $\begin{array}{c}\text { Orien } \\
\text { tac }\end{array}$ & $\begin{array}{l}\text { Orient } \\
\text { pared }\end{array}$ & Granul & $\begin{array}{l}\text { Se } \\
\text { lec }\end{array}$ & $\begin{array}{l}\mathrm{Re} \\
\mathrm{don}\end{array}$ & comp mayor & comp aislados & \\
\hline PA22 S1 & 103 & & 109 & 2 & 2 & 2 & 1 & 2 & 2 & 1 & $5 Y R$ 5/2 & 2 & 2 & 1 & & 4 y $5>, 1$ & 2 & $3 a 4$ & Q trasl, Q fel, fel alt & mica, sed rojas & 2 \\
\hline PA22 S1 & 103 & & 110 & 1 & 2 & 1 & 1 & 2 & 2 & 4 & $5 Y R$ 5/4, 4/1 & 1 & 2 & 1 & & 4 y $5>$ & 4 & $3 a 5$ & Q trasl, sed bl o fel alt, sed rojas & sed marrones, mica fina & 4 \\
\hline PA22 S1 & 103 & & 111 & 2 & 1 & 2 & 1 & 2 & 5 & 5 & $5 Y R$ 3/1, 4/3 (nuc) & 1 & 2 & 2 & & 3 y $4>, 2$ & 2 & $2 a 3$ & mica muy abund & Q trasl, Q-fel, sed rojas & 1 \\
\hline PA22 S1 & 103 & & 112 & 1 & 2 & 2 & 1 & 2 & 1 & 1 & 5YR 5/6 & 1 & 2 & 1 & & 4 y $5>, 3$ & 4 & $3 a 4$ & Q trasl, Q-fel, mica & sed bl y fel alt & 2 \\
\hline PA22 S1 & 103 & & 113 & 2 & 1 & 1 & 1 & 2 & 3 & 1 & 5YR $2,5 / 1$ & 1 & 2a3 & 2 & & 4 y $5>, 3$ & 3 & $2 \mathrm{a} 3$ & mica muy abund, Q trasl & Q-fel, sed marrones & 1 \\
\hline PA22 S1 & 103 & & 114 & 1 & 2 & 1 & 1 & 2 & 2 & 4 & 2,5YR 6/8, 5YR 6/4 & 1 & 1a2 & 1 & & 3 y $4>, 5$ & 3 & $3 a 4$ & $\mathrm{Q}$ trasl, biotita, fel alt & Q-fel & 7 \\
\hline PA22 S1 & 103 & & 115 & 2 & 2 & 1 & 1 & 2 & 2 & 4 & $5 Y R$ 5/4, 4/2 & 1 & 2 & 1 & & 2 y $3>$ & 3 & $2 \mathrm{a} 3$ & sed marrones y grises, Q trasl & mica, Q-fel & 4 \\
\hline PA22 S1 & 103 & & 116 & 2 & 2 & 1 & 1 & $2 \mathrm{y} 1$ & 2 & 1 & $5 Y R 3 / 2$ & 2 & 2 & 1 & & 4 y $5>, 1$ y 2 & 2 & $3 a 4$ & Q trasl, Q-fel, biotita & fel alt & 7 \\
\hline PA22 S1 & 103 & & 117 & 1 & 2 & 2 & 1 & 2 & 2 & 4 & $5 Y R 3 / 1,4 / 2$ & 1 & 2 & 1 & & 2 y $3>, 4$ y 5 & 2 & $3 a 4$ & sed marrones y grises, $\mathrm{Q}$ trasl, mica & fel alt & 4 \\
\hline PA22 S1 & 103 & & 118 & 2 & 2 & 2 & 1 & 2 & 2 & 1 & 5YR 6/2 & 2 & 2 & 1 & & 4 y $5>$ & 4 & $4 a 5$ & Q trasl, Q-fel & mica, fel alt, sed marr y rojas & 2 \\
\hline PA22 S1 & 103 & & 119 & 2 & 2 & 1 & 1 & 2 & 2 & 4 & $5 Y R$ 5/3, 5/1 & 1 & 2 & 1 & & 2 y $3>$ & 3 & $3 a 4$ & sed marrones y grises, $\mathrm{Q}$ trasl, mica & fel alt & 4 \\
\hline PA22 S1 & 103 & & 120 & 1 & 2 & 1 & 1 & 2 & 2 & 5 & 2,5YR6/4; 5YR6/2,5/1 & 1 & 2 & 1 & & 4 y $5>, 2$ & 2 & $3 a 4$ & Q trasl, biotita, Q-fel & fel alt & 7 \\
\hline PA22 S1 & 103 & & 121 & 2 & 2 & 1 & 1 & 2 & 2 & 4 & $2,5 Y R$ 5/4, 5/1 & 1 & 2 & 1 & & 2 y $3>, 4$ & 3 & $3 a 4$ & sed marrones, grises y rojas, Q trasl & mica, sed bl,roca osc afan & 4 \\
\hline PA22 S1 & 103 & & 122 & 1 & 2 & 2 & 1 & 2 & 2 & 1 & 5YR 4/1 & 1 & 2 & 1 & & 3 y $4>, 2$ y 5 & 2 & $3 a 4$ & sed marrones y grises, Q trasl & mica, Q-fel, sed rojas & 4 \\
\hline PA22 S1 & 103 & & 123 & 1 & 2 & 1 & 1 & 2 & 2 & 4 & $5 Y R$ 4/1, 5/3 & 2 & 1a2 & 1 & & 2 y $3>, 4$ & 2 & $3 a 4$ & Q trasl, sed grises y marrones & mica fina, sed rojas & 4 \\
\hline PA22 S1 & 103 & & 124 & 1 & 2 & 1 & 1 & $2 \mathrm{y} 1$ & 2 & 4 & $5 Y R \quad 4 / 2,2,5 / 1$ & 2 & $1 \mathrm{a} 2$ & 1 & & 3 y $4>, 1$ & 2 & $3 a 4$ & mica, sed marrones, Q trasl & fel alt & 4 \\
\hline PA22 S1 & 103 & & 126 & 2 & 2 & 2 & 1 & 2 & 2 & 4 & 2,5 YR $5 / 6,5 / 2$ & 1 & 2 & 1 & & 4 y $5>, 3$ & 3 & $3 a 4$ & Q trasl, sed bl o fel alt, mica & sed grises y rojas & 4 \\
\hline PA22 S1 & 103 & & 127 & 2 & 2 & 1 & 1 & 2 & 1 & 1 & 2,5 YR $5 / 6$ & 2 & 2 & 1 & & 3 у $4>, 2$ & 3 & $3 a 4$ & sed marrones y rojas, mica & sed bl o fel alt, Q trasl & 4 \\
\hline PA22 S1 & 103 & & 128 & 1 & 2 & 1 & 1 & 2 & 2 & 5 & $5 Y R$ 6/4, 6/1 & 2 & 1a2 & 2 & & 2 y $3>, 4$ & 2 & $2 \mathrm{a} 3$ & Q trasl, sed o metamorf gris osc, biotita & sed marrones, volc gris, Q-fel, & ?? \\
\hline PA22 S1 & 103 & & 129 & 2 & 2 & 2 & 1 & 2 & 2 & 4 & $5 Y R 5 / 4, N 3 /$ & 1 & 2 & 1 & & 2 y $3>, 4$ & 3 & $2 \mathrm{a} 3$ & sed marrones y grises, $\mathrm{Q}$ trasl & fel alt, sed rojas, mica & 4 \\
\hline PA22 S1 & 103 & & 130 & 2 & 1 & 2 & 1 & $2 \mathrm{y} 1$ & 2 & 1 & $5 Y R \quad 4 / 3$ & 1 & 2 & 2 & & 4 y $5>, 3$ & 3 & $2 a 3$ & mica muy abund, Q trasl & Q-fel, sed rojas, roca osc afan & 1 \\
\hline PA22 S1 & 103 & & 131 & 1 & 2 & 2 & 1 & $2 \mathrm{y} 1$ & 2 & 4 & $5 Y R$ 6/4, 4/1 & 2 & 1a2 & 1 & & 4 y $5>, 3$ & 4 & $3 a 4$ & Q trasl, Q-fel, biotita & fel alt & 7 \\
\hline PA22 S1 & 103 & & 132 & 2 & 2 & 1 & 1 & 2 & 2 & 4 & $5 Y R \quad 4 / 2,3 / 1$ & 2 & 1a2 & 1 & & 2 y $3>$ & 3 & $2 \mathrm{a} 3$ & Q trasl, sed marrones y grises & mica, fel alt & 4 \\
\hline PA22 S1 & 103 & & 133 & 2 & 2 & 2 & 1 & 2 & 2 & 4 & $5 Y R 4 / 3,3 / 1$ & 1 & 2 & 1 & & 3 y $4>, 2$ & 3 & $4 a 5$ & Q trasl, Q ambar, biotita & fel alt, cuarcita? & 7 \\
\hline PA22 S1 & 103 & & 134 & 2 & 2 & 2 & 1 & 2 & 2 & 4 & $5 Y R 3 / 2,3 / 1$ & 1 & 2 & 1 & & 4 y $5>, 2$ y 3 & 3 & $3 a 4$ & Q trasl, mica, Q-fel & fel alt, sed marrones y rojas & 2 \\
\hline PA22 S1 & 103 & & 135 & 2 & 2 & 2 & 1 & 2 & 2 & 4 & 2,5 YR $5 / 4,3 / 1$ & 2 & 2 & 2 & & 1 y $2>, 3$ y 4 & 2 & $2 a 3$ & sed marrones y grises, $\mathrm{Q}$ trasl, mica & sed bl o fel alt, sed rojas & 4 \\
\hline PA22 S1 & 103 & & 136 & 1 & 2 & 1 & 1 & $2 \mathrm{y} 1$ & 2 & 4 & 2,5 YR $5 / 6, N 3 /$ & 2 & 2 & 1 & & 3 y $4>, 2$ y 5 & 3 & $3 a 4$ & Q trasl, mica, sed rojas y marrones & Q-fel & 2 \\
\hline PA22 S1 & 103 & & 137 & 1 & 2 & 1 & 1 & 2 & 2 & 3 & 2,5YR6/6; 5YR 6/1,3/1 & 2 & 1 & 1 & & 4 y $5>, 3$ & 4 & $2 \mathrm{a} 3$ & sed bl o fel alt, Q trasl & sed rojas y marrones, mica & 5 \\
\hline PA22 S1 & 103 & & 138 & 2 & 2 & 2 & 1 & 2 & 2 & 4 & $5 Y R$ 3/2, 2,5/1 & 1 & 2 & 2 & & 4 y $5>, 2$ y 3 & 2 & $2 a 3$ & mica muy abund, Q trasl & sed bl y rojas & 1 \\
\hline PA22 S1 & 103 & & 139 & 1 & 1a2 & 2 & 1 & 2 & 2 & 2 & $5 Y R$ 6/3, N 2,5/ & 2 & 1 & 1 & & 5 & 5 & 3 & $x$ & Biotita muy fina & $? ?$ \\
\hline PA22 S1 & 103 & & 140 & 2 & 2 & 2 & 1 & $2 \mathrm{y} 1$ & 2 & 4 & $2,5 Y R \quad 4 / 6,3 / 1$ & 1 & 2 & 1 & & 2 y $3>, 4$ y 5 & 2 & $3 a 4$ & Q trasl, mica, sed gris, rosadas & fel alt, sed rojas & 4 \\
\hline PA22 S1 & 103 & & 141 & 2 & 2 & 1 & 1 & 2 & 2 & 1 & 7,5 YR $6 / 4$ & 1 & 2 & 2 & & 4 y $5>, 3$ & 3 & 2a4 & Q trasl, sed rojas, sed bl o fel alt & igneas grises, mica, fgto plut & 4 \\
\hline PA22 S1 & 103 & & 142 & 1 & 2 & 1 & 1 & 2 & 1 & 1 & $2,5 Y R 5 / 6$ & 2 & 1 & 2 & & 4 y $5>, 3$ & 4 & $3 a 4$ & sed bl o fel alt, Q-fel, sed rojas & mica, Q trasl & 3 \\
\hline PA22 S2 & $\operatorname{limp}$ & & 145 & 2 & 2 & 2 & 1 & 2 & 2 & 5 & 5YR3/1,5/3, 10R5/6 & 1 & 2 & 1 & & 3 y $4>, 2$ & 3 & $2 \mathrm{a} 3$ & mica muy abund, Q trasl & Q-fel, sed rosas & 1 \\
\hline PA22 S2 & $\operatorname{limp}$ & & 146 & 2 & 2 & 1 & 1 & 2 & 2 & 2 & $2,5 Y R$ 3/1, 6/8 & 1 & 2 & 1 & & 4 y $5>, 2$ y 3 & 2 & $3 a 4$ & Q trasl, sed bl o fel alt, Q fel & biotita & 7 \\
\hline PA22 S2 & $\operatorname{limp}$ & & 147 & 2 & 2 & 2 & 1 & 2 & 1 & 1 & 5YR 6/4 & 1 & 2 & 1 & & 4 y $5>, 2$ & 3 & $3 a 4$ & Q trasl, sed bl o fel alt, Q fel & sed rojas, mica & 2 \\
\hline
\end{tabular}




\begin{tabular}{|c|c|c|c|c|c|c|c|c|c|c|c|c|c|c|c|c|c|c|c|c|c|}
\hline \multirow[b]{2}{*}{\begin{tabular}{|c|}
$\begin{array}{c}\text { Sitio y } \\
\text { est }\end{array}$ \\
\end{tabular}} & \multirow[b]{2}{*}{ UP } & \multirow[b]{2}{*}{ GF } & \multirow[b]{2}{*}{ FNA } & \multicolumn{4}{|c|}{ Fractura } & \multirow{2}{*}{\multicolumn{3}{|c|}{\begin{tabular}{|l|l|l|l|l|l|} 
Ca & Coc \\
vid & ción & lor \\
\end{tabular}}} & \multirow[b]{2}{*}{ Not color } & \multicolumn{7}{|c|}{ Inclusiones } & \multicolumn{2}{|c|}{ Composic } & \multirow[b]{2}{*}{ GP } \\
\hline & & & & $\begin{array}{c}\text { Aspec } \\
\text { to }\end{array}$ & $\begin{array}{l}\text { Tex } \\
\text { tura } \\
\end{array}$ & $\begin{array}{l}\text { Resis } \\
\text { tenc. }\end{array}$ & \begin{tabular}{|l|}
$\mathrm{Re}$ \\
$\mathrm{gul}$
\end{tabular} & & & & & Incl & Dens & $\begin{array}{c}\text { Orien } \\
\text { tac }\end{array}$ & $\begin{array}{l}\text { Orient } \\
\text { pared }\end{array}$ & Granul & \begin{tabular}{l|}
$\mathrm{Se}$ \\
lec
\end{tabular} & $\begin{array}{l}\mathrm{Re} \\
\mathrm{don}\end{array}$ & comp mayor & comp aislados & \\
\hline \begin{tabular}{|l|} 
PA22 S2 \\
\end{tabular} & $\operatorname{limp}$ & & 148 & 2 & 2 & 2 & 1 & $2 \mathrm{y} 1$ & 2 & 4 & $5 Y R 6 / 4,5 / 2$ & 1 & 2 & 2 & & 1 y $2>, 3$ y 4 & 2 & $3 a 4$ & sed bl a grises, Q trasl, sed rojas & mica, Q-fel & 4 \\
\hline RH 2-1 & Sup & 1 & & 1 & 2 & 2 & 1 & 2 & 4 & 4 & 7.5 YR $3 / 2$ y $2 / 0$ & 1 & 2 & 2 & & & 2 & $2 \mathrm{a} 3$ & mica abund, Q trasl, Q-fel & sed marrones y bl, fel alt & 1 \\
\hline RH 2-1 & 301 & 1 & & 1 & 2 & 2 & 1 & 2 & 4 & 4 & $7.5 Y R \quad 4 / 2$ y $2 / 0$ & 1 & 2 & 2 & & & 2 & $2 \mathrm{a} 3$ & mica abund, Q trasl, Q-fel & sed rojas, marrones y bl, fel alt & 1 \\
\hline RH 2-1 & 152 & 2 & & 1 & 2 & 2 & 1 & 2 & 1 & 1 & $2.5 Y R 5 / 6$ & 1 & 2 & 1 & & & 2 & $3 a 5$ & mica abund, Q trasl, Q-fel & fel alt, sed rojas, grises & 1 \\
\hline RH 2-1 & 302 & 2 & & 1 & 2 & 2 & 1 & 2 & 1 & 1 & $2.5 Y R$ 5/4 & 1 & 2 & 1 & & & 2 & $3 a 4$ & mica abund, Q trasl, sed rojas & Q fel, fel alt & 1 \\
\hline RH 2-1 & 402 & 2 & & 1 & 2 & 2 & 1 & 2 & 1 & 1 & $2.5 Y R$ 5/4 & 1 & 2 & 1 & & & 2 & $3 a 4$ & mica abund, Q trasl, Q-fel & sed rojas y marrones, fel alt & 1 \\
\hline RH 2-1 & 201 & 3 & & 1 & 2 & 2 & 1 & $2 \mathrm{y} 1$ & 1 & 4 & $5 Y R$ 5/3 (nuc) y $4 / 1$ & 1 & $2 \mathrm{a} 3$ & 1 & & & 2 & 3 & mica abund, Q trasl & sed moradas y rojas, fel alt & 1 \\
\hline RH 2-1 & 152 & 3 & & 1 & 2 & 2 & 1 & 2 & 3 & 1 & $5 Y R 3 / 1$ & 1 & 2a3 & 2 & & & 2 & 3 & mica abund, Q trasl, Q-fel & fel alt, sed rojas y grises & 1 \\
\hline RH 2-1 & 152 & 3 & & 1 & 2 & 2 & 1 & $2 \mathrm{y} 1$ & 2 & 4 & $5 Y R 5 / 4$ y $4 / 1$ & 1 & 2 & 1 & & & 2 & $2 \mathrm{a} 3$ & mica abund, Q trasl & sed rojas y marr, fel alt, Q-fel & 1 \\
\hline RH 2-1 & 301 & 4 & & 1 & 2 & 2 & 1 & 2 & 2 & 4 & $5 Y R$ $4 / 4$ y $3 / 1$ & 1 & 2 & 1 & & & 2 & 3 & mica abund, sed grises, rojas y marron & fel alt, Q trasl, Q-fel & 1 \\
\hline RH 2-1 & 302 & 4 & & 1 & 2 & 2 & 1 & $2 \mathrm{y} 1$ & 2 & 4 & $5 Y R$ $4 / 3$ y $3 / 1$ & 1 & 2 & 1 & & & 2 & $3 a 4$ & mica muy abund, Q trasl, Q-fel & fel alt, sed marrones y rojas & 1 \\
\hline RH 2-1 & 402 & 5 & & 1 & 2 & 2 & 1 & 2 & 2 & 1 & $2.5 Y R$ 5/6 & 1 & 2 & 1 & & & 3 & $3 a 4$ & mica, Q trasl, sed rojas & fel alt,sed grises, roca osc afan & 4 \\
\hline RH 2-1 & 152 & 6 & & 1 & 2 & 2 & 1 & 2 & 3 & 1 & 7.5YR $2 / 0$ & 1 & 2 & 2 & & & 2 & 3 & mica fina, sed marrones y grises & Q trasl, Q-fel & 4 \\
\hline RH 2-1 & 401 & 7 & & 1 & 2 & 2 & 1 & $2 \mathrm{y} 1$ & 1 & 1 & $2.5 Y R \quad 4 / 6$ & 1 & 2 & 2 & & & 2 & $3 a 5$ & Q trasl, mica, sed rojas & Q-fel, fel alt, cuarcita & 4 \\
\hline RH 2-1 & Sup & 8 & & 1 & 2 & 1 & 1 & 2 & 1 & 4 & 5YR $6 / 4$ y $5 / 4$ & 1 & $2 \mathrm{a} 3$ & 1 & & & 1 & $2 \mathrm{a} 3$ & sed grises, rosadas y rojas & fel alt, mica, Q trasl & 4 \\
\hline $\mathrm{RH} 2-1$ & 100 & 8 & & 1 & 2 & 1 & 1 & 2 & 1 & 1 & 5YR 5/4 & 1 & $2 \mathrm{a} 3$ & 1 & & & 1 & $2 \mathrm{a} 3$ & sed grises y rojas, Q trasl & mica, Q-fel & 4 \\
\hline RH 2-1 & Sup & & 2 & 2 & 2 & 2 & 1 & 2 & 2 & 4 & $5 Y R 5 / 6$ y $5 / 3$ & 1 & 2 & 2 & & & 1 & $2 \mathrm{a} 4$ & Q trasl, mica, fel alt, sed rojas y bl & sed grises, Q-fel & 4 \\
\hline RH 2-1 & Sup & & 3 & 1 & 2 & 2 & 1 & 2 & 1 & 1 & 5YR 5/4 & 1 & 2 & 1 & & & 3 & 3 & Q trasl, Q-fel, fel alt & sed rojas, marrones y grises & 4 \\
\hline $\mathrm{RH} 2-1$ & Sup & & 4 & 1 & 2 & 1 & 1 & 2 & 1 & 1 & $2.5 \mathrm{YR} 6 / 6$ & 1 & 2 & 1 & & & 3 & $2 \mathrm{a} 4$ & mica abund, Q trasl & Q-fel, Q ambar, sed marr y gris & 1 \\
\hline RH 2-1 & Sup & & 5 & 2 & 2 & 2 & 1 & $2 \mathrm{y} 1$ & 2 & 1 & $2.5 Y R 3 / 2$ & 1 & $2 \mathrm{a} 3$ & 1 & & & 2 & 3 & Q trasl, Q-fel, sed marrones y grises & sed rojas, mica & 4 \\
\hline RH 2-1 & Sup & & 6 & 1 & 2 & 1 & 1 & 2 & 1 & 1 & 2.5YR 5/4 & 1 & 2 & 1 & & & 2 & $3 a 4$ & Q trasl, mica, Q-fel, sed rojas & fel alt & 4 \\
\hline RH 2-1 & Sup & & 7 & 1 & 2 & 2 & 1 & 2 & 1 & 1 & $2.5 Y R 5 / 6$ & 1 & 2 & 2 & & & 2 & $3 a 4$ & Q trasl, mica, fel alt & sed rosas y rojas, Q-fel & 4 \\
\hline $\mathrm{RH} 2-1$ & Sup & & 8 & 2 & 2 & 2 & 1 & 2 & 2 & 1 & $2.5 Y R 3 / 4$ & 1 & 2 & 1 & & & 2 & $3 a 4$ & Q trasl, mica abund, Q-fel, sed rojas & sed grises, fel alt & 1 \\
\hline $\mathrm{RH} 2-1$ & Sup & & 9 & 1 & 2 & 2 & 1 & $2 \mathrm{y} 1$ & 2 & 4 & $2.5 Y R$ T/8 y $5 / 4$ & 1 & 2 & 1 & & & 1 & $2 \mathrm{a} 4$ & Q trasl, mica, sed grises y marrones & fel alt, Q-fel & 4 \\
\hline RH 2-1 & Sup & & 10 & 1 & 2 & 2 & 1 & 2 & 1 & 1 & $2.5 Y R$ 5/4 & 1 & 2 & 1 & & & 1 & $2 \mathrm{a} 3$ & Q trasl, Q-fel, mica & fel alt, sed rojas, rosas y grises & 4 \\
\hline RH 2-1 & Sup & & $11 / 12$ & 2 & 2 & 2 & 1 & 2 & 4 & 4 & $5 Y R$ $5 / 3$ y $5 / 4$ & 1 & 2 & 1 & & & 3 & $3 a 5$ & Q trasl, Q-fel, fel alt, sed marrones & sed grises, mica fina & 4 \\
\hline RH 2-1 & Sup & & 13 & 1 & 2 & 2 & 1 & 2 & 1 & 1 & 5YR 5/4 & 1 & 2 & 1 & & & 2 & $2 \mathrm{a} 3$ & Q trasl, fel alt, mica & sed rojas y moradas, Q-fel & 4 \\
\hline RH 2-1 & Sup & & 14 & 1 & 2 & 2 & 1 & 2 & 1 & 1 & $2.5 Y R 5 / 6$ & 1 & 2 & 1 & & & 3 & $3 a 4$ & Q trasl muy abund, Q-fel, mica & sed rosadas y rojas, fel alt & 2 \\
\hline RH 2-1 & Sup & & $20-22$ & 1 & 2 & 2 & 1 & 2 & 1 & 1 & $2.5 Y R 5 / 4$ & 1 & 2 & 1 & & & 2 & $2 \mathrm{a} 3$ & Q trasl, fel alt, Q-fel & sed rojas, moradas y bl, mica & 4 \\
\hline RH 2-1 & Sup & & 23 & 1 & 2 & 2 & 2 & 2 & 1 & 1 & 2.5YR 5/4 & 1 & 2 & 1 & & & 1 & $3 a 4$ & $\mathrm{Q}$ trasl, mica, sed rojas, moradas y bl & fel alt, Q-fel & 4 \\
\hline $\mathrm{RH} 2-1$ & Sup & & 24 & 1 & 2 & 2 & 1 & 2 & 2 & 4 & $2.5 Y R 5 / 6$ y $4 / 2$ & 1 & 2 & 1 & & & 2 & $3 a 4$ & Q trasl, mica, Q-fel, fel alt & sed rojas, moradas y bl & 4 \\
\hline RH 2-1 & Sup & & 25 & 1 & 2 & 2 & 1 & $2 \mathrm{y} 1$ & 1 & 1 & $2.5 Y R 5 / 4$ & 1 & 2 & 1 & & & 2 & $3 a 4$ & Q trasl abund, mica & sed rojas, marr, grises, fel alt & 2 \\
\hline RH 2-1 & Sup & & 46 & 1 & 2 & 1 & 1 & 2 & 2 & 4 & $2.5 Y R 5 / 4$ y $5 / 1$ & 2 & 2 & 1 & & & 3 & $3 a 4$ & mica muy abund, Q trasl, Q-fel & sed rojas y marrones & 1 \\
\hline \begin{tabular}{|l|}
$\mathrm{RH}$ \\
\end{tabular} & Sup & & 49 & 1 & 2 & 1 & $2 \mathrm{a} 3$ & 2 & 1 & 2 & 2.5 YR $5 / 8$ y $3 / 4$ & 2 & 1 & 1 & & & 4 & $3 a 4$ & Q trasl, fel alt & sed grises, Q-fel & 5 \\
\hline RH 2-1 & Sup & & 50 & 1 & 2 & 1 & 2 & 2 & 1 & 1 & $2.5 Y R 5 / 8$ & 2 & 2 & 1 & & & 3 & $2 \mathrm{a} 4$ & Q trasl, mica, fel alt, Q-fel & sed rojas y grises & 4 \\
\hline \begin{tabular}{|l|} 
RH10-1 \\
\end{tabular} & 102 & 7 & & 1 & 2 & 2 & 1 & 2 & 4 & 2 & $7.5 Y R 2 / 0$ y $5 / 4$ & 1 & 2 & 1 & & & 2 & $3 a 5$ & sed marrones, $Q$ trasl, mica fina & fel alt, sed grises, Q-fel & 4 \\
\hline
\end{tabular}




\begin{tabular}{|c|c|c|c|c|c|c|c|c|c|c|c|c|c|c|c|c|c|c|c|c|c|}
\hline \multirow[b]{2}{*}{$\begin{array}{c}\text { Sitio y } \\
\text { est }\end{array}$} & \multirow[b]{2}{*}{ UP } & \multirow[b]{2}{*}{ GF } & \multirow[b]{2}{*}{ FNA } & \multicolumn{4}{|c|}{ Fractura } & \multirow[b]{2}{*}{\begin{tabular}{|l|} 
Ca \\
vid
\end{tabular}} & \multirow{2}{*}{\multicolumn{2}{|c|}{$\begin{array}{l}\text { Coc Co } \\
\text { ción lor } \\
\end{array}$}} & \multirow[b]{2}{*}{ Not color } & \multicolumn{7}{|c|}{ Inclusiones } & \multicolumn{2}{|c|}{ Composic } & \multirow[b]{2}{*}{ GP } \\
\hline & & & & $\begin{array}{c}\text { Aspec } \\
\text { to }\end{array}$ & \begin{tabular}{|l|} 
\\
tex \\
tura
\end{tabular} & \begin{tabular}{l|} 
Resis \\
tenc.
\end{tabular} & $\begin{array}{l}\mathbf{R e} \\
\text { gul }\end{array}$ & & & & & Incl & Dens & $\begin{array}{c}\text { Orien } \\
\text { tac }\end{array}$ & $\begin{array}{l}\text { Orient } \\
\text { pared }\end{array}$ & Granul & $\begin{array}{l}\text { Se } \\
\text { lec }\end{array}$ & $\begin{array}{l}\mathbf{R e} \\
\mathrm{don}\end{array}$ & comp mayor & comp aislados & \\
\hline $\mathrm{RH} 10-1$ & 202 & 7 & & 1 & 2 & 2 & 1 & 2 & 4 & 2 & $7.5 Y R$ 3/0 y $5 / 4$ & 1 & 2 & 2 & & & 2 & $3 a 4$ & Q trasl, Q-fel, sed marrones & fel alt, mica fina, sed grises & 4 \\
\hline $\mathrm{RH} 10-1$ & 102 & 1 & & 1 & 2 & 2 & 1 & 2 & 4 & 2 & 5YR 4/3, 7.5YR 2/0 & 1 & 2 & 2 & & & 2 & $3 a 5$ & Q trasl, sed rojas, Q-fel & mica muy fina, fel alt & 4 \\
\hline $\mathrm{RH} 10-1$ & 102 & 4 & & 1 & 2 & 2 & 1 & 2 & 1 & 1 & 5YR 5/4 & 1 & 2 & 2 & & & 2 & $3 a 5$ & mica, Q trasl, Q-fel, sed rojas & fel alt & 4 \\
\hline $\mathrm{RH} 10-1$ & 102 & 4 & & 1 & 2 & 2 & 1 & 2 & 1 & 1 & $5 Y R$ S/4 & 1 & 2 & 2 & & & 1 & $3 a 5$ & Q trasl, Q-fel, sed rojas y moradas & fel alt, mica & 4 \\
\hline RH10-1 & 102 & 3 & & 1 & 2 & 2 & 1 & $2 \mathrm{y} 1$ & 2 & 4 & $5 Y R$ 4/2 y $3 / 1$ & 1 & 2 & 1 & & & 1 & $2 \mathrm{a} 4$ & mica, fel alt, Q trasl & sed rojas, Q-fel & 4 \\
\hline RH10-1 & 102 & 3 & & 1 & 2 & 2 & 1 & 2 & 2 & 4 & $5 Y R 5 / 2$ y $3 / 1$ & 1 & 2 & 1 & & & 1 & $2 \mathrm{a} 4$ & Q trasl, mica, sed rojas & Q-fel, fel alt & 4 \\
\hline $\mathrm{RH} 10-1$ & 102 & 3 & & 1 & 2 & 2 & 1 & $2 \mathrm{y} 1$ & 1 & 1 & $5 Y R 5 / 3$ & 1 & 2 & 2 & & & 1 & $3 a 4$ & Q trasl, mica, Q-fel & sed rojas, fel alt & 4 \\
\hline $\mathrm{RH} 10-1$ & 102 & 3 & & 1 & 2 & 2 & 1 & 2 & 1 & 1 & $5 Y R 5 / 3$ & 1 & 2 & 1 & & & 1 & $3 a 4$ & mica, Q trasl, fel alt & sed rojas escasas y peq & 4 \\
\hline RH10-1 & 102 & 2 & & 1 & 2 & 1 & 1 & 2 & 2 & 5 & 10R 5/6, 5YR 5/2 & 1 & 2 & 1 & & & 2 & $3 a 5$ & mica abund, Q trasl, sed rojas & fel alt & 1 \\
\hline $\mathrm{RH} 10-1$ & 102 & 2 & & 1 & 2 & 1 & 1 & 2 & 2 & 5 & 10R 5/6, 5YR 5/2 & 1 & 2 & 2 & & & 2 & $3 a 5$ & mica abund, sed rojas & sed bl o fel alt, Q-fel & 1 \\
\hline $\mathrm{RH} 10-1$ & 102 & & 11 & 1 & 2 & 2 & 1 & 2 & 1 & 1 & 5YR 5/4 & 1 & 2 & 1 & & & 1 & $3 a 4$ & mica abund, Q trasl, fel alt & sed rojas, Q fel & 1 \\
\hline $\mathrm{RH} 10-1$ & 202 & 5 & & 1 & 2 & 1 & 1 & 2 & 2 & 4 & $5 Y R$ 6/4 y $3 / 1$ & 1 & 2 & 1 & & & 2 & $2 \mathrm{a} 4$ & mica, Q trasl, fel alt & sed rojas, Q fel & 4 \\
\hline $\mathrm{RH} 10-1$ & Sup & 6 & & 1 & 1 & 2 & 1 & 2 & 2 & 4 & $5 Y R \quad 4 / 4$ y $3 / 1$ & 1 & 2 & 2 & & & 2 & 3 & mica abund, Q trasl, sed rojas & Q fel, sed bl o fel alt & 1 \\
\hline $\mathrm{RH} 10-1$ & 202 & & 1 & $x$ & $x$ & $x$ & $\mathrm{x}$ & $x$ & 1 & $x$ & $x$ & 1 & 2 & $x$ & & & 2 & 3 & mica, Q trasl, Q-fel & sed rojas & 4 \\
\hline $\mathrm{RH} 10-1$ & 202 & & 2 & 1 & 2 & 2 & 1 & 2 & 3 & 1 & $7.5 Y R 2 / 0$ & 1 & $2 \mathrm{a} 3$ & 2 & & & 1 & $3 a 5$ & mica, Q trasl, Q-fel, sed marrones & fel alt, sed grises & 4 \\
\hline $\mathrm{RH} 10-1$ & 202 & & 3 & 2 & 2 & 3 & 1 & 2 & 2 & 5 & $5 Y R \quad 4 / 4$ (nuc) y $3 / 1$ & 1 & 2 & 2 & & & 2 & $3 a 5$ & mica muy abund, Q trasl, Q-fel & sed bl o fel alt, sed rojas & 1 \\
\hline RH10-1 & 102 & & 5 & 1 & 2 & 2 & 1 & 2 & 1 & 1 & $5 Y R 5 / 3$ & 1 & 2 & 1 & & & 2 & $3 a 5$ & Q trasl, Q-fel & fel alt, sed rojas & 4 \\
\hline $\mathrm{RH} 10-1$ & 100 & & 6 & 1 & 2 & 1 & 1 & 2 & 1 & 1 & 5YR 5/6 & 1 & $2 a 3$ & 1 & & & 2 & $2 \mathrm{a} 5$ & Q trasl, Q-fel, sed rojas, fel alt & cuarc, ígneas grises, mica fina & 4 \\
\hline $\mathrm{RH} 10-1$ & 100 & & 7 & 1 & 2 & 1 & 1 & 2 & 1 & 1 & 5YR 4/4 & 1 & 2 & 1 & & & 2 & 3 & Q trasl, Q-fel, sed rojas & sed grises, cuarc & 4 \\
\hline RH10-1 & 100 & & 8 & 1 & 2 & 1 & 1 & 2 & 2 & 5 & $5 Y R 3 / 1$ (nuc) y $5 / 4$ & 1 & 2 & 2 & & & 2 & $4 a 5$ & $\mathrm{Q}$ trasl, micas, sed rojas & fel alt, Q-fel & 4 \\
\hline RH10-1 & 202 & & 9 & 2 & 1 & 2 & 1 & 2 & 4 & 2 & 5 YR 4/4, 7.5YR $2 / 0$ & 1 & 3 & 2 & & & 3 & 3 & mica muy abund, Q-fel, Q trasl & igneas gris, mineral osc, fel alt & 1 \\
\hline $\mathrm{RH} 10-1$ & 202 & & 10 & 2 & 1 & 2 & 1 & 2 & 4 & 4 & 5YR 4/4, 7.5YR 2/0 & 1 & 3 & 2 & & & 3 & 3 & mica muy abund, Q-fel, Q trasl & sed bl o fel alt & 1 \\
\hline $\mathrm{RH} 10-1$ & Sup & & 12 & 1 & 2 & 1 & 1 & 2 & 1 & 1 & $5 Y R 4 / 3$ & 1 & 2 & 1 & & & 1 & $3 a 4$ & fel alt, sed rojas, marrones y bl & Q-fel, Q trasl, mica & 4 \\
\hline $\mathrm{RH} 10-1$ & Sup & & 13 & 1 & 2 & 1 & 1 & 2 & 1 & 1 & 5YR 5/4 & 1 & 2 & 2 & & & 1 & $3 a 4$ & sed rojas, marrones y moradas & fel alt, Q trasl, Q-fel, mica & 4 \\
\hline $\mathrm{RH} 10-1$ & Sup & & 14 & 1 & 2 & 2 & & $2 \mathrm{y} 1$ & 1 & 1 & 5YR 6/4 & 1 & 3 & 1 & & & 1 & 2 & Q trasl, mica, Q-fel & fel alt, sed rojas, marr y grises & 4 \\
\hline $\mathrm{RH} 10-1$ & Sup & & 15 & 1 & 2 & 1 & 1 & 2 & 1 & 1 & 5YR 4/4 & 1 & 2 & 1 & & & 2 & 2 & Q trasl, mica, Q-fel & sed grises, rosas, marrones & 4 \\
\hline $\mathrm{RH} 10-1$ & Sup & & 16 & 1 & 2 & 3 & 1 & 2 & 3 & 1 & 5YR 3/1 & 1 & 2 & 1 & & & 2 & 4 & Q trasl, Q-fel, mica fina & sed marrones, rojas y fel alt & 4 \\
\hline $\mathrm{RH} 10-1$ & Sup & & 17 & 1 & 2 & 1 & 1 & 2 & 4 & 4 & $5 Y R \quad 4 / 3$ y $3 / 1$ & 1 & 2 & 2 & & & 2 & $3 a 5$ & Q trasl, Q-fel, sed rojas y marrones & fel alt, sed grises & 4 \\
\hline $\mathrm{RH} 10-1$ & Sup & & 18 & 1 & 2 & 1 & 2 & $2 \mathrm{y} 1$ & 2 & 4 & $5 Y R \quad 4 / 2$ y $5 / 8$ & 1 & $2 a 3$ & 1 & & & 3 & 3 & Q trasl, Q-fel & sed marrones, grises y rojas & 4 \\
\hline $\mathrm{RH} 10-1$ & Sup & & 19 & 1 & 2 & 2 & 1 & 2 & 1 & 1 & 5YR $4 / 4$ & 1 & 2 & 1 & & & 1 & $3 a 5$ & mica abund, sed rojas, marron y claras & Q-fel, sed grises & 1 \\
\hline $\mathrm{RH} 10-1$ & Sup & & 20 & 1 & 2 & 1 & 1 & 2 & 2 & 4 & $2.5 Y R 5 / 6$ y $4 / 2$ & 1 & 2 & 1 & & & 2 & $3 a 5$ & Q-fel, Q trasl & sed rojas, marr, claras, mica & 4 \\
\hline $\mathrm{RH} 10-1$ & Sup & & 21 & 1 & 2 & 1 & 1 & 2 & 1 & 1 & $2.5 Y R 5 / 6$ & 1 & 2 & 1 & & & 2 & $3 a 5$ & sed rosadas y bl, rojas y marrones & Q-fel, Q trasl & 3 \\
\hline $\mathrm{RH} 10-1$ & Sup & & 22 & 1 & 2 & 2 & 1 & 2 & 1 & 1 & $2.5 Y R 5 / 8$ & 1 & 1 & 1 & & & 3 & 2 & Q-fel, fel alt & sed rojas y blancas & 5 \\
\hline RH10-1 & Sup & & 25 & 1 & 2 & 2 & 2 & 2 & 1 & 1 & 5YR 5/4 & 1 & 2 & 1 & & & 2 & 3 & mica muy abund, sed rojas a marrones & Q trasl, fel alt, Q-fel & 1 \\
\hline $\mathrm{RH} 10-1$ & Sup & & 26 & 1 & 2 & 2 & 1 & $2 \mathrm{y} 1$ & 2 & 5 & 2.5YR4/8, 5YR4/1(nuc) & 1 & 2 & 1 & & & 1 & $3 a 4$ & Q trasl, mica, sed marrones, Q-fel & plut con mica, fel y $Q$ & 4 \\
\hline $\mathrm{RH} 10-1$ & Sup & & 27 & 1 & 2 & 2 & 1 & 2 & 1 & 1 & 5YR 5/4 & 1 & 2 & 1 & & & 2 & 3 & mica abund, sed rojas & sed bl o fel alt, Q trasl & 1 \\
\hline
\end{tabular}




\begin{tabular}{|c|c|c|c|c|c|c|c|c|c|c|c|c|c|c|c|c|c|c|c|c|c|}
\hline \multirow[b]{2}{*}{$\begin{array}{c}\text { Sitio y } \\
\text { est }\end{array}$} & \multirow[b]{2}{*}{ UP } & \multirow[b]{2}{*}{ GF } & \multirow[b]{2}{*}{ FNA } & \multicolumn{4}{|c|}{ Fractura } & \multirow{2}{*}{\multicolumn{3}{|c|}{\begin{tabular}{|l|l|l|} 
Ca & Coc & Co \\
vid & ción & lor \\
\end{tabular}}} & & \multicolumn{7}{|c|}{ Inclusiones } & \multicolumn{2}{|c|}{ Composic } & \multirow[b]{2}{*}{ GP } \\
\hline & & & & $\begin{array}{c}\text { Aspec } \\
\text { to }\end{array}$ & $\left|\begin{array}{c}\text { Tex } \\
\text { tura }\end{array}\right|$ & $\begin{array}{l}\text { Resis } \\
\text { tenc. }\end{array}$ & $\begin{array}{l}\mathrm{Re} \\
\text { gul }\end{array}$ & & & & & Incl & Dens & $\begin{array}{c}\text { Orien } \\
\text { tac }\end{array}$ & $\left|\begin{array}{l}\text { Orient } \\
\text { pared }\end{array}\right|$ & Granul & $\begin{array}{l}\text { Se } \\
\text { lec }\end{array}$ & $\begin{array}{c}\text { Re } \\
\text { don }\end{array}$ & comp mayor & comp aislados & \\
\hline $\mathrm{RH} 10-1$ & Sup & & 28 & 1 & 2 & 1 & 1 & 2 & 1 & 1 & 5YR 5/4 & 1 & 2 & 1 & & & 2 & $3 a 5$ & Q trasl, mica, fel alt, sed rojas & Q-fel, litoc plut? & 4 \\
\hline $\mathrm{RH} 10-1$ & Sup & & 29 & 1 & 2 & 2 & 1 & 2 & 1 & 1 & $2.5 Y R 5 / 8$ & 1 & 2 & 1 & & & 2 & 3 & mica abund, Q-trasl & sed bl o fel alt, Q-fel & 1 \\
\hline $\mathrm{RH} 10-1$ & Sup & & 30 & 1 & 2 & 2 & 2 & 2 & 1 & 1 & $2.5 Y R \quad 4 / 8$ & 2 & 2 & 1 & & & 2 & $2 a 3$ & Q trasl, mica fina, sed rojas y blancas & Q-fel & 4 \\
\hline $\mathrm{RH} 10-1$ & Sup & & 31 & 2 & 2 & 2 & 1 & 2 & 1 & 1 & $5 Y R$ 5/4 & 1 & $2 \mathrm{a} 3$ & 2 & & & 3 & 3 & mica muy abund, Q trasl, Q-fel & sed rojas, fel alt & 1 \\
\hline RH10-1 & Sup & & 32 & 1 & 2 & 1 & 2 & 2 & 1 & 1 & 5YR 5/4 & 1 & $2 \mathrm{a} 3$ & 1 & & & 2 & 3 & mica abund, Q trasl, Q-fel & sed marrones, rojas y bl, fel alt & 1 \\
\hline RH10-1 & Sup & & $33 / 34$ & 1 & 2 & 1 & 1 & 2 & 1 & 1 & $2.5 Y R \quad 4 / 6$ & 1 & 2 & 1 & & & 1 & $3 a 5$ & Q trasl, Q-fel, fel alt & sed rojas, marr y grises, mica & 4 \\
\hline $\mathrm{RH} 10-1$ & Sup & & 35 & 1 & 2 & 1 & 1 & 2 & 2 & 5 & 2.5YR5/6; 5YR4/1(nuc) & 1 & 2 & 1 & & & 1 & $3 a 5$ & Q trasl, mica fina, sed marrones y rojas & Q-fel, sed grises & 4 \\
\hline $\mathrm{RH} 10-1$ & Sup & & 36 & 1 & 2 & 2 & 2 & 2 & 1 & 1 & $5 Y R$ 5/4 & 1 & 2 & 2 & & & 2 & 3 & Q trasl, mica, sed rojas, fel alt & Q-fel, roca osc afan & 4 \\
\hline RH19-1 & 103 & 1 & & 1 & 2 & 1 & 2 & 2 & 1 & 1 & 5YR 5/4 & 1 & 2 & 1 & & & 3 & 5 & mica abund, sed bl, Q trasl & Q-fel, sed rojas & 1 \\
\hline $\mathrm{RH} 19-1$ & 104 & mis & & 1 & 2 & 1 & 2 & 2 & 3 & 1 & 7.5 YR $2 / 0$ & 1 & 1 & 2 & & & 1 & 5 & igneas gris, mica, Q-fel & $\mathrm{x}$ & 5 \\
\hline RH19-1 & 201 & 2 & & 1 & 2 & 2 & 1 & 2 & 2 & 1 & 5YR $4 / 1$ & 1 & 2 & 1 & & & 2 & 5 & fel alt, sed rojas, claras y moradas & mica, Q & 4 \\
\hline RH19-1 & 203 & 2 & & 1 & 2 & 2 & 1 & 2 & 2 & 1 & 5YR 4/1 & 1 & 2 & 2 & & & 2 & 5 & sed moradas, mica & Q-fel & 4 \\
\hline $\mathrm{RH} 19-1$ & 102 & 3 & & 1 & 2 & 2 & 1 & 2 & 1 & 1 & 5YR 4/4 & 1 & 2 & 1 & & & 25 & $5 a 6$ & Q trasl, Q-fel abund & sed rojas y marrones, mica fina & 4 \\
\hline $\mathrm{RH} 19-1$ & 202 & 5 & & 1 & 2 & 1 & 2 & 2 & 2 & 4 & $10 R 5 / 8$ y $3 / 1$ & 1 & 1 & 2 & & & 1 & 4 & Q trasl, sed rojas y grises grandes & fel alt, Q-fel, mica fina & 5 \\
\hline RH19-1 & 203 & 4 & & 1 & 2 & 2 & 1 & 2 & 4 & 4 & 5YR 4/4, 7.5YR 30 & 1 & 2 & 2 & & & 25 & $3 a 5$ & mica abund, Q-fel, sed grises y rojas & sed bl o fel alt & 1 \\
\hline $\mathrm{RH} 19-1$ & Sup & & 1 & 1 & 2 & 2 & 2 & 2 & 2 & 4 & $5 Y R 4 / 1$ y $4 / 2$ & 1 & 2 & 2 & & & 13 & $3 a 5$ & mica, Q-fel, sed rojas & fel alt & 4 \\
\hline RH19-1 & Sup & & 2 & 1 & 2 & 1 & 1 & 2 & 3 & 1 & $7.5 Y R 3 / 0$ & 1 & 2 & 2 & & & 1 & 3 & mica fina, Q-fel, fel alt & sed bl, marrones y rojas & 4 \\
\hline $\mathrm{RH} 19-1$ & Sup & & $4 / 5$ & 1 & 2 & 1 & 1 & 2 & 4 & 4 & 2.5YR5/4, 7.5YR3/0 & 2 & 2 & 1 & & & 2 & $4 a 5$ & mica abund, Q trasl, Q-fel, fel alt & sed rojas y claras & 1 \\
\hline RH19-1 & Sup & & 6 & 1 & 2 & 2 & 2 & 2 & 1 & 1 & 10R 5/6 & 2 & 2 & 2 & & & 2 & $3 a 5$ & Q-fel, mica, sed grises & sed rojas, roca negra afan & 4 \\
\hline RH19-1 & Sup & & 7 & 1 & 2 & 1 & 2 & $2 \mathrm{y} 1$ & 2 & 5 & 10R 5/6, 5YR 5/3 & 1 & 2 & 2 & & & 2 & $2 \mathrm{a} 5$ & Q abund, Q-fel, mica fina & fel alt, sed rojas y bl & 2 \\
\hline RH19-7 & 102 & 1 & & 1 & 2 & 1 & 1 & $2 \mathrm{y} 1$ & 1 & 1 & 5 YR 6/6 & 1 & 1a2 & 1 & & 2,4 y 5 & 3 & $3 a 4$ & sed bl o fel alt & Q trasl, sed rojas, mica & 3 \\
\hline $\mathrm{RH} 19-7$ & 100 & 1 & & 1 & 2 & 1 & 2 & 2 & 1 & 1 & $5 Y R 6 / 6$ & 1 & 2 & 1 & & 2,4 y 5 & 3 & $2 \mathrm{a} 4$ & sed bl o fel alt, sed rojas & Q trasl, mica & 3 \\
\hline RH19-7 & 203 & 1 & & 1 & 2 & 1 & 2 & 2 & 1 & 1 & $2.5 Y R 6 / 6$ & 1 & 1a2 & 1 & & 2,4 y 5 & 35 & $3 a 4$ & sed rosas y bl (o fel alt) & sed rojas,marr,Q trasl y ambar & 3 \\
\hline $\mathrm{RH} 19-7$ & 202 & 1 & & 1 & 2 & 1 & 1 & 2 & 1 & 1 & 5 YR $6 / 6$ & 1 & 2 & 1 & & 2,4 y 5 & 3 & $3 a 4$ & sed rosas y bl (o fel alt) & sed rojas, mica & 3 \\
\hline $\mathrm{RH} 19-7$ & 102 & 1 & & 1 & 2 & 1 & 1 & 2 & 1 & 1 & 5YR 6/6 & 1 & 1a2 & 1 & & 2,4 y 5 & 3 & $3 a 4$ & sed bl o fel alt & sed rojas, mica & 3 \\
\hline $\mathrm{RH} 19-7$ & 101 & 2 & & 1 & 2 & 2 & 1 & 2 & 1 & 1 & 5YR 6/6 & 1 & 2 & 1 & & 1 y 2,5 & 2 & $4 a 5$ & sed bl o fel alt, sed rojas & Q trasl, mica & 3 \\
\hline $\mathrm{RH} 19-7$ & 201 & 2 & & 1 & 2 & 2 & 1 & $2 \mathrm{y} 1$ & 1 & 1 & 5YR 6/6 & 1 & 2 & 1 & & 2,4 y 5 & 3 & $4 a 5$ & sed bl o fel alt, sed rojas & Q trasl, mica & 3 \\
\hline $\mathrm{RH} 19-7$ & 100 & 3 & & 1 & 2 & 1 & 2 & 2 & 1 & 1 & $2.5 Y R$ 6/6 & 1 & 2 & 1 & & 4 y $5>$ & 35 & $3 a 4$ & sed bl y rosas, sed rojas y grises & Q trasl, mica & 3 \\
\hline RH19-7 & Sup & 3 & & 1 & 2 & 1 & 2 & 2 & 1 & 1 & 5 YR $6 / 6$ & 1 & 2 & 1 & & 4 y $5>, 1$ y 2 & 3 & $3 a 4$ & sed bl y rosas, sed rojas, Q trasl & Q-fel, fel alt, mica & 3 \\
\hline $\mathrm{RH} 19-7$ & 202 & 4 & & 1 & 2 & 2 & 1 & 2 & 1 & 1 & $2.5 Y R 5 / 4$ & 1 & 2 & 1 & & 4 y $5>, 1$ y 2 & 2 & $2 a 3$ & Q trasl, mica, sed bl o fel alt & sed rojas, rosas y grises & 4 \\
\hline $\mathrm{RH} 19-7$ & 202 & 4 & & 1 & 2 & 1 & 1 & 2 & 1 & 1 & $2,5 Y R$ 6/6 & 1 & 2 & 1 & & 4 y $5>, 3$ & 4 & $2 \mathrm{a} 3$ & Q trasl, sed bl y rojas, mica & $x$ & 4 \\
\hline RH19-7 & 205 & 5 & & 2 & 2 & 2 & 1 & $2 \mathrm{y} 1$ & 1 & 1 & 2,5 YR $5 / 6$ & 2 & 2 & 1 & & 4 y $5>, 3$ & 4 & $3 a 4$ & Q trasl, sed bl o fel alt, sed rojas & mica & 4 \\
\hline $\mathrm{RH} 19-7$ & 102 & 5 & & 1 & 2 & 2 & 1 & $2 \mathrm{y} 1$ & 1 & 1 & $2,5 Y R$ 5/6 & 1 & 2 & 1 & & 3 y $4>, 1$ y 2 & 3 & $3 a 4$ & sed marrones y rojas, Q trasl & mica, sed bl & 4 \\
\hline RH19-7 & Sup & 7 & & 1 & 2 & 1 & 1 & 2 & 2 & 4 & 2,5YR5/6; 5YR5/4(nuc) & 1 & 2 & 1 & & 4 y $5>, 1$ & 2 & $3 a 4$ & Q trasl, sed marr y rojas, sed bl o fel alt & mica & 4 \\
\hline RH19-7 & 100 & 7 & & 1 & 2 & 1 & 1 & 2 & 1 & 1 & 5YR 6/4 & 1 & 2 & 1 & & 4 y $5>, 3$ & 3 & $2 \mathrm{a} 3$ & Q trasl, sed rojas y marr, sed bl o fel alt & mica & 4 \\
\hline $\mathrm{RH} 19-7$ & 103 & 8 & & 1 & 2 & 1 & 1 & 2 & 2 & 4 & $10 R$ $4 / 8$ y $3 / 1$ & 1 & 2 & 1 & & 4 y $5>, 1$ y 2 & 2 & $4 a 5$ & Q trasl, sed marrones, mica & Q-fel, fel alt, sed grises & 4 \\
\hline
\end{tabular}




\begin{tabular}{|c|c|c|c|c|c|c|c|c|c|c|c|c|c|c|c|c|c|c|c|c|c|}
\hline \multirow[b]{2}{*}{$\begin{array}{c}\text { Sitio y } \\
\text { est }\end{array}$} & \multirow[b]{2}{*}{ UP } & \multirow[b]{2}{*}{ GF } & \multirow[b]{2}{*}{ FNA } & \multicolumn{4}{|c|}{ Fractura } & \multirow{2}{*}{\multicolumn{3}{|c|}{\begin{tabular}{|l|l|l|} 
Ca & Coc Co \\
vid & ción & lor \\
\end{tabular}}} & \multirow{3}{*}{$\frac{\text { Not color }}{2.5 Y R ~ 4 / 4 \text { y } 2.5 / 0}$} & \multicolumn{7}{|c|}{ Inclusiones } & \multicolumn{2}{|l|}{ Composic } & \multirow[b]{2}{*}{ GP } \\
\hline & & & & $\begin{array}{c}\text { Aspec } \\
\text { to }\end{array}$ & \begin{tabular}{|l|} 
\\
tex \\
tura
\end{tabular} & \begin{tabular}{|l|} 
Resis \\
tenc.
\end{tabular} & $\begin{array}{l}\text { Re } \\
\text { gul }\end{array}$ & & & & & Incl & Dens & $\begin{array}{c}\text { Orien } \\
\text { tac }\end{array}$ & $\begin{array}{l}\text { Orient } \\
\text { pared }\end{array}$ & Granul & $\begin{array}{l}\text { Se } \\
\text { lec }\end{array}$ & $\begin{array}{l}\mathbf{R e} \\
\mathrm{don}\end{array}$ & comp mayor & comp aislados & \\
\hline $\mathrm{RH} 19-7$ & 103 & 8 & & 1 & 2 & 2 & 1 & 2 & 4 & 4 & & 1 & 2 & 1 & & 4 y $5>, 2$ & 2 & $3 a 4$ & Q trasl, mica, sed marrones y moradas & sed grises, fel alt & 4 \\
\hline $\mathrm{RH} 19-7$ & 205 & 9 & & 1 & 2 & 1 & 2 & 2 & 4 & 4 & $2,5 Y R 5 / 6, N 4 /$ & 1 & 2 & 1 & & 4 y $5>, 1$ & 2 & $4 a 5$ & sed rojas, marrones y grises, $\mathrm{Q}$ trasl & mica fina, Q-fel & 4 \\
\hline $\mathrm{RH} 19-7$ & 202 & 9 & & 1 & 2 & 1 & 1 & 2 & 4 & 4 & $5 Y R 6 / 3, N 3 /$ & 1 & 2 & 1 & & 4 y $5>, 1$ y 2 & 2 & $4 a 5$ & sed bl o fel alt, sed rojas a marr, Q trasl & mica fina & 4 \\
\hline $\mathrm{RH} 19-7$ & 101 & 10 & & 1 & 2 & 1 & 1 & 2 & 4 & 4 & $2,5 Y R$ 4/1, N 3/ & 2 & $1 \mathrm{a} 2$ & 1 & & 4 y $5>$ & 4 & $4 a 5$ & Q trasl, sed marrones y grises & fel alt, mica fina & 2 \\
\hline $\mathrm{RH} 19-7$ & 101 & 10 & & 1 & 2 & 2 & 2 & 2 & 4 & 4 & $7.5 Y R \quad 4 / 2$ y $2 / 0$ & 1 & $1 \mathrm{a} 2$ & 1 & & 4 y $5>, 3$ & 3 & $3 a 4$ & Q trasl, mica, sed grises & fel alt, Q-fel & 2 \\
\hline $\mathrm{RH} 19-7$ & 202 & 11 & & 2 & 2 & 2 & 1 & 2 & 4 & 4 & $5 Y R$ 4/3, N 3/ & 1 & $2 a 3$ & 2 & & 2 y $3>, 4$ y 5 & 3 & $2 a 3$ & mica muy abund, Q trasl & sed bl o fel alt, sed rojas & 1 \\
\hline $\mathrm{RH} 19-7$ & 201 & 11 & & 2 & 1 & 2 & 1 & 2 & 4 & 2 & $5 Y R 4 / 3, N 3 /$ & 1 & $2 \mathrm{a} 3$ & 2 & & 3 y $4>, 5$ & 3 & $2 \mathrm{a} 3$ & mica muy abund, Q trasl & sed bl o fel alt, sed rojas & 1 \\
\hline $\mathrm{RH} 19-7$ & 201 & 11 & & 2 & 1 & 2 & 1 & 2 & 4 & 2 & $5 Y R$ 5/4, N3/ & 1 & $2 \mathrm{a} 3$ & 2 & & 3 у $4>, 5$ & 3 & $2 \mathrm{a} 3$ & mica muy abund, Q trasl & sed bl o fel alt, sed rojas & 1 \\
\hline $\mathrm{RH} 19-7$ & 202 & 12 & & 1 & 2 & 2 & 1 & 2 & 4 & 2 & & 1 & 2 & 1 & & 4 y $5>, 3$ & 4 & $4 a 5$ & Q trasl, Q-fel, mica & sed bl o fel alt, sed rojas & 2 \\
\hline $\mathrm{RH} 19-7$ & 102 & 12 & & 1 & 2 & 2 & 1 & 2 & 4 & 2 & & 1 & 2 & 1 & & 4 y $5>, 1$ y 2 & 2 & $4 a 5$ & Q trasl, sed rojas, sed bl o fel alt, mica & Q-fel & 2 \\
\hline RH19-7 & R16 & 13 & & 1 & 2 & 2 & 2 & 2 & 4 & 4 & 2.5 YR $2.5 / 0$ y $2.5 / 4$ & 1 & 2 & 1 & & 3 y $4>, 2$ & 3 & $3 a 4$ & Q trasl, mica & sed marrones, Q-fel & 2 \\
\hline $\mathrm{RH} 19-7$ & 107 & 13 & & 1 & 2 & 2 & 2 & 2 & 3 & 1 & 7.5YR $2 / 0$ & 1 & 2 & 1 & & 3 y $4>, 2$ & 3 & $3 a 4$ & Q trasl, mica & Q-fel, fel alt, sed marr y grises & 2 \\
\hline $\mathrm{RH} 19-7$ & 102 & 14 & & 1 & 2 & 2 & 1 & 2 & 4 & 4 & & 1 & 2 & 1 & & 3 y $4>$ & 3 & $3 a 4$ & Q trasl, mica, sed rojas & sed bl o fel alt, Q-fel & 4 \\
\hline $\mathrm{RH} 19-7$ & 101 & 14 & & 1 & 2 & 2 & 1 & 2 & 4 & 4 & & 1 & 2 & 1 & & 4 y $5>, 3$ & 4 & $3 a 5$ & Q trasl, mica, sed rojas & sed bl o fel alt, Q-fel & 4 \\
\hline $\mathrm{RH} 19-7$ & 103 & 15 & & 1 & 2 & 1 & 1 & 2 & 3 & 1 & $7.5 Y R 3 / 0$ & 1 & $1 \mathrm{a} 2$ & 1 & & 3 y $4>, 2$ & 3 & $3 a 4$ & Q trasl, sed rojas, bl y marrones & fel alt, mica fina & 4 \\
\hline RH19-7 & 101 & 15 & & 1 & 2 & 1 & 1 & 2 & 4 & 4 & & 1 & $1 \mathrm{a} 2$ & 1 & & 4 y $5>, 3$ & 3 & $3 a 4$ & Q trasl, sed marrones, sed bl o fel alt & sed rojas, mica fina & 4 \\
\hline $\mathrm{RH} 19-7$ & 202 & 17 & & 2 & 2 & 1 & 1 & 2 & 4 & 4 & 5YR 6/4, 7.5YR 2/0 & 1 & 2 & 1 & & 2 y $3>, 4$ & 3 & $3 a 5$ & Q trasl, Q-fel, mica & sed marrones y rojas, fel alt & 2 \\
\hline $\mathrm{RH} 19-7$ & 202 & 17 & & 2 & 2 & 1 & 1 & 2 & 4 & 4 & & 1 & 2 & 1 & & 2 y $3>, 4$ & 3 & $3 a 4$ & Q trasl, Q-fel, mica & sed marrones y rojas, fel alt & 2 \\
\hline $\mathrm{RH} 19-7$ & 100 & 18 & & 1 & 2 & 1 & 1 & 2 & 4 & 4 & $2.5 Y R$ 5/4 y $2.5 / 0$ & 1 & 2 & 1 & & 2 y $3>, 4$ y 5 & 2 & $3 a 5$ & Q trasl abund, fel alt, sed bl a marrones & mica, sed rojas & 2 \\
\hline $\mathrm{RH} 19-7$ & 100 & 18 & & 1 & 2 & 1 & 1 & 2 & 4 & 4 & $2.5 Y R$ 5/4 y $2.5 / 0$ & 1 & 2 & 1 & & 2 y $3>, 5$ & 2 & $3 a 5$ & Q trasl abund, fel alt, sed bl a marrones & mica, sed rojas & 2 \\
\hline $\mathrm{RH} 19-7$ & 201 & 19 & & 1 & 2 & 1 & 1 & 2 & 1 & 1 & 5YR 5/4 & 1 & 2 & 2 & & 4 y $5>, 2$ & 2 & 3 & Q trasl y sed rojas abund, mica & sed grises, fel alt & 4 \\
\hline $\mathrm{RH} 19-7$ & 201 & 19 & & 1 & 2 & 1 & 1 & 2 & 2 & 5 & $5 Y R 5 / 4$ (nuc) y $4 / 2$ & 1 & 2 & 1 & & 4 y $5>, 2$ & 2 & $3 a 4$ & Q trasl y sed rojas abund, Q-fel, mica & sed grises, fgto plut marrón & 4 \\
\hline $\mathrm{RH} 19-7$ & 101 & 19 & & 1 & 2 & 1 & 1 & 2 & 1 & 1 & 5YR 5/4 & 1 & 2 & 2 & & 4 y $5>, 2$ y 3 & 2 & $2 \mathrm{a} 3$ & Q trasl, sed rojas, mica, sed bl o fel alt & sed marrones & 4 \\
\hline $\mathrm{RH} 19-7$ & 101 & 19 & & 1 & 2 & 1 & 1 & 2 & 1 & 1 & 5YR 5/4 & 1 & 2 & 1 & & 4 y $5>, 2$ y 3 & 2 & $3 a 4$ & mica, sed rojas, sed bl o fel alt, Q trasl & sed grises, Q-fel & 4 \\
\hline $\mathrm{RH} 19-7$ & 101 & 19 & & 1 & 2 & 1 & 1 & 2 & 2 & 4 & $5 Y R 3 / 1,5 / 2$ & 1 & 2 & 1 & & 4 y $5>, 2$ y 3 & 2 & $2 \mathrm{a} 4$ & Q trasl, sed bl o fel alt, sed rojas, mica & sed marrones & 4 \\
\hline RH19-7 & 205 & 19 & & 1 & 2 & 1 & 2 & 2 & 1 & 1 & 5YR $4 / 4$ & 1 & 2 & 1 & & 4 y $5>, 2$ & 2 & $3 a 4$ & Q trasl, sed bl o fel alt, sed rojas, mica & Q-fel & 4 \\
\hline $\mathrm{RH} 19-7$ & 202 & 19 & & 1 & 2 & 1 & 1 & 2 & 2 & 4 & $5 Y R 5 / 4,4 / 1$ & 1 & $2 \mathrm{a} 3$ & 1 & & 4 y $5>, 1$ y 2 & 2 & $3 a 4$ & sed rojas, mica, Q trasl, sed bl o fel alt & Q-fel & 4 \\
\hline $\mathrm{RH} 19-7$ & 101 & 19 & & 1 & 2 & 1 & 2 & 2 & 2 & 4 & $5 Y R 3 / 1,4 / 3$ & 1 & $1 \mathrm{a} 2$ & 1 & & 3 y $4>, 2$ & 3 & $3 a 4$ & Q trasl, mica, sed bl o fel alt & sed rojas y marrones, Q-fel & 4 \\
\hline $\mathrm{RH} 19-7$ & 201 & 19 & & 1 & 2 & 1 & 1 & 2 & 1 & 1 & 5YR $6 / 4$ & 1 & 2 & 2 & & 3 y $4>, 2$ & 3 & $3 a 4$ & sed rojas, mica, Q trasl, sed bl o fel alt & Q-fel & 4 \\
\hline $\mathrm{RH} 19-7$ & 201 & 19 & & 1 & 2 & 1 & 1 & 2 & 2 & 4 & $5 Y R 6 / 4,5 / 1$ & 1 & 2 & 1 & & 4 y $5>, 2$ & 3 & $3 a 4$ & Q trasl, mica, sed bl o fel alt & sed rojas & 4 \\
\hline RH19-7 & 101 & 19 & & 1 & 2 & 1 & 1 & 2 & 1 & 1 & 5YR 5/4 & 1 & 2 & 1 & & 3 y $4>, 2$ & 3 & $3 a 4$ & mica, sed bl o fel alt, Q trasl & sed rojas & 4 \\
\hline $\mathrm{RH} 19-7$ & 101 & 19 & & 1 & 2 & 1 & 1 & 2 & 1 & 2 & $5 Y R 3 / 1,5 / 3$ & 1 & 2 & 1 & & 4 y $5>, 1$ y 2 & 2 & $2 \mathrm{a} 4$ & mica, sed bl o fel alt, Q trasl & sed rojas, rosas y grises & 4 \\
\hline $\mathrm{RH} 19-7$ & 201 & 19 & & 1 & 2 & 1 & 1 & 2 & 2 & 5 & 5YR 3/2, 3/1 (nuc) & 1 & 2 & 1 & & 4 y $5>, 2$ y 3 & 3 & $3 a 4$ & $\mathrm{Q}$ trasl, mica, sed bl fel alt & sed rojas, Q-fel & 4 \\
\hline $\mathrm{RH} 19-7$ & 102 & 19 & & 1 & 2 & 1 & 1 & 2 & 1 & 1 & 5YR 5/4 & 1 & 2 & 1 & & 4 y $5>, 1$ y 2 & 3 & $2 \mathrm{a} 3$ & Q trasl, mica, sed bl o fel alt & sed rojas, Q-fel & 4 \\
\hline $\mathrm{RH} 19-7$ & 202 & 20 & & 1 & 2 & 2 & 1 & $2 \mathrm{y} 1$ & 2 & 4 & $5 Y R \quad 4 / 4,4 / 1$ & 1 & 2 & 1 & & 3 y $4>, 1$ y 2 & 2 & $2 a 3$ & mica, Q trasl, sed rojas y marrones & ígneas grises, fel alt & 4 \\
\hline $\mathrm{RH} 19-7$ & 101 & 20 & & 1 & 2 & 1 & 1 & 2 & 1 & 1 & 5YR 5/4 & 1 & 2 & 1 & & 3 y $4>, 1$ y 2 & 2 & $3 a 4$ & mica, Q trasl, sed bl o fel alt & sed rojas y marrones & 4 \\
\hline
\end{tabular}




\begin{tabular}{|c|c|c|c|c|c|c|c|c|c|c|c|c|c|c|c|c|c|c|c|c|c|}
\hline \multirow[b]{2}{*}{$\begin{array}{c}\text { Sitio y } \\
\text { est }\end{array}$} & \multirow[b]{2}{*}{ UP } & \multirow[b]{2}{*}{ GF } & \multirow[b]{2}{*}{ FNA } & \multicolumn{4}{|c|}{ Fractura } & \multirow[b]{2}{*}{\begin{tabular}{l|} 
Ca \\
vid
\end{tabular}} & \multirow{2}{*}{\multicolumn{2}{|c|}{$\begin{array}{ll}\text { Coc } & \text { Co } \\
\text { ción lor }\end{array}$}} & \multirow{3}{*}{$\begin{array}{c}\text { Not color } \\
5 Y R 3 / 1,4 / 4 \text { (nuc) }\end{array}$} & \multicolumn{7}{|c|}{ Inclusiones } & \multicolumn{2}{|l|}{ Composic } & \multirow[b]{2}{*}{ GP } \\
\hline & & & & $\begin{array}{c}\text { Aspec } \\
\text { to }\end{array}$ & \begin{tabular}{|l|l|}
$c$ & $\begin{array}{l}\text { Tex } \\
\text { tura }\end{array}$ \\
\end{tabular} & $\begin{array}{l}\text { Resis } \\
\text { tenc. }\end{array}$ & $\begin{array}{l}\text { Re } \\
\text { ul }\end{array}$ & & & & & Incl & Dens & $\begin{array}{c}\text { Orien } \\
\text { tac }\end{array}$ & $\begin{array}{l}\text { Orient } \\
\text { pared }\end{array}$ & Granul & & $\begin{array}{l}\mathrm{Re} \\
\mathrm{don}\end{array}$ & comp mayor & comp aislados & \\
\hline RH19-7 & 202 & 20 & & 1 & 2 & 1 & 1 & 2 & 5 & 5 & & 1 & 2 & 1 & & 4 y $5>, 2$ y 3 & 3 & $3 a 4$ & mica, Q trasl, sed bl o fel alt & sed marrones y grises & 4 \\
\hline RH19-7 & 102 & 20 & & 1 & 2 & 1 & 2 & 2 & 1 & 1 & $5 Y R \quad 4 / 3$ & 1 & $1 \mathrm{a} 2$ & 2 & & 4 y $5>, 2$ & 3 & $3 a 5$ & mica, Q trasl, sed bl o fel alt & sed rojas y marrones & 4 \\
\hline RH19-7 & 202 & 20 & & 1 & 2 & 1 & 1 & 2 & 2 & 4 & $5 Y R 5 / 3,4 / 1$ & 1 & 2 & 1 & & 3 y $4>, 2$ & 3 & $2 \mathrm{a} 4$ & mica, Q trasl, sed bl o fel alt & sed rojas & 4 \\
\hline RH19-7 & 202 & 20 & & 1 & 2 & 2 & 1 & $2 \mathrm{y} 1$ & 2 & 1 & 2,5 YR 4/4 & 1 & 2 & 1 & & 4 y $5>, 2$ & 3 & $3 a 5$ & mica, Q trasl, sed bl o fel alt & sed rojas, marrones y grises & 4 \\
\hline RH19-7 & 205 & 20 & & 1 & 2 & 2 & 2 & 2 & 2 & 4 & $10 R 4 / 3$ y $4 / 1$ & 1 & 2 & 1 & & 3 y $4>, 1$ y 2 & 2 & $3 a 4$ & Q trasl, mica, sed bl o fel alt & sed rojas y grises, Q-fel & 4 \\
\hline RH19-7 & 101 & 20 & & 1 & 2 & 1 & 1 & 2 & 1 & 1 & 5YR 5/4 & 1 & 2 & 1 & & 3 y $4>, 2$ & 2 & $3 a 4$ & mica, Q trasl, sed bl o fel alt & sed rojas y grises, Q-fel & 4 \\
\hline RH19-7 & 202 & 20 & & 1 & 2 & 2 & 1 & 2 & 2 & 1 & $5 Y R 4 / 3$ & 1 & 2 & 1 & & 4 y $5>, 2$ & 3 & $2 \mathrm{a} 3$ & mica, Q trasl, sed bl o fel alt & sed rojas y grises, Q-fel & 4 \\
\hline RH19-7 & 100 & 20 & & 1 & 2 & 1 & 1 & 2 & 2 & 4 & $5 Y R 5 / 4,4 / 2$ & 1 & 2 & 1 & & 4 y $2>, 3$ & 4 & $3 a 4$ & mica, Q trasl, sed bl o fel alt & sed rojas y grises, Q-fel & 4 \\
\hline RH19-7 & R5 & 21 & & 2 & 2 & 2 & 1 & 2 & 2 & 5 & 5YR 3/1, 4/3 (nuc) & 1 & 2 & 2 & & 4 y $5>, 3$ & 3 & $2 \mathrm{a} 3$ & mica muy abund, Q trasl & sed bl o fel alt, sed rojas & 1 \\
\hline RH19-7 & 201 & 21 & & 2 & 1 & 2 & 1 & $2 \mathrm{y} 1$ & 2 & 4 & $5 Y R 5 / 4,3 / 2$ & 1 & $2 a 3$ & 2 & & 4 y $5>, 3$ & 3 & $2 \mathrm{a} 3$ & mica muy abund, $\mathrm{Q}$ trasl & sed bl o fel alt & 1 \\
\hline RH19-7 & 102 & 21 & & 2 & 1 & 2 & 1 & 2 & 2 & 4 & $5 Y R 4 / 4,3 / 1$ & 1 & $2 a 3$ & 2 & & 4 y $5>, 3$ & 3 & $2 a 3$ & mica muy abund, Q trasl & sed bl o fel alt, sed rojas & 1 \\
\hline RH19-7 & 107 & 22 & & 1 & 2 & 2 & 1 & 2 & 2 & 1 & $5 Y R 4 / 3$ & 1 & 2 & 1 & & 4 y $5>, 3$ & 3 & $3 a 4$ & Q trasl, sed bl o fel alt, mica & Q-fel, sed rojas y grises & 4 \\
\hline RH19-7 & 102 & 22 & & 1 & 2 & 1 & 1 & 2 & 2 & 1 & 5YR 3/1 & 1 & 2 & 1 & & 4 y $5>, 2$ y 3 & 3 & $3 a 4$ & Q trasl, mica, sed bl o fel alt & Q-fel, sed marrones & 4 \\
\hline $\mathrm{RH} 19-7$ & 205 & 23 & & 1 & 2 & 1 & 1 & 2 & 1 & 5 & 5YR 4/6, 5/6 (nuc) & 1 & 2 & 1 & & 2 y $3>, 4$ & 3 & $2 \mathrm{a} 3$ & Q trasl, sed rojas y ros, sed bl o fel alt & mica fina, $\mathrm{Q}$-fel & 4 \\
\hline RH19-7 & 205 & 23 & & 1 & 2 & 2 & 1 & 2 & 1 & 5 & 5YR 4/6, 5/6 (nuc) & 1 & 2 & 2 & & 2 y $3>, 4$ & 3 & $2 a 3$ & Q trasl, sed rojas, sed bl o fel alt & Q-fel, mica fina & 4 \\
\hline RH19-7 & 202 & 24 & & 1 & 2 & 1 & 1 & $2 \mathrm{y} 1$ & 2 & 4 & 7,5YR 4/2, 3/1 & 1 & 2 & 1 & & 4 y $5>, 3$ & 4 & $3 a 4$ & Q trasl abund, mica abund & fel alt, sed rojas y marrones & 2 \\
\hline RH19-7 & 100 & & $1 / 2$ & 1 & 2 & 1 & 1 & 2 & 1 & 1 & $10 \mathrm{R} 6 / 6$ & 1 & $1 \mathrm{a} 2$ & 1 & & 2 y $3>$ & 2 & $3 a 4$ & sed bl y rosadas abund & sed rojas, mica fina, $\mathrm{Q}$ trasl & 3 \\
\hline RH19-7 & 202 & & 3 & 1 & 2 & 2 & 1 & 2 & 1 & 1 & 2,5 YR $5 / 6$ & 1 & 2 & 1 & & 4 y $5>, 2$ & 3 & $3 a 4$ & mica, sed bl, gris y rojas, fel alt, Q trasl & Q-fel & 4 \\
\hline RH19-7 & 102 & & 4 & 1 & 2 & 2 & 1 & 2 & 4 & 4 & $2,5 Y R \quad 4 / 2,4 / 1$ & 2 & $1 \mathrm{a} 2$ & 1 & & 4 y $5>, 1$ y 3 & 2 & $2 a 3$ & sed marrones a gris osc, $\mathrm{Q}$ trasl & mica fina, sed rojas, fel alt & 4 \\
\hline $\mathrm{RH} 19-7$ & 100 & & 5 & 2 & 2 & 2 & 1 & 2 & 2 & 4 & $7,5 Y R 3 / 2,3 / 1$ & 1 & 2 & 1 & & 4 y $5>, 3$ & 4 & $3 a 4$ & Q trasl muy abund, mica fina & sed rojas, fel alt & 2 \\
\hline RH19-7 & 201 & & 6 & 1 & 2 & 1 & 1 & 2 & 2 & 4 & 7,5 YR $5 / 3,3 / 1$ & 2 & 2 & 1 & & $5>, 4$ y 3 & 4 & $3 a 4$ & $\mathrm{Q}$ trasl muy abund, mica & fel alt, sed rojas & 2 \\
\hline RH19-7 & 201 & & 7 & 1 & 2 & 1 & 1 & $2 \mathrm{y} 1$ & 4 & 4 & $7,5 Y R$ 4/3, 2,5/1 & 2 & 2 & 1 & & 4 y $5>, 3$ & 3 & $3 a 4$ & Q trasl abund, mica, sed bl o fel alt & sed rojas & 2 \\
\hline RH19-7 & 107 & & 8 & 1 & 2 & 2 & 1 & 2 & 4 & 4 & 7.5YR 4/2 y $3 / 1$ & 1 & $1 \mathrm{a} 2$ & 1 & & 2 y $3>$ & 2 & $2 \mathrm{a} 3$ & Q trasl, mica, sed marrones y grises & Q-fel & 4 \\
\hline RH19-7 & 202 & & 9 & 2 & 2 & 2 & 1 & 2 & 3 & 1 & N 2,5/ & 2 & 2 & 1 & & 4 y $5>, 3$ & 3 & $3 a 4$ & Q trasl abund, sed marrones,rojas, mica & fel alt & 2 \\
\hline RH19-7 & 100 & & 10 & 2 & 2 & 2 & 1 & 2 & 4 & 4 & $5 Y R \quad 4 / 2,2,5 / 1$ & 2 & 2 & 1 & & 4 y $5>$ & 4 & $3 a 4$ & Q trasl abund, sed rojas, mica fina & fel alt & 2 \\
\hline RH19-7 & 101 & & 11 & 1 & 2 & 1 & 1 & 2 & 2 & 5 & 5YR 4/2, 4/1(nuc) & 1 & 2 & 1 & & 4 y $5>, 2$ y 3 & 3 & $3 a 4$ & Q trasl, sed grises, mica & sed rojas, Q-fel & 4 \\
\hline RH19-7 & 202 & & 12 & 2 & 1 & 2 & 1 & 2 & 3 & 1 & $\mathrm{~N} 2,5 /$ & 1 & 2 & 2 & & 4 y $5>, 2$ y 3 & 3 & $2 a 3$ & mica muy abund, Q trasl & sed bl o fel alt & 1 \\
\hline RH19-7 & 201 & & 13 & 1 & 2 & 1 & 1 & 2 & 3 & 1 & $\mathrm{~N} \mathrm{2,5/}$ & 2 & 2 & 1 & & 4 y $5>, 3$ & 3 & $3 a 4$ & mica abund, Q trasl, sed grises & sed rojas y rosas & 1 \\
\hline RH19-7 & 101 & & 14 & 2 & 2 & 2 & 1 & $2 \mathrm{y} 1$ & 4 & 4 & $5 Y R$ 3/2, N 2,5 & 2 & 2 & 2 & & 4 y $5>, 3$ & 4 & $2 a 3$ & Q trasl, mica, sed bl o fel alt & sed rojas & 4 \\
\hline RH19-7 & 202 & & 15 & 1 & 2 & 1 & 1 & 2 & 1 & 1 & 2,5 YR $5 / 6$ & 1 & 1 & 1 & & 2 y $3>$ & 3 & $3 a 4$ & sed bl, grises y rojas & Q trasl, mica fina, Q-fel & 3 \\
\hline RH19-7 & 100 & & 16 & 1 & 2 & 1 & 1 & 2 & 2 & 1 & 5YR 4/2 & 1 & $1 \mathrm{a} 2$ & 1 & & 3 y $4>, 2$ & 2 & $2 \mathrm{a} 3$ & Q trasl, mica, sed rojas & Q-fel, fel alt & 4 \\
\hline RH19-7 & 102 & & 17 & 2 & 2 & 1 & 1 & 2 & 3 & 1 & $5 Y R 2,5 / 1$ & 1 & 2a3 & 1 & & 2 y $3>$ & 3 & $1 \mathrm{a} 2$ & mica muy abund, cuarzo & sed rojas & 1 \\
\hline RH19-7 & 201 & & 18 & 1 & 2 & 1 & 1 & $2 \mathrm{y} 1$ & 2 & 5 & 5YR 3/2, 4/3 (nuc) & 1 & 2 & 1 & & 4 y $5>, 2$ & 2 & $3 a 4$ & Q trasl, sed rosas a bl o fel alt, mica & sed rojas, Q-fel & 4 \\
\hline RH19-7 & 201 & & 21 & 1 & 2 & 2 & 1 & 2 & 2 & 5 & $7,5 Y R \quad 6 / 4,4 / 2$ & 1 & 2 & 1 & & 4 y $5>, 1$ & 3 & $3 a 4$ & Q trasl abund, sed rojas, mica & sed bl o fel alt, roca osc afan & 2 \\
\hline RH19-7 & 202 & & 22 & 1 & 2 & 1 & 2 & $2 \mathrm{y} 1$ & 2 & 5 & $7,5 Y R 6 / 4,4 / 1$ & 2 & $1 \mathrm{a} 2$ & 1 & & 3 y $4>, 2$ & 3 & $3 a 4$ & sed bl y grises, sed rojas, Q trasl & mica, Q-fel & 3 \\
\hline RH19-7 & 103 & & 23 & 1 & 2 & 2 & 1 & 2 & 1 & 1 & 2,5 YR $5 / 6$ & 1 & 2 & 1 & & 3 y $4>, 2$ & 2 & $3 a 4$ & Q trasl, mica abund, sed bl o fel alt & sed rojas y moradas & 4 \\
\hline
\end{tabular}




\begin{tabular}{|c|c|c|c|c|c|c|c|c|c|c|c|c|c|c|c|c|c|c|c|c|c|}
\hline \multirow[b]{2}{*}{$\begin{array}{c}\text { Sitio y } \\
\text { est }\end{array}$} & \multirow[b]{2}{*}{ UP } & \multirow[b]{2}{*}{ GF } & \multirow[b]{2}{*}{ FNA } & \multicolumn{4}{|c|}{ Fractura } & \multirow[b]{2}{*}{$\begin{array}{l}\text { Ca } \\
\text { vid }\end{array}$} & \multirow{2}{*}{\multicolumn{2}{|c|}{\begin{tabular}{l|l} 
Coc & Co \\
ción & lor \\
\end{tabular}}} & \multirow[b]{2}{*}{ Not color } & \multicolumn{7}{|c|}{ Inclusiones } & \multicolumn{2}{|c|}{ Composic } & \multirow[b]{2}{*}{ GP } \\
\hline & & & & $\begin{array}{c}\text { Aspec } \\
\text { to }\end{array}$ & \begin{tabular}{|l|l|}
$c$ & $\begin{array}{l}\text { Tex } \\
\text { tura }\end{array}$ \\
\end{tabular} & $\begin{array}{l}\text { Resis } \\
\text { tenc. }\end{array}$ & $\begin{array}{l}\mathrm{Re} \\
\text { gul }\end{array}$ & & & & & Incl & Dens & $\begin{array}{c}\text { Orien } \\
\text { tac }\end{array}$ & $\begin{array}{l}\text { Orient } \\
\text { pared }\end{array}$ & Granul & & $\begin{array}{c}\mathrm{Re} \\
\mathrm{don}\end{array}$ & comp mayor & comp aislados & \\
\hline RH19-7 & 102 & & $24 / 25$ & 1 & 2 & 2 & 1 & 2 & 1 & 1 & 2,5 YR $5 / 4$ & 1 & 2 & 1 & & 4 y $5>, 3$ & 4 & $3 a 4$ & mica, sed bl o fel alt, Q trasl & sed rojas y grises, Q-fel & 4 \\
\hline RH19-7 & 202 & & $26 / 27$ & 1 & 2 & 1 & 1 & 2 & 2 & 2 & 10R $5 / 6,3 / 1$ & 1 & 2 & 1 & & 2 y $3>, 4$ & 2 & $3 a 4$ & sed rojas y marrones, $\mathrm{Q}$ trasl & sed grises, mica fina & 4 \\
\hline RH19-7 & 201 & & 28 & 1 & 2 & 2 & 1 & 2 & 1 & 1 & 2,5 YR $5 / 4$ & 2 & 2 & 1 & & 4 y $5>, 2$ & 3 & $3 a 4$ & Q trasl, sed bl o fel alt, mica & sed rojas y grises, Q-fel & 4 \\
\hline RH19-7 & 202 & & 29 & 1 & 2 & 1 & 1 & 2 & 1 & 1 & 2,5 YR $5 / 8$ & 1 & $1 \mathrm{a} 2$ & 1 & & 3 y $4>, 1$ y 2 & 2 & $3 a 4$ & sed rosas y bl, Q trasl & mica, sed rojas,marrones, Q-fel & 3 \\
\hline RH19-7 & 202 & & 30 & 1 & 2 & 1 & 1 & 2 & 1 & 1 & 2,5 YR $5 / 8$ & 1 & $1 \mathrm{a} 2$ & 1 & & 4 y $5>, 2$ y 3 & 3 & $3 a 4$ & sed rosas y bl, Q trasl & mica, sed rojas,marrones, Q-fel & 3 \\
\hline RH19-7 & 100 & & 31 & 1 & 2 & 1 & 1 & $2 \mathrm{y} 1$ & 1 & 1 & 2,5YR 5/8 & 1 & $1 \mathrm{a} 2$ & 1 & & 4 y $5>, 2$ y 3 & 3 & $3 a 4$ & sed rosas, bl y grises, $Q$ trasl & mica, sed rojas, Q-fel & 3 \\
\hline RH19-7 & 100 & & $32-34$ & 1 & 2 & 1 & 1 & 2 & 2 & 1 & 5YR 3/1 & 1 & $1 \mathrm{a} 2$ & 1 & & 4 y $5>, 1$ y 2 & 2 & $3 a 4$ & Q trasl abund, fel alt, Q-fel, mica & sed claras & 2 \\
\hline RH19-7 & 201 & & $35 / 36$ & 2 & 2 & 1 & 1 & 2 & 5 & 5 & 5YR 5/3 (nuc), 3/1 & 1 & 2 & 2 & & 4 y $5>, 1$ y 2 & 2 & $3 a 4$ & Q trasl abund, sed bl y grises, mica & fel alt & 2 \\
\hline RH19-7 & 205 & & $37 / 38$ & 2 & 2 & 1 & 1 & 2 & 3 & 1 & N 3/ & 2 & 2 & 1 & & 4 y $5>, 3$ & 4 & $3 a 4$ & Q trasl abund, fel alt, Q-fel, micas & sed rojas y marrones & 2 \\
\hline RH19-7 & 202 & & 39 & 1 & 2 & 1 & 1 & 2 & 4 & 4 & 2,5YR 4/4, 3/1 & 1 & 2 & 2 & & 3 y $4>, 2$ & 3 & $2 \mathrm{a} 3$ & Q trasl, sed bl y grises o fel alt, mica & sed rojas & 4 \\
\hline RH19-7 & 205 & & 40 & 1 & 2 & 1 & 1 & 2 & 2 & 4 & $5 Y R 3 / 3,2,5 / 1$ & 1 & 2 & 1 & & 2 y $3>, 1$ y 4 & 2 & $3 a 4$ & Q trasl, sed rojas, mica & sed bl o fel alt, Q-fel & 4 \\
\hline RH19-7 & 205 & & 41 & 1 & 2 & 2 & 1 & 2 & 2 & 4 & $5 Y R 3 / 2,2,5 / 1$ & 1 & 2 & 1 & & 3 y $4>, 1$ y 2 & 2 & $3 a 4$ & Q trasl, mica, sed marrones, Q-fel & fel alt, sed rojas & 4 \\
\hline RH19-7 & 100 & & 42 & 1 & 2 & 1 & 1 & 2 & 2 & 5 & $5 Y R \quad 4 / 3,4 / 1$ (nuc) & 1 & 2 & 1 & & 4 y $5>, 2$ y 3 & 2 & $3 a 4$ & Q trasl, mica, sed bl y rosas o fel alt & sed rojas, Q-fel & 4 \\
\hline RH19-7 & 202 & & 43 & 1 & 2 & 1 & 1 & 2 & 4 & 4 & $5 Y R$ 4/2, N 2,5/ & 1 & 2 & 1 & & 4 y $5>, 3$ & 4 & $3 a 4$ & Q trasl, sed bl o fel alt, mica & sed rojas & 4 \\
\hline RH19-7 & 201 & & 44 & 1 & 2 & 1 & 1 & 2 & 4 & 4 & $5 Y R$ 3/2; N 2,5/ & 2 & 2 & 2 & & 4 y $5>, 2$ y 3 & 2 & $2 a 3$ & Q trasl, sed bl y grises o fel alt, mica & sed rojas & 4 \\
\hline RH19-7 & 202 & & 45 & 2 & 2 & 1 & 1 & $2 \mathrm{y} 1$ & 3 & 1 & $\mathrm{~N} 3 /$ & 1 & 2 & 1 & & 2 y $3>, 4$ & 3 & $4 a 5$ & Q trasl abund, sed marrones y grises & mica fina & 2 \\
\hline RH19-7 & 101 & & 47 & 1 & 2 & 1 & 1 & 2 & 4 & 4 & 5YR 5/3; N 2,5/ & 1 & 2 & 1 & & 4 y $5>$ & 4 & $3 a 4$ & Q trasl abund, sed bl o fel alt, mica & sed rojas & 2 \\
\hline RH19-7 & 100 & & 48 & 2 & 1 & 2 & 1 & 2 & 4 & 4 & $5 Y R$ 5/3; N 2,5/ & 2 & $2 \mathrm{a} 3$ & 2 & & 4 y $5>$ & 3 & $2 a 3$ & mica muy abund, $\mathrm{Q}$ trasl & Q-fel, fel alt, sed marr y rojas & 1 \\
\hline RH19-7 & 201 & & 49 & 2 & 1 & 2 & 1 & 2 & 3 & 1 & $\mathrm{~N} 2,5 /$ & 1 & $2 a 3$ & 2 & & 4 y $5>, 3$ & 3 & $2 a 3$ & mica muy abund, Q trasl & sed bl y grises o fel alt, Q-fel & 1 \\
\hline $\mathrm{RH} 19-7$ & 202 & & 50 & 1 & 2 & 2 & 1 & 2 & 2 & 4 & $5 Y R$ 4/1, 3/1 & 2 & 2 & 1 & & 4 y $5>, 3$ & 4 & $3 a 4$ & Q terasl abund, sed bl o fel alt, mica & sed rojas & 2 \\
\hline RH19-7 & 107 & & 51 & 2 & 2 & 2 & 1 & 2 & 1 & 1 & 2,5 YR $4 / 6$ & 1 & $2 \mathrm{a} 3$ & 2 & & 4 y $5>, 1$ y 2 & 2 & $2 a 3$ & mica muy abund, Q trasl, Q-fel & sed bl o fel alt, sed rojas & 1 \\
\hline RH19-7 & 201 & & 52 & 2 & 2 & 2 & 1 & 2 & 4 & 4 & $5 Y R$ 3/2; N 2,5/ & 1 & $2 a 3$ & 2 & & 3 y $4>, 2$ & 3 & $2 a 3$ & mica muy abund, Q trasl & sed grises,bl o fel alt, sed rojas & 1 \\
\hline RH19-7 & 202 & & 53 & 1 & 2 & 2 & 1 & 2 & 2 & 1 & $7,5 Y R$ 5/2 & 2 & 2 & 1 & & 4 y $5>, 3$ & 4 & $3 a 4$ & Q trasl abund, mica & sed rojas, fel alt, Q-fel & 2 \\
\hline RH19-7 & 202 & & 54 & 1 & 2 & 1 & 1 & 2 & 5 & 5 & 2,5YR 4/1, 4/3 (nuc) & 2 & $1 \mathrm{a} 2$ & 1 & & 4 y $5>, 2$ & 2 & $3 a 4$ & Q trasl abund, mica, sed rojas & Q-fel, fel alt & 2 \\
\hline RH19-7 & 102 & & 55 & 2 & 2 & 2 & 1 & 2 & 2 & 4 & 7,5YR 4/2; N 2,5/ & 1 & 2 & 2 & & 4 y $5>, 3$ & 3 & $2 \mathrm{a} 3$ & mica abund, Q trasl & sed bl,grises o fel alt, sed rojas & 1 \\
\hline RH19-7 & 102 & & 56 & 1 & 2 & 1 & 1 & 2 & 4 & 4 & $2,5 Y R$ 5/6, 3/1 & 1 & 2 & 1 & & 4 y $5>, 2$ y 3 & 3 & $3 a 4$ & Q trasl, mica, sed rojas, sed bl o fel alt & Q-fel & 4 \\
\hline RH19-7 & 102 & & 57 & 1 & 2 & 1 & 1 & 2 & 2 & 4 & $\mathrm{~N} 3 /, 5 \mathrm{YR} 4 / 4$ & 2 & $1 \mathrm{a} 2$ & 1 & & 4 y $5>, 3$ & 3 & $3 a 4$ & sed rojas, Q trasl, mica & sed grises, bl o fel alt, Q-fel & 4 \\
\hline RH19-7 & 103 & & 58 & 1 & 2 & 2 & 1 & 2 & 5 & 5 & 7,5YR 4/1, 5/3 & 2 & 2 & 1 & & 4 y $5>, 3$ & 3 & $3 a 4$ & $\mathrm{Q}$ trasl abund, mica & sed grises y bl o fel alt, Q-fel & 2 \\
\hline RH19-7 & 100 & & 59 & 1 & 2 & 2 & 1 & 2 & 2 & 1 & 5YR $4 / 2$ & 1 & 2 & 1 & & 1 y $2>, 4$ y 5 & 2 & $4 a 5$ & sed marrones, grises y rojas, Q trasl & Q- fel, fel alt, mica fina & 4 \\
\hline RH19-7 & 201 & & 60 & 2 & 1 & 2 & 1 & 2 & 3 & 1 & $\mathrm{~N} 2,5 /$ & 1 & $2 a 3$ & 2 & & 4 y $5>$ & 3 & $2 a 3$ & mica muy abund & Q trasl, sed bl o fel alt & 1 \\
\hline RH19-7 & 102 & & 61 & 1 & 2 & 2 & 1 & 2 & 5 & 5 & $5 Y R$ 3/1, 5/3 (nuc) & 2 & 2 & 1 & & 4 y $5>, 3$ & 3 & $3 a 4$ & Q trasl, sed bl o fel alt, sed rojas, mica & Q-fel & 4 \\
\hline RH19-7 & 102 & & 62 & 1 & 2 & 1 & 1 & 2 & 2 & 1 & $7,5 Y R 5 / 3$ & 1 & 2 & 1 & & 4 y $5>, 2$ y 3 & 2 & $3 a 4$ & Q trasl, sed rojas, marrones y bl & fel alt, mica fina, Q-fel, igneas & 4 \\
\hline RH19-7 & 201 & & 63 & 1 & 2 & 1 & 2 & 2 & 4 & 4 & $5 Y R$ 5/3; N 2,5/ & 2 & 2 & 1 & & 4 y $5>, 2$ y 3 & 3 & $3 a 4$ & Q trasl abund, mica, sed bl o fel alt & sed rojas, Q-fel & 2 \\
\hline RH19-7 & 202 & & 66 & 1 & 2 & 2 & 1 & 2 & 2 & 4 & $5 Y R$ 6/4, 4/1 & 2 & 2 & 2 & & 2 y $3>, 4$ & 2 & $3 a 4$ & Q trasl, sed grises y rojas, mica & fel alt, Q-fel & 4 \\
\hline RH19-7 & 101 & & 67 & 1 & 2 & 1 & 1 & 2 & 2 & 4 & 7,5YR 4/1; N2,5/ & 2 & 2 & 1 & & 4 y $5>, 2$ y 3 & 3 & $3 a 4$ & Q trasl, sed marrones y grises & sed rojas, fel alt, mica fina & 4 \\
\hline RH19-7 & 201 & & 68 & 2 & 2 & 2 & 1 & 2 & 2 & 4 & $5 Y R 5 / 4,3 / 2$ & 1 & $2 \mathrm{a} 3$ & 1 & & 3 y $4>, 2$ & 3 & $3 a 4$ & Q trasl abund, sed rojas, sed grises & mica, sed bl o fel at & 2 \\
\hline
\end{tabular}




\begin{tabular}{|c|c|c|c|c|c|c|c|c|c|c|c|c|c|c|c|c|c|c|c|c|c|}
\hline \multirow[b]{2}{*}{$\begin{array}{c}\text { Sitio y } \\
\text { est }\end{array}$} & \multirow[b]{2}{*}{ UP } & \multirow[b]{2}{*}{ GF } & \multirow[b]{2}{*}{ FNA } & \multicolumn{4}{|c|}{ Fractura } & \multirow[b]{2}{*}{\begin{tabular}{|l|l|} 
Ca \\
lid
\end{tabular}} & \multirow{2}{*}{\multicolumn{2}{|c|}{\begin{tabular}{|l|l} 
Coc Co \\
ción lo
\end{tabular}}} & \multirow[b]{2}{*}{ Not color } & \multicolumn{7}{|c|}{ Inclusiones } & \multicolumn{2}{|c|}{ Composic } & \multirow[b]{2}{*}{ GP } \\
\hline & & & & $\begin{array}{c}\text { Aspec } \\
\text { to }\end{array}$ & \begin{tabular}{|l|l|}
$c$ & $\begin{array}{l}\text { Tex } \\
\text { tura }\end{array}$ \\
\end{tabular} & $\begin{array}{l}\text { Resis } \\
\text { tenc. }\end{array}$ & $\begin{array}{l}\mathbf{R e} \\
\text { gul }\end{array}$ & & & & & Incl & Dens & $\begin{array}{c}\text { Orien } \\
\text { tac }\end{array}$ & $\begin{array}{l}\text { Orient } \\
\text { pared }\end{array}$ & Granul & & $\begin{array}{l}\mathrm{Re} \\
\mathrm{don}\end{array}$ & comp mayor & comp aislados & \\
\hline RH19-7 & 202 & & 69 & 2 & 2 & 2 & 1 & 2 & 2 & 4 & $2,5 Y R \quad 4 / 6,3 / 1$ & 1 & $2 \mathrm{a} 3$ & 1 & & 3 y $4>, 2$ & 3 & $3 a 4$ & Q trasl abund, sed grises y rojas & mica, sed bl o fel at & 2 \\
\hline RH19-7 & 203 & & 70 & 1 & 2 & 2 & 1 & 2 & 2 & 4 & $5 Y R 5 / 3,3 / 1$ & 1 & 2 & 2 & & 3 y $4>, 2$ & 2 & $3 a 4$ & Q trasl, sed bl o fel alt, mica & sed grises, marrones y rojas & 4 \\
\hline RH19-7 & 201 & & 71 & 1 & 2 & 1 & 1 & 2 & 2 & 4 & $5 Y R 4 / 3,6 / 3$ & 1 & 2 & 1 & & 3 y $4>, 2$ y 1 & 2 & $3 a 4$ & sed rojas y bl o fel alt, Q trasl, mica & sed grises, Q-fel & 4 \\
\hline RH19-7 & 201 & & 72 & 2 & 2 & 2 & 1 & 2 & 2 & 1 & $5 Y R \quad 4 / 3$ & 1 & 2 & 1 & & 4 y $5>, 1$ y 2 & 2 & $3 a 4$ & mica abund, Q trasl & sed bl o fel alt, sed rojas & 1 \\
\hline RH19-7 & 201 & & 73 & 1 & 2 & 1 & 1 & 2 & 2 & 4 & $5 Y R 5 / 4,4 / 1$ & 1 & 2 & 1 & & 4 y $5>, 1$ y 2 & 2 & $3 a 4$ & Q trasl, sed bl y grises o fel alt & sed rojas, mica & 4 \\
\hline RH19-7 & 205 & & 74 & 2 & 2 & 1 & 1 & $2 \mathrm{y} 1$ & 5 & 5 & $5 Y R 3 / 1,4 / 2$ (nuc) & 1 & 2 & 1 & & 4 y $5>, 1$ y 2 & 2 & $2 \mathrm{a} 4$ & Q trasl, sed bl y grises o fel alt, mica & sed rojas, Q-fel & 4 \\
\hline $\mathrm{RH} 19-7$ & 202 & & 75 & 1 & 2 & 2 & 1 & $2 \mathrm{y} 1$ & 2 & 2 & $7,5 Y R$ 5/3, 3/1 & 2 & $1 \mathrm{a} 2$ & 1 & & 4 y $5>, 3$ & 4 & $3 a 4$ & Q trasl abund, sed bl o fel alt & mica, sed rojas, Q-fel & 2 \\
\hline RH19-7 & 102 & & 76 & 1 & 2 & 1 & 1 & 2 & 4 & 4 & $2,5 Y R$ 5/4, 4/1 & 1 & 2 & 1 & & 3 y $4>, 1$ y 2 & 2 & $2 \mathrm{a} 3$ & $\mathrm{Q}$ trasl, sed grises y bl o fel alt & sed rojas, mica, Q-fel & 4 \\
\hline RH19-7 & 202 & & 77 & 1 & 2 & 1 & 1 & 2 & 3 & 1 & N 2,5/ & 2 & $1 \mathrm{a} 2$ & 1 & & 4 y $5>, 2$ & 3 & $3 a 4$ & Q trasl, mica, sed marrones & sed bl o fel alt, sed rojas & 4 \\
\hline RH19-7 & 102 & & 78 & 1 & 2 & 1 & 2 & 2 & 3 & 1 & $\mathrm{~N} 2,5 /$ & 1 & 2 & 1 & & 4 y $5>, 1$ y 2 & 3 & $3 a 4$ & sed marrones y grises, mica, $\mathrm{Q}$ trasl & fel alt, sed rojas & 4 \\
\hline RH19-7 & 201 & & 79 & 1 & 2 & 1 & 1 & $2 \mathrm{y} 1$ & 3 & 1 & N 3/ & 1 & 2 & 2 & & 1 y $2>, 4$ & 3 & $3 a 4$ & sed marrones y grises, mica, $\mathrm{Q}$ trasl & fel alt, sed rojas & 4 \\
\hline RH19-7 & 201 & & 80 & 1 & 2 & 1 & 1 & 2 & 2 & 1 & $5 Y R 5 / 3$ & 1 & 2 & 1 & & 4 y $5>, 2$ y 3 & 2 & $3 a 4$ & Q trasl, sed marrones y rojas & Q- fel, sed grises, fel alt & 4 \\
\hline RH19-7 & 202 & & 81 & 2 & 1 & 2 & 1 & 2 & 4 & 4 & $5 Y R$ 4/3; N 2,5/ & 1 & 2 & 2 & & 2 y $3>, 4$ & 3 & $2 \mathrm{a} 3$ & mica muy abund, Q trasl & sed grises y rojas, fel alt & 1 \\
\hline RH19-7 & 201 & & 82 & 1 & 2 & 1 & 1 & 2 & 2 & 5 & 5YR 5/6, 3/1(nuc) & 1 & $1 \mathrm{a} 2$ & 1 & & 4 y $5>, 1$ & 2 & $2 \mathrm{a} 3$ & Q trasl, sed marrones y grises, mica & fel alt, sed rojas & 4 \\
\hline RH19-7 & 101 & & 83 & 1 & 2 & 1 & 1 & 2 & 2 & 4 & $5 Y R 5 / 4,3 / 1$ & 1 & 2 & 2 & & 3 y $4>$ & 4 & $3 a 4$ & sed bl a grises o fel alt, mica, $\mathrm{Q}$ trasl & sed rosas a rojas & 4 \\
\hline RH19-7 & 102 & & 84 & 1 & 2 & 2 & 1 & 2 & 2 & 5 & 5YR 3/1, 4/2 (nuc) & 1 & 2 & 1 & & 4 y $5>, 3$ & 4 & $3 a 4$ & Q trasl, sed bl o fel alt, mica & sed rojas, roca osc afan & 4 \\
\hline RH19-7 & 102 & & 86 & 1 & 2 & 1 & 1 & 2 & 2 & 5 & 5YR 5/3, 4/1 (nuc) & 1 & $1 \mathrm{a} 2$ & 1 & & 4 y $5>, 1$ & 3 & $3 a 4$ & Q trasl, mica, sed bl o fel alt & sed rojas y grises, Q-fel & 4 \\
\hline RH19-7 & 102 & & 87 & 2 & 2 & 2 & 1 & 2 & 2 & 1 & 5YR 5/4 & 1 & 2 & 1 & & 4 y $5>, 3$ & 4 & $2 a 3$ & Q trasl, mica, sed bl o fel alt & sed rojas, roca osc afan & 4 \\
\hline RH19-7 & 100 & & 88 & 1 & 2 & 1 & 1 & 2 & 2 & 4 & $5 Y R$ 4/3, 3/1 & 1 & $1 \mathrm{a} 2$ & 2 & & 4 y $5>, 2$ y 3 & 3 & $3 a 4$ & Q trasl, sed bl o fel alt, sed rojas, mica & Q-fel, roca osc afan & 4 \\
\hline $\mathrm{RH} 19-7$ & 101 & & 89 & 1 & 2 & 1 & 1 & 2 & 2 & 4 & $5 Y R 5 / 4,5 / 1$ & 1 & 2 & 1 & & 3 y $4>, 2$ & 3 & $3 a 4$ & Q trasl, sed bl o fel alt, sed marr y rojas & mica fina, Q-fel & 4 \\
\hline RH19-7 & 102 & & 90 & 1 & 2 & 1 & 1 & 2 & 2 & 1 & $5 Y R 3 / 1$ & 2 & $1 \mathrm{a} 2$ & 1 & & 4 y $5>, 3$ & 3 & $3 a 4$ & Q trasl, sed marrones, mica & Q-fel & 4 \\
\hline RH19-7 & 101 & & 91 & 1 & 2 & 2 & 1 & 2 & 1 & 1 & $2,5 Y R$ 5/6 & 2 & 2 & 1 & & 4 y $5>; 3$ & 3 & $3 a 4$ & Q trasl, sed rojas, bl o fel alt & mica fina, roca osc afan & 4 \\
\hline RH19-7 & 102 & & 92 & 1 & 2 & 1 & 1 & 2 & 2 & 1 & $5 Y R 3 / 1$ & 2 & $1 \mathrm{a} 2$ & 1 & & 4 y $5><, 3$ & 3 & $3 a 4$ & $\mathrm{Q}$ trasl, sed grises y rojas, mica & fel alt & 4 \\
\hline RH19-7 & 102 & & 93 & 2 & 2 & 2 & 1 & 2 & 4 & 4 & $5 Y R$ 6/2; N 2,5/ & 1 & 2 & 2 & & 4 y $5>, 2$ y 3 & 3 & $2 \mathrm{a} 3$ & mica muy abund, Q trasl & fel alt, sed grises & 1 \\
\hline RH19-7 & Sup & & 94 & 1 & 2 & 2 & 1 & $2 \mathrm{y} 1$ & 3 & 1 & N 3/ & 1 & 2 & 2 & & 3 y $4>, 2$ & 3 & $3 a 4$ & Q trasl abund, sed grises y bl o fel alt & Q-fel, mica & 2 \\
\hline RH19-7 & Sup & & 95 & 2 & 2 & 2 & 1 & 2 & 2 & 5 & $5 Y R \quad 4 / 4$ (nuc) y $3 / 1$ & 1 & $2 a 3$ & 2 & & 4 y $5>, 1$ y 2 & 2 & $2 a 3$ & mica muy abund, Q trasl & Q-fel, fel alt, sed rojas & 1 \\
\hline RH19-7 & Sup & & $96 / 97$ & 1 & 2 & 1 & 1 & 2 & 1 & 1 & $2.5 Y R$ G/6 & 1 & 2 & 1 & & 3 y $4>, 2$ & 3 & $3 a 4$ & sed bl, Q trasl & Q-fel, sed rojas y marrones & 3 \\
\hline RH19-7 & Sup & & 98 & 1 & 2 & 1 & 1 & $2 \mathrm{y} 1$ & 1 & 1 & 2.5 YR $6 / 6$ & 1 & $1 \mathrm{a} 2$ & 1 & & 3 y $4>, 2$ & 3 & $3 a 4$ & sed bl, Q trasl & Q-fel, sed marron y rojas, mica & 3 \\
\hline RH19-7 & Sup & & 99 & 1 & 2 & 1 & 1 & 2 & 2 & 3 & $2.5 Y R$ 6/6 y $4 / 2$ (nuc) & 1 & 1 & 1 & & 3 y $4>, 1$ y 2 & 2 & $3 a 4$ & sed bl y rosas, Q trasl & mica fina, sed marrones y rojas & 3 \\
\hline RH19-7 & Sup & & 100 & 1 & 2 & 1 & 1 & 2 & 2 & 2 & $2.5 Y R$ 5/6 y $4 / 2$ (nuc) & 2 & 1 & 1 & & $5>, 3$ y 4 & 4 & $4 a 5$ & Q trasl, Q-fel, fel alt & sed rojas, marrones, grises & 5 \\
\hline RH19-7 & Sup & & 101 & 1 & 2 & 1 & 1 & 2 & 1 & 1 & 2.5 YR $6 / 4$ & 1 & 2 & 1 & & 2 у $3>, 4$ & 3 & $3 a 4$ & sed bl y rosas o fel alt, Q trasl & Q-fel, sed marrones, mica fina & 3 \\
\hline RH19-7 & Sup & & 102 & 1 & 2 & 2 & 2 & 2 & 1 & 1 & 2.5 YR $5 / 6$ & 1 & 2 & 1 & & 2 y $3>, 4$ & 3 & $3 a 4$ & Q trasl, mica, sed rosas y bl, sed rojas & Q-fel & 4 \\
\hline RH19-7 & Sup & & 103 & 1 & 2 & 1 & 1 & 2 & 2 & 3 & 2.5 YR $5 / 8$ y $4 / 0$ (nuc) & 1 & 2 & 1 & & 4 y $5>, 1$ y 2 & 2 & $3 a 4$ & Q trasl, sed marrones y rojas & Q fel, mica fina & 4 \\
\hline TA1-1 & 103 & 1 & & 1 & 2 & 2 & 1 & 2 & 2 & 1 & 5YR 5/4 & 1 & 2 & 1 & 2 & 2 y $3>, 4$ & 2 & $2 \mathrm{a} 3$ & Q abund, mica abund & sed rojas, sed bl o fel alt & 2 \\
\hline TA1-1 & 103 & 1 & & 1 & 2 & 2 & 1 & 2 & 2 & 1 & 5YR 5/3 & 1 & 2 & 1 & 2 & 2 y $3>, 4$ & 2 & $2 \mathrm{a} 3$ & Q abund, mica abund & sed rojas, sed bl o fel alt & 2 \\
\hline TA1-1 & 103 & 1 & & 1 & 2 & 1 & 1 & 2 & 2 & 1 & $5 Y R 5 / 4$ & 1 & 2 & 1 & 1 & 2 y $3>, 1$ y 4 & 1 & $2 \mathrm{a} 3$ & Q abund, mica abund & sed rojas, sed bl o fel alt & 2 \\
\hline
\end{tabular}




\begin{tabular}{|c|c|c|c|c|c|c|c|c|c|c|c|c|c|c|c|c|c|c|c|c|c|}
\hline \multirow[b]{2}{*}{$\begin{array}{c}\text { Sitio y } \\
\text { est }\end{array}$} & \multirow[b]{2}{*}{ UP } & \multirow[b]{2}{*}{ GF } & \multirow[b]{2}{*}{ FNA } & \multicolumn{4}{|c|}{ Fractura } & \multirow[b]{2}{*}{$\begin{array}{ll}\text { Ca } \\
\text { vid }\end{array}$} & \multirow{2}{*}{\multicolumn{2}{|c|}{\begin{tabular}{|l|l|l|l|l|l|l|} 
Coc & có́n \\
lor
\end{tabular}}} & \multirow[b]{2}{*}{ Not color } & \multicolumn{7}{|c|}{ Inclusiones } & \multicolumn{2}{|c|}{ Composic } & \multirow[b]{2}{*}{ GP } \\
\hline & & & & $\begin{array}{c}\text { Aspec } \\
\text { to }\end{array}$ & \begin{tabular}{|l|l|} 
& $\begin{array}{l}\text { Tex } \\
\text { tura }\end{array}$ \\
\end{tabular} & $\begin{array}{l}\text { Resis } \\
\text { tenc. }\end{array}$ & $\begin{array}{l}\mathbf{R e} \\
\text { gul }\end{array}$ & & & & & Incl & Dens & $\begin{array}{c}\text { Orien } \\
\text { tac }\end{array}$ & $\begin{array}{l}\text { Orient } \\
\text { pared }\end{array}$ & Granul & $\begin{array}{l}\mathrm{Se} \\
\text { lec }\end{array}$ & $\begin{array}{l}\mathrm{Re} \\
\mathrm{don}\end{array}$ & comp mayor & comp aislados & \\
\hline TA1-1 & 103 & 1 & & 1 & 2 & 1 & 1 & 2 & 2 & 1 & 5 YR 5/3 & 1 & 2 & 1 & 1 & 2 y $3>, 4$ & 2 & $2 \mathrm{a} 3$ & Q abund, mica abund & sed rojas, sed bl o fel alt & 2 \\
\hline TA1-1 & 103 & 1 & & 1 & 2 & 1 & 1 & 2 & 2 & 4 & $5 Y R 3 / 1,4 / 3$ & 1 & 2 & 1 & 1 & 2 y $3>, 1$ y 4 & 1 & $2 \mathrm{a} 3$ & Q abund, mica abund & sed rojas, sed bl o fel alt & 2 \\
\hline TA1-1 & 103 & 1 & & 1 & 2 & 2 & 1 & 2 & 2 & 1 & $5 Y R 4 / 3$ & 1 & 2 & 1 & 1 & 2 у $3>, 4$ & 2 & $2 \mathrm{a} 3$ & Q abund, mica abund & sed rojas, sed bl o fel alt & 2 \\
\hline TA1-1 & 103 & 1 & & 1 & 2 & 2 & 1 & 2 & 2 & 1 & $5 Y R 5 / 4$ & 1 & 2 & 1 & 2 & 2 y $3>, 1$ y 4 & 1 & $2 \mathrm{a} 3$ & Q abund, mica abund & sed rojas, sed bl o fel alt & 2 \\
\hline TA1-1 & 103 & 1 & & 1 & 2 & 1 & 1 & 2 & 2 & 1 & 5YR 5/4 & 1 & 2 & 1 & 2 & 2 y $3>, 4$ & 2 & $2 \mathrm{a} 3$ & Q abund, mica abund & sed rojas, sed bl o fel alt, Q-fel & 2 \\
\hline TA1-1 & 103 & 1 & & 1 & 2 & 1 & 1 & 2 & 2 & 1 & 5YR 5/4 & 1 & 2 & 1 & 1 & 2 у $3>, 4$ & 2 & $2 \mathrm{a} 3$ & Q abund, mica abund & sed rojas, sed bl o fel alt & 2 \\
\hline TA1-1 & 202 & 1 & & 1 & 2 & 2 & 1 & 2 & 2 & 4 & $5 Y R 2,5 / 1,5 / 3$ & 1 & 2 & 1 & 2 & 2 y $3>, 1$ y 4 & 1 & $2 \mathrm{a} 3$ & Q abund, mica abund & sed rojas, sed bl o fel alt & 2 \\
\hline TA1-1 & 103 & 2 & & 1 & 2 & 1 & 1 & 2 & 2 & 4 & $2,5 Y R \quad 4 / 1,5 / 6$ & 1 & 2 & 1 & 0 & 2 y $3>, 4$ y 5 & 1 & $3 a 4$ & sed bl abund, Q & sed rosas, mica fina & 3 \\
\hline TA1-1 & 103 & 2 & & 1 & 2 & 1 & 1 & 2 & 2 & 4 & $2,5 Y R \quad 4 / 1,5 / 6$ & 1 & 2 & 1 & 0 & 2 y $3>, 4$ y 5 & 1 & $3 a 4$ & sed bl abund, Q & sed rojas, mica fina & 3 \\
\hline TA1-1 & 103 & 2 & & 1 & 2 & 1 & 2 & 2 & 1 & 1 & $2,5 Y R$ 6/6 & 1 & 2 & 1 & 1 & 2 y $3>, 4$ & 2 & $3 a 4$ & sed bl abund, Q & sed rojas, mica fina & 3 \\
\hline TA1-1 & 103 & 2 & & 1 & 2 & 1 & 1 & 2 & 1 & 4 & $2,5 Y R$ \%/6 & 1 & 2 & 1 & 0 & 2 y $3>, 4$ & 2 & $3 a 4$ & sed bl abund, Q & sed rojas, mica fina & 3 \\
\hline TA1-1 & 103 & 3 & & 1 & 2 & 1 & 1 & 2 & 2 & 1 & $5 Y R \quad 4 / 2$ & 1 & 2 & 1 & 2 & 3 y $4>, 5$ & 3 & $2 \mathrm{a} 3$ & mica, sed bl y Q & sed rojas y moradas & 4 \\
\hline TA1-1 & 103 & 3 & & 1 & 2 & 2 & 1 & 2 & 2 & 1 & 5YR 3/1 & 1 & 2 & 1 & 2 & 2 y $3>, 4$ & 2 & $2 \mathrm{a} 3$ & mica, sed bl y grises & sed rojas y $\mathrm{Q}$ & 4 \\
\hline TA1-1 & 103 & 3 & & 1 & 2 & 1 & 1 & 2 & 2 & 1 & $5 Y R 5 / 2$ & 1 & 2 & 2 & 2 & 2 y $3>, 4$ & 2 & $2 \mathrm{a} 3$ & mica, Q, sed bl & sed rojas y moradas & 4 \\
\hline TA1-1 & 103 & 4 & & 1 & 2 & 2 & 1 & 2 & 2 & 1 & 5YR 3/1 & 1 & 2 & 2 & 2 & 2 y $3>, 4$ & 2 & $2 \mathrm{a} 3$ & Q abund, mica abund & sed bl o fel alt, sed grises & 2 \\
\hline TA1-1 & 103 & 4 & & 1 & 2 & 2 & 1 & 2 & 2 & 4 & $5 Y R 3 / 1,5 / 4$ & 1 & $2 \mathrm{a} 3$ & 1 & 2 & 2 у $3>, 4$ & 2 & $2 \mathrm{a} 3$ & Q abund, mica abund & sed bl o fel alt, sed grises & 2 \\
\hline TA1-1 & 103 & 4 & & 1 & 2 & 2 & 1 & 2 & 1 & 1 & 5YR $5 / 3$ & 1 & 2 & 1 & 2 & 3 y $4>, 1$ y 2 & 1 & $2 \mathrm{a} 3$ & Q abund, mica abund & sed bl o fel alt, sed rojas & 2 \\
\hline TA1-1 & 103 & 5 & & 1 & 2 & 1 & 1 & 2 & 2 & 4 & 5YR 6/6, 7.5YR 6/2 & 1 & 2 & 1 & 0 & 3 y $4>, 2$ & 2 & $3 a 4$ & sed bl abund, Q, mica & sed rojas y rosas & 3 \\
\hline TA1-1 & 103 & 6 & & 1 & 2 & 1 & 1 & 2 & 1 & 1 & 5YR 5/6 & 2 & 1 & 1 & 0 & 4 y $5>, 3$ & 4 & $3 a 4$ & sed bl, Q & mica, sed rojas y rosas & 3 \\
\hline TA1-1 & 103 & 7 & & 1 & 2 & 2 & 1 & 2 & 2 & 1 & $5 Y R 5 / 4$ & 1 & $2 \mathrm{a} 3$ & 1 & 1 & 3 y $4>, 2$ & 2 & $2 \mathrm{a} 3$ & Q abund, mica abund & sed bl o fel alt & 2 \\
\hline TA1-1 & 103 & 7 & & 1 & 2 & 2 & 1 & 2 & 2 & 1 & 5YR 5/4 & 1 & 2 & 1 & 1 & 3 y $4>, 2$ & 2 & $2 \mathrm{a} 3$ & Q abund, mica, sed bl o fel alt & sed rojas & 2 \\
\hline TA1-1 & 102 & & 1 & 1 & 2 & 2 & 1 & 2 & 3 & 1 & N 2,5/ & 1 & 2 & 1 & 1 & 3 y $4>, 2$ & 2 & $3 a 4$ & $\mathrm{Q}$, mica, sed grises & sed marrones, sed bl o fel alt & 4 \\
\hline TA1-1 & 202 & & $2 / 3$ & 1 & 2 & 1 & 1 & 2 & 1 & 1 & $2,5 Y R 5 / 6$ & 1 & 1a2 & 1 & 1 & 4 y $5>, 3$ & 4 & $2 a 3$ & Q, mica, sed bl o fel alt, sed rojas & & 4 \\
\hline TA1-1 & 103 & & $4 / 5$ & 1 & 2 & 2 & 1 & 2 & 1 & 1 & $2,5 Y R$ 5/6 & 2 & 2 & 1 & 1 & 4 y $5>, 3$ & 3 & $2 \mathrm{a} 4$ & Q, mica, sed marrones y rojas & sed bl o fel alt & 4 \\
\hline TA1-1 & 103 & & 6 & 1 & 2 & 2 & 1 & $2 \mathrm{y} 1$ & 2 & 1 & $5 Y R 5 / 3$ & 1 & 2 & 1 & 1 & 3 y $4>, 2$ & 2 & $2 \mathrm{a} 3$ & Q abund, mica, sed bl o fel alt & sed rojas & 2 \\
\hline TA1-1 & 103 & & 7 & 1 & 2 & 1 & 1 & 2 & 2 & 4 & $2,5 Y R$ 5/6, 7,5YR 5/4 & 1 & 2 & 1 & 1 & 3 y $4>, 2$ & 2 & 2a4 & Q, mica, sed rojas & sed bl o fel alt & 4 \\
\hline TA1-1 & 103 & & 8 & 1 & 2 & 1 & 1 & 2 & 4 & 4 & $5 Y R \quad 4 / 3, N 2.5 /$ & 1 & 2 & 1 & 2 & 3 y $4>, 2$ & 3 & $3 a 4$ & Q abund, mica, sed marrones y grises & sed bl o fel alt & 2 \\
\hline TA1-1 & 103 & & 9 & 1 & 2 & 2 & 1 & $2 \mathrm{y} 1$ & 4 & 4 & 7,5YR 5/2; N 3/ & 1 & 2 & 1 & 1 & 3 y $4>, 1$ y 2 & 1 & $3 a 4$ & Q, sed rojas y marrones, mica & sed bl o fel alt & 4 \\
\hline TA1-1 & 103 & & 10 & 1 & 2 & 1 & 1 & 2 & 2 & 4 & $5 Y R \quad 4 / 2,3 / 1$ & 1 & 2 & 2 & 1 & 4 y $5>, 2$ & 2 & $2 \mathrm{a} 4$ & mica abund, Q, sed rojas & sed bl o fel alt & 1 \\
\hline TA1-1 & 202 & & 11 & 1 & 2 & 1 & 1 & 2 & 1 & 1 & $2,5 Y R 5 / 6$ & 1 & 2 & 1 & 1 & 3 y $4>, 2$ & 2 & $3 a 4$ & sed bl abund, sed rojas, $\mathrm{Q}$ & mica fina & 3 \\
\hline TA1-1 & 103 & & $12 / 13$ & 1 & 2 & 1 & 1 & 2 & 2 & 4 & $2,5 Y R$ 4/4, 3/1 & 1 & 2 & 1 & 1 & 3 y $4>, 1$ & 1 & $2 \mathrm{a} 4$ & Q abund, sed rojas y marrones & mica, sed bl & 4 \\
\hline TA1-1 & 202 & & 14 & 1 & 2 & 2 & 1 & 2 & 2 & 5 & $5 Y R 5 / 4,4 / 2$ & 1 & 2 & 1 & 2 & 1 y $2>, 4$ & 1 & $2 \mathrm{a} 4$ & mica muy abund, Q abund & sed rojas y sed bl o fel alt & 1 \\
\hline TA1-1 & 103 & & 15 & 1 & 2 & 2 & 1 & 2 & 2 & 1 & 7,5 YR $5 / 3$ & 1 & 2 & 1 & 2 & 1 y $2>, 4$ & 1 & 2a4 & mica muy abund, Q abund & sed rojas y sed bl o fel alt & 1 \\
\hline TA1-1 & 103 & & 18 & 1 & 2 & 1 & 1 & 2 & 2 & 4 & N 2.5/, 5YR 4/3 & 1 & 2 & 1 & 1 & 3 y $4>, 2$ & 2 & $3 a 4$ & Q muy abund, mica & sed bl o fel alt, Q-fel & 2 \\
\hline TA1-1 & 201 & & 19 & 1 & 2 & 2 & 1 & 2 & 2 & 1 & $5 Y R 5 / 3$ & 1 & 2 & 1 & 2 & 3 y $4>, 2$ & 2 & $3 a 4$ & Q abund, mica & sed rojas, Q-fel & 2 \\
\hline TA1-1 & 103 & & 20 & 1 & 2 & 2 & 1 & 2 & 2 & 4 & $2,5 Y R 4 / 3,2,5 / 1$ & 1 & 2 & 1 & 1 & 3 y $4>, 1$ y 2 & 1 & $3 a 4$ & Q abund, mica, sed rojas & Q-fel & 2 \\
\hline
\end{tabular}




\begin{tabular}{|c|c|c|c|c|c|c|c|c|c|c|c|c|c|c|c|c|c|c|c|c|c|}
\hline \multirow[b]{2}{*}{$\begin{array}{c}\text { Sitio y } \\
\text { est }\end{array}$} & \multirow[b]{2}{*}{ UP } & \multirow[b]{2}{*}{ GF } & \multirow[b]{2}{*}{ FNA } & \multicolumn{4}{|c|}{ Fractura } & \multirow[b]{2}{*}{$\begin{array}{l}\text { Ca } \\
\text { vid }\end{array}$} & \multirow{2}{*}{\multicolumn{2}{|c|}{$\begin{array}{l}\text { Coc Co } \\
\text { ción lor }\end{array}$}} & \multirow[b]{2}{*}{ Not color } & \multicolumn{7}{|c|}{ Inclusiones } & \multicolumn{2}{|c|}{ Composic } & \multirow[b]{2}{*}{ GP } \\
\hline & & & & $\begin{array}{c}\text { Aspec } \\
\text { to }\end{array}$ & \begin{tabular}{|l|l|} 
& $\begin{array}{l}\text { Tex } \\
\text { tura }\end{array}$ \\
\end{tabular} & $\begin{array}{l}\text { Resis } \\
\text { tenc. }\end{array}$ & $\begin{array}{l}\mathbf{R e} \\
\text { gul }\end{array}$ & & & & & Incl & Dens & $\begin{array}{c}\text { Orien } \\
\text { tac }\end{array}$ & $\begin{array}{l}\text { Orient } \\
\text { pared }\end{array}$ & Granul & $\begin{array}{l}\mathrm{Se} \\
\mathrm{lec}\end{array}$ & $\begin{array}{l}\mathrm{Re} \\
\mathrm{don}\end{array}$ & comp mayor & comp aislados & \\
\hline TA1-1 & Sup & & 21 & 1 & 2 & 1 & 1 & 2 & 1 & 1 & 2,5 YR 5/6 & 1 & 2 & 1 & 2 & 3 y $4>, 2$ & 2 & $3 a 4$ & Q abund, mica abund & Q-fel, sed rojas, sed bl o fel alt & 2 \\
\hline TA1-1 & Sup & & 22 & 1 & 2 & 1 & 1 & 2 & 2 & 5 & $5 Y R 5 / 4,6 / 4$ (nuc) & 1 & 2 & 1 & 1 & 3 y $4>, 2$ & 2 & $3 a 4$ & Q abund, mica & sed rojas, sed bl o fel alt & 2 \\
\hline TA1-1 & Sup & & 23 & 1 & 2 & 2 & 1 & 2 & 1 & 1 & 5YR 5/4 & 1 & 2 & 1 & 1 & 4 y $5>, 3$ & 3 & $3 a 4$ & Q, mica, sed rojas y bl & sed rosas & 4 \\
\hline TA1-1 & Sup & & 24 & 1 & 2 & 1 & 1 & 2 & 1 & 1 & 2,5 YR $5 / 6$ & 1 & 1a2 & 1 & 1 & 4 y $5>$ & 4 & $3 a 4$ & Q, sed rojas y bl & mica fina, Q-fel & 4 \\
\hline TA1-1 & Sup & & 25 & 1 & 2 & 2 & 1 & 2 & 2 & 4 & $2,5 Y R$ 3/2, 2,5/1 & 1 & 2 & 1 & 1 & 3 y $4>, 2$ & 2 & $3 a 4$ & Q muy abund, mica & sed rojas, sed bl y grises & 2 \\
\hline TA1-1 & Sup & & 26 & 1 & 2 & 1 & 1 & 2 & 2 & 4 & $7,5 Y R$ 4/, 5/2 & 1 & 2 & 1 & 1 & 3 y $4>, 2$ & 2 & $3 a 4$ & Q abund, mica, sed bl o fel alt & sed rojas, Q-fel & 2 \\
\hline TA1-1 & Sup & & 27 & 1 & 2 & 1 & 1 & 2 & 1 & 1 & 5YR 5/4 & 1 & 2 & 1 & 1 & 2 y $3>, 1$ & 1 & $3 a 4$ & Q muy abund, mica & sed rojas, Q-fel & 2 \\
\hline TA1-1 & Sup & & 28 & 1 & 2 & 1 & 1 & 2 & 2 & 5 & $5 Y R$ 5/4, 4/1 (nuc) & 1 & 2 & 1 & 1 & 2 у $3>, 4$ & 2 & $3 a 4$ & Q abund, mica abund & sed rojas & 2 \\
\hline TA1-1 & Sup & & 29 & 1 & 2 & 1 & 1 & 2 & 1 & 1 & 5YR 5/4 & 1 & 2 & 1 & 2 & 3 y $4>, 2$ & 2 & $2 \mathrm{a} 4$ & mica abund, $\mathrm{Q}$ & sed rojas, sed bl y grises & 1 \\
\hline $\mathrm{SC} 3$ & Sup & & 1 & 1 & 2 & 1 & 1 & 2y1 & 1 & 1 & 5YR 6/6 & 1 & 2 & 2 & 1 & 4 y $5>, 3$ & 3 & $4 a 5$ & sed bl y rosadas & mica, Q, sed rojas & 3 \\
\hline $\mathrm{SC} 3$ & Sup & & 2 & 1 & 2 & 1 & 2 & 2 & 1 & 1 & $2,5 Y R 5 / 6$ & 2 & 1 & 2 & 1 & 4 y $5>, 3$ & 4 & $3 a 4$ & sed grises, mica & $x$ & 5 \\
\hline $\mathrm{SC} 3$ & Sup & & 3 & 1 & 2 & 1 & 1 & 2 & 1 & 1 & $2,5 Y R$ T/6 & 2 & 1 & 1 & 1 & $5>, 4$ & 5 & $3 a 4$ & Q, mica, sed bl o fel alt & Q-fel, incl negras & 5 \\
\hline $\mathrm{SC} 3$ & Int & & 4 & 1 & 2 & 1 & 1 & 2 & 2 & 4 & $2,5 Y R \quad 4 / 1,4 / 4$ & 1 & 2 & 1 & 1 & 3 y $4>$ & 3 & $4 a 5$ & sed grises y marrones, $\mathrm{Q}$ & sed rojas, mica fina, Q-fel & 8 \\
\hline $\mathrm{SC} 3$ & Sup & & 5 & 1 & 2 & 1 & 1 & 2 & 1 & 1 & $2,5 Y R$ 5/6 & 1 & 1 & 1 & 0 & 3 y $4>, 2$ & 2 & $3 a 4$ & sed grises y marrones & mica fina, sed bl o fel alt & 8 \\
\hline $\mathrm{SC} 3$ & Sup & & 6 & 1 & 2 & 1 & 1 & 2 & 2 & 4 & $5 Y R$ 5/4, 4/2 & 2 & 1 & 1 & 1 & 4 y $5>, 3$ & 4 & $3 a 4$ & mica abund, sed grises y bl & Q, sed rojas & 5 \\
\hline $\mathrm{SC} 3$ & Ext & & 7 & 1 & 2 & 1 & 1 & 2 & 2 & 3 & 2,5YR 5/6, 4/1 (nuc) & 1 & 2 & 1 & 0 & 4 y $5>, 3$ & 3 & $4 a 5$ & sed bl y grises & mica fina, sed rojas, $Q$ & 3 \\
\hline $\mathrm{SC} 3$ & Int & & 9 & 1 & 2 & 1 & 2 & $2 \mathrm{y1}$ & 1 & 1 & 2,5 YR 5/8 & 2 & 1 & 1 & 0 & 4 y $5>, 3$ & 3 & $3 a 4$ & sed bl o fel alt, grises, Q, mica fina & Q-fel & 5 \\
\hline $\mathrm{SC} 3$ & Sup & & 10 & 1 & 2 & 2 & 1 & $2 \mathrm{y} 1$ & 2 & 4 & $5 Y R$ 3/1, 4/3 & 2 & 1a2 & 1 & 1 & 4 y $5>, 3$ & 3 & $4 a 5$ & mica, Q, sed bl o fel alt, rojas & Q-fel & 8 \\
\hline $\mathrm{SC} 3$ & Sup & & 11 & 1 & 2 & 1 & 1 & 2 & 1 & 1 & 5YR 6/8 & 1 & 2 & 1 & 1 & 3 y $4>, 2$ & 2 & $4 a 5$ & sed bl y grises, $Q$, mica fina & sed rojas, Q-fel & 3 \\
\hline SC 3 & Ext & & 12 & 1 & 2 & 1 & 1 & 2 & 2 & 5 & $2,5 Y R$ 5/4, 5/1 (nuc) & 1 & 2 & 2 & 1 & 4 y $5>, 3$ & 3 & $4 a 5$ & sed bl y grises, $\mathrm{Q}$, mica fina & sed rojas, Q-fel & 3 \\
\hline $\mathrm{SC} 3$ & Sup & & 13 & 1 & 2 & 1 & 1 & 2 & 1 & 1 & 5YR 6/6 & 1 & 2 & 1 & 1 & 4 y $5>, 1$ & 2 & $3 a 5$ & sed bl, mica abund, Q & sed rojas y osc, Q-fel & 3 \\
\hline $\mathrm{SC} 3$ & Int & & 14 & 1 & 2 & 1 & 1 & 2 & 2 & 5 & $2,5 Y R$ 5/6, 4/1 (nuc) & 2 & 2 & 1 & 0 & 4 y $5>$ & 4 & $4 a 5$ & sed rojas y grises, $Q$, mica fina & & 8 \\
\hline SC 3 & Int & & 15 & 1 & 2 & 1 & 1 & 2 & 2 & 5 & $2,5 Y R 5 / 6,6 / 1$ (nuc) & 1 & 2 & 1 & 1 & 3 y $4>, 1$ & 1 & $3 a 4$ & sed grises, rojas y bl o fel alt, Q & mica fina, Q-fel & 8 \\
\hline $\mathrm{SC} 3$ & Int & & 16 & 1 & 2 & 1 & 1 & 2 & 2 & 5 & $2,5 Y R$ 6/6, 6/1 (nuc) & 1 & 2 & 1 & 1 & 4 y $5>, 2$ & 2 & $3 a 4$ & sed grises, rojas y bl o fel alt, $\mathrm{Q}$ & mica fina, Q-fel, incl negras & 8 \\
\hline SC 3 & Int & & 17 & 1 & 2 & 1 & 1 & 2 & 2 & 5 & 2,5YR5/6; 5YR7/4(nuc) & 1 & 2 & 1 & 1 & 4 y $5>, 1$ y 2 & 1 & $3 a 4$ & sed grises, rojas y bl o fel alt, $Q$ & mica fina, Q-fel, incl negras & 8 \\
\hline $\mathrm{SC} 3$ & Sup & & 18 & 1 & 2 & 1 & 1 & $2 \mathrm{y} 1$ & 2 & 4 & $5 Y R \quad 4 / 3,5 / 4$ & 1 & 2 & 1 & 1 & 3 y $4>, 1$ & 1 & $3 a 4$ & sed grises, rojas y bl o fel alt, $Q$ & Q-fel, incl negras & 8 \\
\hline $\mathrm{SC} 3$ & Sup & & 19 & 1 & 2 & 1 & 1 & $2 \mathrm{y} 1$ & 2 & 5 & 2,5YR5/6; 5YR6/3(nuc) & 1 & 2 & 1 & 1 & 3 y $4>, 2$ & 2 & $3 a 4$ & sed rojas y grises, bl o fel alt, $Q$ & mica fina, Q-fel & 8 \\
\hline $\mathrm{SC} 3$ & Int & & 20 & 1 & 2 & 1 & 1 & $2 \mathrm{y} 1$ & 1 & 1 & 2,5 YR $5 / 6$ & 1 & 1 & 1 & 1 & 3 y $4>, 2$ y 5 & 2 & $3 a 5$ & sed bl, rojas y rosas & mica fina, $\mathrm{Q}$ & 3 \\
\hline $\mathrm{SC} 3$ & Int & & 21 & 1 & 2 & 1 & 1 & 2 & 2 & 5 & $2,5 Y R$ 5/6, 6/2 (nuc) & 1 & 2 & 1 & 1 & 3 y $4>, 5$ & 3 & $3 a 4$ & sed bl, rojas, grises, Q & mica fina & 3 \\
\hline $\mathrm{SC} 3$ & Sup & & $22 / 23$ & 1 & 2 & 2 & 1 & 2 & 2 & 1 & 5YR 4/2 & 1 & $2 \mathrm{a} 3$ & 1 & 1 & 2 y $3>, 4$ & 2 & $3 a 4$ & sed bl muy abund & sed rojas, Q, mica fina & 3 \\
\hline $\mathrm{SC} 3$ & Sup & & 24 & 1 & 2 & 2 & 1 & 2 & 2 & 4 & $5 Y R$ 3/1, 5/2 & 1 & 2 & 1 & 1 & 2 у $3>, 1$ & 1 & $3 a 4$ & sed bl, marrones y grises & Q, sed rojas, mica fina & 8 \\
\hline SC 3 & Sup & & 25 & 1 & 2 & 1 & 1 & 2 & 1 & 1 & 2,5 YR 5/6 & 1 & 2 & 1 & 1 & 3 y $4>, 2$ & 2 & $3 a 4$ & sed bl, rojas y rosas & Q, mica fina, Q-fel & 3 \\
\hline SC 3 & Int & & 26 & 1 & 2 & 1 & 1 & 2 & 1 & 1 & 2,5 YR $5 / 6$ & 1 & 2 & 1 & 0 & 2 y $3>, 4$ & 2 & $3 a 4$ & sed grises, marrones y blancas & Q, mica fina & 8 \\
\hline $\mathrm{SC} 3$ & Ext & & 29 & 1 & 2 & 2 & 1 & 2 & 2 & 1 & $2,5 Y R 5 / 1$ & 1 & 2 & 1 & 1 & 2 y $3>, 4$ & 2 & $3 a 4$ & sed bl abund, sed marrones y rojas & Q, Q-fel, mica fina & 3 \\
\hline $\mathrm{SC} 3$ & Ext & & 30 & 1 & 2 & 1 & 1 & $2 \mathrm{y} 1$ & 1 & 1 & $2,5 Y R 5 / 6$ & 2 & 1 & 1 & 0 & 5 & 5 & $4 a 5$ & sed bl, rojas, $\mathrm{Q}$ & mica fina & 5 \\
\hline SC 3 & Sup & & 31 & 1 & 2 & 1 & 1 & $2 \mathrm{y} 1$ & 1 & 1 & 2,5 YR $5 / 6$ & 2 & 1 & 1 & 0 & 5 & 5 & $4 a 5$ & sed bl, rojas, Q & mica fina & 5 \\
\hline
\end{tabular}




\begin{tabular}{|c|c|c|c|c|c|c|c|c|c|c|c|c|c|c|c|c|c|c|c|c|c|}
\hline \multirow[b]{2}{*}{$\begin{array}{c}\text { Sitio y } \\
\text { est }\end{array}$} & \multirow[b]{2}{*}{ UP } & \multirow[b]{2}{*}{ GF } & \multirow[b]{2}{*}{ FNA } & \multicolumn{4}{|c|}{ Fractura } & \multirow[b]{2}{*}{\begin{tabular}{|l|l} 
Ca \\
vid
\end{tabular}} & \multirow{2}{*}{\multicolumn{2}{|c|}{\begin{tabular}{|l|l|l|l|l|l|l|l} 
Coc \\
ción lor
\end{tabular}}} & \multirow[b]{2}{*}{ Not color } & \multicolumn{7}{|c|}{ Inclusiones } & \multicolumn{2}{|c|}{ Composic } & \multirow[b]{2}{*}{ GP } \\
\hline & & & & $\begin{array}{c}\text { Aspec } \\
\text { to }\end{array}$ & \begin{tabular}{|l|} 
\\
Tex \\
tura
\end{tabular} & $\begin{array}{l}\text { Resis } \\
\text { tenc. }\end{array}$ & $\begin{array}{l}\mathrm{Re} \\
\text { gul }\end{array}$ & & & & & Incl & Dens & $\begin{array}{c}\text { Orien } \\
\text { tac }\end{array}$ & $\begin{array}{l}\text { Orient } \\
\text { pared }\end{array}$ & Granul & $\begin{array}{l}\mathrm{Se} \\
\mathrm{lec}\end{array}$ & $\begin{array}{l}\mathrm{Re} \\
\mathrm{don}\end{array}$ & comp mayor & comp aislados & \\
\hline SC 3 & Sup & & 32 & 1 & 2 & 1 & 1 & $2 \mathrm{y} 1$ & 1 & 1 & 2,5 YR 5/6 & 2 & 1 & 1 & 0 & 5 & 5 & $4 a 5$ & sed bl, rojas, Q & mica fina & 5 \\
\hline $\mathrm{SC} 3$ & Int & & 33 & 1 & 2 & 1 & 1 & $2 \mathrm{y} 1$ & 1 & 1 & 2,5 YR $5 / 6$ & 2 & 1 & 1 & 0 & 5 & 5 & $4 a 5$ & sed bl, rojas, $\mathrm{Q}$ & mica fina & 5 \\
\hline SC 3 & Sup & & 34 & 1 & 2 & 1 & 1 & 2 & 2 & 4 & $5 Y R \quad 4 / 1,5 / 2$ & 1 & 2 & 1 & 1 & 3 y $4>, 2$ & 2 & $3 a 5$ & sed marrones, grises y rojas, $Q$ & mica fina & 8 \\
\hline $\mathrm{SC} 3$ & Sup & & 35 & 1 & 2 & 1 & 1 & 2 & 2 & 5 & $2.5 Y R$ 4/1, 4/4 (nuc) & 1 & 1a2 & 1 & 1 & 3 y $4>, 2$ & 2 & $3 a 4$ & sed bl, rojas y marrones & Q, Q-fel, mica fina & 3 \\
\hline SC 3 & Sup & & 36 & 1 & 2 & 1 & 1 & 2 & 2 & 5 & $2,5 Y R$ 5/6, 5/1 (nuc) & 1 & 2 & 1 & 1 & 2 y $3>, 4$ & 2 & $3 a 5$ & sed marrones y rojas, $\mathrm{Q}$ & sed bl, mica fina, Q-fel & 8 \\
\hline SC 3 & Sup & & 37 & 1 & 2 & 1 & 1 & 2 & 2 & 4 & $5 Y R$ 5/4, 5/1 & 2 & 1 & 1 & 0 & 5 & 5 & $4 a 5$ & sed bl, grises y rojas & mica fina, Q-fel & 5 \\
\hline SC 3 & Sup & & 38 & 1 & 2 & 1 & 1 & 2 & 2 & 5 & $5 Y R 6 / 3,5 / 1$ (nuc) & 1 & 2 & 1 & 1 & 3 y $4>, 2$ & 3 & $3 a 5$ & sed bl abund, sed rojas & mica fina, $\mathrm{Q}$ & 3 \\
\hline $\mathrm{SC} 3$ & Sup & & $39-42$ & 1 & 2 & 1 & 1 & 2 & 1 & 1 & 2,5 YR $5 / 6$ & 2 & 1 & 1 & 0 & 5 & 5 & $4 a 5$ & sed bl y rojas & mica fina & 5 \\
\hline SC 3 & Sup & & 43 & 1 & 2 & 1 & 1 & 2 & 2 & 4 & $2,5 Y R$ 5/6, 5/2 & 1 & 2 & 1 & 0 & 3 y $4>, 2$ & 3 & $3 a 4$ & sed bl abund, marrones y rojas & Q, mica fina & 3 \\
\hline SC 3 & Sup & & $44 / 45$ & 1 & 2 & 1 & 1 & 2 & 1 & 1 & $2,5 Y R 5 / 6$ & 1 & 2 & 1 & 0 & 3 y $4>, 2$ & 3 & $3 a 4$ & sed bl, marrones, rojas, grises & Q, mica fina, Q-fel & 8 \\
\hline SC 3 & Sup & & 46 & 1 & 2 & 1 & 1 & 2 & 2 & 4 & 2,5YR 5/6; 5YR 6/6 & 1 & 2 & 1 & 0 & 4 y 5,3 & 3 & $3 a 5$ & Q abund, sed marrones, rojas y bl & Q-fel, mica fina & 2 \\
\hline SC 3 & Sup & & 47 & 1 & 2 & 2 & 1 & 2 & 1 & 1 & $2,5 Y R$ 5/6 & 1 & 2 & 1 & 0 & 3 y $4>, 2$ & 2 & $3 a 4$ & sed marrones, rojas y grises & Q, mica fina & 8 \\
\hline SC 3 & Sup & & 48 & 1 & 2 & 1 & 1 & 2 & 2 & 4 & $2,5 Y R$ 5/6, 5/4 & 2 & 1 & 2 & 0 & 4 y $5>$ & 4 & $3 a 4$ & sed marrones y grises, $\mathrm{Q}$ & mica fina & 5 \\
\hline SC 3 & Int & & 49 & 1 & 2 & 2 & 1 & 2 & 1 & 1 & $2,5 Y R 6 / 4$ & 1 & 2 & 1 & 1 & 2 y $3>$ & 3 & $3 a 5$ & sed bl, marrones, rojas, Q & Q-fel, mica fina & 8 \\
\hline SC 3 & Int & & 50 & 1 & 2 & 1 & 1 & 2 & 1 & 1 & $2,5 Y R 5 / 6$ & 1 & 2 & 1 & 0 & 4 y $5>, 2$ & 3 & $3 a 4$ & sed bl, marrones y rojas & Q, mica fina, Q-fel & 3 \\
\hline SC 3 & Int & & 51 & 1 & 2 & 1 & 1 & 2 & 2 & 5 & 5YR 6/4, 3/1 (nuc) & 2 & $1 \mathrm{a} 2$ & 2 & 0 & 4 y $5>$ & 3 & $3 a 4$ & sed bl, marrones y rojas, Q & mica fina & 8 \\
\hline $\mathrm{SC} 3$ & Ext & & 53 & 1 & 2 & 1 & 1 & 2 & 1 & 1 & 2,5 YR $6 / 6$ & 1 & 2 & 1 & 1 & 4 y $5>, 3$ & 3 & $3 a 4$ & sed bl abund, sed rojas & Q-fel,mica fina & 3 \\
\hline SC 3 & Ext & & 54 & 1 & 2 & 1 & 1 & 2 & 2 & 1 & 5YR 5/1 & 2 & 2 & 1 & 1 & 4 y $5>$ & 4 & $3 a 5$ & Q abund, sed grises & mica fina & 8 \\
\hline $\mathrm{SC} 3$ & Sup & & 55 & 1 & 2 & 2 & 1 & 2 & 2 & 5 & $5 Y R$ 6/6, 6/1 (nuc) & 1 & 2 & 1 & 1 & 2 y $3>, 4$ & 2 & $3 a 4$ & sed bl, rojas, $\mathrm{Q}$ & mica, Q-fel & 3 \\
\hline $\mathrm{SC} 3$ & Int & & 56 & 1 & 2 & 1 & 1 & 2 & 2 & 4 & $5 Y R 5 / 3,4 / 2$ & 1 & 2 & 1 & 1 & 2 y $3>, 4$ & 2 & $3 a 4$ & sed rojas, marrones y bl, Q & mica fina. Q-fel & 8 \\
\hline SC 3 & Int & & 57 & 1 & 2 & 1 & 1 & 2 & 2 & 5 & 2,5YR6/6; 5YR5/1(nuc) & 1 & $1 \mathrm{a} 2$ & 1 & 1 & 3 y $4>, 2$ & 2 & $3 a 4$ & sed bl abund, sed rojas & Q, mica fina, Q-fel & 3 \\
\hline $\mathrm{SC} 3$ & Ext & & 58 & 1 & 2 & 1 & 1 & $2 \mathrm{y} 1$ & 1 & 1 & $5 Y R 5 / 6$ & 1 & 2 & 1 & 1 & 3 y $4>, 2$ & 2 & $3 a 4$ & sed bl, grises y rojas & Q, mica fina & 3 \\
\hline SC 3 & Sup & & $59 / 60$ & 1 & 2 & 1 & 1 & 2 & 1 & 1 & 5YR 6/4 & 2 & 2 & 1 & 2 & 4 y $5>$ & 4 & $3 a 4$ & sed bl, mica, Q & sed rojas y grises, Q-fel & 3 \\
\hline SC 3 & Sup & & 61 & 1 & 2 & 1 & 2 & 2 & 2 & 4 & $5 Y R$ 6/6, 5/1 & 1 & 2 & 2 & 1 & 3 y $4>, 2$ & 2 & $3 a 5$ & sed bl, grises, $\mathrm{Q}$ & sed rojas, mica fina, Q-fel & 3 \\
\hline SC 3 & Int & & 62 & 1 & 2 & 1 & 1 & 2 & 1 & 1 & 5YR 5/4 & 2 & 1 & 1 & 0 & 5 & 5 & $4 a 5$ & sed rojas, bl, mica fina & $x$ & 5 \\
\hline SC 3 & Sup & & 63 & 1 & 2 & 1 & 1 & 2 & 2 & 5 & $5 Y R 5 / 4,4 / 1$ (nuc) & 1 & 2 & 1 & 1 & 3 y $4>, 2$ & 2 & $3 a 4$ & sed bl, rojas, marrones, mica, Q & Q-fel & 8 \\
\hline SC 3 & Ext & & 64 & 1 & 2 & 1 & 1 & 2 & 1 & 1 & $2,5 Y R$ 4/6 & 2 & 2 & 2 & 1 & 4 y $5>, 3$ & 3 & $3 a 4$ & sed bl abund, rojas y rosadas & Q, mica fina & 3 \\
\hline $\mathrm{SC} 3$ & Int & & 65 & 1 & 2 & 2 & 1 & 2 & 1 & 1 & 2,5 YR $4 / 4$ & 1 & 2 & 1 & 2 & $5>$ & 4 & $3 a 5$ & Q abund, mica & sed bl o fel alt, Q-fel & 2 \\
\hline $\mathrm{SC} 3$ & Int & & 66 & 1 & 2 & 1 & 1 & 2 & 1 & 1 & 5YR 6/6 & 1 & 2 & 1 & 1 & 3 y $4>, 2$ & 4 & $3 a 5$ & sed bl, rojas, Q & mica fina, Q-fel & 8 \\
\hline SC 3 & Sup & & 67 & 1 & 2 & 2 & 1 & 2 & 2 & 1 & $5 Y R 5 / 2$ & 1 & 2 & 1 & 1 & 2 y $3>, 4$ & 2 & $3 a 4$ & sed bl y grises abund, $\mathrm{Q}$ & mica fina, Q-fel & 3 \\
\hline SC 3 & Sup & & 68 & 1 & 2 & 1 & 1 & 2 & 1 & 1 & 5YR 6/4 & 1 & 2 & 1 & 1 & $4 y 5>, 2$ & 2 & $3 a 4$ & sed bl abund, mica, Q & Q-fel & 3 \\
\hline SC 3 & Ext & & 69 & 1 & 2 & 1 & 1 & 2 & 2 & 5 & $5 Y R$ 4/1, 5/3 (nuc) & 1 & 2 & 1 & 1 & 3 y $4>, 2$ & 2 & $3 a 4$ & sed bl abund, sed rojas & Q, mica fina & 3 \\
\hline $\mathrm{SC} 3$ & Sup & & 70 & 1 & 2 & 1 & 1 & 2 & 1 & 1 & 2,5 YR $5 / 6$ & 1 & $1 \mathrm{a} 2$ & 1 & 0 & 3 y $4>, 1$ y 2 & 1 & $3 a 4$ & sed marrones y grises & sed bl o fel alt, mica fina & 8 \\
\hline $\mathrm{SC} 3$ & Sup & & 73 & 1 & 2 & 1 & 1 & 2 & 2 & 1 & 5 YR $4 / 2$ & 2 & $1 \mathrm{a} 2$ & 1 & 0 & 3 y $4>$ & 3 & $3 a 4$ & sed marrones abund, sed bl, Q & Q- fel, mica fina & 8 \\
\hline SC 3 & Ext & & 74 & 1 & 2 & 1 & 1 & 2 & 2 & 5 & $5 Y R 5 / 4,4 / 2$ (nuc) & 2 & 1a2 & 1 & 0 & 3 y $4>$ & 3 & $3 a 4$ & sed marrones abund, sed bl, Q & Q-fel, mica fina & 8 \\
\hline SC 3 & Ext & & 75 & 1 & 2 & 1 & 1 & 2 & 2 & 1 & $2,5 Y R 5 / 1$ & 2 & 1 & 1 & 0 & 4 y $5>$ & 4 & $3 a 5$ & sed marrones, grises, bl o fel alt, Q-fel & mica & 5 \\
\hline
\end{tabular}




\begin{tabular}{|c|c|c|c|c|c|c|c|c|c|c|c|c|c|c|c|c|c|c|c|c|c|}
\hline \multirow[b]{2}{*}{$\begin{array}{c}\text { Sitio y } \\
\text { est }\end{array}$} & \multirow[b]{2}{*}{ UP } & \multirow[b]{2}{*}{ GF } & \multirow[b]{2}{*}{ FNA } & \multicolumn{4}{|c|}{ Fractura } & \multirow[b]{2}{*}{$\begin{array}{ll}\text { Ca } \\
\text { vid }\end{array}$} & \multirow{2}{*}{\multicolumn{2}{|c|}{\begin{tabular}{|l|l|l|l|l|l|l|l} 
Coc \\
ción lor
\end{tabular}}} & \multirow[b]{2}{*}{ Not color } & \multicolumn{7}{|c|}{ Inclusiones } & \multicolumn{2}{|c|}{ Composic } & \multirow[b]{2}{*}{ GP } \\
\hline & & & & $\begin{array}{c}\text { Aspec } \\
\text { to }\end{array}$ & \begin{tabular}{|l|l|} 
& $\begin{array}{l}\text { Tex } \\
\text { tura }\end{array}$ \\
\end{tabular} & $\begin{array}{l}\text { Resis } \\
\text { tenc. }\end{array}$ & $\begin{array}{l}\mathrm{Re} \\
\text { gul }\end{array}$ & & & & & Incl & Dens & $\begin{array}{c}\text { Orien } \\
\text { tac }\end{array}$ & $\begin{array}{l}\text { Orient } \\
\text { pared }\end{array}$ & Granul & $\begin{array}{l}\mathrm{Se} \\
\text { lec }\end{array}$ & $\begin{array}{l}\mathrm{Re} \\
\mathrm{don}\end{array}$ & comp mayor & comp aislados & \\
\hline SC 3 & Ext & & 76 & 1 & 2 & 1 & 1 & $2 \mathrm{y} 1$ & 2 & 1 & $5 Y R 4 / 2$ & 1 & 2 & 1 & 1 & 2 y $3>, 1$ & 2 & $3 a 4$ & sed marrones, rojas y bl & Q, mica fina & 8 \\
\hline $\mathrm{SC} 3$ & Sup & & 77 & 1 & 2 & 1 & 1 & $2 \mathrm{y} 1$ & 1 & 1 & $5 Y R 7 / 6$ & 1 & 2 & 1 & 1 & 3 y $4>, 1$ y 2 & 1 & $3 a 4$ & sed bl abund, sed rojas & Q-fel, mica fina & 3 \\
\hline SC 3 & Sup & & 78 & 1 & 2 & 1 & 1 & 2 & 1 & 1 & 2,5 YR $5 / 4$ & 1 & 2 & 1 & 1 & 4 y $5>, 3$ & 3 & $3 a 5$ & sed bl abund, rojas y rosadas & Q, mica fina, fel alt? & 3 \\
\hline $\mathrm{SC} 3$ & Int & & $79-81$ & 1 & 2 & 1 & 1 & 2 & 1 & 1 & 5YR 6/6 & 1 & 2 & 1 & 1 & 2 y $3>, 1$ & 2 & $3 a 4$ & sed bl abund, rojas y rosadas & mica fina, Q-fel & 3 \\
\hline SC 3 & Sup & & 82 & 1 & 2 & 1 & 1 & 2 & 2 & 1 & $5 Y R \quad 4 / 2$ & 1 & 2 & 1 & 1 & 2 y $3>, 4$ & 2 & $3 a 4$ & sed marrones, rojas y bl, Q & mica fina, Q-fel & 8 \\
\hline $\mathrm{SC} 3$ & Sup & & 83 & 1 & 2 & 1 & 1 & 2 & 2 & 5 & $2,5 Y R$ 5/6, 5/2 (nuc) & 2 & 2 & 1 & 1 & 3 y $4>, 2$ & 2 & $3 a 4$ & sed marrones, rojas y bl & mica fina, Q-fel & 8 \\
\hline $\mathrm{SC} 3$ & Int & & 84 & 1 & 2 & 1 & 1 & 2 & 1 & 1 & $2,5 Y R$ K/6 & 1 & 2 & 1 & 1 & 3 y $4>, 2$ & 2 & $3 a 4$ & sed bl abund, rojas y rosadas & mica fina, Q-fel & 3 \\
\hline SC 3 & Ext & & 85 & 1 & 2 & 1 & 1 & 2 & 2 & 1 & 5YR 4/1 & 1 & $1 \mathrm{a} 2$ & 2 & 0 & 1 y $2>, 3$ & 2 & $3 a 4$ & sed grises, bl y rosaddas & Q, mica fina & 8 \\
\hline $\mathrm{SC} 3$ & Int & & 86 & 1 & 2 & 1 & 1 & 2 & 2 & 1 & 5YR 4/1 & 1 & 1a2 & 1 & 0 & 1 y $2>, 3$ & 2 & $3 a 4$ & sed grises, bl, rosadas y rojas & Q, mica fina & 8 \\
\hline $\mathrm{SC} 3$ & Sup & & 87 & 1 & 2 & 1 & 1 & 2 & 1 & 1 & $2,5 Y R 6 / 4$ & 1 & 2 & 1 & 1 & 2 y $3>, 1$ & 2 & $3 a 4$ & sed bl y rojas abund & Q, mica fina & 3 \\
\hline SC 3 & Ext & & 88 & 1 & 2 & 2 & 1 & $2 \mathrm{y} 1$ & 2 & 4 & $5 Y R$ 6/4, 4/1 & 1 & 2 & 1 & 0 & 2 y $3>$ & 2 & $3 a 4$ & sed bl abund, sed rojas & Q-fel, mica fina & 3 \\
\hline SC 3 & Ext & & 89 & 1 & 2 & 2 & 1 & $2 \mathrm{y} 1$ & 1 & 1 & $5 Y R 6 / 4$ & 1 & 2 & 1 & 1 & 2 у $3>, 4$ & 2 & $3 a 4$ & sed bl abund, rojas y grises, $\mathrm{Q}$ & Q-fel, mica fina & 3 \\
\hline $\mathrm{SC} 3$ & Int & & 90 & 1 & 2 & 1 & 1 & $2 \mathrm{y} 1$ & 1 & 1 & 5YR 6/6 & 1 & 2 & 1 & 1 & 3 y $4>, 1$ y 2 & 1 & $3 a 4$ & sed bl abund, rojas y marrones & Q-fel, mica fina & 3 \\
\hline SC 3 & Ext & & 91 & 1 & 2 & 1 & 1 & 2 & 2 & 4 & $5 Y R$ 6/6, 4/1 & 1 & 2 & 1 & 1 & 3 y $4>, 1$ y 2 & 1 & $3 a 4$ & sed bl abund, rojas, Q & Q-fel, mica fina & 3 \\
\hline SC 3 & Int & & 92 & 1 & 2 & 1 & 1 & 2 & 2 & 4 & $5 Y R$ 5/4, 4/2 & 1 & 2 & 1 & 1 & 2 y $3>, 1$ & 2 & $3 a 4$ & sed marrones y rojas abund, bl, Q & Q-fel & 8 \\
\hline SC 3 & Sup & & 93 & 1 & 2 & 1 & 1 & 2 & 2 & 3 & $5 Y R 5 / 4,4 / 1,6 / 4$ & 1 & $1 \mathrm{a} 2$ & 1 & 0 & 4 y $5>, 2$ & 2 & $3 a 5$ & sed bl y grises abund, rojas & Q, mica fina & 3 \\
\hline SC 3 & Sup & & 95 & 1 & 2 & 1 & 1 & 2 & 1 & 1 & 5YR 5/4 & 1 & 2 & 1 & 1 & 4 y $5>$ & 4 & $3 a 5$ & Q abund, sed bl o fel alt & sed rojas, mica fina & 2 \\
\hline SC 3 & Sup & & 96 & 1 & 2 & 2 & 1 & 2 & 2 & 1 & $5 Y R 5 / 3$ & 1 & $2 \mathrm{a} 3$ & 1 & 2 & 4 y $5>, 3$ & 3 & $3 a 5$ & mica abund, $\mathrm{Q}$ & sed rojas & 1 \\
\hline SC 3 & Sup & & 97 & 1 & 2 & 2 & 1 & 2 & 3 & 1 & $5 Y R 3 / 1$ & 2 & 2 & 1 & 1 & 4 y $5>$ & 3 & $3 a 4$ & mica abund, Q & sed rojas y bl o fel alt & 1 \\
\hline SC 3 & Sup & & 98 & 1 & 2 & 2 & 1 & 2 & 1 & 4 & $2,5 Y R \quad 6 / 4,5 / 6$ & 1 & 2 & 1 & 1 & 3 y $4>, 1$ & 2 & $3 a 5$ & sed bl, rojas y marrones, $\mathrm{Q}$ & Q-fel, mica fina & 3 \\
\hline SC 3 & Sup & & 99 & 1 & 2 & 1 & 1 & 2 & 1 & 1 & 5YR 5/4 & 1 & 2 & 1 & 1 & 3 y $4>, 1$ y 2 & 1 & $3 a 5$ & sed bl, rojas y marrones, $\mathrm{Q}$ & Q- fel, mica fina & 3 \\
\hline SC 3 & Int & & 100 & 1 & 2 & 2 & 1 & 2 & 2 & 1 & $5 Y R 4 / 3$ & 2 & 2 & 1 & 1 & 3 y $4>, 2$ & 2 & $3 a 4$ & sed marrones, grises y bl & Q, mica fina & 8 \\
\hline SC 3 & Sup & & 101 & 1 & 2 & 2 & 1 & 2 & 2 & 1 & $5 Y R$ T/2 & 1 & 2 & 1 & 1 & 4 y $5>, 3$ & 3 & $3 a 4$ & sed bl, Q, sed rojas & mica fina, Q-fel & 3 \\
\hline SC 3 & Sup & & 102 & 1 & 2 & 1 & 1 & 2 & 2 & 4 & 2,5 YR $4 / 2,5 / 6$ & 1 & 2 & 1 & 1 & 3 y $4>, 2$ & 2 & $3 a 4$ & sed bl abund, sed rojas, Q & mica fina, Q-fel & 3 \\
\hline SC 3 & Sup & & 103 & 1 & 2 & 1 & 1 & 2 & 1 & 1 & $5 Y R 6 / 6$ & 1 & 2 & 1 & 1 & 2 y $3>, 4$ & 2 & $3 a 4$ & sed bl abund, rosadas y rojas & Q, mica fina, Q-fel & 3 \\
\hline SC 3 & Sup & & 104 & 1 & 2 & 2 & 1 & 2 & 3 & 1 & N 2,5/ & 2 & 2 & 1 & 1 & 3 y $4>, 2$ & 2 & $3 a 5$ & Q abund, mica, sed bl & Q-fel & 2 \\
\hline SC 3 & Sup & & 105 & 1 & 2 & 1 & 1 & 2 & 2 & 4 & $2,5 Y R \quad 4 / 1,5 / 4$ & 1 & $1 \mathrm{a} 2$ & 1 & 1 & 3 y $4>$ & 3 & $3 a 4$ & sed bl, grises y rojas, $\mathrm{Q}$ & mica fina, Q-fel & 3 \\
\hline SC 3 & Sup & & 106 & 1 & 2 & 2 & 1 & 2 & 2 & 4 & $5 Y R$ 4/3, 5/6 & 2 & 1 & 1 & 0 & 4 y $5>, 2$ & 2 & $3 a 5$ & sed rojas, mica & $\mathrm{Q}$, sed bl & 5 \\
\hline SC 3 & Int & & 107 & 1 & 2 & 1 & 1 & 2 & 2 & 5 & 2,5YR5/6; 5YR6/3(nuc) & 1 & 2 & 1 & 1 & 2 y $3>, 1$ & 2 & $3 a 5$ & sed bl, grises, rosadas y rojas & Q, mica fina & 3 \\
\hline SC 3 & Sup & & 108 & 1 & 2 & 1 & 1 & $2 \mathrm{y} 1$ & 2 & 4 & $5 Y R 3 / 1,5 / 2$ & 2 & 1a2 & 1 & 0 & 3 y $4>$ & 3 & $3 a 4$ & sed grises, bl y marrones & mica fina, Q-fel & 8 \\
\hline SC 3 & Sup & & 109 & 1 & 2 & 1 & 1 & 2 & 2 & 5 & 2,5YR6/6, 5YR5/2(nuc) & 2 & 2a3 & 2 & 1 & 2 y $3>, 4$ & 2 & $2 \mathrm{a} 4$ & sed bl o fel alt abund, Q y mica abund & Q-fel & 3 \\
\hline SC 3 & Ext & & 110 & 1 & 2 & 1 & 1 & 2 & 2 & 1 & 5YR 5/4 & 1 & 2 & 1 & 1 & 1 y $2>, 3$ & 1 & $3 a 4$ & sed marrones, bl y rojas & Q, Q-fel, mica fina & 8 \\
\hline SC 3 & Sup & & 111 & 1 & 2 & 2 & 1 & 2 & 2 & 1 & $5 Y R 3 / 2$ & 2 & 2 & 1 & 0 & 3 y $4>, 2$ & 2 & $3 a 4$ & sed grises y marrones, $Q$ & mica fina, $Q$-fel & 8 \\
\hline SC 3 & Int & & 114 & 1 & 2 & 1 & 1 & 2 & 1 & 1 & $2,5 Y R$ T/6 & 1 & 2 & 1 & 1 & 1 y $2>, 3$ & 2 & $3 a 4$ & sed marrones, grises y bl. Q & Q-fel, mica fina & 8 \\
\hline SC 3 & Ext & & 115 & 1 & 2 & 1 & 1 & 2 & 2 & 5 & $5 Y R$ 4/3, 3/1, 5/4 & 1 & 1a2 & 1 & 1 & 3 y $4>, 2$ & 2 & $3 a 5$ & Q abund, sed rojas y rosas & mica fina, Q-fel & 2 \\
\hline SC 3 & Sup & & 116 & 1 & 2 & 1 & 1 & 2 & 2 & 4 & $5 Y R 5 / 4,7 / 6$ & 1 & 2 & 1 & 1 & 3 y $4>, 2$ & 2 & $3 a 4$ & sed bl abund, sed rojas, $\mathrm{Q}$ & mica fina, incl osc, Q-fel & 3 \\
\hline
\end{tabular}




\begin{tabular}{|c|c|c|c|c|c|c|c|c|c|c|c|c|c|c|c|c|c|c|c|c|c|}
\hline \multirow[b]{2}{*}{$\begin{array}{c}\text { Sitio y } \\
\text { est }\end{array}$} & \multirow[b]{2}{*}{ UP } & \multirow[b]{2}{*}{ GF } & \multirow[b]{2}{*}{ FNA } & \multicolumn{4}{|c|}{ Fractura } & \multirow[b]{2}{*}{$\begin{array}{l}\text { Ca } \\
\text { vid }\end{array}$} & \multirow{2}{*}{\multicolumn{2}{|c|}{$\begin{array}{l}\text { Coc Co } \\
\text { ción lor }\end{array}$}} & \multirow[b]{2}{*}{ Not color } & \multicolumn{7}{|c|}{ Inclusiones } & \multicolumn{2}{|c|}{ Composic } & \multirow[b]{2}{*}{ GP } \\
\hline & & & & $\begin{array}{c}\text { Aspec } \\
\text { to }\end{array}$ & \begin{tabular}{|l|l|} 
& $\begin{array}{l}\text { Tex } \\
\text { tura }\end{array}$ \\
\end{tabular} & $\begin{array}{l}\text { Resis } \\
\text { tenc. }\end{array}$ & $\begin{array}{l}\mathbf{R e} \\
\text { gul }\end{array}$ & & & & & Incl & Dens & $\begin{array}{c}\text { Orien } \\
\text { tac }\end{array}$ & $\begin{array}{l}\text { Orient } \\
\text { pared }\end{array}$ & Granul & $\begin{array}{l}\mathrm{Se} \\
\mathrm{lec}\end{array}$ & $\begin{array}{l}\mathrm{Re} \\
\mathrm{don}\end{array}$ & comp mayor & comp aislados & \\
\hline $\mathrm{SC} 3$ & Ext & & 117 & 1 & 2 & 1 & 1 & 2 & 2 & 2 & $2,5 Y R$ 5/6, 4/1 & 2 & 1 & 1 & 0 & 3 y $4>$ & 3 & $3 a 4$ & sed grises y rojas, $\mathrm{Q}$ & mica fina, Q-fel & 8 \\
\hline $\mathrm{SC} 3$ & Int & & 118 & 1 & 2 & 1 & 1 & 2 & 2 & 5 & $5 Y R$ 6/4; N 3/ (nuc) & 2 & 1a2 & 1 & 0 & 4 y $5>, 2$ & 2 & $3 a 4$ & sed bl y grises, rojas & mica fina, Q- fel & 3 \\
\hline SC 3 & Int & & 119 & 1 & 2 & 1 & 1 & 2 & 2 & 4 & 2,5 YR $5 / 6,7 / 3$ & 2 & 2 & 1 & 1 & 4 y $5>, 2$ & 2 & $3 a 4$ & sed bl abund, Q, sed rojas & mica, Q-fel & 3 \\
\hline $\mathrm{SC} 3$ & Ext & & 120 & 1 & 2 & 1 & 1 & 2 & 2 & 4 & $5 Y R$ 4/1, 6/4 & 1 & 2 & 1 & 0 & 3 y $4>, 2$ & 2 & $3 a 5$ & sed marrones, rojas y bl, Q & mica, Q-fel & 8 \\
\hline SC 3 & Ext & & 121 & 1 & 2 & 1 & 1 & 2 & 2 & 1 & 5YR 4/1 & 1 & 1a2 & 1 & 0 & 3 y $4>, 2$ & 2 & $3 a 4$ & sed bl y grises abund, y rojas, $Q$ & mica, Q-fel & 3 \\
\hline SC 3 & Int & & 122 & 1 & 2 & 1 & 1 & 2 & 2 & 4 & $5 Y R \quad 4 / 1,5 / 3$ & 2 & $1 \mathrm{a} 2$ & 1 & 0 & 4 y $5>, 3$ & 3 & $3 a 4$ & sed grises, marrones y rojas, $\mathrm{Q}$ & mica fina, Q-fel & 8 \\
\hline SC 3 & Int & & 123 & 1 & 2 & 1 & 1 & 2 & 1 & 1 & $2,5 Y R$ 4/4 & 2 & $1 \mathrm{a} 2$ & 1 & 0 & 3 y $4>, 2$ & 2 & $3 a 4$ & sed rojas, marrones y bl, Q & mica fina, Q-fel & 8 \\
\hline $\mathrm{SC} 3$ & Int & & 124 & 1 & 2 & 1 & 1 & 2 & 2 & 4 & 5YR 5/3; N 3/ & 1 & 2 & 1 & 0 & 2 у $3>$ & 2 & $3 a 4$ & sed marrones, grises y rojas, $Q$ & mica fina, Q-fel & 8 \\
\hline SC 3 & Ext & & 125 & 1 & 2 & 2 & 1 & 2 & 1 & 1 & 5YR 5/4 & 1 & 2 & 1 & 1 & 3 y $4>, 2$ & 2 & $3 a 4$ & sed bl abund, rojas, $\mathrm{Q}$ & mica fina, Q-fel & 3 \\
\hline SC 3 & Sup & & 126 & 1 & 2 & 2 & 1 & 2 & 1 & 1 & $2,5 Y R 5 / 6$ & 2 & 1 & 1 & 0 & 4 y $5>$ & 4 & $3 a 4$ & Q, mica, sed bl o fel alt & $\mathrm{x}$ & 5 \\
\hline SC 3 & Ext & & 127 & 1 & 2 & 1 & 1 & 2 & 1 & 1 & $2,5 Y R 6 / 6$ & 1 & 2 & 1 & 1 & 4 y $5>, 2$ & 2 & $3 a 4$ & sed rojas y bl, Q & mica, Q-fel & 8 \\
\hline SC 3 & Int & & 128 & 1 & 2 & 1 & 2 & 2 & 1 & 1 & $2,5 Y R$ 6/6 & 1 & 2 & 1 & 1 & 3 y $4>, 2$ & 2 & $3 a 5$ & sed bl abund, sed rosadas y rojas & mica fina, Q, Q-fel & 3 \\
\hline SC 3 & Sup & & 129 & 1 & 2 & 2 & 1 & 2 & 1 & 1 & 5YR 6/4 & 1 & 2 & 1 & 2 & 3 y $4>, 2$ & 2 & $3 a 4$ & mica y Q abund & sed rojas, Q-fel & 1 \\
\hline $\mathrm{SC} 3$ & Sup & & 130 & 1 & 2 & 1 & 1 & 2 & 1 & 1 & $2,5 Y R 5 / 6$ & 1 & 2 & 1 & 1 & 2 y $3>, 1$ & 2 & $3 a 4$ & sed bl, grises y rojas & Q-fel, mica fina & 8 \\
\hline SC 3 & Int & & 131 & 1 & 2 & 1 & 1 & 2 & 2 & 5 & 2,5 YR 5/6, 4/2 (nuc) & 1 & 1 & 1 & 0 & 3,4 y 5 & 3 & $3 a 4$ & sed bl, rojas & Q, mica fina & 5 \\
\hline SC 3 & Int & & 132 & 1 & 2 & 2 & 1 & 2 & 1 & 1 & $2,5 Y R$ 5/6 & 1 & 2 & 1 & 1 & 3 y $4>, 2$ & 2 & $3 a 4$ & sed bl, rosadas, grises y rojas & mica fina, Q-fel & 8 \\
\hline $\mathrm{SC} 3$ & Int & & 134 & 1 & 2 & 1 & 1 & 2 & 2 & 4 & $5 Y R 4 / 1,5 / 3$ & 1 & 2 & 1 & 1 & 3 y $4>, 2$ & 2 & $3 a 4$ & sed rojas abund, sed bl, Q, mica & Q-fel & 8 \\
\hline SC 3 & Int & & 135 & 1 & 2 & 1 & 1 & 2 & 2 & 4 & $2,5 Y R 5 / 6,6 / 4$ & 1 & 2 & 1 & 1 & 3 y $4>, 2$ & 2 & $3 a 4$ & sed rojas, marrones y bl & Q, mica fina & 8 \\
\hline $\mathrm{SC} 3$ & Sup & & 136 & 1 & 2 & 1 & 1 & 2 & 1 & 1 & 2,5 YR $5 / 4$ & 1 & 2 & 1 & 1 & 2 y $3>, 4$ & 2 & $3 a 4$ & sed bl abund, sed rojas, Q & mica fina, Q-fel & 3 \\
\hline $\mathrm{SC} 3$ & Sup & & 137 & 1 & 2 & 1 & 1 & 2 & 2 & 4 & $5 Y R$ 4/3, 2,5YR 5/6 & 1 & 2 & 1 & 1 & 2 y $3>, 4$ & 2 & $3 a 4$ & sed bl y grises abund, sed rojas, $\mathrm{Q}$ & mica fina, incl osc, Q-fel & 3 \\
\hline SC 3 & Ext & & 138 & 1 & 2 & 1 & 1 & 2 & 2 & 4 & $5 Y R \quad 4 / 4,6 / 4$ & 1 & 2 & 1 & 1 & 3 y $4>, 2$ & 2 & $3 a 4$ & sed bl abund, sed rojas & mica fina, Q-fel & 3 \\
\hline SC 3 & Sup & & 139 & 1 & 2 & 1 & 1 & $2 \mathrm{y} 1$ & 1 & 1 & $2,5 Y R 5 / 6$ & 2 & 2 & 1 & 1 & 3 y $4>, 2$ & 2 & $3 a 5$ & sed rojas y marrones abund, $\mathrm{Q}$ & sed bl, mica fina, Q-fel & 8 \\
\hline SC 3 & Sup & & 140 & 1 & 2 & 2 & 1 & $2 \mathrm{y} 1$ & 1 & 1 & 5YR 5/4 & 1 & 2a3 & 1 & 2 & 3 y $4>, 2$ & 2 & $2 \mathrm{a} 4$ & mica abund, $\mathrm{Q}$ abund & sed rojas, Q-fel & 1 \\
\hline SC 3 & Int & & 141 & 1 & 2 & 1 & 1 & 2 & 2 & 4 & $5 Y R$ 6/6, 2,5YR 5/6 & 1 & 2 & 1 & 1 & 3 y $4>, 2$ & 3 & $3 a 4$ & sed rojas, bl y grises, Q & mica fina, Q-fel & 8 \\
\hline SC 3 & Int & & 142 & 1 & 2 & 2 & 1 & 2 & 2 & 5 & 5YR 4/1, 5/4 (nuc) & 1 & 2 & 1 & 1 & 2 y 3,4 & 2 & $3 a 4$ & sed bl y grises, rojas & mica fina, Q-fel & 3 \\
\hline SC 3 & Int & & 143 & 1 & 2 & 1 & 1 & 2 & 1 & 1 & 5YR 5/4 & 2 & 1a2 & 1 & 1 & 4 y $5>$ & 4 & $3 a 5$ & Q abund, mica, sed bl & sed rojas, Q-fel & 2 \\
\hline SC 3 & Int & & 144 & 1 & 2 & 1 & 1 & 2 & 2 & 2 & 2,5YR 6/6; N 4/ & 1 & 1a2 & 1 & 1 & 3 y $4>, 2$ & 2 & $3 a 4$ & sed grises y bl, sed rojas, $\mathrm{Q}$ & mica fina, Q-fel & 3 \\
\hline $\mathrm{SC} 3$ & Ext & & 145 & 1 & 2 & 2 & 1 & 2 & 2 & 4 & 2,5 YR $3 / 1,5 / 4$ & 1 & 2a3 & 1 & 2 & 4 y $5>, 3$ & 3 & 2a4 & mica abund, Q abund & sed bl, sed rojas, Q-fel & 1 \\
\hline SC 3 & Ext & & 146 & 1 & 2 & 1 & 1 & 2 & 1 & 1 & 2,5 YR $5 / 6$ & 1 & 2 & 1 & 0 & 4 y $5>, 3$ & 3 & $3 a 5$ & sed bl abund, rosadas y rojas & $\mathrm{Q}$, mica & 3 \\
\hline SC 3 & Ext & & 147 & 1 & 2 & 2 & 1 & $2 \mathrm{y} 1$ & 1 & 1 & $2,5 Y R 4 / 6$ & 1 & 2 & 1 & 1 & 2 y $3>, 4$ & 2 & $3 a 4$ & sed rojas, rosadas y bl & Q, mica fina, Q-fel & 8 \\
\hline SC 3 & Int & & 148 & 1 & 2 & 2 & 1 & 2 & 2 & 1 & $5 Y R 4 / 2$ & 1 & 2 & 1 & 1 & 3 y $4>, 2$ & 2 & $3 a 4$ & sed marrones y rojas, sed bl, Q & mica fina, Q-fel & 8 \\
\hline SC 3 & Int & & 149 & 1 & 2 & 1 & 1 & 2 & 2 & 4 & 2,5 YR $4 / 2,4 / 6$ & 1 & 2 & 1 & 1 & 3 y $4>, 2$ & 2 & $3 a 4$ & sed bl abund, sed rojas y rosas & Q, mica fina & 3 \\
\hline $\mathrm{SC} 3$ & Sup & & 150 & 1 & 2 & 2 & 1 & 2 & 2 & 1 & 5 YR $4 / 3$ & 1 & 2 & 1 & 1 & 3 y $4>, 2$ & 2 & $3 a 4$ & sed bl abund, sed rojas & $\mathrm{Q}$, mica & 3 \\
\hline $\mathrm{SC} 3$ & Sup & & 153 & 1 & 2 & 1 & 1 & 2 & 2 & 5 & 5 YR $6 / 6,6 / 2$ (nuc) & 1 & 2 & 1 & 1 & 3 y $4>, 2$ & 2 & $3 a 4$ & Q abund, mica, sed bl & sed rojas, Q-fel & 2 \\
\hline SC 3 & Sup & & 154 & 1 & 2 & 1 & 1 & 2 & 2 & 4 & $\mathrm{~N} 3 /, 6 /$ & 1 & 2 & 1 & 0 & 4 y $5>, 1$ & 1 & $3 a 4$ & sed bl, marrones y rojas, Q & mica fina, Q-fel & 8 \\
\hline SC 3 & Sup & & 155 & 1 & 2 & 1 & 1 & 2 & 2 & 1 & $5 Y R 4 / 3$ & 1 & 2 & 1 & 1 & 2 y $3>, 1$ & 2 & $3 a 4$ & sed bl abund, marrones y rojas, Q & mica fina, Q-fel & 3 \\
\hline
\end{tabular}




\begin{tabular}{|c|c|c|c|c|c|c|c|c|c|c|c|c|c|c|c|c|c|c|c|c|c|}
\hline \multirow[b]{2}{*}{$\begin{array}{c}\text { Sitio y } \\
\text { est }\end{array}$} & \multirow[b]{2}{*}{ UP } & \multirow[b]{2}{*}{ GF } & \multirow[b]{2}{*}{ FNA } & \multicolumn{4}{|c|}{ Fractura } & \multirow{2}{*}{\multicolumn{3}{|c|}{\begin{tabular}{|l|l|l|l|l|l|} 
Ca & Coc \\
vid & ción & lor \\
\end{tabular}}} & \multirow[b]{2}{*}{ Not color } & \multicolumn{7}{|c|}{ Inclusiones } & \multicolumn{2}{|c|}{ Composic } & \multirow[b]{2}{*}{ GP } \\
\hline & & & & $\begin{array}{c}\text { Aspec } \\
\text { to }\end{array}$ & \begin{tabular}{|l|} 
\\
tex \\
tura
\end{tabular} & $\begin{array}{l}\text { Resis } \\
\text { tenc. }\end{array}$ & $\begin{array}{l}\mathrm{Re} \\
\text { gul }\end{array}$ & & & & & Incl & Dens & $\begin{array}{c}\text { Orien } \\
\text { tac }\end{array}$ & $\begin{array}{l}\text { Orient } \\
\text { pared }\end{array}$ & Granul & & $\begin{array}{c}\mathrm{Re} \\
\mathrm{don}\end{array}$ & comp mayor & comp aislados & \\
\hline SC 3 & Int & & 156 & 1 & 2 & 2 & 1 & 2 & 1 & 1 & 5YR 5/4 & 1 & 2 & 1 & 1 & 3 y $4>, 2$ & 2 & $3 a 4$ & sed marrones, rojas y grises, $\mathrm{Q}$ & mica fina, Q-fel & 8 \\
\hline SC 3 & Int & & 157 & 1 & 2 & 1 & 1 & 2 & 2 & 4 & $2,5 Y R$ 4/1, 5/4 & 1 & 2 & 1 & 1 & 2 y $3>, 1$ & 1 & $3 a 4$ & sed bl y grises abund, sed rojas, $\mathrm{Q}$ & mica fina, Q-fel & 3 \\
\hline SC 3 & Int & & 158 & 1 & 2 & 2 & 1 & $2 \mathrm{y} 1$ & 2 & 5 & 2,5YR4/6, 4/1(nuc) & 1 & 2 & 1 & 1 & 3 y $4>, 2$ & 2 & $3 a 4$ & sed marrones, rojas y bl & mica fina, Q-fel & 8 \\
\hline SC 3 & Ext & & 159 & 1 & 2 & 2 & 1 & 2 & 1 & 1 & $2,5 Y R$ 5/6 & 1 & 2 & 1 & 1 & 3 y $4>$ & 3 & $3 a 5$ & sed rojas, marrones y bl, Q & Q-fel, mica fina & 8 \\
\hline SC 3 & Ext & & 160 & 1 & 2 & 1 & 1 & 2 & 2 & 5 & 2,5YR 5/4, 4/1 (nuc) & 1 & 2 & 1 & 1 & 3 y $4>, 1$ y 2 & 1 & $3 a 4$ & sed bl, rojas y marrones & Q, mica fina, Q-fel & 8 \\
\hline SC 3 & Int & & 161 & 1 & 2 & 2 & 1 & 2 & 2 & 5 & 5YR 6/6, 5/1 (nuc) & 1 & 2 & 1 & 1 & 3 y $4>, 2$ & 2 & $3 a 5$ & sed rojas, marrones y bl, Q & Q-fel, mica fina & 8 \\
\hline SC 3 & Int & & 162 & 1 & 2 & 1 & 1 & 2 & 2 & 5 & 10R 4/1, 5/6 (nuc) & 1 & 2 & 1 & 0 & 4 y $5>, 2$ & 2 & $3 a 4$ & sed bl abund, sed rojas, Q & mica fina, Q-fel & 3 \\
\hline SC 3 & Int & & 163 & 1 & 2 & 1 & 1 & 2 & 2 & 4 & $5 Y R \quad 4 / 4,4 / 2$ & 1 & 2 & 1 & 1 & 3 y $4>, 1$ y 2 & 1 & $3 a 4$ & sed bl abund, sed rojas y marrones & Q, mica fina, Q-fel & 3 \\
\hline SC 3 & Int & & 164 & 1 & 2 & 1 & 1 & 2 & 2 & 1 & 5YR 5/4 & 2 & 2 & 1 & 1 & 4 y $5>$ & 4 & $3 a 5$ & sed marrones, grises y bl, $\mathrm{Q}$ & Q-fel, mica fina & 8 \\
\hline SC 3 & Ext & & 165 & 1 & 2 & 2 & 1 & 2 & 1 & 1 & 2,5YR 5/6 & 1 & 2 & 1 & 1 & 3 y $4>, 1$ y 2 & 1 & $3 a 4$ & sed rojas y marrones & sed bl, Q-fel, mica fina & 8 \\
\hline SC 3 & Int & & 166 & 1 & 2 & 1 & 1 & $2 \mathrm{y} 1$ & 2 & 5 & $5 Y R 4 / 4,5 / 2$ (nuc) & 1 & 2 & 1 & 1 & 3 y $4>, 1$ & 1 & $3 a 5$ & sed marrones y grises, $\mathrm{Q}$ & sed rojas, mica fina, Q-fel & 8 \\
\hline SC 3 & Int & & 167 & 1 & 2 & 2 & 1 & 2 & 2 & 4 & $2,5 Y R$ 4/1, 5/6 & 1 & 2 & 1 & 1 & 3 y $4>, 1$ y 2 & 1 & $3 a 4$ & sed bl abund, sed grises & Q, sed rojas, mica fina & 3 \\
\hline SC 3 & Ext & & 168 & 1 & 2 & 1 & 1 & 2 & 1 & 1 & $2,5 Y R 5 / 4$ & 1 & 2 & 1 & 1 & 3 y $4>, 2$ & 2 & $3 a 4$ & sed bl abund, sed marrones y rojas & Q, mica fina & 3 \\
\hline $\mathrm{SC} 3$ & Ext & & 169 & 1 & 2 & 2 & 1 & 2 & 3 & 1 & $\mathrm{~N} 3 /$ & 1 & 2 & 1 & 2 & 3 y $4>, 2$ & 2 & $3 a 4$ & Q y mica abund & sed bl o fel alt, Q-fel & 2 \\
\hline SC 3 & Ext & & 170 & 1 & 2 & 2 & 1 & 2 & 2 & 4 & 5YR $2,5 / 1,3 / 1$ & 1 & 2 & 1 & 2 & 3 y $4>, 2$ & 2 & $2 \mathrm{a} 4$ & mica abund y $\mathrm{Q}$ abund & Q- fel, sed rojas & 1 \\
\hline SC 3 & Int & & 171 & 1 & 2 & 1 & 1 & 2 & 2 & 4 & 2,5YR 5/6; 5YR 6/4 & 1 & 2 & 1 & 0 & 3 y $4>, 2$ & 2 & $3 a 4$ & sed bl abund, rosadas y rojas & mica fina, Q-fel & 3 \\
\hline $\mathrm{SC} 3$ & Int & & 173 & 1 & 2 & 2 & 1 & 2 & 2 & 5 & 2,5YR 4/1, 5/6 (nuc) & 1 & 2 & 1 & 1 & 3 y $4>, 2$ & 2 & $3 a 4$ & sed marrones, rojas y bl & Q, mica fina, Q-fel & 8 \\
\hline SC 3 & Ext & & 174 & 1 & 2 & 1 & 1 & 2 & 1 & 1 & 2,5YR 5/6 & 2 & 2 & 1 & 1 & 4 y $5>$ & 5 & $4 a 5$ & Q abund, incl osc indet & sed rojas, mica fina, Q-fel & 2 \\
\hline SC 3 & Int & & 175 & 1 & 2 & 1 & 1 & 2 & 2 & 1 & $5 Y R \quad 4 / 2$ & 1 & 2 & 1 & 1 & 2 y $3>, 4$ & 2 & $3 a 4$ & sed marrones, rojas, bl, Q & mica, Q-fel & 8 \\
\hline $\mathrm{SC} 3$ & Ext & & 176 & 1 & 2 & 1 & 1 & 2 & 1 & 1 & 2,5YR 4/6 & 1 & $1 \mathrm{a} 2$ & 1 & 1 & 3 y $4>, 2$ & 2 & $3 a 4$ & sed rojas, grises, mica & Q, Q-fel & 8 \\
\hline $\mathrm{SC} 3$ & Ext & & 177 & 1 & 2 & 1 & 1 & $2 \mathrm{y} 1$ & 1 & 1 & 5YR 5/6 & 2 & 2 & 1 & 1 & 4 y $5>, 3$ & 3 & $3 a 5$ & Q abund, sed bl y rosas, incl osc indet & mica, sed rojas, Q-fel & 9 \\
\hline SC 3 & Sup & & 178 & 1 & 2 & 1 & 1 & 2 & 1 & 1 & $2,5 Y R$ 5/6 & 2 & 2 & 1 & 0 & 4 y $5>$ & 4 & $4 a 5$ & Q abund, incl osc indet, mica, sed bl & sed rojas, Q-fel & 9 \\
\hline SC 3 & Int & & 179 & 1 & 2 & 1 & 1 & 2 & 1 & 1 & $2,5 Y R$ 5/6 & 1 & 2 & 1 & 1 & 4 y $5>, 3$ & 3 & $4 a 5$ & Q abund, sed rojas, mica & sed bl o fel alt, incl osc, Q-fel & 9 \\
\hline SC 3 & Sup & & 180 & 1 & 2 & 1 & 1 & 2 & 1 & 1 & $2,5 Y R$ 5/6 & 1 & 2 & 1 & 1 & 4 y $5>, 3$ & 3 & $3 a 5$ & Q abund, sed bl o fel alt, mica & incl osc indet, sed rojas, Q-fel & 9 \\
\hline SC 3 & Int & & 181 & 1 & 2 & 1 & 1 & 2 & 1 & 1 & $2,5 Y R \quad 4 / 6$ & 1 & 2 & 1 & 1 & 4 y $5>, 3$ & 3 & $3 a 5$ & Q abund, sed bl o fel alt, mica & incl osc indet, sed rojas, Q-fel & 9 \\
\hline SC 3 & Int & & 182 & 1 & 2 & 1 & 1 & 2 & 1 & 1 & $2,5 Y R$ 5/6 & 1 & 2 & 1 & 1 & 3 y $4>$ & 3 & $3 a 5$ & Q abund, sed bl o fel alt, sed rojas & incl osc indet, mica, Q-fel & 9 \\
\hline $\mathrm{SC} 3$ & Sup & & 183 & 1 & 2 & 1 & 1 & 2 & 1 & 1 & 10R 5/8 & 1 & 2 & 1 & 1 & 4 y $5>, 3$ & 3 & $3 a 5$ & Q abund, sed bl o fel alt, mica & incl osc indet, sed rojas, Q-fel & 9 \\
\hline $\mathrm{SC} 3$ & Sup & & 184 & 1 & 2 & 1 & 1 & 2 & 1 & 1 & 10R $5 / 8$ & 1 & 2 & 1 & 1 & 4 y $5>, 3$ & 3 & $3 a 5$ & Q abund, sed bl o fel alt, mica & incl osc indet, sed rojas, Q-fel & 9 \\
\hline SC 3 & Sup & & 185 & 1 & 2 & 1 & 1 & 2 & 2 & 1 & 10YR $7 / 4$ & 1 & 2 & 1 & 1 & 3 y $4>, 2$ & 2 & $3 a 4$ & Q, incl osc volc? & sed rojas, mica, Q-fel & ?? \\
\hline $\mathrm{SC} 3$ & Int & & 186 & 1 & 2 & 1 & 1 & 2 & 1 & 1 & 2,5 YR $5 / 6$ & 1 & 2 & 1 & 1 & 4 y $5>, 3$ & 3 & $3 a 5$ & Q abund, sed bl o fel atl, incl osc indet & mica, Q-fel, sed rojas & 9 \\
\hline SC 3 & Sup & & 187 & 1 & 2 & 1 & 2 & 2 & 1 & 1 & $2,5 Y R$ 5/6 & 1 & $1 \mathrm{a} 2$ & 1 & 1 & 4 y $5>, 3$ & 3 & $3 a 4$ & Q, mica, incl bl de Q-fel & incl osc indet & 9 \\
\hline SC 3 & Sup & & 188 & 1 & 2 & 1 & 1 & 2 & 1 & 1 & 10R 5/8 & 1 & $1 \mathrm{a} 2$ & 1 & 1 & 4 y $5>, 3$ & 3 & $3 a 4$ & Q, sed bl o fel alt, mica & Q-fel, incl osc indet & 9 \\
\hline $\mathrm{SC} 3$ & Sup & & 189 & 1 & 2 & 1 & 1 & 2 & 1 & 1 & 2,5YR 5/6 & 1 & 1 & 1 & 1 & 4 y $5>, 3$ & 3 & $3 a 4$ & Q, sed bl o fel alt, Q-fel & mica, incl osc indet & 9 \\
\hline $\mathrm{SC} 3$ & Sup & & 192 & 1 & 2 & 1 & 1 & 2 & 1 & 1 & $2,5 Y R$ 5/6 & 1 & 2 & 1 & 1 & 4 y $5>, 3$ & 3 & $3 a 4$ & Q abund, sed bl o fel alt, incl osc indet & mica, Q-fel, sed rojas & 9 \\
\hline $\mathrm{SC} 3$ & Ext & & 193 & 1 & 2 & 1 & 1 & 2 & 1 & 1 & $2,5 Y R 5 / 8$ & 1 & 2 & 1 & 1 & 4 y $5>, 2$ y 3 & 2 & $3 a 4$ & Q, sed bl o fel alt, incl osc indet & Q-fel, mica, sed rojas & 9 \\
\hline $\mathrm{SC} 3$ & Ext & & 194 & 1 & 2 & 1 & 1 & 2 & 1 & 1 & $2,5 Y R 5 / 8$ & 1 & 2 & 1 & 1 & 4 y $5>, 2$ & 2 & $3 a 5$ & Q, sed bl o fel alt, cuarc?. Incl osc indet & Q-fel, mica & 9 \\
\hline
\end{tabular}




\begin{tabular}{|c|c|c|c|c|c|c|c|c|c|c|c|c|c|c|c|c|c|c|c|c|c|}
\hline \multirow[b]{2}{*}{$\begin{array}{l}\text { Sitio y } \\
\text { est }\end{array}$} & \multirow[b]{2}{*}{ UP } & \multirow[b]{2}{*}{ GF } & \multirow[b]{2}{*}{ FNA } & \multicolumn{4}{|c|}{ Fractura } & \multirow[b]{2}{*}{\begin{tabular}{|l|} 
Ca \\
vid
\end{tabular}} & \multirow{2}{*}{\multicolumn{2}{|c|}{$\begin{array}{l}\text { Coc Co } \\
\text { ción lor }\end{array}$}} & \multirow[b]{2}{*}{ Not color } & \multicolumn{7}{|c|}{ Inclusiones } & \multicolumn{2}{|c|}{ Composic } & \multirow[b]{2}{*}{ GP } \\
\hline & & & & $\begin{array}{c}\text { Aspec } \\
\text { to }\end{array}$ & \begin{tabular}{|l|l|} 
& $\begin{array}{l}T e x \\
\text { tura }\end{array}$ \\
\end{tabular} & \begin{tabular}{|l} 
Resis \\
tenc.
\end{tabular} & $\begin{array}{l}\mathrm{Re} \\
\text { gul }\end{array}$ & & & & & Incl & Dens & $\begin{array}{c}\text { Orien } \\
\text { tac }\end{array}$ & $\begin{array}{l}\text { Orient } \\
\text { pared }\end{array}$ & Granul & \begin{tabular}{l|}
$\mathrm{Se}$ \\
lec
\end{tabular} & $\begin{array}{c}\mathbf{R e} \\
\text { don }\end{array}$ & comp mayor & comp aislados & \\
\hline SC 3 & Int & & 195 & 1 & 2 & 1 & 1 & 2 & 1 & 1 & $2,5 Y R \quad 4 / 4$ & 1 & 2 & 1 & 1 & 3 y $4>, 2$ & 2 & $3 a 4$ & sed bl, sed marrones y rojas & mica fina, Q-fel & 8 \\
\hline SC 3 & Ext & & 196 & 1 & 2 & 1 & 1 & 2 & 1 & 1 & $2,5 Y R$ 5/8 & 1 & 2 & 1 & 1 & 4 y $5>, 2$ y 3 & 2 & $3 a 4$ & Q abund, Q-fel, mica & incl osc indet, sed rojas & 9 \\
\hline SC 3 & Sup & & 197 & 1 & 2 & 1 & 1 & 2 & 1 & 1 & $2,5 Y R$ 5/8 & 1 & 2 & 1 & 1 & 4 y $5>$ & 4 & $3 a 5$ & Q, sed bl o fel alt, incl osc indet & mica, sed rojas, Q-fel & 9 \\
\hline TC 2 & Conj $\mathrm{A}$ & & 1 & 1 & 2 & 2 & 1 & 2 & 2 & 1 & 5YR 4/2 & 2 & 1a2 & 1 & 0 & 2 y $3>, 4$ & 2 & $3 a 4$ & $\mathrm{Q}$, sed grises y marrones & mica, sed rojas & 8 \\
\hline TC 2 & Conj A & & 2 & 1 & 2 & 1 & 1 & 2 & 1 & 1 & 10R 5/6 & 1 & 1a2 & 1 & 0 & 3 y $4>, 2$ & 2 & $3 a 4$ & sed bl abund, sed rosadas & mica, sed rojas & 3 \\
\hline TC 2 & Conj A & & 3 & 1 & 2 & 1 & 1 & $2 \mathrm{y} 1$ & 1 & 1 & $2,5 Y R$ 5/8 & 2 & 1 & 1 & 0 & 4 y $5>$ & 4 & $3 a 4$ & sed rojas, bl & mica fina & 5 \\
\hline TC 2 & Conj A & & 4 & 1 & 2 & 1 & 1 & 2 & 2 & 5 & 2,5YR 4/6, 4/3 (nuc) & 2 & 1 & 1 & 2 & 4 y $5>$ & 4 & $3 a 4$ & mica, sed rojas & sed bl & 5 \\
\hline TC 2 & Conj A & & 5 & 1 & 2 & 1 & 1 & 2 & 2 & 4 & 2,5 YR $5 / 6,5 / 2$ & 1 & 1a2 & 2 & 1 & 3 y $4>, 2$ & 2 & $2 \mathrm{a} 4$ & sed rojas, marrones, bl & mica fina & 8 \\
\hline TC 2 & Conj $\mathrm{A}$ & & 6 & 1 & 2 & 2 & 1 & 2 & 2 & 1 & $2,5 Y R \quad 4 / 2$ & 1 & 2 & 1 & 1 & 2 y $3>$ & 2 & $2 \mathrm{a} 4$ & sed bl, grises, marrones & Q, sed rojas, mica fina & 8 \\
\hline TC 2 & Conj A & & 7 & 1 & 2 & 1 & 1 & 2 & 2 & 4 & 2,5YR5/6; 7,5YR6/4 & 1 & 2 & 1 & 1 & 4 y $5>, 3$ & 3 & $3 a 4$ & Q abund, mica, sed bl & sed rojas & 2 \\
\hline TC 2 & Conj A & & 8 & 1 & 2 & 1 & 2 & 2 & 1 & 1 & $2,5 Y R$ 5/6 & 2 & 1 & 1 & 1 & 4 y $5>$ & 4 & $3 a 4$ & sed bl, rojas, Q & mica fina & 5 \\
\hline TC 2 & Conj A & & 9 & 1 & 2 & 1 & 2 & $2 \mathrm{y} 1$ & 1 & 1 & $10 R 5 / 6$ & 2 & 1 & 1 & 0 & 4 y $5>$ & 4 & $3 a 4$ & $\mathrm{Q}$, sed bl y rojas & mica fina & 5 \\
\hline TC 2 & Conj A & & 10 & 1 & 2 & 1 & 1 & 2 & 2 & 5 & 5YR 5/3, 4/1 (nuc) & 1 & 2 & 1 & 1 & 3 y $4>, 2$ & 2 & $3 a 4$ & sed bl, grises y rojas & mica fina & 8 \\
\hline TC 2 & Conj A & & 11 & 1 & 2 & 2 & 1 & $2 \mathrm{y} 1$ & 1 & 1 & $2,5 Y R$ 5/4 & 2 & 2 & 1 & 0 & 3 y $4>, 2$ & 2 & $3 a 4$ & sed bl, rojas, marrones & Q, mica fina & 8 \\
\hline TC 2 & Conj A & & 12 & 1 & 2 & 1 & 2 & 2 & 1 & 1 & 2,5 YR 5/6 & 2 & 1 & 1 & 0 & 4 y $5>, 3$ & 3 & $3 a 4$ & sed bl, Q-fel & sed marrones, mica fina & 5 \\
\hline TC 2 & Conj A & & 13 & 1 & 2 & 1 & 1 & 2 & 1 & 1 & 2,5 YR 5/6 & 2 & 1 & 2 & 0 & 4 y $5>$ & 4 & $3 a 4$ & sed bl abund, sed rojas & mica fina & 3 \\
\hline TC 2 & Conj A & & 14 & 1 & 2 & 1 & 1 & 2 & 1 & 1 & 2,5YR 5/6 & 1 & 1a2 & 1 & 1 & 3 y $4>, 2$ & 2 & $3 a 4$ & sed bl abund, sed rojas & mica fina, Q-fel & 3 \\
\hline TC 2 & Conj A & & 15 & 1 & 2 & 1 & 1 & 2 & 1 & 1 & 10R 5/6 & 2 & 1 & 1 & 0 & 4 y $5>$ & 4 & $3 a 5$ & sed rojas y grises & mica fina, Q-fel & 5 \\
\hline TC 2 & Conj A & & 16 & 1 & 2 & 2 & 1 & 2 & 2 & 1 & $2,5 Y R$ 3/1 & 1 & 2 & 1 & 1 & 2 y $3>, 4$ & 2 & $3 a 4$ & sed bl, girses, Q & sed rojas, Q & 8 \\
\hline TC 2 & Conj A & & 17 & 1 & 2 & 2 & 1 & $2 \mathrm{y} 1$ & 2 & 4 & 2,5 YR $5 / 6,5 / 3$ & 1 & 2 & 2 & 1 & 3 y $4>, 2$ & 2 & $3 a 4$ & sed rojas y bl & Q-fel, mica fina & 8 \\
\hline TC 2 & Conj A & & 18 & 1 & 2 & 1 & 1 & 2 & 2 & 5 & $2,5 Y R$ 5/4, 5/2 (nuc) & 1 & 2 & 1 & 1 & 3 y 4 & 2 & $3 a 4$ & sed bl, grises y rojas & mica, Q-fel & 8 \\
\hline TC 2 & Conj A & & 19 & 1 & 2 & 2 & 1 & 2 & 2 & 1 & $2,5 Y R$ 5/2 & 1 & 2 & 1 & 1 & 3 y $4>, 2$ & 2 & $3 a 4$ & sed bl abund, sed grises & incl negra indet, Q-fel, mica & 3 \\
\hline TC 2 & Conj A & & 20 & 1 & 2 & 1 & 2 & 2 & 2 & 1 & $2,5 Y R \quad 4 / 2$ & 2 & 1 & 1 & 1 & 4 y $5>, 3$ & 3 & $3 a 4$ & sed grises & mica fina, sed rojas & 5 \\
\hline TC 2 & Conj $\mathrm{A}$ & & 21 & 1 & 2 & 1 & 1 & $2 \mathrm{y} 1$ & 1 & 1 & 2,5YR 5/6 & 1 & $1 \mathrm{a} 2$ & 1 & 1 & 3 y $4>$ & 3 & $3 a 5$ & sed bl abund & sed rojas, mica fina, Q-fel & 3 \\
\hline TC 2 & Conj A & & 22 & 1 & 2 & 1 & 1 & 2 & 1 & 1 & $5 Y R 6 / 6$ & 1 & 2 & 1 & 1 & 3 y $4>, 2$ & 2 & $3 a 4$ & sed bl abund, Q, mica & sed rojas, Q-fel & 3 \\
\hline TC 2 & Conj A & & 23 & 1 & 2 & 1 & 1 & 2 & 1 & 1 & $2,5 Y R$ 5/4 & 2 & 1 & 1 & 0 & 4 y $5>$ & 4 & $3 a 5$ & sed marrones y rojas & mica fina & 5 \\
\hline TC 2 & Conj A & & 24 & 1 & 2 & 2 & 1 & 2 & 1 & 1 & 2,5 YR $5 / 6$ & 1 & 2 & 1 & 1 & 3 y $4>, 2$ & 2 & $3 a 4$ & sed bl, grises y rojas & mica fina, Q-fel & 8 \\
\hline TC 2 & Conj A & & 25 & 1 & 2 & 1 & 1 & 2 & 2 & 5 & 2,5YR 5/6, 5/1 (nuc) & 2 & 2 & 1 & 1 & 3 y $4>, 2$ & 2 & $3 a 4$ & sed bl, marrones y rojas & mica, Q-fel & 8 \\
\hline TC 2 & Conj A & & 26 & 1 & 2 & 1 & 1 & 2 & 2 & 4 & $5 Y R$ 5/4, 6/1 & 1 & 2 & 1 & 1 & 2 y $3>, 1$ & 2 & $3 a 4$ & sed bl, grises y rojas & Q-fel, mica fina & 8 \\
\hline TC 2 & Conj A & & 27 & 1 & 2 & 1 & 1 & 2 & 1 & 1 & $2,5 Y R$ 6/6 & 1 & 2 & 1 & 0 & 3 y $4>, 2$ & 2 & $3 a 4$ & sed bl y rosadas abund & sed rojas, mica fina & 3 \\
\hline TC 2 & Conj A & & 28 & 1 & 2 & 1 & 1 & 2 & 1 & 1 & 2,5YR 5/6 & 2 & 1 & 2 & 0 & 4 y $5>$ & 4 & $2 \mathrm{a} 4$ & sed bl y grises, mica & sed rojas & 5 \\
\hline TC 2 & Conj A & & 29 & 1 & 2 & 1 & 1 & $2 \mathrm{y} 1$ & 1 & 1 & $2,5 Y R$ 5/6 & 2 & 2 & 1 & 1 & 4 y $5>, 3$ & 3 & $3 a 4$ & sed bl, grises y rojas & mica fina, Q-fel & 8 \\
\hline TC 2 & Conj A & & 30 & 1 & 2 & 1 & 1 & 2 & 1 & 1 & $2,5 Y R 6 / 6$ & 1 & 2 & 1 & 1 & 3 y $4>, 2$ & 2 & $3 a 4$ & sed bl y rosadas abund, sed rojas & Q, mica fina & 3 \\
\hline TC 2 & Conj A & & 31 & 1 & 2 & 1 & 1 & 2 & 1 & 1 & $2,5 Y R$ 6/4 & 2 & 2 & 2 & 1 & 4 y $5>, 3$ & 3 & $3 a 5$ & sed bl y rosadas abund & sed rojas, mica fina, Q-fel & 3 \\
\hline TC 2 & Conj A & & 32 & 1 & 2 & 1 & 2 & 2 & 2 & 2 & 2,5 YR $5 / 4,4 / 1$ & 2 & 1 & 1 & 0 & 4 y $5>$ & 4 & $3 a 4$ & $\mathrm{x}$ & sed grises, rojas, Q, mica fina & 5 \\
\hline TC 2 & Conj $\mathrm{A}$ & & 33 & 1 & 2 & 1 & 1 & 2 & 2 & 1 & 5YR 6/2 & 1 & 2 & 1 & 1 & 2 y $3>, 1$ & 2 & $3 a 4$ & sed bl y grieses abund, sed rojas & Q-fel, mica fina & 3 \\
\hline TC 2 & Conj A & & 34 & 1 & 2 & 1 & 1 & 2 & 1 & 1 & $2,5 Y R 5 / 6$ & 2 & 1 & 1 & 0 & 3 y $4>$ & 4 & $4 \mathrm{a} 5$ & $\mathrm{x}$ & sed rojas, mica fina & 5 \\
\hline TC 2 & Conj A & & 35 & 1 & 2 & 1 & 1 & 2 & 1 & 1 & $5 Y R 7 / 6$ & 1 & 2 & 1 & 1 & 3 y $4>, 2$ & 2 & $3 a 4$ & sed bl y rosadas abund, sed rojas & Q, mica fina & 3 \\
\hline TC 2 & Conj A & & 36 & 1 & 2 & 1 & 1 & 2 & 1 & 1 & $2,5 Y R$ 5/6 & 2 & 1 & 1 & 0 & 4 y $5>$ & 4 & $3 a 5$ & sed bl y grises & sed rojas, mica fina & 5 \\
\hline
\end{tabular}




\begin{tabular}{|c|c|c|c|c|c|c|c|c|c|c|c|c|c|c|c|c|c|c|c|c|c|}
\hline \multirow[b]{2}{*}{$\begin{array}{c}\text { Sitio y } \\
\text { est }\end{array}$} & \multirow[b]{2}{*}{ UP } & \multirow[b]{2}{*}{ GF } & \multirow[b]{2}{*}{ FNA } & \multicolumn{4}{|c|}{ Fractura } & \multirow{2}{*}{\multicolumn{3}{|c|}{\begin{tabular}{c|c|c} 
Ca & Coc Co \\
vid & ción & lor
\end{tabular}}} & \multirow[b]{2}{*}{ Not color } & \multicolumn{7}{|c|}{ Inclusiones } & \multicolumn{2}{|c|}{ Composic } & \multirow[b]{2}{*}{ GP } \\
\hline & & & & $\begin{array}{c}\text { Aspec } \\
\text { to }\end{array}$ & \begin{tabular}{|l|l|}
$c$ & $\begin{array}{l}\text { Tex } \\
\text { tura }\end{array}$ \\
\end{tabular} & \begin{tabular}{|l} 
Resis \\
tenc.
\end{tabular} & $\begin{array}{l}\mathrm{Re} \\
\text { gul }\end{array}$ & & & & & Incl & Dens & $\begin{array}{c}\text { Orien } \\
\text { tac }\end{array}$ & $\begin{array}{l}\text { Orient } \\
\text { pared }\end{array}$ & Granul & \begin{tabular}{l|}
$\mathrm{Se}$ \\
$\mathrm{lec}$
\end{tabular} & $\begin{array}{l}\mathrm{Re} \\
\mathrm{don}\end{array}$ & comp mayor & comp aislados & \\
\hline TC 2 & Conj A & & 37 & 1 & 2 & 2 & 1 & 2 & 1 & 1 & 5YR 6/4 & 1 & 2 & 1 & 1 & 3 y $4>, 2$ & 2 & $3 a 4$ & sed bl, rojas y marrones & Q-fel, mica fina & 8 \\
\hline TC 2 & Conj $\mathrm{A}$ & & 38 & 1 & 2 & 1 & 1 & $2 \mathrm{y} 1$ & 1 & 1 & $5 Y R 7 / 4$ & 1 & 2 & 1 & 1 & 4 y $5>, 2$ & 23 & $3 a 4$ & sed bl y grises abund & sed rojas, $Q$, mica fina & 3 \\
\hline TC 2 & Conj A & & 39 & 1 & 2 & 2 & 1 & 2 & 1 & 1 & $5 Y R 5 / 4$ & 1 & 2 & 2 & 1 & 2 y $3>, 1$ & 2 & $3 a 4$ & sed bl, marrones y rojas & Q-fel, mica fina & 8 \\
\hline TC 2 & Conj A & & 40 & 1 & 2 & 1 & 1 & 2 & 1 & 1 & $2,5 Y R 5 / 6$ & 2 & 1 & 1 & 0 & 3 y $4>$ & 4 & $3 a 4$ & sed bl y grises & sed rojas, mica fina & 5 \\
\hline TC 2 & Conj A & & 41 & 1 & 2 & 1 & 1 & $2 \mathrm{y} 1$ & 1 & 1 & 2,5 YR $5 / 6$ & 2 & 1 & 1 & 0 & 3 y $4>$ & 4 & $3 a 4$ & sed grises, rojas & Q-fel, mica fina & 5 \\
\hline TC 2 & Conj A & & 42 & 1 & 2 & 1 & 1 & 2 & 1 & 1 & 2,5 YR $6 / 4$ & 1 & 2 & 1 & 1 & 3 y $4>, 2$ & 23 & $3 a 4$ & sed bl abund, $\mathrm{Q}$ & sed rojas, mica, incl osc indet & 3 \\
\hline TC 2 & Conj $\mathrm{A}$ & & 43 & 1 & 2 & 1 & 1 & $2 \mathrm{y} 1$ & 1 & 1 & $2,5 Y R 5 / 6$ & 2 & 1 & 1 & 0 & 4 y $5>$ & 45 & $3 a 5$ & $x$ & sed rojas, mica, Q-fel & 5 \\
\hline TC 2 & Conj A & & 44 & 1 & 2 & 1 & 1 & $2 \mathrm{y} 1$ & 1 & 1 & $2,5 Y R 4 / 6$ & 2 & 1 & 1 & 1 & 4 y $5>$ & 4 & $3 a 4$ & sed bl o fel alt & sed rojas, mica, Q-fel & 5 \\
\hline TC 2 & Conj A & & 45 & 1 & 2 & 1 & 1 & $2 \mathrm{y} 1$ & 2 & 5 & 2,5YR 4/1, 6/4 (nuc) & 1 & 2 & 1 & 1 & 3 y $4>, 2$ & 2 & $3 a 4$ & sed bl abund, sed rojas y marrones & Q-fel, mica fina & 3 \\
\hline TC 2 & Conj A & & 46 & 1 & 2 & 1 & 1 & 2y1 & 2 & 4 & $2,5 Y R$ 5/3, 5/6 & 2 & 2 & 1 & 0 & 3 y $4>, 2$ & 2 & $3 a 4$ & sed bl abund, sed rojas & mica fina, Q-fel & 3 \\
\hline TC 2 & Conj $\mathrm{A}$ & & 47 & 1 & 2 & 1 & 1 & $2 \mathrm{y} 1$ & 1 & 1 & $2,5 Y R 5 / 6$ & 2 & 1 & 1 & 1 & 4 y $5>$ & 4 & $3 a 4$ & sed bl y rojas & mica fina & 5 \\
\hline TC 2 & Conj A & & 48 & 1 & 2 & 1 & 1 & $2 \mathrm{y} 1$ & 1 & 1 & $2,5 Y R 5 / 6$ & 2 & 1 & 1 & 0 & 4 y $5>, 3$ & 3 & $3 a 4$ & Q, sed bl y rojas & Q-fel, mica fina & 5 \\
\hline TC 2 & Conj A & & 49 & 1 & 2 & 1 & 1 & $2 \mathrm{y} 1$ & 1 & 1 & 2,5YR 5/4 & 2 & 1 & 1 & 0 & 5> & 5 & $4 a 5$ & $\mathrm{x}$ & sed marrones, mica fina & 5 \\
\hline TC 2 & Conj A & & 50 & 1 & 2 & 1 & 1 & 2 & 1 & 1 & 2,5 YR $5 / 6$ & 2 & 1 & 1 & 0 & 4 y $5>$ & 4 & $3 a 4$ & sed grises, $\mathrm{Q}$ & mica fina, sed rojas & 5 \\
\hline TC 2 & Conj $\mathrm{A}$ & & 51 & 1 & 2 & 1 & 1 & 2 & 1 & 1 & $2,5 Y R 5 / 6$ & 1 & 2 & 1 & 1 & 3 y $4>, 2$ & 2 & $3 a 4$ & sed bl abund, sed rojas & mica, Q-fel & 3 \\
\hline TC 2 & Conj A & & 52 & 1 & 2 & 1 & 1 & 2 & 2 & 5 & 2,5YR 5/4, 5/1 (nuc) & 2 & 2 & 1 & 0 & 4 y $5>$ & 4 & $3 a 5$ & Q abund, sed osc, mica & sed bl o fel alt & ?? \\
\hline TC 2 & Conj A & & 54 & 1 & 2 & 1 & 1 & 2 & 1 & 1 & 10R $5 / 6$ & 2 & 1 & 1 & 0 & $5>$ & 5 & $4 a 5$ & $\mathrm{x}$ & sed bl, rojas, mica fina & 5 \\
\hline TC 2 & Conj $\mathrm{A}$ & & 55 & 1 & 2 & 1 & 1 & 2 & 2 & 3 & 2,5YR 5/6, N4/ (nuc) & 2 & 1 & 1 & 0 & 4 y $5>$ & 4 & $3 a 5$ & Q abund, Q-fel & sed bl o fel alt & 5 \\
\hline TC 2 & Conj A & & 56 & 1 & 2 & 1 & 1 & 2 & 1 & 1 & 2,5 YR $5 / 6$ & 2 & 1 & 1 & 0 & 4 y $5>$ & 4 & $4 a 5$ & $\mathrm{x}$ & sed bl, rojas, mica fina & 5 \\
\hline TC 2 & Conj A & & 57 & 1 & 2 & 1 & 1 & 2 & 1 & 1 & $2,5 Y R \quad 4 / 6$ & 1 & 2 & 1 & 1 & 4 y $5>, 3$ & 3 & $3 a 5$ & Q abund, sed marrones & sed bl o fel alt, mica & 2 \\
\hline TC 2 & Conj A & & 58 & 1 & 2 & 1 & 1 & 2 & 1 & 1 & 2,5 YR $6 / 6$ & 2 & 2 & 1 & 0 & 4 y $5>$ & 4 & $3 a 5$ & Q abund, sed rojas & Q-fel, sed bl o fel alt, mica & 2 \\
\hline TC 2 & Conj $\mathrm{A}$ & & 59 & 1 & 2 & 1 & 1 & 2 & 2 & 4 & $5 Y R$ 3/1, 4/2 & 1 & 2 & 1 & 1 & 3 y $4>, 2$ & 2 & $2 \mathrm{a} 4$ & mica abund, $\mathrm{Q}$ & sed rojas y marr, sed bl o fel alt & 1 \\
\hline TC 2 & Conj A & & 60 & 1 & 2 & 2 & 1 & 2 & 2 & 4 & $5 Y R$ 5/6, 3/1 & 1 & 2 & 1 & 2 & 3 y $4>, 1$ y 2 & 1 & $2 \mathrm{a} 4$ & mica abund, $\mathrm{Q}$ & sed rojas, sed bl o fel alt & 1 \\
\hline TC 2 & Conj A & & 61 & 1 & 2 & 2 & 1 & 2 & 2 & 4 & $5 Y R 5 / 4,6 / 4$ & 1 & 2 & 1 & 1 & 3 y $4>, 2$ & 2 & $3 a 4$ & sed bl, grises, marrones & Q-fel, mica fina & 8 \\
\hline TC 2 & Conj A & & 62 & 1 & 2 & 2 & 1 & 2 & 1 & 1 & $5 Y R 6 / 4$ & 1 & 2 & 1 & 1 & 3 y $4>, 2$ & 2 & $2 \mathrm{a} 4$ & mica abund, $\mathrm{Q}$ & sed bl, sed marrones, Q-fel & 1 \\
\hline TC 2 & Conj A & & 63 & 1 & 2 & 1 & 1 & 2 & 1 & 1 & 2,5 YR $5 / 4$ & 1 & 2 & 1 & 1 & 3 y $4>, 2$ & 2 & $3 a 4$ & sed bl y rojas & mica, Q-fel & 8 \\
\hline TC 2 & Conj A & & 64 & 1 & 2 & 2 & 1 & 2 & 3 & 1 & 5YR $2,5 / 1$ & 1 & 2 & 1 & 1 & 3 y $4>, 1$ y 2 & 1 & $3 a 4$ & sed bl y rojas & Q-fel, mica fina & 8 \\
\hline TC 2 & Conj A & & 65 & 1 & 2 & 1 & 1 & 2 & 1 & 1 & 2,5 YR $5 / 6$ & 1 & 2 & 1 & 1 & 3 y $4>, 2$ & 2 & 2a4 & mica abund, sed bl & sed rojas, Q-fel & 1 \\
\hline TC 2 & Conj A & & 66 & 1 & 2 & 2 & 1 & 2 & 3 & 1 & 5YR $2,5 / 1$ & 2 & 2 & 1 & 1 & 2 y $3>$ & 2 & $3 a 4$ & sed grises y marrones & Q-fel, mica fina & 8 \\
\hline TC 2 & Conj A & & 67 & 1 & 2 & 2 & 1 & 2 & 2 & 5 & 2,5YR 5/6, 5/1 (nuc) & 1 & 2 & 1 & 2 & 2 y $3>, 1$ y 4 & 1 & 2a4 & mica abund, $\mathrm{Q}$ & sed rojas, Q-fel & 1 \\
\hline TC 2 & Conj A & & 68 & 1 & 2 & 1 & 1 & 2 & 2 & 4 & 2,5YR 5/6; 5YR 4/2 & 1 & 2 & 1 & 1 & 3 y $4>, 2$ & 2 & $3 a 4$ & sed grsies y marrones, $\mathrm{Q}$ & sed bl o fel alt & 8 \\
\hline TC 2 & Conj A & & 69 & 1 & 2 & 1 & 1 & 2 & 2 & 1 & 5YR 3/1 & 1 & 2 & 1 & 1 & 3 у $4>, 2$ & 2 & $3 a 4$ & sed bl abund, grises y rojas & Q-fel, mica fina & 8 \\
\hline TC 2 & Conj $\mathrm{A}$ & & 70 & 1 & 2 & 2 & 1 & 2 & 1 & 1 & 5YR 6/4 & 1 & 2 & 1 & 1 & 3 y $4>, 2$ & 2 & $3 a 4$ & sed bl y rojas, marrones & Q, mica fina, Q-fel & 8 \\
\hline TC 2 & Conj A & & 73 & 1 & 2 & 1 & 1 & 2 & 1 & 1 & $2,5 Y R 5 / 6$ & 1 & 2 & 1 & 1 & 3 y $4>, 2$ & 2 & $3 a 5$ & $\mathrm{Q}$, sed rojas y marrones & sed bl o fel alt, Q-fel, mica fina & 8 \\
\hline TC 2 & Conj A & & 74 & 1 & 2 & 1 & 1 & 2 & 2 & 4 & 2,5 YR $4 / 1,4 / 6$ & 1 & 2 & 1 & 1 & 2 у $3>, 1$ & 2 & $3 a 4$ & sed marrones y rojas, sed bl & Q-fel, mica fina & 8 \\
\hline TC 2 & Conj A & & 75 & 1 & 2 & 1 & 1 & 2 & 2 & 1 & $5 Y R 5 / 3$ & 1 & 2 & 2 & 2 & 3 y $4>, 1$ y 2 & 1 & 2a4 & mica abund, Q & sed rojas, Q-fel & 1 \\
\hline
\end{tabular}




\begin{tabular}{|c|c|c|c|c|c|c|c|c|c|c|c|c|c|c|c|c|c|c|c|c|c|}
\hline \multirow[b]{2}{*}{$\begin{array}{c}\text { Sitio y } \\
\text { est }\end{array}$} & \multirow[b]{2}{*}{ UP } & \multirow[b]{2}{*}{ GF } & \multirow[b]{2}{*}{ FNA } & \multicolumn{4}{|c|}{ Fractura } & \multirow{2}{*}{\multicolumn{3}{|c|}{\begin{tabular}{l|l|l} 
Ca & Coc Co \\
vid & ción lor \\
\end{tabular}}} & \multirow[b]{2}{*}{ Not color } & \multicolumn{7}{|c|}{ Inclusiones } & \multicolumn{2}{|c|}{ Composic } & \multirow[b]{2}{*}{ GP } \\
\hline & & & & $\begin{array}{c}\text { Aspec } \\
\text { to }\end{array}$ & \begin{tabular}{|l|l|}
$c$ & $\begin{array}{l}\text { Tex } \\
\text { tura }\end{array}$ \\
\end{tabular} & $\begin{array}{l}\text { Resis } \\
\text { tenc. }\end{array}$ & $\begin{array}{l}\mathrm{Re} \\
\text { gul }\end{array}$ & & & & & Incl & Dens & $\begin{array}{c}\text { Orien } \\
\text { tac }\end{array}$ & $\begin{array}{l}\text { Orient } \\
\text { pared }\end{array}$ & Granul & & $\begin{array}{c}\mathrm{Re} \\
\mathrm{don}\end{array}$ & comp mayor & comp aislados & \\
\hline TC 2 & Conj A & & 76 & 1 & 2 & 1 & 1 & 2 & 2 & 4 & $2,5 Y R$ 5/6, 5/1 & 1 & 2 & 1 & 1 & 3 y $4>, 2$ & 2 & $3 a 4$ & sed bl, marrones y rojas & Q-fel, mica fina & 8 \\
\hline TC 2 & Conj A & & 77 & 1 & 2 & 1 & 1 & 2 & 2 & 1 & 7,5YR 5/1 & 1 & 2 & 2 & 1 & 2 y $3>, 1$ y 4 & 1 & $3 a 4$ & sed grises y marrones & sed bl, mica fna, Q-fe & 8 \\
\hline TC 2 & Conj A & & 78 & 1 & 2 & 1 & 1 & 2 & 2 & 5 & $5 Y R$ 5/4, 5/1 (nuc) & 1 & 2 & 2 & 2 & 3 y $4>, 2$ & 2 & $2 a 4$ & mica abund, Q & sed rojas, sed bl o fel alt & 1 \\
\hline TC 2 & Conj A & & 79 & 1 & 2 & 1 & 1 & 2 & 1 & 1 & $2,5 Y R$ T/6 & 1 & 2 & 1 & 1 & 3 y $4>, 2$ & 2 & $3 a 4$ & sed grises y bl, sed rojas & mica fina, Q-fel & 8 \\
\hline TC 2 & Conj A & & 80 & 1 & 2 & 1 & 1 & 2 & 2 & 4 & $5 Y R$ 6/3, 4/1 & 1 & 2 & 1 & 1 & 3 y $4>, 1$ y 2 & 1 & $3 a 4$ & sed bl, marrones y rojas & mica fina, Q-fel & 8 \\
\hline TC 2 & Conj A & & 81 & 1 & 2 & 2 & 1 & 2 & 2 & 1 & 5YR $2,5 / 2$ & 1 & 2 & 1 & 1 & 3 y $4>, 1$ y 2 & 1 & $3 a 4$ & sed bl, grises y rojas & Q-fel, mica fina & 8 \\
\hline TC 2 & Conj A & & 82 & 1 & 2 & 1 & 2 & 2 & 1 & 1 & $2,5 Y R$ T/6 & 1 & 2 & 1 & 0 & 3 y $4>, 2$ & 2 & $3 a 4$ & sed bl abund, rosadas y rojas & mica fina, Q-fel & 3 \\
\hline TC 2 & Conj A & & 83 & 1 & 2 & 2 & 1 & 2 & 1 & 1 & $2,5 Y R$ T/6 & 1 & 2 & 1 & 2 & 3 y $4>, 2$ & 2 & $2 a 4$ & mica abund, sed bl & sed rojas, Q, Q-fel & 1 \\
\hline TC 2 & Conj A & & 84 & 1 & 2 & 1 & 1 & 2 & 2 & 5 & 2,5YR 6/3, 4/1 (nuc) & 1 & 2 & 1 & 1 & 3 y $4>, 2$ & 2 & $3 a 4$ & sed marrones y rojas, $\mathrm{Q}$ & sed bl, Q-fel, mica fina & 8 \\
\hline TC 2 & Conj A & & 85 & 1 & 2 & 1 & 1 & $2 \mathrm{y} 1$ & 1 & 1 & 5YR 5/4 & 1 & 2 & 2 & 2 & 3 y $4>, 2$ & 2 & $2 \mathrm{a} 4$ & mica abund, Q & sed rojas y bl, Q-fel & 1 \\
\hline TC 2 & Conj A & & 86 & 1 & 2 & 1 & 1 & 2 & 1 & 1 & 2,5 YR $5 / 6$ & 1 & 2 & 2 & 2 & 3 y $4>, 2$ & 2 & $2 \mathrm{a} 4$ & mica abund, Q & sed rojas, bl, Q-fel & 1 \\
\hline TC 2 & Conj A & & 87 & 1 & 2 & 1 & 1 & 2 & 2 & 4 & $2,5 Y R$ 5/2, 5/4 & 1 & 2 & 1 & 1 & 3 y $4>, 2$ & 2 & $3 a 4$ & sed grises y marrones & sed bl, Q-fel, mica fina & 8 \\
\hline TC 2 & Conj A & & 88 & 1 & 2 & 1 & 1 & 2 & 1 & 1 & 5YR 5/6 & 1 & 2 & 1 & 1 & 3 y $4>, 2$ & 2 & $3 a 4$ & sed grises y marrones & sed bl, Q-fel, mica fina & 8 \\
\hline TC 2 & Conj $\mathrm{A}$ & & 89 & 1 & 2 & 2 & 1 & 2 & 2 & 4 & 5YR $2,5 / 1,4 / 2$ & 1 & 2 & 1 & 1 & 2 y $3>, 4$ & 2 & $3 a 4$ & sed grises y marrones & Q, mica fina & 8 \\
\hline TC 2 & Conj A & & 90 & 1 & 2 & 1 & 1 & 2 & 2 & 4 & 5YR $2,5 / 1,4 / 2$ & 1 & 2 & 1 & 1 & 2 y $3>, 4$ & 2 & $3 a 4$ & sed grises y marones, sed bl & Q-fel, mica fina & 8 \\
\hline TC 2 & Conj A & & 91 & 1 & 2 & 2 & 1 & 2 & 2 & 4 & $5 Y R$ 4/1, 6/4 & 1 & 2 & 1 & 1 & 3 y $4>, 2$ & 2 & $3 a 4$ & sed bl, grises y rojas & Q-fel, mica fina & 8 \\
\hline TC 2 & Conj A & & 93 & 1 & 2 & 1 & 1 & 2 & 1 & 1 & 5YR 5/4 & 1 & 2 & 2 & 2 & 3 y $4>, 2$ & 2 & $2 \mathrm{a} 4$ & mica abund, Q & sed bl o fel alt, sed rojas & 1 \\
\hline TC 2 & Conj A & & 94 & 1 & 2 & 1 & 1 & 2 & 2 & 5 & $5 Y R$ 5/4, 4/1 (nuc) & 1 & 2 & 1 & 1 & 3 y 4 & 3 & $3 a 4$ & Q abund, sed rojas y bl & Q-fel, mica fina & 2 \\
\hline TC 2 & Conj A & & 95 & 1 & 2 & 1 & 1 & 2 & 2 & 4 & $5 Y R$ 4/1, 5/3 & 1 & 2 & 1 & 1 & 3 y $4>, 2$ & 2 & $3 a 4$ & sed grises y marrones & Q, Q-fel, mica fina & 8 \\
\hline $\mathrm{TC} 2$ & Conj A & & 96 & 1 & 2 & 1 & 1 & 2 & 2 & 5 & 5 YR 3/2, 2,5/1 (nuc) & 1 & 2 & 1 & 1 & 3 y $4>, 1$ y 2 & 1 & $3 a 4$ & sed bl, grises y marrones & Q-fel, mica fina & 8 \\
\hline TC 2 & Conj A & & 97 & 1 & 2 & 1 & 1 & 2 & 2 & 4 & $5 Y R \quad 4 / 4,5 / 2$ & 1 & 2 & 1 & 1 & 3 y $4>, 1$ y 2 & 1 & $3 a 4$ & Q abund, sed rojas y bl & mica, Q-fel & 2 \\
\hline TC 2 & Conj $\mathrm{A}$ & & 98 & 1 & 2 & 1 & 1 & 2 & 2 & 5 & $5 Y R$ 6/3, 4/1 (nuc) & 2 & 2 & 1 & 1 & 3 y $4>$ & 3 & $3 a 4$ & Q abund, sed grises & Q-fel, mica fina & 2 \\
\hline TC 2 & Conj A & & 99 & 1 & 2 & 1 & 1 & 2 & 2 & 4 & $5 Y R 3 / 1,5 / 4$ & 1 & 2 & 1 & 1 & 2 y $3>, 1$ & 2 & $3 a 4$ & sed bl y marrones & Q-fel, mica fina & 8 \\
\hline TC 2 & Conj A & & 100 & 1 & 2 & 1 & 1 & 2 & 2 & 5 & 5YR 6/6, 6/1 (nuc) & 1 & 2 & 1 & 1 & 3 y $4>, 1$ y 2 & 1 & $3 a 4$ & sed bl y marrones & Q, Q-fel, mica fina & 8 \\
\hline TC 2 & Conj A & & 101 & 1 & 2 & 1 & 1 & 2 & 2 & 4 & $2,5 Y R$ 6/6, 6/1 & 1 & 2 & 1 & 1 & 3 y $4>, 2$ & 2 & $3 a 4$ & sed bl abund, sed rojas & mica, Q-fel & 3 \\
\hline TC 2 & Conj A & & 102 & 1 & 2 & 1 & 1 & 2 & 2 & 4 & $2,5 Y R \quad 4 / 3,5 / 8$ & 1 & 2 & 1 & 1 & 3 y $4>, 2$ & 2 & $3 a 4$ & sed bl, grises y rojas & Q, Q-fel, mica fina & 8 \\
\hline TC 2 & Conj A & & 103 & 1 & 2 & 2 & 1 & 2 & 1 & 1 & 5YR 5/4 & 1 & 2 & 1 & 1 & 3 y $4>, 2$ & 2 & $2 a 4$ & mica y Q abund & sed marrones, Q-fel & 1 \\
\hline TC 2 & Conj A & & 104 & 1 & 2 & 2 & 1 & 2 & 2 & 5 & $2,5 Y R$ 5/6, 5/2 (nuc) & 1 & 2 & 1 & 1 & 3 y $4>, 2$ & 2 & $3 a 4$ & sed bl, grises y marrones & Q-fel, mica fina & 8 \\
\hline TC 2 & Conj A & & 105 & 1 & 2 & 1 & 1 & 2 & 2 & 5 & $5 Y R$ 5/4, 5/2 (nuc) & 1 & 2 & 1 & 1 & 3 y $4>, 2$ & 2 & $3 a 4$ & sed bl, marrones y rojas & Q-fel, mica fina & 8 \\
\hline TC 2 & Conj A & & 106 & 1 & 2 & 1 & 1 & 2 & 2 & 5 & $5 Y R$ 5/6, 4/1 (nuc) & 2 & 1 & 1 & 1 & 4 y $5>$ & 4 & $3 a 4$ & $\mathrm{Q}$ & sed bl o fel alt, cuarc? & 5 \\
\hline TC 2 & Conj A & & 107 & 1 & 2 & 1 & 1 & 2 & 2 & 4 & 5YR $2,5 / 1,4 / 2$ & 1 & 2 & 1 & 1 & 3 y $4>, 2$ & 2 & $3 a 4$ & sed bl, marrones y rojas & Q-fel, mica fina & 8 \\
\hline TC 2 & Conj A & & 108 & 1 & 2 & 2 & 1 & 2 & 2 & 1 & $7,5 Y R 6 / 3$ & 1 & 2 & 1 & 1 & 3 y $4>, 2$ & 2 & $2 \mathrm{a} 4$ & mica abund, $\mathrm{Q}$ & sed bl o fel alt, Q-fel & 1 \\
\hline TC 2 & Conj A & & 109 & 1 & 2 & 1 & 1 & 2 & 2 & 1 & 5YR 5/2 & 1 & 2 & 1 & 1 & 3 y $4>, 2$ & 2 & $2 \mathrm{a} 4$ & mica abund, $\mathrm{Q}$ & sed bl o fel alt, sed rojas, Q-fel & 1 \\
\hline TC 2 & Conj A & & 112 & 1 & 2 & 1 & 1 & 2 & 1 & 1 & $2,5 Y R 5 / 6$ & 2 & 1 & 1 & 1 & 4 y $5>$ & 4 & $4 a 5$ & $x$ & sed bl, mica fina, Q-fel & 5 \\
\hline TC 2 & Conj A & & 113 & 1 & 2 & 2 & 1 & 2 & 2 & 4 & $5 Y R 3 / 2,5 / 3$ & 1 & 2 & 1 & 1 & 3 y $4>, 2$ & 2 & $3 a 4$ & sed bl, marrones y rojas & mica, Q-fel & 8 \\
\hline TC 2 & Conj A & & 114 & 1 & 2 & 1 & 1 & 2 & 2 & 4 & 2,5 YR $6 / 6,6 / 2$ & 1 & 2 & 1 & 1 & 3 y $4>, 2$ & 2 & $3 a 4$ & sed bl abund, grises y rojas & mica, Q-fel & 3 \\
\hline
\end{tabular}




\begin{tabular}{|c|c|c|c|c|c|c|c|c|c|c|c|c|c|c|c|c|c|c|c|c|c|}
\hline \multirow[b]{2}{*}{$\begin{array}{c}\text { Sitio y } \\
\text { est }\end{array}$} & \multirow[b]{2}{*}{ UP } & \multirow[b]{2}{*}{ GF } & \multirow[b]{2}{*}{ FNA } & \multicolumn{4}{|c|}{ Fractura } & \multirow[b]{2}{*}{$\begin{array}{l}\text { Ca } \\
\text { vid }\end{array}$} & \multirow{2}{*}{\multicolumn{2}{|c|}{$\begin{array}{l}\text { Coc Co } \\
\text { ción } \\
\end{array}$}} & \multirow[b]{2}{*}{ Not color } & \multicolumn{7}{|c|}{ Inclusiones } & \multicolumn{2}{|c|}{ Composic } & \multirow[b]{2}{*}{ GP } \\
\hline & & & & \begin{tabular}{|c|}
$\begin{array}{c}\text { Aspec } \\
\text { to }\end{array}$ \\
\end{tabular} & \begin{tabular}{|l|l|}
$c$ & $\begin{array}{l}\text { Tex } \\
\text { tura }\end{array}$ \\
\end{tabular} & $\begin{array}{l}\text { Resis } \\
\text { tenc. }\end{array}$ & $\begin{array}{lll}\text { Re } \\
\text { ul }\end{array}$ & & & & & Incl & Dens & \begin{tabular}{|c} 
Orien \\
tac
\end{tabular} & $\begin{array}{l}\text { Orient } \\
\text { pared }\end{array}$ & Granul & & $\begin{array}{l}\mathrm{Re} \\
\mathrm{don}\end{array}$ & comp mayor & comp aislados & \\
\hline TC 2 & Conj $\mathrm{A}$ & & 115 & 1 & 2 & 1 & 1 & 2 & 2 & 2 & $2,5 Y R$ 4/1, 5/6 & 2 & 1 & 1 & 1 & 4 y $5>$ & 4 & $3 a 4$ & $\mathrm{Q}$ & sed bl o fel alt, mica fina & 5 \\
\hline TC 2 & Conj $\mathrm{A}$ & & 116 & 1 & 2 & 1 & 1 & 2 & 2 & 4 & $2,5 Y R$ 5/1, 5/4 & 1 & 2 & 1 & 1 & 3 y $4>, 2$ & 2 & $3 a 4$ & sed bl y rojas & mica, Q-fel & 8 \\
\hline TC 2 & Conj $\mathrm{A}$ & & 117 & 1 & 2 & 1 & 1 & 2 & 2 & 2 & $2,5 Y R$ 5/6, 4/1 & 2 & 1 & 1 & 0 & 4 y $5>$ & 4 & $4 a 5$ & sed grises & Q, Q-fel & 5 \\
\hline TC 2 & Conj $\mathrm{A}$ & & 118 & 1 & 2 & 2 & 1 & 2 & 2 & 4 & 2,5 YR $5 / 6,6 / 2$ & 1 & 2 & 1 & 1 & 3 y $4>, 2$ & 2 & $3 a 4$ & sed bl abund, rosadas y rojas & Q, Q-fel, mica fina & 3 \\
\hline $\mathrm{TC} 2$ & Conj A & & 119 & 1 & 2 & 1 & 1 & 2 & 1 & 1 & $2,5 Y R \quad 4 / 6$ & 1 & 2 & 1 & 1 & 3 y $4>, 2$ & 2 & $3 a 4$ & sed bl, grises y marrones & Q, Q-fel, mica fina & 8 \\
\hline TC 2 & Conj $\mathrm{A}$ & & 120 & 1 & 2 & 1 & 1 & 2 & 1 & 1 & 2,5YR 5/4 & 1 & 2 & 1 & 1 & 3 y $4>, 2$ & 2 & $3 a 4$ & sed bl, marrones y rojas & Q-fel, mica fina & 8 \\
\hline TC 2 & Conj $\mathrm{A}$ & & 121 & 1 & 2 & 1 & 1 & 2 & 1 & 1 & $2,5 Y R$ T/6 & 1 & 2 & 1 & 1 & 3 y $4>, 2$ & 2 & $3 a 4$ & sed bl abund, sed rojas & Q-fel, mica fina & 3 \\
\hline TC 2 & Conj $\mathrm{A}$ & & 122 & 1 & 2 & 1 & 1 & $2 \mathrm{y} 1$ & 1 & 1 & $2,5 Y R$ T/6 & 1 & 1 & 1 & 0 & 4 y $5>$ & 4 & $3 a 5$ & sed bl & mica fina, Q-fel & 5 \\
\hline TC 2 & Conj $\mathrm{A}$ & & 123 & 1 & 2 & 2 & 1 & 2 & 2 & 1 & 5YR 5/3 & 2 & 1a2 & 1 & 1 & 4 y $5>$ & 4 & $3 a 4$ & Q abund & sed bl, sed grises, mica, Q-fel & 2 \\
\hline TC 2 & Conj A & & 124 & 1 & 2 & 2 & 1 & 2 & 2 & 4 & $5 Y R 5 / 4,5 / 1$ & 1 & 2 & 2 & 2 & 3 y $4>, 2$ & 2 & $2 \mathrm{a} 4$ & mica abund, $\mathrm{Q}$ & sed bl o fel alt & 1 \\
\hline TC 2 & Conj $\mathrm{A}$ & & 125 & 1 & 2 & 1 & 1 & 2 & 1 & 1 & $2,5 Y R$ 5/6 & 2 & 2 & 1 & 2 & 3 y $4>, 2$ & 2 & $2 \mathrm{a} 4$ & mica abund & sed bl y rojas, Q-fel & 1 \\
\hline TC 2 & Conj $\mathrm{A}$ & & 126 & 1 & 2 & 2 & 1 & 2 & 2 & 1 & $2,5 Y R 5 / 8$ & 1 & 2 & 1 & 1 & 3 y $4>, 1$ y 2 & 1 & $3 a 4$ & sed bl abund, rosadas y rojas & mica fina, Q-fel & 3 \\
\hline TC 2 & Conj $\mathrm{A}$ & & 127 & 1 & 2 & 2 & 1 & $2 \mathrm{y} 1$ & 2 & 4 & $5 Y R 2,5 / 1,5 / 3$ & 1 & 2 & 1 & 1 & 3 y $4>, 2$ & 2 & $3 a 4$ & sed bl y grises & Q-fel, mica fina & 8 \\
\hline TC 2 & Conj $\mathrm{A}$ & & 128 & 1 & 2 & 1 & 1 & 2 & 1 & 1 & $2,5 Y R$ 5/6 & 1 & 2 & 1 & 1 & 3 y $4>, 2$ & 2 & $3 a 4$ & sed bl, marrones y rojas, Q & Q-fel, mica fina & 8 \\
\hline TC 2 & Conj $\mathrm{A}$ & & 129 & 1 & 2 & 1 & 1 & 2 & 1 & 1 & 5YR 7/4 & 1 & 2 & 1 & 1 & 3 y $4>, 2$ & 2 & $3 a 4$ & sed bl abund, rojas, Q & mica fina, Q-fel & 3 \\
\hline TC 2 & Conj A & & 130 & 1 & 2 & 2 & 1 & 2 & 2 & 1 & $5 Y R 5 / 1$ & 1 & 2 & 1 & 0 & 3 y $4>, 1$ y 2 & 1 & $3 a 4$ & sed grises y marrones & Q-fel, mica fina & 8 \\
\hline TC 2 & Conj $\mathrm{A}$ & & 132 & 1 & 2 & 2 & 1 & 2 & 2 & 1 & $5 Y R \quad 4 / 3$ & 2 & 2 & 1 & 1 & 3 y $4>, 2$ & 2 & $3 a 4$ & sed grises y marrones, $\mathrm{Q}$ & Q-fel, mica fina & 8 \\
\hline TC 2 & Conj B & & $133 / 34$ & 1 & 2 & 1 & 1 & $2 \mathrm{y} 1$ & 1 & 1 & 5YR 7/4 & 2 & 1 & 1 & 0 & $5>$ & 5 & $3 a 5$ & $x$ & sed grises y marrones, mica fin & 5 \\
\hline TC 2 & Conj B & & 135 & 1 & 2 & 1 & 1 & 2 & 1 & 1 & $2,5 Y R$ 5/8 & 2 & 1 & 1 & 0 & 4 y $5>$ & 4 & $3 a 5$ & $x$ & sed bl, mica fina, Q-fel & 5 \\
\hline $\mathrm{TC} 2$ & Conj B & & 136 & 1 & 2 & 1 & 1 & 2 & 1 & 1 & 2,5 YR $5 / 6$ & 2 & 1 & 1 & 1 & 4 y $5>$ & 4 & $3 a 5$ & sed bl y rojas & Q-fel, mica fina & 5 \\
\hline TC 2 & Conj B & & 137 & 1 & 2 & 2 & 1 & 2 & 2 & 1 & $5 Y R 4 / 1$ & 1 & 2 & 1 & 2 & 3 y $4>$ & 3 & $2 \mathrm{a} 4$ & mica abund, Q & Q-fel, sed bl o fel alt & 1 \\
\hline TC 2 & Conj B & & 138 & 1 & 2 & 1 & 1 & 2 & 1 & 1 & $2,5 Y R \quad 4 / 4$ & 2 & 1 & 1 & 1 & 4 y $5>$ & 4 & $3 a 4$ & $x$ & sed grises, mica, Q-fel & 5 \\
\hline TC 2 & Conj B & & 139 & 1 & 2 & 1 & 1 & $2 \mathrm{y} 1$ & 1 & 1 & 2,5 YR $5 / 6$ & 2 & 1 & 1 & 1 & 4 y $5>$ & 4 & $3 a 4$ & $x$ & sed grises, mica fina & 5 \\
\hline $\mathrm{TC} 2$ & Conj B & & 140 & 1 & 2 & 1 & 1 & 2 & 1 & 1 & $2,5 Y R$ 5/6 & 2 & $1 \mathrm{a} 2$ & 2 & 1 & 4 y $5>, 3$ & 3 & $3 a 4$ & sed bl abund & sed rojas, Q-fel, mica fina & 3 \\
\hline TC 2 & Conj B & & 141 & 1 & 2 & 1 & 1 & 2 & 1 & 1 & $5 Y R 6 / 6$ & 1 & 2 & 1 & 0 & 4 y $5>, 3$ & 3 & $3 a 5$ & sed bl abund, Q & sed rojas, Q-fel, mica fina & 3 \\
\hline TC 2 & Conj B & & 142 & 1 & 2 & 1 & 1 & 2 & 1 & 1 & 5YR 6/6 & 1 & 2 & 1 & 0 & 4 y $5>, 3$ & 3 & $3 a 5$ & sed bl abund, Q & sed rojas, Q-fel, mica fina & 3 \\
\hline TC 2 & Conj B & & 143 & 1 & 2 & 1 & 1 & 2 & 1 & 1 & $2,5 Y R$ T/6 & 2 & 1 & 2 & 0 & 4 y $5>$ & 4 & $3 a 4$ & $x$ & mica, sed bl y rojas & 5 \\
\hline TC 2 & Conj B & & 144 & 1 & 2 & 1 & 1 & $2 \mathrm{y} 1$ & 1 & 1 & 2,5 YR $5 / 6$ & 2 & 1 & 1 & 0 & 4 y $5>$ & 4 & $3 a 5$ & $x$ & sed rojas, bl, mica fina & 5 \\
\hline TC 2 & Conj B & & 145 & 1 & 2 & 1 & 1 & $2 \mathrm{y} 1$ & 1 & 1 & 2,5 YR $5 / 6$ & 2 & 1a2 & 1 & 0 & 4 y $5>, 2$ & 2 & $3 a 5$ & sed grises? abund & sed bl o fel alt, mica fina & ?? \\
\hline TC 2 & Conj B & & 146 & 1 & 2 & 1 & 1 & 2 & 2 & 4 & $2,5 Y R$ 5/6, 5/1 & 2 & 1 & 1 & 0 & 3 y $4>, 2$ & 2 & $3 a 4$ & sed bl y rojas & mica fina, Q-fel & 5 \\
\hline TC 2 & Conj B & & 147 & 1 & 2 & 1 & 1 & 2 & 1 & 1 & $2,5 Y R$ 5/4 & 1 & 1a2 & 1 & 1 & 4 y $5>$ & 4 & $3 a 5$ & Q, Q-fel, sed bl o fel alt & sed rojas, mica fina & 5 \\
\hline TC 2 & Conj B & & 148 & 1 & 2 & 1 & 1 & 2y1 & 1 & 1 & 2,5 YR 5/4 & 2 & 2 & 1 & 0 & 4 y $5>, 3$ & 3 & $3 a 4$ & sed bl abund, sed rojas & Q, Q-fel, mica fina & 3 \\
\hline TC 2 & Conj B & & 149 & 1 & 2 & 1 & 1 & $2 \mathrm{y} 1$ & 2 & 4 & 5YR 5/4, 2,5YR 5/6 & 2 & 1 & 2 & 1 & 4 y $5>, 3$ & 3 & $3 a 4$ & sed grises y marrones, $\mathrm{Q}$, mica & Q-fel & 5 \\
\hline TC 2 & Conj B & & 152 & 1 & 2 & 1 & 1 & 2 & 1 & 1 & $2,5 Y R 5 / 6$ & 2 & 1 & 1 & 1 & 4 y $5>, 3$ & 3 & $3 a 4$ & sed bl y rojas & mica fina, Q-fel & 5 \\
\hline TC 2 & Conj B & & 153 & 1 & 2 & 1 & 1 & 2 & 1 & 1 & $5 Y R 7 / 6$ & 1 & 2 & 1 & 0 & 3 y $4>, 2$ & 2 & $3 a 5$ & sed bl abund, rosadas y rojas, $\mathrm{Q}$ & Q-fel, mica fina & 3 \\
\hline TC 2 & Conj B & & 154 & 1 & 2 & 1 & 1 & 2 & 2 & 5 & $5 Y R 5 / 2,7 / 2$ (nuc) & 1 & 2 & 1 & 0 & 3 y $4>, 2$ & 2 & $3 a 4$ & sed bl abund, rosadas y rojas & Q, Q-fel, mica fina & 3 \\
\hline
\end{tabular}




\begin{tabular}{|c|c|c|c|c|c|c|c|c|c|c|c|c|c|c|c|c|c|c|c|c|c|}
\hline \multirow[b]{2}{*}{$\begin{array}{c}\text { Sitio y } \\
\text { est }\end{array}$} & \multirow[b]{2}{*}{ UP } & \multirow[b]{2}{*}{ GF } & \multirow[b]{2}{*}{ FNA } & \multicolumn{4}{|c|}{ Fractura } & \multirow[b]{2}{*}{\begin{tabular}{|l|l} 
Ca \\
vid
\end{tabular}} & \multirow{2}{*}{\multicolumn{2}{|c|}{\begin{tabular}{|l|l|l|l|l|l|l|l} 
Coc \\
ción lor
\end{tabular}}} & \multirow[b]{2}{*}{ Not color } & \multicolumn{7}{|c|}{ Inclusiones } & \multicolumn{2}{|c|}{ Composic } & \multirow[b]{2}{*}{ GP } \\
\hline & & & & $\begin{array}{c}\text { Aspec } \\
\text { to }\end{array}$ & \begin{tabular}{|l|l|} 
& $\begin{array}{l}\text { Tex } \\
\text { tura }\end{array}$ \\
\end{tabular} & $\begin{array}{l}\text { Resis } \\
\text { tenc. }\end{array}$ & $\begin{array}{l}\mathrm{Re} \\
\text { gul }\end{array}$ & & & & & Incl & Dens & $\begin{array}{c}\text { Orien } \\
\text { tac }\end{array}$ & $\begin{array}{l}\text { Orient } \\
\text { pared }\end{array}$ & Granul & $\begin{array}{l}\mathrm{Se} \\
\text { lec }\end{array}$ & $\begin{array}{l}\mathrm{Re} \\
\mathrm{don}\end{array}$ & comp mayor & comp aislados & \\
\hline TC 2 & Conj B & & 155 & 1 & 2 & 1 & 1 & 2 & 1 & 1 & 5YR 5/4 & 1 & 2 & 1 & 1 & 2 y $3>, 4$ & 2 & $3 a 4$ & sed bl abund, sed marrones & Q, mica fina & 3 \\
\hline TC 2 & Conj B & & 156 & 1 & 2 & 1 & 1 & 2 & 1 & 1 & 5YR 5/4 & 1 & 2 & 1 & 1 & 2 y $3>, 4$ & 2 & $3 a 4$ & sed bl abund, sed marrones & Q, mica fina & 3 \\
\hline TC 2 & Conj B & & 157 & 1 & 2 & 1 & 1 & 2 & 1 & 1 & 5YR 5/4 & 2 & 1 & 1 & 0 & 4 y $5>, 3$ & 3 & $3 a 5$ & sed grises & sed bl o fel alt, mica & 5 \\
\hline TC 2 & Conj B & & 158 & 1 & 2 & 1 & 1 & $2 \mathrm{y} 1$ & 1 & 1 & $2,5 Y R 4 / 6$ & 2 & 1 & 1 & 0 & 4 y $5>$ & 4 & $3 a 4$ & $x$ & sed marrones, mica fina & 5 \\
\hline TC 2 & Conj B & & 159 & 1 & 2 & 1 & 1 & $2 \mathrm{y} 1$ & 1 & 1 & $2,5 Y R 5 / 8$ & 2 & 1 & 1 & 0 & $5>$ & 5 & $3 a 5$ & $x$ & sed marrones, mica fina & 5 \\
\hline TC 2 & Conj B & & 160 & 1 & 2 & 1 & 1 & $2 \mathrm{y} 1$ & 2 & 1 & $5 Y R 4 / 3$ & 2 & 1a2 & 1 & 0 & 4 y $5>, 3$ & 3 & $3 a 4$ & sed marrones y grises & sed bl o fel alt, Q, mica fina & 8 \\
\hline TC 2 & Conj B & & 161 & 1 & 2 & 1 & 1 & $2 \mathrm{y} 1$ & 1 & 1 & $2,5 Y R$ 5/4 & 2 & 1 & 1 & 1 & 4 y $5>$ & 4 & $3 a 4$ & sed marrones y grises, mica & $x$ & 5 \\
\hline TC 2 & Conj B & & $162 / 63$ & 1 & 2 & 1 & 1 & 2 & 1 & 1 & $2,5 Y R 5 / 6$ & 2 & 1 & 1 & 0 & 4 y $5>, 3$ & 3 & $3 a 5$ & sed bl y rojas & mica, Q & 5 \\
\hline TC 2 & Conj B & & $164 / 65$ & 1 & 2 & 1 & 1 & 2 & 1 & 1 & $2,5 Y R$ 6/6 & 1 & 2 & 1 & 1 & 3 y $4>, 2$ & 2 & $3 a 4$ & sed bl abund, rosadas y rojas & Q, mica fina, Q-fel & 3 \\
\hline TC 2 & Conj B & & 166 & 1 & 2 & 1 & 1 & 2 & 2 & 4 & $2,5 Y R \quad 6 / 8,5 / 4$ & 1 & 2 & 1 & 0 & 3 y $4>$ & 3 & $3 a 4$ & sed bl abund, rojas & Q, mica fina, Q-fel & 3 \\
\hline TC 2 & Conj B & & $167 / 68$ & 1 & 2 & 1 & 1 & 2 & 1 & 1 & $5 Y R 7 / 4$ & 1 & 2 & 1 & 1 & 3 y $4>, 2$ & 2 & $3 a 4$ & sed bl abund, rosadas y rojas & Q-fel, mica fina & 3 \\
\hline TC 2 & Conj B & & 169 & 1 & 2 & 1 & 1 & 2 & 1 & 1 & $2,5 Y R 5 / 4$ & 2 & 1 & 1 & 1 & 4 y $5>$ & 4 & $3 a 4$ & sed bl y rojas & Q-fel, mica fina & 5 \\
\hline TC 2 & Conj B & & 170 & 1 & 2 & 1 & 1 & 2 & 1 & 1 & 5YR 5/4 & 1 & 2 & 1 & 1 & 3 y $4>, 2$ & 2 & $3 a 4$ & sed grises, marrones y rojas & sed bl o fel alt, mica fina & 8 \\
\hline TC 2 & Conj B & & 171 & 1 & 2 & 1 & 1 & $2 \mathrm{y} 1$ & 1 & 1 & $2,5 Y R 5 / 8$ & 2 & 1 & 1 & 1 & 4 y $5>, 3$ & 3 & $3 a 4$ & sed marrones y rojas, $\mathrm{Q}$ & mica fina, Q-fel & 5 \\
\hline TC 2 & Conj B & & 172 & 1 & 2 & 1 & 1 & $2 \mathrm{y} 1$ & 1 & 1 & $2,5 Y R$ 4/6 & 2 & 1 & 1 & 1 & 4 y $5>$ & 4 & $3 a 4$ & Q, mica & sed bl y rojas & 5 \\
\hline TC 2 & Conj B & & 173 & 1 & 2 & 1 & 1 & $2 \mathrm{y} 1$ & 1 & 1 & $2,5 Y R$ 5/6 & 2 & 1 & 1 & 0 & 4 y $5>$ & 4 & $3 a 4$ & sed grises y marrones & Q-fel, mica fina & 5 \\
\hline TC 2 & Conj B & & 175 & 1 & 2 & 1 & 1 & $2 \mathrm{y} 1$ & 2 & 5 & 5YR 6/3. 4/2 (nuc) & 1 & 2 & 1 & 1 & 3 y $4>, 2$ & 2 & $3 a 4$ & sed bl abund, rojas, $\mathrm{Q}$ & Q-fel, mica fina & 3 \\
\hline TC 2 & Conj B & & 176 & 1 & 2 & 1 & 1 & $2 \mathrm{y} 1$ & 2 & 4 & $2,5 Y R 5 / 6,4 / 3$ & 2 & 1 & 1 & 0 & 4 y $5>$ & 4 & $3 a 4$ & sed grises $\mathrm{y}$ bl o fel alt & Q-fel, mica fina & 5 \\
\hline TC 2 & Conj B & & 177 & 1 & 2 & 1 & 1 & 2 & 1 & 1 & 5YR 7/6 & 1 & 2 & 1 & 1 & 3 y $4>, 2$ & 2 & $3 a 4$ & sed bl, rosadas y rojas & Q, mica fina & 3 \\
\hline TC 2 & Conj B & & 178 & 1 & 2 & 1 & 1 & 2 & 1 & 4 & 2,5 YR $5 / 6,5 / 8$ & 2 & 1 & 1 & 0 & $5>$ & 5 & $2 \mathrm{a} 4$ & $x$ & mica, sed grises, Q-fel & 5 \\
\hline TC 2 & Conj B & & 179 & 1 & 2 & 1 & 1 & 2 & 1 & 1 & $2,5 Y R 5 / 8$ & 1 & $1 \mathrm{a} 2$ & 1 & 1 & 3 y $4>$ & 3 & $3 a 4$ & sed bl abund & sed rojas, Q-fel, mica fina & 3 \\
\hline TC 2 & Conj B & & 180 & 1 & 2 & 2 & 1 & 2 & 1 & 1 & $2,5 Y R 5 / 6$ & 1 & 2 & 1 & 1 & 3 y $4>, 2$ & 2 & $3 a 4$ & sed bl abund, Q & sed rojas, Q-fel, mica fina & 3 \\
\hline TC 2 & Conj B & & 181 & 1 & 2 & 1 & 1 & 2 & 1 & 1 & 5YR 5/6 & 1 & 1 & 1 & 1 & 4 y $5>$ & 4 & $3 a 4$ & sed grises, mica & Q, Q-fel & 5 \\
\hline TC 2 & Conj B & & 182 & 1 & 2 & 2 & 1 & 2 & 2 & 4 & $2,5 Y R \quad 5 / 2,5 / 6$ & 2 & 2 & 1 & 0 & 3 y $4>, 2$ & 2 & $3 a 4$ & sed bl abund, Q, sed rojas & Q-fel, mica fina & 3 \\
\hline TC 2 & Conj B & & 183 & 1 & 2 & 1 & 1 & $2 \mathrm{y} 1$ & 1 & 1 & $2,5 Y R 5 / 6$ & 1 & 1a2 & 1 & 0 & 4 y $5>, 3$ & 3 & $3 a 4$ & sed bl abund, sed rojas, Q & Q-fel, mica fina & 3 \\
\hline TC 2 & Conj B & & 184 & 1 & 2 & 1 & 1 & 2 & 1 & 1 & $2,5 Y R 5 / 6$ & 2 & 1 & 1 & 0 & 4 y $5>$ & 4 & $3 a 4$ & sed marrones y rojas, incl osc & $x$ & 5 \\
\hline TC 2 & Conj B & & 185 & 1 & 2 & 1 & 1 & 2 & 1 & 1 & $2,5 Y R 7 / 4$ & 1 & 2 & 1 & 0 & 3 y $4>, 2$ & 2 & $3 a 4$ & sed bl abund, Q, sed rojas & Q-fel, mica fina & 3 \\
\hline TC 2 & Conj B & & 186 & 1 & 2 & 1 & 1 & 2 & 1 & 1 & 2,5 YR 5/6 & 1 & 1a2 & 1 & 0 & 3 y $4>, 2$ & 2 & $3 a 4$ & sed bl abund, Q, sed rojas & Q-fel, mica fina & 3 \\
\hline TC 2 & Conj B & & 187 & 1 & 2 & 1 & 1 & 2 & 2 & 1 & 7,5 YR 5/4 & 2 & 1 & 1 & 1 & 4 y $5>$ & 4 & $3 a 4$ & sed grises & Q, Q-fel, mica fina & 5 \\
\hline TC 2 & Conj B & & 188 & 1 & 2 & 1 & 1 & 2 & 1 & 1 & $2,5 Y R 5 / 8$ & 2 & 1 & 1 & 0 & 4 y $5>$ & 4 & $3 a 4$ & sed bl, rojas & Q, mica fina, Q-fel & 5 \\
\hline TC 2 & Conj B & & 189 & 1 & 2 & 1 & 1 & $2 \mathrm{y} 1$ & 1 & 1 & $2,5 Y R 5 / 8$ & 1 & 1a2 & 1 & 1 & 4 y $5>, 3$ & 3 & $3 a 4$ & sed bl abund, sed rojas & Q, mica fina, Q-fel & 3 \\
\hline TC 2 & Conj B & & 190 & 1 & 2 & 1 & 1 & $2 \mathrm{y} 1$ & 1 & 1 & 5YR 5/4 & 2 & 1 & 1 & 1 & 4 y $5>$ & 4 & $3 a 4$ & sed bl, rojas & Q-fel, mica fina & 5 \\
\hline TC 2 & Conj B & & 191 & 1 & 2 & 2 & 1 & 2 & 1 & 1 & 5YR 5/6 & 1 & 2 & 1 & 1 & 3 y $4>, 2$ & 2 & $3 a 4$ & sed bl abund, sed rojas & Q-fel, mica fina & 3 \\
\hline TC 2 & Conj B & & 194 & 1 & 2 & 2 & 1 & 2 & 2 & 1 & $5 Y R 4 / 6$ & 1 & 2 & 1 & 1 & 3 y $4>, 2$ & 2 & $3 a 4$ & sed marrones y rojas & mica & 8 \\
\hline TC 2 & Conj B & & 195 & 1 & 2 & 2 & 1 & 2 & 1 & 1 & $2,5 Y R$ 5/6 & 1 & 2 & 1 & 1 & 3 y $4>, 2$ & 2 & $3 a 4$ & sed bl, grises y rojas & Q, mica fina & 8 \\
\hline TC 2 & Conj B & & 196 & 1 & 2 & 2 & 1 & 2 & 2 & 1 & 5YR 4/4 & 1 & 2 & 1 & 2 & 3 y $4>, 2$ & 2 & $2 \mathrm{a} 4$ & mica abund, Q, sed rojas & Q-fel & 1 \\
\hline
\end{tabular}




\begin{tabular}{|c|c|c|c|c|c|c|c|c|c|c|c|c|c|c|c|c|c|c|c|c|c|}
\hline \multirow[b]{2}{*}{$\begin{array}{c}\text { Sitio y } \\
\text { est }\end{array}$} & \multirow[b]{2}{*}{ UP } & \multirow[b]{2}{*}{ GF } & \multirow[b]{2}{*}{ FNA } & \multicolumn{4}{|c|}{ Fractura } & \multirow[b]{2}{*}{$\begin{array}{l}\text { Ca } \\
\text { vid }\end{array}$} & \multirow{2}{*}{\multicolumn{2}{|c|}{$\begin{array}{l}\text { Coc Co } \\
\text { ción lor }\end{array}$}} & \multirow[b]{2}{*}{ Not color } & \multicolumn{7}{|c|}{ Inclusiones } & \multicolumn{2}{|c|}{ Composic } & \multirow[b]{2}{*}{ GP } \\
\hline & & & & \begin{tabular}{|c|}
$\begin{array}{c}\text { Aspec } \\
\text { to }\end{array}$ \\
\end{tabular} & $\begin{array}{l}\text { Tex } \\
\text { tura }\end{array}$ & \begin{tabular}{|l|} 
Resis \\
tenc.
\end{tabular} & $\begin{array}{lll}\text { Re } \\
\text { ul }\end{array}$ & & & & & Incl & Dens & $\begin{array}{c}\text { Orien } \\
\text { tac }\end{array}$ & $\begin{array}{l}\text { Orient } \\
\text { pared }\end{array}$ & Granul & $\begin{array}{l}\text { Se } \\
\text { lec }\end{array}$ & $\begin{array}{l}\mathrm{Re} \\
\mathrm{don}\end{array}$ & comp mayor & comp aislados & \\
\hline TC 2 & Conj B & & 197 & 1 & 2 & 2 & 1 & 2 & 1 & 1 & $5 Y R 4 / 6$ & 1 & 2 & 1 & 2 & 3 y $4>, 2$ & 2 & $2 \mathrm{a} 4$ & mica abund, Q, sed rojas & Q-fel & 1 \\
\hline TC 2 & Conj B & & 198 & 1 & 2 & 1 & 1 & $2 \mathrm{y} 1$ & 2 & 4 & $5 Y R$ 5/4, 4/1 & 2 & $1 \mathrm{a} 2$ & 1 & 1 & 3 y $4>$ & 3 & $3 a 4$ & sed grises y marrones & mica, Q & 8 \\
\hline TC 2 & Conj B & & 199 & 1 & 2 & 2 & 1 & 2 & 2 & 1 & $5 Y R \quad 4 / 3$ & 1 & 2 & 1 & 2 & 3 y $4>, 2$ & 2 & $2 \mathrm{a} 4$ & mica abund, Q, sed rojas & Q-fel & 1 \\
\hline TC 2 & Conj B & & 200 & 1 & 2 & 1 & 1 & 2 & 1 & 1 & $2,5 Y R 5 / 6$ & 1 & 2 & 1 & 1 & 3 y $4>, 2$ & 2 & $3 a 4$ & sed bl y rosadas abund, sed rojas, $\mathrm{Q}$ & mica fina, Q-fel & 3 \\
\hline TC 2 & Conj B & & 201 & 1 & 2 & 2 & 1 & 2 & 2 & 4 & $5 Y R$ 5/4; N3/ & 1 & 2 & 1 & 1 & 3 y $4>, 2$ & 2 & $3 a 4$ & sed grises, marrones y bl & mica fina, Q-fel & 8 \\
\hline TC 2 & Conj B & & 202 & 1 & 2 & 1 & 1 & 2 & 2 & 4 & 2,5YR 5/6, 5YR 5/4 & 1 & 2 & 1 & 1 & 3 y $4>, 2$ & 2 & $3 a 4$ & sed marrones, grises & mica fina, Q-fel & 8 \\
\hline TC 2 & Conj B & & 203 & 1 & 2 & 1 & 1 & 2 & 1 & 1 & $2,5 Y R 6 / 6$ & 1 & 2 & 1 & 1 & 4 y $5>, 2$ y 3 & 2 & $3 a 4$ & sed bl abund, rojas, Q & mica fina, Q-fel & 3 \\
\hline TC 2 & Conj B & & 204 & 1 & 2 & 1 & 1 & $2 \mathrm{y} 1$ & 2 & 4 & 2,5 YR $4 / 1,6 / 6$ & 1 & 2 & 1 & 1 & 3 y $4>, 2$ & 2 & $3 a 4$ & sed bl abund, rosadas y rojas & Q, mica fina, Q-fel & 3 \\
\hline TC 2 & Conj B & & 205 & 1 & 2 & 2 & 1 & 2 & 2 & 5 & 5YR5/6; 2,5YR5/6(nuc) & 1 & 2 & 1 & 0 & 3 y $4>, 2$ & 2 & $3 a 4$ & sed marrones y grises, $\mathrm{Q}$ & mica fina, Q-fel & 8 \\
\hline TC 2 & Conj B & & $206 / 07$ & 1 & 2 & 1 & 1 & $2 \mathrm{y} 1$ & 2 & 4 & $2,5 Y R \quad 4 / 2,5 / 6$ & 1 & 2 & 1 & 0 & 3 y $4>, 2$ & 2 & $3 a 4$ & sed grises, marrones y bl & Q, mica fina, Q-fel & 8 \\
\hline TC 2 & Conj B & & 208 & 1 & 2 & 2 & 1 & $2 \mathrm{y} 1$ & 2 & 4 & $2,5 Y R$ 3/1, 4/4 & 1 & 2 & 1 & 1 & 3 y $4>, 1$ y 2 & 1 & $3 a 4$ & sed marrones, grises, $\mathrm{Q}$, sed bl & mica fina, Q-fel & 8 \\
\hline TC 2 & Conj B & & 209 & 1 & 2 & 1 & 1 & 2 & 2 & 2 & $7,5 Y R$ 5/4, 5/1 & 1 & 2 & 1 & 0 & 3 y $4>, 2$ & 2 & $3 a 4$ & sed grises y marrones & mica fina & 8 \\
\hline TC 2 & Conj B & & 210 & 1 & 2 & 1 & 1 & 2 & 2 & 4 & $2,5 Y R$ 4/1, 5/6 & 1 & 2 & 1 & 0 & 3 y $4>, 2$ & 2 & $3 a 4$ & sed rojas abund, Q, sed bl & mica fina & 8 \\
\hline TC 2 & Conj B & & 211 & 1 & 2 & 1 & 1 & $2 \mathrm{y} 1$ & 2 & 5 & $2,5 Y R$ 5/6, 6/2 (nuc) & 2 & 2 & 1 & 1 & 3 y $4>, 2$ & 2 & $3 a 4$ & sed marrones abund, sed bl & mica fina, Q-fel & 8 \\
\hline TC 2 & Conj B & & 212 & 1 & 2 & 1 & 1 & 2 & 1 & 1 & 2,5 YR 5/6 & 2 & 2 & 1 & 0 & 2 y $3>$ & 2 & $3 a 4$ & sed marrones y grises & mica fina & 8 \\
\hline TC 2 & Conj C & & 213 & 1 & 2 & 2 & 1 & 2 & 1 & 1 & 2,5 YR $5 / 6$ & 2 & 1 & 1 & 0 & 4 y $5>$ & 4 & $3 a 4$ & sed bl y grises, mica & Q-fel & 5 \\
\hline TC 2 & Conj C & & 215 & 1 & 2 & 1 & 1 & 2 & 2 & 4 & 2,5 YR $5 / 3,5 / 6$ & 1 & 2 & 1 & 1 & 3 y $4>, 2$ & 2 & $3 a 5$ & sed rojas, bl, y rosadas & Q, mica, Q-fel & 8 \\
\hline TC 2 & Conj C & & 216 & 1 & 2 & 1 & 1 & 2 & 1 & 1 & $2,5 Y R$ 6/6 & 1 & 2 & 1 & 1 & 3 y $4>, 2$ & 2 & $3 a 4$ & sed bl abund, rosadas y rojas & mica fina, Q-fel & 3 \\
\hline TC 2 & Conj C & & 217 & 1 & 2 & 1 & 1 & 2 & 1 & 1 & 2,5 YR $5 / 6$ & 2 & 1 & 1 & 0 & 4 y $5>$ & 4 & $3 a 4$ & sed rojas & mica fina, Q-fel & 5 \\
\hline TC 2 & Conj C & & 218 & 1 & 2 & 1 & 1 & $2 \mathrm{y} 1$ & 1 & 1 & $2,5 Y R 5 / 6$ & 2 & 1 & 1 & 1 & 4 y $5>, 3$ & 3 & $3 a 4$ & sed rojas & mica, Q-fel & 5 \\
\hline TC 2 & Conj C & & 219 & 1 & 2 & 1 & 1 & 2 & 1 & 1 & 2,5 YR $5 / 6$ & 1 & 1a2 & 1 & 0 & 4 y $5>, 3$ & 3 & $3 a 4$ & sed bl abund, sed rojas & mica fina, Q-fel & 3 \\
\hline TC 2 & Conj C & & 220 & 1 & 2 & 1 & 1 & 2 & 1 & 1 & $2,5 Y R$ 5/8 & 2 & 1 & 1 & 1 & 4 y $5>$ & 4 & $3 a 5$ & $\mathrm{Q}$, mica, sed bl & Q-fel & 5 \\
\hline TC 2 & Conj C & & 221 & 1 & 2 & 1 & 1 & 2 & 1 & 1 & $2,5 Y R 5 / 6$ & 2 & 1 & 1 & 1 & 4 y $5>$ & 4 & $3 a 4$ & sed bl y rojas, $Q$ & mica fina & 5 \\
\hline TC 2 & Conj C & & 222 & 1 & 2 & 1 & 1 & 2 & 1 & 1 & 2,5 YR $7 / 4$ & 1 & 2 & 1 & 0 & 3 y $4>, 2$ & 2 & $3 a 5$ & sed bl abund, rojas, Q & mica fina, Q-fel & 3 \\
\hline TC 2 & Conj C & & 223 & 1 & 2 & 1 & 1 & 2 & 1 & 1 & $2,5 Y R$ 5/6 & 2 & 1 & 1 & 0 & 4 y $5>, 3$ & 3 & $3 a 4$ & sed bl, grises y rojas & mica fina & 5 \\
\hline TC 2 & Conj C & & 224 & 1 & 2 & 1 & 1 & 2 & 1 & 1 & 2,5 YR $5 / 6$ & 1 & 2 & 2 & 0 & 3 y $4>, 2$ & 2 & $3 a 4$ & sed bl abund, grises y rojas & Q, mica fina & 3 \\
\hline TC 2 & Conj C & & 225 & 1 & 2 & 1 & 1 & $2 \mathrm{y} 1$ & 1 & 1 & 2,5 YR $6 / 6$ & 1 & 2 & 1 & 1 & 3 y $4>, 2$ & 2 & $3 a 4$ & sed bl abund, rojas y rosadas & mica fina, Q-fel & 3 \\
\hline TC 2 & Conj C & & 226 & 1 & 2 & 2 & 1 & $2 \mathrm{y} 1$ & 1 & 1 & $2,5 Y R$ 6/6 & 1 & 2 & 1 & 1 & 3 y $4>, 2$ & 2 & $3 a 4$ & sed bl y rosadas abund, sed rojas & mica, Q-fel & 3 \\
\hline TC 2 & Conj C & & 227 & 1 & 2 & 2 & 1 & 2 & 1 & 1 & $2,5 Y R 6 / 6$ & 1 & 2 & 1 & 1 & 3 y $4>, 2$ & 2 & $3 a 4$ & sed bl abund, rosadas y rojas & mica fina, Q-fel & 3 \\
\hline TC 2 & Conj C & & 228 & 1 & 2 & 1 & 1 & 2 & 2 & 4 & $5 Y R \quad 4 / 2,5 / 4$ & 2 & 2 & 1 & 0 & 3 y $4>, 2$ & 2 & $3 a 4$ & sed marrones y rojas & sed bl o fel alt, mica fina, Q-fel & 8 \\
\hline TC 2 & Conj C & & 229 & 1 & 2 & 1 & 1 & 2 & 1 & 1 & 2,5 YR $5 / 6$ & 1 & $1 \mathrm{a} 2$ & 1 & 1 & 4 y $5>, 3$ & 3 & $3 a 5$ & sed bl, rojas, Q & Q-fel, mica fina & 8 \\
\hline TC 2 & Conj C & & 230 & 1 & 2 & 1 & 2 & 2 & 1 & 1 & 2,5 YR $5 / 6$ & 2 & 1 & 1 & 1 & 4 y $5>, 3$ & 3 & $3 a 4$ & sed bl y rojas & Q-fel, mica fina & 5 \\
\hline TC 2 & Conj D & & 231 & 1 & 2 & 1 & 1 & $2 \mathrm{y} 1$ & 1 & 1 & 2,5 YR $5 / 6$ & 1 & 2 & 2 & 1 & 3 y $4>, 2$ & 2 & $3 a 4$ & sed bl abund, sed rojas & Q, Q-fel, mica fina & 3 \\
\hline TC 2 & Conj D & & 234 & 1 & 2 & 1 & 1 & 2 & 2 & 5 & 2,5YR 5/6, 5/3 (nuc) & 1 & 2 & 1 & 1 & 3 y $4>, 1$ y 2 & 1 & $3 a 4$ & sed marrones y rojas, bl & Q, mica, Q-fel & 8 \\
\hline TC 2 & Conj D & & 235 & 1 & 2 & 1 & 1 & 2 & 1 & 1 & 5YR 7/4 & 1 & 2 & 1 & 1 & 3 y $4>, 2$ & 2 & $3 a 4$ & sed bl abund, rosadas y rojas & mica fina, Q-fel & 3 \\
\hline TC 2 & Conj D & & 236 & 1 & 2 & 1 & 1 & 2 & 1 & 1 & 2,5 YR $6 / 6$ & 1 & 2 & 1 & 1 & 3 y $4>, 2$ & 2 & $3 a 4$ & sed bl abund, rosadas y rojas & mica fina, Q-fel & 3 \\
\hline
\end{tabular}




\begin{tabular}{|c|c|c|c|c|c|c|c|c|c|c|c|c|c|c|c|c|c|c|c|c|c|}
\hline \multirow[b]{2}{*}{$\begin{array}{c}\text { Sitio y } \\
\text { est }\end{array}$} & \multirow[b]{2}{*}{ UP } & \multirow[b]{2}{*}{ GF } & \multirow[b]{2}{*}{ FNA } & \multicolumn{4}{|c|}{ Fractura } & \multirow{2}{*}{\multicolumn{3}{|c|}{\begin{tabular}{l|l|l} 
Ca & Coc Co \\
vid & ción lor \\
\end{tabular}}} & \multirow[b]{2}{*}{ Not color } & \multicolumn{7}{|c|}{ Inclusiones } & \multicolumn{2}{|c|}{ Composic } & \multirow[b]{2}{*}{ GP } \\
\hline & & & & $\begin{array}{c}\text { Aspec } \\
\text { to }\end{array}$ & \begin{tabular}{|l|l|}
$c$ & $\begin{array}{l}\text { Tex } \\
\text { tura }\end{array}$ \\
\end{tabular} & $\begin{array}{l}\text { Resis } \\
\text { tenc. }\end{array}$ & $\begin{array}{l}\mathrm{Re} \\
\text { gul }\end{array}$ & & & & & Incl & Dens & \begin{tabular}{|c} 
Orien \\
tac
\end{tabular} & $\begin{array}{l}\text { Orient } \\
\text { pared }\end{array}$ & Granul & & $\begin{array}{l}\mathrm{Re} \\
\mathrm{don}\end{array}$ & comp mayor & comp aislados & \\
\hline TC 2 & Conj D & & 237 & 1 & 2 & 2 & 1 & 2 & 1 & 1 & 2,5 YR $4 / 6$ & 2 & 2 & 1 & 1 & 3 y $4>, 2$ & 2 & $3 a 4$ & sed marrones y rojas & sed bl o fel alt, mica fina & 8 \\
\hline TC 2 & Conj D & & 238 & 1 & 2 & 1 & 1 & 2 & 1 & 1 & 2,5 YR $5 / 6$ & 2 & 1 & 1 & 0 & 4 y $5>, 3$ & 3 & $3 a 4$ & sed bl, rojas & Q-fel, mica fina & 5 \\
\hline TC 2 & Conj D & & 239 & 1 & 2 & 1 & 1 & 2 & 1 & 1 & 2,5 YR $5 / 6$ & 2 & 1 & 1 & 1 & 4 y $5>$ & 4 & $3 a 4$ & sed bl abund, rojas & mica fina, Q-fel & 5 \\
\hline TC 2 & Conj D & & 240 & 1 & 2 & 1 & 1 & $2 \mathrm{y} 1$ & 1 & 1 & $2,5 Y R$ T/6 & 1 & 2 & 1 & 1 & 3 y $4>, 2$ & 2 & $3 a 4$ & sed bl abund, rosadas y rojas & Q-fel, mica fina & 3 \\
\hline TC 2 & Conj D & & 241 & 1 & 2 & 1 & 1 & 2 & 1 & 1 & $2,5 Y R 5 / 6$ & 2 & 1 & 1 & 0 & 4 y $5>, 3$ & 3 & $3 a 4$ & sed bl, grises y rojas & Q-fel, mica fina & 5 \\
\hline TC 2 & Conj D & & 242 & 1 & 2 & 1 & 1 & 2 & 1 & 1 & 2,5 YR $4 / 6$ & 2 & 1 & 1 & 0 & 4 y $5>, 3$ & 3 & $3 a 4$ & sed bl, rojas & mica fina & 5 \\
\hline TC 2 & Conj D & & 243 & 1 & 2 & 1 & 1 & $2 \mathrm{y} 1$ & 2 & 4 & $2,5 Y R$ 5/6, 5/4 & 2 & 1 & 1 & 0 & 3 y $4>, 2$ & 2 & $3 a 4$ & sed grises & sed marrones, mica fina & 5 \\
\hline TC 2 & Conj D & & 244 & 1 & 2 & 1 & 1 & 2 & 1 & 1 & $2,5 Y R$ 5/6 & 2 & 1 & 1 & 1 & 4 y $5>, 3$ & 3 & $3 a 4$ & sed bl abund, rojas & mica fina, Q-fel & 5 \\
\hline TC 2 & Conj D & & 245 & 1 & 2 & 1 & 1 & $2 \mathrm{y} 1$ & 2 & 1 & $5 Y R 6 / 3$ & 1 & 2 & 1 & 1 & 3 y $4>, 2$ & 2 & $3 a 5$ & sed bl abund, rojas, $\mathrm{Q}$ & Q-fel, mica fina & 3 \\
\hline TC 2 & Conj D & & 246 & 1 & 2 & 1 & 1 & 2 & 1 & 1 & 5YR 7/4 & 1 & 2 & 1 & 1 & 2 y $3>, 1$ y 4 & 1 & $3 a 4$ & sed bl abund, rojas & Q-fel, mica fina & 3 \\
\hline TC 2 & Conj D & & 247 & 1 & 2 & 1 & 1 & 2 & 1 & 1 & 2,5 YR $5 / 6$ & 2 & 2 & 1 & 0 & 4 y $5>, 3$ & 3 & $3 a 5$ & sed bl, marrones y rojas & Q-fel, mica fina & 8 \\
\hline TC 2 & Conj D & & 248 & 1 & 2 & 1 & 1 & 2 & 2 & 4 & 5YR 6/4; 2,5YR 6/6 & 1 & 2 & 1 & 1 & 3 y $4>, 2$ & 2 & $3 a 4$ & sed bl abund, Q & sed rojas, mica & 3 \\
\hline TC 2 & Conj D & & 249 & 1 & 2 & 2 & 1 & 2 & 2 & 1 & 7,5YR 5/4 & 1 & 2 & 1 & 1 & 3 y $4>, 1$ y 2 & 1 & $3 a 4$ & sed marrones, sed bl, mica & sed rojas, Q-fel & 8 \\
\hline TC 2 & Conj D & & 250 & 1 & 2 & 1 & 1 & 2 & 1 & 1 & $5 Y R$ 6/4 & 1 & 2 & 1 & 1 & 3 y $4>$ & 3 & $3 a 4$ & sed bl abund, sed rojas & $\mathrm{Q}$, mica & 3 \\
\hline TC 2 & Conj D & & 251 & 1 & 2 & 2 & 1 & 2 & 2 & 2 & N5/; 2,5YR 5/6 & 2 & 2 & 1 & 2 & 3 y $4>$ & 3 & $2 \mathrm{a} 4$ & mica abund, Q & sed rojas, Q-fel & 1 \\
\hline TC 2 & Conj D & & 252 & 1 & 2 & 1 & 1 & 2 & 1 & 1 & $2,5 Y R$ 6/6 & 1 & 2 & 1 & 1 & 3 y $4>, 2$ & 2 & $3 a 4$ & sed bl abund, rosadas y rojas & mica, Q-fel & 3 \\
\hline TC 2 & Conj D & & 254 & 1 & 2 & 2 & 1 & 2 & 1 & 1 & 2,5YR 6/6 & 1 & 2 & 1 & 1 & 3 y $4>, 2$ & 2 & $3 a 4$ & sed bl abund, rosadas y rojas & Q, Q-fel, mica fina & 3 \\
\hline TC 2 & Conj D & & 255 & 1 & 2 & 1 & 1 & $2 \mathrm{y} 1$ & 2 & 5 & 2,5 YR 4/6, 5/6 (nuc) & 2 & $1 \mathrm{a} 2$ & 1 & 1 & 3 y $4>, 2$ & 2 & $3 a 4$ & sed bl, grises y rojas & Q, mica fina, Q-fel & 8 \\
\hline TC 2 & Conj D & & 256 & 1 & 2 & 1 & 1 & 2 & 1 & 1 & 5YR 5/6 & 1 & 2 & 1 & 1 & 3 y $4>, 2$ & 2 & $3 a 4$ & sed grises, rojas y marrones & Q-fel, mica fina & 8 \\
\hline $\mathrm{TC} 2$ & Conj D & & 257 & 1 & 2 & 1 & 1 & 2 & 1 & 1 & 2,5 YR $6 / 6$ & 1 & 2 & 1 & 1 & 3 y $4>, 2$ & 2 & $3 a 5$ & sed bl abund, rojas, Q & mica fina, Q-fel & 3 \\
\hline TC 2 & Conj D & & 258 & 1 & 2 & 2 & 1 & 2 & 1 & 1 & $2,5 Y R$ 5/6 & 2 & 2 & 1 & 1 & 3 y $4>, 2$ & 2 & $3 a 4$ & sed grises y marrones abund & Q-fel, mica fina & 8 \\
\hline TC 2 & Conj D & & 259 & 1 & 2 & 1 & 1 & 2 & 1 & 1 & $2,5 Y R 5 / 6$ & 2 & 1 & 2 & 1 & 3 y $4>$ & 3 & $3 a 4$ & sed bl y grises & sed rojas, mica & 5 \\
\hline TC 2 & Conj D & & 260 & 1 & 2 & 1 & 1 & $2 \mathrm{y} 1$ & 2 & 4 & $7,5 Y R$ 5/4, 5/2 & 2 & 1 & 1 & 1 & 4 y $5>, 3$ & 3 & $3 a 4$ & sed bl y grises & Q, Q-fel, mica fina & 5 \\
\hline $\mathrm{TC} 2$ & Conj D & & 261 & 1 & 2 & 1 & 1 & 2 & 2 & 4 & $2,5 Y R$ 5/3, 5/6 & 2 & 1 & 2 & 1 & 4 y $5>$ & 4 & $4 a 5$ & $x$ & sed rojas, mica, sed bl o fel alt & 5 \\
\hline TC 2 & Conj D & & 262 & 1 & 2 & 1 & 1 & 2 & 1 & 1 & 2,5 YR $5 / 6$ & 2 & 1 & 2 & 1 & 3 y $4>, 2$ & 2 & $3 a 4$ & sed bl y grises & sed rojas, mica fina, Q-fel & 5 \\
\hline TC 2 & Conj D & & 263 & 1 & 2 & 1 & 1 & 2 & 2 & 4 & $7,5 Y R$ 3/1, 5/2 & 2 & 2 & 1 & 0 & 3 y $4>.2$ & 2 & $3 a 4$ & sed bl, grises y marrones & Q, mica fina & 8 \\
\hline TC 2 & Conj D & & 264 & 1 & 2 & 1 & 1 & 2 & 1 & 1 & $2,5 Y R$ T/6 & 2 & 1 & 1 & 1 & 4 y $5>$ & 4 & $3 a 4$ & sed bl, rosadas y rojas & Q, mica fina & 5 \\
\hline TC 2 & Conj D & & 265 & 1 & 2 & 1 & 1 & 2 & 1 & 1 & 5YR 7/6 & 1 & 2 & 1 & 1 & 3 y $4>, 2$ & 2 & $3 a 4$ & sed bl abund, sed rojas & mica fina, Q-fel & 3 \\
\hline TC 2 & Conj D & & 266 & 1 & 2 & 2 & 1 & 2 & 2 & 5 & 7,5YR 4/2, 5/4 (nuc) & 1 & 2 & 1 & 1 & 3 y $4>, 2$ & 2 & $3 a 4$ & sed grises, marrones y rojas & Q, Q-fel, mica fina & 8 \\
\hline TC 2 & Conj D & & 267 & 1 & 2 & 2 & 1 & 2 & 1 & 1 & 5YR 5/4 & 1 & 2 & 1 & 1 & 3 y $4>, 2$ & 2 & $3 a 4$ & sed grises y marrones & Q-fel, mica fina & 8 \\
\hline TC 2 & Conj D & & 268 & 1 & 2 & 1 & 1 & 2 & 1 & 1 & $2,5 Y R$ \%/6 & 1 & 2 & 1 & 1 & 3 y $4>, 2$ & 2 & $3 a 4$ & sed bl abund, sed rojas, Q & mica fina, Q-fel & 3 \\
\hline TC 2 & Conj D & & 269 & 1 & 2 & 1 & 1 & 2 & 1 & 1 & $2,5 Y R 5 / 6$ & 2 & 2 & 1 & 1 & 3 y $4>, 2$ & 2 & $3 a 4$ & sed rojas, rosadas & Q, sed bl o fel alt, mica fina & 8 \\
\hline TC 2 & Conj D & & 270 & 1 & 2 & 1 & 1 & $2 \mathrm{y} 1$ & 1 & 1 & 5YR 5/4 & 1 & 2 & 1 & 1 & 3 y $4>, 2$ & 2 & $3 a 4$ & sed bl, marrones y rojas & Q, Q-fel, mica fina & 8 \\
\hline TC 2 & Conj D & & 273 & 1 & 2 & 1 & 1 & 2 & 1 & 1 & 2,5 YR $5 / 6$ & 2 & 1 & 1 & 0 & 4 y $5>$ & 4 & $2 \mathrm{a} 4$ & $x$ & mica, sed rojas, Q & 5 \\
\hline TC 2 & Conj D & & 274 & 1 & 2 & 1 & 1 & 2 & 1 & 1 & 2,5 YR $4 / 4$ & 2 & 2 & 1 & 0 & 3 y $4>, 2$ & 2 & $3 a 4$ & sed marrones y rojas, $\mathrm{Q}$, mica & Q-fel & 8 \\
\hline TC 2 & Conj D & & 275 & 1 & 2 & 1 & 1 & 2 & 1 & 4 & 2,5 YR $5 / 3,6 / 6$ & 1 & 2 & 1 & 1 & 3 y $4>, 2$ & 2 & $3 a 4$ & sed bl abund, sed rojas, Q & mica fina, Q-fel & 3 \\
\hline
\end{tabular}




\begin{tabular}{|c|c|c|c|c|c|c|c|c|c|c|c|c|c|c|c|c|c|c|c|c|c|}
\hline \multirow[b]{2}{*}{$\begin{array}{c}\text { Sitio y } \\
\text { est }\end{array}$} & \multirow[b]{2}{*}{ UP } & \multirow[b]{2}{*}{ GF } & \multirow[b]{2}{*}{ FNA } & \multicolumn{4}{|c|}{ Fractura } & \multirow[b]{2}{*}{$\begin{array}{l}\text { Ca } \\
\text { vid }\end{array}$} & \multirow{2}{*}{\multicolumn{2}{|c|}{$\begin{array}{l}\text { Coc Co } \\
\text { ción lor }\end{array}$}} & \multirow[b]{2}{*}{ Not color } & \multicolumn{7}{|c|}{ Inclusiones } & \multicolumn{2}{|c|}{ Composic } & \multirow[b]{2}{*}{ GP } \\
\hline & & & & \begin{tabular}{|c|}
$\begin{array}{c}\text { Aspec } \\
\text { to }\end{array}$ \\
\end{tabular} & \begin{tabular}{|l|l|}
$c$ & $\begin{array}{l}\text { Tex } \\
\text { tura }\end{array}$ \\
\end{tabular} & \begin{tabular}{|l} 
Resis \\
tenc.
\end{tabular} & $\begin{array}{l}\mathrm{Re} \\
\text { gul }\end{array}$ & & & & & Incl & Dens & $\begin{array}{c}\text { Orien } \\
\text { tac }\end{array}$ & $\begin{array}{l}\text { Orient } \\
\text { pared }\end{array}$ & Granul & \begin{tabular}{l|}
$\mathrm{Se}$ \\
$\mathrm{lec}$
\end{tabular} & $\begin{array}{l}\mathrm{Re} \\
\mathrm{don}\end{array}$ & comp mayor & comp aislados & \\
\hline TC 2 & Conj D & & 276 & 1 & 2 & 1 & 1 & 2 & 1 & 1 & 2,5 YR $5 / 6$ & 1 & 2 & 1 & 0 & 3 y $4>, 2$ & 2 & $3 a 4$ & sed rojas y marrones, $\mathrm{Q}$ & Q-fel, mica fina & 8 \\
\hline TC 2 & Conj E & & $277 a 80$ & 1 & 2 & 1 & 1 & 2 & 1 & 1 & $2,5 Y R 5 / 6$ & 2 & 1 & 1 & 1 & 4 y $5>, 3$ & 32 & $2 \mathrm{a} 4$ & mica, sed rojas & sed bl, Q-fel & 5 \\
\hline TC 2 & Conj $\mathrm{F}$ & & 281 & 1 & 2 & 1 & 1 & 2 & 1 & 1 & $2,5 Y R 5 / 6$ & 2 & 1 & 1 & 0 & 4 y $5>$ & 45 & $3 a 4$ & sed bl y grises & sed rojas, Q-fel, mica fina & 5 \\
\hline TC 2 & Conj $\mathrm{F}$ & & 282 & 1 & 2 & 1 & 1 & 2 & 1 & 1 & $2,5 Y R 5 / 6$ & 2 & 1 & 1 & 0 & 4 y $5>$ & 4 & $3 a 4$ & sed bl y grises & sed rojas, Q-fel, mica fina & 5 \\
\hline TC 2 & Conj $\mathrm{F}$ & & 283 & 1 & 2 & 1 & 1 & 2 & 2 & 4 & $2,5 Y R$ 5/6, 5/4 & 2 & 1 & 2 & 1 & 4 y $5>$ & 4 & $3 a 4$ & sed bl y rojas & mica, Q-fel & 5 \\
\hline TC 2 & Conj $\mathrm{F}$ & & 284 & 1 & 2 & 2 & 1 & 2 & 1 & 1 & $5 Y R 6 / 4$ & 1 & 2 & 1 & 1 & 3 y $4>, 2$ & 23 & $3 a 5$ & sed bl abund, sed rojas, $\mathrm{Q}$ & Q-fel, mica fina & 3 \\
\hline TC 2 & Conj $\mathrm{F}$ & & 285 & 1 & 2 & 2 & 1 & 2 & 1 & 1 & $5 Y R 5 / 6$ & 1 & 1 & 1 & 1 & 4 y $5>$ & 4 & $3 a 4$ & sed bl & mica, sed rojas, Q-fel & 5 \\
\hline TC 2 & Conj $\mathrm{F}$ & & 286 & 1 & 2 & 2 & 1 & 2 & 2 & 1 & $2,5 Y R 4 / 4$ & 1 & 2 & 1 & 1 & 3 y $4>, 2$ & 2 & $3 a 4$ & sed grises y marrones & mica, Q-fel & 8 \\
\hline TC 2 & Conj $\mathrm{F}$ & & 287 & 1 & 2 & 1 & 1 & 2 & 2 & 4 & 2,5YR 5/4, 10R 6/6 & 1 & 2 & 1 & 1 & 3 y $4>, 2$ & 2 & $3 a 4$ & sed bl abund, Q & sed rojas, mica, Q-fel & 3 \\
\hline TC 2 & Conj $\mathrm{F}$ & & 288 & $x$ & $\mathrm{x}$ & $\mathrm{x}$ & $x$ & $x$ & 1 & 1 & $2,5 Y R$ 5/6 & 1 & 1a2 & 1 & 1 & 3 y $4>, 2$ & 2 & $3 a 4$ & sed bl abund, sed rojas & Q, mica & 3 \\
\hline TC 2 & Conj F & & 289-91 & 1 & 2 & 1 & 1 & $2 \mathrm{y} 1$ & 2 & 4 & $2,5 Y R$ 5/6, 5/2 & 1 & 2a3 & 1 & 1 & 4 y $5>, 3$ & 3 & 2a4 & Q abund, mica, sed bl, Q-fel & sed rojas & 2 \\
\hline TC 2 & Conj F & & $292 / 93$ & 1 & 2 & 1 & 1 & 2 & 1 & 1 & $2,5 Y R 5 / 6$ & 1 & 2 & 1 & 1 & 3 y $4>, 2$ & 2 & $3 a 4$ & sed bl abund, sed rojas, Q & Q-fel, mica fina & 3 \\
\hline TC 2 & Conj $\mathrm{F}$ & & 294 & 1 & 2 & 1 & 1 & 2 & 2 & 4 & 10R $6 / 6,4 / 2$ & 1 & 2 & 1 & 1 & 3 y $4>, 2$ & 2 & $3 a 4$ & sed bl abund, sed rojas, Q & Q-fel, mica fina & 3 \\
\hline TC 2 & Conj $\mathrm{F}$ & & 295 & 1 & 2 & 1 & 1 & 2 & 1 & 1 & 2,5 YR 5/6 & 1 & 2 & 1 & 1 & 3 y $4>, 2$ & 2 & $3 a 4$ & sed bl abund, sed rojas y marrones & Q-fel, mica fina & 3 \\
\hline TC 2 & Conj F & & 296 & 1 & 2 & 1 & 1 & 2 & 2 & 5 & 5 YR 5/6, 5/2 (nuc) & 1 & 2 & 1 & 1 & 3 y $4>, 2$ & 2 & $3 a 4$ & sed bl, Q, sed rojas & Q-fel, mica fina & 3 \\
\hline TC 2 & Conj $\mathrm{F}$ & & 297 & 1 & 2 & 1 & 1 & 2 & 1 & 1 & $2,5 Y R 6 / 4$ & 1 & 2 & 1 & 1 & 3 y $4>, 2$ & 2 & $3 a 4$ & sed bl abund, rosadas y rojas, $\mathrm{Q}$ & mica fina, Q-fel & 3 \\
\hline TC 2 & Conj $\mathrm{F}$ & & 299 & 1 & 2 & 1 & 1 & 2 & 2 & 4 & $5 Y R$ 4/4, 4/1 & 1 & 2 & 1 & 1 & 3 y $4>, 2$ & 2 & $3 a 4$ & sed grises y marrones & Q, mica fina, Q-fel & 8 \\
\hline TC 2 & Conj F & & 300 & 1 & 2 & 1 & 1 & 2 & 2 & 5 & $2,5 Y R$ 5/6, 5/1 (nuc) & 1 & 2 & 1 & 1 & 3 y $4>, 2$ & 2 & $3 a 4$ & sed marrones y grises & mica fina, Q-fel & 8 \\
\hline TC 2 & Conj F & & 301 & 1 & 2 & 1 & 1 & 2 & 2 & 4 & 2,5 YR $5 / 6,4 / 2$ & 1 & 2 & 1 & 1 & 3 y $4>, 2$ & 2 & $3 a 4$ & Q, sed grises y marrones, mica & Q-fel & 8 \\
\hline TC 2 & Conj $\mathrm{F}$ & & 302 & 1 & 2 & 2 & 1 & 2 & 1 & 1 & $7,5 Y R 7 / 4$ & 2 & 2 & 1 & 1 & 4 y $5>, 3$ & 3 & $2 \mathrm{a} 4$ & mica abund, sed rojas, bl, Q & Q-fel & 1 \\
\hline TC 2 & Conj $\mathrm{F}$ & & 303 & 1 & 2 & 1 & 1 & 2 & 1 & 1 & $2,5 Y R 7 / 4$ & 1 & 2 & 2 & 1 & 3 y $4>, 1$ y 2 & 1 & $3 a 4$ & sed bl abund, Q, sed rojas & Q-fel, mica fina & 3 \\
\hline TC 2 & Conj F & & 304 & 1 & 2 & 1 & 1 & 2 & 1 & 1 & $2,5 Y R 5 / 6$ & 2 & 2 & 1 & 1 & 3 y $4>, 2$ & 2 & $3 a 4$ & sed marrones y rojas & sed bl o fel alt, mica fina, Q-fel & 8 \\
\hline TC 2 & Conj $\mathrm{F}$ & & 305 & 1 & 2 & 1 & 1 & 2 & 1 & 1 & $2,5 Y R 6 / 6$ & 1 & 2 & 1 & 0 & 3 y $4>$ & 3 & $3 a 4$ & sed bl y rojas, incl osc indet & Q-fel, mica & 8 \\
\hline TC 2 & Conj F & & 306 & 1 & 2 & 1 & 1 & 2 & 1 & 1 & 2,5 YR $5 / 6$ & 2 & 2 & 1 & 2 & 3 y $4>, 2$ & 2 & $2 \mathrm{a} 4$ & Q y mica abund & Q-fel, incl osc indet & 2 \\
\hline TC 2 & Conj $\mathrm{F}$ & & 307 & 1 & 2 & 2 & 1 & 2 & 2 & 4 & $7,5 Y R \quad 4 / 3,5 / 1$ & 1 & 2 & 2 & 1 & 3 y $4>, 2$ & 2 & $3 a 4$ & sed grises y marrones & mica fina, Q-fel & 8 \\
\hline TC 2 & Conj $\mathrm{F}$ & & 308 & 1 & 2 & 1 & 1 & 2 & 1 & 1 & $2,5 Y R 5 / 6$ & 2 & 1 & 2 & 1 & 4 y $5>, 3$ & 3 & $3 a 4$ & sed grises y marrones & mica, Q-fel & 5 \\
\hline TC 2 & Conj F & & 309 & 1 & 2 & 1 & 1 & 2 & 2 & 4 & $2,5 Y R$ 5/4, 4/1 & 2 & 2 & 1 & 1 & 3 y $4>, 2$ & 2 & $3 a 4$ & sed marrones y rojas, $\mathrm{Q}$ & mica, sed bl o fel alt, Q-fel & 8 \\
\hline TC 2 & Conj $\mathrm{F}$ & & 310 & 1 & 2 & 1 & 1 & $2 \mathrm{y} 1$ & 1 & 1 & 10R $5 / 6$ & 2 & 1 & 1 & 0 & 4 y $5>, 3$ & 3 & $3 a 4$ & $x$ & sed rojas, bl, mica fina & 5 \\
\hline TC 2 & Conj F & & 311 & 1 & 2 & 1 & 1 & $2 \mathrm{y} 1$ & 1 & 1 & 10R 5/6 & 2 & 1 & 1 & 0 & 4 y $5>, 3$ & 3 & $3 a 4$ & $x$ & sed rojas, bl, mica fina & 5 \\
\hline TC 2 & Conj $\mathrm{F}$ & & 312 & 1 & 2 & 1 & 1 & 2 & 1 & 1 & 10R 5/4 & 2 & 1 & 1 & 0 & 4 y $5>, 3$ & 3 & $3 a 4$ & $x$ & sed grises y rojas, $Q$, mica fina & 5 \\
\hline TC 2 & Conj $\mathrm{F}$ & & 313 & 1 & 2 & 1 & 1 & 2 & 1 & 1 & $2,5 Y R 5 / 4$ & 1 & 2 & 1 & 1 & 3 y $4>, 2$ & 2 & $3 a 4$ & sed bl abund, sed rojas & mica fina, Q-fel & 3 \\
\hline TC 2 & Conj F & & 314 & 1 & 2 & 1 & 1 & 2 & 1 & 1 & 5YR 7/4 & 1 & 2 & 1 & 1 & 3 у $4>, 2$ & 2 & $3 a 4$ & sed bl abund, sed rojas, $Q$ & mica fina, Q-fel & 3 \\
\hline TC 2 & Conj F & & 315 & 1 & 2 & 2 & 1 & 2 & 1 & 1 & $2,5 Y R 5 / 6$ & 2 & 2 & 1 & 0 & 4 y $5>$ & 4 & $3 a 4$ & Q abund, mica, Q-fel & sed rojas & 2 \\
\hline TC 2 & Conj $\mathrm{F}$ & & 318 & 1 & 2 & 1 & 1 & 2 & 1 & 1 & $2,5 Y R 5 / 6$ & 1 & 2 & 1 & 0 & 3 y $4>, 2$ & 2 & $3 a 4$ & sed marrones, grises y bl & Q, incl osc indet, mica, Q-fel & 8 \\
\hline TC 2 & Terraza & & 319 & 1 & 2 & 2 & 1 & 2 & 2 & 5 & 2,5YR 5/8, 4/3 (nuc) & 2 & 2 & 1 & 1 & 4 y $5>, 3$ & 3 & $3 a 5$ & Q abund, mica, sed bl o fel alt & incl osc indet, Q-fel & 2 \\
\hline TC 2 & Terraza & & 320 & 1 & 2 & 2 & 1 & 2 & 2 & 5 & 2,5YR 5/6. 5/1 (nuc) & 1 & 2 & 1 & 1 & 3 y $4>, 1$ y 2 & 1 & $3 a 5$ & Q abund, sed bl y marrones, mica & Q-fel & 2 \\
\hline
\end{tabular}




\begin{tabular}{|c|c|c|c|c|c|c|c|c|c|c|c|c|c|c|c|c|c|c|c|c|c|}
\hline \multirow[b]{2}{*}{$\begin{array}{c}\text { Sitio y } \\
\text { est }\end{array}$} & \multirow[b]{2}{*}{ UP } & \multirow[b]{2}{*}{ GF } & \multirow[b]{2}{*}{ FNA } & \multicolumn{4}{|c|}{ Fractura } & \multirow[b]{2}{*}{$\begin{array}{l}\text { Ca } \\
\text { vid }\end{array}$} & \multirow{2}{*}{\multicolumn{2}{|c|}{$\begin{array}{ll}\text { Coc } & \text { Co } \\
\text { ción } & \text { lor } \\
\end{array}$}} & \multirow[b]{2}{*}{ Not color } & \multicolumn{7}{|c|}{ Inclusiones } & \multicolumn{2}{|c|}{ Composic } & \multirow[b]{2}{*}{ GP } \\
\hline & & & & $\begin{array}{c}\text { Aspec } \\
\text { to }\end{array}$ & \begin{tabular}{|l|l|} 
& $\begin{array}{l}\text { Tex } \\
\text { tura }\end{array}$ \\
\end{tabular} & $\begin{array}{l}\text { Resis } \\
\text { tenc. }\end{array}$ & $\begin{array}{l}\mathrm{Re} \\
\text { gul }\end{array}$ & & & & & Incl & Dens & $\begin{array}{c}\text { Orien } \\
\text { tac }\end{array}$ & $\begin{array}{l}\text { Orient } \\
\text { pared }\end{array}$ & Granul & $\begin{array}{l}\mathrm{Se} \\
\text { lec }\end{array}$ & $\begin{array}{l}\mathrm{Re} \\
\mathrm{don}\end{array}$ & comp mayor & comp aislados & \\
\hline TC 2 & Terraza & & 321 & 1 & 2 & 1 & 1 & 2 & 1 & 1 & 5YR $6 / 4$ & 1 & 2 & 1 & 1 & 3 y $4>, 2$ & 2 & $3 a 4$ & sed bl abund, sed rojas, Q & Q-fel, mica fina & 3 \\
\hline TC 2 & Terraza & & 322 & 1 & 2 & 1 & 1 & $2 \mathrm{y} 1$ & 1 & 1 & $5 Y R 4 / 4$ & 1 & 2 & 1 & 1 & 3 y $4>, 2$ & 2 & $3 a 4$ & sed bl, grises y marrones & mica fina, Q-fel & 8 \\
\hline TC 2 & Terraza & & 323 & 1 & 2 & 1 & 1 & 2 & 2 & 5 & 5YR 4/1, 5/4 (nuc) & 2 & 2 & 2 & 1 & 4 y $5>$ & 4 & $3 a 4$ & Q y mica abund & sed bl o fel alt, Q-fel & 2 \\
\hline TC 2 & Terraza & & 324 & 1 & 2 & 1 & 1 & 2 & 1 & 1 & 2,5 YR 5/6 & 1 & 2 & 1 & 1 & 3 y $4>, 2$ & 2 & $3 a 4$ & sed bl, grises y rojas & mica fina, Q-fel & 8 \\
\hline TC 2 & Terraza & & $325 / 26$ & 1 & 2 & 1 & 1 & 2 & 2 & 1 & $7,5 Y R$ 6/3 & 1 & 2 & 1 & 1 & 3 y $4>, 2$ & 2 & $3 a 4$ & Q, sed bl, marrones y rojas & mica, Q-fel & 8 \\
\hline TC 2 & Terraza & & 327 & 1 & 2 & 1 & 1 & 2 & 1 & 1 & $2,5 Y R 5 / 6$ & 2 & 2 & 1 & 0 & 3 y $4>, 2$ & 2 & $3 a 4$ & sed marrones, rojas, grises & Q-fel, mica fina & 8 \\
\hline TC 2 & Terraza & & 328 & 1 & 2 & 1 & 1 & 2 & 1 & 1 & $2,5 Y R 5 / 6$ & 1 & 2 & 1 & 0 & 3 y $4>, 2$ & 2 & $3 a 4$ & sed bl, marrones y rojas, $\mathrm{Q}$ & mica fina, Q-fel & 8 \\
\hline TC 2 & Terraza & & 329 & 1 & 2 & 1 & 1 & 2 & 1 & 1 & 2,5 YR $5 / 6$ & 1 & 2 & 1 & 0 & 3 y $4>, 2$ & 2 & $3 a 4$ & sed bl, marrones y rojas, $\mathrm{Q}$ & mica fina, Q-fel & 8 \\
\hline TC 2 & Terraza & & 330 & 1 & 2 & 1 & 1 & $2 \mathrm{y} 1$ & 1 & 1 & 5YR 7/4 & 1 & 2 & 1 & 1 & 3 y $4>, 2$ & 2 & $3 a 4$ & sed bl abund, rosadas y rojas & Q-fel, mica fina & 3 \\
\hline TC 2 & Terraza & & 331 & 1 & 2 & 1 & 1 & $2 \mathrm{y} 1$ & 2 & 4 & $2,5 Y R$ 5/6, 3/1 & 2 & 2 & 1 & 0 & 3 y $4>, 2$ & 2 & $3 a 4$ & sed marrones y grises, $\mathrm{Q}$ & mica fina, Q-fel & 8 \\
\hline TC 2 & Terraza & & 332 & 1 & 2 & 1 & 1 & 2 & 1 & 1 & $5 Y R$ 5/6 & 2 & 1 & 1 & 0 & 4 y $5>, 3$ & 3 & $3 a 4$ & sed grises y rojas & mica, Q-fel & 5 \\
\hline TC 2 & Terraza & & 333 & 1 & 2 & 1 & 1 & $2 \mathrm{y} 1$ & 1 & 1 & 5YR 6/4 & 1 & 2 & 1 & 1 & 3 y $4>, 2$ & 2 & $3 a 4$ & sed bl abund, rojas, Q & mica fina, Q-fel & 3 \\
\hline TC 2 & Terraza & & 334 & 1 & 2 & 1 & 1 & 2 & 1 & 1 & $2,5 Y R \quad 4 / 4$ & 2 & 1 & 1 & 1 & 4 y $5>$ & 4 & $3 a 4$ & $x$ & sed rojas, mica, Q,sed bl-fel alt & 5 \\
\hline TC 2 & Terraza & & 335 & 1 & 2 & 1 & 1 & 2 & 1 & 1 & $7,5 Y R 7 / 4$ & 1 & 2 & 1 & 1 & 3 y $4>, 2$ & 2 & $3 a 4$ & sed bl abund, rosadas y rojas & Q-fel, mica fina & 3 \\
\hline TC 2 & Terraza & & 336 & 1 & 2 & 1 & 1 & 2 & 1 & 1 & 2,5 YR $5 / 6$ & 1 & 2 & 1 & 1 & 3 y $4>, 2$ & 2 & $3 a 4$ & sed bl abund, rosadas y rojas & Q, Q-fel, mica fina & 3 \\
\hline TC 2 & Terraza & & 337 & 1 & 2 & 1 & 1 & 2 & 1 & 1 & 10R $5 / 6$ & 1 & $1 a 2$ & 1 & 0 & 4 y $5>, 3$ & 3 & $3 a 4$ & sed bl abund, rojas & Q, mica, Q-fel & 3 \\
\hline TC 2 & Terraza & & 339 & 1 & 2 & 1 & 1 & 2 & 1 & 1 & 2,5 YR $5 / 6$ & 2 & 1 & 1 & 0 & 4 y $5>$ & 4 & $3 a 4$ & sed grises y marrones & Q-fel, Q, mica fina & 5 \\
\hline TC 2 & Terraza & & 340 & 1 & 2 & 1 & 1 & 2 & 1 & 1 & 10R $6 / 6$ & 1 & 2 & 1 & 1 & 3 y $4>, 2$ & 2 & $3 a 5$ & sed bl abund, rojas, Q & Q-fel, mica fina & 3 \\
\hline TC 2 & Terraza & & 341 & 1 & 2 & 1 & 1 & 2 & 2 & 4 & 10R 6/6; 2,5YR 4/2 & 1 & 2 & 1 & 1 & 3 y $4>, 2$ & 2 & $3 a 5$ & sed bl abund, rojas, Q & Q-fel, mica fina & 3 \\
\hline TC 2 & Terraza & & 342 & 1 & 2 & 2 & 1 & 2 & 1 & 1 & $5 Y R$ 5/4 & 1 & 2 & 1 & 1 & 3 y $4>, 2$ & 2 & $3 a 4$ & sed marrones, grises y bl & Q-fel, mica fina & 8 \\
\hline TC 2 & Terraza & & 343 & 1 & 2 & 1 & 1 & 2 & 1 & 1 & $5 Y R$ 5/4 & 1 & 2 & 1 & 1 & 3 y $4>, 2$ & 2 & $3 a 4$ & sed marrones, grises y bl & Q-fel, mica fina & 8 \\
\hline TC 2 & Terraza & & 344 & 1 & 2 & 1 & 1 & 2 & 2 & 4 & $\mathrm{~N} 4 /, \mathrm{N} 3 /$ & 2 & 2 & 2 & 0 & 4 y $5>$ & 4 & $3 a 4$ & mica y Q abund & sed bl o fel alt, Q-fel & 2 \\
\hline TC 2 & Terraza & & 345 & 1 & 2 & 1 & 1 & 2 & 1 & 1 & $2,5 Y R 5 / 6$ & 2 & 1 & 1 & 1 & 4 y $5>$ & 4 & $3 a 4$ & sed grises y marrones & Q-fel, mica fina & 5 \\
\hline TC 2 & Terraza & & 346 & 1 & 2 & 1 & 1 & 2 & 1 & 1 & 5YR 5/4 & 1 & 2 & 1 & 0 & 3 y $4>, 2$ & 2 & $3 a 4$ & sed grises, marrones y rojas & Q, mica fina, Q-fel & 8 \\
\hline TC 2 & Terraza & & 347 & 1 & 2 & 1 & 1 & 2 & 1 & 1 & $2,5 Y R 6 / 6$ & 2 & 2 & 1 & 0 & 4 y $5>, 3$ & 3 & $3 a 4$ & sed bl, Q, Q-fel, sed rojas & mica & 3 \\
\hline TC 2 & Terraza & & 348 & 1 & 2 & 1 & 1 & 2 & 1 & 1 & $2,5 Y R 5 / 6$ & 1 & $1 \mathrm{a} 2$ & 1 & 1 & 4 y $5>, 3$ & 3 & $3 a 4$ & sed bl abund, rojas, Q & Q-fel, mica fina & 3 \\
\hline TC 2 & Terraza & & 349 & 1 & 2 & 1 & 1 & 2 & 1 & 1 & 5YR 5/4 & 1 & 2 & 1 & 1 & 3 y $4>, 2$ & 2 & $3 a 4$ & sed marrones, grises y bl & Q-fel, mica fia & 8 \\
\hline TC 2 & Terraza & & 350 & 1 & 2 & 1 & 1 & 2 & 1 & 1 & $2,5 Y R 5 / 8$ & 1 & 2 & 1 & 1 & 3 y $4>, 1$ y 2 & 1 & $3 a 4$ & sed bl, rosadas y rojas & Q, Q-fel, mica fina & 3 \\
\hline TC 2 & Terraza & & 351 & 1 & 2 & 1 & 1 & 2 & 2 & 5 & 2,5YR5/6; 5YR6/4(nuc) & 1 & 2 & 1 & 2 & 3 y $4>, 2$ & 2 & $2 \mathrm{a} 4$ & mica abund, $\mathrm{Q}$ & sed bl o fel alt, sed rojas, Q-fel & 1 \\
\hline TC 2 & Terraza & & 352 & 1 & 2 & 1 & 1 & 2 & 2 & 4 & $\mathrm{~N} 4 /, \mathrm{N} 3 /$ & 2 & 2 & 2 & 2 & 3 y $4>, 2$ & 2 & 2a4 & mica abund, $\mathrm{Q}$ & sed bl o fel alt, Q-fel & 1 \\
\hline TC 2 & Terraza & & 353 & 1 & 2 & 1 & 1 & 2 & 1 & 1 & $2,5 Y R 5 / 4$ & 1 & 2 & 1 & 1 & 3 y $4>, 2$ & 2 & $3 a 4$ & sed grises, marrones y bl & Q-fel, mica fina & 8 \\
\hline TC 2 & Terraza & & 354 & 1 & 2 & 1 & 1 & 2 & 2 & 5 & $2,5 Y R$ 5/6, 5/2 (nuc) & 1 & 2 & 1 & 1 & 3 y $4>, 2$ & 2 & $3 a 4$ & sed marrones y grises, mica & sed bl o fel alt & 8 \\
\hline TC 2 & Terraza & & 355 & 1 & 2 & 1 & 1 & 2 & 2 & 4 & $2,5 Y R$ 5/4, 4/1 & 1 & 2 & 1 & 1 & 3 y $4>, 2$ & 2 & $3 a 4$ & sed marrones y grises & Q, Q-fel, mica fina & 8 \\
\hline TC 2 & Terraza & & 358 & 1 & 2 & 1 & 1 & $2 \mathrm{y} 1$ & 1 & 1 & $5 Y R 5 / 4$ & 1 & 2 & 2 & 1 & 3 y $4>, 2$ & 2 & $3 a 4$ & sed grises y marrones & Q, Q-fel, mica fina & 8 \\
\hline TC 2 & Terraza & & 359 & 1 & 2 & 1 & 1 & 2 & 1 & 1 & $2,5 Y R 5 / 6$ & 2 & 1 & 1 & 0 & 4 y $5>$ & 4 & $3 a 4$ & $\mathrm{x}$ & sed bl, Q, Q-fel, mica fina & 5 \\
\hline TC 2 & Terraza & & 360 & 1 & 2 & 1 & 1 & 2 & 1 & 1 & 2,5 YR $5 / 6$ & 2 & 1 & 1 & 0 & 4 y $5>$ & 4 & $3 a 4$ & sed bl & sed rojas, Q-fel, mica fina & 5 \\
\hline
\end{tabular}




\begin{tabular}{|c|c|c|c|c|c|c|c|c|c|c|c|c|c|c|c|c|c|c|c|c|c|}
\hline \multirow[b]{2}{*}{$\begin{array}{c}\text { Sitio y } \\
\text { est }\end{array}$} & \multirow[b]{2}{*}{ UP } & \multirow[b]{2}{*}{ GF } & \multirow[b]{2}{*}{ FNA } & \multicolumn{4}{|c|}{ Fractura } & \multirow{2}{*}{\multicolumn{3}{|c|}{\begin{tabular}{|l|l|l|l|l|l|} 
Ca & Coc \\
vid & ción & lor \\
\end{tabular}}} & \multirow[b]{2}{*}{ Not color } & \multicolumn{7}{|c|}{ Inclusiones } & \multicolumn{2}{|c|}{ Composic } & \multirow[b]{2}{*}{ GP } \\
\hline & & & & $\begin{array}{c}\text { Aspec } \\
\text { to }\end{array}$ & $\begin{array}{l}\text { Tex } \\
\text { tura } \\
\end{array}$ & \begin{tabular}{|l|} 
Resis \\
tenc.
\end{tabular} & $\begin{array}{l}\text { Re } \\
\text { gul }\end{array}$ & & & & & Incl & Dens & $\begin{array}{c}\text { Orien } \\
\text { tac }\end{array}$ & $\begin{array}{l}\text { Orient } \\
\text { pared }\end{array}$ & Granul & & $\begin{array}{l}\mathbf{R e} \\
\text { don } \\
\end{array}$ & comp mayor & comp aislados & \\
\hline TC 2 & Terraza & & 361 & 1 & 2 & 1 & 1 & 2 & 1 & 1 & $2,5 Y R$ 5/6 & 1 & 2 & 1 & 1 & 3 y $4>, 2$ & 2 & $3 a 4$ & sed bl, grises y marrones & Q-fel, mica fina & 8 \\
\hline TC 2 & Terraza & & 362 & 1 & 2 & 1 & 1 & 2 & 2 & 5 & 2,5YR 5/6, 5/2 (nuc) & 1 & 2 & 1 & 1 & 3 y $4>, 1$ y 2 & 1 & $2 \mathrm{a} 4$ & mica abund, $\mathrm{Q}$ & sed rojas, Q-fel & 1 \\
\hline TC 2 & Terraza & & 363 & 1 & 2 & 1 & 1 & 2 & 1 & 1 & 2,5 YR $5 / 6$ & 1 & 2 & 1 & 1 & 3 y $4>, 2$ & 2 & $3 a 4$ & sed bl abund, rojas y marrones & Q, Q-fel, mica fina & 3 \\
\hline TC 2 & Terraza & & 364 & 1 & 2 & 1 & 1 & 2 & 1 & 1 & $2,5 Y R 6 / 6$ & 1 & 2 & 1 & 1 & 3 y $4>, 2$ & 2 & $3 a 4$ & sed bl abund, rosadas y rojas & Q, Q-fel, mica fina & 3 \\
\hline TC 2 & Terraza & & 365 & 1 & 2 & 1 & 1 & 2 & 1 & 1 & $2,5 Y R \quad 4 / 4$ & 1 & 2 & 1 & 1 & 3 y $4>, 2$ & 2 & $3 a 4$ & sed grises, marrones y bl & Q-fel, mica fina & 8 \\
\hline TC 2 & Terraza & & 366 & 1 & 2 & 1 & 1 & 2 & 1 & 1 & $2,5 Y R 5 / 6$ & 1 & 2 & 1 & 1 & 3 y $4>, 2$ & 2 & $3 a 4$ & sed grises, marrones y bl & Q-fel, mica fina & 8 \\
\hline TC 2 & Terraza & & 367 & 1 & 2 & 2 & 1 & 2 & 2 & 4 & $2,5 Y R$ 4/1, 5/6 & 1 & 2 & 1 & 1 & 3 y $4>, 2$ & 2 & $3 a 4$ & sed grises, marrones y bl & Q-fel, mica fina & 8 \\
\hline TC 2 & Ladera & & 368 & 1 & 2 & 1 & 1 & 2 & 1 & 1 & 2,5 YR $5 / 6$ & 2 & 1 & 2 & 1 & 4 y $5>, 2$ & 2 & $3 a 4$ & sed bl, Q & sed rojas, Q-fel, mica fina & 5 \\
\hline TC 2 & Ladera & & 369 & 1 & 2 & 1 & 1 & 2 & 2 & 4 & $2,5 Y R \quad 4 / 3,6 / 6$ & 1 & 2 & 1 & 1 & 3 y $4>, 2$ & 2 & $3 a 5$ & sed bl abund, rosadas y rojas & Q, Q-fel, mica fina & 3 \\
\hline TC 2 & Ladera & & 370 & 1 & 2 & 1 & 1 & 2 & 2 & 1 & $7,5 Y R \quad 4 / 2$ & 2 & 1 & 1 & 1 & 3 y $4>$ & 3 & $3 a 4$ & $x$ & sed grises, mica fina & 5 \\
\hline TC 2 & Ladera & & 371 & 1 & 2 & 1 & 1 & 2 & 1 & 1 & 5YR 5/6 & 2 & 1 & 1 & 1 & 4 y $5>$ & 4 & $3 a 4$ & sed bl y grises & mica, Q-fel & 5 \\
\hline TC 2 & Ladera & & 372 & 1 & 2 & 1 & 1 & 2 & 2 & 1 & $\mathrm{~N} 4 /$ & 2 & 1 & 1 & 1 & 4 y $5>$ & 4 & $3 a 4$ & $x$ & sed bl y grises, mica fina, Q-fel & 5 \\
\hline TC 2 & Ladera & & 373 & 1 & 2 & 1 & 1 & 2 & 1 & 1 & $2,5 Y R$ 5/6 & 2 & 1 & 1 & 0 & 4 y $5>$ & 4 & $3 a 4$ & sed grises, mica & Q-fel & 5 \\
\hline TC 2 & Ladera & & 374 & 1 & 2 & 1 & 1 & $2 \mathrm{y} 1$ & 1 & 1 & 10R 5/6 & 2 & 1 & 1 & 0 & 4 y $5>$ & 4 & $3 a 4$ & sed grises, mica & Q-fel & 5 \\
\hline TC 2 & Ladera & & 375 & 1 & 2 & 1 & 1 & $2 \mathrm{y} 1$ & 1 & 1 & $2,5 Y R$ 5/6 & 2 & 1 & 1 & 0 & 4 y $5>, 3$ & 3 & $3 a 4$ & sed bl & sed rojas, Q-fel, mica fina & 5 \\
\hline TC 2 & Ladera & & 376 & 1 & 2 & 1 & 1 & $2 \mathrm{y} 1$ & 1 & 1 & $2,5 Y R$ 5/6 & 2 & 1 & 1 & 0 & 4 y $5>, 3$ & 3 & $3 a 4$ & sed bl & sed rojas, Q, Q-fel, mica fina & 5 \\
\hline
\end{tabular}




\section{ANEXO IV}

\section{Planilla de descripción de cortes delgados y conteo de puntos en microscopio petrográfico}

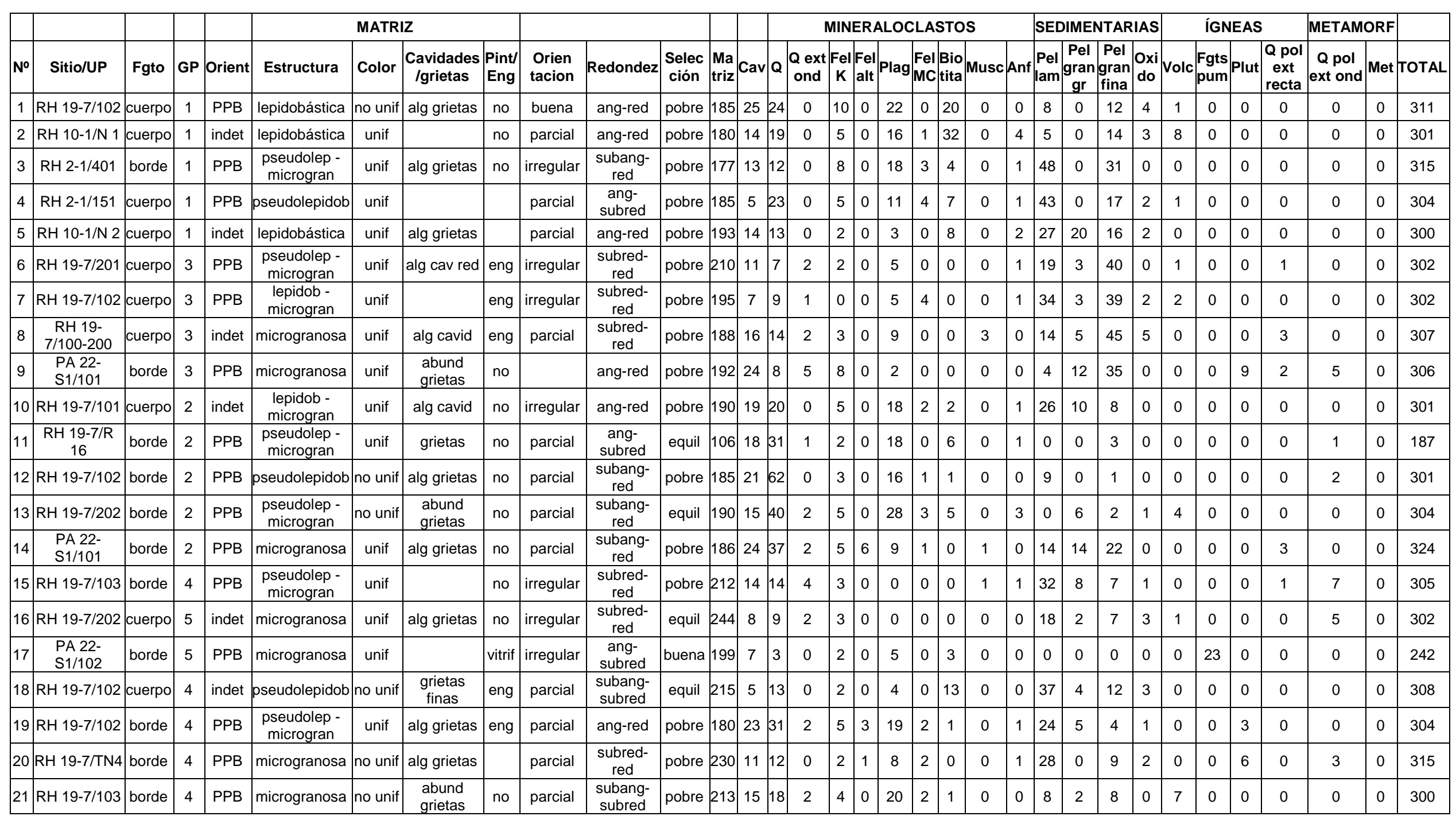




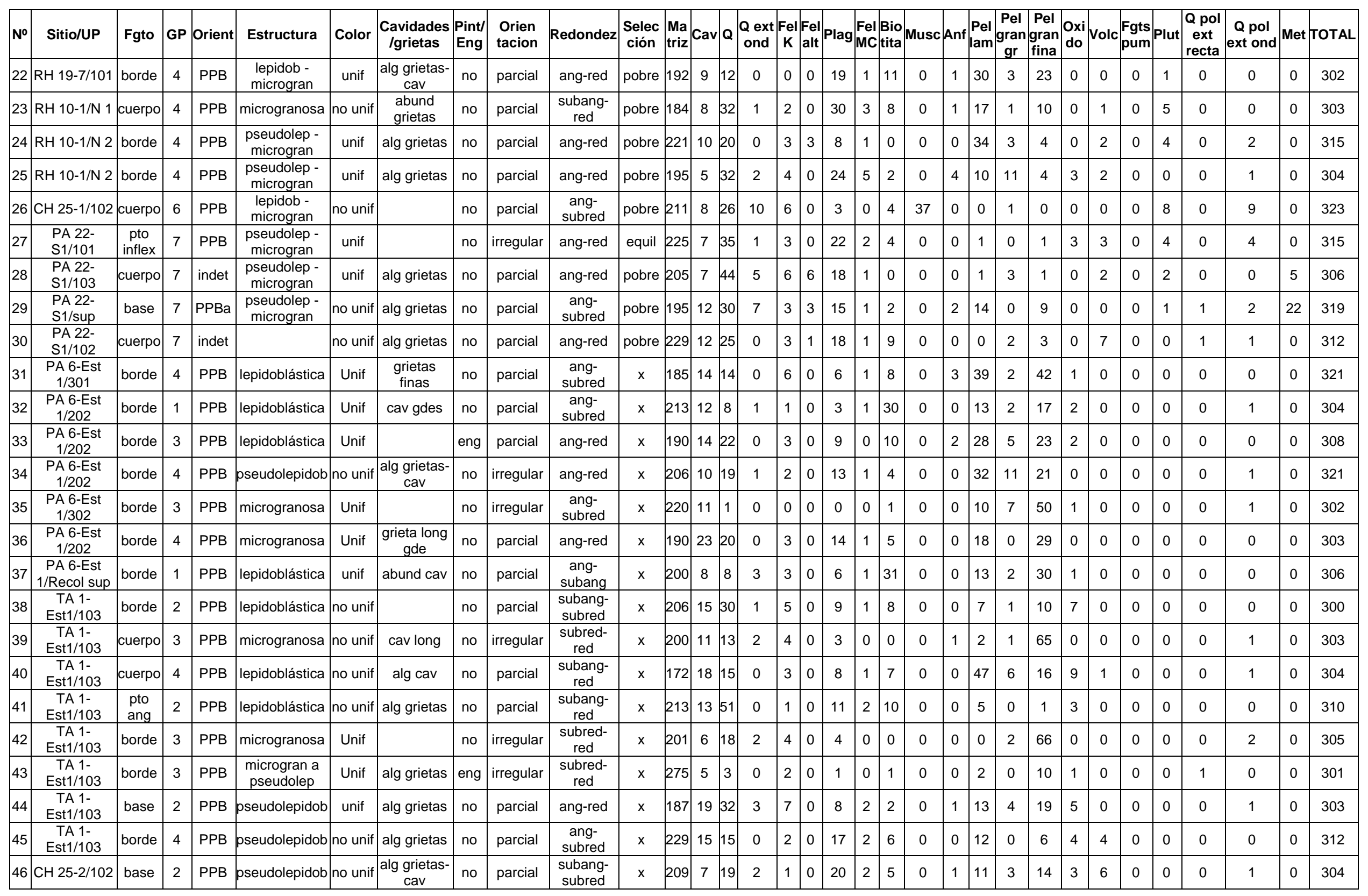




\begin{tabular}{|c|c|c|c|c|c|c|c|c|c|c|c|c|c|c|c|c|c|c|c|c|c|c|c|c|c|c|c|c|c|c|c|c|c|}
\hline $\mathbf{N}^{\mathbf{0}}$ & Sitio/UP & Fgto & GP & Orient & Estructura & Color & $\begin{array}{c}\text { Cavidades } \\
\text { Igrietas }\end{array}$ & $\begin{array}{l}\text { Pint/ } \\
\text { Eng }\end{array}$ & $\begin{array}{c}\text { Orien } \\
\text { tacion }\end{array}$ & Redondez & $\begin{array}{c}\text { Selec } \\
\text { ción }\end{array}$ & $\left|\begin{array}{c}\text { Ma } \\
\text { triz }\end{array}\right|$ & Cav & $Q$ & $\begin{array}{l}Q \text { ext } F \\
\text { ond }\end{array}$ & $\begin{array}{l}\text { Fel|F } \\
\text { K }\end{array}$ & $\left|\begin{array}{l}\text { Fel } \\
\text { alt }\end{array}\right|$ & Plag & \begin{tabular}{|l|l}
$\mathrm{Fel}$ & $\mathrm{B}$ \\
$\mathrm{MC}$ & $\mathrm{ti}$
\end{tabular} & $\begin{array}{l}\text { Bio } \\
\text { tita }\end{array}$ & A & Anf & \begin{tabular}{|l|c|c} 
Pel & P \\
lam & \\
la & \\
\end{tabular} & \begin{tabular}{c|c} 
Pel & $F$ \\
gran & $g$ \\
gr & $f$ \\
\end{tabular} & \begin{tabular}{c|c} 
Pel \\
gran \\
fina
\end{tabular} & $\begin{array}{l}\text { Oxi } \\
\text { do }\end{array}$ & Volc $\left.\right|_{p} ^{F}$ & $\mid \begin{array}{l}\text { Fgts } \\
\text { pum }\end{array}$ & Plut & $\begin{array}{c}\text { Q pol } \\
\text { ext } \\
\text { recta }\end{array}$ & $\left|\begin{array}{c}\text { Q pol } \\
\text { ext ond }\end{array}\right|$ & Met $T$ & TOTAL \\
\hline 47 & $\mathrm{CH} 25-2 / 102$ & cuerpo & 1 & indet & lepidoblástica & Unif & \begin{tabular}{|c|} 
alg grietas- \\
cav
\end{tabular} & no & parcial & $\begin{array}{l}\text { subang- } \\
\text { red }\end{array}$ & $x$ & 230 & 15 & 15 & 1 & 2 & 0 & 10 & \begin{tabular}{|l|l|}
4 & 1
\end{tabular} & 13 & 0 & 0 & 0 & 3 & 3 & 0 & 0 & 0 & 4 & 0 & 0 & 2 & 302 \\
\hline 48 & $\mathrm{CH} 25-2 / 102$ & \begin{tabular}{|c|} 
pto \\
inflex
\end{tabular} & 2 & PPB & pseudolepidob & Unif & $\begin{array}{c}\text { alg grietas- } \\
\text { cav }\end{array}$ & no & irregular & $\begin{array}{l}\text { subang- } \\
\text { red }\end{array}$ & $\mathrm{x}$ & 186 & 10 & 34 & 2 & 4 & 0 & 17 & 3 & 5 & 0 & 0 & 13 & 4 & 24 & 5 & 5 & 0 & 2 & 0 & 0 & 0 & 314 \\
\hline 49 & $\mathrm{CH} 25-2 / 102$ & cuerpo & 4 & indet & lepidoblástica r & no unif & grietas long & no & parcial & $\begin{array}{l}\text { subang- } \\
\text { subred }\end{array}$ & $x$ & 162 & 22 & 24 & 0 & 2 & 0 & 2 & \begin{tabular}{|l|l}
2 & 2 \\
\end{tabular} & 29 & 1 & 1 & 32 & 0 & 38 & 0 & 0 & 0 & 0 & 0 & 0 & 0 & 315 \\
\hline 50 & $\mathrm{CH} 25-2 / 102$ & borde & 2 & PPB & pseudolepidob r & no unif & $\begin{array}{c}\text { grieta gde } \\
\text { long }\end{array}$ & no & parcial & $\begin{array}{c}\text { ang- } \\
\text { subang }\end{array}$ & $\mathrm{x}$ & 133 & 12 & 20 & 0 & 4 & 0 & 10 & 3 & 1 & 0 & 0 & 14 & 0 & 12 & 1 & 4 & 0 & 0 & 0 & 0 & 0 & 214 \\
\hline 51 & $\begin{array}{c}\text { SC } 3 / \text { Rec } \\
\text { Sup }\end{array}$ & borde & 5 & PPB & microgranosa & Unif & alg grietas & eng & irregular & $\begin{array}{l}\text { subang- } \\
\text { subred }\end{array}$ & buena & 265 & 11 & 13 & 4 & 0 & 2 & 5 & 0 & 2 & 0 & 1 & 0 & 0 & 6 & 2 & 0 & 0 & 0 & 0 & 1 & 0 & 312 \\
\hline 52 & $\begin{array}{l}\text { SC } 3 / \operatorname{Rec} \\
\text { Sup }\end{array}$ & cuerpo & 8 & indet & microgranosa & Unif & alg grietas & eng & parcial & $\begin{array}{l}\text { subang- } \\
\text { subred }\end{array}$ & equil & 255 & 7 & 1 & 2 & 0 & 0 & 1 & 0 & 0 & 0 & 0 & 2 & 7 & 28 & 2 & 0 & 0 & 0 & 2 & 0 & 0 & 307 \\
\hline 53 & $\begin{array}{c}\text { SC 3-Est } 2 \text { y } \\
\text { 3/Rec Sup }\end{array}$ & borde & 8 & PPB & pseudolepidob & dif bic & alg grietas & eng & parcial & $\begin{array}{l}\text { subang- } \\
\text { subred }\end{array}$ & pobre & 193 & 10 & 6 & 1 & 2 & 0 & 2 & 0 & 0 & 0 & 0 & \begin{tabular}{l|l}
28 & 1 \\
\end{tabular} & 12 & 53 & 1 & 0 & 0 & 0 & 0 & 3 & 0 & 311 \\
\hline 54 & $\begin{array}{l}\text { SC } 3 / \operatorname{Rec} \\
\text { Sup }\end{array}$ & borde & 3 & PPB & microgranosa & dif tric & $\begin{array}{c}\text { algunas } \\
\text { cav }\end{array}$ & eng & irregular & $\begin{array}{l}\text { subang- } \\
\text { subred }\end{array}$ & pobre & 230 & 6 & 5 & 4 & 0 & 0 & 2 & 0 & 1 & 0 & 0 & 21 & 1 & 31 & 2 & 3 & 0 & 0 & 0 & 1 & 0 & 307 \\
\hline 55 & $\begin{array}{c}\text { SC 3-Est } \\
\text { 1/Rec Sup }\end{array}$ & borde & 8 & PPB & microgranosa & dif tric & $\begin{array}{c}\text { alg grietas- } \\
\text { cav }\end{array}$ & no & parcial & $\begin{array}{l}\text { subang- } \\
\text { subred }\end{array}$ & pobre & 200 & 6 & 11 & 5 & 0 & 0 & 0 & 0 & 1 & 0 & 0 & 13 & 6 & 52 & 1 & 0 & 0 & 0 & 0 & 8 & 0 & 303 \\
\hline 56 & $\begin{array}{c}\text { SC } 3 / \operatorname{Rec} \\
\text { Sup }\end{array}$ & borde & 5 & PPB & microgranosa $\mathrm{r}$ & no unif & $\begin{array}{c}\text { escasas } \\
\text { cav }\end{array}$ & no & irregular & $\begin{array}{c}\text { subang- } \\
\text { subred }\end{array}$ & equil & 285 & 4 & 2 & 0 & 0 & 0 & 1 & 0 & 0 & 0 & 0 & 0 & 0 & 13 & 1 & 0 & 0 & 0 & 0 & 0 & 0 & 306 \\
\hline 58 & $\begin{array}{l}\text { SC } 3 / \operatorname{Rec} \\
\text { Sup }\end{array}$ & borde & 2 & PPB & pseudolepidob & Uni & $\begin{array}{l}\text { abund } \\
\text { grietas }\end{array}$ & no & parcial & $\begin{array}{l}\text { ang- } \\
\text { subred }\end{array}$ & pobre & 197 & 135 & 57 & 2 & 1 & 0 & 5 & \begin{tabular}{|l|l}
1 & 2 \\
1
\end{tabular} & 23 & 0 & 0 & 0 & 1 & 0 & 0 & 5 & 0 & 0 & 0 & 2 & 0 & 307 \\
\hline 59 & $\begin{array}{l}\text { SC 3/Rec } \\
\text { Sup }\end{array}$ & \begin{tabular}{|c|} 
pto \\
inflex
\end{tabular} & 1 & PPB & lepidoblástica & unif & $\begin{array}{c}\text { escasas } \\
\text { cav }\end{array}$ & no & parcial & $\begin{array}{c}\text { ang- } \\
\text { subang }\end{array}$ & pobre & 190 & 9 & 10 & 0 & 3 & 1 & 47 & 13 & 37 & 0 & 0 & 0 & 0 & 0 & 4 & 1 & 0 & 0 & 0 & 0 & 0 & 303 \\
\hline 60 & $\begin{array}{c}\text { SC } 3 / \operatorname{Rec} \\
\text { Sup }\end{array}$ & erpo & 9 & indet & microgranosa & Unif & $\begin{array}{c}\text { escasas } \\
\text { cav }\end{array}$ & no & irregular & $\begin{array}{l}\text { subang- } \\
\text { subred }\end{array}$ & pobre & 272 & 5 & 5 & 0 & 0 & 5 & 13 & 0 & 1 & 0 & 1 & 0 & 0 & 0 & 0 & 0 & 0 & 11 & 0 & 2 & 0 & 315 \\
\hline 61 & $\begin{array}{l}\text { TC 2-Conj } \\
\text { A/Rec sup }\end{array}$ & borde & 8 & PPB & microgranosa & dif tric & $\begin{array}{c}\text { alg grietas- } \\
\text { cav }\end{array}$ & no & parcial & $\begin{array}{l}\text { subang- } \\
\text { subred }\end{array}$ & pobre & 180 & 10 & 2 & 0 & 0 & 0 & 0 & 0 & 1 & 0 & 0 & $\begin{array}{ll}7 & 2 \\
\end{array}$ & 23 & 77 & 4 & 0 & 0 & 0 & 0 & 0 & 0 & 304 \\
\hline 62 & $\begin{array}{l}\text { TC 2-Conj } \\
\text { A/Rec sup }\end{array}$ & orde & 3 & PPB & microgranosa & dif bic & $\begin{array}{c}\text { alg grietas- } \\
\text { cav }\end{array}$ & no & parcial & $\begin{array}{l}\text { subang- } \\
\text { subred }\end{array}$ & pbre & 220 & 11 & 7 & 0 & 0 & 0 & 2 & 0 & 1 & 0 & 0 & 29 & 2 & 33 & 0 & 0 & 0 & 0 & 0 & 0 & 0 & 305 \\
\hline 63 & $\begin{array}{l}\text { TC 2-Conj } \\
\text { A/Rec sup }\end{array}$ & rde & 1 & PPB & lepidoblástica & dif bic & cav gdes & no & parcial & $\begin{array}{c}\text { ang- } \\
\text { subred }\end{array}$ & pobre & 210 & 7 & 32 & 1 & 0 & 0 & 0 & 05 & 53 & 0 & 0 & 0 & 0 & 5 & 0 & 0 & 0 & 1 & 0 & 0 & 0 & 309 \\
\hline 64 & $\begin{array}{l}\text { TC 2-Conj } \\
\text { B/Rec Sup }\end{array}$ & borde & 5 & PPB & pseudolepidob & unif & \begin{tabular}{|c|} 
alg grietas- \\
cav
\end{tabular} & eng? & regular & $\begin{array}{l}\text { subred- } \\
\text { red }\end{array}$ & quil & 294 & 2 & 0 & 0 & 0 & 0 & 1 & 0 & 2 & 0 & 0 & 0 & 0 & 1 & 1 & 0 & 0 & 0 & 0 & 1 & 0 & 302 \\
\hline 65 & $\begin{array}{l}\text { TC 2-Conj } \\
\text { B/Rec Sup }\end{array}$ & borde & 5 & PPB & microgranosa & dif bic & cav gdes & eng & parcial & $\begin{array}{l}\text { subang- } \\
\text { subred }\end{array}$ & pobre & 260 & 19 & 5 & 3 & 0 & 1 & 1 & 0 & 1 & 0 & 0 & 1 & 0 & 13 & 1 & 0 & 0 & 0 & 0 & 4 & 0 & 309 \\
\hline 66 & $\begin{array}{l}\text { TC 2-Conj } \\
\text { B/Rec Sup }\end{array}$ & de & 1 & РB & eudolepidob & unif & cav gdes & no & arcial & $\begin{array}{c}\text { ang- } \\
\text { subang }\end{array}$ & bre & 215 & 17 & 21 & 1 & 2 & 0 & 21 & 12 & 28 & 0 & 1 & 0 & 0 & 0 & 0 & 2 & 0 & 0 & 0 & 0 & 0 & 309 \\
\hline 67 & $\begin{array}{l}\text { TC 2-Conj } \\
\text { B/Rec Sup }\end{array}$ & base & 5 & indet & microgranosa $\mathrm{r}$ & no unif & cav gdes & no & irregular & $\begin{array}{l}\text { subang- } \\
\text { subred }\end{array}$ & equil & 250 & 13 & 12 & 1 & 0 & 1 & 6 & 0 & 7 & 0 & 1 & 0 & 0 & 0 & 0 & 0 & 14 & 0 & 0 & 0 & 0 & 305 \\
\hline 68 & $\begin{array}{l}\text { TC 2-Conj } \\
\text { C/Rec Sup }\end{array}$ & borde & 5 & PPB & microgranosa & dif tric & cav gdes & no & irregular & $\begin{array}{l}\text { subang- } \\
\text { subred }\end{array}$ & pobre & 271 & 5 & 8 & 0 & 0 & 0 & 3 & 0 & 1 & 0 & 0 & 2 & 1 & 9 & 1 & 2 & 0 & 0 & 0 & 1 & 0 & 304 \\
\hline 70 & $\begin{array}{l}\text { TC 2-Conj } \\
\text { D/Rec Sup }\end{array}$ & borde & 8 & PPB & microgranosa & dif bic & $\begin{array}{c}\text { alg grietas- } \\
\text { cav }\end{array}$ & no & parcial & $\begin{array}{l}\text { subang- } \\
\text { subred }\end{array}$ & bre & 230 & 14 & 4 & 3 & 0 & 0 & 0 & 0 & 1 & 0 & 0 & 4 & 1 & 51 & 0 & 2 & 0 & 0 & 0 & 2 & 0 & 312 \\
\hline
\end{tabular}

